\section{Pacific Northwest} National Laboratory

Operated by Battelle for the U.S. Department of Energy

\section{Hanford Site Groundwater Monitoring for Fiscal Year 2003}

Editors

M. J. Hartman

L. F. Morasch

W. D. Webber

March 2004

Prepared for the U.S. Department of Energy under Contract DE-AC06-76RL0 1830 


\section{DISCLAIMER}

This report was prepared as an account of work sponsored by an agency of the United States Government. Reference herein to any specific commercial product, process, or service by trade name, trademark, manufacturer, or otherwise does not necessarily constitute or imply its endorsement, recommendation, or favoring by the United States Government or any agency thereof, or Battelle Memorial Institute.

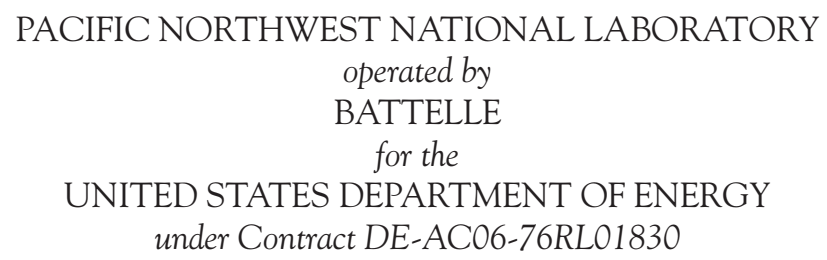

Printed in the United States of America

Available to DOE and DOE contractors from the Office of Scientific and Technical Information, P.O. Box 62, Oak Ridge, TN 37831; prices available from (615) 576-8401.

Available to the public from the National Technical Information Service, U.S. Department of Commerce, 5285 Port Royal Rd., Springfield, VA 22161

This document was printed on recycled paper. 


\title{
Hanford Site Groundwater Monitoring for Fiscal Year 2003
}

\author{
Editors \\ M. J. Hartman \\ L. F. Morasch \\ W. D. Webber
}

March 2004

Prepared for the U.S. Department of Energy

by Pacific Northwest National Laboratory under Contract DE-AC06-76RL01830, with contributions from Bechtel Hanford, Inc.; CH2M HILL Hanford, Inc.; CH2M HILL Hanford Group, Inc.; Fluor Hanford, Inc.; Lawrence Berkley National Laboratory; S.M. Stoller Corporation; Stanford University; and Utah State University

Pacific Northwest National Laboratory Richland, Washington 99352 


\section{Abstract}

This report presents the results of groundwater and vadose zone monitoring and remediation for fiscal year 2003 (October 2002 through September 2003) on the U.S. Department of Energy's Hanford Site, Washington.

The most extensive contaminant plumes in groundwater are tritium, iodine-129, and nitrate, which all had multiple sources and are very mobile in groundwater. The largest portions of these plumes are migrating from the central Hanford Site to the southeast, toward the Columbia River. Concentrations of tritium, nitrate, and some other contaminants continued to exceed drinking water standards in groundwater discharging to the river in some locations. However, contaminant concentrations in river water remained low and were far below standards.

Carbon tetrachloride and associated organic constituents form a relatively large plume beneath the central part of the Hanford Site. Hexavalent chromium is present in smaller plumes beneath the reactor areas along the river and beneath the central part of the site. Strontium-90 exceeds standards beneath all but one of the reactor areas, and technetium-99 and uranium are present in the 200 Areas. Uranium exceeds standards in the 300 Area in the south part of the Hanford Site. Minor contaminant plumes with concentrations greater than standards include carbon-14, cesium-137, cis-1,2-dichloroethene, cyanide, fluoride, plutonium, and trichloroethene.

Monitoring for the Comprehensive Environmental Response, Compensation, and Liability Act is conducted in 11 groundwater operable units. The purpose of this monitoring is to define and track plumes and to monitor the effectiveness of interim remedial actions. Interim groundwater remediation in the 100 Areas continued with the goal of reducing the amount of chromium $(100-\mathrm{K}, 100-\mathrm{D}$, and 100-H) and strontium-90 (100-N) reaching the Columbia River. The objective of two interim remediation systems in the 200 West Area is to prevent the spread of carbon tetrachloride and technetium-99/uranium plumes.

Resource Conservation and Recovery Act groundwater monitoring continued at 24 waste management areas during fiscal year 2003:

- 15 under interim or final status detection programs and data indicate that they are not adversely affecting groundwater

- 7 under interim status groundwater quality assessment programs to assess contamination

- 2 under final status corrective-action programs.

During calendar year 2003, drillers completed seven new RCRA monitoring wells, nine wells for CERCLA, and two wells for research on chromate bioremediation.

Vadose zone monitoring, characterization, and remediation continued in fiscal year 2003. Remediation and associated monitoring continued at a soil-vapor extraction system in the 200 West Area, which removes gaseous carbon tetrachloride from the vadose zone. Soil vapor also was sampled to locate carbon tetrachloride sites with the potential to impact groundwater in the future. DOE uses geophysical methods to monitor potential movement of contamination beneath single-shell tank farms. During fiscal year 2003, DOE monitored selected boreholes within each of the 12 single-shell tank farms. In general, the contaminated areas appeared to be stable over time. DOE drilled new boreholes at the T Tank Farm to characterize subsurface contamination near former leak sites.

The System Assessment Capability is a set of computer modules simulating movement of contaminants from waste sites through the vadose zone and groundwater. In fiscal year 2003, it was updated with the addition of an atmospheric transport module and with newer versions of models including an updated groundwater flow and transport model. 
This report is available on the Internet through the Groundwater Performance Assessment Project's web site: http://groundwater.pnl.gov/. Inquiries regarding this report may be directed to Ms. Mary J. Hartman, Pacific Northwest National Laboratory, P.O. Box 999, Richland, Washington 99352 or by electronic mail to mary.hartman@pnl.gov. 


\section{Acknowledgments}

This report represents the efforts of dozens of individuals who contribute to the Groundwater Performance Assessment Project: planners, schedulers, samplers, laboratory technicians, data management staff, site scientists, editors, text processors, and staff in graphics and duplicating.

John Fruchter and Stuart Luttrell managed the Groundwater Performance Assessment Project and the Groundwater Monitoring Task, respectively. Dot Stewart managed the monumental tasks of sampling and analysis, quality control, and data management.

Most of the graphics for this report were generated by Mickie Chamness and Chris Newbill, who put in many hours to meet our tight schedule. David Lanigan, Joanne Rieger, and Elaine Schneider also assisted with graphics.

Thanks to Bill Deutsch for providing a peer review and to many other reviewers whose comments and suggestions helped us improve this report. As usual, our team of editors and text processors worked tirelessly to produce a clear, polished document in a format that works in paper or electronic form. Thanks to Kathy Neiderhiser for her tremendous dedication, efficiency, and attention to detail; thanks also to Lila Andor, Rose Urbina, and Jennifer Zohn for their invaluable assistance.

Mary Hartman

Launa Morasch

Bill Webber 


\section{Report Contributors}

The production of the Hanford Site Groundwater Monitoring for Fiscal Year 2003 requires the knowledge, skill, expertise, and cooperation of many people and several organizations. The contributions and cooperation, often under demanding time constraints, of the following authors are gratefully acknowledged. The authors' names are listed on their respective sections of the report.

CH2M HILL Hanford, Inc.

D. A. St. John

CH2M HILL Hanford Group, Inc.
C. S. Cearlock
C. D. Wittreich
D. A. Myers

Fluor Hanford, Inc.
J. E. Auten
R. O. Mahood
V. J. Rohay
R. A. Del Mar
R. F. Raidl
D. B. Erb
K. D. Reynolds

\section{Lawrence Berkley National Laboratory}

M. J. Singleton

\section{S.M. Stoller Corporation}

R. G. McCain

\section{Stanford University}

J. G. Catalano

\section{Utah State University}

R. Mackley

\section{Pacific Northwest National Laboratory}
D. B. Barnett
C. J. Murray
M. D. Sweeney
C. F. Brown
S. M. Narbutovskih
C. J. Thompson
P. E. Dresel
D. R. Newcomer
P. D. Thorne
M. J. Fayer
R. E. Peterson
E. C. Thornton
E. J. Freeman
E. M. Pierce
Z. Wang
P. L. Gassman
S. P. Reidel
A. L. Ward
G. W. Gee
J. T. Rieger
M. D. White
D. G. Horton
H. T. Schaef
B. A. Williams
G. V. Last
R. J. Serne
Y. Xie
M. J. Lindberg
D. S. Sklarew
Z. F. Zhang
J. W. Lindberg
R. M. Smith
J. P. McDonald
D. L. Stewart 


\section{Summary}

\section{Introduction}

The Hanford Site, a facility in the U.S. Department of Energy (DOE) nuclear weapons complex, encompasses 1,517 square kilometers northwest of the city of Richland along the Columbia River in southeast Washington State. The federal government acquired the site in 1943, and until the 1980s it was dedicated primarily to the production of plutonium for national defense and the management of resulting waste. In 1995, all unrestricted discharge of radioactive liquid waste to the ground was discontinued. Today, DOE's mission on the Hanford Site is to restore the Columbia River corridor and transition the central portion of the site toward its long-term waste management role.

DOE has monitored groundwater on the Hanford Site since the 1940s to help determine what chemical and radiological contaminants have made their way into the groundwater. As regulatory requirements for monitoring increased in the 1980s, there began to be some overlap between various programs. DOE established the Groundwater Performance Assessment Project (groundwater project) in 1996 to ensure protection of the public and the environment while improving the efficiency of monitoring activities. The groundwater

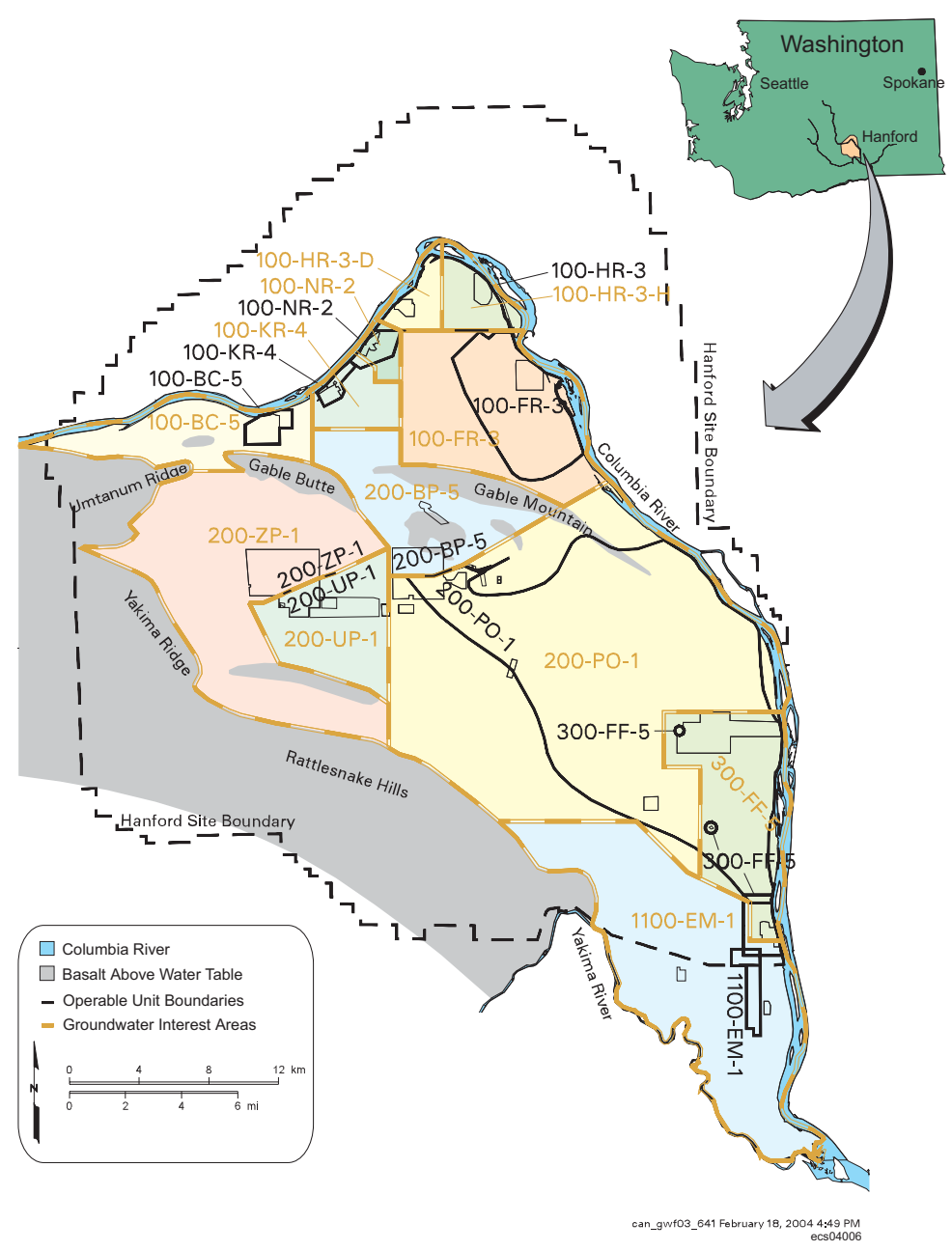

Groundwater is the water that fills the pores or cracks between grains in a layer of sediment or rock. Groundwater monitoring helps determine what contamination exists beneath the Hanford Site. This information will help regulators and DOE make cleanup decisions.

Hanford Site groundwater monitoring is organized by areas of interest, which are informally named after the groundwater operable units. 
This report is written to meet the requirements in the CERCLA, RCRA, Atomic Energy Act of 1954, and Washington Administrative Code.

The Groundwater Project sampled $\sim 710$ wells during fiscal year 2003.

Iodine-129, nitrate, and tritium are the most widespread contaminants. project is designed to support all groundwater monitoring needs at the site, eliminate redundant sampling and analysis, and establish a cost-effective hierarchy for groundwater monitoring activities.

Contamination may reach the Columbia River by moving down through the vadose zone, into the groundwater, and then into the river. The analysis of groundwater samples helps determine the potential effects that contaminants could have on human health and the environment. DOE works with the regulators, such as the U.S. Environmental Protection Agency (EPA) and the Washington State Department of Ecology (Ecology), to make cleanup decisions based on sound technical information and the technical capabilities available.

\section{Highlights and Emerging Issues}

DOE's major accomplishments related to groundwater monitoring in fiscal year 2003, and emerging issues of potential concern, are outlined below.

\section{Groundwater Monitoring Capabilities}

Groundwater Sampling - Workers sampled 710 monitoring wells and 79 shoreline aquifer tubes to determine the distribution and movement of contaminants. Many of the wells were sampled multiple times during the year.

Sample Analysis - One thousand seven hundred and twenty-three samples of Hanford groundwater were analyzed for chromium, 1,181 for nitrate, and 908 for tritium. Other constituents frequently analyzed include carbon tetrachloride, technetium-99, and uranium, which were analyzed in $\sim 600$ samples.

Adequacy of Monitoring Networks - Water levels in the 200 Areas continued to drop, causing more monitoring wells to go dry in fiscal year 2003. Changes in groundwater flow or chemistry also affect the effectiveness of monitoring networks.

New Wells - DOE, Ecology, and EPA agreed to revise a Tri-Party Agreement milestone to allow prioritization of drilling for Comprehensive Environmental Response, Compensation, and Liability Act (CERCLA) and Atomic Energy Act of 1954 (AEA) wells along with Resource

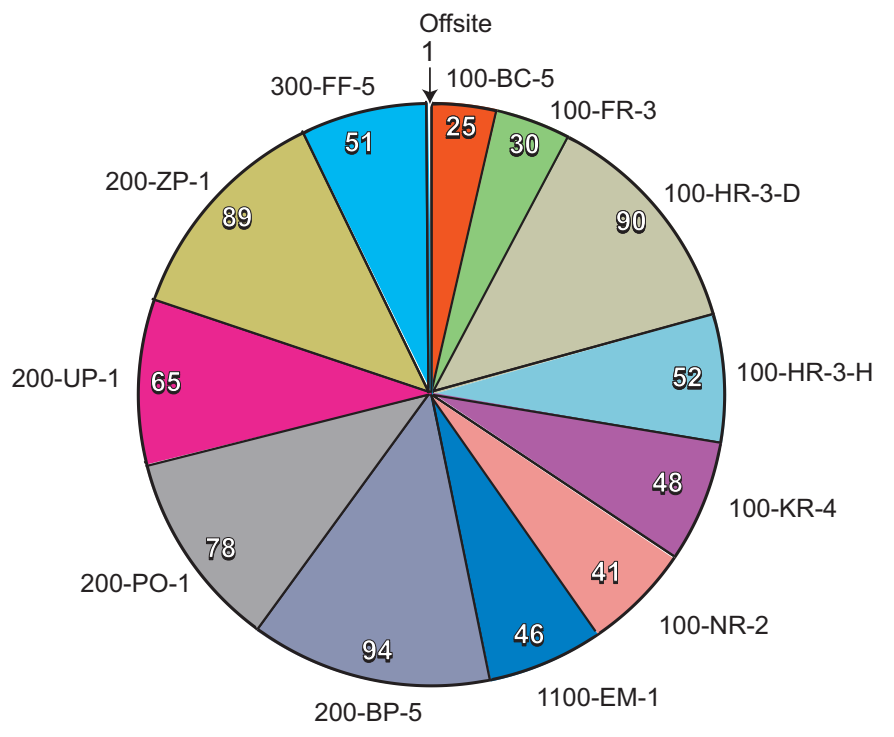

ecs04001

This chart shows the number of wells sampled in each groundwater interest area in fiscal year 2003. 
Conservation and Recovery Act (RCRA) wells. During calendar year 2003, drillers completed seven new RCRA monitoring wells, nine wells for CERCLA, and two wells for research on chromate bioremediation.

River Shoreline Monitoring - DOE monitors aquifer sampling tubes near the Columbia River to track contaminants entering the river. In fiscal year 2004, DOE will install additional tubes in the 100-B/C, 100-K, 100-D, 100-H, 100-F, and 300 Areas.

\section{Tracking Groundwater Contamination}

Site-Wide Tritium Plume - Monitoring indicated that the Hanford Site's largest contaminant plume is gradually decreasing in size and is not affecting Richland's watersupply wells. The plume is expected to continue to shrink.

Tritium in 100-K Area - Tritium concentrations increased in two wells near the KE Basin and one well near the KW Basin in fiscal year 2003. However, supporting data indicate that the rise was not due to new leakage from the basins. DOE continued to investigate tritium in the vicinity of a burial ground in the 100-K Area. Results indicated the presence of a vadose zone source along with an underlying plume in the groundwater.

Chromium in 100-D Area - Chromium levels continued to increase sharply in the central 100-D Area, between the influence of the two interim remedial action systems where it could migrate to the Columbia River. DOE and the regulators will expand remedial measures to address this change.

Carbon Tetrachloride Plume - This plume beneath the 200 West Area is gradually spreading at the $5-\mathrm{mg} / \mathrm{L}$ contour, but the high-concentration portion of the plume is contained. In some locations, carbon tetrachloride concentrations are higher deep in the aquifer than near the water table. This issue will continue to be studied in fiscal year 2004.

\section{Groundwater Operable Units}

Interim Remedial Actions - Remediation systems continued to limit the spread of groundwater contamination in the 100 and 200 Areas. Since their inception, remedial

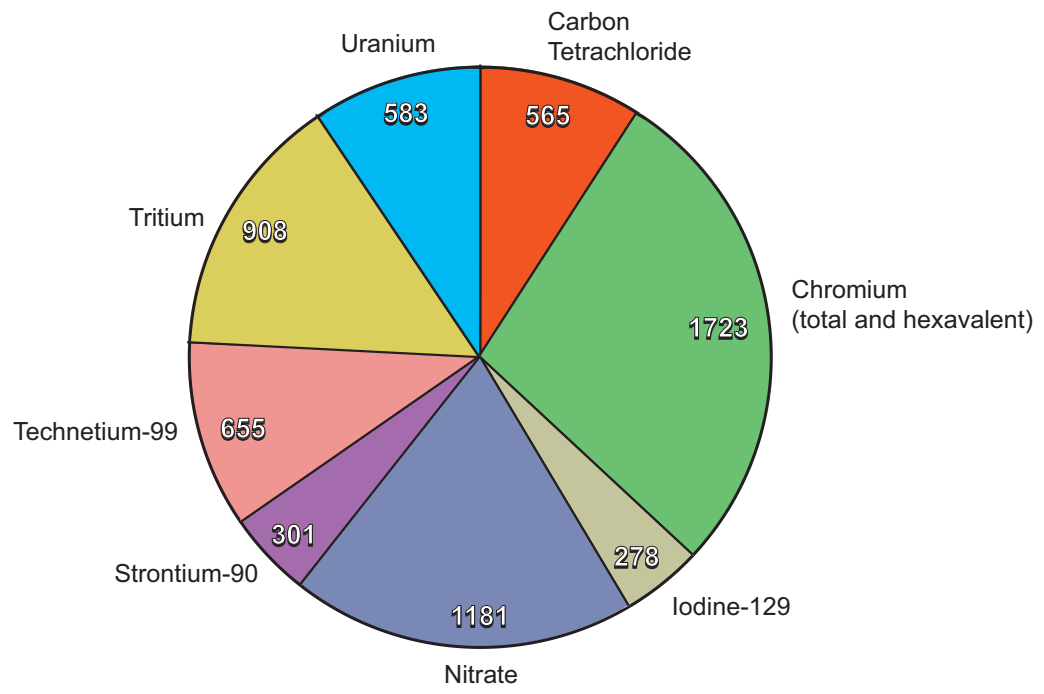

ecs04002

The groundwater project requests specific laboratory analyses based on the well's location, historical contaminant trends, and regulatory requirements. This graph shows the number of analyses for the most common constituents during fiscal year 2003.
Monitoring wells

provide samples of groundwater from

across the Hanford

Site. DOE uses

information gained

from these samples

to evaluate risk to

human health and

the environment. 


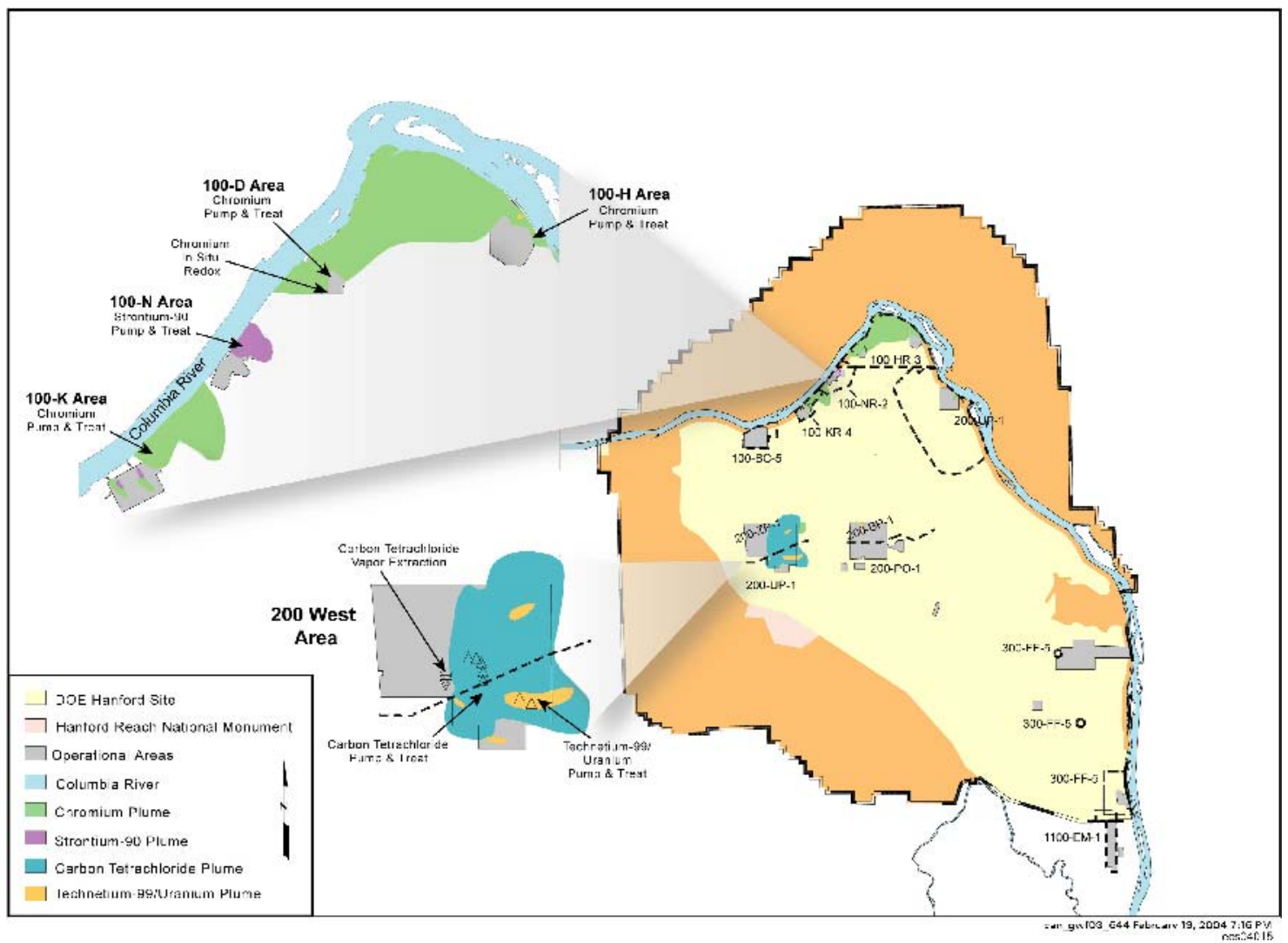

DOE operates five pump-and-treat systems, one in situ remediation system, and one soil-gas extraction system to remove contaminants and limit their movement in groundwater and the vadose zone.

Groundwater can

be pumped from the subsurface and

treated to remove contaminants. This process, referred to as a pump-andtreat system, is being used at Hanford to remove carbon tetrachloride, chromium, strontium-90, technetium-99, and uranium. measures have treated over 7 billion liters of groundwater to remove carbon tetrachloride, chromium, strontium-90, technetium-99, and uranium. DOE is evaluating alternative technologies for strontium-90 remediation.

Monitored Natural Attenuation - Average trichloroethene concentrations in compliance wells in the 1100-EM-1 Operable Unit remained below the drinking water standard for the third year in a row. This contaminant has been attenuating naturally. Average trichloroethene concentrations also remained below the drinking water standard in the 300-FF-5 Operable Unit, but uranium is slow to attenuate.

CERCLA Sampling and Analysis Plans - DOE released new plans for long-term groundwater monitoring in the 100-BC-5, 100-FR-3, and 200-BP-5 Operable Units in fiscal year 2003. A sampling and analysis plan for the 200-PO-1 Operable Unit was drafted in fiscal year 2003 and released in fiscal year 2004.

Working Toward Final Remediation Decisions - Final decisions for groundwater remediation have been made only for the 1100-EM-1 Operable Unit. DOE and the regulators are beginning the process to determine what information is needed to make final decisions for the 100-BC-5, 100-FR-3, 200-BP-5, 200-UP-1, 200-ZP-1, 200-PO-1, and 300-FF-5 Operable Units.

\section{Waste Facility Monitoring}

Resource Conservation and Recovery Act (RCRA) - The groundwater project continued to monitor 24 RCRA sites in fiscal year 2003. RCRA monitoring provided no evidence of new contamination from sites in detection programs. Seven sites continued to be monitored under assessment programs, and two under final status corrective action. 


\begin{tabular}{|c|c|c|}
\hline \multicolumn{3}{|c|}{ Groundwater Remediation } \\
\hline Remedial Action Site & Startup Date & Progress From Startup to September 2003 \\
\hline 100-K Area 100-KR-4 Pump-and-Treat & 1997 & $\begin{array}{l}\text { Decreases chromium to river; } 213 \text { kilograms chromium } \\
\text { removed. }\end{array}$ \\
\hline 100-N Area 100-NR-2 Pump-and-Treat & 1995 & $\begin{array}{l}\text { Diverts strontium-90 from river; } 1.45 \text { curies strontium-90 } \\
\text { removed; } \sim 12 \text { curies decayed naturally. }\end{array}$ \\
\hline 100-D Area 100-HR-3 Pump-and-Treat & 1997 & $\begin{array}{l}\text { Decreases chromium to river; } 161 \text { kilograms chromium } \\
\text { removed. }\end{array}$ \\
\hline 100-D Area 100-HR-3 In Situ Redox & 1999 & $\begin{array}{l}\text { Decreases chromium concentration downgradient of } \\
\text { barrier. }\end{array}$ \\
\hline 100-H Area 100-HR-3 Pump-and-Treat & 1997 & $\begin{array}{l}\text { Decreases chromium to river; } 34 \text { kilograms chromium } \\
\text { removed. }\end{array}$ \\
\hline 200 West Area 200-ZP-1 Pump-and-Treat & 1994 & $\begin{array}{l}\text { Prevents high-concentration portion of carbon tetrachlo- } \\
\text { ride plume from spreading; } 7,668 \text { kilograms removed. }\end{array}$ \\
\hline 200 West Area Soil-Vapor Extraction & 1992 & $\begin{array}{l}\text { Prevents carbon tetrachloride movement to ground- } \\
\text { water; } 78,100 \text { kilograms removed from vadose zone. }\end{array}$ \\
\hline 200 West Area 200-UP-1 Pump-and-Treat & 1994 & $\begin{array}{l}\text { Decreases migration of contaminants; } 102 \text { grams } \\
\text { technetium- } 99 \text { ( } 1.7 \text { curies) and } 180 \text { kilograms uranium } \\
\text { removed. }\end{array}$ \\
\hline 300-FF-5 Natural Attenuation & $\begin{array}{l}\text { Not } \\
\text { applicable }\end{array}$ & $\begin{array}{l}\text { Average trichloroethene concentrations below target } \\
\text { level; uranium concentrations above target level. }\end{array}$ \\
\hline $1100-E M-1$ Natural Attenuation & $\begin{array}{c}\text { Not } \\
\text { applicable }\end{array}$ & $\begin{array}{l}\text { Average trichloroethene concentrations below } 5 \mu \mathrm{g} / \mathrm{L} \\
\text { since } 2001 \text {. }\end{array}$ \\
\hline
\end{tabular}

Evaluation of Alternative RCRA Statistical Methods - The groundwater project completed data collection for alternative statistical methods at the 216-B-3 pond and 316-5 process trenches. The project will release a report on the results of applying these methods in fiscal year 2004.

Other Regulated Units - The groundwater project continued to monitor four waste disposal sites regulated under state requirements other than RCRA. Monitoring results at the following regulated units remained within permit limits: 400 Area process ponds, StateApproved Land Disposal Site, and 200 Area Treated Effluent Disposal Facility. At the Solid Waste Landfill, specific conductance, $\mathrm{pH}$, chloride, and sulfate exceeded their background threshold levels in one or more samples.

Environmental Restoration Disposal Facility-Concentrations of some constituents of concern were elevated but reflect migration of contaminant plumes from sources in the 200 West Area.

\section{Groundwater Modeling}

Site-Wide Groundwater Model - In fiscal year 2003, development focused on calibration based on an alternative conceptual model.

System Assessment Capability - This integrated system of computer models and databases simulates the movement of contaminants from waste sites through the vadose zone and groundwater. In fiscal year 2003, the model was updated; an atmospheric transport module was added and newer versions of groundwater flow and transport modules were incorporated into the system.

\section{Vadose Zone}

Tank Farm Characterization - In fiscal years 2002 and 2003, DOE drilled boreholes at the T and TX-TY Tank Farms to characterize subsurface contamination near former leak 
sites. Results for TX Tank Farm indicated that the magnitude of contamination is not as great as that found in boreholes at other tank farms. Results for T Tank Farm will be available in 2004.

Tank Farm Monitoring - DOE uses geophysical methods to monitor potential movement of contamination beneath single-shell tank farms. During fiscal year 2003, DOE monitored selected boreholes within each of the 12 single-shell tank farms. In general, the contaminated area appeared to be stable over time.

Carbon Tetrachloride Characterization - Soil vapor near the Plutonium Finishing Plant (200 West Area) was sampled to locate carbon tetrachloride sites with the potential to affect groundwater in the future. Results suggest that there are no active sources of contamination in the upper vadose zone at the locations sampled.

Wells that were formerly sampled for the groundwater project have gone dry as the water table declined. Most of the wells are in the 200 West Area.

\begin{tabular}{|c|c|c|c|c|}
\hline Fiscal Year & 200 West & 200 East & Other Areas & Total \\
\hline 1998 & 2 & 1 & 2 & 5 \\
\hline 1999 & 9 & 0 & 1 & 10 \\
\hline 2000 & 12 & 2 & 2 & 16 \\
\hline 2001 & 7 & 0 & 1 & 8 \\
\hline 2002 & 10 & 2 & 1 & 13 \\
\hline 2003 & 6 & 2 & 3 & 11 \\
\hline Total & 46 & 7 & 10 & 63 \\
\hline
\end{tabular}

\section{Groundwater Flow and Movement}

\section{A groundwater}

monitoring network

strategically

located across the

Hanford Site helps

determine changes

in the direction of

groundwater flow

as the site returns

to pre-Hanford

conditions.
Groundwater in the unconfined aquifer generally flows from west to east across the Hanford Site to discharge areas along the Columbia River. The direction of groundwater flow is inferred from water-table elevations, barriers to flow (e.g., basalt or mud units at the water table), and the distribution of contaminants.

General directions of groundwater flow are illustrated on the map (page xv) for March 2003. Beneath the reactor areas, groundwater flows generally toward the Columbia River. Farther inland, north of Gable Mountain, flow is toward the northeast and east. Groundwater flows eastward beneath the 200 Areas and then flows to the southeast or north through the gap between Gable Butte and Gable Mountain. Groundwater converges on the 300 Area from the northwest, west, and southwest and discharges into the Columbia River to the east. Groundwater in the Richland North Area flows generally eastward to the Columbia River.

The natural pattern of groundwater flow was altered during the Hanford Site's operating years by the formation of mounds in the water table. The mounds were created by the discharge of large volumes of wastewater to the ground and were present in each reactor area and beneath the 200 Areas. Since effluent disposal decreased significantly in the 1990s, these mounds are disappearing.

East of the 200 East Area, a fine-grained confining unit creates a barrier to movement in the surrounding unconfined aquifer. Beneath this confining unit, the uppermost aquifer is a permeable unit in the Ringold Formation. Groundwater flow in this confined aquifer still is influenced by a recharge mound. 
Groundwater in the upper basalt-confined aquifer generally flows from west to east across the Hanford Site, up through the unconfined aquifer, and into the Columbia River. Vertical gradients between the basalt-confined aquifer and the unconfined aquifer are upward on most of the Hanford Site. Therefore, there is little potential for contaminants to migrate from the unconfined aquifer into the basalt-confined aquifer, where it could move offsite. Downward gradients are measured beneath the west portion of the Hanford Site and north and east of the Columbia River.

\section{Groundwater Monitoring and Remediation}

This section summarizes results of Hanford Site groundwater monitoring for various requirements, including RCRA and CERCLA. Progress on groundwater remediation also is summarized.

\section{Overview}

DOE has developed a plan to accelerate cleanup of Hanford's groundwater, which will return it to its beneficial use where practicable or will at least prevent further degradation. Specific results that can be expected using the accelerated plan include the following: (a) remediate high-risk waste sites, (b) shrink the contaminated area, (c) reduce recharge, (d) remediate groundwater, and (e) monitor groundwater. The maps on the following pages show the distribution of nine principal groundwater

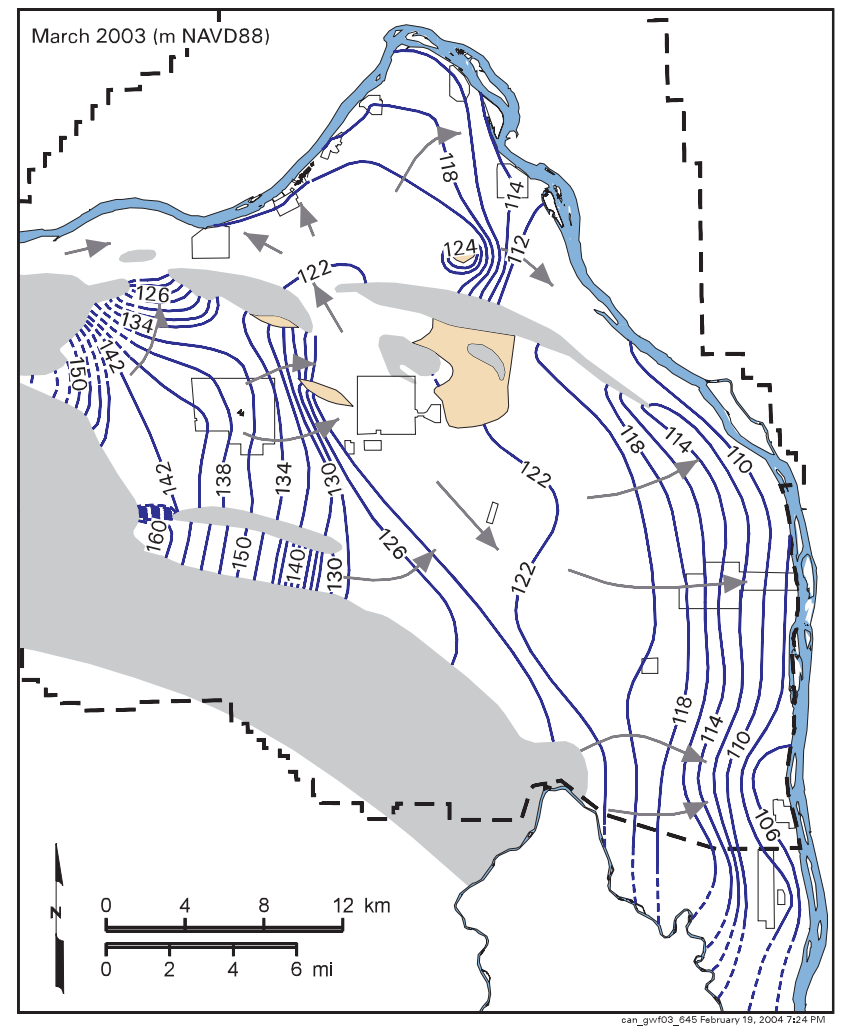

This map shows the water table and inferred flow directions in March 2003. Shaded areas show where the unconfined aquifer is absent. contaminant plumes.

The tritium and iodine-129 plumes have the largest areas with concentrations exceeding drinking water standards. The dominant plumes had sources in the 200 East Area and extend toward the east and southeast. Technetium-99 exceeds standards in smaller plumes, one of which has moved northward from the 200 East Area. Uranium is less mobile than tritium, iodine-129, or technetium-99; small plumes are found in the 100-H, 200 East, 200 West, and 300 Areas. Strontium-90 is not very mobile in groundwater, but it exceeds standards in each of the 100 Areas except 100-D. Other radionuclides including cesium-137, cobalt-60, and plutonium are even less mobile in the subsurface and rarely exceed drinking water standards in Hanford Site groundwater.

Nitrate is a widespread contaminant in Hanford Site groundwater, with plumes originating from the 100 and 200 Areas and from offsite industry and agriculture. Carbon tetrachloride forms a large plume beneath the 200 West Area, the most widespread organic contaminant on the Hanford Site. Other organic contaminants include chloroform and trichloroethene. Chromium contamination underlies the 100-K, 100-D, and 100-H Areas. Local plumes of chromium contamination also are present in the 200 Areas.

The following text discusses groundwater contamination, monitoring, and remediation in each of the 11 groundwater operable units and in the confined aquifers.

\section{0-BC-5 Operable Unit}

This operable unit includes the groundwater beneath the 100-B/C Area, located in the northwest Hanford Site. Most of the groundwater contamination is found in the north portion of the area, beneath former waste trenches and retention basins. Tritium and strontium-90 exceeded drinking water standards in several wells. Nitrate and chromium were somewhat elevated, but have been below drinking water standards in recent years. 


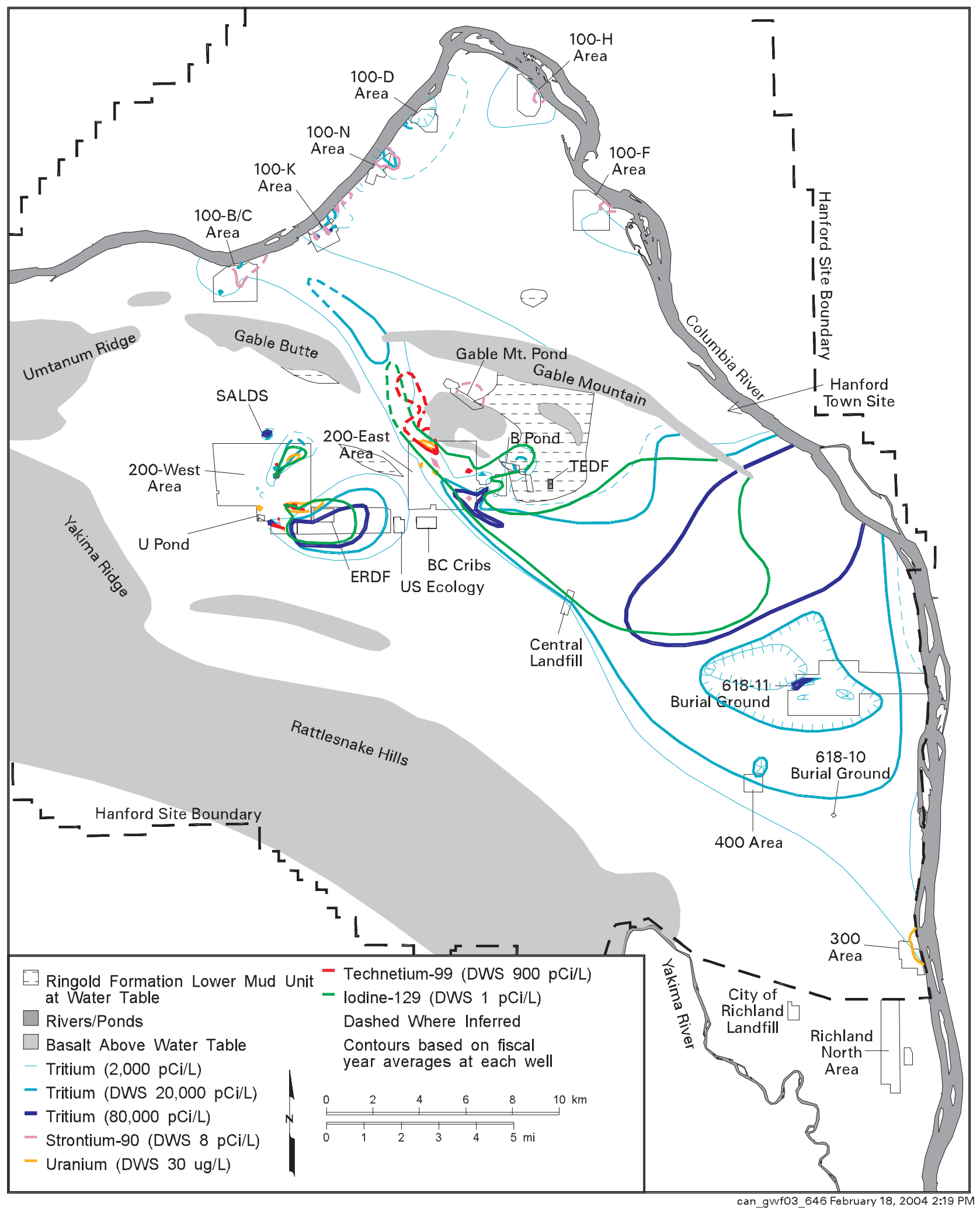

This map shows the distribution of major radionuclides in groundwater at concentrations above drinking water standards during fiscal year 2003. 


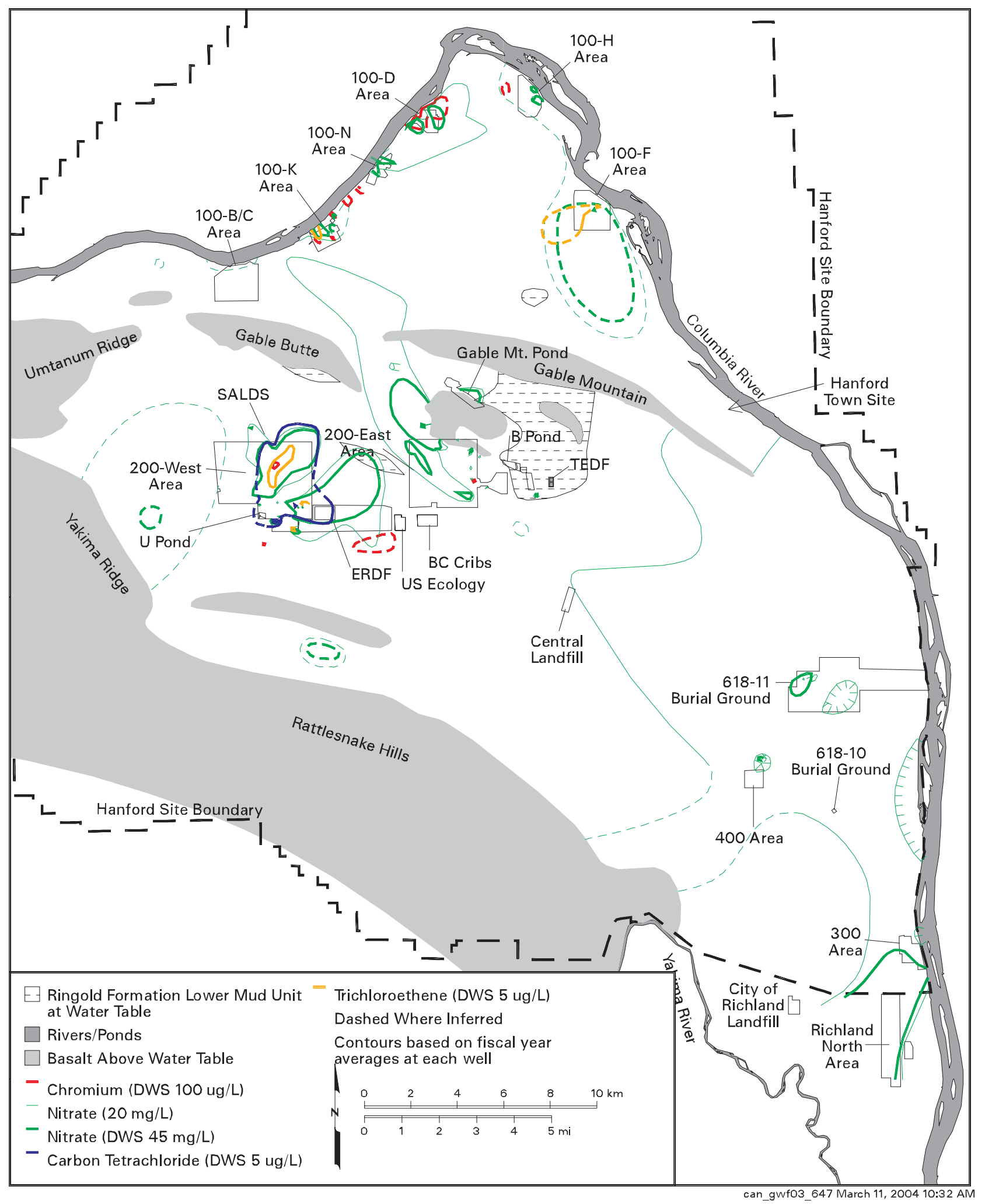

This map shows the distribution of major hazardous chemicals in groundwater at concentrations above drinking water standards during fiscal year 2003. 


\section{Tritium \\ concentrations \\ increased in some \\ 100-K Area wells \\ in fiscal year 2003.}

EPA approved a new sampling and analysis plan at the end of September 2003. The new plan, which is being implemented in fiscal year 2004, revises the monitoring program slightly and calls for the addition of more aquifer sampling tubes to monitor contaminants near the Columbia River. There is no active groundwater remediation in the 100-B/C Area.

\section{0-KR-4 Operable Unit}

The principal groundwater issues in this operable unit include (a) chromium contamination associated with past disposal to an infiltration trench near the river, (b) monitoring near K Basins, which have contaminated groundwater in the past with tritium, and (c) tritium associated with a burial ground. In addition to chromium and tritium, constituents of concern include carbon-14, strontium-90, technetium-99, nitrate, and trichloroethene.

CERCLA Interim Action. A pump-and-treat system operates as a CERCLA interim action to reduce the amount of chromium entering the Columbia River at $100-\mathrm{K}$ Area. Two new extraction wells, one new injection well, and one new monitoring well were installed in fiscal year 2003. Also, an existing monitoring well was converted to an extraction well.

Chromium concentrations appear to be decreasing with time as a result of pump-andtreat operation and the attenuation of the plume by natural processes, such as dispersion. Concentrations remained above the remediation goal $(22 \mu \mathrm{g} / \mathrm{L})$ in most of the compliance wells, however.

K Basins. Tritium concentrations increased sharply in fiscal year 2003 in several wells near the basins. The locations of the wells, groundwater flow direction, and concentrations
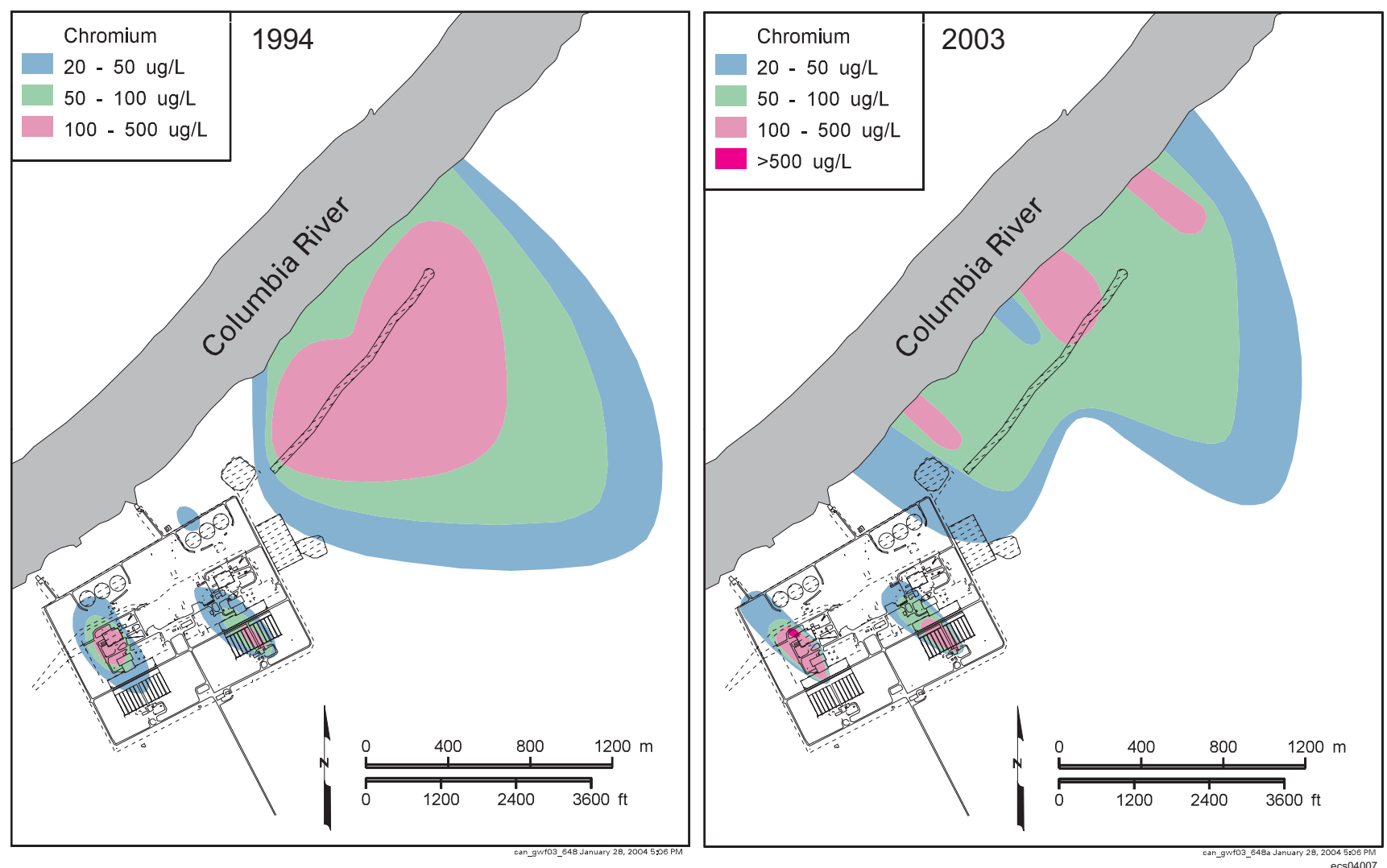

A pump-and-treat system in the 100-K Area reduces the amount of chromium entering the Columbia River. Concentrations decreased in most areas since 1994. 
of co-contaminants indicate the increases in tritium were caused by infiltration through former cribs and do not represent new leakage from the basins.

Results of a soil-gas survey conducted near a 100-K Area burial ground in fiscal year 2003 indicated the presence of tritium in the vadose zone as well as in the underlying groundwater.

\section{0-NR-2 Operable Unit}

The primary groundwater contaminant in the $100-\mathrm{N}$ Area is strontium-90, which originated at two liquid waste disposal cribs. The extent of the plume has changed little in over 12 years; however, concentrations increased during the 1990s because of changing water levels and the end of effluent discharge. Tritium also was present in waste discharged to the $100-\mathrm{N}$ cribs. Tritium concentrations in groundwater are declining, and the plume is shrinking. Nitrate, sulfate, and petroleum hydrocarbons also are present in 100-N Area groundwater.

CERCLA Interim Action. A pump-and-treat system in the 100-N Area operates to reduce the movement of strontium-90 toward the Columbia River. Since strontium-90 binds to sediment grains, pump-and-treat is not an effective way to clean up the aquifer. Concentrations remained far above the drinking water standard in fiscal year 2003. DOE is investigating alternative methods for remediation of the strontium-90 plume.

116-N-1, 116-N-3, 120-N-1, and 120-N-2 (1301-N, 1325-N, 1324-N/NA) Facilities. Four RCRA units are located in the 100-N Area. During fiscal year 2003, RCRA monitoring indicated that these sites are not contaminating groundwater with non-radioactive, hazardous constituents. However, the $120-\mathrm{N}-1$ percolation pond added sulfate, a nonhazardous constituent, to the groundwater.

\section{Pump-and-treat is not an effective way to clean up strontium-90 contamination.}
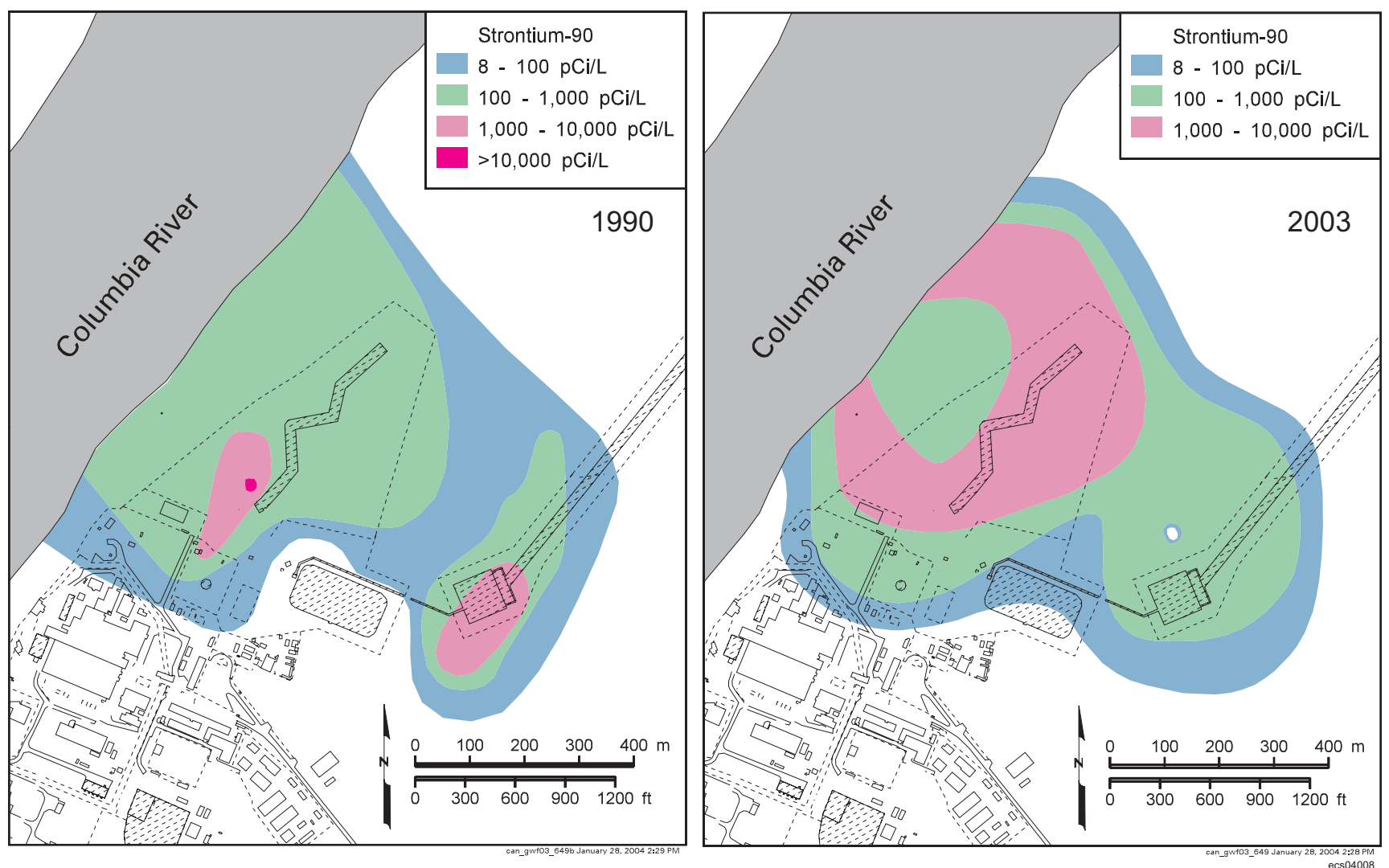

Concentrations of strontium-90 in the 100-N Area increased after 1990, but the overall shape of the plume remained about the same in 2003. 


\section{Chromium concentrations are increasing in the central 100-D Area.}

\section{0-HR-3-D Operable Unit}

The 100-HR-3 Operable Unit underlies the 100-D and 100-H Areas and the region between. Hexavalent chromium is the primary contaminant of concern in the 100-D Area. The source of this contaminant was sodium dichromate added to reactor cooling water to inhibit corrosion, which was discharged to cribs and ditches. Chromium is distributed in two plumes that have merged in recent years. Other contaminant plumes include tritium, nitrate, and sulfate.

CERCLA Interim Actions. The north chromium plume is the target of a pump-andtreat system, which is designed to reduce the amount of chromium entering the Columbia River. In fiscal year 2003, concentrations remained above the remediation goal $(22 \mu \mathrm{g} / \mathrm{L})$ in compliance wells. The southwest chromium plume is being remediated with an in situ system that immobilizes chromium in the aquifer. Chromium concentrations downgradient of the remediation system have declined in some wells and aquifer tubes; however, levels remained above the remediation goal $(20 \mu \mathrm{g} / \mathrm{L})$.

In fiscal year 2003, chromium concentrations increased in the central 100-D Area, bypassing both remediation systems. DOE and regulators are working together to expand the remediation systems so they intercept the changing plume.

\section{0-HR-3-H Operable Unit}

The east part of the 100-HR-3 Operable Unit underlies the 100-H Area. Hexavalent chromium is the primary constituent of concern, but the plume is smaller and concentrations
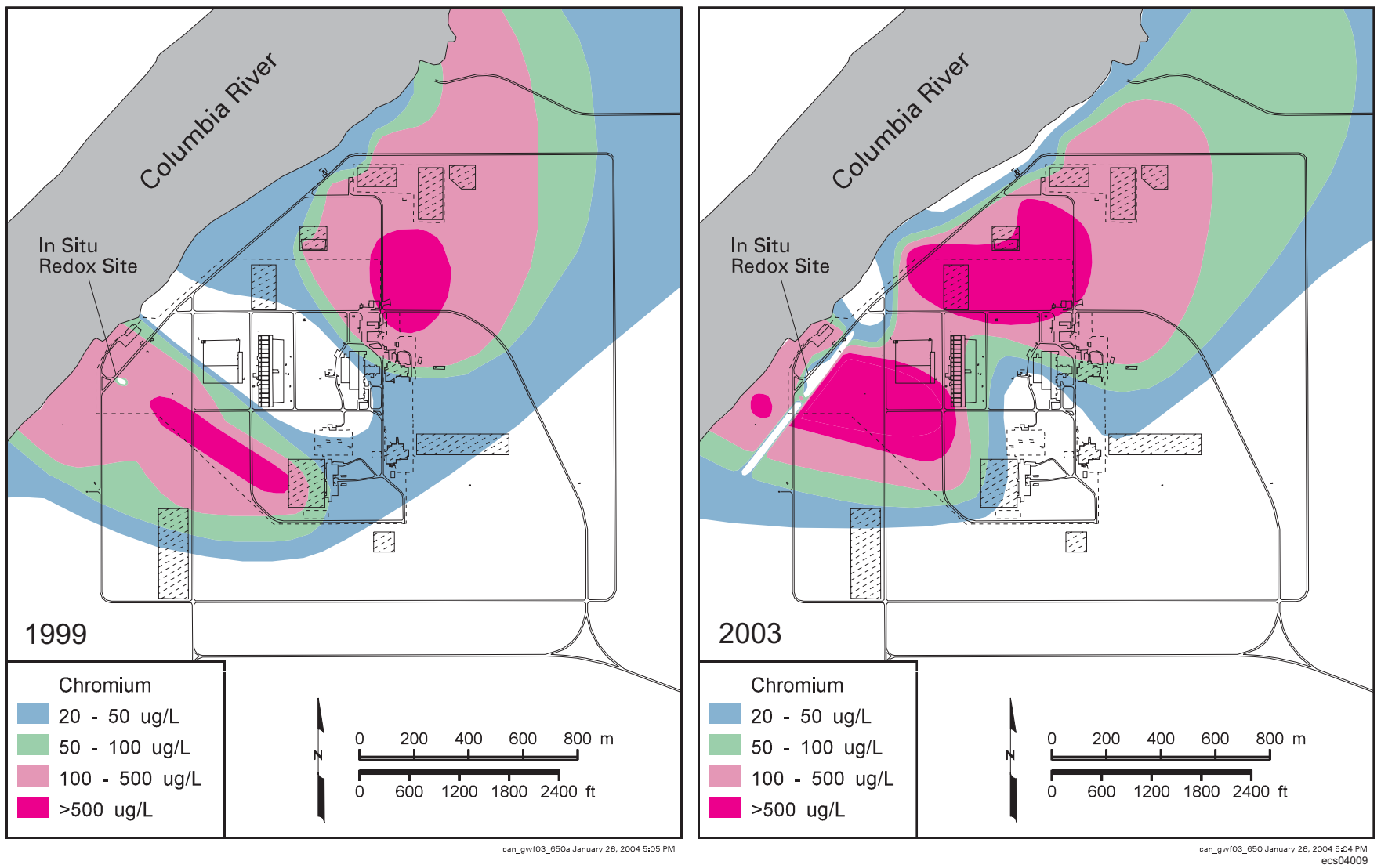

To decrease the amount of chromium entering the Columbia River in the 100-D Area, DOE operates a pump-andtreat system in the north and an in situ treatment system in the south. Chromium contamination has moved into the central 100-D Area in recent years, beyond the influence of either remediation system. DOE will expand the interim remedial action to intercept the central part of the plume near the river. 
are lower than in the 100-D Area. Nitrate also is elevated, but concentrations have declined from their peak levels. Strontium-90 exceeds the drinking water standard beneath former retention basins. Technetium-99 and uranium are elevated in a small area.

CERCLA Interim Action. The chromium plume is the target of a pump-and-treat system. Chromium concentrations have decreased in recent years due to remediation and natural processes. However, concentrations in some compliance wells remained above the remediation goal $(22 \mu \mathrm{g} / \mathrm{L})$.

116-H-6 (183-H) Evaporation Basins. These former basins are the only RCRA site in the 100-H Area. Leakage from the basins contaminated groundwater with chromium, nitrate, technetium-99, and uranium. The site is monitored during the post-closure period to track contaminant trends during the operation of the CERCLA interim action for chromium.

\section{0-FR-3 Operable Unit}

Nitrate exceeds the drinking water standard beneath much of the 100-F Area and the downgradient region. Other groundwater contaminants include strontium-90 and trichloroethene.

EPA approved a new sampling and analysis plan at the end of September 2003. The new plan, which is being implemented in fiscal year 2004, revises the monitoring program slightly and calls for the addition of more aquifer sampling tubes to monitor contaminants near the Columbia River. There is no active groundwater remediation in the 100-FR-3 Operable Unit.
Interim remedial actions in the

100 Areas reduce

the amount of

hexavalent

chromium entering

the Columbia

River.
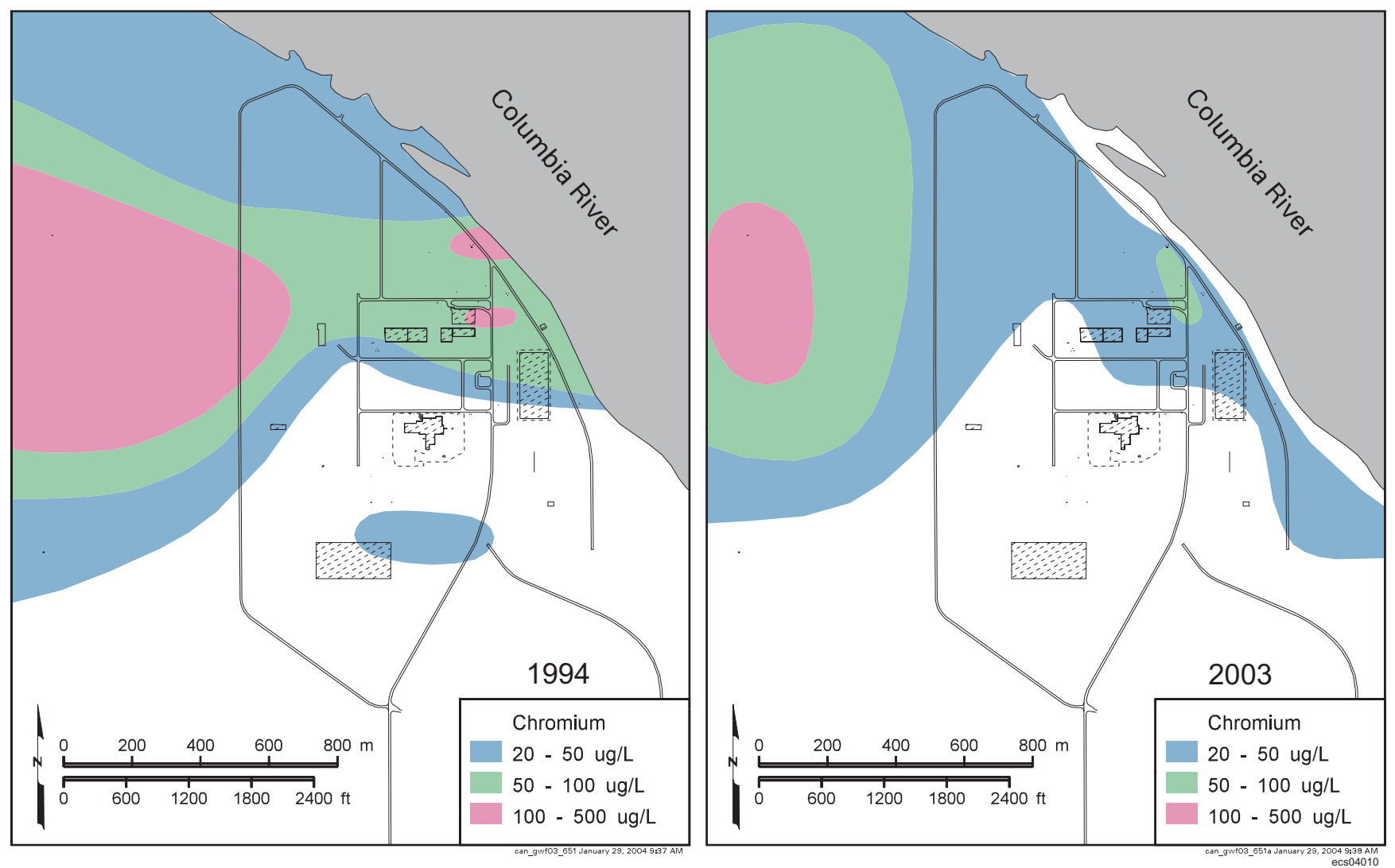

A pump-and-treat system in the $100 \mathrm{H}$-Area reduces the amount of chromium entering the Columbia River. Between 1994 and 2003, concentrations decreased through most of the plume. The decrease is the result of remediation and natural processes. 


\section{A pump-and-treat system prevents the spread of the high- \\ concentration \\ portion of the \\ carbon \\ tetrachloride \\ plume.}

\section{0-ZP-1 Operable Unit}

This operable unit encompasses the northern portion of the 200 West Area. The primary contaminant of concern is carbon tetrachloride, which forms the largest plume of chlorinated hydrocarbons on the Hanford Site. The contamination is principally from waste disposal associated with the Plutonium Finishing Plant, where organic chemicals were used to process plutonium. Trichloroethene and chloroform also are associated with this plume. Other contaminants include tritium, nitrate, chromium, fluoride, iodine-129, technetium-99, and uranium.

There are four RCRA sites, one other regulated unit, and one CERCLA interim action for groundwater in the 200-ZP-1 Operable Unit:

CERCLA Interim Action. A groundwater pump-and-treat system is operating in this operable unit to prevent the spread of the central, high-concentration portion of the carbon tetrachloride plume. The remediation is proving effective, and the plume has shrunk at

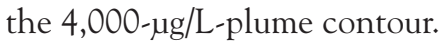

Low-Level Burial Grounds Waste Management Areas 3 and 4. Groundwater monitoring under interim status requirements continued in fiscal year 2003. Monitoring results indicate no releases attributable to these waste management areas.

A downgradient monitoring well for Waste Management Area 4 went dry in fiscal year 2003. Monitoring networks for both of these waste management areas contain fewer than the optimal number of wells for monitoring.
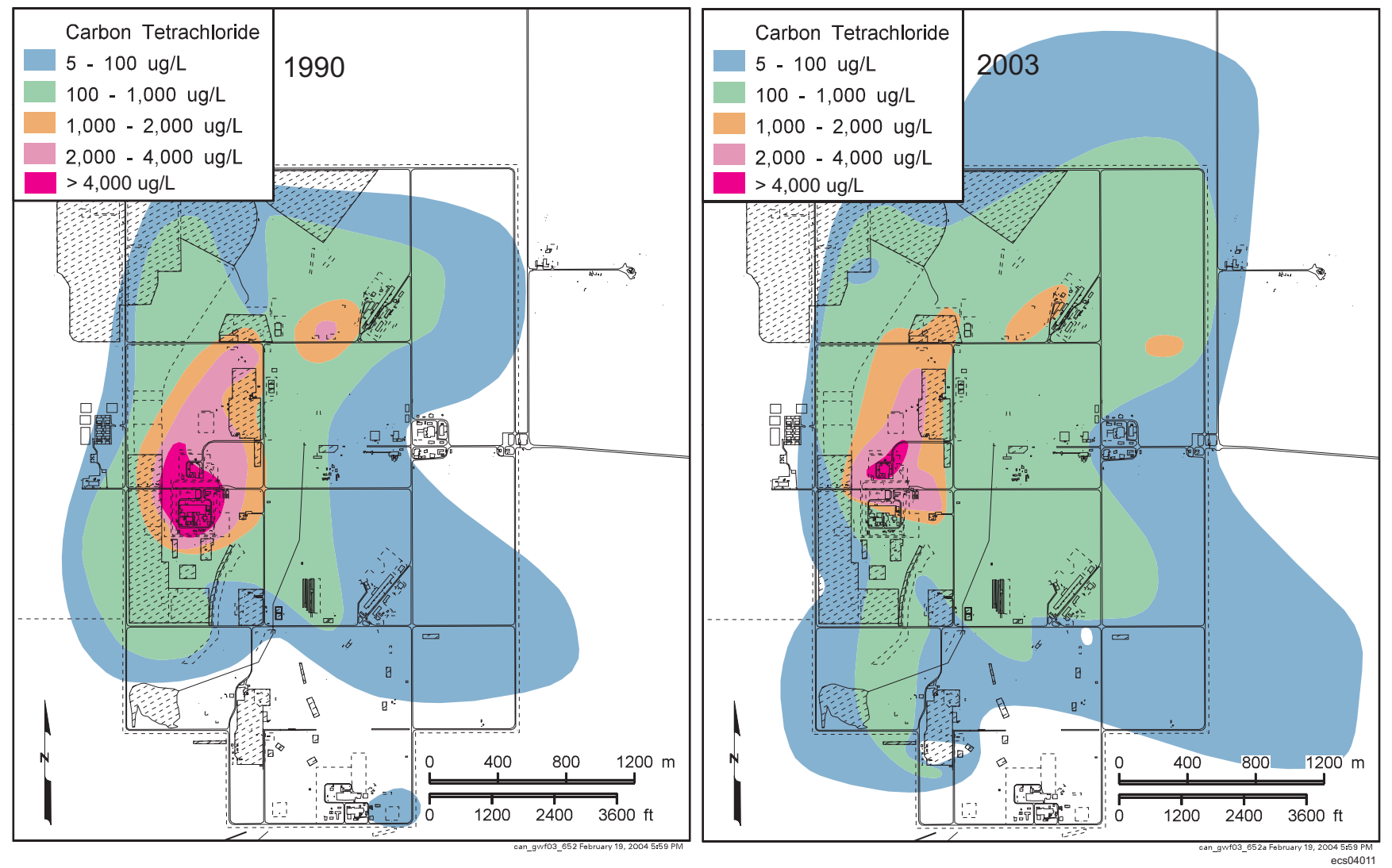

The carbon tetrachloride plume beneath the 200 West Area spread between 1990 and 2003. Since 1996, a pumpand-treat system is helping prevent further spreading of the heart of the plume, shown here in pink and red. 
In June 2002, DOE submitted an application to incorporate the low-level burial grounds into the Hanford Facility RCRA Permit. As part of the application, new groundwater monitoring wells, constituents, and statistical evaluations are proposed. Workshops with Ecology to address this application began in fiscal year 2003.

Waste Management Area $\boldsymbol{T}$. Results of groundwater quality assessment monitoring continued to suggest that the waste management area has not contributed to dangerous waste contamination of the uppermost aquifer in the area. Carbon tetrachloride, trichloroethene, chromium, and nitrate are present in groundwater, but the contamination is believed to have originated at other facilities.

Waste Management Area TX-TY. Assessment monitoring continued in fiscal year 2003. Chromium concentrations are elevated in groundwater; the most likely source is the waste management area. However, other sources of chromium contamination are located nearby. Some nitrate contamination may be from Waste Management Area TX-TY, but other sources nearby clearly have contributed. Carbon tetrachloride and trichloroethene contamination from other sources also is present.

State-Approved Land Disposal Site. This active disposal facility is regulated under a state waste discharge permit. Groundwater is monitored for tritium and 15 other constituents. Concentrations did not exceed permit enforcement limits during fiscal year 2003.

\section{0-UP-1 Operable Unit}

This operable unit underlies the south 200 West Area. The primary contaminants of concern are technetium-99 and uranium. Tritium, iodine-129, and nitrate plumes have origins in this operable unit. Sources of carbon tetrachloride were primarily within the 200-ZP-1 Operable Unit, but the contamination underlies the 200-UP-1 Operable Unit as well.

There are four RCRA sites, one CERCLA interim action, and a CERCLA disposal site in the 200-UP-1 Operable Unit. Monitoring activities are summarized below.

CERCLA Interim Action. A groundwater pump-and-treat system is operating near U Plant to contain the technetium-99 and uranium plumes there. During the fiscal year, the high concentration portions of the technetium- 99 and uranium plumes $(9,000 \mathrm{pCi} / \mathrm{L}$ and $480 \mu \mathrm{g} / \mathrm{L}$ contours, respectively) were hydraulically contained. Although more sampling is required to confirm the trend, technetium-99 appears to have been remediated to below the remediation goal at all wells in the baseline plume area. Uranium concentrations remained above the remediation goal in one well.

During the fiscal year, one monitoring well in the baseline area went dry, leaving only one monitoring well to track plume behavior. Two wells went dry in another portion of the operable unit. A new monitoring well was installed south of the baseline plume area to replace another dry well.

216-U-12 Crib. Assessment monitoring continued in fiscal year 2003. The crib is one of several sources that have contributed to a nitrate plume in the area. Closure of the crib will be coordinated with and conducted under CERCLA. The monitoring network contains just two useable downgradient wells and no upgradient wells.

216-S-10 Pond and Ditch. Indicator parameter data have not indicated that the 216-S-10 facility has affected groundwater quality in the uppermost aquifer beneath the site. In fiscal year 2003, one well went dry and a new well was installed. The current RCRA monitoring network consists of only two downgradient wells.

Waste Management Area S-SX. Assessment monitoring continued in fiscal year 2003. Results continued to indicate that sources within the tank farms have contaminated groundwater with chromium. Concentrations of nitrate, chromium, and the non-RCRAregulated constituent technetium-99 increased significantly during the year in one
Pump-and-treat

systems in the

200 West Area are

interim actions for

groundwater

remediation until a

final remedy can be

identified.
A groundwater

pump-and-treat

system is operating

near U Plant to

contain the

technetium-99 and

uranium plumes

there. The high

concentration

portions of the

plumes were

hydraulically

contained. 

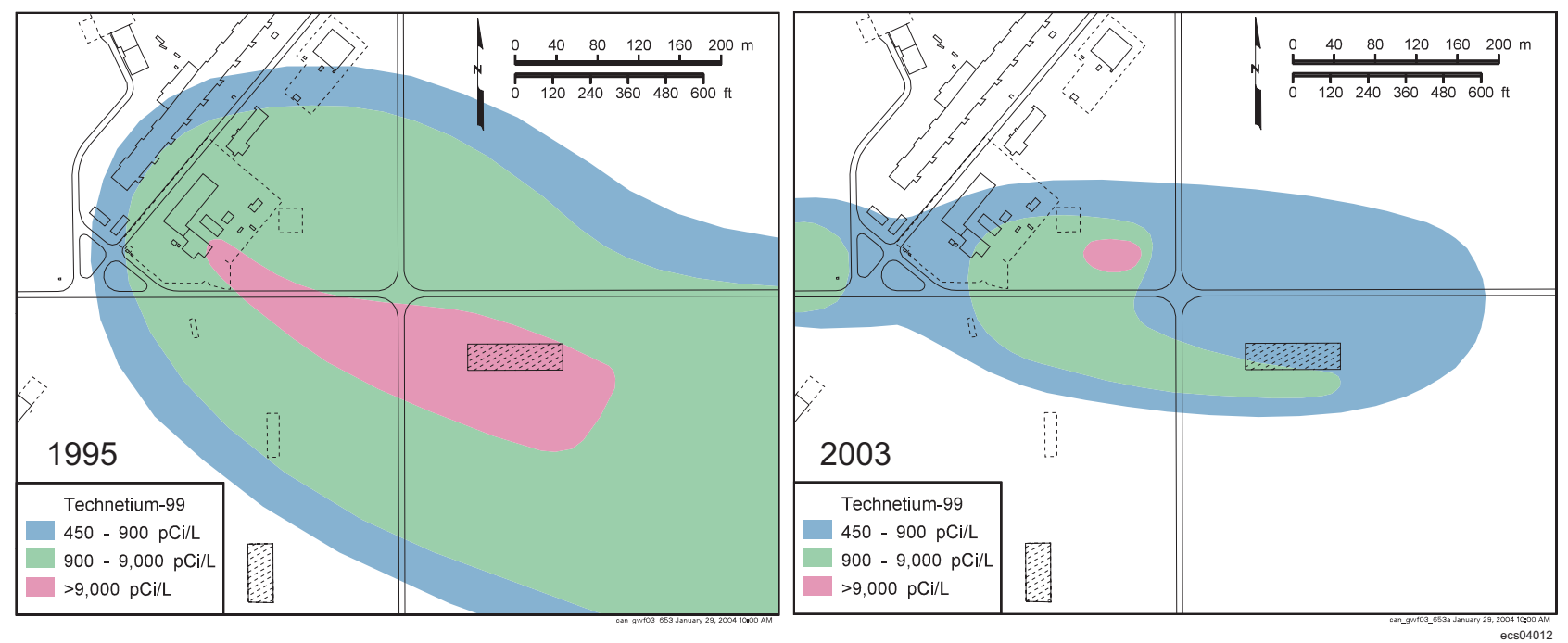

A pump-and-treat system at the 200-UP-1 Operable Unit (200 West Area) has decreased the size of the technetium-99 plume. The system began to operate in fall 1995. However, many monitoring wells in the plume have gone dry, making interpretation of plume size less certain.
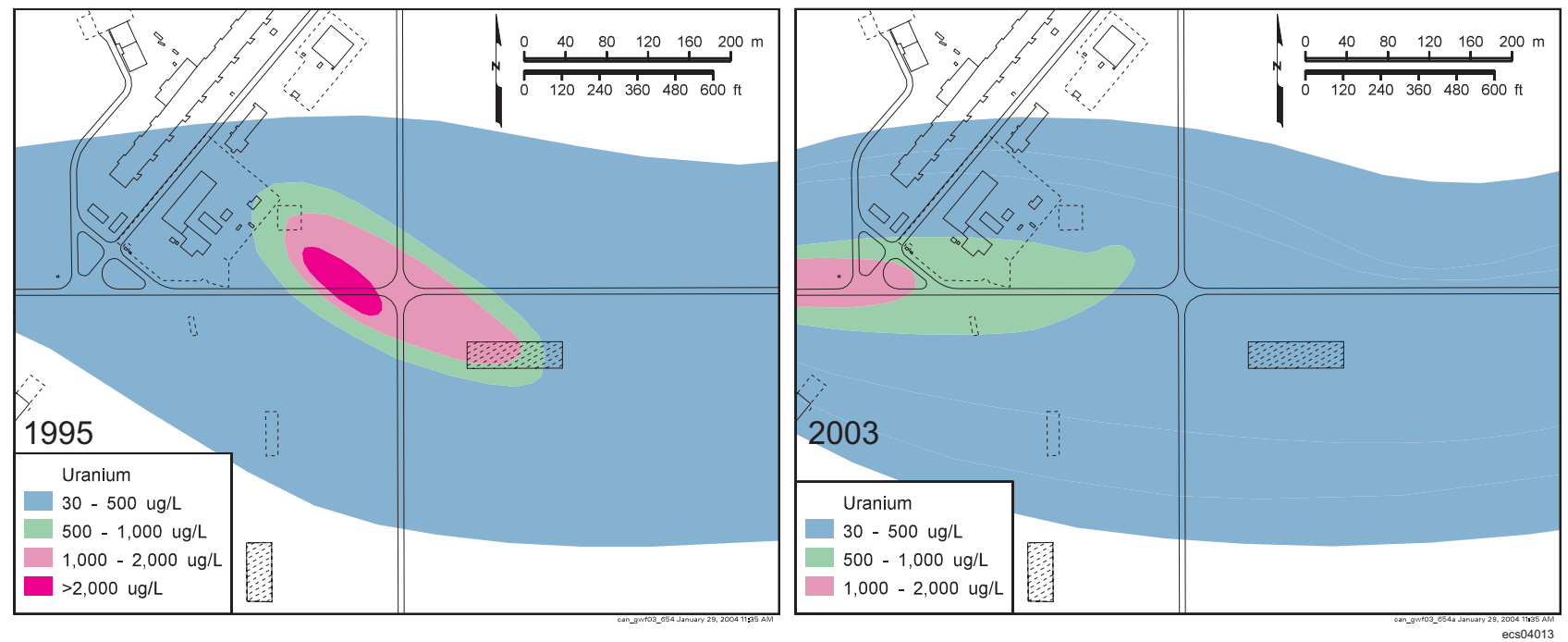

Uranium contamination in the 200-UP-1 Operable Unit (200 West Area) is not responding to the pump-and-treat system as quickly as the technetium-99. Unlike technetium-99, uranium interacts with sediment grains, slowing its movement and response to remediation.

monitoring well. At the request of Ecology, the practice of purging at least 4,546 liters of water from the well after each quarterly sampling event was started in March 2003. Data from a vertical sampling study in the same well show that pumped water is a blend of water entering the well from all parts of the screened interval. Therefore, the vertical location of the sample pump intake does not have a significant effect on measured constituent concentrations, as long as the well is purged adequately before a sample is collected.

Waste Management Area $\boldsymbol{U}$. Assessment monitoring continued in fiscal year 2003. The waste management area has affected groundwater quality with nitrate and possibly chromium. During fiscal year 2003, nitrate concentrations continued to increase in downgradient wells in the south half of the waste management area. 
Environmental Restoration Disposal Facility. Results of groundwater monitoring continued to indicate that the facility has not adversely impacted groundwater quality. Higher concentrations of gross beta and unfiltered chromium were detected in fiscal year 2003. Future results will be evaluated to confirm any increasing trends.

\section{0-BP-5 Operable Unit}

This operable unit includes groundwater beneath the north 200 East Area. A technetium-99 plume extends northward between Gable Mountain and Gable Butte. Other contaminants include uranium, iodine-129, cobalt-60, cyanide, strontium-90, cesium-137, plutonium, tritium, and nitrate.

CERCLA monitoring activities had been interrupted during the past several years in the 200-BP-5 Operable Unit because of waste management issues. Sampling activities resumed in late fiscal year 2003 following approval of new sampling and analysis and waste control plans. There is no active groundwater remediation in this operable unit.

There are five RCRA sites in the 200-BP-5 Operable Unit. Monitoring activities are summarized below.

Waste Management Area B-BX-BY. Assessment monitoring continued at this site in fiscal year 2003. Contamination observed in downgradient wells around this waste management area primarily is due to vertical movement of residual waste left in the soil under the tank farms.

Waste Management Area $\boldsymbol{C}$. This site continued to be monitored under an interim status indicator evaluation program in fiscal year 2003. Indicator parameters did not exceed critical mean values. Four new monitoring wells were installed.

216-B-63 Trench. Results of interim status detection monitoring continued to support the interpretation that this facility has not impacted groundwater with hazardous constituents.

Low-Level Waste Management Areas 1 and 2. Groundwater monitoring under interim status requirements continued at these RCRA sites in fiscal year 2003. Monitoring results indicated no releases attributable to these waste management areas.

\author{
A technetium-99 \\ plume extends from \\ the 200 East Area \\ to the north.
}

\begin{tabular}{|c|c|c|c|c|}
\hline \multicolumn{5}{|c|}{ Area of Contaminant Plumes at Levels Above Drinking Water Standards (square kilometers) } \\
\hline $\begin{array}{c}\text { Constituent } \\
\text { (drinking water standard) }\end{array}$ & $\begin{array}{l}\text { Fiscal Year } \\
2000\end{array}$ & $\begin{array}{l}\text { Fiscal Year } \\
2001\end{array}$ & $\begin{array}{l}\text { Fiscal Year } \\
2002\end{array}$ & $\begin{array}{l}\text { Fiscal Year } \\
2003\end{array}$ \\
\hline Carbon tetrachloride $(5 \mu \mathrm{g} / \mathrm{L})$ & 9.8 & 9.8 & 9.9 & 10.6 \\
\hline Chromium (100 pg/L) & 2.8 & 2.8 & 2.6 & 2.6 \\
\hline lodine-129 (1 pCi/L) & 89.6 & $79.5^{(a)}$ & 79.4 & 75.5 \\
\hline Nitrate (45 mg/L) & 36.3 & 38.4 & 35.7 & 36.2 \\
\hline Strontium-90 (8 pCi/L) & 2.8 & 2.7 & 2.7 & 2.6 \\
\hline Technetium-99 (900 pCi/L) & 2.3 & 2.4 & 2.3 & 2.3 \\
\hline Trichloroethene $(5 \mu \mathrm{g} / \mathrm{L})$ & 4.2 & 4.3 & $3.4^{(a)}$ & 3.4 \\
\hline Tritium $(20,000$ pCi/L) & 152 & 151 & 142 & 136 \\
\hline Uranium $(20 / 30 \mu \mathrm{g} / \mathrm{L})^{(b)}$ & 2.0 & 1.6 & 1.5 & 1.4 \\
\hline Combined Plumes & 210 & 208 & 196 & 190 \\
\hline \multicolumn{5}{|c|}{$\begin{array}{l}\text { (a) These large changes in estimates of plume area are caused by changing interpretations of the data and changes to } \\
\text { the monitoring network. Changes in actual plume size are usually more gradual. } \\
\text { (b) Area of uranium plume based on } 20 \mathrm{mg} / \mathrm{L} \text { standard in } 2000 \text { and } 30 \mathrm{mg} / \mathrm{L} \text { standard in subsequent years. }\end{array}$} \\
\hline
\end{tabular}



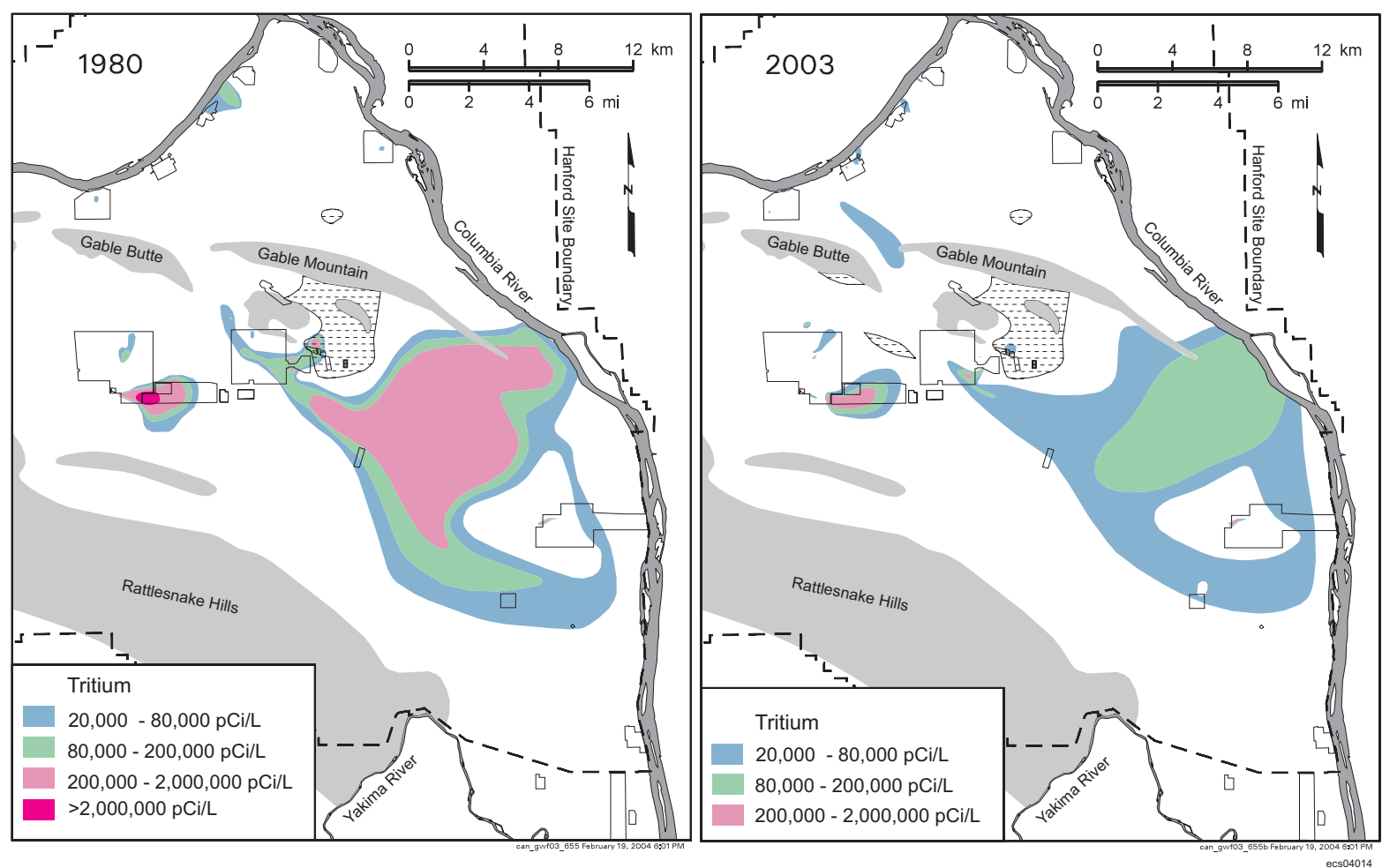

Site-wide tritium plumes in 1980 and 2003 are shown in the above maps. Concentrations in the heart of the plume have decreased over the years; the south margin has ceased its southward migration.

Tritium

concentrations

generally are

decreasing

southeast of the

200 East Area.
In June 2002, DOE submitted an application to incorporate the low-level burial grounds into the Hanford Facility RCRA Permit. As part of the application, new groundwater monitoring wells, constituents, and statistical evaluations are proposed. Workshops with Ecology to address this application began in fiscal year 2003.

Liquid Effluent Retention Facility. A 2001 letter from Ecology directed DOE to discontinue statistical evaluation of groundwater sample results because all but two wells have gone dry. DOE has continued to sample the two remaining wells and is exploring alternative approaches to monitoring the facility.

\section{0-PO-1 Operable Unit}

This operable unit encompasses the south portion of the 200 East Area and a large portion of the Hanford Site extending to the east and southeast. The operable unit encompasses widespread plumes of tritium, nitrate, and iodine-129. Concentrations of tritium continued to decline as the plume attenuates naturally due to radioactive decay and dispersion. Other contaminants include strontium-90 and technetium-99, but these are limited to very small areas.

During fiscal year 2003, a draft sampling and analysis plan for the operable unit was prepared and submitted to the regulator. The new plan was approved in fiscal year 2004.

There are six RCRA sites and three other regulated units in the 200-PO-1 Operable Unit:

PUREX Cribs. Three cribs (216-A-10, 216-A-36B, and 216-A-37-1) are monitored jointly under a RCRA interim status assessment program. The cribs have contributed to widespread contaminant plumes in the area, including nitrate and the non-RCRA constituents tritium and iodine-129. The nitrate plume is generally attenuating throughout 
most of its area, except near the PUREX cribs. In recent years, the concentration of nitrate in near-field wells at the PUREX cribs has either held steady or increased.

During fiscal year 2003, one monitoring well at the PUREX cribs went dry. An existing well was added to the network to replace the dry well.

Waste Management Area $\boldsymbol{A}$ - $\boldsymbol{A} \boldsymbol{X}$. This RCRA site continued to be monitored under an interim status indicator evaluation program in fiscal year 2003. Indicator parameters did not exceed critical mean values. Two new monitoring wells were installed.

216-A-29 Ditch. The groundwater beneath this site is monitored as required by interim status detection regulations. To date, the facility has not contaminated groundwater with regulated constituents, although sulfate attributable to manmade sources has been detected in two wells.

Integrated Disposal Facility. This planned facility will be an expandable, lined, RCRA-compliant landfill. Construction is scheduled to begin in 2004. The Part B permit application was submitted to Ecology and is scheduled to be incorporated into the Hanford Facility RCRA Permit in 2004. Four out of seven monitoring wells have been installed.

216-B-3 Pond. This RCRA site continued to be monitored under a temporary, alternative monitoring plan in fiscal year 2003. In fiscal year 2001, the regulator granted a variance to apply a new approach to groundwater monitoring for a 2 -year trial period. The trial approach uses statistical methods based on within-well comparisons instead of the standard upgradient/downgradient comparisons. The final samples for the trial period were collected in July 2003, and an evaluation of the approach is currently underway.

Nonradioactive Dangerous Waste Landfill. This RCRA site is located in the 600 Area, within the footprint of the 200-PO-1 regional plume. During fiscal year 2003, interim status detection monitoring continued to show no evidence of contamination from this facility.

Solid Waste Landfill. This facility is regulated under state dangerous waste regulations. In fiscal year 2003, specific conductance, $\mathrm{pH}$, chloride, and sulfate exceeded their background threshold levels in one or more samples.

200 Area Treated Effluent Disposal Facility. A state waste discharge permit governs groundwater sampling and analysis in the three monitoring wells at this facility. No permit criteria for constituents in groundwater were exceeded in fiscal year 2003. The groundwater monitoring network continues to show that effluent from the facility is not taking a direct route to the uppermost aquifer, which is confined.

4608 B/C Process Ponds. The 4608 B/C ponds (also called the 400 Area process ponds), are regulated under a state waste discharge permit. Groundwater quality met permit conditions in fiscal year 2003. The permit was recently modified, and groundwater monitoring was no longer required as of October 1, 2003.

\section{0-FF-5 Operable Unit}

This operable unit is divided into two general regions: the 300 Area and the $300-$ FF-5 North region, which includes the 618-11 burial ground, the 618-10 burial ground, and the $316-4$ cribs.

Constituents from 300 Area sources include uranium and volatile organic compounds. The size of the 300 Area uranium plume is generally consistent from year to year, but concentrations are variable throughout the year as a result of changes in river stage. A plume of trichloroethene in the 300 Area is attenuating naturally, and average concentrations remained below the drinking water standard in fiscal year 2003. Trichloroethene contamination in this area is associated with other hydrocarbons (e.g., cis-1,2-dichloroethene). Strontium-90 is elevated in a single well. The interim action chosen for the 300-FF-5 Operable Unit includes natural attenuation of the uranium and organic contamination in the 300 Area.
In some areas, $\mathrm{DOE}$ and the regulators agree that natural processes will clean up groundwater contamination.

Groundwater is monitored throughout the process to determine if concentrations are falling, as expected. This approach is being applied in the 300 Area and 1100-EM-1 Operable Unit. 


\section{Trichloroethene \\ concentrations \\ continued to be \\ below the cleanup \\ level in the \\ 1100-EM-1 \\ Operable Unit.}

\section{Confined aquifers}

are capped by less

permeable layers

that cannot

transmit much

water. Confined

aquifers at Hanford

occur beneath clay

or basalt layers.
Contaminants from the north part of the operable unit include tritium, uranium, various volatile organic compounds, petroleum hydrocarbons, and tributyl phosphate. Tritium concentrations in groundwater near the 618-11 burial ground have decreased in recent years but remained among the highest on the Hanford Site during fiscal year 2003. This high-concentration contamination is limited to a narrow plume extending $\sim 1$ kilometer to the east.

316-5 Process Trenches. This former disposal facility is the only RCRA site in the 300-FF-5 Operable Unit. The trenches have contributed to groundwater contamination, which will be remediated under CERCLA. While the CERCLA interim action (natural attenuation) is in progress, the trenches are monitored under a final status, corrective action monitoring program.

\section{0-EM-1 Operable Unit}

This operable unit includes a small, narrow plume of trichloroethene, which is attenuating naturally. Annual average concentrations have remained below the drinking water standard since fiscal year 2001. Contaminants also flow into the area from offsite sources (e.g., nitrate from agriculture and industry).

The city of Richland maintains a well field in the 1100-EM-1 groundwater interest area. Wells are monitored frequently to detect any changes in Hanford contaminants near these wells. The tritium plume from the 200 East Area has not been detected in these wells. Low levels of tritium, similar to Columbia River water, continued to be detected.

The selected remedy for 1100-EM-1 Operable Unit groundwater is monitored natural attenuation of volatile organic compounds.

\section{Confined Aquifers}

Although most of Hanford's groundwater contamination is in the unconfined aquifer, DOE monitors wells in deeper aquifers because of the potential for downward migration of contamination and the potential migration of contamination offsite through the basaltconfined aquifer.

The Ringold Formation confined aquifer occurs within fluvial sand and gravel comprising the lowest sedimentary unit of the Ringold formation. It is confined below by basalt and above by the lower mud unit. Groundwater in this aquifer flows generally west to east in the vicinity of the 200 West Area. In the central portion of the aquifer, flow converges on the 200 East Area from the west, south, and east. Groundwater discharges from the confined aquifer into the overlying unconfined aquifer near the 200 East Area.

While effluent disposal was occurring at the B Pond system, groundwater mounding forced groundwater and any associated contamination a limited distance into the Ringold Formation confined aquifer. Groundwater analyses for fiscal year 2003 at the 200 Area Treated Effluent Disposal Facility continued to demonstrate isolation of the confined aquifer from disposal activities.

Within the upper basalt-confined aquifer system, groundwater occurs within basalt fractures and joints, interflow contacts, and sedimentary interbeds. Groundwater in the upper basalt-confined aquifer system generally flows from west to east across the Hanford Site toward the Columbia River.

Results of sampling basalt-confined groundwater show that tritium was detected in some wells at very low levels, while iodine-129, strontium-90, gamma-emitting isotopes, and uranium isotopes were not detected. Cyanide, nitrate, and technetium-99 were elevated in one well in the north part of the 200 East Area, but contaminant migration during well construction is responsible for this contamination. Contaminants on the Hanford Site have not migrated through the upper basalt-confined aquifer system to offsite sample locations south and southeast of the Hanford Site. 


\section{Well Installation, Maintenance, and Decommissioning}

Ecology, EPA, and DOE negotiated an integrated well drilling list that coordinates and prioritizes the requirements of various groundwater monitoring regulations. During calendar year 2003, a total of 18 new wells were installed at Hanford. These included 7 for RCRA monitoring, 9 for CERCLA operable units, and 2 for research on chromate bioremediation. Two hundred and forty-three wells received maintenance, and sixty-three wells were decommissioned (filled with grout) because they are no longer needed, were in poor condition, or were in the way of remediation sites.

\section{Modeling}

Computer simulations of groundwater flow and contaminant movement help predict future conditions and assess the effects of remediation systems. During fiscal year 2003, modelers calibrated the consolidated groundwater flow and transport site-wide model based on an alternative conceptual model.

The System Assessment Capability is an integrated assessment tool that includes several linked computer models designed to simulate the movement of contaminants from waste sites through the vadose zone, groundwater, and Columbia River to receptors. It also incorporates modules that calculate the risks to human health and the environment. During fiscal year 2003, the System Assessment Capability was updated; an atmospheric transport module was added and newer versions of the groundwater flow and transport modules were added. The three-dimensional "base case" site-wide groundwater model was used in the initial assessment performed during 2002. In fiscal year 2003, the model grid was refined around the contaminant plume areas.

\section{Vadose Zone}

Subsurface source characterization, vadose zone monitoring, soil-vapor monitoring, and sediment sampling were conducted in fiscal year 2003.

Baseline spectral gamma logging and neutron moisture logging of boreholes continued at selected past-practice, liquid disposal facilities. Subsequent logging events will be compared to this baseline to monitor the movement of subsurface contamination. In fiscal year 2003, logging activities were completed in and around Waste Management Area B-BX-BY.

DOE drilled two new characterization boreholes in the T Tank Farm. The boreholes were placed in the vicinity of the site of the largest documented tank leak in the Hanford Site's history. Spectral gamma logging detected cesium-137, europium-154, europium-152, tin-126, and cobalt-60. Additional results will become available in fiscal year 2004.

DOE drilled three characterization boreholes in the TX Tank Farm in fiscal year 2002, and results became available in fiscal year 2003. One of the boreholes was drilled to investigate the largest and deepest occurrence of uranium in Waste Management Area TX-TY. Spectral gamma logging detected cesium-137 in that borehole. The other boreholes were drilled to investigate vadose zone contamination related to another past leak site. Spectral gamma logging detected cesium-137, cobalt-60, and uranium-238. Analyses of core samples from the boreholes in TX Tank Farm indicate that the magnitude of contamination is not as great as that found in boreholes at other tank farms. The data do not establish the vertical extent of tank contamination because contamination was found at the bottom of the boreholes. 
The results of

vadose zone

characterization

studies improve

understanding of

the distribution and

movement of

contamination

between the ground

surface and the

water table.
Boreholes and test pits were excavated to gather characterization data to support remediation of the 216-A-29 ditch, 216-B-63 trench, and 216-S-10 pond and ditch. Spectral gamma logging detected cesium-137 in two of the three boreholes. Additional results will be available in fiscal year 2004 .

Soil vapor was sampled and analyzed near the Plutonium Finishing Plant (200 West Area) to locate carbon tetrachloride release sites with the potential to impact groundwater in the future. Carbon tetrachloride was detected at low concentrations in 6 of the 17 sites sampled. At each of these six sites, the highest concentration was detected in the deepest sample. The relatively low concentrations suggest that there are no active sources of contamination in the upper vadose zone at these locations.

DOE conducted laboratory experiments to help predict the movement of uranium in the vadose zone in the 300 Area. Predicted distribution coefficient values range from 0 to $1 \mathrm{~mL} / \mathrm{g}$ in the near-surface vadose zone and 2 to $4 \mathrm{~mL} / \mathrm{g}$ in unconfined aquifer sediment that is not influenced by dilution with Columbia River water.

Leachate from the Solid Waste Landfill is sampled quarterly. During fiscal year 2003, several analytes continued to be found in the landfill leachate in concentrations above groundwater quality criteria. Chloride and total dissolved solids exceeded groundwater quality criteria for the first time in fiscal year 2003. The volume of leachate generated increased during the year because of above average rainfall during the winter of 2002/2003. Soil gas also is monitored quarterly at the landfill. No contaminants of concern exceeded reporting limits.

Leachate from the Environmental Restoration Disposal Facility continued to be collected and sampled. Selenium, nitrate, gross alpha, gross beta, carbon-14, technetium-99, and uranium showed possible increasing concentration trends over the past 3 years. However, in groundwater, concentrations of these constituents remained stable or decreased, and it appears that the facility has not had an impact on groundwater.

DOE uses geophysical methods to monitor potential movement of contamination beneath single-shell tank farms. During fiscal year 2003, DOE monitored selected boreholes within each of the 12 single-shell tank farms. In general, the contaminated areas appeared to be stable over time.

DOE monitors carbon tetrachloride in soil vapor near vadose zone remediation systems in the 200 West Area. At the end of fiscal year 2003, 78,100 kilograms of carbon tetrachloride had been removed from the vadose zone since extraction operations started in 1991. 


\section{Contents}

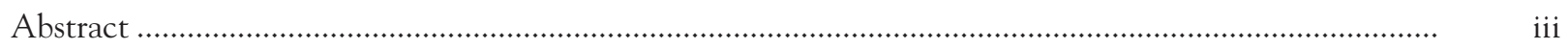

Acknowledgments ...........................................................................................................................

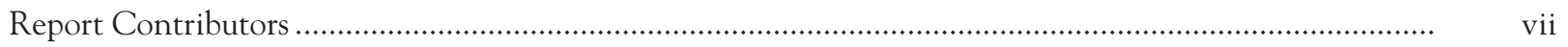

Summary

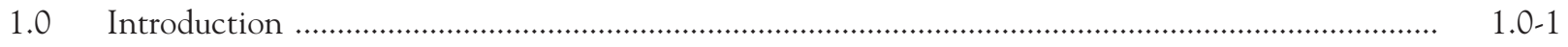

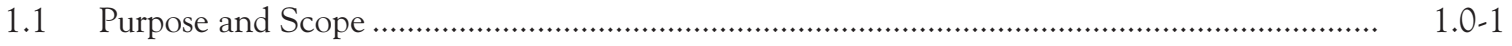

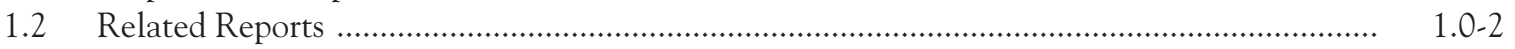

1.3 Groundwater Remediation Project ……......................................................................... $1.0-2$

1.4 Helpful Information ............................................................................................. $1.0-3$

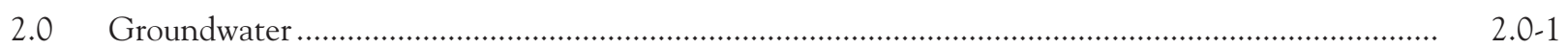

2.1 Overview of Hanford Site Groundwater ……...................................................................... 2.1-1

2.1.1 Groundwater Flow ................................................................................................ 2... 2.1

2.1.1.1 March 2003 Water Table ......................................................................... 2.. 2.1-2

2.1.1.2 Water-Table Changes from Fiscal Year 2002 ............................................... 2.1-2

2.1.2 Groundwater Contaminants .................................................................................. 2.1.3

2.1.3 Groundwater Remediation ................................................................................... 2.. 2.1

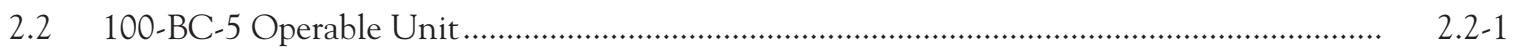

2.2.1 Groundwater Contaminants ....................................................................... 2.2.1

2.2.1.1 Strontium-90 ................................................................................. 2... 2.

2.2.1.2 Tritium ........................................................................................ $2.2-2$

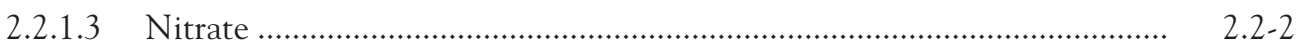

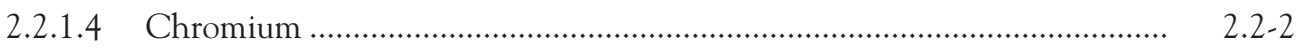

2.2.2 CERCLA Groundwater Monitoring …….............................................................. 2.2.2

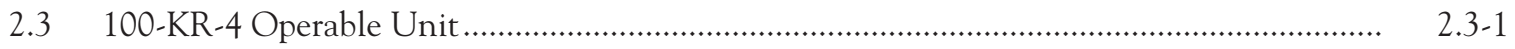

2.3.1 Groundwater Contaminants ................................................................................ 2...2

2.3.1.1 Chromium ..................................................................................... 2.3.

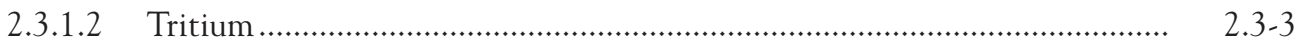

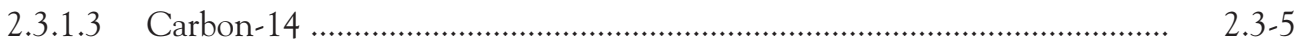

2.3.1.4 Strontium-90 ..................................................................................... 2... $2.3-5$

2.3.1.5 Other Constituents ................................................................................. 2... 2.3-6

2.3.2 CERCLA Interim Remedial Action for Chromium …………................................ 2... 2.3

2.3.2.1 Progress During Fiscal Year 2003 .............................................................. 2... 2.3

2.3.2.2 Influence on Aquifer Conditions ........................................................ 2... 2.3-7

2.3.3 AEA Monitoring ............................................................................................. 2... $2.3-8$

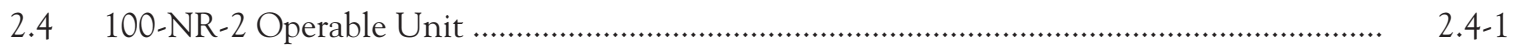

2.4.1 Groundwater Contaminants ................................................................................. 2.. 2.4

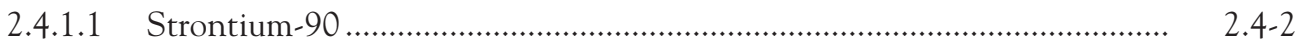

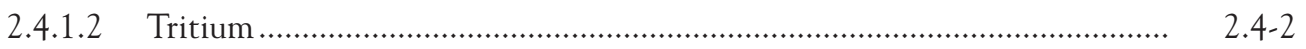

2.4.1.3 Nitrate ….................................................................................... 2... $2.4-2$

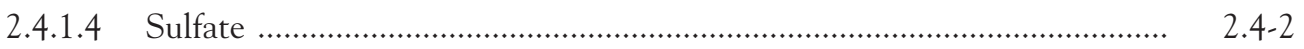

2.4.1.5 Petroleum Products .................................................................................. 2.. 2.4 
2.4.1.6 Manganese and Iron ................................................................................. 2.. 2.4-3

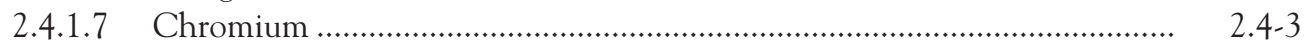

2.4.2 CERCLA Interim Groundwater Remediation for Strontium-90 .............................. 2.4. 2.4

2.4.3 RCRA Groundwater Monitoring …………................................................................ 2.. 2.4.4

2.4.3.1 116-N-1 Liquid Waste Disposal Facility .................................................. 2... 2.4-5

2.4.3.2 120-N-2 Surface Impoundment and 120-N-1 Percolation Pond .............. 2.. 2.4-5

2.4.3.3 116-N-3 Liquid Waste Disposal Facility …………………………….......... 2... 2.4

2.4.4 AEA Monitoring ................................................................................................ 2... 2.4

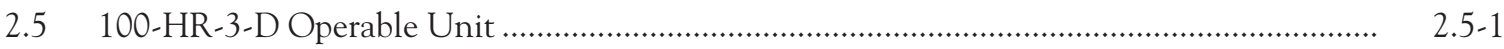

2.5.1 Groundwater Contaminants ................................................................................ 2.. 2.5-1

2.5.1.1 Chromium ............................................................................. $2.5-2$

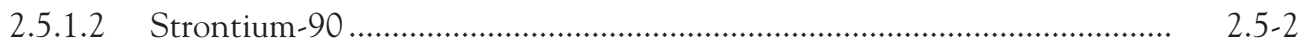

2.5.1.3 Tritium ................................................................... 2.... 2.5

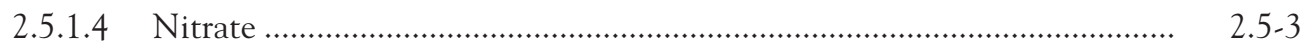

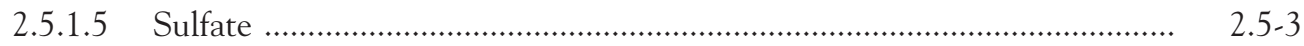

2.5.2 CERCLA Interim Groundwater Remediation for Chromium ………….................. 2.. 2.5-3

2.5.2.1 Pump-and-Treat System ........................................................................... 2.. 2.5-3

2.5.2.2 In Situ Redox Manipulation System ………........................................... 2... 2.5-4

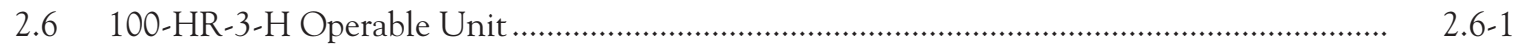

2.6.1 Groundwater Contaminants .................................................................................. 2.6-1

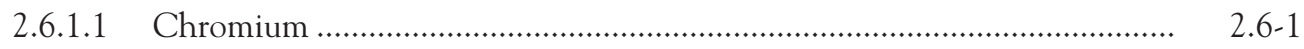

2.6.1.2 Strontium-90 ..................................................................... $2.6-2$

2.6.1.3 Technetium-99 and Uranium ........................................................... 2.. 2.6-2

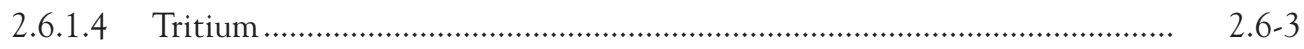

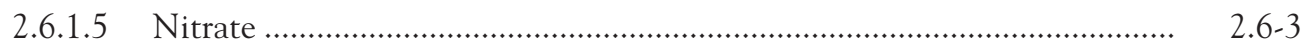

2.6.2 CERCLA Interim Groundwater Remediation for Chromium .................................. 2.. 2.6.3

2.6.2.1 Progress During Fiscal Year 2003 .............................................................. 2... 2.6

2.6.2.2 Influence on Aquifer Conditions ............................................................ 2... 2.6-3

2.6.3 RCRA Groundwater Monitoring for the 116-H-6 Evaporation Basins .................... 2.. 2.6-4

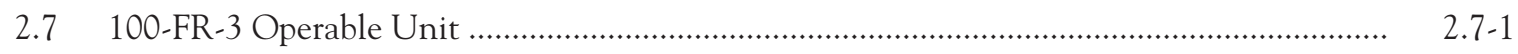

2.7.1 Groundwater Contaminants ............................................................................... 2...

2.7.1.1 Nitrate ....................................................................................... 2... $2.7-1$

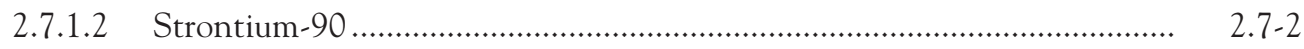

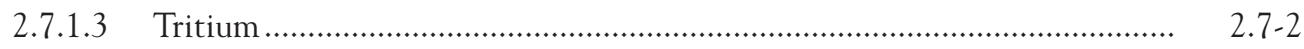

2.7.1.4 Trichloroethene …............................................................................ $2.7-2$

2.7.1.5 Gross Alpha and Gross Beta .................................................................. 2... 2.7-2

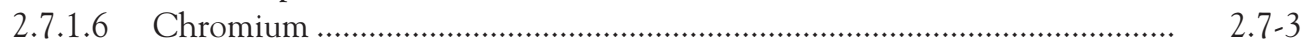

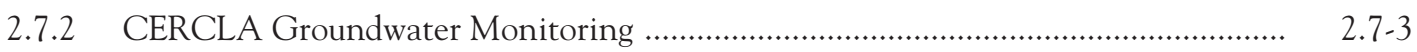

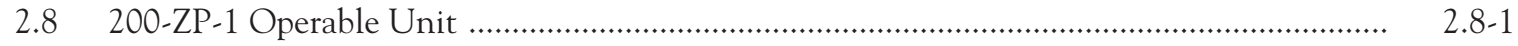

2.8.1 Groundwater Contaminants ............................................................................ 2... 2.8

2.8.1.1 Carbon Tetrachloride ..................................................................... 2... 2.8

2.8.1.2 Trichloroethene …….......................................................................... 2.. 2.8

2.8.1.3 Chloroform ......................................................................................... 2.. 2.8

2.8.1.4 Nitrate ……........................................................................... $2.8-3$

2.8.1.5 Chromium ................................................................................ 2... $2.8-4$

2.8.1.6 Arsenic and Cadmium ........................................................................ 2.. 2.8

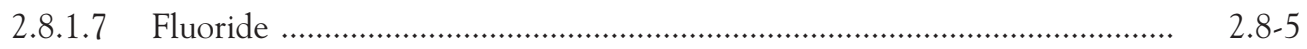

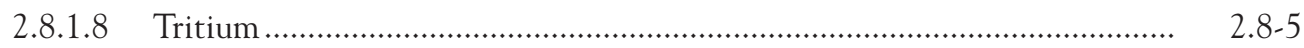

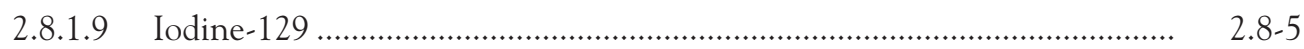




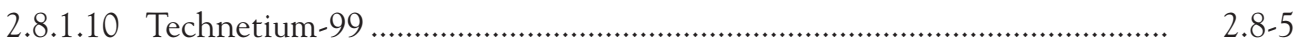

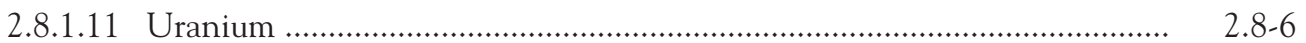

2.8.2 CERCLA Interim Groundwater Remediation for Carbon Tetrachloride ................. 2.. 2.8

2.8.2.1 Progress During Fiscal Year 2003 ................................................................ 2... 2.8

2.8.2.2 Influence on Aquifer Conditions ............................................................. 2... 2.8

2.8.3 RCRA Groundwater Monitoring ………............................................................... 2.. 2.8

2.8.3.1 Waste Management Area T ...................................................................... 2.. 2.9

2.8.3.2 Waste Management Area TX-TY ............................................................. 2... 2.8

2.8.3.3 Low-Level Waste Management Area 3 …………………………………..... 2.. 2.8-11

2.8.3.4 Low-Level Waste Management Area 4 …………………………………... 2.. 2.8-12

2.8.4 AEA Monitoring ............................................................................................ 2.. 2.8 13

2.8.4.1 Waste Management Areas T and TX-TY .............................................. 2... 2.13

2.8.4.2 Low-Level Waste Management Area 3 ......................................................... 2... 2.8-16

2.8.4.3 Low-Level Waste Management Area 4 ……............................................... 2.. 2.8-16

2.8.5 Groundwater Monitoring for the State-Approved Land Disposal Site ..................... 2.8-17

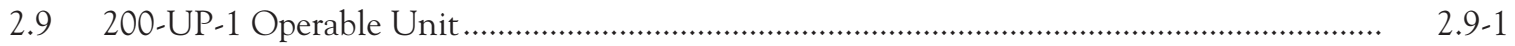

2.9.1 Groundwater Contaminants ............................................................................. 2.9. 2.9.

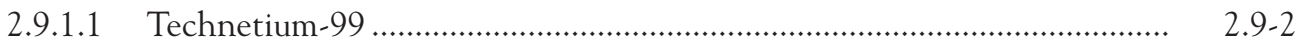

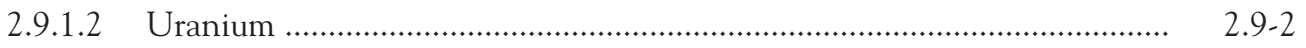

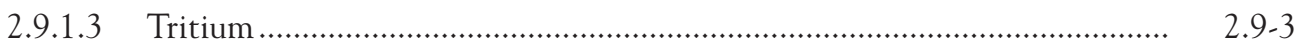

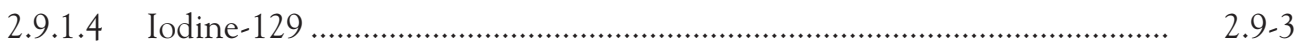

2.9.1.5 Strontium-90 .................................................................................... 2.9.

2.9.1.6 Chlorinated Hydrocarbons ................................................................... 2... 2.9

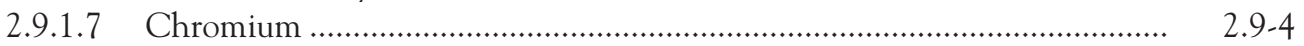

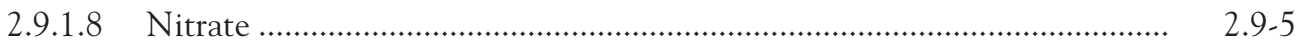

2.9.1.9 Other Constituents .............................................................................. 2. 2.9-5

2.9.2 CERCLA Groundwater Monitoring ………......................................................... 2... 2.9

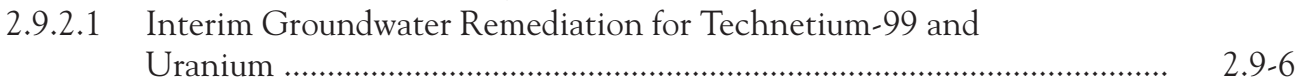

2.9.2.2 Groundwater Monitoring at the Environmental Restoration
Disposal Facility .................................................................................. 2... 2.9-8

2.9.3 RCRA Groundwater Monitoring ………….......................................................... 2.9. 2.9

2.9.3.1 216-U-12 Crib ................................................................................ 2.9.9

2.9.3.2 Waste Management Area U ……………............................................... 2...9-10

2.9.3.3 Waste Management Area S-SX ............................................................... 2... 2.9-11

2.9.3.4 216-S-10 Pond and Ditch …………………............................................. 2... 2.9-15

2.9.4 AEA Monitoring ......................................................................................... 2. 2.9-16

2.9.4.1 Waste Management Area U ………………….......................................... 2... 2.9-16

2.9.4.2 Waste Management Area S-SX ………….................................................... 2... 2.9-16

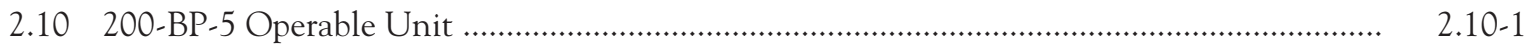

2.10.1 Groundwater Contaminants ................................................................................. 2.. $2.10-2$

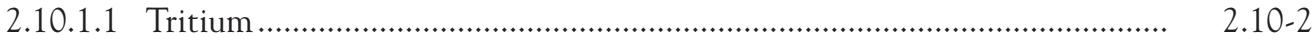

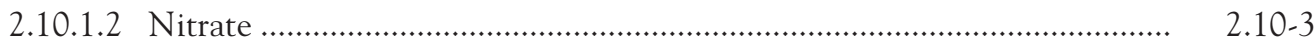

2.10.1.3 Iodine-129 ........................................................................................ 2... $2.10-3$

2.10.1.4 Technetium-99 ................................................................................ 2... $2.10-3$

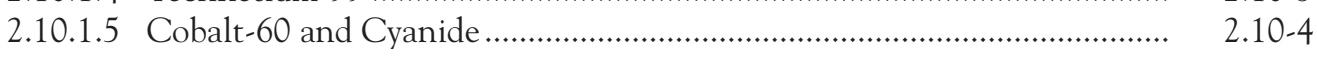

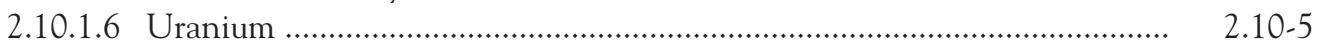

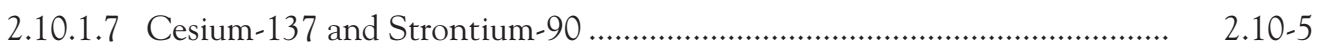

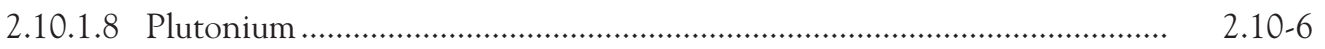

2.10-1.9 Other Constituents ......................................................................... 2.10-6

2.10.2 CERCLA Groundwater Monitoring ………….......................................................... 2.10-6 
2.10.3 RCRA Groundwater Monitoring ....

2.10.3.1 Waste Management Area B-BX-BY ........................................................ 2.10-7

2.10.3.2 216-B-63 Trench .................................................................................... 2.10-8

2.10.3.3 Low-Level Waste Management Area 1 ................................................. 2.10-8

2.10.3.4 Low-Level Waste Management Area 2 .................................................. 2... 2.10-9

2.10.3.5 Liquid Effluent Retention Facility ..................................................... 2.10

2.10.3.6 Waste Management Area C ................................................................. 2.10-10

2.10.4 AEA Monitoring

2.10.4.1 Waste Management Area B-BX-BY ........................................................ 2... 2.10-11

2.10.4.2 Low-Level Waste Management Area 1 ................................................... 2... 2.10-12

2.10.4.3 Low-Level Waste Management Area 2 .................................................. 2... 2.10-13

2.10.4.4 Waste Management Area C ............................................................. 2.10 2.14

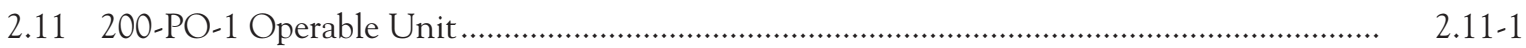

2.11.1 Groundwater Contaminants .......................................................................... 2.11-2

2.11.1.1 Tritium ......................................................................................... 2... $2.11-2$

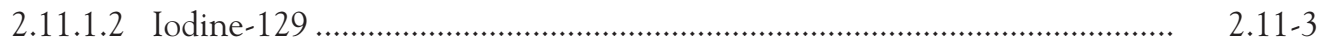

2.11.1.3 Nitrate ......................................................................................... 2.... $2.11-3$

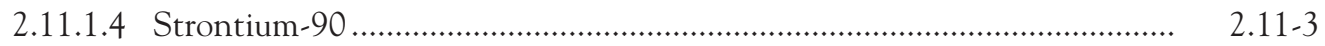

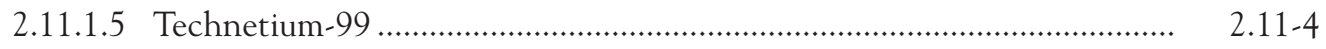

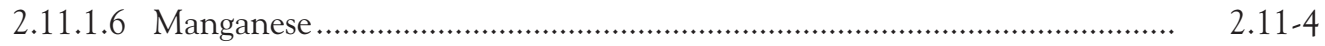

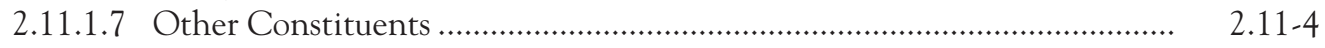

2.11.2 CERCLA Groundwater Monitoring ................................................................ 2... 2...

2.11.3 RCRA Groundwater Monitoring ........................................................................ 2... 2. $11-5$

2.11.3.1 PUREX Cribs ..................................................................................... 2... 2.11-6

2.11.3.2 Waste Management Area A-AX ........................................................... 2.11-6

2.11.3.3 216-A-29 Ditch .................................................................................... 2.11-7

2.11.3.4 Integrated Disposal Facility ................................................................. 2.11-8

2.11.3.5 216-B-3 Pond Facility ........................................................................ 2... 2.11-9

2.11.3.6 Nonradioactive Dangerous Waste Landfill ........................................ 2... 2.11-10

2.11.4 AEA Monitoring ..................................................................................... 2.11-11

2.11.4.1 Waste Management Area A-AX ............................................................. 2... 2.11-11

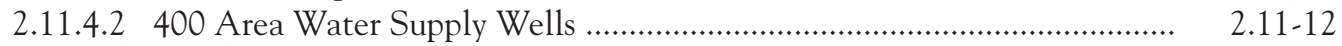

2.11.5 Washington Administrative Code .................................................................... 2.11-12

2.11.5.1 200 Area Treated Effluent Disposal Facility ......................................... 2... 2.11-13

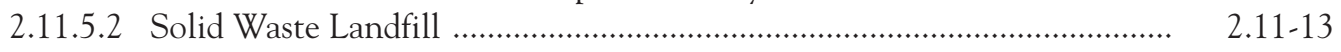

2.11.5.3 400 Area Process Ponds ..................................................................... 2... 2.11-16

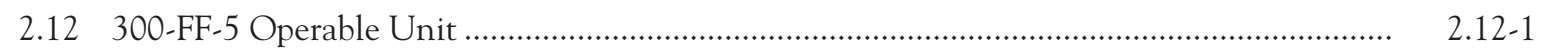

2.12.1 Groundwater Contaminants .......................................................................... 2.12-2

2.12.1.1 Uranium ................................................................................... 2. $2.12-2$

2.12.1.2 Chlorinated Hydrocarbons ............................................................... 2.... 2...

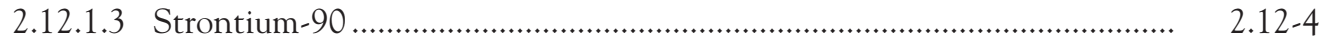

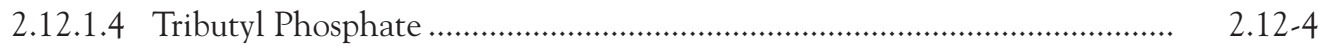

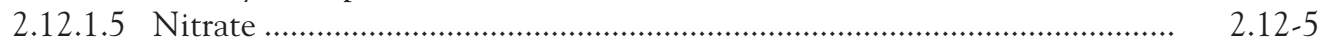

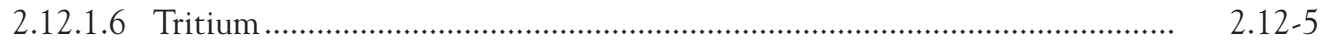

2.12.1.7 Petroleum Hydrocarbons …............................................................ 2.12-6

2.12.2 CERCLA Groundwater Monitoring and Interim Action ..................................... 2.12-6

2.12.3 RCRA Groundwater Monitoring at the 316-5 Process Trenches .......................... 2.12-8

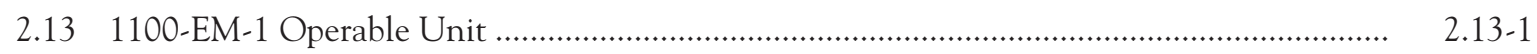

2.13.1 Groundwater Contaminants ....................................................................... 2.13-1

2.13.1.1 Chlorinated Hydrocarbons ................................................................... 2... 2.13-2

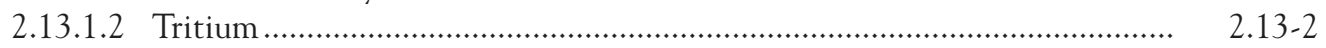




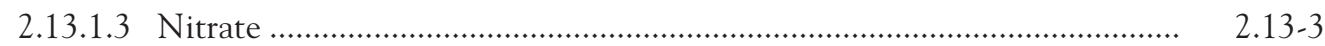

2.13.1.4 Gross Alpha and Uranium .................................................................... 2.13-3

2.13.1.5 Other Constituents .............................................................................. 2... 2.13-4

2.13.2 CERCLA Groundwater Monitoring …………………………………………......... 2.13-4

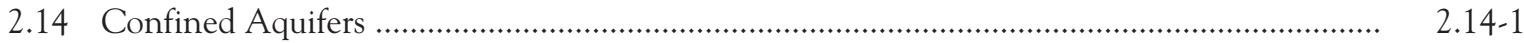

2.14.1 Ringold Formation Confined Aquifer …….............................................................. 2.. 2.14-1

2.14.1.1 Groundwater Flow in the Ringold Formation Confined Aquifer ............ 2. 2.14-1

2.14.1.2 Groundwater Quality in the Ringold Confined Aquifer ........................... 2.. 2.14-2

2.14.2 Upper Basalt-Confined Aquifer ................................................................................ 2.. 2.14-2

2.14.2.1 Groundwater Flow in the Upper Basalt-Confined Aquifer ...................... 2. 2.14-3

2.14.2.2 Groundwater Quality in the Upper Basalt-Confined Aquifer .................. 2.14-4

3.0 Vadose Zone

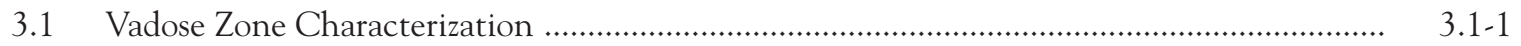

3.1.1 Tank Farm Characterization …….......................................................................... 3.1.1

3.1.1.1 Characterization at Waste Management Area T ........................................ 3.. 3.1

3.1.1.2 Characterization at Waste Management Area TX-TY ................................ 3.. 3.1-2

3.1.1.3 Summary of Significant Findings from the Field Investigation Report for Waste Management Area B-BX-BY ....................................................... 3.1. 3

3.1.2 Borehole Geophysics for Vadose Zone Characterization ............................................ 3.1.4

3.1.3 Characterization at the 200-PW-1 Operable Unit ................................................... 3.1-6

3.1.4 Characterization of the 200-CS-1 Operable Unit ................................................... 3.1-7

3.1.5 300 Area Uranium Leach and Adsorption Studies ................................................. 3.1-8

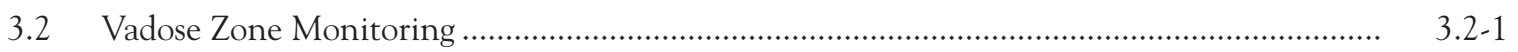

3.2.1 Leachate and Soil-Gas Monitoring at the Solid Waste Landfill ............................... 3.2.1

3.2.2 Leachate Monitoring at the Environmental Restoration Disposal Facility .............. 3.2.2

3.2.3 Vadose Zone Monitoring at Single-Shell Tank Farms ............................................... 3.2. 3.

3.2.4 Carbon Tetrachloride Monitoring and Remediation .............................................. 3.2.4

3.2.4.1 Soil-Vapor Extraction ............................................................................. $3.2-5$

3.2.4.2 Monitoring at Off-Line Wells and Probes ................................................... 3.2. 3.2.

3.2.4.3 Passive Soil-Vapor Extraction ……………............................................. $3.2-6$

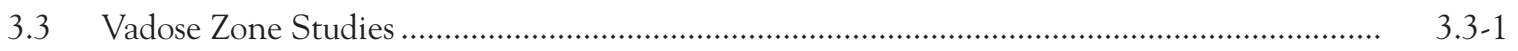

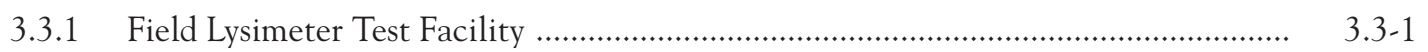

3.3.2 Vadose Zone Water Fluxmeter Improvements and Tests .......................................... 3... 3.4

3.3.3 Mineralogical and Bulk-Rock Geochemical Signatures of Ringold and
Hanford Formation Sediment ..................................................................................

3.3.4 Isotopic Investigation of Vadose Zone Pore Water .................................................. 3.3-5

3.3.5 Hydrologic Performance of a Prototype 1,000-Year Hanford Barrier ......................... 3.. 3.7

3.3.6 STOMP-Based Tool to Optimize Surface Barrier Design ......................................... 3.3-8

3.3.7 Impact of Clastic Dikes on Vadose Zone Flow ........................................................... 3.3-10

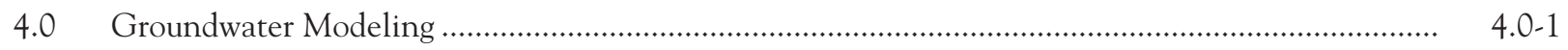

4.1 Site-Wide Groundwater Flow and Transport Model .............................................................. 4.0 4.

4.1.1 Development and Calibration of Alternative Conceptual Model 2 ……................. 4.. 4.0-1

4.1.2 Background Information on the Site-Wide Groundwater Model ............................ 4.. 4.0-2

4.2 System Assessment Capability ............................................................................................. $4.0-3$

4.3 Local-Scale Modeling of Pump-and-Treat Systems .............................................................. 4.0-3 
5.0 Well Installation, Maintenance, and Decommissioning

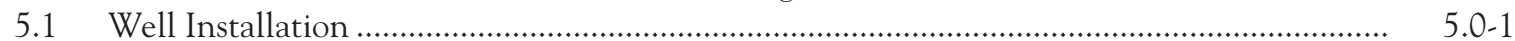

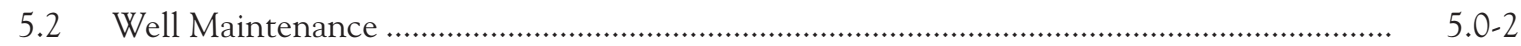

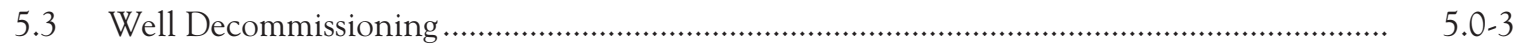

6.0 References

$6.0-1$

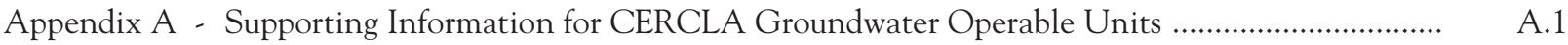

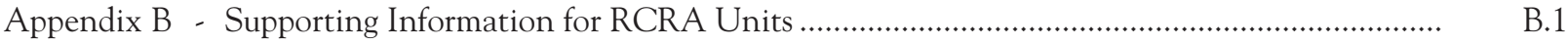

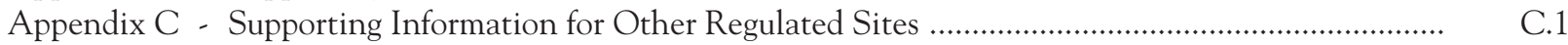

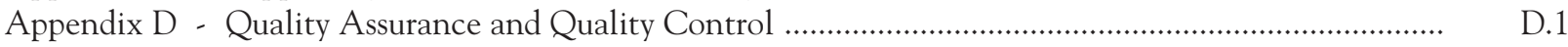

\section{Tables}

1.1-1 Regulated Units and Groundwater Operable Units on the Hanford Site ................................. 1.0-4

2.1-1 Number of Groundwater Analyses by Groundwater Interest Area, Fiscal Year 2003 .............. 2.1-6

2.1-2 Maximum Concentrations of Selected Groundwater Contaminants in Fiscal Year 2003 ......... 2.1-7

2.9-1 Summary of Contaminant Mass Removed from the Aquifer during Pump-and-Treat Operations at the 200-UP-1 Operable Unit - Fiscal Year 2003 and Totals Since Startup of Operations .

2.9-2 Vertical Variation of Groundwater Composition Measured in the Wellbore of Well 299-W23-19 and Estimated for the Adjacent Aquifer During the End of a 4,013-Liter Purge on September 23, 2003.

2.9-3 Quantity of Treated Groundwater and Technetium-99 Mass Removed from the Aquifer During Extended Purging at Well 299-W23-19

2.11-1 Ranges of Reported Volatile Organic Compound Concentrations in Solid Waste Landfill Wells During Fiscal Year 2003

2.14-1 Potential Contaminants in Ringold Confined Aquifer, Fiscal Years 2001 through 2003 .......... 2.14-6

2.14-2 Potential Contaminants in Upper Basalt-Confined Aquifer, Fiscal Years 2001 through 2003

3.1-1 Summary of Significant Borehole Logging Results from Fiscal Year 2003 Characterization Boreholes at the T and TX Tank Farms

3.1-2 Selective Extraction Results for Uranium in Six Near-Surface Sediment Samples

3.2-1 Carbon Tetrachloride Inventory in Primary Disposal Sites ................................................. 3.2-7

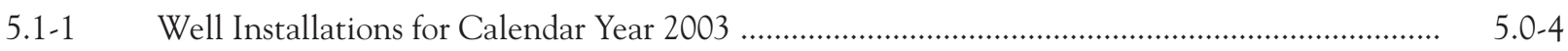

5.1-2 Vadose Characterization Wells, Soil-Gas Probes, and GeoProbe/Push Installations for

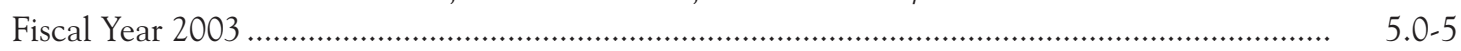

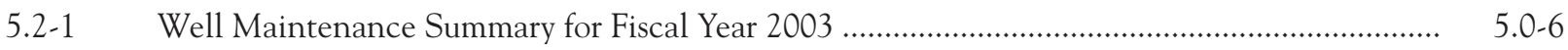

5.3-1 Wells Decomissioned During Fiscal Year 2003 ......................................................................... 5... 


\section{Figures}

2.1-1 Groundwater Operable Units and Groundwater Interest Areas on the Hanford Site ............... 2.1-9

2.1-2 Groundwater Monitoring Wells in the 600 Area .................................................................... 2.1-11

2.1-3 Hanford Site and Outlying Areas Water-Table Map, March 2003 .......................................... 2.. 2.1-13

2.1-4 Water Level in Well 299-E32-8, Northwest 200 East Area ...................................................... 2.1-14

2.1-5 Average Fiscal Year 2003 Tritium Concentrations on the Hanford Site, Top of

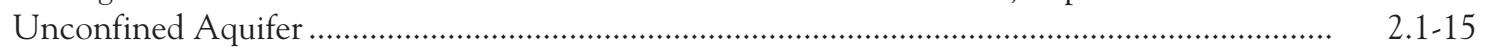

2.1-6 Average Fiscal Year 2003 Nitrate Concentrations on the Hanford Site, Top of Unconfined Aquifer ............................................................................................................ 2.1.16

2.1-7 Average Fiscal Year 2003 Iodine-129 Concentrations on the Hanford Site, Top of

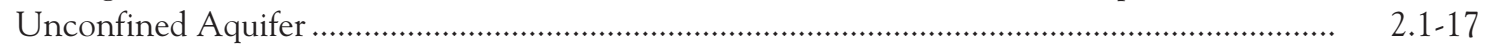

2.1-8 Dissolved Chromium at Selected Aquifer Tube Sites for Selected Years, 100 Areas ................ 2.1-18

2.2-1 Groundwater Monitoring Wells in the 100-B/C Area .......................................................... 2.2-4

2.2-2 100-B/C Area Water-Table Map, March 2003 ....................................................................... 2.2.5

2.2-3 Average Strontium-90 Concentrations in the 100-B/C Area, Top of Unconfined Aquifer ...... 2.2-6

2.2-4 Strontium-90 Concentrations and Water Levels Near 116-C-1 Trench ................................... 2.2-7

2.2-5 Strontium-90 Concentrations and Water Levels Near 116-B-1 Trench .................................... 2.2-7

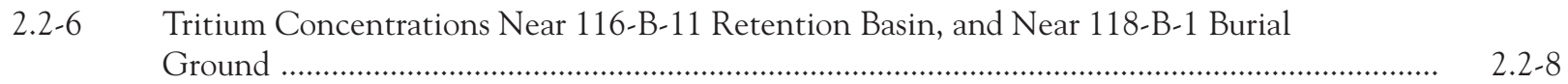

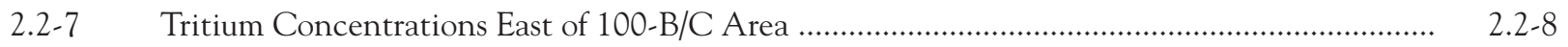

2.3-1 Location Map for 100-K Area Facilities, Waste Sites, Monitoring Wells, and Shoreline 2.3-9

2.3-2 Chromium Distribution in 100-K Area Groundwater, Fiscal Year 2003 ................................... 2.3-10

2.3-3 Chromium Concentrations in Pump-and-Treat Performance Monitoring Wells ...................... 2.. 2.3-11

2.3-4 Increasing Chromium Concentrations at the Southwest Edge of Plume Associated with the

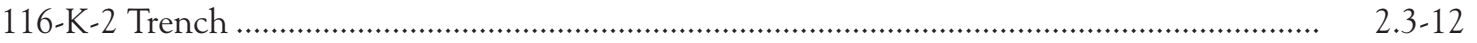

2.3-5 Chromium Concentrations Near KE Water Treatment Plant Basins ..................................... 2... 2.3-12

2.3-6 Chromium Concentrations Near KW Reactor ........................................................................ 2.3-13

2.3-7 Tritium Distribution in 100-K Area Groundwater, Fiscal Year 2003 .......................................... 2.. 2.3-14

2.3-8 Tritium and Carbon-14 Concentrations Near the 116-KE-1 Crib ........................................... 2... 2.15

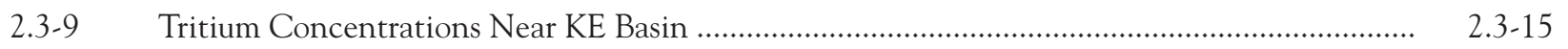

2.3-10 Tritium and Carbon-14 Concentrations Near the 116-KW-1 Crib ........................................... 2.3-16

2.3-11 Tritium Concentrations Near KW Basin ............................................................................. 2... 2.16

2.3-12 Tritium Concentrations Near 118-K-1 Burial Ground .............................................................. 2.. 2.3-17

2.3-13 Helium Isotope Ratios in Soil Gas Near 118-K-1 Burial Ground .............................................. 2... 2.3-18

2.3-14 Strontium-90 and Gross Beta Concentrations Near KE Basin ................................................ 2.3.19

2.3-15 Tritium Concentrations in Wells Downgradient of the Pump-and-Treat Injection Site ........... 2.3-19

2.4-1 Groundwater Monitoring Wells in the 100-N Area .................................................................. 2.4-7

2.4-2 Water Table Beneath 100-N Area, March 2003 .................................................................... 2... 2.8

2.4-3 Average Strontium-90 Concentrations in the 100-N Area, Top of Unconfined Aquifer .......... 2.4-9

2.4-4 Strontium-90 Concentrations and Water Level Near the 116-N-1 Facility .............................. 2.. 2.4-10 
2.4-5 Average Tritium Concentrations in the 100-N Area, Top of the Unconfined Aquifer ...........

2.4-6 Tritium Concentrations North of the 116-N-1 Facility

2.4-7 Nitrate Concentrations and Water Level Near the 116-N-1 Facility ...........

2.4-8 Average Sulfate Concentrations in the 100-N Area, Top of Unconfined Aquifer

2.4-9 Sulfate Concentrations in 100-N Area Wells

2.4-10 Petroleum Hydrocarbons Near Former Petroleum Leak Site .....

2.4-11 Strontium-90 Concentrations in 100-N Area Extraction Wells......

2.5-1 Groundwater Monitoring Wells in the 100-D Area

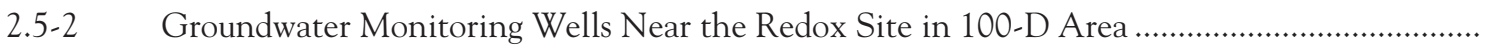

2.5-3 100-D Area Water-Table Map, March 2003

2.5-4 Average Dissolved Chromium Concentrations in the 100-D Area, Top of Unconfined Aquifer.....

2.5-5 Average Dissolved Chromium Concentrations Near the Redox Site, 100-D Area, August-September 2003

2.5-6 Dissolved Chromium Concentrations in South 100-D Area

2.5-7 Dissolved Chromium Concentrations in Compliance Wells Downgradient of Early-Emplaced Redox Barrier.

2.5-8 Dissolved Chromium Concentrations in Compliance Wells Downgradient of Late-Emplaced Redox Barrier .

2.5-9 Hexavalent Chromium in Aquifer Tubes at 100-D Area, Fiscal Year 2003.

2.5.10 Dissolved Chromium Concentrations in Central 100-D Area

2.5-11 Tritium Concentrations in the South 100-D Area ......

2.5-12 Sulfate Concentrations Downgradient of the Redox Barrier

2.5-13 Dissolved Chromium Concentrations in Compliance Wells for the 100-HR-3 Pump-andTreat System at 100-D Area

2.6-1 Groundwater Monitoring Wells in the 100-H Area...

2.6-2 Water Table Beneath 100-H Area, March 2003

2.6-6 Technetium-99 and Uranium Concentrations Northeast of 116-H-6 Evaporation Basins .........

2.6-7 Average Nitrate Concentrations in the 100-H Area, Top of Unconfined Aquifer

2.6-8 Dissolved Chromium Concentrations in a Compliance Wells for the 100-HR-3 Pumpand-Treat System at 100-H Area

2.7-1 Groundwater Monitoring Wells in the 100-F Area......

2.7-2 100-F Area Water-Table Map, March 2003

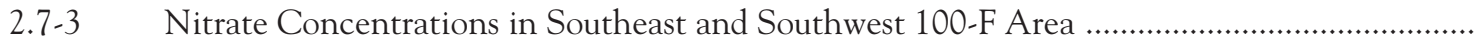

2.7-4 Nitrate Concentrations Southwest and South of 100-F Area

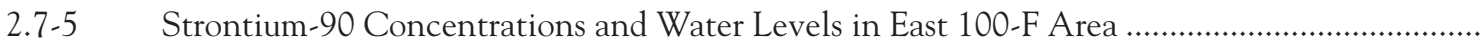

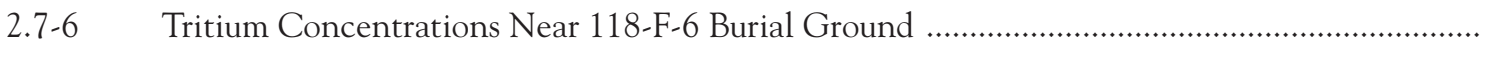

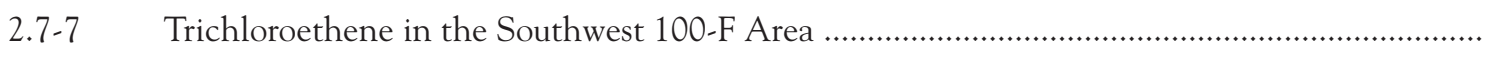

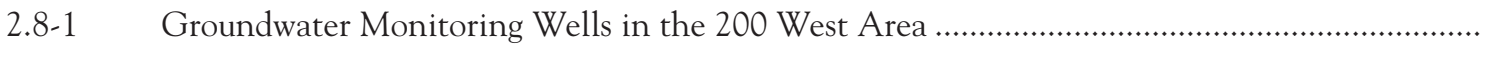

2.8-2 Water-Table Contours in the 200 West Area 
2.8-3 Average Carbon Tetrachloride Concentrations in 200 West Area, Top of Unconfined Aquifer

2.8-4 Carbon Tetrachloride Concentrations Northeast of the 200 West Area in Well 699-48-71 ....

2.8-5 Average Trichloroethene Concentrations in Central and North 200 West Area, Top of Unconfined Aquifer

2.8-6 Average Nitrate Concentrations in the Central and North 200 West Area, Top of Unconfined Aquifer

2.8-7 Average Dissolved Chromium Concentrations Near Waste Management Area T and TX-TY, Top of Unconfined Aquifer..

2.8-8 Average Fluoride Concentrations in North 200 West Area, Top of Unconfined Aquifer .......... Average Tritium Concentrations in the North 200 West Area, Top of Unconfined Aquifer ...

2.8-10 Tritium Concentrations versus Time in Wells 299-W14-12 and 299-W14-13 at Waste Management Area TX-TY...

2.8-11 Average Iodine-129 Concentrations in the North 200 West Area, Top of Unconfined Aquifer

2.8-12 Average Technetium-99 Concentrations in the North 200 West Area, Top of Unconfined Aquifer

2.8-13 Technetium-99 Concentrations in Selected Wells at Waste Management Area T ...................

2.8-14 Carbon Tetrachloride Concentrations at Extraction Well 299-W15-32, Near the 216-Z-9 Trench

2.8-15 Chromium Concentrations versus Time for Selected Upgradient Wells at Waste Management Area T

2.8-16 Chromium Concentration versus Time for Selected Wells North of Waste Management Area T

2.8-17 Chromium and Technetium-99 Concentrations versus Time for Selected Wells Downgradient of Waste Management T

2.8-18 Chromium Concentrations in Well 299-W14-13, East of Waste Management Area TX-TY

2.8-19 Nickel Concentrations in Well 299-W7-1, North of Low-Level Waste Management Area 3

2.8-20 Specific Conductance versus Depth Below the Water Table in Well 299-W10-28 ...................

2.8-21 Specific Conductance versus Depth in the Screened Interval of Well 299-W14-13

2.8-22 Nitrate Concentration in Groundwater Samples Collected During Drilling of New RCRA Well 299-W15-44, Waste Management Area TX-TY.

2.8-23 Concentrations of Selected Constituents versus Depth in the Screened Interval of Well 299-W14-13 at Waste Management Area TX-TY

2.8-24 Tritium Concentrations in Groundwater for the SALDS Tritium-Tracking Network, Fiscal Year 2003, Indicating Changes from Fiscal Year 2002 Results

2.9-1 Facilities and Groundwater Monitoring Wells in the 200 West Area

2.9-2 Average Technetium-99 Concentrations in the 200-UP-1 Groundwater Interest Area, Top of Unconfined Aquifer

2.9-3 Technetium-99 Concentrations at Waste Management Area S-SX

2.9-4 Average Uranium Concentrations in the 200-UP-1 Groundwater Interest Area, Top of Unconfined Aquifer

2.9-5 Average Tritium Concentrations in the 200-UP-1 Groundwater Interest Area, Top of Unconfined Aquifer 
2.9-6 Average Iodine-129 Concentrations in the 200-UP-1 Groundwater Interest Area, Top of Unconfined Aquifer

2.9-7 Average Nitrate Concentrations in the 200-UP-1 Groundwater Interest Area, Top of Unconfined Aquifer

2.9-8 Technetium-99 Concentrations in Extraction and Monitoring Wells at the 200-UP-1 Pump-and-Treat Area

2.9-9 Uranium Concentrations in Extraction and Monitoring Wells at the 200-UP-1 Pump-andTreat Area

2.9-10 Average Technetium-99 Concentrations in the 200-UP-1 Pump-and-Treat Area, Top of Unconfined Aquifer

2.9-11 Average Uranium Concentrations in the 200-UP-1 Pump-and-Treat Area, Top of Unconfined Aquifer

2.9-12 Average Nitrate Concentrations at Waste Management Area S-SX, Top of Unconfined Aquifer.

2.9-13 Average Chromium Concentrations at Waste Management Area S-SX, Top of Unconfined Aquifer.

2.9-14 Wellbore-Fluid Specific Conductance Logs Collected in Well 299-W23-19 at Waste Management Area S-SX

2.9-15 Wellbore-Fluid Specific Conductance Measurements Collected in Well 299-W23-19 at Waste Management Area S-SX

2.9-16 Wellbore-Fluid Specific Conductance Measurements Collected during Sampling on September 23, 2003 in Well 299-W23-19

2.9-17 Chromium Concentrations Near the 216-S-10 Pond and Ditch

2.9-18 Chromium and Nitrate Concentrations in Well 299-W26-7 Near the 216-S-10 Pond and Ditch

2.9-19 Average Technetium-99 Concentrations at Waste Management Area S-SX, Top of Unconfined Aquifer

2.9-20 Average Tritium Concentrations at Waste Management Area S-SX, Top of Unconfined Aquifer

2.10-1 Groundwater Monitoring Wells in the 200 East Area 200-BP-5 Operable Unit

2.10-6 Average Technetium-99 Concentrations in the North 200 East Area, Top of Unconfined Aquifer.

2.10-7 Technetium-99 Concentrations in Wells 299-E33-7 and 299-E33-38 at the BY Cribs and Well 699-49-57A North of 200 East Area

2.10-8 Average Uranium Concentrations in the Vicinity of BY Cribs, Top of Unconfined Aquifer ...

2-10-9 Strontium-90 Concentrations in Wells 299-E28-23 and 299-E28-25 at the 216-B-5 Injection Well Site 
2.10-11 Hydrograph for Wells at Waste Management Area B-BX-BY Showing the Distinct Increase in Water Levels

2.10-12 Nitrate Concentrations in Low-Level Waste Management Area 2 Wells 299-E34-7, 299-E27-10, and 299-E27-9

2.10-13 Trend Plots of Technetium-99 Concentrations at Waste Management Area B-BX-BY

2.10-14 Technetium-99 Concentrations Compared to Nitrate Concentrations for Upgradient Well 299-E27-7 at Waste Management C

2.11-1 Groundwater Monitoring Wells in the 200 East Area

2.11-2 Tritium Concentrations at the 216-A-36B Crib, Well 299-E17-14

2.11-3 Tritium Concentrations at the 216-A-36B Crib, Well 299-E17-9

2.11-4 Iodine-129 Concentrations at the 216-A-36B Crib, Well 299-E17-14 .....

2.11-5 Iodine-129 Concentrations at the 216-A-10 Crib, Well 299-E17-1....

$2.11-22$

2.11-6 Nitrate Concentrations at Upgradient Well 299-E24-18 for the PUREX Cribs ...

2.11-7 Nitrate Concentrations at the 216-A-36B Crib, Well 299-E17-14

2.11-8 Strontium-90 Concentrations at the 216-A-36B Crib

$2.11-24$

2.11-9 Manganese Concentrations at the 216-A-10 Crib .

$2.11-24$

2.11-10 Specific Conductance in Wells Monitoring Waste Management Area A-AX ......................... 2. 2.11-25

2.11-11 Groundwater Monitoring Wells at the Central Landfill and Vicinity .....

$2.11-26$

2.11-12 Total Organic Carbon Concentrations at Upgradient Well 699-26-35A, Shared by the Solid Waste Landfill and Nonradioactive Dangerous Waste Landfill

2.11-13 Chromium and Technetium-99 Trends at Waste Management Area AX, Well 299-E24-19 ....

2.11-14 Chromium and Technetium-99 Trends at Waste Management Area A-AX, Well 299-E25-46

2.11-15 Groundwater Monitoring Wells in the 400 Area

2.11-16 Comparison of Tritium Concentrations in 400 Area Drinking Water Wells

2.11-17 Average Nitrate Concentrations in 400 Area Process Pond Area, Top of Unconfined Aquifer.

2.11-18 Nitrate Concentrations in Wells Monitoring the 400 Area Process Ponds

2.12-1 Groundwater Monitoring Wells in the Richland North and 300 Areas ....................................

2.12-2 Subdivisions of the 300-FF-5 Operable Unit

2.12-11

2.12-3 Groundwater Flow Direction in the Richland North and 300 Areas

2.12-4 Uranium Concentrations in the Richland North and 300 Areas, December 2002, Top of Unconfined Aquifer

2.12-5 Uranium Concentrations in the Richland North and 300 Areas, June 2003, Top of Unconfined Aquifer

2.12-6 300 Area Wells Showing Long-Term Gradual Decline in Uranium Concentrations Since 1997

2.12-7 300 Area Wells Showing Increases in Uranium Concentrations Until 2000 ........................... 2.12-18

2.12-8 Uranium Concentrations in Well 399-1-10A

2.12-9 Uranium Concentrations in Well 399-8-5A

2.12-10 Location of Monitoring Wells in the 300 North Area

2.12-11 Average Trichloroethene Concentrations in the Richland North and 300 Areas, Top of Unconfined Aquifer. 
2.12-13 Nitrate Concentrations in the Richland North and 300 Areas

2.12-14 Average Tritium Concentrations in Groundwater in the Richland North and 300 Areas, Top of Unconfined Aquifer .....

2.12-15 Tritium Concentrations in Wells Monitoring the 300 Area

2.12-16 Tritium Concentrations at Well 699-13-3A Near 618-11 Burial Ground.....

2.12-17 Tritium Concentrations During 2003 in Plume Associated with the 618-11 Burial Ground

2.13-1 Trichloroethene Concentrations Near the U.S. Department of Energy's Inactive Horn Rapids Landfill

2.13-2 Tritium Concentrations in Wells Monitoring the 1100-EM-1 Groundwater Interest Area ......

2.13-3 Nitrate Concentrations in Wells Monitoring the 1100-EM-1 Groundwater Interest Area.......

2.13-4 Uranium Concentrations Near the U.S. Department of Energy's Inactive Horn Rapids Landfill

2.14-1 Potentiometric Surface Map of Ringold Formation Confined Aquifer, Central Hanford Site, March 2003

2.14-2 Groundwater Monitoring Wells Sampled in the Ringold and Upper Basalt-Confined Aquifers, Fiscal Years 2001 through 2003

2.14-3 Potentiometric Surface Map of Upper Basalt-Confined Aquifer System, March 2003

2.14-4 Distribution of Chemical and Radiological Constituents in the Upper Basalt-Confined Aquifer, Fiscal Years 2001 through 2003

3.1-1 Electrical Conductivity and pH versus Depth in Characterization Borehole C3831 at the TX Tank Farm

3.1-2 Concentations of Contaminant Indicators Technetium-99, Nitrate, and Sodium versus Depth in Characterization Boreholes at TX Tank Farm

3.1-3 Cobalt-60 Contamination in the Vadose Zone Near Waste Management Area B-BX-BY .......

3.1-4 Uranium-238 Contamination in the Vadose Zone Near Waste Management Area B-BX-BY

3.1-5 Locations of Boreholes and Test Pits for Characterization of the 216-A-29 Ditch and 216-B-63 Trench

3.1-6 Locations of Borehole B8828 and Test Pits at the 216-S-10 Ditch and Pond System

3.2-1 Leachate Collection Volumes at the Solid Waste Landfill.....

3.2-2 Locations of Carbon Tetrachloride Vapor-Extraction Wells at the 216-Z-1A/216-Z-12/ 216-Z-18 and the 216-Z-9 Well Fields

3.2-3 Time Series Concentrations and Mass of Carbon Tetrachloride in Soil Vapor Extracted from the 216-Z-1A/216-Z-12/216-Z-18 Well Field

3.3-1 View of the Field Lysimeter Test Facility Looking Southwest Toward Rattlesnake Mountain

3.3-2 Drawing of the Field Lysimeter Test Facility

3.3-3 Water Fluxmeter with Solution Collection Capability

3.3-4 Water Fluxmeter Data Showing Drainage from Soil Materials Tested at the Hanford Site ......

3.3-5 Temporal Variation in Mean Soil Water Storage on the North and South Plots at the Prototype Hanford Barrier, November 1994 through September 2003

3.3-6 Cumulative Amounts of Water Diverted by the Asphalt Pad from the Side-Slope Plots at the Prototype Hanford Barrier in September 1994 through September 2003

3.3-7 Primary Environmental Interactions Governing Functional Performance of a Typical 1,000-Year Capillary Barrier 
3.3-8 Simulated Aqueous Saturation as a Function of Depth within a Layered Soil

3.3-9 STOMP Simulated Air and Soil Surface Temperature for Water and Heat Flow in a Layered Soil System Typical of a Capillary Barrier ..................................................................... 3.. 3-16

4.1-1 Facies Zones Defined for Alternative Conceptual Model 2, Unit 1 ........................................... 4. 4.0-5

4.1-2 Facies Zones Defined for Alternative Conceptual Model 2, Unit 5 ........................................... 4.0 4.6

4.1-3 Runoff Areas Applied to Model Elements Updated System Assessment Capability Model Grid

4.1-4 Updated System Assessment Capability Model Grid …............................................................ 4. 4.0-8

5.1-1 Groundwater Monitoring Wells Installed in Calendar Year 2003 ............................................. 5.0-8 


\subsection{Introduction}

\section{J. Hartman}

The U.S. Department of Energy (DOE) monitors groundwater at the Hanford Site to fulfill a variety of state and federal regulations, including the Atomic Energy Act of 1954, the Resource Conservation and Recovery Act (RCRA), the Comprehensive Environmental Response, Compensation, and Liability Act (CERCLA), and Washington Administrative Code. DOE manages these activities through the Groundwater Performance Assessment Project (groundwater project; formerly Hanford Groundwater Monitoring Project), which is conducted by Pacific Northwest National Laboratory.

\subsection{Purpose and Scope}

Hanford Site Groundwater Monitoring for Fiscal Year 2003 presents results of groundwater monitoring, vadose zone monitoring and characterization, and groundwater modeling. This report also summarizes groundwater remediation and well installation activities. Monitoring results primarily rely on data from samples collected between October 1, 2002, and September 30, 2003. Data received after November 14, 2003, may not have been considered in the interpretations.

Groundwater remediation and associated monitoring of pumping wells is the responsibility of Fluor Hanford, Inc. Vadose zone monitoring and characterization are conducted by Bechtel Hanford, Inc.; CH2M HILL Hanford Group, Inc.; Fluor Hanford, Inc.; and Pacific Northwest National Laboratory.

Table 1.1-1 summarizes highlights or changes for CERCLA groundwater operable units, RCRA sites, and other regulated units and indicates where to find additional information in this report. Supporting information for CERCLA groundwater operable units is presented in Appendix A. Appendices B and C present similar information for RCRA sites and other waste units, respectively. Appendix D describes results of the quality control program.

Background information, including descriptions of regulatory requirements, waste sites, analytical methods, regional geology, and statistics is included in a separatelypublished companion volume, Hanford Site Groundwater: Setting, Sources and Methods (PNNL-13080), and in the most recent update, which was provided in PNNL-13788, Appendix C. Those changes have been incorporated into the electronic version of this groundwater monitoring report.
CERCLA regulates waste sites that were active before RCRA took effect. It covers sites where radioactive or hazardous waste was disposed or leaked and also requires groundwater monitoring where appropriate.

This report is designed to meet the following objectives:

- Provide a comprehensive report of groundwater conditions on the Hanford Site.

- Fulfill the reporting requirements of RCRA, CERCLA (for operable units with no active groundwater remediation), DOE orders, and Washington Administrative Code.

- Summarize the results of groundwater monitoring conducted to assess the effects of interim remedial actions conducted under CERCLA.

- Describe the results of vadose zone monitoring and characterization.

- Summarize groundwater modeling activities.

- Summarize the installation, maintenance, and decommissioning of Hanford Site monitoring wells. 
As in previous reports, the compact disk accompanying this report contains groundwater data for the fiscal year and historical data for selected constituents.

\subsection{Related Reports}

Other reports and databases relating to Hanford Site groundwater include the following:

\section{RCRA regulates \\ facilities used to \\ treat, store, or \\ dispose of \\ hazardous, non- \\ radioactive waste. \\ At Hanford, the \\ law applies to sites \\ that contained \\ hazardous or mixed \\ (hazardous and \\ radioactive) waste. \\ RCRA stipulates \\ requirements for \\ monitoring the \\ groundwater \\ beneath these sites.}

- Hanford Environmental Information System (HEIS) - This is the main environmental database for the Hanford Site that stores groundwater chemistry data, as well as other environmental data (e.g., soil chemistry, survey data).

- Quarterly data transmittals - DOE transmits informal reports quarterly to the Washington State Department of Ecology after groundwater data collected for the RCRA program have been verified and evaluated. These reports describe changes or highlights of the quarter with reference to HEIS for the analytical results.

- Fiscal Year 2002 Annual Summary Report for the 200-UP-1 and 200-ZP-1 Pump-and-Treat Operations (DOE/RL-2002-67) - This report describes results of remediation and monitoring in two groundwater operable units in the 200 West Area.

- Calendar Year 2002 Annual Summary Report for the 100-HR-3, 100-KR-4, and 100-NR-2 Operable Unit Pump-and-Treat Operations (DOE/RL-2003-09) - This report describes results of remediation and monitoring in groundwater operable units in the $100-\mathrm{K}, 100-\mathrm{N}$, 100-D, and 100-H Areas.

- Fiscal Year 2002 Annual Summary Report for the In Situ Redox Manipulation Operations (DOE/RL-2003-05) - This report describes activities related to the remediation system in the southwest 100-D Area.

- Aquifer Sampling Tube Results for Fiscal Year 2003 (PNNL-14444) - This report presents results of analyses of water samples collected from monitoring points along the 100 Areas shoreline October 2002 through January 2003.

- Hanford Site Environmental Report for Calendar Year 2002 (PNNL-14295) - This annual report summarizes environmental data, describes environmental management performance, and reports the status of compliance with environmental regulations.

- Hanford Site Climatological Data Summary 2002 with Historical Data (PNNL-14242) This annual report summarizes data on temperature, precipitation, and other weather conditions that may impact groundwater recharge.

\subsection{Groundwater Remediation Project}

The goal of the Groundwater Remediation Project is to protect human health and the environment from Hanford contaminants. Fluor Hanford, Inc. manages the Groundwater Remediation Project for DOE. The groundwater project is under the umbrella of the Groundwater Remediation Project.

The Groundwater Remediation Project has five focus areas (DOE/RL-2002-68):

- Remediating high-risk waste sites.

- Reducing recharge (preventing water from moving contaminants through the soil).

- Shrinking the contaminated area.

- Remediating groundwater.

- Monitoring groundwater. 
The Groundwater Remediation Project also is working to develop and apply technology that solves some of Hanford's toughest groundwater problems. In addition, the project performs site-wide assessments aimed at understanding contaminant behavior and associated risks and manages Hanford's key environmental data systems.

Throughout its work, the Groundwater Remediation Project will continually seek the active involvement of state and federal regulators, tribal governments, the state of Oregon, stakeholders, and the public.

\subsection{Helpful Information}

All of the groundwater and aquifer tube data from fiscal year 2003, including anomalous values and data flags, are included in the data files that accompany this report and in the HEIS database.

This report uses the following conventions for displaying data.

Contaminant plume maps:

- Are based on average fiscal year 2003 data for each well, excluding data that appear erroneous.

- Use data from fiscal years 2001 and 2002 if there were no new data for a well in fiscal year 2003.

Trend plots:

- Use open symbols to show levels of contaminants so low the laboratory could not detect them. These results are typically reported and plotted as values that represents the detection limit.

- Display analytical results that appear to be erroneous if they do not distort the scale or obscure the data trends. If the outlying data distort the figure, they are not plotted.

Chemical results:

- Express nitrate and nitrite as the $\mathrm{NO}_{3}$ and $\mathrm{NO}_{2}$ ions, respectively.

- Figures showing chromium include total chromium in filtered samples and hexavalent chromium in filtered or unfiltered samples. Dissolved chromium in Hanford Site groundwater is virtually all hexavalent, so filtered total chromium represents hexavalent chromium.

- Are compared with state or federally enforceable drinking water standards. Although Hanford Site groundwater is not generally used for drinking, these levels provide perspective on contaminant concentrations. Radionuclide concentrations also are compared with DOE derived concentration guides (Table 5.2 of PNNL-13080).

\section{Conversion Table}

The primary units of measurement in this report are metric. To convert metric units to English units, use the information provided in this table.

\begin{tabular}{|c|c|c|}
\hline Multiply & By & To Obtain \\
\hline centimeters & 0.394 & inches \\
\hline meters & 3.28 & feet \\
\hline kilometers & 0.621 & miles \\
\hline kilograms & 2.205 & pounds \\
\hline liters & 0.2642 & gallons \\
\hline square meters & 10.76 & square feet \\
\hline hectares & 2.47 & acres \\
\hline square kilometers & 0.386 & square miles \\
\hline cubic meters & 1.308 & cubic yards \\
\hline curie & $3.7 \times 10^{10}$ & becquerel \\
\hline picocurie & 0.03704 & becquerel \\
\hline rem & 0.01 & sievert \\
\hline${ }^{\circ} \mathrm{C}$ & $\left({ }^{\circ} \mathrm{C} \times 9 / 5\right)+32$ & ${ }^{\circ} \mathrm{F}$ \\
\hline
\end{tabular}

\section{Units of Measure}

$\mathrm{\mu g} / \mathrm{L} \quad$ micrograms per liter $\mu \mathrm{S} / \mathrm{cm}$ microsiemens per centimeter $\mathrm{mg} / \mathrm{L} \quad$ milligrams per liter $\mathrm{mL} / \mathrm{g}$ milliliters per gram $\mathrm{mM}$ millimolar $\mathrm{mm} / \mathrm{yr}$ millimeters per year $\mathrm{pCi} / \mathrm{g}$ picocuries per gram $\mathrm{pCi} / \mathrm{L}$ picocuries per liter $\mathrm{pCi} / \mathrm{mg}$ picocuries per milligram $\mathrm{ppb}$ parts per billion ppm parts per million

ppmv parts per million volume 
Table 1.1-1. Regulated Units and Groundwater Operable Units on the Hanford Site

\begin{tabular}{|c|c|c|c|}
\hline Site or Operable Unit & $\begin{array}{c}\text { Type of Monitoring } \\
\text { Program }\end{array}$ & Text & FY 2003 Highlights \\
\hline \multicolumn{4}{|c|}{ CERCLA Groundwater Operable Units (well/constituent tables in Appendix A) } \\
\hline $100-B C-5$ & Long-term monitoring & 2.2 & New sampling and analysis plan \\
\hline $100-F R-3$ & Long-term monitoring & 2.7 & New sampling and analysis plan \\
\hline $\begin{array}{l}\text { 100-HR-3 } \\
\text { (D pump and treat) }\end{array}$ & IRA; interim ROD & 2.5 & Chromium $>$ remediation goal \\
\hline $\begin{array}{l}\text { 100-HR-3 } \\
\text { (D redox site) }\end{array}$ & IRA; interim ROD & 2.5 & Chromium > remediation goal; barrier complete \\
\hline $\begin{array}{l}\text { 100-HR-3 } \\
\text { (H pump and treat) }\end{array}$ & IRA; interim ROD & 2.6 & Chromium $>$ remediation goal \\
\hline $100-\mathrm{KR}-4$ & IRA; interim ROD & 2.3 & Chromium $>$ remediation goal \\
\hline $100-N R-2$ & IRA; interim ROD & 2.4 & No decrease in plume size \\
\hline 1100-EM-1 & $\begin{array}{l}\text { Natural attenuation; } \\
\quad \text { final ROD }\end{array}$ & 2.13 & Average TCE $<5 \mu \mathrm{g} / \mathrm{L}$ \\
\hline $200-\mathrm{BP}-5$ & Long-term monitoring & 2.10 & New sampling and analysis plan \\
\hline 200-PO-1 & Long-term monitoring & 2.11 & New draft sampling and analysis plan \\
\hline 200-UP-1 & Interim action $\mathrm{ROD}$ & 2.9 & $\begin{array}{l}\text { Technetium-99 < remediation goal; uranium }>\text { remediation } \\
\text { goal }\end{array}$ \\
\hline $200-\mathrm{ZP}-1$ & Interim action $\mathrm{ROD}$ & 2.8 & Heart of plume contained \\
\hline 300-FF-5 (300 Area) & $\begin{array}{l}\text { Natural attenuation; } \\
\text { interim ROD }\end{array}$ & 2.12 & Average TCE $<5 \mu \mathrm{g} / \mathrm{L}$; uranium remains elevated \\
\hline 300-FF-5 (north) & $\begin{array}{l}\text { Operations and } \\
\text { Maintenance plan }\end{array}$ & 2.12 & Tritium levels decreasing \\
\hline \multicolumn{4}{|c|}{ RCRA Units (well location maps, well/constituent tables, statistics tables, and flow rates in Appendix B) } \\
\hline $116-\mathrm{N}-1(1301-\mathrm{N})$ facility & Indicator evaluation & 2.4.3.1 & No CIP exceedance ${ }^{(a)}$ \\
\hline $116-\mathrm{N}-3(1325-\mathrm{N})$ facility & Indicator evaluation & 2.4.3.3 & No CIP exceedance ${ }^{(a)}$ \\
\hline $\begin{array}{l}\text { 120-N-1, 120-N-2 } \\
(1324-\mathrm{N} / \mathrm{NA}) \text { facilities }\end{array}$ & Indicator evaluation & 2.4.3.2 & No CIP exceedance ${ }^{(a)}$ \\
\hline $\begin{array}{l}\text { 116-H-6 }(183-\mathrm{H}) \\
\text { evaporation basins }\end{array}$ & Corrective action & 2.6 .3 & $\begin{array}{l}\text { Monitoring during IRA; chromium, nitrate, technetium-99, } \\
\text { uranium }\end{array}$ \\
\hline 216-A-29 ditch & Indicator evaluation & 2.11.3.3 & No CIP exceedance ${ }^{(a)}$ \\
\hline $216-\mathrm{B}-3$ pond & Indicator evaluation & 2.11.3.5 & Demonstration of alternative statistical method \\
\hline 216-B-63 trench & Indicator evaluation & 2.10.3.2 & No CIP exceedance ${ }^{(a)}$ \\
\hline 216-S-10 pond and ditch & Indicator evaluation & 2.9.3.4 & No CIP exceedance; ${ }^{(a)}$ two downgradient wells remain \\
\hline $216-\mathrm{U}-12 \mathrm{crib}$ & Assessment & 2.9.3.1 & $\begin{array}{l}\text { Continued assessment; two downgradient wells remain; } \\
\text { new monitoring plan }\end{array}$ \\
\hline $316-5$ process trenches & Corrective action & 2.12 .3 & $\begin{array}{l}\text { Monitoring during natural attenuation IRA; demonstration } \\
\text { of alternative statistical method }\end{array}$ \\
\hline LERF & Indicator evaluation & 2.10.3.5 & Insufficient wells; no statistical comparisons \\
\hline LLWMA 1 & Indicator evaluation & 2.10.3.3 & No CIP exceedance ${ }^{(a)}$ \\
\hline LLWMA 2 & Indicator evaluation & 2.10.3.4 & No CIP exceedance ${ }^{(a)}$ \\
\hline LLWMA 3 & Indicator evaluation & 2.8.3.1 & No CIP exceedance ${ }^{(a)}$ \\
\hline LLWMA 4 & Indicator evaluation & 2.8.3.2 & No CIP exceedance; ${ }^{(a)}$ two downgradient wells remain \\
\hline NRDWL & Indicator evaluation & 2.11.3.6 & No CIP exceedance \\
\hline PUREX cribs & Assessment & 2.11.3.1 & Continued assessment; nitrate \\
\hline SST WMA A-AX & Indicator evaluation & 2.11.3.2 & No CIP exceedance ${ }^{(a)}$ \\
\hline
\end{tabular}


Table 1.1-1. (contd)

\begin{tabular}{|c|c|c|c|}
\hline Site or Operable Unit & $\begin{array}{l}\text { Type of Monitoring } \\
\text { Program }\end{array}$ & Text & FY 2003 Highlights \\
\hline \multicolumn{4}{|c|}{ RCRA Units (well location maps, well/constituent tables, statistics tables, and flow rates in Appendix B) (contd) } \\
\hline SST WMA B-BX-BY & Assessment & 2.10.3.1 & Continued assessment; nitrate, nitrite \\
\hline SST WMA C & Indicator evaluation & 2.10.3.6 & Temporarily ceased CIP comparisons \\
\hline SST WMA S-SX & Assessment & 2.9.3.3 & Continued assessment; chromium \\
\hline SST WMA T & Assessment & 2.8.4.3 & Continued assessment \\
\hline SST WMA TX-TY & Assessment & 2.8.4.4 & Continued assessment; chromium \\
\hline SST WMA U & Assessment & 2.9.3.3 & Continued assessment; nitrate \\
\hline \multicolumn{4}{|c|}{ Other Regulated Units (well location maps, well/constituent tables in Appendix C) } \\
\hline $100-\mathrm{K}$ basins & AEA & 2.3 .3 & No leaks detected \\
\hline 200 Area TEDF & WAC $173-216$ & 2.11.5.1 & No influence in upper aquifer \\
\hline $4608 \mathrm{~B} / \mathrm{C}$ process ponds & WAC $173-216$ & 2.11.5.3 & No permit limits exceeded \\
\hline ERDF & CERCLA & Appendix C & No impact on groundwater \\
\hline SALDS & WAC 173-216 & 2.8 .5 & $\begin{array}{l}\text { No permit limits exceeded; tritium plume possibly reached } \\
200 \text { West boundary; two dry wells }\end{array}$ \\
\hline SWL & WAC 173-304 & 2.11.5.2 & $\begin{array}{l}\text { Five constituents exceeded background or standards; low } \\
\text { levels of organics }\end{array}$ \\
\hline
\end{tabular}

(a) Analysis of CIP provided no evidence of groundwater contamination with hazardous constituents from the unit.

AEA $=$ Atomic Energy Act of 1954.

CERCLA = Comprehensive Environmental Response, Compensation, and Liability Act.

CIP $=$ Contamination indicator parameters.

ERDF $=$ Environmental Restoration Disposal Facility.

$\mathrm{FY} \quad=$ Fiscal year.

IRA $\quad=$ Interim remedial action.

LERF $\quad=$ Liquid Effluent Retention Facility.

LLWMA = Low-level waste management area.

NRDWL = Nonradioactive Dangerous Waste Landfill.

PUREX = Plutonium-Uranium Extraction Plant.

RCRA = Resource Conservation and Recovery Act.

ROD $=$ Record of decision.

SALDS = State-Approved Land Disposal Site.

SST $=$ Single-shell tank.

SWL $\quad=$ Solid Waste Landfill.

TCE $=$ Trichloroethene.

TEDF $\quad=$ Treated Effluent Disposal Facility.

WAC $=$ Washington Administrative Code.

WMA $=$ Waste management area.

For additional information on contaminants that are found at the Hanford Site, see "Summary Fact Sheets for Selected Environmental Contaminants to Support Health Risk Analysis" (Peterson et al. 2002), available on the website of Environmental Assessment Division, Argonne National Laboratory (http://www.ead.anl.gov). Click on "publications" and search for the title. 


\subsection{Groundwater}

This section discusses groundwater flow and chemistry on the Hanford Site. Section 2.1 gives a general overview of site-wide flow and plumes. Sections 2.2 through 2.13 describe groundwater for each of the groundwater interest areas/operable units. These regions are presented in geographic order (north to south, west to east). Monitoring of specific units under the Comprehensive Environmental Response, Compensation, and Liability Act, Resource Conservation and Recovery Act, or Washington Administrative Code are discussed within relevant sections. Section 2.14 describes groundwater flow and chemistry in the confined aquifers.

Waste sites, hydrogeology, and methods of sampling and analysis are described in Hanford Site Groundwater: Settings, Sources, and Methods (PNNL-13080). 


\subsection{Overview of Hanford Site Groundwater}

\section{J. Hartman and J. P. McDonald}

This section provides a broad picture of groundwater flow and contaminant distribution beneath the Hanford Site. Details for specific locations are included in Sections 2.2 through 2.14. Supporting information for Resource Conservation and Recovery Act (RCRA), Comprehensive Environmental Response, Compensation, and Liability Act (CERCLA), and other regulated units is compiled in Appendices A, B, and C.

The uppermost aquifer beneath most of the Hanford Site is unconfined and is composed of unconsolidated to semiconsolidated sediment of the Hanford and Ringold Formations, which was deposited on the basalt bedrock. In some areas, deeper parts of the aquifer are confined locally by layers of silt and clay. Confined aquifers occur within the underlying basalt and associated sedimentary interbeds.

For site characterization and cleanup, waste sites are grouped into source operable units, and the groundwater beneath the sites is divided into groundwater operable units. For the purposes of this report and for data review and interpretation in fiscal year 2003, the Groundwater Performance Assessment Project (groundwater project) divides the Hanford Site into geographic areas of interest for groundwater monitoring. Figure 2.1-1 illustrates these areas of interest and the operable units boundaries.

Well location maps for each geographic region are included in Sections 2.2 through 2.14. Wells in the 600 Area (i.e., portions of the Hanford Site other than the former operational areas) are shown in Figure 2.1-2.

Monitoring points near the river, called aquifer sampling tubes (or simply aquifer tubes), provide additional information on water quality near the Columbia River. Most of the aquifer tubes are located in the 100 Areas and the Hanford town site. Their locations are shown on well location maps in Sections 2.2 through 2.7.

\subsubsection{Groundwater Flow}

During March and early April 2003, 887 water-level measurements were collected from the unconfined aquifer system and the underlying confined aquifers beneath the Hanford Site. These data are used to (1) prepare contour maps that indicate the general direction of groundwater movement within an aquifer; (2) determine hydraulic gradients, which in conjunction with the hydraulic properties of the aquifer, are used to compute groundwater flow velocities; (3) support groundwater model calibration; and (4) interpret sampling results. This section describes the results of a regional-scale analysis of these data for the unconfined aquifer, which is the aquifer most affected by Hanford operations. Flow in the

\section{DOE monitors}

groundwater

quality all across

the Hanford Site to

know what

contaminants are

present and how

they are moving.

Groundwater is the water that fills the pores or cracks between grains in a layer of sediment or rock. Monitoring the groundwater helps determine what contamination exists beneath the Hanford Site. This information will help regulators and DOE make cleanup decisions based on scientific information and technical capabilities.

DOE has monitored groundwater on the Hanford Site since the 1940s to help determine what chemical and radiological contaminants have made their way to groundwater and how they have migrated in groundwater. Groundwater monitoring is a part of the cleanup mission and will remain a component of long-term stewardship after remediation is completed. 


\section{Groundwater in the unconfined aquifer generally flows west to east beneath the Hanford Site and discharges to the Columbia River.}

Over much of the Hanford Site, the water table continued to decline. The declining water table caused some monitoring wells to go dry; new wells are planned. confined aquifer in the lower Ringold Formation and the upper basalt-confined aquifer is discussed in Section 2.14. For more information regarding water-level monitoring activities, see PNNL-13021.

\subsubsection{March 2003 Water Table}

Figure 2.1-3 presents the March 2003 water-table map for the Hanford Site. Groundwater in the unconfined aquifer generally flows from west to east and discharges to the Columbia River. Steep gradients occur in the west, east, and north regions of the site. Shallow gradients occur southeast of the 100-F Area, and in a broad arc extending from west of the 100-B/C Area trending southeast between Gable Butte and Gable Mountain (Gable Gap), and through the 200 East Area into the central portion of the Hanford Site. The steep gradients in the west and east are due to the presence of the relatively low permeability sediment of the Ringold Formation at the water table, while the low gradient areas are associated with the highly permeable sand and gravel of the Hanford formation.

North of Gable Butte and Gable Mountain, groundwater generally flows from west to east and discharges to the Columbia River. Groundwater enters this region from the Columbia River west of the 100-B/C Area, through Gable Gap, and through the gap between Umtanum Ridge and Gable Butte. An apparent groundwater mound exists 2 kilometers north of Gable Mountain, and is associated with low conductivity Ringold Formation muds at the water table.

Past effluent discharges at U Pond and other facilities caused a groundwater mound to form beneath the 200 West Area. These discharges had largely ceased by the mid-1990s, but a remnant mound remains, which is apparent from the shape of the water-table contours passing through the 200 West Area. Currently, this mound is 12 meters above the estimated pre-Hanford water table. Scientists predict that when equilibrium conditions are established, the water table may be $\sim 5$ to 7 meters higher than the pre-Hanford water table because of artificial recharge from offsite irrigation (PNNL-11801).

Groundwater flow in the central portion of the Hanford Site, encompassing the 200 East Area, is significantly affected by the presence of a buried flood channel, which lies in a northwest to southeast orientation (PNNL-12261). The water table in this area is relatively flat because of the presence of highly permeable sediment of the Hanford formation at the water table. Groundwater flow in this region also is significantly affected by the presence of low permeability sediment of the Ringold Formation at the water table east and northeast of the 200 East Area, as well as basalt above the water table. The water table beneath the 200 East Area is $\sim 2.4$ meters higher than pre-Hanford conditions. Scientists estimate that when equilibrium conditions are established in the 200 East Area, the water table will be near its pre-Hanford elevation (PNNL-11801).

\subsubsection{Water-Table Changes from Fiscal Year 2002}

In the 200 East Area, the water table decline from March 2002 to March 2003 averaged 0.04 meter. This is significantly smaller than the decline measured in previous years (e.g., 0.19 meter in fiscal year 2002; PNNL-14187). The region affected by this smaller than normal decline extends from Gable Gap through the 200 East Area to the Central Landfill, i.e., in the highly conductive sediment of the Hanford formation. The water-table elevation actually increased in the south part of the 200 East Area and into the surrounding 600 Area. This fluctuation in the water table is demonstrated by the hydrograph for well 299-E32-8 in the northwest part of the 200 East Area (Figure 2.1-4). The cause of this fluctuation remains unclear.

Over much of the rest of the Hanford Site, the long-term decline in the water-table elevation continued, although increases did occur in some areas. North of Gable Butte and Gable Mountain, the water-table elevation increased in many areas along the Columbia River, and in the highly permeable sediment from the 100-B/C Area to Gable Gap. These increases are attributed to changes in river stage. In the 200 West Area, the water table 
declined by an average of 0.26 meter (in those areas not influenced by pump-and-treat remediation systems). The largest water-table elevation increase was 1.33 meters in well 1199-39-16E at the city of Richland North Well Field, and the largest decrease was 0.72 meter in well 399-4-10 in the 300 Area.

\subsubsection{Groundwater Contaminants}

During fiscal year 2003, Hanford Site staff sampled 710 wells and 79 aquifer tubes for radiological and chemical constituents. Many of the wells were sampled multiple times, for a total of 1,788 well trips.

Chromium (total or hexavalent) was the most frequently analyzed constituent, analyzed 1,723 times. Anions, iodine-129, metals, technetium-99, strontium-90, and volatile organic compounds were other commonly analyzed constituents (Table 2.1-1). The data from many wells on the Hanford Site are used to meet the objectives of multiple regulations, including RCRA, CERCLA, and the Atomic Energy Act of 1954. Sampling and analysis are coordinated to avoid unnecessary costs.

Monitoring water quality along the river is accomplished by collecting samples from (a) aquifer sampling tubes having sample ports at several depths beneath the shoreline, (b) riverbank springs, and (c) near-shore river water. Use of aquifer sampling tubes at riverbank springs is included in CERCLA monitoring plans for groundwater operable units in the 100 and 300 Areas. Representatives from the U.S. Environmental Protection Agency and Washington State Department of Ecology meet annually with the U.S. Department of Energy (DOE) and its contractors to plan the annual aquifer sampling tube event, which usually occurs during the fall months (DOE/RL-2000-59).

Tritium, nitrate, and iodine-129 are the most widespread contaminants associated with past Hanford Site operations. Their distribution in the unconfined aquifer is shown in Figures 2.1-5, 2.1-6, and 2.1-7. The most prominent portions of these plumes originated at waste sites in the 200 Areas and spread toward the southeast. Nitrate and tritium also had significant sources in the 100 Areas.

Other contaminant plumes include:

- Carbon tetrachloride and associated trichloroethene in the 200 West Area.

- Chromium in the 100 Areas.

- Chromium in the 600 Area south of the 200 Areas.

- Strontium-90 in the 100 Areas.

- Technetium-99 and uranium that extend eastward from the 200 West Area.

- Technetium-99 and uranium with minor amounts of cyanide and cobalt-60 in the northwest 200 East Area.

- Uranium in the 300 Area.

The distribution of hexavalent chromium in aquifer tubes along the 100 Areas is illustrated in Figure 2.1-8. The highest concentrations are detected along the south 100-D Area shoreline. In most cases, concentrations have decreased in recent years.

Table 2.1-2 lists contaminants and refers to the sections in this report where they are discussed. The table highlights contaminants that exceed water quality standards. Analytical results including fiscal year 2003 and historical data are included in the data files accompanying this report.

Available data indicate that the vast majority of contamination on the Hanford Site remains near the water table. Relatively few wells are completed deeper in the aquifer, but in most cases, these detect lower levels of contamination than their shallow counterparts.
Tritium, nitrate, and iodine-129 are

the most widespread contaminants on

the Hanford Site. 


\section{DOE is working to clean up groundwater contamination that may pose a risk to human health or the environment. Remedial actions reduce the movement of contaminants until final cleanup decisions are made.}

A confined aquifer in the Ringold sediment east of the 200 East Area is contaminated with tritium at levels near those in the unconfined aquifer. However, tritium levels drop sharply a short distance downgradient, as discussed in Section 2.14. Deeper still, in the upper basalt-confined aquifer $\sim 25$ meters below the water table, contamination has been detected in only two wells, both near the 200 East Area (see Section 2.14).

The discharge of the Columbia River along the Hanford Reach is controlled by releases from the Priest Rapids Dam, located upstream of the Hanford Site. Daily discharge cycles can cause river elevation changes of up to several meters along the reactor areas. These fluctuations create a bank storage zone containing highly variable water movement patterns. The influx of river water may dilute contamination carried toward the river by groundwater, prior to its discharge through the riverbed sediment and river bank springs. Seasonal discharge cycles also influence the release of groundwater into the river environment.

\subsubsection{Groundwater Remediation}

DOE is working to clean up groundwater contamination that may pose a risk to human health or the environment. Decision-making efforts are organized by groundwater operable unit. The text below summarizes the status of remediation in each operable unit. Additional detail is provided elsewhere in Chapter 2 and Appendix A.

The regulators have created records of decision for seven groundwater operable units:

- 100-HR-3 (100-D and 100-H Areas) and 100-KR-4 (100-K Area) - Chromium may pose a threat to aquatic organisms in the Columbia River. In the 100-K, 100-D, and 100-H Areas, interim action pump-and-treat systems reduce the amount of chromium reaching the river. Also in the 100-D Area, an innovative treatment method immobilizes chromium in the aquifer. In fiscal year 2003, chromium concentrations at all these interim action sites remained above remediation goals (ROD 1996a, 1999a).

- 100-NR-2 (100-N Area) - Strontium-90 concentrations remained much higher than the drinking water standard in wells at the river shore in fiscal year 2003. DOE has operated a pump-and-treat system for strontium-90 as an interim action since 1995 and is investigating alternative remediation methods (ROD 1999b).

- 200-UP-1 (200 West Area) - DOE has operated an interim action pump-and-treat system for technetium-99 and uranium since 1995. In fiscal year 2003, some concentrations of uranium remained above remediation goals. Many of the wells monitoring this area have gone dry, so the sizes of the current plumes are uncertain (ROD 1997).

- 200-ZP-1 (200 West Area) - DOE has operated an interim action pump-and-treat system to prevent carbon tetrachloride from spreading since 1994. In fiscal year 2003, the system continued to limit migration of the heart of the plume (ROD 1995a).

- 300-FF-5 (300 Area and satellite areas to the north) - The interim action involves natural attenuation of the cis-1,2-dichloroethene, trichloroethene, and uranium plumes in the 300 Area. In fiscal year 2003, concentrations of the organic contaminants were low, but uranium remained elevated (ROD 1996b).

- 1100-EM-1 (Richland North Area) - DOE and regulators have determined that the final cleanup action will be monitored attenuation of the contaminant plumes (ROD 1993).

At four operable units, there is no imminent threat to human health or the environment, so no interim remedial actions are required.

- 100-BC-5 (100-B/C Area)

- 100-FR-3 (100-F Area) 
- 200-BP-5 (north 200 East Area)

- 200-PO-1 (south 200 East Area and southeast tritium plume)

Waste sites and plumes will continue to be monitored until there are final records of decision, which may stipulate active remediation or rely on natural processes. 
Table 2.1-1. Number of Groundwater Analyses by Groundwater Interest Area, Fiscal Year 2003

\begin{tabular}{|c|c|c|c|c|c|c|c|c|c|c|c|c|c|}
\hline Constituent & $\begin{array}{l}\text { Site } \\
\text { Total } \\
\end{array}$ & $\underline{100-B C-5}$ & 100-KR-4 & $\underline{100-N R-2}$ & 100-HR-3-D & $100-\mathrm{HR}-3-\mathrm{H}$ & $\underline{100-F R-3}$ & 200-ZP-1 & 200-UP-1 & 200-BP-5 & 200-PO-1 & $300-\mathrm{FF}-5$ & $\underline{1100-E M-1}$ \\
\hline $\begin{array}{l}\text { Carbon } \\
\text { tetrachloride }\end{array}$ & 565 & 0 & 2 & 1 & 0 & 0 & 18 & 241 & 71 & 8 & 73 & 117 & 35 \\
\hline $\begin{array}{l}\text { Chromium (total + } \\
\text { hexavalent) }\end{array}$ & 1,723 & 27 & 211 & 48 & 435 & 191 & 38 & 219 & 143 & 202 & 181 & 22 & 7 \\
\hline Iodine-129 & 278 & 0 & 0 & 0 & 0 & 1 & 0 & 97 & 62 & 52 & 51 & 11 & 4 \\
\hline Nitrate & 1,181 & 15 & 65 & 43 & 72 & 58 & 21 & 264 & 173 & 214 & 159 & 55 & 43 \\
\hline Strontium-90 & 301 & 16 & 57 & 43 & 16 & 24 & 22 & 20 & 11 & 35 & 48 & 9 & 0 \\
\hline Technetium-99 & 655 & 1 & 12 & 1 & 9 & 39 & 0 & 218 & 148 & 195 & 21 & 9 & 3 \\
\hline Tritium & 908 & 18 & 92 & 34 & 49 & 36 & 18 & 206 & 121 & 180 & 66 & 71 & 18 \\
\hline Uranium & 583 & 0 & 0 & 0 & 43 & 38 & 0 & 59 & 121 & 165 & 9 & 134 & 14 \\
\hline
\end{tabular}


Table 2.1-2. Maximum Concentrations of Selected Groundwater Contaminants in Fiscal Year 2003

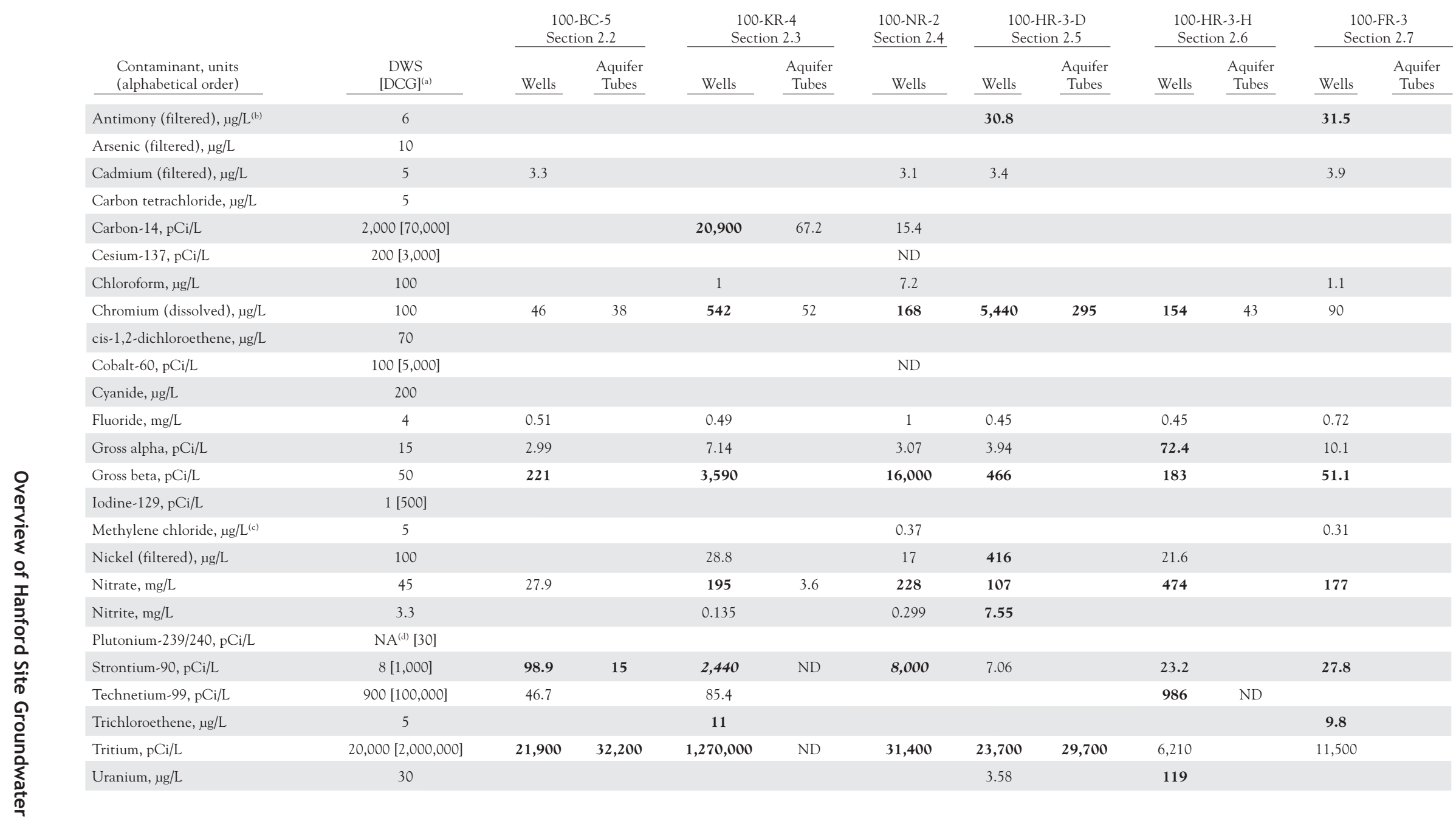


Table 2.1.2. (contd)

\begin{tabular}{|c|c|c|c|c|c|c|c|}
\hline $\begin{array}{l}\text { Contaminant, units } \\
\text { (alphabetical order) }\end{array}$ & $\begin{array}{c}\text { DWS } \\
{\left[\text { [DCG }^{(a)}\right.}\end{array}$ & $\begin{array}{c}\begin{array}{c}200-Z P-1 \\
\text { Section } 2.8 \\
\text { Wells }\end{array} \\
\end{array}$ & $\begin{array}{c}\begin{array}{c}\text { 200-UP-1 } \\
\text { Section 2.9 }\end{array} \\
\text { Wells } \\
\end{array}$ & 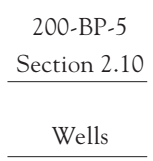 & 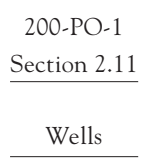 & 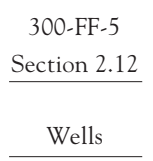 & $\begin{array}{c}\text { 1100-EM-1 } \\
\text { Section } 2.13 \\
\text { Wells } \\
\end{array}$ \\
\hline Antimony (filtered), $\mu \mathrm{g} / \mathrm{L}^{(\mathrm{b})}$ & 6 & 29.2 & 31.1 & 51.1 & 44.8 & & 29.8 \\
\hline Arsenic (filtered), $\mu \mathrm{g} / \mathrm{L}$ & 10 & 4.1 & 8.7 & 7.6 & 9.2 & & \\
\hline Cadmium (filtered), $\mu \mathrm{g} / \mathrm{L}$ & 5 & 3.2 & 3.1 & 4.6 & 3.3 & & \\
\hline Carbon tetrachloride, $\mu \mathrm{g} / \mathrm{L}$ & 5 & 6,200 & 690 & & 0.29 & 0.35 & \\
\hline Carbon-14, pCi/L & $2,000[70,000]$ & & & & & & \\
\hline Cesium-137, $\mathrm{pCi} / \mathrm{L}$ & $200[3,000]$ & & & 1,170 & & & \\
\hline Chloroform, $\mu \mathrm{g} / \mathrm{L}$ & 100 & 31 & 20 & & 0.46 & 3 & 4.4 \\
\hline Chromium (dissolved), $\mu \mathrm{g} / \mathrm{L}$ & 100 & 592 & 209 & 54.9 & 6,250 & 7.3 & \\
\hline cis-1,2-dichloroethene, ug/L & 70 & 0.09 & & & & 160 & $48^{(e)}$ \\
\hline Cobalt-60, $\mathrm{pCi} / \mathrm{L}$ & $100[5,000]$ & & & 48.4 & & & \\
\hline Cyanide, $\mu \mathrm{g} / \mathrm{L}$ & 200 & 6.4 & & 275 & & & \\
\hline Fluoride, $\mathrm{mg} / \mathrm{L}$ & 4 & 4.3 & 0.7 & 0.98 & 1.3 & 0.52 & $4.3^{(\mathrm{s}: \mathrm{s})}$ \\
\hline Gross alpha, pCi/L & 15 & 6.73 & 13.9 & 324 & 10.7 & 43.9 & $77^{(\mathrm{s}, \mathrm{s})}$ \\
\hline Gross beta, $\mathrm{pCi} / \mathrm{L}$ & 50 & 4,390 & 71,200 & 12,100 & 79.7 & 97.5 & $34.7^{(\mathrm{fg}, \mathrm{g})}$ \\
\hline Iodine-129, $\mathrm{pC} \mathrm{i} / \mathrm{L}$ & $1[500]$ & 36.7 & 35.3 & 3.65 & 11.9 & & \\
\hline Methylene chloride, $\mu \mathrm{g} / \mathrm{L}^{(c)}$ & 5 & 18 & 7 & & 4.2 & 1.8 & 5.4 \\
\hline Nickel (filtered), $\mu \mathrm{g} / \mathrm{L}$ & 100 & 328 & 120 & 133 & 864 & 41.6 & \\
\hline Nitrate, $\mathrm{mg} / \mathrm{L}$ & 45 & 2,160 & 1,930 & 735 & 170 & 134 & $261^{(f, g)}$ \\
\hline Nitrite, mg/L & 3.3 & 0.361 & 0.46 & 1.12 & 0.233 & 0.069 & 0.043 \\
\hline Plutonium-239/240, pCi/L & $\mathrm{NA}^{(d)}[30]$ & & & 74.8 & & & \\
\hline Strontium-90, pCi/L & $8[1,000]$ & 1.29 & 53.6 & 5,680 & 21.4 & 4.03 & \\
\hline Technetium-99, pCi/L & $900[100,000]$ & 11,117 & 188,000 & 10,600 & 287 & 319 & 27 \\
\hline Trichloroethene, $\mu \mathrm{g} / \mathrm{L}$ & 5 & 18 & 11 & & 0.88 & 7.2 & $27^{(\mathrm{eff})}$ \\
\hline Tritium, $\mathrm{pCi} / \mathrm{L}$ & $20,000[2,000,000]$ & $2,170,000$ & 634,000 & 27,600 & $5,570,000$ & $3,670,000$ & 251 \\
\hline Uranium, $\mu \mathrm{g} / \mathrm{L}$ & 30 & 367 & 1,190 & 554 & 7.19 & 235 & $18^{(1)}$ \\
\hline
\end{tabular}

Note: Table lists highest concentration for fiscal year 2003 in each groundwater interest area. Concentrations in bold exceed drinking water standards. Concentrations in bold italic exceed DOE derived concentration guides. Blank space indicates the constituent was undetected or not analyzed.

(a) DWS = Drinking water standard; DCG = DOE derived concentration guide. See PNNL-13080 for more information on these standards.

(b) Detection limit is higher than DWS. Not a known contaminant of interest on the Hanford Site.

(c) Common laboratory contaminant.

(d) There is no drinking water standard for plutonium-239/240

(e) City of Richland date; not in HEIS.

(f) From offsite contaminant source.

(g) Framatome ANP data; not in HEIS.

HEIS = Hanford Environmental Information System.

$\mathrm{NA}=$ Not applicable.

ND $=$ Not detected. 


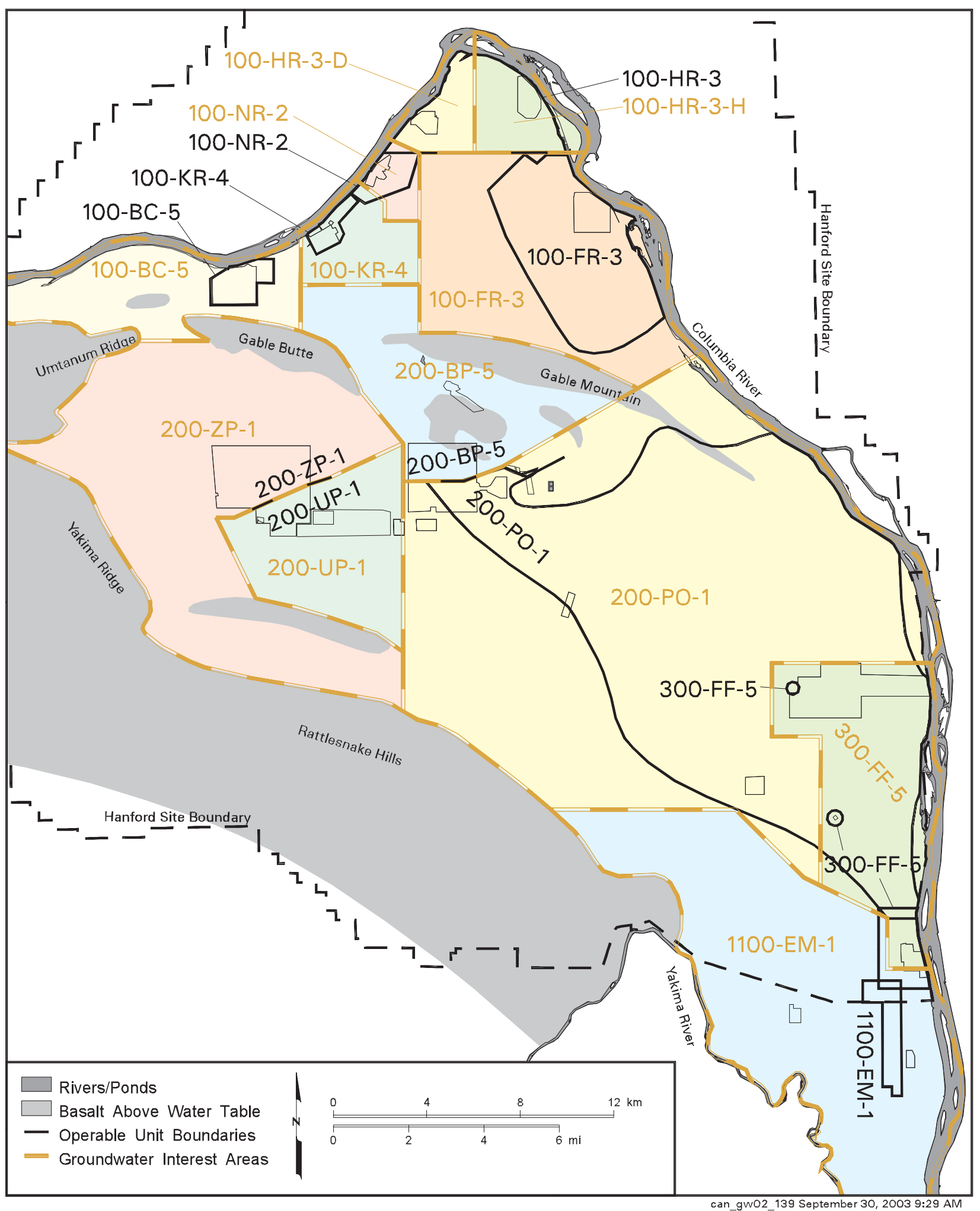

Figure 2.1-1. Groundwater Operable Units and Groundwater Interest Areas on the Hanford Site 


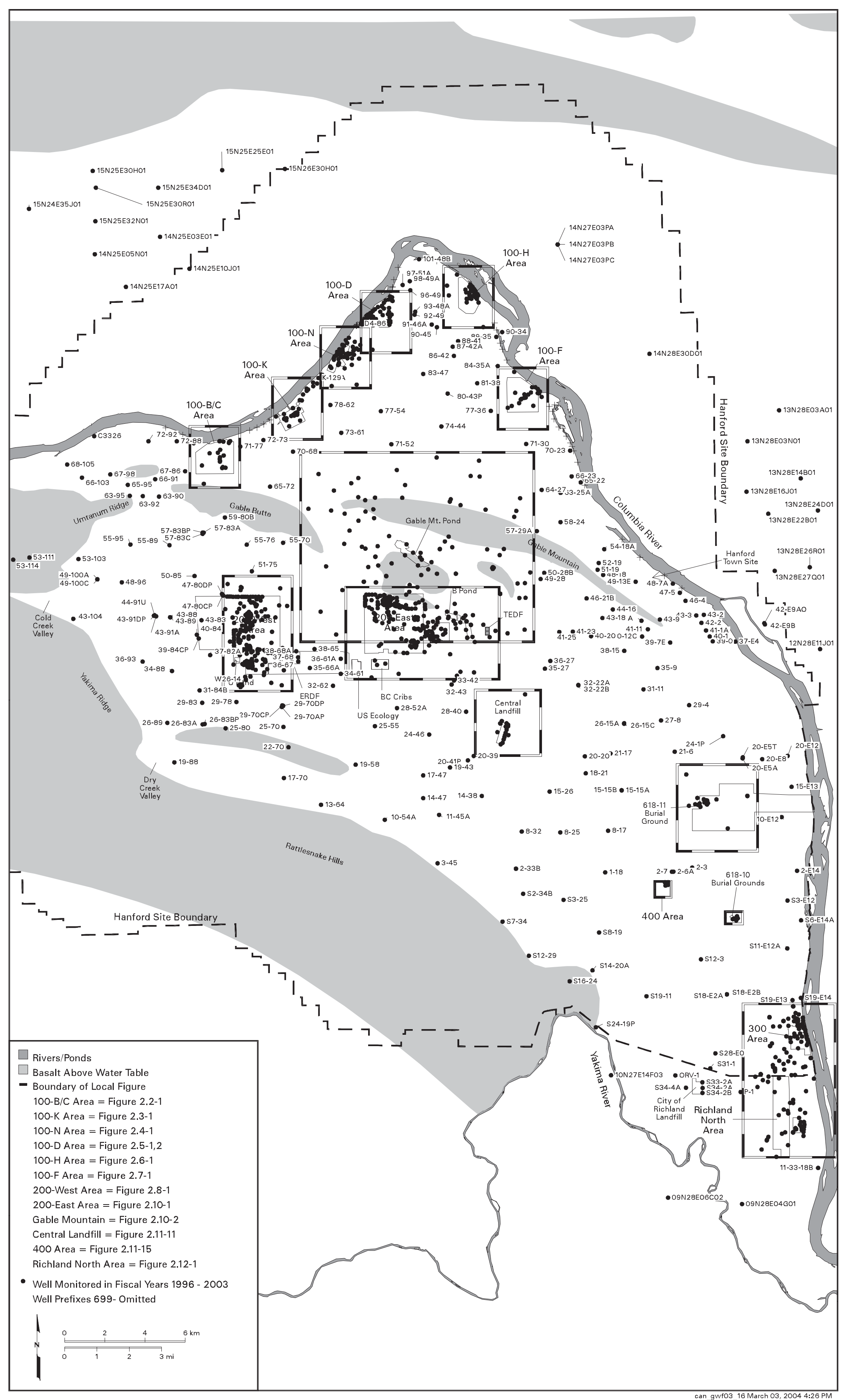

Figure 2.1-2. Groundwater Monitoring Wells in the 600 Area 


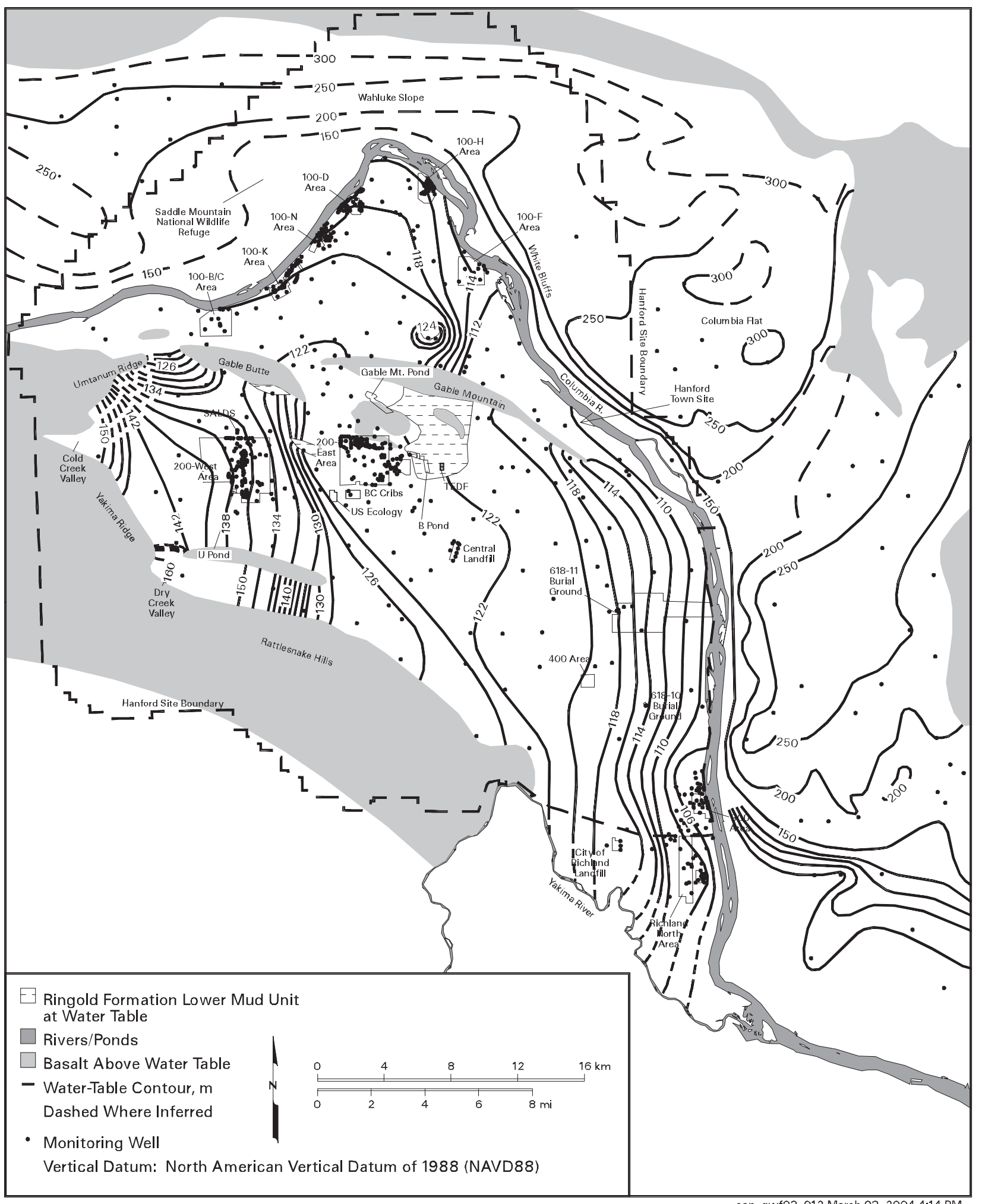

can gwf03 012 March 03, 2004 4:14 PM

Figure 2.1.3. Hanford Site and Outlying Areas Water-Table Map, March 2003 


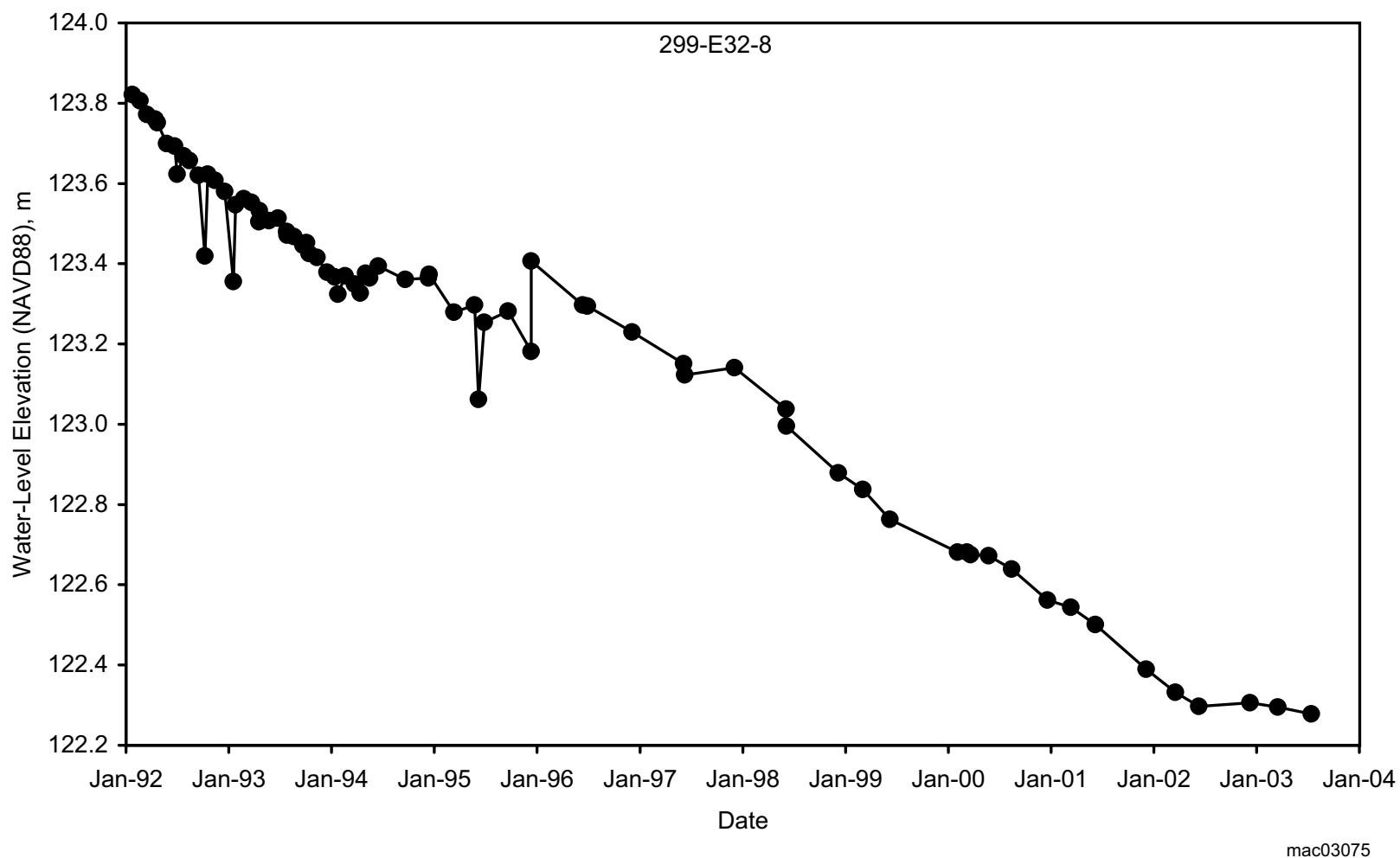

Figure 2.1-4. Water Level in Well 299-E32-8, Northwest 200 East Area 


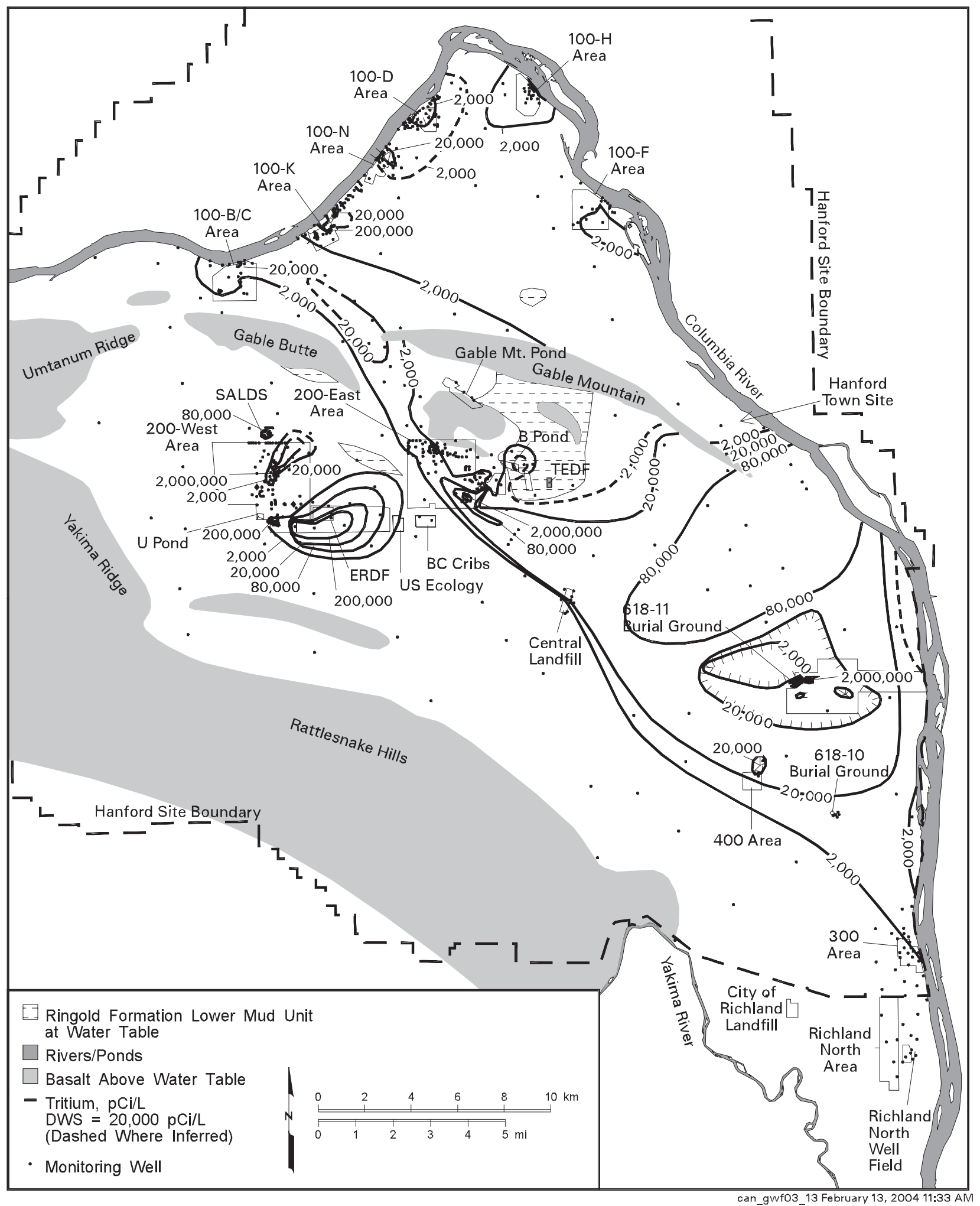

Figure 2.1 -5. Average Fiscal Year 2003 Tritium Concentrations on the Hanford Site, Top of Unconfined Aquifer 


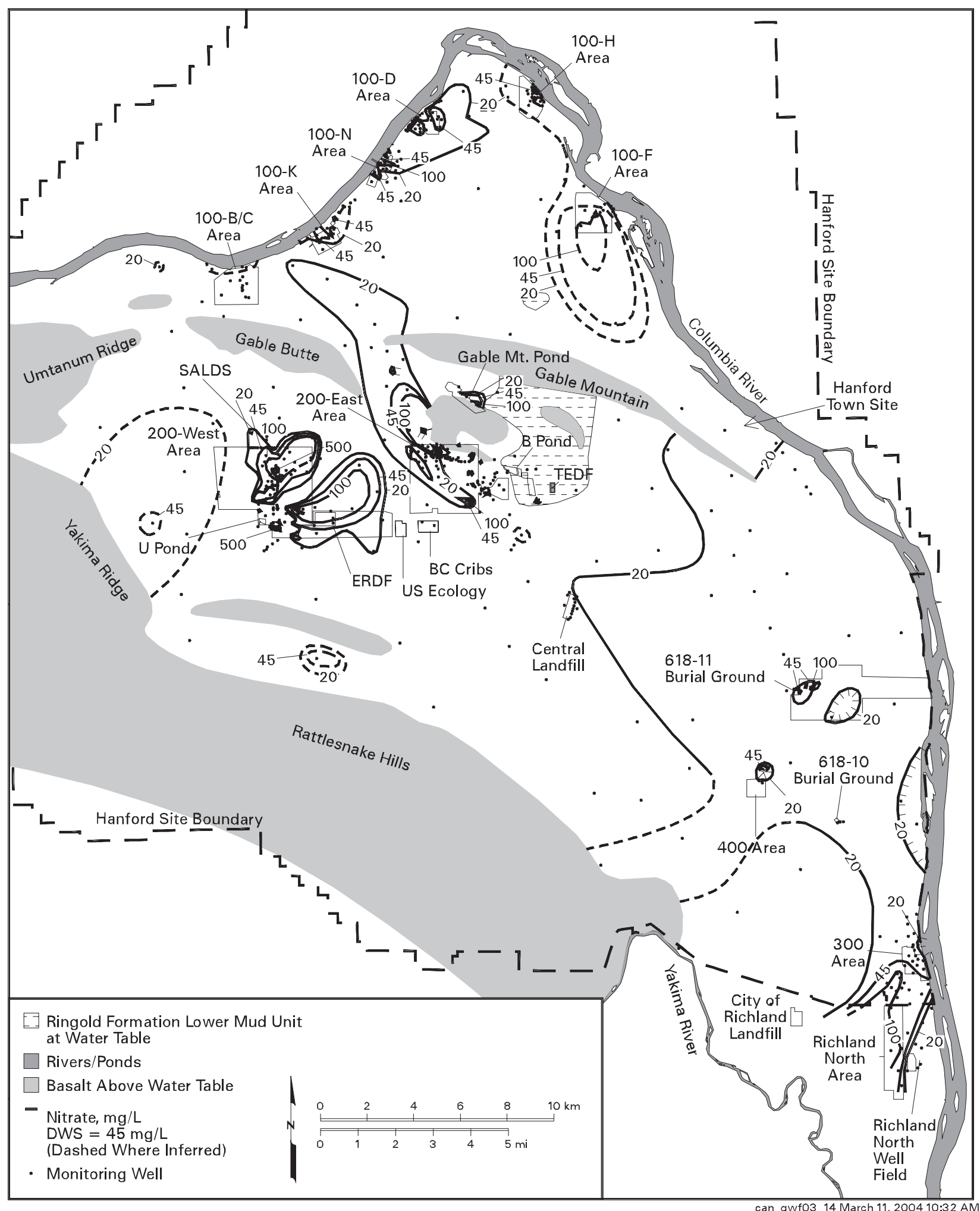

Figure 2.1-6. Average Fiscal Year 2003 Nitrate Concentrations on the Hanford Site, Top of Unconfined Aquifer 


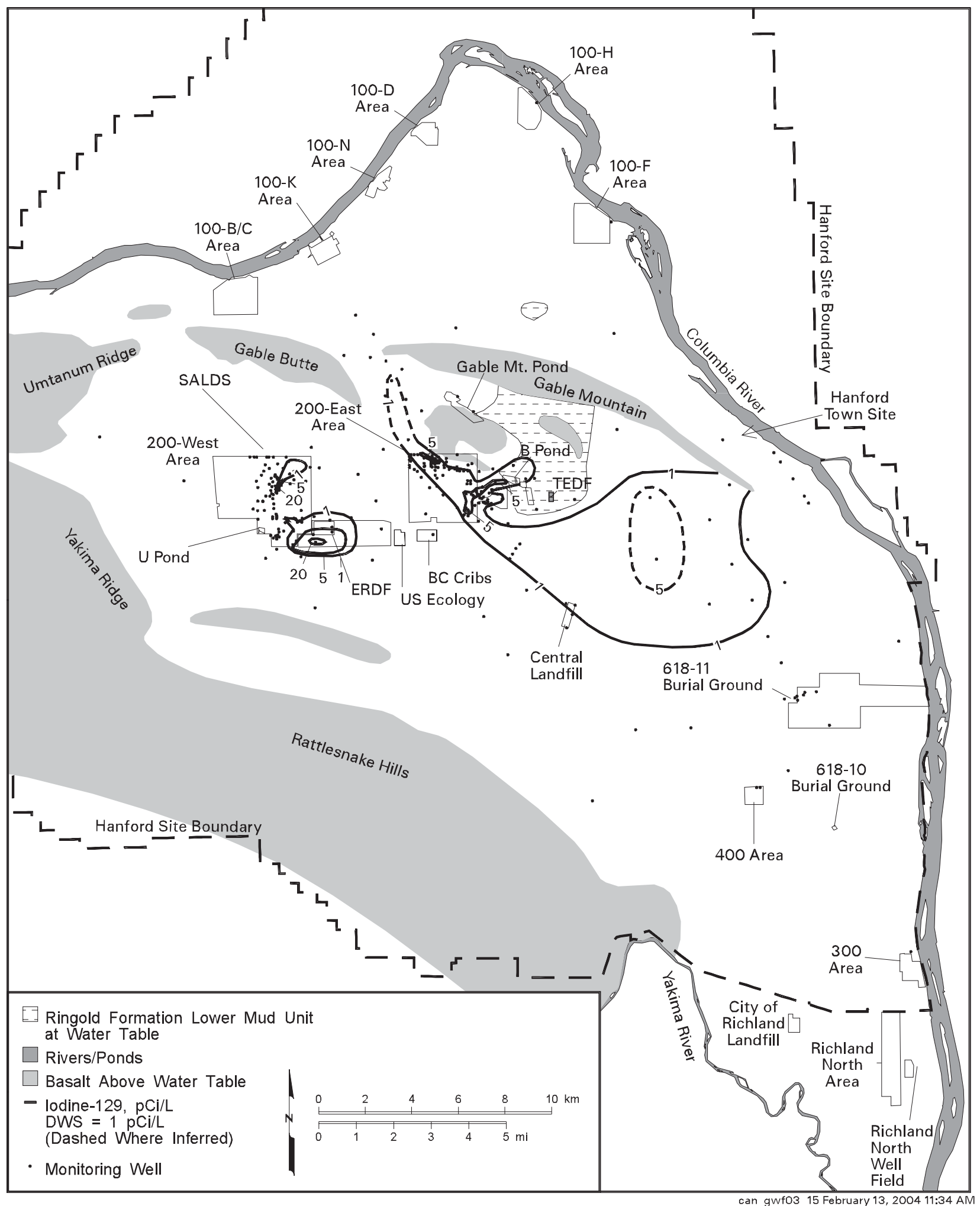

Figure 2.1-7. Average Fiscal Year 2003 Iodine-129 Concentrations on the Hanford Site, Top of Unconfined Aquifer 


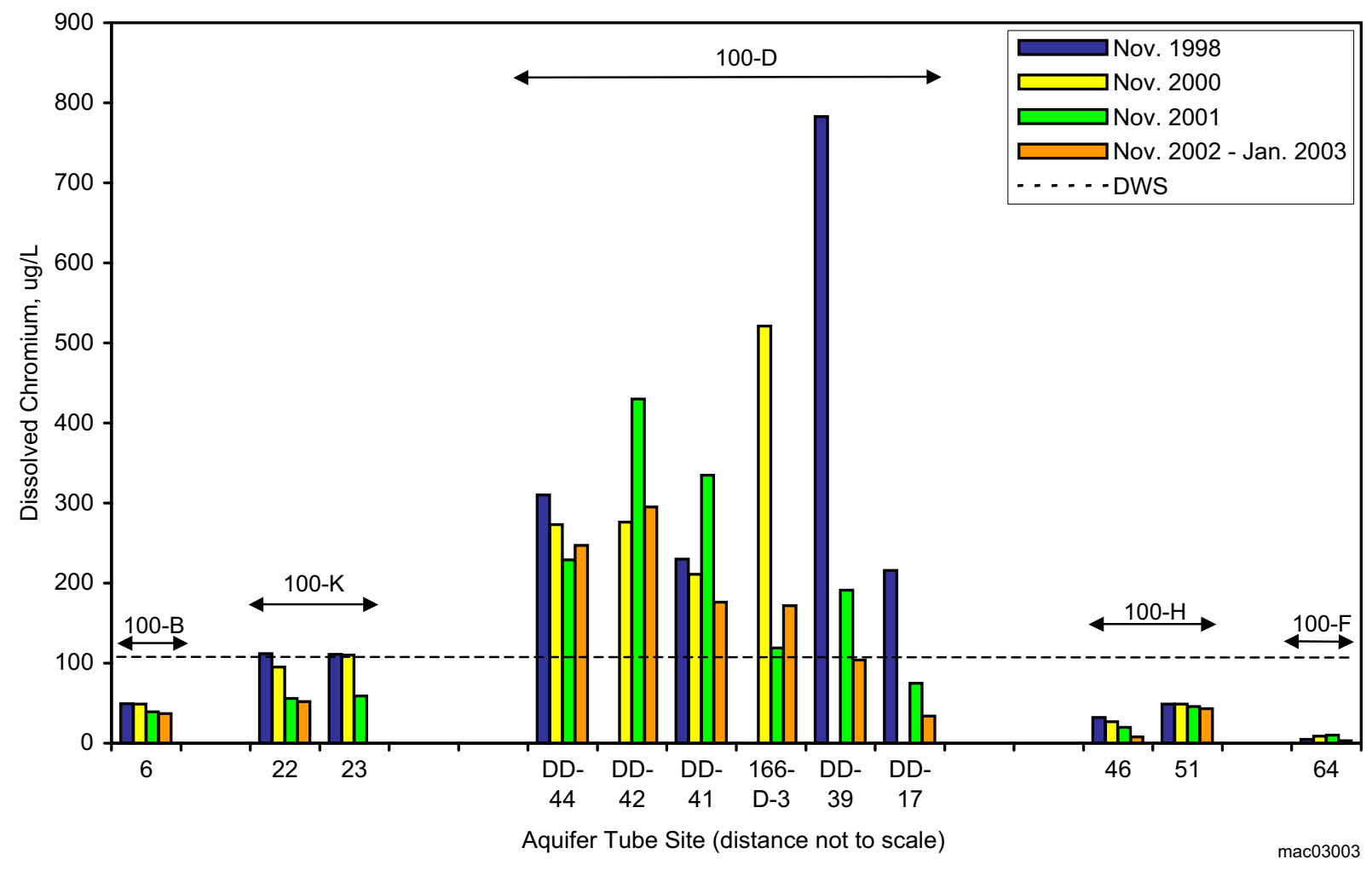

Figure 2.1-8. Dissolved Chromium at Selected Aquifer Tube Sites for Selected Years, 100 Areas (PNNL-14444) 


\subsection{0-BC-5 Operable Unit}

\section{J. Hartman}

The scope of this section is the $100-\mathrm{BC}-5$ groundwater interest area, which includes the 100-BC-5 Operable Unit (Figure 2.1-1). Figure 2.2-1 shows facilities, wells, and shoreline monitoring sites in this region. Groundwater contaminants of concern include strontium-90, tritium, nitrate, and chromium.

Groundwater flows primarily to the north toward the Columbia River beneath the $100-\mathrm{B} / \mathrm{C}$ Area (Figure 2.2-2). The hydraulic gradient is very flat in the south $100-\mathrm{B} / \mathrm{C}$ Area and in the west part of the interest area (Figure 2.1-3). At times the river elevation is higher than the water table, and the river recharges the aquifer west of $100-\mathrm{B} / \mathrm{C}$ Area.

The remainder of this section describes contaminant plumes and concentration trends for the contaminants of concern under the Comprehensive Environmental Response, Compensation, and Liability Act (CERCLA) or Atomic Energy Act of 1954 (AEA) monitoring. There are no active waste disposal facilities or Resource Conservation and Recovery Act (RCRA) sites in the 100-B/C Area.

\subsubsection{Groundwater Contaminants}

This section describes distributions and trends for strontium-90, tritium, nitrate, and chromium beneath the 100-BC-5 groundwater interest area.

\subsubsection{Strontium-90}

The strontium-90 plume beneath 100-B/C Area is wedge-shaped, with an apex in the central 100-B/C Area, extending and spreading north toward the Columbia River (Figure 2.2-3). The plume has not changed significantly in at least 10 years.

Strontium-90 concentrations continued to exceed the $8 \mathrm{pCi} / \mathrm{L}$ drinking water standard in several wells and in two aquifer tubes. In most wells, the concentrations are variable but are not increasing or decreasing overall. The maximum strontium- 90 concentration in fiscal year 2003 was 99 pCi/L in well 199-B3-46, near the 116-C-1 trench (Figure 2.2-4). Concentrations are variable in this well, but there is no clear relationship between concentrations and water levels. Concentrations vary directly with water level in some wells (e.g., well 199-B3-1; Figure 2.2-5).

Strontium-90 is limited to the top of the aquifer. None is detected in deeper well 199-B2-12.

\section{Strontium-90 and tritium exceeded drinking water standards in groundwater at the 100-BC-5 Operable Unit during fiscal year 2003. Both contaminants are limited to the upper aquifer and are not detected in deep wells.}

Groundwater monitoring in the 100-BC-5 groundwater interest area includes CERCLA and AEA monitoring:

CERCLA Monitoring

- Thirteen wells and one seep were sampled as scheduled; one seep was not flowing; samples from one well were not analyzed for three constituents (see Appendix A).

- A new sampling and analysis plan was developed and approved in fiscal year 2003 for implementation in fiscal year 2004.

\section{AEA Monitoring}

- Monitoring is integrated with CERCLA to avoid duplication.

- Two wells that were not in the CERCLA plan were sampled to improve coverage. 


\section{Tritium, nitrate, and chromium concentrations in groundwater are below drinking water standards beneath the 100-BC-5 Operable Unit.}

\subsubsection{Tritium}

A tritium plume with concentrations above $2,000 \mathrm{pCi} / \mathrm{L}$ underlies the north $100-\mathrm{B} / \mathrm{C}$ Area and extends west and east of the area boundaries (Figure 2.1-5). In most wells, tritium concentrations showed a peak in about 1997 to 1998 and have declined since then. Thus, the area of the plume has decreased.

In fiscal year 2003, concentrations exceeded the $20,000 \mathrm{pCi} / \mathrm{L}$ drinking water standard in one well near the Columbia River and in a nearby aquifer tube (Figure 2.2-6). Concentrations also typically exceed the standard in one well near the 118-B-1 burial ground, but that well was not scheduled for sampling in fiscal year 2003.

Data from well 699-72-73 and aquifer tube 14-D, east of the 100-B/C Area (see Figure 2.1-2 for well location), indicate that tritium and technetium-99 from the 200 Areas have migrated north toward the Columbia River. The tritium concentration in well 699-72-73 peaked at over $20,000 \mathrm{pCi} / \mathrm{L}$ in 2001 but declined to $13,000 \mathrm{pCi} / \mathrm{L}$ in fiscal year 2003 (Figure 2.2-7). Aquifer tube 14-D detected 7,800 pCi/L of tritium in November 2002.

Tritium is limited to the upper aquifer. No tritium was detected in deeper well 199-B2-12, which is completed beneath the shallow tritium plume near the former retention basin and disposal trenches.

\subsubsection{Nitrate}

Nitrate is not a major groundwater contaminant in the 100-BC-5 groundwater interest area. Concentrations continued to be below the $45 \mathrm{mg} / \mathrm{L}$ drinking water standard. Concentrations in several wells (199-B2-13, 199-B3-47, and 199-B3-1) in the north 100-B/C Area exceeded $20 \mathrm{mg} / \mathrm{L}$ in fiscal year 2003 . Nitrate concentrations in those wells are variable. Some of the variability appears to relate to river stage, as a higher water table mobilizes contaminated water from the lower vadose zone.

Like tritium, nitrate concentrations are very low in deep well 199-B2-12.

\subsubsection{Chromium}

Chromium concentrations have remained below the $100 \mu \mathrm{g} / \mathrm{L}$ drinking water standard in the 100-B/C Area in recent years. Dissolved chromium concentrations exceed $20 \mu \mathrm{g} / \mathrm{L}$ in an area approximately coincident with the strontium-90 plume.

The highest chromium concentration in fiscal year 2003 was detected in well 199-B3-47 $(46 \mu \mathrm{g} / \mathrm{L})$. Concentrations have been steady or decreasing in recent years. Chromium concentrations in nearby aquifer tubes 5 and 6 were comparable to those in groundwater $(\sim 38 \mu \mathrm{g} / \mathrm{L})$.

\subsubsection{CERCLA Groundwater Monitoring}

No groundwater remediation decisions have been made for the 100-BC-5 Operable Unit. Until such decisions are made, the Groundwater Performance Assessment Project monitors plume extent and contaminant trends, as discussed in the preceding sections.

The sampling and analysis plan that was in effect during fiscal year 2003 (PNNL-13326) specified annual sampling of 9 wells and 2 seeps and biennial sampling of 12 wells (Appendix A). Of these, 13 wells and 2 seeps were scheduled for sampling in fiscal year 2003. All 13 wells were sampled, but gross alpha, gross beta, and strontium-90 were not analyzed in one of the wells (699-63-90) south of the $100-\mathrm{B} / \mathrm{C}$ Area. The impact of this omission is minimal, since the well is upgradient from contaminant sources in the operable unit. One seep was not sampled for the 100-BC-5 Operable Unit because it was not flowing at the time of 
sampling in fall 2002. It was sampled in September 2003 for another project. Those data will be included in the Hanford Site Environmental Report for 2003.

The U.S. Environmental Protection Agency approved a new sampling and analysis plan at the end of September 2003 (DOE/RL-2003-38). The new plan, which is being implemented in fiscal year 2004, revises the monitoring program slightly and calls for the addition of more aquifer sampling tubes to monitor contaminants near the Columbia River. 


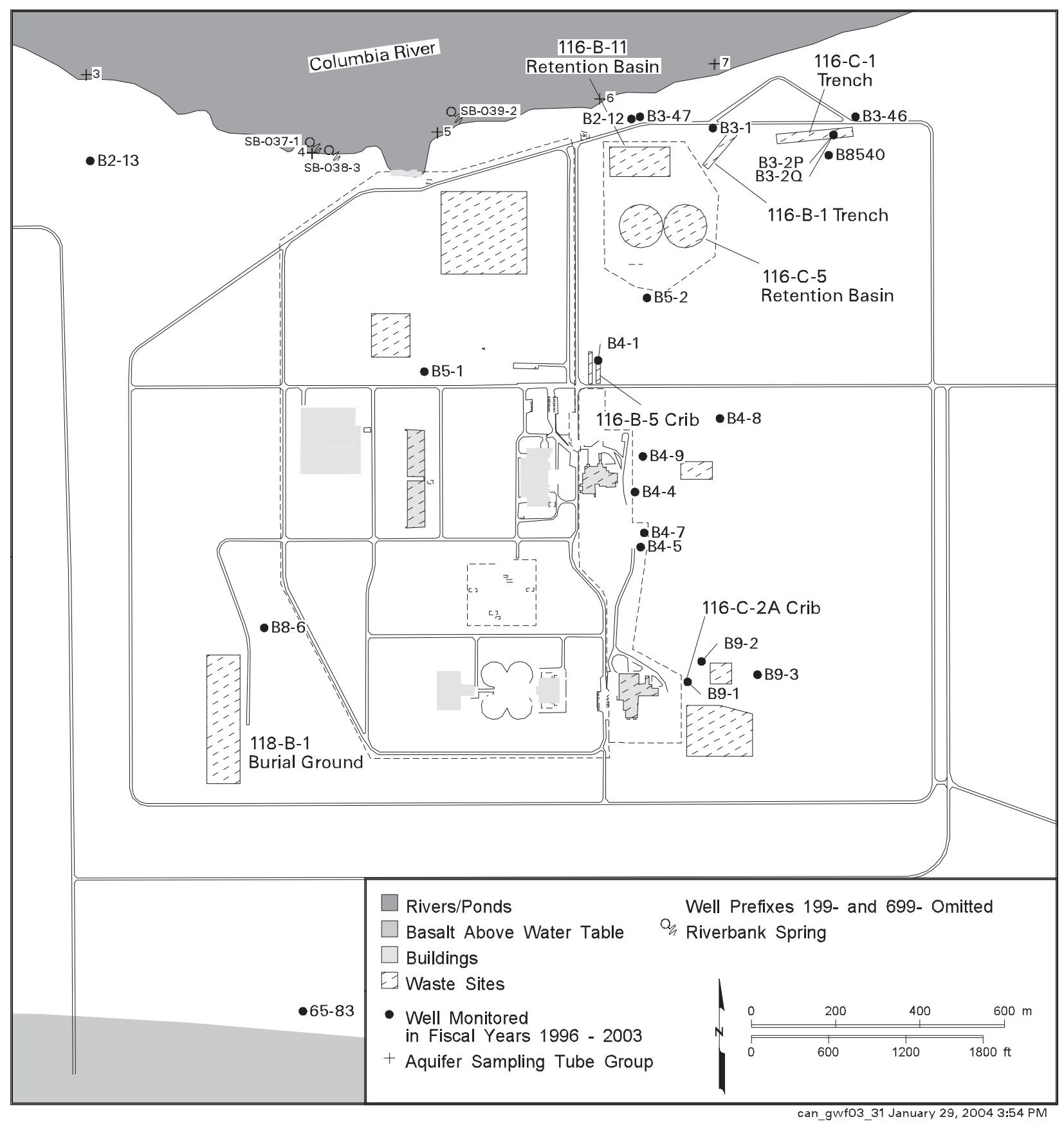

Figure 2.2-1. Groundwater Monitoring Wells in the 100-B/C Area 


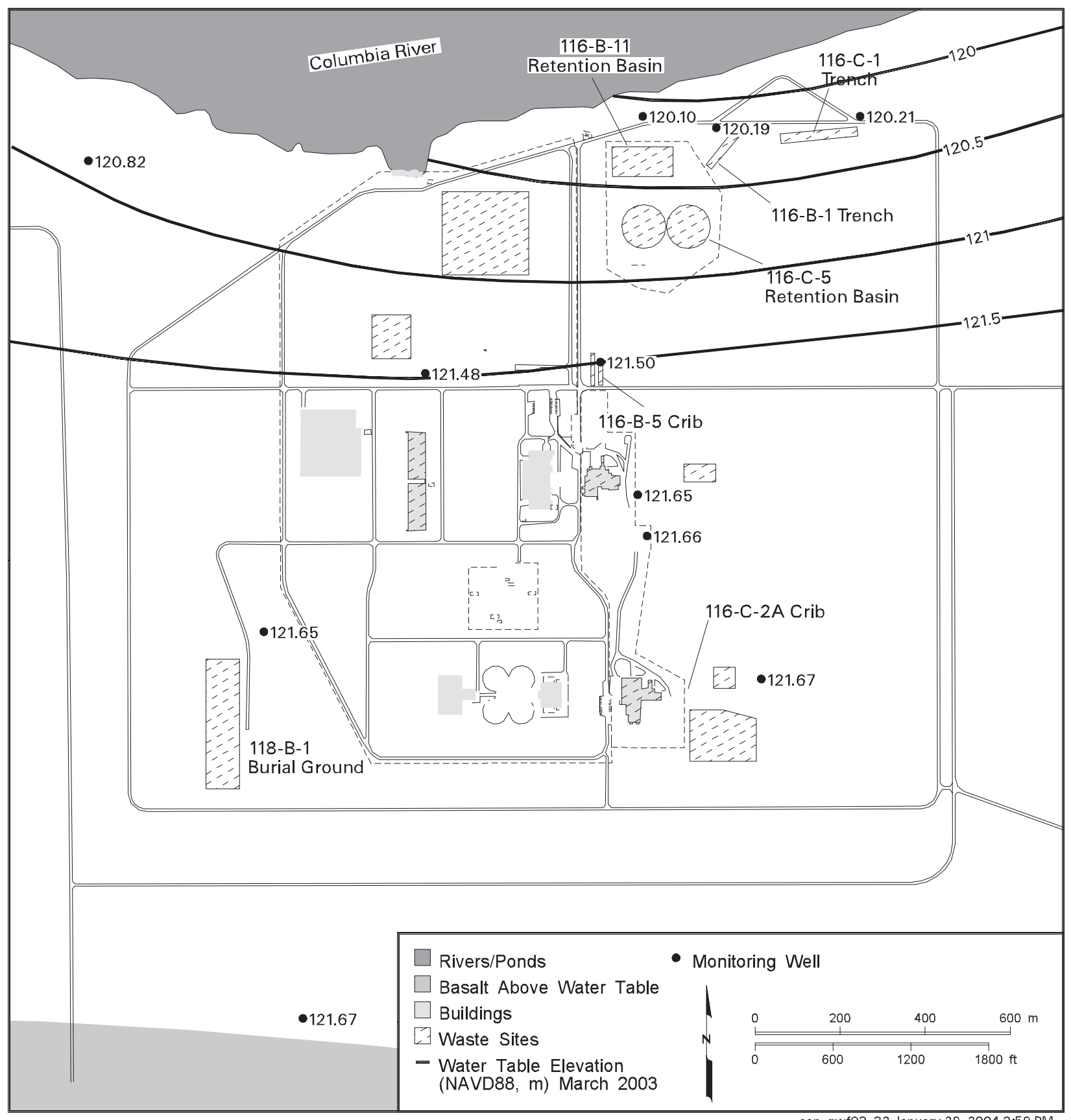

can gwf03 32 January 29, 2004 3:59 PM

Figure 2.2.2. 100-B/C Area Water-Table Map, March 2003 


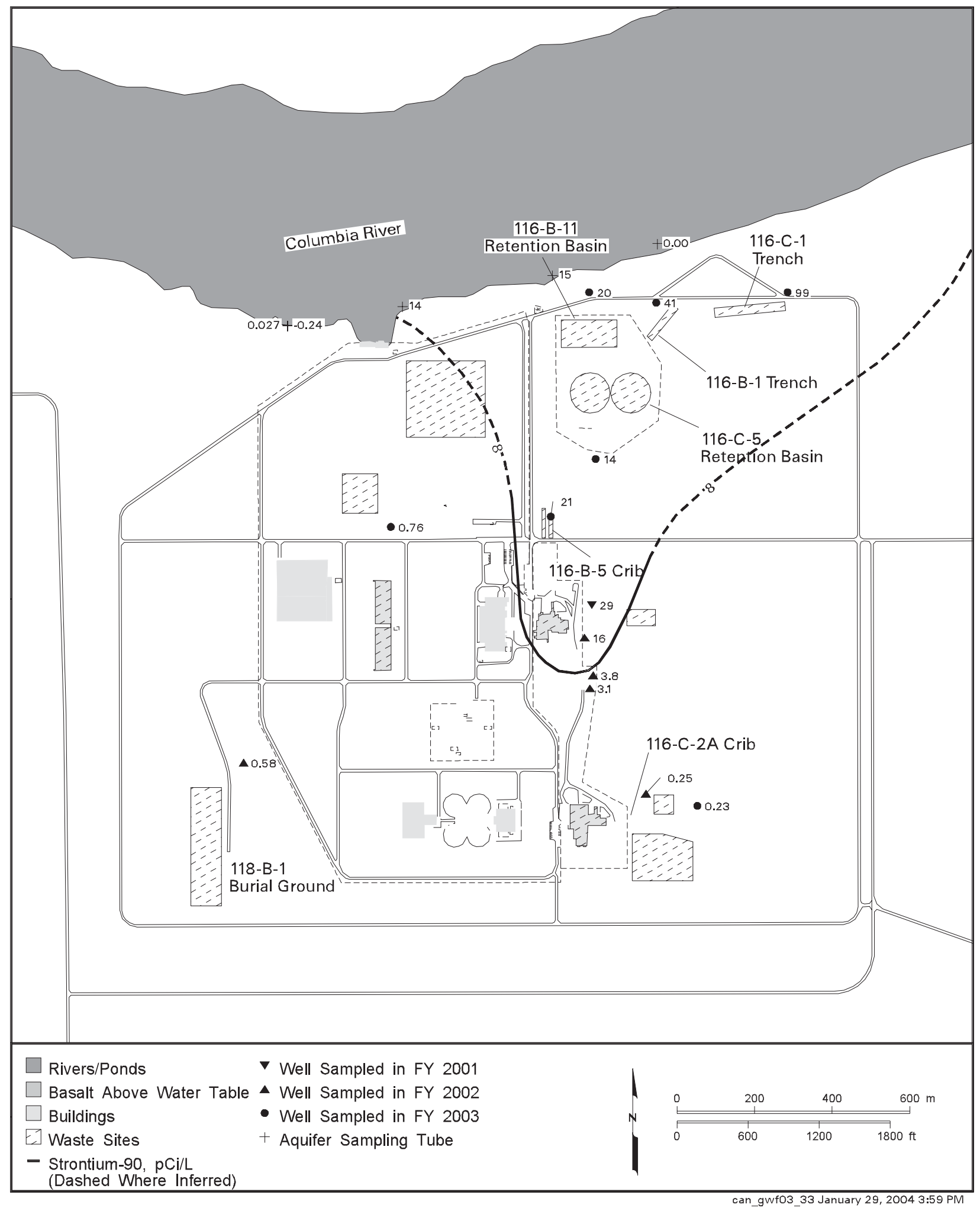

Figure 2.2-3. Average Strontium-90 Concentrations in the 100-B/C Area, Top of Unconfined Aquifer 


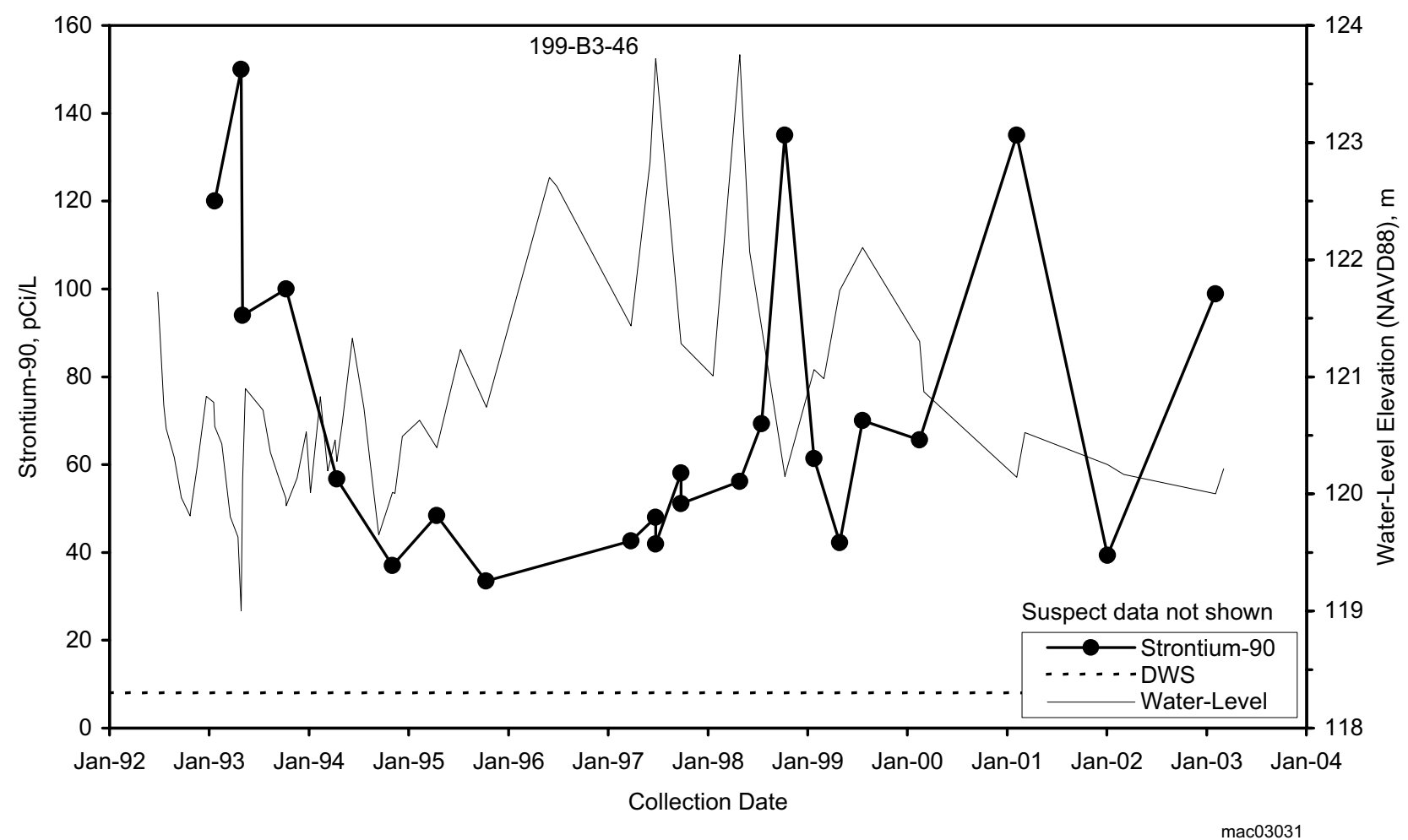

Figure 2.2-4. Strontium-90 Concentrations and Water Levels Near 116-C-1 Trench

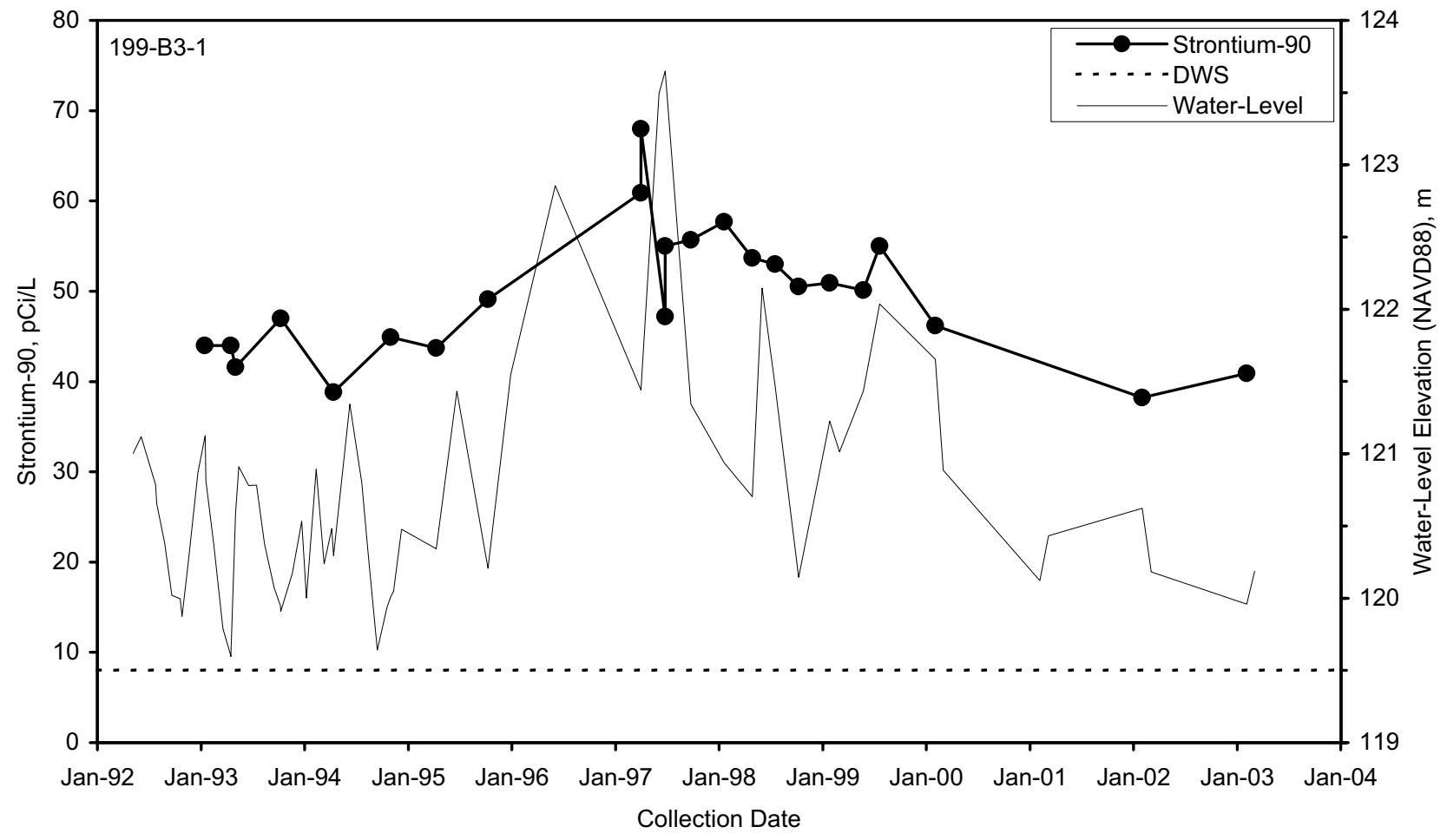

Figure 2.2-5. Strontium-90 Concentrations and Water Levels Near 116-B-1 Trench 


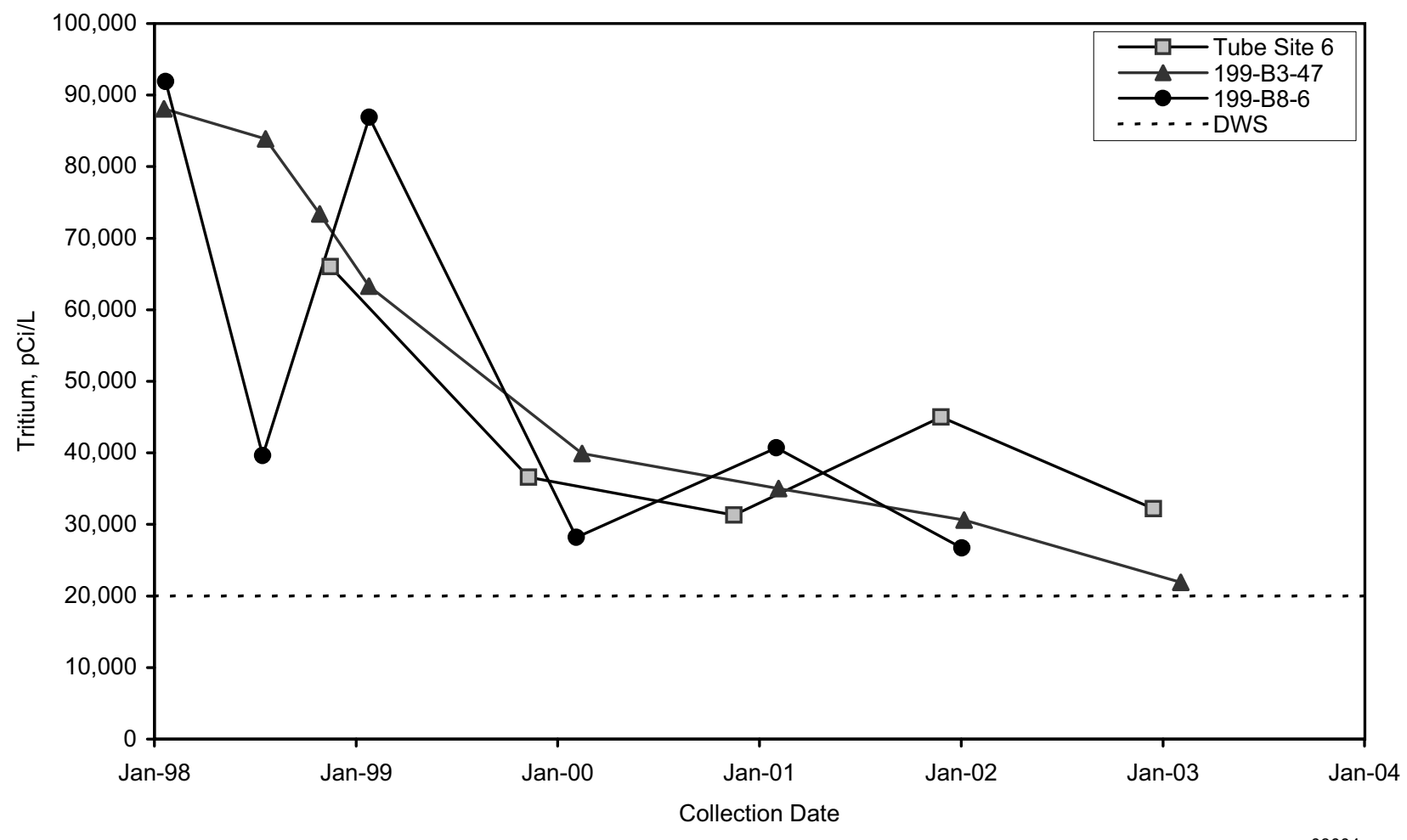

$\operatorname{mac} 03004$

Figure 2.2-6. Tritium Concentrations Near 116-B-11 Retention Basin (well 199-B3-47 and tube site 6), and Near 118-B-1 Burial Ground (well 199-B8-6)

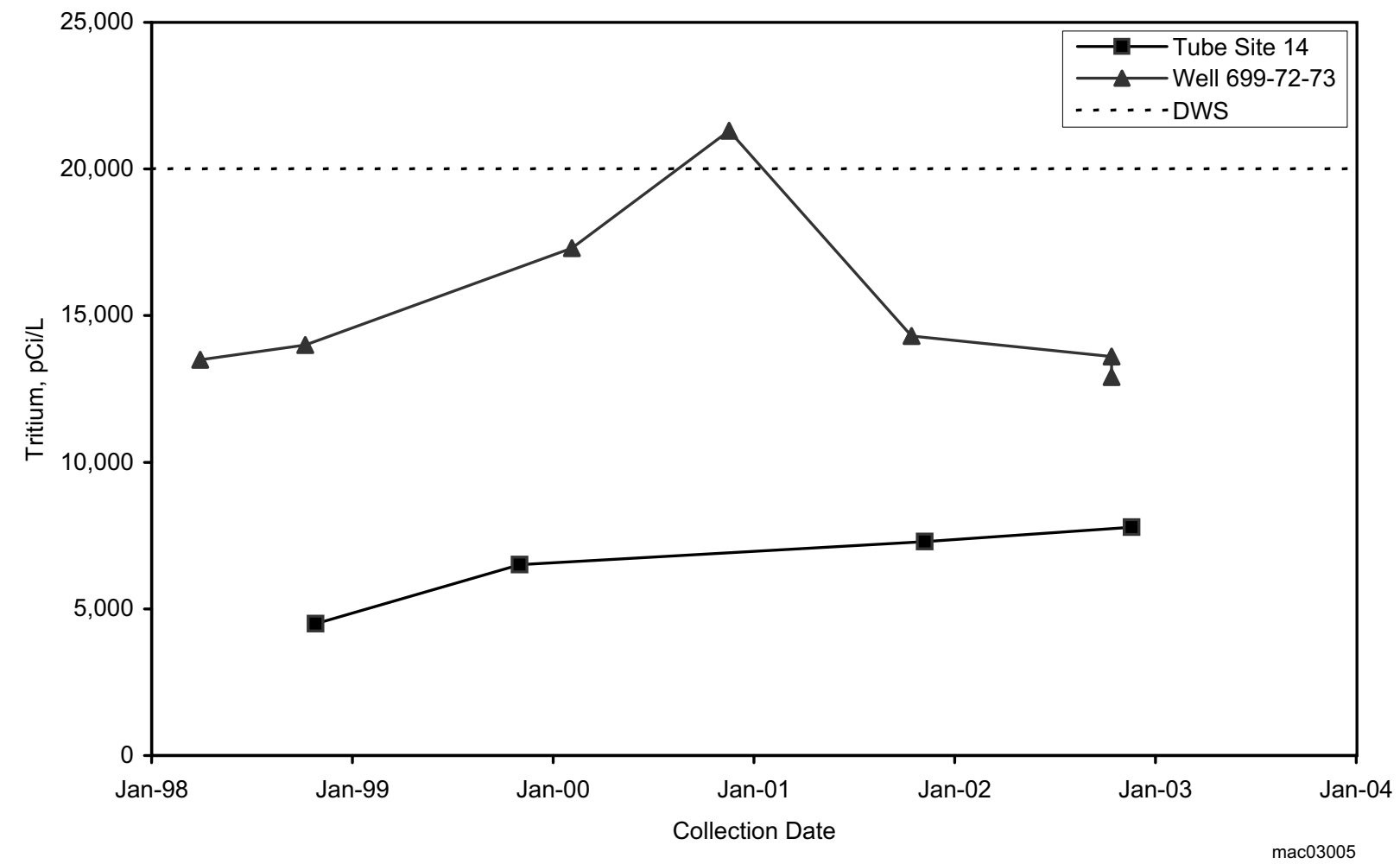

Figure 2.2-7. Tritium Concentrations East of 100-B/C Area 


\subsection{0-KR-4 Operable Unit}

\section{R. E. Peterson}

This section discusses groundwater beneath the 100-KR-4 Operable Unit, which includes the facilities and waste sites within the limited area defined by security fencing, and the adjacent past-practices facilities and waste sites that are associated with former reactor operations. A description of reactor operations and waste sites can be found in WHC-SDEN-TI-239, which is the primary source for historical information presented below. The operable unit lies within a larger groundwater interest area, as defined by the Groundwater Performance Assessment Project (groundwater project) (Figure 2.1-1). Figure 2.3-1 is a location map showing $100-\mathrm{K}$ Area facilities, waste sites, monitoring wells, and shoreline monitoring sites.

The principal groundwater issues in the operable unit involve (a) groundwater contamination associated with past discharges to the ground near the KE and KW reactor buildings, (b) groundwater contamination associated with past disposal to a large infiltration trench located near the river, and (c) groundwater conditions near fuel storage basins at each reactor building. Emerging issues include unexplained changes in tritium concentrations near the KW condensate crib, the KE Basin, and the 118-K-1 burial ground. Contaminants of concern, or potential concern, being monitored in groundwater include carbon-14, strontium-90, technetium-99, tritium, chromium, nitrate, and trichloroethene. The hexavalent form of chromium has been identified as a contaminant of concern that warrants interim remedial action. This form of chromium, which is fully soluble in water, is recognized as toxic to aquatic organisms in the Columbia River.
Chromium is the contaminant of concern currently being treated by interim remedial action.

Groundwater monitoring in the 100-KR-4 groundwater interest area includes CERCLA and AEA monitoring:

\section{CERCLA Long-Term Monitoring}

- Twenty-seven wells are sampled annually for contaminants of concern and constituents of interest.

- Riverbank springs (two locations) and aquifer sampling tubes (eight locations) are sampled annually along the 100-K Area river shore.

- During fiscal year 2003, all wells were sampled as scheduled, though one of the two riverbank spring sites scheduled was not flowing.

\section{CERCLA Interim Remedial Action Performance Evaluation}

- Four compliance wells are sampled monthly for hexavalent chromium.

- Seven performance wells are sampled quarterly to track changes in chromium and co-contaminant concentrations.

- Treatment system influent and effluent chromium concentrations are sampled quarterly.

- During fiscal year 2003, all wells were sampled as scheduled except for a monthly event missed for three wells because of equipment problems.

\section{AEA Monitoring}

- Four wells are sampled quarterly to detect shielding water loss to the ground from the KW and KE Basins.

- Seven wells are sampled quarterly to monitor plumes created by past leakage from the KE Basin.

- Riverbank springs (one location) and aquifer tubes (four locations) are sampled annually.

- In fiscal year 2003, all wells were sampled as scheduled. 
Groundwater flow is generally to the northwest, toward the Columbia River.
Groundwater flow beneath the 100-K Area is generally to the northwest, with discharge to the Columbia River occurring through the riverbed sediment, and to a limited degree, as riverbank springs (see Figure 2.3-1 for water-table elevation contours; flow direction is generally perpendicular to contours). The average rate of flow toward the river is in the range 0.1 to 0.3 meter per day. The best-supported estimate for movement between the KE Reactor and the river is based on the migration of a plume created by a leak from the KE Basin in 1993 (0.12 meter per day), which suggests a 10- to 12-year travel time for contaminants that do not sorb to sediment, such as tritium, to travel from the vicinity of the KE Reactor to the river (PNNL-14031).

For most of the operable unit, the current movement of contaminant plumes is controlled by the flow of groundwater under natural conditions, i.e., there are no effluent disposal operations that alter gradients. The exception is the region to the northeast of the KE Reactor where the pump-and-treat system is operating. Here, treated effluent is injected back into the aquifer. A mound has formed on the water table, and a radial flow pattern has developed around the injection sites (DOE/RL-2003-09).

Near the Columbia River, groundwater is influenced by fluctuations in river discharge, which is controlled by releases from Priest Rapids Dam. The pattern of movement and the rate at which groundwater discharges to the river are affected by these fluctuations. Because river water infiltrates the banks during periods of high river discharge, contaminants carried by groundwater may become diluted prior to release to the river via riverbank springs and through riverbed sediment.

During 2003, remedial actions at the 100-K Area involved removal of contaminated facilities and soil associated with past operations; operation of a pump-and-treat system to reduce a chromium plume beneath the infiltration trench; and removal/re-packaging of irradiated fuel stored in basins at each reactor building.

Groundwater monitoring in the $100-\mathrm{K}$ Area is conducted under two regulatory drivers: Comprehensive Environmental Response, Compensation, and Liability Act (CERCLA) (100-KR-4 Operable Unit) and Atomic Energy Act of 1954 (AEA) requirements (K Basins). CERCLA requirements are further subdivided into monitoring conducted to (a) characterize and track all contaminants of concern in the operable unit, and (b) evaluate the performance of the pump-and-treat system that removes the chromium from groundwater contaminated by effluents associated with the $116-\mathrm{K}-2$ trench.

During fiscal year 2003, all sampling and analysis activities were completed as described in published monitoring plans. Exceptions include the loss of one monitoring well (199-K-33) because of remedial action excavation activity; the addition of several wells to the pump-and-treat system; and minor changes to scheduling dates and analysis suites in response to new information that became available during the year.

\subsubsection{Groundwater Contaminants}

Of the various contaminants found in groundwater at the 100-KR-4 Operable Unit, only hexavalent chromium has been identified as a contaminant of concern that warrants interim remedial action (ROD 1996a). Additional contaminants of potential concern are present, but decisions on whether to pursue active remediation of these plumes, or to rely on natural attenuation processes, have yet to be made.

\subsubsection{Chromium}

Chromium was used in large quantities at each of the single-pass production reactor areas during the years of operation (1955 through 1971 for KE and KW Reactors). The hexavalent form of chromium is fully soluble in water and is toxic to aquatic organisms and humans. The relevant Washington State standards are: $10 \mu \mathrm{g} / \mathrm{L}$ for aquatic organisms (measured as hexavalent chromium) and $100 \mu \mathrm{g} / \mathrm{L}$ (measured as total chromium) for drinking water supplies. 
The distribution of chromium in groundwater beneath the 100-K Area during 2003 is shown in Figure 2.3-2. The contour patterns reflect the various source locations and the direction of plume migration inferred from water-table elevations.

Chromium Beneath 116-K-2 Trench. The largest area of chromium contamination is associated with the $116-\mathrm{K}-2$ trench, which received significant volumes of reactor coolant. The interpretation shown in Figure 2.3-2 assumes that chromium detected in well 699-78-62, which is east of the 100-K Area (Figure 2.3-1), was pushed inland by radial flow around a mound beneath the $116-\mathrm{K}-2$ trench during the operating years. If this assumption is incorrect, the area of contamination is considerably less. The trench plume is the target of a pump-and-treat system intended to protect aquatic receptors in the Columbia River by extracting and treating groundwater (ROD 1996a), thus reducing the flux of chromium to the river ecosystem and the total amount of chromium in the environment. The system began operating in October 1997 (see Section 2.3.2).

Concentrations in the trench plume are typically $<200 \mu \mathrm{g} / \mathrm{L}$ and appear to be decreasing with time or remaining nearly constant, with exceptions at several locations. The decrease is a combined consequence of the pump-and-treat operation and natural attenuation by dispersion. Figure 2.3-3 illustrates typical concentration trends for performance monitoring wells within this plume area.

Exceptions to the decreasing trends occur at wells 199-K-111A and 199-K-18, both located near the southwest edge of the plume where concentrations are increasing (Figure 2.3-4). The cause for these trends is believed to be related to the altered flow pattern in the area as a result of the extraction and injection of groundwater. At the northeast end of the trench, recently installed wells reveal the presence of chromium that reflects past migration of trench effluents away from the trench footprint. Concentrations at new wells $199-\mathrm{K}-126$ and 199-K-130 show relatively constant or variable trends, though their monitoring record is brief. Older wells near the shoreline opposite the trench show gradually decreasing concentrations, as do aquifer sampling tubes along the shoreline downstream from the trench (PNNL-14444).

Chromium Near $\boldsymbol{K E}$ and $\boldsymbol{K W}$ Reactors. Two additional areas contain elevated concentrations of chromium, although the extent of each is poorly defined. Near KE Reactor, a plume extends from the southeast side of the water treatment plant basins, where contaminated soil in the vicinity of a former sodium dichromate storage tank and railcar transfer station is the likely source. Periodic events appear to remobilize chromium and create concentration changes in groundwater, as seen at well 199-K-36 (Figure 2.3-5). Leakage of clean water from the water treatment plant basins may provide a driving mechanism. Migration downgradient beyond the KE Reactor does not appear to have occurred.

Near KW Reactor, elevated chromium concentrations are present at several wells, with the suspected source being sodium dichromate in the vadose zone at unknown locations. Candidate locations include the storage tank and transfer station at the southeast side of the KW water treatment basins (same as at KE), and also the underground piping associated with the system used to add sodium dichromate to clean coolant makeup water. Figure 2.3-6 shows concentration trends for wells located within this plume. Monitoring near the Columbia River at well 199-K-31, aquifer tube site AT-17, and riverbank spring SK-063 does not show evidence that this plume has reached the river.

\subsubsection{Tritium}

Tritium was common in effluents discharged during reactor operations. However, some of the tritium currently observed in groundwater was introduced after the shutdown of the reactors in 1971. Current sources and potential sources for providing tritium to groundwater include shielding water contained in the KE and KW Basins; the reactor atmosphere condensate cribs and underlying soil column to the east of each reactor building; and possibly materials contained in the $118-\mathrm{K}-1$ burial ground. Tritium has a radioactive
The largest area of chromium contamination is associated with past disposal to the 116-K-2 trench. Concentrations are decreasing or constant in most wells. 


\section{Recent increases in tritium concentration at wells near fuel storage basins are unexplained, but} there is no evidence of new basin leaks.

Plume areas (square kilometers) above the drinking water standard at the 100-KR-4 Operable Unit:

Chromium - 0.23

Nitrate -0.30

Strontium-90 - 0.17

Trichloroethene -0.15

Tritium -0.28 decay half-life of 12.3 years. The drinking water standard for this radionuclide is $20,000 \mathrm{pCi} / \mathrm{L}$, and it is not considered threatening to the river ecosystem.

The distribution of tritium in groundwater beneath the 100-K Area during 2003 is shown in Figure 2.3-7. The contour patterns reflect several past and present source locations, as well as the direction of plume migration inferred from water-table elevations. The highest tritium concentrations are associated with conditions downgradient of the 116-KE-1 and $116-\mathrm{KW}-1$ cribs at each reactor (both cribs are scheduled for removal during December 2003). Carbon-14, a less mobile constituent than tritium, is a co-contaminant at these waste sites. Because tritium is present in the shielding water of each fuel storage basin, concentrations in groundwater are closely monitored for evidence of shielding water loss to the ground (PNNL-14033). Technetium-99 is another mobile radionuclide contained in shielding water and is used to help differentiate shielding water from other contaminant sources.

Tritium Near KE Reactor. The plume shown in Figure 2.3-7 near KE Reactor has been formed by tritium from leaks to the ground from KE Basin (1976 to 1979 and again in 1993), continued release from the vadose zone beneath the 116-KE-1 crib, and possible releases from the vadose zone beneath the 116-KE-3 drain field. The tritium distribution reflects a coalescing of plumes from these sources and the timing of release from each source. The highest concentrations are immediately downgradient of the 116-KE-1 crib. Recent trends for tritium and carbon-14 at a well near this source are shown in Figure 2.3-8.

Tritium concentration trends in wells most likely to detect shielding water loss from KE Basin are shown in Figure 2.3-9. The recent increases at wells 199-K-27 and 199-K-109A are unexplained, although there is no evidence suggesting current loss of shielding water to the ground. Technetium-99, a second indicator of shielding water, has not been detected at these wells. The earlier increased concentrations at well 199-K-29 in 2001 to 2002 are believed to reflect the plume from the 116-KE-1 crib.

Tritium Near $\boldsymbol{K W}$ Reactor. The tritium plume mapped near the KW Reactor is associated with effluent disposed to the 116-KW-1 crib during the operating years. An unexplained increase in tritium concentrations at well 199-K-106A, located downgradient of the crib, began in 2001 and abruptly peaked in 2003 (Figure 2.3-10). Other constituents showing a similar trend include nitrate and groundwater temperature. Also, technetium-99 was detected at low concentrations ( 25 to $65 \mathrm{pCi} / \mathrm{L}$ ) in samples collected during the peak tritium concentrations. The origin for technetium-99 at this location is unknown. The cause for the recent change in the tritium trend at well $199-\mathrm{K}-106 \mathrm{~A}$ is presumed to be remobilization of contaminants in the 116-KW-1 crib and underlying soil column, although a driving mechanism has not been positively identified.

There is no groundwater evidence suggesting water loss from the KW Basin in recent years. Tritium concentrations in wells most likely to detect shielding water are shown in Figure 2.3-11. The groundwater concentrations are well below concentrations in KW Basin shielding water and are currently in the range 600 to $850 \mathrm{pCi} / \mathrm{L}$. (Note: The most recent result for well 199-K-34 is a suspected outlier and currently under review.)

Tritium Near the 118-K-1 Burial Ground. Tritium concentrations at well $199-\mathrm{K}-111 \mathrm{~A}$, located at the northwest corner of the burial ground, began rising abruptly in mid-2000 to a peak value of $98,200 \mathrm{pCi} / \mathrm{L}$ in April 2002 (Figure 2.3-12). Since that time, concentrations have steadily declined. The source for the tritium was the subject of a detailed investigation during 2002 of groundwater movement and soil gas in the vicinity of the burial ground (PNNL-14031). The best explanation to date is that a tritium plume lies to the east of the well, i.e., beneath the burial ground. This plume has been displaced to the west under the influence of the mound that has formed beneath the pump-and-treat injection site. Supporting this idea is (a) the pattern of groundwater movement inferred 
from water-table elevations, (b) gradually increasing chromium concentrations as the pump-and-treat plume shifts somewhat to the west, and (c) the absence of other constituents that would identify known tritium sources.

An additional soil-gas survey was conducted during 2003 along the perimeter of the burial ground on the side closest to the river. Soil gas was analyzed for helium isotopes (helium-3 is a decay product of tritium). An excess of helium-3, as compared to ambient air amounts, was measured at all sites, indicating the nearby presence of tritium (Figure 2.3-13). The pattern of isotope ratios suggests the likelihood of a tritium source in the burial ground, along with an underlying groundwater plume. The plume may be the same as that observed at downgradient wells $199-\mathrm{K}-18$ and $199-\mathrm{K}-120 \mathrm{~A}$, the latter a pump-andtreat extraction well.

Tritium Near 116-K-2 Trench. Groundwater downgradient of the trench typically contains low concentrations of tritium, i.e., $<2,000 \mathrm{pCi} / \mathrm{L}$. The exception occurs at the southwest end of the trench, where concentrations range between 40,000 and $80,000 \mathrm{pCi} / \mathrm{L}$ at wells 199-K-18 and 199-K-120A (a pump-and-treat system extraction well). The source for this tritium is uncertain; it may represent past disposal to the $100-\mathrm{K}$ crib (116-K-1 waste site) or possibly tritium from a source farther inland, such as a previously unidentified burial ground source.

Tritium is being re-introduced to the aquifer via injection of the effluent from the pumpand-treat system. The average tritium concentration in effluent was $12,600 \mathrm{pCi} / \mathrm{L}$ in 2000 (DOE/RL-2001-04), and most of the tritium comes from extraction well 199-K-120A. Injected effluent appears to have started arriving at downgradient well 199-K-119A in 2000 , as shown by increasing tritium concentrations, which reached $\sim 3,500 \mathrm{pCi} / \mathrm{L}$ during 2003.

\subsubsection{Carbon-14}

Condensate from atmosphere gas for the KE and KW Reactors contained carbon-14 (along with tritium) and was discharged to infiltration cribs. Release of carbon-14 from the cribs and/or underlying soil continues to re-supply groundwater plumes even though discharge to the cribs ended in 1971. The half-life of carbon-14 is 5,730 years. The radionuclide exchanges with carbon in carbonate minerals, and so its movement is more restricted and variable than a non-retarded constituent like tritium. The drinking water standard is $2,000 \mathrm{pCi} / \mathrm{L}$, and that standard has been exceeded at several wells downgradient of the reactor complexes.

Current concentrations of carbon-14 at wells immediately downgradient from the 116-KE-1 and 116-KW-1 cribs are shown in Figures 2.3-8 and 2.3-10. Concentrations near the $116-\mathrm{KE}-1 \mathrm{crib}$ are between 5,000 and $7,000 \mathrm{pCi} / \mathrm{L}$, and near the $116-\mathrm{KW}-1$ crib are between 15,000 and $22,000 \mathrm{pCi} / \mathrm{L}$. The two plumes do not appear to have reached the Columbia River, as indicated by low concentrations in aquifer sampling tubes.

\subsubsection{Strontium-90}

Strontium-90 was released to the environment at $100-\mathrm{K}$ Area primarily via used reactor coolant. It was also present in fuel storage basin shielding water, which was discharged to nearby drain fields/injection wells during the reactor operating period. It is moderately mobile in the environment and has a half-life of $\sim 29$ years. The drinking water standard is $8 \mathrm{pCi} / \mathrm{L}$, which is based on a radiological dose rate, and the DOE derived concentration guide is $1,000 \mathrm{pCi} / \mathrm{L}$.

Strontium-90 Near the $\boldsymbol{K} \boldsymbol{E}$ and $\boldsymbol{K} \boldsymbol{W}$ Reactors. The highest concentrations in 100-K Area groundwater have been observed near the northwest corner of the KE Reactor, at well 199-K-109A, and reached a peak of $\sim 18,000 \mathrm{pCi} / \mathrm{L}$ in 1997 . Since 2000, concentrations have been generally declining at that location and current concentrations are $\sim 1,200 \mathrm{pCi} / \mathrm{L}$ (Figure 2.3-14), which still exceeds the DOE derived concentration guide. The gross beta observed in groundwater at this location appears to be caused primary by strontium- 90 .
A soil-gas survey near the 118-K-1

burial ground

indicated the

presence of tritium

in the vadose zone.

\author{
Strontium-90 \\ was apparently \\ remobilized during \\ the 1990s by \\ infiltrating water, \\ affecting underlying \\ groundwater.
}




\section{Nitrate and trichloroethene concentrations exceed drinking water standards in some 100-K Area monitoring wells.}

The highly elevated concentrations during 1997 have been attributed to remobilization of strontium-90 in the soil beneath the 116-KE-3 drain field by infiltration of water from leaking fire hydrant service lines, possibly exacerbated by an unusually high water table (PNNL-12023). Use of the drain field ended in 1971.

Strontium-90 concentrations are lower at equivalent locations near KW Reactor and range from 20 to $50 \mathrm{pCi} / \mathrm{L}$, with essentially constant trends. Leakage from hydrant service lines has not been observed near the northwest corner of the KW Basin. There are indications of temporarily elevated levels during the high water-table conditions in 1996 and 1997 based on gross beta measurements and one strontium-90 result.

Strontium-90 Near the 116-K-2 Trench. The effluent disposed to the 116-K-2 trench contained strontium-90, which is still present in groundwater affected by trench operations. The highest concentrations are generally $<40 \mathrm{pCi} / \mathrm{L}$ and limited in areal extent; most observed concentrations are near or below the $8 \mathrm{pCi} / \mathrm{L}$ drinking water standard. Also, most concentration trends indicate a gradual decline, with the exception being at wells near the southwest end of the trench (see discussion of chromium trends in Section 2.3.1.1).

\subsubsection{Other Constituents}

Nitrate is widely distributed beneath the $100-\mathrm{K}$ Area, with potential sources that include currently active septic systems and past-practices waste sites. The distribution patterns do not clearly delineate specific source sites. Nitrate exceeds the $45 \mathrm{mg} / \mathrm{L}$ drinking water standard in some areas. Concentration trends vary depending on monitoring location; the cause for the variability is likely to be shifts in plume position.

Trichloroethene has been detected in wells 199-K-106A and 199-K-33, which are located downgradient of the 116-KE-1 crib, at concentrations above the $5 \mu \mathrm{g} / \mathrm{L}$ drinking water standard. Concentrations in fiscal year 2003 were $\sim 10 \mu \mathrm{g} / \mathrm{L}$ (Note: well 199-K-33 was decommissioned in June 2003). Concentrations have steadily declined from 1994 levels of $\sim 36 \mu \mathrm{g} / \mathrm{L}$ in well 199-K-106A and $\sim 20 \mu \mathrm{g} / \mathrm{L}$ in well 199-K-33.

In the past, several metals have been measured in filtered samples at concentrations above the drinking water standard (e.g., aluminum, iron, manganese, and nickel). These occurrences have not been positively connected to waste sites or waste streams. They are not considered contaminants of concern because of (a) limited areal extent, (b) sporadic occurrence, and (c) possibility that they are influenced by well construction and do not represent groundwater conditions.

\subsubsection{CERCLA Interim Remedial Action for Chromium}

This interim remedial action involves a pump-and-treat system designed to remove hexavalent chromium from groundwater in the region between the $116-\mathrm{K}-2$ trench and the Columbia River (DOE/RL-96-84). Hexavalent chromium poses a threat to aquatic organisms that use the riverbed substrate for habitat.

The remedial action objectives for the 100-KR-4 Operable Unit (ROD 1996a) are:

- Protect aquatic receptors in the river bottom from contaminants in groundwater entering the Columbia River.

- Protect human health by preventing exposure to contaminant in the groundwater.

- Provide information that will lead to the final remedy.

The contaminant of concern is hexavalent chromium. The record of decision specifies the cleanup goal at compliance wells as $22 \mu \mathrm{g} / \mathrm{L}$. EPA specified enhancements needed to the system in their 5-year review (EPA 2001). Fall chinook salmon, which spawn in riverbed gravels, are of particular concern in the Hanford Reach. As described in the record of decision (ROD 1996a), the protection standard for aquatic life is $11 \mu \mathrm{g} / \mathrm{L}$ as measured in riverbed substrate porewater. Because some dilution of contaminants by river water occurs along the pathway between the aquifer and riverbed substrate, the record of decision considers a value of $22 \mu \mathrm{g} / \mathrm{L}$ in near-river compliance wells as being protective of aquatic life.

The interim remedial action consists of a pumpand-treat system involving nine extraction wells, five injection wells, and an ion-exchange resin 
treatment system that removes hexavalent chromium. The system began operating in October 1997. Performance monitoring of the pump-and-treat system is described in an interim remedial action monitoring plan (DOE/RL-96-90). Four wells, located between the extraction wells and the Columbia River, have been identified as compliance monitoring locations. Seven additional wells are used to help evaluate the performance of the system on aquifer conditions. Approximately five aquifer sampling tube sites along the rivershore are also monitored. Lists of sampling frequencies and analyses performed are included in Appendix A.

The results of the interim remedial action for chromium are described in an annual summary report for each calendar year, which is prepared by the remedial action contractor (e.g., DOE/RL-2003-09). Highlights from the summary report for calendar year 2002, with updates for volumes treated and mass removed through September 2003, are presented in the following sections.

\subsubsection{Progress During Fiscal Year 2003}

During the period October 1, 2002, through September 30, 2003, 510.3 million liters of groundwater were extracted and treated, with 37.9 kilograms of chromium removed. Since the startup of operations in October 1997, the total volume extracted is 2,069 million liters and total mass of chromium removed is $\sim 213$ kilograms.

Several changes in the extraction/injection well network occurred during fiscal year 2003: newly installed wells include extraction wells 199-K-127 and 199-K-129; injection well 199-K-128; and monitoring well 199-K-130. Also, well 199-K-126 was converted to an extraction well.

\subsubsection{Influence on Aquifer Conditions}

Changes in chromium concentrations within the target plume area suggest that in general the level of contamination is decreasing with time. Chromium concentrations in compliance wells 199-K-20 and 199-K-112A are shown in Figure 2.3-3, and Section 2.3.1 provides additional discussion. This decrease is resulting from the pump-and-treat operation and the reduction in the level of contamination by natural processes, such as dispersion. No facility operations or discharges to waste sites are known to be current sources of recharge to the chromium plume, although some chromium may continue to be slowly released from the vadose zone beneath the $116-\mathrm{K}-2$ trench.

Chromium concentrations in aquifer sampling tubes along the shore segment affected by the plume appear to have decreased with time, although the results are limited in number and are not adjusted for mixing with river water (PNNL-14444). When results are available for tube samples from several depths at a particular site, the deeper site has the higher concentration, thus revealing the diluting effect of river water that infiltrates the riverbank during high river stage. Additional tubes sites along this shore segment are being installed during fall 2003 to provide increased monitoring capability (WMP-18051).

The injection of treated effluent at five wells has created a mound of uncertain magnitude on the water table. The injected treated effluent appears to have migrated downgradient as far as extraction wells 199-K-119A and 199-K-125A, as shown by the increasing tritium concentrations in those wells during recent years (Figure 2.3-15; Note: tritium concentrations are higher in the injected effluent than in groundwater near the extraction wells). The mounding may also have caused the boundary of the chromium plume, and perhaps an unmapped tritium plume, to shift to the west, where the boundary(ies) are now detected at well 199-K-111A (Figures 2.3-4 and 2.3-12).

Uncertainties regarding the pump-and-treat system's influence on aquifer conditions involve the (1) extent of plume inland of the trench, and whether or not chromium observed at well 699-78-62 is part of the plume; (2) source for chromium and tritium at wells 199-K-18 and 199-K-120A, where concentrations are increasing; and (3) height and extent of the mound created at the injection site.
Levels of chromium contamination appear to be generally decreasing in the area of the pumpand-treat system. 


\subsubsection{AEA Monitoring (K Basins)}

Basins within the KE and KW Reactor buildings have been used to store irradiated fuel from the last run of the 100-N Reactor, along with other miscellaneous fuel recovered during remedial actions at other reactor areas. The fuel is being removed, re-packaged, and moved to a better storage facility in the Central Plateau as part of the Spent Nuclear Fuels Project. Tri-Party Agreement Milestone M-34-00 covers the fuel removal and basin cleanup project.

Groundwater monitoring and characterization near the $\mathrm{K}$ Basins are conducted under a subtask within the groundwater project. The sampling and analysis schedule compliments schedules associated with the 100-KR-4 Operable Unit. The monitoring plan (PNNL-14033) describes the objectives for the subtask:

- Characterize groundwater conditions between the K Basins and the Columbia River to provide a periodic status of current conditions and the attenuation of plumes.

- Distinguish between groundwater contamination associated with K Basins and contamination from other past-practices sources to help guide operational and remedial action decisions.

- Maintain a strategy for the potential expansion of monitoring capabilities to respond to future basin-related issues.

Results of this subtask's activities are reported quarterly to the U.S. Department of Energy and the Spent Nuclear Fuels Project via email. Discussions of contaminants potentially associated with the basins (e.g., tritium, technetium-99, and strontium-90) are included in Section 2.3.1. 


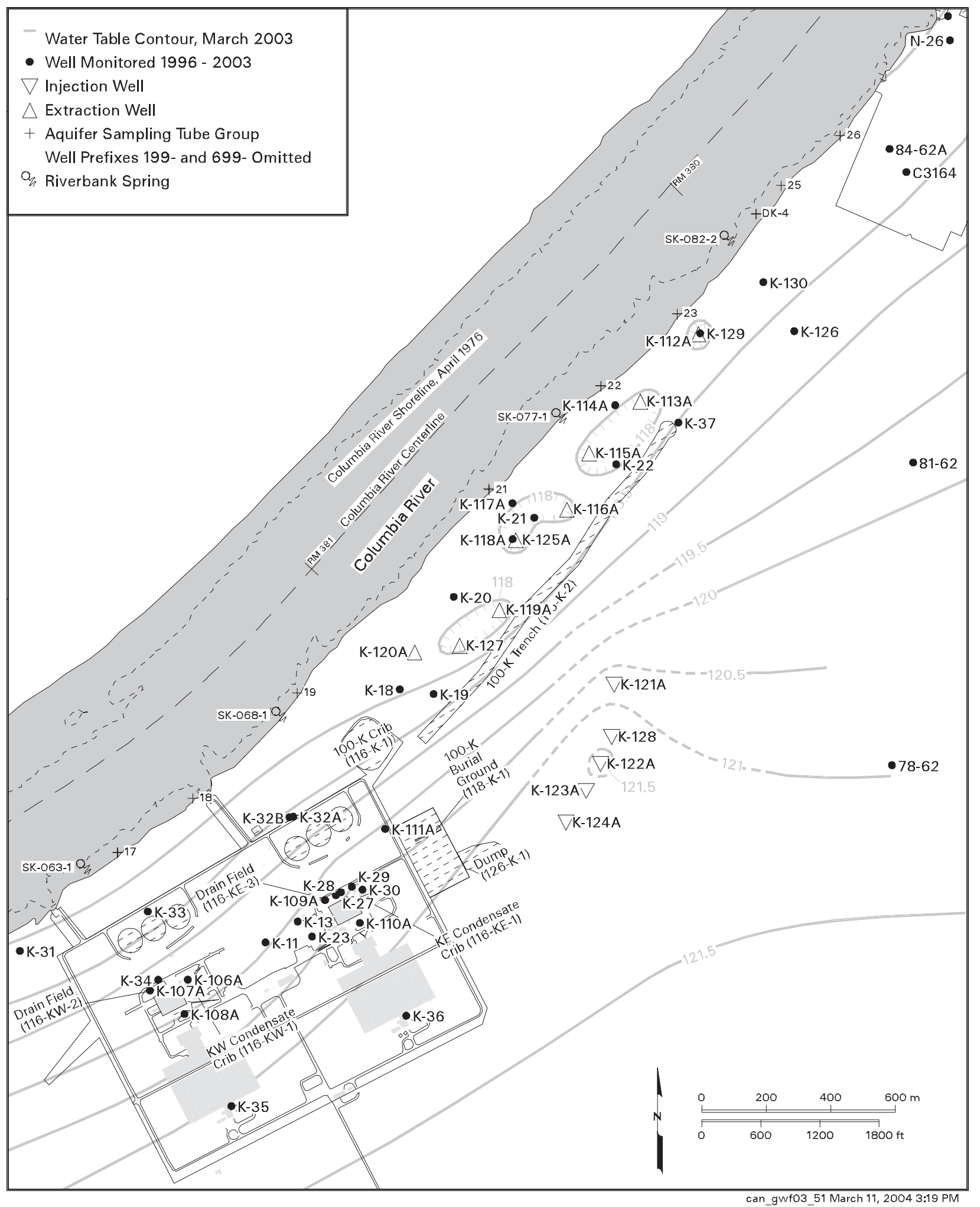

Figure 2.3-1. Location Map for 100-K Area Facilities, Waste Sites, Monitoring Wells, and Shoreline Monitoring Sites 


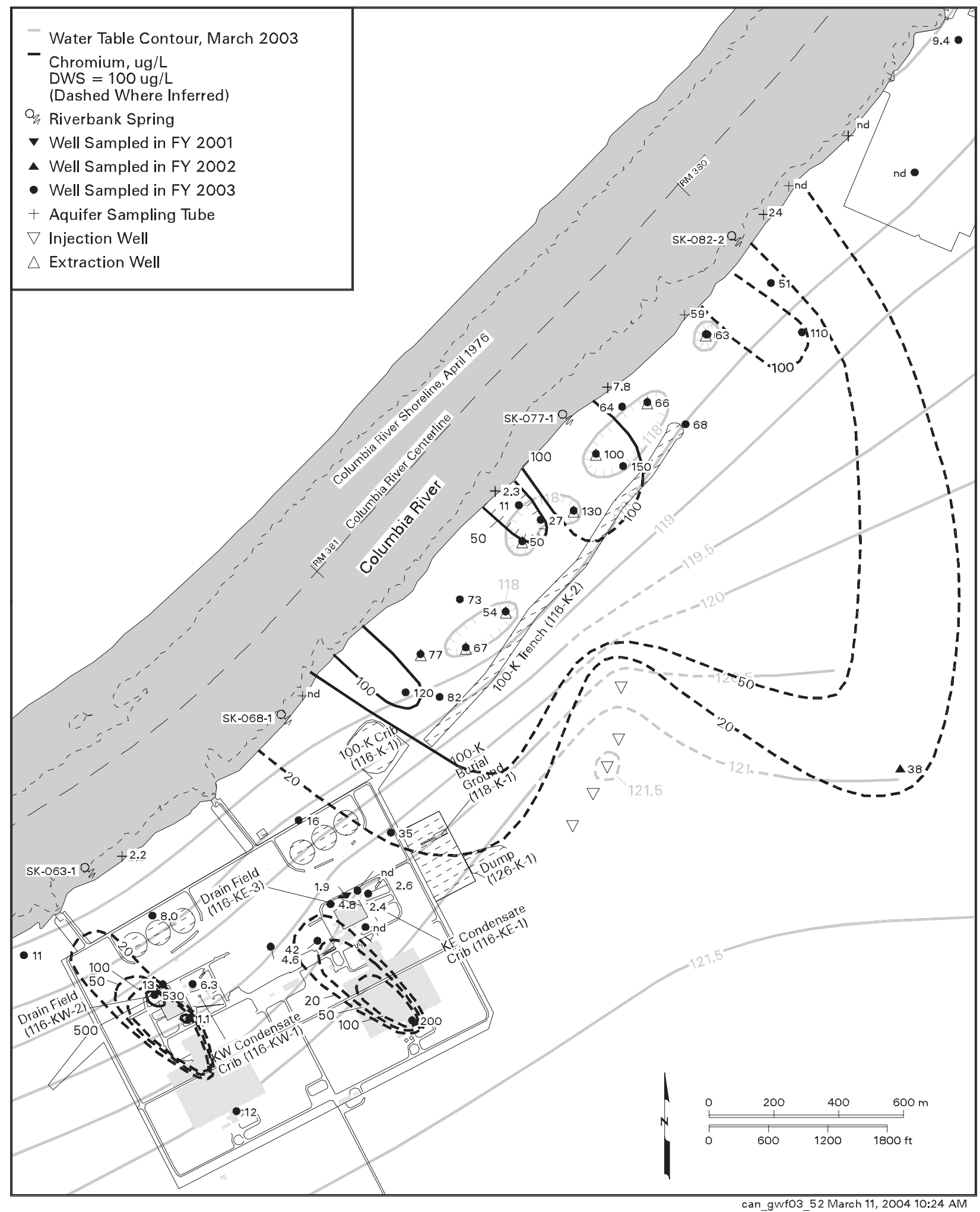

Figure 2.3-2. Chromium Distribution in 100-K Area Groundwater, Fiscal Year 2003 

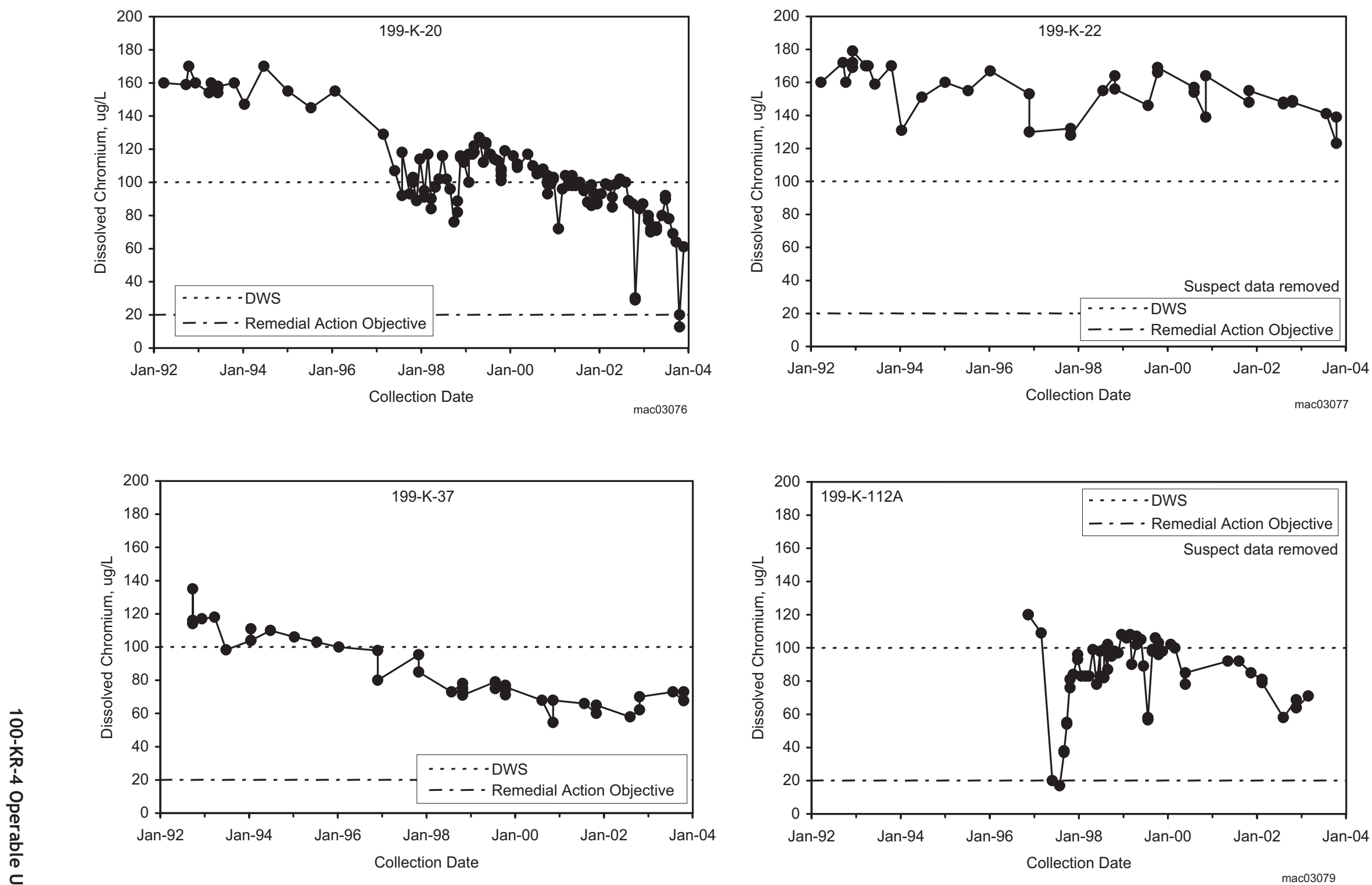

Figure 2.3-3. Chromium Concentrations in Pump-and-Treat Performance Monitoring Wells 


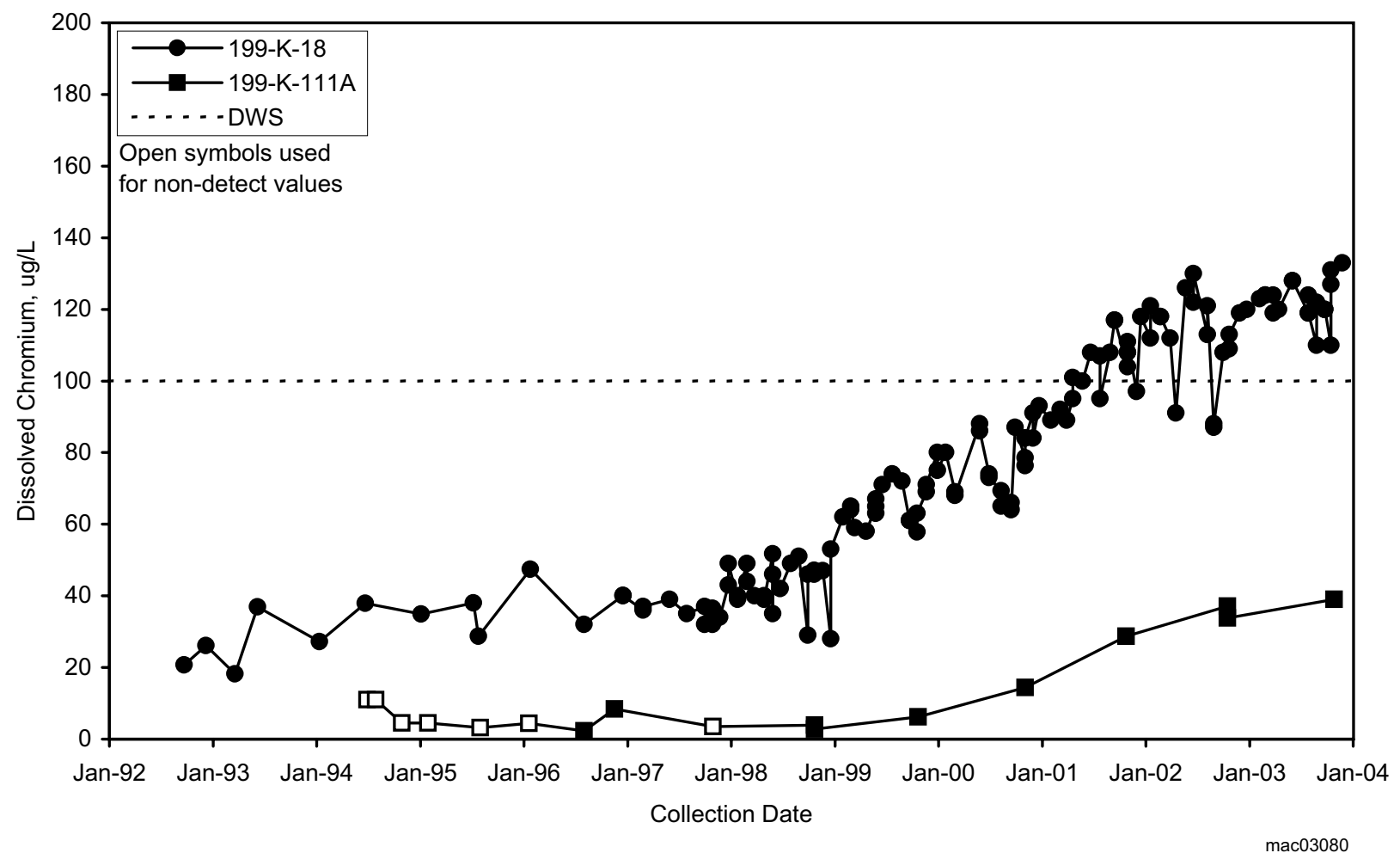

Figure 2.3-4. Increasing Chromium Concentrations at the Southwest Edge of Plume Associated with the 116-K-2 Trench

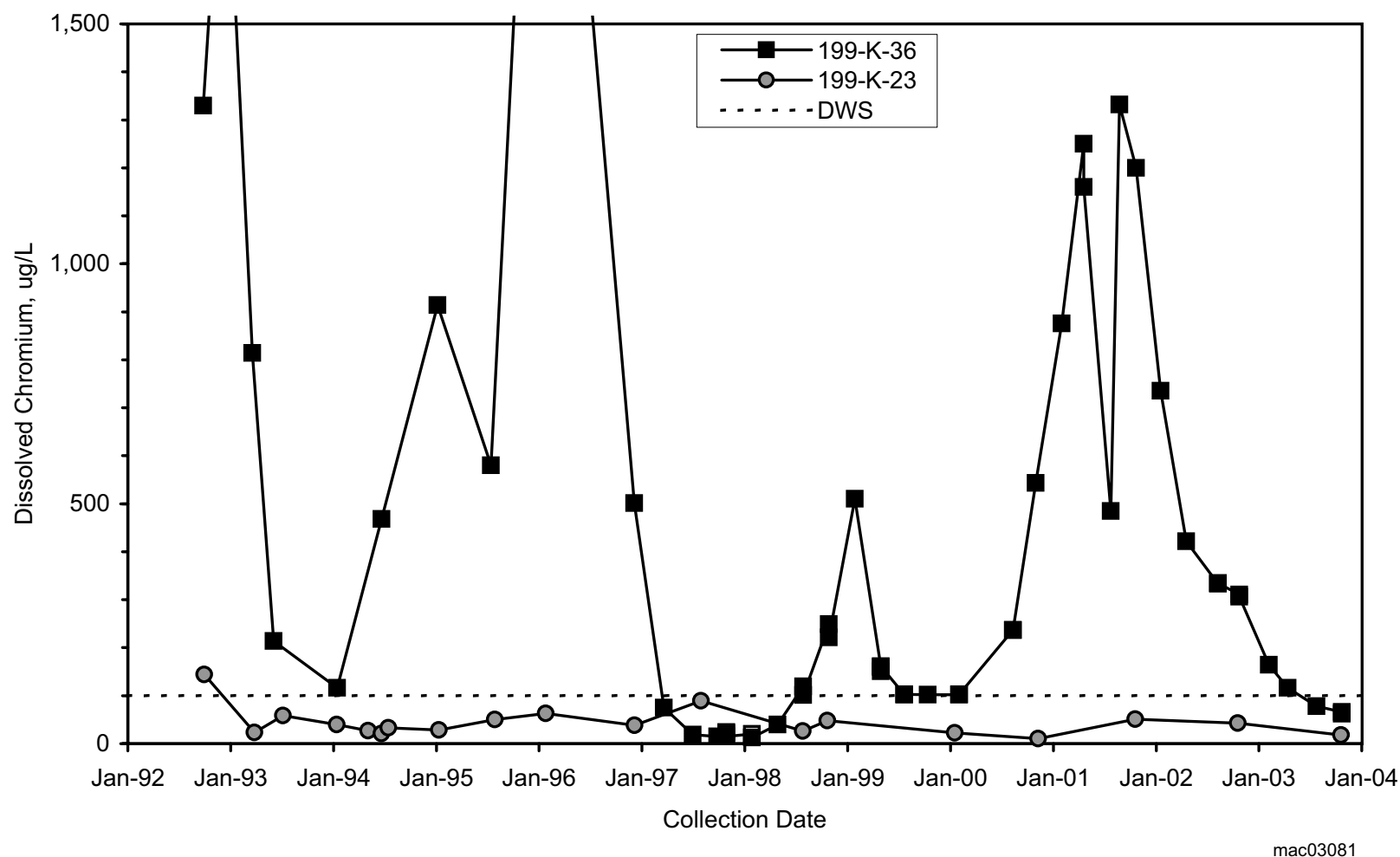

Figure 2.3-5. Chromium Concentrations Near KE Water Treatment Plant Basins 


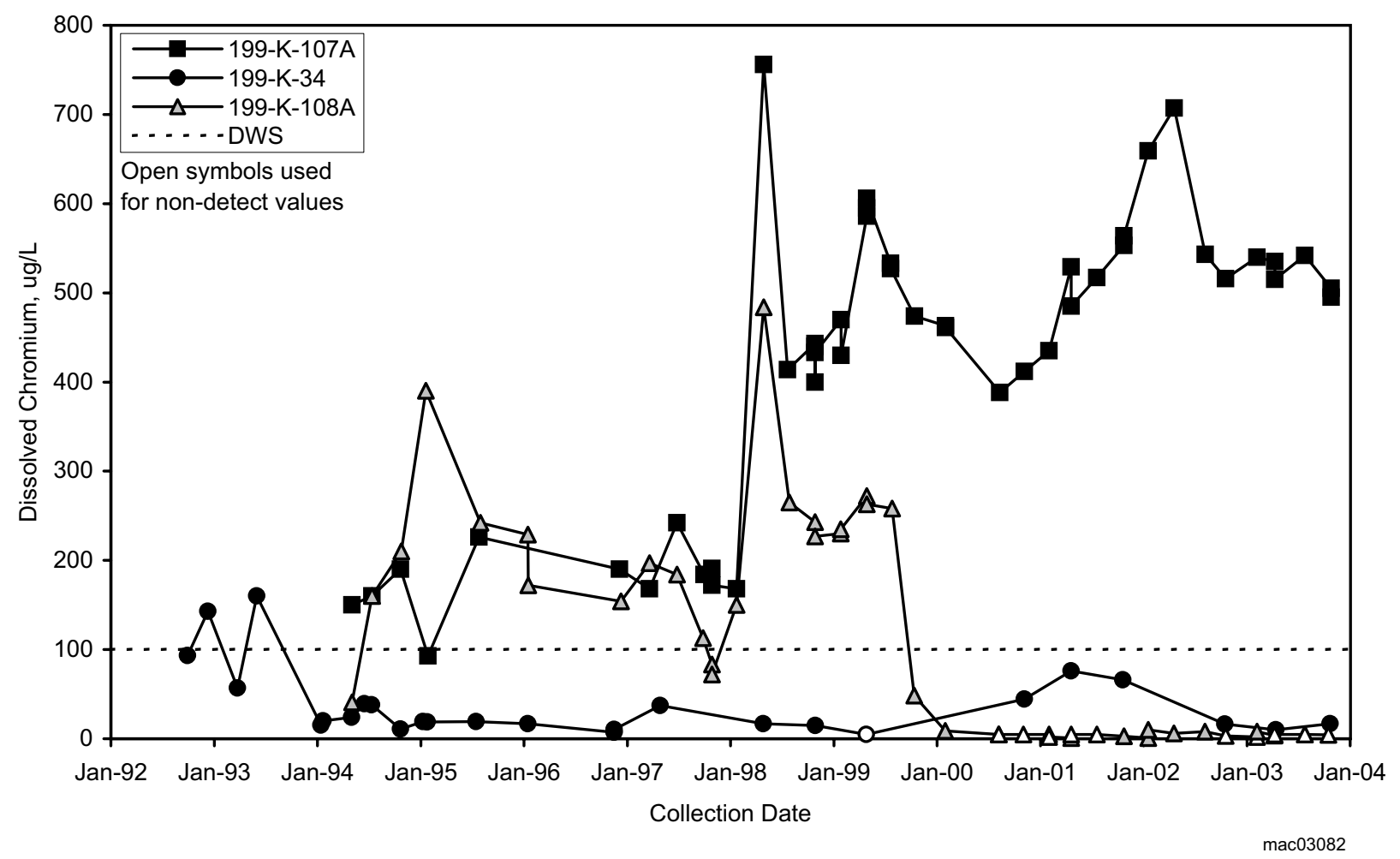

Figure 2.3-6. Chromium Concentrations Near KW Reactor 


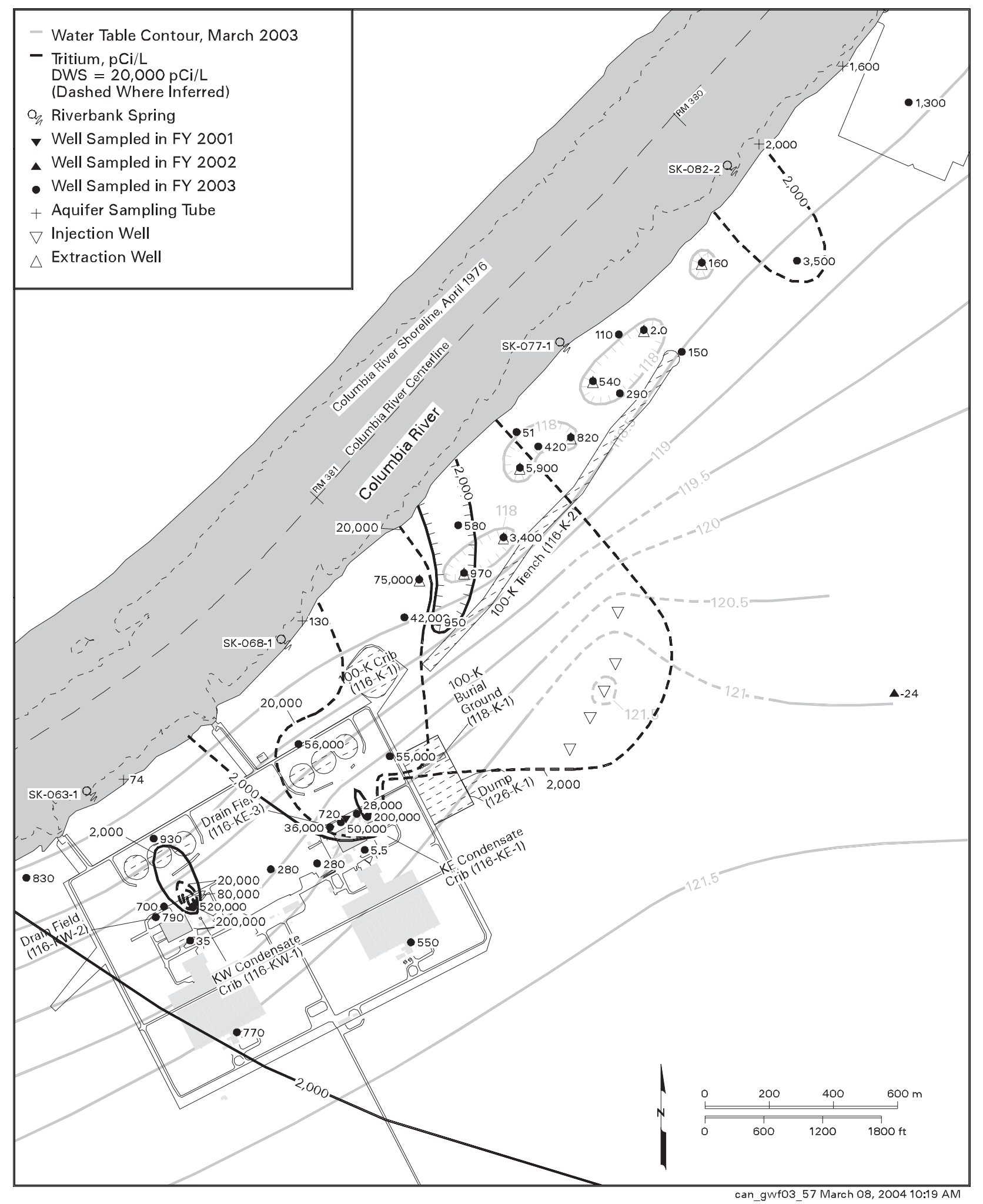

Figure 2.3-7. Tritium Distribution in 100-K Area Groundwater, Fiscal Year 2003 


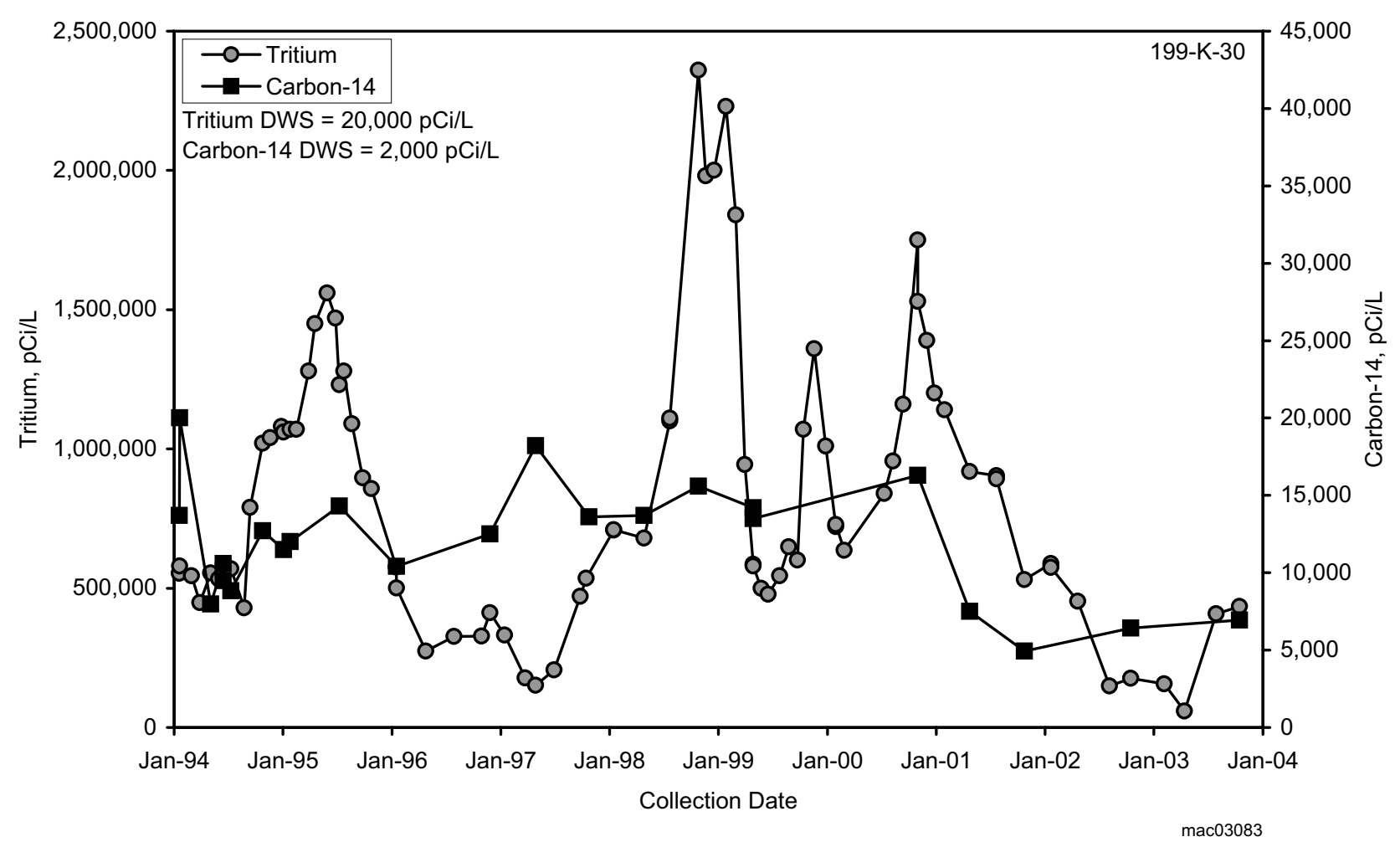

Figure 2.3-8. Tritium and Carbon-14 Concentrations Near the 116-KE-1 Crib

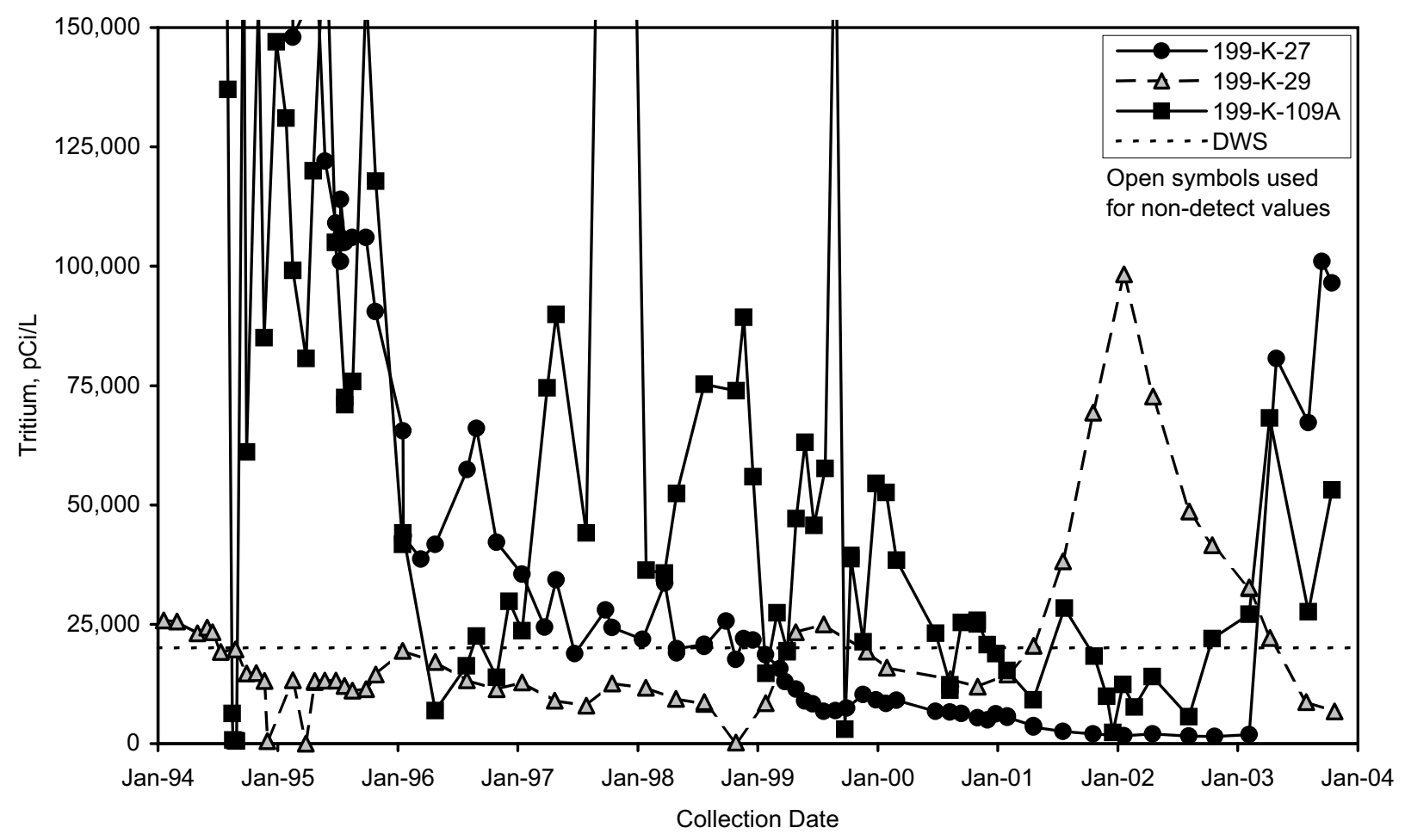

Figure 2.3-9. Tritium Concentrations Near KE Basin 


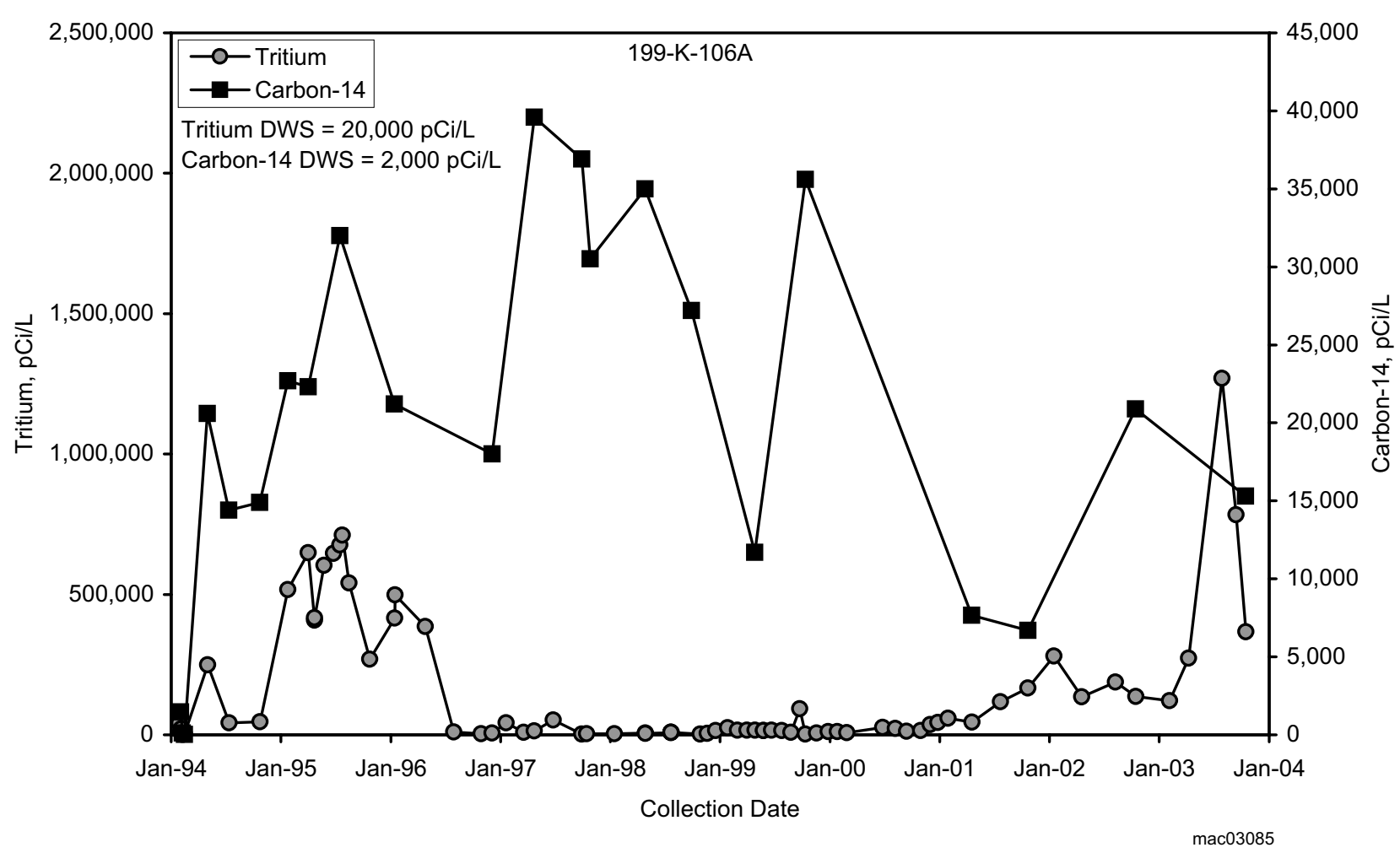

Figure 2.3-10. Tritium and Carbon-14 Concentrations Near the 116-KW-1 Crib

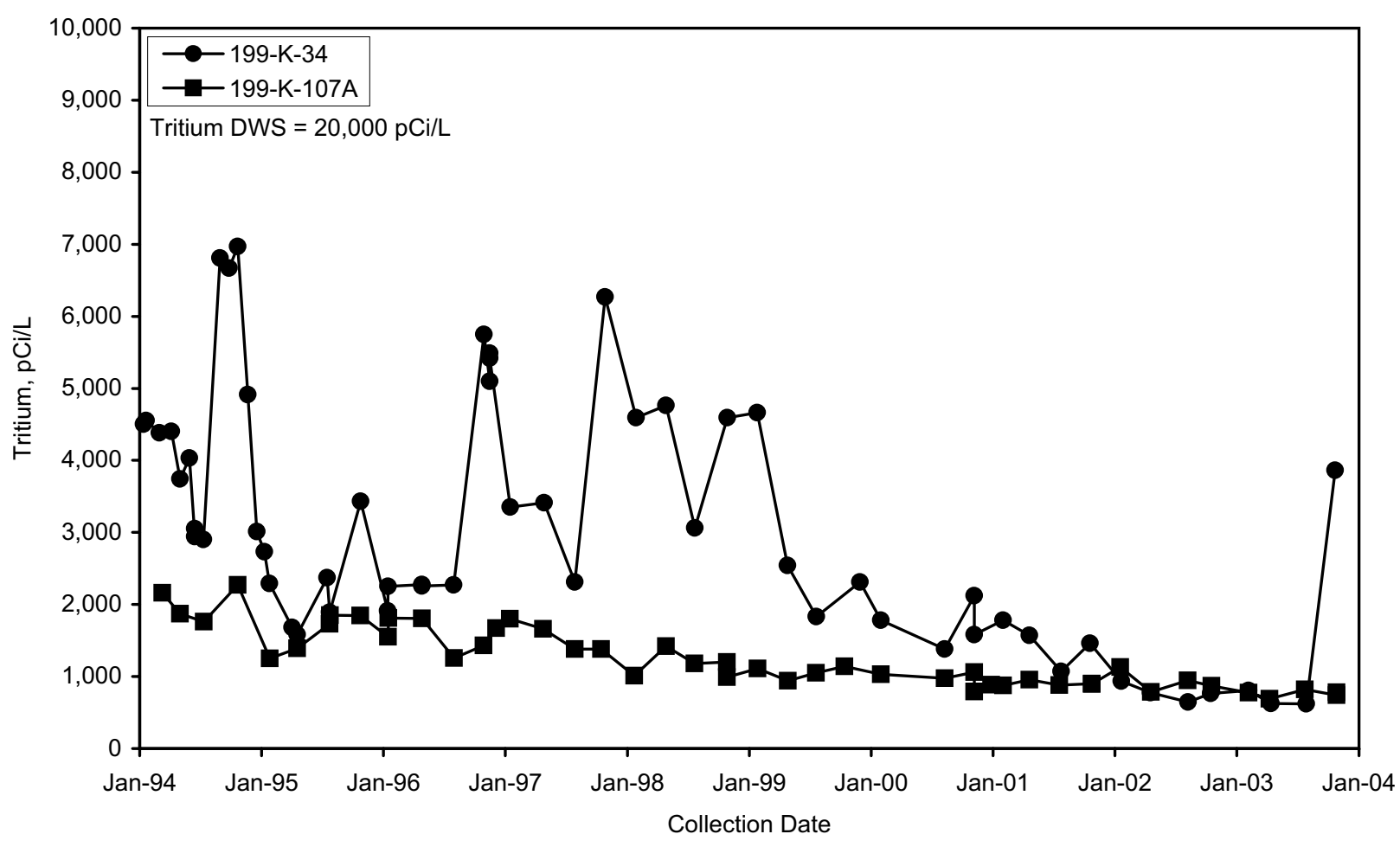

Figure 2.3-11. Tritium Concentrations Near KW Basin 


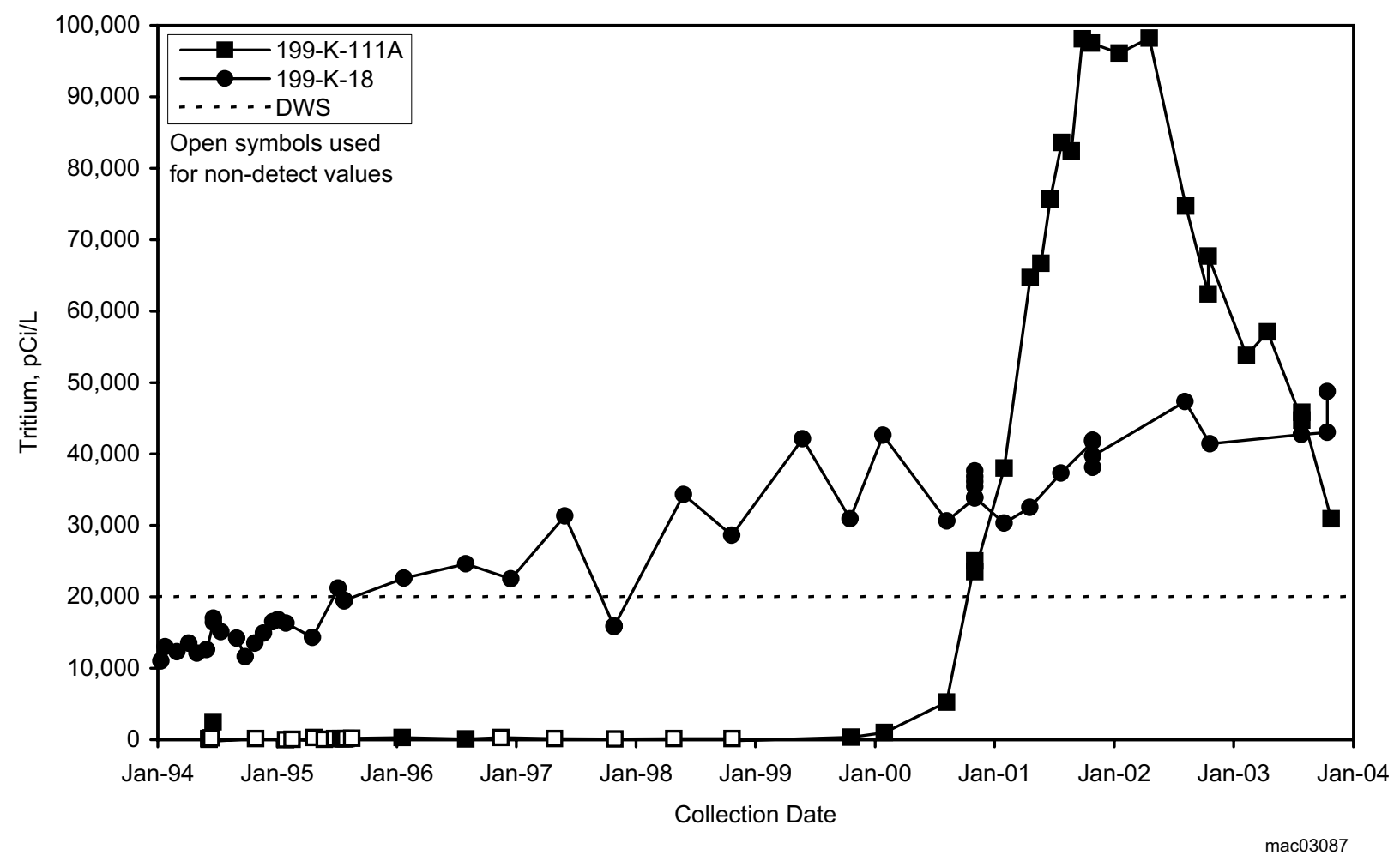

Figure 2.3-12. Tritium Concentrations Near 118-K-1 Burial Ground 


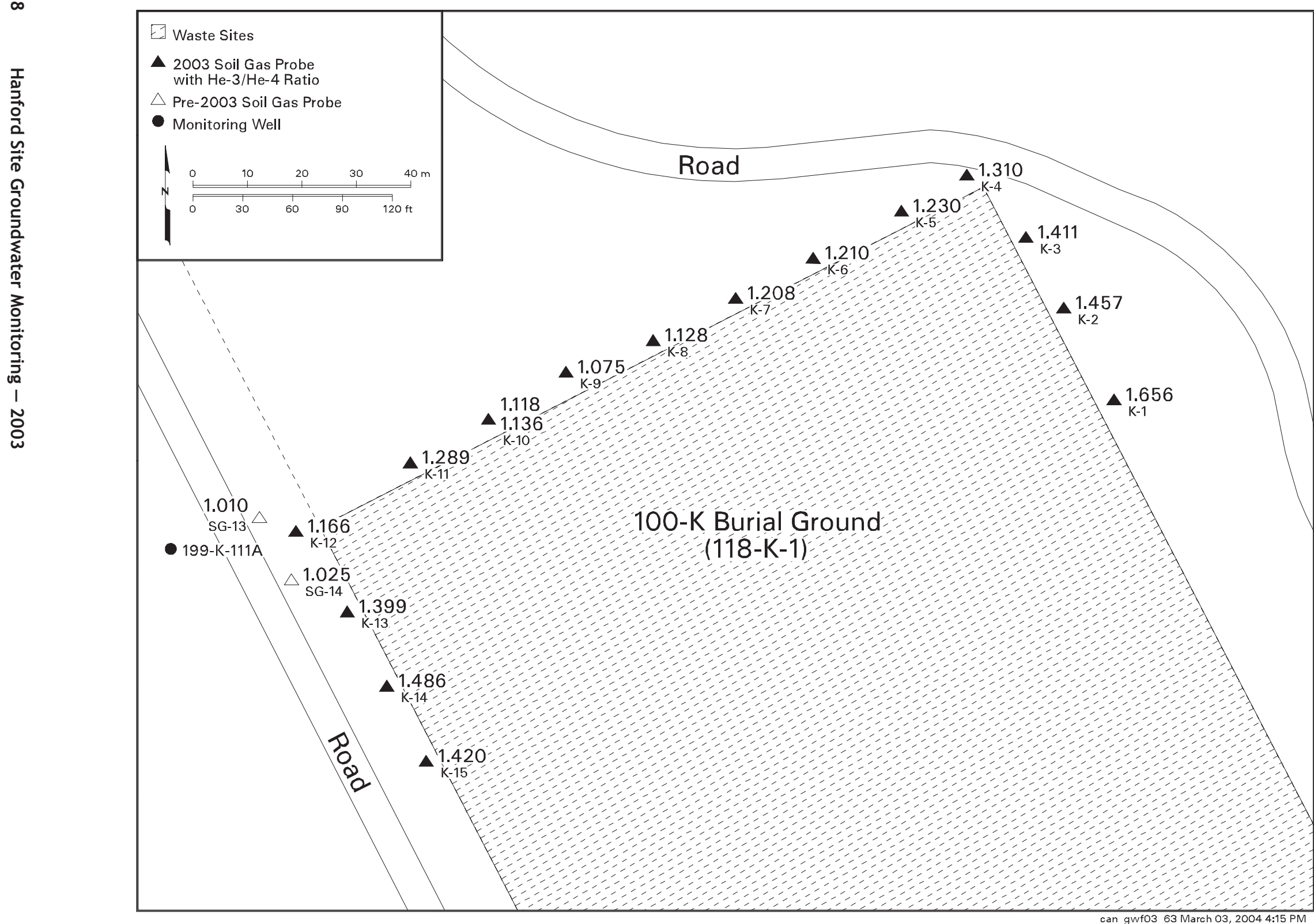

Figure 2.3-13. Helium Isotope Ratios in Soil Gas Near 118-K-1 Burial Ground 


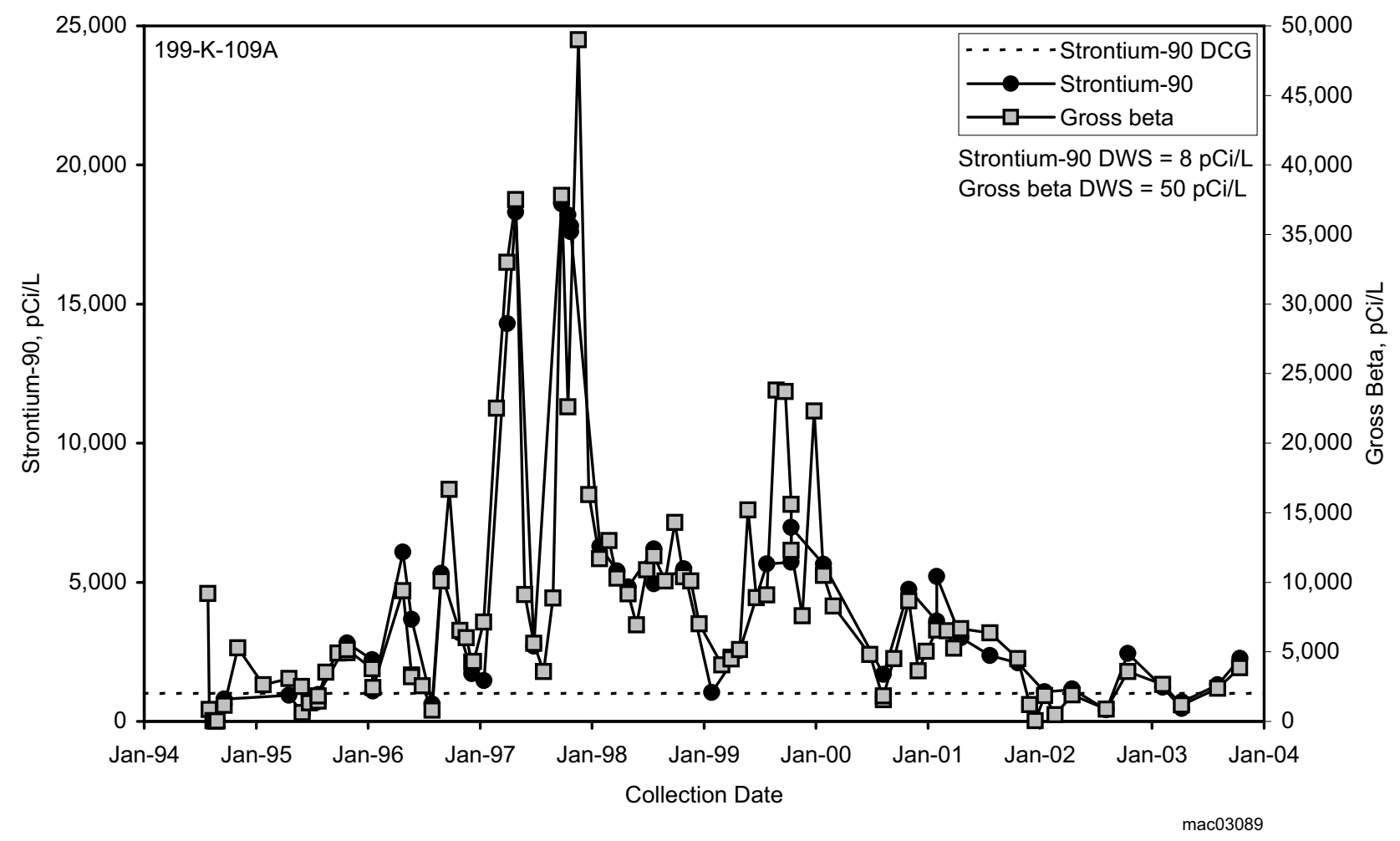

Figure 2.3-14. Strontium-90 and Gross Beta Concentrations Near KE Basin

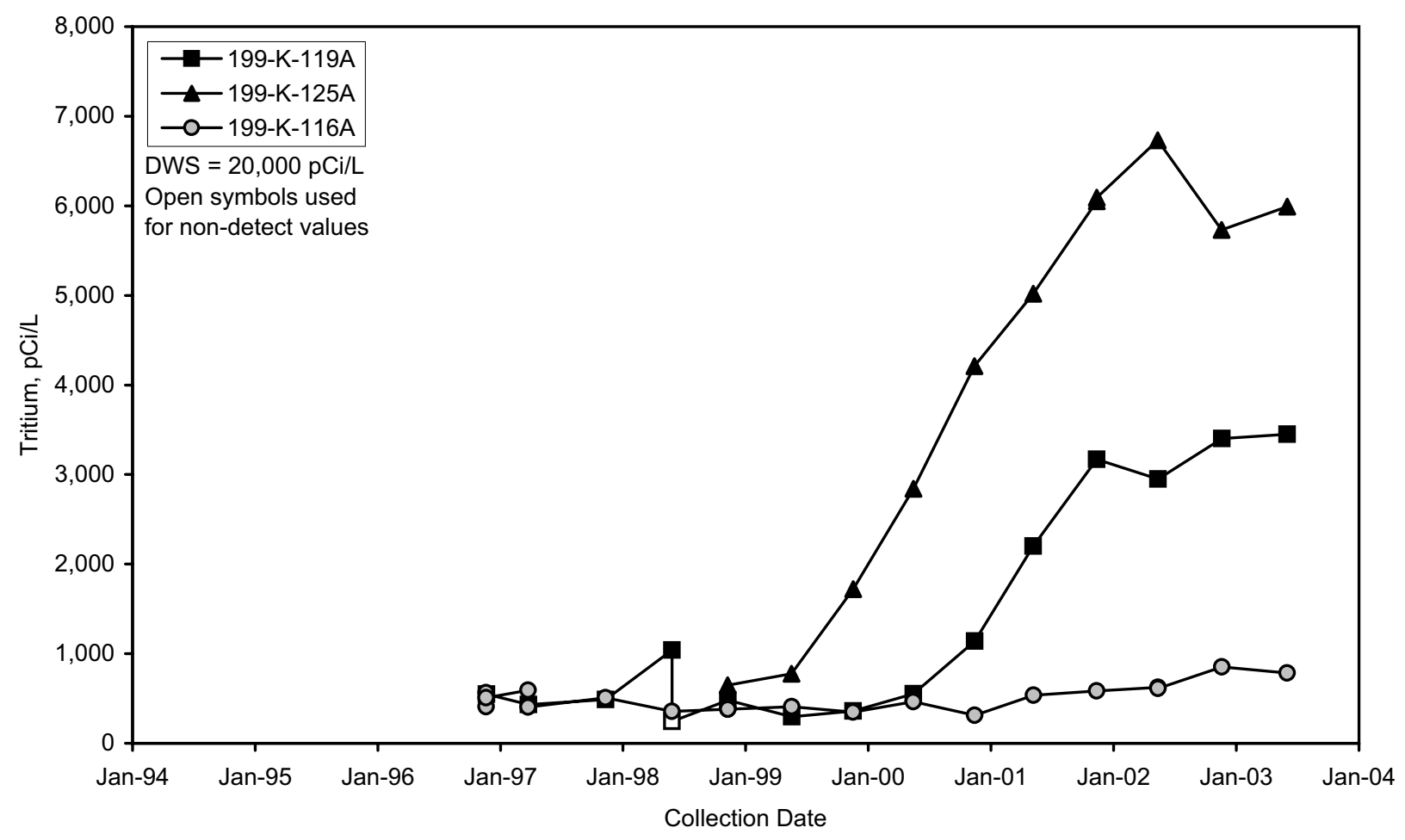

Figure 2.3-15. Tritium Concentrations in Wells Downgradient of the Pump-and-Treat Injection Site 


\subsection{0-NR-2 Operable Unit}

\section{J. Hartman and R. F. Raidl}

The scope of this section is the 100-NR-2 groundwater interest area, which includes the 100-NR-2 Operable Unit (Figure 2.1-1). Figure 2.4-1 shows facilities, wells, and shoreline monitoring sites in this region. Strontium-90 is the contaminant of greatest significance in groundwater at this operable unit. Groundwater is monitored to assess the performance of an interim action pump-and-treat system for strontium-90, to track other contaminant plumes, for three Resource Conservation and Recovery Act (RCRA) sites, and the Atomic Energy Act of 1954 (AEA). In addition to the strontium-90 plume, contaminants of concern include tritium, nitrate, sulfate, petroleum hydrocarbons, manganese, and chromium.

Groundwater flows primarily to the north and northwest, toward the Columbia River (Figure 2.4-2). Water levels fluctuate with river stage.

The remainder of this section describes contaminant plumes and concentration trends for the contaminants of concern under the Comprehensive Environmental Response, Compensation, and Liability Act (CERCLA), ${ }^{(a)}$ RCRA, or AEA monitoring.

\subsubsection{Groundwater Contaminants}

This section describes distributions and trends for the constituents of interest for the 100-NR-2 groundwater interest area.

Groundwater monitoring in the 100-NR-2 groundwater interest area includes CERCLA, RCRA, and AEA monitoring:

\section{CERCLA Monitoring}

- Six wells are sampled semiannually for strontium-90 and co-contaminants.

- Fifteen wells are sampled annually for strontium-90 and/or co-contaminants.

- In fiscal year 2003, all wells were sampled as scheduled.

\section{RCRA Monitoring}

- Five wells are sampled semiannually for the 116-N-1 facility.

- Five wells are sampled semiannually for the 120-N-1 and 120-N-2 facilities.

- Five wells were sampled semiannually for the 116-N-3 facility.

- In fiscal year 2003, one RCRA well was not sampled as scheduled (see text and Appendix B).

- Monitoring is coordinated with other programs to avoid duplication.

\section{AEA Monitoring}

- Thirty-one wells were sampled for contaminants and general chemistry.

- Seven wells are scheduled for triennial sampling; next scheduled sampling is fiscal year 2005.

- Monitoring is coordinated with other programs to avoid duplication.

(a) Past-practice monitoring in this operable unit is regulated under RCRA past-practice monitoring, which follows the same groundwater monitoring activities as CERCLA. This report uses the term CERCLA for simplicity. 


\section{Strontium-90 is the most significant groundwater contaminant beneath the 100-NR-2 Operable Unit. The general shape of the plume has not changed in many years.}

Plume areas (square kilometers) above the drinking water standard at the 100-NR-2 Operable Unit:

Nitrate -0.21

Strontium-90 - 0.58

Tritium -0.27

\subsubsection{Strontium-90}

The size and shape of the strontium-90 plume change very little from year to year, extending from beneath the $116-\mathrm{N}-1$ and $116-\mathrm{N}-3$ facilities to the Columbia River (Figure 2.4-3). The contamination is limited to the top 5 meters of the aquifer.

Changes in strontium- 90 concentrations often relate to water-table fluctuations because strontium-90 from the vadose zone is mobilized by a high water table (Figure 2.4-4). Concentrations are highest in well 199-N-67, where the maximum value in fiscal year 2003 was $8,000 \mathrm{pCi} / \mathrm{L}$, exceeding the DOE derived concentration guide of $1,000 \mathrm{pCi} / \mathrm{L}$.

One riverbank spring (spring 8-13) was sampled in September 2002, but it is not located in the strontium-90 plume and no strontium-90 was detected. A series of steel casings set into the gravel at the river shore, called seep wells, were sampled in October 2002. The highest strontium-90 concentration was $82 \mathrm{pCi} / \mathrm{L}$ in seep well 3, located near well 199-N-46 (PNNL-14295, APP. 2). This value exceeded the drinking water standard ( $8 \mathrm{pCi} / \mathrm{L})$. There are no aquifer tubes monitoring the shoreline at the 100-N Area.

\subsubsection{Tritium}

The tritium plume has diminished in the years since effluent discharge to the 166-N-1 and 166-N-3 facilities ceased (Figure 2.4-5). The highest concentrations are currently in wells near the Columbia River. Tritium contamination is observed throughout the upper aquifer and also in well 199-N-80, which monitors a confined Ringold aquifer.

Tritium concentrations have declined throughout the plume, though the rate of decline slowed in fiscal year 2003 (Figure 2.4-6). The maximum concentration was 31,400 pCi/L in well 199-N-14, which exceeded the $20,000 \mathrm{pCi} / \mathrm{L}$ drinking water standard.

Seep 8-13, located along the north portion of the 100-N Area shoreline, showed $7,140 \mathrm{pCi} / \mathrm{L}$ tritium in fall 2002. Tritium was undetected in all seep wells in fall 2002. The non-detect results may be caused in part by dilution with river water. Aquifer tube results from the south 100-D Area indicate migration of the 100-N tritium plume along the shoreline (see Section 2.5).

\subsubsection{Nitrate}

Nitrate concentrations exceed the $45 \mathrm{mg} / \mathrm{L}$ drinking water standard in various locations of the 100-N Area. The source of contamination has not been defined. In fiscal year 2003, nitrate concentrations exceeded the standard in three wells (199-N-2, 199-N-3, 199-N-67) near the 116-N-1 facility, two wells (199-N-21, 199-N-26) in the southwest 100-N Area, and one well (199-N-32) near the 116-N-3 facility. In the past, nitrate exceeded the standard in well 199-N-59 near the 120-N-1 percolation pond, but the well could not be sampled in fiscal year 2003 because it was dry.

Nitrate concentrations in many wells increased in the mid-to-late 1990s (e.g., Figure 2.4-7). Similar trends were observed in wells throughout the 100 Areas. Those nitrate increases were accompanied by higher water levels; however, since then, there is not a clear correlation between water levels and nitrate. The maximum nitrate concentration detected in fiscal year 2003 was $228 \mathrm{mg} / \mathrm{L}$ in well 199-N-67, a sharp increase from the previous year (Figure 2.4-7).

Anomalously low nitrate concentrations continued to be observed in well 199-N-18 (undetected in fiscal year 2003). The low concentrations are believed to be caused by chemical reduction of the nitrate caused by biodegradation of hydrocarbons (Section 2.4.1.5).

\subsubsection{Sulfate}

The former 120-N-1 percolation pond introduced non-hazardous constituents, including sulfate and sodium, to 100-N Area groundwater. Sulfate concentrations remained elevated in groundwater north and northwest of the 120-N-1 site (Figure 2.4-8). A second area of 
elevated sulfate concentrations underlies the $116-\mathrm{N}-3$ trench. This contamination is residual from previous flow conditions that carried sulfate from the $120-\mathrm{N}-1$ percolation pond inland and then toward the north.

The highest sulfate concentration in fiscal year 2003 was $196 \mathrm{mg} / \mathrm{L}$ in well 199-N-3, at the north edge of the main plume. Well 199-N-59, adjacent to the former source, had sulfate concentrations above the $250 \mathrm{mg} / \mathrm{L}$ secondary drinking water standard in previous years, but it could not be sampled in fiscal year 2003 because it was dry.

Figure 2.4-9 shows sulfate trends. Sulfate concentrations are declining in wells adjacent to the 120-N-1 percolation pond (e.g., well 199-N-72) and to the northwest (e.g., well 199-N-21). In well 199-N-3 at the north edge of the plume, concentrations remained stable in fiscal years 2002 and 2003. Sulfate concentrations probably have peaked at this location and will decline in coming years.

Near the 116-N-3 facility, sulfate concentrations increased in the late 1990s as the residual contaminant plume moved northward into this area. Concentrations have remained stable since 2000.

\subsubsection{Petroleum Products}

Petroleum products from a 1960s leak (DOE/RL-95-111) continued to be detected in 100-N Area groundwater, but concentrations were lower than in the previous 2 years. Of the affected wells, 199-N-18 is closest to the former leak site and had the highest levels of groundwater contamination (Figure 2.4-10).

In April 2003, the Groundwater Performance Assessment Project (groundwater project; formerly the Hanford Groundwater Monitoring Project) measured $\sim 2$ centimeters of free product floating on the water table in well 199-N-18. A sample of the free layer was analyzed for diesel and the result was $630,000 \mathrm{mg} / \mathrm{L}$. A sample collected from the water column had a result of $1,600 \mathrm{mg} / \mathrm{L}$.

Fluor Hanford, Inc. began a remedial action to remove the free product from well 199-N-18 in October 2003. A passive treatment method removes residual amounts of diesel from the well. The method employs a polymer that selectively absorbs petroleum from the surface of the water like a sponge. A cylinder of the material is lowered into the well for a 2-week period, after which it is removed, weighed, and replaced with a new unit. This procedure will be repeated every 2 weeks for a year. The 1 -year observation period will be used to evaluate the mass removal rate of the petroleum hydrocarbon from well 199-N-18.

Evidence of low levels of hydrocarbon contamination has been observed in wells 199-N-3, 199-N-19, and 199-N-96A in the past (PNNL-14187, Section 2.4). In fiscal year 2003, the only evidence of contamination in these wells was slightly elevated total organic carbon in well $199-\mathrm{N}-3$ and one low detection $(0.9 \mathrm{mg} / \mathrm{L})$ of diesel in well 199-N-96A.

\subsubsection{Manganese and Iron}

Manganese continued to exceed the $50 \mu \mathrm{g} / \mathrm{L}$ secondary drinking water standard in two wells in the 100-N Area. The affected wells are 199-N-16 (1,110 $\mu \mathrm{g} / \mathrm{L})$ and 199-N-18 $(3,700 \mu \mathrm{g} / \mathrm{L})$. Iron also exceeded its secondary drinking water standard $(300 \mu \mathrm{g} / \mathrm{L})$ in these wells (2,810 and 21,700 $\mu \mathrm{g} / \mathrm{L}$ in wells $199-\mathrm{N}-16$ and 199-N-18, respectively).

Both wells are located in areas of hydrocarbon contamination. Biodegradation of the hydrocarbons creates reducing conditions, which increases the solubility of metals such as manganese and iron.

\subsubsection{Chromium}

Only one well in the $100-\mathrm{N}$ Area has chromium concentrations above the $100-\mu \mathrm{g} / \mathrm{L}$ drinking water standard. Well 199-N-80, which is completed in a thin, confined aquifer in

\section{The sulfate plume continued to move downgradient and concentrations are generally declining.}

Petroleum products continued to be detected in 100-N Area groundwater, but concentrations were lower than in the previous 2 years. 


\section{A pump-and-treat system at the 100-NR-2 Operable Unit satisfied its objectives in fiscal year 2003, but has not affected the distribution or concentration of strontium-90 in the aquifer to any observable extent.}

the Ringold Formation, typically has chromium concentrations of $\sim 170 \mu \mathrm{g} / \mathrm{L}$. The source for chromium in this deep horizon is unknown.

Chromium concentrations have increased in shallow well 199-N-41, located near the $116-\mathrm{N}-3$ trench, reaching $15 \mu \mathrm{g} / \mathrm{L}$ in fiscal year 2003. Concentrations in other 100-N Area shallow wells are lower.

\subsubsection{CERCLA Interim Groundwater Remediation for Strontium-90}

A pump-and-treat system has been operating in the 100-N Area since 1995 as part of an interim action for the 100-NR-2 Operable Unit (ROD 1999b). The objectives of the pump-and -treat system are:

- Reduce strontium-90 contaminant flux from the groundwater to the Columbia River.

- Evaluate commercially available treatment options for strontium-90.

- Provide data necessary to set demonstrable strontium-90 groundwater cleanup standards.

Figure 2.4-1 displays extraction/injection well locations and Appendix A lists sampling frequencies and constituents. All of the wells scheduled for sampling under CERCLA were sampled as scheduled in fiscal year 2003.

The pump-and-treat system satisfied its objectives in fiscal year 2003, but has not affected the distribution or concentration of strontium-90 in the aquifer to any observable extent. The extraction wells create a hydraulic sink between the 116-N-1 facility and the Columbia River and, thus, reduce or reverse the hydraulic gradient in the groundwater toward the Columbia River. The reduction or reversal of the hydraulic gradient results in less groundwater and strontium-90 discharging to the Columbia River through the N Springs area. However, the pump-and-treat system is not capable of controlling the water discharged because of the cyclical river stage and bank storage effects of the Columbia River. An upcoming annual report on the 100-NR-2 interim action will include a complete description of the progress and effectiveness of the remedial action in calendar year 2003.

The extraction wells have created an area of lower strontium-90 concentrations between the 116-N-1 trench and the Columbia River (Figure 2.4-3). However, this area does not represent significant clean up of the aquifer. The low concentrations are believed to be caused by (a) drawdown of the water table (strontium-90 concentrations are highest at the top of the aquifer and in the vadose zone); and (b) dilution with river water drawn in by pumping.

Figure 2.4-11 shows strontium-90 concentrations with time in 100-N Area extraction wells. Concentrations vary in response to a fluctuating water table and other changes in groundwater flow, but there are no clear, overall upward or downward trends.

\subsubsection{RCRA Groundwater Monitoring}

The 100-NR-2 Operable Unit contains three RCRA sites with groundwater monitoring requirements. This section summarizes results of statistical comparisons for fiscal year 2003. 
RCRA groundwater data are available in the Hanford Environmental Information System and on the data files accompanying this report. Additional information, including well/ constituent lists, maps, flow rates, and critical mean tables, are included in Appendix B.

\subsubsection{116-N-1 Liquid Waste Disposal Facility}

RCRA monitoring indicates that this facility is not contaminating groundwater with non-radioactive, hazardous constituents. All of the wells were sampled as scheduled.

Downgradient well 199-N-3 continued to have $\mathrm{pH}$ values below the critical range ( 7.23 to 8.55) in March and September 2003 (7.21 and 7.13, respectively). The below-background $\mathrm{pH}$ is part of the overall distribution of $\mathrm{pH}$ in the area and does not indicate contamination from the facility. Low $\mathrm{pH}$ is related to biodegradation of petroleum hydrocarbons (see Section 2.4.1.5).

Specific conductance in well 199-N-3 exceeded the critical mean value in March and September 2003. Such exceedances are common in this well and are related to a nonhazardous, high-conductance plume from an upgradient facility. Detection monitoring will continue.

\subsubsection{120-N-2 Surface Impoundment and 120-N-1 Percolation Pond}

RCRA monitoring indicates that these facilities are not contaminating groundwater with hazardous constituents. Well 199-N-59 could not be sampled in fiscal year 2003 because it was dry. The other wells were sampled as scheduled.

Average specific conductance values in wells downgradient of the facilities continued to exceed the critical mean values in fiscal year 2003. A previous groundwater quality assessment indicated that the high specific conductance is caused by the non-hazardous constituents sulfate and sodium.

This site is entering its post-closure period, and the groundwater monitoring plan will be revised in fiscal year 2004 .

\subsubsection{116-N-3 Liquid Waste Disposal Facility}

RCRA monitoring indicates that this facility is not contaminating groundwater with non-radioactive, hazardous constituents. All of the wells were sampled as scheduled.

Average specific conductance values in downgradient well 199-N-41 exceeded the critical mean value in fiscal year 2003 . This was a continuation of previous exceedances noted in 1999 through 2002. The exceedance was caused by past discharges of non-hazardous constituents to an upgradient facility (see Section 2.4.1.4 and Figure 2.4-8).

\subsubsection{AEA Monitoring}

The groundwater project conducts monitoring under AEA to supplement CERCLA and RCRA monitoring in the 100-N Area. In addition to tracking plumes and trends, AEA monitoring addresses the following objectives:

- Monitor strontium-90 concentrations in individual extraction wells (not currently required under CERCLA).

During fiscal year 2003, the pump-and-treat system extracted 114 million liters of groundwater from the 100-N Area, removing $\sim 0.19$ curies of strontium-90. The pump-and-treat system has removed $\sim 1.45$ curies of strontium-90 from the 100-N Area groundwater since startup in 1995, compared to a total inventory in the aquifer estimated to exceed 75 curies. Current estimates indicate that it will take $>300$ years before the strontium 90 concentrations reach permissible levels (DOE/RL-95-110) as a result of radioactive decay. For this reason, DOE is investigating and evaluating alternative remediation technologies.

\author{
RCRA detection \\ monitoring \\ continued in fiscal \\ year 2003 and \\ provided no \\ evidence of \\ contamination \\ with hazardous \\ constituents.
}

No cesium-137 or cobalt-60 was detected in 100-N Area groundwater in fiscal year 2003. 


\section{A borehole in \\ the Hanford \\ Generating Plant \\ area was sampled \\ for the first time. \\ Results were \\ consistent with \\ local water quality.}

- Monitor for potential effects of surface remediation of the 116-N-1 and 116-N-3 facilities (strontium-90, cesium-137, and cobalt-60).

- Monitor petroleum hydrocarbons in wells surrounding 199-N-18 (wells 199-N-3, 199-N-19, and 199-N-96A).

- Sample boreholes in the Hanford Generating Plant, south of 100-N Area.

Strontium-90 results were discussed in Sections 2.4.1.1 and 2.4.2 and petroleum hydrocarbons were discussed in Section 2.4.1.5.

Monitoring of wells downgradient of the $116-\mathrm{N}-1$ and $116-\mathrm{N}-3$ facilities showed no indication of adverse effects of surface remediation and associated dust-control water.

In fiscal year 2003, the groundwater project sampled borehole C3164, located south of the main 100-N Area (Figure 2.4-1). The borehole is cased but unscreened; it is assumed to recharge through the open bottom of the casing. The sampled depth probably represents the bottom of the upper aquifer or finer-grained units below. Most contaminants were undetected or at background levels. Tritium was detected at $1,320 \mathrm{pCi} / \mathrm{L}$, which is consistent with general distribution patterns in the 100 Areas. Manganese $(46 \mu \mathrm{g} / \mathrm{L})$ and sulfate (200 mg/L) were detected at levels near their secondary drinking water standards. The ion chemistry indicates the water is similar to that in well 199-N-59, located adjacent to the 120-N-1 percolation pond. There are no plans to sample borehole C3164 routinely. 


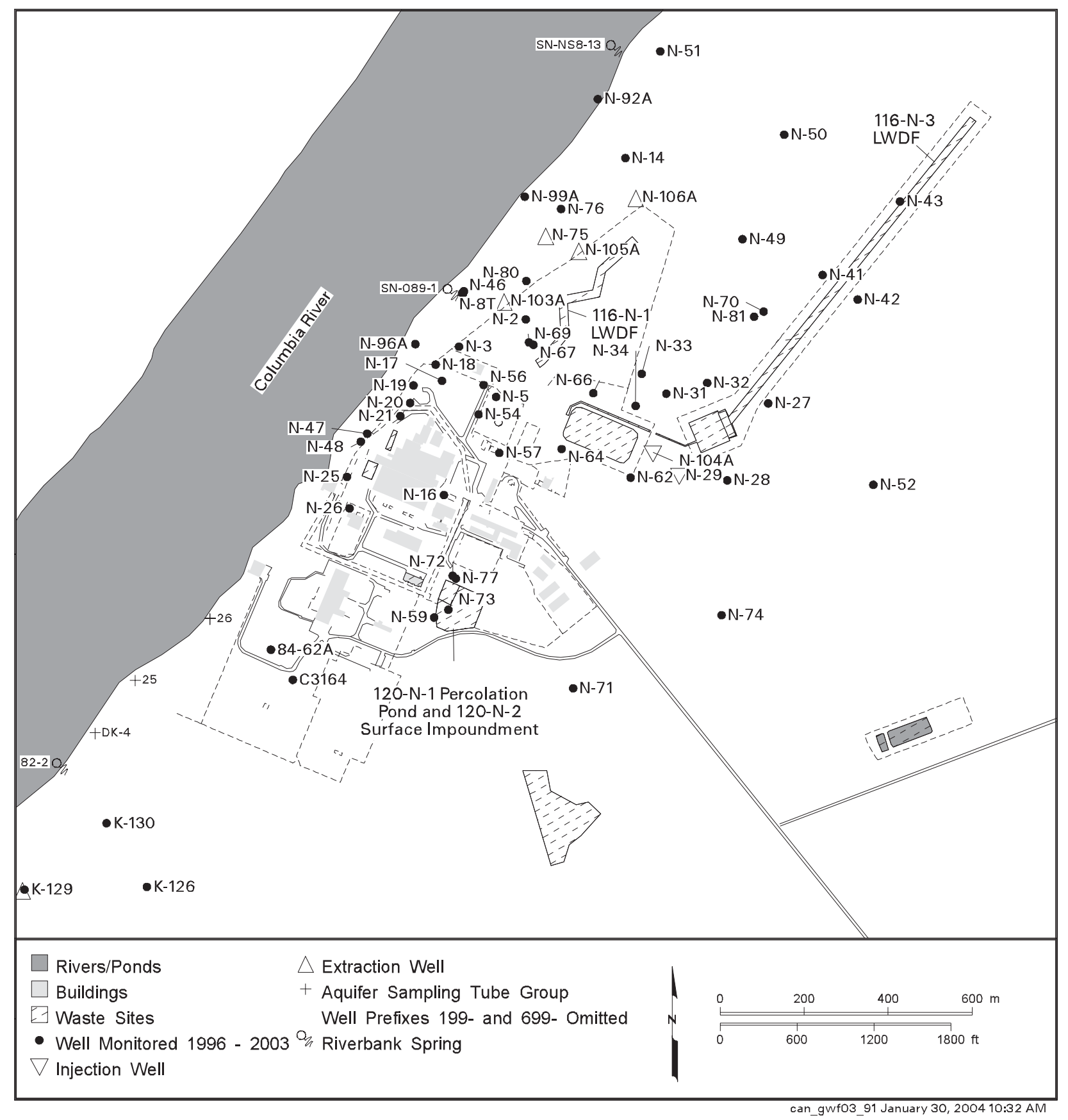

Figure 2.4-1. Groundwater Monitoring Wells in the 100-N Area 


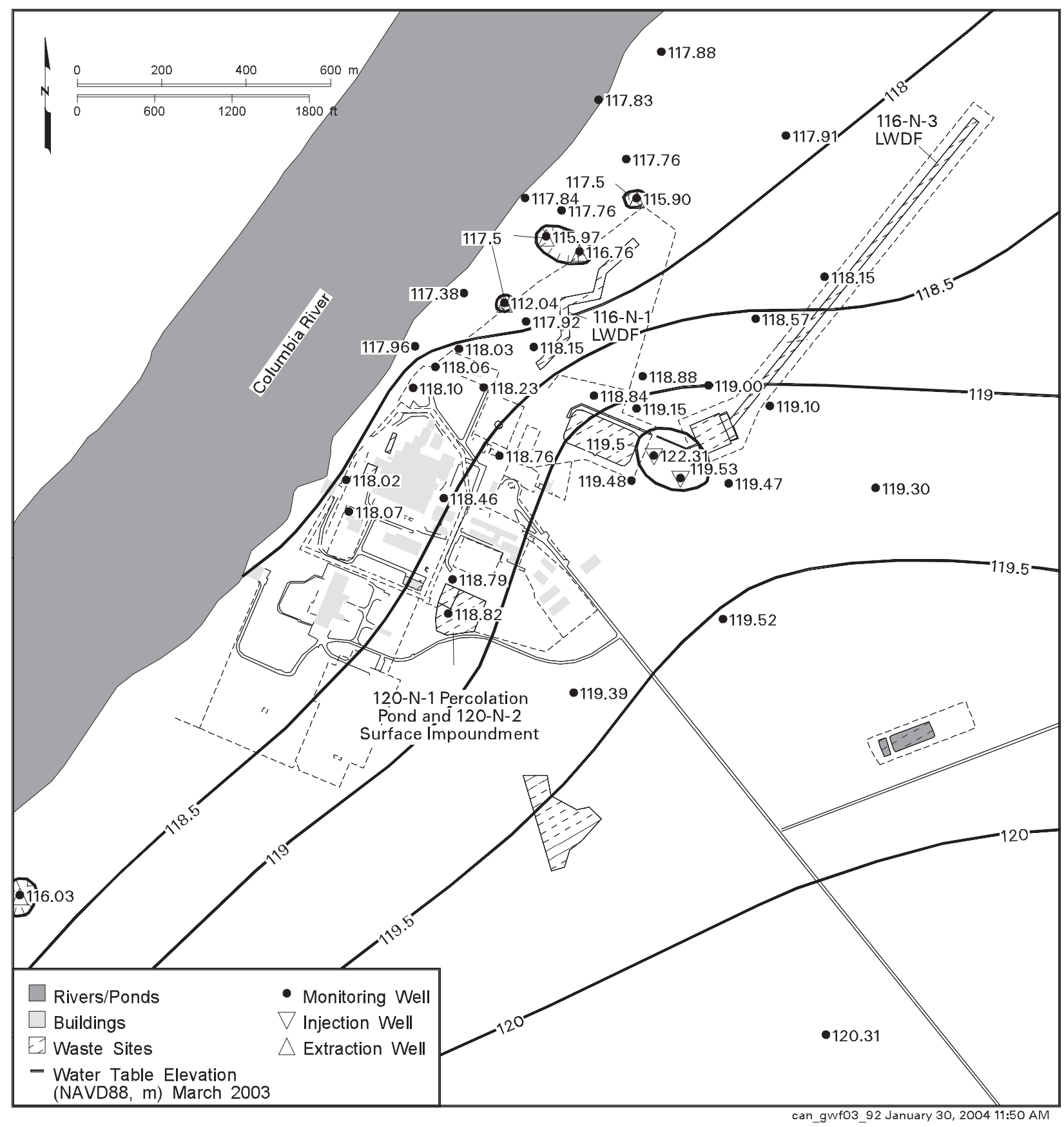

Figure 2.4-2. Water Table Beneath 100-N Area, March 2003 


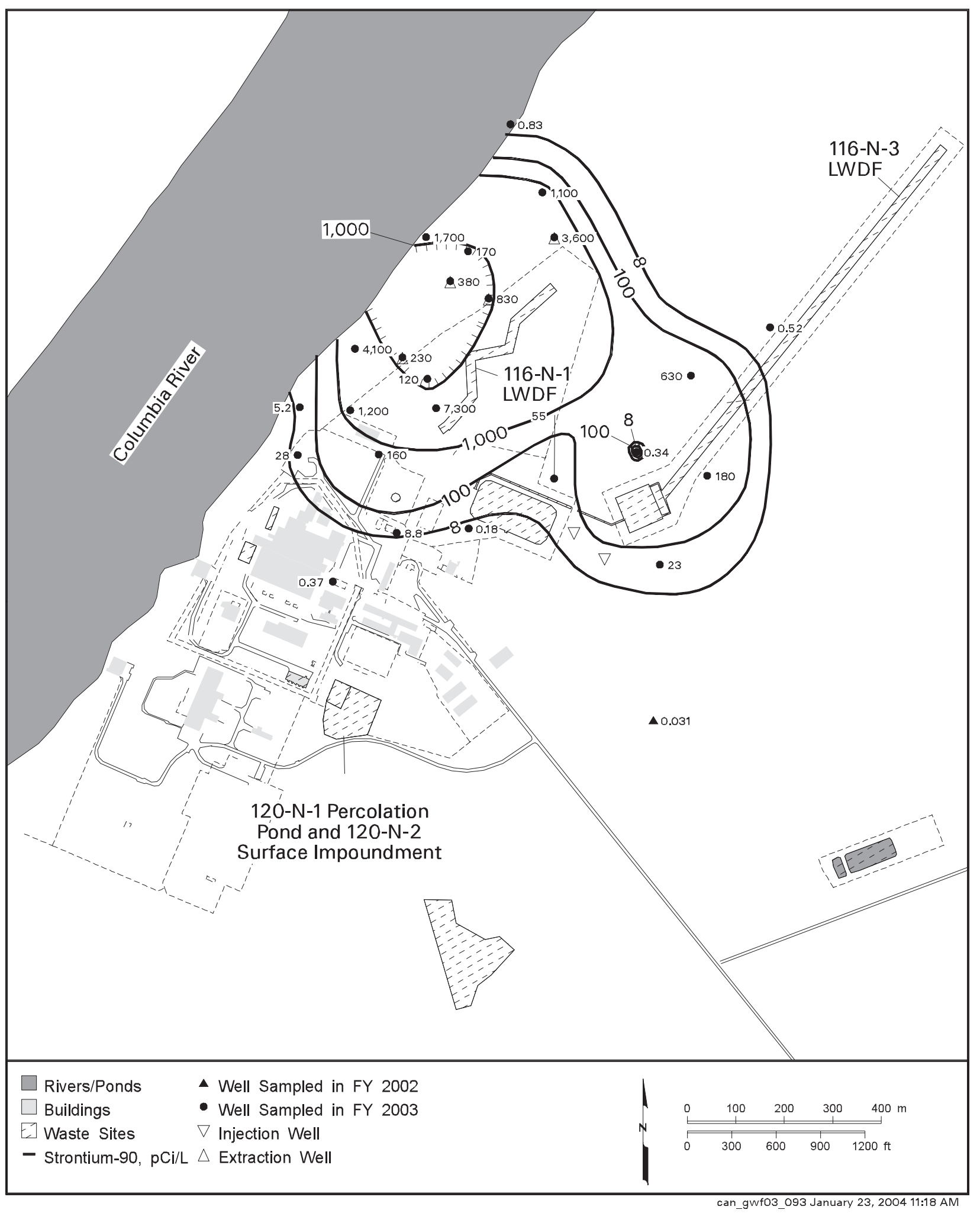

Figure 2.4-3. Average Strontium-90 Concentrations in the 100-N Area, Top of Unconfined Aquifer 


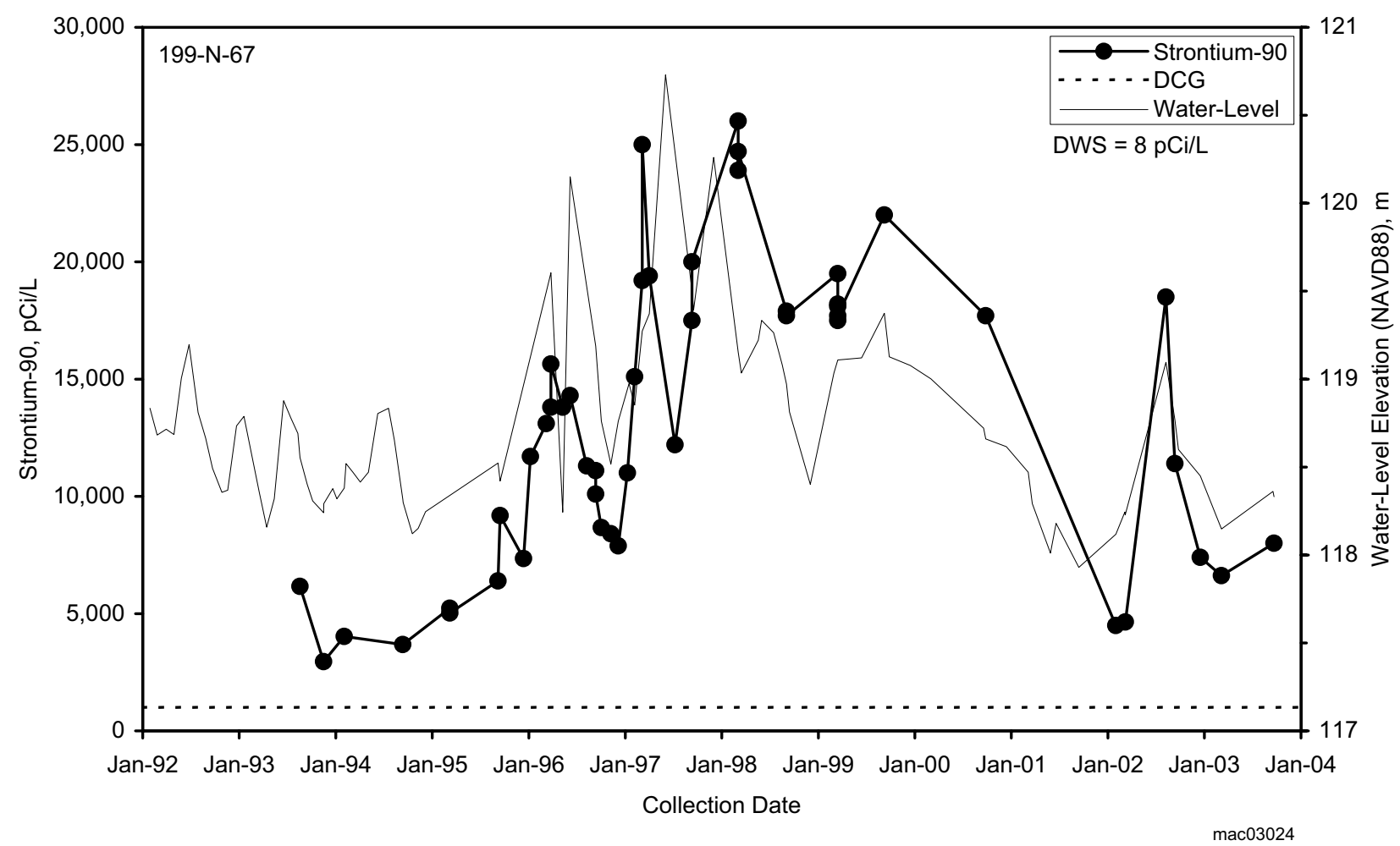

Figure 2.4-4. Strontium-90 Concentrations and Water Level Near the 116-N-1 Facility 


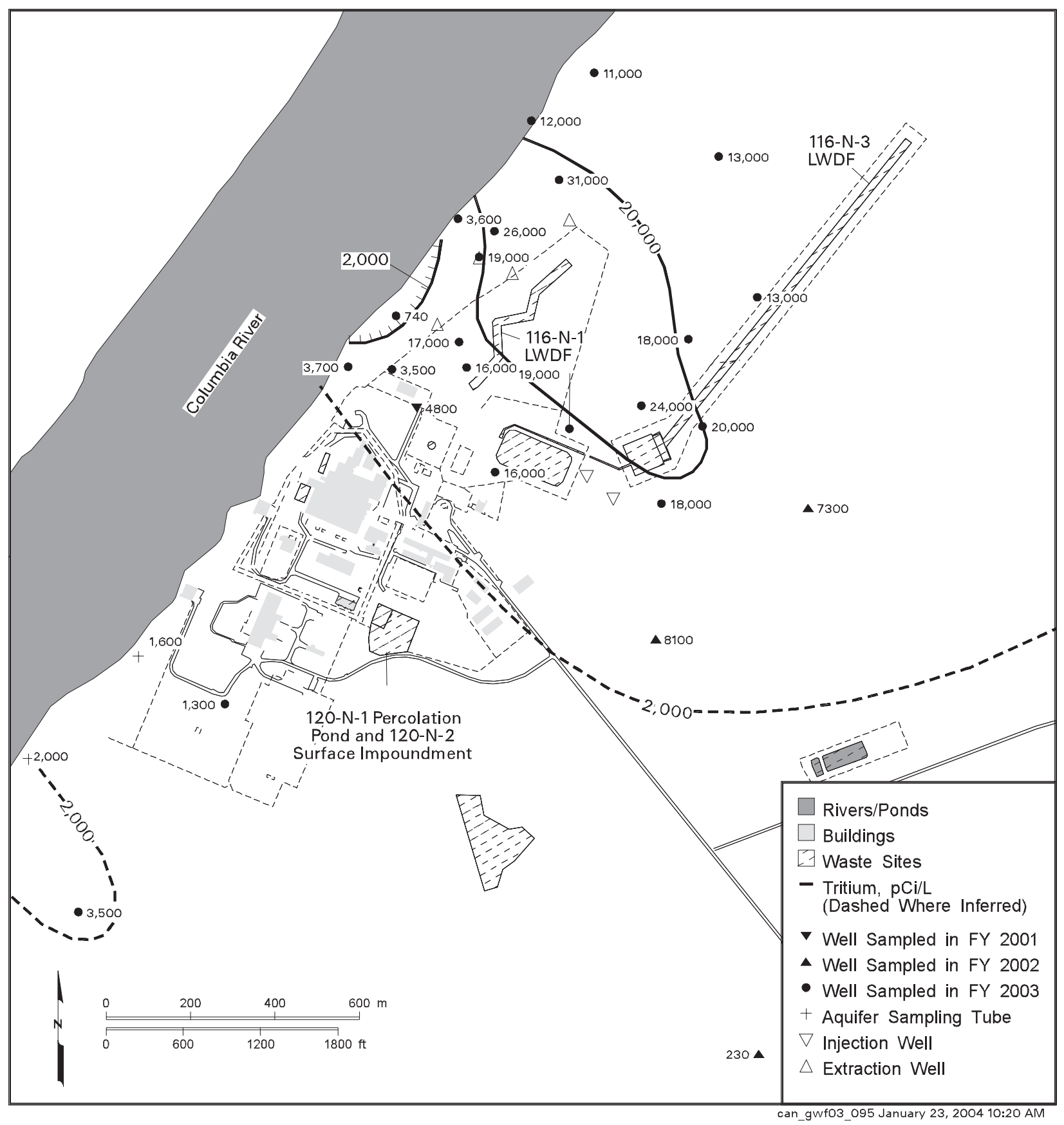

Figure 2.4-5. Average Tritium Concentrations in the 100-N Area, Top of Unconfined Aquifer 


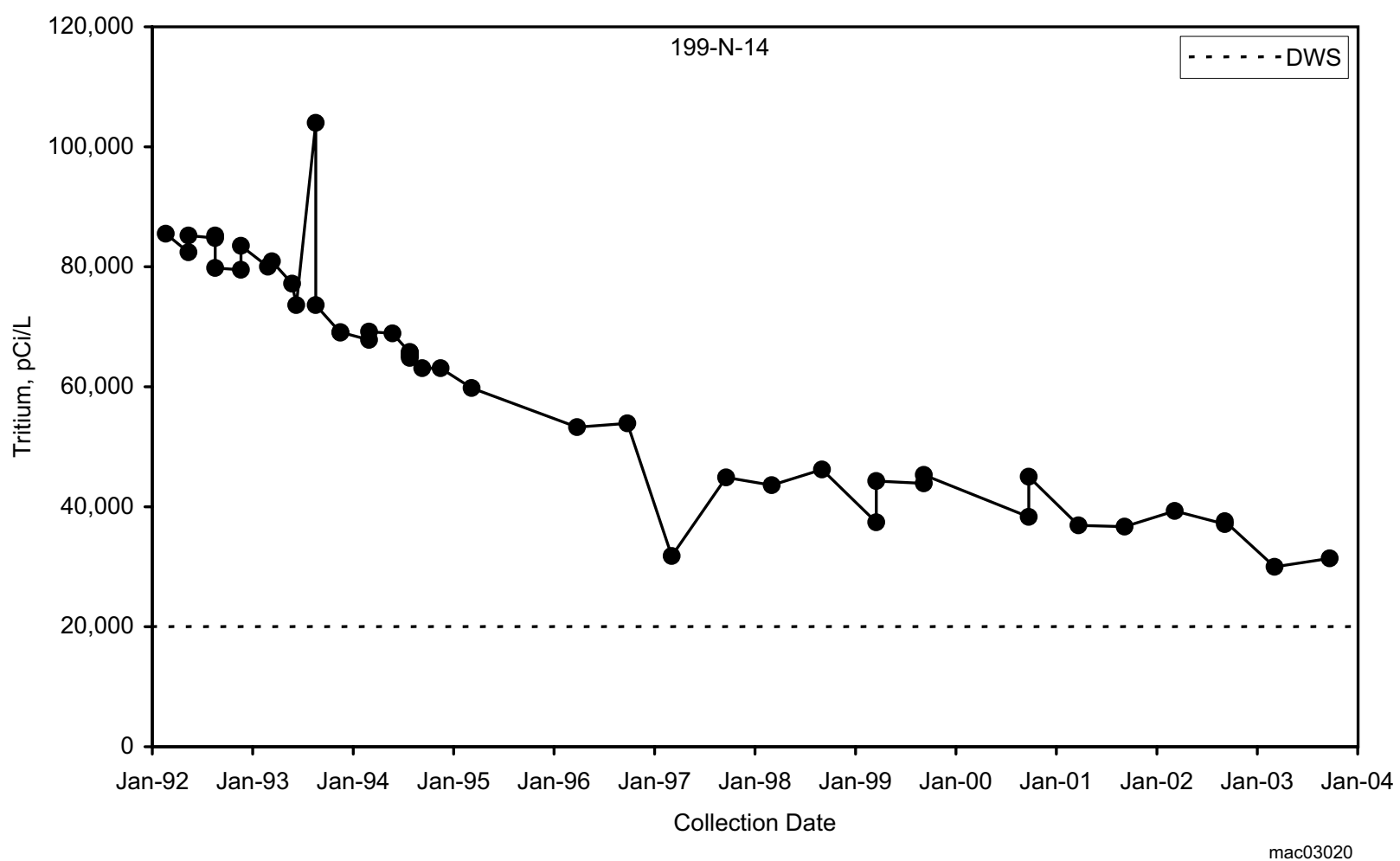

Figure 2.4-6. Tritium Concentrations North of the 116-N-1 Facility

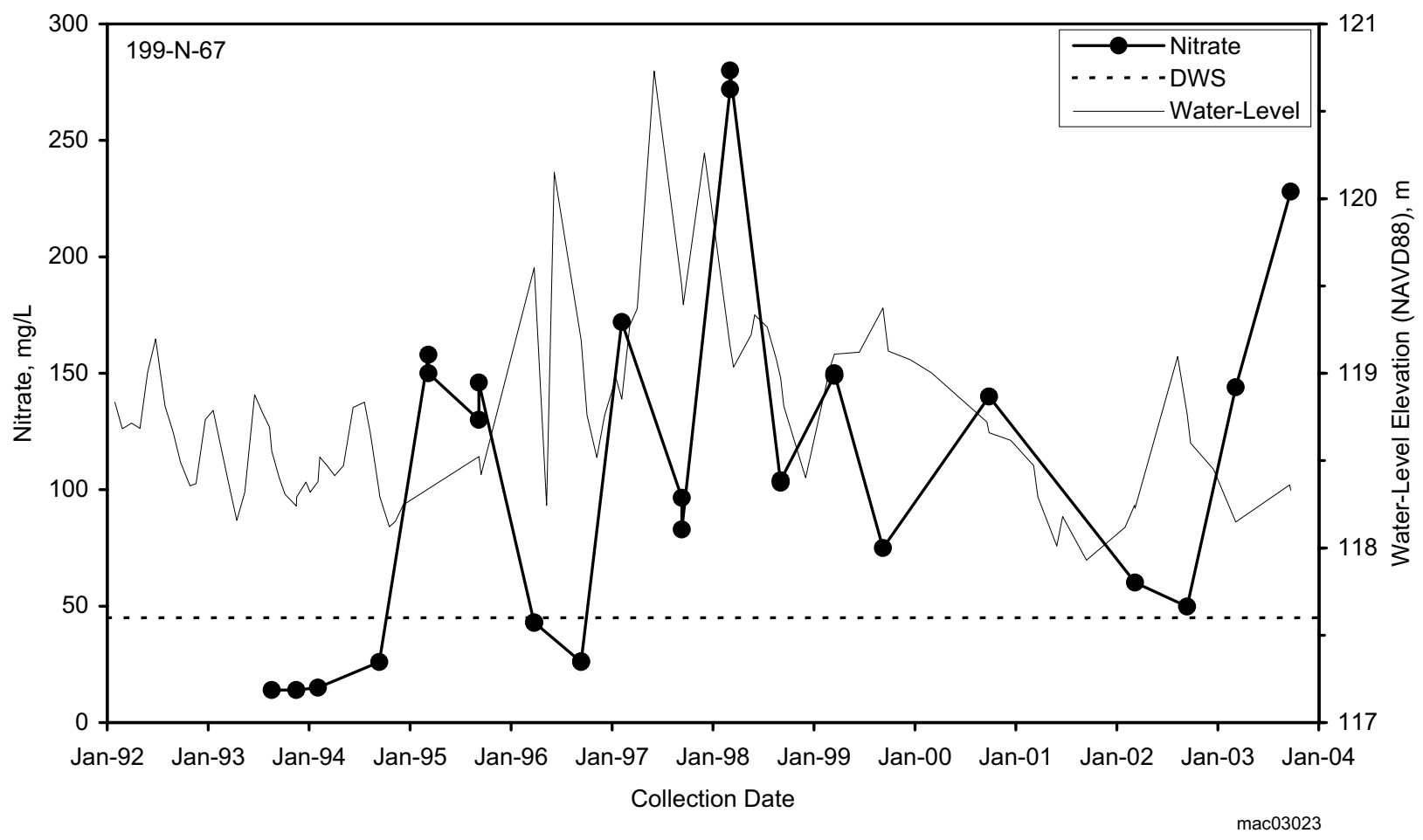

Figure 2.4-7. Nitrate Concentrations and Water Level Near the 116-N-1 Facility 


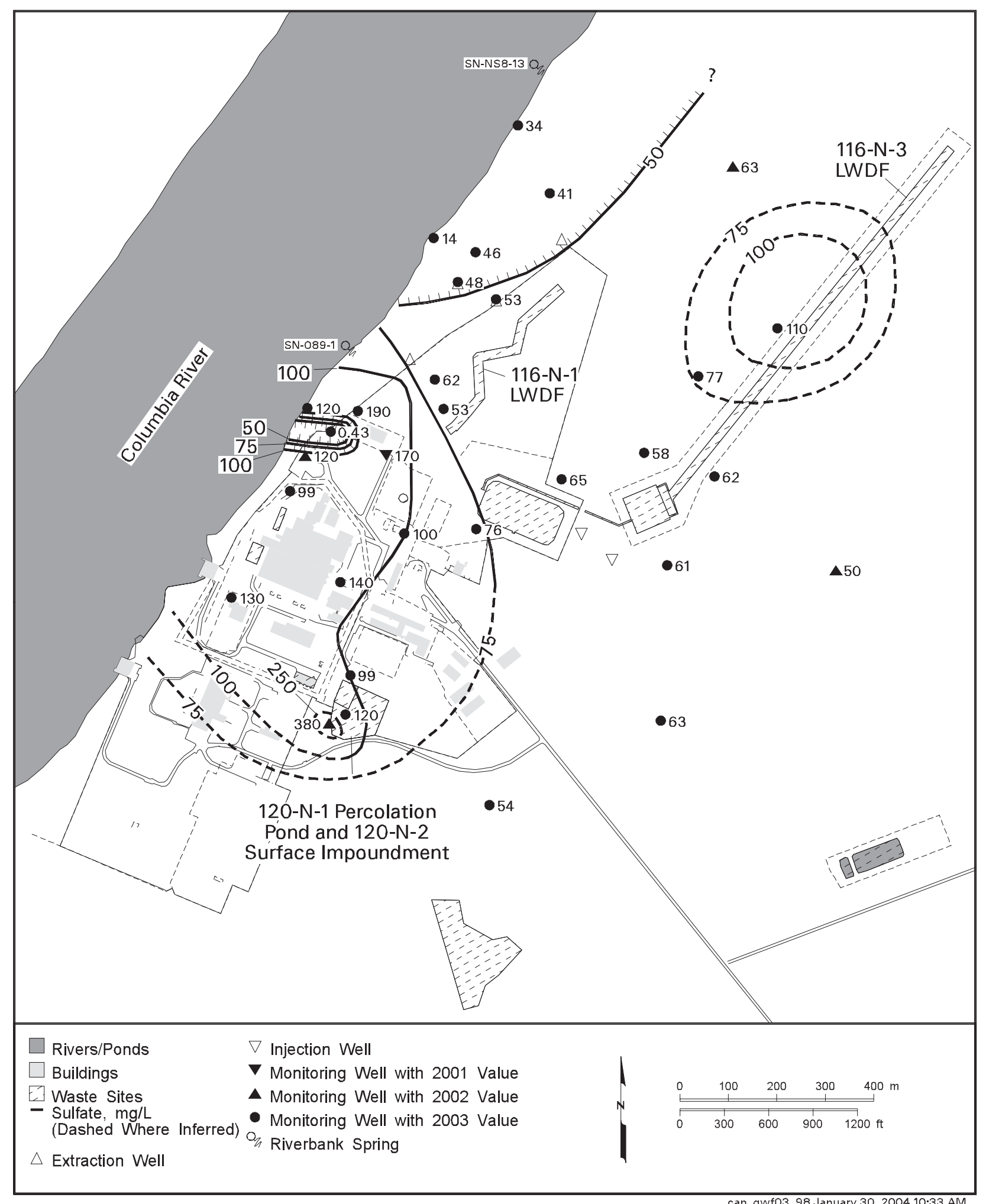

Figure 2.4-8. Average Sulfate Concentrations in the 100-N Area, Top of Unconfined Aquifer 


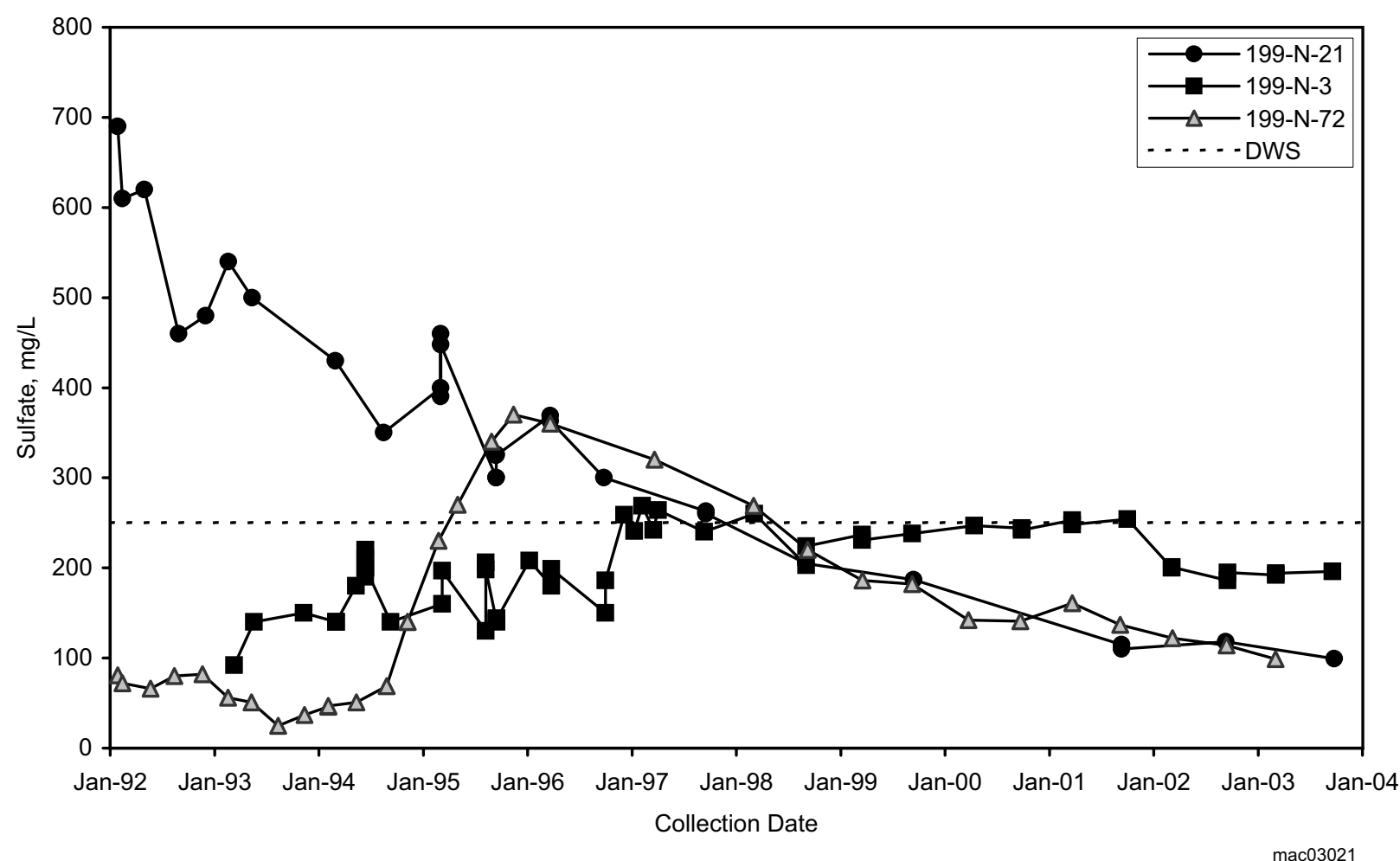

Figure 2.4-9. Sulfate Concentrations in 100-N Area Wells

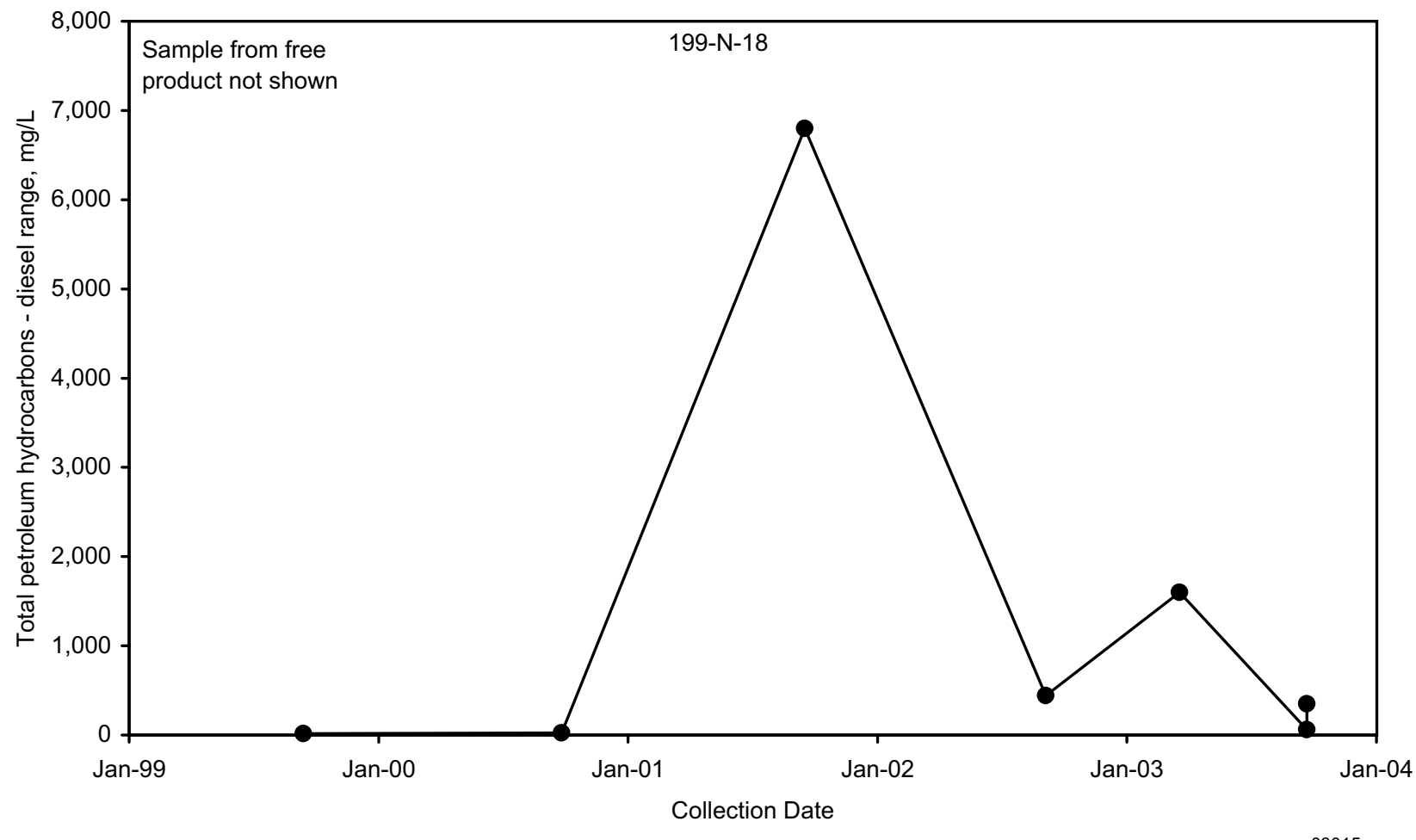

Figure 2.4-10. Petroleum Hydrocarbons Near Former Petroleum Leak Site 

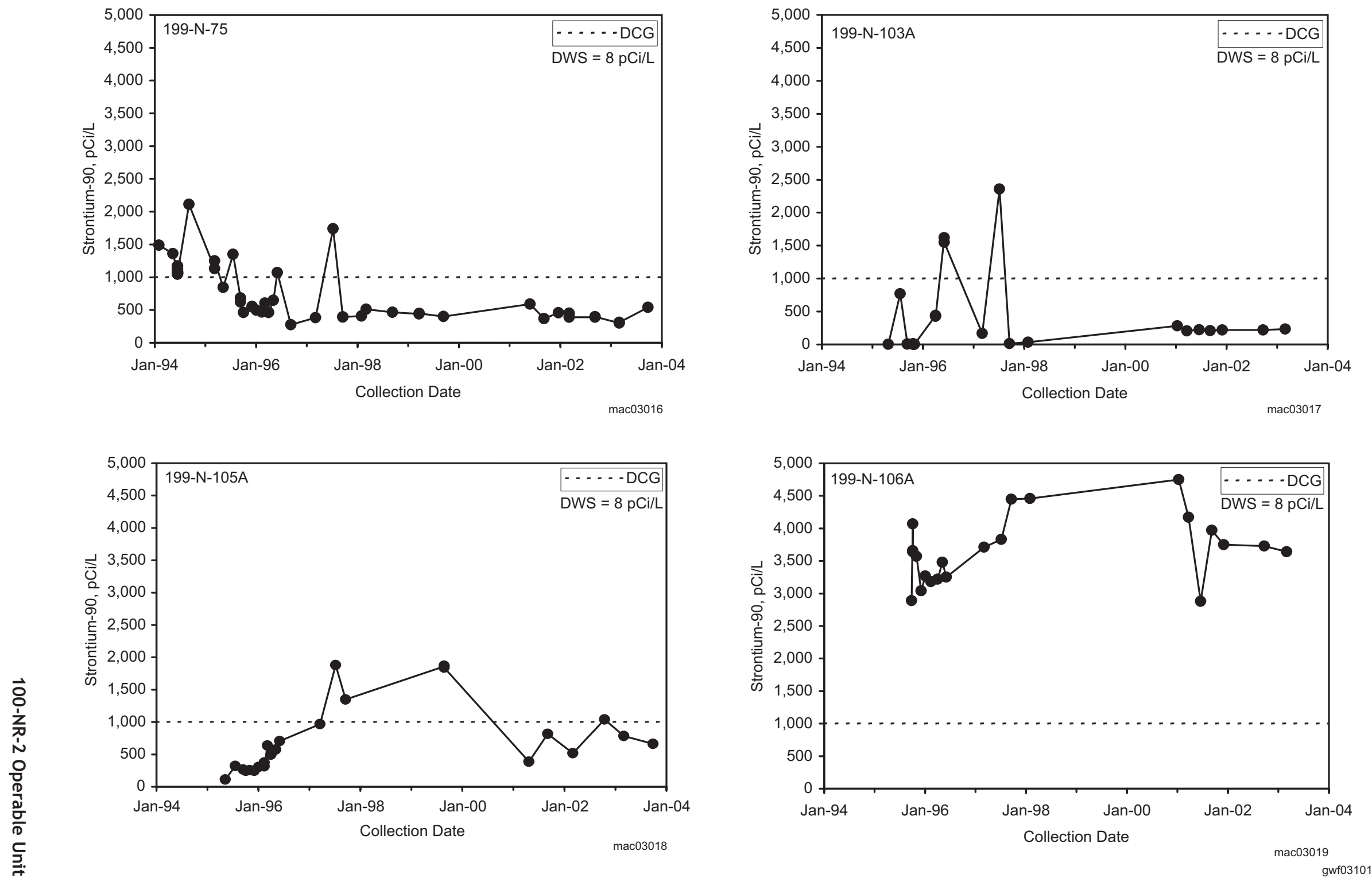

Figure 2.4-11. Strontium-90 Concentrations in 100-N Area Extraction Wells 


\subsection{0-HR-3-D Operable Unit}

\section{J. Hartman, R. O. Mahood, and R. F. Raidl}

The scope of this section is the 100-HR-3-D groundwater interest area, which occupies the west half of the 100-HR-3 Operable Unit (Figure 2.1-1). Figures 2.5-1 and 2.5-2 show facilities, wells, and shoreline monitoring sites in this region. Hexavalent chromium is the contaminant of greatest significance in groundwater. Groundwater is monitored to assess the performance of two Comprehensive Environmental Response, Compensation, and Liability Act (CERCLA) interim actions for chromium: a pump-and-treat system and an in situ reduction-oxidation manipulation (redox) system. Groundwater also is monitored to track other contaminant plumes including strontium-90, tritium, nitrate, and sulfate.

Groundwater flows primarily to the north and northwest, to the Columbia River (Figure 2.5-3). Near the Columbia River, including the redox site, the average flow direction is toward the northwest. Farther inland, average flow is northward.

The remainder of this section describes contaminant plumes and concentration trends for the constituents of interest under CERCLA ${ }^{(a)}$ and Atomic Energy Act of 1954 (AEA) monitoring.

\subsubsection{Groundwater Contaminants}

This section describes the distribution and trends of chromium, strontium-90, tritium, nitrate, and sulfate in groundwater in the 100-D Area.

Groundwater monitoring in the 100-HR-3-D groundwater interest area includes CERCLA and AEA monitoring:

CERCLA Monitoring - Pump-and-Treat System

- Two compliance wells and 33 monitoring wells are sampled monthly to biennially for chromium and co-contaminants.

- Four extraction wells are sampled quarterly for chromium; co-contaminants are sampled semiannually.

- Four shoreline seeps are sampled annually.

- In fiscal year 2003, all wells were sampled as scheduled; two seeps were not (see Appendix A).

CERCLA Monitoring - Redox System

- Seven compliance wells, 14 barrier wells, and 11 other monitoring wells are sampled quarterly to annually for chromium and co-contaminants.

- Samples are collected at aquifer tubes annually for chromium and field parameters.

- In fiscal year 2003, six wells and three aquifer tubes were not sampled as scheduled (see Appendix A).

\section{AEA Monitoring}

- Thirty-five wells are sampled annually to quarterly for contaminants and general chemistry.

- Sampling is coordinated with CERCLA sampling to avoid duplication.

(a) Past-practice monitoring in this operable unit is regulated under RCRA past-practice monitoring, which follows the same groundwater monitoring activities as CERCLA. This report uses the term CERCLA for simplicity. 


\section{Hexavalent \\ chromium is the \\ contaminant of \\ greatest concern in \\ the 100-D Area. \\ Two remediation \\ systems help reduce \\ the amount of \\ chromium reaching \\ the Columbia \\ River: a pump- \\ and-treat system \\ in the north and \\ in situ remediation \\ in the southwest.}

\subsubsection{Chromium}

A chromium plume underlies most of the 100-D Area (Figures 2.5-4 and 2.5-5). The plume has two lobes that were formerly separate plumes: a south lobe with unknown sources near the former 183-DR filter plant, and a north lobe with sources in the central 100-D Area. The lobes are joined at the 100- $\mathrm{gg} / \mathrm{L}$ contour (drinking water standard) and perhaps the $500-\mu g / L$ contour.

The south lobe of the chromium plume is oriented southeast-northwest, approximately perpendicular to the Columbia River. The plume has spread northward in recent years. The chromium concentrations here are the highest on the Hanford Site, with a fiscal year 2003 maximum value of 5,440 $\mathrm{gg} / \mathrm{L}$ in well 199-D5-39 (Figure 2.5-6). Concentrations rose steeply in 2001 as the plume apparently moved northward, and levels have been variable since then. Wells in the south part of the plume, e.g., well 199-D5-43, declined in 2001 and 2002, also as a result of plume migration. Levels remained relatively low in fiscal year 2003.

The south chromium plume is intersected by the redox barrier, which terminates the highest-concentration portion of the plume (Figure 2.5-5). The area downgradient of the initial injection wells (those injected during 1999 and 2000) shows the largest impact of the remediation. For example, wells 199-D4-23 and 199-D4-38 showed steep declines in chromium concentrations in 2000 and 2001 (e.g., Figure 2.5-7). However, in nearby well 199-D4-39, chromium concentrations declined sharply in 2000 but have been highly variable since then. Sulfate concentrations have increased in all these wells in the past 2 years, indicating the presence of residual chemicals from dithionite injection into redox barrier wells. Areas downgradient of portions of the barrier created later (2001 through 2003) show less impact of remediation (e.g., wells 199-D4-83, 199-D4-84, and 199-D4-86; Figure 2.5-8). Well 199-D4-85 is an exception, and shows a sharp decline in chromium and an increase in sulfate in fiscal year 2003. Section 2.5.2 contains more information about the redox system and related impact on the aquifer.

Aquifer sampling tubes provide additional monitoring points along the 100-D Area shoreline (Figure 2.5-9). The highest concentrations are in the southwest chromium plume at the redox site, with a maximum $295 \mu \mathrm{g} / \mathrm{L}$ at tube site 42, sampled in December 2002. Chromium concentrations in several of the tubes in this region have declined in recent years, possibly due, in part, to remediation effects (PNNL-14444).

The north lobe of the chromium plume was formerly oriented south-north, but has spread westward in recent years. Part of this plume is influenced by the 100-HR-3-D pump-and-treat system, which is designed to reduce the flux of chromium to the river (see Section 2.5.2.1).

Chromium concentrations have increased markedly in several wells that formerly were between the south and north plumes. For example, levels exceeded 1,000 $\mu \mathrm{g} / \mathrm{L}$ in wells 199-D5-20 and 199-D5-41 in fall 2003 (Figure 2.5-10). These increases are believed to represent westward movement of the north plume, but could also be caused by mobilization of chromium from the vadose zone or movement of the south plume.

\subsubsection{Strontium-90}

Strontium-90 continued to be detected in a few wells in the 100-D Area in fiscal year 2003 at levels below the drinking water standard $(8 \mathrm{pCi} / \mathrm{L})$. In the north 100-D Area, several wells detected strontium-90 in the 1 to $3 \mathrm{pCi} / \mathrm{L}$ range, and well 199-D8-68 had a result of $7.1 \mathrm{pCi} / \mathrm{L}$. Farther south, strontium-90 was detected in well 199-D5-15 at $3.08 \mathrm{pCi} / \mathrm{L}$, but was undetected in nearby wells. There are no clear increasing or decreasing trends in the data. 


\subsubsection{Tritium}

Fiscal year 2003 tritium concentrations ranged from below detection limits to above the $20,000 \mathrm{pCi} / \mathrm{L}$ drinking water standard. The highest concentrations were detected in wells in the south 100-D Area, and are believed to represent groundwater flowing northward from the 100-N Area. Part of the 100-N Area tritium plume moved inland when groundwater mounds were present beneath liquid waste disposal facilities, and that contamination is now moving north and northwest. The highest value in the 100-D Area was $23,700 \mathrm{pCi} / \mathrm{L}$ in well 199-D4-19, where concentrations are increasing (Figure 2.5-11). The tritium concentration in an aquifer tube near that well was $29,700 \mathrm{pCi} / \mathrm{L}$.

Tritium concentrations continued to be above $10,000 \mathrm{pCi} / \mathrm{L}$ in the central $100-\mathrm{D}$ Area (wells 199-D5-15, 199-D5-16, 199-D5-17, and 199-D5-18) in fiscal year 2003. Levels have been fairly stable in recent years.

An area of low tritium concentrations $(<2,000 \mathrm{pCi} / \mathrm{L})$ extends from the former 183-DR filter plant to the river and north to the 116-D-7 retention basins. This area formerly had low chromium concentrations as well, possibly because of dilution with clean water that leaked from the 182-D reservoir.

\subsubsection{Nitrate}

Nitrate distribution is generally similar to chromium in the 100-D Area; both constituents form two-lobed plumes. Nitrate concentrations continued to exceed the $45 \mathrm{mg} / \mathrm{L}$ drinking water standard in both lobes, with a maximum concentration of $107 \mathrm{mg} / \mathrm{L}$ in well 199-D2-6. The south lobe of the plume is truncated by the redox system, which converts the nitrate to nitrite. Nitrite concentrations tend to be elevated in redox injection wells and occasionally in downgradient wells and exceeded the drinking water standard $(3.3 \mathrm{mg} / \mathrm{L})$ in two injection wells.

Nitrate trends in the central 100-D Area do not follow chromium trends. Nitrate concentrations are not increasing as sharply as are chromium concentrations.

\subsubsection{Sulfate}

Like chromium and nitrate, the sulfate plume beneath 100-D Area has two lobes. Excluding wells influenced by the redox system, concentrations all were below the $250 \mathrm{mg} / \mathrm{L}$ secondary drinking water standard (maximum $196 \mathrm{mg} / \mathrm{L}$ in well 199-D2-6 in the south 100-D Area).

Injections of sodium dithionite solution at the redox site increases sulfate concentrations in the barrier and in some downgradient wells and aquifer tubes. For example, sulfate concentrations increased in wells 199-D4-23 and 199-D4-85 in fiscal year 2003 (Figure 2.5-12). The maximum concentration downgradient of the barrier was $390 \mathrm{mg} / \mathrm{L}$ in well 199-D4-23.

\subsubsection{CERCLA Interim Groundwater Remediation for Chromium}

Two interim remedial actions operate in the 100-D Area: a pump-and-treat system in the north 100-D Area and an in situ remediation treatment system in the southwest 100-D Area.

\subsubsection{Pump-and-Treat System}

The pump-and-treat system in the 100-HR-3-D Operable Unit includes four extraction wells located near the former 116-D-7 and 116-DR-9 retention basins. The system began operating in July 1997. Groundwater is pumped from extraction wells 199-D8-53, 199-D8-54A, 199-D8-68, and 199-D8-72, and then is pumped to the 100-H Area where it

\section{Tritium contamination in the south 100-D Area may have originated in the 100-N Area.}


is treated and injected into the aquifer. Details regarding 100-HR-3-D pump-and-treat operations may be found in an upcoming interim action report that will be issued by the U.S. Department of Energy (DOE).

Remedial action monitoring is described in DOE/RL-96-90. Figure 2.5-1 displays well locations and Appendix A lists sampling frequencies and constituents.

\section{Progress During Fiscal Year 2003}

The 100-D Area pump-and-treat system is reducing overall contamination in the operable unit by removing contaminant mass. During fiscal year 2003, the system extracted $\sim 241$ million liters of groundwater from the 100-D Area, removing 39.2 kilograms of hexavalent chromium. The withdrawn water was piped to the 100-H Area where it was treated and injected into the aquifer.

The remedial action objectives of the 100-HR-3 Operable Unit (ROD 1996a, 1999a) are:

- Protect aquatic receptors in the river bottom from contaminants in groundwater entering the Columbia River.

- Protect human health by preventing exposure to contaminant in the groundwater.

- Provide information that will lead to the final remedy.

The contaminant of concern is hexavalent chromium. The record of decision sets the cleanup goal at compliance wells as $22 \mu \mathrm{g} / \mathrm{L}$ for the pump-and-treat system and $20 \mu \mathrm{g} / \mathrm{L}$ for the redox system. EPA specified enhancements needed to the pump-and-treat system in their 5-year review (EPA 2001).
A total of $\sim 161.3$ kilograms of hexavalent chromium has been removed from the plume targeted for interim action since startup of the system in July 1997. An additional $~ 30$ kilograms of hexavalent chromium were removed during a pilot-scale test conducted in the 100-D reactor area between August 1992 and August 1994 (DOE/RL-95-83). The total hexavalent chromium in the plume has been estimated at 590 kilograms (DOE/RL-94-95). This amount is not including the chromium plume in the southwest 100-D Area nor in the vadose zone.

All of the wells scheduled for sampling under CERCLA were sampled as scheduled in fiscal year 2003. Two seeps could not be sampled (see Appendix A).
During fiscal year 2003, the pump-

and-treat system extracted

241 million liters

of groundwater

from the 100-D

Area, removing

$\sim 39.2$ kilograms

of hexavalent

chromium.

\section{Influence on Aquifer Conditions}

Chromium concentrations remain elevated in the north 100-D Area. The plume continued to move in fiscal year 2003 (see Section 2.5.1.1).

Hexavalent chromium concentrations in compliance wells vary inversely with river stage. The ranges of concentration observed in fiscal year 2003 were similar to those observed in fiscal year 2002. Figure 2.5-13 shows chromium trends for the two compliance wells, 199-D8-69 and 199-D8-70. Chromium remained above the remedial action goal $(22 \mu \mathrm{g} / \mathrm{L})$ in both of the wells throughout fiscal year 2003. Concentrations were lowest in the spring and early summer.

Results of performance monitoring are incorporated with the discussion of general contamination in Section 2.5.1.

Results of operational monitoring, and additional details about the pump-and-treat system, will be included in an annual report on the 100-HR-3, 100-KR-4, and 100-NR-2 pump-and-treat systems.

\subsubsection{In Situ Redox Manipulation System}

This treatment system uses a change in reduction-oxidation (redox) potential to reduce dissolved hexavalent chromium in groundwater to trivalent chromium, a much less soluble species. Objectives of the redox interim action are the same as for the 100-D Area pumpand-treat system except that the remedial action goal for chromium at the redox site is $20 \mu \mathrm{g} / \mathrm{L}$. Remedial action monitoring is described in DOE/RL-99-51 and Appendix A. 


\section{Progress During Fiscal Year 2003}

Treatment of the aquifer surrounding the last five treatment zone wells was completed in fiscal year 2003. The treatment zone is now $\sim 680$ meters in length, aligned parallel to the Columbia River shoreline and 100 to 200 meters inland.

The treatment zone is designed to reduce the concentration of hexavalent chromium in groundwater to $<20 \mu \mathrm{g} / \mathrm{L}$ at seven compliance wells situated between the treatment zone and Columbia River. The $20 \mu \mathrm{g} / \mathrm{L}$ goal was met at one of the seven compliance wells at the end of fiscal year 2003. Institutional controls continue to protect the public by preventing exposure to hexavalent chromium in the groundwater. Sampling and analysis of groundwater from compliance wells, monitoring wells, aquifer sampling tubes, and redox treatment zone wells continues to provide information leading to selection of the final remedy.

An automated water-level monitoring system installed in eleven wells and at the Columbia River also provides information leading to selection of the final remedy. The network was expanded from nine wells to eleven wells in fiscal year 2003. Hydrographs of data from the automated water-level monitoring systems installed in four wells showed responses to the re-filling of the 182-D reservoir in July and the development of a low groundwater mound below the reservoir.

Six wells were not sampled one of the four quarters scheduled (see Appendix A). Three aquifer tubes could not be sampled because they did not produce water.

\section{Influence on Aquifer Conditions}

Chromium concentrations in compliance wells have been variable or decreasing since monitoring began (see Section 2.6.1.1 for more discussion and Figure 2.5-7 for examples of trends). Wells 199-D4-23, 199-D4-38, and 199-D4-85 show overall decreasing trends. Wells 199-D4-39, 199-D4-83, and 199-D4-86 show large variations in chromium concentrations. Chromium concentrations in well 199-D4-84 are fairly steady. Only in well 199-D4-86 did the concentration of hexavalent chromium decrease to less than the goal of $20 \mu \mathrm{g} / \mathrm{L}$ in fiscal year 2003. Chromium concentrations in the redox compliance wells are not affected as strongly by bank storage effects as are the pump-and-treat compliance wells. Specific conductance and chromium concentrations in the redox compliance wells do not correlate with water levels.

In recent years, chromium concentrations increased unexpectedly within the redox treatment zone in wells 199-D4-26, 199-D4-31, and 199-D4-37, based on operational monitoring data (not in the Hanford Environmental Information System database). The remaining areas of the in situ redox manipulation treatment zone appear to be intact and functioning as designed. DOE is working with the regulators to develop a corrective action to the apparent breakdown of portions of the barrier, as well as to the movement of chromium past the north end of the redox barrier.

Other effects of the redox system observed in wells within and downgradient of the treatment zone include decreases in dissolved oxygen and nitrate and increases in arsenic, gross beta, nitrite, sulfate, and some metals. The increases in metals are due to increased solubility in the reducing aquifer conditions. Increased sulfate is a result of incomplete recovery of the reaction products following the reduction treatment. Elevated gross beta activity (up to $466 \mathrm{pCi} / \mathrm{L}$ ) is due to potassium-40 naturally present in the injected solution.

\section{DOE completed}

the redox treatment

barrier in fiscal

year 2003.

Chromium

concentrations

declined in some

downgradient

wells. 


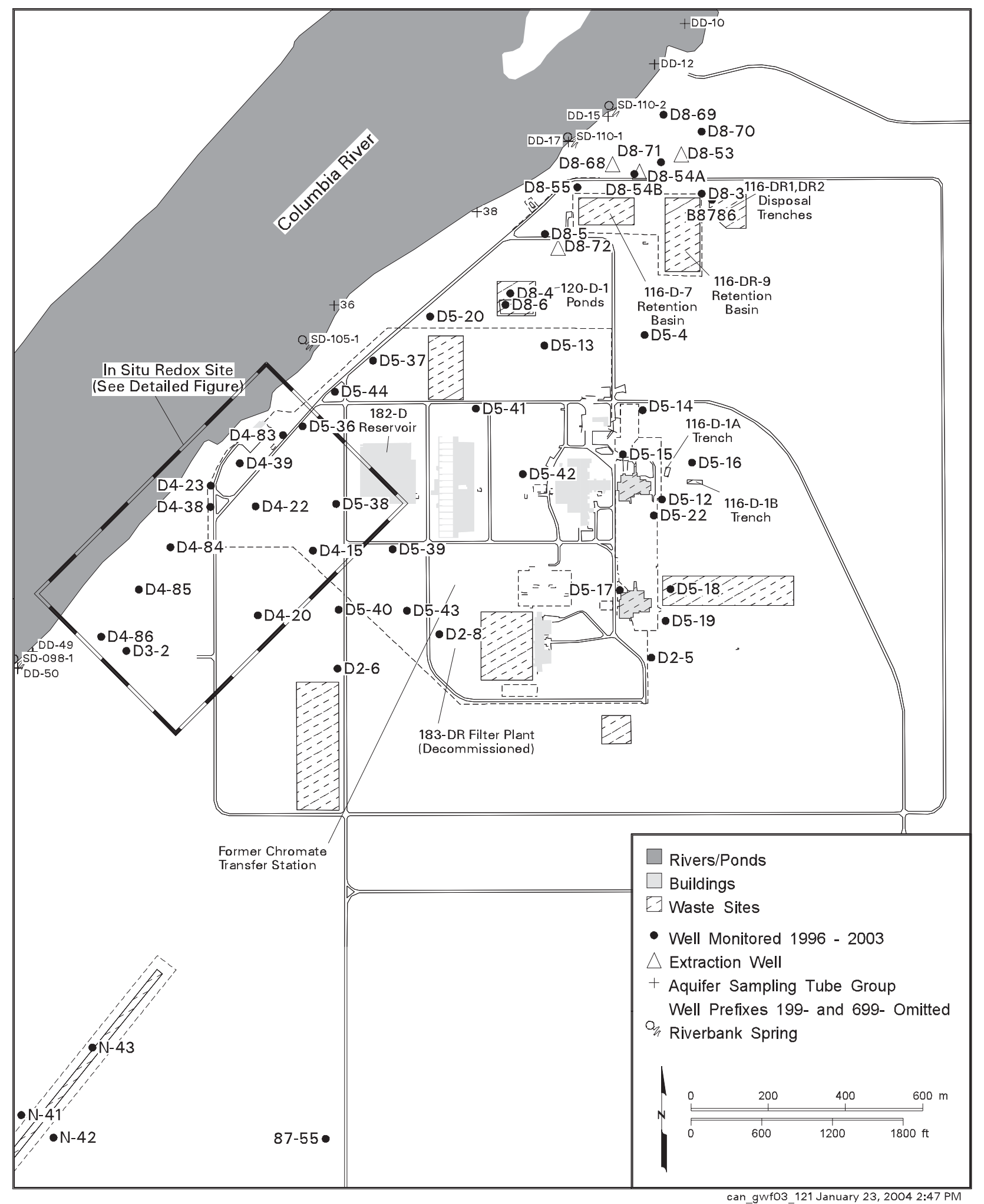

Figure 2.5-1. Groundwater Monitoring Wells in the 100-D Area 


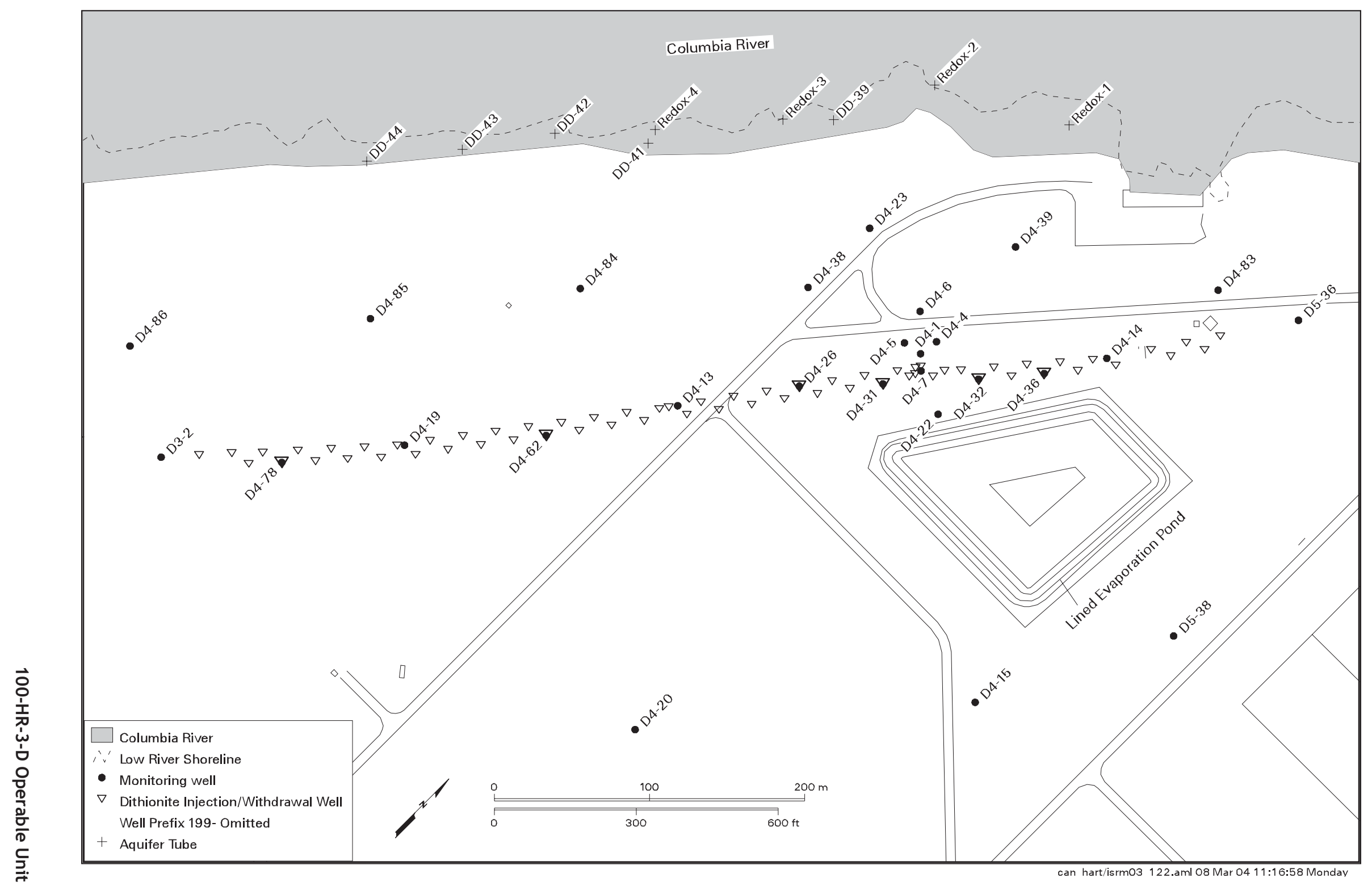

Figure 2.5-2. Groundwater Monitoring Wells Near the Redox Site in 100-D Area 


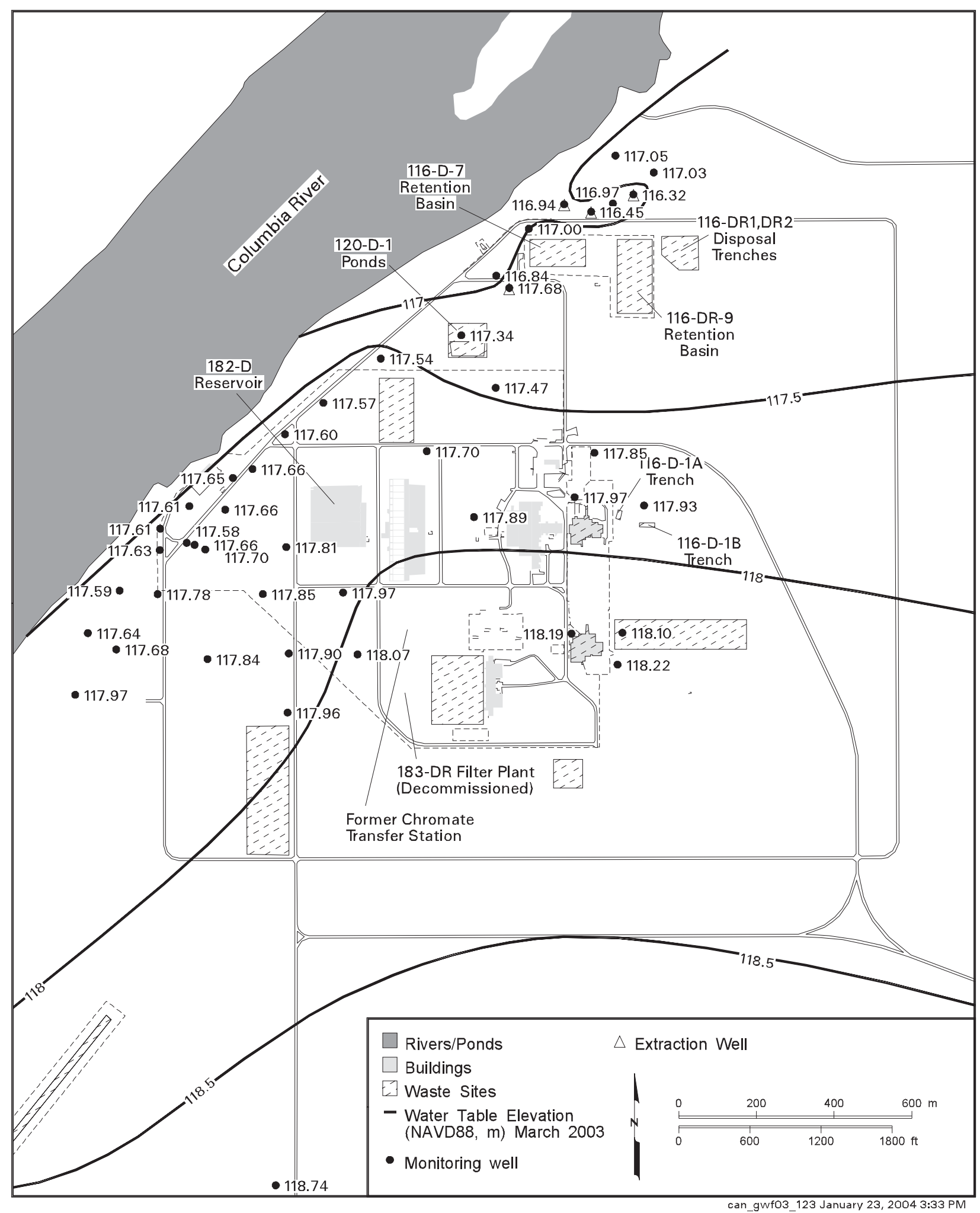

Figure 2.5-3. 100-D Area Water-Table Map, March 2003 


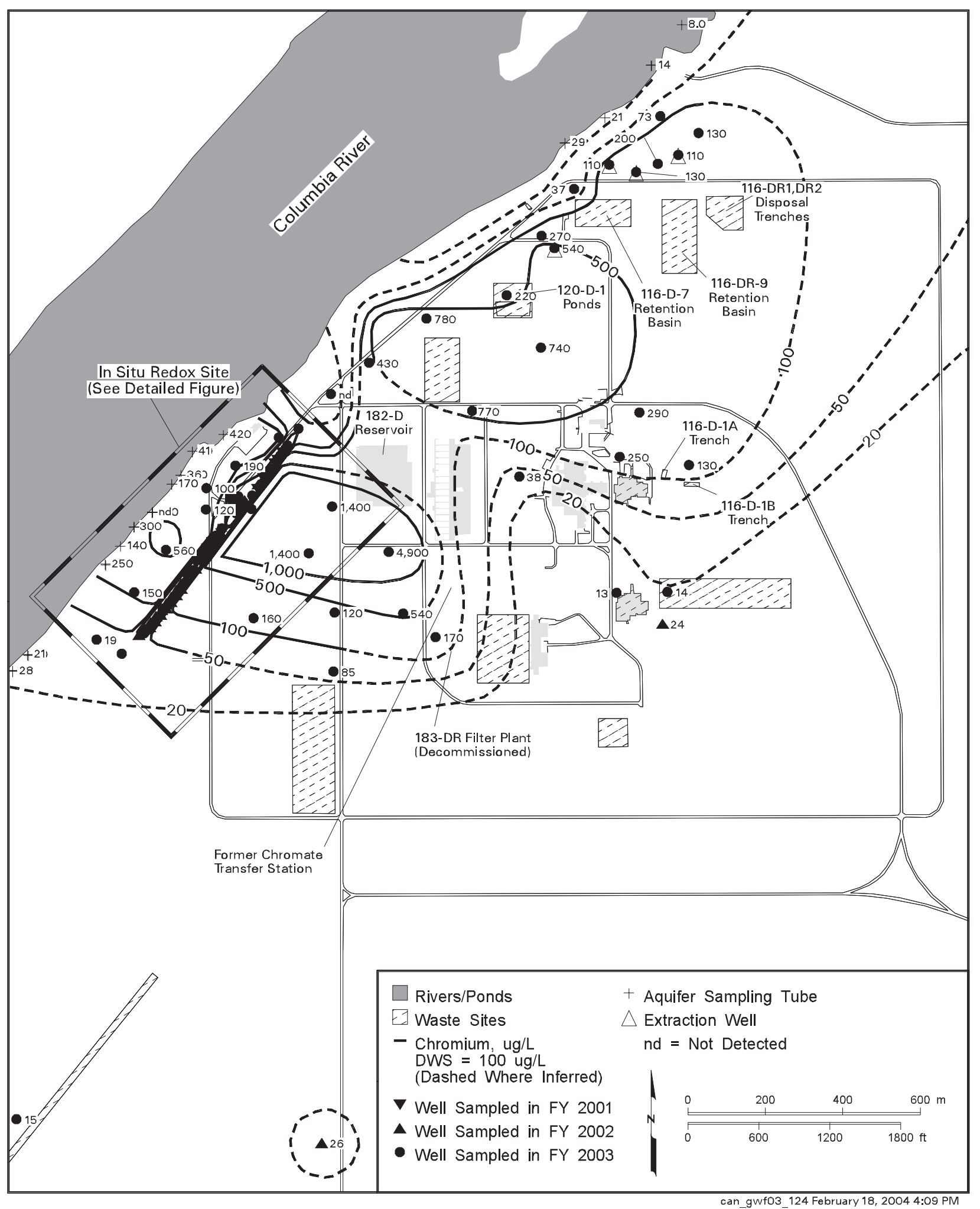

Figure 2.5-4. Average Dissolved Chromium Concentrations in the 100-D Area, Top of Unconfined Aquifer 


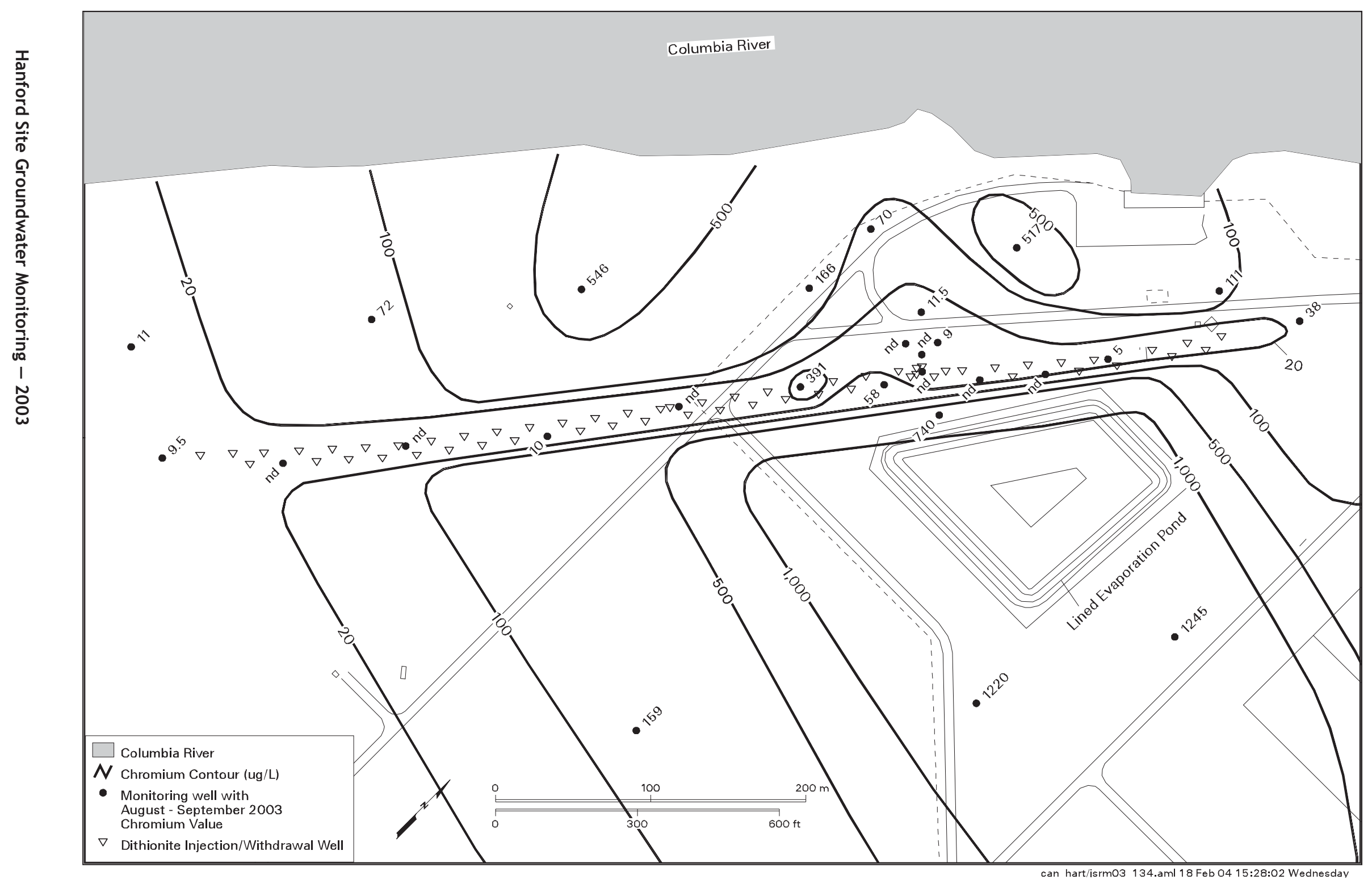

Figure 2.5-5. Average Dissolved Chromium Concentrations Near the Redox Site, 100-D Area, August-September 2003 


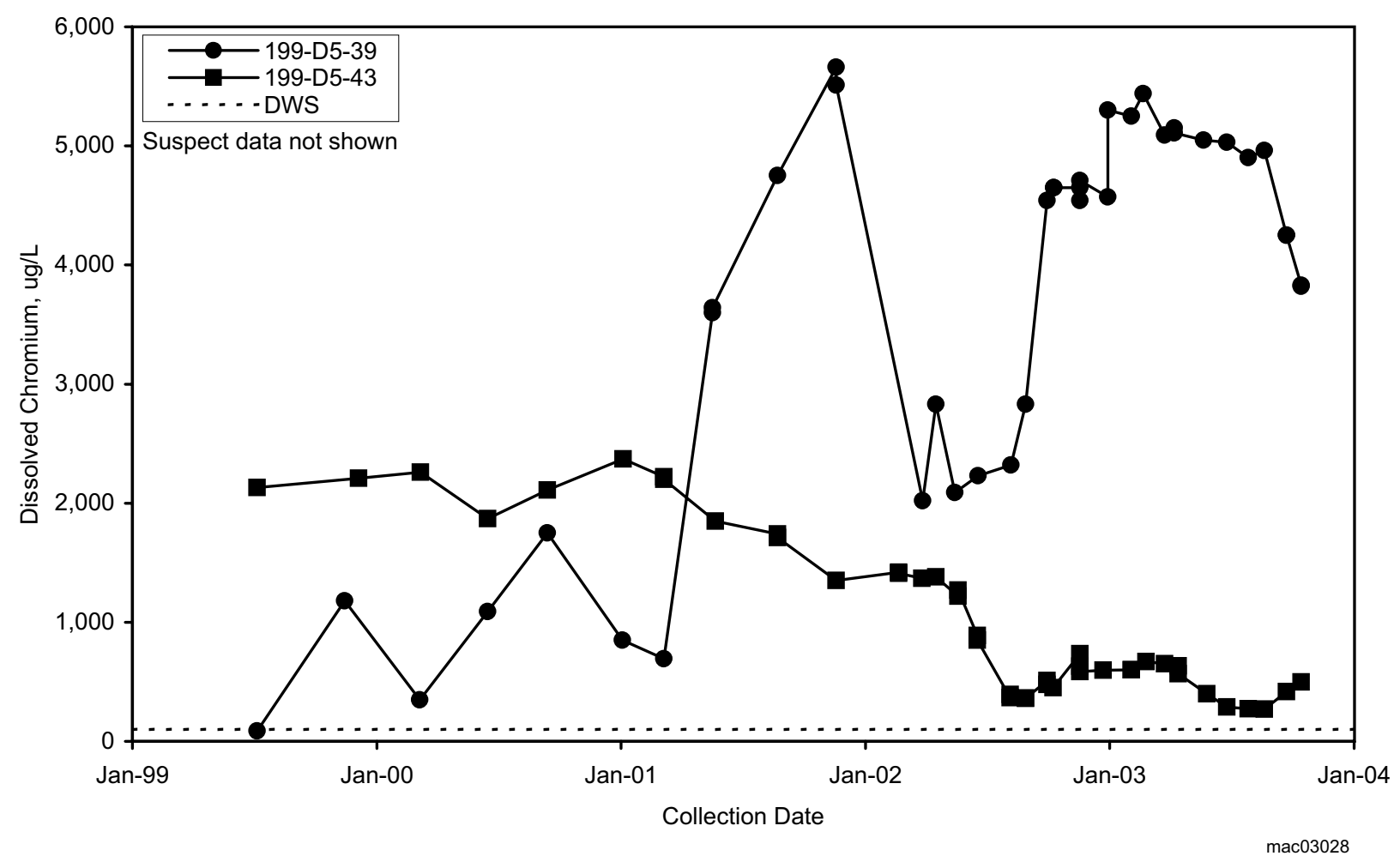

Figure 2.5-6. Dissolved Chromium Concentrations in South 100-D Area

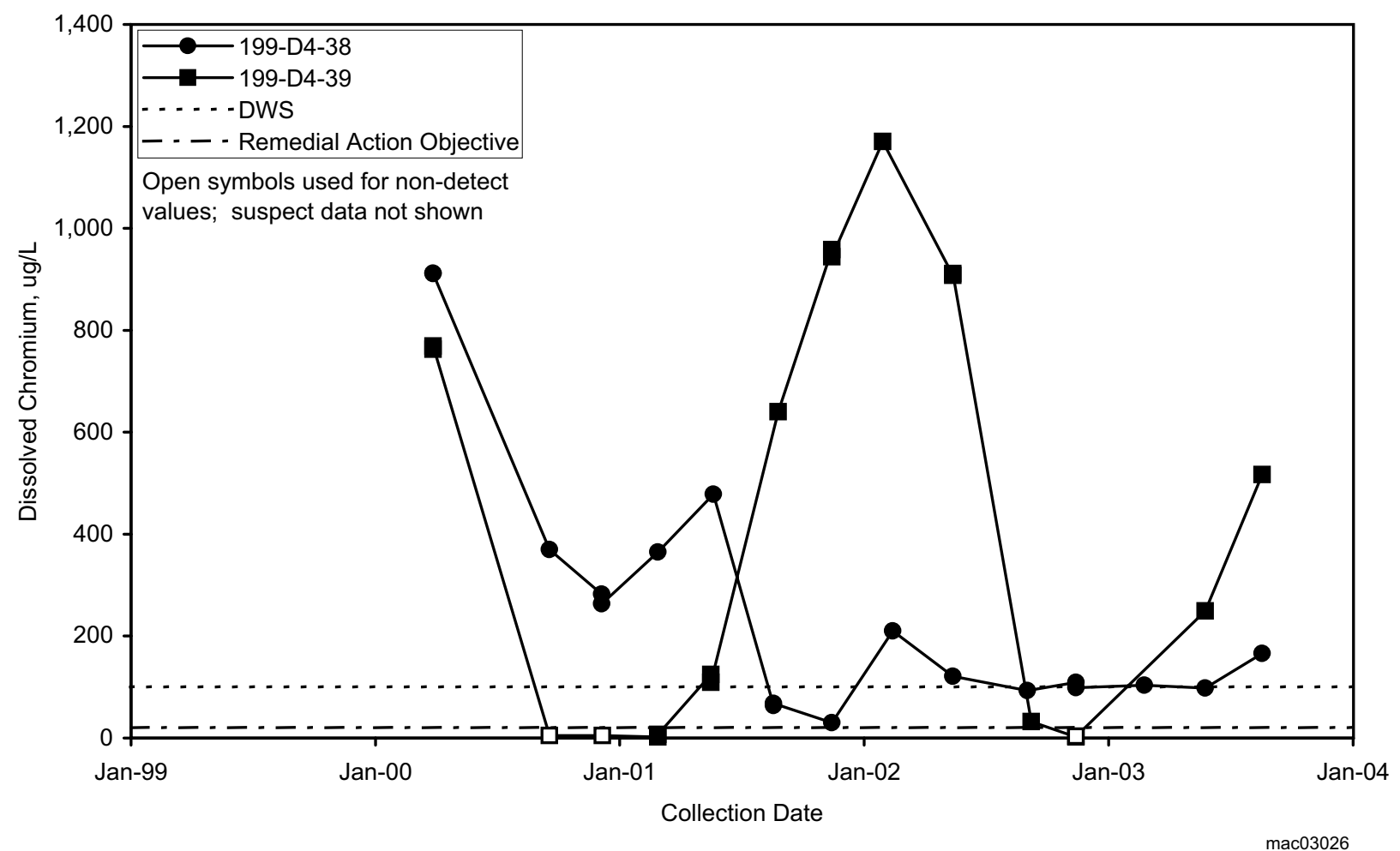

Figure 2.5-7. Dissolved Chromium Concentrations in Compliance Wells Downgradient of Early-Emplaced Redox Barrier 


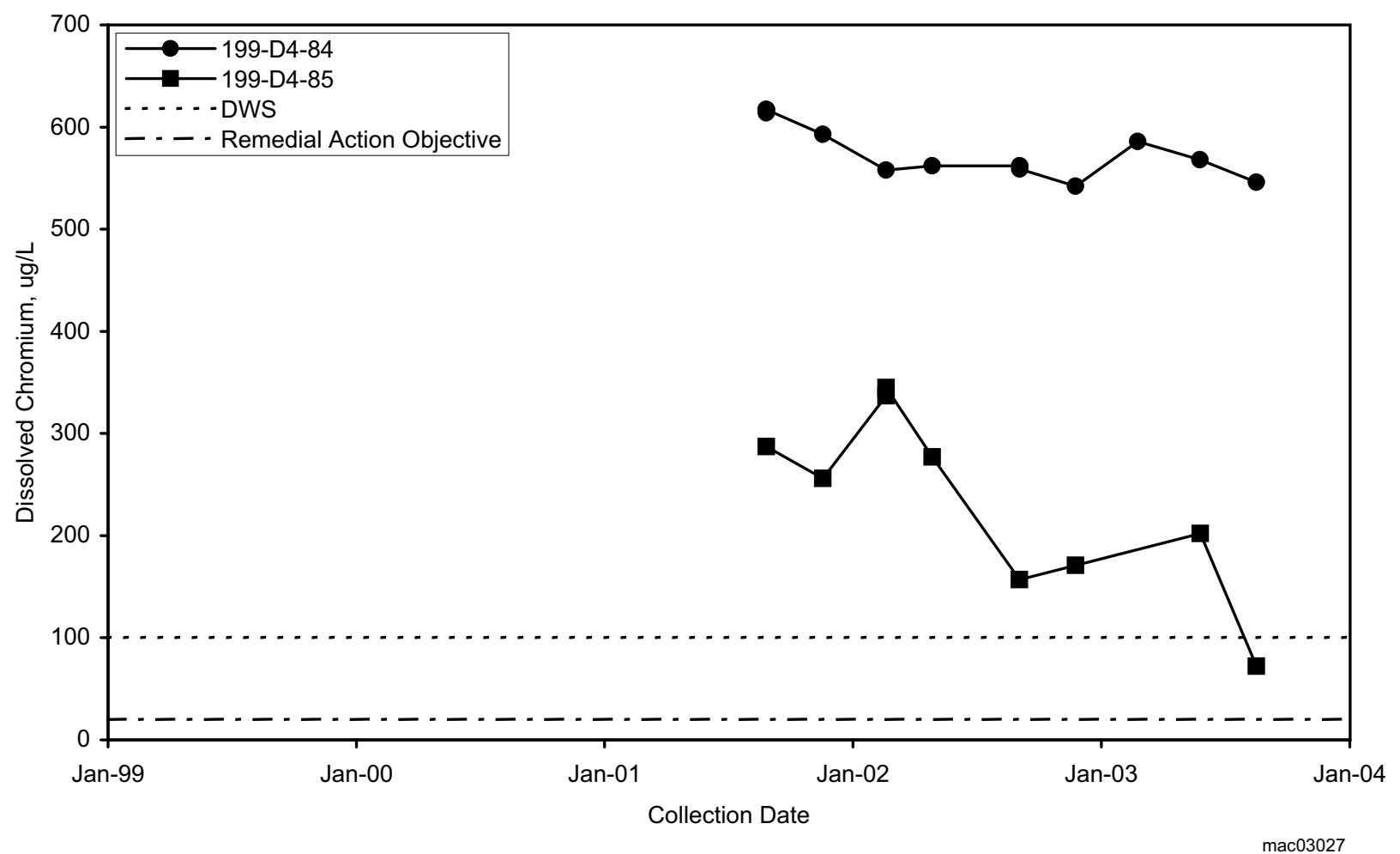

Figure 2.5-8. Dissolved Chromium Concentrations in Compliance Wells Downgradient of Late-Emplaced Redox Barrier

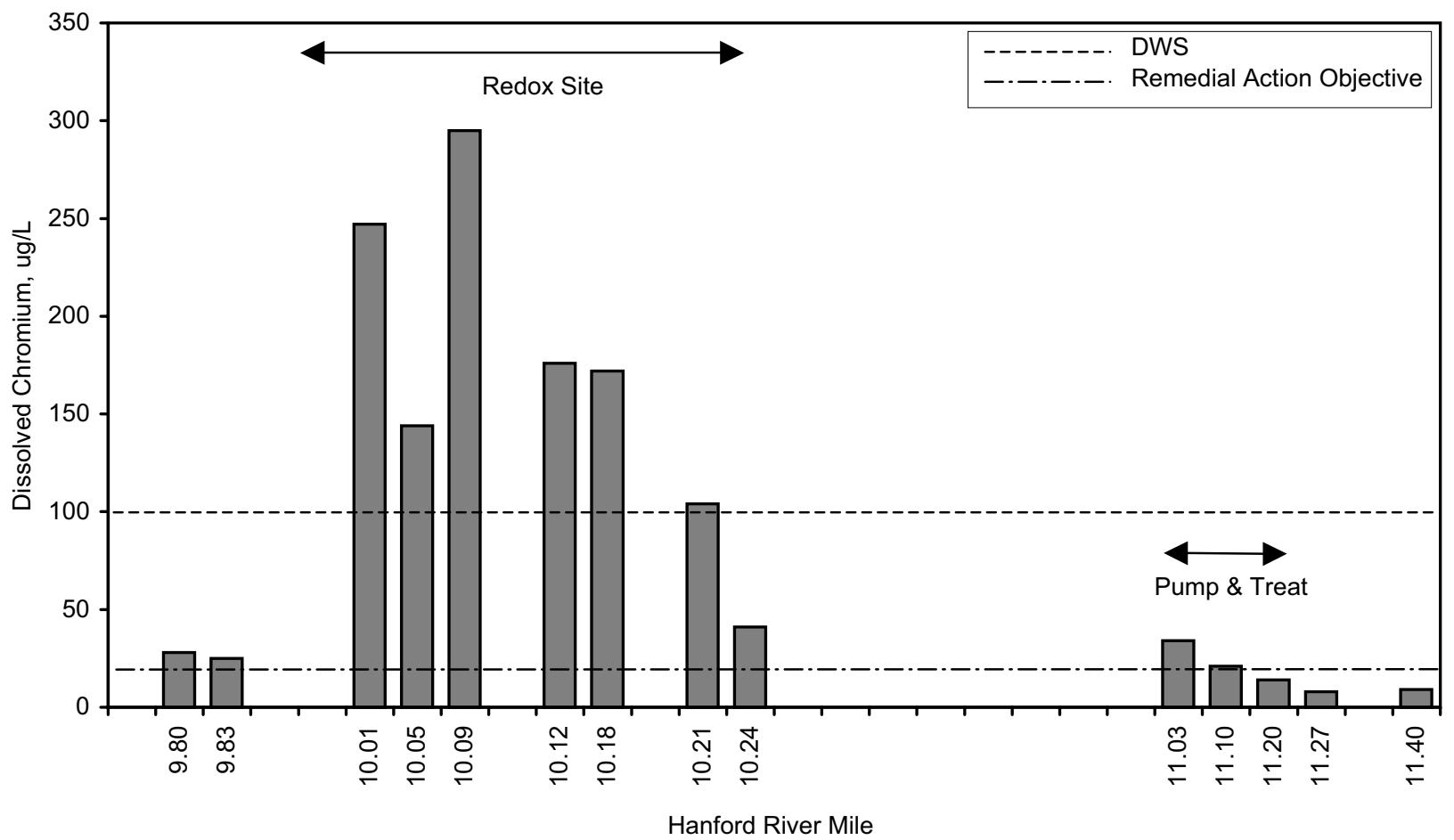

$\operatorname{mac} 03001$

Figure 2.5-9. Hexavalent Chromium in Aquifer Tubes at 100-D Area, Fiscal Year 2003 


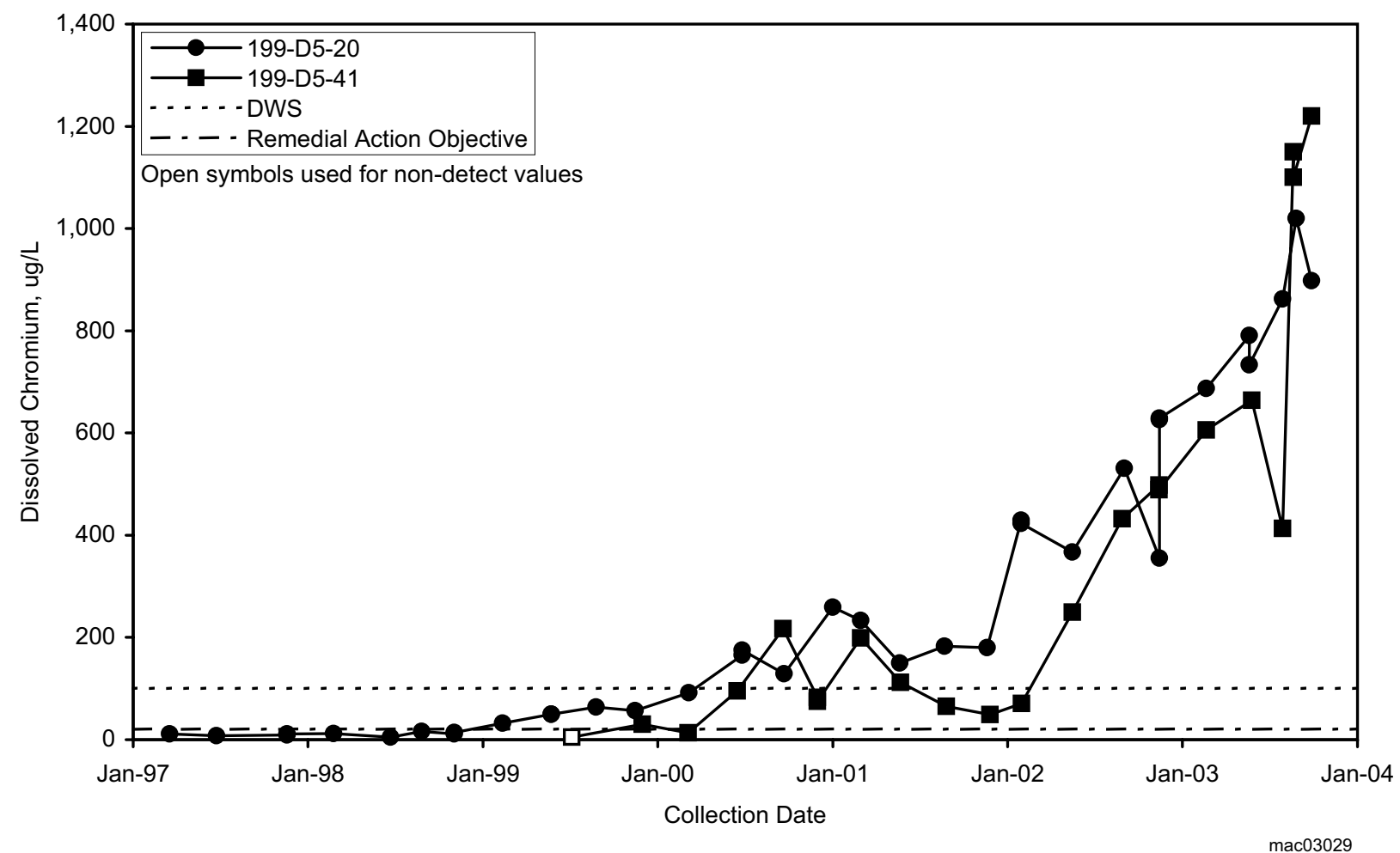

Figure 2.5-10. Dissolved Chromium Concentrations in Central 100-D Area

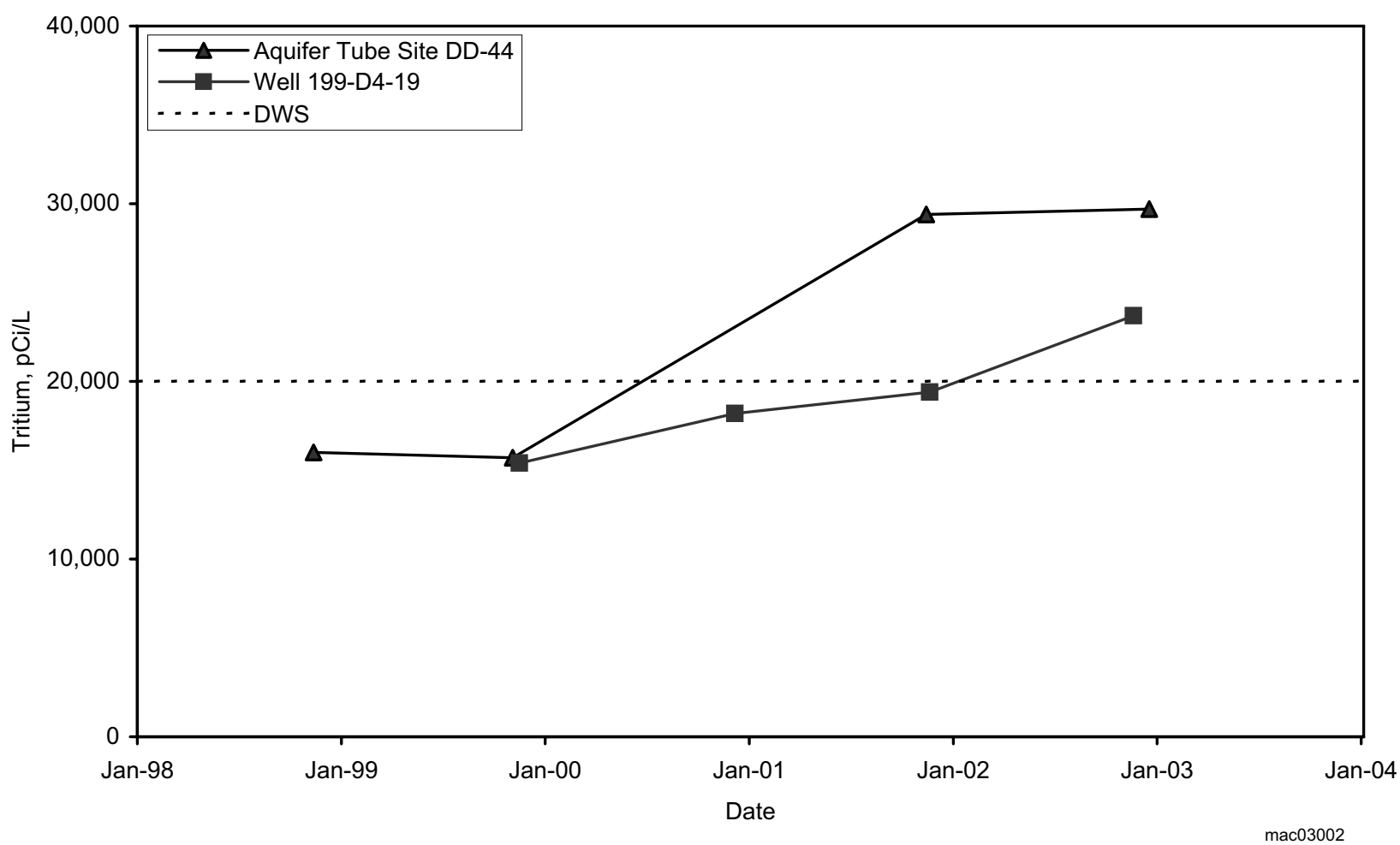

Figure 2.5-11. Tritium Concentrations in the South 100-D Area 


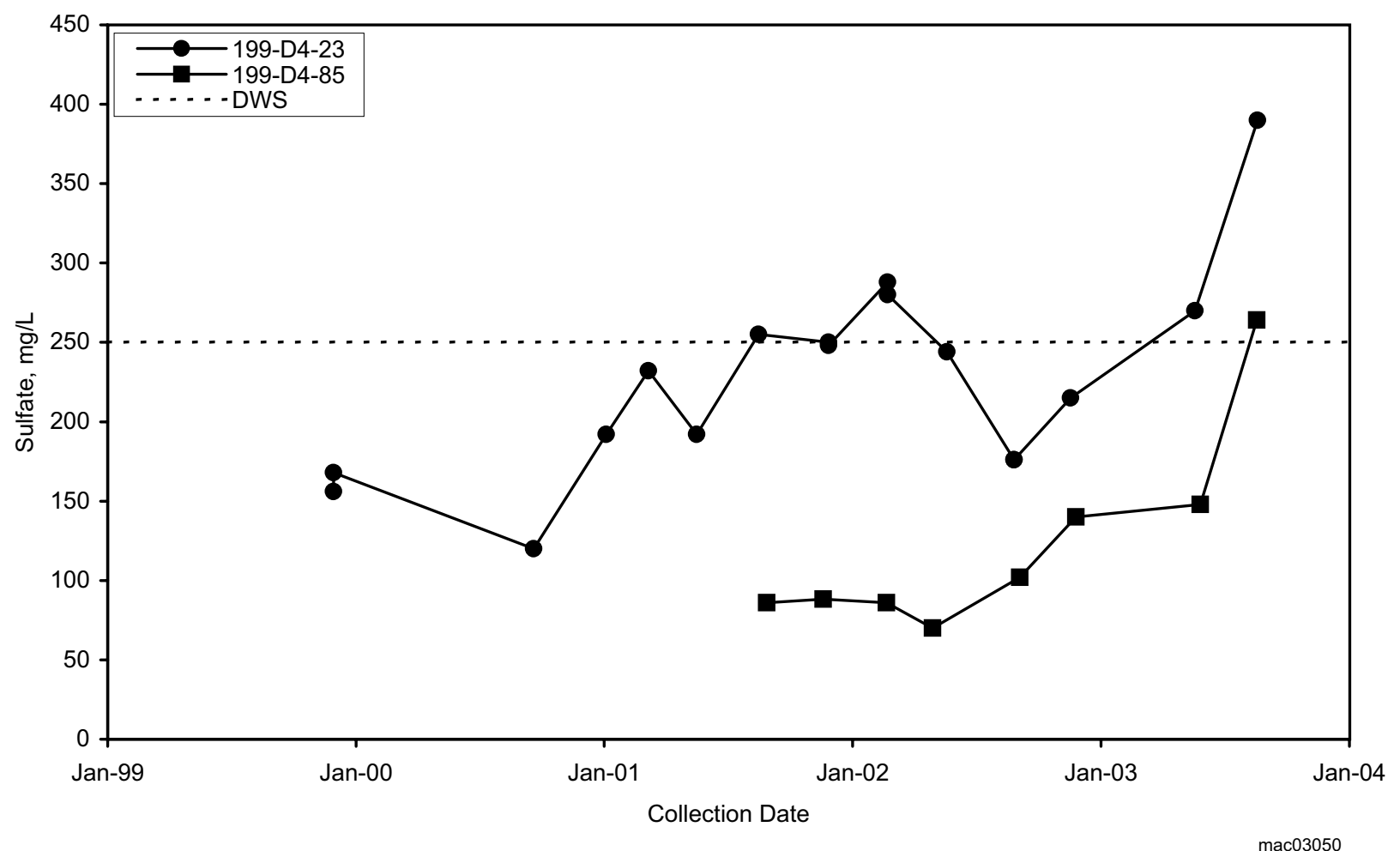

Figure 2.5-12. Sulfate Concentrations Downgradient of the Redox Barrier

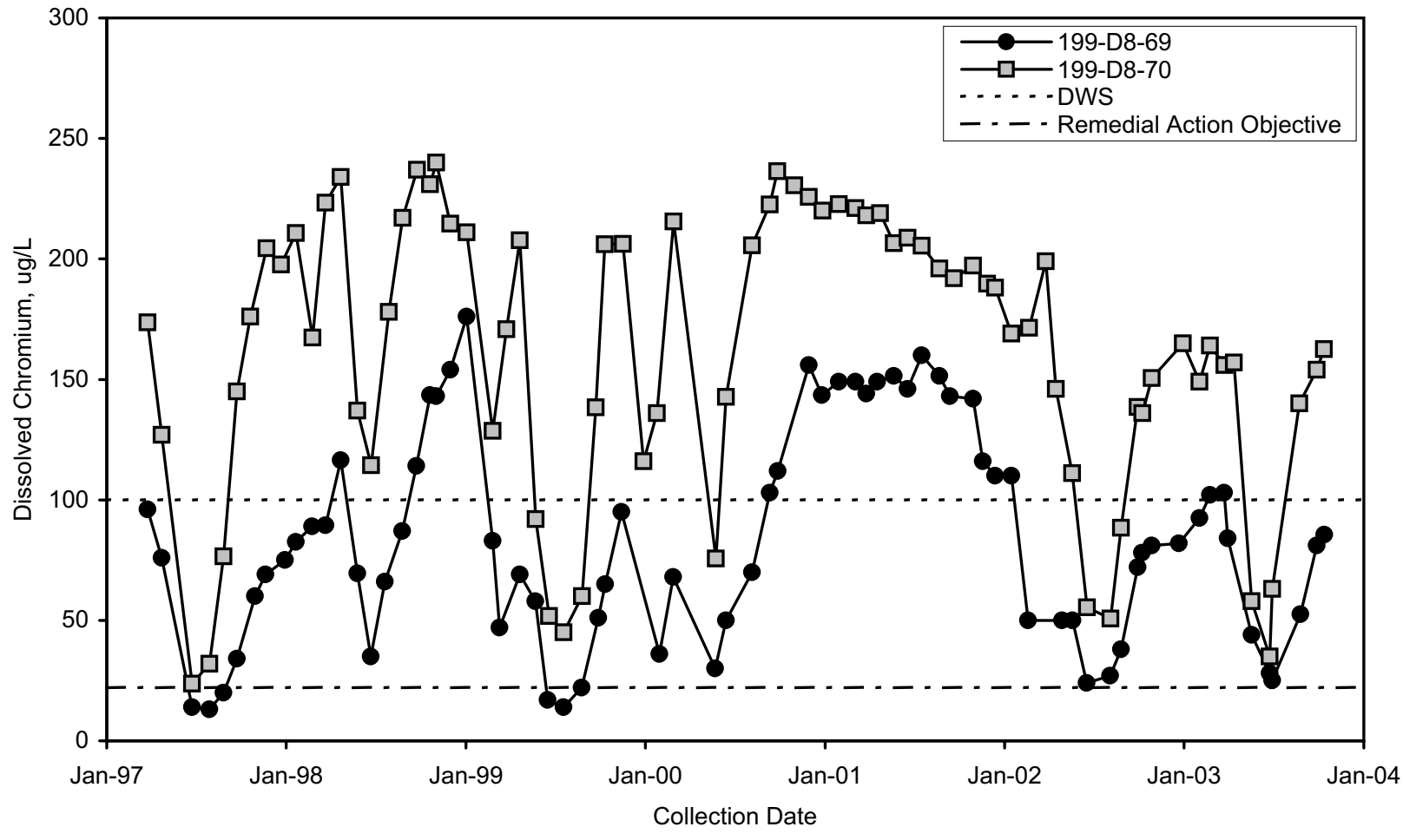

$\operatorname{mac} 03049$

Figure 2.5-13. Dissolved Chromium Concentrations in Compliance Wells for the 100-HR-3 Pump-and-Treat System at 100-D Area 


\subsection{0-HR-3-H Operable Unit}

\section{J. Hartman and R. F. Raidl}

The scope of this section is the 100-HR-3-H groundwater interest area, which is the east portion of the 100-HR-3 Operable Unit (Figure 2.1-1). Figure 2.6-1 shows facilities, wells, and shoreline monitoring sites in this region. Chromium is the contaminant of greatest significance in groundwater. Groundwater is monitored to assess the performance of an interim action pump-and-treat system for chromium, to track other contaminant plumes, and for the 116-H-6 evaporation basins, a Resource Conservation and Recovery Act (RCRA) unit. In addition to the chromium plume, contaminants of concern include nitrate, strontium-90, technetium-99, tritium, and uranium.

Groundwater flows primarily from the southwest to northeast, toward the Columbia River (Figure 2.6-2). Groundwater flows generally toward the northeast across the entire horn of the Columbia River north of Gable Mountain, so groundwater approaching the 100-H Area may contain contaminants that originated in the 100-D and 100-N Areas.

The remainder of this section describes contaminant plumes and concentration trends for the constituents of interest under Comprehensive Environmental Response, Compensation, and Liability Act (CERCLA), ${ }^{\text {(a) }}$ RCRA, or Atomic Energy Act of 1954 (AEA) monitoring.

\subsubsection{Groundwater Contaminants}

This section describes monitoring results for chromium, strontium-90, technetium-99 and uranium, nitrate, and tritium.

\subsubsection{Chromium}

Dissolved chromium is elevated beneath much of the 100-H Area at levels exceeding the remedial action goal of $22 \mu \mathrm{g} / \mathrm{L}$ (see Section 2.6.2) (Figure 2.6-3). The plume had various

Groundwater monitoring in the 100-HR-3-H groundwater interest area includes CERCLA, RCRA, and AEA monitoring:

\section{CERCLA Monitoring}

- Four compliance wells are sampled monthly for chromium and annually for co-contaminants.

- Up to six extraction wells are sampled quarterly for chromium and semiannually for co-contaminants.

- Fourteen performance wells are sampled semiannually for chromium.

- In fiscal year 2003, all wells were sampled as scheduled.

RCRA Monitoring - 116-H-6 Evaporation Basins

- Four downgradient wells are sampled annually for chromium, nitrate, technetium-99, and uranium.

- Sampling is coordinated with CERCLA to avoid duplication.

- In fiscal year 2003, all wells were sampled as scheduled.

AEA Monitoring

- Twenty-two wells are sampled annually for contaminants and general chemistry.

- Deep wells are sampled triennially (deep unconfined, confined Ringold, and basalt-confined aquifers).

- Sampling is coordinated with CERCLA and RCRA to avoid duplication.

(a) Past-practice monitoring in this operable unit is regulated under RCRA past-practice, which follows the same groundwater monitoring activities as CERCLA. This report uses the term CERCLA for simplicity. 


\section{Chromium concentrations at \\ 100-H Area vary with river stage but are declining overall.}

Plume areas (square kilometers) above the drinking water standard at the 100-HR-3-H Operable Unit:

Chromium - 0.14

Nitrate -0.16

Strontium-90 -0.17

Technetium-99 $-<0.01$

Uranium -0.01 sources, but the highest concentrations in fiscal year 2003 continued to be near the former 116-H-6 evaporation basins, where well 199-H4-5 detected the maximum value, $84 \mu \mathrm{g} / \mathrm{L}$. Aquifer tubes in this region yielded results of $8 \mu \mathrm{g} / \mathrm{L}$ in January 2003, but the samples were believed to be diluted by river water. The highest chromium concentration in an aquifer tube near 100-H Area was $43 \mu \mathrm{g} / \mathrm{L}$ in tube 51-D, south of the main 100-H Area. A portion of the chromium plume appears to be migrating along the river (PNNL-14444).

Upgradient wells 699-97-43 and 699-96-43 also have elevated chromium concentrations, probably reflecting movement of an old contaminant plume that originated in the 100-D Area when a water table mound was present there (WHC-SD-EN-TI-023). Chromium concentrations were near or above the $100 \mu \mathrm{g} / \mathrm{L}$ drinking water standard in these wells. Chromium from upgradient sources also is detected in aquifer sampling tubes north of the 100-H Area (e.g., $40 \mu \mathrm{g} / \mathrm{L}$ in November 2001 in tube 44-M).

Chromium concentrations vary with river stage but are declining overall. For example, well 199-H4-3, located just downgradient of the former 116-H-6 evaporation basins, historically has had the highest chromium concentrations, but its maximum in fiscal year 2003 was $73 \mu \mathrm{g} / \mathrm{L}$ (Figure 2.6-4).

Chromium concentrations in deeper wells 199-H4-12C and 199-H4-15CS continued to exceed the $100 \mu \mathrm{g} / \mathrm{L}$ drinking water standard (maximum $154 \mu \mathrm{g} / \mathrm{L}$ ), but are declining. The source of this deeper chromium is unknown.

\subsubsection{Strontium-90}

Strontium-90 concentrations exceed the $8 \mathrm{pCi} / \mathrm{L}$ drinking water standard beneath a portion of the southeast $100-\mathrm{H}$ Area near the former retention basin and disposal trenches. The plume distribution has not changed appreciably in at least 10 years. The highest concentrations in fiscal year 2003 were $\sim 20 \mathrm{pCi} / \mathrm{L}$. Concentrations are somewhat variable but are neither increasing nor decreasing overall. Strontium-90 was undetected in aquifer tubes near the 100-H Area.

\subsubsection{Technetium-99 and Uranium}

Technetium-99 is elevated in groundwater downgradient of the former 116-H-6 evaporation basins, but levels remained below the $900 \mathrm{pCi} / \mathrm{L}$ drinking water standard in all but one well.

Well 199-H4-3, immediately downgradient of the 116-H-6 evaporation basins, historically has shown the highest technetium-99 concentrations and detected $321 \mathrm{pCi} / \mathrm{L}$ in fiscal year 2003 (Figure 2.6-5). Concentrations have declined two orders of magnitude since the mid-1990s, but remained steadily below the drinking water standard during the past 3 years. Closer to the Columbia River, technetium-99 and uranium concentrations in well 199-H4-4 historically have shown high variability with river stage, with peak concentrations in the fall when river stage is low. For the past 2 years, however, fall values have remained low (Figure 2.6-5).

Uranium also is elevated in groundwater downgradient of the former 116-H-6 evaporation basins, and exceeded the $30 \mu \mathrm{g} / \mathrm{L}$ drinking water standard in two wells. The maximum concentration was $119 \mu \mathrm{g} / \mathrm{L}$ in well 199-H4-3.

Technetium-99 and uranium concentrations increased sharply in well 199-H4-9 in November 2002, both exceeding their drinking water standards (Figure 2.6-6). This well is located at the northeast corner of the 116- $\mathrm{H}-6$ evaporation basins. The influence of extraction wells 199-H4-12A and 199-H4-15A may have altered flow directions, causing more contaminated groundwater from beneath the former basins to flow through this well.

Technetium-99 was analyzed in one aquifer tube sample in fiscal year 2003, tube 46-D. The tube is located downgradient of the 116-H-6 evaporation basins and no technetium-99 was detected. No tube samples were analyzed for uranium. 


\subsubsection{Tritium}

Tritium concentrations are generally below $5,000 \mathrm{pCi} / \mathrm{L}$ beneath the $100-\mathrm{H}$ Area. Concentrations vary seasonally in wells near the river and are declining in most inland wells. Concentrations are slightly higher in upgradient wells (e.g., 6,210 pCi/L in well 699-96-43) but are declining.

\subsubsection{Nitrate}

Nitrate concentrations continued to exceed the $45 \mathrm{mg} / \mathrm{L}$ drinking water standard in numerous wells near the former 116-H-6 evaporation basins and in several wells in the southeast 100-H Area (Figure 2.6-7). The maximum concentrations are usually detected in well 199-H4-3 (255 mg/L in fiscal year 2003). Trends in that area vary seasonally, but the peaks have diminished over the years, and concentrations are declining overall.

The nitrate concentrations in well 199-H4-9, northeast of the basins, increased sharply in fiscal year 2003 to $474 \mathrm{mg} / \mathrm{L}$. Similar increases were observed for technetium-99 and uranium. Nearby well 199-H4-8 also had a sudden increase in nitrate. These changes are believed to be related to flow direction changes due to extraction wells.

Nitrate trends in other wells are variable, and the causes of increases/decreases often are not known.

\subsubsection{CERCLA Interim Groundwater Remediation for Chromium}

\author{
Nitrate \\ concentrations \\ exceed drinking \\ water standards \\ near the former \\ 116-H-6 evaporation \\ basins and in \\ southeast \\ 100-H Area.
}

A pump-and-treat system operates in the $100-\mathrm{H}$ Area as part of an interim action for the 100-HR-3-H Operable Unit (ROD 1996a). Interim remedial action monitoring is described in DOE/RL-96-90. Figure 2.6-1 displays locations of extraction and injection wells and Appendix A lists sampling frequencies and constituents.

\subsubsection{Progress During Fiscal Year 2003}

The 100-H Area pump-and-treat system is reducing overall contamination in the operable unit by removing contaminant mass. During fiscal year 2003, the pump-and-treat system extracted $\sim 186$ million liters of groundwater from the $100-\mathrm{H}$ Area, removing about 4.8 kilograms of hexavalent chromium.

The pump-and-treat system has removed about 33.2 kilograms of hexavalent chromium from the 100-H Area groundwater since startup in July 1997. This represents a large fraction of the estimated 42 kilograms of chromium estimated in the plume in 1992 (WHC-SA-1674-VA). That estimate did not include chromium from upgradient nor in the vadose zone.

The remedial action objectives for the 100-HR-3 Operable Unit (ROD 1996a) are:

- Protect aquatic receptors in the river bottom from contaminants in groundwater entering the Columbia River.

- Protect human health by preventing exposure to contaminant in the groundwater.

- Provide information that will lead to the final remedy.

The contaminant of concern is hexavalent chromium. The record of decision specifies the cleanup goal at compliance wells as $22 \mu \mathrm{g} / \mathrm{L}$. EPA specified enhancements needed to the system in their 5-year review (EPA 2001).

All of the wells scheduled for sampling under CERCLA were sampled as scheduled in fiscal year 2003.

\subsubsection{Influence on Aquifer Conditions}

Chromium concentrations in 100-H Area groundwater have declined, and the size of the plume has shrunk since the pump-and-treat system began to operate in 1997. These changes are likely due to a combination of natural processes (e.g., dispersion) and the effects of the pump-and-treat system. 
During fiscal year

2003, the pump-

and-treat system

at 100-H Area

extracted

$\sim 186$ million liters

of groundwater,

removing about

4.8 kilograms of

hexavalent

chromium.
Hexavalent chromium concentrations in compliance wells vary inversely with river stage. The ranges of concentration observed in fiscal year 2003 were similar to those observed in fiscal year 2002. Figure 2.6-8 shows chromium trends for two of the compliance wells, 199-H4-4 and 199-H4-63. Chromium declined beneath the remedial action goal (22 $\mu \mathrm{g} / \mathrm{L})$ in both of the wells in the spring and early summer, but exceeded that level for the rest of the year. In the other two compliance wells (199-H4-5 and 199-H4-64), chromium concentrations were above the goal throughout the year, though levels were lowest in the spring and early summer.

Results of performance monitoring are incorporated with the discussion of general contamination in Section 2.6.1. Results of operational monitoring, and additional details about the pump-and-treat system, will be included in an upcoming annual report on the 100-HR-3, 100-KR-4, and 100-NR-2 pump-and-treat systems.

\subsubsection{RCRA Groundwater Monitoring for the 116-H-6 Evaporation Basins}

The 116-H-6 (183-H) evaporation basins are the only RCRA site in the 100-H Area. The site is monitored during the post-closure period under corrective action monitoring requirements of WAC 173-303-645(11). The objective of monitoring is to track contaminant trends during the operation of the CERCLA interim action for chromium. Additional information is included in Appendix B.

The four wells in the RCRA network were sampled as scheduled in fiscal year 2003 for the constituents of interest listed in the groundwater monitoring plan: chromium, fluoride, nitrate, technetium-99, and uranium. The latter two constituents are not regulated under RCRA but were included in the monitoring plan for completeness and were incorporated by reference in the Hanford Facility RCRA Permit (Ecology 1994). The permit will be modified in fiscal year 2004 to revise the constituent list.

Trends in the constituents of interest (except fluoride) were discussed in Section 2.6.1. Fluoride concentrations remained low $(<300 \mu \mathrm{g} / \mathrm{L})$ in groundwater downgradient of the 116-H-6 evaporation basins. 


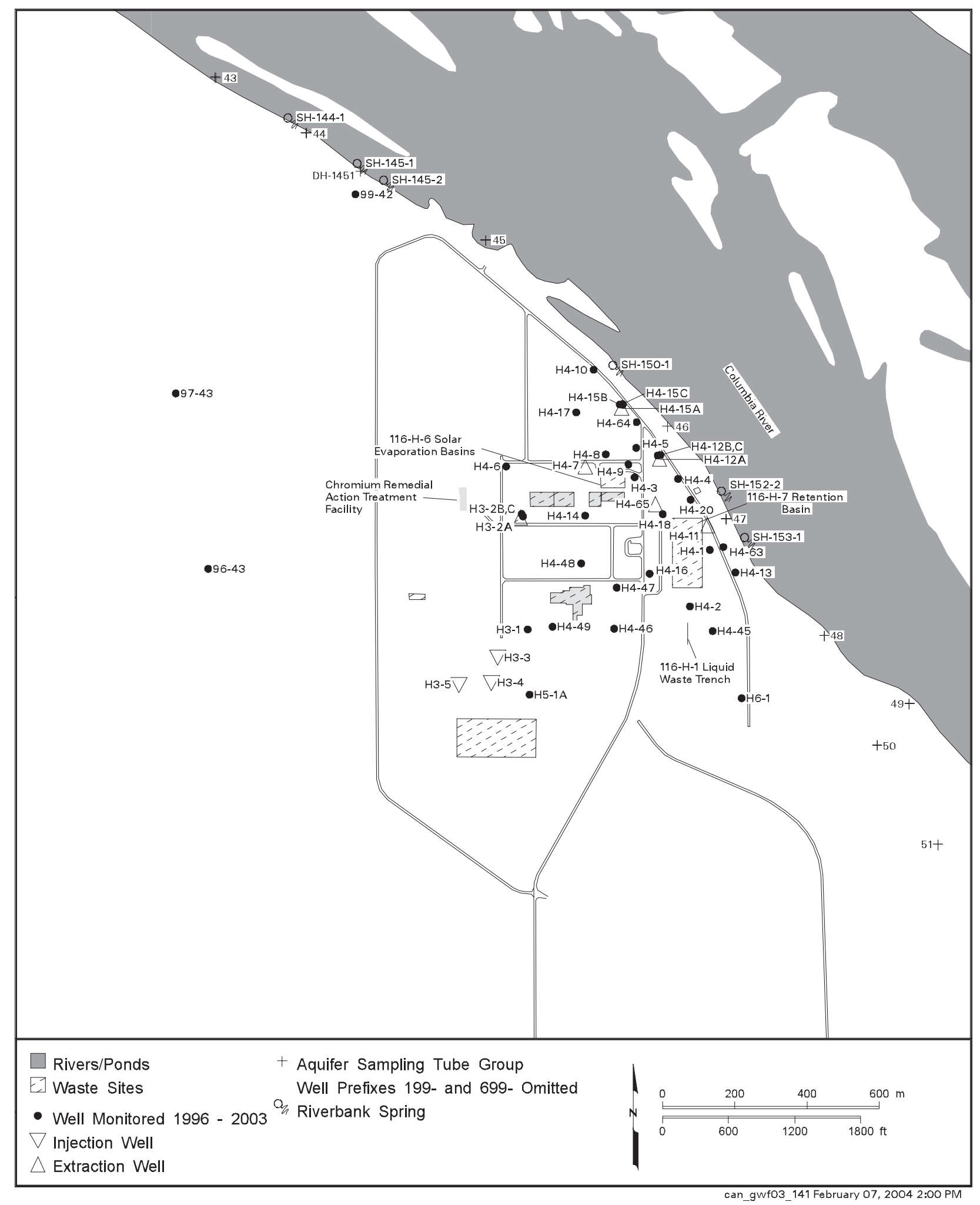

Figure 2.6-1. Groundwater Monitoring Wells in the 100-H Area 


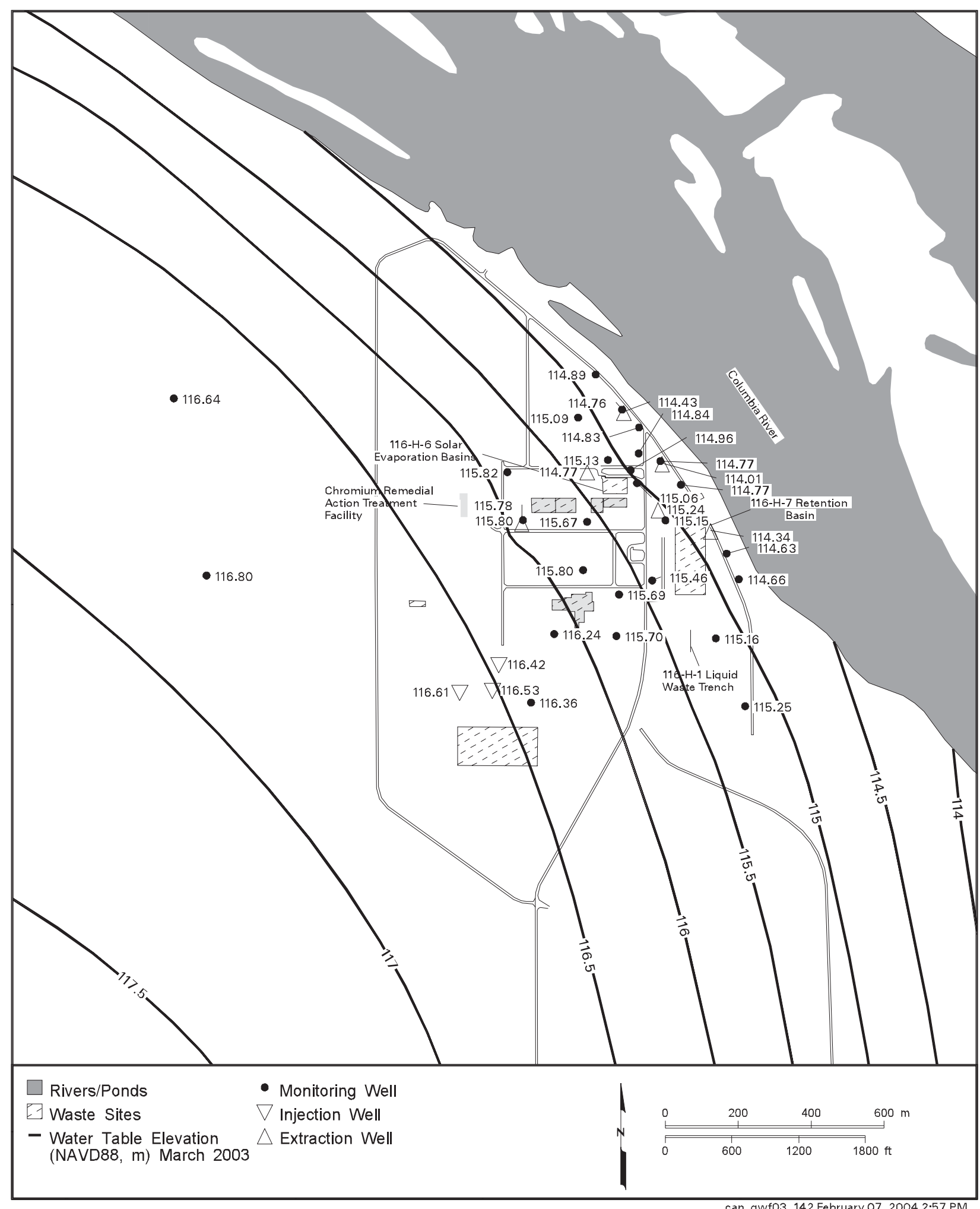

Figure 2.6-2. Water Table Beneath 100-H Area, March 2003 


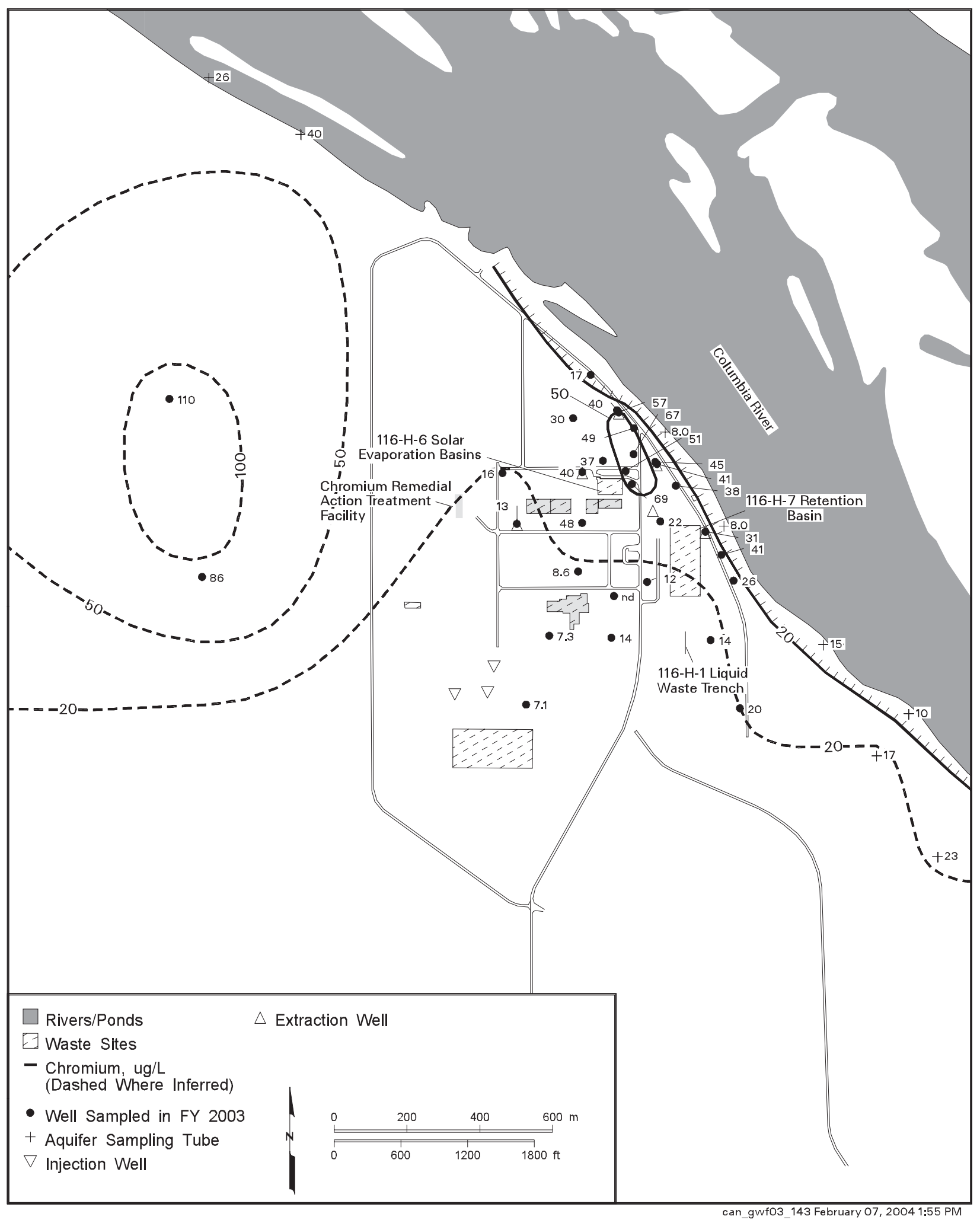

Figure 2.6-3. Average Chromium Concentrations in the 100-H Area, Top of Unconfined Aquifer 


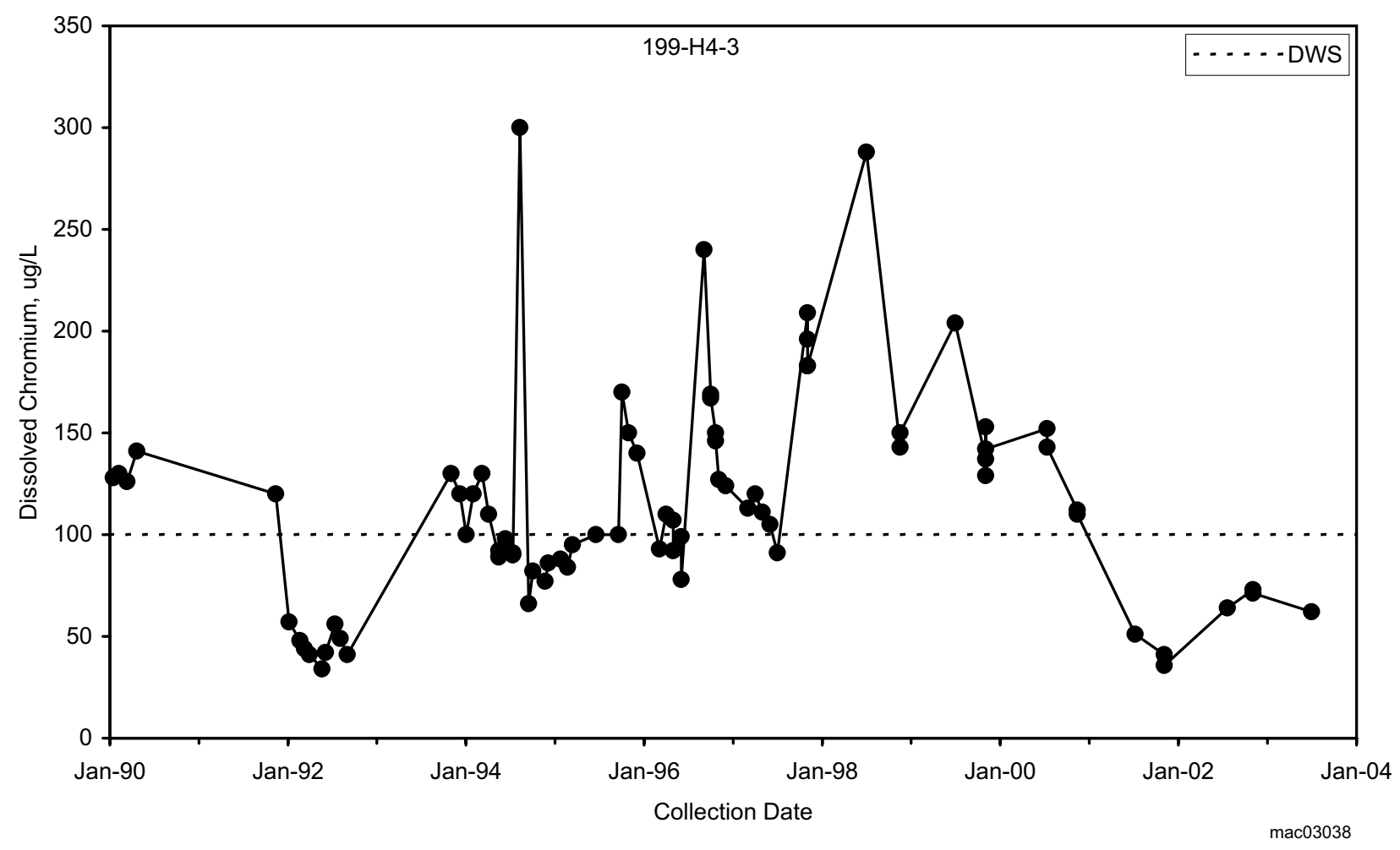

Figure 2.6-4. Dissolved Chromium Concentrations East of 116-H-6 Evaporation Basins

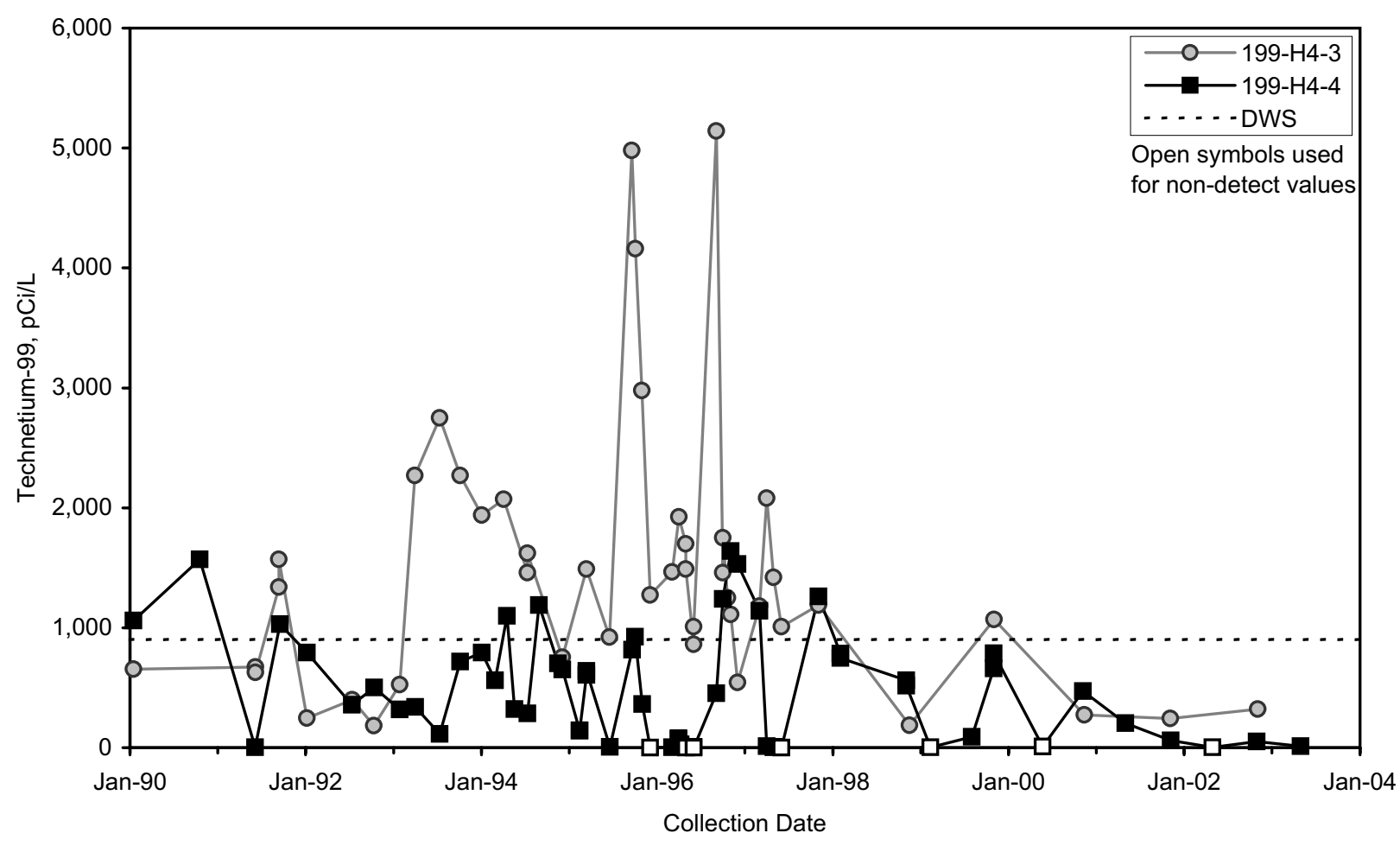

Figure 2.6-5. Technetium-99 Concentrations East of 116-H-6 Evaporation Basins 

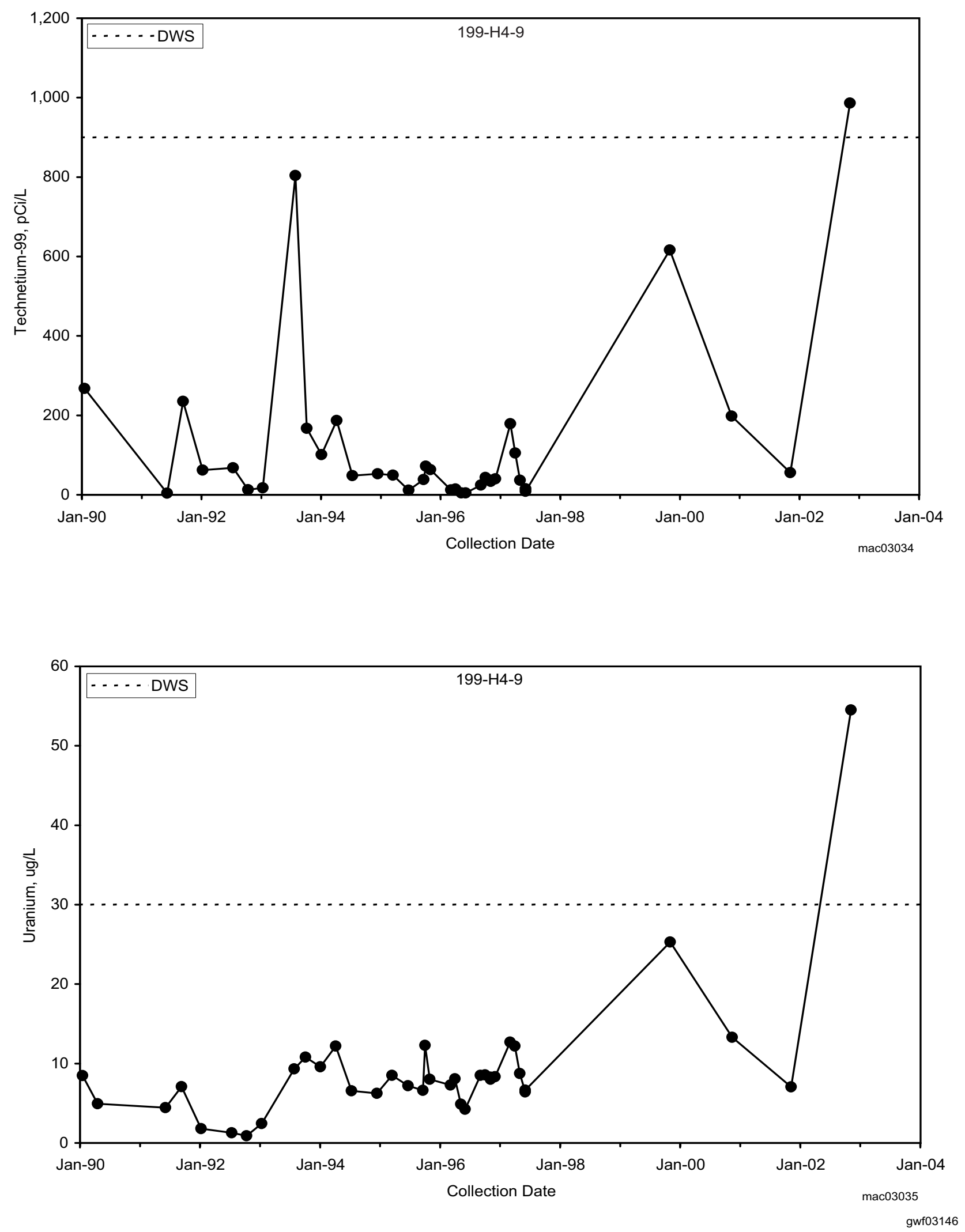

Figure 2.6-6. Technetium-99 and Uranium Concentrations Northeast of 116-H-6 Evaporation Basins 


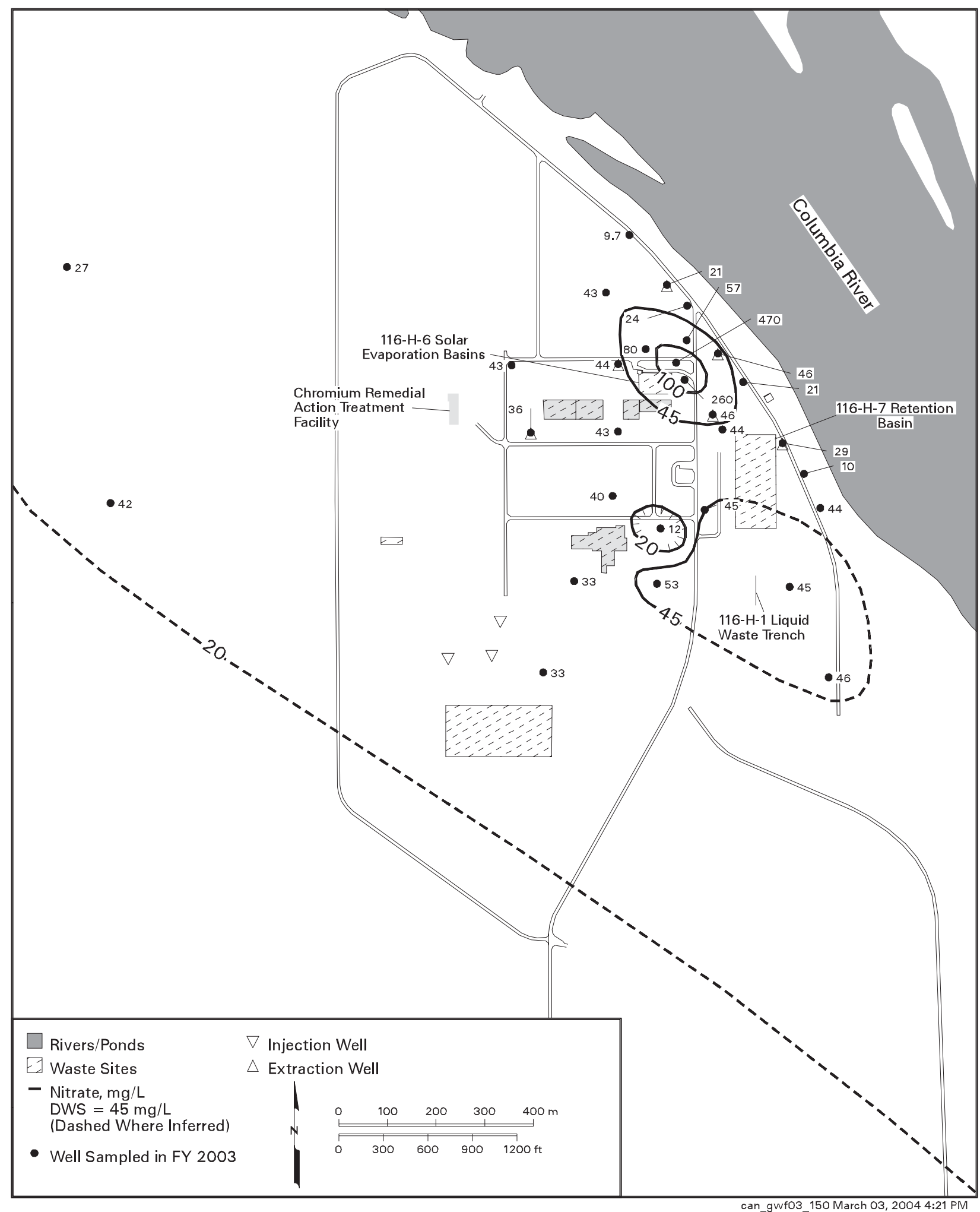

Figure 2.6-7. Average Nitrate Concentrations in the 100-H Area, Top of Unconfined Aquifer 


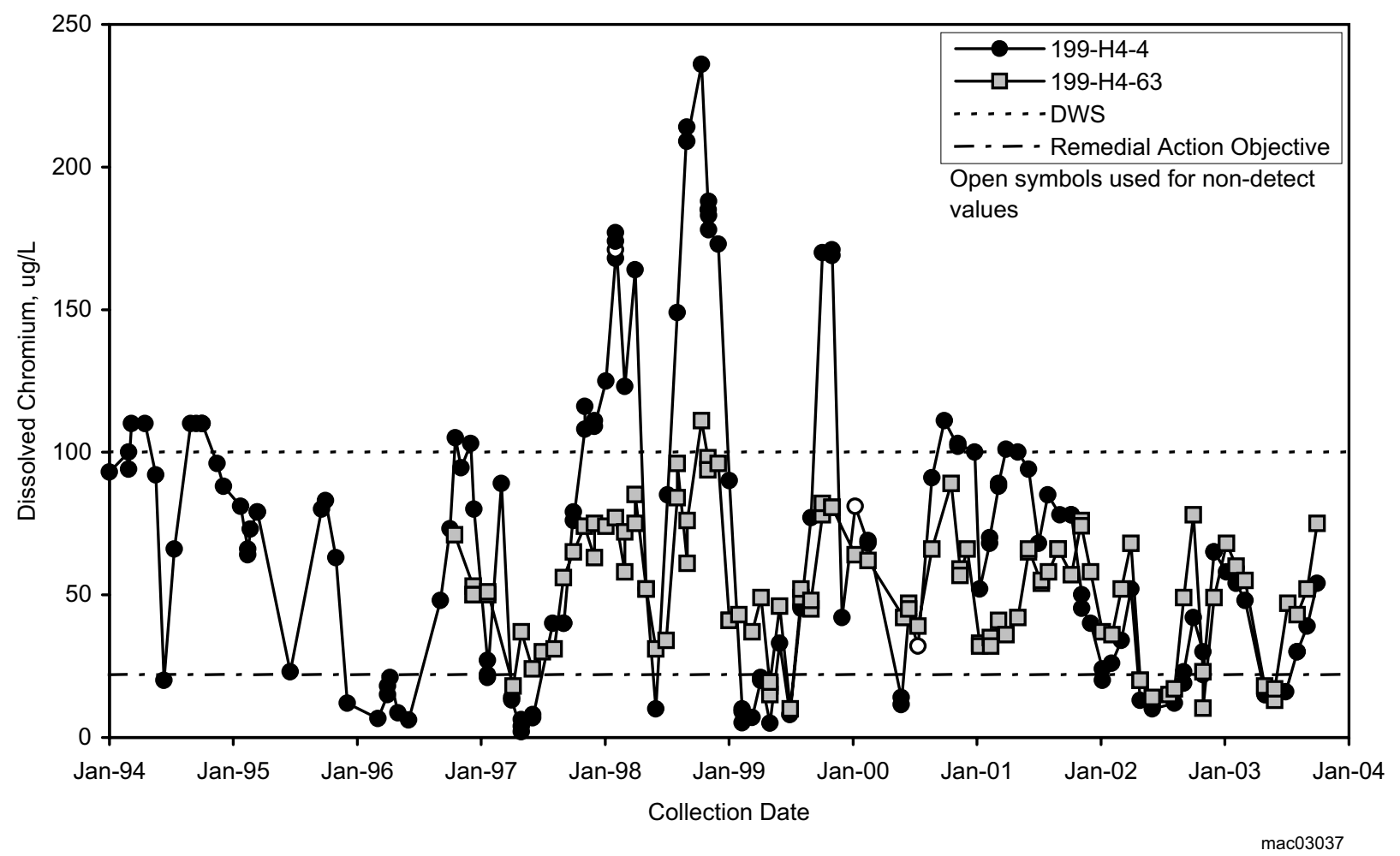

Figure 2.6-8. Dissolved Chromium Concentrations in Compliance Wells for the 100-HR-3 Pump-and-Treat System at $100-\mathrm{H}$ Area 


\subsection{0-FR-3 Operable Unit}

\section{J. Hartman}

The scope of this section is the 100-FR-3 groundwater interest area, which encompasses the 100-FR-3 Operable Unit and a large section of the area north of Gable Mountain (see Figure 2.1-1). Figure 2.7-1 shows facilities, wells, and shoreline monitoring sites in this region. Nitrate is the most widely distributed groundwater contaminant. Other contaminants include strontium-90, tritium, and trichloroethene. Groundwater is monitored to track contaminant plumes and trends.

Groundwater flows primarily to the east and southeast beneath the 100-F Area (Figure 2.7-2). Movement of the nitrate plume indicates flow to the south-southeast.

Most of the former waste sites in the 100-F Area have been excavated and backfilled. There are no active disposal facilities or Resource Conservation and Recovery Act (RCRA) units in this area.

The remainder of this section describes contaminant plumes and concentration trends for the constituents of interest under Comprehensive Environmental Response, Compensation, and Liability Act (CERCLA) or Atomic Energy Act of 1954 (AEA) monitoring.

\subsubsection{Groundwater Contaminants}

This section describes the distribution and trends of nitrate, strontium-90, tritium, trichloroethene, gross alpha, gross beta, and chromium in groundwater beneath the 100-FR-3 groundwater interest area.

\subsubsection{Nitrate}

The distribution of the nitrate plume beneath the 100-FR-3 groundwater interest area did not change significantly in fiscal year 2003. Nitrate concentrations exceed the drinking water standard $(45 \mathrm{mg} / \mathrm{L})$ in a large plume that extends from the central $100-\mathrm{F}$ Area toward the south-southeast, into the 600 Area (Figure 2.1-6).

Most wells in 100-F Area have decreasing or steady trends in nitrate (e.g., well 199-F8-4; Figure 2.7-3). Nitrate concentrations in some 100-F Area wells showed peaks in around 1997 (e.g., well 199-F7-1, Figure 2.7-3), similar to what was observed in other 100 Area locations on the Hanford Site. Concentrations have subsequently declined, but the cause of the peaks is unknown.

Groundwater monitoring in the 100-FR-3 groundwater interest area includes CERCLA and AEA monitoring:

\section{CERCLA Monitoring}

- Selected wells and constituents are sampled quarterly.

- Nine wells and three seeps are sampled annually.

- Fourteen wells are sampled biennially.

- Seventeen wells and two seeps were sampled as scheduled in fiscal year 2003.

- Two seeps were not sampled (see Appendix A).

- A new sampling and analysis plan was developed and approved in fiscal year 2003 for implementation in fiscal year 2004.

\section{AEA Monitoring}

- The objectives are shared with CERCLA and monitoring is fully integrated. 


\section{The strontium-90 plume has not changed significantly in at least 10 years.}

Wells in the south 100-F Area continued to detect the highest nitrate concentrations. The maximum concentration detected in fiscal year 2003 was $177 \mathrm{mg} / \mathrm{L}$ in well 199-F7-3, in the southwest 100-F Area, which shows an increasing trend (Figure 2.7-4). Well 699-71-30, 1.5 kilometers south of 100-F Area, detected over $100 \mathrm{mg} / \mathrm{L}$ of nitrate in fiscal year 2003 (Figure 2.7-4), part of an increasing trend as the plume moves downgradient.

Nitrate concentrations in well 199-F5-43B, completed deeper in the Ringold Formation, are very low $(<0.5 \mathrm{mg} / \mathrm{L})$. There is an upward hydraulic gradient between the two wells.

\subsubsection{Strontium-90}

Strontium-90 concentrations continued to exceed the $8 \mathrm{pCi} / \mathrm{L}$ drinking water standard beneath a portion of the 100-F Area around the $116-\mathrm{F}-14$ retention basin and nearby disposal trenches. The plume has not changed significantly in the past 10 years.

Well 199-F5-1 had the highest strontium-90 concentrations in fiscal year 2003 at $28 \mathrm{pCi} / \mathrm{L}$ (Figure 2.7-5). Concentrations in groundwater vary with water level. High water levels mobilize strontium-90 in the lower vadose zone, increasing concentrations in groundwater. Fiscal year 2003 had relatively low river stage, and correspondingly low strontium-90 concentrations. Nearby well 199-F5-3 typically has strontium-90 concentrations in the hundreds but it was not scheduled for sampling in fiscal year 2003. Well 199-F5-3 was not included in the sampling and analysis plan that was in effect in fiscal year 2003 (PNNL-13327) because there had been difficulty sampling it in the past. The well is included in the new sampling and analysis plan (DOE/RL-2003-49), and DOE will attempt to identify and repair the problems with the well.

Like other 100-F Area contaminants, strontium-90 appears to be limited to
Plume areas (square kilometers) above the drinking water standard at the 100-FR-3 Operable Unit:

Nitrate -12.70

Strontium-90-0.16

Trichloroethene -2.37 the shallow portion of the aquifer. No strontium-90 is detected in deep well 199-F5-43B, while adjacent well 199-F5-43A typically detects 2 to $4 \mathrm{pCi} / \mathrm{L}$ of strontium-90.

\subsubsection{Tritium}

Tritium concentrations exceed $2,000 \mathrm{pCi} / \mathrm{L}$ beneath the south $100-\mathrm{F}$ Area, but were all below the $20,000 \mathrm{pCi} / \mathrm{L}$ drinking water standard in fiscal year 2003 . The plume extends southward into the 600 Area (Figure 2.1-5), but its axis strikes approximately southeast instead of south-southeast like the nitrate plume.
Concentrations of tritium are declining and ranged from undetected to $11,500 \mathrm{pCi} / \mathrm{L}$ in fiscal year 2003. The latter concentration was in well 199-F8-3, located near the 118-F-6 burial ground (Figure 2.7-6).

\subsubsection{Trichloroethene}

Trichloroethene is consistently detected in several 100-F Area wells, and a few wells in the southwest 100-F Area typically exceed the $5 \mu \mathrm{g} / \mathrm{L}$ drinking water standard. Of the wells sampled in fiscal year 2003, the maximum concentration was $9.8 \mu \mathrm{g} / \mathrm{L}$ in well 199-F7-3, which shows an increasing trend (Figure 2.7-7). The highest concentrations of trichloroethene are typically detected in well 199-F7-1 and in well 699-77-36, located in the nearby 600 Area, but those wells were not scheduled for sampling in fiscal year 2003. Concentrations in those wells are decreasing overall.

Farther north, concentrations in well 199-F7-2 hover around the drinking water standard. Closer to the Columbia River, wells 199-F5-45 and 199-F5-46 also detect trichloroethene. Concentrations in those two wells were below the drinking water standard in fiscal year 2003. Nearly 4 kilometers west of the 100-F Area, well 699-85-47 has consistently detected $\sim 2 \mu \mathrm{g} / \mathrm{L}$ trichloroethene in recent years.

\subsubsection{Gross Alpha and Gross Beta}

Gross alpha and gross beta concentrations are measured in 100-F Area groundwater samples to screen for radionuclides. 
Gross alpha activity is probably due to uranium, which has been detected in the 100-F Area but no longer is analyzed. The maximum gross alpha concentration in fiscal year 2003 was $10 \mathrm{pCi} / \mathrm{L}$, a typical level in the $100-\mathrm{F}$ Area and below the $15 \mathrm{pCi} / \mathrm{L}$ drinking water standard.

Gross beta concentrations in wells in the east 100-F Area ranged up to $51 \mathrm{pCi} / \mathrm{L}$ (well 199-F5-1) in fiscal year 2003, reflecting the presence of strontium-90, as discussed in Section 2.7.1.2. Concentrations also exceeded background levels in some wells in the south 100-F Area where there is no strontium-90. For example, well 199-F8-4 detected $24 \mathrm{pCi} / \mathrm{L}$ beta in fiscal year 2003. There are no current data on beta emitters other than strontium-90. The drinking water standard for gross beta is $50 \mathrm{pCi} / \mathrm{L}$.

\subsubsection{Chromium}

Dissolved chromium concentrations continued to be above background in several wells in the east 100-F Area. Levels were below the $100 \mu \mathrm{g} / \mathrm{L}$ drinking water standard in fiscal year 2003 and are declining in most wells. Concentrations are typically highest in wells near the former retention basins and disposal trenches. For example, the maximum concentration in fiscal year 2003 was $90 \mu \mathrm{g} / \mathrm{L}$ in well 199-F5-46. The maximum chromium concentration in an aquifer tube was in the same region of $100-\mathrm{F}$ Area, $14 \mu \mathrm{g} / \mathrm{L}$ in tube 63-M.

\subsubsection{CERCLA Groundwater Monitoring}

No groundwater remediation decisions have been made for the 100-FR-3 Operable Unit. Until such decisions are made, the groundwater project monitors contaminant plumes and trends as discussed in the preceding sections.

The sampling and analysis plan that was in effect during fiscal year 2003 (PNNL-13327) specified annual sampling of 9 wells and 3 seeps, and biennial sampling of 14 wells. Two wells are sampled quarterly for selected constituents (see Appendix A). Seventeen of the wells were scheduled for sampling in fiscal year 2003 and all were sampled successfully. Two of the three shoreline seeps were not sampled because the specific conductance of the water was the same as river water, so it did not represent discharging groundwater.

The U.S. Environmental Protection Agency approved a new sampling and analysis plan at the end of September 2003 (DOE/RL-2003-49). The new plan, which is being implemented in fiscal year 2004, revises the monitoring program slightly and calls for the addition of more aquifer sampling tubes to monitor contaminants near the Columbia River.
Until groundwater remediation decisions are made for the 100-FR-3 Operable Unit, the groundwater project will continue to monitor contaminant plumes and trends. 


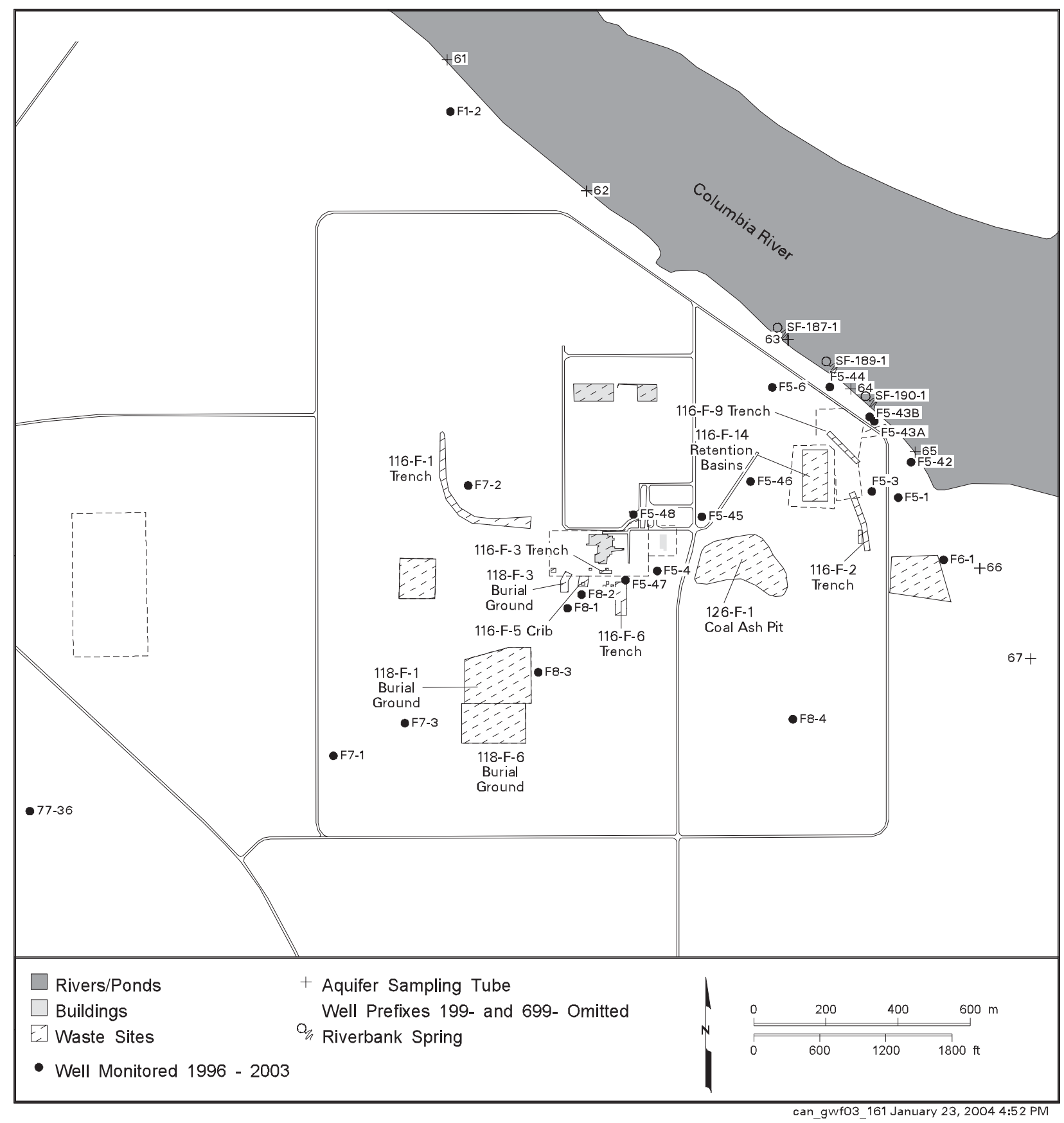

Figure 2.7-1. Groundwater Monitoring Wells in the 100-F Area 


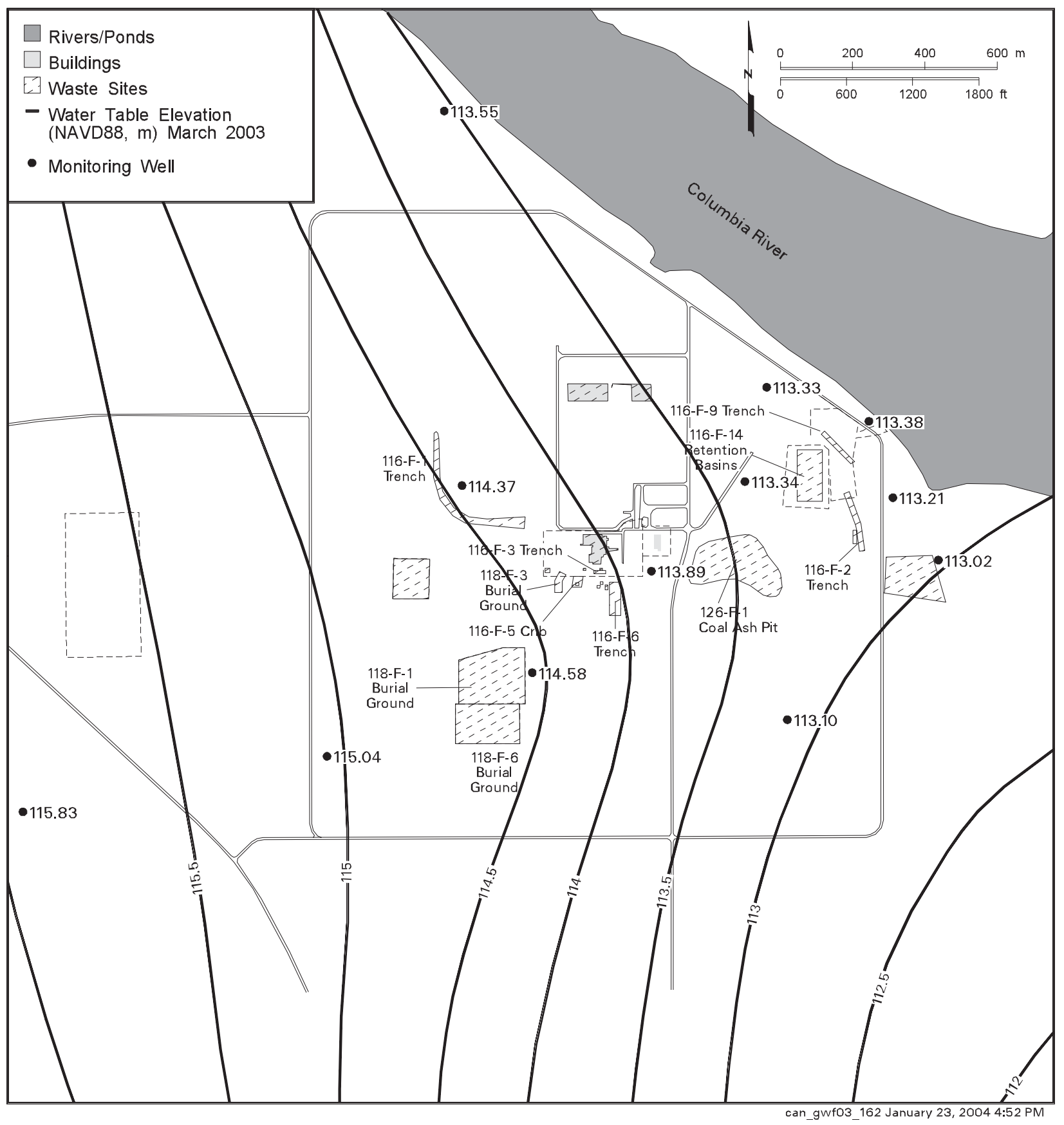

Figure 2.7-2. 100-F Area Water-Table Map, March 2003 


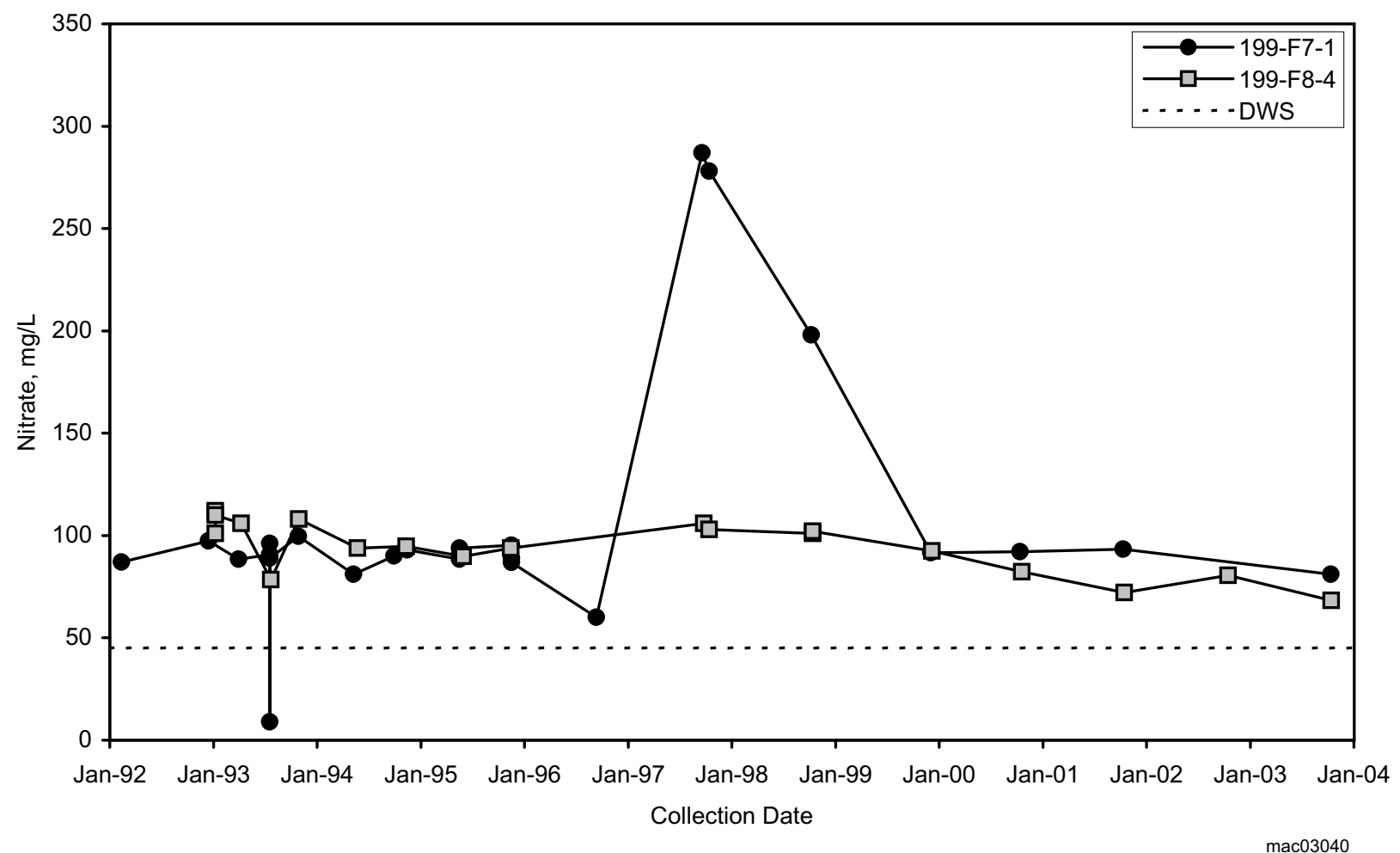

Figure 2.7-3. Nitrate Concentrations in Southeast (Well 199-F8-4) and Southwest 100-F Area (Well 199-F7-1)

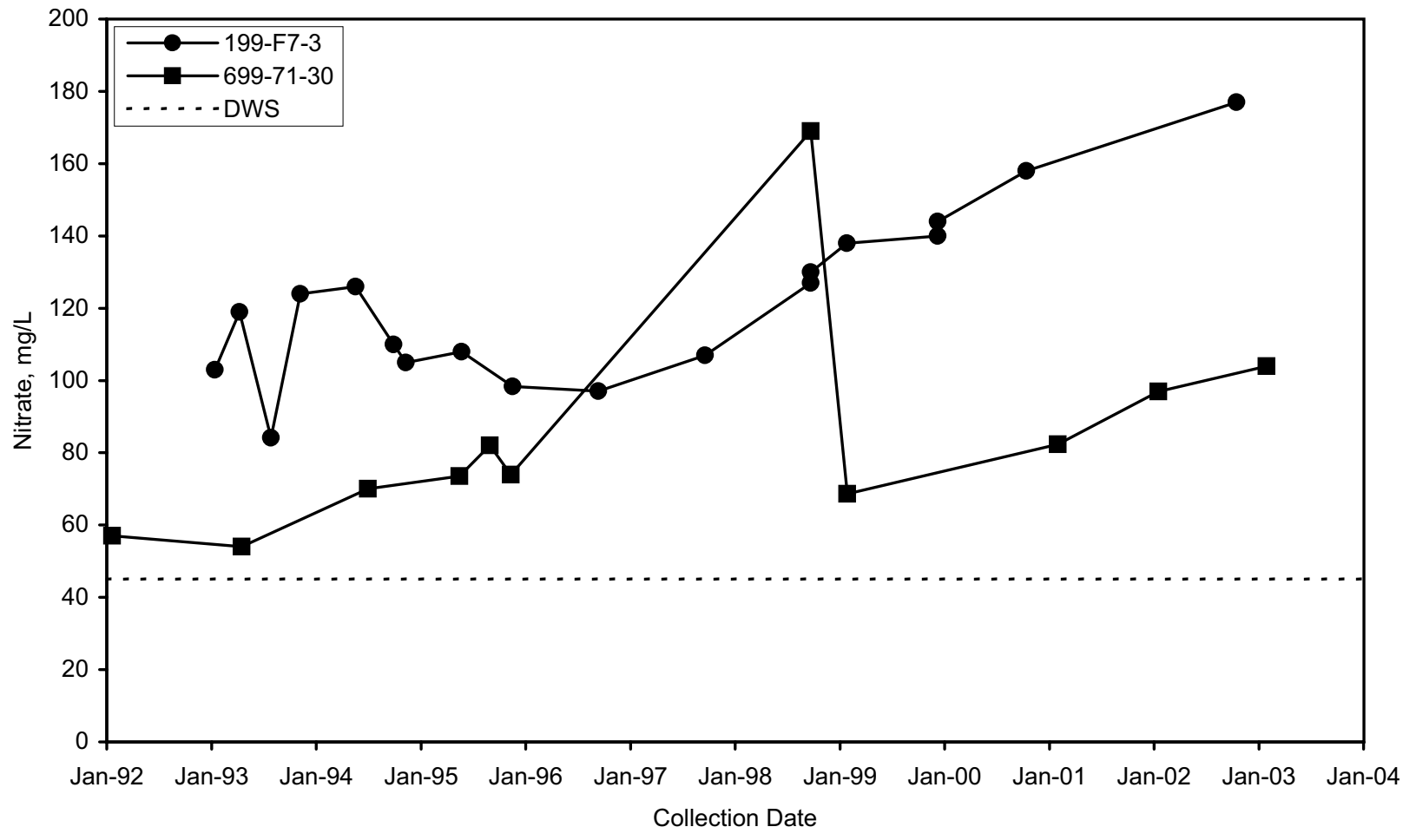

$\operatorname{mac} 03041$

Figure 2.7-4. Nitrate Concentrations Southwest (Well 199-F7-3) and South (Well 699-71-30) of 100-F Area 


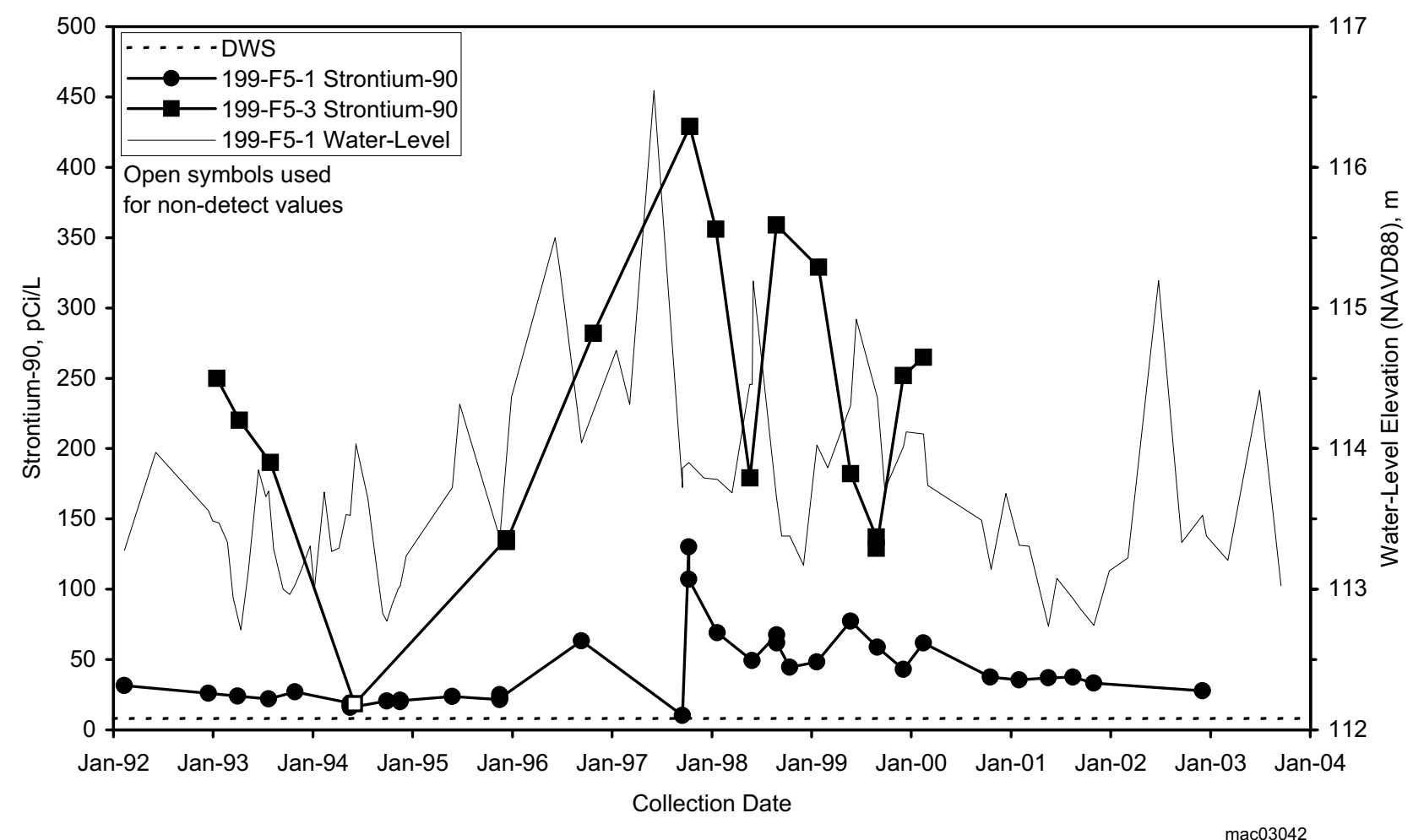

Figure 2.7-5. Strontium-90 Concentrations and Water Levels in East 100-F Area

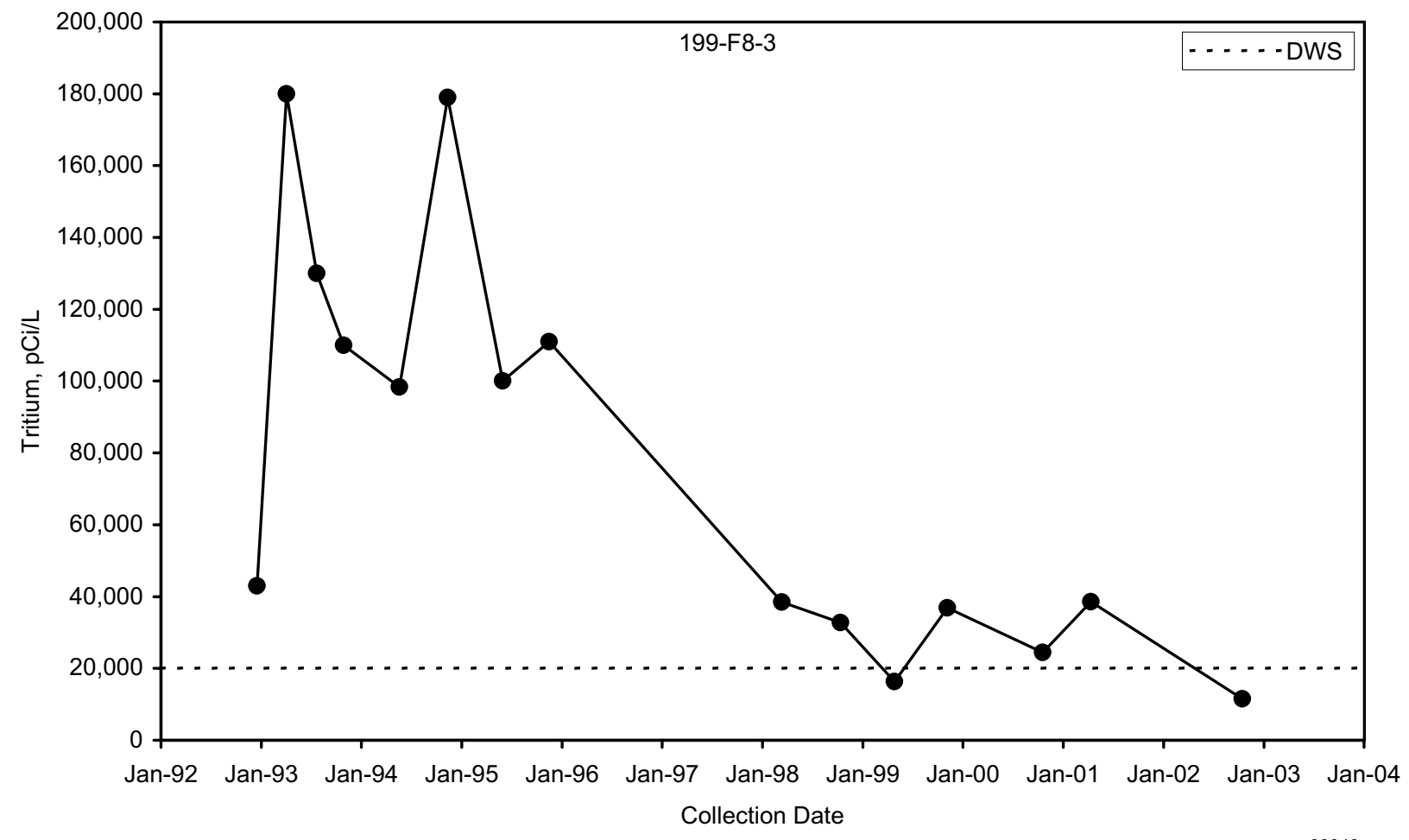

Figure 2.7-6. Tritium Concentrations Near 118-F-6 Burial Ground 


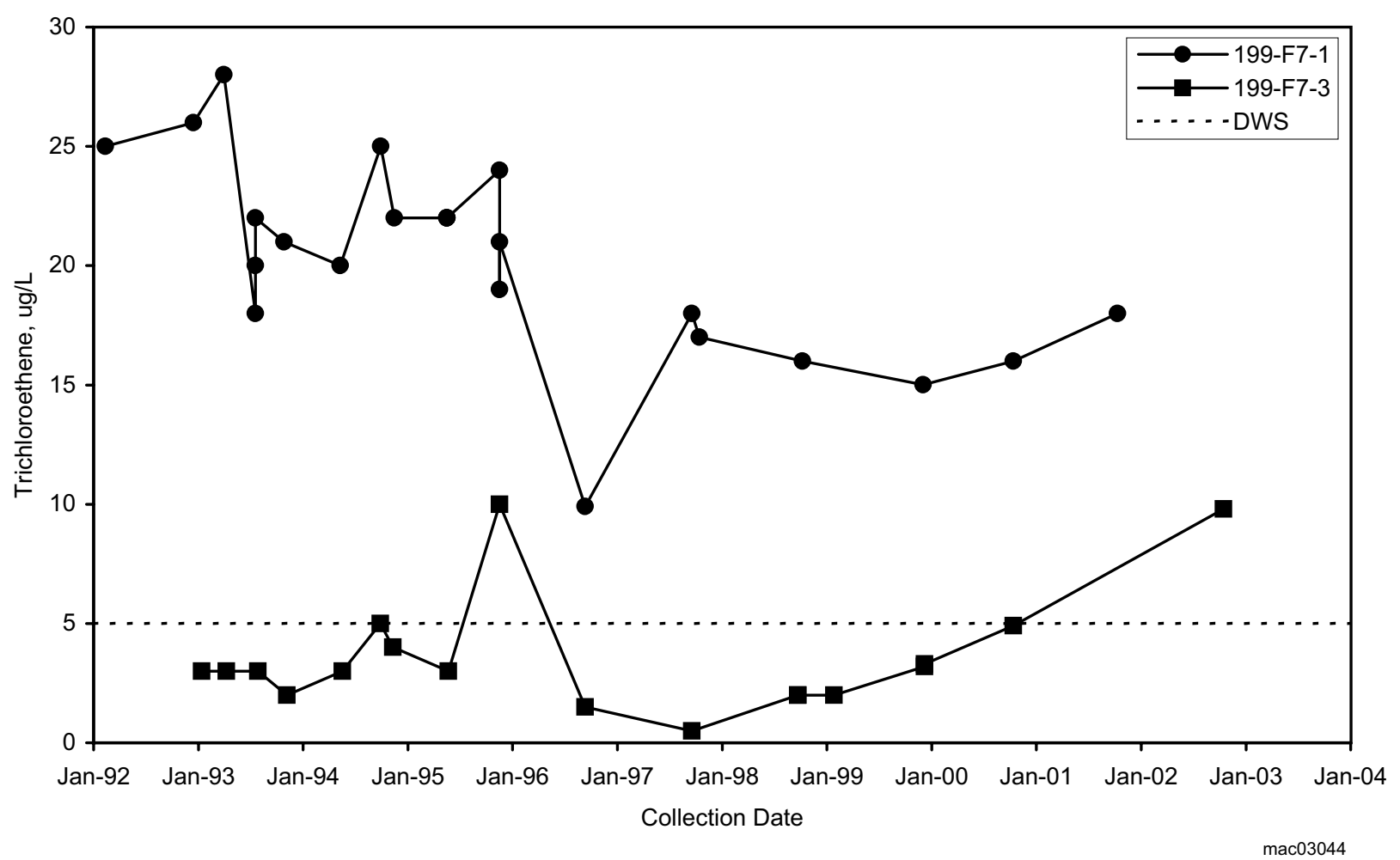

Figure 2.7-7. Trichloroethene in the Southwest 100-F Area 


\subsection{0-ZP-1 Operable Unit}

\section{P. E. Dresel, D. B. Barnett, D. B. Erb, and D. G. Horton}

The scope of this section encompasses the 200-ZP-1 Operable Unit and surroundings. This region is informally termed the 200-ZP-1 groundwater interest area (Figure 2.1-1). Figure 2.8-1 shows facilities and wells in this region. Groundwater is monitored to assess the performance of an interim action pump-and-treat system for carbon tetrachloride contamination, to track other contaminant plumes, and for four Resource Conservation and Recovery Act (RCRA) units and the State-Approved Land Disposal Site. The major contamination plumes in this area include carbon tetrachloride, chloroform, trichloroethene, nitrate, chromium, fluoride, tritium, iodine-129, technetium-99, and uranium.

Within the 200-ZP-1 Operable Unit, interim actions have been implemented for remediation of carbon tetrachloride, chloroform, and trichloroethene in the vicinity of the 216-Z liquid waste disposal units (e.g., cribs and trenches). Remediation of other groundwater contaminants will be determined through the Remedial Investigation/ Feasibility Study Process. A Remedial Investigation/Feasibility Study Work Plan for the 200-ZP-1 Operable Unit will be prepared in fiscal year 2004.

Groundwater flows primarily to the east in the 200-ZP-1 groundwater interest area (Figure 2.8-2). The water table in the 200 West Area was raised by past discharge of

Groundwater monitoring in the 200-ZP-1 groundwater interest area includes CERCLA, RCRA, WAC, and AEA monitoring:

CERCLA Monitoring

- Five extraction wells are sampled monthly (when operating).

- Three wells are sampled quarterly.

- Fourteen wells are sampled semiannually.

- Twenty-nine wells are sampled annually.

- Twelve wells are sampled biennially.

- In fiscal year 2003, four wells were not sampled as scheduled (see Appendix A).

RCRA Monitoring

- Thirteen wells are sampled semiannually for Low-Level Waste Management Area 3.

- Seven wells are sampled semiannually for Low-Level Waste Management Area 4.

- Thirteen wells are sampled quarterly to semiannually for Waste Management Area T.

- Sixteen wells are sampled quarterly to semiannually for Waste Management Area TX-TY.

- In fiscal year 2003, four RCRA wells were not sampled as scheduled (see text and Appendix B).

WAC 173-216 Monitoring

- Nineteen wells are sampled quarterly to semiannually for the State-Approved Land Disposal Site.

- In fiscal year 2003, two wells were not sampled as scheduled (see Appendix C).

\section{Other AEA Monitoring}

- Thirteen wells are sampled semiannually for performance assessment at Low-Level Waste Management Area 3.

- Thirteen wells are sampled semiannually for performance assessment at Low-Level Waste Management Area 4.

- Fourteen wells are sampled quarterly to annually.

- In fiscal year 2003, one well was not sampled as scheduled (see Appendix C). 


\section{Groundwater flows west to east except where affected by pumping or injection.}

wastewater and the aquifer is still responding to the termination of discharges. The flow direction is thus changing with time, particularly in the north part of the area.

Groundwater in the north portion of the 200 West Area predominantly flows toward the east-northeast but is locally influenced by the 200-ZP-1 Operable Unit pump-andtreat system and effluent discharges to the State-Approved Land Disposal Site (Figure 2.8-2). The flow direction in the north part of the operable unit has changed $~ 35$ degrees over the past decade from a north-northeast direction to a more easterly direction. This is due to decreased effluent discharges to the soil column in the 200 West Area, which is causing flow to return to its pre-Hanford direction.

Flow in the central part of the 200 West Area (the south part of the 200-ZP-1 Operable Unit) is heavily influenced by the operation of the 200-ZP-1 groundwater pump-and-treat remediation system. This system extracts water from the vicinity of the $216-Z$ cribs and trenches shown on Figure 2.8-1, treats it to remove carbon tetrachloride, then re-injects the water into the aquifer to the west of the area. A small groundwater mound is associated with the injection wells, and a region of drawdown is associated with the extraction wells, causing flow to converge on the extraction zone from all directions. These flow conditions are expected to continue until the end of the pump-and-treat program, at which time the flow direction will resume a west to east pattern.

The remainder of this section describes contaminant plumes and concentration trends for the contaminants of concern under Comprehensive Environmental Response, Compensation, and Liability Act (CERCLA), RCRA, or Atomic Energy Act of 1954 (AEA) monitoring.

\subsubsection{Groundwater Contaminants}

The groundwater contaminants of concern discussed below are defined in the 200-ZP-1 sampling and analysis plan (DOE/RL-2002-17). In addition to the contaminants of concern on this list, a fluoride plume has been defined within the 200-ZP-1 Operable Unit and will be discussed in this section.

Plume areas (square kilometers) above the drinking water standard at the 200-ZP-1 Operable Unit:

*Carbon tetrachloride - 10.6

Chromium -0.05

Fluoride -0.02

Iodine- $129-0.66$

Nitrate - 6.16

Technetium-99 -0.01

Trichloroethene -0.80

Tritium -0.79

Uranium - 0.14

*Also includes portion of plumes beneath 200-UP-1 Operable Unit.

\subsubsection{Carbon Tetrachloride}

Carbon tetrachloride contamination is found at levels greater than the $5 \mu \mathrm{g} / \mathrm{L}$ drinking water standard in the groundwater under most of the 200 West Area (Figure 2.8-3). The main sources are believed to be the $216-\mathrm{Z}$ cribs and trenches that received waste from the Plutonium Finishing Plant. Other possible carbon tetrachloride sources exist in the north part of the operable unit and investigation of carbon tetrachloride in the vadose zone in Low-Level Waste Management Area 4 is discussed in Section 3.1.3. The maximum carbon tetrachloride levels are found near the Plutonium Finishing Plant and range up to 6,200 $\mu \mathrm{g} / \mathrm{L}$.

Carbon tetrachloride remediation is the subject of the 200-ZP-1 interim record of decision (ROD 1995a). The target for remediation is the area with concentrations $>2,000$ to $3,000 \mu \mathrm{g} / \mathrm{L}$ in the vicinity of the $216-\mathrm{Z}$ cribs and trenches. The remediation activities are summarized in Section 2.8.2.

Significant features of the carbon tetrachloride plume include:

- The area of carbon tetrachloride $>4,000 \mu \mathrm{g} / \mathrm{L}$ in the vicinity of the $216-\mathrm{Z}$ cribs and trenches is decreasing due to the remediation (see Section 2.8.2.1).

- An area of carbon tetrachloride at levels $>2,000 \mu \mathrm{g} / \mathrm{L}$ extends north to the vicinity of Waste Management Area TX-TY. The west side of this lobe is defined by a new monitoring well, 299-W15-43, where the average concentration was 1,900 $\mu \mathrm{g} / \mathrm{L}$. This well was drilled early in fiscal year 2003. Sampling for carbon tetrachloride at well 299-W15-44 located northeast of extraction well 299-W15-34 showed a concentration of $2,900 \mu \mathrm{g} / \mathrm{L}$ in August 2003. The carbon tetrachloride contamination reaches the 
north part of Waste Management Area TX-TY where concentrations in well 299-W15-765 averaged 3,200 $\mu \mathrm{g} / \mathrm{L}$. Thus, the contamination at levels above 2,000 $\mu \mathrm{g} / \mathrm{L}$ extends beyond the capture zone of the 200-ZP-1 remediation system (see Section 2.8.2).

- Carbon tetrachloride extends beyond the 200 West Area boundary in several directions. The concentration is increasing in well 699-48-71 as the plume moves to the northeast (Figure 2.8-4). Concentrations in wells to the southeast, downgradient of the Environmental Restoration Disposal Facility, remain fairly steady at levels around the drinking water standard.

- Levels of carbon tetrachloride $>1,000 \mu \mathrm{g} / \mathrm{L}$ are seen in the north part of the operable unit. Well 299-W11-10 near the east boundary of the 200 West Area consistently shows high carbon tetrachloride concentrations. The extent beyond the area boundary for this high concentration has not been determined since there are no wells downgradient.

- In the past several years, increasing concentrations of carbon tetrachloride have been seen west and south of the tank farms in Waste Management Area S-SX (in the 200-UP-1 Operable Unit). Concentrations appear to have leveled off or declined in several wells in this area but more time is needed to confirm the trends.

- Carbon tetrachloride concentrations are declining in several wells west of Low-Level Waste Management Area 4. Some of this decline is due to injection of treated water from the 200-ZP-1 remediation system; however, some of the decline may be due to changing plume dimensions beyond the area where injected water is displacing the plume.

- Although data from wells completed above the Ringold lower mud unit at the base of the unconfined aquifer typically show low carbon tetrachloride concentrations, data from vertical profile sampling often show the highest concentrations are not at the water table but at intermediate depths in the aquifer.

\subsubsection{Trichloroethene}

Trichloroethene is also detected at levels above the drinking water standard in the 200-ZP-1 Operable Unit and the contamination extends into the 200-UP-1 Operable Unit (Figure 2.8-5). Levels are lower and the extent is generally less than for carbon tetrachloride. The maximum trichloroethene detected in fiscal year 2003 was $18 \mu \mathrm{g} / \mathrm{L}$ in extraction well 299-W15-34, where the annual average concentration was $7.2 \mu \mathrm{g} / \mathrm{L}$.

\subsubsection{Chloroform}

Chloroform concentrations in the 200-ZP-1 wells remained below the $80 \mu \mathrm{g} / \mathrm{L}$ drinking water standard. The maximum concentration detected was $31 \mu \mathrm{g} / \mathrm{L}$. Possible chloroform sources include biodegradation of carbon tetrachloride and as a by-product of water treatment.

\subsubsection{Nitrate}

Nitrate continued to be present in groundwater at concentrations in excess of the $45 \mathrm{mg} / \mathrm{L}$ drinking water standard beneath much of the 200-ZP-1 Operable Unit (Figure 2.8-6). The maximum concentration in this vicinity during fiscal year 2003 (omitting suspect values) was 2,160 mg/L in well 299-W10-4 near the 216-T-36 crib, south of Waste Management Area T. The 216-T-32 and 216-T-7 cribs, west of Waste Management Area $\mathrm{T}$, also appear to contribute to the high nitrate concentrations. The nitrate contamination is more widespread than the iodine-129, technetium-99, or tritium contamination discussed in Sections 2.8.1.9, 2.8.1.10 and 2.8.1.8, respectively. There probably are multiple sources of nitrate in this area, including disposal facilities farther south.
The area of carbon

tetrachloride

$>4,000 \mu g / \mathrm{L}$ is

decreasing due to

remediation.

However, the

contamination at

levels above

2,000 $\mu \mathrm{g} / \mathrm{L}$ extends

beyond the capture

zone of the

remediation

system. 


\section{A well near the 216-T-36 crib has the highest nitrate concentration on the Hanford Site, $>2,000 \mathrm{mg} / \mathrm{L}$.}

\section{Chromium contamination originated at cribs and trenches west of T Tank Farm.}

Elevated nitrate on the east side of Waste Management Area TX-TY, in well 299-W14-13, is correlated with elevated chromium, tritium, iodine-129, and technetium-99. Because of the lower levels in surrounding wells, this contamination is interpreted as being from a nearby source.

Nitrate is found at concentrations greater than the drinking water standard at considerable depth within the unconfined aquifer in the north part of the operable unit. For example, $394 \mathrm{mg} / \mathrm{L}$ of nitrate was detected in fiscal year 2002 in a sample from well 299-W6-3 that is completed $\sim 60$ meters below the water table. This well is completed above the top of the Ringold Formation lower mud unit and was not sampled in fiscal year 2003. Nitrate contamination is found at levels above the drinking water standard in the 200-ZP-1 extraction wells. Since nitrate is not removed in the treatment system, it is re-injected into the aquifer upgradient of the 200 West Area.

Elevated nitrate levels are found in the west part of the Hanford Site. This contamination is believed to be due to offsite agriculture. One well (699-36-93, see Figure 2.1-2 for location) in the west part of the Hanford Site had nitrate levels $(49 \mathrm{mg} / \mathrm{L})$ above the drinking water standard (45 mg/L) in fiscal year 2003.

\subsubsection{Chromium}

Chromium contamination is found at levels above the $100 \mu \mathrm{g} / \mathrm{L}$ drinking water standard in the immediate vicinity of Waste Management Areas T and TX-TY (Figure 2.8-7). The plume in the vicinity of Waste Management Area T has changed little in size over the past decade. The highest levels are found near the 216-T-36 crib, upgradient of Waste Management Area T, in well 299-W10-4 where the annual average concentration was $330 \mu \mathrm{g} / \mathrm{L}$.

The most likely source for the chromium at Waste Management Area T is one or more of the cribs and trenches west and southwest of the tank farm. Chromium from these facilities would have been moving north across well 299-W10-1 prior to 1997 and then east across the north part of the waste management area after 1997. The Waste Management Area T tank farm does not appear to be a source of chromium in this area as discussed in more detail in Section 2.8.3.1.

Chromium is also elevated east of Waste Management Area TX-TY in well 299-W14-13. The concentrations detected in this well in fiscal year 2003 were variable, ranging from 427 to $592 \mu \mathrm{g} / \mathrm{L}$ in filtered samples. Chromium concentrations are increasing in well 299-W14-15, indicating the contamination may be migrating to the south. The chromium contamination is associated with elevated nitrate, tritium, technetium-99, and iodine-129. The contamination is discussed further in Section 2.8.3.2.

In late fiscal year 2002, an elevated chromium result for a filtered sample was reported on the north side of Low-Level Waste Management Area 3. This result was considered suspect and investigated in fiscal year 2003. The investigation is described in further detail in Section 2.8.2.3 and was determined to be probably caused by a sampling issue such as a filter failure.

\subsubsection{Arsenic and Cadmium}

Arsenic is listed as a contaminant of concern in the 200-ZP-1 sampling and analysis plan (DOE/RL-2002-17), and sampling for arsenic is specified for six wells. Arsenic was not detected at levels above the $10 \mu \mathrm{g} / \mathrm{L}$ drinking water standard in any of the samples.

Cadmium is also listed as a contaminant of concern; sampling for cadmium in filtered samples is specified for 22 wells. Three of those wells, 299-W6-2, 299-W6-7, and 299-W18-24, were not sampled because they have gone dry. Several other wells were also analyzed for cadmium because they were sampled for other metals. Cadmium was below the $5 \mu \mathrm{g} / \mathrm{L}$ drinking water standard in all samples. 


\subsubsection{Fluoride}

Fluoride contamination at levels greater than the primary drinking water standard of $4 \mathrm{mg} / \mathrm{L}$ is restricted to a small area around Waste Management Area T (Figure 2.8-8). Fluoride contamination from the tank farm has not been ruled out, but the nearby cribs are believed to be a more likely source.

\subsubsection{Tritium}

Tritium contamination at levels greater than the drinking water standard in the 200-ZP-1 Operable Unit is mainly restricted to a plume extending northeast from waste disposal facilities in the vicinity of Waste Management Areas T and TX-TY. In addition, tritium from permitted discharge at the State-Approved Land Disposal Site is found in the groundwater (Figure 2.8-9). Tritium at the State-Approved Land Disposal Site is discussed in Section 2.8.5.

The highest tritium concentrations were in well 299-W14-13, located east of Waste Management Area TX-TY, where the annual average concentration was 1.9 million $\mathrm{pCi} / \mathrm{L}$. The maximum tritium concentration detected in this well was 2.17 million $\mathrm{pCi} / \mathrm{L}$, which is greater than the DOE derived concentration guide. Well 299-W14-13 replaced well 299-W14-12, and the trend plot for these two wells indicates that the high contamination levels at this location are a recent phenomenon (Figure 2.8-10). High levels of chromium, nitrate, technetium-99, and iodine-129 are associated with the tritium contamination. The contamination is migrating to the south and beginning to impact well 299-W14-15. This contamination is discussed further in Sections 2.8.3.2 and 2.8.4.2.

Overall, tritium levels in the 200-ZP-1 Operable Unit are fairly low with only four wells having average concentrations $>30,000 \mathrm{pCi} / \mathrm{L}$ in fiscal year 2003 . Aside from wells 299-W14-13 and 299-W14-15, well 299-W11-12 had an average tritium concentration of 52,100 pCi/L and well 299-W6-10 had an average tritium concentration of 35,000 pCi/L. Well 299-W11-12 is located southeast of Waste Management Area T, so the waste management area is probably not a major tritium source.

\subsubsection{9 lodine-129}

An iodine-129 plume is found in the 200-ZP-1 Operable Unit, emanating from the vicinity of Waste Management Area TX-TY and extending to the northeast (Figure 2.8-11). The highest concentration detected in fiscal year 2003 was in well 299-W14-13, where the maximum concentration was $36.7 \mathrm{pCi} / \mathrm{L}$. The interpretation of iodine- 129 is hampered by several samples being reported as non-detect at values greater than the drinking water standard. This occurs because high technetium- 99 concentrations in the well require the laboratory's use of small sample volumes for iodine-129 analyses. The small sample volumes result in non-confirmation of a secondary iodine-129 gamma energy peak needed to confirm the presence of iodine-129. The iodine-129 plume is drawn conservatively by including these values that have elevated detection limits. The values occur in wells that often show detected values at approximately the same levels and appear to form a consistent plume, suggesting that iodine- 129 may actually be present. Iodine- 129 contamination at levels above the drinking water standard does not appear to extend beyond the 200 West Area boundary.

\subsubsection{Technetium-99}

Technetium-99 within the 200-ZP-1 Operable Unit is found at levels above the $900 \mathrm{pCi} / \mathrm{L}$ drinking water standard only on the downgradient side of Waste Management Areas T and TX-TY (Figure 2.8-12). However, evidence points to multiple sources of technetium-99 within those areas.

Near Waste Management Area T, technetium-99 concentrations continued to increase in wells on the east side (downgradient) of the tank farm (Figure 2.8-13). The increase is most notable in the wells along the southeast edge of the waste management area where concentrations increased by $50 \%$ to $60 \%$ in fiscal year 2003 . Well 299-W11-39, near the
Tritium contamination originated from waste disposal facilities near Waste Management Areas T and TX-TY.

Iodine-129 concentrations in one well in the 200-ZP-1 Operable Unit are among the highest on the Hanford Site. 


\section{Technetium-99 \\ exceeds the \\ drinking water \\ standard in only \\ a few wells in \\ the 200-ZP-1 \\ Operable Unit. \\ Concentrations \\ increased in some \\ wells during fiscal \\ year 2003.}

\section{The pump-and-}

treat system is

successfully

containing and

capturing the

high concentration

portion of

the carbon

tetrachloride plume

near the top of

the aquifer. northeast corner of the waste management area, had the highest concentration in the area with values in fiscal year 2003 ranging from 6,790 to $10,500 \mathrm{pCi} / \mathrm{L}$.

Although technetium-99 is also increasing upgradient of Waste Management Area T, near the 216-T-36 crib, levels remain below the drinking water standard and far lower than found on the downgradient side of the waste management area. The increase in technetium-99 near the 216-T-36 crib corresponds to an increase in chromium and nitrate. Thus, the increase in technetium-99 is also likely attributed to the 216-T-5, 216-T-7, or 216-T-36 cribs. The higher levels of contamination on the downgradient side are likely attributable to sources within the tank farm. Technetium-99 contamination around Waste Management Area $\mathrm{T}$ is discussed in greater detail in Section 2.8.4.1.

Technetium-99 concentrations east of Waste Management Area TX-TY in well 299-W14-13 continue to be much higher than in surrounding wells and show a generally increasing trend. The fiscal year average concentration in this well was $8,280 \mathrm{pCi} / \mathrm{L}$. This contamination is associated with elevated levels of chromium, nitrate, tritium, and iodine-129. Contamination exhibited in this area is discussed further in Section 2.8.4.1.

In the past, technetium-99 concentrations were greater than the drinking water standard on the south side of Waste Management Area TX-TY, but concentrations decreased in fiscal year 2003. This area is within the capture zone of the 200-ZP-1 extraction wells so the flow direction is approximately to the south. Some technetium-99 is detectable in the 200-ZP-1 extraction wells. Levels average less than half the drinking water standard. Since technetium is not removed by the treatment system, technetium-99 is being re-injected to the aquifer in the treated water.

Well 299-W15-15, lying north-northeast of the injection wells, has exhibited increasing technetium-99 concentrations, rising from $18 \mathrm{pCi} / \mathrm{L}$ in May 1994 to $136 \mathrm{pCi} / \mathrm{L}$ in July 2003. This change suggests that injected water is flowing toward this monitoring well. The increase in technetium-99 at this well has accompanied a marked decrease in carbon tetrachloride concentrations, from 1,125 $\mu \mathrm{g} / \mathrm{L}$ in May 1994, and a maximum of 1,850 $\mu \mathrm{g} / \mathrm{L}$ in January 1997 to $24 \mu \mathrm{g} / \mathrm{L}$ in July 2003 . The technetium-99 occurrence may result at least in part from technetium-99 in water injected by the 200-ZP-1 pump-and-treat system. However, the concentrations are over one-third the highest technetium-99 concentration in any extraction well. This, and the distance of the wells in question from the injection wells, suggests the possibility that part of the technetium may be from an upgradient source. Technetium-99 may have moved to the west under past flow conditions and be re-entering the area under present flow conditions. Well 299-W18-23 is located closer to the injection wells but has lower technetium-99 concentrations.

\subsubsection{Uranium}

Few analyses for uranium were performed on groundwater samples from the 200-ZP-1 Operable Unit during fiscal year 2003 because most wells showed insignificant levels in previous monitoring. Some wells monitored near the single-shell tank farms are sampled for gross alpha measurements, which would show an increase if uranium contamination appeared. Uranium was detected above the $30 \mu \mathrm{g} / \mathrm{L}$ drinking water standard in well 299-W11-37 and near the southwest corner (upgradient) of Low-Level Waste Management Area 4 in well 299-W18-21. The uranium is detected far from major disposal facilities, so the source of the contamination is unknown. The uranium concentration detected in well 299-W11-37 ranged from 192 to $367 \mu \mathrm{g} / \mathrm{L}$. The concentration in well 299-W18-21 was barely above the drinking water standard (30.1 to $30.7 \mu \mathrm{g} / \mathrm{L}$ ).

\subsubsection{CERCLA Interim Groundwater Remediation for Carbon Tetrachloride}

The pump-and-treat system for the 200-ZP-1 Operable Unit is successfully containing and capturing the high concentration portion of the carbon tetrachloride plume near the 
top of the aquifer in the vicinity of the $216-Z$ cribs and trenches. The pump-and-treat system for the 200-ZP-1 Operable Unit was implemented in three phases as an interim remedial action.

Contamination in the groundwater was reduced in the area of highest concentrations through mass removal. Hydraulic control of the plume is being maintained by the extraction and injection system. Additional information was collected through the drilling of new boreholes, hydraulic monitoring, contaminant monitoring, and treatment system operations. The current remediation system is designed to capture the baseline 2,000 - to 3,000- $\mathrm{gg} / \mathrm{L}$ plume depicted in the record of decision (ROD 1995a).

A summary of the remediation activities and progress is given in the following sections. For more details, see DOE/RL-2003-58.

\subsubsection{Progress During Fiscal Year 2003}

A new sampling and analysis plan (DOE/RL-2002-17) was implemented for the 200-ZP-1 Operable Unit during fiscal year 2003. It specified annual or semiannual sampling schedules for wells with stable and changing contaminant trends, respectively. New wells are sampled quarterly for the first year and semiannually the second year. Wells in areas with very slowly changing concentrations are sampled biennially. This sampling schedule is being revised in the remedial investigation/feasibility study work plan for the 200-ZP-1 Operable Unit (to be published) to support fiscal year 2004 sampling.

Carbon tetrachloride contamination was reduced in the area of highest concentrations through mass removal. Approximately 253.6 million liters of contaminated groundwater were treated in fiscal year 2003 at an average flow rate of 513 liters per minute. New extraction wells to replace wells 299-W15-32 and 299-W15-33 will become operational during fiscal year 2004 and will be equipped with larger screened intervals to increase production rate. Extraction well concentrations ranged from 900 to $6,200 \mu \mathrm{g} / \mathrm{L}$, while influent concentrations measured at the influent tank ranged from 2,800 to 4,300 $\mu \mathrm{g} / \mathrm{L}$. The pump in well 299-W15-33 broke down at the end of July 2002 and was replaced at the end of November. Thereafter, it was operated on a limited basis through January 1, 2003. Since January 1, the well has operated continuously. Well 299-W15-32 was off-line from mid-December 2002 to mid-February 2003 due to a leak detection system problem.

Treatment of 253.6 million liters of groundwater resulted in the removal of 819.3 kilograms of carbon tetrachloride during fiscal year 2003. Since startup of pump-and-treat system operations in August 1994, treatment of almost 2.15 billion liters of groundwater has led to the removal of over 7,668 kilograms of carbon tetrachloride.

Well 299-W15-37, formerly an extraction well, was converted to a monitoring well during fiscal year 2001. Concentrations of carbon tetrachloride decreased to $73 \mu \mathrm{g} / \mathrm{L}$ in March 2003, indicating there is no loss of control of the plume in the southern-most part of the plume. Carbon tetrachloride concentrations at extraction well 299-W15-36 have been consistently below the remedial action objective of 2,000 $\mu \mathrm{g} / \mathrm{L}$ since May 1998. As shown in Figure 2.8-3, continued pumping at this well is drawing a portion of the plume to the southeast, away from the main body of carbon tetrachloride contamination. For these reasons, consideration is being given to shutting down this extraction well.

Technetium-99 samples are collected to ascertain if the pump-and-treat system is being affected by radiological contamination. Technetium-99 is not retained in the treatment system and none of the values observed anywhere in the system exceed the drinking water

During fiscal
year 2003, the
pump-and-treat
system extracted
$\sim 254$ milion liters
of groundwater,
removing
819 kilograms of
carbon tetrachloride.




\section{During fiscal year 2003, the $>2,000-\mu g / L$ center of the carbon tetrachloride plume maintained a similar shape and size to that of fiscal year 2002. The 4,000- $\mu g / L-p l u m e$ contour has shrunk.}

standard of $900 \mathrm{pCi} / \mathrm{L}$ for technetium-99. Technetium-99 acts as a tracer and is detected in injection well samples and at surrounding monitoring wells. As discussed in Section 2.8.1.10, technetium-99 in monitoring wells on the east side of Low-Level Waste Management Area 4, near the injection wells, appears to be due to the injection of treated water.

\subsubsection{Influence on Aquifer Conditions}

During fiscal year 2003, the $>2,000-\mu \mathrm{g} / \mathrm{L}$ center of the carbon tetrachloride plume maintained a similar shape and size to that of fiscal year 2002 (see Figure 2.8-3). The 4,000- $\mathrm{gg} / \mathrm{L}$-plume contour has shrunk as shown by declining concentrations at extraction well 299-W15-33 and monitoring well 299-W15-31A. Well 299-W15-33 was off-line between August and November 2002, awaiting a replacement pump, and then ran on a limited schedule through December 2002. This change in pumping is believed to have enhanced the declining concentrations at this well. During fiscal year 2002, wells

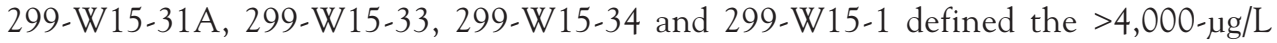
contour; during fiscal year 2003, only two wells (299-W15-1 and 299-W15-34) now define that plume. The center of the contaminant mass is being drawn toward well 299-W15-34.

Concentration trends at the extraction wells imply that the center of the dissolved mass arrived at the extraction wells several years ago. For example, carbon tetrachloride concentrations have declined dramatically from $>8,000 \mu \mathrm{g} / \mathrm{L}$ in 1997 to 2,200 $\mu \mathrm{g} / \mathrm{L}$ in 2003 at extraction well 299-W15-32, located near the 216-Z-9 trench, regarded as the primary source of the carbon tetrachloride contamination (Figure 2.8-14).

Monitoring wells between the injection and extraction wells at the 200-ZP-1 Operable Unit have declining carbon tetrachloride concentrations. At well 299-W15-16, concentrations have declined from 7,800 $\mu \mathrm{g} / \mathrm{L}$ in October 1997 to 1,800 $\mu \mathrm{g} / \mathrm{L}$ in July 2003. Similarly, at well 299-W15-31A, concentrations have declined from 7,500 $\mu \mathrm{g} / \mathrm{L}$ in October 1999 to $3,450 \mu \mathrm{g} / \mathrm{L}$ in July 2003.

Regional groundwater flow in the vicinity of the extraction wells is still to the eastnortheast in the 200-ZP-1 Operable Unit pump-and-treat system (Figure 2.8.2). Water levels continue to decline at an annual rate of $\sim 0.36$ meter per year (DOE/RL-2003-58). Locally, within the extraction/injection system, the flow seems to be more to the northeast and north-northeast. The extraction wells influence water levels and flow direction north of the extraction wells. The $>2,000-\mu \mathrm{g} / \mathrm{L}$ plume area north of the extraction wells is attributed to either another source of carbon tetrachloride west of the plume or a part of the original plume not detected in baseline evaluations.

The high concentration part of the plume $(>4,000 \mu \mathrm{g} / \mathrm{L})$ in the immediate vicinity of the $216-Z$ cribs and trenches was contained hydraulically during fiscal year 2003 . This conclusion is based on the measured radius of influence of the pumping wells across the high concentration area and in monitoring wells situated between the pumping wells. The pumping influence extends over 124 meters from extraction well 299-W15-33 to monitoring well 299-W15-31A where a negligible drawdown of 0.01 meter was observed, down from 0.08 meter during fiscal year 2002. The smaller drawdown was probably due to less pumping time at well 299-W15-33.

\subsubsection{RCRA Groundwater Monitoring}

The 200-ZP-1 Operable Unit contains four RCRA sites with groundwater monitoring requirements. This section summarizes the results of detection monitoring at two sites and the status of assessment monitoring at the other two sites. RCRA groundwater data are available in the Hanford Environmental Information System and on the data files accompanying this report. Additional information including well and constituent, lists, maps, flow rates, and statistical tables are included in Appendix B. 


\subsubsection{Waste Management Area T}

The objective of RCRA groundwater monitoring at Waste Management Area T is to assess the extent and rate of movement of dangerous wastes in groundwater that have a source from the waste management area. Waste Management Area $\mathrm{T}$ is located in the north-central part of the 200 West Area and consists of the T Tank Farm and ancillary equipment (e.g., diversion boxes and pipelines). The tank farm contains twelve 2-millionliter tanks and four 208,000-liter tanks constructed between 1943 and 1944. Seven of the tanks in the waste management area are known or suspected to have leaked. A well location map for this waste management area is shown in Appendix B. This site continued to be monitored under an assessment program during fiscal year 2003. The well and analyte lists for this unit are given in Appendix B.

Calculated average linear velocities in wells at Waste Management Area T range from 0.017 to 0.28 meter per day with most values $<0.1$ meter per day. Groundwater flow velocities as determined from aquifer tracer tests range between 0.022 and 0.024 (PNNL-13378; PNNL-14113). Groundwater flow direction at the waste management area is between 85 and 98 degrees from north as determined by trend surface analyses (PNNL-13378; PNNL-14113). Details concerning groundwater flow rate and direction are in Appendix B.

The monitoring network for Waste Management Area $T$ includes eleven wells that are sampled quarterly and two wells sampled semiannually. One new RCRA assessment monitoring well is planned to be installed in calendar year 2004. The new well is to assess the vertical extent of contamination near the northeast corner of the waste management area.

Waste Management Area T was originally placed in assessment monitoring because of elevated specific conductance in downgradient well 299-W10-15 (WHC-SD-EN-AP-132). However, it remained in assessment because of contaminants observed in downgradient well 299-W11-27 (PNNL-11809). Carbon tetrachloride, trichloroethene, chromium, nitrate, and fluoride are found in groundwater beneath Waste Management Area T. However, the results of groundwater monitoring in fiscal year 2003 continue to suggest that the waste management area has not contributed to dangerous waste contamination of the uppermost aquifer in the area. Carbon tetrachloride and trichloroethene contamination is attributed to Plutonium Finishing Plant operations and is discussed in Section 2.8.1. Nitrate contamination also is attributed to Plutonium Finishing Plant operations as well as past-practice disposal to crib and trenches near Waste Management Area T. Chromium and fluoride contamination is attributed to cribs and trenches upgradient of the waste management area.

A plume map depicting the fiscal year 2003 average chromium concentration in wells near the Waste Management Area T is shown in Figure 2.8-7. The map shows that chromium is elevated in several wells at the waste management area. The highest concentrations are in upgradient wells 299-W10-28 and 299-W10-4 where chromium reached 215 and $347 \mu \mathrm{g} / \mathrm{L}$, respectively, in 2003. Figure 2.8-15 shows trend plots for chromium in upgradient wells at the waste management area. Prior to about 1997 when groundwater flow direction was toward the north, several wells on the north (then downgradient) side of the waste management area had relatively high chromium concentrations. Also, prior to 1997, well 299-W10-1, which was lateral to the tank farm with respect to groundwater flow direction but downgradient of the 216-T-5 trench and the 216-T-7 crib and tile field, had chromium concentrations exceeding $200 \mu \mathrm{g} / \mathrm{L}$. After flow direction changed toward the east in about 1997, chromium concentrations dropped to $<40 \mu \mathrm{g} / \mathrm{L}$ in well 299-W10-1, decreased in all of the north wells (Figure 2.8-16), and began increasing in well 299-W10-4. Finally, since December 2000, chromium has exceeded the drinking water standard in two downgradient wells, 299-W11-41 (average for fiscal year 2003, $141 \mu \mathrm{g} / \mathrm{L}$ ) and 299-W11-42 (average for fiscal year 2003, $132 \mu \mathrm{g} / \mathrm{L})$.
Assessment

monitoring at

Waste Management

Area T suggests

that the waste

management area

has not contributed

to dangerous waste

contamination of

the uppermost

aquifer in the area. 
The most likely source for the chromium at Waste

Management Area $T$ is one or more of the cribs and trenches west and southwest of the tank farm.
Considering the above history, the most likely source for the chromium at Waste Management Area $T$ is one or more of the cribs and trenches west and southwest of the tank farm: the 216-T-5 trench, the 216-T-7 crib and tile field, and 216-T-36 crib. Chromium from these facilities would have been moving north across well 299-W10-1 prior to 1997 and then east across the north wells and the rest of the waste management area after 1997.

The most likely source of chromium in the downgradient wells 299-W11-41 and 299-W11-42 at Waste Management Area T is one or more of the facilities upgradient of the waste management area. Figure 2.8-17 shows the trend plot for chromium and technetium-99, a non-RCRA-regulated constituent, for the two wells. The most likely source for the technetium-99 is the waste management area. The figure shows that the concentrations of technetium-99 and chromium do not track each other through time. If the technetium-99 is from the waste management area, a different source for the chromium is indicated. The most likely source or sources are past-practice facilities located upgradient of the waste management area.

Fluoride exceeded the primary drinking water standard of $4 \mathrm{mg} / \mathrm{L}$ in three wells at Waste Management Area T during 2003 and exceeded the secondary drinking water standard of $2 \mathrm{mg} / \mathrm{L}$ in four additional wells. Fluoride contamination in the 200-ZP-1 groundwater interest area is discussed in Section 2.8.1.7.

\subsubsection{Waste Management Area TX-TY}

The objective of RCRA groundwater monitoring at Waste Management Area TX-TY is to assess the extent and rate of movement of dangerous wastes in groundwater that have a source from the waste management area. Waste Management Area TX-TY is located in the north-central part of the 200 West Area and consists of the TX and TY Tank Farms and ancillary equipment (e.g., diversion boxes and pipelines). The tank farms contain twenty-four 2.9-million-liter tanks constructed between 1944 and 1952. Twelve of the tanks in the waste management area are known or suspected to have leaked.

Waste Management Area TX-TY was originally placed in RCRA assessment monitoring because of elevated specific conductance in downgradient wells 299-W10-27 and 299-W14-12 (WHC-SD-EN-AP-132). A well location map for this waste management area is shown in Appendix B. This site continued to be monitored under an assessment program in fiscal year 2003. The well and analyte lists for this unit are also given in Appendix B.

The monitoring network for Waste Management Area TX-TY includes fourteen wells that are sampled quarterly and two wells sampled semiannually. One well, 299-W10-27, was not sampled during the second quarter of 2003 because of pump problems. Also, two of the quarterly wells, 299-W14-19 and 299-W15-44, are new wells and were added to the monitoring network during May 2003. One new RCRA assessment monitoring well is planned to be installed during calendar year 2004. The new well is to assess the vertical extent of contamination downgradient of the waste management area.

Calculated average linear flow velocities in wells at Waste Management Area TX-TY range from 0.0007 to 2.46 meters per day with most values $<0.1$ meter per day. Groundwater flow velocities as determined from aquifer tracer tests range between 0.041 and 0.311 (PNNL-13378; PNNL-14113; PNNL-14186). Groundwater flow direction varies beneath the site. Trend surface analysis for the northeast part of the waste management area, at the TY Tank Farm, shows a groundwater flow direction of 108 degrees (PNNL-13378). Farther south, along the downgradient side of TX Tank Farm, groundwater flow direction changes from 108 degrees at well 299-W14-13 to 133 degrees at well 299-W14-14 (PNNL-13378; PNNL-14311; PNNL-14186). South of Waste Management Area TX-TY, groundwater flow direction, as determined by water-level measurements, is toward the south or southwest. The change in flow direction at Waste Management Area TX-TY is due to the 200-ZP-1 pump-and-treat system. In the north part of the waste 
management area, flow direction generally follows the pre-Hanford Site direction of east to southeast. In the south part of the site, groundwater flow direction is greatly influenced by the pump-and-treat extraction wells. Details concerning groundwater flow rate and direction are in Appendix B.

Carbon tetrachloride, trichloroethene, chromium, and nitrate are the only dangerous waste constituents found in groundwater at Waste Management Area TX-TY. Carbon tetrachloride and trichloroethene contamination is attributed to Plutonium Finishing Plant operations and is discussed in Section 2.8.1. Nitrate contamination also is attributed to Plutonium Finishing Plant operations as well as past-practice disposal to crib and trenches in the area. Some nitrate contamination may be from Waste Management Area TX-TY, although distinguishing the different sources is extremely difficult.

Chromium was detected above the drinking water standard of $100 \mu \mathrm{g} / \mathrm{L}$ only in well 299-W14-13 at Waste Management Area TX-TY during fiscal year 2003 (Figure 2.8-7). Figure 2.8-18 shows a time series plot of chromium concentration in the well. The maximum chromium concentration found in fiscal year 2003 was 592 pCi/L. Chromium concentrations in wells adjacent to well 299-W14-13 were all less than the drinking water standard during the fiscal year indicating that the chromium contamination is limited to the area of well 299-W14-13. However, chromium concentration increased from 27 to $90 \mu \mathrm{g} / \mathrm{L}$ before falling during fiscal year 2003 to $69 \mu \mathrm{g} / \mathrm{L}$ in well 299-W14-15, located south of well 299-W14-13, suggesting that the chromium contamination may be moving southward. Further analytical results are needed to confirm this during fiscal year 2004.

The most likely source for the chromium in well 299-W14-13 is Waste Management Area TX-TY. However, the series of cribs 216-T-26 through 216-T-28, located north of well 299-W14-13, are also a potential source for, or at least may have contributed to, the contamination.

\subsubsection{Low-Level Waste Management Area 3}

Groundwater monitoring under interim status requirements continued at this RCRA site during fiscal year 2003. The well network was sampled semiannually for indicator and site-specific parameters (see Appendix B). All 11 wells attempted for sampling in fiscal year 2003 were successfully sampled.

An application was submitted to the Washington State Department of Ecology (Ecology) in June 2002 to incorporate the low-level burial grounds into the Hanford Facility RCRA Permit (Ecology 1994). This would have the effect of changing the groundwater monitoring requirements for the burial grounds from interim status monitoring to final status monitoring. As part of the application, new groundwater monitoring wells, constituents, and statistical evaluations are proposed. Workshops with Ecology to address this application are in progress.

The groundwater flow in this portion of the 200 West Area is to the east-northeast (70 degrees) with a calculated gradient of 0.0014 . The flow direction is returning to preHanford conditions, and it will change until the direction is predominantly west to east. The estimated flow rate at Low-Level Waste Management Area 3, using this gradient is 0.001 to 0.14 meter per day (see Appendix B).

Under current flow directions, wells 299-W10-19 and 299-W10-20 remain upgradient of the east portion of the waste management area but are downgradient of the southwest part of the waste management area. Nitrate and carbon tetrachloride routinely exceed drinking water standards in these wells due to plumes originating from sources to the south and are not believed to be a result of waste disposal at this site. Because the contamination is due to upgradient sources, these wells continue to be treated as upgradient wells for statistical purposes.

Indicator parameter (specific conductance, $\mathrm{pH}$, total organic carbon, and total organic halides) data from designated upgradient wells were statistically evaluated and values from
Waste Management

Area TX-TY may

have contributed to

chromium

contamination in

groundwater. 
downgradient wells were compared to values established from the upgradient wells. Statistical comparison values were not exceeded in any wells monitoring the waste management area during fiscal year 2003.

In late fiscal year 2002, an elevated chromium result for a filtered sample from well 299-W7-7 was reported on the north side of Low-Level Waste Management Area 3. This result was considered suspect and investigated in fiscal year 2003. Time series samples were collected for filtered metals, unfiltered metals, and hexavalent chromium during purging. Only the first sample, prior to purging, showed significantly elevated hexavalent chromium. Chromium was elevated in all unfiltered samples. Turbidity was $\sim 4$ to 5 NTU during sampling, showing that the elevated unfiltered chromium is not a function of high turbidity. Thus, the earlier anomalous result was likely caused by a sampling issue such as a filter failure. This well is nearly dry and produces very little water, which may also influence the chromium results, particularly the unfiltered values.

Nickel concentrations continue to increase in well 299-W7-1, on the north side of Low-Level Waste Management Area 3 (Figure 2.8-19). This increase was first seen early in fiscal year 2000. Manganese and iron are also elevated in this well, although iron concentrations declined below the secondary drinking water standard in fiscal year 2003. Corrosion of well materials is suspected to be the cause of the increase in these metals. Like other wells on the north side of Low-Level Waste Management Area 3, this well is nearly dry.

\subsubsection{Low-Level Waste Management Area 4}

Groundwater monitoring under interim status requirements continued at this RCRA site in fiscal year 2003. The well network was sampled semiannually for indicator and sitespecific parameters (see Appendix B). Of the seven wells where sampling was attempted during fiscal year 2003, sampling was successful in six of the wells. Only a partial sample was obtained in the first round of sampling from well 299-W18-24, and it was flagged as dry and removed from the sample schedule prior to the second sampling event. This leaves only one downgradient well completed at the top of the uppermost aquifer and one downgradient well at the bottom of the unconfined aquifer. The other four wells in the network are upgradient wells.

An application was submitted to Ecology in June 2002 to incorporate the low-level burial grounds into the Hanford Facility RCRA Permit (Ecology 1994). This would have the effect of changing the groundwater monitoring requirements for the burial grounds from interim status monitoring to final status monitoring. As part of the application, new groundwater monitoring wells, constituents, and statistical evaluations are proposed. Workshops with Ecology to address this application are in progress.

The groundwater flow in this portion of the 200 West Area is generally to the east (90 degrees) with a calculated gradient of 0.003 . The flow direction is affected to a large degree by the 200-ZP-1 pump-and-treat system, which has extraction wells to the east and injection wells to the west of this RCRA site. The estimated flow rate at Low-Level Waste Management Area 4, using this gradient is 0.02 to 0.7 meter per day (see Appendix B).

Downgradient well 299-W15-16 continued to exceed the statistical comparison value for total organic halides. This well was originally an upgradient well under past flow conditions and is still affected by contamination from sources in or near the $216-Z$ cribs and trenches. The U.S. Department of Energy reported the exceedance to the U.S. Environmental Protection Agency and Ecology in August 1999. The elevated total organic halide concentrations are attributed to carbon tetrachloride from Plutonium Finishing Plant operations (see Section 2.8.1.1). However, potential sources of carbon tetrachloride and other volatile organic compounds were detected in the trenches and vadose zone within the 218-W4-C burial ground during fiscal year 2002. Investigation of the vadose zone continued in fiscal year 2003 as part of the 200-PW-1 Operable Unit (see Section 3.1). Statistical comparison values for fiscal year 2004 are listed in Appendix B. 
Nitrate continues to exceed the drinking water standard at many monitoring wells in Low-Level Waste Management Area 4. This contamination is not believed to be related to waste disposal at the burial grounds. Some of the nitrate contamination is related to injection of 200-ZP-1 treated water upgradient of the burial ground. The treatment system does not remove nitrate from the water.

In the southwest corner of Low-Level Waste Management Area 4, upgradient monitoring well 299-W18-21 has slowly increasing nitrate concentrations that have not been associated with the large contaminant plumes of the 200 West Area. The fiscal year 2003 average nitrate concentration in this well was $100 \mathrm{mg} / \mathrm{L}$. Only a few trenches have received waste in this part of the burial ground, so it is unlikely that the contamination is related to the burial ground itself.

\subsubsection{AEA Monitoring}

AEA groundwater monitoring is performed throughout the 200-ZP-1 groundwater interest area. This section provides information on monitoring of radionuclides from Waste Management Areas T and TX-TY because radionuclide releases from these sites are not regulated under RCRA. Performance assessment groundwater monitoring at LowLevel Burial Grounds 3 and 4 is also discussed.

\subsubsection{Waste Management Areas T and TX-TY}

Technetium-99 contamination at the northeast corner of Waste Management Area T in fiscal year 2003 is described in Section 2.8.1.10. Most of the technetium-99 at this location is believed to be from the waste management area. The abrupt appearance of technetium-99 in groundwater at the northeast corner of the waste management area has been attributed to elimination of water leaking from a pipeline at the northeast corner of the waste management area in 1995 (PNNL-11809). Prior to 1995, existing contaminants would have been diluted by the leaked water.

Data from wells drilled around the waste management areas in recent years show increasing trends in technetium-99. Well 299-W11-39, located south of well 299-W10-24, was drilled in 2001. Technetium-99 concentration has subsequently increased in the well to $10,500 \mathrm{pCi} / \mathrm{L}$ in mid-2003. Three wells were drilled south of well 299-W11-39 in late 2000 and early 2001. These wells had relatively low technetium-99 concentrations immediately after drilling ( 300 to $400 \mathrm{pCi} / \mathrm{L})$. Since that time, technetium-99 concentrations in the area have increased substantially. During fiscal year 2003, the highest technetium-99 concentration in those wells was 2,600 pCi/L in well 299-W11-41.

Apparently, technetium-99 is migrating toward the south along the east edge of the $\mathrm{T}$ Tank Farm from the northeast corner of the waste management area. This migration is coincident with a shift in groundwater flow direction from toward the northeast before 1996 to 1997 to toward the east or slightly southeast after 1997.

Vertical Sampling. Past analyses of depth-discrete sampling during drilling and comparison of samples from adjacent wells that sample different parts of the aquifer have shown that some contaminants are stratified in the upper most aquifer (PNNL-13441; PNNL-13929; PNNL-14099). Three efforts were undertaken at Waste Management Areas T and TX-TY during fiscal year 2003 to better define vertical concentration gradients for contaminants of concern in the upper most aquifer. These efforts included (1) specific conductance profiles, (2) depth-discrete sampling during drilling of two new wells, and (3) multi-level, depth-discrete sampling in the screened interval of a highly contaminated well.

Specific Conductance Profiles. Specific conductance measurements were taken at 0.5- to 1-meter intervals through the screened intervals of seven groundwater monitoring wells around the T, TX, and TY Tank Farms. Specific conductance provides an indicator

\section{Groundwater \\ beneath Waste \\ Management Areas \\ $T$ and TX-TY is \\ contaminated with \\ technetium-99.}




\section{In fiscal year 2003, DOE used various techniques to study how contamination varies with depth in the aquifer.}

for contaminants such as nitrate and technetium-99 at the tank farm areas. Significant differences in specific conductance with depth were found in four of these wells.

The most pronounced difference was found at well 299-W10-28 (Figure 2.8-20), located upgradient of Waste Management Area T. The specific conductance data from the well show a marked increase through the upper 4 meters of the screened interval below which specific conductance remains unchanged. In general, specific conductance reflects high nitrate (and sodium and calcium) concentrations in the Waste Management Areas T and TX-TY vicinity. At well 299-W10-28, the data suggest the nitrate concentration increases downward in the aquifer from the water table to $\sim 4$ meters depth. This is consistent with previous investigations that suggest that nitrate is generally relatively deep in the aquifer and probably represents a regional nitrate plume in the area.

Also shown on Figure 2.8-20 are the values of specific conductance measured after purging the well for the four routine pumped quarterly groundwater samples taken prior to the specific conductance profile. The values are shown at the depth of the pump intake. The pumped values appear to be an average of the low conductance water at the water table and the relatively high conductance water deeper in the screened interval.

Specific conductance profiles measured in wells 299-W11-39 and 299-W11-42 at Waste Management Area T shows similar trends to that of well 299-W10-28, but the magnitude of the changes are much less than that seen at well 299-W10-28.

Figure 2.8-21 shows a specific conductance profile measured in the screened interval of well 299-W14-13, a downgradient well at Waste Management Area TX-TY. Well 299-W14-13 is in a highly contaminated area, and the specific conductance profile looks much different that those from wells at Waste Management Area T (Figure 2.8-20).

Specific conductance in well 299-W14-13 decreases with depth between $\sim 1$ and 4 meters below the water table. However, there appears to be a maximum between 0.5 and 1.5 meters. The relatively shallow specific conductance plume suggests a nearby source for the contamination in the well because the contamination has not traveled far enough to vertically disperse throughout the aquifer. The specific conductance values near the bottom of the screened interval are still fairly high and probably reflect downward movement of high specific conductance water within the well bore. A downward flow rate of $\sim 0.011$ meter per minute was measured from vertical tracer tests and later confirmed by electromagnetic flow meter survey (PNNL-13378).

Also shown on Figure 2.8-21 are four specific conductance values measured during routine pumped quarterly sampling prior to the profile measurement. All of the pumped specific conductance values are less than the profile values measured under ambient flow conditions. The specific conductance of the pumped samples are lower that the specific conductance of the profile because the profile is affected by the downward flow of high specific conductance water found near the water table. After purging the well, the sampled water is a mixture of the high specific conductance water near the water table and lower specific conductance water from deeper in the aquifer.

Sampling During Drilling. Sampling of groundwater brought to the surface during drilling can give an indication of vertical chemical variations within the aquifer. Two new wells were sampled in this way during 2003. Air lifted samples of groundwater and cuttings were collected from wells 299-W14-19 and 299-W15-44 during drilling at TX Tank Farm in 2003. The samples were collected at 6-meter intervals below the water table. No high levels of contamination were encountered but several metals and anions showed concentration variations with depth in the aquifer. Of the analytes tested, nitrate is of the most interest. Additional samples were collected for analysis of nitrate in the field. The nitrate data from well 299-W15-44 are shown in Figure 2.8-22. Results from well 299-W14-19 are similar. 
Figure 2.8-22 shows that nitrate in well 299-W15-44 is relatively high at the water table and decreases with depth to $\sim 20$ meters below the water table. This is followed by an increase in concentration at $\sim 60$ meters below the water table, below which nitrate concentrations remain fairly constant to the bottom of the borehole. In all wells that have been sampled during drilling at Waste Management Areas T and TX-TY, nitrate has been found to vary in concentration with depth in the aquifer (PNNL-12125; PNNL-12124; PNNL-13830; PNNL-13200; PNNL-14249). In most wells with sufficient samples to define a trend, nitrate concentrations increased with depth. The relatively high nitrate concentrations found near the water table in well 299-W15-44 are interpreted to be from nearby sources; the deeper nitrate probably represents a more regional and dispersed plume.

Multi-Level Dialysis Sampling. Well 299-W14-13 is located on the east (downgradient) side of Waste Management Area TX-TY in an area of high chromium, nitrate, technetium-99, iodine-129, and tritium groundwater contamination. A previous investigation indicated that vertical concentration gradients exist in the uppermost aquifer at this location (PNNL-14099). This is supported by the specific conductance profile of the well 299-W14-13 (Figure 2.8-21). Multi-level, depth-discrete sampling was done in the well during fiscal year 2003 to better define the vertical gradients and to help determine the source or sources of contamination in the well.

A multi-level, dialysis sampling device was deployed in well 299-W14-13. The sampling device was left in the well for $\sim 1$ month to allow equilibration of the water in the dialysis tubes with the groundwater. Samples were obtained every 1.5 meters from $\sim 1$ meter below the top of the aquifer to the bottom of the well screen, which is $\sim 9$ meters below the water table. Samples were analyzed for major cations, anions, tritium, and technetium-99.

In addition, one sample was collected from $\sim 4$ centimeters below the water table using a mini-bailer. The bailed sample was analyzed for chromium and nitrate in the field and chromium and technetium-99 in the laboratory.

The analytical results from both the multi-level dialysis and the bailed samples are shown on Figure 2.8-23. The results show that, except for a zone at about 2.5 meters below the water table, the concentrations of most cations and anions are fairly constant throughout the screened interval of the aquifer. Neither the geologist's log nor the geophysical logs show any evidence of changes in the formation at 2.5 meters below the water table, so the reason for the increased concentrations at that depth is unknown.

Nitrate and technetium-99 show increases in concentration with decreasing depth from $\sim 4$ to 5 meters below the water table upward to the shallowest dialysis sample. For nitrate, there is an extremely large increase in concentration between the shallowest dialysis sample and the bailed sample near the water table (Figure 2.8-23). For technetium-99, there is a concentration decrease between the same two samples. It is not known whether the technetium-99 concentration decreases from 1 meter depth with decreasing depth or if the concentration continues to increase with decreasing depth to some unknown depth before dropping to the value in the bailed sample.

The squares on Figure 2.8-23 represent the concentrations of the various constituents in routine pumped quarterly samples collected during the quarters prior to and after the dialysis samples were collected. The data show that for most cations and anions, the concentrations in the pumped samples are similar to the dialysis concentrations throughout the screened interval. Exceptions are calcium, chromium, nitrate, and technetium-99. The pumped concentrations of calcium, chromium, and technetium-99 are substantially less than the concentrations under ambient flow conditions. For nitrate, the opposite is true.

Well 299-W14-13 has a downward flow gradient within the well bore (PNNL-13378). This implies a possible zone of lower permeability near the top of the screened interval and relatively higher permeability near the bottom of the screened interval. Alternatively, the downward flow may, in part, be driven by differences in density. If the major cation and

\author{
Nitrate and \\ technetium-99 \\ concentrations \\ were highest in the \\ shallowest samples.
}

\section{Pumped concentrations of calcium, chromium, and technetium-99 are substantially less than the ambient concentrations.} For nitrate, the opposite is true. 
There is no evidence

that Low-Level

Waste Management

Areas 3 or 4 have

contaminated

groundwater with

radionuclides or

hazardous

constituents. anion concentrations at 1 meter depth are increased proportionally to the nitrate concentration at 4 centimeters depth, the resulting salinity of the water at 4 centimeters is 2.3 per thousand. This is in contrast to the estimated salinity from the deepest dialysis sample, which is 0.63 per thousand. The difference in salinity between the top and bottom of the screened interval may be sufficient to cause a downward, density driven flow within the well bore. Whatever the mechanism of downward flow, it appears that contaminants in a zone of relatively high concentration near the water table are transported downward in the well to become diluted with less contaminated water at depth. This is important because the well itself is helping spread contamination.

When well 299-W14-13 is purged, all the water standing in the wellbore is removed. Subsequently, the pumped samples consist of relatively high concentrations of contaminants from a zone near the water table diluted with a greater volume of less contaminated water from a less concentrated zone at depth. This yields the weighted average concentrations in the pumped samples shown on Figure 2.8-23.

\subsubsection{Low-Level Waste Management Area 3}

Performance assessment monitoring of radionuclides at Low-Level Waste Management Area 3 is designed to complement the RCRA detection monitoring and is aimed specifically at monitoring radionuclide materials that are not regulated under RCRA. The current goal of performance assessment monitoring at Low-Level Waste Management Area 3 is to gather data to assess changes in concentrations at downgradient wells using statistical tests and to provide sufficient supporting information from upgradient wells to interpret the changes. Under the current monitoring plan (DOE/RL-2000-72), technetium-99, iodine-129, and uranium are monitored specifically for performance assessment.

Section 2.8.3.1 discusses flow conditions and chemical constituents monitored under RCRA requirements at Low-Level Waste Management Area 3. There is no evidence that Low-Level Waste Management Area 3 has contaminated groundwater with radionuclides or hazardous constituents.

Contaminant characteristics for radionuclides in groundwater at Low-Level Waste Management Area 3 include the following:

- Technetium-99 concentrations are all $<100 \mathrm{pCi} / \mathrm{L}$ and generally show steady or declining trends. The highest concentration in fiscal year 2003 was 66 pCi/L in well 299-W10-21, located on the south edge of the 218-W-3A burial ground. Although this well is currently downgradient of the 218-W-3A burial ground, it has likely been impacted by activities to the south that imposed northerly flow for a time. This contamination is not attributed to a burial ground source.

- Uranium concentrations at Low-Level Waste Management Area 3 are $<3 \mu \mathrm{g} / \mathrm{L}$. There is no evidence of a burial ground source.

- Iodine-129 was not detected in any wells at Low-Level Waste Management Area 3. The minimum detectable activity is $\sim 0.3 \mathrm{pCi} / \mathrm{L}$.

- Tritium concentrations were all less than the drinking water standard and were nondetect in most wells.

\subsubsection{Low-Level Waste Management Area 4}

Performance assessment monitoring of radionuclides at Low-Level Waste Management Area 4 is designed to complement the RCRA detection monitoring and is aimed specifically at monitoring radionuclide materials that are not regulated under RCRA. The current goal of performance assessment monitoring at Low-Level Waste Management Area 4 is to gather data to assess changes in concentrations at downgradient wells using statistical tests and to provide sufficient supporting information from upgradient wells to interpret the changes. Under the current monitoring plan (DOE/RL-2000-72), technetium-99, iodine-129, and uranium are monitored specifically for performance assessment. 
Section 2.8.3.2 discusses flow conditions and chemical constituents monitored under RCRA requirements at Low-Level Waste Management Area 4. Although carbon tetrachloride has been detected in the vadose zone, no link with groundwater contamination has yet been established. There is no evidence that Low-Level Waste Management Area 4 has contaminated groundwater with radionuclides.

Contaminant characteristics for radionuclides at Low-Level Waste Management Area 4 include the following:

- Technetium-99 concentrations remained slightly elevated in two wells on the west (upgradient) of Low-Level Waste Management Area 4 (wells 299-W15-15 and 299-W18-23). Technetium-99 concentrations were all $<150 \mathrm{pCi} / \mathrm{L}$. As discussed in Section 2.8.1.10, this occurrence may result at least in part from technetium-99 in water injected by the 200-ZP-1 pump-and-treat system. However, the concentrations are over one-third the highest technetium-99 concentration in any extraction well. This, and the distance of the wells in question from the injection wells, suggests that part of the technetium-99 may be from an upgradient source. Technetium-99 may have moved to the west under past flow conditions and be re-entering the area under present flow conditions.

- Uranium concentrations are elevated in upgradient well 299-W18-21 in the southwest corner of the waste management area. Concentrations were just over the $30 \mu \mathrm{g} / \mathrm{L}$ drinking water standard.

- Iodine-129 was not detected in Low-Level Waste Management Area 4 wells. The minimum detectable activity is $\sim 0.3 \mathrm{pCi} / \mathrm{L}$.

- Tritium levels were all less than the drinking water standard.

\subsubsection{Groundwater Monitoring for the State-Approved Land Disposal Site}

The Hanford Site 200 Area Effluent Treatment Facility processes contaminated aqueous wastes derived from Hanford Site facilities. The treated wastewater occasionally contains tritium, which is not removed by the Effluent Treatment Facility, and is discharged to the 200 Area State-Approved Land Disposal Site. Through August 31 of fiscal year 2003, 96 million liters of water were discharged to the State-Approved Land Disposal Site.

Groundwater monitoring for tritium and other constituents and water-level measurements are required by the state-issued permit at the State-Approved Land Disposal Site. The current network consists of 3 proximal monitoring wells and 16 tritium-tracking wells (Figure 2.8-24). Proximal wells were sampled in October 2002, and January, February, April, and September of 2003 (see Appendix C). Tritium-tracking wells were sampled in January and September 2003. Water-level measurements in three wells nearest the StateApproved Land Disposal Site indicate the continuation of a small hydraulic mound beneath the site as a result of discharges. This feature is directing groundwater flow radially outward a short distance before the regional northeasterly flow predominates. This condition also places several wells south of the State-Approved Land Disposal Site hydraulically downgradient of the facility.

Some of the wells south of the State-Approved Land Disposal Site in the tritiumtracking network have gone dry or are projected to soon be dry. Well 299-W7-6 went dry, preventing collection of the September 2003 sample from this well. Likewise, difficulties in obtaining a sample from well 299-W7-9 suggest that this well may have produced its final sample in January 2003. So far, the tritium-tracking network remains adequate to track effluent from the State-Approved Land Disposal Site, but the loss of these wells could affect numerical modeling calibration.
The State-Approved Land Disposal Site is used for disposal of treated water that occasionally contains tritium. 
Average tritium concentrations

decreased in all

three proximal

wells at the

State-Approved

Land Disposal

Site during fiscal

year 2003.
Average tritium concentrations decreased in all three State-Approved Land Disposal Site proximal wells during fiscal year 2003 compared with fiscal year 2002 (Figure 2.8-24). Sporadic detections in well 299-W7-5 suggest that tritium from the State-Approved Land Disposal Site may be reaching the north edge of the 200 West Area (due south of the facility), or that this well is peripherally influenced by the tritium plume from the 200 West Area. During fiscal year 2003, maximum tritium concentrations for StateApproved Land Disposal Site proximal wells were 189,000 pCi/L in well 699-48-77A, (February 2003), 430,000 pCi/L in well 699-48-77C (October 2002), and 220,000 pCi/L in well 699-48-77D (October 2002).

Concentrations of all chemical constituents with permit limits were well within those limits during all of fiscal year 2003. Acetone, benzene, tetrahydrofuran, cadmium, chloroform, lead, and mercury were below method detection limits in all samples. Concentrations of major cations and anions are mostly below background concentrations due to dilution by the clean water discharged to the State-Approved Land Disposal Site.

Comparison of head distribution in March 2003 (Figure 2.8-2) and reported fiscal year 2003 tritium concentrations, with numerical predictions of these quantities for 2000 and 2005, suggests that modeling performed in 1997 slightly overestimated the areal spread of tritium around the State-Approved Land Disposal Site to date. Contouring of March 2003 groundwater flow potential near the site (but away from the mound) appears to show a more easterly component compared with both 2000 and 2005 model times and the fiscal year 2002 potential map. 


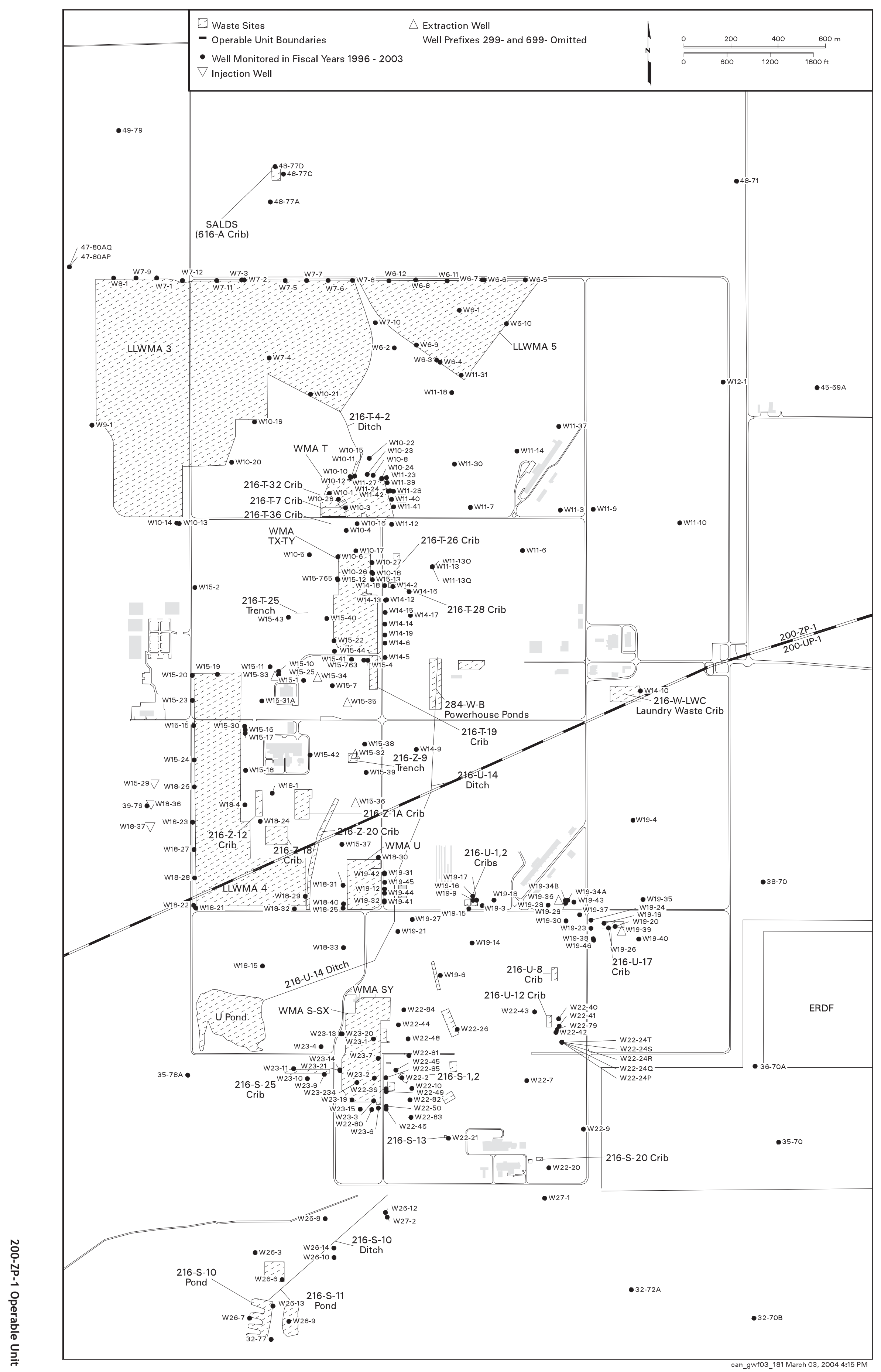

Figure 2.8-1. Groundwater Monitoring Wells in the 200 West Area 


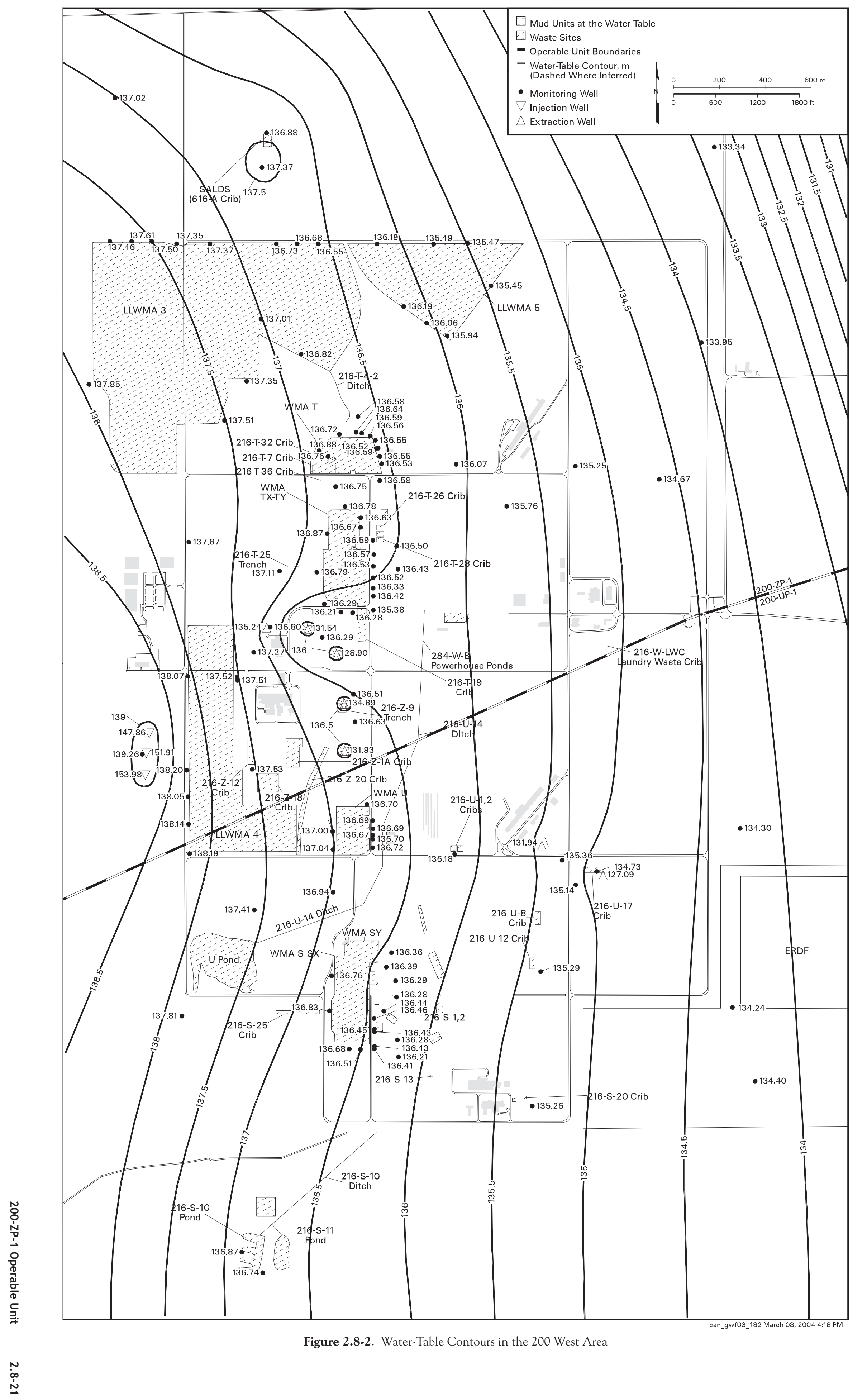




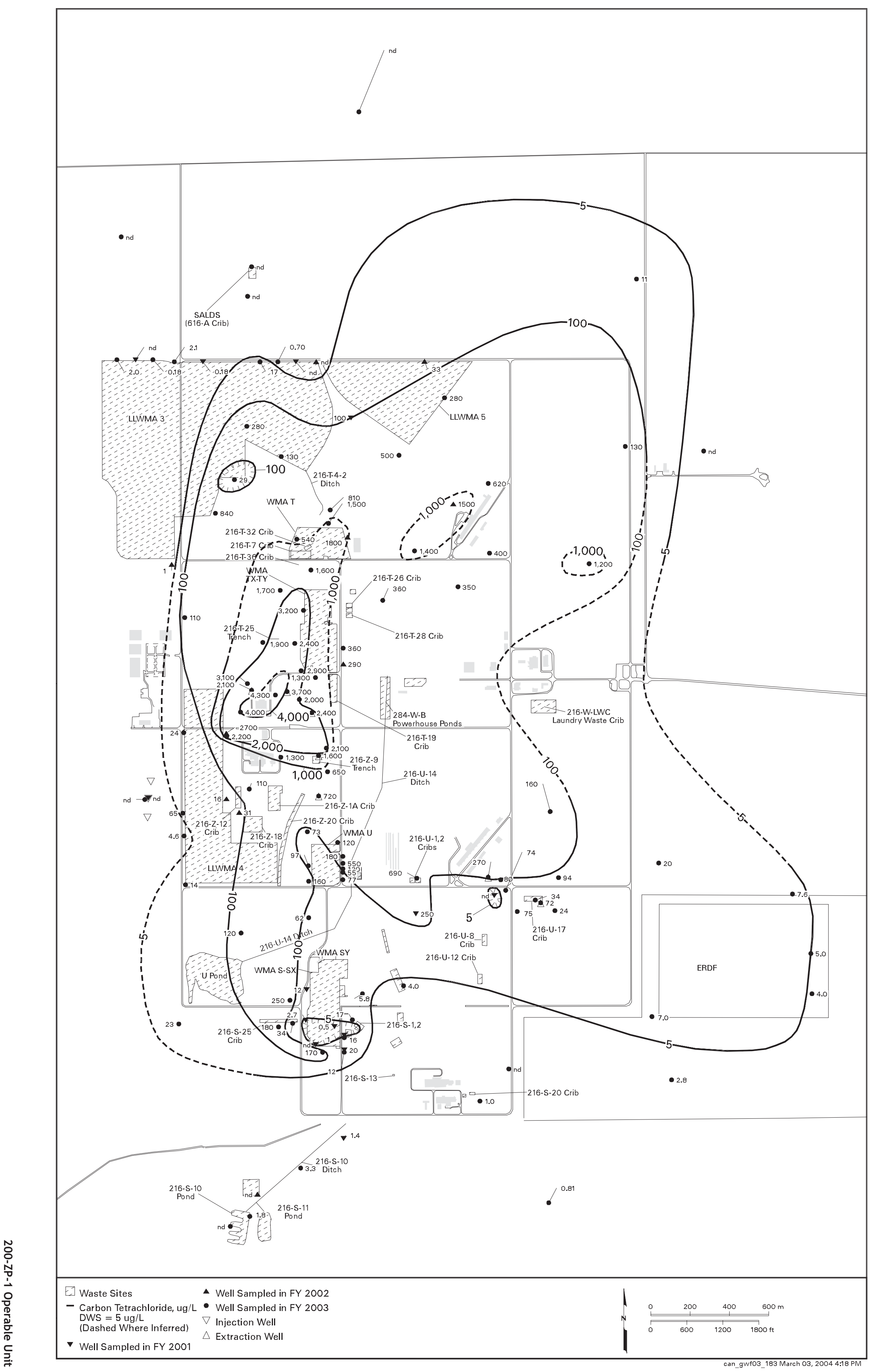

Figure 2.8-3. Average Carbon Tetrachloride Concentrations in 200 West Area, Top of Unconfined Aquifer 


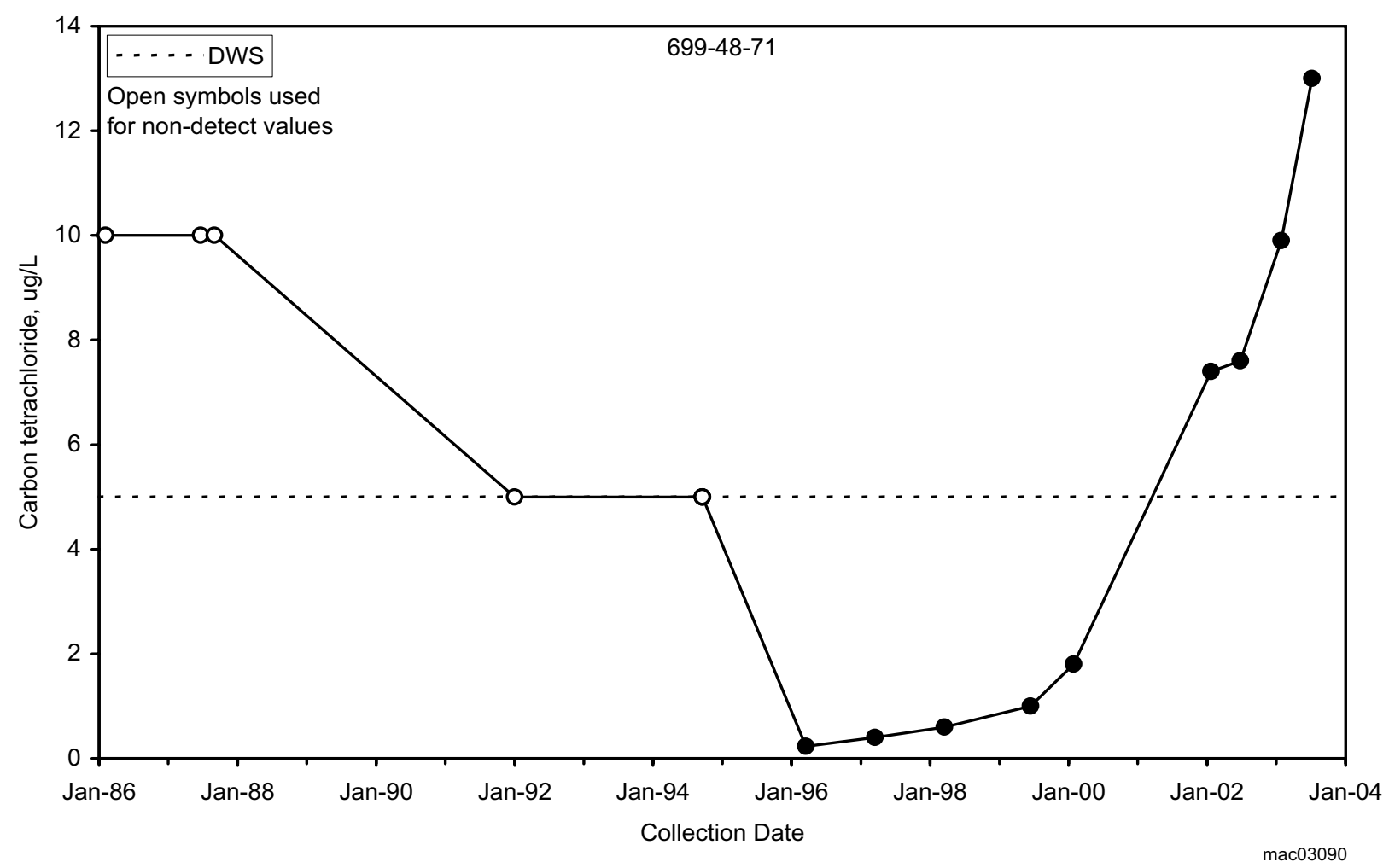

Figure 2.8-4. Carbon Tetrachloride Concentration Northeast of the 200 West Area in Well 699-48-71 


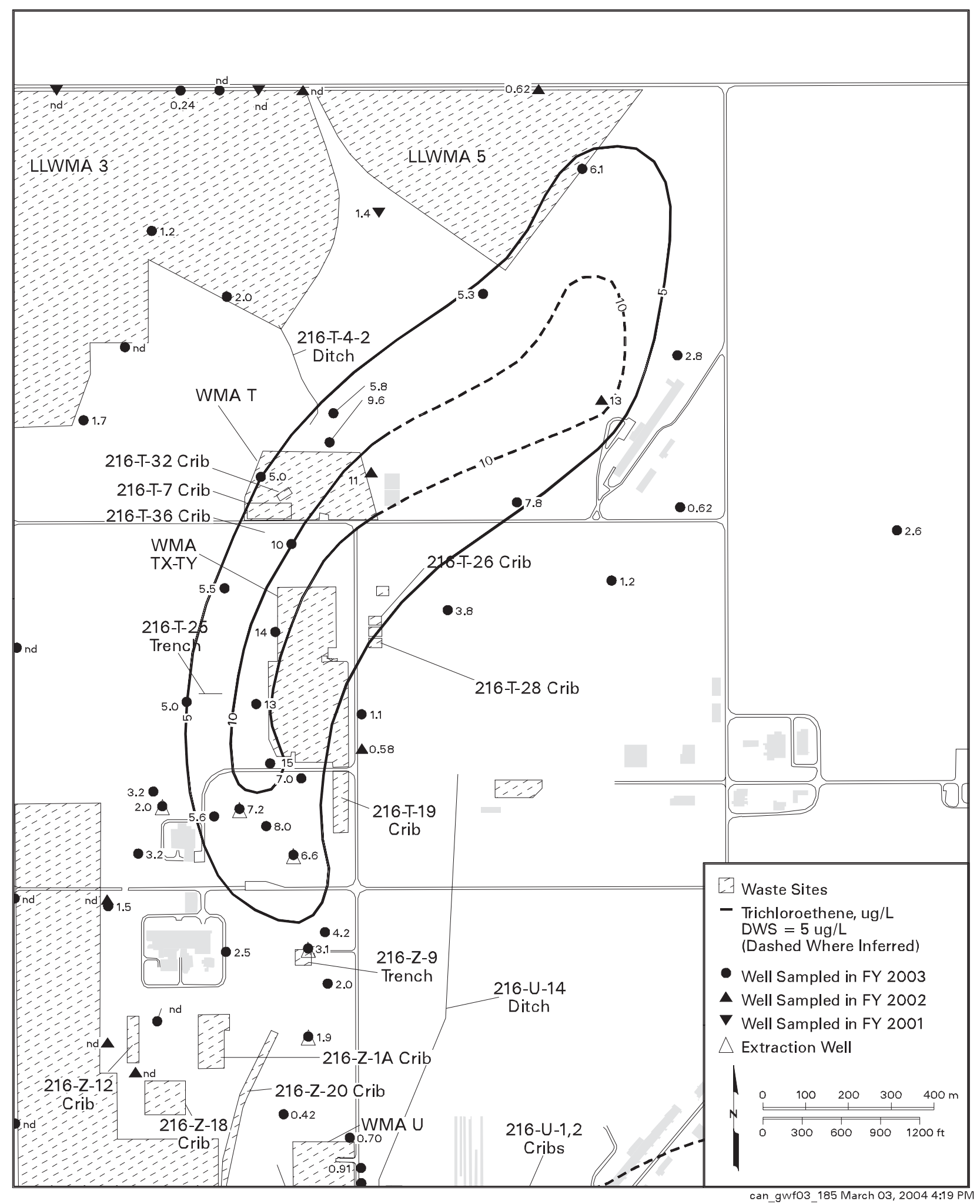

Figure 2.8-5. Average Trichloroethene Concentrations in Central and North 200 West Area, Top of Unconfined Aquifer 


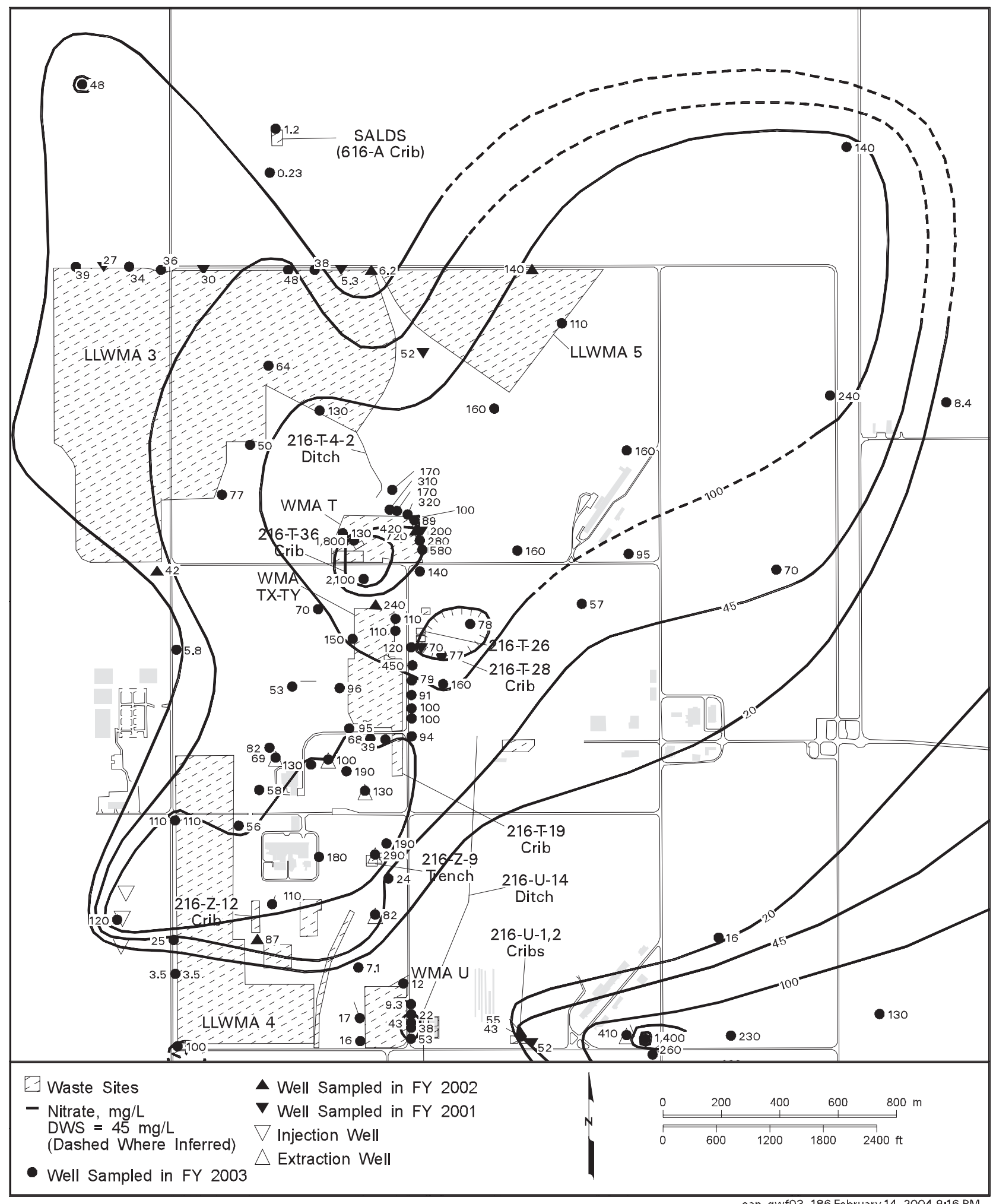

Figure 2.8-6. Average Nitrate Concentrations in the Central and North 200 West Area, Top of Unconfined Aquifer 


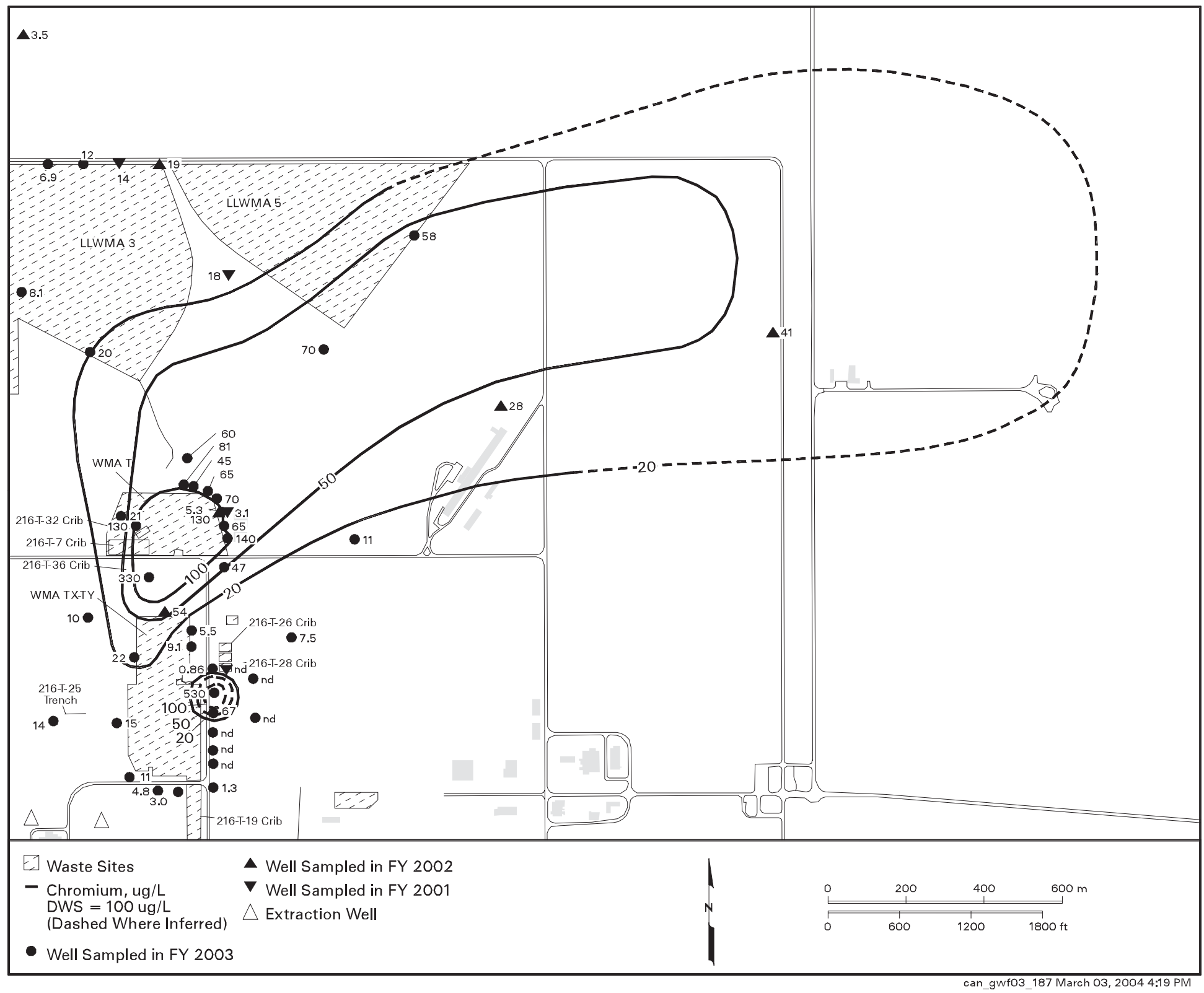

Figure 2.8-7. Average Dissolved Chromium Concentrations Near Waste Management Areas T and TX-TY, Top of Unconfined Aquifer 


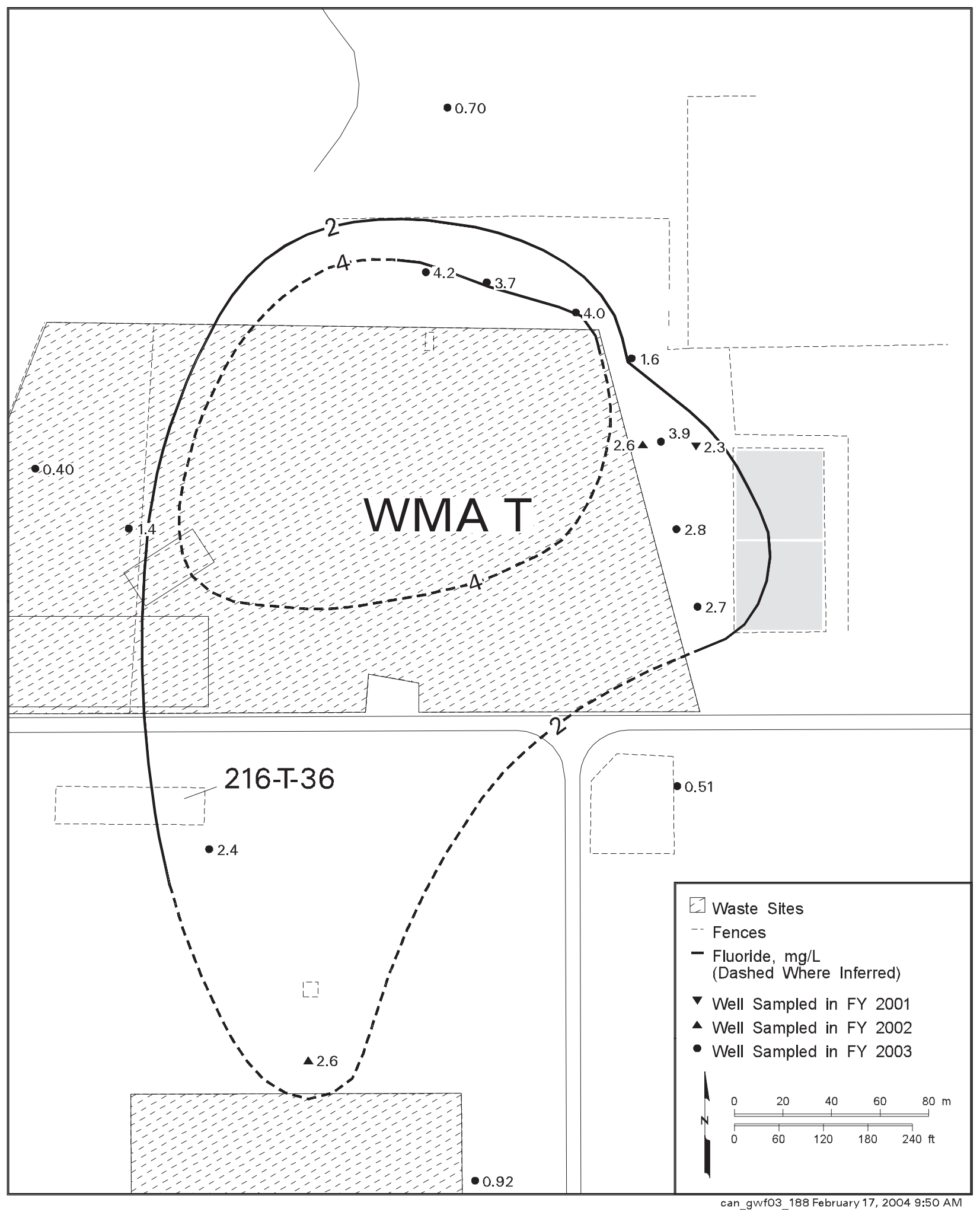

Figure 2.8-8. Average Fluoride Concentrations in North 200 West Area, Top of the Unconfined Aquifer 


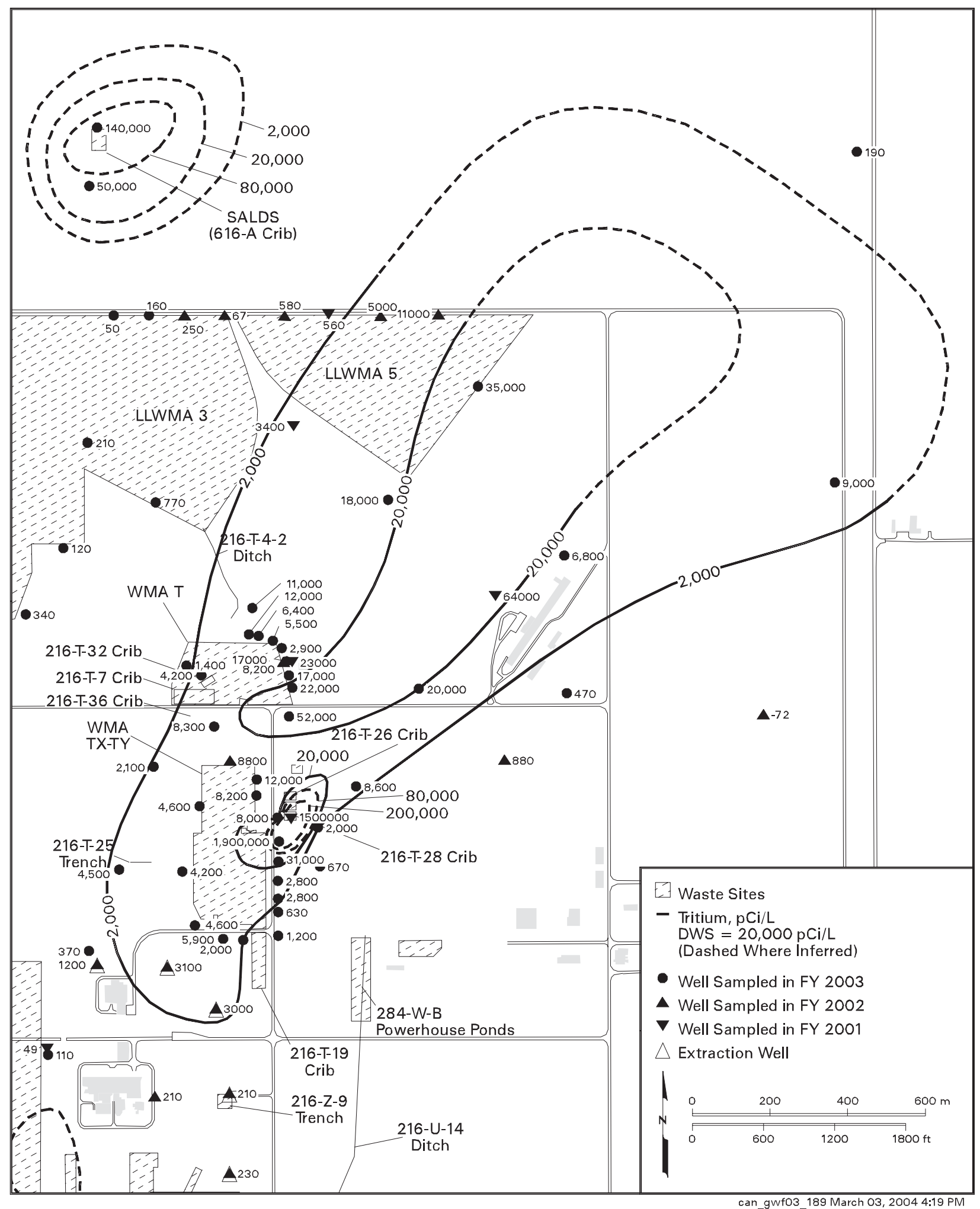

Figure 2.8-9. Average Tritium Concentrations in the North 200 West Area, Top of Unconfined Aquifer 


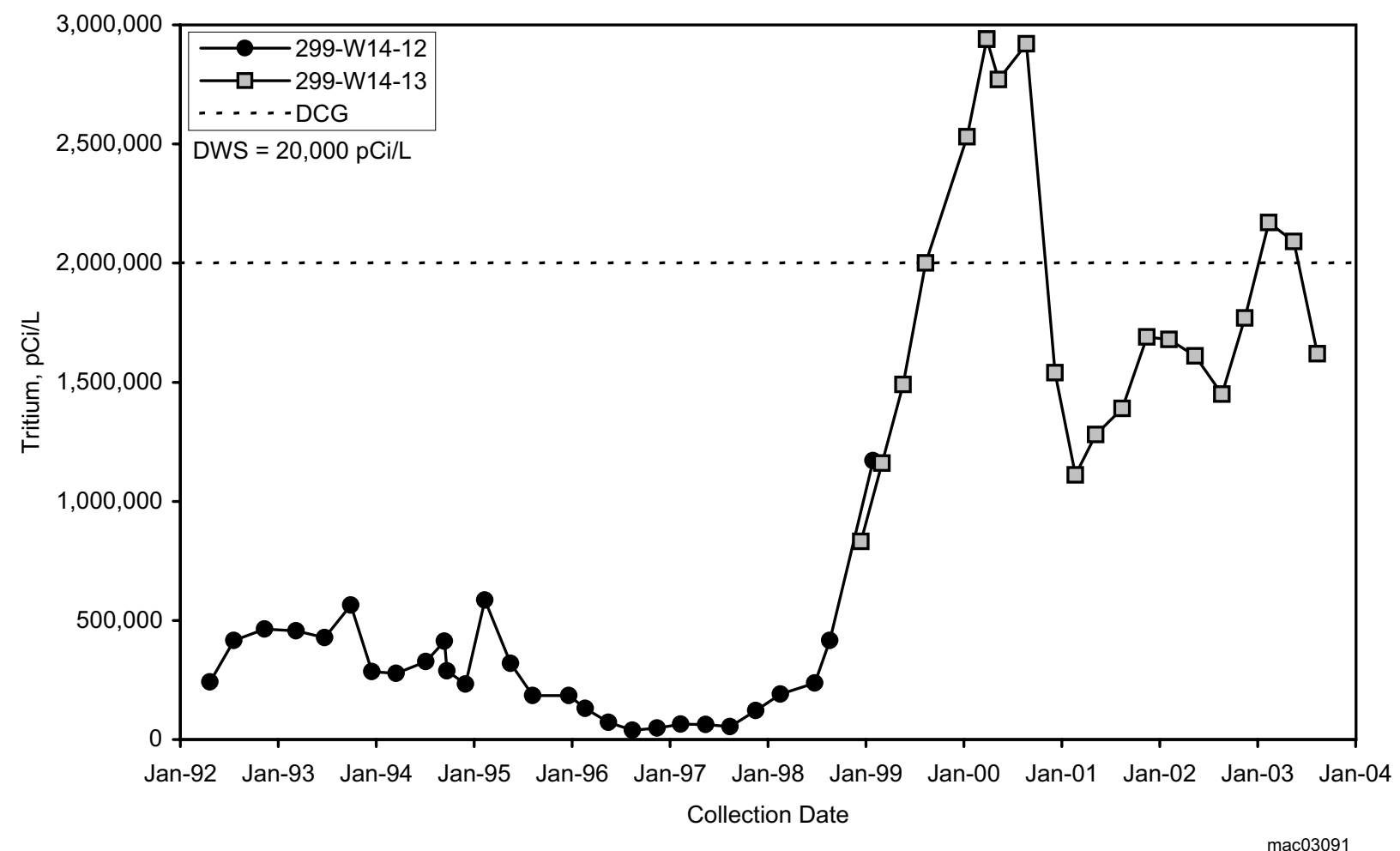

Figure 2.8-10. Tritium Concentrations versus Time in Wells 299-W14-12 and 299-W14-13 at Waste Management Area TX-TY 


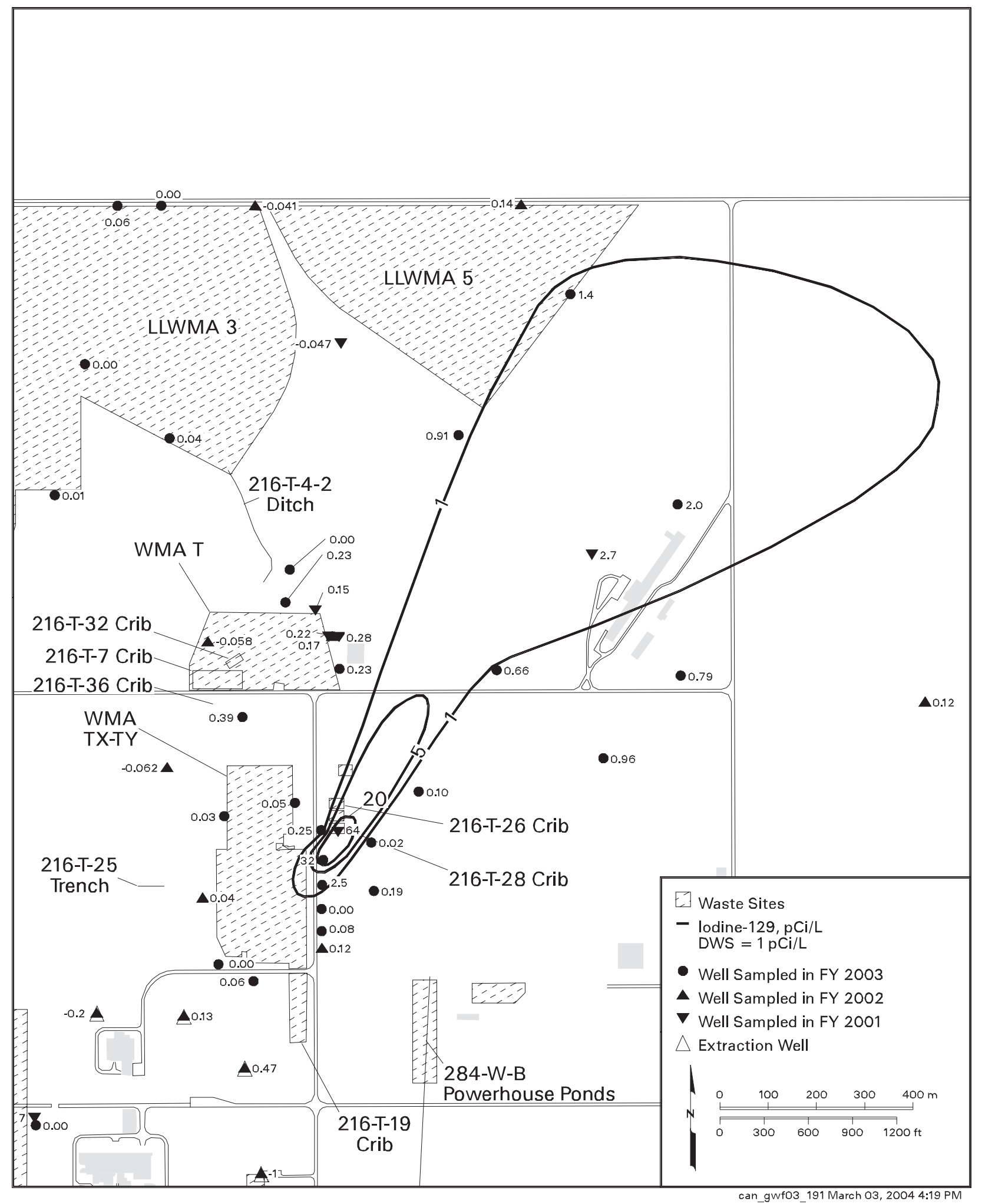

Figure 2.8-11. Average Iodine-129 Concentrations in the North 200 West Area, Top of Unconfined Aquifer 


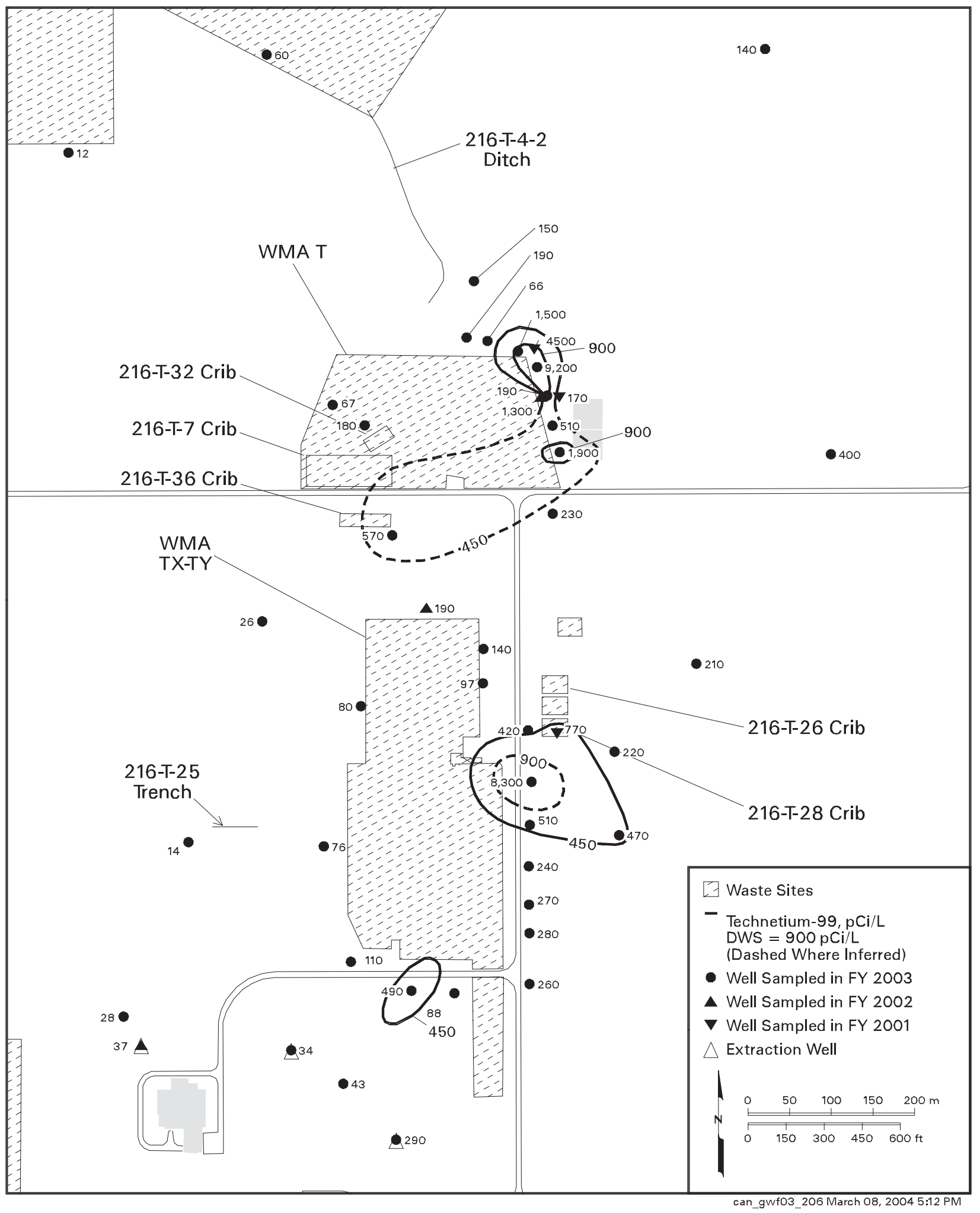

Figure 2.8-12. Average Technetium-99 Concentrations in the North 200 West Area, Top of Unconfined Aquifer 


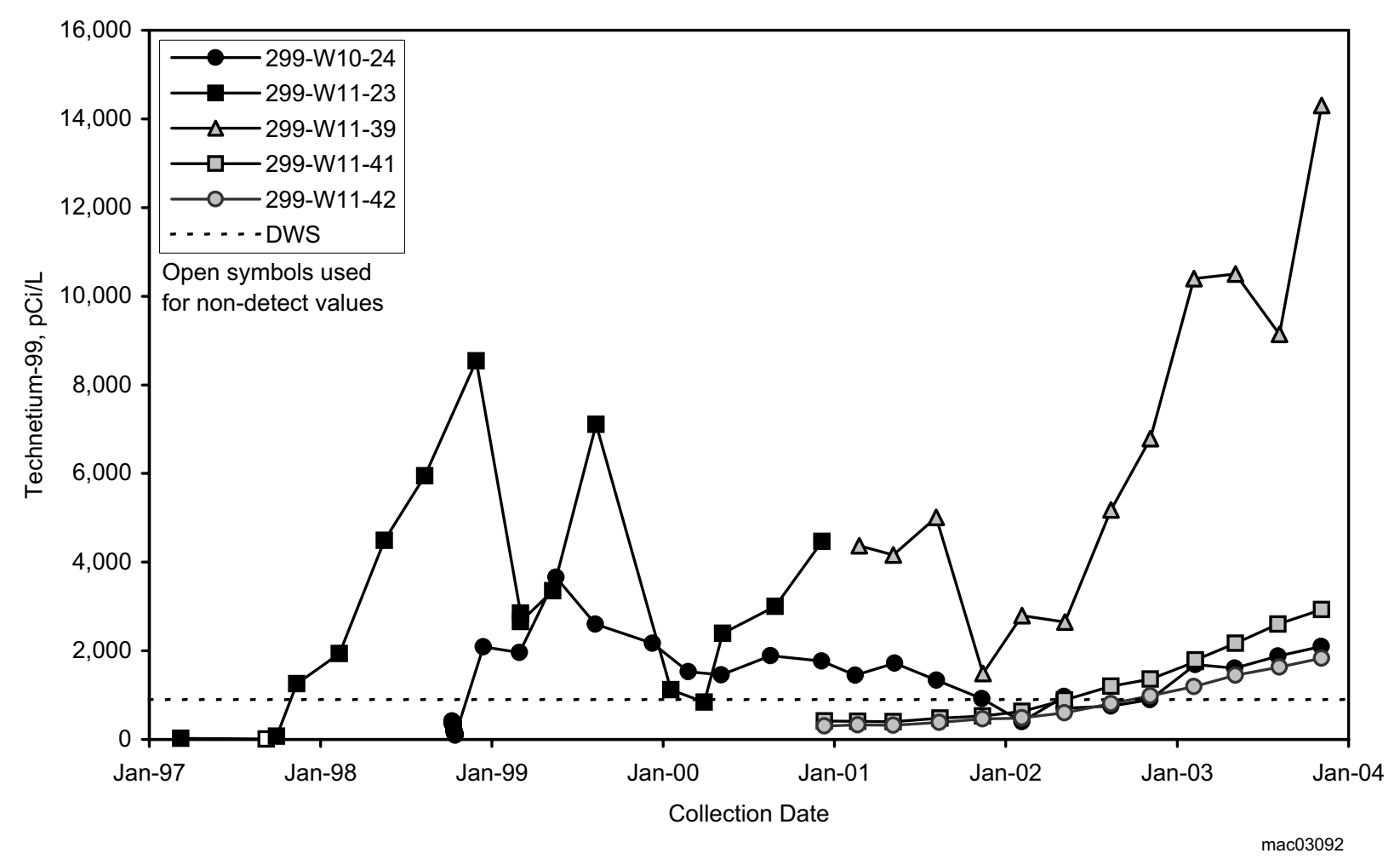

Figure 2.8-13. Technetium-99 Concentrations in Selected Wells at Waste Management Area T

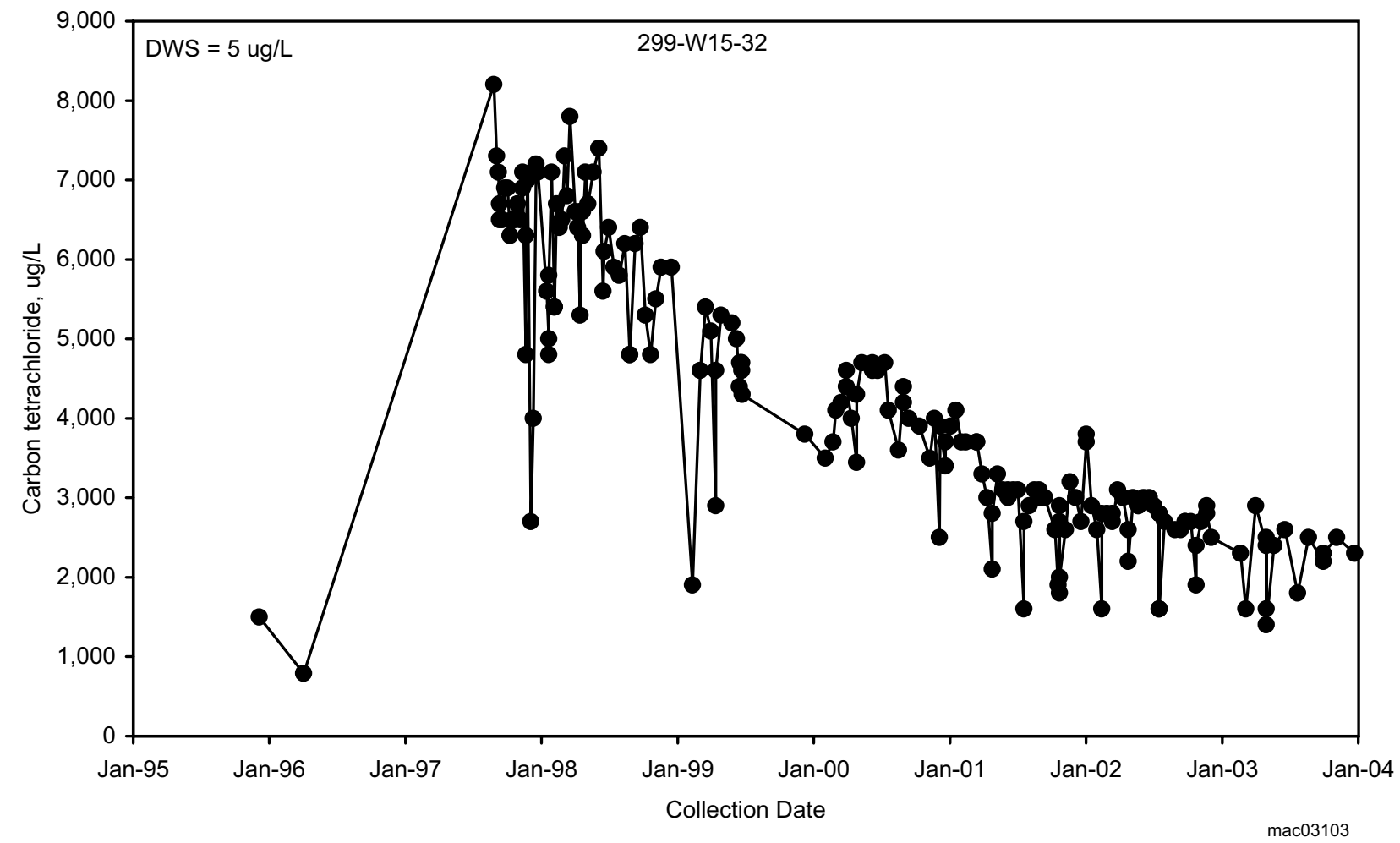

Figure 2.8-14. Carbon Tetrachloride Concentrations at Extraction Well 299-W15-32, Near the 216-Z-9 Trench 


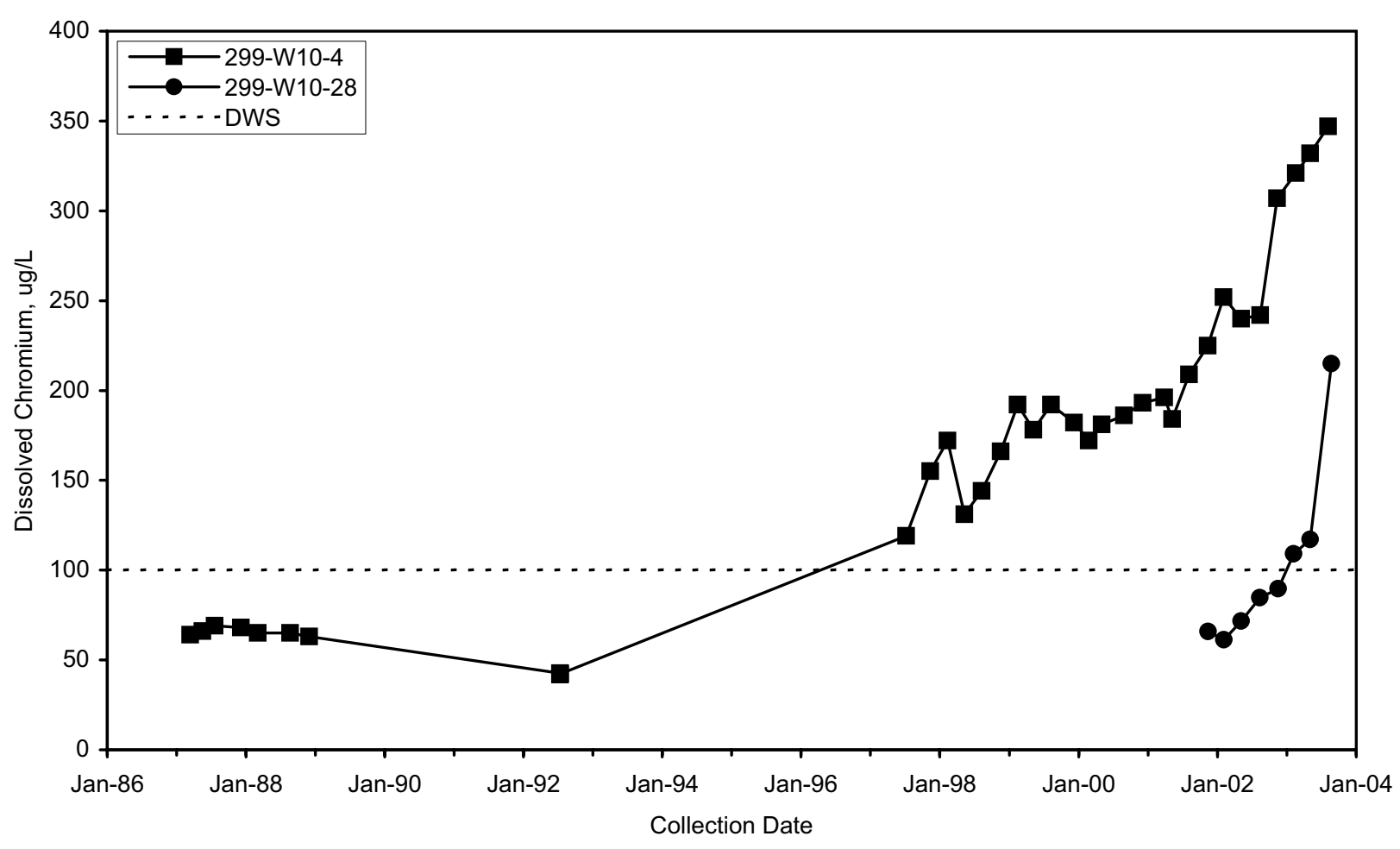

$\operatorname{mac} 03093$

Figure 2.8-15. Chromium Concentrations versus Time for Selected Upgradient Wells at Waste Management Area T

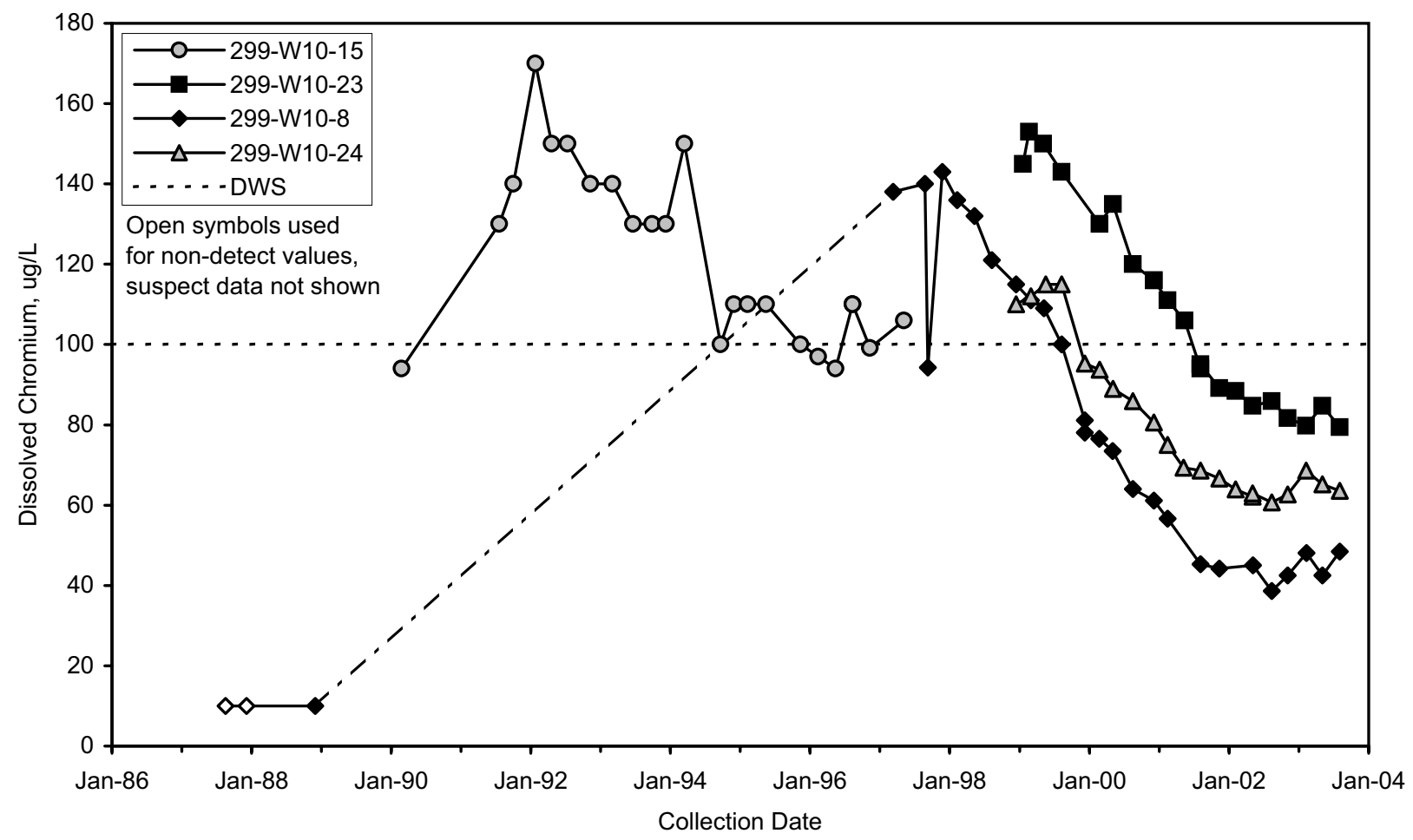

$\operatorname{mac} 03094$

Figure 2.8-16. Chromium Concentrations versus Time for Selected Wells North of Waste Management Area T 


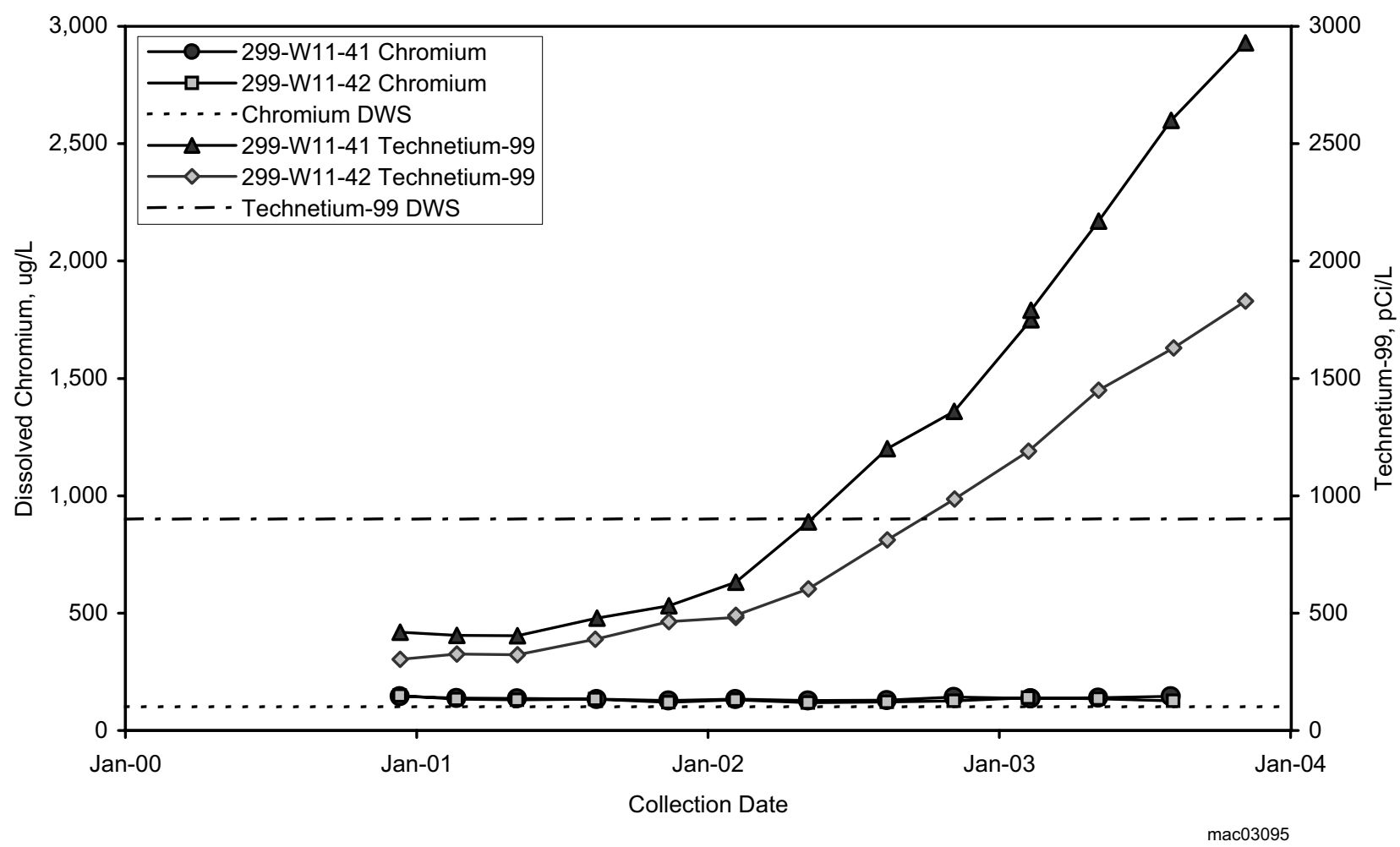

Figure 2.8-17. Chromium and Technetium-99 Concentrations versus Time for Selected Wells Downgradient of Waste Management Area T

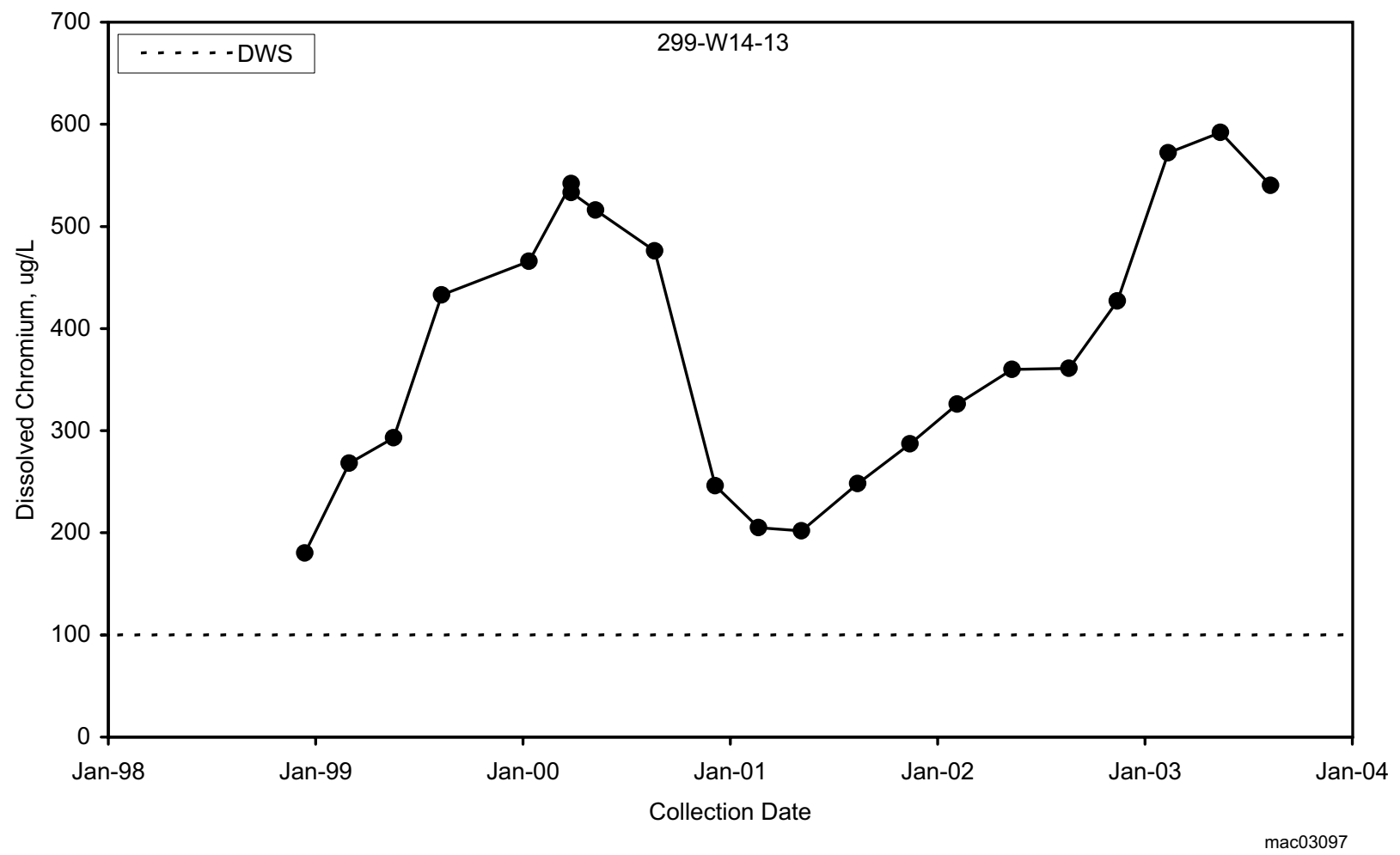

Figure 2.8-18. Chromium Concentrations in Well 299-W14-13, East of Waste Management Area TX-TY 


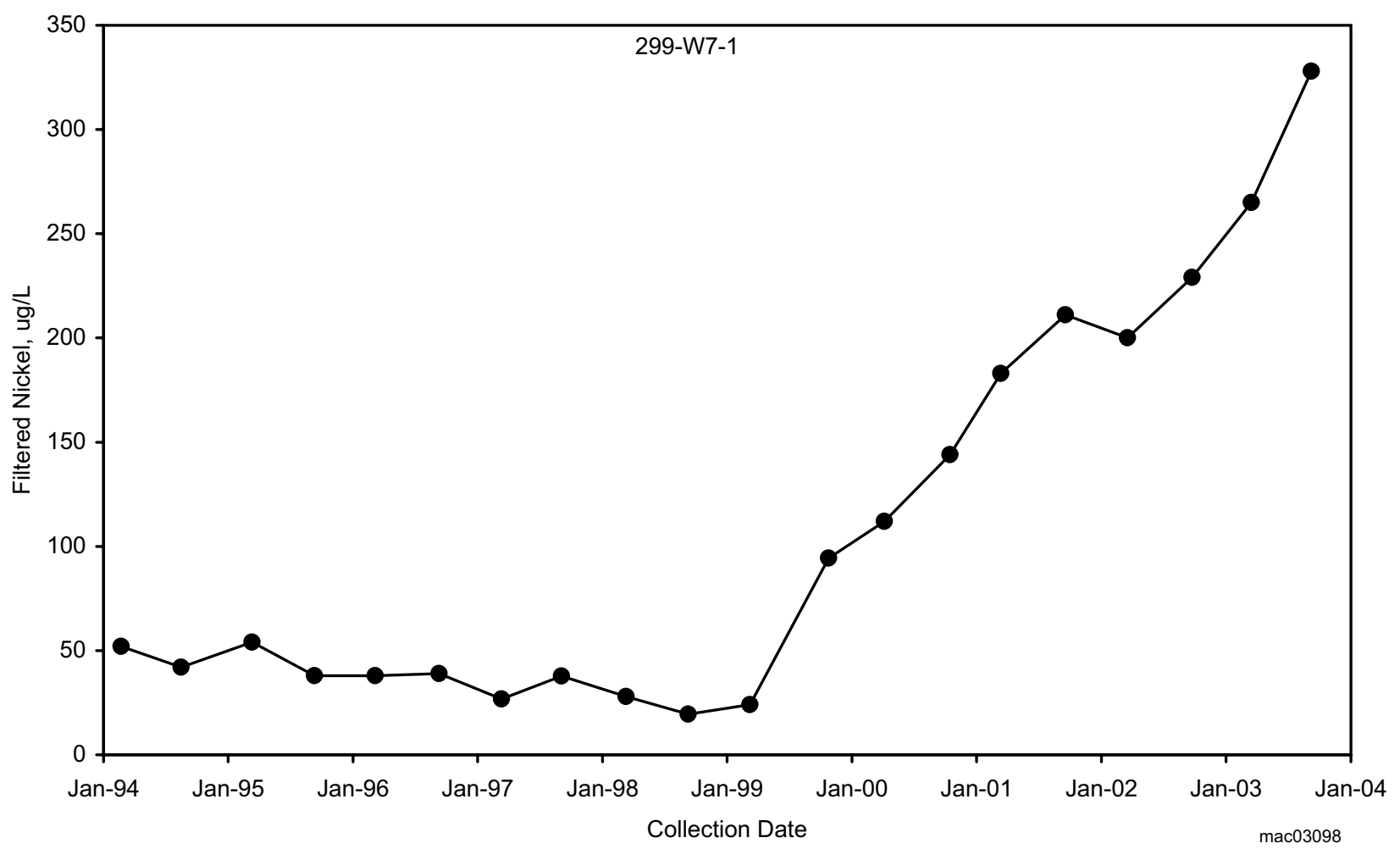

Figure 2.8-19. Nickel Concentrations in Well 299-W7-1, North of Low-Level Waste Management Area 3

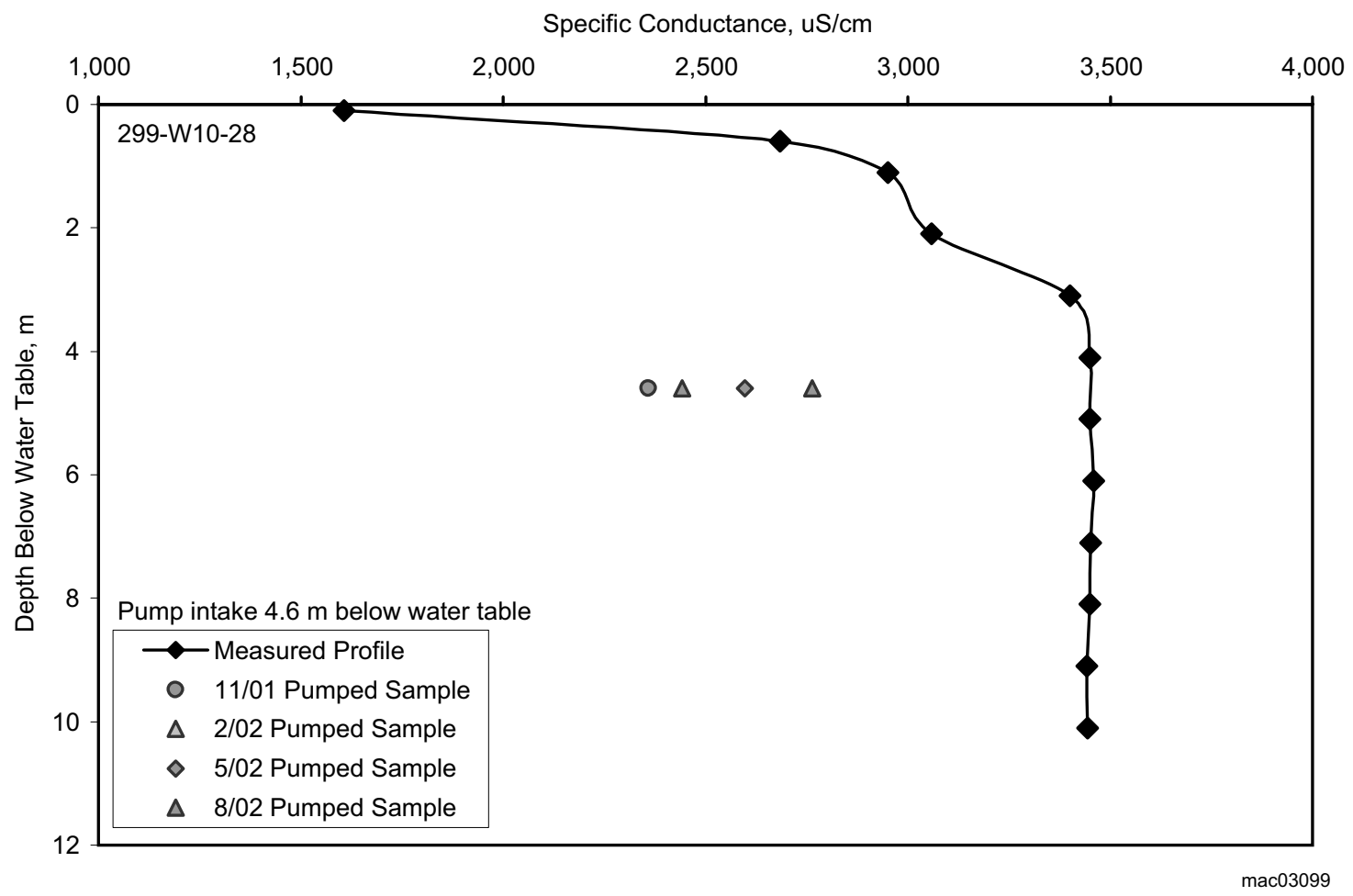

Figure 2.8-20. Specific Conductance versus Depth Below the Water Table in Well 299-W10-28 


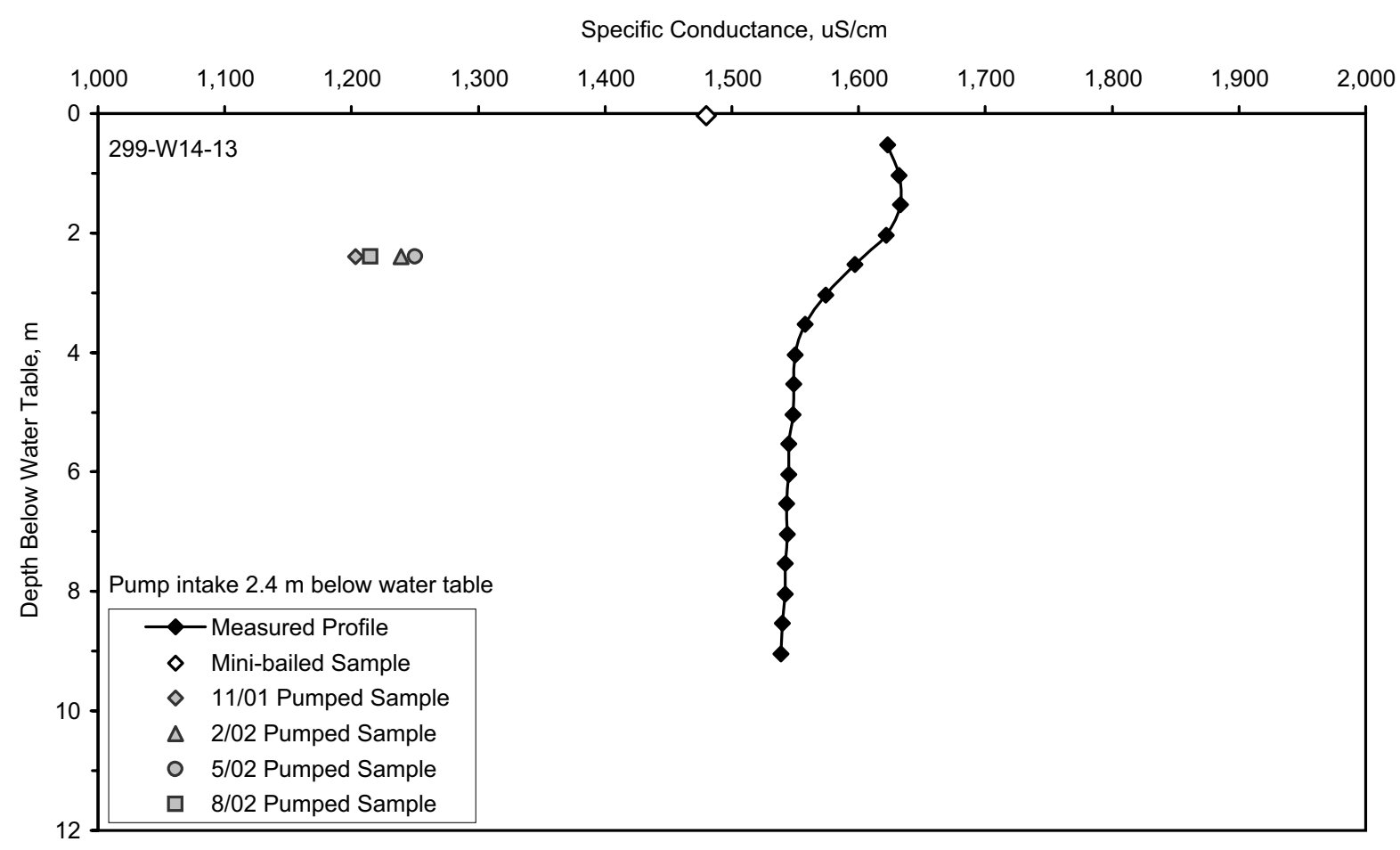

$\operatorname{mac} 03100$

Figure 2.8-21. Specific Conductance versus Depth in the Screened Interval of Well 299-W14-13

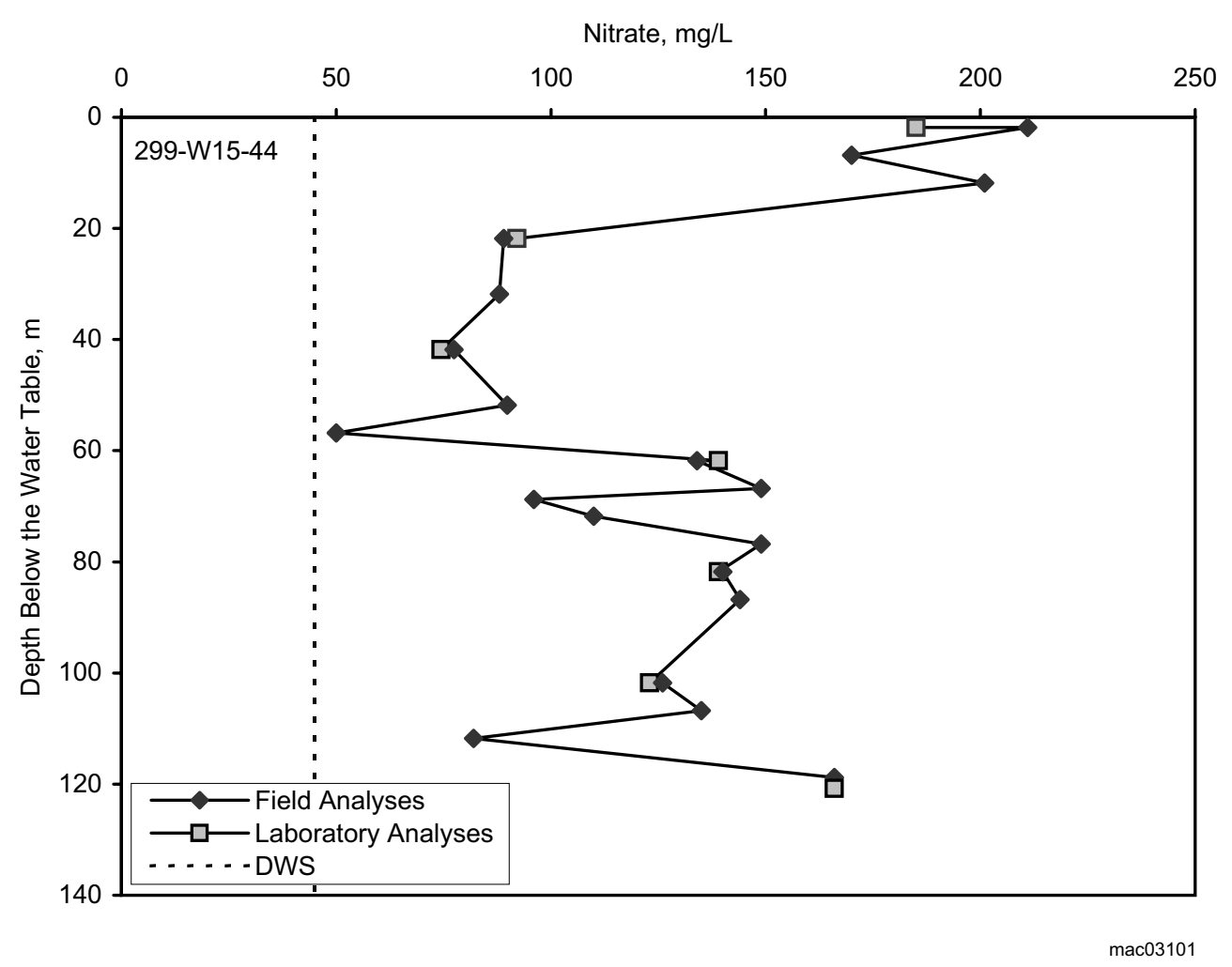

Figure 2.8-22. Nitrate Concentration in Groundwater Samples Collected During Drilling of New RCRA Well 299-W15-44, Waste Management Area TX-TY 

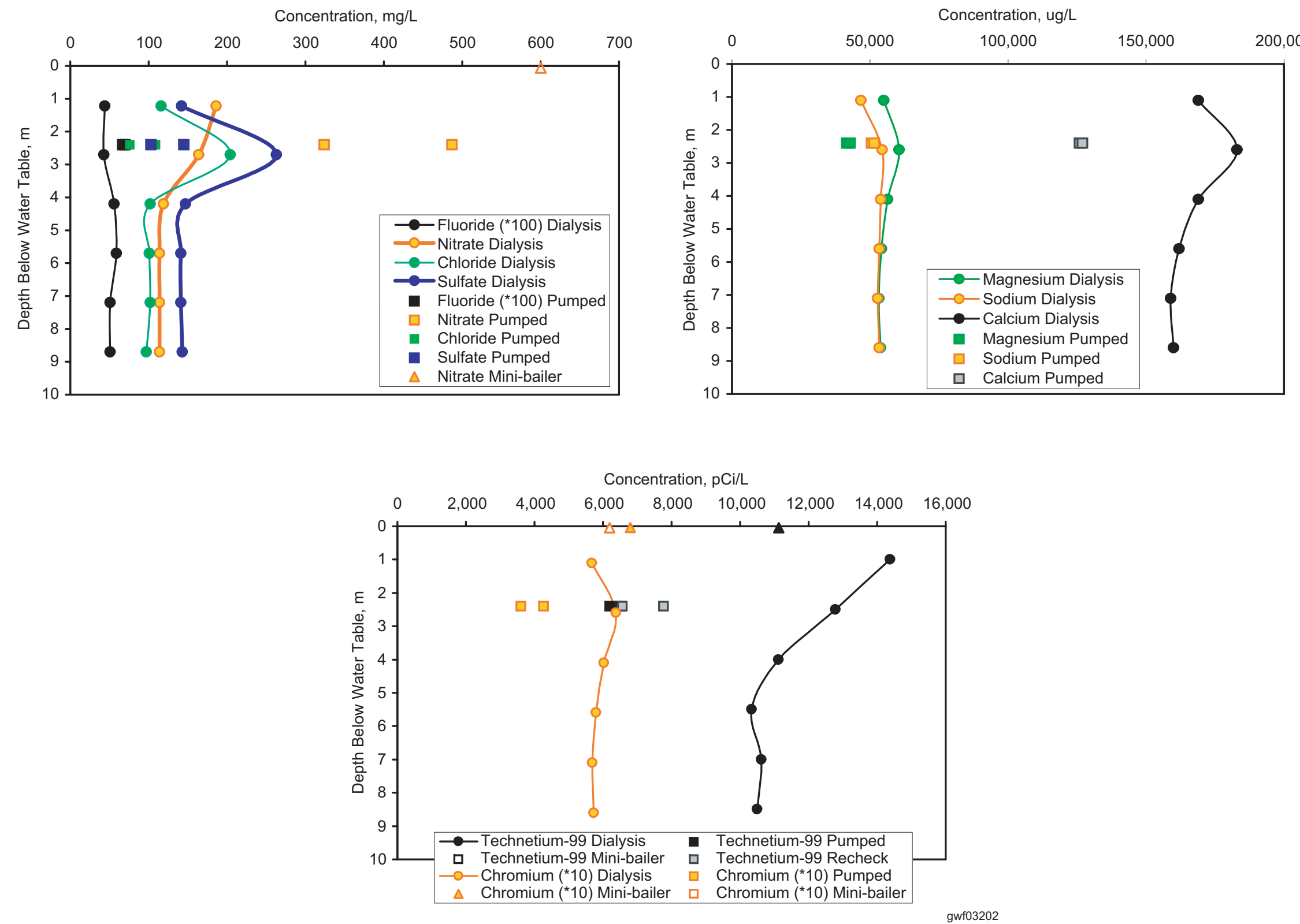

Figure 2.8-23. Concentrations of Selected Constituents versus Depth in the Screened Interval of Well 299-W14-13 at Waste Management Area TX-TY 


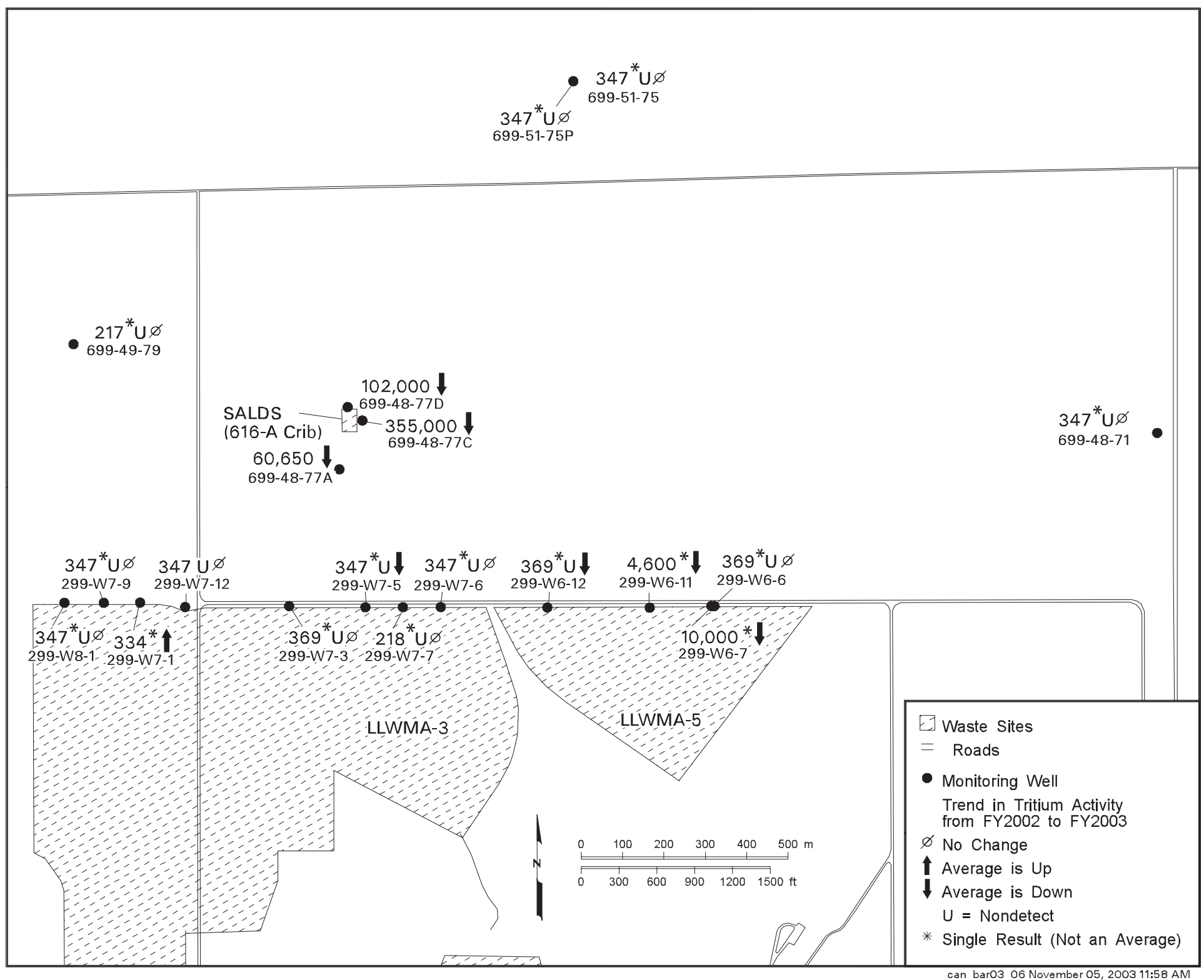

Figure 2.8-24. Tritium Concentrations in Groundwater for the SALDS Tritium-Tracking Network, Fiscal Year 2003, Indicating Change from Fiscal Year 2002 Results. (As indicated in the legend, these results are either averages for fiscal year 2003 or single results, i.e., sampled only once.) 


\subsection{0-UP-1 Operable Unit}

\section{J. P. McDonald, D. B. Erb, R. M. Smith, R. L. Weiss, and B. A. Williams}

The scope of this section is the 200-UP-1 groundwater interest area, which includes the 200-UP-1 groundwater operable unit (Figure 2.1-1). Figure 2.9-1 shows facilities and groundwater monitoring wells in this region. Technetium-99, uranium, tritium, iodine-129, nitrate, and carbon tetrachloride are the contaminants of greatest significance in groundwater and form extensive plumes within the region. Groundwater is monitored (1) to assess the performance of an interim action pump-and-treat system for technetium-99 and uranium; (2) to track existing contaminant plumes within the operable unit; (3) for the Environmental Restoration Disposal Facility under a Comprehensive Environmental Response, Compensation, and Liability Act (CERCLA) ${ }^{(\mathrm{a})}$ record of decision (ROD 1995b); and (4) for the Resource Conservation and Recovery Act (RCRA) units at Waste Management Areas S-SX and U, 216-U-12 crib, and 216-S-10 pond and ditch. In addition to the above mentioned plumes, contaminants of concern include strontium-90, trichloroethene, chloroform, chromium, cadmium, and arsenic. While not listed as a contaminant of concern, 1,4-dioxane was detected in groundwater in this region during fiscal year 2003.

Groundwater monitoring in the 200-UP-1 groundwater interest area includes CERCLA, RCRA, and AEA monitoring:

\section{CERCLA Monitoring}

- Four wells are sampled annually at the pump-and-treat area.

- Three extraction wells are sampled annually and semiannually at the pump-and-treat area.

- One newly installed monitoring well is sampled quarterly at the pump-and-treat area.

- Twenty-nine wells are sampled annually, semiannually, and biennially for 12 constituents of concern throughout the remainder of the 200-UP-1 Operable Unit (outside of the pump-and-treat area).

- Four wells are sampled semiannually at the Environmental Restoration Disposal Facility.

- In fiscal year 2003, three wells were not sampled as scheduled because they were dry (see Appendix A).

\section{RCRA Monitoring}

- Two wells are sampled quarterly at the 216-U-12 crib.

- Eight wells are sampled quarterly at Waste Management Area U.

- Sixteen wells are sampled quarterly at Waste Management Area S-SX.

- Four wells are sampled semiannually, including one newly installed well, for the 216-S-10 pond and ditch.

- In fiscal year 2003, one well (299-W26-7) was not sampled as scheduled because it was dry (see Appendix B).

- Sampling is coordinated with other programs to avoid duplication.

\section{AEA Monitoring}

- Four wells are sampled annually for contaminants, radionuclides, and general chemistry not otherwise scheduled under CERCLA and RCRA.

- In fiscal year 2003, one well (699-37-82A) was not sampled as scheduled because it was dry.

- Sampling is coordinated with CERCLA and RCRA sampling to avoid duplication.

(a) Past-practice monitoring in this operable unit is regulated under RCRA past-practice, which follows the same groundwater monitoring activities as CERCLA. This report uses the term CERCLA for simplicity. 
Groundwater flows primarily to the east within the 200-UP-1 groundwater interest area (Figure 2.8-2). Water levels have been falling in this area since the 1980s, and flow directions have changed from southeast to east during this time. From March 2002 to March 2003, the water-table elevation fell by an average of 0.21 meter. Groundwater flow is not significantly influenced by the pump-and-treat system at the 200-UP-1 operable unit. There are only two extraction wells associated with this system, so the hydraulic effect is localized.

The remainder of this section describes contaminant plumes and concentration trends for the contaminants of concern under CERCLA, RCRA, or Atomic Energy Act of 1954 (AEA) monitoring.

\subsubsection{Groundwater Contaminants}

Technetium-99

concentrations

declined

downgradient of

the 216-U-1,2 cribs

due to the effects of

a pump-and-treat

system.
The following sections give an overview of the contaminant plumes and contaminants of concern for the 200-UP-1 groundwater interest area. It is a summary of the combined results of CERCLA, RCRA, and AEA monitoring performed in this area.

\subsubsection{Technetium-99}

Technetium-99 occurs in two regions of the 200-UP-1 groundwater interest area: an extensive plume downgradient from the 216-U-1,2 cribs and two small plumes at Waste Management Area S-SX (Figure 2.9-2). The large plume originated from the 216-U-1,2 cribs, which were active in the 1950s and 1960s. When effluent was disposed at the nearby 216-U-16 crib in the mid-1980s, it migrated north along a caliche layer and mobilized the technetium-99 and uranium in the soil column beneath the 216-U-1,2 cribs further adding to the plume. During fiscal year 2003, concentrations continued to decline in this plume due to the operation of an interim remedial action pump-and-treat system. The maximum annual average concentration associated with this plume was $11,000 \mathrm{pCi} / \mathrm{L}$ found in well 299-W19-43 (the maximum annual average during fiscal year 2002 was $18,000 \mathrm{pCi} / \mathrm{L}$ ). This well replaced well 299-W19-36 as an extraction well in May 2003. By the end of the fiscal year, all measured concentrations in this plume were below the remedial action objective of 9,000 pCi/L. At well 699-38-70, downgradient of the pump-and-treat system, the technetium-99 concentration fell below the drinking water standard $(900 \mathrm{pCi} / \mathrm{L})$, which suggests that the pump-and-treat system has been successful at hydraulically containing the high concentration portion of this plume. Refer to Section 2.9.2 for a more thorough discussion of this technetium-99 plume and the pump-andtreat remediation system.

At Waste Management Area S-SX, a narrow plume of technetium-99 originates from the southwest corner of the waste management area. During the fiscal year, technetium-99 concentrations at well 299-W23-19 (at the southwest corner of this waste management area near the source of this plume) rose above the U.S. Department of Energy (DOE) derived concentration guide of $100,000 \mathrm{pCi} / \mathrm{L}$ (Figure 2.9-3). The peak concentration during the year was $188,000 \mathrm{pCi} / \mathrm{L}$ measured in January (the highest technetium-99 concentration in groundwater ever measured at Hanford), and the annual average concentration was $118,000 \mathrm{pCi} / \mathrm{L}$. By the end of the fiscal year, the concentration had fallen to $\sim 75,000 \mathrm{pCi} / \mathrm{L}$, which is below the DOE derived concentration guide. This plume continues to migrate to the east-southeast. The front of the plume has entered a region of sparse well coverage and cannot be tracked further. Refer to Section 2.9.4.2 for more information about this technetium-99 plume.

\subsubsection{Uranium}

Within the 200-UP-1 groundwater interest area, uranium primarily occurs in an extensive plume downgradient from the 216-U-1,2 cribs (Figure 2.9-4). The plume extends a total of $\sim 1.5$ kilometers to the east and northeast. The uranium originated from the $216-\mathrm{U}-1,2$ 
cribs, which were active in the 1950s and 1960s. Additional mass was added to the plume when effluent disposed of at the nearby 216-U-16 crib in the mid-1980s migrated north along a caliche layer and mobilized the technetium-99 and uranium in the soil column beneath the 216-U-1,2 cribs.

An interim remedial action pump-and-treat system continued to operate during fiscal year 2003, and measured concentrations in this plume generally declined or remained stable. By the end of the fiscal year, measured uranium concentrations were at or below the remedial action objective of $480 \mu \mathrm{g} / \mathrm{L}$ for all wells within the pump-and-treat area, although additional data are needed to confirm these trends. The maximum annual average concentration associated with this plume during fiscal year 2003 was $835 \mu \mathrm{g} / \mathrm{L}$ in well 299-W19-43 (the maximum annual average during fiscal year 2002 was $1,720 \mu \mathrm{g} / \mathrm{L}$ in well 299-W19-36). By July 2003, the measured concentration at well 299-W19-43 was down to $480 \mu \mathrm{g} / \mathrm{L}$. Due to the tendency for uranium to sorb to soil particles, uranium concentrations are not falling as rapidly as the technetium-99 concentrations have, and all measured uranium concentrations remain above the drinking water standard $(30 \mu \mathrm{g} / \mathrm{L})$.

A small uranium plume is depicted in Figure 2.9-4 beneath the 216-S-13 crib. This facility was active in the 1950s and 1960s, resulting in significantly high uranium concentrations in well 299-W22-21, which monitored the groundwater beneath the crib. This well was periodically sampled up until 1997, but has since gone dry. Uranium concentrations in this well were frequently above the drinking water standard, suggesting residual uranium was leaching from the soil column beneath this crib. It is reasonable to assume this leaching continues.

\subsubsection{Tritium}

Disposal facilities associated with the Reduction Oxidation (REDOX) Plant are the primary sources of tritium in the 200-UP-1 groundwater interest area. The REDOX Plant operated from 1952 until 1967, although effluent releases continued to occur after this time. A large tritium plume emanates from the south part of the 200 West Area to the east and northeast (extending $\sim 4$ kilometers), and a small tritium plume extends $\sim 550$ meters to the east-southeast from the vicinity of the 216-S-25 crib (Figure 2.9-5).

Eleven wells within the large plume were sampled for tritium during fiscal year 2003; concentrations declined in seven of the wells, increased in three, and were unchanged in one. The overall picture is of a plume that has nearly stopped spreading in most directions and is contracting in some areas as radioactive decay dominates over advective transport. At the east edge of the plume, concentrations increased in well 699-36-61A (from $49,400 \mathrm{pCi} / \mathrm{L}$ in fiscal year 2000 to $52,900 \mathrm{pCi} / \mathrm{L}$ in fiscal year 2003) indicating that the plume is continuing to move farther east, although at a slow rate. Movement within this plume is slow because of low-permeability sediment in the aquifer. Along the north and central parts of the plume, concentrations declined during the fiscal year. The peak concentration measured in this plume during the fiscal year was $634,000 \mathrm{pCi} / \mathrm{L}$ in well 299-W22-9, which is down from $914,000 \mathrm{pCi} / \mathrm{L}$ in the same well the year before. (The tritium drinking water standard is $20,000 \mathrm{pCi} / \mathrm{L}$, and the $\mathrm{DOE}$ derived concentration guide is 2 million $\mathrm{pCi} / \mathrm{L}$.)

The tritium plume from the vicinity of the 216-S-25 crib continues to migrate to the east-southeast, passing beneath Waste Management Area S-SX. Wells 299-W22-49, 299-W22-82, and 299-W22-83, downgradient of this tank farm, all had increasing tritium concentrations during the fiscal year. Tritium exceeded the drinking water standard in wells 299-W22-82 and 299-W22-83 during the year. The front of this plume has now entered an area of sparse well coverage and will not be able to be tracked further (the next downgradient well is $\sim 600$ meters away).

\subsubsection{4 lodine-129}

Iodine-129 plumes in the 200-UP-1 groundwater interest area originate from both U Plant and REDOX Plant disposal facilities (Figure 2.9-6). One plume emanates from
Uranium responds more slowly than technetium-99 to the pump-and-treat system.

The tritium plume emanating from the southeast 200 West Area has nearly stopped spreading in most directions and is contracting in some areas. 


\section{A portion of the iodine-129 plume is migrating to the east out of the 200 West Area.}

\section{Carbon tetrachloride is widespread in the 200-UP-1 groundwater interest area. The plume originated in the 200-ZP-1 groundwater interest area.}

the vicinity of the 216-U-1,2 cribs, while another originates from the south part of the 200 West Area. At the current level of monitoring detail, these plumes merge downgradient and become indistinguishable. This combined plume (as denoted by the $1-\mathrm{pCi} / \mathrm{L}$ contour level) extends to the east and northeast a total distance of $\sim 3.5$ kilometers.

Sixteen wells within the iodine-129 plume were sampled during fiscal year 2003. Concentrations generally increased in the north and central part of the plume outside of the 200 West Area boundary. Concentrations within the south part generally declined or were unchanged. This indicates that a high concentration portion of this plume is migrating to the east out of the 200 West Area into the surrounding 600 Area. The maximum iodine-129 concentration measured within the 200-UP-1 groundwater interest area was $35.3 \mathrm{pCi} / \mathrm{L}$ in well 699-35-70. (The drinking water standard for iodine-129 is $1 \mathrm{pCi} / \mathrm{L}$, and the DOE derived concentration guide is $500 \mathrm{pCi} / \mathrm{L}$.)

\subsubsection{Strontium-90}

During the fiscal year, 11 analyses for strontium-90 were performed on samples collected from 9 wells within the groundwater interest area. Strontium-90 was found above detection limits in only one well: 299-W22-10, located downgradient of the 216-S-1,2 cribs. The result was $54 \mathrm{pCi} / \mathrm{L}$, which is above the $8 \mathrm{pCi} / \mathrm{L}$ drinking water standard, but below the DOE derived concentration guide of $1,000 \mathrm{pCi} / \mathrm{L}$. The previous sample result was $76 \mathrm{pCi} / \mathrm{L}$ collected during fiscal year 2002.

The 216-S-1,2 cribs received highly acidic, REDOX Plant waste from 1952 to 1956. In 1955, the waste is believed to have corroded the casing of a nearby well (299-W22-3), which allowed the effluent to bypass the soil column and flow down the well directly into groundwater. Because strontium-90 is not very mobile in groundwater, this plume has remained in the vicinity of these cribs.

\subsubsection{Chlorinated Hydrocarbons}

Carbon tetrachloride is widespread in the 200-UP-1 groundwater interest area. The maximum measured concentration was $690 \mu \mathrm{g} / \mathrm{L}$ in well 299-W19-9 at the 216-U-1,2 cribs. Carbon tetrachloride originates from disposal facilities associated with the Plutonium Finishing Plant, which is part of the 200-ZP-1 groundwater interest area. For a more thorough discussion of carbon tetrachloride in the 200 West Area, see Section 2.8.

Chloroform is a degradation product of carbon tetrachloride. A total of 70 chloroform analyses were performed on samples from 48 wells within the 200-UP-1 groundwater interest area, and there were no exceedances of the $100 \mu \mathrm{g} / \mathrm{L}$ drinking water standard. The maximum measured concentration was $20 \mu \mathrm{g} / \mathrm{L}$ in well 299-W18-40, an upgradient well for Waste Management Area U.

Trichloroethene is found within the 200-UP-1 groundwater interest area above the drinking water standard $(5 \mu \mathrm{g} / \mathrm{L})$ in two small plumes - one near the pump-and-treat system and another downgradient of the 216-S-20 crib. The peak measured concentration at the pump-and-treat system during the fiscal year was $7 \mu \mathrm{g} / \mathrm{L}$ in 299-W19-35, which is largely unchanged from the year before. The peak measured concentration downgradient of the 216-S-20 crib was $11 \mu \mathrm{g} / \mathrm{L}$ in well 299-W22-20, down from $15 \mu \mathrm{g} / \mathrm{L}$ the year before. There were no other exceedances of the drinking water standard. In fiscal year 2002, trichloroethene exceeded the drinking water standard at well 299-W19-34B $(6 \mu \mathrm{g} / \mathrm{L})$, completed deep in the aquifer at the pump-and-treat site, but this well was not sampled during fiscal year 2003 (it is scheduled for biennial sampling).

\subsubsection{Chromium}

Chromium is found in four regions of the 200-UP-1 groundwater interest area: at Waste Management Area S-SX, at the 216-S-10 pond and ditch, downgradient from the 216-S-20 crib, and in the 600 Area east and southeast of the 200 West Area. During the 
fiscal year, samples from three wells exceeded the drinking water standard of $100 \mu \mathrm{g} / \mathrm{L}$ : well 299-W26-7 at the 216-S-10 pond and ditch, well 299-W22-50 at Waste Management Area S-SX, and well 699-32-62 in the 600 Area. The maximum measured concentration was $209 \mu \mathrm{g} / \mathrm{L}$ at well 299-W26-7. Chromium was not analyzed for at well 299-W22-20 downgradient of the 216-S-20 crib during the fiscal year, but the result for fiscal year 2002 was $381 \mu \mathrm{g} / \mathrm{L}$. Chromium at Waste Management Area S-SX is discussed in Section 2.9.3.3, and chromium at the 216-S-10 pond and ditch is discussed in Section 2.9.3.4.

Chromium is frequently detected in filtered samples east and southeast of the 200 West Area. The concentration in well 699-32-62 was $174 \mu \mathrm{g} / \mathrm{L}$ in fiscal year 2003, down from $201 \mu \mathrm{g} / \mathrm{L}$ in fiscal year 2000. The chromium concentrations have declined slowly since chromium was first analyzed at this well in 1992. The sources and extent of this contamination are uncertain. The location of this plume is consistent with disposal to the REDOX ponds/ditches south and southwest of the 200 West Area. Chromium is detected in several other wells in this area, but its extent to the south of well 699-32-62 is poorly defined.

\subsubsection{Nitrate}

Nitrate plumes in the 200-UP-1 groundwater interest area originate from both U Plant and REDOX Plant disposal facilities and are widespread throughout the area. The multiple sources of nitrate from U Plant include the 216-U-1,2; 216-U-8; and 216-U-12 cribs. The nitrate plumes from these and other sources merge downgradient into a single large plume, which extends to the east and northeast a total distance of $\sim 4$ kilometers (Figure 2.9-7). Nitrate sources from the REDOX Plant disposal facilities may also have contributed to this plume. This plume continues to migrate slowly to the east, as evidenced by increasing nitrate concentrations in well 699-40-62 (82 mg/L in fiscal year 2003, up from $69 \mathrm{mg} / \mathrm{L}$ in fiscal year 2000). The nitrate drinking water standard is $45 \mathrm{mg} / \mathrm{L}$. Waste Management Area $U$ is also a source of nitrate. Nitrate concentrations rose above the drinking water standard for the first time at this site in fiscal year 2003 (53 mg/L annual average concentration in well 299-W19-41). The peak measured nitrate concentration in the 200-UP-1 groundwater interest area was 1,930 mg/L in well 299-W19-43, an extraction well at the 200-UP-1 pump-and-treat system.

Nitrate also occurs in two small plumes associated with REDOX Plant disposal facilities: one near the 216-S-20 crib and another near the 216-S-25 crib. In well 299-W22-20, downgradient of the $216-\mathrm{S}-20 \mathrm{crib}$, the measured nitrate concentration this fiscal year was $92 \mathrm{mg} / \mathrm{L}$, up from $73 \mathrm{mg} / \mathrm{L}$ the year before. From 1952 through 1972, this crib received waste from laboratory hoods and decontamination sinks in the 222-S Building, along with laboratory waste from the 300 Area.

There is a nitrate plume associated with the tritium plume emanating from the vicinity of the 216-S-25 crib. In well 299-W23-9, at the downgradient end of this crib, nitrate concentrations have been increasing over the past 3 years. The fiscal year 2003 concentration was $480 \mathrm{mg} / \mathrm{L}$, up from $350 \mathrm{mg} / \mathrm{L}$ the year before. Nitrate also appears to be associated with the technetium-99 plume in this vicinity. The peak nitrate concentration in this area occurred in well 299-W23-19 at the southwest corner of Waste Management Area S-SX; the January 2003 sample yielded a nitrate concentration of 1,680 mg/L. This is much higher than the nitrate concentrations upgradient around the $216-\mathrm{S}-25 \mathrm{crib}$, so Waste Management Area S-SX is also a source of nitrate.

\subsubsection{Other Constituents}

1,4-dioxane was detected in a sample collected from well 299-W22-20, which is located downgradient from the 216-S-20 crib. The well was sampled in January 2003, and the result was $160 \mu \mathrm{g} / \mathrm{L}$ for field duplicate samples. This result was confirmed by a laboratory re-analysis of both samples. An examination of the laboratory analysis method (gas chromatography/mass spectrometry) output data for previous annual samples back to fiscal
Multiple sources of nitrate created a large plume, which is moving to the east. 


\section{1,4-dioxane was}

detected in a single well downgradient

of the 216-S-20 crib.

The 200-UP-1

pump-and-treat

system is

remediating

technetium-99

and uranium

contamination. year 2000, showed that 1,4-dioxane was detected in 2002 (at $110 \mu \mathrm{g} / \mathrm{L}$ ), but not in the earlier samples. During the fiscal year, 46 analyses for 1,4-dioxane were performed on samples from 43 wells within the entire groundwater interest area, and there were no other detections of this constituent.

1,4-dioxane is typically used as a solvent stabilizer and is added to solvents such as 1,1,1-trichloroethane or trichloroethene. It is classified as a probable human carcinogen, and it is highly soluble and mobile in groundwater. The U.S. Environmental Protection Agency (EPA) has not established a drinking water standard, but has estimated that consumption of drinking water with a concentration of $3 \mu \mathrm{g} / \mathrm{L}$ would result in a lifetime cancer risk of $1.0 \times 10^{-6}$. The state of Washington has established a groundwater quality standard of $7 \mu \mathrm{g} / \mathrm{L}$ (WAC 173-200). The probable source appears to be the 216-S-20 crib, but this has not been confirmed. From 1952 through 1972, this crib received waste from laboratory hoods and decontamination sinks in the 222-S Building, along with laboratory waste from the 300 Area.

Arsenic and cadmium are both listed as contaminants of concern for the 200-UP-1 Operable Unit. During the fiscal year, there were no arsenic results for a filtered sample above the $10 \mu \mathrm{g} / \mathrm{L}$ drinking water standard; however, arsenic was detected above the drinking water standard in one unfiltered sample - 12.3 $\mathrm{gg} / \mathrm{L}$ in well 699-36-67 at the Environmental Restoration Disposal Facility. For cadmium, there were no results above the $5 \mu \mathrm{g} / \mathrm{L}$ drinking water standard.

\subsubsection{CERCLA Groundwater Monitoring}

Within the 200-UP-1 groundwater interest area, CERCLA groundwater monitoring is conducted for the 200-UP-1 Operable Unit as well as the Environmental Restoration Disposal Facility. The results of this monitoring are described in the following sections.

\subsubsection{Interim Groundwater Remediation for Technetium-99 and Uranium}

During the fiscal year, the 200-UP-1 Operable Unit was monitored in accordance with a sampling and analysis plan issued during June 2002 (DOE/RL-2002-10). The objectives of this monitoring are to determine the spatial extent of existing contaminant plumes within the operable unit and to assess the performance of an interim remedial action pumpand-treat system. Appendix A presents the monitoring well network for the 200-UP-1 Operable Unit, including a well list, sampling frequencies, and analyte lists. Well locations within the 200 West Area are shown in Figure 2.9-1. This network was revised in the Remedial Investigation/Feasibility Study Work Plan for the 200-UP-1 Groundwater Operable Unit (DOE/RL-92-76) to support fiscal year 2004 sampling by increasing the frequency of sampling in the vicinity of the pump-and-treat system and reducing the frequency in other areas.

During the fiscal year, three wells scheduled in the sampling and analysis plan were not sampled because they were dry: 299-W19-14 ( 150 meters south of the 216-U-1,2 cribs), 299-W23-14 (upgradient well at Waste Management Area S-SX), and 299-W26-12 (at the 216-S-10 pond and ditch). Well 299-W23-21 was installed in 2000 as a replacement well for 299-W23-14, so it was sampled instead. Well 299-W19-20 (at the 
pump-and-treat area) did not have sufficient water to operate the sampling pump, so a bailer was used to collect one last sample from this well, which is now considered dry.

The remainder of this section addresses monitoring performed to determine the effectiveness of the pump-and-treat system at the 200-UP-1 Operable Unit. Results of monitoring to determine the spatial extent of contaminant plumes is combined with other monitoring results and summarized in Section 2.9.1.

\section{Progress During Fiscal Year 2003}

The pump-and-treat system at the 200-UP-1 Operable Unit is designed to contain the high concentration portions of the technetium-99 and uranium plumes emanating from the 216-U-1,2 cribs, and to reduce the concentrations in these plumes. During the fiscal year, 98.3 million liters of contaminated water from the 200-UP-1 Operable Unit were treated at the Effluent Treatment Facility. Almost 707.5 million liters have been treated since startup of remediation activities in fiscal year 1994. During the fiscal year, 21.2 kilograms of uranium and 11.8 grams $(0.2$ curies $)$ of technetium- 99 were removed from the aquifer. In addition, 2.8 kilograms of carbon tetrachloride and 4,158 kilograms of nitrate (secondary contaminants of concern) were removed from the aquifer. These values along with the amount of mass removed since startup of operations is given in Table 2.9-1.

The average extraction system pumping rate for the year was 178.2 liters per minute, which is below the remedial design of 189.3 liters per minute. Water was extracted from well 299-W19-39 all year. In May 2003, well 299-W19-43 replaced well 299-W19-36 as the second extraction well. This increased the total pumping rate to 195.7 liters per minute, which was maintained to the end of the fiscal year.

Due to declining groundwater levels, the capability for monitoring and tracking changes in plume configuration continues to be hampered by the loss of monitoring wells in the baseline plume area. Well 299-W19-20 went dry after being sampled in January 2003. This leaves only one monitoring well, 299-W19-37, in the baseline area. Two other nearby wells, 299-W19-35 and 299-W19-40, are compliance wells used to demonstrate control of the plume, but well 299-W19-40 is expected to go dry within the next 4 years.

A new monitoring well, 299-W19-46, was installed south of the baseline plume area to replace well 299-W19-38 that went dry in January 2001. This re-establishes a monitoring point at the south area of the baseline plumes. A new well is to be drilled upgradient of well 299-W19-20 in fiscal year 2004. For more detailed information about operations during fiscal year 2003, refer to DOE/RL 2003-58.

\section{Influence on Aquifer Conditions}

By the end of the fiscal year, all measured technetium-99 and uranium concentrations were at or below their respective remedial action objectives at all wells in the baseline plume area (i.e., that portion of the plume originally designed to be contained by the treatment system), although more sampling is required to confirm these trends. In addition, the high concentration portions of the technetium-99 and uranium plumes were hydraulically contained throughout the year. Figures 2.9-8 and 2.9-9 show measured technetium-99 and uranium concentrations for several wells in the pump-and-treat area. Figures 2.9-10 and 2.9-11 show the technetium-99 and uranium plumes at the pump and treat area, based on average concentrations for the fiscal year.

During the fiscal year, only well 299-W19-43 yielded technetium-99 and uranium sample results above their respective remedial action objectives. This well was sampled in January 2003 (prior to being converted to an extraction well), and the results were $18,200 \mathrm{pCi} / \mathrm{L}$ for technetium-99 and 1,190 $\mu \mathrm{g} / \mathrm{L}$ for uranium. This well was sampled again in July after being converted to an extraction well, and concentrations declined to 3,390 pCi/L for technetium-99 (below the remedial action objective) and $480 \mu \mathrm{g} / \mathrm{L}$ for uranium (equal to the remedial action objective).
Since its inception,

the pump-and-treat system has removed 102 grams of technetium-99 and 180 kilograms of uranium.

During the fiscal year, the high concentration portions of the plumes were hydraulically contained. 


\section{Contaminant}

concentrations

declined below the

cleanup target

levels in

monitoring wells

sampled in fiscal

year 2003. Many

wells have gone

dry, however.
Uranium concentrations declined to below the remedial action objective at well 299-W19-36, the other extraction well within the high concentration part of the plumes. The uranium concentration declined from $995 \mu \mathrm{g} / \mathrm{L}$ in August 2002 to $458 \mu \mathrm{g} / \mathrm{L}$ in January 2003. Technetium-99 concentrations declined from an average of $8,915 \mathrm{pCi} / \mathrm{L}$ in August 2002 to $4,600 \mathrm{pCi} / \mathrm{L}$ in January 2003. The area around wells 299-W19-36 and 299-W19-43 will require additional monitoring and sampling to determine if these declines continue. At downgradient extraction well 299-W19-39, technetium-99 and uranium concentrations have remained well below their respective remedial action objectives.

Technetium-99 concentrations in compliance wells 299-W19-40 and 299-W19-35, and in monitoring well 299-W19-37 midway between the extraction wells, remained below the drinking water standard throughout the fiscal year. Uranium concentrations in these wells showed variable to declining trends; however, concentrations at all wells remain above the drinking water standard $(30 \mu \mathrm{g} / \mathrm{L})$. At well 299-W19-46, groundwater was sampled at 6-meter intervals during installation of this well to establish a vertical profile of contaminant distributions. Only one sample exceeded the technetium-99 drinking water standard $-1,360 \mathrm{pCi} / \mathrm{L}$ at a depth of 12.8 meters below the water table. All quarterly sample results have averaged $158 \mathrm{pCi} / \mathrm{L}$, well below the drinking water standard. The highest uranium concentrations were 131 and $134 \mu \mathrm{g} / \mathrm{L}$ at depths of 7.6 and 13.7 meters below the static water table. Quarterly analyses for the rest of fiscal year 2003 have averaged $146 \mu \mathrm{g} / \mathrm{L}$.

During fiscal year 2003, the annual rate of water-level decline was $~ 0.38$ meter, which is similar to the 0.36 -meter decline observed in fiscal year 2002. The water-level decline has affected the pumping rates at the extraction wells, and thereby has affected the radius of influence of each well. The radius of influence for well 299-W19-39 is estimated at 180 meters, a slight decline from the fiscal year 2002 value of 205 meters. This radius still appears to be adequate with respect to the baseline plume. The data from compliance well 299-W19-40 also supports the effectiveness of well 299-W19-39 at capturing the contaminants. The radii of influence at extraction wells 299-W19-36 and 299-W19-43 are smaller, but are adequately capturing contamination in the upgradient part of the plume.

\subsubsection{Groundwater Monitoring at the Environmental Restoration Disposal Facility}

The Environmental Restoration Disposal Facility is a low-level, mixed waste facility where waste from surface remedial actions on the Hanford site is disposed. The site is designed to meet RCRA standards, although it is not permitted as a RCRA facility. Groundwater monitoring is conducted in accordance with a CERCLA record of decision (ROD 1995b). One upgradient well (699-36-70A) and three downgradient wells (699-37-68, 699-36-67, and 699-35-66A) are sampled semiannually, typically in the second and fourth quarters of the fiscal year. All four wells were sampled as planned during fiscal year 2003, although some wells were sampled later than others due to maintenance issues. For a discussion of leachate monitoring at this facility, see Section 3.2.2. Appendix C contains additional information regarding the Environmental Restoration Disposal Facility. See BHI-01684 for calendar year 2002 groundwater and leachate monitoring results.

Results of groundwater monitoring at the Environmental Restoration Disposal Facility continue to indicate that the facility has not adversely impacted groundwater quality. Several constituents are present in the groundwater at or above drinking water standards (tritium, iodine-129, nitrate, and carbon tetrachloride), but these results are due to plumes originating from the 200 West Area. Potential out of trend values (high) were noted for two downgradient wells during the fiscal year: gross beta in 699-35-66A, and gross beta, unfiltered chromium, and possibly unfiltered zinc in 699-37-68. These high trend results for gross beta and chromium continue from the previous sampling events and look like actual increasing trends. Future results will be evaluated to confirm this. The unfiltered zinc 
results for well 699-37-68 have been somewhat erratic, possibly due to variability of suspended solids in the sample. Early zinc values for this well were elevated ( 400 to $\sim 2,000 \mu \mathrm{g} / \mathrm{L}$ ) and were assumed to result from galvanic corrosion of well components. After repairs in 2000, initial results showed much lower zinc values. Future results will be evaluated to determine if upward trends continue. Some erratic results were noted for other metals results from unfiltered samples. Variability due to suspended solids likely accounts for the results seen. All filtered samples were much more consistent and showed values within the variability seen historically.

\subsubsection{RCRA Groundwater Monitoring}

Groundwater monitoring in accordance with RCRA regulations is performed at four sites within the 200-UP-1 groundwater interest area. Assessment monitoring is conducted at three of these sites (216-U-12 crib, Waste Management Area S-SX, and Waste Management Area U), and detection monitoring is conducted at one site (216-S-10 pond and ditch). RCRA groundwater monitoring is limited to hazardous waste constituents. Radionuclide releases from these sites are tracked under AEA monitoring and are discussed in Section 2.9.4.

\subsubsection{216-U-12 Crib}

The $216-U-12$ crib is located $\sim 600$ meters south of $U$ Plant in the southeast portion of the 200 West Area. The crib is an unlined, gravel-bottom, percolation crib 3 meters by 30 meters, and 4.6 meters deep. The crib received process effluent from $U$ plant, including the 224-U Building, and operated from 1960 through 1972 and from 1981 until February 1988. A map of this facility, the well sampling and constituent list, and sampling frequency is provided in Appendix B.

The number of network monitoring wells remains the same as last year. Declining water levels in the 200 West Area have reduced the 216-U-12 crib monitoring network from the original four wells to just two downgradient wells (299-W22-79 and 699-36-70A), which is fewer than the minimum required number of wells. These wells are sampled quarterly for the constituents of interest (see Appendix B). The Washington State Department of Ecology (Ecology), EPA, and DOE annually negotiate installation of future monitoring wells under Tri-Party Milestone M-24-00 (Ecology et al. 1998).

The current objectives of interim status assessment monitoring for the 216-U-12 crib include the following:

- Continue groundwater monitoring to assess the migration of potential dangerous waste constituents out of the vadose zone into the groundwater.

- Monitor the known contaminants until a near-term interim corrective action is defined.

- Monitor under interim status assessment until a final status monitoring plan is implemented following closure of the facility.

These objectives do not include delineating the existing known plumes. The existing plumes co-mingle with plumes from other U Plant and REDOX Plant area sources, making it difficult to distinguish the specific plumes emanating from the 216-U-12 crib. In addition, the existing groundwater plumes are already being delineated by CERCLA and AEA monitoring.

Based on a revised and updated groundwater monitoring assessment plan for the 216-U-12 crib (PNNL-14301), closure of the crib will be coordinated with and conducted under CERCLA per the U Plant waste sites closure area focused feasibility study (DOE/RL-2003-23) and proposed plan (DOE/RL-2003-24). RCRA groundwater monitoring objectives will remain the same from now until closure of the crib and then shift to a final status post-closure plan that is outlined in the revised groundwater monitoring
The 216-U-12 crib contributed to nitrate contamination. A new monitoring plan was published in fiscal year 2003. 


\section{RCRA monitoring} shows that Waste Management Area U contaminated groundwater with nitrate. assessment plan. The updated groundwater monitoring assessment plan (PNNL-14301) proposes a revised well network and a list of constituents based on the knowledge gained from monitoring data collected over the past 11 years for this site. It also provides the current interpretation of groundwater flow and contamination occurrence. Additionally, a conceptual model of contaminant transport through the vadose zone beneath the crib is presented in the plan to assist in developing an appropriate and cost-effective monitoring and clean up approach for this facility.

The 216-U-12 crib was placed into assessment status due to elevated specific conductance downgradient of the facility. Elevated calcium and nitrate are the major contributors to the specific conductance. These constituents are being evaluated through quarterly groundwater monitoring. The regional nitrate and technetium- 99 plumes are a co-mingled series of smaller plumes with sources from several cribs (216-U-1,2; 216-U-8; and 216-U-12) in the U Plant area.

The key indicator parameter, specific conductance, continued to decline in both wells. Nitrate remains above the $45 \mathrm{mg} / \mathrm{L}$ drinking water standard in both wells but is declining as expected. A co-contaminant, technetium-99 (which is not regulated under RCRA), remains elevated slightly above background but is declining similar to nitrate in the network wells. Sulfate was elevated above the background trend during the September sampling in well 699-36-70A; this measurement will be compared to future results to determine if it is real. All other constituents remained on trend at or near background throughout the year.

Based on regional groundwater elevations, the direction of groundwater flow continues relatively unchanged to the east-southeast to east (Figure 2.8-2). The pre-Hanford flow direction in the vicinity of the 216-U-12 crib is believed to have been from west to east, and it is expected that groundwater flow will eventually return to a more easterly direction. Average linear velocities have declined slightly since last year and range from 0.01 to 0.003 meter per day (see Appendix B).

\subsubsection{Waste Management Area U}

The objective of RCRA groundwater monitoring at Waste Management Area U is to assess the rate of movement and extent of hazardous waste constituents in groundwater beneath the site. Waste Management Area U was placed into assessment status in 2000 when specific conductance in groundwater monitoring wells downgradient of the waste management area exceeded upgradient levels (PNNL-13185). An assessment of that finding determined that the waste management area had affected groundwater quality with elevated concentrations of nitrate and possibly chromium in wells downgradient of the waste management area (PNNL-13282). The contaminant concentrations did not exceed their respective drinking water standards, and the area affected appeared to be limited to the southeast corner of the waste management area. A groundwater quality assessment plan (PNNL-13612) was prepared in 2001. The plan was modified in 2003 (PNNL-13612ICN-1) to include monitoring of new wells 299-W18-40, 299-W19-44, and 299-W19-45 and to remove volatile and some radioactive constituents from the analyte list. The plan as modified serves as the current plan by which groundwater quality is assessed at Waste Management Area U. Results of radionuclide monitoring of Waste Management Area U are discussed in Section 2.9.4.

The monitoring network includes eight wells, two upgradient and six downgradient of the waste management area, sampled quarterly (see Appendix B for the location map, well list, constituents, and sampling frequency). All eight wells were sampled each quarter during fiscal year 2003. As part of the Tri-Party Agreement M-24 milestone process for installation of new wells, it was decided to construct one additional well in 2004 on the northeast side of the waste management area, due east of the 244-UR vault.

Groundwater Flow. Groundwater flow conditions at Waste Management Area U have varied greatly over the past several decades because of changing wastewater disposal in areas surrounding the waste management area, but groundwater flow has been generally 
to the east since 1996. During fiscal year 2003, the groundwater flow direction and velocity have remained the same as in the previous year. The rate at which the water table is dropping has also remained constant at $\sim 0.3$ meter per year during fiscal year 2003.

A gyroscope survey of well 299-W18-40 was conducted in January 2003 to determine if anomalous water level results were due to deviation of the well from vertical. The survey showed that the well had a 6.7-meter horizontal deviation from vertical at the water table, resulting in a 0.37 -meter vertical error in water level measurements for the well. Once this correction was applied, the water-level data were consistent with regional water-level trends and historical trends for nearby well 299-W18-25, which went dry in 2001.

The average linear velocity calculated based on a hydraulic conductivity of 6.12 meters per day, a specific yield of 0.17 determined in well 299-W19-42 (PNNL-13378), and a gradient of 0.0021 is $\sim 0.08$ meter per day (see Appendix B). This rate is consistent with the regional groundwater flow interpretation.

Groundwater Contamination. Groundwater chemistry beneath Waste Management Area $U$ in fiscal year 2003 has remained similar to that presented in past years for wells downgradient of the waste management area, but contaminant concentrations have begun to rise in upgradient wells. The waste management area has been identified as the source for a small contaminant plume that is limited to the south half of the downgradient (east) side of the site. This plume is delineated easily by the extent of elevated specific conductance because the plume contains soluble salts comprised of the anions nitrate, chloride, and sulfate that are accompanied by the cations calcium, magnesium, and sodium. Soluble radioactive species are also contained in the plume and are discussed in Section 2.9.4. Of the plume constituents, only nitrate and chromium are relevant to RCRA groundwater monitoring.

During fiscal year 2003, nitrate concentrations continued to increase in downgradient wells (299-W19-41, 299-W19-44, and 299-W19-12) on the south half of the waste management area, indicating that the site is still affecting groundwater quality. The nitrate distribution in the area is shown in Figure 2.9-7. Nitrate concentrations increased above the drinking water standard of $45 \mathrm{mg} / \mathrm{L}$ only in well 299-W19-41 where they remained above that limit for the entire year. Nitrate concentrations also continued to increase in both upgradient wells; by the end of the year, upgradient nitrate concentrations were $~ 25 \%$ to $50 \%$ of the concentration found in downgradient wells. These data indicate that regional upgradient plumes are encroaching into groundwater beneath the waste management area.

The only well with concentrations of chromium above the area background level of $\sim 5 \mu \mathrm{g} / \mathrm{L}$ is well 299-W19-41 where chromium concentrations continued to decrease from 16 to $10 \mu \mathrm{g} / \mathrm{L}$ during the year. A water sample collected in August reportedly contained less than $4.4 \mu \mathrm{g} / \mathrm{L}$ chromium, but a drop of this magnitude is considered suspect. These chromium data indicate that the chromium source has been affected in some way to reduce or eliminate the amount of chromium reaching the water table. In addition, because chromium concentrations have decreased and nitrate concentrations have increased in this well, they clearly have different sources.

Other than nitrate in well 299-W19-41, carbon tetrachloride is the only other hazardous constituent found in groundwater beneath Waste Management Area U at concentrations above its drinking water standard of $5 \mu \mathrm{g} / \mathrm{L}$. The regional carbon tetrachloride distribution (Figure 2.8-3) indicates that the source of carbon tetrachloride found in the Waste Management Area U vicinity is from liquid waste disposal sites from the Plutonium Finishing Plant located northwest of the waste management area.

\subsubsection{Waste Management Area S-SX}

The objective of RCRA groundwater monitoring at Waste Management Area S-SX is to assess the rate of movement and extent of hazardous waste constituents found in groundwater beneath the site. Waste Management Area S-SX was placed into assessment

\section{Groundwater chemistry downgradient of Waste Management Area U was similar to the previous year.}




\section{Sources within \\ Waste Management Area S-SX have contaminated groundwater with nitrate and chromium. The south portion of the plumes expanded in fiscal year 2003.}

status in 1996 at the direction of Ecology because of elevated specific conductance and technetium-99 (not regulated by RCRA) in downgradient monitoring wells. A groundwater quality assessment plan (WHC-SD-EN-AP-191) was prepared in 1996 and the planned assessment work conducted in 1996 and 1997. An assessment of the waste management area determined (first determination) that multiple sources within the waste management area had affected groundwater quality with elevated concentrations of nitrate, technetium-99, and chromium in wells downgradient of the waste management area (PNNL-11810). A second groundwater quality assessment plan (PNNL-12114) was prepared in 1999 to further evaluate the contamination found. Since that time, two groundwater quality assessment reports were published (PNNL-13441; PNNL-13801) covering the time period from November 1997 through December 2001 and the assessment plan was revised twice (PNNL-12114-ICN-1; PNNL-12114-ICN-2) to account for new wells added to the monitoring network and revisions to the sampling and analysis schedule. The plan as modified serves as the current plan by which groundwater quality is assessed at Waste Management Area S-SX.

The monitoring network consists of 16 wells: two upgradient and 13 downgradient of the waste management area, and one well located within the area. The wells are sampled quarterly (see Appendix B for the location map, well list, constituents, and sampling frequency). All 16 wells were sampled each quarter during fiscal year 2003. As part of the Tri-Party Agreement M-24 milestone process for installation of new wells, it was decided to construct one additional well in 2004 southeast of the waste management area, due south of well 299-W22-46, to better define the south boundary of a contaminant plume in this area.

Groundwater Flow. During fiscal year 2003, the groundwater flow direction and velocity remained the same as in the previous year, in spite of the falling water table. The rate at which the water table is dropping remained the same as last year, which is estimated at 0.3 meter per year. This decline was the same in all wells across the waste management area, so hydraulic gradients have remained stable. Estimates of groundwater flow velocity, using travel times for tritium and technetium-99 between monitoring wells in the vicinity of Waste Management Area S-SX, suggest groundwater flow rates of 25 to 50 meters per year or 0.07 to 0.14 meter per day. Calculated average linear velocities (using Darcy's method) based on hydraulic conductivity and tracer test data, also suggest similar flow rates (0.009 to 0.36 meter per day; see Appendix B).

The groundwater flow direction inferred from water-table elevation contours suggests an east-southeast flow direction over the larger area around the waste management area (Figure 2.8-2). This direction of flow is consistent with the shape of the contaminant plume on the south side of the waste management area and the direction in which it is expanding.

Groundwater Contamination. Groundwater beneath this waste management area is contaminated with nitrate, hexavalent chromium, and a radioactive constituent (discussed in Section 2.9.4) attributed to two general source areas within the waste management area. One source area is in the S Tank Farm and one is to the south in the SX Tank Farm. The nitrate and chromium plumes are depicted in Figures 2.9-12 and 2.9-13, which show average concentrations for the fiscal year. Carbon tetrachloride is also present in groundwater beneath the waste management area, but its source is upgradient of the waste management area (Figure 2.8-3). Tritium is also present beneath the waste management area, but it emanates from an upgradient source (see Section 2.9.4).

The north plume, with an apparent source in the S Tank Farm, has migrated eastward through well 299-W22-48, where chromium and nitrate concentrations have leveled-off and even decreased in the second half of the year at $\sim 33 \mu \mathrm{g} / \mathrm{L}$ and $63.0 \mathrm{mg} / \mathrm{L}$, respectively. The bulk of the contaminant plume responsible for these observations is limited to an area between well 299-W22-44 on the north and 299-W22-81 on the south, where chromium and nitrate concentrations are significantly less than in well 299-W22-48. 
The contaminant plumes located in the south portion of the waste management area are comprised of nitrate, chromium, and a radioactive constituent just as in the S Tank Farm plume to the north. The nitrate originates from the tank farm as well as from the 216-S-25 crib, an upgradient source. A smaller plume originates from the north part of the SX Tank Farm, and appears to be merging with the larger plume due to lateral dispersion. The width of the larger plume has changed little during fiscal year 2003, but the longitudinal extent of the plume and internal plume concentrations have changed significantly. Figure 2.9-12 shows average concentrations for the fiscal year, but by the end of the year, the downgradient migrating front had moved through and beyond the farthest downgradient monitoring well 299-W22-83. Nitrate concentrations in this well more than doubled during the fiscal year to $45.2 \mathrm{mg} / \mathrm{L}$, just greater than the drinking water standard of $45 \mathrm{mg} / \mathrm{L}$. Chromium concentrations increased by more than five-fold to $41 \mu \mathrm{g} / \mathrm{L}$, indicating that the distal end of the plume is expanding.

Within the south plume from the S-SX Tank Farm, concentrations of the major constituents (nitrate and chromium) also changed significantly in the source area as represented by well 299-W23-19 and in the middle of the plume as represented by wells 299-W22-46 and 299-W22-50. In well 299-W23-19, nitrate and chromium concentrations increased significantly during the year. Nitrate concentrations spiked to an all time high of 1,680 mg/L in January 2003 and have since that time decreased to $722 \mathrm{mg} / \mathrm{L}$ in September 2003. During the same time, chromium increased from a low of $\sim 16 \mu \mathrm{g} / \mathrm{L}$ in October 2002 to a high of $\sim 60 \mu \mathrm{g} / \mathrm{L}$ in September 2003. There are no known changes in tank farm operations or water releases at the site to account for these changes and earlier large fluctuations in concentrations.

In the middle of the south plume, both nitrate and chromium concentrations continued to increase so that by September 2003, concentrations of both constituents exceeded their respective drinking water standards. This south plume could be characterized as having a source nitrate concentration of $\sim 1,000 \mathrm{mg} / \mathrm{L}$ that decreases to $\sim 75 \mathrm{mg} / \mathrm{L}$ just beyond the downgradient margin of the waste management area, that further decreases to $45 \mathrm{mg} / \mathrm{L}$ at the farthest downgradient monitoring well. Chromium concentrations have a similar trend with the source concentration of $140 \mu \mathrm{g} / \mathrm{L}$ (in 2001) that decreases to $~ 120 \mu \mathrm{g} / \mathrm{L}$ just beyond the downgradient boundary of the waste management area, that further decreases to $40 \mu \mathrm{g} / \mathrm{L}$ at the farthest downgradient monitoring well.

Specific Conductance Measurements in Well 299-W23-19. Well 299-W23-19 was re-configured in February and March 2003 so samples could be obtained without entering the tank farm. At that time, a permanent sampling pump and four specific conductance probes were installed in the well. Also, at the request of Ecology, the practice of purging at least 3,785 liters of water from the well after each quarterly sampling event was started in March (see Section 2.9.4.2).

As reported in the fiscal year 2002 annual report, specific conductance was measured at half meter intervals through the screened interval in well 299-W23-19 using a specific conductance probe. This work was done to test the possibility that fluctuations in sample groundwater chemistry reflected actual variations in the plume. Specific conductance is a measure of the quantity of the major dissolved constituents such as calcium, magnesium, chloride, and nitrate in the water. Because these constituents are major components of the contaminant plume, specific conductance is an easily measured indicator of the plume location. Specific conductance profiles were developed on four dates from September 20, 2002 through March 11, 2003 (Figure 2.9-14). An original profile developed shortly after the well was completed in 1999 is provided for comparison. These data indicate that the aquifer chemistry differed between sampling dates. However, the three profiles measured in fiscal year 2003 all exhibit the same pattern of increasing specific conductance from the water table to between 3 and 4.5 meters below the water table where the measurements stabilized from that point to the bottom of the well. The range in specific conductance indicated by these profiles is consistent with the variations in groundwater chemistry measured in well 299-W23-19 in the past.
In fiscal year 2003,

a permanent

sampling pump and

four specific

conductance probes

were installed in

well 299-W23-19.

Data from these

probes indicates

that contamination

occurs primarily in

the upper part of

the aquifer. 


\section{Results of recent studies in well 299-W23-19 show that the vertical location of the sample pump intake will not have a significant effect on measured constituent concentrations.}

The specific conductance profile measured on March 11, 2003, was obtained using the bottom specific conductance probe (\# 4) while the pump and four-probe assembly was placed in the well. Specific conductance measurements have been recorded at intervals no longer than 30 minutes for each of the probes since that date. These data are presented in Figure 2.9-15. This figure shows that sampling on March 12, June 18, and September 23 greatly perturbed the water chemistry in the well and that dissolved solids (as indicated by specific conductance) in the well decreased $\sim 40 \%$ to $50 \%$ during the 6 months. This decreasing trend is consistent with the drop in nitrate concentrations discussed previously. Figure 2.9-16 presents an expanded view of the data during the September 23 sampling and purging event.

Figure 2.9-16 shows the magnitude of the difference in groundwater composition between static and dynamic conditions in the well. Prior to 0800 hours, measurements were made under static conditions. When the pump was turned on, specific conductance increased in the upper three probes, but dropped in probe \#4, the deepest probe located $\sim 1$ meter below the pump intake and $\sim 0.7$ meter above the bottom of the well. Probe locations are shown in Figure 2.9-14. Because the pump intake is set between probes $\# 3$ and $\# 4$, water pumped to the ground surface would have a composition that is a blend of water passing these two probes. However, because of the erratic responses observed in the data from probe \#4, that data was not considered in the following assessment. For purposes of interpreting the data presented in Figure 2.9-16, it is assumed that the aquifer is isotropic and homogeneous; therefore, the amount of water entering the well would be the same at all vertical locations from the water table to the bottom of the well screen. Therefore, the amount of water produced by any interval of the well screen is only a function of the interval length. Based on these data and this assumption, an interpretation of the vertical distribution of plume compositions is presented in Table 2.9-2.

As water is pumped from the well, the well is recharged with water from the aquifer. Because of the location of the pump intake, the composition of water passing probes $\# 1, \# 2$, and $\# 3$ is a blend of water entering the well above their respective locations. Using a simple mixing model, the average concentration of the water entering the well within a specific interval can be calculated. Probe $\# 1$ reflects the composition of water entering the uppermost 1.2 meters of the aquifer $-\sim 2,100 \mu \mathrm{S} / \mathrm{cm}$. Probe $\# 2$ represents a blend of water from the upper 3.1 meters of the aquifer, but the concentration of water entering the well between the two probes is considerably greater $(2,915 \mu \mathrm{S} / \mathrm{cm})$ than that entering above probe $\# 1$ in order to raise the mean composition of the water passing probe $\# 2$ by $500 \mu \mathrm{S} / \mathrm{cm}$. Applying this same logic and simple mixing to the other intervals in the well, the specific conductance of the water entering from each interval is calculated and presented in Table 2.9-2. As previously stated, data from probe \#4 were not used in this analysis. Therefore, the concentration of the deepest zone is an average of all water entering the well below probe $\# 3$. This assessment of the data indicates that the plume, as delineated by elevated specific conductance, is located mainly in the upper 3 to 4 meters of the aquifer. The lower plume boundary is reasonably sharp with the groundwater composition falling significantly over, at most, a 2-meter interval. Similar results were observed in the first two pumping events on March 12 and June 18.

These calculations assume that flow is uniform across the well screen. To test this assumption, a simple uncertainty analysis was performed by varying the assumed flow rate in each interval. Assuming higher flow from the upper part of the screen produces aquifer specific conductance estimates for the lower part that are not physically possible (i.e., less than zero). When flow was assumed to be higher in the lower part of the screen, the aquifer specific conductance estimates remained higher in the upper part. Therefore, the conclusion that the plume is located primarily in the upper part of the aquifer is considered valid, even under conditions of non-uniform flow.

These data show that the pumped water is a blend of water entering the well from all parts of the screened interval and not just that portion of the screen near the pump intake. 
Therefore, the vertical location of the sample pump intake will not have a significant effect on measured constituent concentrations, as long as the well is purged adequately before a sample is collected. In addition, water samples collected from this well under static conditions, such as with a bailer or a low purge technique or with a down-well sensor, may not yield data that are representative of the aquifer. This is because the water composition within the well under static conditions is not representative of the vertical distribution of contaminants in the aquifer.

\subsubsection{216-S-10 Pond and Ditch}

The 216-S-10 pond and ditch was active from 1951 through 1991, and received effluent primarily from the REDOX Plant chemical sewer. The site is monitored semiannually under RCRA interim status indicator evaluation to detect any effect on groundwater that may occur from past facility operations. The list of monitored wells, sampling frequency, constituents, and the facility well location map are provided in Appendix B. An updated and revised RCRA groundwater monitoring plan (PNNL-14070) was published in 2002. RCRA groundwater monitoring has been conducted in accordance with interim status requirements since 1991. The 216-S-10 facility has not received liquid waste since October 1991 and is scheduled to be closed under a Part B Permit after 2006 in accordance with the Tri-Party Agreement (Ecology et al. 1998) permit modification schedule, and in accordance with a future CERCLA record of decision.

The water table beneath the 216-S-10 pond and ditch continued to decline in fiscal year 2003. The current RCRA monitoring network consists of only two downgradient wells (the others having gone dry): well 299-W26-13 located near the pond and new well 299-W26-14 located just east of the central portion of the ditch. The upgradient well, 299-W26-7, went dry sometime between June and September 2003. RCRA requirements for interim status monitoring specify that a minimum of one upgradient and three downgradient monitoring wells are needed to monitor the site. The updated groundwater monitoring plan (PNNL-14070) proposes to deepen two existing dry wells to bring the facility back in compliance with RCRA requirements. Ecology, DOE, and EPA will negotiate installations of future monitoring wells under the Tri-Party Agreement Milestone M-24-00 (Ecology et al. 1998).

The only exceedance of a drinking water standard occurred in the shallow upgradient well 299-W26-7 for hexavalent chromium (currently above the $100 \mu \mathrm{g} / \mathrm{L}$ drinking water standard), and in the deep well 299-W27-2 for carbon tetrachloride. Nickel also is elevated in well 299-W27-2. The carbon tetrachloride is believed to have come from an upgradient source. The source of nickel is unknown, but it might be related to corrosion of the well casing or screen. The long, gradual increase in nickel concentrations, followed by a downward trend, suggests this occurrence is not an analytical or sampling artifact. During the June 2003 sampling event, total organic carbon was reported elevated in all the network wells and has been flagged for further evaluation. This elevated total organic carbon appears to be a laboratory error.

Chromium concentrations at well 299-W26-7 have varied in the past 10 years (Figure 2.9-17). This may be caused by short-term releases migrating through the vadose zone. For example, historical records document a 1983 release to the 216-S-10 facility of a highsalt waste (simulated tank waste) containing hexavalent chromium. Although well 299-W26-7 was designated an upgradient well, it is located very close to one lobe of the pond system and could easily have been affected by drainage spreading laterally in the vadose zone (see Appendix B). The June 2003 chromium value was $209 \mu \mathrm{g} / \mathrm{L}$, up from the December 2002 value of $200 \mu \mathrm{g} / \mathrm{L}$; however, this well has gone dry, which could have affected the latest measured chromium concentrations. Chromium concentrations in new well 299-W26-13, located nearly downgradient of well 299-W26-7, to date have not been elevated.

\section{Comparisons of RCRA indicator parameters at the 216-S-10 pond and ditch show no statistically significant differences, but elevated chromium and nitrate in the upgradient well 299-W26-7 could have come from this facility.}
All but two of the monitoring wells for the 216-S-10 pond and ditch have gone dry. 
Waste Management

Area U has

contaminated

groundwater with

technetium-99,

although

concentrations are

below the drinking

water standard.

\section{Concentrations of}

technetium-99 in

well 299-W23-19, at

Waste Management

Area S-SX, reached

$188,000 \mathrm{pCi} / \mathrm{L}$ in

January 2003, the

highest value

ever measured

in Hanford

groundwater.
Nitrate concentrations are covariate with chromium concentrations in wells 299-W26-7, 299-W26-9, 299-W26-10, and 299-W26-12 (e.g., Figure 2.9-18). The upgradient well 299-W26-7 had the highest nitrate concentrations. This and other data presented in PNNL-14070 suggests that the 216-S-10 pond could be the source of this latest nitrate and chromium increase. Although chromium and nitrate are elevated in the upgradient wells, significant concentrations of these constituents have not been detected in the downgradient wells. Comparisons of RCRA indicator parameters (specific conductance, $\mathrm{pH}$, total organic carbon, and total organic halogens) at the 216-S-10 pond and ditch show no statistically significant differences (i.e., constituents in the downgradient wells are not elevated compared to the upgradient well). Therefore, this site remains in detection monitoring.

Based on regional groundwater elevations, the groundwater flow direction continues toward the east-southeast. The average linear velocity has not changed significantly since last year. Background values of contaminant indicator parameters for the facility have been re-calculated using values from the now dry upgradient well, 299-W26-7 (see Appendix B).

\subsubsection{AEA Monitoring}

AEA groundwater monitoring is performed throughout the 200-UP-1 groundwater interest area. This section provides information on monitoring of radionuclides from Waste Management Areas U and S-SX, because radionuclide releases from these sites are not regulated under RCRA.

\subsubsection{Waste Management Area U}

Technetium-99 has been detected in groundwater on the downgradient (east) side of Waste Management Area U, and its presence was attributed to the waste management area. During fiscal year 2003, technetium-99 concentrations have tended to decrease in those wells (299-W19-12, 299-W19-41, and 299-W19-44) within the contaminant plume emanating from beneath the site. All measured concentrations during the fiscal year were below the drinking water standard of $900 \mathrm{pCi} / \mathrm{L}$.

It appears that a technetium-99 regional plume is encroaching into the area around Waste Management Area U. During fiscal year 2003, technetium-99 was either detected for the first time or concentrations began to increase in wells located outside and upgradient of the plume area. Concentrations of technetium-99 inside the local plume averaged between 240 to $450 \mathrm{pCi} / \mathrm{L}$ while concentrations in the wells outside the local plume were less than $100 \mathrm{pCi} / \mathrm{L}$.

\subsubsection{Waste Management Area S-SX}

Technetium-99 and tritium have been detected in groundwater beneath Waste Management Area S-SX. The areal distributions of these two constituents in the vicinity of the waste management area are shown in Figures 2.9-19 and 2.9-20. These two figures suggest that the source for the tritium is the 216-S-25 crib located west (upgradient) of the waste management area; there are two sources of technetium-99 within the waste management area. The orientation of the tritium plume and the south technetium-99 plume is the same and consistent with the east-southeast direction of groundwater flow in the area. During fiscal year 2003, technetium-99 concentrations varied in the same manner as nitrate in all of the wells located in the two plumes emanating from the waste management area. Technetium-99 reached a maximum concentration of $188,000 \mathrm{pCi} / \mathrm{L}$ in well 299-W23-19 in January 2003, which is above the DOE derived concentration guide of $100,000 \mathrm{pCi} / \mathrm{L}$. Concentrations subsequently declined to $\sim 75,000 \mathrm{pCi} / \mathrm{L}$ by the end of the fiscal year. The farthest downgradient monitoring wells for both technetium-99 plumes had concentrations at $\sim 3,500$ to $4,000 \mathrm{pCi} / \mathrm{L}$, where they may have begun to level off. 
Technetium-99 capture and treatment at well 299-W23-19 during sampling, as agreed to by DOE and Ecology, was implemented beginning with the March 12, 2003, sampling event. Responsibility for pumping and treating of groundwater was transferred from $\mathrm{CH} 2 \mathrm{M}$ HILL Hanford Group, Inc. to Fluor Hanford, Inc. after re-completion of the wellhead to allow sampling of the well without entering the tank farm. The practice of treating a day's worth of groundwater pumping each quarter (a goal of at least 3,785 liters) and disposing of it at the Effluent Treatment Facility was implemented.

Table 2.9-3 presents the date, amount of water collected, and a calculation of the mass and activity of technetium-99 removed from the aquifer. A total of $\sim 0.001$ curies ( 0.067 grams) of technetium-99 has been recovered through fiscal year 2003. The sample of March 12, 2003, was below the target of 3,785 liters due to filter problems. The Effluent Treatment Facility requires that influent water not contain particles larger than 5 microns. A filter on the truck clogged with +5 micron material and slowed the pumping rate. A new filter design was adapted for the purgewater truck, and pumping rates have been able to meet the target volume in the last two quarters. 
Table 2.9-1. Summary of Contaminant Mass Removed from the Aquifer during Pump-and-Treat Operations at the 200-UP-1 Operable Unit - Fiscal Year 2003 and Totals Since Startup of Operations

\begin{tabular}{lcc}
\multicolumn{1}{c}{ Contaminant } & Fiscal Year 2003 & Since Startup (March 1994) \\
Uranium & $21.2 \mathrm{~kg}$ & $179.5 \mathrm{~kg}$ \\
Technetium-99 & $11.8 \mathrm{~g}(0.2 \mathrm{Ci})$ & $102 \mathrm{~g}(1.73 \mathrm{Ci})$ \\
Carbon tetrachloride & $2.8 \mathrm{~kg}$ & $25.7 \mathrm{~kg}$ \\
Nitrate & $4,158 \mathrm{~kg}$ & $27,344 \mathrm{~kg}$
\end{tabular}

Table 2.9-2. Vertical Variation of Groundwater Composition Measured in the Wellbore of Well 299-W23-19 and Estimated for the Adjacent Aquifer During the End of a 4,013-Liter Purge on September 23, 2003

\begin{tabular}{|c|c|c|c|c|}
\hline $\begin{array}{c}\text { Measurement } \\
\text { Point }^{(a)} \\
\end{array}$ & $\begin{array}{c}\text { Depth Below } \\
\text { Water Table }(\mathrm{m}) \\
\end{array}$ & $\begin{array}{c}\text { Interval } \\
\text { Length }^{(\mathrm{b})}(\mathrm{m}) \\
\end{array}$ & $\begin{array}{c}\text { Measured In-Well } \\
\text { Specific Conductance } \\
(\mu \mathrm{S} / \mathrm{cm}) \\
\end{array}$ & $\begin{array}{c}\text { Estimated Aquifer } \\
\text { Specific Conductance } \\
\text { Over the Interval }{ }^{(c)}(\mu \mathrm{S} / \mathrm{cm}) \\
\end{array}$ \\
\hline Probe \#1 & 1.2 & 1.2 & 2,100 & 2,100 \\
\hline Probe \#2 & 3.1 & 1.9 & 2,600 & 2,915 \\
\hline Probe \#3 & 4.9 & 1.8 & 1,900 & 694 \\
\hline Pump Intake & 5.8 & 0.9 & 1,450 & 663 \\
\hline Well Bottom & 7.7 & 1.9 & Not measured & \\
\hline
\end{tabular}

(a) Data from probe \#4 are considered unreliable and are not used in this estimate.

(b) The interval length is the distance between probes, between probe \#3 and the pump intake, between probe \#1 and the water table, or between the pump intake and the well bottom.

(c) It is assumed that the aquifer is homogenous and isotropic, i.e., water enters the well uniformly across the entire saturated portion of the screen during pumping. Therefore, the specific conductance in the aquifer for an interval was computed assuming that the quantity of water entering the well across that interval is only a function of the interval length.

Table 2.9-3. Quantity of Treated Groundwater and Technetium-99 Mass Removed from the Aquifer During Extended Purging at Well 299-W23-19

\begin{tabular}{|c|c|c|c|c|}
\hline Sample Date & $\begin{array}{l}\text { Volume of Water } \\
\text { Treated Liters (gal) }\end{array}$ & $\begin{array}{c}\text { Technetium- } 99 \\
\text { Concentration } \\
(\mathrm{pCi} / \mathrm{L})\end{array}$ & $\begin{array}{c}\text { Activity of } \\
\text { Technetium-99 } \\
\text { Removed (Ci) }\end{array}$ & $\begin{array}{c}\text { Mass of } \\
\text { Technetium-99 } \\
\text { Removed (g) }\end{array}$ \\
\hline March 12, 2003 & $2,725(720)$ & 133,000 & 0.00036 & 0.021 \\
\hline June 18,2003 & $4,028(1,064)$ & 120,000 & 0.00048 & 0.028 \\
\hline September 23, 2003 & $4,013(1,060)$ & 74,300 & 0.00030 & 0.018 \\
\hline Totals & $10,766(2,844)$ & NA & 0.00114 & 0.067 \\
\hline
\end{tabular}

NA $=$ Not applicable 


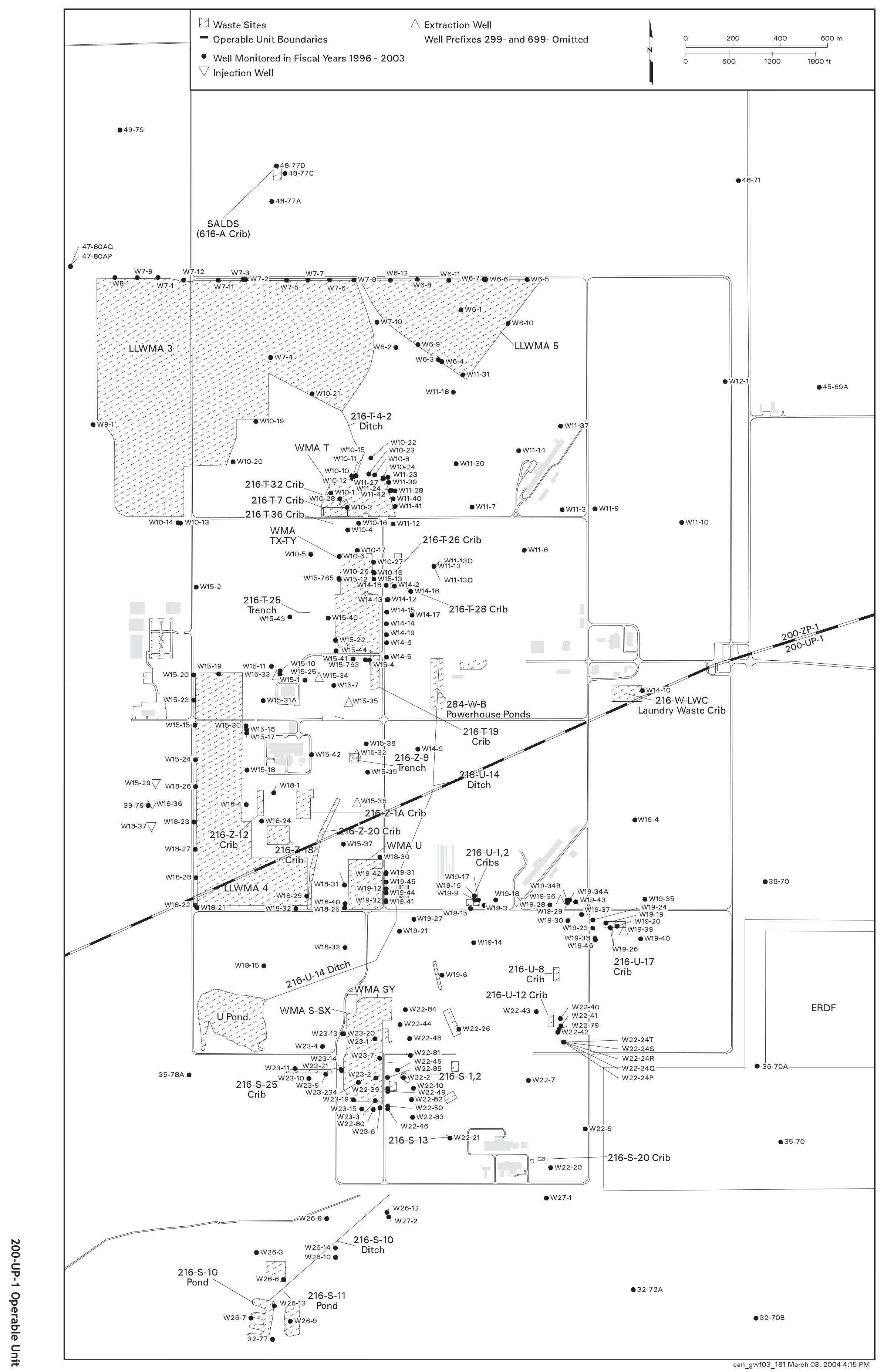

Figure 2.9-1. Facilities and Groundwater Monitoring Wells in the 200 West Area 


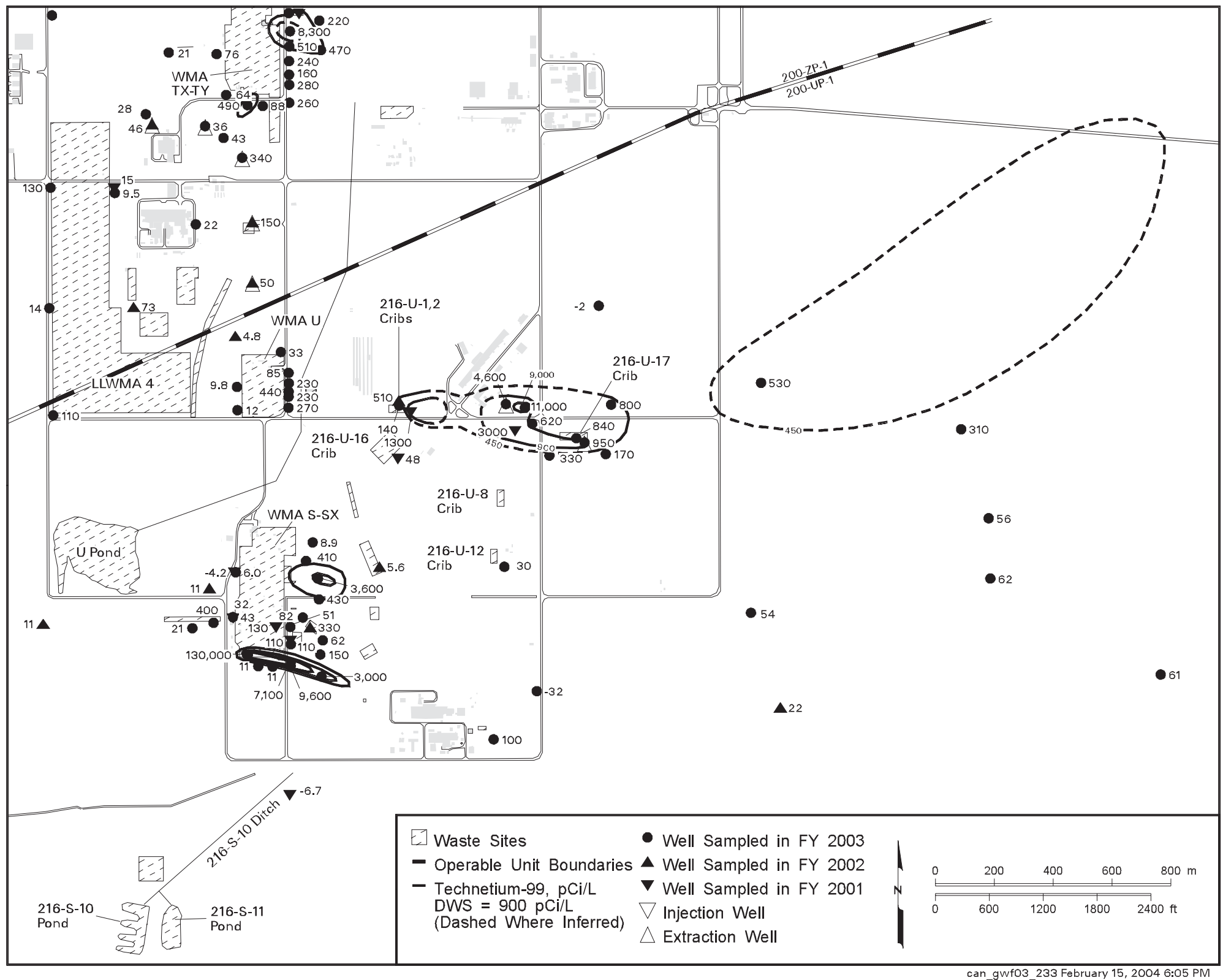

Figure 2.9-2. Average Technetium-99 Concentrations in the 200-UP-1 Groundwater Interest Area, Top of Unconfined Aquifer 


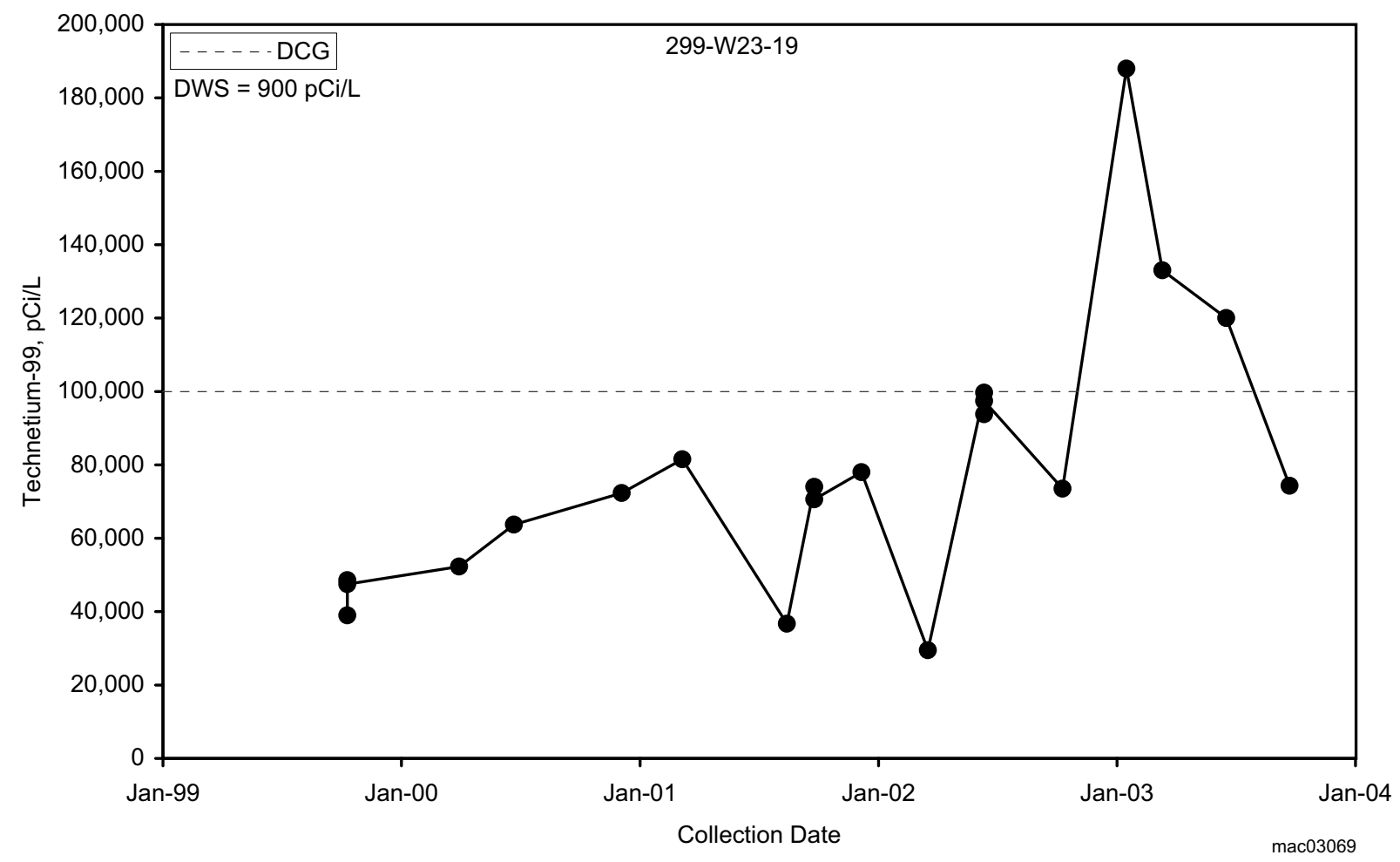

Figure 2.9-3. Technetium-99 Concentrations at Waste Management Area S-SX 


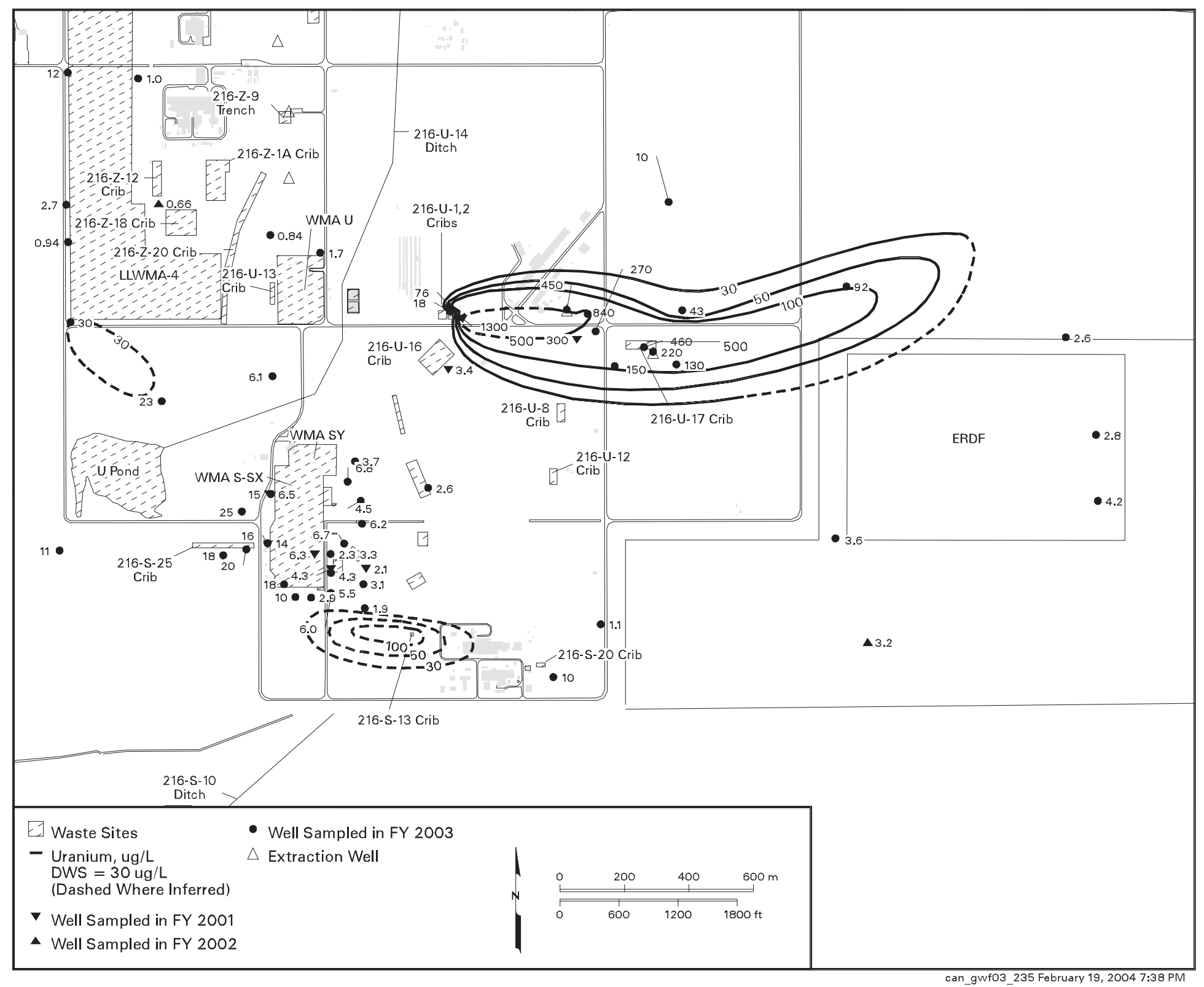

Figure 2.9-4. Average Uranium Concentrations in the 200-UP-1 Groundwater Interest Area, Top of Unconfined Aquifer 


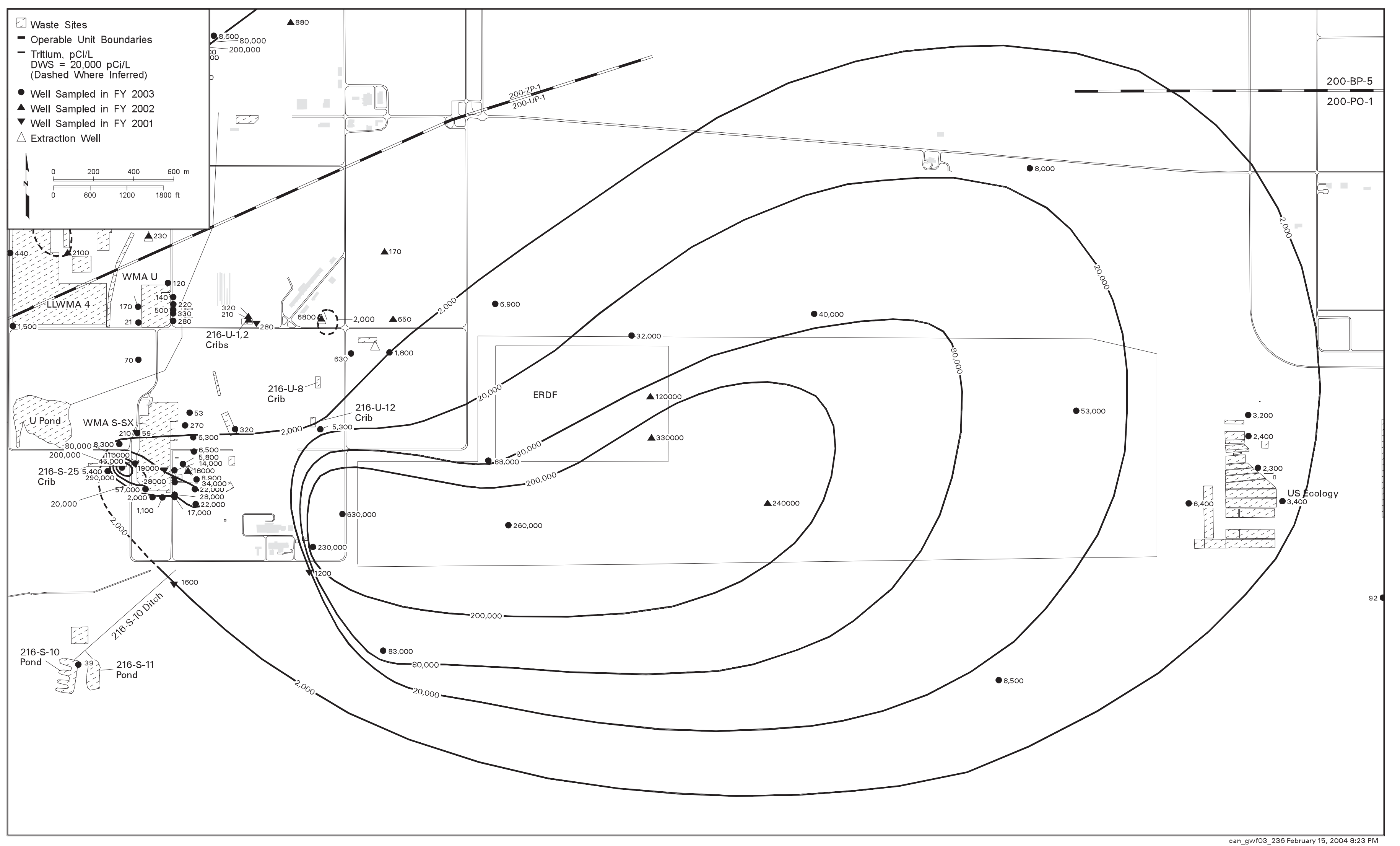

Figure 2.9-5. Average Tritium Concentrations in the 200-UP-1 Groundwater Interest Area, Top of Unconfined Aquifer

200-UP-1 Operable Unit

2.9-25 


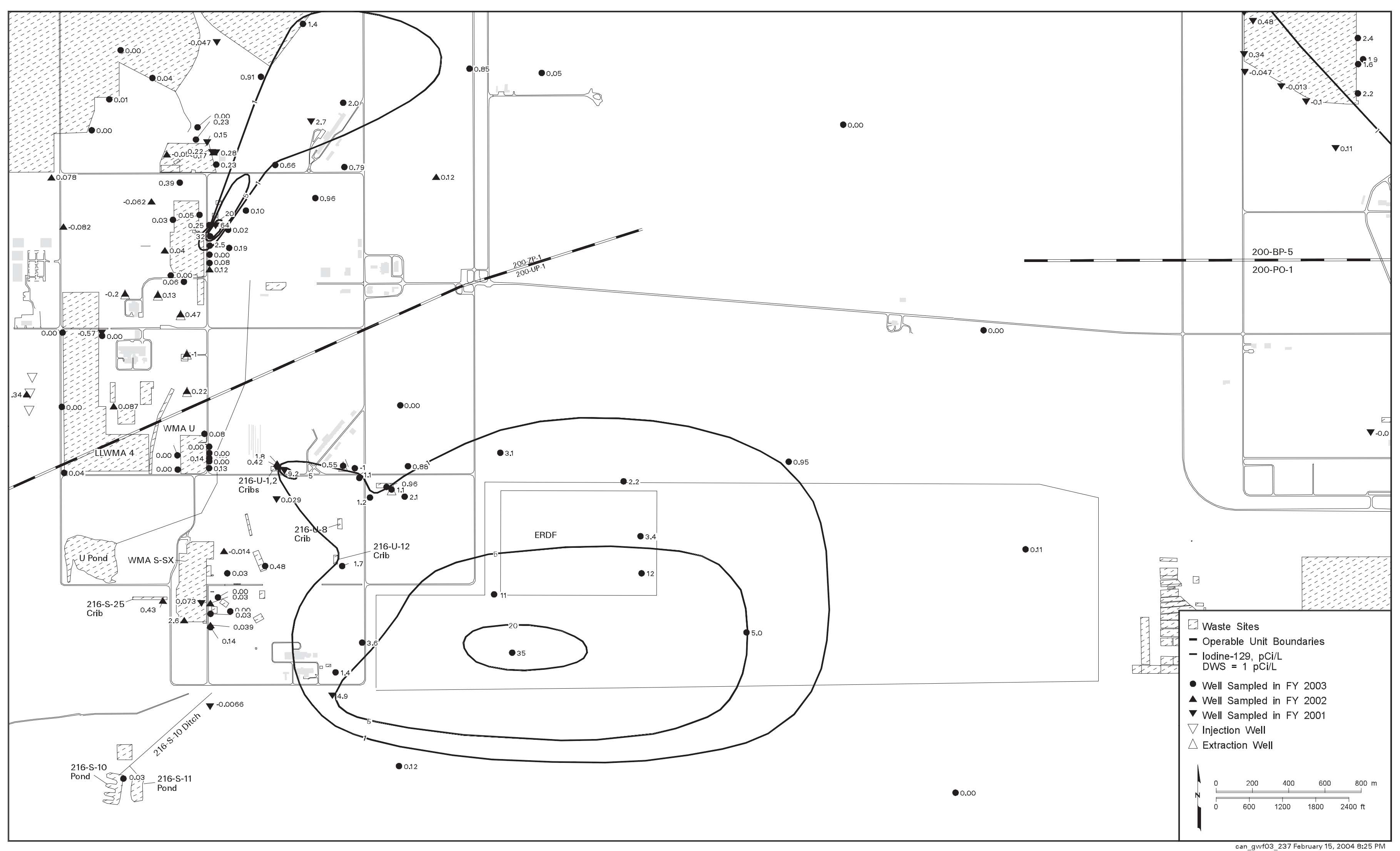

Figure 2.9-6. Average Iodine-129 Concentrations in the 200-UP-1 Groundwater Interest Area, Top of Unconfined Aquifer 


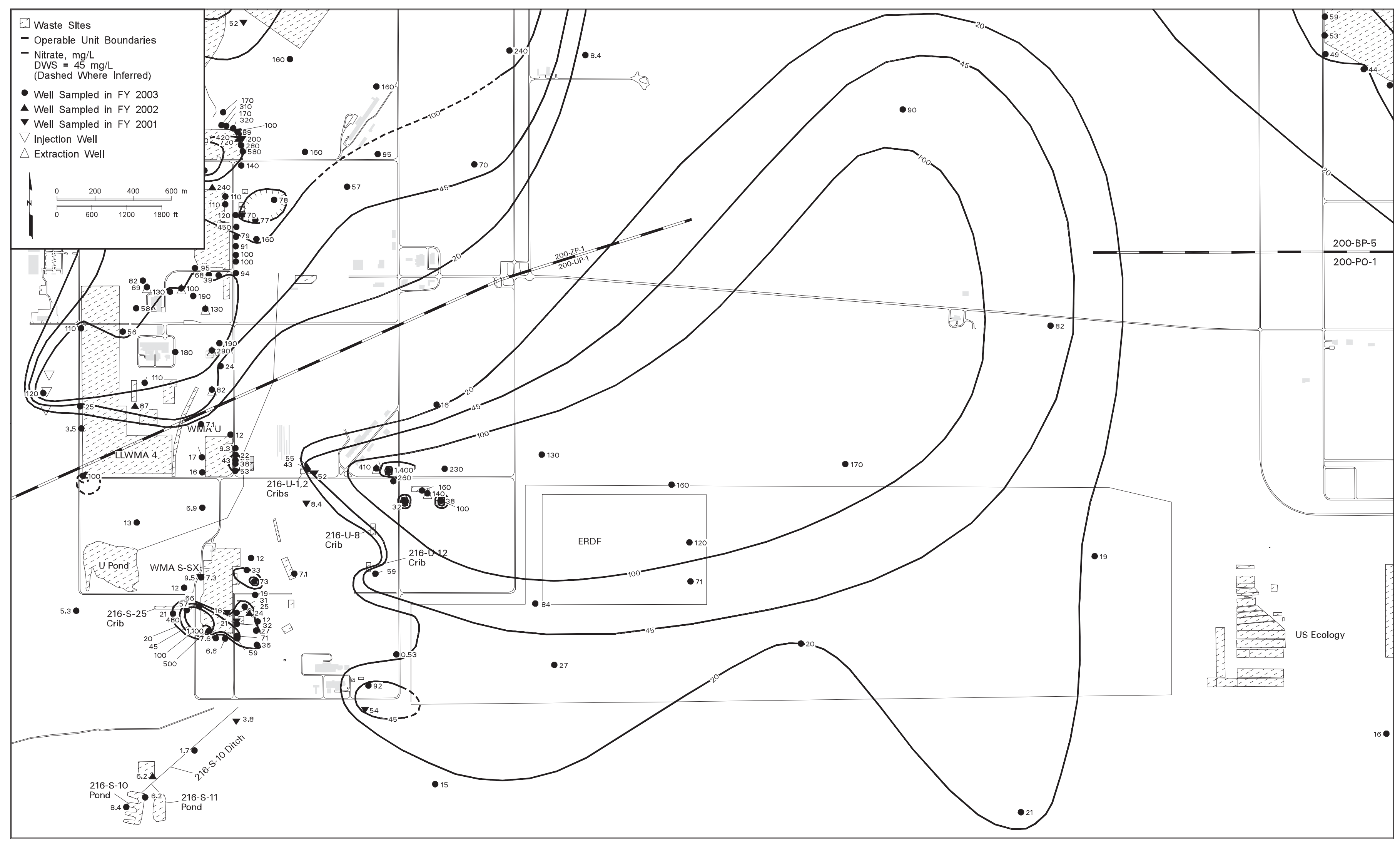

Figure 2.9-7. Average Nitrate Concentrations in the 200-UP-1 Groundwater Interest Area, Top of Unconfined Aquifer 


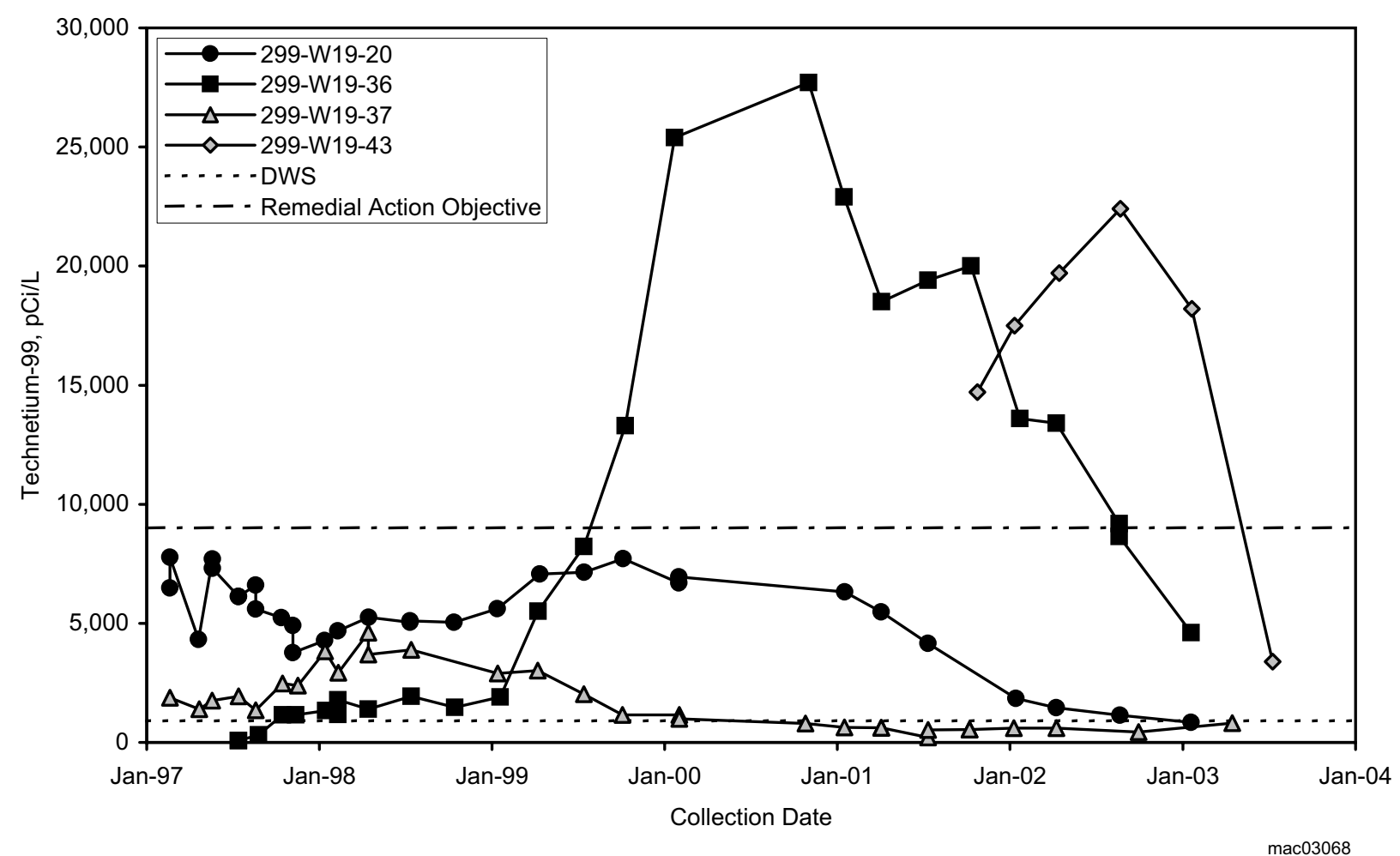

Figure 2.9-8. Technetium-99 Concentrations in Extraction and Monitoring Wells at the 200-UP-1 Pump-andTreat Area (Well 299-W19-43 replaced well 299-W19-36 as an extraction well in May 2003.)

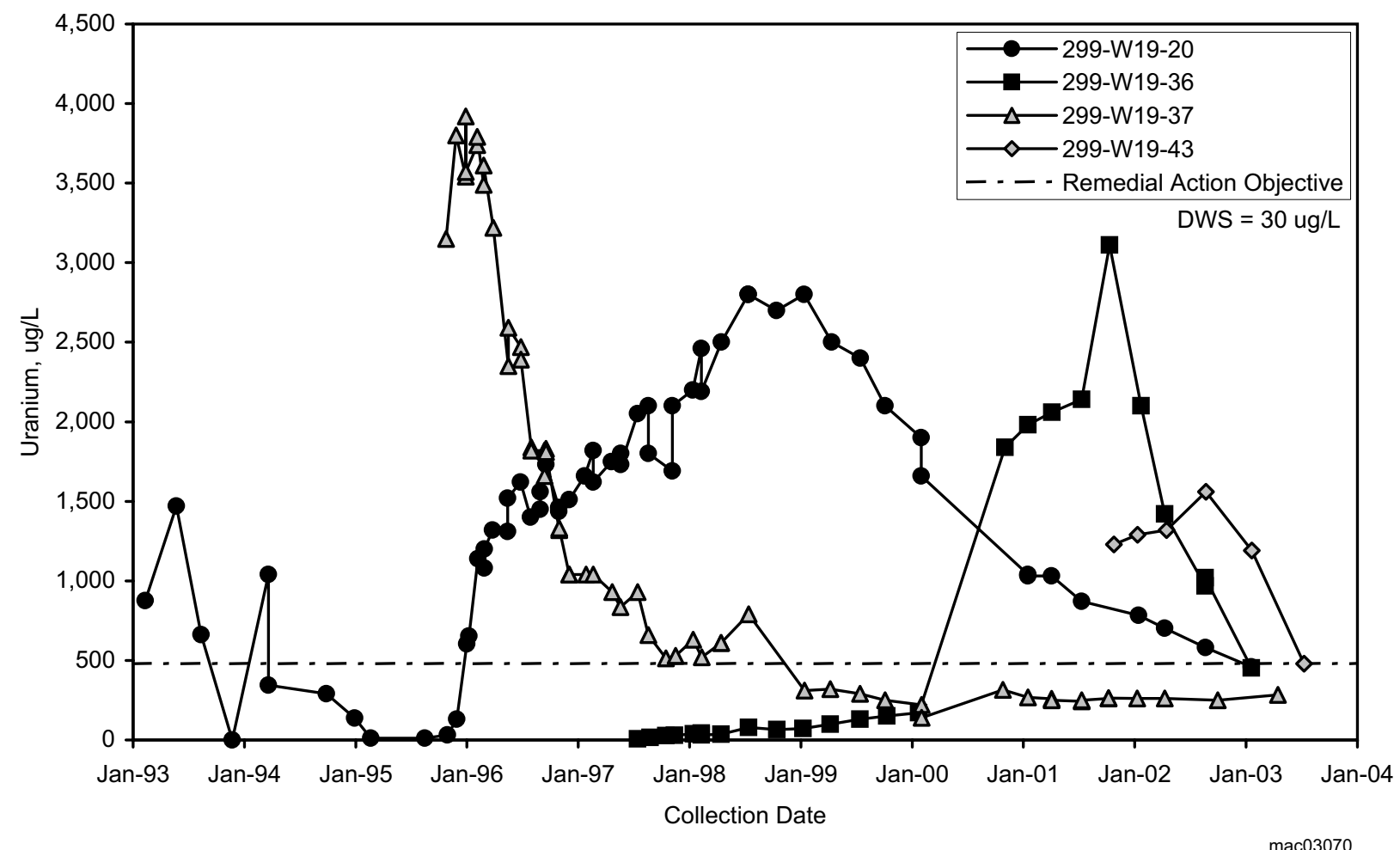

Figure 2.9-9. Uranium Concentrations in Extraction and Monitoring Wells at the 200-UP-1 Pump-and-Treat Area (Well 299-W19-43 replaced well 299-W19-36 as an extraction well in May 2003.) 


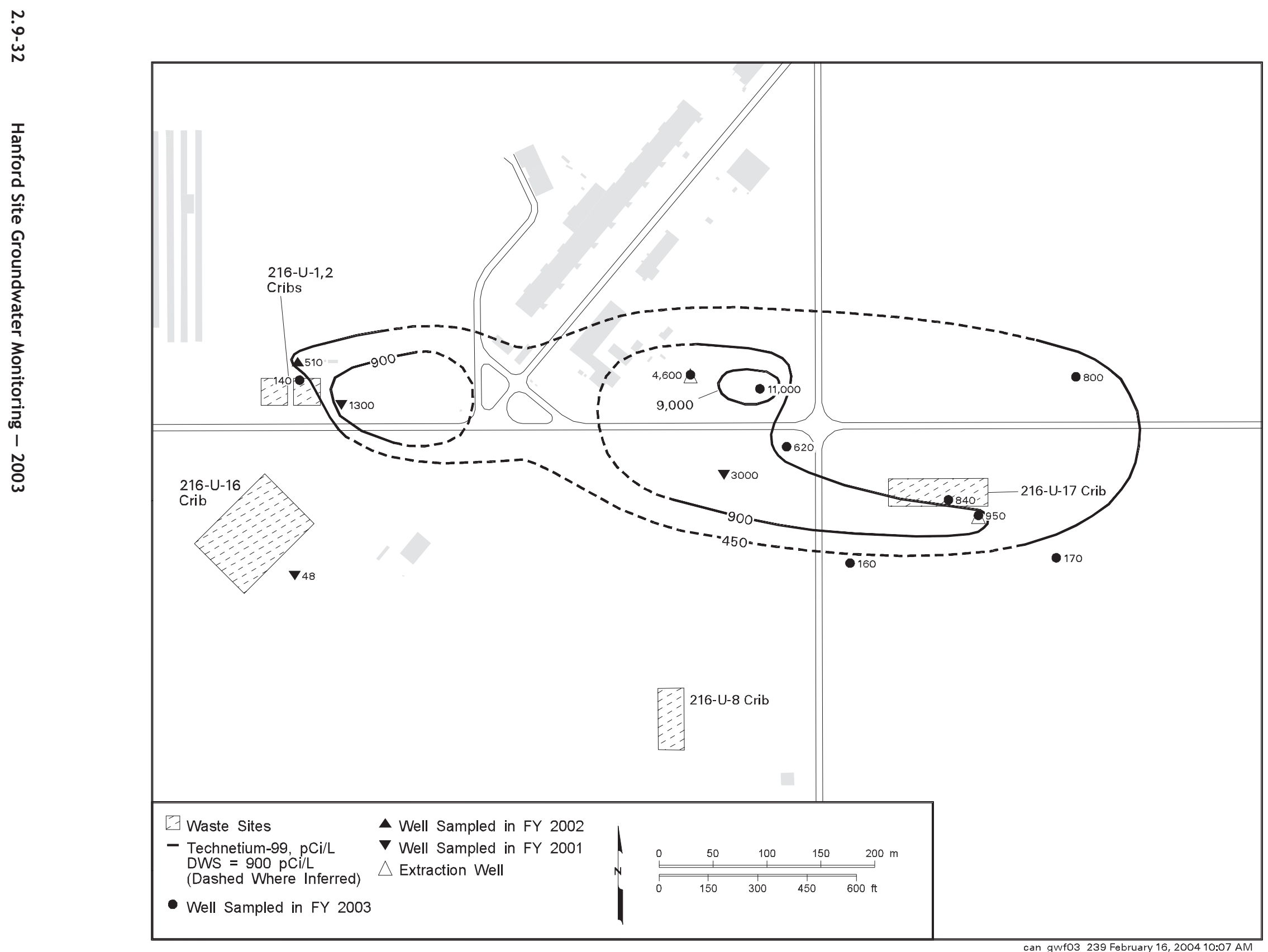

Figure 2.9-10. Average Technetium-99 Concentrations in the 200-UP-1 Pump-and-Treat Area, Top of Unconfined Aquifer 


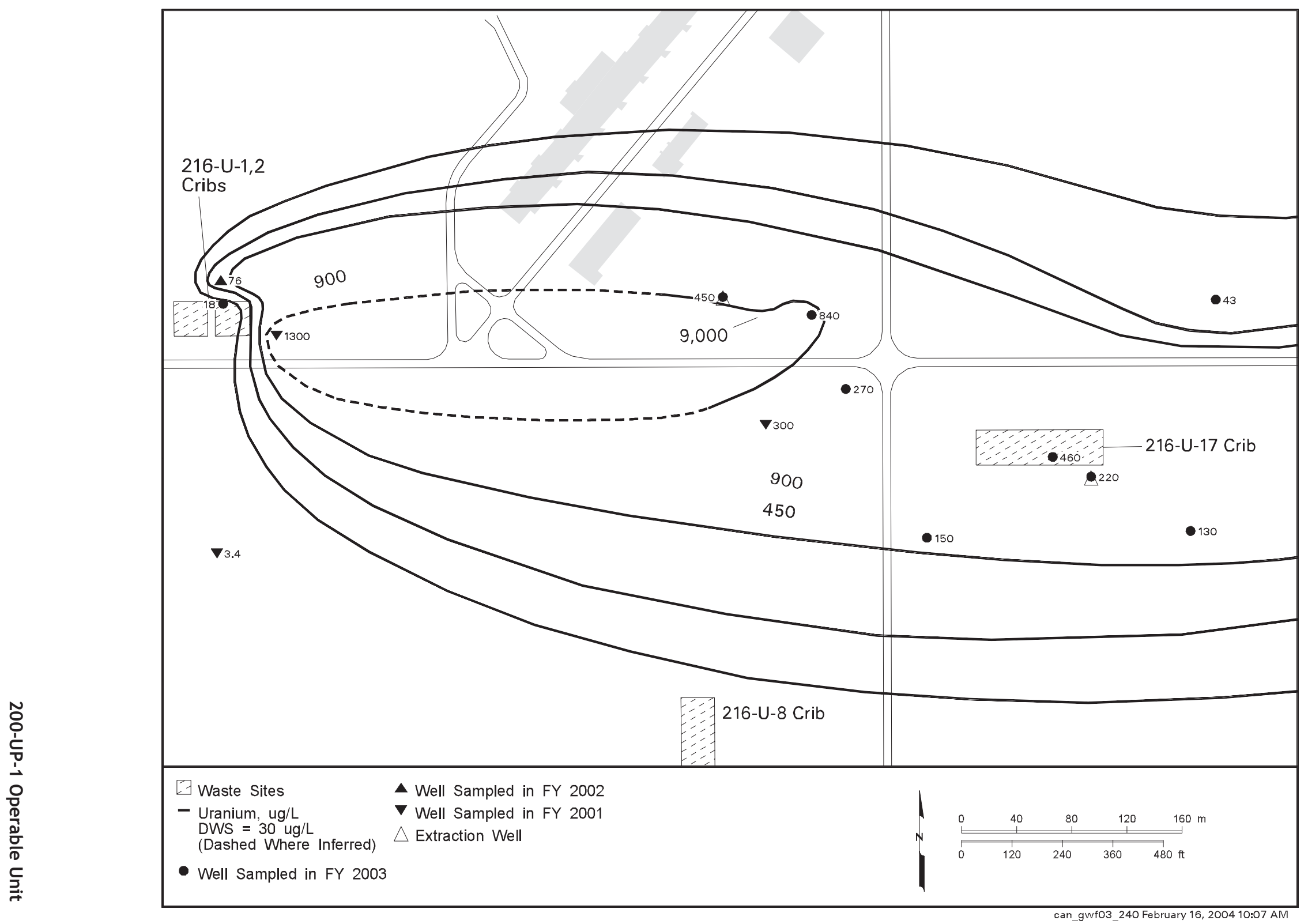

Figure 2.9-11. Average Uranium Concentrations in the 200-UP-1 Pump-and-Treat Area, Top of Unconfined Aquifer 


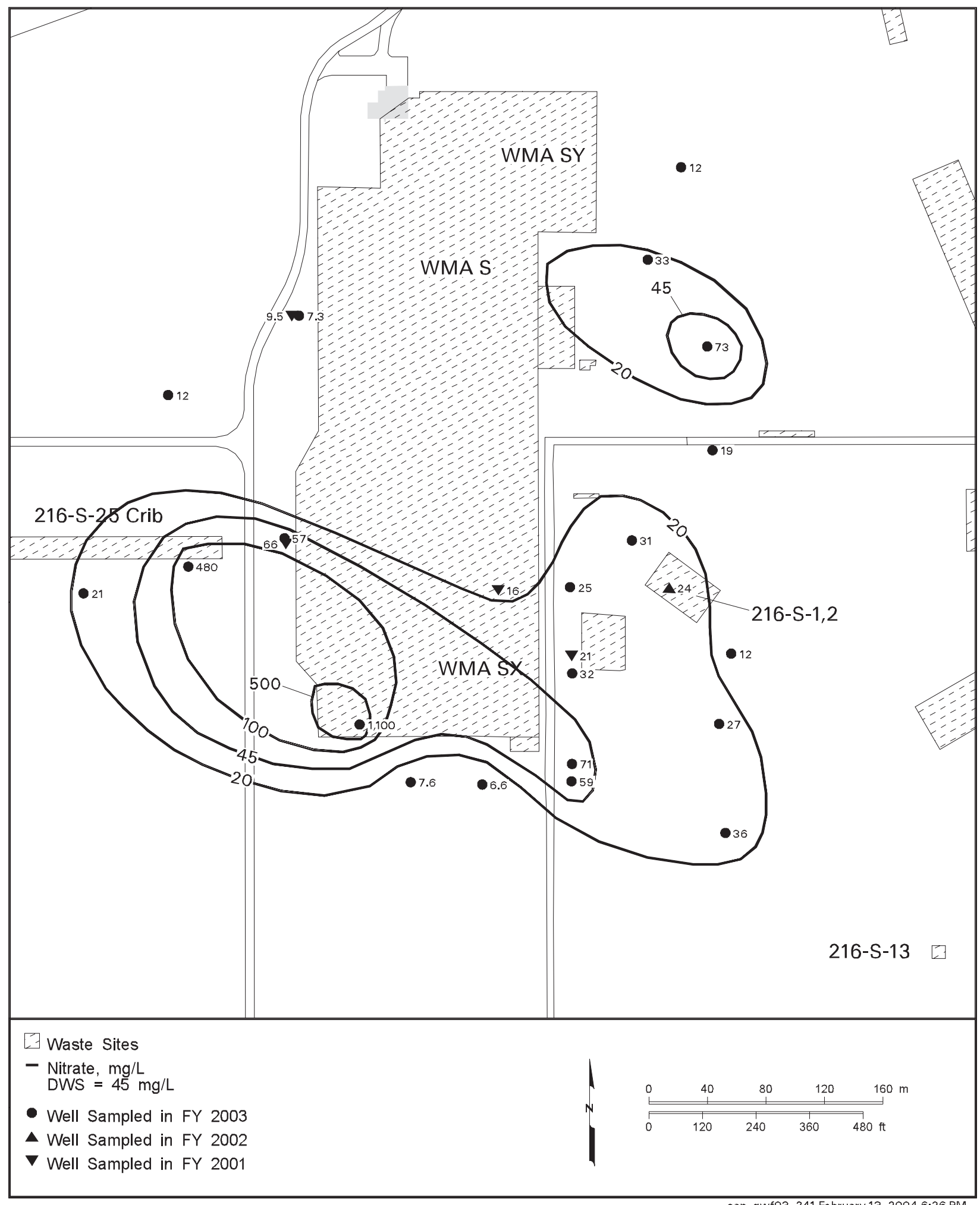

Figure 2.9-12. Average Nitrate Concentrations at Waste Management Area S-SX, Top of Unconfined Aquifer 


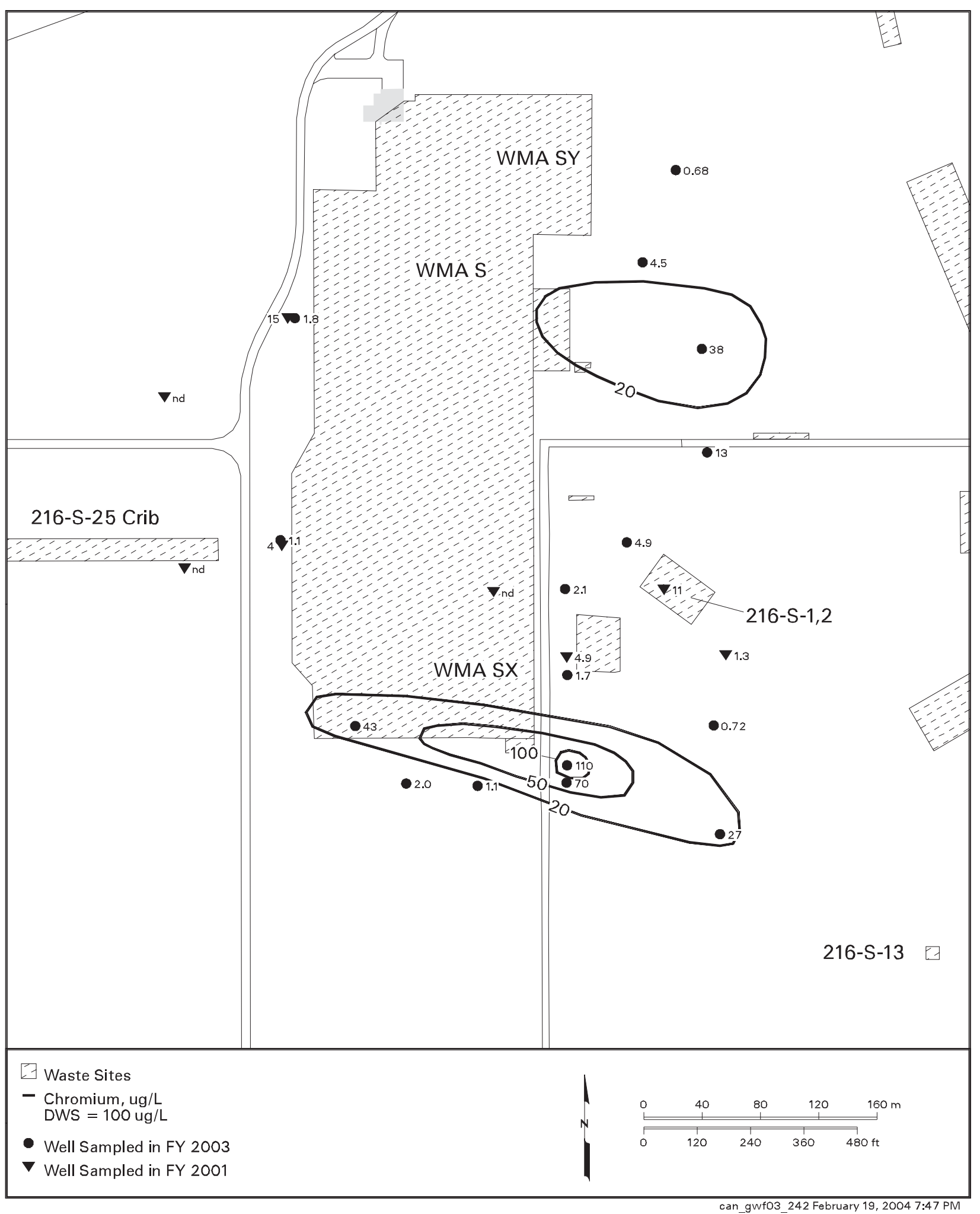

Figure 2.9-13. Average Chromium Concentrations at Waste Management Area S-SX, Top of Unconfined Aquifer 


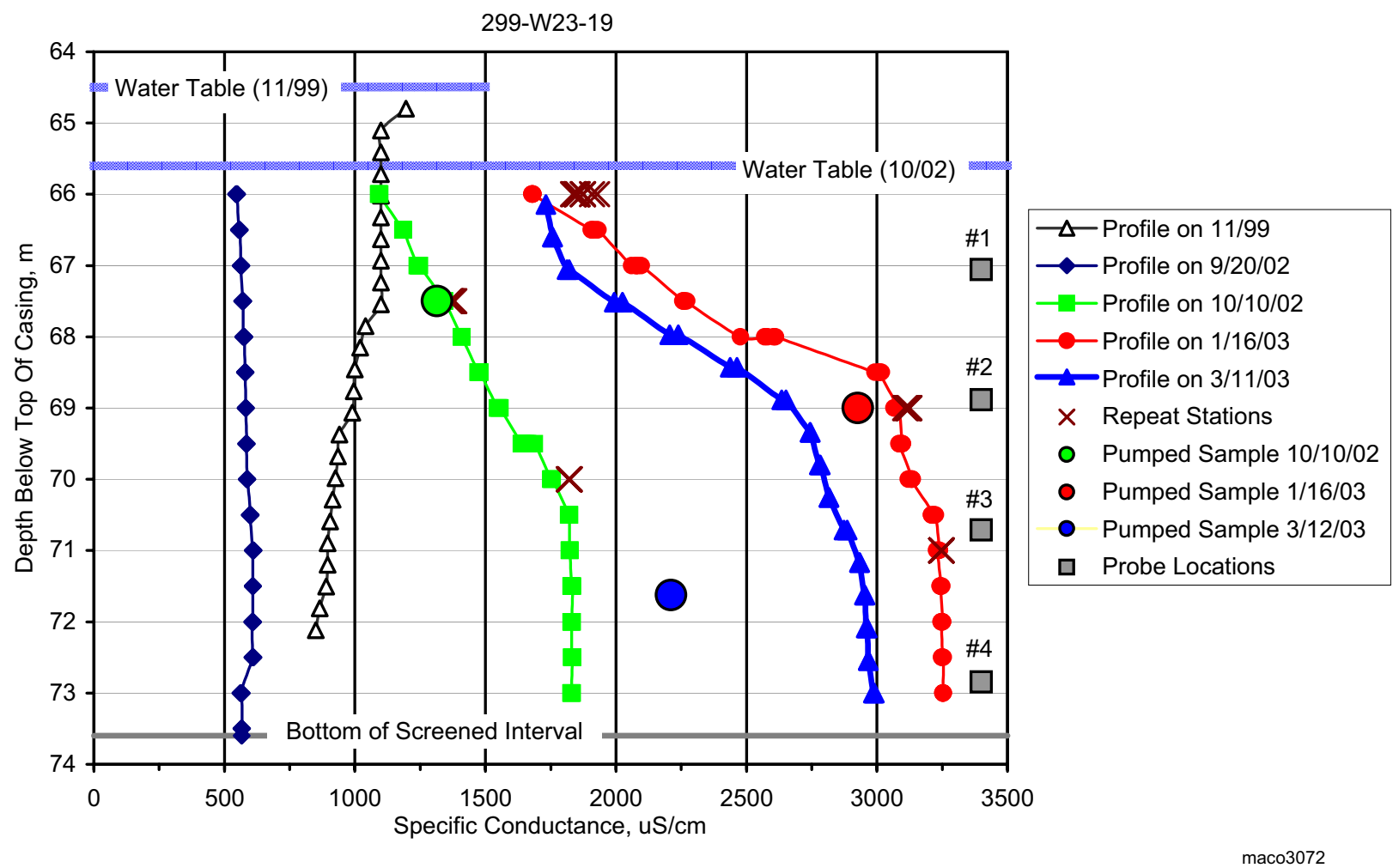

Figure 2.9-14. Wellbore-Fluid Specific Conductance Logs Collected in Well 299-W23-19 at Waste Management Area S-SX

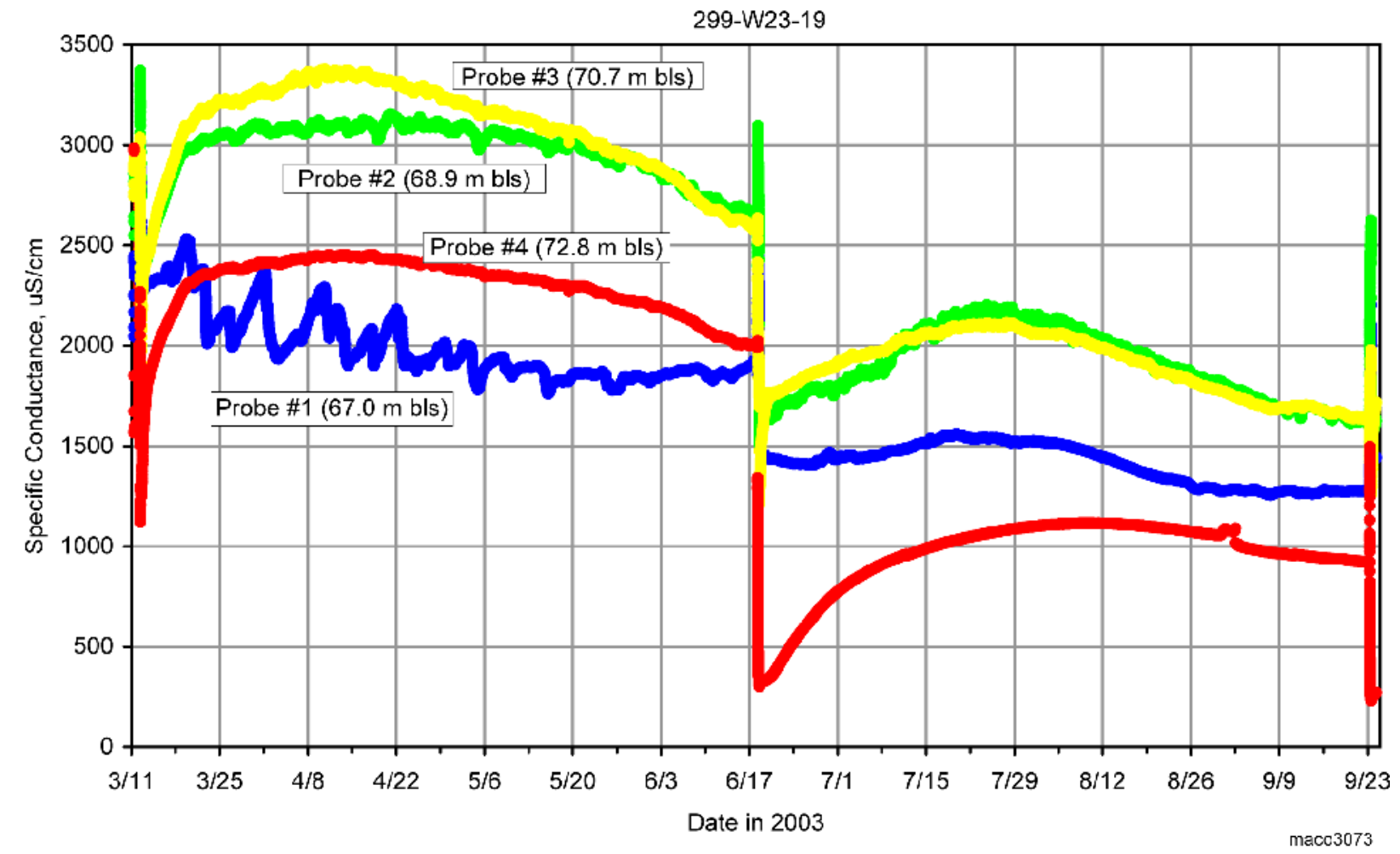

Figure 2.9-15. Wellbore-Fluid Specific Conductance Measurements Collected in Well 299-W23-19 at Waste Management Area S-SX (Data from probe \#4 are shown for information purposes but are considered unreliable.) 


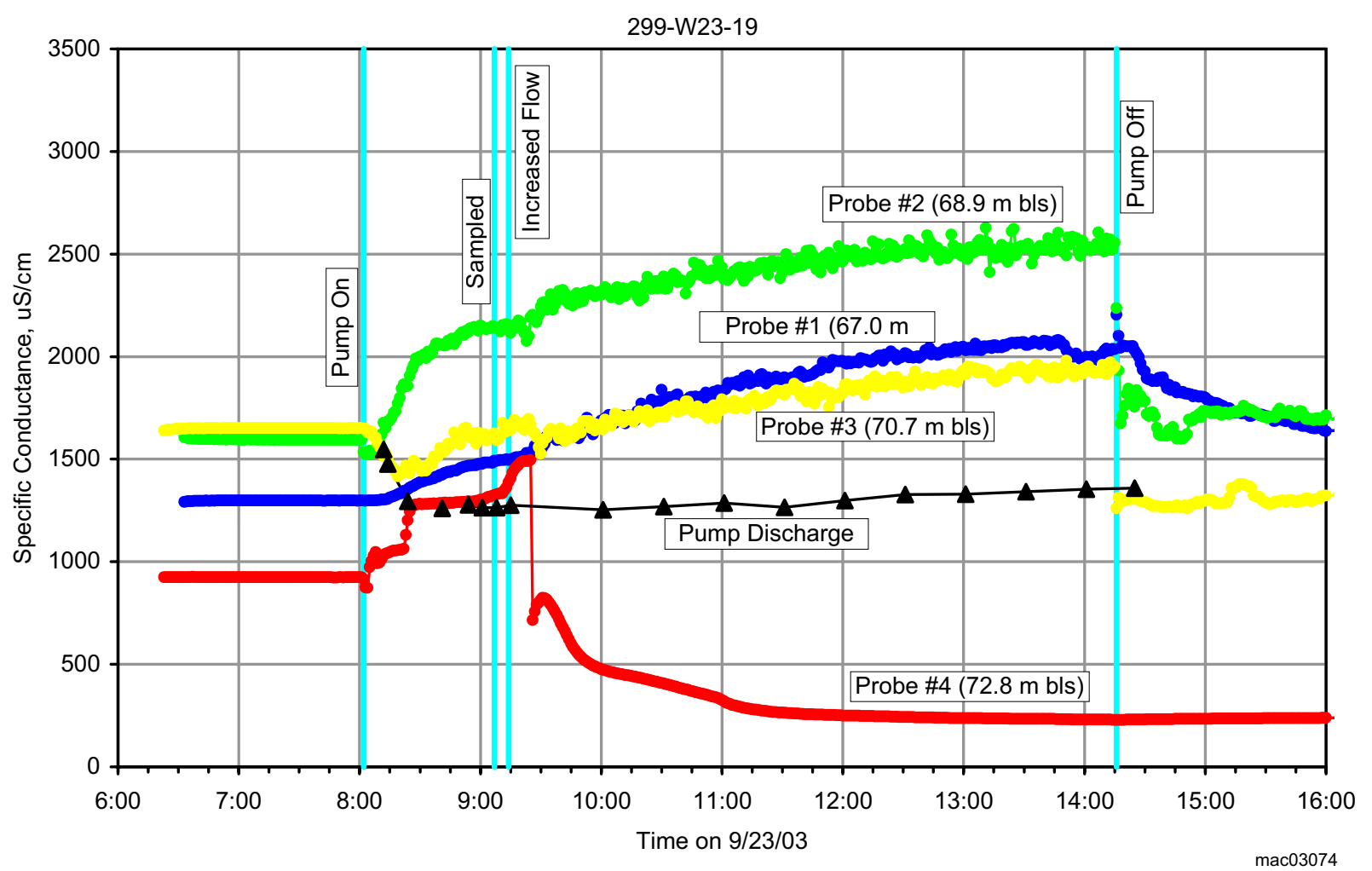

Figure 2.9-16. Wellbore=Fluid Specific Conductance Measurements Collected during Sampling on September 23, 2003 in Well 299-W23-19 (Data from probe \#4 are shown for information purposes but are considered unreliable.)

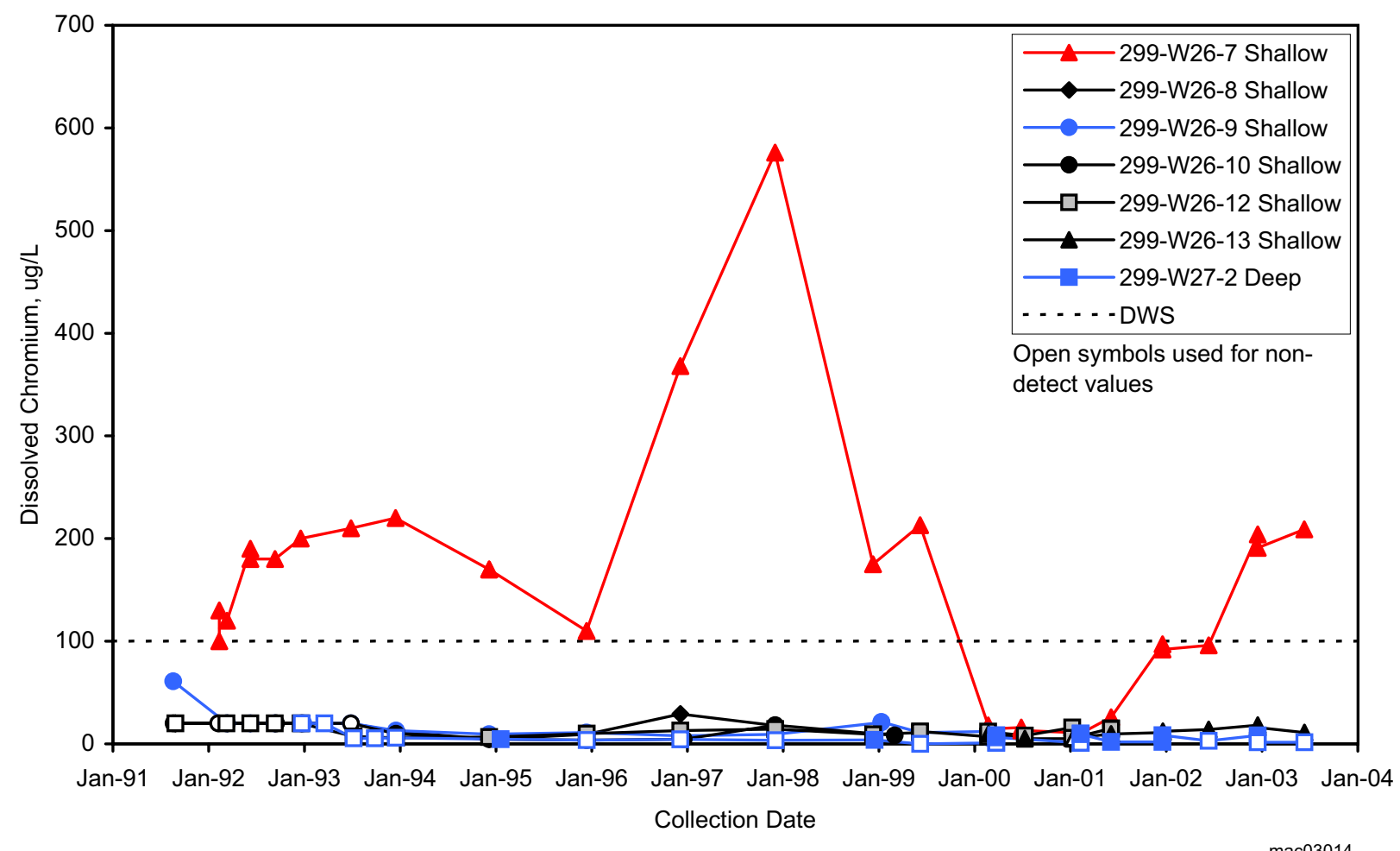

Figure 2.9-17. Chromium Concentrations Near the 216-S-10 Pond and Ditch 


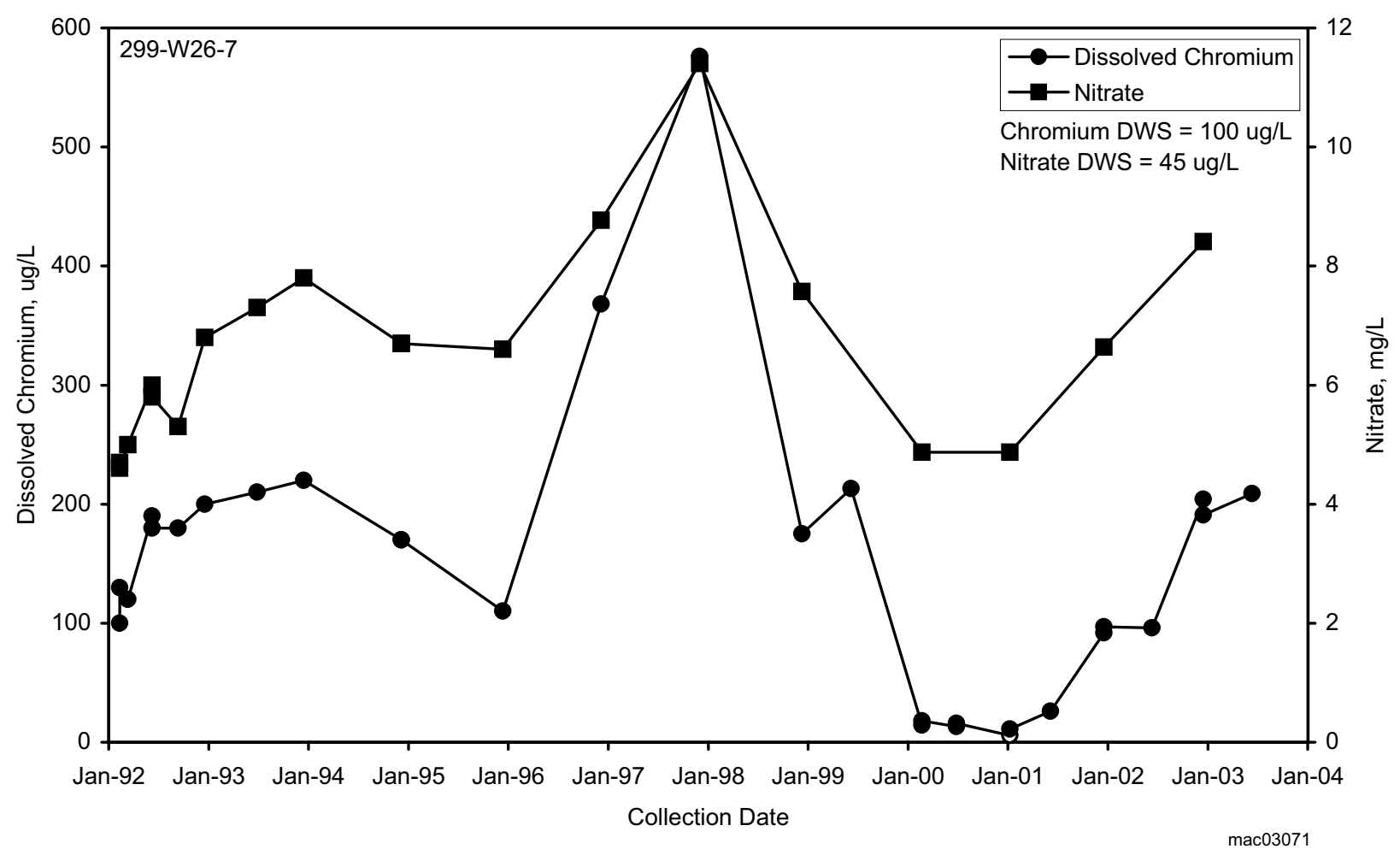

Figure 2.9-18. Chromium and Nitrate Concentrations in Well 299-W26-7 Near the 216-S-10 Pond and Ditch 


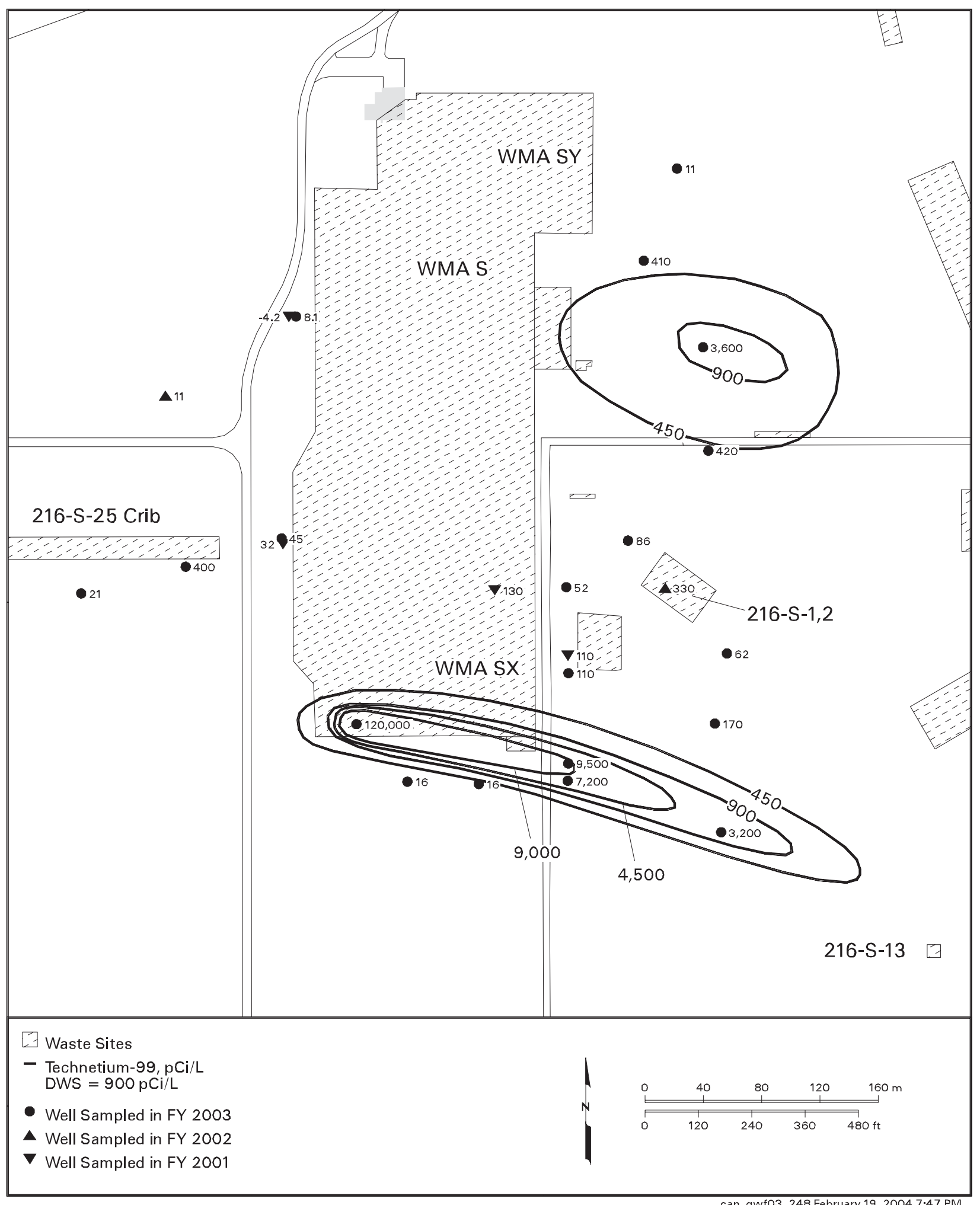

Figure 2.9-19. Average Technetium-99 Concentrations at Waste Management Area S-SX, Top of Unconfined Aquifer 


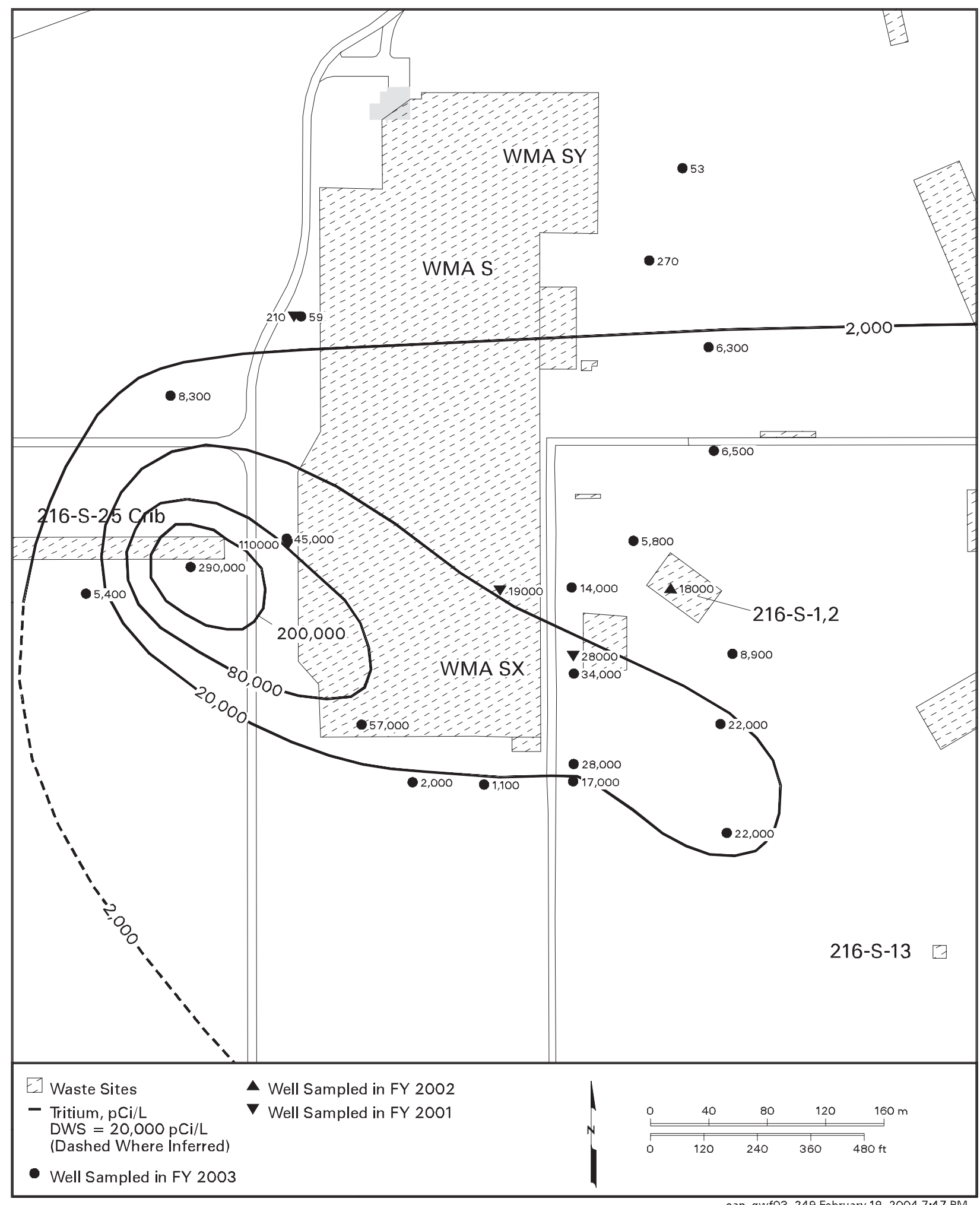

Figure 2.9-20. Average Tritium Concentrations at Waste Management Area S-SX, Top of Unconfined Aquifer 


\subsection{0-BP-5 Operable Unit}

\section{E. C. Thornton, P. E. Dresel, S. M. Narbutovskih, and M. D. Sweeney}

The scope of this section is the 200-BP-5 groundwater interest area, which includes the 200-BP-5 Operable Unit (Figure 2.1-1). This operable unit includes several Resource Conservation and Recovery Act (RCRA) units and Comprehensive Environmental Response, Compensation, and Liability Act (CERCLA) past-practice sites in the north part of the 200 East Area and extends to the north to Gable Gap. Figures 2.10-1 and 2.10-2 show facilities and wells in this operable unit. The south part of the 200 East Area lies within the 200-PO-1 Operable Unit and is discussed in Section 2.11. The boundary between the two operable units is shown in Figure 2.10-1.

Technetium-99 is the contaminant of greatest concern in the 200-BP-5 Operable Unit owing to its mobility and broad areal extent of contamination. Groundwater is monitored in this operable unit to define the regional extent of technetium-99 and other significant contaminants across the operable unit as well as the local extent of contamination

Groundwater monitoring in the 200-BP-5 Operable Unit includes CERCLA, RCRA, and AEA monitoring:

CERCLA Monitoring

- CERCLA sampling was interrupted in the first part of the fiscal year during preparation of a sampling and analysis plan and waste control plan for the 200-BP-5 Operable Unit.

- Following approval of these plans, limited sampling resumed late in fiscal year 2003.

- Sampling of all nine wells at the 216-B-5 injection well site was completed.

- Sampling of eight wells at Gable Mountain Pond was completed.

- One well could not be sampled at Gable Mountain Pond because it is dry (see Appendix A).

- Sampling of six wells in Gable Gap area north of the 200 East Area was completed.

- Two wells could not be sampled in fiscal year 2003 at Gable Gap because of mechanical problems (see Appendix A).

RCRA Monitoring

- Twenty-six wells are sampled quarterly to semiannually at Waste Management Area B-BX-BY.

- Twelve wells are sampled quarterly to semiannually at the 216-B-63 trench.

- Seventeen wells are sampled semiannually at Low-Level Waste Management Area 1.

- Twelve wells are sampled semiannually at Low-Level Waste Management Area 2.

- Two wells are sampled semiannually at the Liquid Effluent Retention Facility.

- Five wells are sampled quarterly at Waste Management Area C.

- All RCRA wells were sampled as scheduled (see Appendix B).

AEA Monitoring

- Twenty-six wells are sampled quarterly to semiannually at Waste Management Area B-BX-BY.

- Seventeen wells are sampled semiannually at Low-Level Waste Management Area 1.

- Twelve wells are sampled semiannually at Low-Level Waste Management Area 2.

- Five wells are sampled quarterly at Waste Management Area C.

- Wells are sampled annually to triennially within the 200-BP-5 Operable Unit for constituents related to general water chemistry.

- Six guard wells are sampled annually at Gable Gap.

- Wells are sampled annually to triennially in the upper basalt-confined aquifers (see Section 2.14.1). 


\section{Technetium-99 is}

the contaminant

of greatest

concern in the

200-BP-5 Operable

Unit.

\section{The tritium plume} extends northward through Gable Gap, but concentrations declined in fiscal year 2003. associated with specific RCRA units in the area. Other contaminants of concern for this operable unit include tritium, uranium, iodine-129, cobalt-60, cyanide, strontium-90, cesium-137, plutonium-239/240, and nitrate.

The small differences in water-table elevation across the operable unit make it difficult to determine the direction of groundwater flow from water-table maps (Figure 2.1-3). Techniques used to determine groundwater flow in the 200-BP-5 Operable Unit consist of plume and contaminant trend plots, water-level trend surface analysis, water-level hydrographs for multiple wells, and in situ flow measurements at groundwater wells. These techniques have been applied extensively in an effort to understand the direction of groundwater flow around the RCRA units in the 200-BP-5 Operable Unit and are discussed in more detail later in Section 2.10.3. General inferences regarding groundwater flow direction based on plume configurations (especially tritium, nitrate, iodine-129, and technetium-99) are also discussed in Section 2.10.1.

Groundwater currently entering the 200 East Area from the west divides and flows to the Columbia River along two separate paths: one to the southeast and one to the northwest though Gable Gap. The water table has been declining following the decrease in liquid effluent discharges to the soil in the 200 East Area. However, during fiscal year 2003, the water-level decline has diminished throughout the 200 East Area, and water levels actually increased in some areas.

Section 2.10.1 provides general information regarding geometry of contaminant plumes and concentration trends for contaminants of concern. Specific information regarding contaminant distribution for RCRA units within the 200-BP-5 Operable Unit is presented in Section 2.10.3.

\subsubsection{Groundwater Contaminants}

This section describes the distribution of groundwater contaminants of concern in the 200-BP-5 Operable Unit. Specific information is provided for several CERCLA units (the 216-B-5 reverse well, BY cribs, and Gable Gap area) as well as general information regarding regional contaminant distribution.

\subsubsection{Tritium}

Tritium contamination is widespread throughout the northwest part of the 200 East Area. The contamination extends north through the gap between Gable Mountain and Gable Butte toward the Columbia River and southeast through the 200-PO-1 Operable Unit (Figure 2.10-3). Tritium contamination from the 200-BP-5 Operable Unit has declined greatly because of natural decay and dispersion. The highest concentrations are in the south part of the 200 East Area and represent contamination from the 200-PO-1 Operable Unit that moved to the northwest under past flow conditions. A number of waste disposal facilities contributed to the plume.

Tritium concentrations in the 200-BP-5 Operable Unit have declined since 1990. Wells in the vicinity of the 216-B-5 injection well had concentrations of tritium below the drinking water standard in fiscal year 2003.

Tritium at levels above the drinking water standard can be found between Gable Mountain and Gable Butte and extends to the northwest (Figure 2.10-3). Concentrations in monitoring well 699-61-62 in Gable Gap continued to decline with a measured value for fiscal year 2003 of 24,000 pCi/L (see Figures 2.1-2 and 2.10-2 for locations of 600 Area wells). Tritium concentrations in wells 699-60-60 and 699-64-62 have also declined somewhat and were at levels of 28,000 and $21,000 \mathrm{pCi} / \mathrm{L}$, respectively, in fiscal year 2003. Well 699-72-73, located between the 100-B/C and 100-K Areas, exceeded the drinking water standard for the first time in fiscal year 2001 but declined to $14,000 \mathrm{pCi} / \mathrm{L}$ in fiscal year 2002 and 13,000 pCi/L in fiscal year 2003. 
Tritium values have increased recently at the south end of Waste Management Area B-BX-BY. The maximum average tritium value in this region in fiscal year 2003 was $19,000 \mathrm{pCi} / \mathrm{L}$ in well 299-E33-334.

\subsubsection{Nitrate}

A nitrate plume originating in the 200 East Area extends beyond the boundary fence line northwest towards the Columbia River (Figure 2.10-4). The plume within the 200 East Area has two parts: (1) a west plume that extends through the west portion of Low-Level Waste Management Area 1 and (2) an east plume extending from the BY and surrounding cribs toward the northwest. The two plumes join northwest of the 200 East Area and extend through the gap between Gable Butte and Gable Mountain to the Columbia River at levels less than the drinking water standard (45 mg/L).

The west part of the nitrate plume, extending through Low-Level Waste Management Area 1, appears to be a portion of a larger plume extending from the 200-PO-1 Operable Unit. This plume apparently moved to the northwest under past flow conditions during the period of high discharge to 200 East Area facilities and B Pond.

The highest nitrate concentrations are in the vicinity of the BY and 216-B-8 cribs. High concentrations of nitrate are associated with the cobalt-60, cyanide, and technetium-99 plume originating from the BY cribs. The highest nitrate concentrations measured in fiscal year 2003, however, were found in well 299-E33-16, near the 216-B-8 crib, where the fiscal year 2003 average concentration was $585 \mathrm{mg} / \mathrm{L}$. The ratio of nitrate to technetium-99 in well 299-E33-16 is high compared to the ratio of nitrate to technetium-99 in wells near the BY cribs, indicating an additional nitrate source in the area (PNNL-14187).

Nitrate continued to be detected in wells monitoring Gable Mountain Pond at levels above the drinking water standard in fiscal year 2003 (Figure 2.10-4). The highest nitrate concentration measured in fiscal year 2003 was a value of $163 \mathrm{mg} / \mathrm{L}$ reported for well 699-53-47B.

\subsubsection{3 lodine-129}

Contamination from iodine-129 is present throughout the west portion of the 200-BP-5 Operable Unit. Like the tritium plume, the iodine-129 plume extends to the northwest toward the Gable Mountain/Gable Butte gap and southeast through the 200-PO-1 Operable Unit (Figure 2.10-5). Unlike tritium, however, levels greater than the iodine-129 drinking water standard $(1 \mathrm{pCi} / \mathrm{L})$ have not passed the gap between Gable Mountain and Gable Butte. A band of elevated iodine-129 concentrations $(\sim 5 \mathrm{pCi} / \mathrm{L})$ extends through Waste Management Area B-BX-BY to the northeast corner of Low-Level Waste Management Area 1. Interpretation of the iodine-129 configuration in this area is complicated by elevated detection limits that result from interference of technetium-99. In addition, the current laboratory reporting system produced some values reported as not detected at levels greater than the drinking water standard $(1 \mathrm{pCi} / \mathrm{L})$.

\section{The highest nitrate concentrations are in the vicinity of the $B Y$ and 216-B-8 cribs.}

\subsubsection{Technetium-99}

A plume of technetium-99 extends from the area of the BY cribs and Waste Management Area B-BX-BY to beyond the 200 East north boundary to the northwest (Figure 2.10-6). A significant portion of the plume is to the north and is interpreted to represent early releases of technetium-99 from the BY cribs. Detection of technetium-99 at levels lower than the $900 \mathrm{pCi} / \mathrm{L}$ drinking water standard north of the gap between Gable Mountain and Gable Butte indicates that in the past technetium-99 moved north into, and through, the gap.

Technetium-99 was not routinely measured in groundwater prior to the late 1980s, limiting the information on historical trends. Thus, there is considerable uncertainty in the extent of technetium-99 contamination. Interpretation of the exact configuration and extent of the technetium-99 plume north of the 200 East Area is also complicated by the variable concentrations seen in wells that are relatively close together (see Figure 2.1-2 for 


\section{A plume of technetium-99 extends from the area of the \\ $B Y$ cribs to beyond the 200 East north boundary. The plume has moved through Gable Gap at levels below the drinking water standards.}

600 Area well locations). For example, concentrations of technetium-99 less than the drinking water standard were consistently detected in well 699-49-55A since the early 1990s (16 pCi/L in fiscal year 2001). This well was used as the injection well in 1995 for pump-and-treat operations and has had very low technetium-99 values since then.

Six wells were successfully sampled in the Gable Gap area late in fiscal year 2003. Five of these wells showed an increase in technetium-99 while one had a slight decrease. Well 699-49-57A has higher and increasing concentrations $(4,850 \mathrm{pCi} / \mathrm{L}$ in fiscal year 2003 versus $3200 \mathrm{pCi} / \mathrm{L}$ in fiscal year 2001) as shown in Figure 2.10-7.

Well 699-52-57, located north of well 699-49-57A, had consistently low technetium-99 concentrations $(<90 \mathrm{pCi} / \mathrm{L})$ throughout the 1990s; however, the water table fell below the screen in 1999 so the well can no longer be sampled. A review of well construction and logging information suggests that this well was not drilled to the top of the basalt and may lie in an erosional window where the Elephant Mountain Member has been removed, thereby juxtaposing the unconfined aquifer in the Hanford formation and the upper basalt-confined aquifer in the Rattlesnake interbed. DOE/RL-2001-49 proposed that well 699-52-57 be deepened, if possible, to permit sampling activities to continue at this location and to obtain additional geological information.

DOE/RL-2001-49 proposed that an additional monitoring well be installed south of Gable Gap and on the west margin of the technetium-99 plume (see DOE/RL-2001-49 for specific location). This well will serve to better define plume extent and geometry and is needed to replace wells in Gable Gap that have gone dry (e.g., wells 699-52-57, $699-52-54,699-50-53 \mathrm{~A}$, and 699-50-53B). Installation of new wells in this area is also important from a hydrogeological standpoint because additional wells will provide information regarding groundwater flow (based on the gradient of the water table) and will help to better define the elevation of the top of the basalt in this area and the geometry of the anticlinal structure in the gap. The latter information is needed to support predictions of future groundwater flow through the gap.

In the late 1990s, rising technetium-99 concentrations were seen in the BY crib area in wells 299-E33-7 and 299-E33-38 (Figure 2.10-7). During late 1997 and 1998, technetium-99 increased sooner in well 299-E33-7 than in well 299-E33-38. In early 1999, the trends for both wells began to track together and reached an apparent maximum in late 2000. These trends may indicate southward movement of the contaminant plume beginning in the late 1990s, or they may reflect pervasive transport of contamination from the vadose zone at the BY cribs and relatively recent breakthrough into the saturated zone. In particular, the high concentration of technetium-99 in well 299-E33-38 (average of 9,800 pCi/L in fiscal year 2003) suggests a continuing source of contamination from the BY cribs to groundwater. A general correlation of concentration trends for technetium-99, nitrate, cobalt-60, and cyanide in wells 299-E33-7 and 299-E33-38 and local distribution of these constituents suggests that the primary source of technetium-99 contamination is related to past discharges of ferrocyanide waste to the BY cribs.

\subsubsection{Cobalt-60 and Cyanide}

Cobalt-60 and cyanide continue to be detected in a number of wells in the 200-BP-5 Operable Unit. Cobalt-60 has a relatively short half-life (5.3 years), and is currently only found at levels less than the drinking water standard $(100 \mathrm{pCi} / \mathrm{L})$. Cyanide is also a minor contaminant but is found at levels above the drinking water standard (200 $\mu \mathrm{g} / \mathrm{L})$. These constituents are useful for distinguishing contaminant groups and contaminant sources. Cyanide and cobalt-60 are generally found together in this area.

The maximum cyanide concentrations in this area in fiscal year 2003 were $232 \mu \mathrm{g} / \mathrm{L}$ from well 299-E33-38 and $275 \mu \mathrm{g} / \mathrm{L}$ from well 299-E33-7, both located in the BY cribs. Cyanide contamination trends in these wells are similar to those of technetium-99 and nitrate and appear to be related to past discharges of ferrocyanide waste to the BY cribs. 
The highest cobalt-60 values in fiscal year 2003 also were detected in wells monitoring the BY cribs, and the cribs are believed to be the source of this contamination. The highest cobalt-60 concentrations in fiscal year 2003 was in well 299-E33-7, located in the north part of the BY cribs, where the December 2002 result was $48.4 \mathrm{pCi} / \mathrm{L}$. Well 299-E33-38, located in the south part of the cribs, had a maximum cobalt -60 value of $45.4 \mathrm{pCi} / \mathrm{L}$, also for December 2002.

\subsubsection{Uranium}

Uranium contamination in the 200-BP-5 Operable Unit is limited to three isolated areas:

- Wells monitoring Waste Management Area B-BX-BY.

- Wells near the 216-B-5 injection well.

- Wells 299-E28-21 and 299-E28-18 at the 216-B-62 crib.

Many wells in all three of these areas exceeded the drinking water standard (30 $\mu \mathrm{g} / \mathrm{L})$ during fiscal year 2003 .

Waste Management Area $\boldsymbol{B}-\boldsymbol{B} \boldsymbol{X}-\boldsymbol{B} \boldsymbol{Y}$. The largest uranium plume in the 200 East Area may have sources at Waste Management Area B-BX-BY. Currently, the highest uranium concentrations in the 200-BP-5 Operable Unit are found within and to the east of the BY Tank Farm (Figure 2.10-8). The contamination is present in a narrow northwest-southeast band but is increasing to the south along the west side of Waste Management Area B-BX-BY. Current interpretation is that the plume likely originates from a release at tank BX-102 (RPP-10098; PNNL-14187). In fiscal year 2003, the highest concentrations were detected in wells 299-E33-9 and 299-E33-44, with annual average concentrations of 450 and $330 \mu \mathrm{g} / \mathrm{L}$, respectively. Section 2.10.4.1 includes additional discussion of uranium at Waste Management Area B-BX-BY.

216-B-5 Injection Well. Uranium contamination is associated with the cesium-137, plutonium, and strontium-90 contamination found at the former 216-B-5 injection well. Sampling of wells at this site resumed in fiscal year 2003 following publication of a revised sampling and analysis plan (DOE/RL-2001-49) and a plan (DOE/RL-2003-30) for disposal of derived waste such as gloves and paper wipes. The highest uranium concentration detected in fiscal year 2003 at this site was $62.4 \mu \mathrm{g} / \mathrm{L}$ in well 299-E28-23, located only $\sim 1$ meter from the injection well. A uranium value of $43.2 \mu \mathrm{g} / \mathrm{L}$ also was reported for well 299-E28-6, located south of the injection well, in fiscal year 2003 .

216-B-62 Crib. Uranium was detected consistently at levels slightly above the drinking water standard $(30 \mu \mathrm{g} / \mathrm{L})$ in wells monitoring the $216-\mathrm{B}-62 \mathrm{crib}$, located west of B Plant. Uranium concentrations were over $200 \mu \mathrm{g} / \mathrm{L}$ in the mid-1980s, but declined to current levels by the early 1990s. The maximum uranium concentration at the 216-B-62 crib was $32 \mu \mathrm{g} / \mathrm{L}$ in well 299-E28-18, which was last sampled in fiscal year 2001. Uranium also has been found along the west side of Low-Level Waste Management Area 1, but no wells exceeded the drinking water standard in fiscal year 2003. The uranium detected near Low-Level Waste Management Area 1 probably originated at the 216-B-62 crib.

\subsubsection{Cesium-137 and Strontium-90}

Cesium-137 and strontium-90 have relatively low mobility and are generally found near their source. Several wells near the 216-B-5 injection well have had elevated concentrations of strontium-90. Four wells (299-E28-2, 299-E28-23, 299-E28-24, and 299-E28-25) had concentrations of strontium-90 above the drinking water standard $(8.0 \mathrm{pCi} / \mathrm{L})$ in fiscal year 2003 . Two of the wells have had concentrations greater than the U.S. Department of Energy (DOE) derived concentration guide $(1,000 \mathrm{pCi} / \mathrm{L})$ in past years and in fiscal year 2003 (Figure 2.10-9). The highest strontium-90

\section{Uranium}

contamination in the

200-BP-5 Operable

Unit is limited to

three isolated areas:

Waste Management

Area B-BX-BY and

surrounding cribs,

216-B-5 injection well, and 216-B-62 crib. 
Wells near the

\section{6-B-5 injection well have elevated concentrations of low-mobility contaminants} including cesium-137, plutonium, and strontium-90. concentration was reported for well 299-E28-23, which averaged 5,655 pCi/L in fiscal year 2003. Strontium-90 also exceeded the DOE derived concentration guide in well 299-E28-25, which averaged 1,940 pCi/L in fiscal year 2003.

Well 299-E28-23 near the 216-B-5 injection well has concentrations of cesium-137 greater than the drinking water standard $(200 \mathrm{pCi} / \mathrm{L})$ but less than the DOE derived concentration guide $(3,000 \mathrm{pCi} / \mathrm{L})$. In fiscal year 2003, an average value of $1,135 \mathrm{pCi} / \mathrm{L}$ was reported for this well, which is somewhat lower than previous years. All other wells sampled at this site had cesium-137 concentrations below the drinking water standard in fiscal year 2003.

Strontium-90 concentrations showed a declining trend in 1997, 2000, and 2003 versus a rising trend before fiscal year 1999 in several wells near Gable Mountain Pond. Strontium-90 was detected in groundwater at levels above the DOE derived concentration guide in the only well that was sampled at Gable Mountain Pond in fiscal year 2000, but was below it in fiscal year 2003. The concentration in the sample from that well, 699-53-47A, was $806 \mathrm{pCi} / \mathrm{L}$ in fiscal year 2003 versus $1,210 \mathrm{pCi} / \mathrm{L}$ in fiscal year 2000 (Figure 2.10-10).

\subsubsection{Plutonium}

Plutonium-239 and plutonium-240 were detected in past years in samples taken from several wells near the 216-B-5 injection well. Plutonium contamination is relatively immobile and, therefore, is found only near the source, which was the injection well. The highest reported plutonium concentration in fiscal year 2003 was for well 299-E28-23, which had a filtered value of $19.4 \mathrm{pCi} / \mathrm{L}$ and an unfiltered value of $74.8 \mathrm{pCi} / \mathrm{L}$. Thus, the unfiltered value for this well exceeded the DOE derived concentration guide for plutonium $(30 \mathrm{pCi} / \mathrm{L})$, but the filtered value was below it. Other wells sampled at the 216-B-5 injection well site were well below the DOE derived concentration guide.

\subsubsection{Other Constituents}

Several other constituents exceeded drinking water standards in the 200-BP-5 Operable Unit in fiscal year 2003. A maximum of $51.1 \mu \mathrm{g} / \mathrm{L}$ was reported for filtered antimony versus the drinking water standard of $6 \mu \mathrm{g} / \mathrm{L}$. This may be a laboratory analytical problem since there are no known sources of antimony in the 200-BP-5 Operable Unit. A maximum value of filtered nickel of $133 \mu \mathrm{g} / \mathrm{L}$ has also been reported, which has a drinking water standard of $100 \mu \mathrm{g} / \mathrm{L}$. It is possible that this may be related to steel corrosion within wells. Numerous measurements of gross alpha and gross beta exceeding their drinking water standard have also been reported during fiscal year 2003 and are related to radionuclide contaminants discussed in the preceding sections.

\subsubsection{CERCLA Groundwater Monitoring}

CERCLA monitoring requirements in the 200-BP-5 Operable Unit have recently been defined in DOE/RL-2001-49. Specific CERCLA units include the 216-B-5 injection well site, the BY cribs, and Gable Mountain. Specific monitoring information regarding these units are discussed above (Section 2.10.1).

CERCLA monitoring activities have been interrupted for the past several years in the 200-BP-5 Operable Unit because of waste management issues. Sampling activities were resumed in late fiscal year 2003 following approval of a sampling and analysis plan (DOE/RL-2001-49) and waste control plan (DOE/RL-2003-30). CERCLA sampling was successfully conducted at nine wells at the 216-B-5 injection well site, eight wells at Gable Mountain Pond, and six wells in the Gable Gap area north of the 200 East Area. 
Wells completed above the basalt in the vicinity of Gable Mountain Pond are becoming difficult to sample because of declining water levels. Sampling was attempted at nine wells late in fiscal year 2003 (see Appendix A for wells sampled and Figure 2.10-2 for well locations). Samples were obtained from eight wells, but well 699-53-48B was determined to be dry.

\subsubsection{RCRA Groundwater Monitoring}

The 200-BP-5 Operable Unit contains six RCRA sites with groundwater monitoring requirements: Waste Management Area B-BX-BY, the 216-B-63 trench, Low-Level Waste Management Areas 1 and 2, the Liquid Effluent Retention Facility, and Waste Management Area C. This section summarizes results of statistical comparisons, assessment studies, and other developments for fiscal year 2003. RCRA groundwater data are available in the Hanford Environmental Information System and on the data files accompanying this report.

\subsubsection{Waste Management Area B-BX-BY}

Single-shell tank farms B, BX, and BY, located in the northwest part of the 200 East Area, comprise Waste Management Area B-BX-BY (see Appendix B). The site was placed in a RCRA groundwater quality assessment program in 1996 when specific conductance at a downgradient well became elevated above the critical mean. This section discusses the local hydrogeology of the waste management area, including the rate and direction of flow, and contaminant monitoring related to RCRA assessment activities. A total of 26 wells were successfully sampled at this unit in fiscal year 2003. RCRA constituent results are presented in this section. A more complete discussion of all contaminants at the B, BX, and BY Tank Farms can be found in Section 2.10.4.1.

The hydraulic gradient is nearly flat across Waste Management Area B-BX-BY, making it difficult to determine upgradient versus downgradient wells from water elevations. A detailed discussion of this problem can be found in PNNL-12086, PNNL-13116, PNNL-13022, and PNNL-13078. Because the potential error exceeds the difference in elevation across the waste management area, water-elevation data should not be used alone to interpret flow directions (PNNL-13022; PNNL-13023; PNNL-13116). Consequently, flow directions were estimated at Waste Management Area B-BX-BY using in situ flow techniques such as the colloidal borescope (PNNL-13404; Narbutovskih et al. 2002). The results of these studies suggested a southerly flow direction across the waste management area. The direction of groundwater flow tends to be southwest from the BY cribs across the north BY Tank Farm and south to southeast through the BX and B Tank Farms.

In addition, the flow rate is close to stagnant under the BY Tank Farm (PNNL-13788). Conversely, in situ flow measurements indicate flow south of the waste management area is quite high. The calculated flow rate using the Darcy equation is $\sim 0.8$ meter per day for fiscal year 2003. For a complete discussion, see PNNL-14187 and Narbutovskih et al. 2002. Presently, the unconfined aquifer in the north is $<1.75$ meters thick and $>4$ meters thick along the south boundary. Water levels stopped declining across the site during fiscal year 2003. Some wells have even shown a distinct increase in water level as shown in Figure 2.10-11. The cause of these changes in water level is currently under investigation.

A 1998 RCRA assessment report (PNNL-11826) concluded that nitrate levels observed above the drinking water standard (45 mg/L) in well 299-E33-41 during 1997 were from residual waste in the vadose zone related to a tank farm leak in 1951. This residual waste had been driven to the groundwater by recent fresh water flooding from broken water lines. Since then, concentrations of nitrate with some nitrite, a little
Water levels stopped declining across

Waste Management Area B-BX-BY during fiscal year 2003. Some wells have even shown a distinct increase in water level. 
The contamination

observed in

downgradient wells

around Waste

Management Area

$B-B X-B Y$ is due,

primarily, to vertical

movement of residual

waste left in the soil

under the tank farms.

\section{Sampling results for}

the 216-B-63 trench

have historically

supported the

interpretation that

the facility has not

affected groundwater. cyanide, and other tank-associated contaminants were found rising beneath and around the BY Tank Farm. A further investigation was conducted to identify the source of this contamination and to determine the rate and extent of groundwater contamination associated with the Waste Management Area B-BX-BY (PNNL-13022). The results of this investigation, presented in PNNL-SA-39825 and PNNL-14187, show that the contamination observed in downgradient wells around Waste Management Area B-BX-BY is due, primarily, to vertical movement of residual waste left in the soil under the tank farms. Although the source of the water driver and vadose zone migration pathways are not clearly understood, the water driver appears to be related, in part, to long-term steady-state recharge from natural precipitation. At this time, it has been reasonably established that the contamination found downgradient in the groundwater at Waste Management Area B-BX-BY is from local, residual soil plumes associated with past tank farm operations.

Current contaminant trends across the site for fiscal year 2003 appear to be related to recent variations in the rate of water level changes (see Section 2.10.4.1). As shown in Figure 2.10-11, water levels have either ceased to drop or have actually increased since the summer of 2002. This change appears to have caused perturbations in contaminant trends although a concrete connection cannot be made. In general, contaminants trends of nitrate tended to decrease during 2001 after peak values were observed at the end of 2000 to early 2001. However, during the latter part of 2002 and throughout 2003, nitrate levels fluctuated slightly or were steady. If water levels resume dropping, recognizable contaminant patterns may once again develop.

\subsubsection{216-B-63 Trench}

Sampling results for the 216-B-63 trench have historically supported the interpretation that the facility has not affected groundwater. The results from the current fiscal year, in which 12 wells were successfully sampled, continue to sustain this view. Of the results reported, only two sampling events at two network wells indicate a statistical exceedance has occurred. Wells 299-E33-33 and 299-E33-36 exceeded the critical mean for total organic carbon early in 2003. The exceedances occurred at a time when a series of anomalously high total organic carbon results were reported across the Hanford Site. Preliminary results indicate that laboratory error may have contributed to the elevated results.

The non-hazardous constituents that had been rising in concentration slowly and persistently over a decade have, in most instances, stabilized or have declined in concentration. Wells in the 216-B-63 trench network have calcium and magnesium results that are either lower than or approximately the same concentration as last year. A significant exception to this trend is the nearly simultaneous increase in sulfate concentration throughout the network. This phenomenon, however, is not restricted solely to this facility but is instead wide spread in the 200 East Area. Sodium was higher in only one well.

The monitoring well network that rings the 216-B-63 trench is shared with both the Low-Level Burial Ground Waste Management Area 2 and the B-BX-BY Tank Farms. Samples are gathered twice a year in spring and fall (see Appendix B). Due to the low hydraulic gradient and the highly transmissive media in 200 East Area, the rate of groundwater movement near the 216-B-63 trench is low, approximating 0.1 meter per day (see Appendix B).

\subsubsection{Low-Level Waste Management Area 1}

Groundwater monitoring under interim status requirements continued at this RCRA site in fiscal year 2003. The well network was sampled twice for indicator and sitespecific parameters (see Appendix B). All 17 wells were successfully sampled during both samplings. 
An application was submitted to the Washington State Department of Ecology (Ecology) in June 2002 to incorporate the low-level burial grounds into the Hanford Facility RCRA Permit (Ecology 1994). This would have the effect of changing the groundwater monitoring requirements for the burial grounds from interim status monitoring to final status monitoring. As part of the application, new groundwater monitoring constituents and statistical evaluations are proposed. Workshops with Ecology to address this application are in progress.

The groundwater gradient in this part of the 200 East Area is almost flat making the determination of groundwater flow direction difficult. Based on contaminant plumes, the flow direction appears to have been to the northwest in recent years. Past analysis of water-level data also indicate flow toward the northwest. Trend surface analysis was performed on water levels collected during four different months (December 2002, March 2003, June 2003, and July 2003). The flow directions ranged from northwest to east-southeast. The calculated gradient is $\sim 0.00006$ with flow rate estimates ranging from $\sim 0.01$ to 1.6 meter per day (see Appendix B). The data suggest that the flow direction is dynamic due to the influence of minor relative water level variation between wells. For this reason, no attempt will be made to update the interim status designation of upgradient and downgradient wells until a stable flow direction is re-established.

Specific conductance continued to exceed the statistical upgradient/downgradient comparison value (critical mean) in downgradient well 299-E33-34, with values ranging from 1,048 to $1,195 \mu \mathrm{S} / \mathrm{cm}$. In fiscal year 2002 , well $299-\mathrm{E} 32-10$ also exceeded the statistical comparison value, but it did not exceed the value in fiscal year 2003 because the comparison value was updated to a higher value. The exceedance is related to the nitrate plume from an upgradient source, not the Low-Level Waste Management Area 1. DOE notified Ecology in 1999. Because no waste has been placed in the north portion of the site and there is a nitrate plume from an upgradient source, no further action is necessary. Statistical comparison values to be used for indicator parameters in fiscal year 2004 are listed in Appendix B.

\subsubsection{Low-Level Waste Management Area 2}

Groundwater monitoring under interim status requirements continued at this RCRA site in fiscal year 2003. The well network was sampled twice for indicator and site-specific parameters (see Appendix B). Of the 12 wells in the network, sampling was successful at 11 for both sampling rounds. One well, 299-E34-3, was declared sample-dry due to declining water levels and was removed from the network.

An application was submitted to Ecology in June 2002 to incorporate the low-level burial grounds in to the Hanford Facility RCRA Permit (Ecology 1994). This would have the effect of changing the groundwater monitoring requirements for the burial grounds from interim status monitoring to final status monitoring. As part of the application, new groundwater monitoring constituents and statistical evaluations are proposed. No new wells were proposed, in spite of wells going dry, because the watertable elevation is receding below the top of the basalt. Where basalt is present above the water table, it is impossible to monitor the unconfined aquifer. Deeper aquifers are isolated from the burial grounds by the low-permeability basalts. Workshops with Ecology to address this application are in progress.

The groundwater gradient in this part of the 200 East Area is almost flat making the determination of groundwater flow direction difficult. Groundwater flow appears to be generally to the west based on small differences in head at wells along the south boundary of Low-Level Waste Management Area 2. Trend surface analysis performed on fiscal year 2002 data indicated flow generally to the southwest; however, no realistic flow direction could be determined from trend surface analysis of fiscal year 2003 data due to further flattening of the water table. For this reason, no attempt will be made to update the statistical tests until a stable flow direction is evident. The basalt surface above the
RCRA monitoring at

Low-Level Waste

Management Areas 1

and 2 indicates the

sites have not affected

groundwater quality. 


\section{Levels of specific conductance, total organic carbon, and total organic halides in an upgradient well at Low-Level Waste Management Area 2 are elevated.} The source is unknown.

\section{The Liquid Effluent Retention Facility is monitored by two wells.}

water table in the north part of Low-Level Waste Management Area 2 constrains possible flow directions for the unconfined aquifer. However, it is possible that the flow is influenced by continued drainage of the unsaturated sediment and recharge flowing down the basalt surface to the saturated aquifer sediment. The gradient calculated from wells along the south boundary of the burial ground is 0.00003 . The estimated flow rate at Low-Level Waste Management Area 2, using this gradient, is 0.04 to 0.6 meter per day (see Appendix B).

Statistical evaluations for this area determined that upgradient well 299-E34-7 continued to exceed the statistical comparison value (critical mean or limit of quantitation) for specific conductance, total organic carbon, and total organic halides. The major contributors to the elevated specific conductance are sulfate, chloride, nitrate, and calcium. The source of the elevated specific conductance is not known. The increase in specific conductance appears to have leveled off during fiscal year 2003.

The cause of the elevated levels of total organic carbon and total organic halides is also not known. Total organic carbon levels declined slightly from fiscal year 2002 . The fiscal year 2003 average total organic carbon concentration was 5,100 $\mu \mathrm{g} / \mathrm{L}$. The average total organic halide concentration was $22.6 \mu \mathrm{g} / \mathrm{L}$, slightly higher than in fiscal year 2002. Fiscal year 2003 samples from well 299-E34-7 were analyzed for an extensive list of constituents and other possible contaminants identified in 40 CFR 264, Appendix IX. The only organic constituent detected was a low level $(0.076 \mu \mathrm{g} / \mathrm{L})$ of Endrin aldehyde in the October 2002 sample. This is an impurity or breakdown product of the pesticide Endrin that has not been sold in the United States since the 1980s. There is no drinking water standard for Endrin aldehyde, but the standard for Endrin is $2 \mu \mathrm{g} / \mathrm{L}$. Endrin aldehyde was not detected in the April 2003 sample. Total analytical results for petroleum hydrocarbon and oil and grease were also non-detect for the fiscal year 2003 samples. Because of the anomalous chemistry in this upgradient well, it is not used in the statistical upgradient/downgradient comparisons. Appendix B lists the statistical comparison values based on data for the other designated upgradient wells.

There are indications that some of the elevated constituents seen in well 299-E34-7 are beginning to impact wells farther southwest, well 299-E27-10 and possibly well 299-E27-9. Sulfate, chloride, nitrate, and calcium are all increasing in these wells but remain at lower concentrations than seen in well 299-E34-7. The concentrations in well 299-E27-10 are higher than in well 299-E27-9, indicating the plume is spreading toward the southwest and west. The concentrations in well 299-E27-10 started rising in 1995 at about the same time as well 299-E34-7 but do not show the sudden increase seen in well 299-E34-7 in about 1997. The nitrate trend for these three wells is shown in Figure 2.10-12 as an example of the increases.

\subsubsection{Liquid Effluent Retention Facility}

The Liquid Effluent Retention Facility is an active, lined facility that is identified in the Hanford Facility RCRA Permit (Ecology 1994). A letter from Ecology directed DOE to discontinue statistical evaluation of groundwater sample results effective January 14, 2001. Since that time, DOE has continued to sample according to WHC-SD-EN-AP-024 and has explored alternative approaches to monitoring groundwater at the facility to measure compliance with hazardous waste regulations.

Two wells were successfully sampled semiannually at the Liquid Effluent Retention Facility in fiscal year 2003 (see Appendix B). Results for specific conductance and sulfate have been rising in concentration since 1994 mirroring a regional trend. No other contamination indicator parameters have shown increases over the fiscal year.

\subsubsection{Waste Management Area C}

Located in the northeast part of the 200 East Area, Waste Management Area C consists of the C Tank Farm, the 244-CR vault, ancillary waste transfer lines, and seven 
diversion boxes (see Appendix B). The following paragraphs describe a summary of monitoring specific to RCRA-regulated constituents and the local hydrogeology of the waste management area. The current state of groundwater contamination associated with this tank farm is further described in Section 2.10.4.4.

A general flow direction to the southwest has been established for this site using in situ flow measurements, plume tracking, and water elevations corrected for borehole deviations from vertical (PNNL-13788). Hydrographs show that the flow direction is still to the southwest, which is consistent with the regional water-table map (PNNL-14187). When the monitoring network was designed, flow was believed to be due west. Three new downgradient wells and one new upgradient well were installed in fiscal year 2003 to improve the capability of the detection network to monitor the site (see Section 5 and Appendix B).

The estimated groundwater flow rates calculated using the Darcy equation range from 1.2 to 2.3 meters per day (see Appendix B). Based on these estimates of flow rate, the groundwater could flow as much as 800 meters per year. The rate of water table decline beneath Waste Management Area $C$ was about 0.3 meter last year. If this rate continues, wells from the original network should be usable for at least 6 years.

Waste Management Area C continued to be monitored under an interim status indicator evaluation program in fiscal year 2003. Five wells were sampled quarterly at the request of Ecology due to rising trends in sulfate and nitrate detected in both upgradient and downgradient wells. In addition, the required detection sampling was conducted twice for indicator and site-specific parameters (see Appendix B).

During fiscal year 2003, the site was monitored with the original configuration of wells (see Appendix B). Because the upgradient well was experiencing variable specific conductance values, no upgradient/downgradient comparisons could be made for this indicator parameter for fiscal year 2003. Initial sampling that was undertaken during installation indicates that the new upgradient well will give stable results. This new well is scheduled for the required four RCRA sampling events in fiscal year 2004. Results from these four events will be used to calculate a new critical mean for specific conductance. Upgradient/downgradient comparisons will begin during fiscal year 2005. The indicator parameters ( $\mathrm{pH}$, total organic carbon, and total organic halide) did not exceed the upgradient/downgradient comparison values in downgradient wells during fiscal year 2003 .

\subsubsection{AEA Monitoring}

This section describes AEA monitoring conducted at the single-shell tank farms and low-level burial grounds in the 200-BP-5 Operable Unit. Results of AEA monitoring conducted in the 600 Area in fiscal year 2003 (primarily the Gable Gap guard wells) are described in Section 2.10.1.

\subsubsection{Waste Management Area B-BX-BY}

The following discussion describes the current state of groundwater contamination associated with Waste Management Area B-BX-BY. Groundwater monitoring at Waste Management Area B-BX-BY has identified several distinct groups of contaminants based on chemical associations, spatial relationships, historic plume movement, knowledge of process chemistry, and characteristic chemical ratios of contaminant concentrations (PNNL-SA-39825; PNNL-14187; PNNL-13116). A plume consisting of nitrate, nitrite, technetium-99, and uranium is located under and east of the BY Tank Farm. Recent assessment studies, based on pattern matching of trend plots and chemical fingerprinting using the ratio of nitrate to technetium-99, suggest most of the groundwater contamination in the vicinity of Waste Management Area B-BX-BY is related to vertical infiltration of residual waste from the vadose zone (PNNL-14187). This waste appears to

\section{Because the upgradient well was experiencing variable specific conductance values, no upgradient/ downgradient comparisons could be made for fiscal year 2003 at Waste Management Area C.}




\section{In general, contaminant trends of nitrate, technetium-99, cyanide, and uranium have continued to decrease or stabilize during fiscal year 2003.}

be driven to the unconfined aquifer by natural precipitation and ruptures of nearby fresh water lines. Past releases from the waste management area have left pockets of contaminated soil in the vadose zone, which are, most likely, the sources of this groundwater contamination (PNNL-SA-39825; PNNL-14187).

Another plume with low levels of nitrate associated with relatively high tritium (close to or exceeding the drinking water standard of $20,000 \mathrm{pCi} / \mathrm{L}$ ) is found along the south border of the waste management area. Movement through the vadose zone from a tritium-rich perched water zone located $\sim 4.6$ meters above the water table under the B and BX Tank Farm is probably the cause of this contamination (RPP-10098; PNNL-14187). Tritium concentrations generally continued to increase in this plume during fiscal year 2003, but at a slower rate than in previous years. Maximum levels exceeded the drinking water standard $(20,000 \mathrm{pCi} / \mathrm{L})$ this year on the southwest corner of the BX Tank Farm at 20,600 pCi/L in August 2003. Farther to the north under the BY cribs, a plume containing high levels of nitrate, cyanide, cobalt-60, and technetium-99 is most likely from the highly contaminated soil under the BY cribs.

Concentrations of nitrate, technetium-99, cyanide, and uranium have continued to decrease or stabilize during fiscal year 2003 as illustrated by the technetium-99 trends shown in Figure 2.10-13. This decrease in contaminant variations during the last year may be due to one of several causes. Measures were taken at the surface of the farm with the placement of earthern berms to avoid surface run off from impacting and interacting with the contaminated subsurface soil. We may be seeing the effect of these precautions in reducing the infiltration driving contamination to the groundwater. Alternatively, the variations observed in the water levels may be causing movement of water in the aquifer, affecting contaminant trends. Results from further monitoring should provide insight to understand these current trends.

The historical discharge of effluent to the ground in and around Waste Management Area B-BX-BY has resulted in complex patterns of groundwater contamination. The highest level of technetium-99 was located beneath the BY cribs to the north and is attributed to discharges to the cribs in the mid-1950s. The technetium-99 was associated with high concentrations of nitrate, cyanide, and some cobalt-60. This contamination forms a plume that is moving southward, affecting the groundwater under the north part of Waste Management Area B-BX-BY. Elevated uranium with technetium-99, nitrate, and nitrite is found locally beneath the BY Tank Farm while a small tritium plume is located along the south margin of the waste management area. Residual waste from the waste management area is, most likely, contributing to the nitrate, technetium-99, uranium, tritium, and other contamination in the vicinity of the BY and BX Tank Farms (PNNL-SA-39825; PNNL-14187). Quarterly monitoring of the groundwater at Waste Management Area B-BX-BY will continue.

\subsubsection{Low-Level Waste Management Area 1}

Performance assessment monitoring of radionuclides at Low-Level Waste Management Area 1 is designed to complement the RCRA detection monitoring and is aimed specifically at monitoring radionuclide materials that are not regulated under RCRA. The current goal of performance assessment monitoring at Low-Level Waste Management Area 1 is to gather data to assess changes in concentrations at downgradient wells using statistical tests and to provide sufficient supporting information from upgradient wells to interpret the changes. Under the current monitoring plan (DOE/RL-2000-72), only technetium-99 is monitored specifically for performance assessment.

Section 2.10.3.3 discusses chemical constituents monitored under RCRA requirements at Low-Level Waste Management Area 1. There is no evidence that Low-Level Waste Management Area 1 has contaminated groundwater with radionuclides or hazardous constituents. 
Contaminant characteristics for radionuclides at Low-Level Waste Management Area 1 include the following:

- Technetium 99 concentrations continued to be elevated in several wells (299-E33-34, 299-E32-10, 299-E33-35) near the northeast corner of Low-Level Waste Management Area 1. Concentrations in 2003 (maximum of 7,150 pCi/L in well 299-E33-34) were lower than the maximum concentration seen in $2001(8,170 \mathrm{pCi} / \mathrm{L}$ in well 299-E33-34). This contamination is from facilities to the east, primarily the BY cribs, and the reduction in contamination is likely due to changing groundwater flow directions.

- Uranium values have stabilized between 90 and $100 \mu \mathrm{g} / \mathrm{L}$ at well 299-E33-34 in the northeast corner of the waste management area after an increase in 2002. This is associated with a relatively recent plume originating in the vicinity of Waste Management Area B-BX-BY. The uranium plume has impacted other wells surrounding this part of the waste management area, but concentrations are not as high.

- Uranium levels are increasing in a number of wells on the west side of Low-Level Waste Management Area 1, including downgradient wells 299-E32-2 and 299-E32-7, but remained below the drinking water standard $(30 \mu \mathrm{g} / \mathrm{L})$. A maximum of $21.5 \mu \mathrm{g} / \mathrm{L}$ was detected in well 299-E32-2. Comparable or higher concentrations have been seen in past years in wells farther south, so it is likely that the increases indicate a shift in preexisting plumes and not new contamination from the waste management area.

- Iodine-129 contamination in this area is consistent with regional plumes and believed to be from upgradient liquid waste facilities, not related to the burial grounds.

- Tritium contamination is also believed to be from regional plumes, not related to the burial grounds. Tritium concentrations were less than the drinking water standard in fiscal year 2003.

\subsubsection{Low-Level Waste Management Area 2}

Performance assessment monitoring of radionuclides at Low-Level Waste Management Area 2 is designed to complement the RCRA detection monitoring and is aimed specifically at monitoring radionuclide materials that are not regulated under RCRA. The current goal of performance assessment monitoring at Low-Level Waste Management Area 2 is to gather data to assess changes in concentrations at downgradient wells using statistical tests and to provide sufficient supporting information from upgradient wells to interpret the changes. Under the current monitoring plan (DOE/RL-2000-72), technetium-99, iodine-129, and uranium are monitored specifically for performance assessment.

Section 2.10.3.4 discusses chemical constituents monitored under RCRA requirements at Low-Level Waste Management Area 2. There is no evidence that Low-Level Waste Management Area 2 has contaminated groundwater with radionuclides or hazardous constituents.

Contaminant characteristics for radionuclides at Low-Level Waste Management Area 2 include the following:

- Iodine-129 concentrations are $<5 \mathrm{pCi} / \mathrm{L}$ in Low-Level Waste Management Area 2 wells. The levels are consistent with the regional iodine-129 plume and do not appear to be related to a burial ground source.

- Uranium concentrations in Low-Level Waste Management Area 2 samples are $<5 \mu \mathrm{g} / \mathrm{L}$ and do not indicate a burial ground source.

- Technetium-99 concentration is increasing in well 299-E27-10 southeast of Waste Management Area 2, where the concentration reached $59 \mathrm{pCi} / \mathrm{L}$ in 2003. This
There is no evidence

that Low-Level

Waste Management

Areas 1 or 2 have

contaminated

groundwater with

radionuclides

or hazardous

constituents. 


\section{Low levels of cyanide that have recently been found in the groundwater at Waste Management Area C suggest that the source may be related to residual tank-related vadose zone waste.}

contamination is believed to be from past disposal of liquid waste in the 200 East Area and unrelated to Low-Level Waste Management Area 2. Other wells in the monitoring network have lower technetium-99 concentrations.

- Tritium contamination is found at levels less than the drinking water standard. The tritium concentrations are consistent with regional plumes.

\subsubsection{Waste Management Area C}

Specific conductance continued to increase in upgradient well 299-E27-7 $(596 \mu \mathrm{S} / \mathrm{cm})$ and cross-gradient well 299-E27-14 $(678 \mu \mathrm{S} / \mathrm{cm})$. The increase in specific conductance is due primarily to rising sulfate and calcium along with some nitrate and chloride (PNNL-14187). Sulfate dominates with the highest value found in well 299-E27-14 at $142 \mathrm{mg} / \mathrm{L}$ in September 2003 (drinking water standard = $250 \mathrm{mg} / \mathrm{L}$ ). There has been a tendency since the mid-to-late 1990s for sulfate and calcium to increase along the basalt subcrop to the north (PNNL-13404). This distribution pattern may be due to leaching of sediment above the basalt with subsequent transport from the subcrop as the water level declines in the area (PNNL-14187). This rising sulfate/calcium trend seen at C Tank Farm may be related to these increases seen further north.

In June 2003, nitrate rose above the drinking water standard of 45 to $46.5 \mathrm{mg} / \mathrm{L}$ on the south side of the waste management area. Nitrate concentrations have been primarily increasing along with the sulfate in all wells except upgradient well 299-E27-7. Levels in this well decreased from a maximum of $27.4 \mathrm{mg} / \mathrm{L}$ in January 2002 to $19.5 \mathrm{mg} / \mathrm{L}$ in September 2002. The current trend appears to be stable with a value of $21.7 \mathrm{mg} / \mathrm{L}$ in September 2003. Since about 1999, technetium-99 has followed a trend similar to nitrate in this upgradient well, reaching a maximum of $2,760 \mathrm{pCi} / \mathrm{L}$ also in January 2002 then declining sharply to the current value of $39 \mathrm{pCi} / \mathrm{L}$ in September 2003 (Figure 2.10-14). The lack of correlation between the sulfate and the technetium-99 concentrations in this upgradient well along with the sharp increase and decrease in technetium-99 and nitrate suggests the technetium-99 has a different source than the more regional sulfate/calcium chemistry. Technetium-99 concentrations continued to increase with the nitrate downgradient at Waste Management Area C and ranged from 2,200 pCi/L on the south side of C Tank Farm to $1,400 \mathrm{pCi} / \mathrm{L}$ to the southwest at the end of fiscal year 2003 .

The use of chemical ratios can be useful to correlate groundwater contamination to possible sources and to differentiate sources of contamination in one well compared to that observed in other wells. The nitrate to technetium-99 ratio in upgradient well 299-E27-7 was 48 in November 2000. At the technetium-99 peak, it dropped to 9.9 in January 2002 as the technetium-99 rose more rapidly than the nitrate (Figure 2.10-14). When the contaminant levels dropped nearly back to those seen in November 2000, the ratio increased to 36 in September 2002. As discussed in PNNL-14187, a similar low ratio of nitrate to technetium-99 $(<10)$ is seen downgradient on the southwest side of the farm. In general, nitrate to technetium-99 ratios lower than 10 suggest the source may be related to residual tank waste in the vadose zone. The low levels of cyanide $(<18 \mu \mathrm{g} / \mathrm{L})$ that have recently been found in the groundwater at this site also suggest the source may be related to residual tank-related vadose zone waste. The C Tank Farm is the only known local source for cyanide (HNF-SD-WM-TI-740).

Another possibility is that the contamination may be related to the upgradient 216-B-3-1 ditch. As part of a continuous ditch system connected to the 216-B-63 trench, this ditch was decommissioned in 1964 after an accidental release of mixed fission products from the PUREX Plant was discharged directly to the 216-B-3-1 ditch (DOE/RL-89-28). However, the sharp rise and fall of the contaminant peak at well 299-E27-7 indicates a short travel distance from the point of entry into the groundwater. Also, there was no cyanide associated with this accidental release. Further insight into the source of the technetium-99 may be possible when data from four new fiscal year 2003 wells are available (see Chapter 5 and Appendix B). 


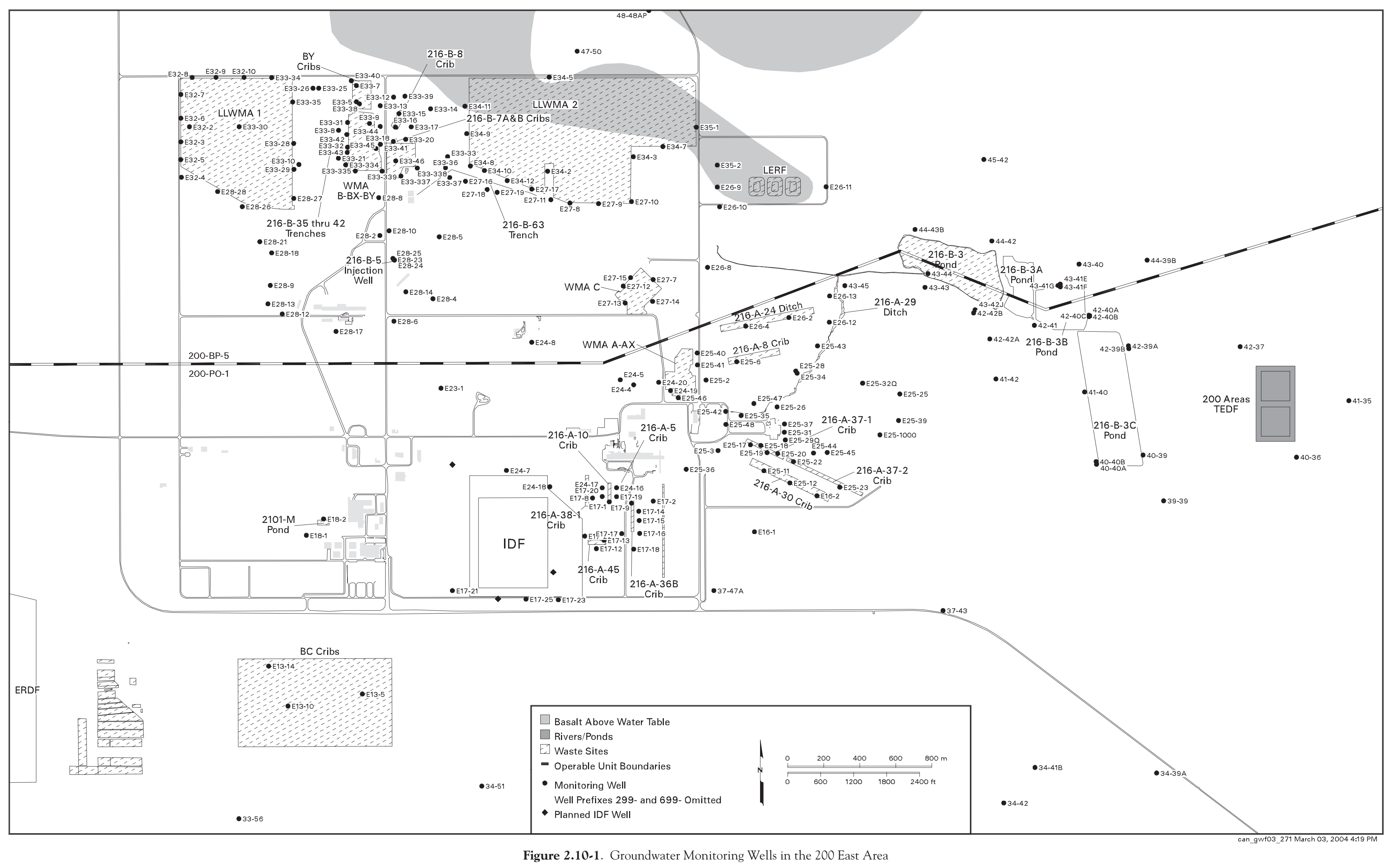




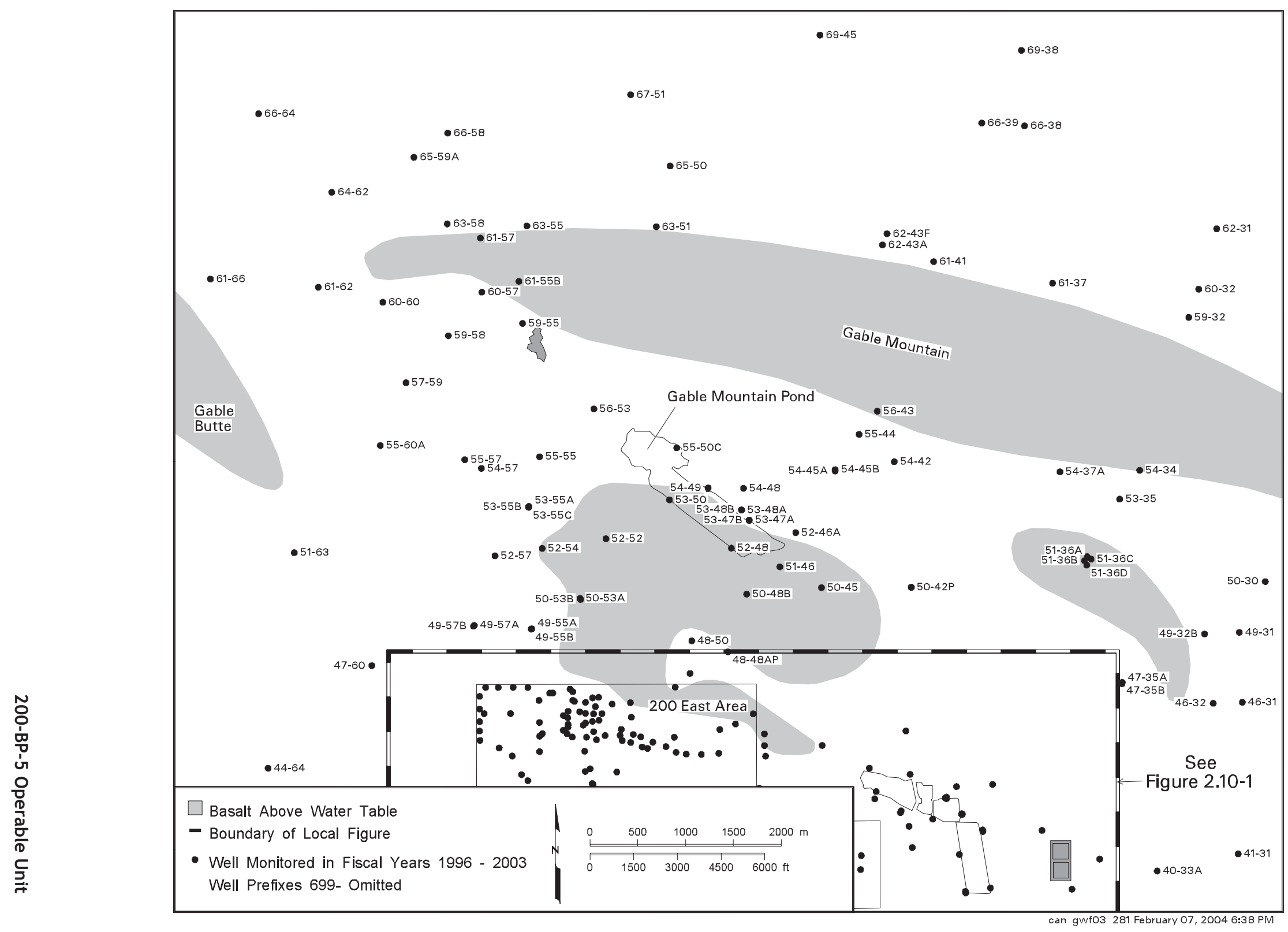

$\stackrel{\stackrel{N}{\overrightarrow{0}}}{\stackrel{i}{v}}$

Figure 2.10-2. Groundwater Monitoring Wells Located in the 600 Area Associated with the 200-BP-5 Operable Unit 


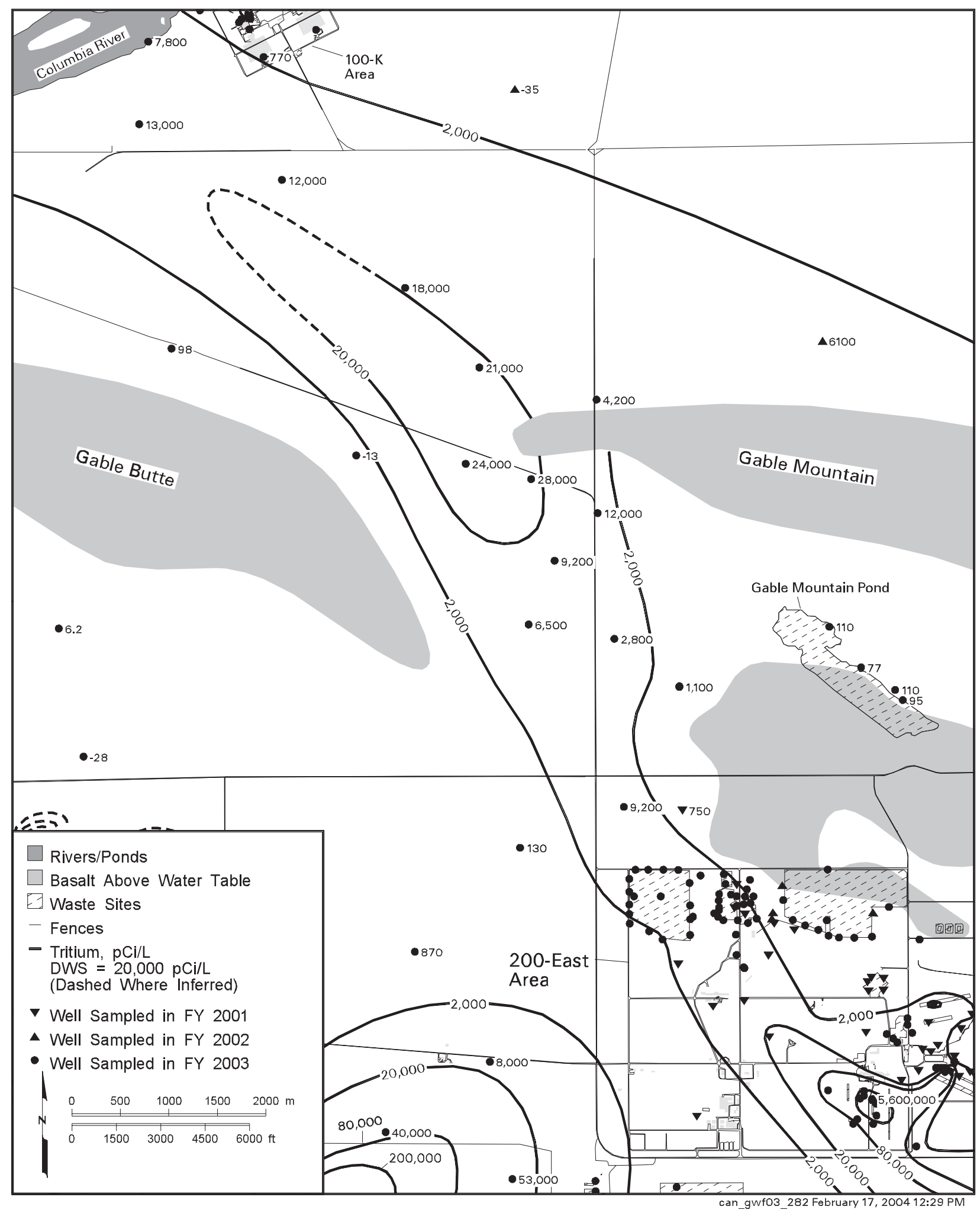

Figure 2.10-3. Average Tritium Concentrations in the 200-BP-5 Operable Unit and Vicinity, Top of Unconfined Aquifer 


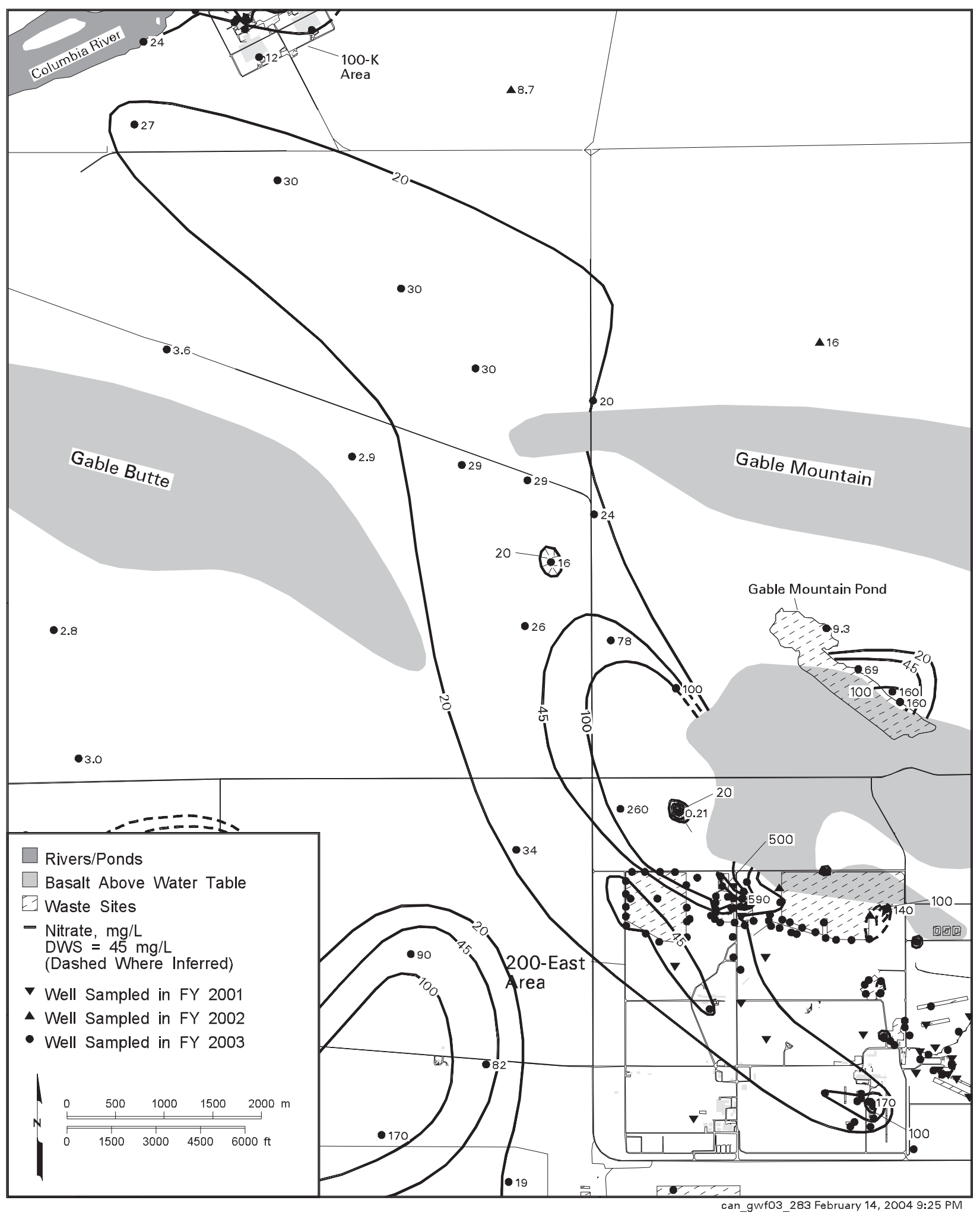

Figure 2.10-4. Average Nitrate Concentrations in the 200-BP-5 Operable Unit and Vicinity, Top of Unconfined Aquifer 


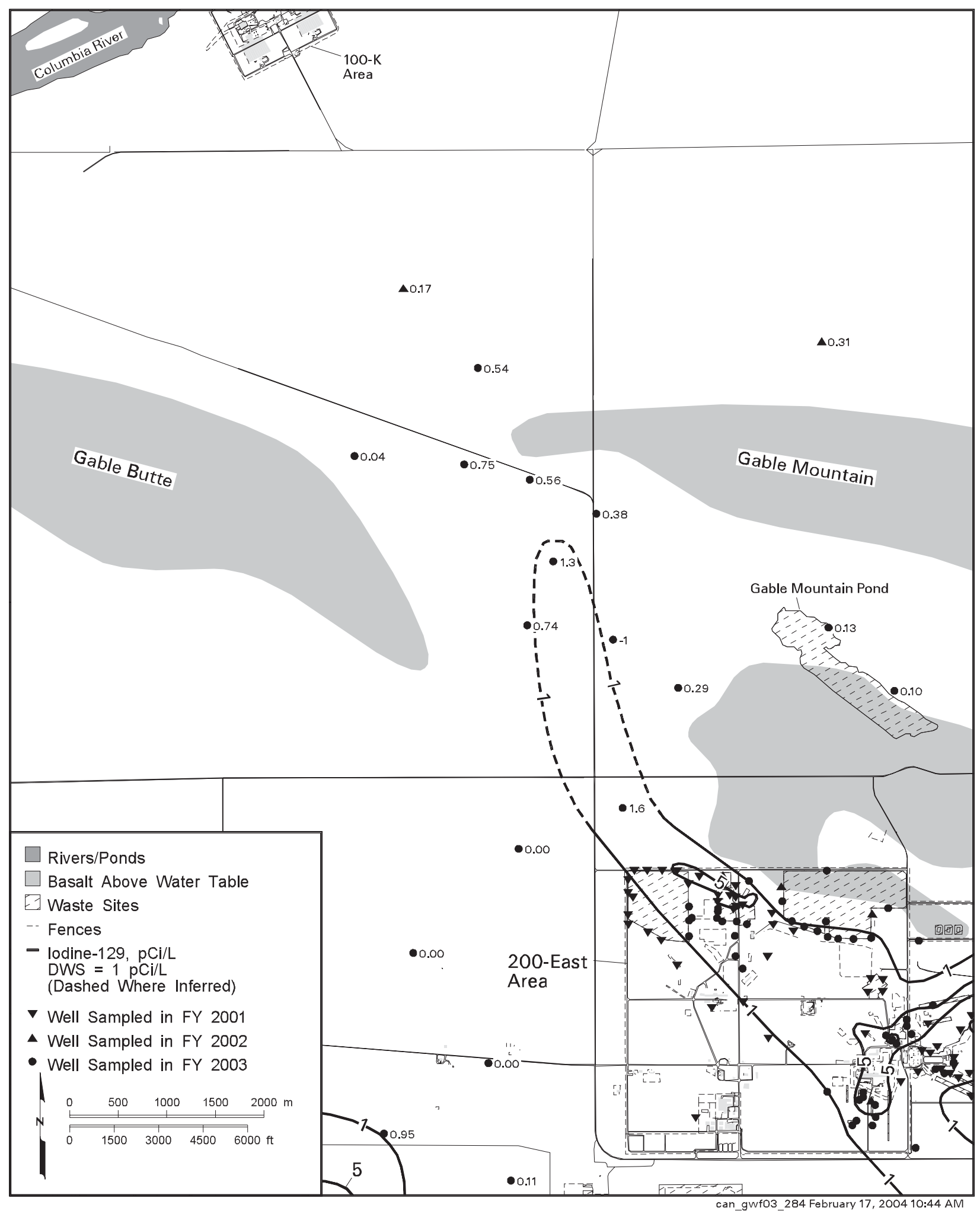

Figure 2.10-5. Average Iodine-129 Concentrations in the 200-BP-5 Operable Unit and Vicinity, Top of Unconfined Aquifer 


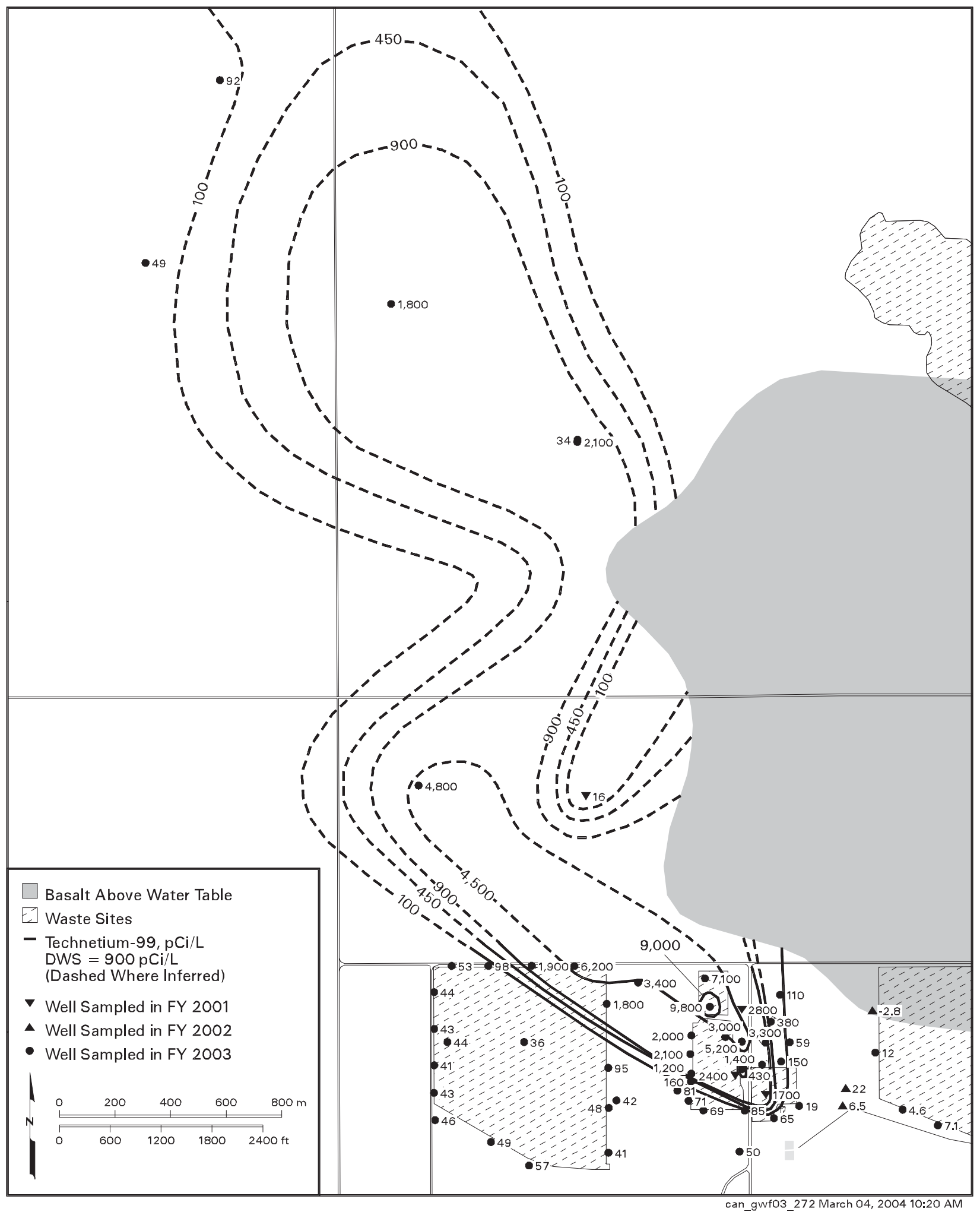

Figure 2.10-6. Average Technetium-99 Concentrations in the North 200 East Area, Top of Unconfined Aquifer 


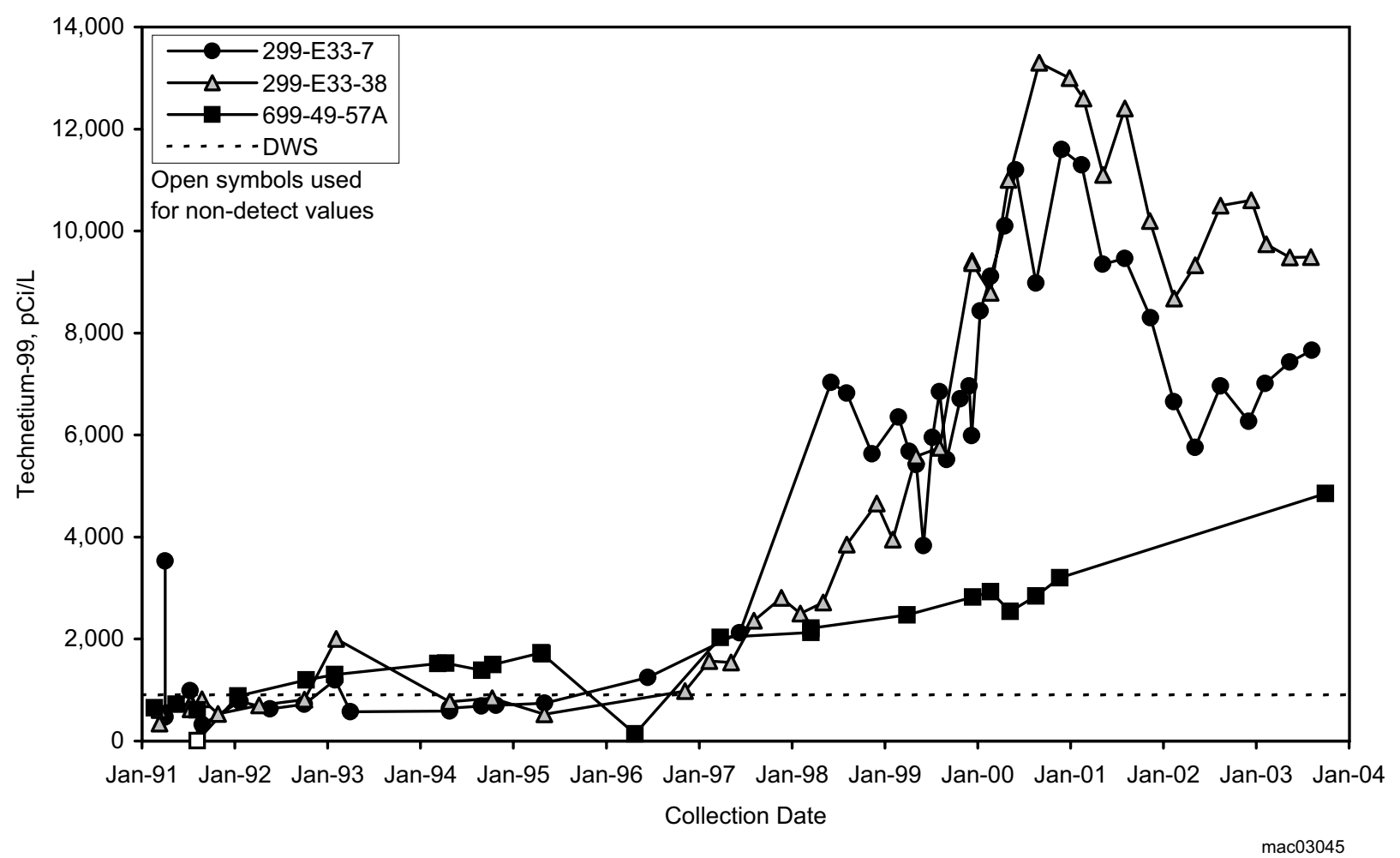

Figure 2.10-7. Technetium-99 Concentrations in Wells 299-E33-7 and 299-E33-38 at the BY Cribs and Well 699-49-57A North of 200 East Area 


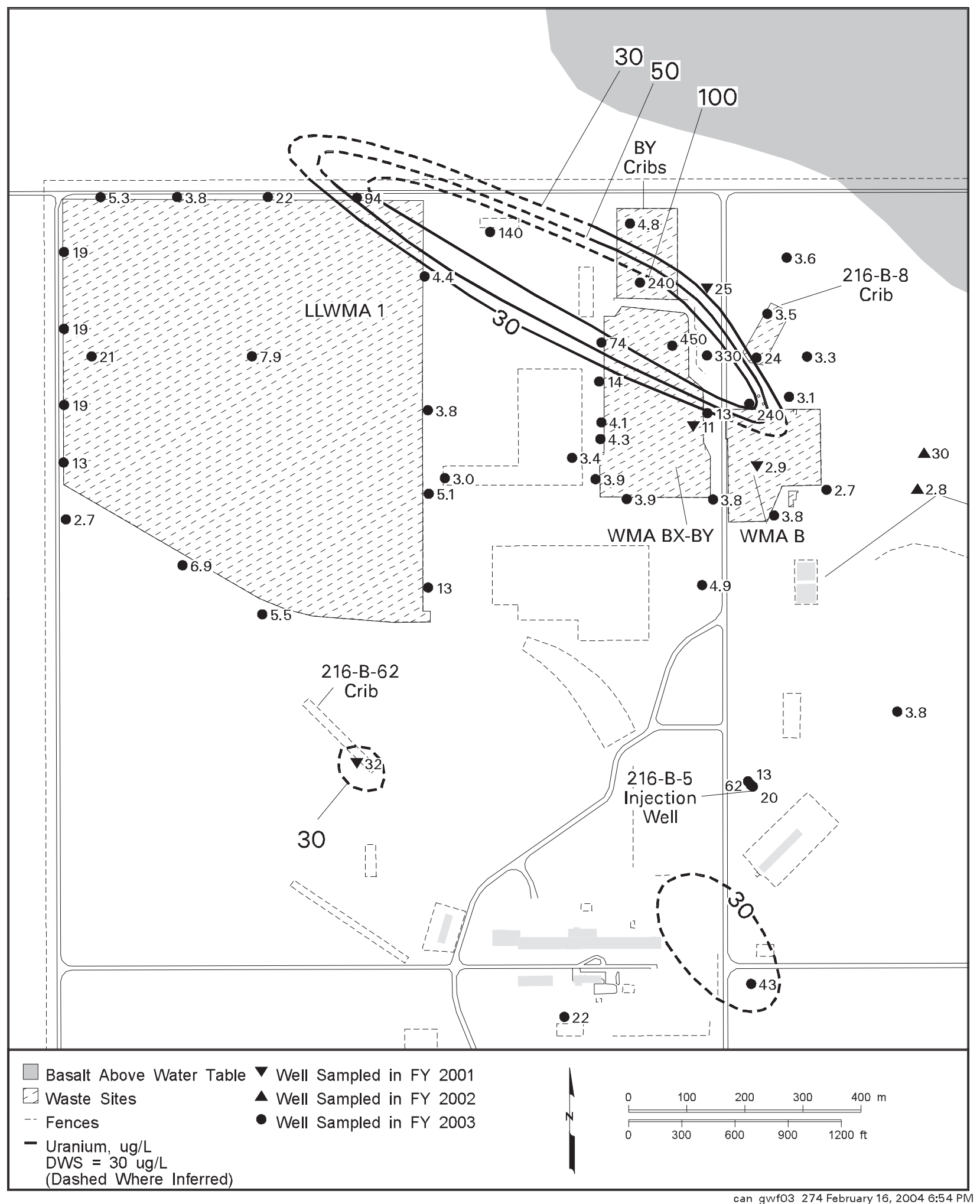

Figure 2.10-8. Average Uranium Concentrations in the Vicinity of BY Cribs, Top of Unconfined Aquifer 


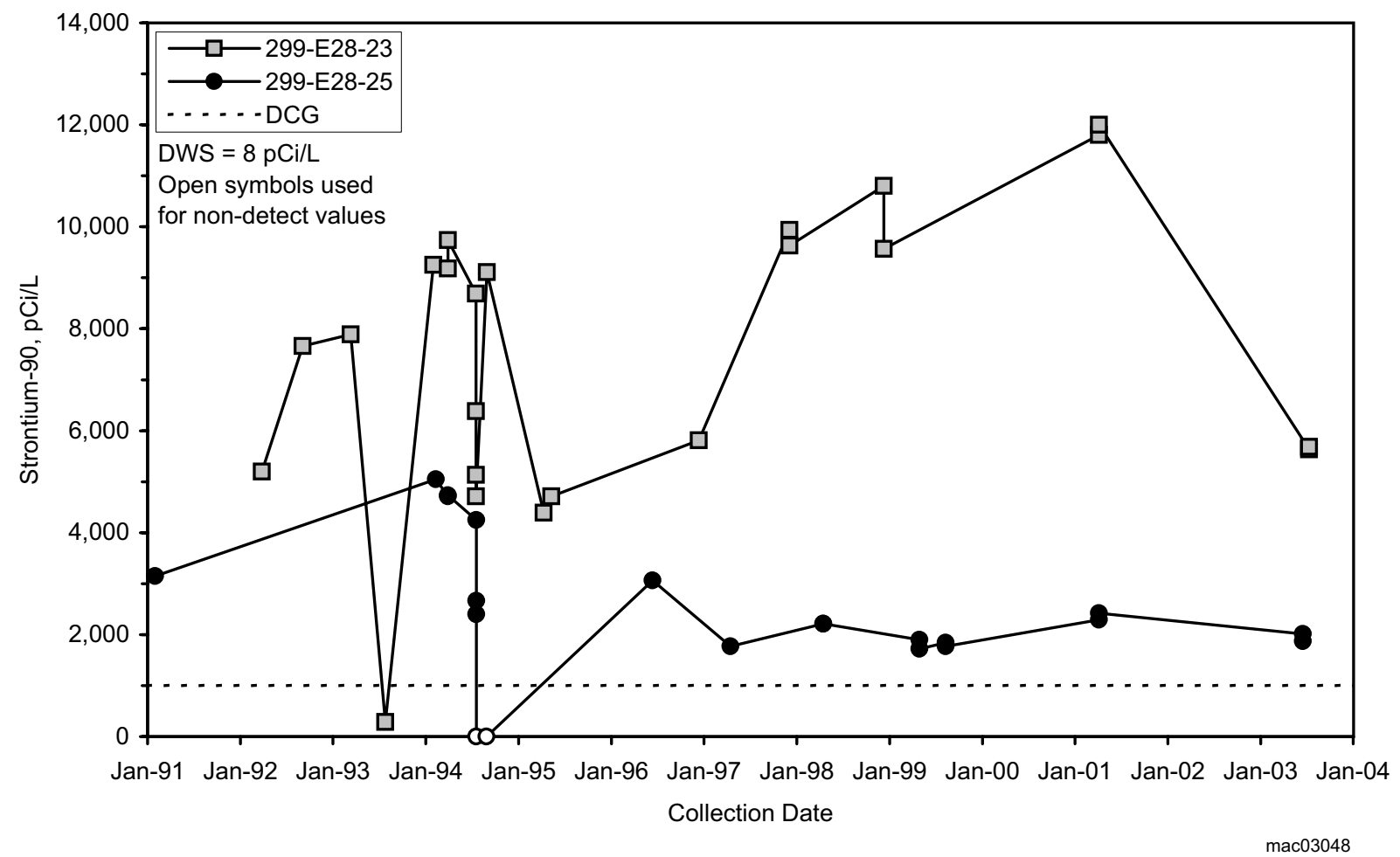

Figure 2.10-9. Strontium-90 Concentrations in Wells 299-E28-23 and 299-E28-25 at the 216-B-5 Injection Well Site 


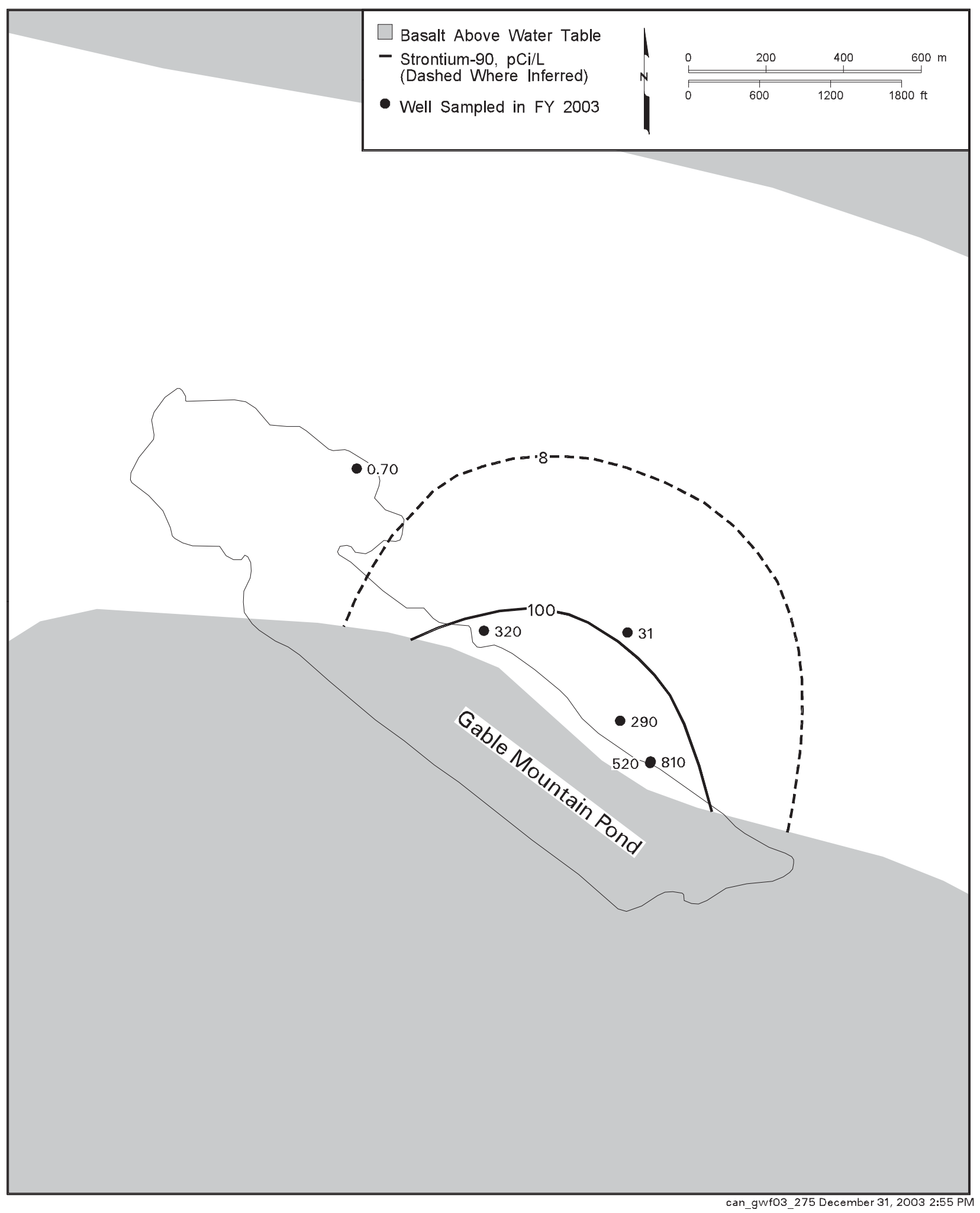

Figure 2.10-10. Strontium-90 Concentrations at Gable Mountain Pond, Top of Unconfined Aquifer 


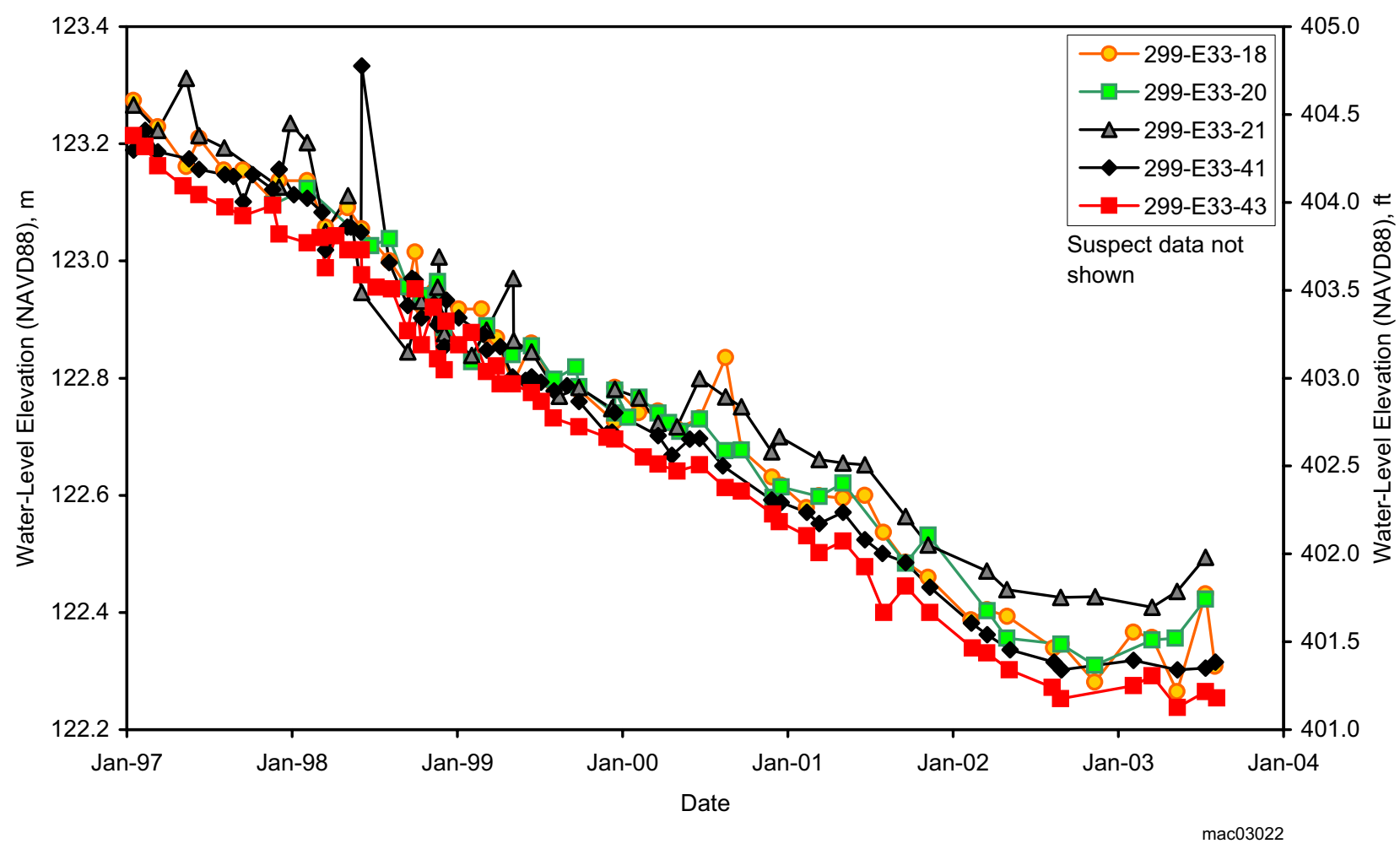

Figure 2.10-11. Hydrograph for Wells at Waste Management Area B-BX-BY Showing the Distinct Increase in Water Levels

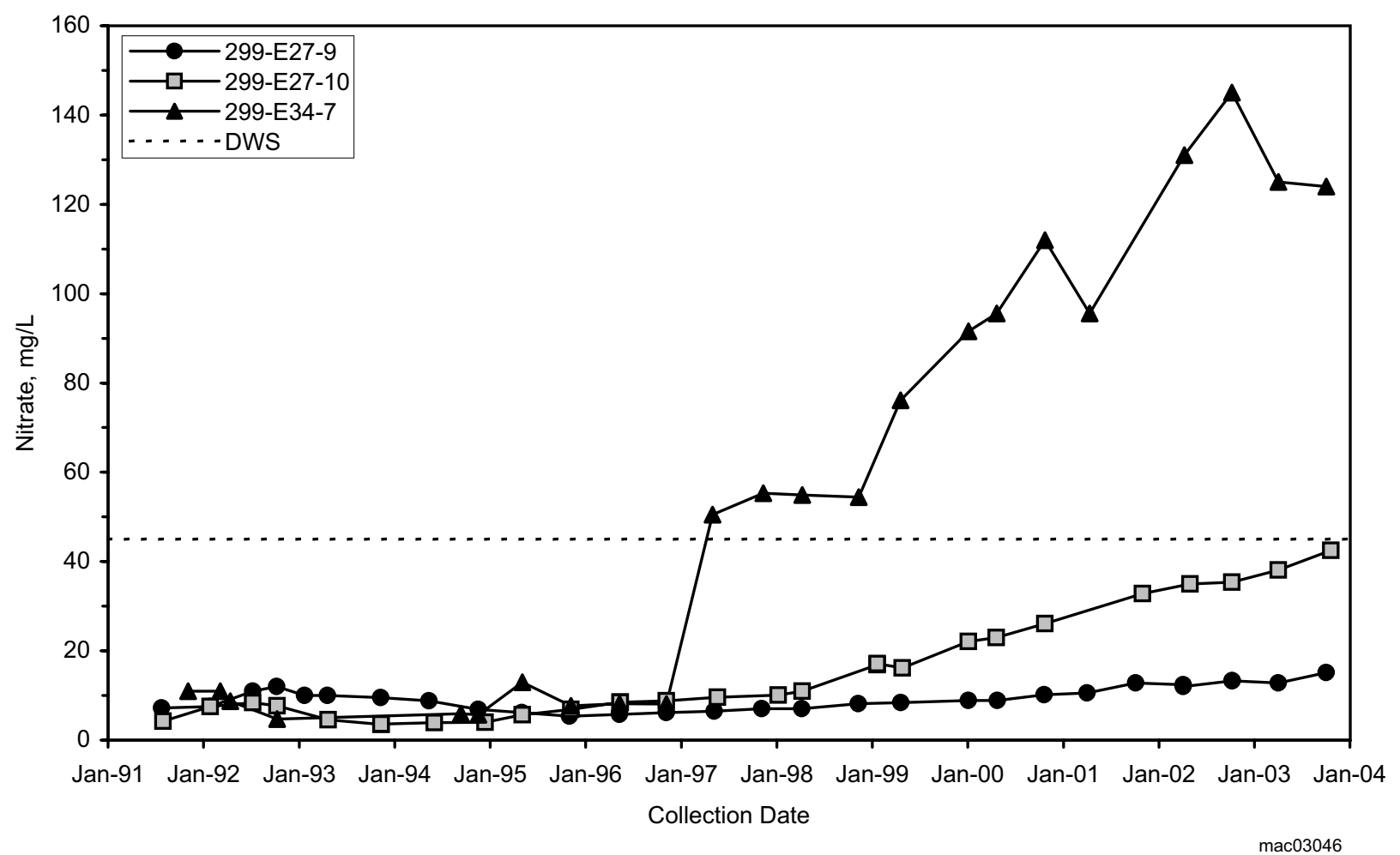

Figure 2.10-12. Nitrate Concentrations in Low-Level Waste Management Area 2 Wells 299-E34-7, 299-E27-10, and 299-E27-9 


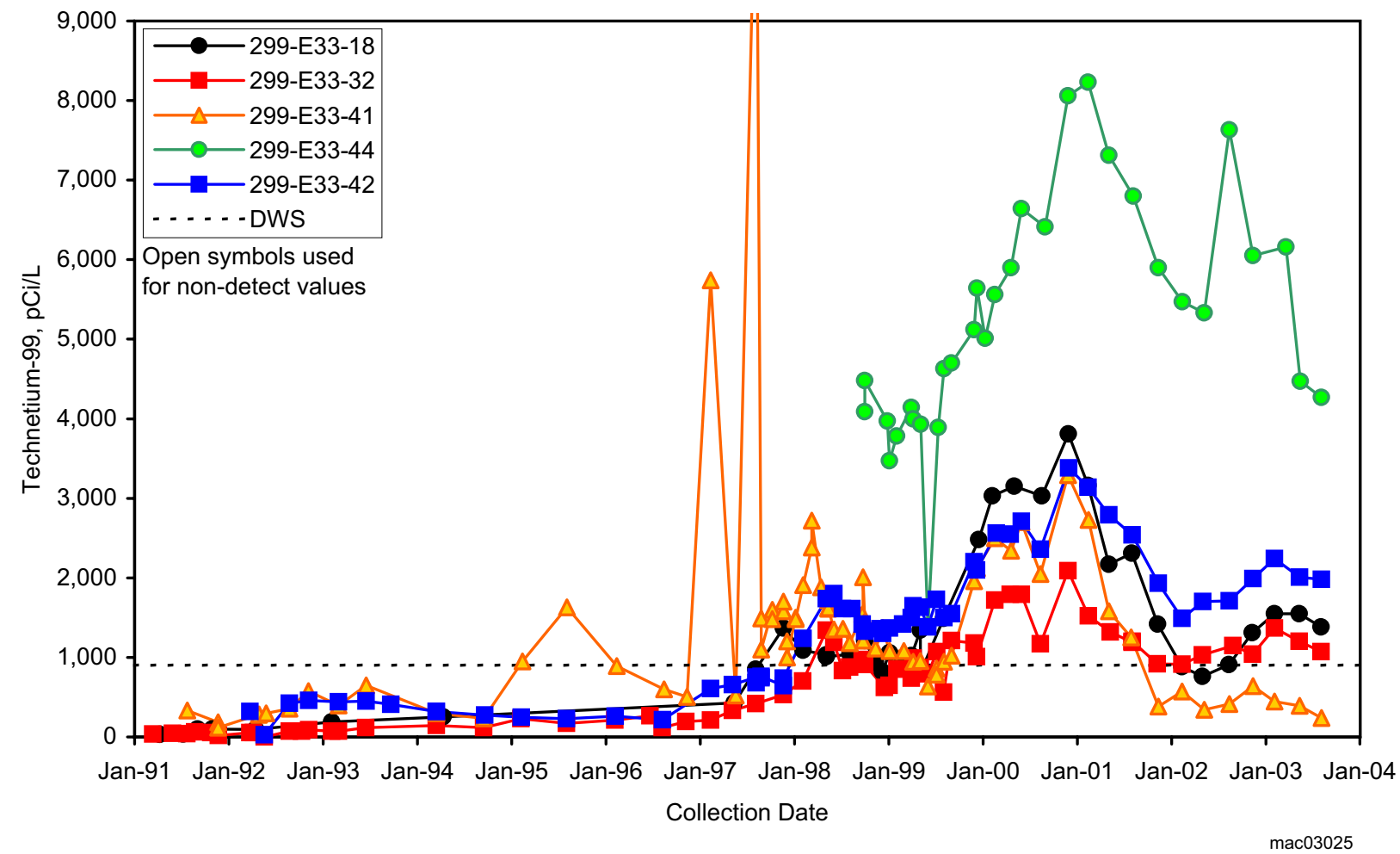

Figure 2.10-13. Trend Plots of Technetium-99 Concentrations at Waste Management Area B-BX-BY

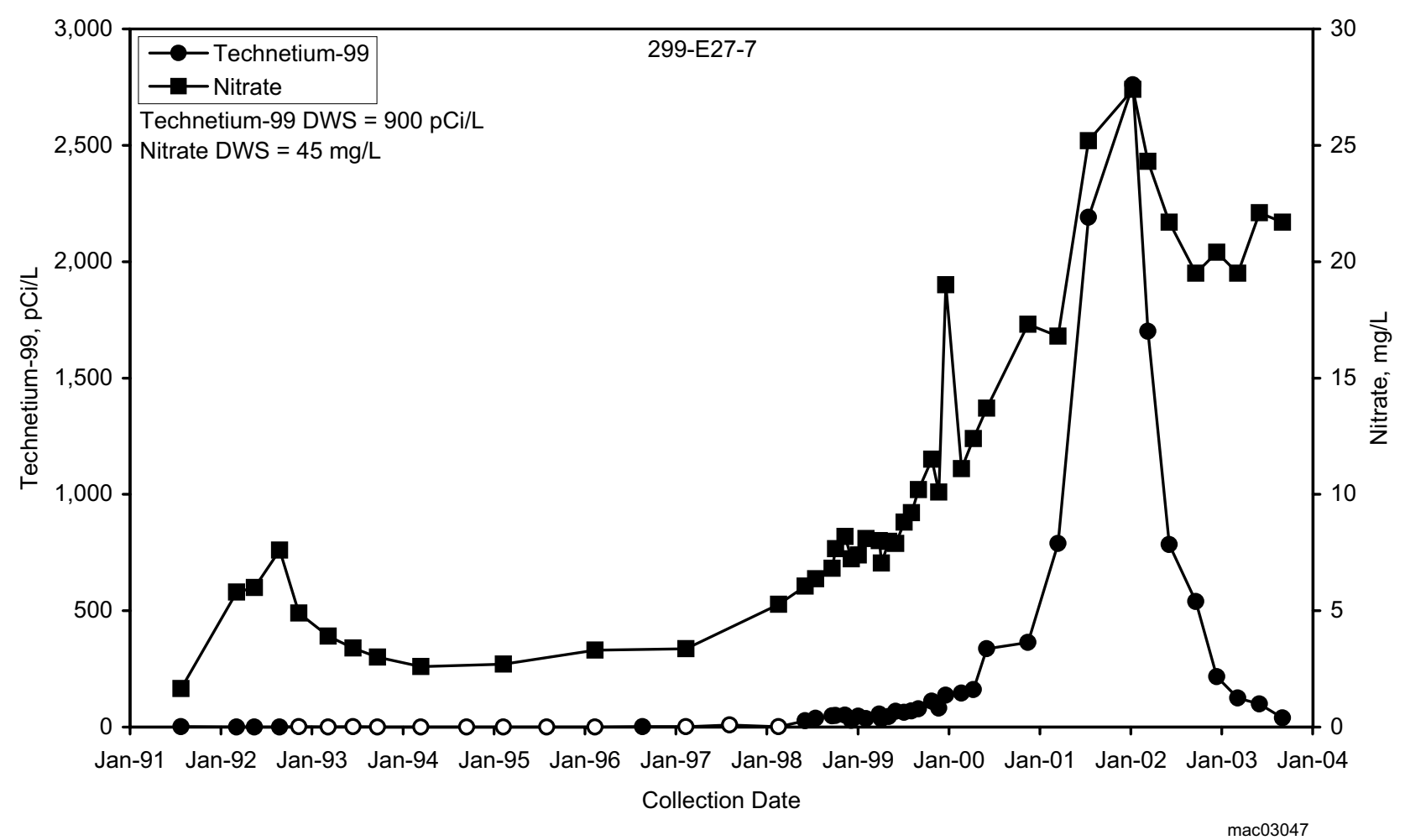

Figure 2.10-14. Technetium-99 Concentrations Compared to Nitrate Concentrations for Upgradient Well 299-E27-7 at Waste Management Area C 


\subsection{0-PO-1 Operable Unit}

\section{J. W. Lindberg, S. M. Narbutovskih, E. C. Thornton, M. D. Sweeney, D. B. Barnett, and D. G. Horton}

The scope of this section is the 200-PO-1 groundwater interest area, which includes the 200-PO-1 Operable Unit (Figure 2.1-1). This area encompasses the south portion of the 200 East Area and a large triangle-shaped portion of the Hanford Site extending to the Hanford town site to the east and the 300-FF-5 groundwater interest area to the southeast. Figure 2.11-1 shows facilities and near-field wells. Figure 2.1-2 shows the locations of 600 Area wells including 200-PO-1 Operable Unit far-field well and shoreline monitoring sites in this region. Tritium, nitrate, and iodine-129 are the contaminants of greatest significance in groundwater.

The primary monitoring objective is to meet the groundwater monitoring requirements for the Comprehensive Environmental Response, Compensation, and Liability Act (CERCLA) ${ }^{(a)}$ and the Atomic Energy Act of 1954 (AEA) as directed in U.S. Department of Energy (DOE)

Groundwater monitoring in the 200-PO-1 groundwater interest area includes CERCLA, RCRA, AEA, and WAC monitoring:

CERCLA Monitoring

- One hundred nineteen wells (78 far-field and 41 near-field wells) are sampled annually to triennially for tritium, nitrate, and iodine-129 plus other constituents depending on location. The 78 far-field wells are also the far-field wells of the PUREX cribs RCRA site.

- In fiscal year 2003, two wells were not sampled as scheduled (see Appendix A for details).

RCRA Monitoring

- Eleven near-field wells are sampled quarterly to triennially for PUREX cribs. One well was not sampled because it went dry.

- Seven wells are sampled semiannually for Waste Management Area A-AX.

- Nine wells are sampled semiannually for the 216-A-29 ditch.

- Four wells are sampled semiannually sampling for the B Pond.

- Nine wells are sampled semiannually for the Nonradioactive Dangerous Waste Landfill.

- Monitoring is coordinated with other programs to avoid duplication.

AEA Monitoring

- Four wells within Waste Management Area A-AX are sampled annually to triennially for radionuclides.

- Three water supply wells at the 400 Area are sampled quarterly to annually for tritium.

- Monitoring is coordinated with RCRA-past practice, RCRA, and WAC sampling to avoid duplication.

WAC Monitoring

- Three wells at the 200 Area Treated Effluent Disposal Facility are sampled quarterly.

- Ten wells at the Solid Waste Landfill are sampled quarterly. One well was not sampled during fiscal year 2003 because it went dry.

- Three wells at the 400 Area Process Ponds are sampled quarterly.

(a) Past-practice monitoring in this operable unit is regulated under RCRA past-practice, which follows the same groundwater monitoring activities as CERCLA. This report uses the term CERCLA for simplicity. 


\section{Groundwater in the 200-PO-1 Operable Unit flows to the southeast and east.}

\section{Concentrations of tritium continue \\ to decline as \\ the plume is \\ attenuating \\ naturally.}

orders. The longer-term goal is to monitor the contaminants of concern until final cleanup decisions are made. Included within the operable unit are six Resource Conservation and Recovery Act (RCRA) units including the Plutonium-Uranium Extraction (PUREX) cribs, Waste Management Area A-AX (single-shell tanks), 216-A-29 ditch, Integrated Disposal Facility, 216-B-3 pond (B Pond), and the Nonradioactive Dangerous Waste Landfill. Three other facilities that are not regulated under RCRA but are subject to Washington Administrative Code (WAC) requirements are the 200 Area Treated Effluent Disposal Facility, Solid Waste Landfill, and 400 Area process ponds. In addition to the tritium, nitrate, and iodine-129 plumes, other contaminants of concern include technetium-99, strontium-90, arsenic, chromium, cyanide, manganese, and vanadium (PNNL-14049).

Groundwater in the unconfined aquifer generally flows southeastward in the west portion of the operable unit and northeastward, eastward, and southeastward in the east portions of the operable unit as groundwater approaches the Columbia River (Figure 2.1-3). A detailed discussion of 200 East Area hydrogeology can be found in PNNL-12261. Further discussions of more local groundwater flow characteristics are found in the sections where individual areas of RCRA-past practice, RCRA, AEA, and WAC groundwater monitoring are discussed.

The remainder of this section describes contaminant plumes and concentration trends for the contaminants of concern under RCRA-past practice, RCRA, AEA, and WAC monitoring.

\subsubsection{Groundwater Contaminants}

This section describes the major contaminants of concern within the 200-PO-1 Operable Unit. Greater details at a various RCRA or WAC facilities are discussed in Sections 2.11.3 and 2.11.5.

\subsubsection{Tritium}

The source for the large tritium plume that extends from the southeast portion of the 200 East Area to the Columbia River (Figure 2.1-5) is in the vicinity of the PUREX cribs. The highest concentrations of tritium (drinking water standard $20,000 \mathrm{pCi} / \mathrm{L}$ ) in this plume remain near these cribs. The highest level recorded during fiscal year 2003 was 5,570,000 pCi/L at well 299-E17-9 near crib 216-A-36B for a sample collected October 28, 2002. This well went dry after the October 28, 2002 sampling event and was replaced by well 299-E17-16 (which had a reported level of 231,000 pCi/L for a sample collected in April 2003). Well 299-E17-9 was the only well in the large tritium plume having a concentration greater than the DOE derived concentration guide $(2$ million $\mathrm{pCi} / \mathrm{L})$. Without well 299-E17-9, the highest reported level of tritium during fiscal year 2003 was $711,000 \mathrm{pCi} / \mathrm{L}$ for a sample collected October 2, 2002 at well 299-E17-14. Thus, the current groundwater monitoring network does not reflect the highest concentration of tritium in the plume.

Concentrations of tritium continue to decline as the plume is attenuating naturally due to radioactive decay and dispersion combined with the general decreasing source that resulted from the termination of PUREX Plant operations. Wells in the east portions of the 200-PO-1 Operable Unit have tritium concentrations above $80,000 \mathrm{pCi} / \mathrm{L}$ (Figure 2.1-5) from an early period of discharge to the PUREX cribs. These wells are expected to continue to experience decreasing concentrations as pulses representing the two periods of PUREX Plant operations move beyond the wells into the river. These wells more distant from the source are sampled only once every 3 years. Most were sampled last during fiscal year 2001 and will be sampled again in fiscal year 2004.

Generally, wells near the PUREX cribs show a steady to decreasing trend as demonstrated in the trend plot for well 299-E17-14 (Figure 2.11-2). The only exception is well 
299-E17-9. This well is the only well showing an upward trend (Figure 2.11-3), and it is the only well to recently go dry. Although there may be a relationship between the well going dry and the recent increase in tritium concentration, there is no way to test it because the well can no longer be sampled.

The zone of lower tritium concentration near Energy Northwest (Figure 2.1-5) may be due to a zone of lower hydraulic conductivity in the unconfined aquifer. At that site, the water table is within the upper portion of the Ringold Formation that locally may have a greater degree of cementation. Tritium at the 618-11 burial grounds is discussed in Section 2.12 .

\subsubsection{2 lodine-129}

The iodine-129 plume (Figure 2.1-7) extends southeast into the 600 Area and appears to coincide with the tritium and nitrate plumes (Figures 2.1-5 and 2.1-6). At the scale that the iodine-129 concentration map is plotted, there appears to be very little difference between this year's map and the corresponding map in last year's groundwater annual report (see Figure 2.1-5 in PNNL-14187). Although the iodine-129 plume is dispersing, it is doing so at a very slow rate.

The highest iodine- 129 concentrations (drinking water standard $1.0 \mathrm{pCi} / \mathrm{L}$ ) detected in the 200 East Area in fiscal year 2003 were near the PUREX cribs (Figure 2.1-7). The maximum concentration of iodine-129 detected in fiscal year 2003 was $11.9 \mathrm{pCi} / \mathrm{L}$ at well 299-E17-14 near the 216-A-36B crib. Concentrations of iodine-129 in groundwater near the PUREX cribs are generally declining slowly or are stable, as shown for wells 299-E17-14 (Figure 2.11-4) and 299-E17-1 (Figure 2.11-5). Concentrations of iodine-129 in wells near the Columbia River on the east side of the 200-PO-1 Operable Unit continue to be $<0.6 \mathrm{pCi} / \mathrm{L}$.

\subsubsection{Nitrate}

High nitrate concentrations continued to be found near the PUREX cribs, and the concentrations are generally decreasing with time. The maximum nitrate concentration detected near the PUREX cribs in fiscal year 2003 was $170 \mathrm{mg} / \mathrm{L}$ in well 299-E17-9, which is near the 216-A-36B crib. The extent of the nitrate plume that originates from the 200 East Area (Figure 2.1-6) is nearly identical to the tritium plume. However, the area with nitrate concentration $>45 \mathrm{mg} / \mathrm{L}$ (the drinking water standard) is more restricted than the area with tritium above its drinking water standard of $20,000 \mathrm{pCi} / \mathrm{L}$. Nitrate at levels above the drinking water standard north of the 400 Area and at Energy Northwest, within the area impacted by the PUREX cribs, can be attributed to wastewater disposal or activities in those areas (see Sections 2.11.4.2 and 2.11.5.3). The nitrate plume (Figure 2.1-6) appears to have receded slightly over previous years throughout most of its extent except for the south-most portions of the plume near the 300 Area (see Section 2.12) and in the immediate vicinity of the PUREX cribs. Nitrate concentrations continue to increase around the 216-A-37-1 crib and in the area upgradient of the PUREX cribs (well 299-E24-18 Figure 2.11-6). At the 216-A-36B and 216-A-10 cribs, the concentrations are steady to slightly increasing as can be seen at well 299-E17-14 as an example (Figure 2.11-7).

\subsubsection{Strontium-90}

There is a small plume of strontium-90 (a beta emitter) at the 216-A-10 and 216-A-36B cribs. It is also detected at Waste Management Area A-AX and at the 216-A-37-1 crib. The only well with strontium-90 concentrations above the drinking water standard ( $8 \mathrm{pCi} /$ L) during fiscal year 2003 was well 299-E17-14 with a maximum of $21.4 \mathrm{pCi} / \mathrm{L}$. Well 299-E17-14 is near the 216-A-36B crib and shows an increasing trend since 1997 (Figure 2.11-8). The impact is localized because of the low mobility of strontium-90 compared to tritium, iodine-129, and nitrate. This result is consistent, in part, with a gross beta concentration of $62.7 \mathrm{pCi} / \mathrm{L}$ in the same well. (Drinking water standard for gross beta is $50 \mathrm{pCi} / \mathrm{L}$.)

\section{The iodine-129 \\ plume is dispersing, but at a very slow rate.}




\subsubsection{Technetium-99}

Technetium-99 is detected at Waste Management Area A-AX in concentrations well below the drinking water standard $(900 \mathrm{pCi} / \mathrm{L})$ and is detected indirectly at the PUREX cribs. The highest concentration during fiscal year 2003 at Waste Management Area A-AX was $287 \mathrm{pCi} / \mathrm{L}$ in well 299-E25-41, which is located in the north portion of Waste Management Area A-AX (see Section 2.11.4.1).

The $62.7 \mathrm{pCi} / \mathrm{L}$ result for gross beta at well 299-E17-14 (at the 216-A-36B crib) is more than can be accounted for from the strontium -90 result $(21.4 \mathrm{pCi} / \mathrm{L})$ in the same well. If the only beta emitter present were strontium-90, gross beta would be $\sim 34 \mathrm{pCi} / \mathrm{L}$. Therefore, the $62.7 \mathrm{pCi} / \mathrm{L}$ must include another beta emitter. The higher result for gross beta is most likely due to technetium-99, another beta emitter. The last technetium-99 result from well 299-E17-14 was 209 pCi/L in fiscal year 1994. Technetium-99 is no longer routinely analyzed in PUREX crib well samples because previous results were significantly less than the drinking water standard, and gross beta analysis could be used as a screening tool for technetium-99 and other beta emitters.

\subsubsection{Manganese}

Filtered manganese concentrations remained elevated at various wells near all three of the PUREX cribs and also at wells of Waste Management Area A-AX, but only one well had reported values that exceeded the secondary drinking water standard $(50 \mu \mathrm{g} / \mathrm{L})$ during fiscal year 2003. The exceedances was at well 299-E17-19 near the $216-\mathrm{A}-10 \mathrm{crib}$ where the reported value of was $57.5 \mu \mathrm{g} / \mathrm{L}$ in October 2002. The trend for filtered manganese at this well, as well as for other PUREX cribs wells, is erratic (Figure 2.11-9) supporting the suggestion that these spurious occurrences are related to corrosion of the well screen or casing (see also Section 2.11.4.1).

\subsubsection{Other Constituents}

Plume areas (square kilometers) above the drinking water standard at the 200-PO-1 Operable Unit:

Chromium - 0.01

Iodine-129-65.10

Nitrate -0.16

Strontium-90-0.01

*Tritium -122

*Includes portion of plume beneath 300-FF-5 Operable Unit.

Arsenic, chromium, cobalt-60, cyanide, and vanadium are also contaminants of concern at various facilities within the 200-PO-1 Operable Unit. Cobalt-60, cyanide, and vanadium are potential contaminants of concerns at the $\mathrm{BC}$ cribs, and will be analyzed when the new sampling and analysis plan for the 200-PO-1 Operable Unit is implemented in fiscal year 2004.

Filtered arsenic and chromium are routinely analyzed in samples of 200-PO-1 Operable Unit wells. Results show that filtered arsenic was detected (e.g., 4.4 to $9.2 \mu \mathrm{g} / \mathrm{L}$ for PUREX cribs wells for fiscal year 2003) but in concentrations similar to Hanford groundwater background values (DOE/RL-96-61). Filtered chromium continued to exceed the drinking water standard $(100 \mu \mathrm{g} / \mathrm{L})$ at wells near the Waste Management Area A-AX (see Section 2.11.4.1), but the elevated results are interpreted to be related to the corrosion of the stainless steel well screen or casing.

\subsubsection{CERCLA Groundwater Monitoring}

The 200-PO-1 Operable Unit contains a large section of the Hanford Site (Figure 2.1-1). Its boundaries are generally defined by the largest contaminant plume of the operable unit, tritium. The north boundary is the line separating the 200-BP-5 Operable Unit with the 200-PO-1 Operable Unit in the 200 East Area and the $2,000 \mathrm{pCi} / \mathrm{L}$ tritium contour line trending eastward toward the Columbia River. The southwest boundary is the $2,000 \mathrm{pCi} / \mathrm{L}$ tritium contour line. The south boundary coincides with the north boundary of the 300-FF-5 Operable Unit, and the east boundary is the Columbia River. The 200-PO-1 Operable Unit also contains the $\mathrm{BC}$ cribs area because they are known to have received liquid waste from PUREX plant operations.

Groundwater monitoring at the 200-PO-1 Operable Unit ensures that requirements for CERCLA and AEA are met as directed in DOE orders. The longer-term goal is to 
monitor the groundwater contaminants of concern until final cleanup decisions are made (i.e., a record of decision has not been written). Major groundwater contaminants of concern are tritium, iodine-129, and nitrate. Minor groundwater contaminants are arsenic, chromium, cobalt-60, cyanide, manganese, strontium-90, technetium-99, and vanadium (see Section 2.11.1 for maps and descriptions of plumes and trends).

A data quality objectives summary report was prepared during fiscal year 2002 in response to the U.S. Environmental Protection Agency (EPA) 5-year review of groundwater remedial actions of the Hanford Site (supported Action Items 200-7 and 200-8) (EPA 2001). During fiscal year 2003, a draft sampling and analysis plan for the operable unit was prepared and submitted to the regulator (Washington State Department of Ecology [Ecology]) for review. The plan was approved in early fiscal year 2004. During fiscal year 2003, the operable unit was monitored according to a temporary plan presented at the Unit Manager's meeting on March 30, 2000. The temporary plan presented was nearly identical to the plan for monitoring the far-field wells in the RCRA PUREX cribs groundwater monitoring plan (PNNL-11523) and later proposed in the draft sampling and analysis plan. The meeting minutes transmittal/approval ${ }^{(b)}$ was signed by representatives of DOE's Richland Operations Office, Ecology, and EPA in August and September 2000. There were no specific changes required to the proposed temporary plan as a result of the meeting. The new sampling and analysis plan (DOE/RL-2003-04) adds requirements for sampling Columbia River shoreline aquifer tubes and two proposed new wells near the BC cribs.

Two wells were not sampled as planned in the 200-PO-1 Operable Unit during fiscal year 2003 (see Figure 2.1-2 for well locations). Well 699-31-31 (located northeast of the Central Landfill) was not sampled because the access road needs repair. Well 699-S11-E12AP was not sampled because of a scheduling error. It is sampled triennially with other wells monitoring the basalt-confined aquifer, but inadvertently was not scheduled annually for the 200-PO-1 Operable Unit. (See Appendix A for additional details including tables of wells and constituents.)

\subsubsection{RCRA Groundwater Monitoring}

The 200-PO-1 Operable Unit contains six RCRA sites with groundwater monitoring requirements (Figure 2.11-1):

- PUREX cribs (216-A-10, 216-A-36B, and 216-A-37-1).

- Single-shell tanks at Waste Management Area A-AX.

- 216-A-29 ditch.

- Integrated Disposal Facility.

- 216-B-3 Pond.

- Nonradioactive Dangerous Waste Facility (Figure 2.1-2).

This section summarizes results of statistical comparisons, assessment studies, and other developments for fiscal year 2003. RCRA groundwater data are available in the Hanford Environmental Information System and in the data files accompanying this report.

(b) Meeting Minutes Transmittal/Approval 082093, Unit Managers' Meeting on March 30, 2000, 200 Area Groundwater and Source Operable Units, 3350 George Washington Way, Richland, Washington, Hanford Project Office, U.S. Environmental Protection Agency, Richland, Washington, August 29, 2002.

\section{A new sampling and analysis plan for the 200-PO-1 Operable Unit was prepared in fiscal year 2003 and implemented in fiscal year 2004.}




\section{RCRA assessment} monitoring shows that the nitrate plume is generally attenuating, except for the area immediately around the PUREX cribs.

\subsubsection{PUREX Cribs}

The PUREX cribs (216-A-10, 216-A-36B, and 216-A-37-1) are monitored in interim status to assess groundwater quality (see Appendix B). Groundwater flow for the two west cribs (216-A-10 and 216-A-36B) is most likely toward the southeast; for the 216-A-37-1 crib, it is south or southwest. (See Appendix B for more information on flow direction and rate information.) The PUREX cribs are located in a region where several groundwater contaminant plumes contain constituents that exceed drinking water standards. The similarities in effluent constituents disposed to these cribs, as well as to the 216-A-45 crib, make determining the contribution of the PUREX cribs difficult. During fiscal year 2003, nitrate and filtered manganese exceeded drinking water standards in PUREX cribs wells (see Sections 2.11.1.3 and 2.11.1.6 for more information on nitrate and manganese).

The PUREX cribs groundwater monitoring plan (PNNL-11523) organized the downgradient wells into two groups, near-field wells and far-field wells. The 11 nearfield wells are shown in Figure 2.11-1 and Appendix B. The far-field wells include 78 wells that coincide with the same wells used for monitoring the major plumes of the 200-PO-1 Operable Unit (Figure 2.1-2). The far-field wells are necessary to monitor the large nitrate plume (Figure 2.1-6) that extends southeastward of the PUREX cribs area to the Columbia River and are discussed in Sections 2.11.1 and 2.11.2.

The nitrate plume (Figure 2.1-6) is generally attenuating, except for the area immediately around the PUREX cribs. In recent years, the concentration of nitrate in PUREX cribs near-field wells has either held steady or rose (see Section 2.11.1.3). The reason for the increased concentrations of nitrate in recent years is not known. However, it may be related to a change in groundwater flow paths that are, in turn, related to the decreased amount of groundwater flow from the B Pond area and a greater contribution of groundwater flow from the northwest.

Manganese remained elevated in a few PUREX cribs wells during fiscal year 2003. However, the elevated values are erratic and may be associated with corrosion of the well screen or casing.

During fiscal year 2003, one well in the near-field network was not sampled as scheduled. The water level in well 299-E17-9 dropped to a level that was too low for effective sampling. The well was replaced with well 299-E17-16. However, this substitute well is located southeast of well 299-E17-9 and does not intercept the groundwater contamination plumes in a location where concentrations are as high as the well 299-E17-9 location.

\subsubsection{Waste Management Area A-AX}

Located along the east border of the 200 East Area, Waste Management Area A-AX consists of the A Tank Farm, AX Tank Farm, AR vault, ancillary waste transfer lines, and seven diversion boxes. This section provides a summary of monitoring specific to RCRA-regulated constituents and the local hydrogeology of the waste management area. The current state of groundwater contamination in this area is presented in Section 2.11.4.1.

Based on local hydrographs and colloidal borescope measurements, it has been determined that the groundwater flow direction ranges from east southeast to southeast (PNNL-14187). The existing well network at Waste Management Area A-AX was designed for groundwater flow to the southwest. An interim change notice to the groundwater monitoring plan for this site (PNNL-13023-ICN-1) was issued July 2002 to document the southwest flow direction. In fiscal year 2003, one upgradient well and one downgradient well were installed to improve the RCRA network capabilities to detect groundwater contamination associated with the two tank farms (see well location map in Appendix B). The upgradient well will be sampled quarterly for the first year to allow its use for critical mean calculations. 
The estimated flow rate at Waste Management Area A-AX is 1.7 to 3.3 meters per day (see Appendix B) depending on the hydraulic conductivity value used in the Darcy equation. The rate of water-table decline beneath Waste Management $\mathrm{A}$-AX averaged 0.25 meter during fiscal year 2003. If this rate continues, wells from the original network should be usable for at least 5 to 6 years.

This site continued to be monitored under an interim status indicator evaluation program in fiscal year 2003. Wells were sampled twice for indicator and site-specific parameters (see Appendix B). Values from downgradient wells were compared to those established from the upgradient well. The indicator parameters (specific conductance, total organic carbon, and total organic halides) did not exceed critical mean values during fiscal year 2003. Therefore, groundwater monitoring during fiscal year 2003 provided no evidence that Waste Management Area A-AX contaminated groundwater.

The $\mathrm{pH}$ value reported in downgradient well 299-E25-46 for December 2002 was 6.81, which is below the critical mean range set at 6.82 to 9.54 . Verification sampling, performed in April 2003, showed this value was in error and that the correct $\mathrm{pH}$ was 7.

Specific conductance values ranged from 317 to $443 \mu \mathrm{S} / \mathrm{cm}$ during fiscal year 2003 (Figure 2.11-10), generally rising across the site but well below the critical mean of $494 \mu \mathrm{S} / \mathrm{cm}$. Upgradient of the A Tank Farm, the maximum upgradient value of $411 \mu \mathrm{S} / \mathrm{cm}$ (December 2002) reflects not only the high nitrate value of $49.6 \mathrm{mg} / \mathrm{L}$ (drinking water standard $45 \mathrm{mg} / \mathrm{L}$ ), but an even greater sulfate value of $54.1 \mathrm{mg} / \mathrm{L}$. Generally, sulfate (along with calcium, nitrate and a little chloride) controls the increasing specific conductance at this site. The sulfate and calcium have been increasing over much of the 200 East Area as the high levels found along the basalt subcrop to the north, move southward across the single-shell tank farms. This year, reported sulfate values ( 14 to $60 \mathrm{mg} / \mathrm{L}$ ) are close to the maximum of the Hanford Site background values reported in WHC-EP-0595 except northeast of site where the maximum value is $91.5 \mathrm{mg} / \mathrm{L}$. Farther north at the C Tank Farm, the maximum sulfate value is $142 \mathrm{mg} / \mathrm{L}$ and increasing.

\subsubsection{216-A-29 Ditch}

The groundwater beneath the 216-A-29 ditch is monitored for evidence of hazardous waste migration as required by interim status guidelines established under state and federal regulations. The groundwater monitoring network at this facility is sampled twice annually for constituents that include contamination indicator parameters, annual groundwater quality parameters, and site-specific constituents. (See Appendix B for list of network wells, their locations, and groundwater constituents monitored.) To date, the facility has not affected groundwater with regulated materials, although sulfate attributable to manmade sources has been detected in two wells. No other constituent result would indicate the 216-A-29 ditch has adversely affected groundwater.

Groundwater beneath the 216-A-29 ditch closely resembles regional patterns. The facility is subject to influences from three nearby storage and disposal units: C Tank Farm, PUREX cribs, B Pond, as well as numerous other waste disposal facilities. Desaturation of the vadose beneath the B Pond continues to create a hydraulic barrier that maintains a regional reversal of groundwater flow. The gradient provided by the groundwater reversal, and the complex hydrostratigraphy beneath the 216-A-29 ditch, drives groundwater south and west from the head end of the ditch. The gradient tends to be small and the Hanford sediments that underlie the facility are highly transmissive. The resulting groundwater flow rate is low, not exceeding $\sim 0.1$ meter per day.

Specific conductance in samples from three wells continued to exceed the critical mean in fiscal year 2003. Elevated sulfate levels have been shown to increase conductivity at the 216-A-29 ditch (WHC-SD-EN-EV-032). Sulfate levels continued to rise in network wells, most of them with concomitant rise in specific conductance. The latest exceedance of specific conductance has been observed at well 299-E26-13.
One upgradient well and one downgradient well were installed to improve the RCRA network for Waste Management Area $A-A X$.

\author{
RCRA monitoring \\ indicates that the \\ 216-A-29 ditch has \\ not affected \\ groundwater with \\ regulated materials.
}


The Integrated Disposal Facility, to be constructed in 2004, will be regulated and monitored under RCRA.
As in other wells, the sulfate concentration has risen in tandem with specific conductance. This association has also been reported near the Liquid Effluent Retention Facility, low-level burial ground Waste Management Unit 2, and Waste Management Areas A-AX and C. All of these facilities reside at the west edge of the decommissioned B Pond. Dissipation of the pond may have slowed the procession of a sulfate plume front that is moving southeast toward the east boundary of 200 East Area.

\subsubsection{Integrated Disposal Facility}

The Integrated Disposal Facility will consist of an expandable, lined landfill covering 25 hectares located in the south-central part of 200 East Area (see Figure 2.11-1 for location of the site and Appendix B for a list of network wells, their locations, and groundwater constituents monitored). The landfill will be divided lengthwise into two distinct cells, one for the disposal of low-level radioactive waste and the other for the disposal of mixed waste. The facility will be a RCRA-compliant landfill (i.e., a double-lined trench with leachate collection system) that is $\sim 442$ meters wide by 555 meters in length and up to 15 meters deep. The landfill will contain four layers of waste containers separated vertically by 0.9 meter of soil. The approximate volume of waste to be deposited will be 100 hectare-meters. The waste will be segregated into a RCRA-permitted side and a non-RCRA-permitted side. Construction will begin on the site in September 2004. Currently, a Part B RCRA permit application has been submitted to Ecology and is scheduled to be incorporated into the Hanford Facility RCRA Permit (Ecology 1994) in February 2004.

The groundwater monitoring network will consist of two upgradient wells and five downgradient wells (see Appendix B). Three wells remain to be installed; two will be installed in the summer of fiscal year 2004; the third will be installed at a future date when required by facility expansion.

The indicator parameters that will be routinely monitored are chromium, specific conductance (field), total organic carbon, total organic halides and $\mathrm{pH}$ (field). Supplemental parameters include alkalinity, anions, inductively coupled plasma metals, and turbidity (see Appendix B).

The indicator parameters will be used to monitor for hazardous constituents reaching the groundwater as a result of Integrated Disposal Facility operations. Total organic carbon and total organic halides are indicator parameters selected to monitor impacts of RCRA-regulated organic constituents on the groundwater quality. Specific conductance is selected as an indicator parameter to monitor the effect of metals and anions on groundwater quality. $\mathrm{pH}$ is a general indicator of groundwater quality. Chromium is included as an indicator parameter because hexavalent chromium is one of the more mobile of the regulated metals expected at the Integrated Disposal Facility and should be one of the first constituents to enter groundwater if the regulated facility impacts groundwater.

Analyses of alkalinity, anions, and metals are to provide supplemental data on general groundwater chemistry beneath the Integrated Disposal Facility. This information aids data interpretation and quality control. Supplemental parameters will not be used in statistical evaluations. Turbidity is analyzed at the well just before sampling and provides an indication of the amount of particulate matter in suspension at the time of sampling.

Monitoring will begin when all wells are ready to be sampled. All indicator parameters will be monitored twice each quarter and supplemental parameters once each quarter to determine background concentrations. After the first year, indicator parameters will be monitored semiannually and supplemental parameters annually. In addition, field measurements of temperature and turbidity will be made at each sampling event. 
During the first sampling event at each well, samples will be collected for analysis of the Appendix IX constituents (40 CFR 264) included in Chapter 1 of the Integrated Disposal Facility permit application.

\subsubsection{216-B-3 Pond Facility (B Pond)}

The B Pond interim status RCRA facility currently consists of the main pond and an adjacent portion of 216-B-3-3 ditch (see Appendix B for well locations). These features are the regulated remnants of a more expansive system of ponds and ditches, most of which have been clean closed (PNNL-13367).

In fiscal year 2001, a new approach to groundwater monitoring (PNNL-13367ICN-1) was implemented by DOE, and a variance for this purpose was granted by the regulators for a 2-year trial period. The trial approach uses intra well comparisons that are based on methods prepared by the American Society for Testing and Materials and apply a combined Shewhart-Cumulative Sum (CUSUM) control chart method of statistical analysis. This technique allows the false-positive rate (the erroneous declaration of contamination) to be kept acceptably low in all wells for all constituents, while providing adequate statistical power to detect real contamination, should it occur. The constituents selected for site-specific monitoring are gross alpha, gross beta, and specific conductance. By agreement with Ecology, DOE has allowed the radionuclide indicators to remain in the RCRA monitoring plan at B Pond by a specific exception to the AEA/ RCRA separation of constituents for the purposes of the trial period. The agreement also requires monitoring of cadmium, lead, mercury, and silver annually for 4 years, then to discontinue these if concentrations remain below drinking water standards. The entire list of constituents is provided in Appendix B.

The final samples for the trial period were collected in July 2003, and an evaluation of the approach is currently underway. Beginning with the January 2004 sampling event, the B Pond system will return to contamination-indicator detection (see Appendix B). The current network wells and hydraulic gradient configuration allows upgradient/downgradient comparisons as prescribed by RCRA/WAC procedures for interim-status facilities.

The groundwater monitoring well network for the B Pond system consists of a total of four wells (see Appendix B). Well 699-44-39B, is located in an area currently upgradient of the B Pond, with three wells (699-42-42B, 699-43-44, and 699-43-45) located at the downgradient edges of the main pond and B-3-3 ditch.

Based on March 2003 water-level measurements, groundwater flows west-southwest beneath the B Pond system at an estimated rate of 0.008 meter per day (see Appendix B). Head measurements in vertically separated wells 699-43-41E and 699-43-41G indicated that a downward flow potential still exists near the main pond. The head difference between these two wells, as determined by March 2003 water levels, was 0.58 meter.

Well 699-43-45 was the only well in the network during the entire trial that has produced results exceeding the lowest control limits (mean +2 sigma). Gross beta in this well $(8.61 \mathrm{pCi} / \mathrm{L})$ briefly exceeded the mean +2 sigma control limit of $8.08 \mathrm{pCi} / \mathrm{L}$ for the Shewhart and CUSUM in early 2002 but have declined during the past year. This exceedance was not confirmed in subsequent sampling at this well. The trends for both conductivity, gross beta, and, to a lesser degree, gross alpha, likely represent a recovery of groundwater to natural concentrations of these parameters, following the historical diluting effects of the B Pond discharges (PNNL-13367).

Of the four metals (cadmium, lead, mercury, and silver), only silver was detected in any of the fiscal year 2003 samples from the B Pond network. Well 699-44-39B produced a silver result of $3.2 \mu \mathrm{g} / \mathrm{L}$ in the January 2003 sample. Particulate iron in the January 2003 sample from well 699-42-42B (364 $\mu \mathrm{g} / \mathrm{L})$ was the only water quality constituent to exceed standards.

\section{An alternative statistical method is being evaluated by RCRA monitoring at} the 216-B-3 Pond. 


\section{Indicator parameters remained below their critical mean values in downgradient wells at the Nonradioactive Dangerous Waste Landfill.}

\subsubsection{Nonradioactive Dangerous Waste Landfill}

Monitoring of the Nonradioactive Dangerous Waste Landfill (see Figure 2.1-2 for location) focuses on the RCRA interim status indicator parameters: $\mathrm{pH}$, specific conductance, total organic carbon, and total organic halides (see Appendix B). Volatile organic compounds are monitored because they may represent groundwater contamination originating from this landfill. Nitrate is present in groundwater and has a source in the 200 East Area (see Section 2.11.1.3). The groundwater quality parameters (chloride, iron, manganese, phenols, sodium, and sulfate) are required analytes but during fiscal year 2003 were either not detected or were not reported in concentrations significantly above background concentrations.

Wells at the Nonradioactive Dangerous Waste Landfill (Figure 2.11-11 and Appendix B) are sampled semiannually, usually in February and August. All of the wells were sampled on schedule during fiscal year 2003.

There were no exceedances of indicator parameters in downgradient wells where valid upgradient/downgradient comparisons could be made. However, reported RCRA indicator parameter results for $\mathrm{pH}$ and total organic carbon exceeded their critical range $(\mathrm{pH})$ or critical mean in three Nonradioactive Dangerous Waste Landfill network wells during fiscal year 2003. The exceedances were reported in wells where the upgradient/ downgradient comparisons are either not used or are not valid.

The exceedances of $\mathrm{pH}$ were in the two deeper wells (699-25-33 A and 699-26-35C) that monitor the lower permeability unit of the Ringold Formation. Groundwater in the lower low permeability unit has different background values groundwater constituents than the Nonradioactive Dangerous Waste Landfill background wells that are screened in the upper portion of the unconfined aquifer near the water table. The exceedances at the two wells ranged from 7.85 to 8.05 and the critical range was 6.64 to 7.85 .

The other exceedance was for total organic carbon in well 699-26-35A, which is an upgradient well that is co-sampled with the Solid Waste Landfill (Figure 2.11-12). Therefore, this exceedance also cannot be used for an upgradient/downgradient comparison. The reported values for total organic carbon at well 699-26-35A ranged from 1,400 to $4,000 \mu \mathrm{g} / \mathrm{L}$, and the critical mean was $1,300 \mu \mathrm{g} / \mathrm{L}$. Some of these reported values are anomalously high probably due to analysis problems. Total organic carbon data from other sites were also anomalously high.

Reported results for required phenol, anion, and inductively coupled plasma metal analytes were all at levels consistent with reported background values.

Seven volatile organic compounds were detected in Nonradioactive Dangerous Waste Landfill network wells during fiscal year 2003 including 1,1,1-trichloroethane, 1,1-dichloroethene, acetone, chloroform, tetrachloroethene, toluene, and trichloroethene. The levels reported were all well below drinking water standards. The source of volatile organic carbons in these wells could either be the Solid Waste Landfill (see Section 2.11.5.2) or the Nonradioactive Dangerous Waste Landfill.

In last year's annual report (PNNL-14187), well 699-25-34B was reported to be dry. Late in fiscal year 2002, the Groundwater Performance Assessment Project (formerly the Hanford Groundwater Monitoring Project) performed routine well maintenance and lowered the pump, which corrected the sampling problem at this well. During fiscal year 2003, no problems were experienced in sampling this well or any of the Nonradioactive Dangerous Waste Landfill wells. Therefore, the current well network is deemed adequate to monitor groundwater at the Nonradioactive Dangerous Waste Landfill, and at this time there are no changes planned for the well network. 


\subsubsection{AEA Monitoring}

The 400 Area water supply wells and the single-shell tanks at Waste Management Area A-AX are monitored under AEA requirements. More on the 400 Area (the 400 Area process ponds) can be found in Section 2.11.5.3. More on RCRA groundwater monitoring compliance at Waste Management Area A-AX can be found in Section 2.11.3.2. These sites are integrated with the 200-PO-1 Operable Unit but have additional monitoring requirements, such as RCRA. General groundwater contamination plumes are contained in Section 2.11.1, but the following sections add additional monitoring details at Waste Management Area A-AX and the 400 Area.

\subsubsection{Waste Management Area A-AX}

This section provides information on the current nature of the unconfined groundwater in the immediate vicinity of the single-shell tanks at Waste Management Area A-AX, including radionuclides. Section 2.11.3.2 describes results of RCRA monitoring.

Technetium-99 levels have increased slightly across the waste management area with the highest value of $234 \mathrm{pCi} / \mathrm{L}$ found to the northeast in well 299-E25-41. The technetium-99 concentration in this well was $220 \mathrm{pCi} / \mathrm{L}$ in fiscal year 2002 . Well 299-E25-41 is downgradient from the AX Tank Farm, which currently has no upgradient coverage. This slight rise means technetium-99 is probably moving into the area from farther north, possibly the same pocket of contamination currently seen at Waste Management Area C (see Section 2.10.4).

Tritium values across the waste management area have increased from a range of 4,150 to $8,750 \mathrm{pCi} / \mathrm{L}$ reported for June 2002 to a range of 5,060 to $12,200 \mathrm{pCi} / \mathrm{L}$ in fiscal year 2003 . The drinking water standard for tritium is $20,000 \mathrm{pCi} / \mathrm{L}$. The highest value of $12,200 \mathrm{pCi} / \mathrm{L}$ is seen upgradient of the site. This local region had higher values of tritium (over 200,000 pCi/L) in the late 1960s when the PUREX Plant was operating. The rising tritium does not appear to be related to the waste management area and is, most likely, part of a regional trend.

In filtered samples from well 299-E24-19, chromium continued to be detected at values above the drinking water standard of $100 \mu \mathrm{g} / \mathrm{L}$, ranging from 462 to $2,510 \mu \mathrm{g} / \mathrm{L}$ in fiscal year 2003. Historically, manganese and nickel also exceed the drinking water standards when chromium concentrations are high (manganese, $50 \mu \mathrm{g} / \mathrm{L}$; nickel, $100 \mu \mathrm{g} / \mathrm{L})$. The elevated concentrations of metals are associated with the corrosion of stainless steel (PNNL-13788) and not with any tank associated waste as shown by comparing chromium concentrations to technetium-99 levels in this well (Figure 2.11-13). Sampling results from purge testing showed that the chromium is from a source close to the well and is not moving through the aquifer. Furthermore, the inverse relationship between chromium concentrations and $\mathrm{pH}$ observed during extended purge tests support a chromium source based on a reduction-oxidation reaction of stainless steel (PNNL-13788).

During fiscal year 2002, elevated chromium $(281 \mu \mathrm{g} / \mathrm{L})$ was observed at well 299-E25-46, which is downgradient from well 299-E24-19. The pH is historically above 7 at this well and above 8 at other wells in the area. Comprehensive purge sampling was conducted in fiscal year 2003. Results showed that after several hours of pumping, the chromium levels rose to high values $(6,250 \mu \mathrm{g} / \mathrm{L})$. The $\mathrm{pH}$, however, dropped below the critical mean of 6.81 . These results confirm the inverse relationship between chromium concentration and $\mathrm{pH}$. The high chromium concentrations in this well are interpreted to be from well corrosion. Camera surveys in fiscal year 2004 confirmed the corrosion problem. As in well 299-E24-19, there does not appear to a connection between the elevated chromium levels and processing waste (Figure 2.11-14). 


\section{Tritium concentrations remained below the drinking water standard in 400 Area water supply wells.}

\subsubsection{400 Area Water Supply Wells}

The 400 Area on the Hanford Site is the location of the Fast Flux Test Facility, a liquid-metal (sodium) cooled test reactor. DOE issued a request for proposals in December 2003 for a small-business contract to complete the accelerated deactivation and final decommissioning of the reactor and its support facilities.

Primary groundwater monitoring activities in the 400 Area include monitoring of the $4608-\mathrm{B} / \mathrm{C}$ ponds (also called the 400 Area process ponds) for compliance with a waste discharge permit, and monitoring of the 400 Area water supply wells. Monitoring is also conducted to provide information needed to describe the nature and extent of site-wide contamination (primarily nitrate, tritium, and iodine-129). This section primarily discusses the monitoring of the 400 Area water supply wells, specifically tritium, and general aspects of groundwater chemistry in the 400 Area. Monitoring activities associated with the 400 Area process ponds are addressed in Section 2.11.5.3. The location of groundwater monitoring and water supply wells in the 400 Area is shown in Figure 2.11-15 and Appendix C.

The Hanford Site water-table map (Figure 2.1-3) indicates that flow is generally to the east-southeast across the 400 Area. The water table is located near the contact of the Hanford and Ringold Formations, which is $\sim 49$ meters below ground surface (WHC-EP-0587). Hanford formation sediment dominates groundwater flow in the 400 Area because of its relatively high permeability compared to that of sediment in the Ringold Formation.

Elevated levels of tritium associated with the groundwater plume from the vicinity of the PUREX Plant in the 200 East Area were identified in 400 Area wells as in previous years (Figure 2.1-5). The lower concentrations of tritium north of the 400 Area are probably related to discharge at the process ponds. Groundwater tritium levels are relevant to the water supply wells, which provide drinking water and emergency supply water for the 400 Area. Well 499-S1-8J serves as the main water supply well, while wells 499-S0-7 and 499-S0-8 are backup supply wells. Well 499-S1-8J has lower tritium concentrations because it is screened at a greater depth than the other two water supply wells. The tritium concentrations in wells 499-S0-7, 499-S0-8, and 499-S1-8J are compared in Figure 2.11-16 to that of the 400 Area drinking water supply. Tritium was measured at levels below the drinking water standard $(20,000 \mathrm{pCi} / \mathrm{L})$ in samples from well 499-S0-7 during fiscal year 2003. Samples collected from well 499-S0-8 exceeded the drinking water standard during the latter part of fiscal year 1999, but all samples collected during fiscal years 2001, 2002, and 2003 were well below the drinking water standard. All samples collected from well 499-S1-8J in fiscal year 2003 were below the drinking water standard.

The sampling of the water supply wells was reduced from monthly to quarterly beginning in fiscal year 2002. Three quarterly samples were collected in fiscal year 2003; the water supply wells could not be sampled in the first quarter because the flush line was plugged.

Tritium remained below the drinking water standard $(20,000 \mathrm{pCi} / \mathrm{L})$ and the 4-millirem-per-year dose equivalent in the drinking water supply, sampled at a tap, for all sampling events in fiscal year 2003 (Figure 2.11-16). Nitrate remained below the drinking water standard in fiscal year 2003 for the water supply wells. Data from fiscal year 2003 and earlier from 400 Area and surrounding wells indicates no other constituents are present at levels above their drinking water standards.

\subsubsection{Washington Administrative Code}

Groundwater monitoring at the 200 Area Treated Effluent Disposal Facility, Solid Waste Landfill, and 400 Area Process Ponds is regulated under WAC. 


\subsubsection{200 Area Treated Effluent Disposal Facility}

The 200 Area Treated Effluent Disposal Facility is located southeast of the B Pond RCRA facility and has received effluent since June 1995. Groundwater beneath the facility is monitored under a Washington State waste discharge permit (WAC 173-216). Three wells, 699-40-36, 699-41-35, and 699-42-37 (Figure 2.11-1), monitor groundwater beneath the facility. Hydrogeologic conditions, groundwater constituents, and monitoring results through fiscal year 2002 are described in PNNL-14098. This is the most recent report (released biannually) specific to the 200 Area Treated Effluent Disposal Facility.

Because there was no unconfined aquifer beneath the 200 Area Treated Effluent Disposal Facility at the time of construction, the groundwater monitoring wells were installed in the confined Ringold Formation aquifer, which was the uppermost aquifer beneath the facility (see also Section 2.14). Thus, these three wells are isolated from the effects of the effluent by the relatively impermeable Ringold unit 8 silt and clay stratum (PNNL-14098). The quarterly analytical results from the wells are used to demonstrate continuation of the isolation.

Based on hydraulic head calculations for March 2003, and estimates of effective porosity and hydraulic conductivity, groundwater flow potential in the confined aquifer beneath the Treated Effluent Disposal Facility is directed southwest at 0.003 meter per day. Historically, major ionic composition and extremely low tritium concentrations have suggested that groundwater in the confined Ringold Formation beneath this facility is older than groundwater in the adjacent unconfined aquifers, and thus unaffected chemically and radiologically by Hanford Site operations. However, hydraulic head continues to decline in all three wells at the Treated Effluent Disposal Facility, as a result of the dissipating pressure effects of historical discharges at the nearby B Pond facility.

Groundwater samples are collected quarterly from wells for a list of constituents required by the state waste-discharge permit ST-4502 (Ecology 2000). Three of the constituents (cadmium, lead, and $\mathrm{pH}$ ) are compared with specific enforcement limits set by the permit (see Appendix C). All scheduled samples were collected during fiscal year 2003, and no enforcement limits were exceeded. Most results for anions, metals, and radionuclide indicators have been below published Hanford Site groundwater background levels (e.g., WHC-EP-0595 and DOE/RL-96-61) since monitoring began at the site.

\subsubsection{Solid Waste Landfill}

The Solid Waste Landfill (see Figure 2.1-2 for location of site) is regulated by the Washington State Department of Ecology under WAC 173-304. WAC 173-304 constituents and site-specific constituents (including volatile organic compounds and filtered arsenic) are analyzed on groundwater samples collected quarterly (see Appendix C). Compliance is determined by comparing results from monitoring downgradient wells with statistically derived background threshold values from upgradient wells. Groundwater flow direction is southeast as determined from general direction of movement of major 200 East Area plumes (see beginning of Section 2.11). Well locations in the Solid Waste Landfill are shown in Figure 2.11-11 and Appendix C.

The Solid Waste Landfill has had little impact on Hanford Site groundwater, except minor volatile organic compound contamination (Table 2.11-1). The contamination was below drinking water standards but exceeded levels defined in WAC 173-200 for the same analytes. Some downgradient wells show higher specific conductance, chloride, sulfate, and coliform bacteria levels, and lower $\mathrm{pH}$ than upgradient wells. The lower $\mathrm{pH}$ apparently is a result of high concentrations of carbon dioxide in the vadose zone resulting from the degradation of sewage material disposed to the Solid Waste Landfill (see Section 5.3 of DOE/RL-93-88; PNL-7147; and WHC-SD-EN-TI-199).
Permit limits were not exceeded in wells downgradient of the 200 Area Treated Effluent Disposal Facility. 
WAC 173-304 Parameters. Each WAC 173-304 parameter is discussed separately below. See Appendix $\mathrm{C}$ for a complete list of all results for required constituents at the Solid Waste Landfill during fiscal year 2003. Table 2.11-1 shows the results for the volatile organic compounds during the same period.

- Temperature - Groundwater temperatures measured during sampling in downgradient wells ranged from $17.1^{\circ} \mathrm{C}$ to $20.6^{\circ} \mathrm{C}$. The reported value of $20.6^{\circ} \mathrm{C}$ was from the background well $699-26-35 \mathrm{~A}$. One reported temperature exceeded the background threshold value of $20.7^{\circ} \mathrm{C}\left(24.2^{\circ} \mathrm{C}\right.$ at downgradient well $699-23-34 \mathrm{~A}$ in August 2003). This reported value is presumed to be a measurement error because it varies significantly from the historical trend. See Appendix $C$ for a total list of fiscal year 2003 background threshold values for WAC 173-304 required parameters.

- Specific conductance - Specific conductance measurements on samples taken from all wells downgradient of the Solid Waste Landfill exceeded the background threshold value of $583 \mu \mathrm{S} / \mathrm{cm}$. The range in downgradient wells was 653 to $843 \mu \mathrm{S} / \mathrm{cm}$. All eight of the downgradient wells also exceeded the maximum

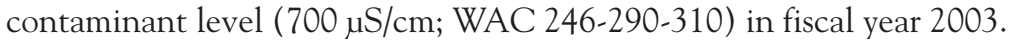

- Field-measured $\boldsymbol{p H}$ - Measured valued ranged from 6.58 to 7.5. Reported results were lower than the background threshold range (6.68 to 7.84) in four downgradient wells: 699-23-34A, 699-23-34B, 699-24-34A, and 699-24-34B.

- Total organic carbon - The reported values of total organic carbon ranged from $<390$ to $8,700 \mu \mathrm{g} / \mathrm{L}$. All downgradient wells and both upgradient wells had reported results that exceeded the background threshold value of $1,090 \mu \mathrm{g} / \mathrm{L}$. These results are surprising considering that last year none of the wells had reported values exceeding the background threshold value. Furthermore, six of the eight downgradient wells had reported results $<390 \mu \mathrm{g} / \mathrm{L}$ in the last quarter of sampling (August 2003), and the seventh downgradient well went dry so it was not sampled during that sampling event. Therefore, the elevated total organic carbon results are suspicious, and a data review has been initiated on these elevated values. Some of these anomalously high total organic carbon values may be due to analysis errors. Total organic carbon analyses have been shown to be in error at other Hanford Site wells in recent years. However, elevated total organic carbon is consistent with what might be expected when groundwater is contaminated with sewage. If the values later prove to be valid, then the use of the present background wells will have to be evaluated because they also had reported elevated total organic carbon during fiscal year 2003.

- Chloride - Chloride concentrations in the downgradient wells ranged from 5.7 to $8.5 \mathrm{mg} / \mathrm{L}$ (one reported value was $0.0083 \mathrm{mg} / \mathrm{L}$, but this is considered an error). Well 699-25-34C had a reported result of $8.5 \mathrm{mg} / \mathrm{L}$ for both the February and May sampling events, and the background threshold value was $7.8 \mathrm{mg} / \mathrm{L}$.

- Nitrate - Nitrate concentrations in downgradient wells ranged from 10.6 to $17.7 \mathrm{mg} / \mathrm{L}$ during fiscal year 2003. Neither the background threshold value $(29 \mathrm{mg} / \mathrm{L})$ nor the drinking water standard $(45 \mathrm{mg} / \mathrm{L}$ ) were exceeded in any well downgradient of the Solid Waste Landfill. The source of nitrate contamination at the Solid Waste Landfill is from upgradient sources in the 200 East Area (see Section 2.11.1.3).

- Nitrite - Nitrite was not detected in any Solid Waste Landfill well during fiscal year 2003. The analysis method detection limit was either 24.3 or $36.1 \mu \mathrm{g} / \mathrm{L}$ depending on the date of analysis, and the background threshold value was $161 \mu \mathrm{g} / \mathrm{L}$.

- Ammonium - Ammonium results at the Solid Waste Landfill for fiscal year 2003 were elevated at six downgradient wells and both upgradient wells during the first sampling event in November 2002. Reported results for all the wells at the other 
three sampling events during fiscal year 2003 were below the analysis method detection limit of 14.5 or $26.3 \mu \mathrm{g} / \mathrm{L}$ (depending on analysis date). As a result the elevated results during the first sampling event are probably in error. The background threshold value was $90 \mu \mathrm{g} / \mathrm{L}$ and the elevated results during the first sampling event ranged from 139 to $320 \mu \mathrm{g} / \mathrm{L}$. Historically, reported results for ammonium in Solid Waste Landfill wells have been less than the analysis method detection limit.

- Sulfate-Reported sulfate results ranged from 41 to $88.9 \mathrm{mg} / \mathrm{L}$ in the downgradient wells during fiscal year 2003. The background threshold value was $47.2 \mathrm{mg} / \mathrm{L}$, and it was exceeded at five of the eight downgradient wells.

- Filtered iron - Reported values for filtered iron ranged from 32.9 to $67.5 \mu \mathrm{g} / \mathrm{L}$ in the downgradient wells. The background threshold value was $160 \mu \mathrm{g} / \mathrm{L}$, which was not exceeded at any of the downgradient wells.

- Filtered zinc - Reported values for filtered zinc during fiscal year 2003 ranged from less than the analysis method detection limit $(1.8 \mu \mathrm{g} / \mathrm{L})$ to $15.6 \mu \mathrm{g} / \mathrm{L}$ in downgradient wells. The background threshold value was $42.3 \mu \mathrm{g} / \mathrm{L}$, and none of the results exceeded it during fiscal year 2003.

- Filtered manganese - Reported values for filtered manganese in the background well during fiscal year 2003 ranged from 0.96 to $7.7 \mu \mathrm{g} / \mathrm{L}$. The background threshold value was $10 \mu \mathrm{g} / \mathrm{L}$, which was not exceeded by any of the reported results from any of the downgradient wells during fiscal year 2003.

- Chemical oxygen demand - Reported results varied from less than the analysis method detection limit $(<3,600 \mu \mathrm{g} / \mathrm{L})$ to $15,000 \mu \mathrm{g} / \mathrm{L}$. The background threshold value was $10,000 \mu \mathrm{g} / \mathrm{L}$. Results at three of the downgradient wells exceeded the background threshold value during fiscal year 2003. However, the results exceeding the background threshold value were only during one sampling event (August 2003). Therefore, the result may be in error. Historically, chemical oxygen demand results at the Solid Waste Landfill are not above the analysis method detection limit.

- Coliform bacteria - One downgradient and one background well had reported results that exceeded the background threshold value (3.7 colonies per 100 milliliters). The highest reported value during fiscal year 2003 was 72,400 colonies per 100 milliliters at well 699-23-34B. Reported results for coliform bacteria at Solid Waste Landfill wells have been apparently random and sporadic and, therefore, suspicious. However, one would expect elevated results for coliform bacteria when sewage was known to be disposed at the Solid Waste Landfill.

Site-Specific Parameters. Site-specific parameters at the Solid Waste Landfill include chlorinated hydrocarbons and two constituents (1,4-dioxane and filtered arsenic) detected by leachate collection system. Slightly elevated concentrations of chlorinated hydrocarbons continued to be detected at the Solid Waste Landfill during fiscal year 2003. Two constituents exceeded the groundwater criteria set forth in WAC 173-200. The range of reported concentrations of chlorinated hydrocarbons is given in Table 2.11-1.

Chlorinated hydrocarbons were detected in all of the monitoring wells at the Solid Waste Landfill, including the background wells. The chlorinated hydrocarbons detected were 1,1,1-trichloroethane, 1,1-dichloroethene, 1,4-dichlorobenzene, carbon tetrachloride, chloroform, tetrachloroethene, and trichloroethene.

Of those detected, only 1,1-dichloroethene and tetrachloroethene equaled or exceeded the WAC 173-200 concentration limits (1.0 and 0.8 $\mu \mathrm{g} / \mathrm{L}$, respectively) during fiscal year 2003. The 1,1-dichloroethene limit $(1.0 \mu \mathrm{g} / \mathrm{L})$ was equaled or exceeded at only one well, 699-23-34B, but tetrachloroethene exceeded the $0.8 \mu \mathrm{g} / \mathrm{L}$ limit at all Solid Waste Landfill wells during fiscal year 2003. None of the reported results exceeded drinking water standards. 
The most likely cause of the widespread, low-level chlorinated hydrocarbon contamination at the Solid Waste Landfill, including the upgradient wells and the adjacent Nonradioactive Dangerous Waste Landfill wells, is the dissolution of vadose zone vapors into groundwater. However, the source of the vapors is uncertain. Possible sources include chlorinated hydrocarbons dissolved in the liquid sewage or the catch tank liquid from the 1100 Area heavy equipment garage and bus shop that were disposed to the Solid Waste Landfill (PNNL-13014).

Filtered arsenic (drinking water standard $10 \mu \mathrm{g} / \mathrm{L}$; WAC 173-200 limit $0.05 \mu \mathrm{g} / \mathrm{L}$ ) was detected at all Solid Waste Landfill wells. The highest concentration detected was $3.4 \mu \mathrm{g} / \mathrm{L}$. Although filtered arsenic was discovered in the leachate collection system at the trenches, the occurrence of arsenic in groundwater at the Solid Waste Landfill is probably due to natural processes (i.e., occurs naturally in Hanford Site groundwater Hanford Site background is $\sim 10 \mu \mathrm{g} / \mathrm{L}-\mathrm{DOE} / \mathrm{RL}-92-23)$, or there is an upgradient source (e.g., 200 East Area).

Another constituent found in the leachate collection system of the Solid Waste Landfill is 1,4-dioxane. Therefore, groundwater samples were specifically tested for this constituent also. It was not detected in any of the network wells. However, the instrument detection limit for 1,4-dioxane in the analytical method used was $11 \mu \mathrm{g} / \mathrm{L}$. The WAC 173-200 limit is $7 \mu \mathrm{g} / \mathrm{L}$.

During fiscal year 2003, the water level in well 699-25-34C dropped low enough that the well no longer can be sampled. Eliminating this well in the downgradient lineup along the southeast side of the landfill leaves a gap for groundwater contamination to potentially flow away from the landfill unnoticed. During fiscal year 2004, the remaining well network will be examined to determine whether it is adequate without the missing well or whether the well should be replaced or deepened.

\subsubsection{400 Area Process Ponds}

The 400 Area process ponds are currently regulated under a WAC 173-216 state waste discharge permit, which was issued on August 1, 1996, and modified on February 10, 1998. This permit defines groundwater enforcement limitations for the facility. Groundwater monitoring is provided by upgradient well 699-8-17 and downgradient wells 699-2-6A and 699-2-7 (Figures 2.1-2 and 2.11-15 and Appendix C), and is undertaken quarterly per the requirements presented in Appendix C. A recent modification of the permit (September 18, 2003) indicates that groundwater monitoring at the 400 Area process ponds will be discontinued effective October 1, 2003. Thus, formal monitoring of groundwater for the 400 Area process ponds will not be undertaken after fiscal year 2003, although limited sampling and analysis of wells 699-8-17, 699-2-6A, and 699-2-7 will continue for other monitoring objectives.

The Hanford Site water-table map (Figure 2.1-3) indicates that flow is generally to the east-southeast in the vicinity of the 400 Area process ponds.

Groundwater quality met permit conditions in fiscal year 2003. The concentration of the unfiltered metals cadmium, chromium, lead, manganese, and mercury were below the limits specified in the discharge permit for the ponds. Total organic carbon, $\mathrm{pH}$, and sulfate were also monitored per the permit requirements. Values for these constituents were similar for the three wells and typical of local groundwater chemistry.

An area of relatively low nitrate concentrations north of the 400 Area appears to be related to discharge of effluent to the process ponds (Figure 2.11-17). However, elevated nitrate concentrations up to $71 \mathrm{mg} / \mathrm{L}$ (drinking water standard if $45 \mathrm{mg} / \mathrm{L}$ ) were found in downgradient well 699-2-7 during fiscal year 2003. Nitrate contamination is attributed to a sanitary sewage lagoon formerly located immediately west and upgradient of the process ponds and later to a drainfield associated with septic tanks located west of the ponds (Figures 2.11-17 and 2.11-18). Groundwater samples associated with 
this well are also frequently elevated with respect to nitrite, which may have been generated by reduction of nitrate to nitrite by natural processes occurring within the aquifer. All nitrite concentrations were below the drinking water standard $(3.3 \mathrm{mg} / \mathrm{L})$, however. Disposal to the lagoon was discontinued in 1983 or 1984 and the lagoon backfilled; the drainfield became inactive in April 1997. Thus, groundwater contamination from these sources is expected to diminish with time, and the average concentration of nitrate in samples collected from well 699-2-7 was, in fact, observed to decrease from 73 to $69 \mathrm{mg} / \mathrm{L}$ between fiscal years 2002 and 2003. Nitrate and nitrite concentrations in samples obtained from the newer downgradient well, 699-2-6A, were not significantly elevated relative to the upgradient well 699-8-17. 
Table 2.11-1. Ranges of Reported Volatile Organic Compound Concentrations in Solid Waste Landfill Wells During Fiscal Year 2003

\begin{tabular}{|c|c|c|c|c|c|c|}
\hline Constituent & $\underline{\text { Limit }}(\mu \mathrm{g} / \mathrm{L})^{(\mathrm{a})}$ & $699-22-35$ & $699-23-34 \mathrm{~A}$ & $699-23-34 \mathrm{~B}$ & $699-24-33$ & $699-24-34 \mathrm{~A}$ \\
\hline Carbon tetrachloride & WAC 0.3 & $<0.16$ & $<0.16-0.26$ & $<0.16-0.29$ & $<0.16-0.2$ & $<0.16$ \\
\hline Chloroform & WAC 7.0 & $<0.12-0.21$ & $<0.12-0.13$ & $<0.12-0.2$ & $<0.12$ & $<0.12$ \\
\hline 1,1-dichloroethene & WAC 1.0 & $0.47-0.95$ & $0.44-0.91$ & $0.34-\mathbf{1 . 0}$ & $0.23-0.69$ & $0.32-0.61$ \\
\hline 1,2-dichloroethane & WAC 0.5 & $<0.18$ & $<0.18$ & $<0.18$ & $<0.18$ & $<0.18$ \\
\hline 1,4-dichlorobenzene & WAC 4.0 & $<0.11$ & $<0.11-0.16$ & $<0.11-0.2$ & $<0.11$ & $<0.11$ \\
\hline cis-1,2-dichloroethene & DWS 70 & $<0.14$ & $<0.14$ & $<0.14$ & $<0.14$ & $<0.14$ \\
\hline trans-1,2-dichloroethene & DWS 100 & $<0.17$ & $<0.17$ & $<0.17$ & $<0.17$ & $<0.17$ \\
\hline Tetrachloroethene & WAC 0.8 & $0.55-\mathbf{1 . 0}$ & $0.96-1.7$ & $0.38-1.2$ & $1.3-2.1$ & $1.1-1.7$ \\
\hline Trichloroethene & WAC 3.0 & $0.24-0.57$ & $0.26-0.66$ & $<0.21-0.54$ & $0.37-0.87$ & $0.36-0.69$ \\
\hline 1,1,1-trichloroethane & WAC 200 & $2.1-2.6$ & $1.6-2.1$ & $1.9-2.6$ & $1.2-1.6$ & $1.5-1.9$ \\
\hline 1,1,2-trichloroethane & DWS 5.0 & $<0.2$ & $<0.2$ & $<0.2$ & $<0.2$ & $<0.2$ \\
\hline 1,4-dioxane & WAC 7.0 & $<11$ & $<11$ & $<11$ & $<11$ & $<11$ \\
\hline Constituent & $\underline{\text { Limit }(\mu g / L)^{(a)}}$ & $699-24-34 \mathrm{~B}$ & $699-24-34 \mathrm{C}$ & $699-24-35$ & $699-25-34 \mathrm{C}$ & $699-26-35 \mathrm{~A}$ \\
\hline Carbon tetrachloride & WAC 0.3 & $<0.16$ & $<0.16$ & $<0.16$ & $<0.16$ & $<0.16$ \\
\hline Chloroform & WAC 7.0 & $<0.12$ & $<0.12$ & $<0.12$ & $<0.12$ & $<0.12-0.16$ \\
\hline 1,1-dichloroethene & WAC 1.0 & $0.32-0.68$ & $0.23-0.42$ & $0.23-0.3$ & $0.2-0.44$ & $0.2-0.23$ \\
\hline 1,2-dichloroethane & WAC 0.5 & $<0.18$ & $<0.18$ & $<0.18$ & $<0.18$ & $<0.18$ \\
\hline 1,4-dichlorobenzene & WAC 4.0 & $<0.11$ & $<0.11$ & $<0.11$ & $<0.11-0.27$ & $<0.11$ \\
\hline cis-1,2-dichloroethene & DWS 70 & $<0.14$ & $<0.14$ & $<0.14$ & $<0.14$ & $<0.14$ \\
\hline trans-1,2-dichloroethene & DWS 100 & $<0.17$ & $<0.17$ & $<0.17$ & $<0.17$ & $<0.17$ \\
\hline Tetrachloroethene & WAC 0.8 & $1.6-2.2$ & $0.35-\mathbf{1 . 9}$ & $0.63-1.1$ & $0.25-\mathbf{1 . 4}$ & $0.4-\mathbf{0 . 8 5}$ \\
\hline Trichloroethene & WAC 3.0 & $0.51-0.77$ & $<0.21-0.69$ & $<0.21-0.4$ & $0.19-0.86$ & $<0.21-0.45$ \\
\hline 1,1,1-trichloroethane & WAC 200 & $1.2-1.9$ & $0.24-1.1$ & $1.2-1.8$ & $0.17-1.1$ & $0.69-1.1$ \\
\hline 1,1,2-trichloroethane & DWS 5.0 & $<0.2$ & $<0.2$ & $<0.2$ & $<0.2$ & $<0.2$ \\
\hline 1,4-dioxane & WAC 7.0 & $<11$ & $<11$ & $<11$ & $<11$ & $<11$ \\
\hline
\end{tabular}




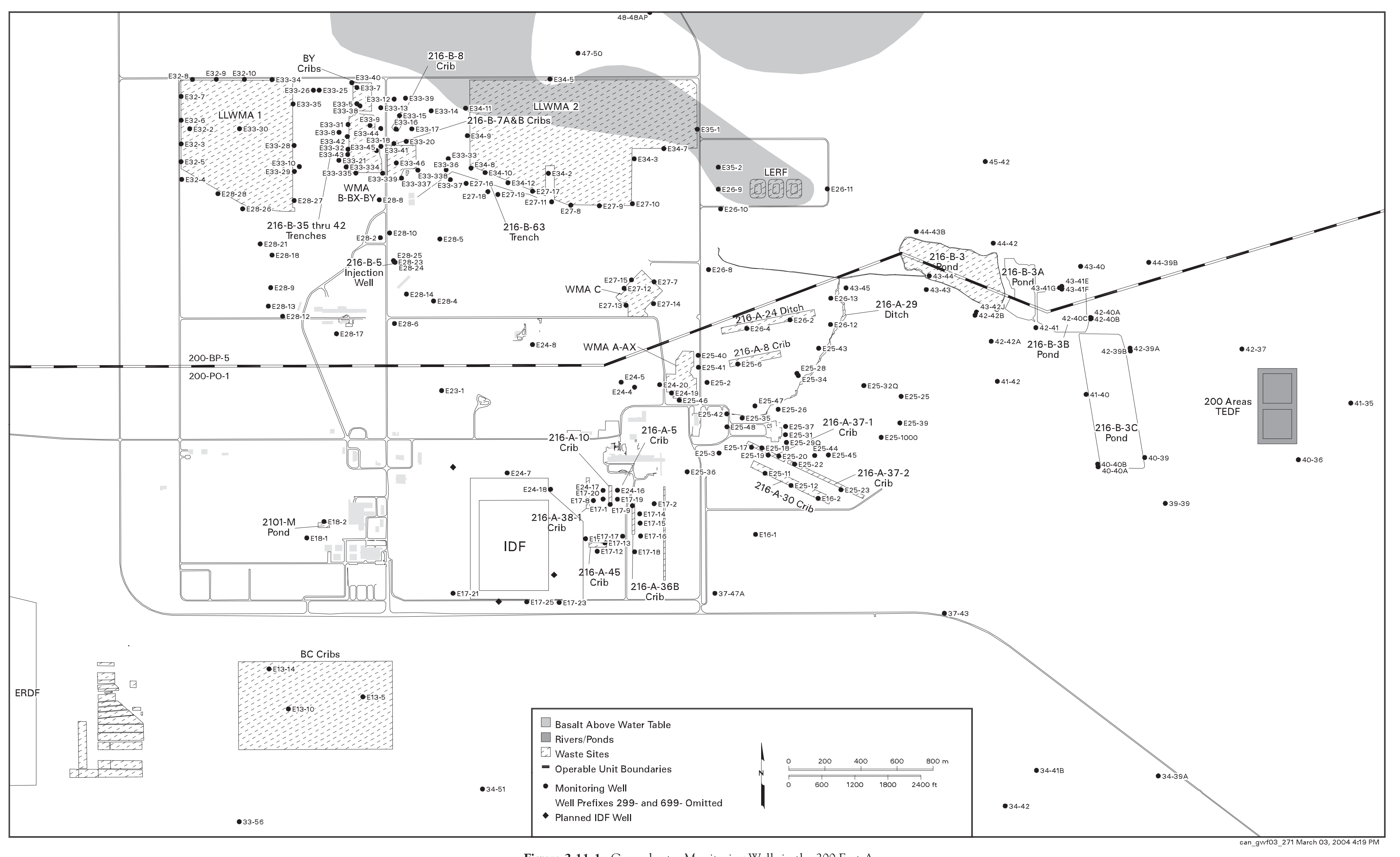

Figure 2.11-1. Groundwater Monitoring Wells in the 200 East Area 


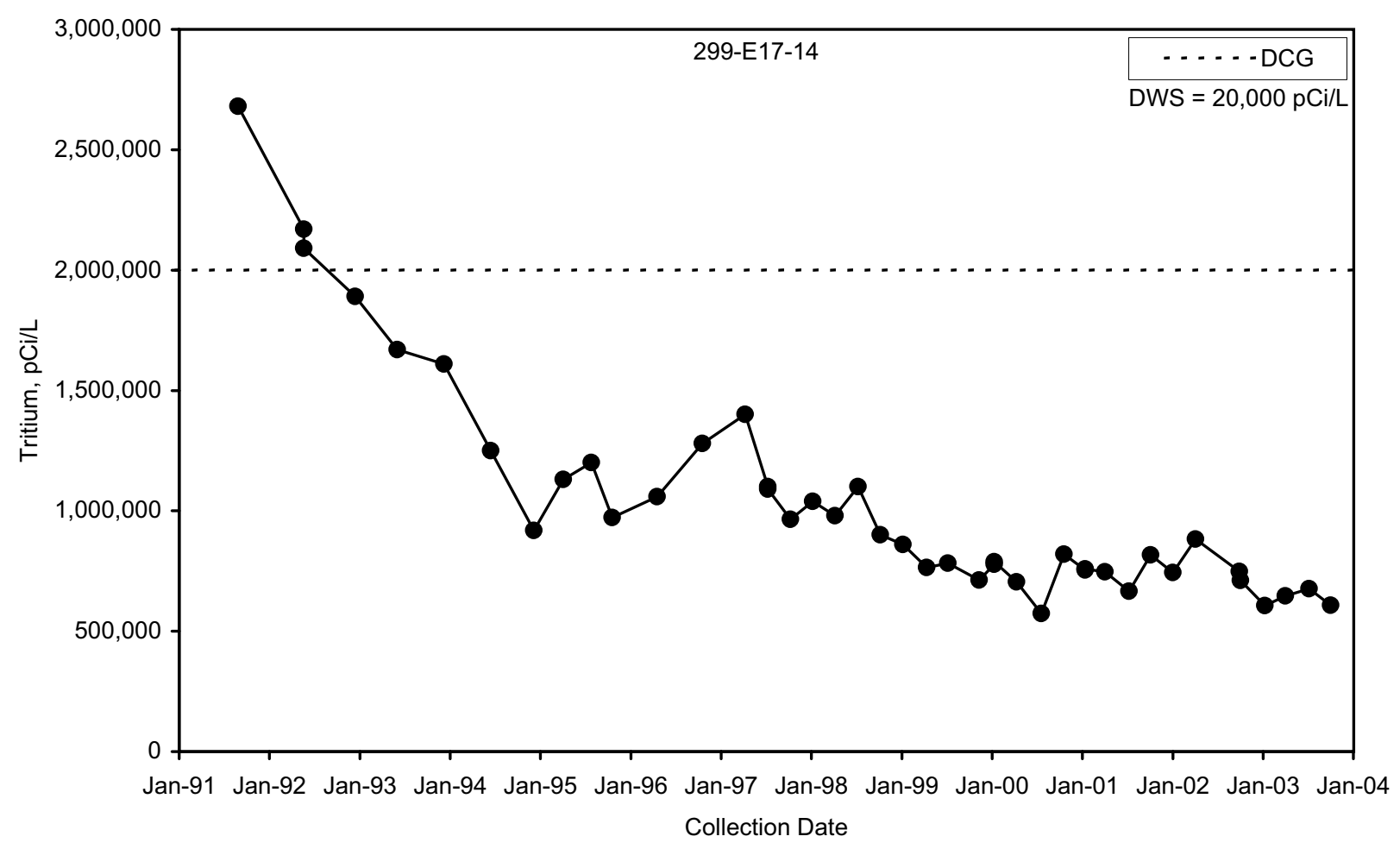

$\operatorname{mac} 03063$

Figure 2.11-2. Tritium Concentrations at the 216-A-36B Crib, Well 299-E17-14

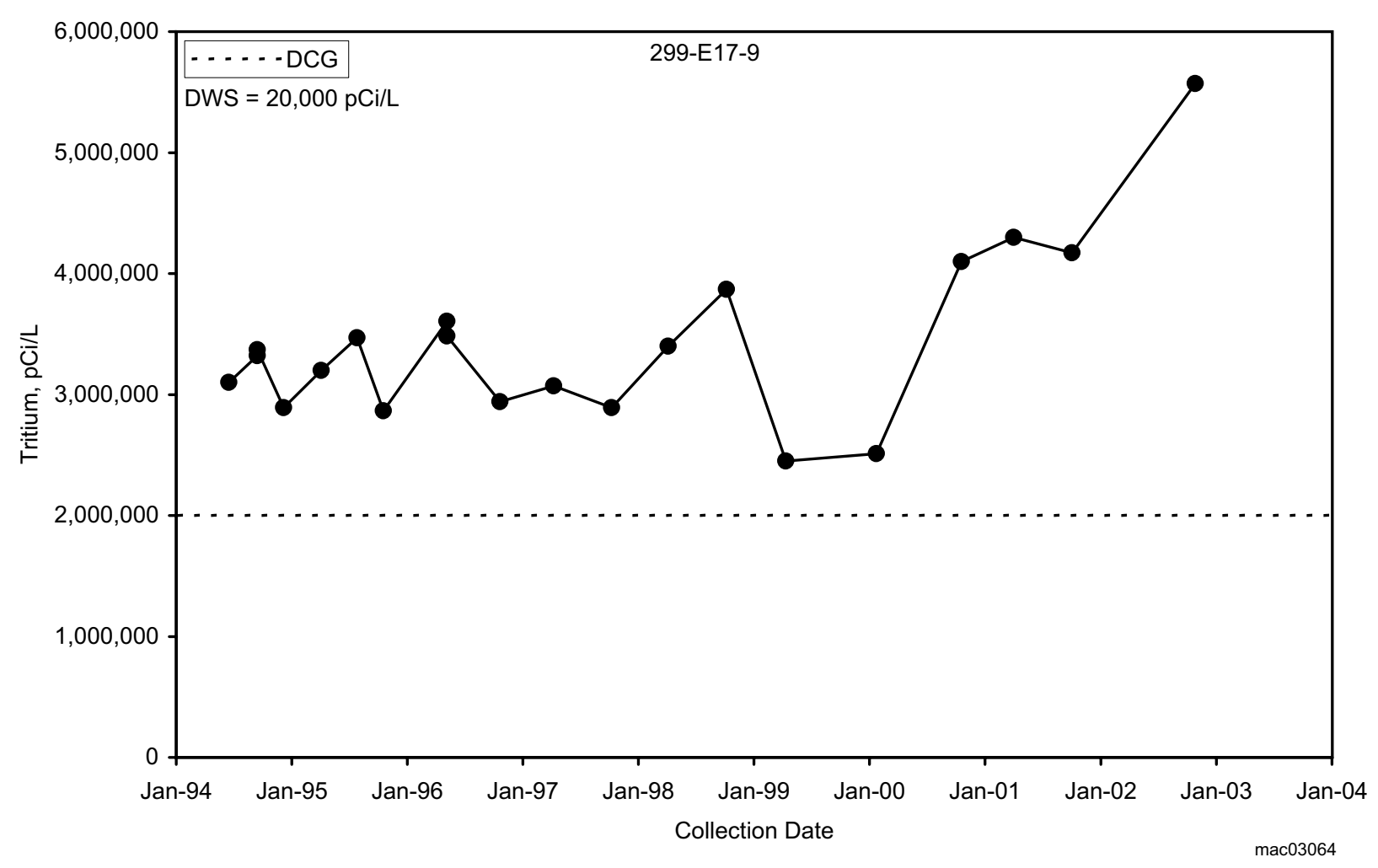

Figure 2.11-3. Tritium Concentrations at the 216-A-36B Crib, Well 299-E17-9 


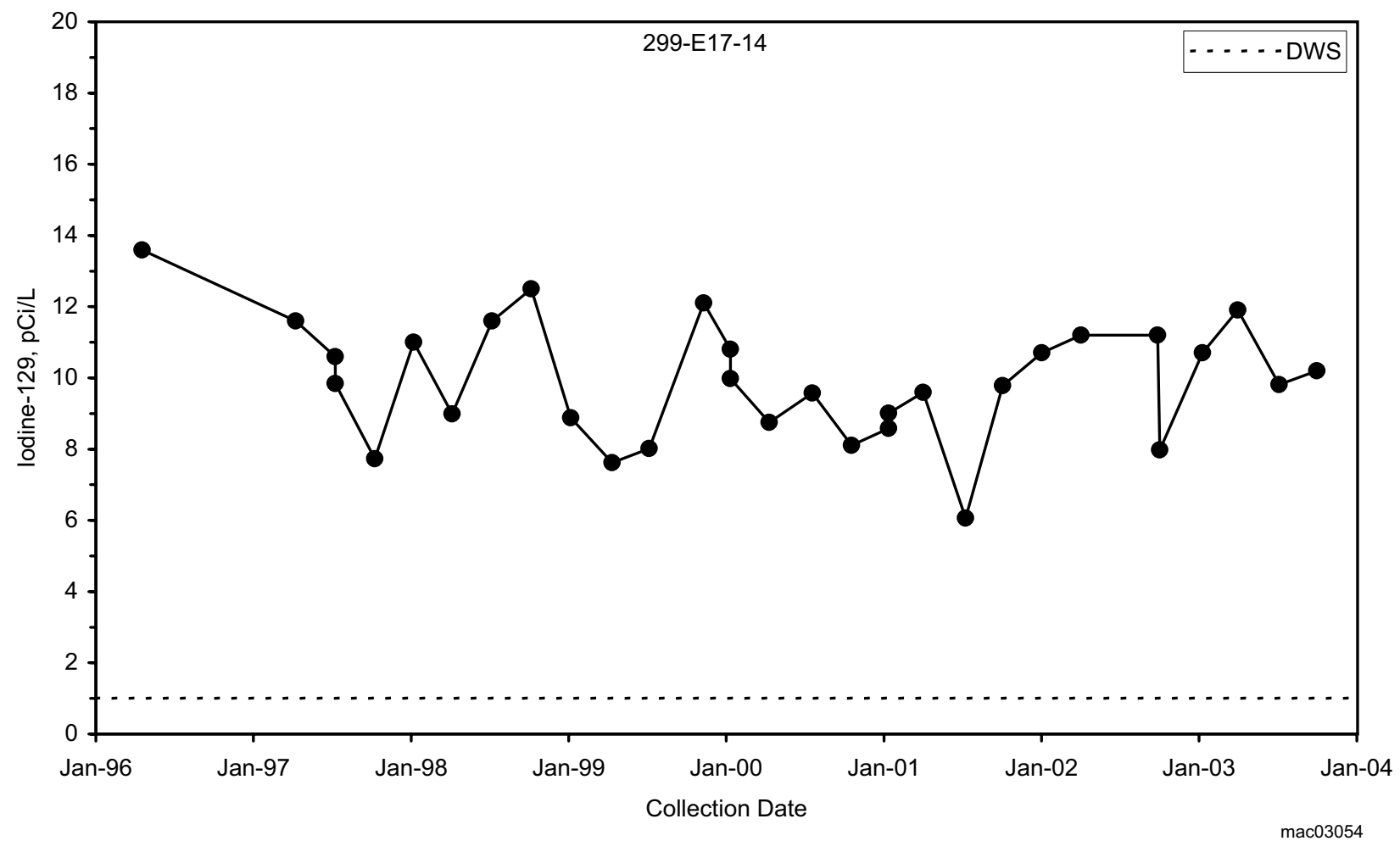

Figure 2.11-4. Iodine-129 Concentrations at the 216-A-36B Crib, Well 299-E17-14

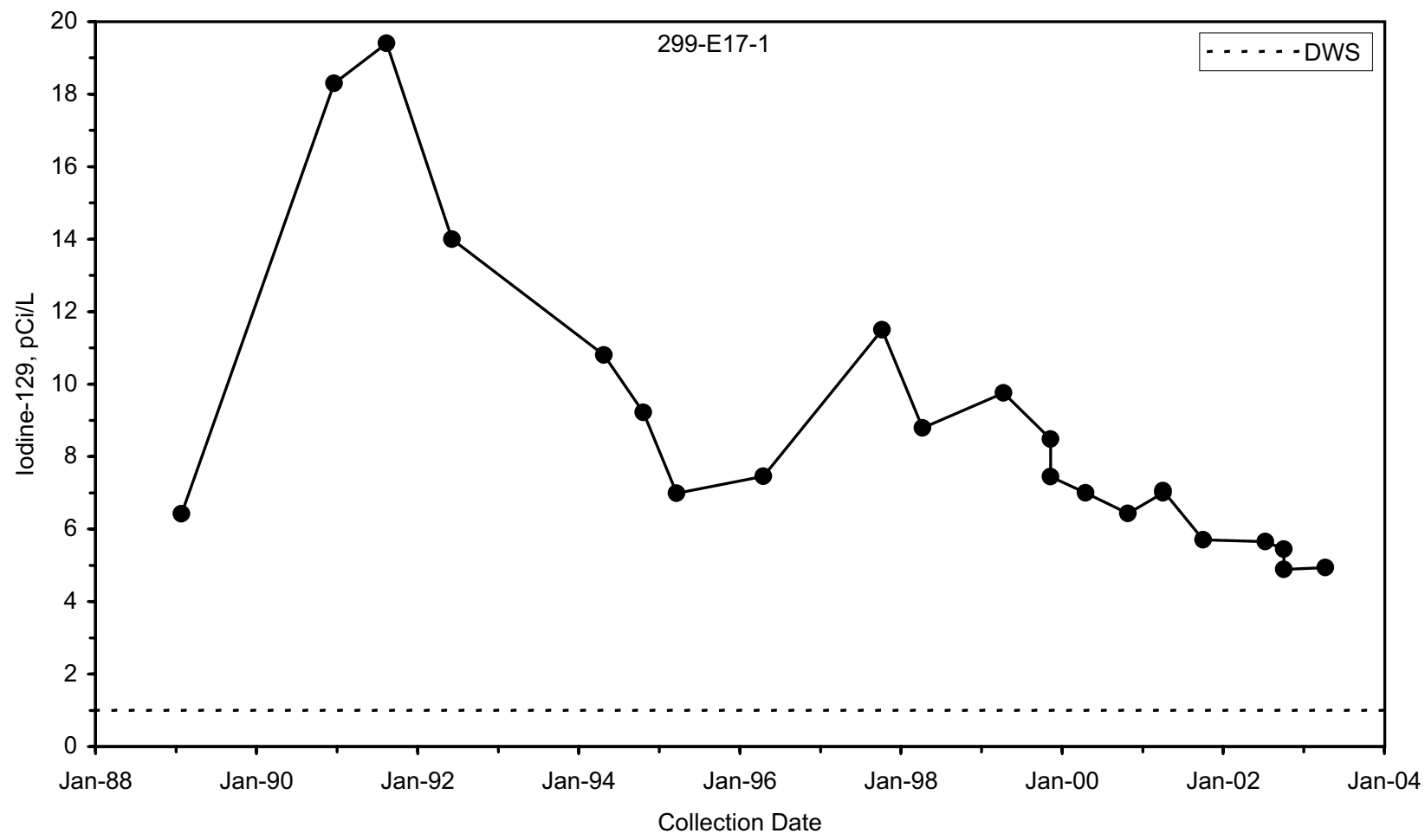

$\operatorname{mac} 03055$

Figure 2.11-5. Iodine-129 Concentrations at the 216-A-10 Crib, Well 299-E17-1 


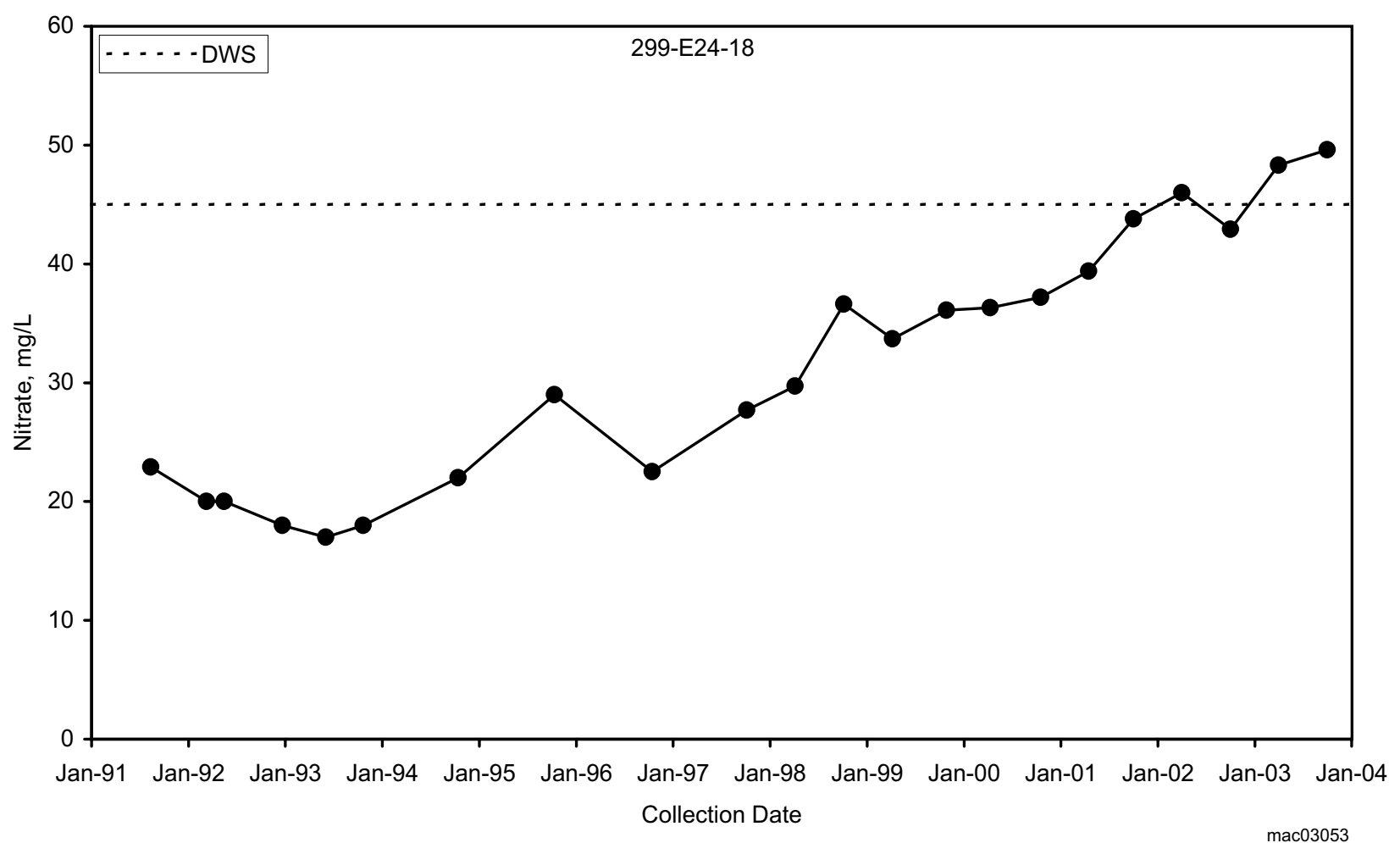

Figure 2.11-6. Nitrate Concentrations at Upgradient Well 299-E24-18 for the PUREX Cribs

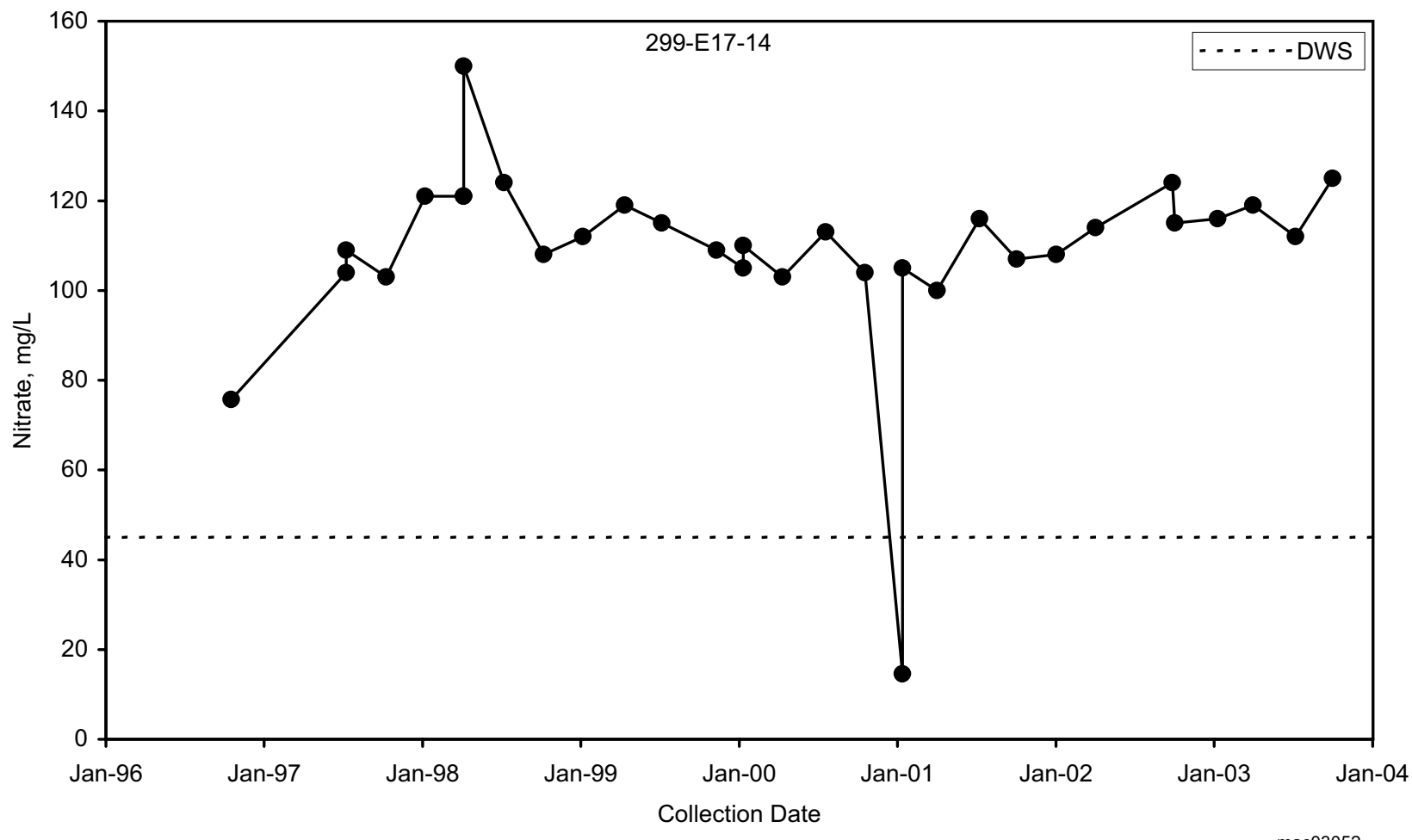

Figure 2.11-7. Nitrate Concentrations at the 216-A-36B Crib, Well 299-E17-14 


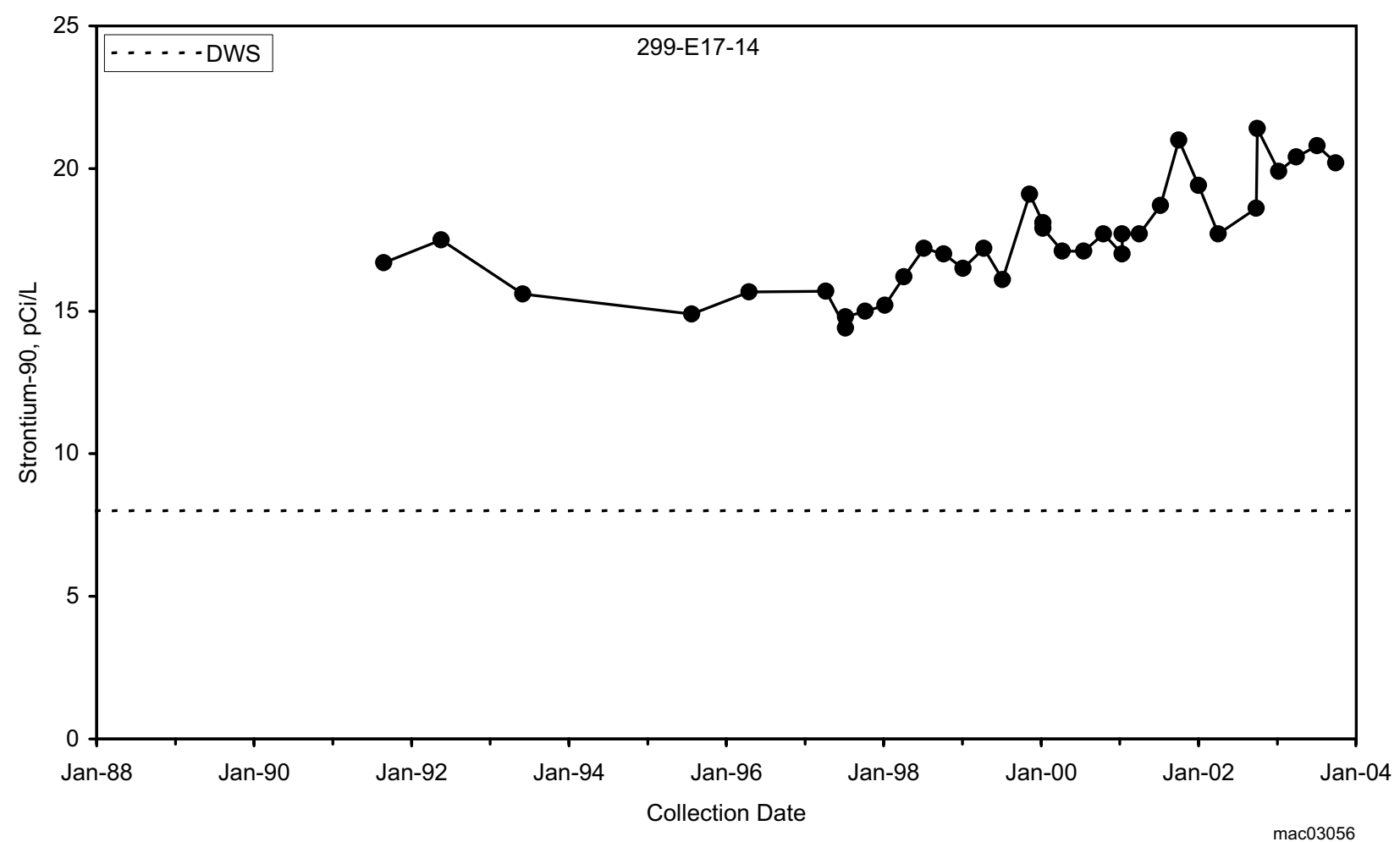

Figure 2.11-8. Strontium-90 Concentrations at the 216-A-36B Crib

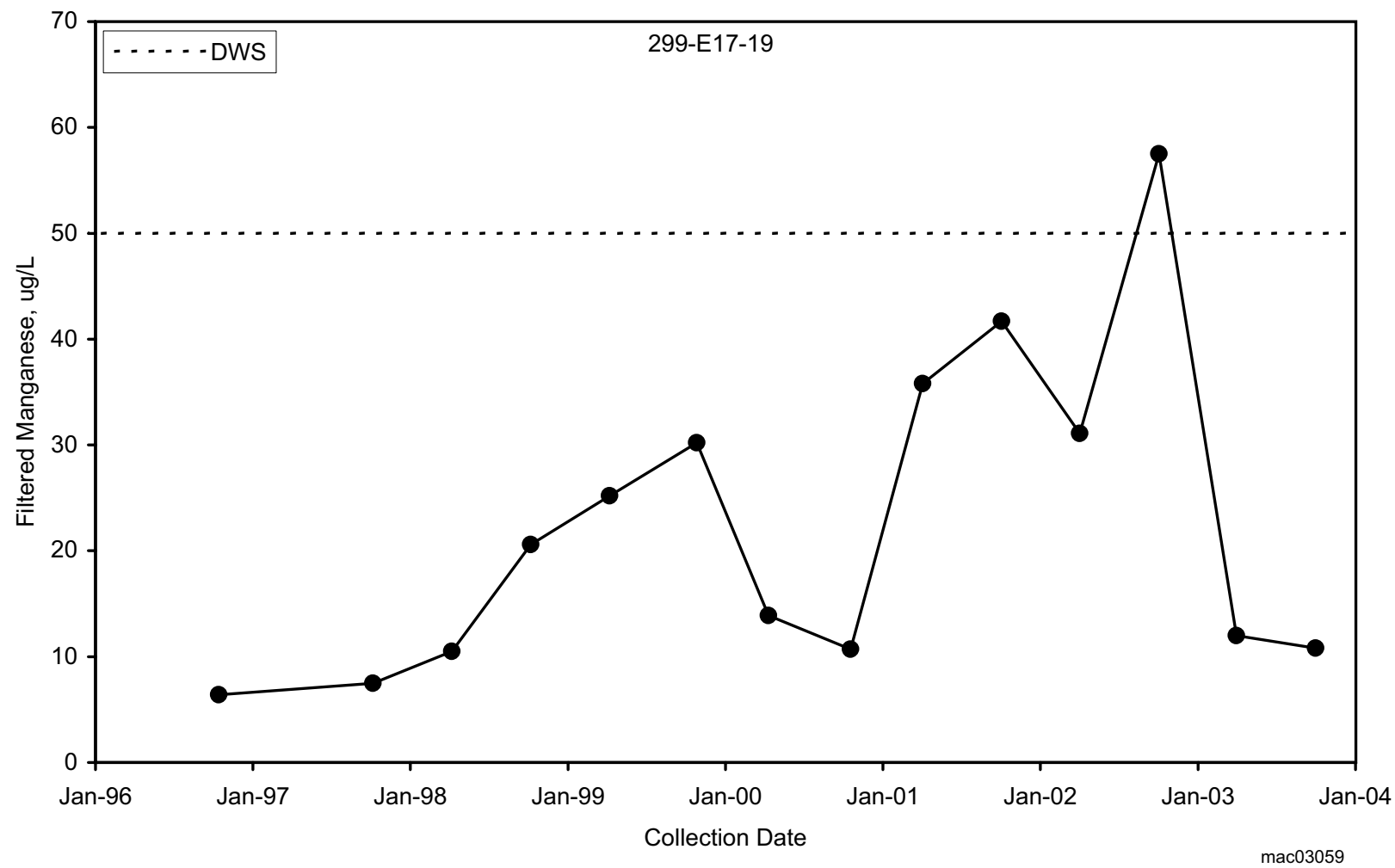

Figure 2.11-9. Manganese Concentrations at the 216-A-10 Crib 


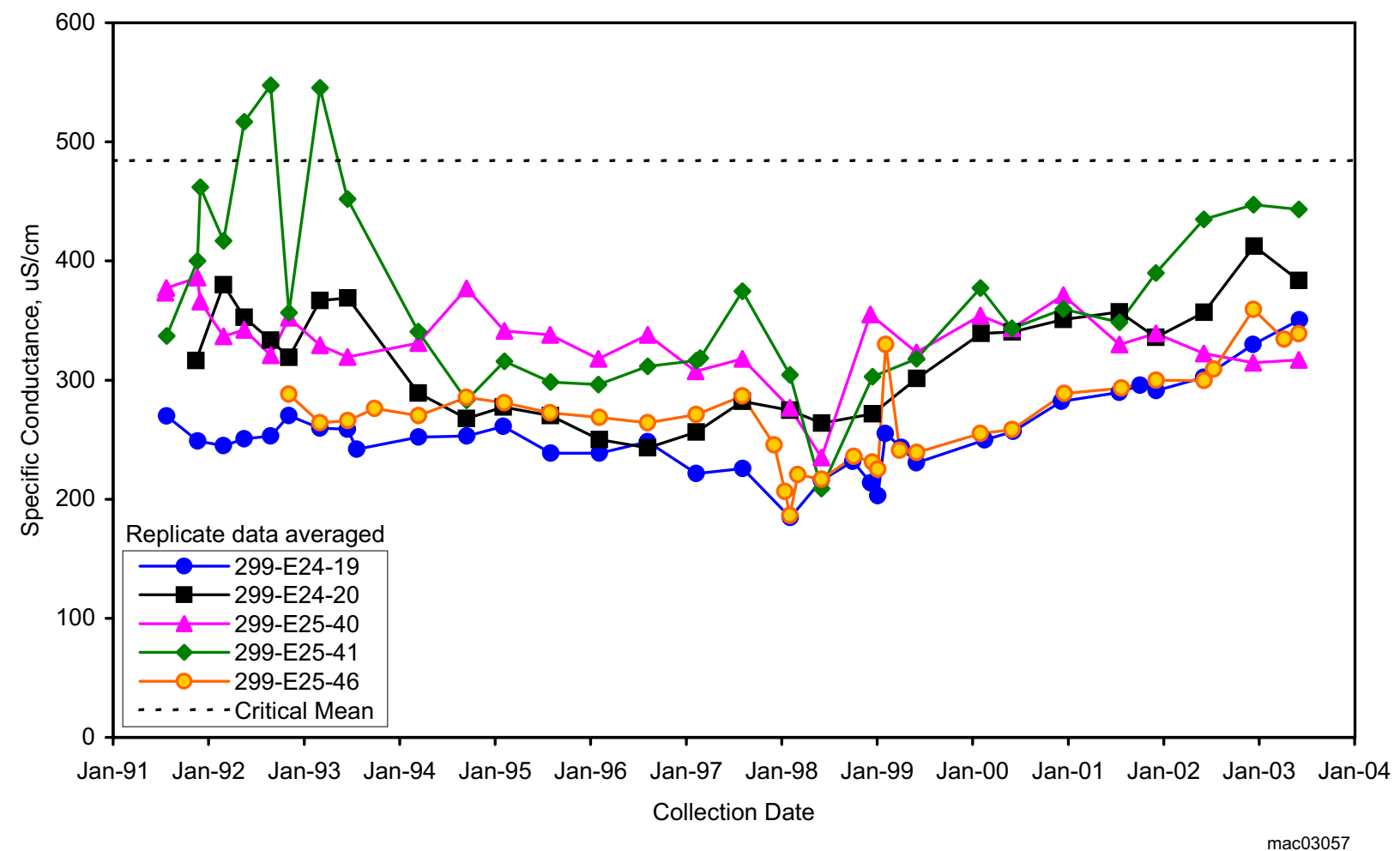

Figure 2.11-10. Specific Conductance in Wells Monitoring Waste Management Area A-AX 


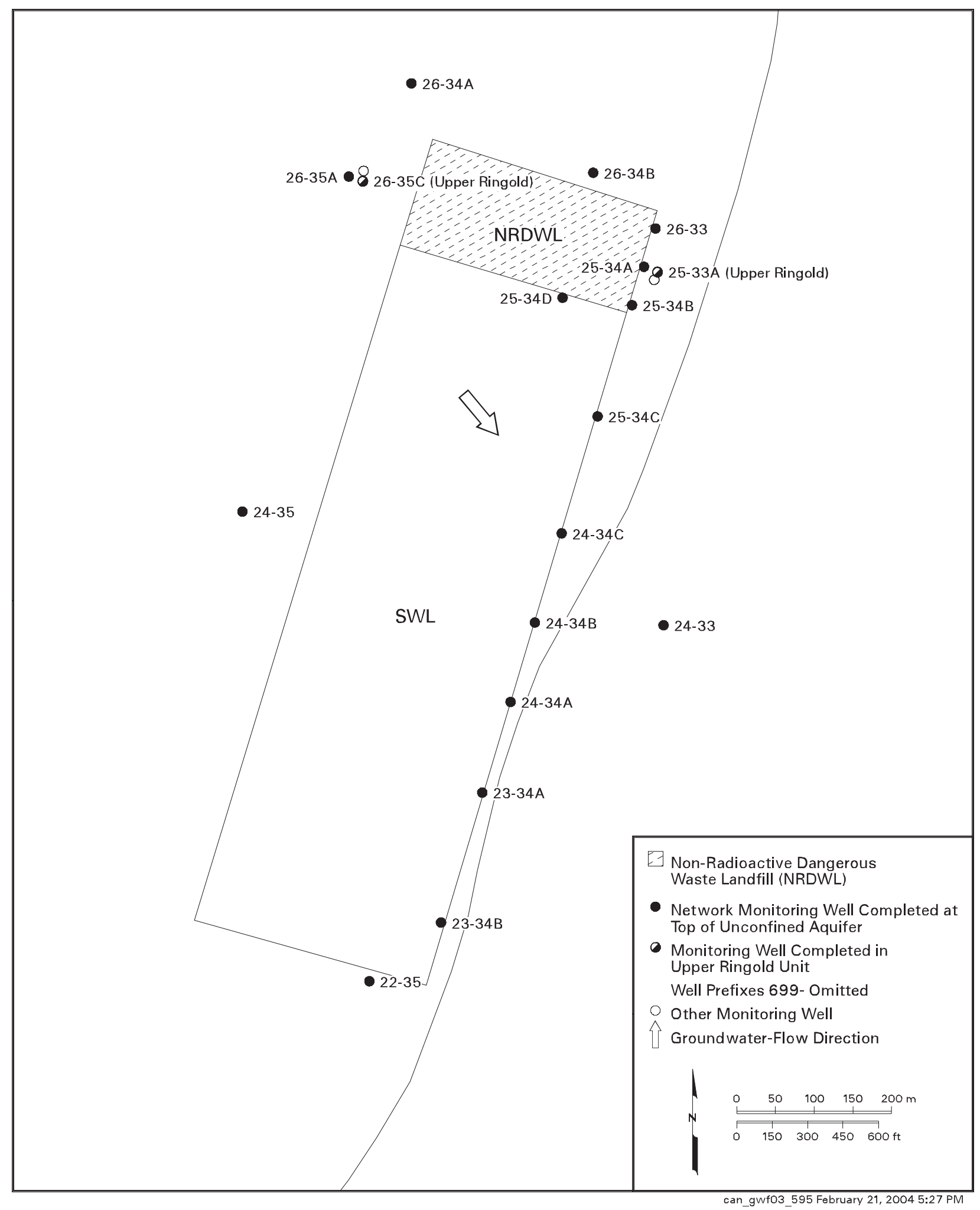

Figure 2.11-11. Groundwater Monitoring Wells at the Central Landfill and Vicinity 


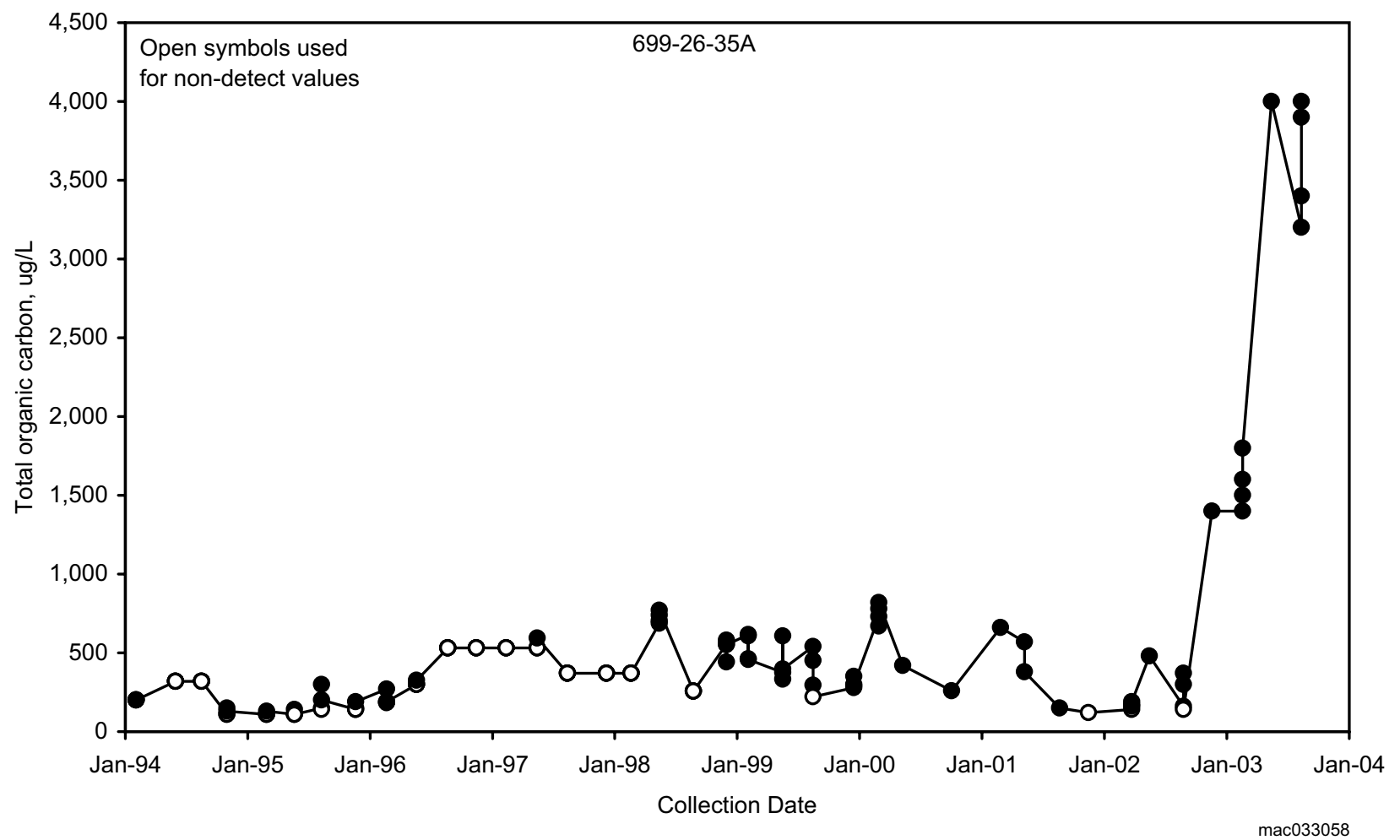

Figure 2.11-12. Total Organic Carbon Concentrations at Upgradient Well 699-26-35A, Shared by the Solid Waste Landfill and Nonradioactive Dangerous Waste Landfill

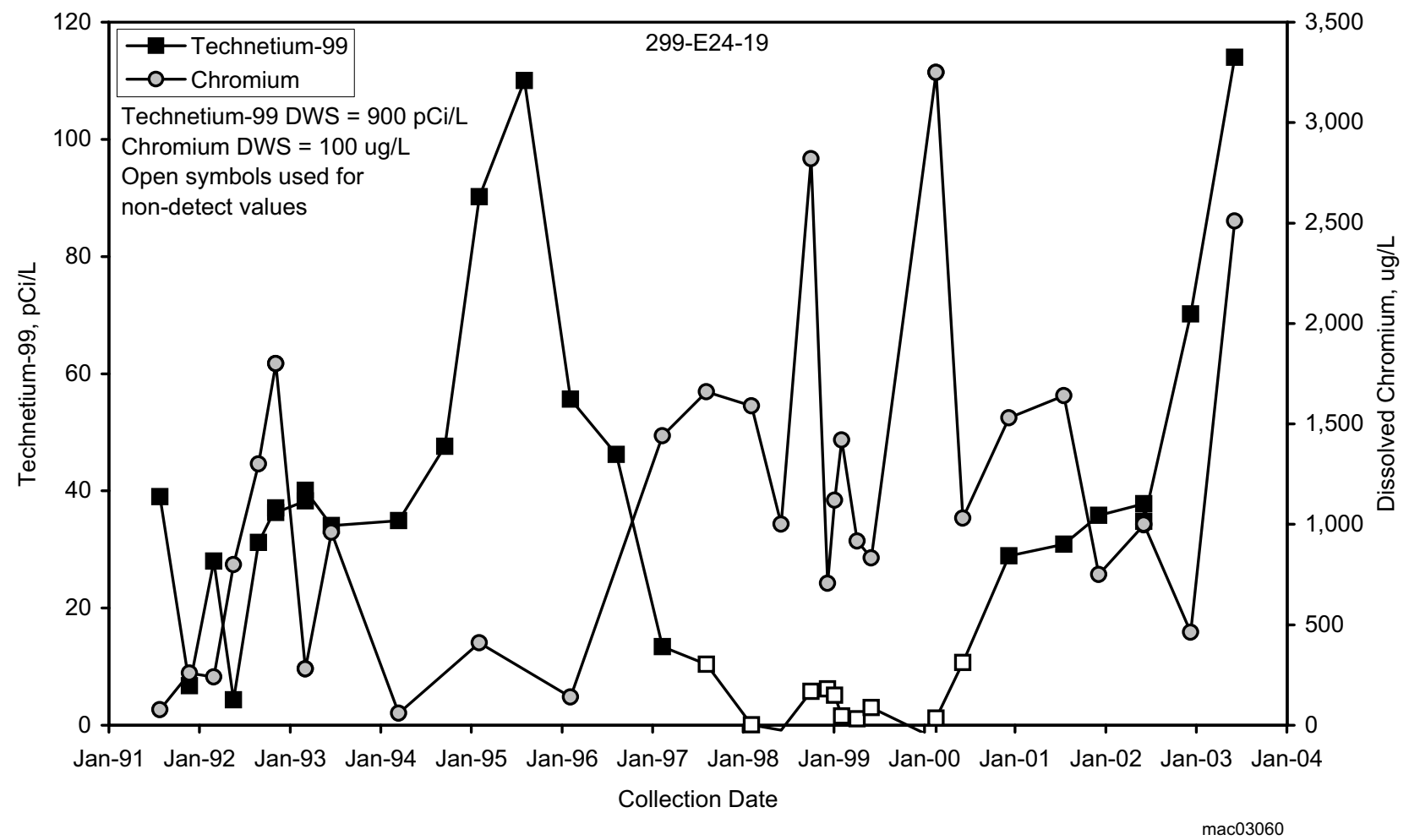

Figure 2.11-13. Chromium and Technetium-99 Trends at Waste Management Area AX, Well 299-E24-19 


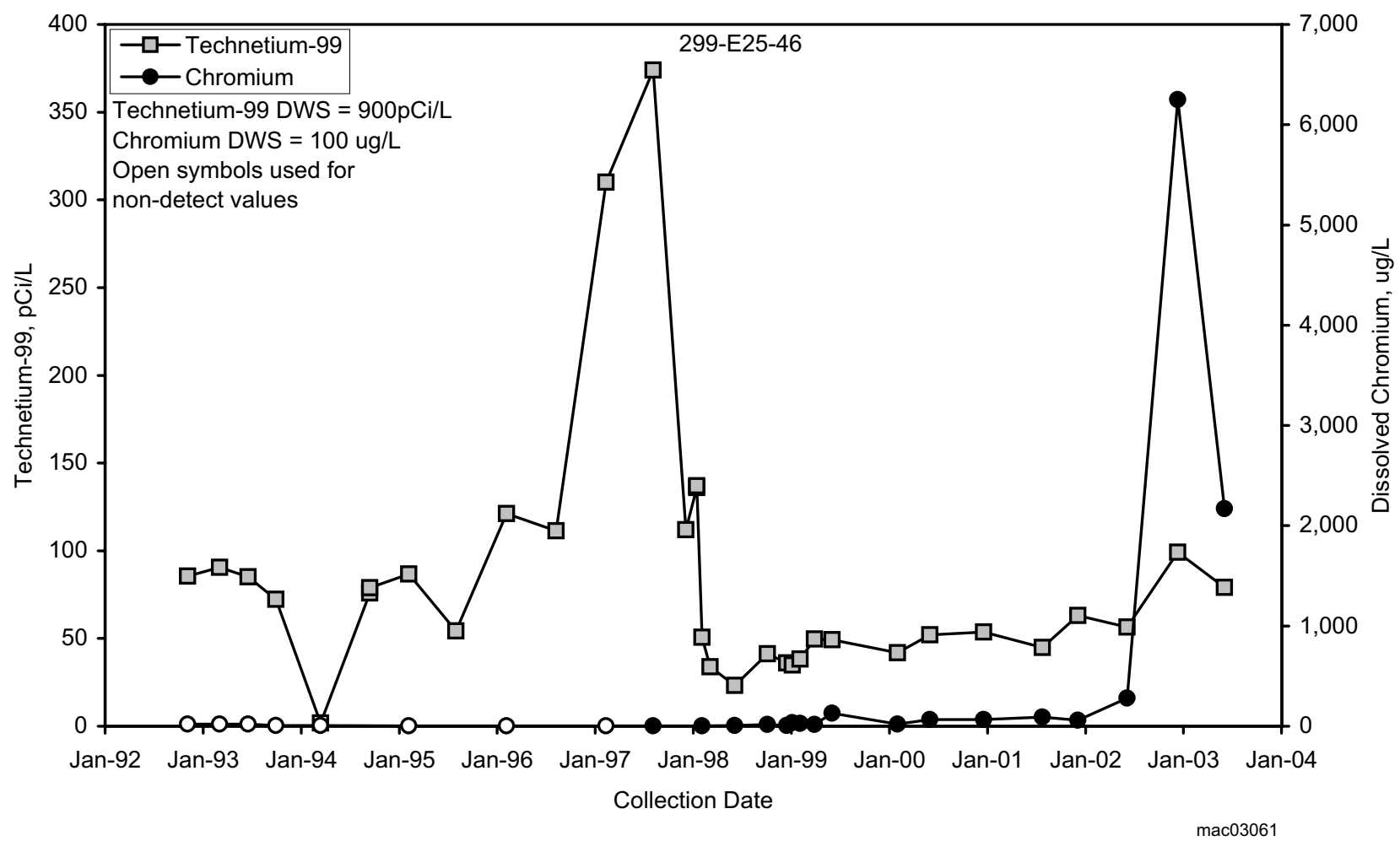

Figure 2.11-14. Chromium and Technetium-99 Trends at Waste Management Area A-AX, Well 299-E25-46 
Ponds

Waste Sites

4608 B/C Network Monitoring Well

Other Monitoring Well

Upgradient Well 699-8-17

Shown on Figure 2.1-2

1

- $50 \quad 100 \quad 150200 \mathrm{~m}$

$N \frac{1}{\frac{1}{110}}$

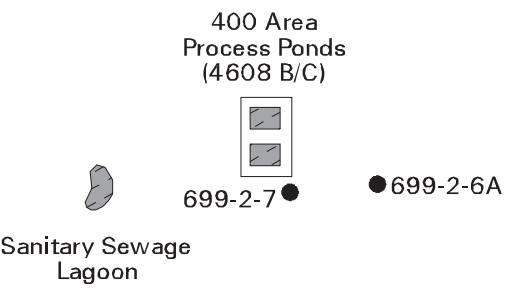

400 Area

$4608 \mathrm{~B} / \mathrm{C})$

Lagoon

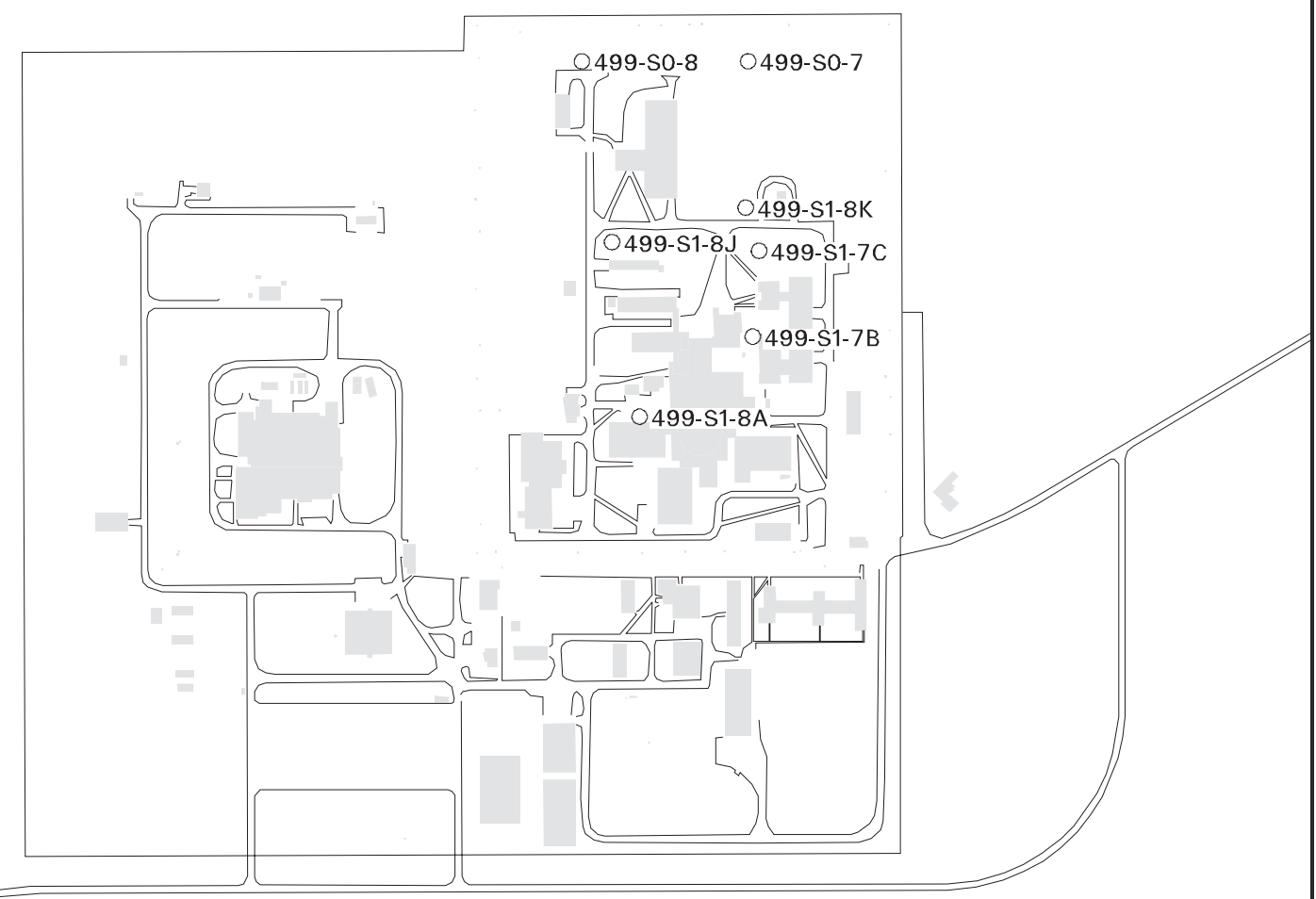

can gwfO3 340 March 08, 2004 12:44 PM

Figure 2.11-15. Groundwater Monitoring Wells in the 400 Area 

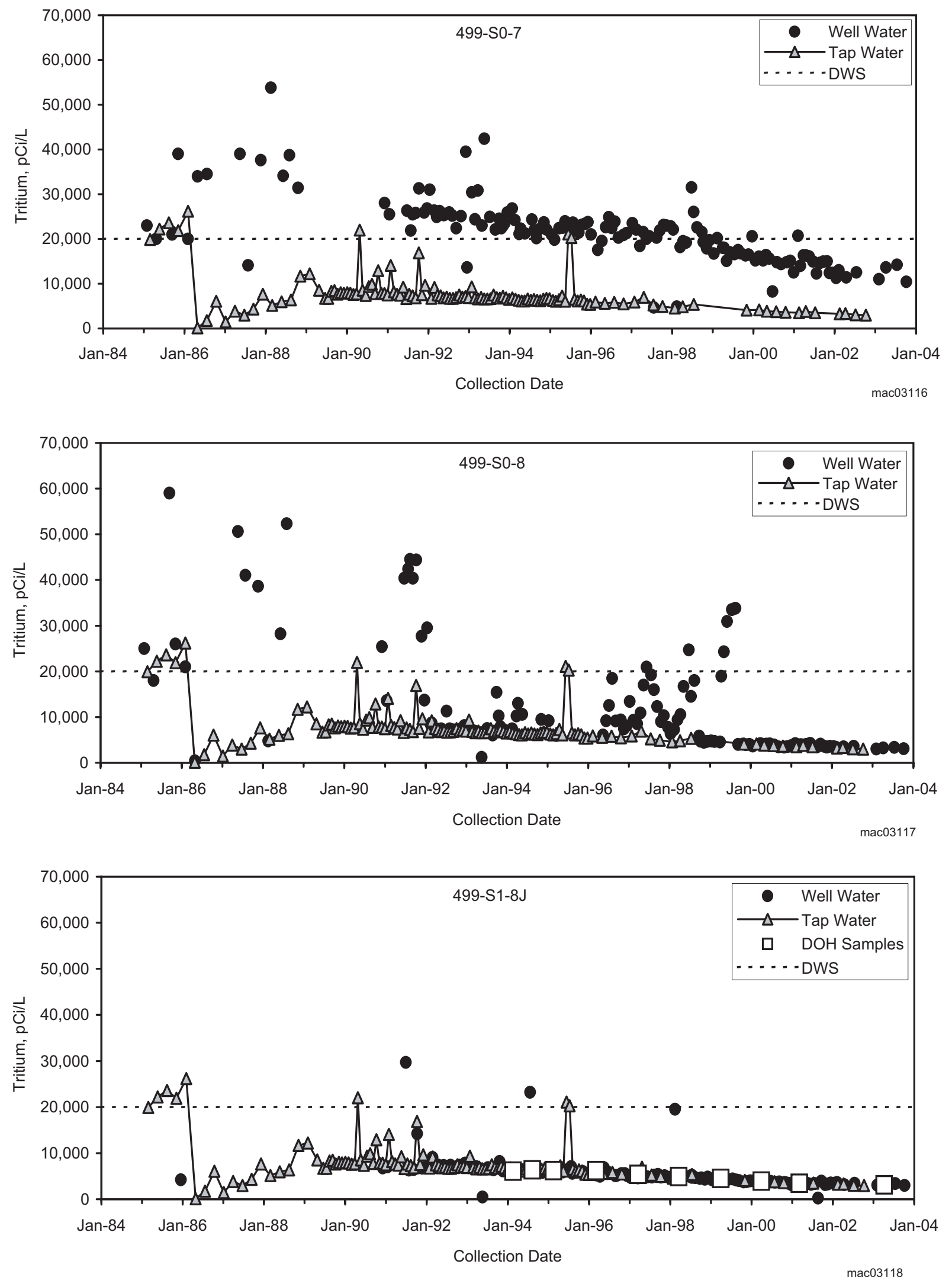

Figure 2.11-16. Comparison of Tritium Concentrations in 400 Area Drinking Water Wells 


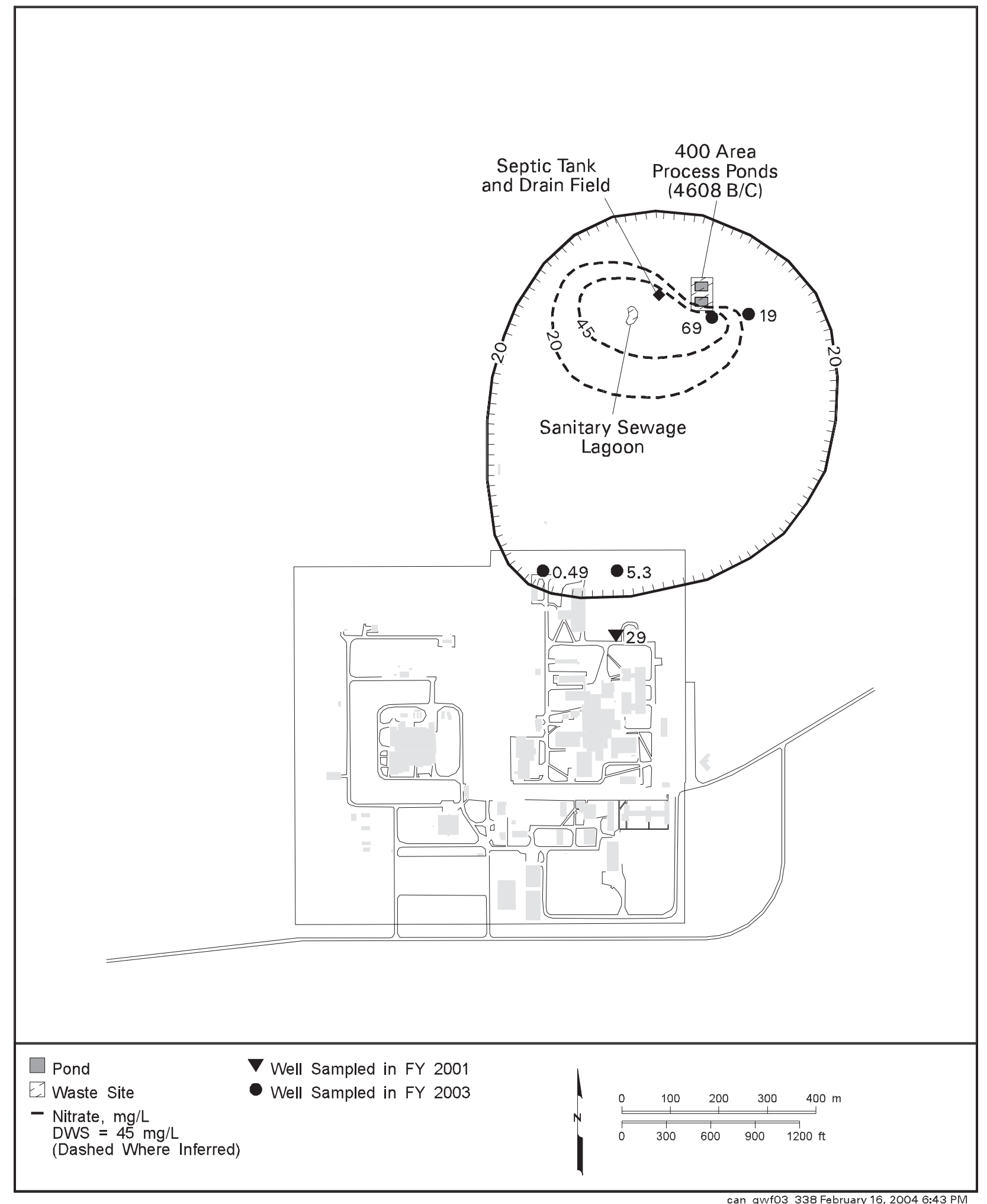

Figure 2.11-17. Average Nitrate Concentrations in 400 Area Process Pond Area, Top of Unconfined Aquifer 


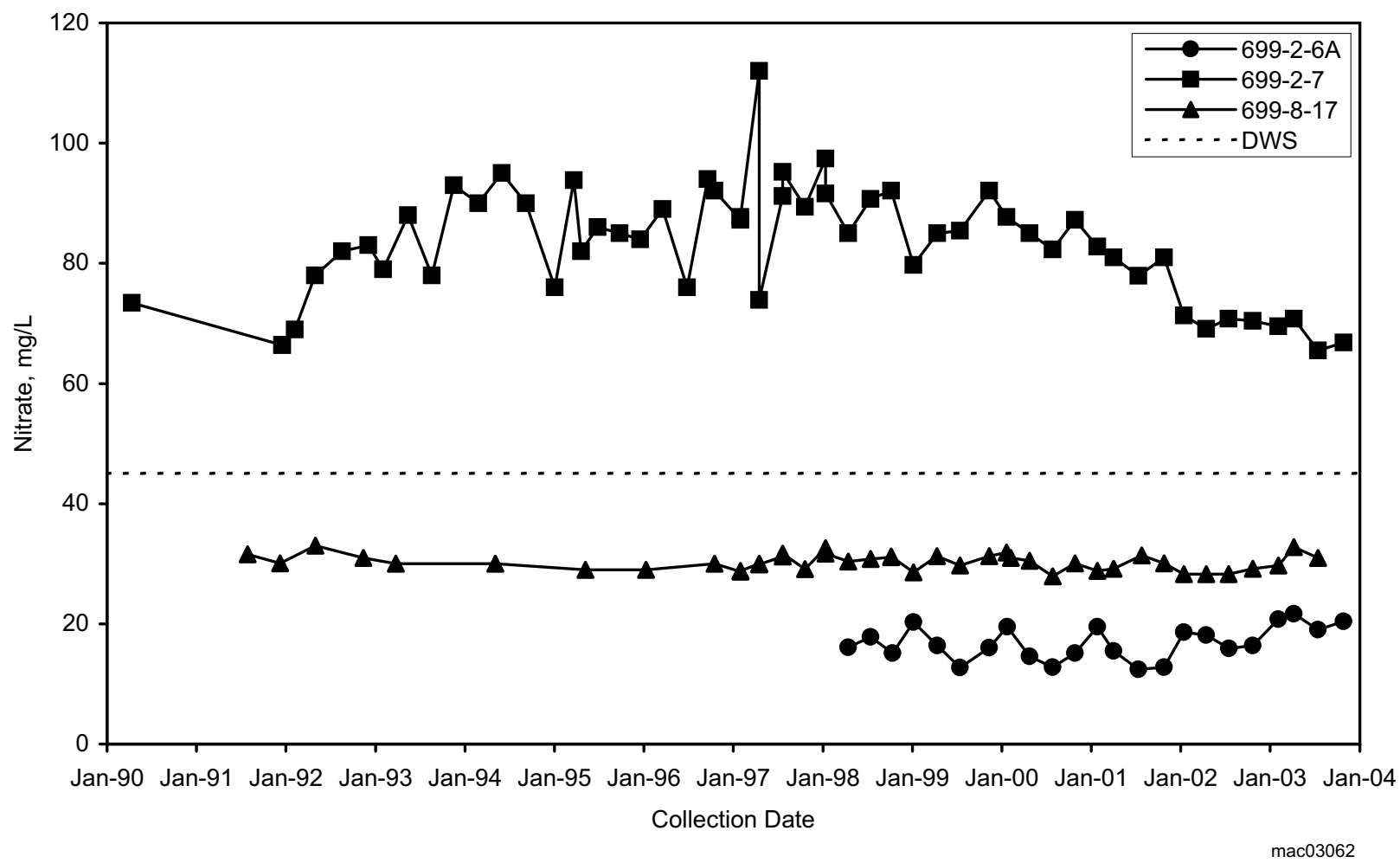

Figure 2.11-18. Nitrate Concentrations in Wells Monitoring the 400 Area Process Ponds 


\subsection{0-FF-5 Operable Unit}

\section{J. W. Lindberg and R. E. Peterson}

The 300-FF-5 Operable Unit is contained within the 300-FF-5 groundwater interest area (see Figure 2.1-1). Figure 2.12-1 shows facilities, wells, and shoreline monitoring sites in this region. Groundwater monitoring and characterization activities are underway to track changes in the extent of contaminants and their concentrations with time. Characterization activities include efforts to (a) identify natural processes that reduce the levels of contaminants of concern, (b) track groundwater contaminant levels and trends with time, and (c) comply with Resource Conservation and Recovery Act (RCRA) regulatory requirements for the 300 Area Process Trenches. Uranium is the contaminant of concern of greatest significance in groundwater at this operable unit. Additional contaminants of concern include cis-1,2-dichloroethene, trichloroethene, tetrachloroethene, vinyl chloride, strontium-90, tributyl phosphate, petroleum hydrocarbons, nitrate, and tritium.

The 300-FF-5 Operable Unit is divided into two general regions: the 300 Area and the 300-FF-5 North region (Figure 2.12-2). The 300 Area contains former nuclear fuel fabrication facilities, fuels research laboratories, liquid effluent disposal sites (e.g., process trenches, process ponds), and several solid waste burial grounds. The contaminants of concern from 300 Area sources are uranium, the volatile organic compounds mentioned above, strontium-90, and petroleum hydrocarbons. Constituents from sources outside of the 300 Area that migrate into the region include tritium and nitrate. The majority of monitoring wells being used in the 300-FF-5 Operable Unit are located in the 300 Area.

The 300-FF-5 North region includes the 618-11 burial ground near Energy Northwest, and the $618-10$ burial ground and 316-4 cribs, which are located between the 618-11 burial

Groundwater monitoring in the 300-FF-5 groundwater interest area includes CERCLA, RCRA, and AEA monitoring:

CERCLA Long-Term Monitoring

- Twenty-three wells are sampled semiannually for uranium and volatile organic compounds.

- Eight wells are sampled semiannually for nitrate (upgradient source).

- Thirteen wells are sampled semiannually for tritium (upgradient source).

- Seventeen wells are sampled semiannually to annually for other groundwater constituents.

- Riverbank springs, sediment, and associated biota are sampled annually (coordinated with Public Safety and Resource Protection Program monitoring).

- In fiscal year 2003, all wells were sampled as planned.

RCRA Corrective Action Monitoring at 316-5 Process Trenches

- Eleven wells were sampled quarterly to semiannually during 2003 for uranium and volatile organic carbons under a proposed groundwater monitoring plan.

- Eight wells were sampled eight times during 2003 for uranium and volatile organic carbons under existing groundwater monitoring plan.

- In fiscal year 2003, all wells were sampled as planned.

- Monitoring was coordinated with other programs to avoid duplication.

AEA Monitoring

- Eight wells are sampled semiannually to annually for uranium to monitor deep unconfined and confined Ringold aquifers.

- Monitoring is coordinated with CERCLA and RCRA sampling to avoid duplication. 


\section{Groundwater flows \\ toward the east and southeast during \\ low-to-normal river stage.}

ground and the 300 Area. Contaminants of concern being monitored in those regions include tritium, uranium, various volatile organic compounds, petroleum hydrocarbons, and tributyl phosphate. A small but highly concentrated plume of tritium is the most notable issue associated with the 300-FF-5 North region. Tritium, iodine-129, and nitrate migrate into the 300-FF-5 North region from upgradient sources in the 200 East Area. There is a significant source for tritium in the 618-11 burial ground, which has resulted in a high concentration, relatively low volume plume downgradient of that waste site. The 300-FF-5 North region uses 11 of the 41 monitoring wells in service for the 300-FF-5 Operable Unit.

Groundwater flow in the unconfined aquifer beneath the 300-FF-5 groundwater interest area is generally to the east and southeast. Beneath the 300 Area, flow in the unconfined aquifer is to the southeast, with flow from regions to the northwest, west, and southwest converging before ultimately discharging to the Columbia River (Figure 2.12-3).

In the immediate vicinity of the $316-5$ process trenches, the flow direction was southeast during March 2003 based on the water-table contours (Figure 2.12-3). The southeast flow direction is typically the direction of groundwater flow in the north portion of the 300 Area when the river stage is in a low-to-normal stage. During higher river stages (as in June 2003), the direction of groundwater flow tends to be more south to southwest in the vicinity of the 316-5 process trenches. Changes in river-stage elevation can be correlated to changes in water-level elevations at wells as far as $\sim 360$ meters from the river (PNL-8580).

The remainder of this section describes contaminant plumes and concentration trends for the contaminants of interest/concern under Comprehensive Environmental Response, Compensation, and Liability Act (CERCLA) and RCRA sampling and analysis plans, and special investigations under the Atomic Energy Act of 1954 (AEA) surveillance requirements.

\subsubsection{Groundwater Contaminants}

Groundwater contaminants include uranium, cis-1,2-dichloroethene, trichloroethene, tetrachloroethene, vinyl chloride, strontium-90, tributyl phosphate, nitrate, tritium, and petroleum hydrocarbons.

\subsubsection{Uranium}

Uranium is a contaminant of concern in groundwater beneath the 300 Area (fuels fabrication effluents) and is moderately mobile in groundwater, with some sorption onto sediment particles. The mobility of uranium within waste sites and underlying vadose zone is highly variable and dependent on the chemical makeup of the waste effluent and the subsurface geochemical environment, especially carbonate concentration, $\mathrm{pH}$, and the surface properties of minerals (PNNL-14022). The drinking water standard for uranium is $30 \mu \mathrm{g} / \mathrm{L}$. Uranium in 300 Area groundwater is typically monitored using chemical analyses of unfiltered samples, while uranium in shoreline media and river water is monitored using analyses for specific isotopes. Data for each type of analysis can be converted to the other to provide comparable data sets.

300 Area Uranium Plume. The persistent uranium plume in the 300 Area, as defined by concentrations exceeding $10 \mu \mathrm{g} / \mathrm{L}$, covers an area of $\sim 1$ square kilometer; concentrations exceeding the 30- $\mu \mathrm{g} / \mathrm{L}$ drinking water standard cover an area of $\sim 0.4$ square kilometer (Figures 2.12-4 and 2.12-5). Although the area of the plume is generally quite consistent from year to year, the concentrations of uranium within the plume are variable throughout the year. These changes within the plume each year are the result of changes in river stage. Throughout most of the year (i.e., August through April), the river maintains low to normal river stages. Figure 2.12-4 shows the uranium plume indicated by results for samples collected in December 2002, which is representative of the August through April time period. 
In June 2003, when the Columbia River was at high stage, concentrations of uranium in the plume changed, as shown in Figure 2.12-5. However, the higher concentration portions of the plume extended downgradient from their principle sources (i.e., the 316-5 process trenches and the 316-3 trenches near well 399-3-11) during both seasonal periods. For the December 2002 map (Figure 2.12-4), the sources are not as easily revealed, probably because the well spacing along the river bank is not close enough to resolve the two zones. For the June 2003 uranium map (Figure 2.12-5), the higher concentration portions of the plume are clearly downgradient of the two source areas.

The areal extent of the uranium plume beneath the 300 Area remained similar to previous years. Concentrations at wells located close to the most recently active waste site (i.e., the 316-5 process trenches) indicate a gradual decline since the mid-1990s (Figure 2.12-6), though levels appear to have remained fairly constant for the most recent sampling results. At locations farther downgradient from this waste site, concentration trends reveal the passage of a relatively high concentration pulse (Figure 2.12-7), which is related to the high river stage during the spring runoffs of 1997 and 1998. Concentrations at other locations within the plume area show variable trends. In the absence of current disposal of effluents to waste sites, and the removal of some past-practices waste sites by excavation, the primary control on long-term concentration trends is probably plume migration. Variability in concentrations at particular wells is also created by fluctuations in water table elevations, which cause remobilization of uranium in the lower vadose zone/capillary fringe during periods of high water table at some locations (PNNL-SA-33304).

The highest concentration of uranium reported during fiscal year 2003 was at well 399-1-10A (235 $\mu \mathrm{g} / \mathrm{L}$ for a sample collected in December 2002). This anomalously high concentration is downgradient of the 618-5 burial ground, which was excavated in October 2002. Figure 2.12-8 shows that the concentration of uranium at well 399-1-10A has been declining since December 2002, and by the end of fiscal year 2003 had dropped below $100 \mu \mathrm{g} / \mathrm{L}$. The dip in the concentration during May and June 2003 is caused by mixing of groundwater with river water during high river stage, which was confirmed by a corresponding drop in specific conductance for the sample. One potential scenario to explain the concentration increase at well 399-1-10A is that uranium in the vadose zone intercepted by the 618-5 excavation was remobilized by moisture applied to the ground (natural precipitation; dust control water), and/or by the physical disturbance caused by excavating activities. The origin of the uranium is most likely former discharges of waste containing uranium to the $316-5$ process trenches.

The isolated occurrence of uranium northwest of the 300 Area (Figures 2.12-4 and 2.12-5) may be related to releases from the 618-7 burial ground. Uranium has been detected at well 399-8-5A at concentrations below the drinking water standard for many years (Figure 2.12-9). A recent value of $25.5 \mu \mathrm{g} / \mathrm{L}$ is anomalously high compared to previous values, and may not be representative of aquifer conditions.

Uranium Near 618-10 Burial Ground. Uranium concentrations above natural background levels $(\sim 8 \mu \mathrm{g} / \mathrm{L})$ are found near the 618-10 burial ground and 316-4 cribs (see Figure 2.12-2 for locations). Wells 699-S6-E4A and 699-S6-E4L (see Figure 2.12-10 for locations) had uranium values higher than background, but less than the drinking water standard $(30 \mu \mathrm{g} / \mathrm{L})$, during 2003 . The highest reported value was $19.7 \mu \mathrm{g} / \mathrm{L}$ at well 699-S6-E4A in a sample collected during January 2003.

\subsubsection{Chlorinated Hydrocarbons}

Trichloroethene, tetrachloroethene, and cis-1,2-dichloroethene were detected in the 300-FF-5 Operable Unit during fiscal year 2003, but only trichloroethene and cis-1,2dichloroethene were reported at concentrations that exceeded the drinking water standards. Vinyl chloride, a contaminant of concern that is a degradation product of trichloroethene, was not detected in 300-FF-5 Operable Unit wells during fiscal year 2003.
The areal extent of

the uranium plume beneath the 300 Area remained similar to previous years, although concentration trends at some wells indicate a long-term gradual decline. 
Trichloroethene, tetrachloroethene, and cis-1,2-dichloroethene were detected in the 300-FF-5 Operable Unit during fiscal year 2003, but only trichloroethene and cis-1,2-dichloroethene were reported in concentrations that exceeded the drinking water standards.
Trichloroethene was detected at 26 wells that monitor water-table conditions in the 300-FF-5 Operable Unit during fiscal year 2003 (Figure 2.12-11), and there are four potential sources:

- 316-5 process trenches - limited to two deeper wells (399-1-16B and 399-1-8) screened at the base of the unconfined aquifer.

- A plume in the upper portion of the unconfined aquifer that extends into the 300 Area from a source off the Hanford Site to the southwest.

- 618-10 burial ground and 316-4 cribs.

- 618-11 burial ground.

The values shown on the plume map in Figure 2.12-11 are averages for all results obtained during the fiscal year, and represent samples collected from the water table. The plume as outlined represents multiple sources, including migration into the 300 Area from sources to the southwest. The latter area of contamination evolved during a period when the groundwater flow pattern was changing because of increased irrigation southwest of the 300 Area.

In the area downgradient from the $316-5$ process trenches, trichloroethene contamination has shown a long-term gradual decline until approximately 2001, when concentrations stabilized between 2 and $3 \mu \mathrm{g} / \mathrm{L}$ at well 399-1-16B, which monitors the bottom of the unconfined aquifer (Figure 2.12-12). During fiscal year 2003, the highest reported concentration for trichloroethene in this area was $7.2 \mu \mathrm{g} / \mathrm{L}$ at well 399-1-7, although this result is out of trend with earlier results and nearby wells. Farther away from the 316-5 process trenches, the highest values for fiscal year 2003 are 3.7 and $3.3 \mu \mathrm{g} / \mathrm{L}$ at wells 399-3-2 and 399-4-12, respectively. Trichloroethene was detected at wells near the 618-10 and 618-11 burial grounds (300-FF-5 North), but at very low concentrations, with the highest concentration being $1.1 \mu \mathrm{g} / \mathrm{L}$ during fiscal year 2003.

Tetrachloroethene (drinking water standard $5.0 \mu \mathrm{g} / \mathrm{L}$ ) was detected at very low concentrations in six wells in the 300 Area and one well near the 618-10 burial ground in the $300-$ FF- 5 North region. The highest concentration reported was $0.48 \mu \mathrm{g} / \mathrm{L}$ at well 399-4-11.

A small area of cis-1,2-dichloroethene contamination (drinking water standard $70 \mu \mathrm{g} / \mathrm{L}$ ) is revealed at two wells that monitor the base of the unconfined aquifer downgradient of the 316-5 process trenches. The highest concentration during fiscal year 2003 was $160 \mu \mathrm{g} / \mathrm{L}$ at well 399-1-16B (Figure 2.12-12). The concentration at this well appears to be relatively constant, with some variability. The highest concentration at the second well (399-1-17B) was $2.8 \mu \mathrm{g} / \mathrm{L}$. This contaminant was detected at nine other wells in the vicinity of the plume associated with the $316-5$ process trenches, but at concentrations $<1 \mu \mathrm{g} / \mathrm{L}$. Cis-1,2-dichloroethene is a degradation product of trichloroethene (Morrison 1998).

\subsubsection{Strontium-90}

Strontium-90 has been detected as an isolated occurrence at well 399-3-11 in previous years (PNNL-13788). The drinking water standard is $8 \mathrm{pCi} / \mathrm{L}$. The highest concentration measured in recent years was $8.7 \mathrm{pCi} / \mathrm{L}$ in 1995 . Since then, the concentration levels measured at well 399-3-11 have varied between 3 and $8 \mathrm{pCi} / \mathrm{L}$. Reported results from well 399-3-11 during fiscal year 2003 ranged from 3.3 to $4.0 \mathrm{pCi} / \mathrm{L}$. The source of strontium-90 is unknown, but it may be the 316-3 trenches located $\sim 60$ meters northnorthwest of well 399-3-11.

\subsubsection{Tributyl Phosphate}

Tributyl phosphate was detected in one well (699-S6-E4A) near the 618-10 burial ground and 316-4 cribs. Concentrations for fiscal year 2003 ranged from 18 to $24 \mu \mathrm{g} / \mathrm{L}$, 
a range much lower than the peak measurement of $1,500 \mu \mathrm{g} / \mathrm{L}$ in 1996 . The semivolatile compound tends to bind in the vadose zone beneath waste sites that received effluent containing tributyl phosphate, where it slowly degrades with time. The tributyl phosphate at well 699-S6-E4A appears to be very localized, and its appearance in groundwater might have been caused by the well rehabilitation work conducted in 1995 and 1996, i.e., tributyl phosphate was dragged downward from the vadose zone. It is not very soluble in water and, therefore, not widely dispersed via water transport mechanisms. There is no drinking water standard for tributyl phosphate.

\subsubsection{Nitrate}

Nitrate concentrations above background levels were detected in all wells in the 300 Area and 300-FF-5 North region. Figures 2.12-13 and 2.1-6 show the distribution of nitrate in the 300 Area and Hanford Site, respectively. Two wells in the southwest part of the 300 Area revealed fiscal year 2003 average nitrate concentrations higher than the drinking water standard of $45 \mathrm{mg} / \mathrm{L}$; well 399-5-1 had a value of $80 \mathrm{mg} / \mathrm{L}$ and well 699-S27-E14 had a value of $58 \mathrm{mg} / \mathrm{L}$. The source of this nitrate is probably offsite industry and agriculture.

The 300-FF-5 North region is within the large nitrate plume coming from the 200 East Area. Background levels of nitrate upgradient of the 618-11 burial ground are in the range of 20 to $30 \mathrm{mg} / \mathrm{L}$. In the vicinity of the $618-11$ burial ground, the concentrations of nitrate were as high as $133 \mathrm{mg} / \mathrm{L}$ during fiscal year 2003 near well 699-12-2C, which may reflect the influence of an active septic system operated by Energy Northwest.

\subsubsection{Tritium}

Tritium observed in the 300-FF-5 Operable Unit is part of a site-wide tritium plume that originates in the 200 East Area (Figure 2.1-5 and Section 2.11.1.1). Concentrations attributable to this plume are $\sim 20,000 \mathrm{pCi} / \mathrm{L}$ in the $300-\mathrm{FF}-5$ North region (includes the $618-10$ and $618-11$ burial grounds) and 100 to $10,000 \mathrm{pCi} / \mathrm{L}$ farther south in the 300 Area region (Figure 2.12-14). Tritium concentrations began to increase in parts of the 300 Area in 2003 after decreasing in 2002, as shown graphically in Figure 2.12-15. As a result, tritium contours shifted slightly to the southwest, indicating that the tritium plume in these areas increased slightly in size between fiscal years 2002 and 2003. Tritium levels continued to show stable levels just north of the 300 Area (well 699-S19-E13 in Figure 2.12-15).

Tritium from 618-11 Burial Ground. This local plume of tritium, which is superimposed on the site-wide plume, was detected in early 1999 at well 699-13-3A, located immediately to the east of the 618-11 burial ground fence. Tritium concentrations exceeded several million picocuries per liter when first discovered. Following the unexpected discovery of such high concentrations of tritium, a special investigation of the groundwater was undertaken to fully characterize the local plume (PNNL-13228). An investigation determined that the 618-11 burial ground was the likely source and the extent of the plume was a relatively narrow tongue extending east-northeast. Concentrations of tritium within the narrow plume after $\sim 1$ kilometer distance from the burial ground were indistinguishable from background levels associated with the site-wide plume (PNNL-13675). For more information on the local tritium plume near the 618-11 burial ground, see PNNL-14187 (Section 2.12.7.3) and Section 2.12 .2 of this document.

Since 1999, the concentration of tritium at well 699-13-3A, where the high concentrations of tritium were first discovered in 1999, rose to $>8$ million $\mathrm{pCi} / \mathrm{L}$ in 2000 and then started a rapid decrease in concentration (Figure 2.12-16). Concentrations at that well during 2003 have decreased to levels below 3 million pCi/L, which still exceeds the DOE derived concentration guide (2 million $\mathrm{pCi} / \mathrm{L})$.

\section{Tritium concentrations}

decreased at the 618-11 burial ground, but still exceeded the DOE derived concentration guide of 2 million $p \mathrm{Ci} / \mathrm{L}$. 


\subsubsection{Petroleum Hydrocarbons}

Petroleum hydrocarbons (both diesel and gasoline) were analyzed in samples collected from wells downgradient of the 618-10 burial ground and 316-4 cribs (wells 699-S6-E4A, 699-S6-E4K, 699-S6-E4L) in the 300-FF-5 North region and downgradient of each of the 618-4 and 618-5 burial grounds (wells 399-1-15 and 399-1-6, respectively) in the north portion of the 300 Area. Petroleum hydrocarbons were not detected in any of these wells during fiscal year 2003.

\subsubsection{CERCLA Groundwater Monitoring and Interim Action}

The interim remedy for the operable unit includes continued groundwater monitoring to verify previously predicted plume behavior and to evaluate the need for additional remedial actions.
Groundwater monitoring at the 300-FF-5 Operable Unit continued in fiscal year 2003 under a revised operation and maintenance plan (DOE/RL-95-73) and a sampling and analysis plan (DOE/RL-2002-11). The operable unit includes groundwater beneath the 300 Area, the 618-10 burial ground and adjacent 316-4 cribs, and the 618-11 burial ground (EPA 2000; see Figure 2.12-2). All wells were sampled as planned in fiscal year 2003. See Appendix A for additional details.

The record of decision for the operable unit (ROD 1996b; EPA 2000) describes the selected interim remedy as:

- Continued monitoring of groundwater that is contaminated above health-based levels to ensure that concentrations continue to decrease.

- Institutional controls to ensure that groundwater use is restricted to prevent unacceptable exposures to groundwater contamination.

The implementation of the interim remedy is described in an updated and expanded operations and maintenance plan (DOE/RL-95-73). Key elements include continued groundwater monitoring to verify previously modeled predictions of contaminant attenuation and to evaluate the need for active remedial measures. The continued monitoring includes gathering more information on (1) the recharge of mapped plumes because of release from the vadose zone, (2) the characteristics of discharge from the aquifer to the Columbia River, and (3) dispersal of contaminants in the river environment via biotic pathways. The intent of monitoring during the interim action period is to build a technical basis for including monitored natural attenuation as a component in a future record of decision, which may also involve active remedial measures.

As stated in the operations and maintenance plan (DOE/RL-95-73), specific monitoring objectives include the following items:

- Verify that natural attenuation reduces groundwater contamination concentrations to drinking water maximum contaminant levels over a reasonable time period.

- Confirm that contaminant concentrations in the river seeps do not exceed ambient water quality criteria or established remediation goals (drinking water standards).

- Validate contaminant fate and transport conceptual models. 
Dissemination of new information on achieving these objectives has been accomplished via monthly briefings at the 300 Area Unit Managers' Meetings (minutes of these meetings are included in the U.S. Department of Energy's [DOE's] Administrative Record for the 300-FF-5 Operable Unit). During 2004, an additional report will be prepared that details the progress made in characterizing the natural processes that influence the level of contamination beneath the 300 Area region of the operable unit.

The CERCLA process includes a requirement for the U.S. Environmental Protection Agency (EPA) to review the effectiveness of their records of decision every 5 years. The results of the first 5 -year review (EPA 2001) indicated that the remedial actions at 300 Area source waste sites were proceeding in an effective manner to protect human health and the environment. EPA re-affirmed that the cleanup goals and remedy selection for groundwater are still appropriate at the time the 5-year review was released. The next 5-year review by EPA will be conducted during 2005 and available to the public by spring 2006.

300 Area. Sampling and analysis activities to support the interim action for the 300 Area portion of the operable unit include semiannual sampling at monitoring wells and annual sampling of riverbank springs, sediment, and associated biota. The semiannual well sampling is scheduled for December and June, with the intent of characterizing average seasonal conditions (December) and the spring period of high water-table elevations (June), which are caused by the spring runoff to the Columbia River (see Figures 2.12-4 and 2.12-5).

Sampling and analysis at various sites, and of various media, along the 300 Area shoreline are being conducted under several programs, including CERCLA operable unit requirements and the DOE Public Safety and Resource Protection Program. Under CERCLA, riverbank springs and aquifer sampling tubes (to be installed fall 2003/winter 2004) are sampled to provide data on groundwater contaminant distributions and trends near the point-of-discharge to the river ecosystem. An integrated effort between the Public Safety and Resource Protection Program's Ecological Monitoring and Compliance Project, and the Surface Environmental Surveillance Project is producing additional data on contaminants at the groundwater/river interface. Media sampled include riverbed pore water and sediment, river water, and various aquatic biota. Clams have been shown to be good indicators of environmental health where uranium-contaminated groundwater discharges to the riverbed (PNNL-13692). Analytical results for samples of groundwater, surface water, sediment, and biota are stored in the Hanford Environmental Information System database. Groundwater data are summarized in an annual report (this document), while results for other media are described in an annual environmental report (e.g., PNNL-14295). Data and interpretations are also presented in topical reports as the need arises.

300-FF-5 North Region. Monitoring the tritium plume that extends downgradient of the 618-11 burial ground continued during 2003, primarily with quarterly sampling of wells used to define the plume. For wells close to the burial ground, concentrations are on a declining trend (see Section 2.12.1.6 and Figure 2.12-16). At other wells, changes in concentrations seem to reflect gradual migration of the plume to the east. An updated plume map is shown in Figure 2.12-17.

Near the 618-10 burial ground, a soil-gas investigation around the perimeter fence was completed as part of planning for two new monitoring wells (PNNL-14320). No evidence of a tritium plume emanating from burial ground sources was discovered. The slightly elevated helium-3/helium-4 ratios at several sites are probably consistent with the underlying tritium in the site-wide plume. Two new monitoring wells were installed in February 2003 along the southeast fence of the burial ground (wells 699-S6-E4K and 699-S6-E4L). Samples from those wells do not reveal any evidence for a groundwater plume whose origin is the burial ground. Water quality conditions at those wells reflect the site-wide tritium plume, which contains co-contaminants nitrate and iodine- 129 .

\section{Monitoring results from two new wells do not reveal any evidence that a groundwater plume originates from the 618-10 burial ground.}




\subsubsection{RCRA Groundwater Monitoring at the 316-5 Process Trenches}

The 300 Area process trenches (316-5) are a RCRA treatment, storage, or disposal unit in the Hanford Facility RCRA Permit (Ecology 1994). From 1975 through 1994, they received effluent discharges of dangerous mixed waste from fuel fabrication and nuclear research laboratories in the 300 Area. Groundwater monitoring at the 300 Area process trenches is conducted in accordance with Washington Administrative Code (WAC) 173-303-645(11), Corrective Action Program, and Part VI, Chapter 1 of the Hanford Facility RCRA Permit (Ecology 1994). The modified closure plan (DOE/RL-93-73), which is incorporated into the Hanford Facility RCRA Permit,

Only two of the contaminants of concern remain above drinking water standards, uranium and cis-1,2-dichloroethene. indicates that groundwater remediation is deferred to the CERCLA 300-FF-5 Operable Unit.

During fiscal year 2003, RCRA groundwater monitoring at the 300 Area process trenches was operated under two groundwater monitoring plans, (1) a proposed revised plan (PNNL-13645) that was in its second year of a 2-year trial period while being evaluated for an alternate sampling schedule and statistical methods, and (2) an existing plan (WHC-SD-EN-AP-185) that has been in operation since 1997. Appendix B provides details on RCRA groundwater monitoring plans and regulatory compliance for the 300 Area process trenches. Contaminants of concern for RCRA monitoring are uranium, cis-1,2-dichloroethene, trichloroethene, and tetrachloroethene. The characteristics in the groundwater flow regime affected by discharges to the 316-5 process trenches are discussed in Section 2.12.1. The sampling frequency at the 11 wells monitored under RCRA ranged from semiannually to monthly during the year, depending on which of the two monitoring plans was in effect at the time of the sampling event (see Appendix B).

Only two contaminants of concern for RCRA monitoring remain above the drinking water standards, uranium and cis-1,2-dichloroethene. Uranium concentrations in wells nearest the process trenches have gradually decreased or remained constant during recent years (Figure 2.12-6). Farther downgradient along the flow path from the process trenches, concentrations increased, then decreased, suggesting the passage of higher concentrations created by high water-table conditions during high river stages of 1997 and 1998 (Figure 2.12-7).

Well 399-1-16B, a well installed at the base of the unconfined aquifer downgradient of the 300 Area process trenches, is the only network well having reported levels of cis-1,2-dichloroethene above the drinking water standard $(70 \mu \mathrm{g} / \mathrm{L})$. The concentration appears to be holding steady, neither significantly increasing nor decreasing in concentration with time (see Figure 2.12-12), although fluctuating from $\sim 130$ to $160 \mu \mathrm{g} / \mathrm{L}$. Other volatile organic compounds such as trichloroethene and tetrachloroethene continue to be detected in network wells at the 300 Area process trenches but generally at levels lower than drinking water standards, except for one apparently anomalous result in well 399-1-7 (see Section 2.12.1.2). 


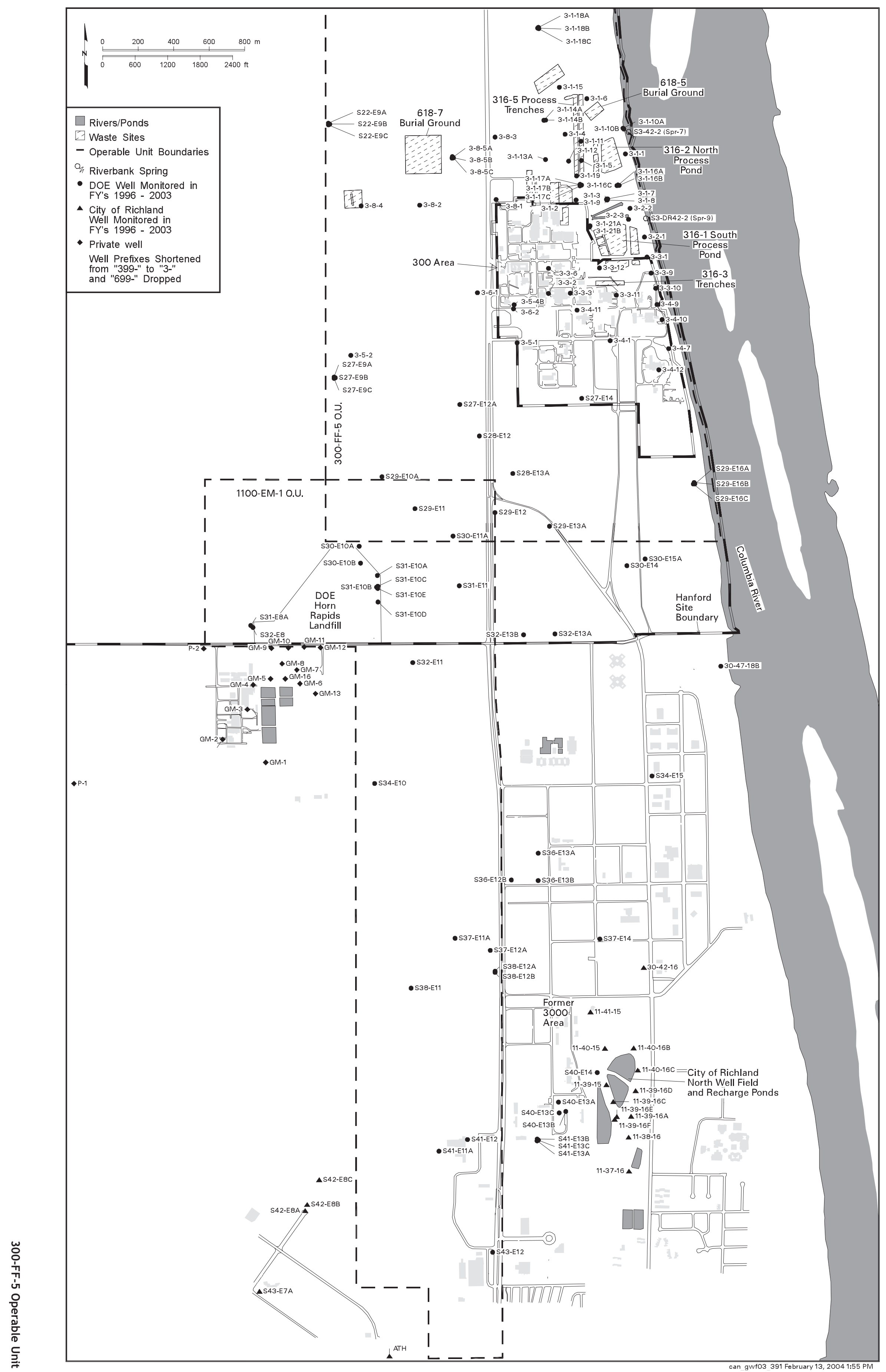

Figure 2.12-1. Groundwater Monitoring Wells in the Richland North and 300 Areas 


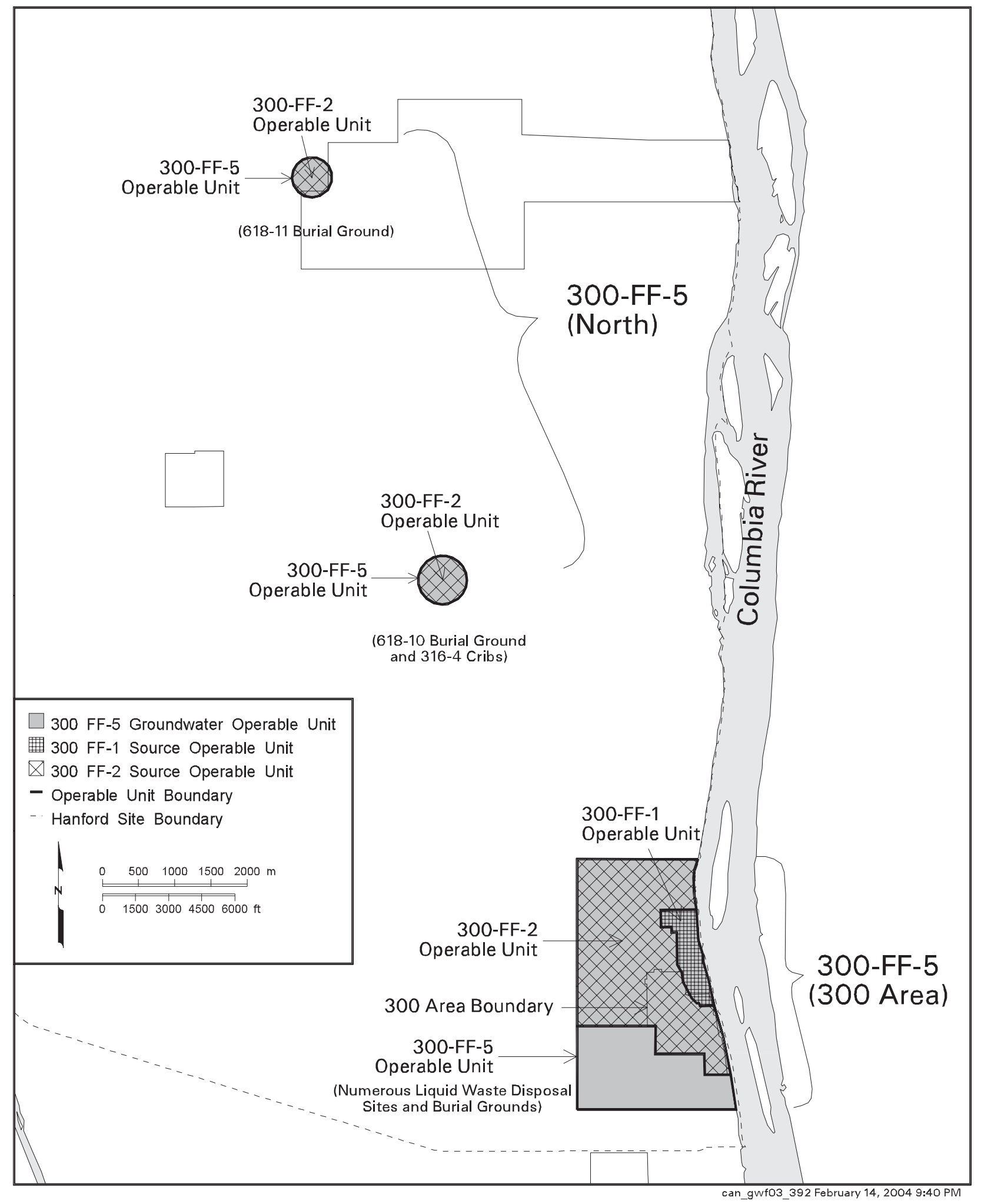

Figure 2.12-2. Subdivisions of the 300-FF-5 Operable Unit 


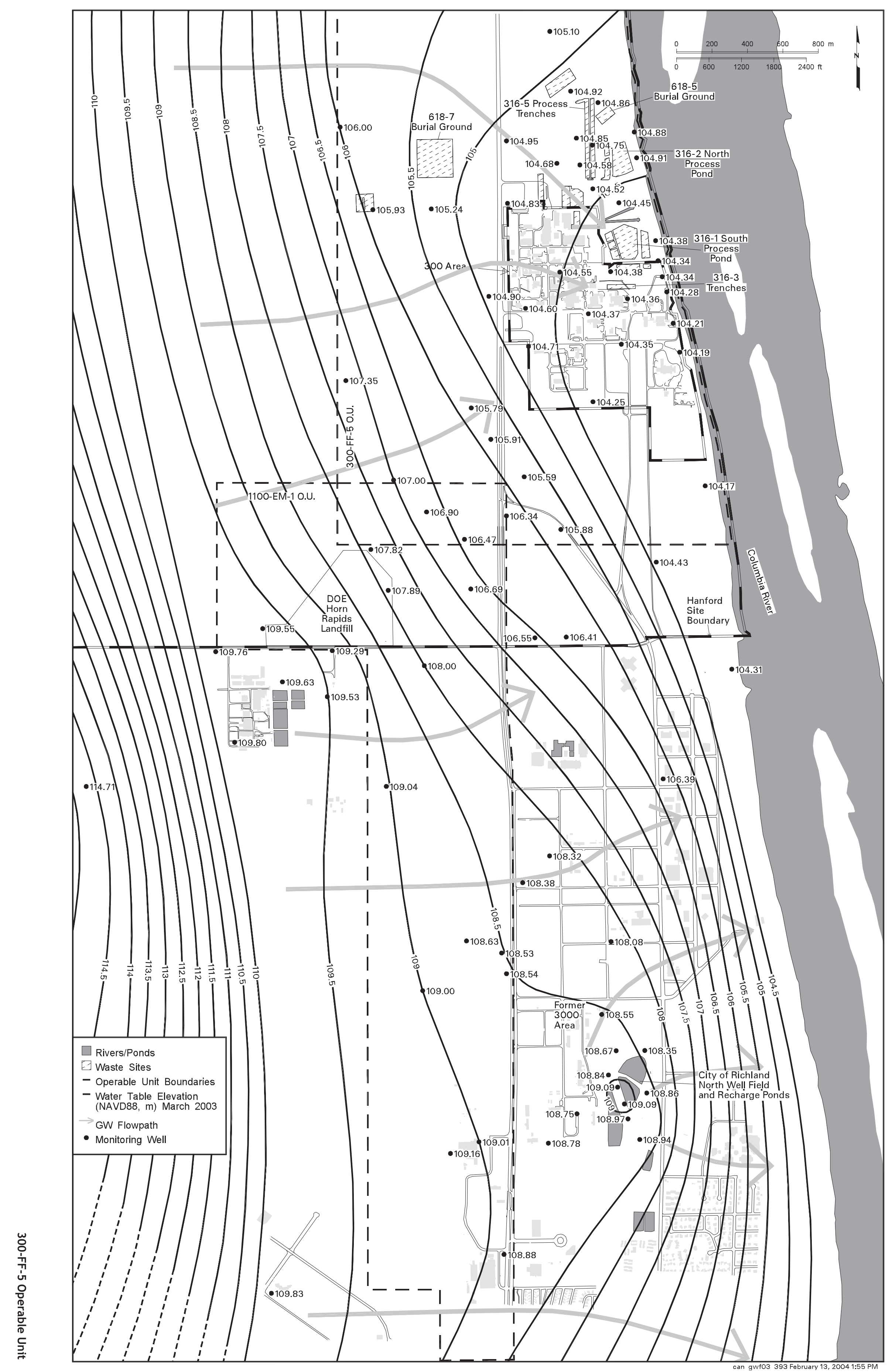

Figure 2.12-3. Groundwater Flow Direction in the Richland North and 300 Areas 


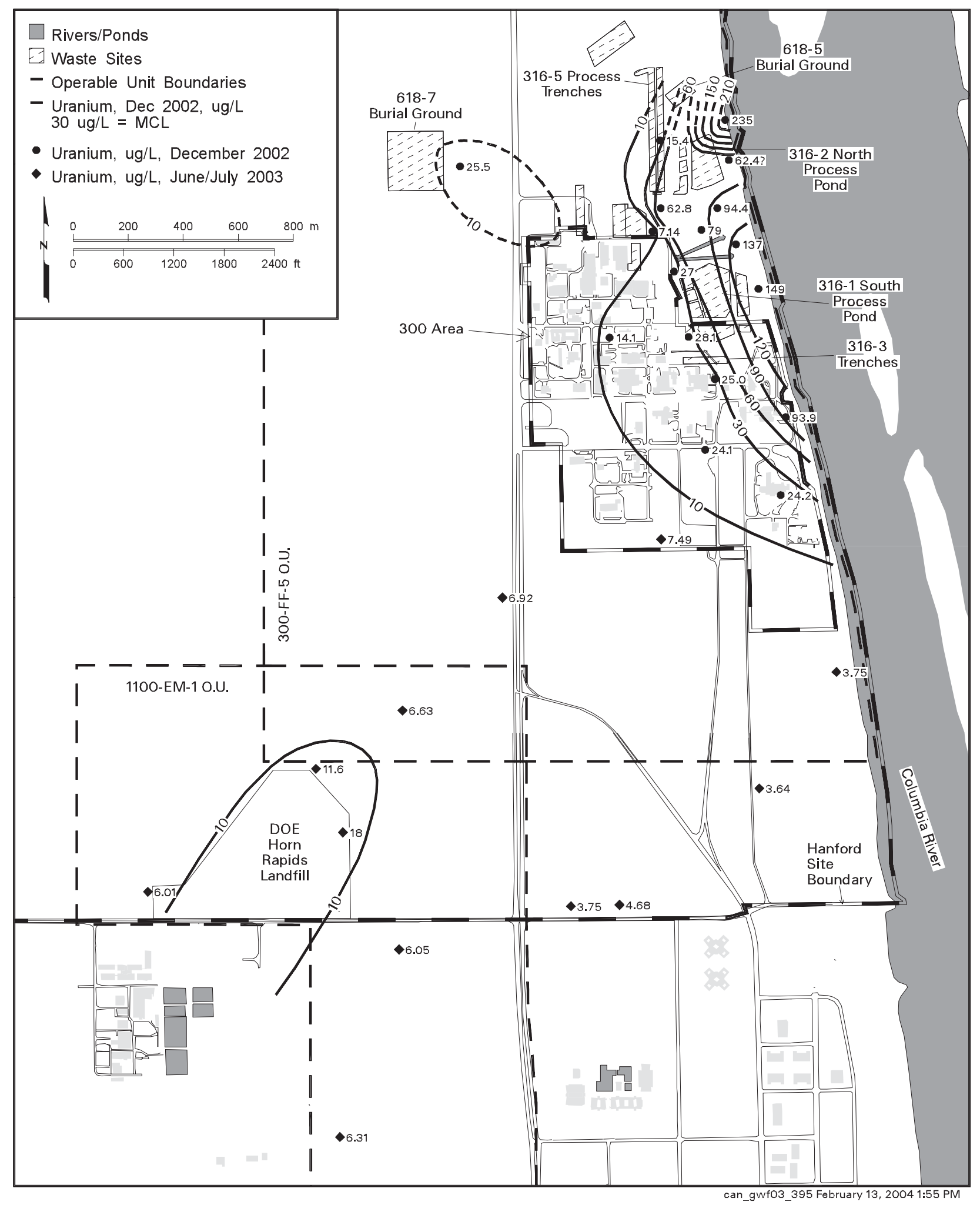

Figure 2.12-4. Uranium Concentrations in the Richland North and 300 Areas, December 2002, Top of Unconfined Aquifer 


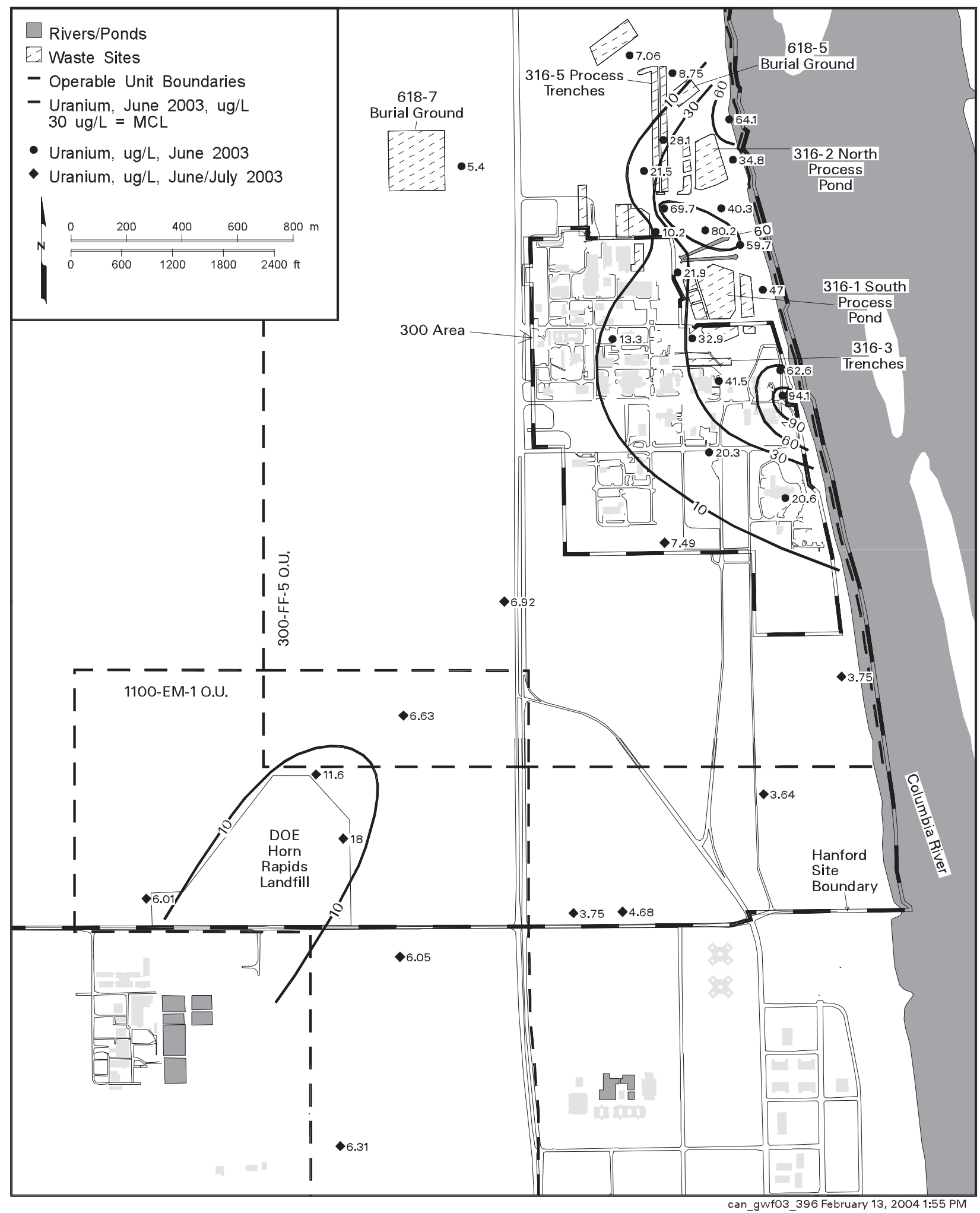

Figure 2.12-5. Uranium Concentrations in the Richland North and 300 Areas, June 2003, Top of Unconfined Aquifer 


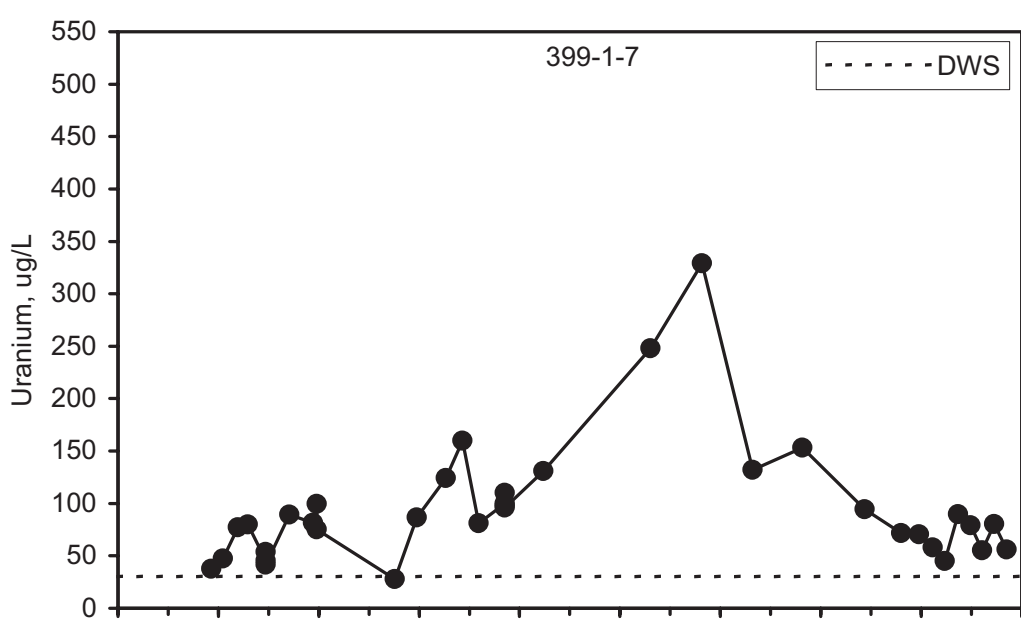

Jan-86 Jan-88 Jan-90 Jan-92 Jan-94 Jan-96 Jan-98 Jan-00 Jan-02 Jan-04 Collection Date $\operatorname{mac} 03107$

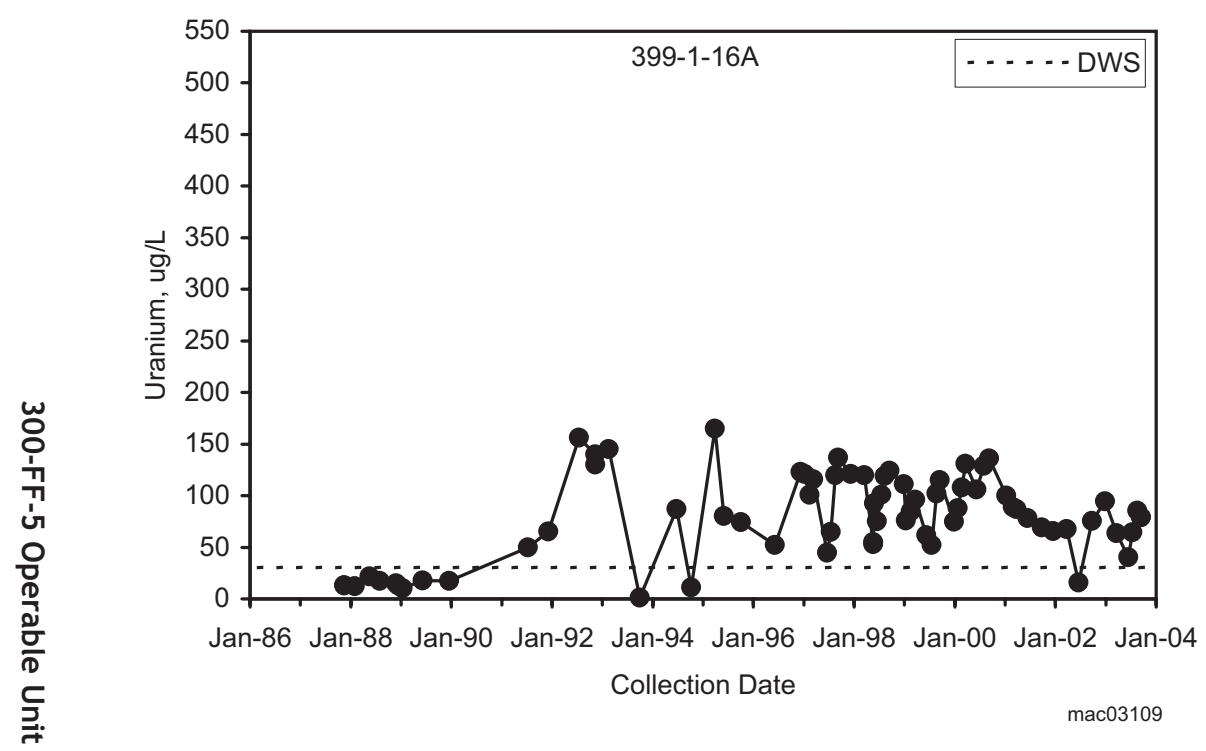

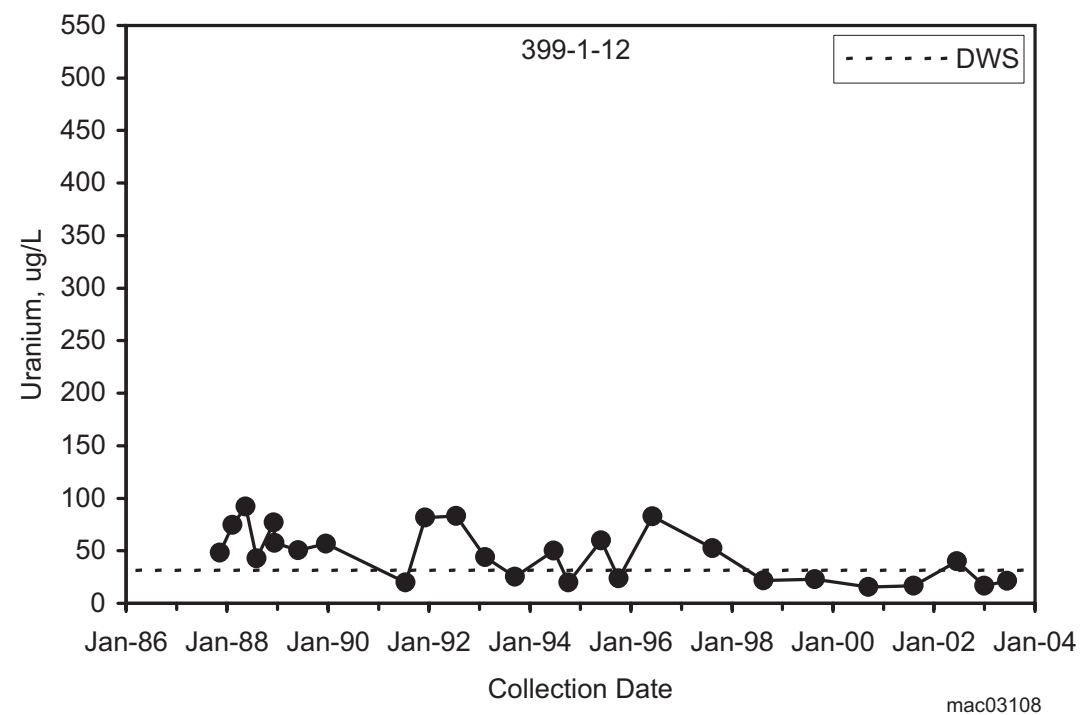

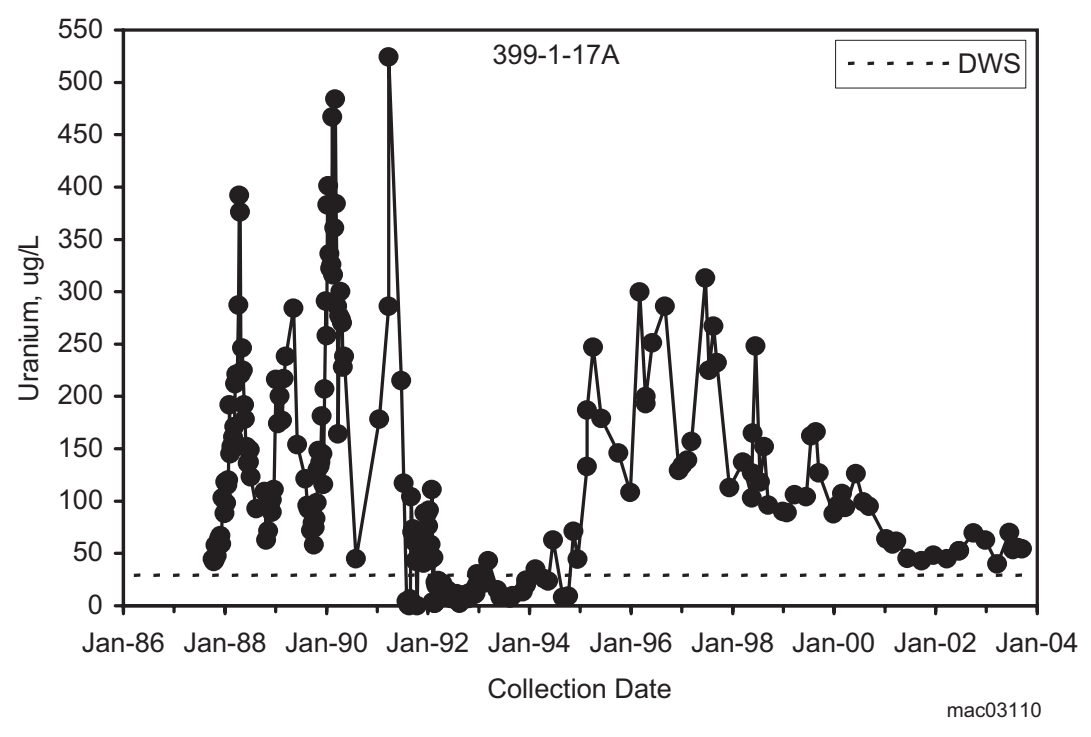

Figure 2.12-6. 300 Area Wells Showing Long-Term Gradual Decline in Uranium Concentrations Since 1997 


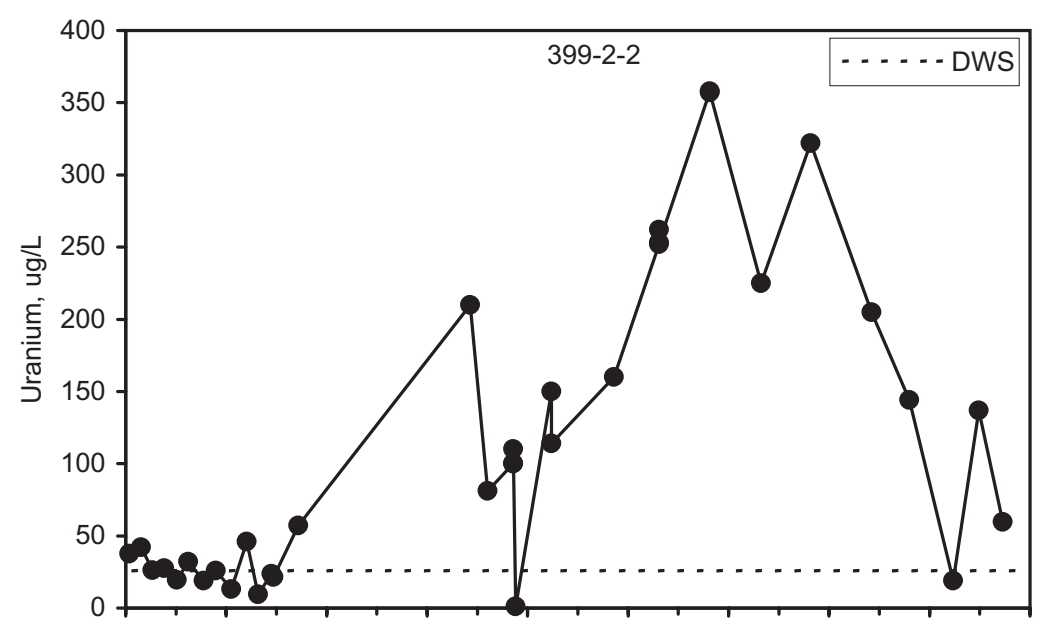

Jan-86 Jan-88 Jan-90 Jan-92 Jan-94 Jan-96 Jan-98 Jan-00 Jan-02 Jan-04 Collection Date

$\operatorname{mac} 03112$

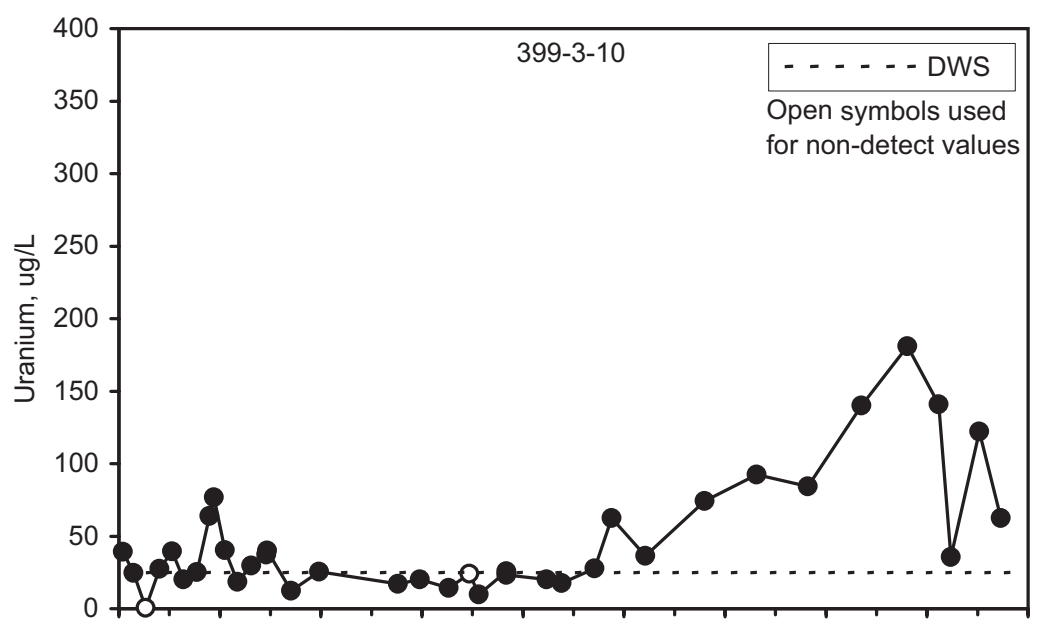

Jan-86 Jan-88 Jan-90 Jan-92 Jan-94 Jan-96 Jan-98 Jan-00 Jan-02 Jan-04 Collection Date

$\operatorname{mac} 03113$

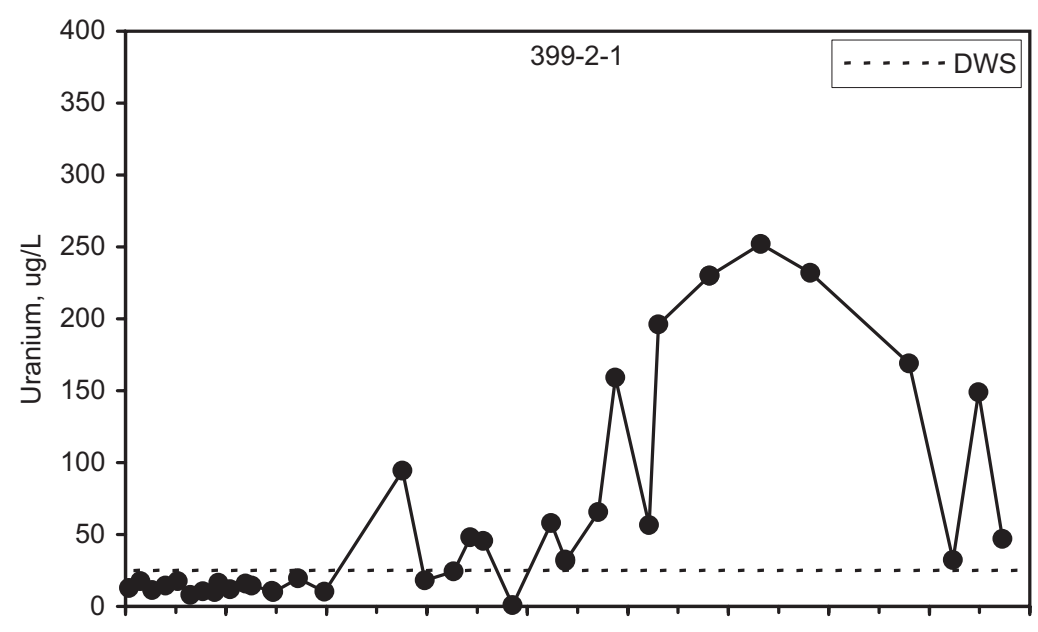

Jan-86 Jan-88 Jan-90 Jan-92 Jan-94 Jan-96 Jan-98 Jan-00 Jan-02 Jan-04 Collection Date

$\operatorname{mac03111}$

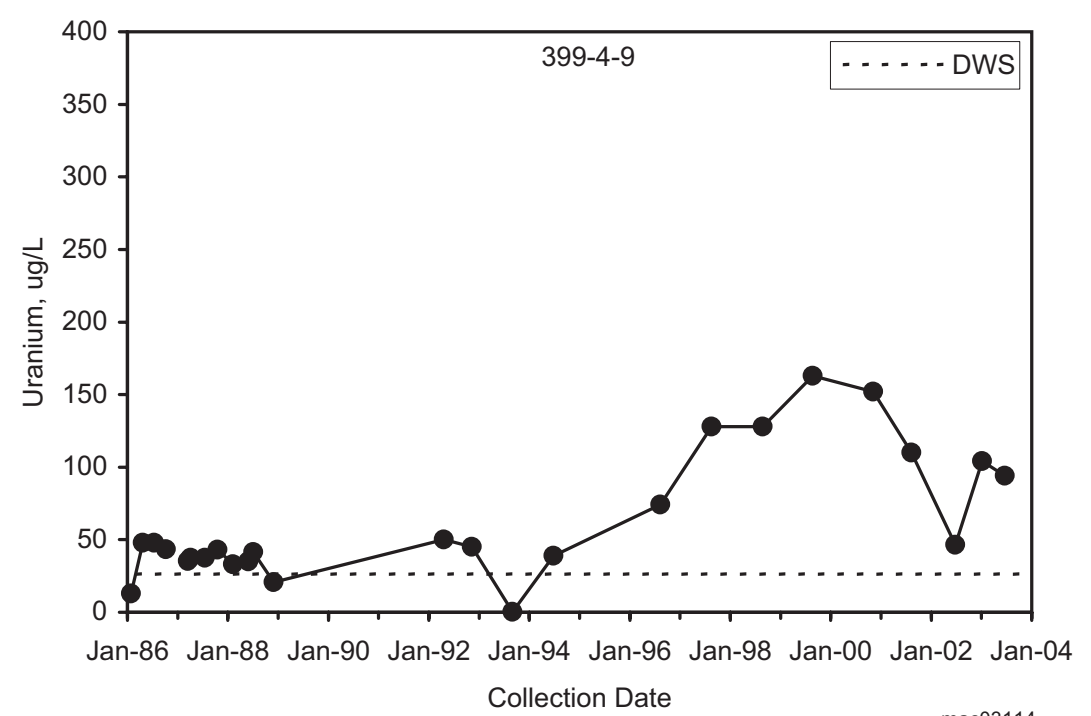

$\operatorname{mac} 03114$

Figure 2.12-7. 300 Area Wells Showing Increases in Uranium Concentrations Until 2000 


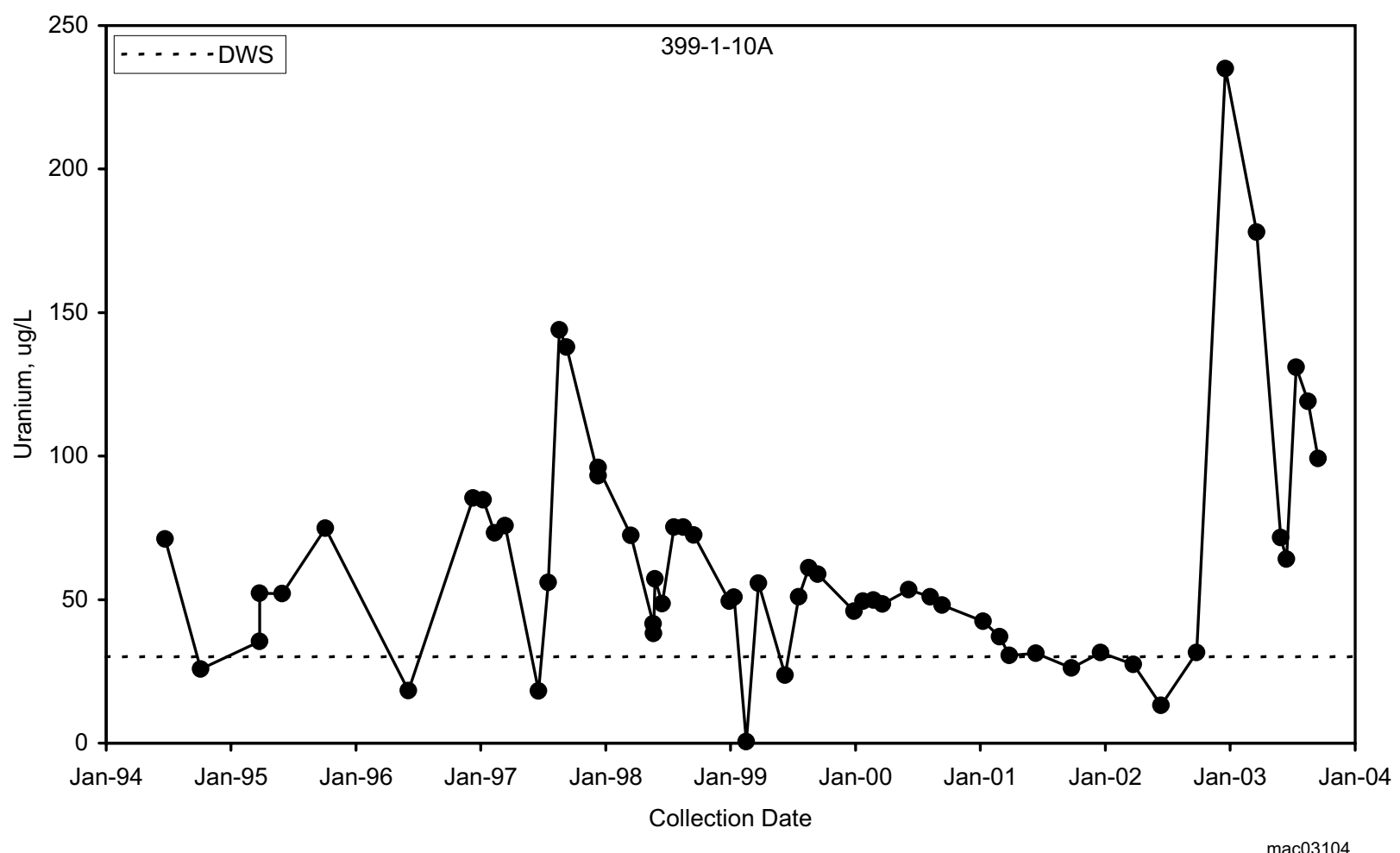

Figure 2.12-8. Uranium Concentrations in Well 399-1-10A

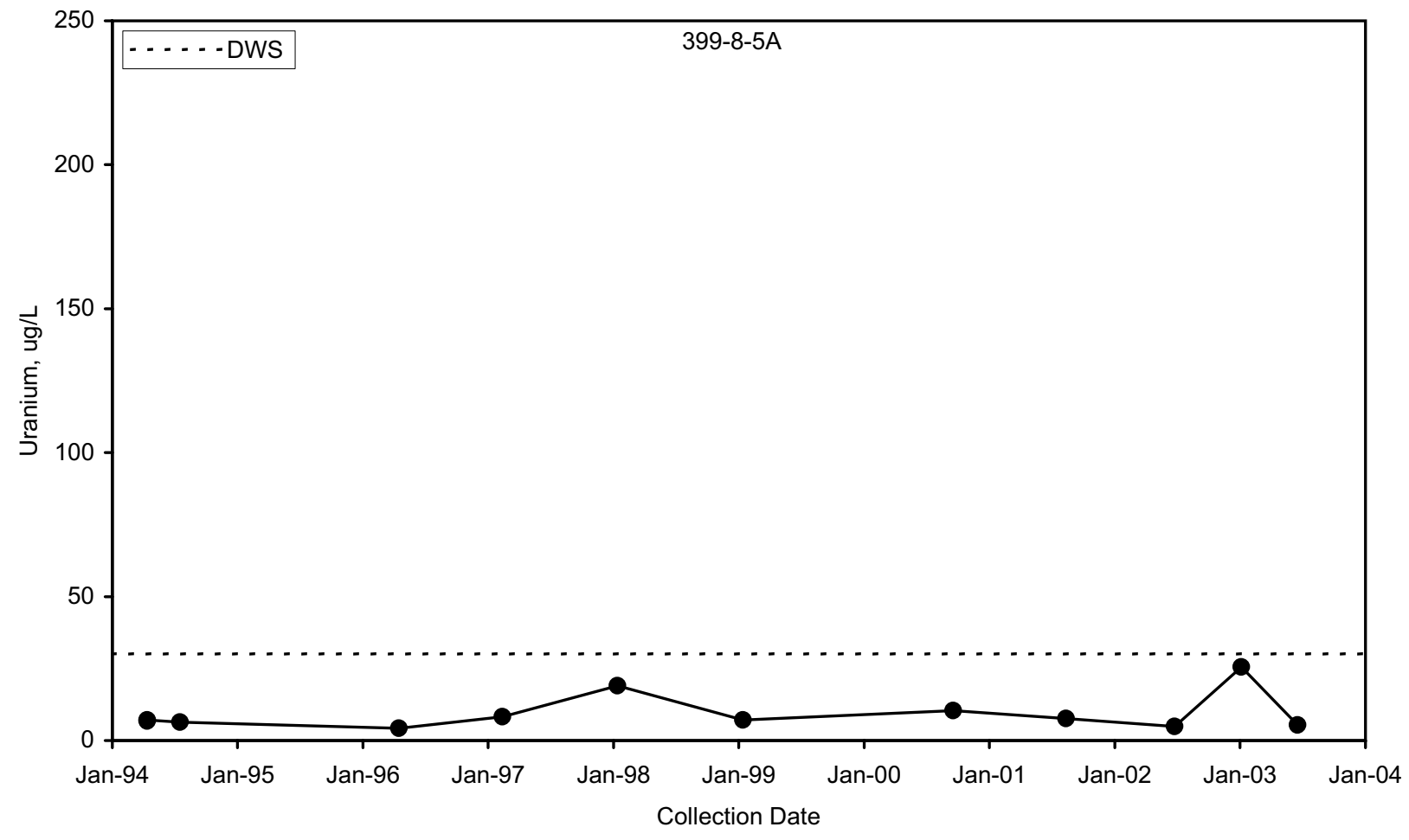

Figure 2.12-9. Uranium Concentrations in Well 399-8-5A 

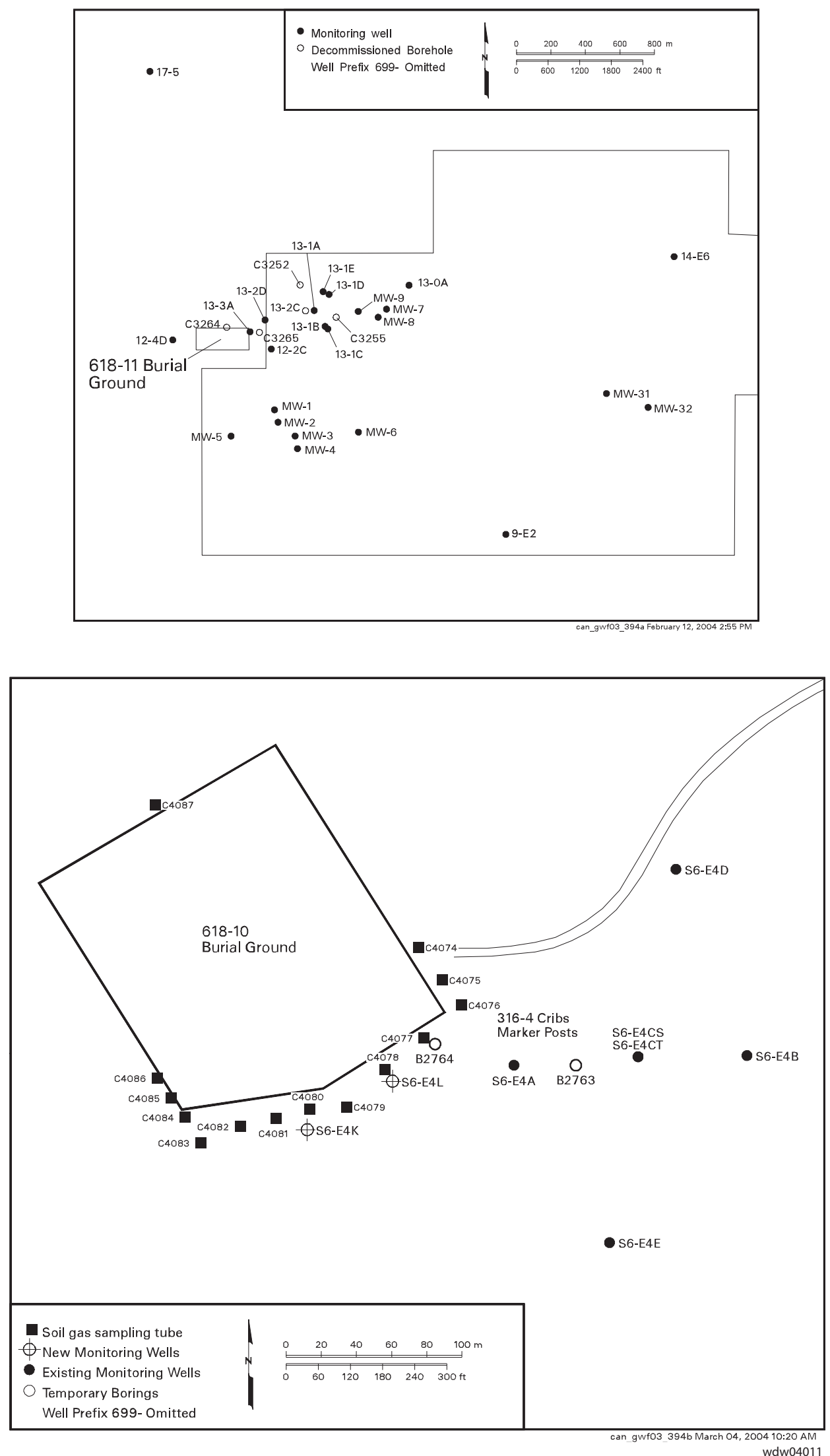

Figure 2.12-10. Location of Monitoring Wells in the 300 North Area 


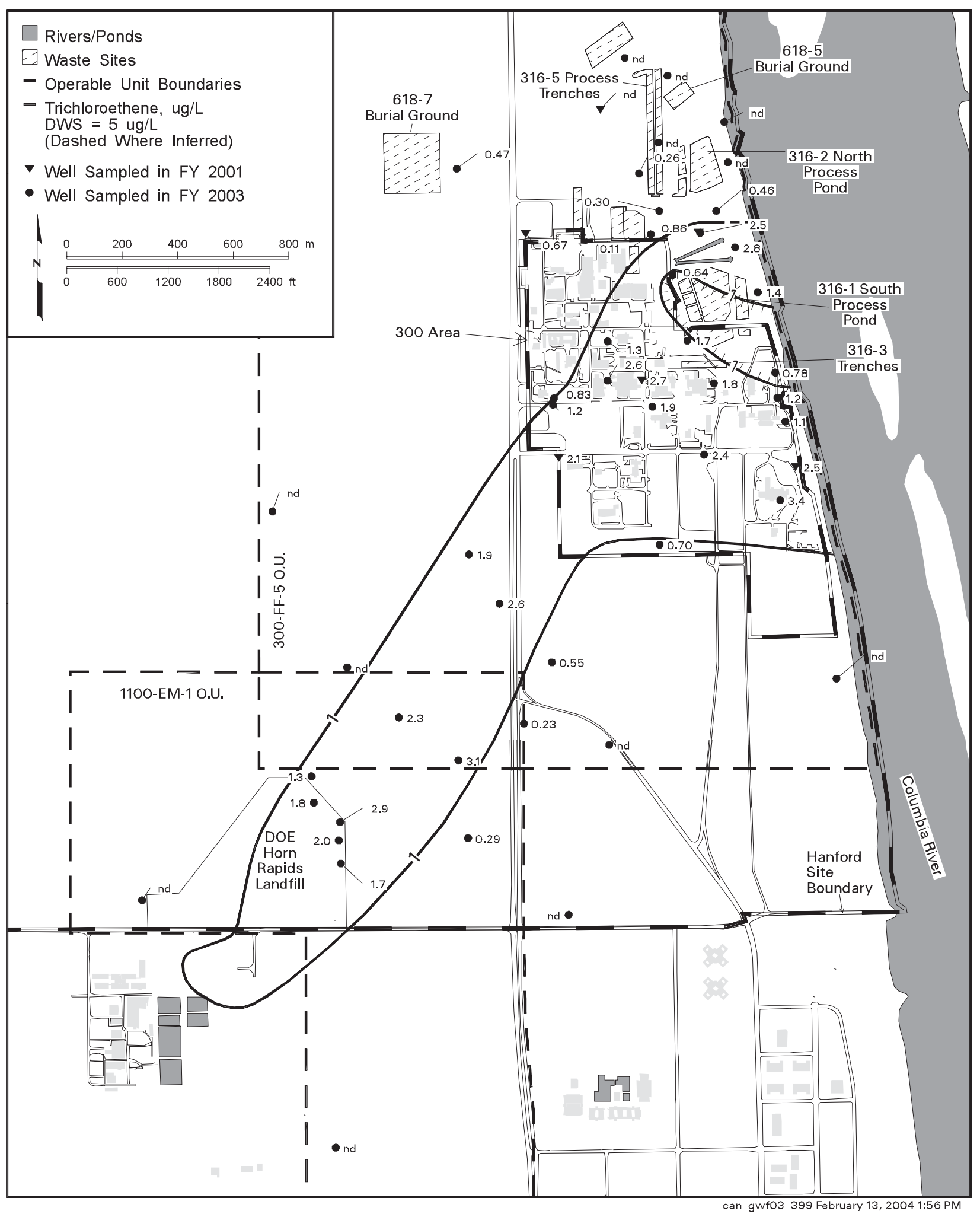

Figure 2.12-11. Average Trichloroethene Concentrations in the Richland North and 300 Areas, Top of Unconfined Aquifer 


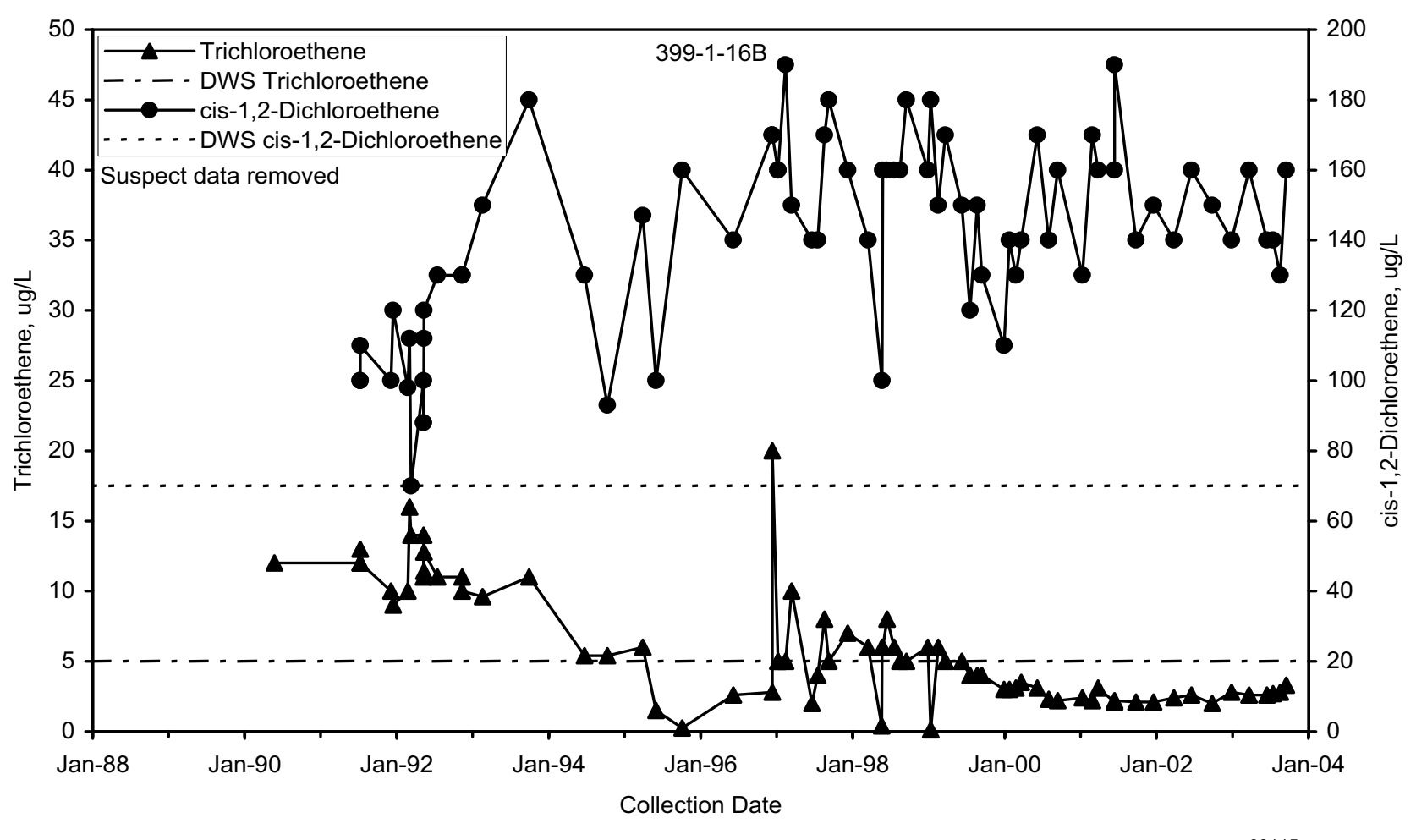

Figure 2.12-12. Trichloroethene and cis-1,2-Dichloroethene Concentrations in Well 399-1-16B 


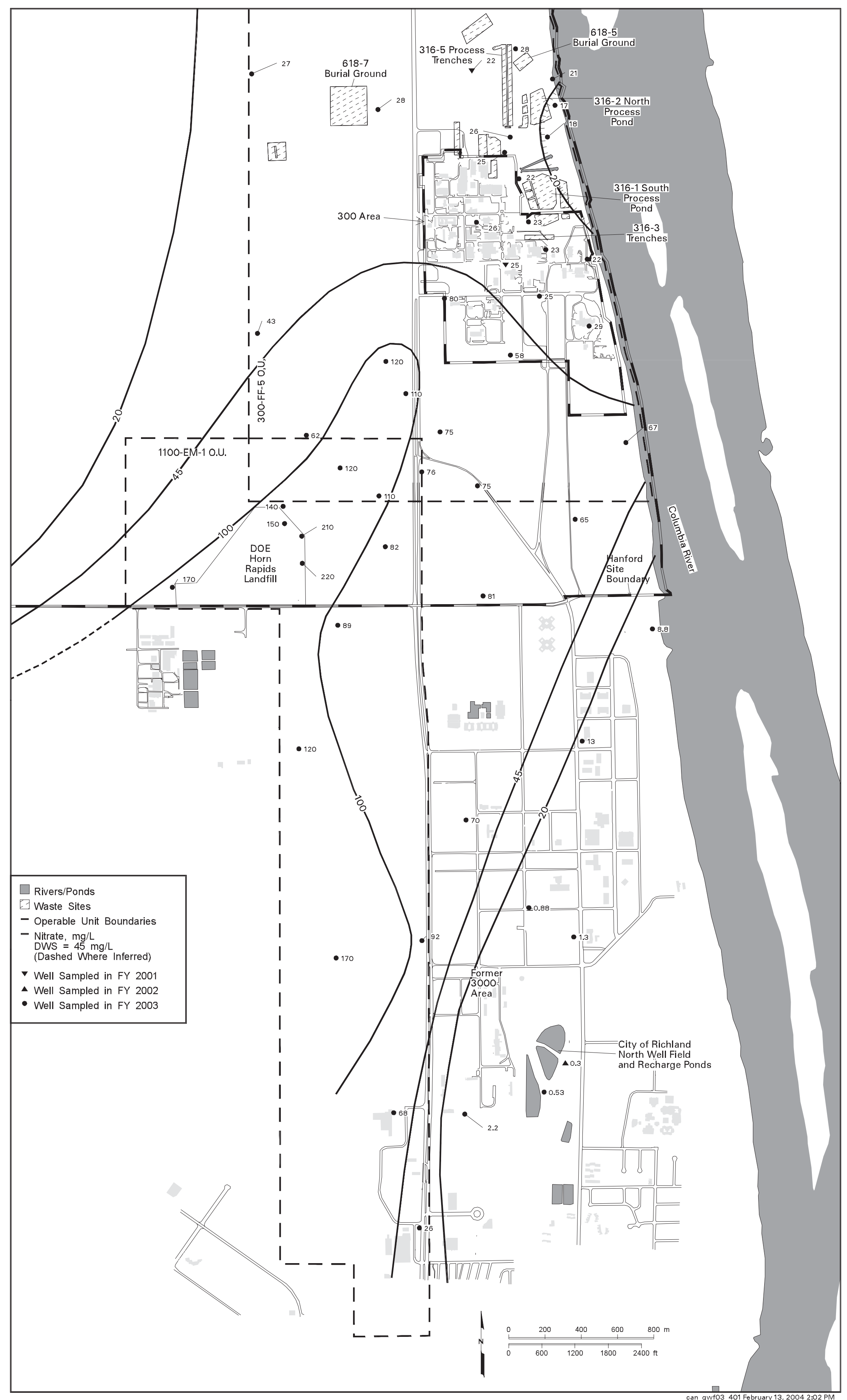

Figure 2.12-13. Nitrate Concentrations in the Richland North and 300 Areas 


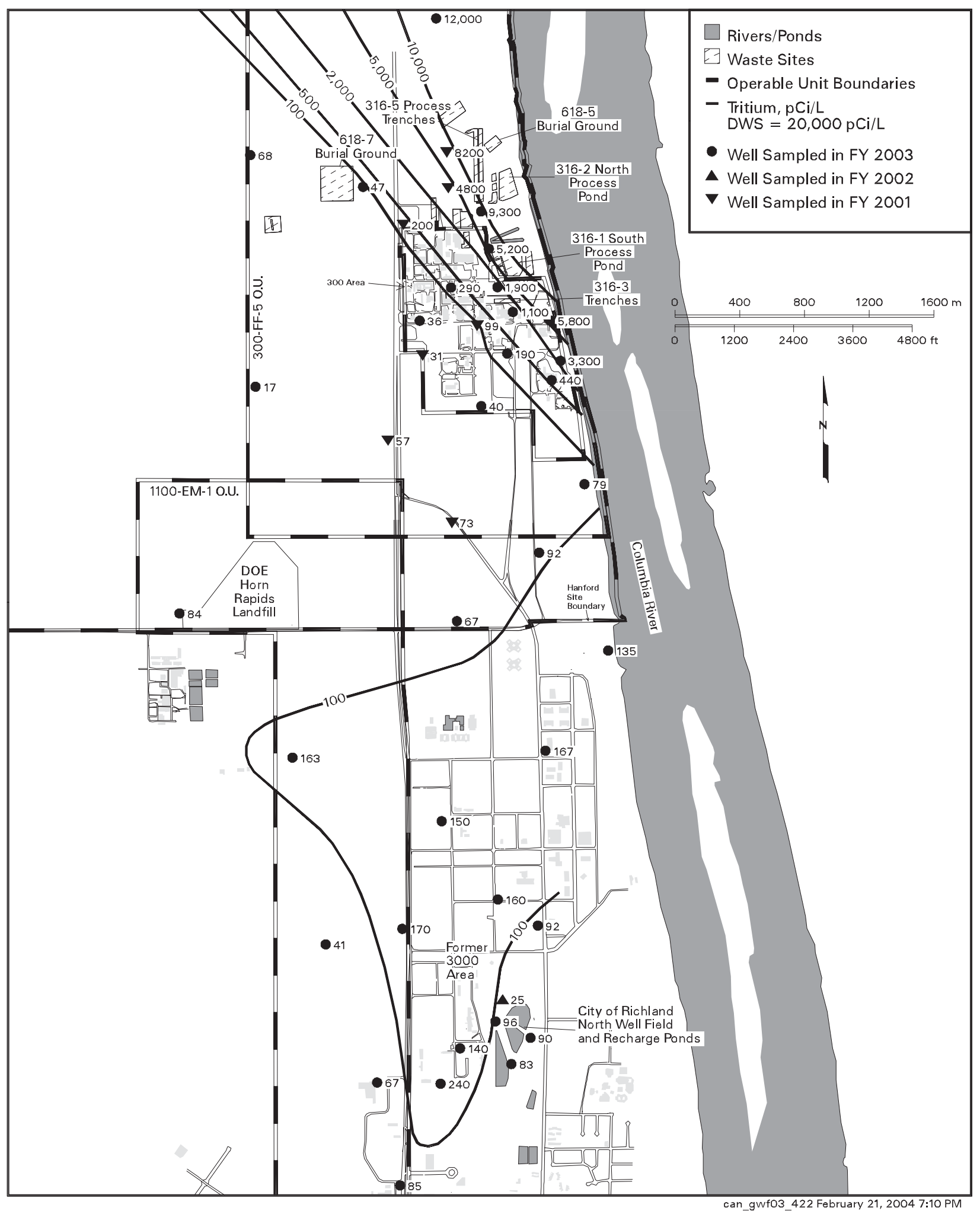

Figure 2.12-14. Average Tritium Concentrations in Groundwater in the Richland North and 300 Areas, Top of Unconfined Aquifer 


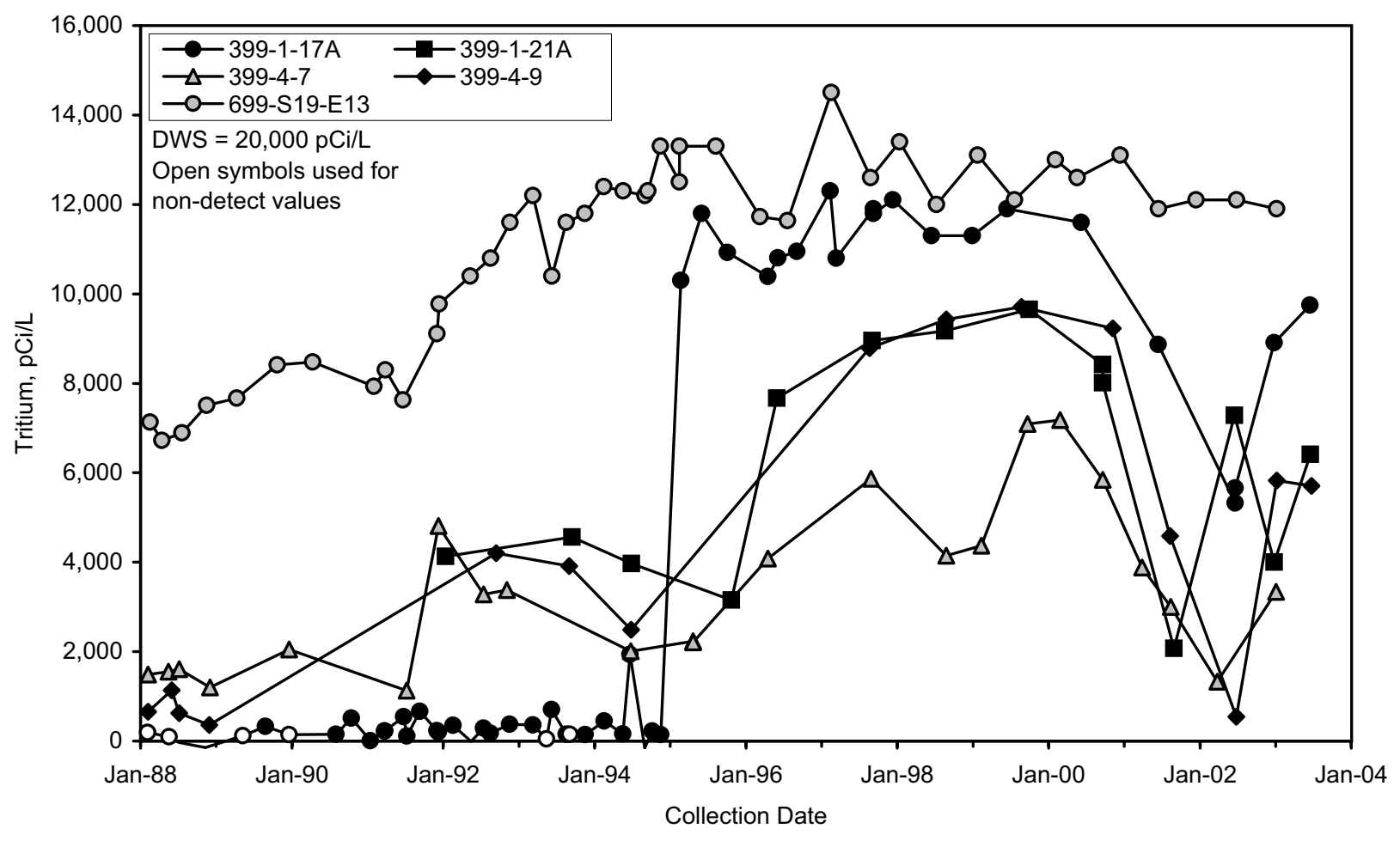

$\operatorname{mac} 03009$

Figure 2.12-15. Tritium Concentrations in Wells Monitoring the 300 Area

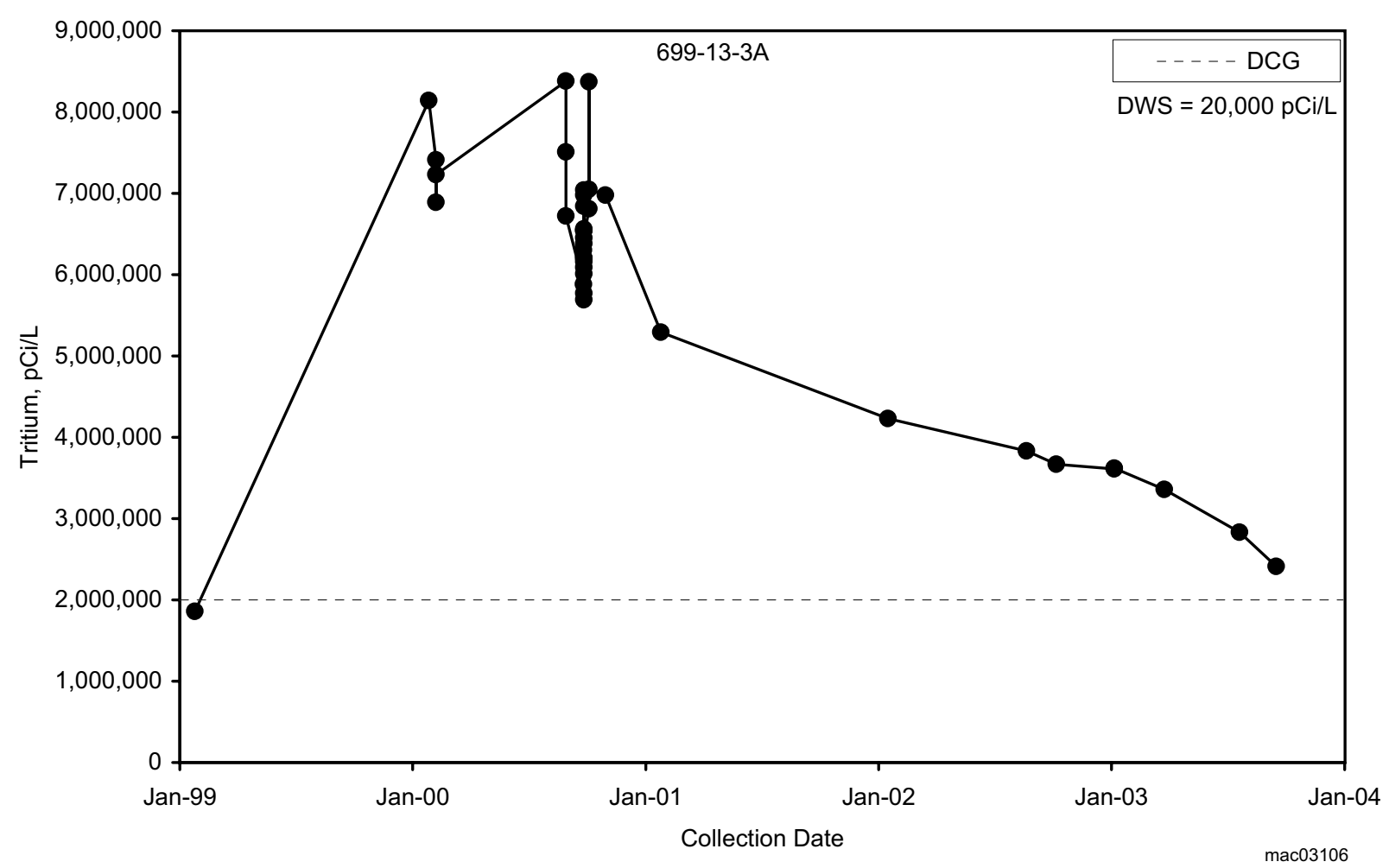

Figure 2.12-16. Tritium Concentrations at Well 699-13-3A Near 618-11 Burial Ground 


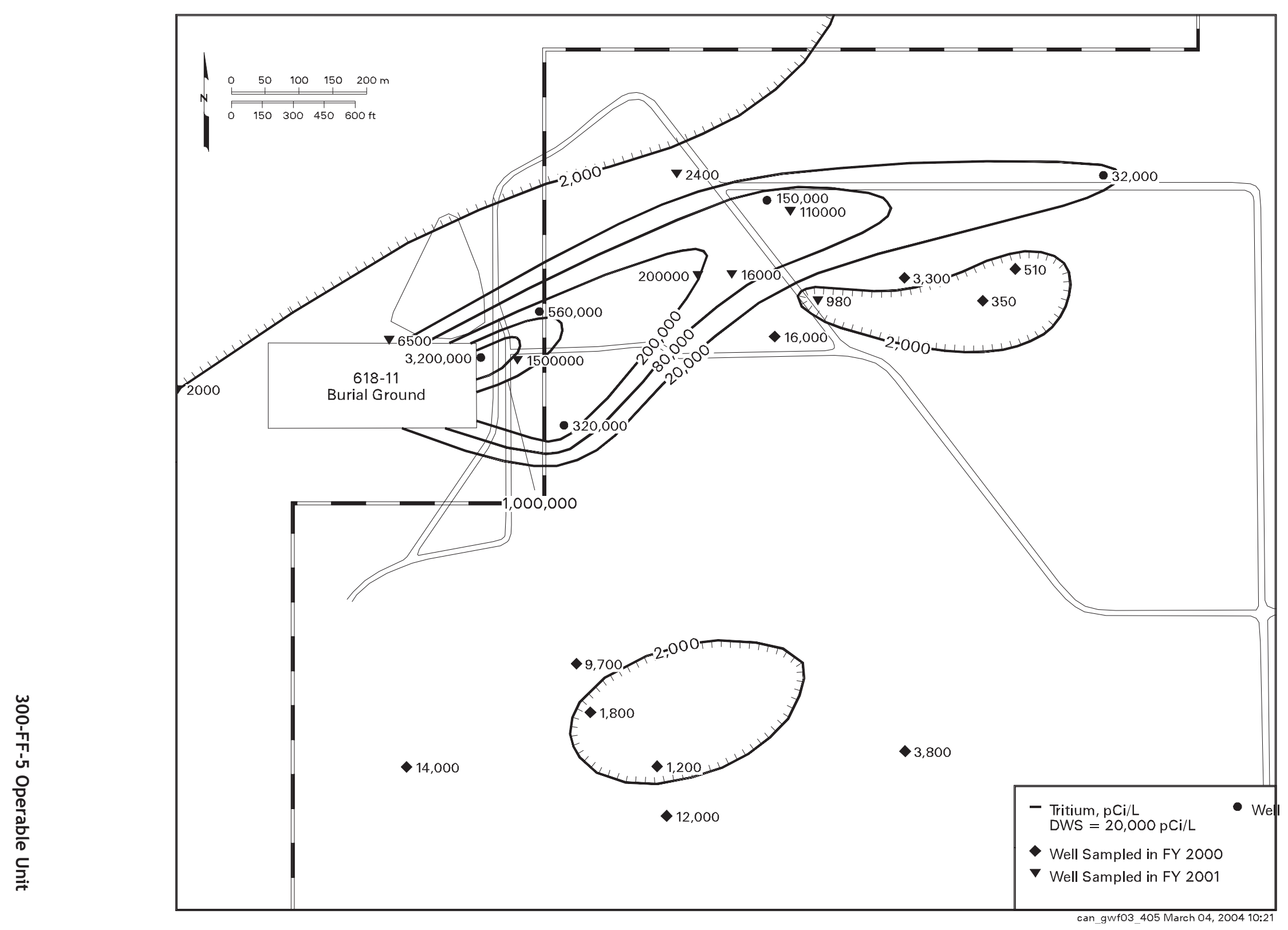

$\stackrel{\sim}{\stackrel{N}{N}}$ 


\subsection{0-EM-1 Operable Unit}

\section{R. Newcomer}

The scope of this section is the 1100-EM-1 groundwater interest area, which includes the 1100-EM-1 Operable Unit, a large portion of the south Hanford Site, and the offsite area to the south of the Hanford Site, including the former 1100 and 3000 Areas (Figure 2.1-1). Figure 2.12-1 shows facilities, wells, and shoreline monitoring sites in this region. The focus of this section will be the central and east portions of the 1100-EM-1 groundwater interest area near the Hanford Site south boundary. Trichloroethene is the contaminant of greatest significance in groundwater. Groundwater is monitored to assess the performance of natural attenuation of volatile organic compounds. In addition to the trichloroethene plume, contaminants of concern include breakdown products of trichloroethene (vinyl chloride and 1,1-dichloroethene) and nitrate.

The 1100-EM-1 groundwater interest area is located in the south part of the Hanford Site and includes an area to the south of the Hanford Site (Figure 2.1-1). Well locations are shown in Figures 2.1-2 and 2.12-1).

Figure 2.12-3 shows the March 2003 water-table elevations and corresponding groundwater flow directions for the east portion of the 1100-EM-1 groundwater interest area. Groundwater in the 1100-EM-1 groundwater interest area generally flows eastward from the Yakima River (Figure 2.1-3) and discharges to the Columbia River. In the northeast part of the 1100-EM-1 groundwater interest area, groundwater flows northeast and converges with groundwater entering the 300 Area before discharging to the Columbia River. In the east-central part of the 1100-EM-1 groundwater interest area, groundwater flow from the west is diverted to the northeast and southeast around a recharge mound before discharging to the Columbia River. Additional information regarding groundwater flow in this area is provided in PNNL-14187.

\subsubsection{Groundwater Contaminants}

This section describes the distribution of groundwater contaminants in the 1100-EM-1 groundwater interest area. Groundwater contaminants discussed are chlorinated hydrocarbons (primarily trichloroethene), tritium, nitrate, uranium, ammonia, fluoride, and chromium.

\section{Trichloroethene is}

the contaminant

of greatest

significance in

groundwater at

the 1100-EM-1

Operable Unit.

Groundwater in the 1100-EM-1 groundwater interest area includes CERCLA and AEA monitoring:

CERCLA Monitoring

- Fourteen compliance wells are sampled annually for trichloroethene, breakdown products, and nitrate.

- One well is sampled annually for filtered chromium.

- In fiscal year 2003, all 1100-EM-1 monitoring wells were sampled as scheduled (see Appendix A).

AEA Monitoring

- Forty wells are sampled annually and semiannually for tritium, volatile organic compounds, nitrate, and general chemistry.

- Five wells are sampled quarterly for tritium.

- A few isolated wells are sampled annually for uranium, gross alpha, gross beta, technetium-99, and ammonia. 


\section{Trichloroethene}

concentrations

continued to

decrease near

DOE's Horn Rapids

Landfill in fiscal

year 2003.

\subsubsection{Chlorinated Hydrocarbons}

Trichloroethene contamination occurs in the 1100-EM-1 groundwater interest area beneath the U.S. Department of Energy's (DOE's) inactive Horn Rapids Landfill and offsite in an industrial facility wells (Figure 2.12-11). The distribution of trichloroethene in the upper part of the unconfined aquifer shows that the plume has an elongated configuration. This configuration indicates a northeast flow direction around the city of Richland's North Well Field recharge ponds and toward the 300 Area.

Average trichloroethene concentrations continued to be $<5 \mu \mathrm{g} / \mathrm{L}$ in all offsite facility wells during fiscal year 2003 (EMF-1865, Addenda 31 and 33). The maximum average trichloroethene concentration of quarterly samples was $4.7 \mu \mathrm{g} / \mathrm{L}$ immediately downgradient of the process lagoons. One quarterly sample that exceeded the drinking water standard showed a maximum trichloroethene concentration of $6.1 \mu \mathrm{g} / \mathrm{L}$ in March 2003. The past use of solvent to install and maintain process lagoon liners at the offsite industrial facility is the only potential source of trichloroethene identified in the east portion of the 1100-EM-1 groundwater interest area (DOE/RL-92-67).

Trichloroethene concentrations have decreased in essentially all the plume areas near DOE's Horn Rapids Landfill. Trichloroethene concentrations decreased by more than an order of magnitude in this area since monitoring began in 1990 (Figure 2.13-1). In fiscal year 2003, average trichloroethene concentrations were all $<5 \mu \mathrm{g} / \mathrm{L}$, ranging from less than detection to $3.1 \mu \mathrm{g} / \mathrm{L}$ downgradient of the landfill. The decreased concentrations in the majority of wells downgradient of DOE's Horn Rapids Landfill suggest that some elements of natural attenuation (e.g., volatilization, passive pumping) may have reduced the plume mass. For a discussion of trichloroethene in the 300 Area, see Section 2.12.1.2.

Potential breakdown products of trichloroethene, including vinyl chloride and 1,1-dichloroethene, continued to show levels less than their respective minimum detection levels during fiscal year 2003.

The city of Richland monitors upper unconfined groundwater quarterly for chemical constituents at their Horn Rapids Sanitary Landfill (formerly Richland Landfill). The landfill is located in the central portion of the 1100-EM-1 groundwater interest area adjacent to the southern boundary of the Hanford Site (see Figure 2.1-2 for location). Chlorinated hydrocarbons were detected in city landfill monitoring wells between $\sim 1$ and 1.5 kilometers south of the Hanford Site boundary at levels above their respective drinking water standards during fiscal year 2003 (City of Richland 2003a, 2003b, 2003c, 2003d). The highest average concentrations, which decreased for all but trichloroethene during fiscal year 2003, were $30 \mu \mathrm{g} / \mathrm{L}$ 1,1-dichloroethene, $48 \mu \mathrm{g} / \mathrm{L}$ cis-1,2-dichloroethene, $60 \mu \mathrm{g} / \mathrm{L}$ tetrachloroethene, and $27 \mu \mathrm{g} / \mathrm{L}$ trichloroethene. During fiscal year 2003, these constituents were found to be below their respective minimum detection limits at an onsite well (699-S31-1) just northeast of the city's sanitary landfill.

\subsubsection{Tritium}

The 200 Area tritium plume extends southward toward the 1100-EM-1 groundwater interest area at levels below $2,000 \mathrm{pCi} / \mathrm{L}$. Tritium continues to be closely monitored because of its potential impact to the city of Richland's North Well Field (Figure 2.13-2). South of the 300 Area, tritium levels were slightly elevated above background in wells near the city of Richland's North Well Field and in wells north of the well field during fiscal year 2003 (Figure 2.12-14). The background geometric mean tritium concentration in the upper part of the unconfined aquifer was determined to be $63.9 \mathrm{pCi} / \mathrm{L}$ (DOE/RL-96-61). The average tritium concentration from monthly Columbia River samples collected at the Richland Pumphouse was $72.1 \mathrm{pCi} / \mathrm{L}$ during fiscal year 2003. However, these levels are far below the drinking water standard $(20,000 \mathrm{pCi} / \mathrm{L})$. Trends in these tritium concentrations have consistently shown fluctuating levels in the last few years, as shown in Figure 2.13-2. Columbia River 
water, which shows slightly elevated tritium levels near the shoreline, is piped to the recharge pond system. Thus, a likely source of the elevated tritium levels is recharge of Columbia River water discharged to the ponds.

Tritium is not migrating in groundwater from the 200 Areas tritium plume to the well field. Several factors limit the migration of the tritium plume into the east portion of the 1100-EM-1 groundwater interest area:

- Groundwater generally flows from west to east between the Yakima River and the Columbia River.

- Artificial recharge from agricultural irrigation in the west and central portions of the 1100-EM-1 groundwater interest area south of the Hanford Site contributes to the eastward flow.

- Groundwater flow is directed outward from the elevated groundwater levels at the city of Richland's North Well Field Recharge Ponds.

These factors produce converging flow lines in the 300 Area and discharge to the Columbia River (Figure 2.12-3). Figure 2.12-14 shows a region of low tritium concentrations between the 200 Areas tritium plume and the slightly elevated tritium concentrations near the North Richland Well Field and Recharge Ponds. Thus, there is no indication that the tritium plume is migrating southward and affecting the well field. Tritium in the 300 Area is discussed in Section 2.12.

\subsubsection{Nitrate}

The nitrate distribution in the east portion of 1100-EM-1 groundwater interest area is shown in Figure 2.12-13. Nitrate contamination in this area is likely the result of industrial and agricultural uses off the Hanford Site. Agricultural uses include application of fertilizers onto irrigation circles in the central portion of the 1100-EM-1 groundwater interest area (Figure 2.12-1).

Concentrations above the drinking water standard $(45 \mathrm{mg} / \mathrm{L})$ are found over much of the east portion of the 1100-EM-1 groundwater interest area and continued to increase in a number of wells in fiscal year 2003 (Figure 2.13-3). Some of the highest nitrate levels occur near an offsite industrial facility and DOE's inactive Horn Rapids Landfill. Elevated nitrate near these areas is likely the result of agricultural activities to the west and southwest. An example of elevated nitrate concentrations showing an increasing trend continues to occur along the west edge of DOE's Horn Rapids Landfill immediately north of the industrial facility (well 699-S31-E8A in Figure 2.13-3). The highest nitrate concentration in this area was $261 \mathrm{mg} / \mathrm{L}$ immediately downgradient of the offsite facility. Nitrate data for the offsite wells are reported in EMF-1865, Addenda 31 and 33. Nitrate concentrations continued to be elevated in wells downgradient of DOE's inactive Horn Rapids Landfill in fiscal year 2003. The highest average nitrate concentration in this area was $224 \mathrm{mg} / \mathrm{L}$. The shape of the plume (as defined by the $100-\mathrm{mg} / \mathrm{L}$ contour) near the offsite industrial facility and DOE's inactive Horn Rapids Landfill indicates that nitrate in these areas continues to migrate in a northeast direction toward the 300 Area. Figure 2.12-13 indicates that groundwater with nitrate levels above the drinking water standard discharges to the Columbia River immediately south of the 300 Area.

The nitrate plume map indicates that the eastward migration of nitrate is being diverted around the groundwater mound that is in the vicinity of the recharge ponds (Figure 2.12-3). Nitrate levels in wells at the well field continued to be lower than ambient groundwater, a result of recharge from infiltration of river water at the recharge ponds.

\subsubsection{Gross Alpha and Uranium}

Elevated levels of gross alpha and uranium occur downgradient of an offsite industrial facility near DOE's inactive Horn Rapids Landfill. The highest gross alpha level was an average of $77 \mathrm{pCi} / \mathrm{L}$ immediately downgradient of this facility during fiscal year 2003

\section{Monitoring data show that the Richland North Well Field is not contaminated by the Hanford Site tritium plume through the groundwater flow system.}




\section{Uranium contamination is present near DOE's inactive Horn Rapids Landfill, but the source is believed to be located offsite.}

(EMF-1865, Addenda 31 and 33). Most of the wells downgradient of the offsite facility showed average gross alpha levels that were above the drinking water standard $(15 \mathrm{pCi} / \mathrm{L})$, which excludes uranium. However, it is probable that the gross alpha levels are largely attributed to uranium because of industrial uses offsite. If gross alpha is attributed to uranium with natural isotopic abundances, then $77 \mathrm{pCi} / \mathrm{L}$ gross alpha is equivalent to $\sim 112 \mu \mathrm{g} / \mathrm{L}$ uranium, which is above the drinking water standard ( $30 \mu \mathrm{g} / \mathrm{L}$ ) for uranium. The offsite facility is not required to analyze samples collected from their wells for uranium.

The distribution of uranium near DOE's inactive Horn Rapids Landfill is shown in Figure 2.12-5. The map shows a small plume of uranium with levels less than the drinking water standard $(30 \mu \mathrm{g} / \mathrm{L})$ near the landfill. Uranium concentrations in wells downgradient of the landfill increased slightly between fiscal year 2002 and fiscal year 2003. Uranium concentrations ranged up to $18 \mu \mathrm{g} / \mathrm{L}$, with the highest concentration immediately downgradient of DOE's Horn Rapids Landfill (Figure 2.13-4). At this time, the landfill is not considered a source of the uranium contamination in groundwater because no known uranium sources exist in the landfill. The shape of the uranium contours suggests a uranium source off the Hanford Site.

\subsubsection{Other Constituents}

Ammonia, fluoride, and gross beta are found at low levels in wells near an offsite industrial facility. Chromium continued to be monitored in one well downgradient of the 1171 Building in the former 1100 Area.

Ammonia - Concentrations of ammonia in the offsite facility wells generally remained steady in fiscal year 2003 (EMF-1865, Addenda 31 and 33). The highest average concentration detected was $13.6 \mathrm{mg} / \mathrm{L}$ ( as $\mathrm{NH}_{3}$ ) in well SPC-GM-10. Ammonia is typically absorbed by plants and soil microorganisms or is taken up as an exchangeable ion on soil particles (Hausenbuiller 1972). However, ammonia is usually less stable than nitrate in a biological system like the soil medium and is rapidly converted to nitrate. Ammonia was detected in seven wells downgradient of the offsite facility in fiscal year 2003. The fact that ammonia is found in the groundwater suggests that relatively high concentrations reached the soil column.

Fluoride - One well downgradient of the offsite industrial facility showed fluoride concentrations above the drinking water standard $(4 \mathrm{mg} / \mathrm{L})$ in fiscal year 2003 (EMF-1865, Addenda 31 and 33). The highest average concentration was $4.3 \mathrm{mg} / \mathrm{L}$ in well SPC-GM-4. Fluoride contamination is most likely the result of past processing at the offsite facility. Average fluoride concentrations in onsite wells for this area continued to be $<1 \mathrm{mg} / \mathrm{L}$.

Gross Beta - Gross beta continued to be detected in wells downgradient of the offsite facility during fiscal year 2003 (EMF-1865, Addenda 31 and 33). The highest average gross beta measurement in fiscal year 2003 was 34.7 pCi/L in well SPC-GM-8. Low levels of technetium-99, detected near DOE's inactive Horn Rapids Landfill, may be related to the gross beta measurements.

Chromium - Filtered chromium, which had been detected above the drinking water standard in the past, was not detected during fiscal year 2003 in one well downgradient of the 1171 Building.

\subsubsection{CERCLA Groundwater Monitoring}

The selected remedy for 1100-EM-1 Operable Unit groundwater is monitored natural attenuation of volatile organic compounds, with institutional controls on drilling of new water supply wells (ROD 1993). The U.S. Environmental Protection Agency 
conducted a 5-year review in 2001, and no groundwater monitoring changes were required at the DOE's Horn Rapids Landfill (EPA 2001).

The monitoring objective was to continue groundwater monitoring of wells downgradient of the DOE's Horn Rapids Landfill during a period of 5 years (DOE/RL-95-50; PNNL-12220). The monitoring was to include annual sampling for trichloroethene, its breakdown products (vinyl chloride, 1,1-dichloroethene), and nitrate (Sections 2.13.1.1 and 2.13.1.3). A secondary objective was to sample chromium in one well downgradient of the 1171 Building. Additional information is provided in Appendix A.

The remedial action objectives for the 1100-EM-1 Operable Unit (ROD 1993) are:

- Attain concentration of $<5 \mu \mathrm{g} / \mathrm{L}$ trichloroethene at designated point of compliance.

- Protect environmental receptors in surface waters by reducing groundwater contaminant concentrations in the plume. 


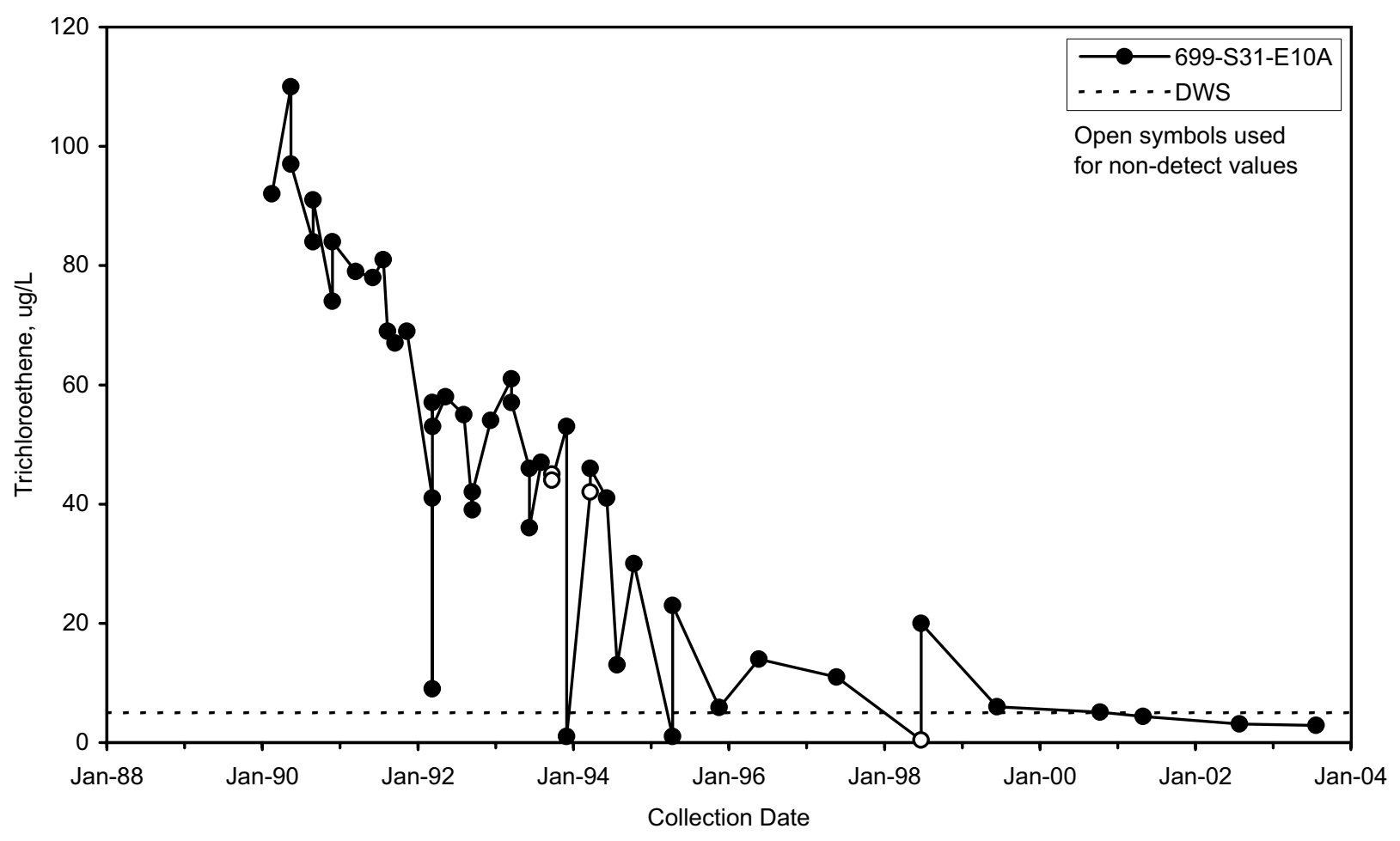

$\operatorname{mac} 03012$

Figure 2.13-1. Trichloroethene Concentrations Near the U.S. Department of Energy's Inactive Horn Rapids Landfill

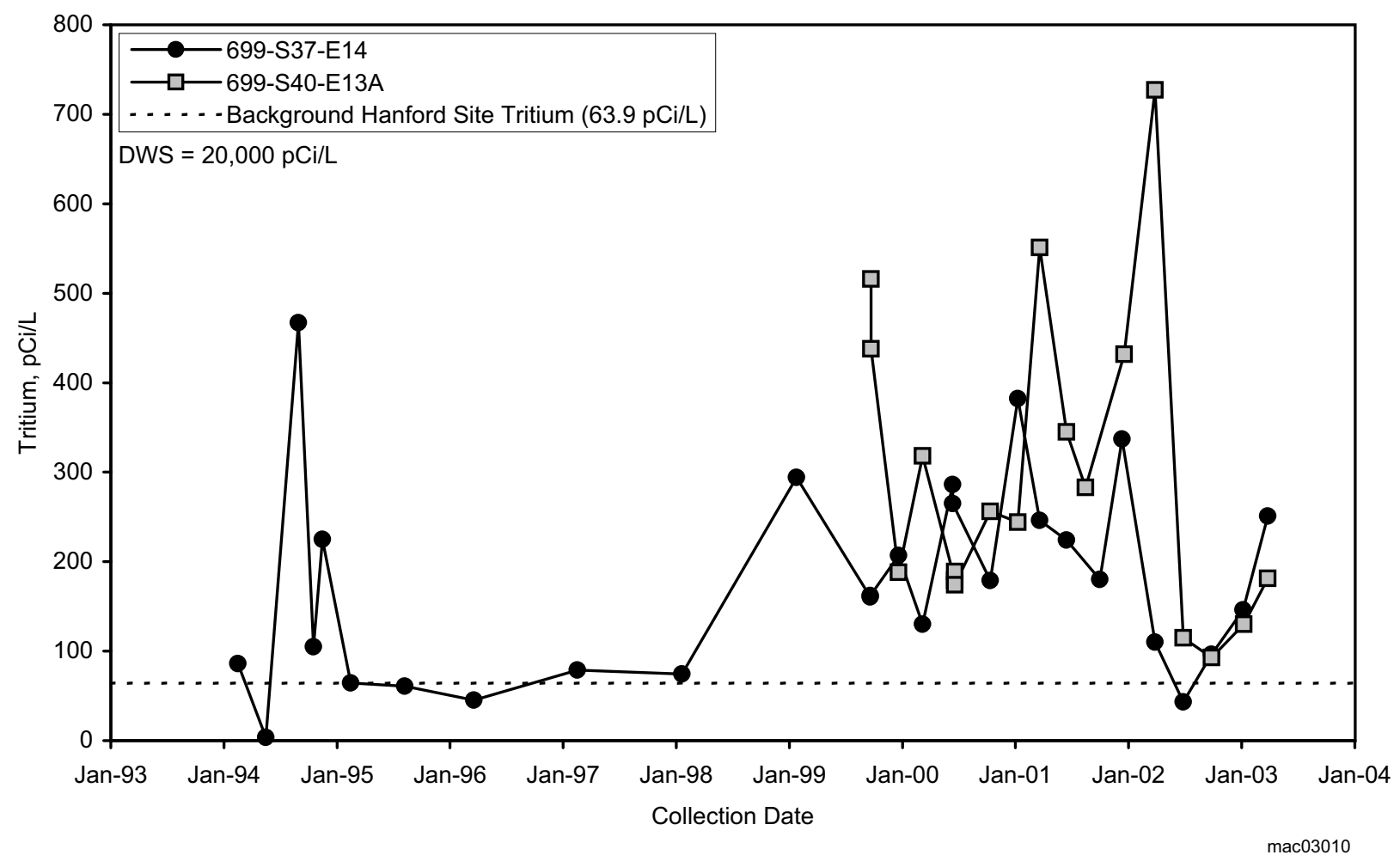

Figure 2.13-2. Tritium Concentrations in Wells Monitoring the 1100-EM-1 Groundwater Interest Area 


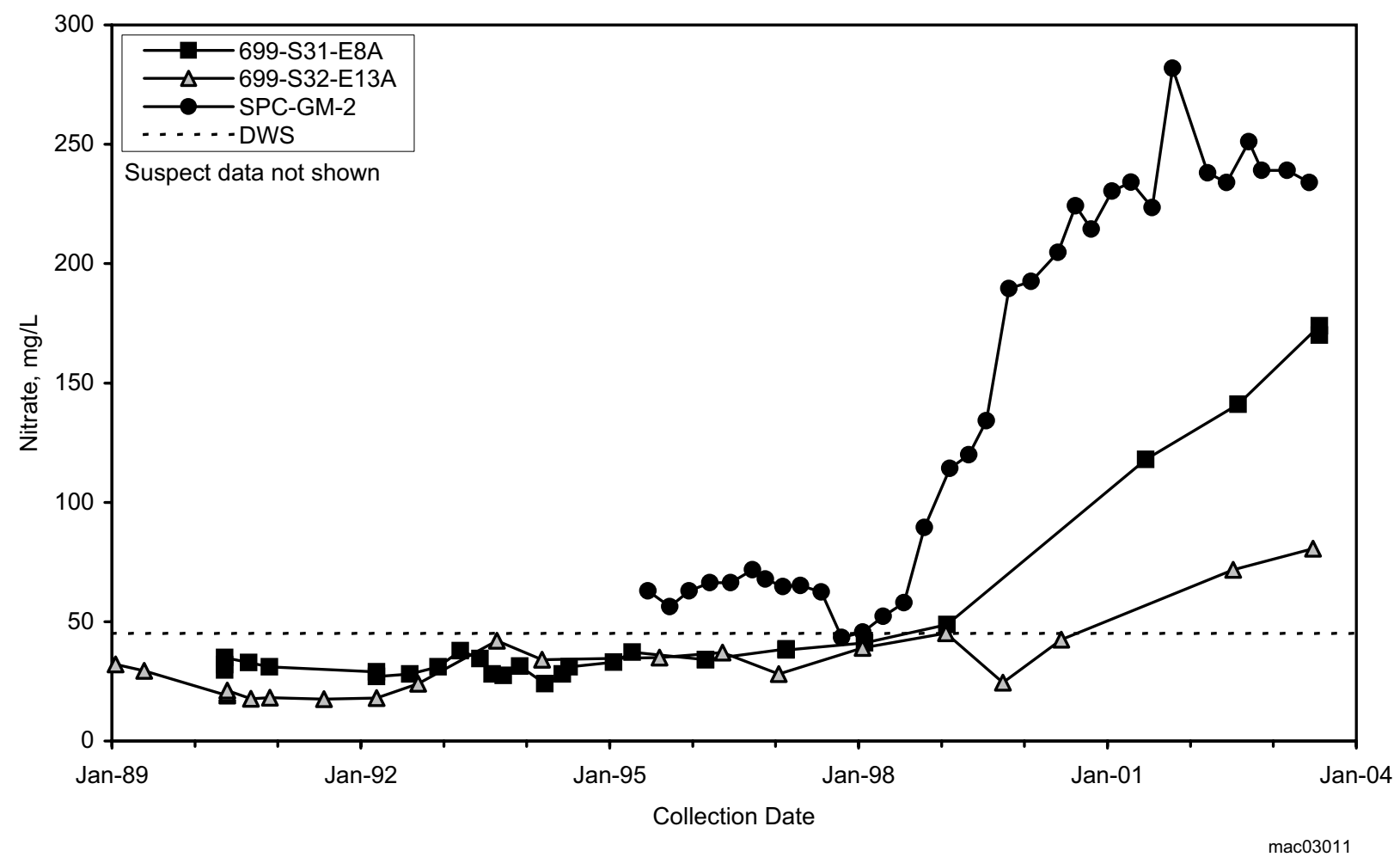

Figure 2.13-3. Nitrate Concentrations in Wells Monitoring the 1100-EM-1 Groundwater Interest Area (data for well SPC-GM2 taken from EMF-1865)

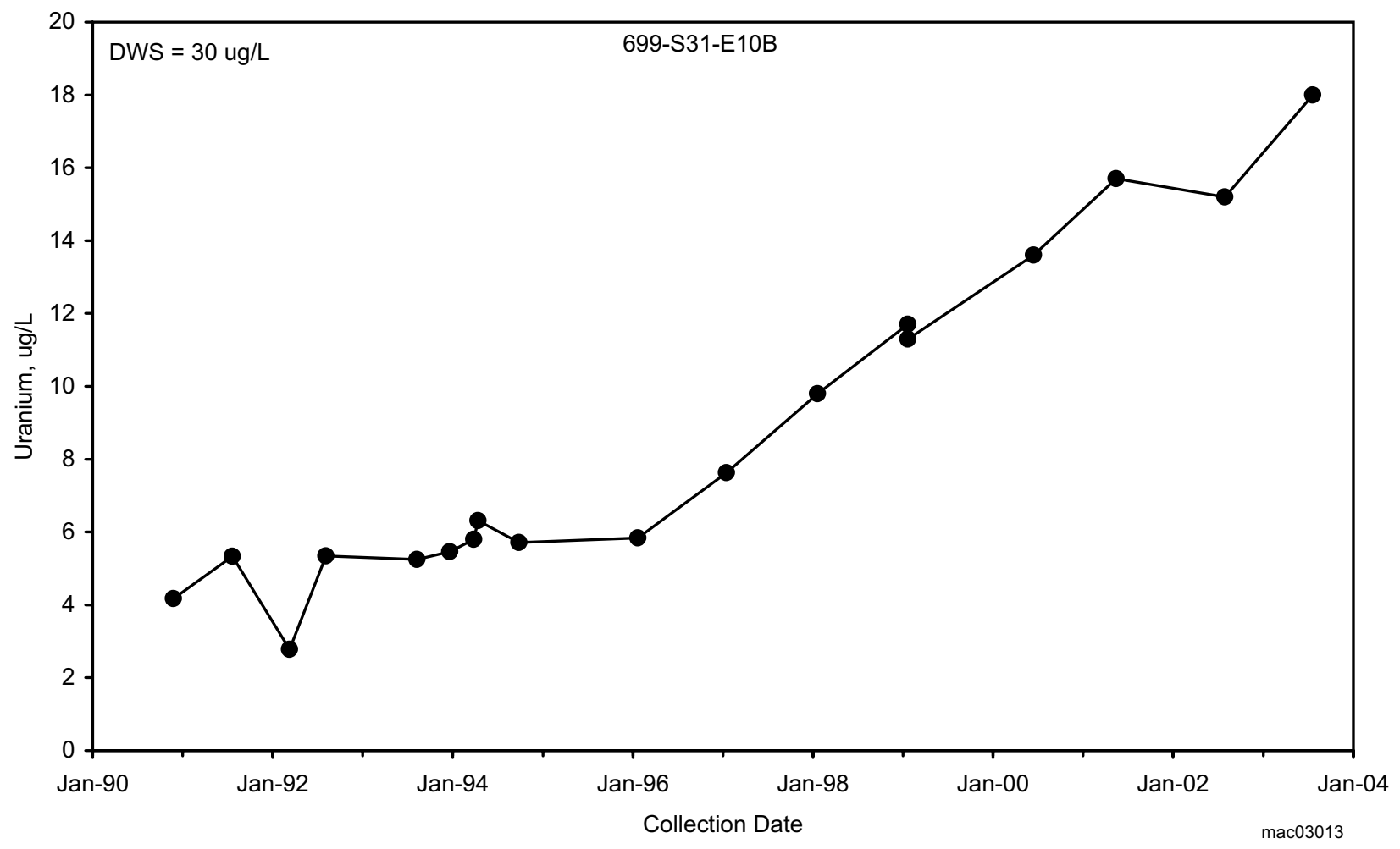

Figure 2.13-4. Uranium Concentrations Near the U.S. Department of Energy's Inactive Horn Rapids Landfill 


\subsection{Confined Aquifers}

\section{R. Newcomer, J. P. McDonald, and D. B. Barnett}

This section describes groundwater flow and quality within the Ringold Formation and upper basalt-confined aquifers. The Ringold Formation confined aquifer is described only for the 200 Areas Central Plateau and the area near the inactive B Pond system because few wells monitor this aquifer. The upper basalt-confined aquifer is described for much of the Hanford Site, primarily the area south of Gable Butte and Gable Mountain.

\subsubsection{Ringold Formation Confined Aquifer}

Groundwater quality in the Ringold Formation confined aquifer is monitored because of the potential for downward migration of contaminants from the overlying unconfined aquifer.

The Ringold Formation confined aquifer occurs within fluvial sand and gravel comprising the lowest sedimentary unit of the Ringold formation (unit 9). It is confined below by basalt and above by the lower mud unit (unit 8).

\subsubsection{Groundwater Flow in the Ringold Formation Confined Aquifer}

Figure 2.14-1 presents the potentiometric surface for a portion of the confined aquifer in the Ringold Formation. This map is incomplete and subject to uncertainty because only a few wells monitor this aquifer.

Groundwater in the Ringold Formation confined aquifer flows generally west to east in the vicinity of the 200 West Area and west to east along the south boundary of the aquifer. These flow patterns indicate that recharge occurs west of the 200 West Area (Cold Creek Valley) as well as from the Dry Creek Valley and possibly the Rattlesnake Hills. In the central portion of the aquifer, flow converges on the 200 East Area from the west, south, and east. The 200 East Area is a discharge area for this aquifer, since the confining mud unit (unit 8) is absent. Hydraulic heads indicate a slight upward gradient in this area, which suggests that groundwater discharging from the confined aquifer recharges the overlying unconfined aquifer. After discharging to the unconfined aquifer, the groundwater is interpreted to flow generally southeastward over the top of the confining unit. This is possible because of the southerly dip of the suprabasalt strata.

A groundwater mound is present northeast of $\mathrm{B}$ Pond as a remnant of past wastewater discharges to this facility. This mound results in southwest flow beneath B Pond, because the May Junction Fault, located east of B Pond, acts as a hydrologic barrier preventing flow to the east (PNNL-12261). A stagnation point occurs south of B Pond, where the flow of water divides with some moving northwest toward the 200 East Area and some moving toward the east or southeast.

The contours on Figure 2.14-1 are similar to the potentiometric surface for the upper basalt-confined aquifer (see Section 2.14.2.1). Hydraulic head and flow patterns in the central portion of the Hanford Site are very similar in both aquifers. The basalt in this area was significantly eroded by late Pleistocene catastrophic flooding (RHO-BWI-LD-5), which facilitates intercommunication between the unconfined and confined aquifers in the Ringold Formation, and the upper basalt-confined aquifer system.

Water levels generally declined in this aquifer during the period from March 2002 to March 2003. Declines ranged from 0.02 to 0.38 meter. The declining water levels are due to the near cessation of wastewater disposal to the soil column at Hanford. The declines were largest in the 200 West Area and the B Pond vicinity. One well in this aquifer along the Rattlesnake Hills showed a water-level increase of 0.10 meter during the same period.
Groundwater in the Ringold Formation confined aquifer flows generally west to east in the vicinity of the 200 West Area and west to east along the south boundary of the aquifer. 


\section{During fiscal \\ year 2003, only a \\ few wells were \\ sampled that are \\ completed in the \\ Ringold Formation \\ confined aquifer. \\ Data indicate that \\ groundwater in this \\ aquifer has not \\ been displaced or \\ diluted by \\ wastewater \\ associated with \\ 200 East Area \\ operations.}

\subsubsection{Groundwater Quality in the Ringold Confined Aquifer}

The 200 Areas Central Plateau and the area near the inactive B Pond system are the two known areas where contamination can migrate from the unconfined aquifer into the confined Ringold aquifer. Groundwater chemistry data for the Ringold Formation confined aquifer are extremely limited because of the lack of deep well completions in the aquifer. During fiscal year 2003, only a few wells were sampled that are completed in the Ringold Formation confined aquifer. Data for constituents of interest are listed in Table 2.14-1.

South and southeast of the B Pond system the major ion composition of groundwater becomes less calcium-bicarbonate type and more of a sodium bicarbonate water. Low tritium concentrations in the area near the 200 Area Treated Effluent Disposal Facility also indicate that groundwater is older in this area and has not been displaced or diluted by wastewater associated with 200 East Area operations (PNNL-13032).

Tritium has been discharged intermittently to the ground at the State-Approved Land Disposal Site since late 1995 . Tritium concentrations up to $980,000 \mathrm{pCi} / \mathrm{L}$ have reached the deepest well (699-48-77C) near this facility during the past few years. Although aquifer tests have indicated confined conditions at depth near this facility, apparently discharged effluent can be driven into these portions of the aquifer if sufficient head is available. An increase in hydraulic head of up to 1 meter above preoperational conditions has resulted from discharges to the State-Approved Land Disposal Site in the immediate vicinity of the facility.

While effluent disposal was occurring at the B Pond system, groundwater mounding increased the driving head and forced groundwater and any associated contamination a limited distance into the confined aquifer. The groundwater moved laterally within the confined aquifer as long as the head remained high from the overlying groundwater mound, although low hydraulic conductivity in the region of the 200 Area Treated Effluent Disposal Facility limited actual flow in a southeasterly direction. Groundwater analyses for fiscal year 2003 at this facility continued to demonstrate isolation of the confined aquifer from disposal activities. Well 699-42-37, which is the well nearest the B Pond system (see Figure 2.11-1 for well locations), typically produces higher concentrations of several major constituents than the more southerly and easterly wells 699-40-36 and 699-41-35, respectively. As an example, sulfate concentration in the January 2003 sample in well 699-42-37 was $26 \mathrm{mg} / \mathrm{L}$, which is 3 to 5 times the average concentrations of sulfate in Treated Effluent Disposal Facility wells 699-40-36 and 699-41-35. The concentration of nitrate for the same period in well $699-42-37$ was only $5.7 \mathrm{mg} / \mathrm{L}$, but this is 10 to 20 times the concentrations of this constituent in the other two Treated Effluent Disposal Facility wells.

\subsubsection{Upper Basalt-Confined Aquifer}

Upper basalt-confined aquifer groundwater quality is monitored because of the potential for downward migration of contaminants from the overlying unconfined aquifer. Contaminants that reach the upper basalt-confined aquifer have the potential to migrate through this aquifer and deeper confined aquifers to areas off the Hanford Site. The upper basalt-confined aquifer is also monitored to assess the potential migration of contaminants onto the Hanford Site from offsite sources. Additional information regarding the potential for contaminants to migrate off the Hanford Site can be found in PNL-10817 and PNNL-14107.

Within the upper basalt-confined aquifer system, groundwater occurs within basalt fractures and joints, interflow contacts, and sedimentary interbeds within the upper Saddle Mountains Basalt. The thickest and most widespread sedimentary unit in this system is the Rattlesnake Ridge Interbed, which is present beneath much of the Hanford Site. Groundwater also occurs within the Levey Interbed, which is present only in the south 
portion of the site. An interflow zone occurs within the Elephant Mountain Member of the upper Saddle Mountains Basalt, and also may be significant to the lateral transmission of water. This system is confined by the dense, low-permeability, interior portions of basalt flows and in some places by Ringold Formation silt and clay units overlying the basalt.

Figure 2.14-2 shows the locations of the upper basalt-confined aquifer monitoring wells on the Hanford Site. Most of the wells are completed in the Rattlesnake Ridge Interbed near the 200 East Area in the central part of the Hanford Site. A few wells are completed in the Elephant Mountain interflow zone, the Levey Interbed, or a composite of one or more interbeds and/or interflow zones within the upper Saddle Mountains Basalt.

\subsubsection{Groundwater Flow in the Upper Basalt-Confined Aquifer}

Groundwater flow rates within the Rattlesnake Ridge Interbed have been estimated to be between 0.7 and 2.9 meters per year (PNL-10817). This flow rate is considerably slower than most estimates for the overlying unconfined aquifer system.

Recharge to the upper basalt-confined aquifer system is believed to occur along the margins of the Pasco Basin and results from the infiltration of precipitation and surface water where the basalt and interbeds are exposed at ground surface. Recharge may also occur through the Hanford/Ringold aquifer system in areas where the hydraulic gradient is downward, and from deeper basalt aquifers where an upward gradient is present. The Yakima River may also be a source of recharge. The Columbia River represents a discharge area for this aquifer system in the south portion of the site, but not for the north portion of the site (PNL-8869). Discharge also occurs to the overlying Hanford/Ringold aquifer system in areas where the hydraulic gradient is upward. Discharge to overlying or underlying aquifers in the vicinity of the Gable Butte-Gable Mountain structural area may occur through erosional windows in the basalt.

Figure 2.14-3 presents an approximation of the March 2003 potentiometric surface for this aquifer system south of Gable Butte and Gable Mountain. The region to the north of Gable Butte and Gable Mountain was not contoured because of insufficient well control. See PNL-8869 for a generalized potentiometric surface map of this area.

South of the Umtanum Ridge/Gable Mountain area, groundwater in the upper basaltconfined aquifer system generally flows from west to east across the Hanford Site toward the Columbia River. In the vicinity of the 200 East Area, the potentiometric surface in Figure 2.14-3 is similar to the potentiometric surface for the Ringold Formation confined aquifer (compare with Figure 2.14-1). The basalt in this area was significantly eroded by late Pleistocene catastrophic flooding, which facilitates aquifer intercommunication. In the vicinity of the 200 East Area and to the immediate north, the vertical hydraulic gradient between the upper basalt-confined aquifer system and the overlying Hanford/Ringold aquifer system is upward. Therefore, it is likely the upper basalt-confined aquifer system currently discharges to the overlying Hanford/Ringold aquifer system in this region.

There is a downward hydraulic gradient from the Hanford/Ringold aquifer system to the upper basalt-confined aquifer in the west portion of the Hanford Site, in the vicinity of the B Pond recharge mound, as well as in the regions north and east of the Columbia River. In the vicinity of B Pond, the vertical head gradient between the unconfined aquifer system and the upper basalt-confined aquifer system has diminished in recent years, but remains downward. In other areas of the Hanford Site, the hydraulic gradient is upward from the upper basalt-confined aquifer to the Hanford/Ringold aquifer system. The May Junction Fault, located east of B Pond and trending north-south, acts as a barrier to groundwater flow in Hanford/Ringold aquifer system (PNNL-12261). It may also impede the movement of water in the upper basalt-confined aquifer system.

Water levels in the upper basalt-confined aquifer declined over most of the site from March 2002 to March 2003, but water levels increased along the Columbia River. The
Groundwater in the upper basaltconfined aquifer system generally flows from west to east across the Hanford Site toward the Columbia River. 


\section{The small amount of contamination detected in the upper basalt-confined aquifer is attributed \\ to areas where confining units of basalt are absent or where wells provided a pathway for migration.}

decline in the 200 East Area and to the immediate north and east (near B Pond) ranged from 0.04 to 0.27 meter over the 12 -month period. Water level declines near the 200 West Area ranged from 0.07 to 0.39 meter. These declines are in response to curtailed effluent disposal activities in the 200 Areas and are consistent with water-level declines in the overlying Hanford/Ringold aquifer system. Along the Columbia River in the east part of the site, the water-level increase ranged from 0.07 to 0.23 meter. These increases are consistent with long-term trends in these wells - it is thought that waterlevels are rising in this area due to offsite irrigation east of the Columbia River (PNL8869).

\subsubsection{Groundwater Quality in the Upper Basalt-Confined Aquifer}

The upper basalt-confined aquifer is affected much less from contamination than the overlying unconfined aquifer system. Contamination found in the upper basaltconfined aquifer is most likely attributed to areas where confining units of basalt have been eroded away or were never deposited and where past disposal of large amounts of wastewater resulted in downward hydraulic gradients. In some areas, wells penetrating the upper basalt-confined aquifer provided a downward pathway for contaminant migration. Because of these factors, intercommunication between the aquifers permitted groundwater flow from the unconfined aquifer to the underlying confined aquifer, thereby increasing the potential to spread contamination.

An area of intercommunication between the unconfined and upper basalt-confined aquifer systems was first identified in the northern part of the 200 East Area (RHO-BWI-ST-5, RHO-RE-ST-12 P). Several confined aquifer wells north and east of the 200 East Area have shown evidence of intercommunication with the overlying unconfined aquifer (PNL-10817). Intercommunication between the unconfined and confined aquifers in this region has been attributed to erosion of the upper Saddle Mountains Basalt and a downward hydraulic gradient that resulted from groundwater mounding associated with past wastewater disposal to the ground. However, the groundwater mound has diminished in recent years (see Section 2.14.1).

Approximately 20 wells completed in the upper basalt-confined aquifer system are routinely sampled on the Hanford Site. Most of these wells are sampled every few years, and a few are sampled annually. Most of the upper basalt-confined aquifer wells scheduled for sampling in fiscal year 2003 were cancelled and re-scheduled for early fiscal year 2004 because of project budget cut-backs in fiscal year 2003. During fiscal years 2001 through 2003, 14 samples were collected from 11 wells and analyzed for chemical and radiological constituents. Many of the samples were analyzed for tritium, iodine-129, and nitrate because these constituents are (1) the most widespread in the overlying unconfined aquifer, (2) are some of the most mobile constituents in groundwater, and (3) provide an early warning for potential contamination in the upper basalt-confined aquifer system. Groundwater samples from the upper basalt-confined aquifer were also analyzed for anions (besides nitrate), cations, cyanide, gross alpha, gross beta, gamma-emitters, strontium-90, technetium-99, and uranium isotopes. Data for the primary constituents of interest are listed in Table 2.14-2. A full data set is included in the data files that accompany this report.

Distribution of sample results for selected constituents and wells across the Hanford Site for fiscal years 2001 through 2003 is shown in Figure 2.14-4. Tritium ranged from less than the detection limits near the discharge area in the east-southeast portion of the Hanford Site to $194 \mathrm{pCi} / \mathrm{L}$ in the 200 East Area near Gable Mountain. Near the 618-11 burial ground, where a source of tritium has contaminated the unconfined aquifer at high levels, tritium was detected at a concentration of $25.2 \mathrm{pCi} / \mathrm{L}$ in the upper basaltconfined aquifer in fiscal year 2001. 
In the north part of the 200 East Area, technetium-99 was elevated in the upper basalt-confined aquifer in one well (Figure 2.14-4). The technetium-99 concentration was 1,120 pCi/L in this well (299-E33-12) in 2001; it was not sampled in 2002 or 2003. However this level, which exceeds the drinking water standard $(900 \mathrm{pCi} / \mathrm{L})$, is slightly lower than concentrations in the last $\sim 10$ years. Contamination in this well is attributed to migration of high-salt waste down the borehole during construction when it was open to both the unconfined and confined aquifers (RHO-RE-ST-12 P). This well is located in the vicinity of a technetium-99 plume in the overlying unconfined aquifer (Section 2.10.1).

Cyanide and nitrate are elevated in an upper basalt-confined aquifer well (299-E33-12) in the north part of the 200 East Area (Figure 2.14-4). However, these co-contaminants are at levels that do not exceed their respective drinking water standards. Concentrations of cyanide and nitrate have not changed significantly at this well in the last $\sim 10$ years. Like technetium-99, this contamination is associated with migration of high-salt waste down the borehole during well construction when it was open to both the unconfined and confined aquifers (RHO-RE-ST-12 P). Cyanide and nitrate are co-contaminants with much higher concentrations in the unconfined aquifer in the north part of the 200 East Area.

Some samples collected from upper basalt-confined aquifer wells near Gable Mountain and the 200 East Area were analyzed for iodine-129. These wells are located beneath or near the iodine-129 plume contained within the overlying unconfined aquifer. Iodine-129 was not detected in the upper basalt-confined aquifer during fiscal years 2001 through 2003 (Table 2.14-2).

Table 2.14-2 indicates that the majority of wells showing elevated nitrate in the upper basalt-confined aquifer occur near Gable Mountain and the 200 East Area. Elevated nitrate in the upper basalt-confined aquifer is a hydrochemical indicator of intercommunication with the overlying contaminated unconfined aquifer (RHO-BWIST-5; RHO-RE-ST-12 P; PNL-10817). Across the rest of the Hanford Site, nitrate levels in the upper basalt-confined aquifer ranged from less than detectable to $\sim 1 \mathrm{mg} / \mathrm{L}$ in fiscal years 2001 through 2003.

Strontium-90 from an upper basalt-confined aquifer well showed a concentration below the minimum detection limits during fiscal year 2001, the most recent year sampled (Table 2.14-2). This well is located near the former Gable Mountain Pond in the central part of the Hanford Site (Figure 2.14-4), where strontium-90 contamination occurs in the overlying unconfined aquifer.

A few samples collected from upper basalt-confined aquifer wells were analyzed for gamma-emitting and uranium isotopes. Gamma-emitting isotopes were not detected in the upper basalt-confined aquifer on the Hanford Site, including the Gable Mountain/ 200 East Area. Uranium isotopes were not detected in this aquifer in the eastern part of the Hanford Site during fiscal years 2001 through 2003 (Figure 2.14-4).

The primary objective for monitoring groundwater within the upper basalt-confined aquifer is to evaluate the potential for migration of contamination off the south portions of the Hanford Site. Monitoring results indicate that contaminants on the Hanford Site have not migrated through the upper basalt-confined aquifer system to the offsite sample locations south and southeast of the Hanford Site (PNNL-14107; PNL-10817).

In summary, cyanide, nitrate, and technetium-99 were elevated in an upper basaltconfined aquifer well in the north part of the 200 East Area. Migration of high-salt waste via the well during its construction is responsible for this contamination. Tritium was detected at very low to undetectable levels, and iodine-129, strontium-90, gammaemitting isotopes, and uranium isotopes were not detected above the minimum detection limits in the upper basalt-confined aquifer. Contaminants on the Hanford Site have not migrated through the upper basalt-confined aquifer system to offsite sample locations south and southeast of the Hanford Site.
Monitoring results indicate that contaminants on the Hanford Site have not migrated through the upper basalt-confined aquifer system to the offsite sample locations. 
Table 2.14-1. Potential Contaminants in Ringold Confined Aquifer, Fiscal Years 2001 through 2003

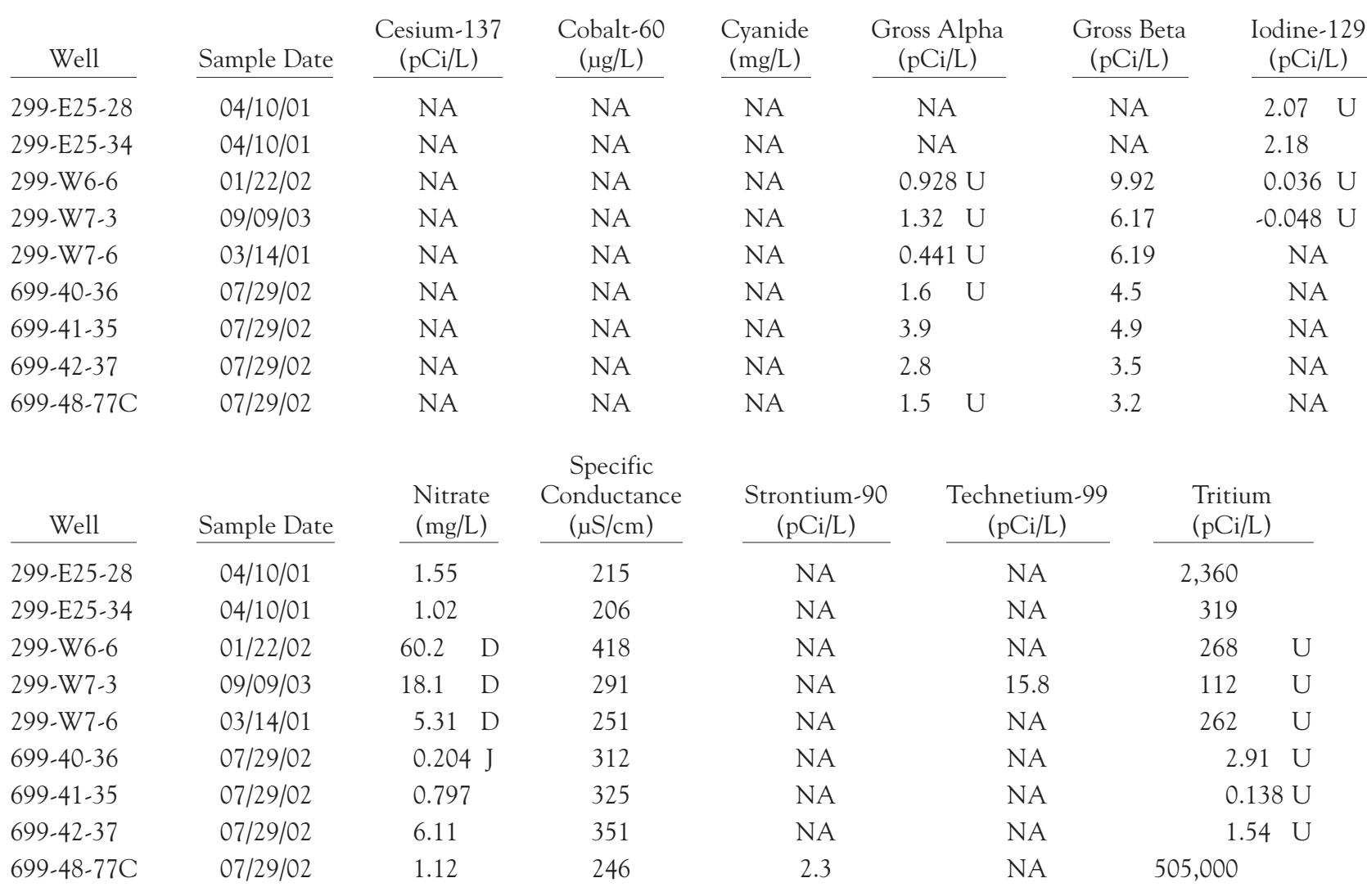

$\mathrm{D}=$ Analyzed at secondary dilution factor.

$\mathrm{J}=$ Estimated value.

$\mathrm{NA}=$ Not analyzed.

$\mathrm{U}=$ Below detection limit.

Negative values occur when a sample has a lower count than the background. 
Table 2.14.2. Potential Contaminants in Upper Basalt-Confined Aquifer, Fiscal Years 2001 through 2003

\begin{tabular}{|c|c|c|c|c|c|c|c|c|c|c|c|c|}
\hline Well & $\begin{array}{c}\text { Sample } \\
\text { Date } \\
\end{array}$ & $\begin{array}{l}\text { Cesium-137 } \\
(\mathrm{pCi} / \mathrm{L}) \\
\end{array}$ & $\begin{array}{c}\text { Cobalt-60 } \\
(\mu \mathrm{g} / \mathrm{L})\end{array}$ & $\begin{array}{c}\text { Cyanide } \\
(\mathrm{mg} / \mathrm{L})\end{array}$ & $\begin{array}{l}\text { Gross alpha } \\
(\mathrm{pCi} / \mathrm{L})\end{array}$ & $\begin{array}{c}\text { Gross beta } \\
(\mathrm{pCi} / \mathrm{L})\end{array}$ & $\begin{array}{l}\text { Iodine-129 } \\
(\mathrm{pCi} / \mathrm{L}) \\
\end{array}$ & $\begin{array}{l}\text { Nitrate } \\
(\mathrm{mg} / \mathrm{L})\end{array}$ & $\begin{array}{c}\text { Specific } \\
\text { Conductance } \\
(\mu \mathrm{S} / \mathrm{cm}) \\
\end{array}$ & $\begin{array}{l}\text { Strontium-90 } \\
\quad(\mathrm{pCi} / \mathrm{L})\end{array}$ & $\begin{array}{l}\text { Technetium-99 } \\
\quad(\mathrm{pCi} / \mathrm{L})\end{array}$ & $\begin{array}{l}\text { Tritium } \\
(\mathrm{pCi} / \mathrm{L}) \\
\end{array}$ \\
\hline 299-E33-12 & 06/12/01 & $1.07 \mathrm{U}$ & $4.37 \mathrm{U}$ & 29 & 2.1 & 330 & $0.21 \mathrm{U}$ & 37.6 & 341 & NA & 1,120 & 194 \\
\hline $399-5-2$ & $06 / 14 / 01$ & NA & NA & NA & $0.25 \mathrm{U}$ & 9.84 & NA & $0.009 \mathrm{U}$ & 351 & NA & NA & $7.55^{(\mathrm{a})}$ \\
\hline $699-13-1 \mathrm{C}$ & 06/28/01 & NA & $\mathrm{NA}$ & NA & $0.83 \mathrm{U}$ & 6.82 & NA & $0.009 \mathrm{U}$ & 336 & NA & NA & 25.2 \\
\hline $699-24-1 \mathrm{P}$ & $11 / 01 / 01$ & NA & NA & NA & 4.18 & 12.3 & NA & $0.009 \mathrm{U}$ & 378 & NA & NA & 11.5 \\
\hline 699-42-E9B & 05/15/01 & $-1.05 \mathrm{U}$ & $1.45 \mathrm{U}$ & NA & $0.868 \mathrm{U}$ & 9.88 & $0.242 \mathrm{U}$ & $0.009 \mathrm{U}$ & 420 & NA & NA & $4.61 \mathrm{U}$ \\
\hline 699-42-E9B & 08/09/02 & $1.64 \mathrm{U}$ & $-3.26 \mathrm{U}$ & NA & $0.415 \mathrm{U}$ & 5.84 & $-0.0745 \mathrm{U}$ & $0.02 \mathrm{U}$ & 425 & NA & NA & $1.2 \mathrm{U}$ \\
\hline 699-42-E9B & 08/09/02 & $-1.07 \mathrm{U}$ & $0.228 \mathrm{U}$ & NA & $-0.119 \mathrm{U}$ & 11.4 & $0.641 \mathrm{U}$ & $0.02 \mathrm{U}$ & 425 & NA & NA & $1.62 \mathrm{U}$ \\
\hline 699-42-E9B & 09/10/03 & $-0.446 \mathrm{U}$ & $-0.696 \mathrm{U}$ & NA & $0.862 \mathrm{U}$ & 6.52 & $0.0105 \mathrm{U}$ & 0.328 & 425 & NA & NA & NA \\
\hline $699-49-57 \mathrm{~B}$ & 06/13/01 & NA & NA & NA & 2.18 & 5.29 & $0.135 \mathrm{U}$ & 1.110 & 301 & NA & $-5.49 \mathrm{U}$ & 21.8 \\
\hline $699-52-46 \mathrm{~A}$ & $06 / 13 / 01$ & NA & NA & NA & 3.52 & 8.28 & NA & 1.640 & 340 & $0.18 \mathrm{U}$ & NA & 20.6 \\
\hline $699-54-34$ & 06/13/01 & NA & NA & NA & $0.748 \mathrm{U}$ & 7.05 & NA & $16.4 \mathrm{DH}$ & 315 & NA & NA & 15.8 \\
\hline $699-56-43$ & 06/14/01 & NA & NA & NA & 2.94 & 4.35 & NA & $4.87 \mathrm{D}$ & 321 & NA & NA & 8.96 \\
\hline 699-S11-E12AP & 05/29/02 & NA & NA & NA & NA & NA & NA & NA & NA & NA & NA & 18.6 \\
\hline 699-S24-19P & $07 / 24 / 01$ & NA & NA & NA & NA & NA & NA & 1.15 & 230 & NA & NA & $43.3 \mathrm{Q}$ \\
\hline \multicolumn{13}{|c|}{ Wells Located South and Southeast of the Hanford Site } \\
\hline 699-ORV-1 & $11 / 06 / 00$ & NA & NA & NA & $0.42 \mathrm{U}$ & 5.15 & NA & 0.102 & 245 & NA & NA & 42.70 \\
\hline 09N28E04G01 & $11 / 06 / 00$ & NA & NA & NA & $0.07 \mathrm{U}$ & 8.87 & NA & $0.049 \mathrm{U}$ & 377 & NA & NA & 46.50 \\
\hline 09N28E06C02 & $11 / 06 / 00$ & NA & NA & NA & $0.82 \mathrm{U}$ & 10.20 & NA & 2.57 & 534 & NA & NA & 55.60 \\
\hline 10N27E14F03 & $11 / 06 / 00$ & NA & NA & NA & $0.90 \mathrm{U}$ & 7.07 & NA & $0.049 \mathrm{U}$ & 282 & NA & NA & 56.20 \\
\hline 10N27E14F03 & $11 / 06 / 00$ & NA & NA & NA & $-0.06 \mathrm{U}$ & 8.07 & NA & $0.049 \mathrm{U}$ & 282 & NA & NA & 56.40 \\
\hline 10N28E24R03 & $10 / 27 / 00$ & NA & NA & NA & $0.57 \mathrm{U}$ & 12.20 & NA & $0.049 \mathrm{U}$ & 382 & NA & NA & 34.60 \\
\hline 10N29E02Q01 & $10 / 27 / 00$ & NA & NA & NA & $-0.18 \mathrm{U}$ & 10.70 & NA & $0.049 \mathrm{U}$ & 456 & NA & NA & 64.30 \\
\hline 10N29E19E01 & $10 / 27 / 00$ & NA & NA & NA & $-0.08 \mathrm{U}$ & 11.50 & NA & $0.049 \mathrm{U}$ & 384 & NA & NA & 56.10 \\
\hline
\end{tabular}

(a) Sample was re-analyzed because batch blank result exceeded criteria.

$\mathrm{D}=$ Analyzed at a secondary dilution factor

$\mathrm{H}=$ Analyzed after recommended holding time.

จ $\mathrm{NA}=$ Not analyzed.

$\quad \mathrm{Q}=$ Associated quality control sample is out of limits.

$\mathrm{U}=$ Below detection limit.

Negative values occur when a sample has a lower count than the background. 


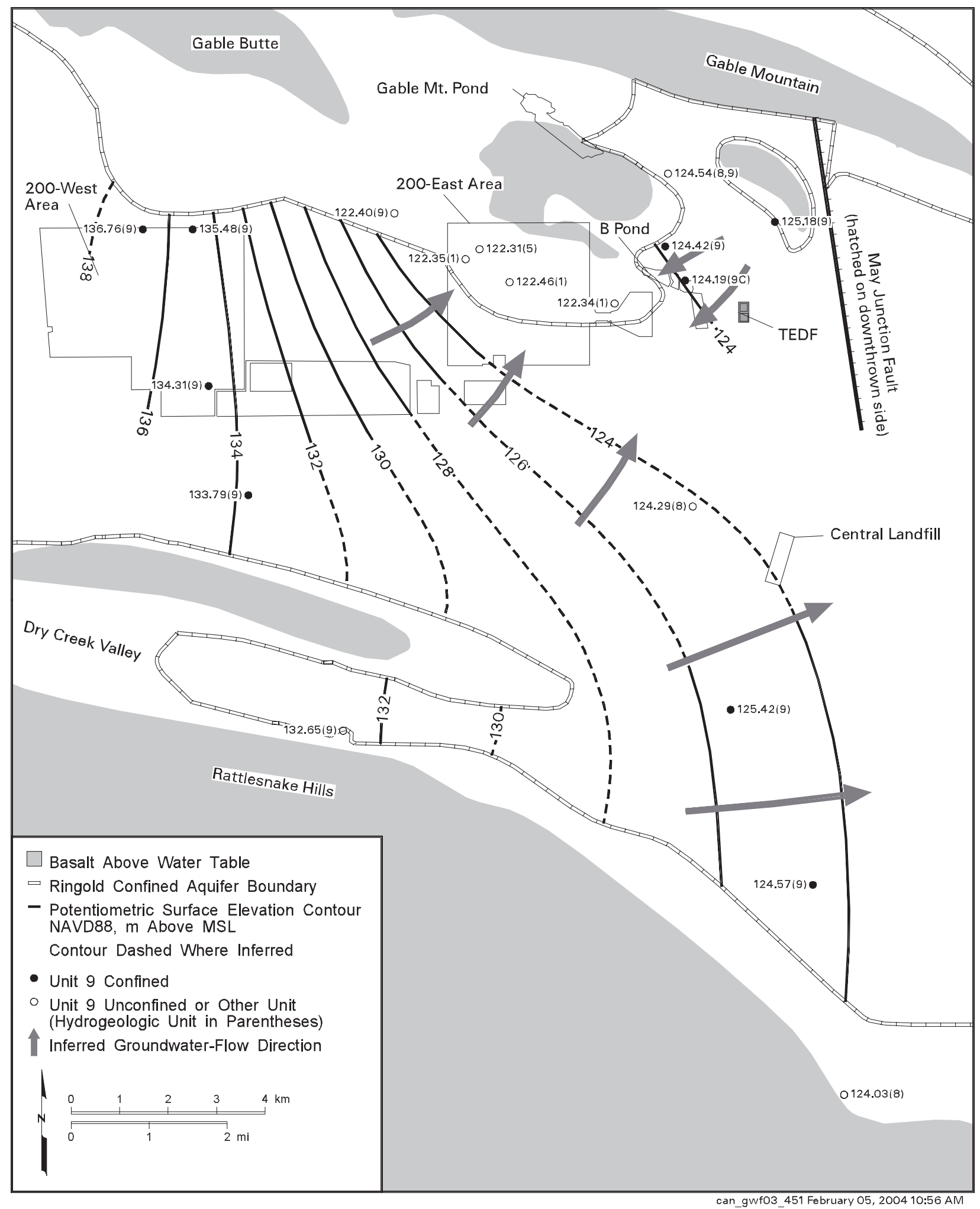

Figure 2.14-1. Potentiometric Surface Map of Ringold Formation Confined Aquifer (Unit 9), Central Hanford Site, March 2003 


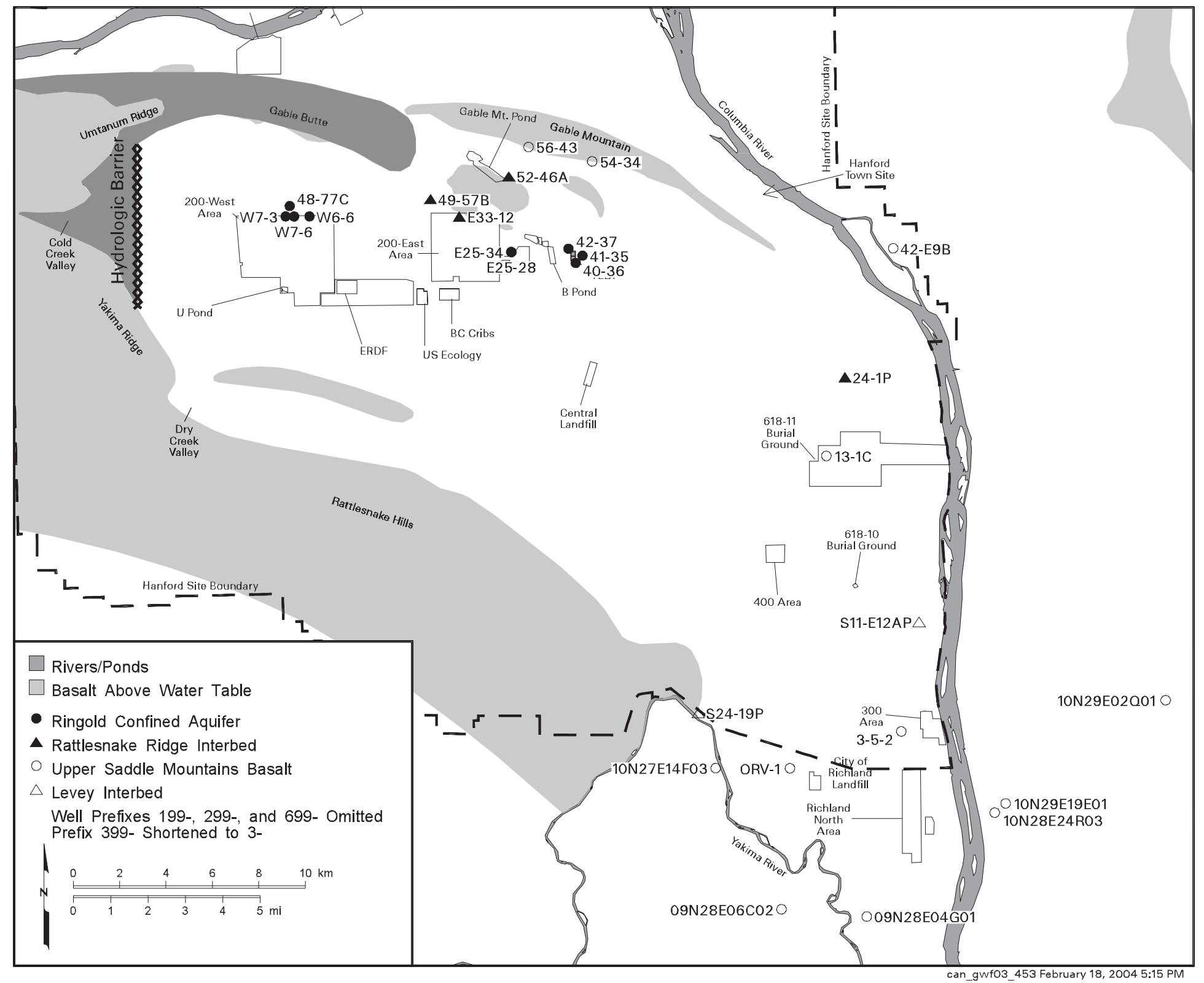

Figure 2.14-2. Groundwater Monitoring Wells Sampled in the Ringold Confined and the Upper Basalt-Confined Aquifers, Fiscal Years 2001 through 2003 


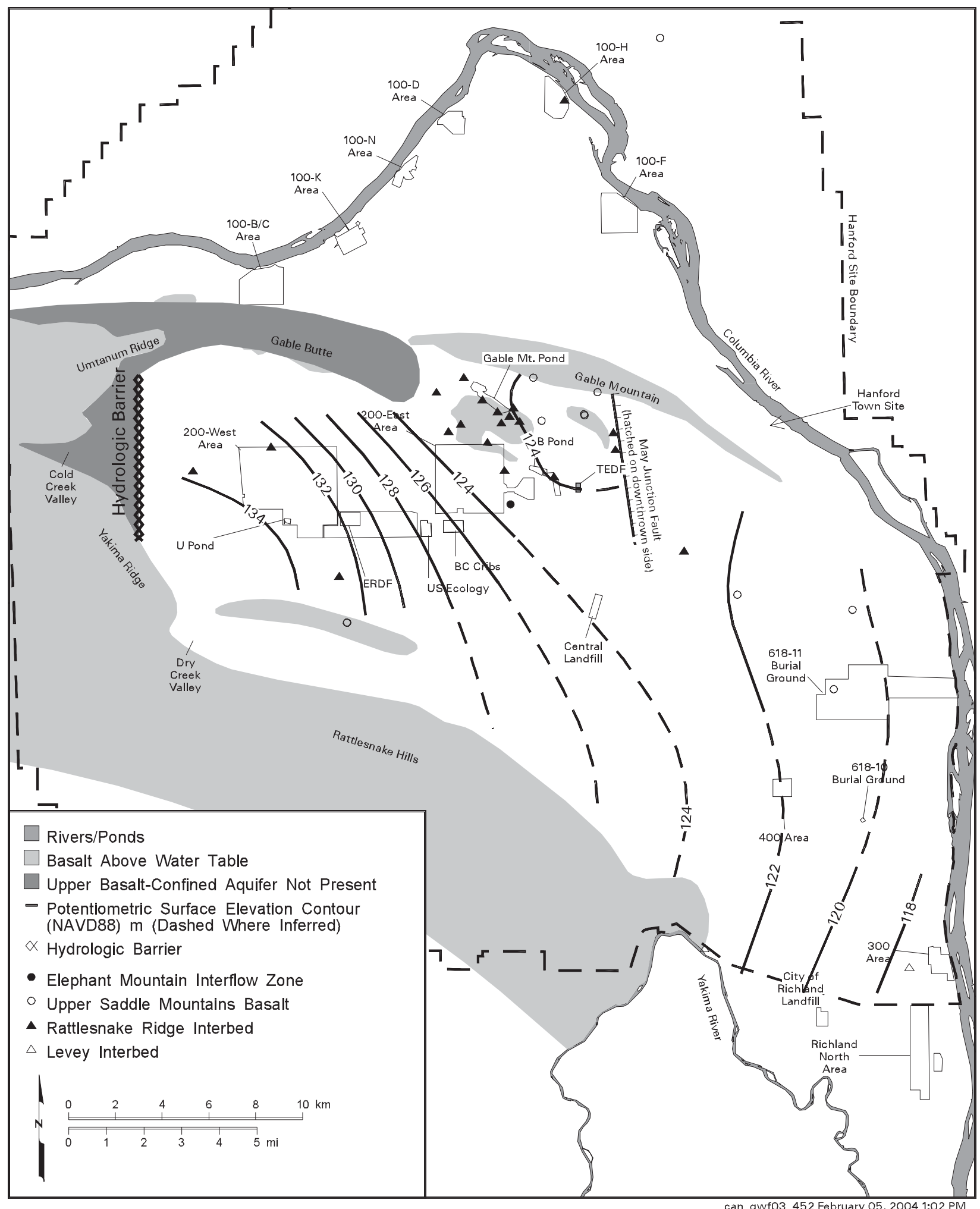

Figure 2.14-3. Potentiometric Surface Map of Upper Basalt-Confined Aquifer System, March 2003 


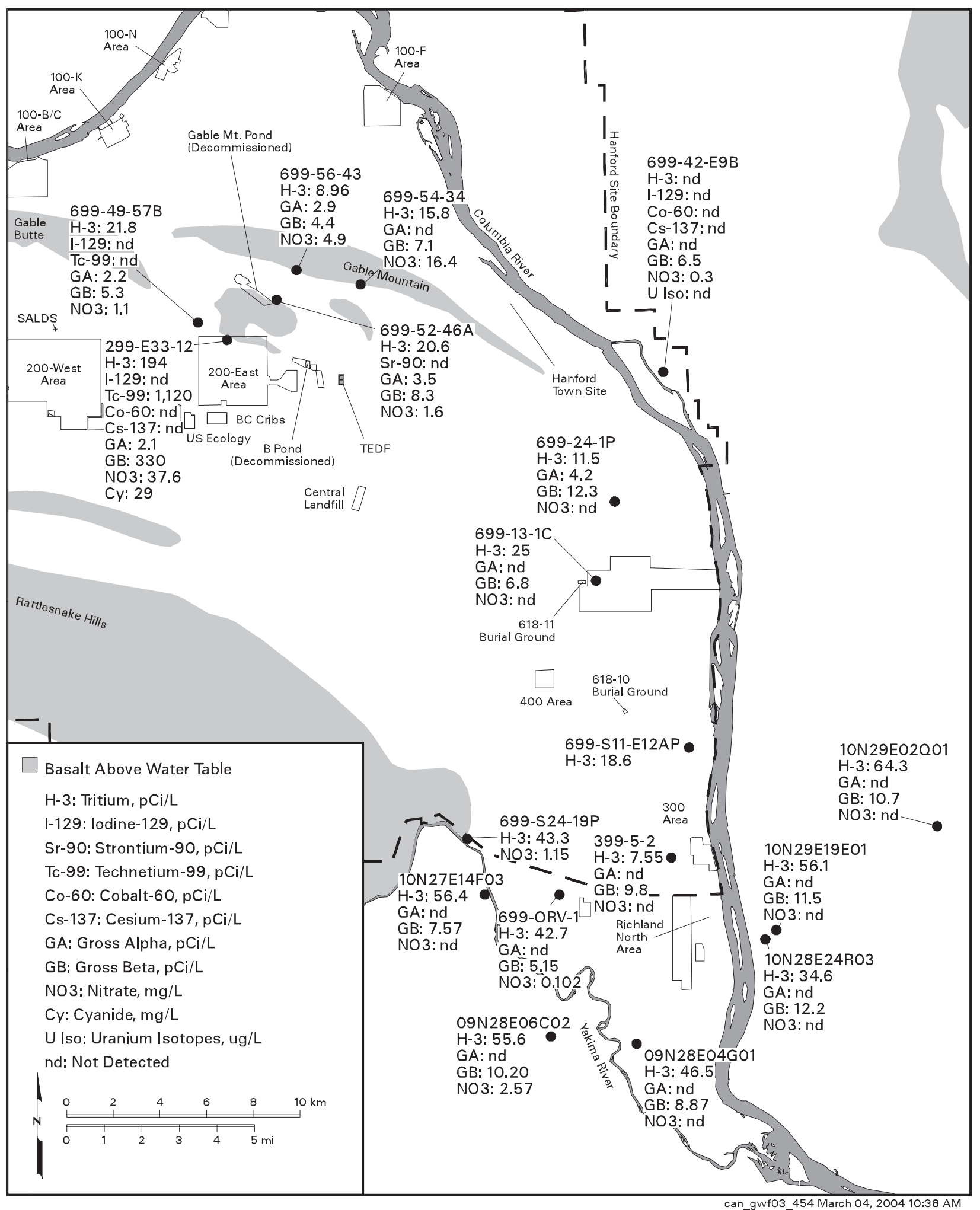

Figure 2.14-4. Distribution of Chemical and Radiological Constituents in the Upper Basalt-Confined Aquifer, Fiscal Years 2001 through 2003 


\subsection{Vadose Zone}

\section{G. Horton}

Radioactive and hazardous waste in the soil column from past intentional liquid waste disposal, unplanned leaks, solid waste burial grounds, and underground tanks at the Hanford Site are potential sources of continuing and future vadose zone and groundwater contamination. Subsurface characterization and vadose zone monitoring were conducted during fiscal year 2003 to better understand the distribution and movement of subsurface vadose zone contamination. Also, several technical studies were completed, and the results could lead to new understandings of moisture and contaminant movement in the vadose zone, contaminant interactions with the soil column, and new and improved methods to characterize and monitor the vadose zone. Finally, vadose zone characterization to assess remediation and post-remediation activities was done in fiscal year 2003 as part of cleanup efforts at the Hanford Site.

This chapter summarizes major findings from those efforts, focused primarily on vadose zone soil contamination associated with past single-shell tank leaks and liquid disposal to ground as a result of spent fuel processing.

An overview of the major soil column sources of groundwater contamination is provided in PNNL-13080. This chapter discusses vadose zone contamination that could affect groundwater in the future. An overall evaluation depends, to a large degree, on the integration of data from monitoring and characterization of the vadose zone and groundwater to present a comprehensive picture of contaminant fate and transport. Significant fiscal year 2003 vadose zone results are summarized in the chapter. However, the bulk of the data interpretation on the effect to groundwater is presented and discussed in Chapter 2. 


\subsection{Vadose Zone Characterization}

\section{G. Horton}

This section describes significant vadose zone characterization activities that occurred during fiscal year 2003. These characterization activities were done to further the understanding of physical and chemical properties of the vadose zone and to define existing vadose zone contamination. During the year, soil-vapor sampling and analysis, geophysical logging, and laboratory analysis of chemical and radiological contaminants in soil samples were done to characterize existing vadose zone contaminant plumes and help plan future remedial actions.

During fiscal year 2003, baseline spectral gamma logging and neutron moisture logging of boreholes continued at selected past-practice, liquid disposal facilities. The results of this characterization will provide a baseline against which to compare subsequent logging events to monitor for subsurface contaminant movement.

The results of extensive geochemical characterization of core samples from Waste Management Area TX-TY became available in fiscal year 2003. These data allow comparison of contaminated vadose zone sediment with uncontaminated sediment and descriptions of contaminant plumes beneath the single-shell tanks in the vicinity of the boreholes. In addition, two boreholes were drilled and sampled at Waste Management Area T. Those results will become available in fiscal year 2004.

Soil-vapor sampling and analysis were done as part of the remedial investigation for the 200-PW-1 Operable Unit. This activity was done to locate carbon tetrachloride release sites with the potential to impact groundwater in the future. Also, boreholes and test pits were excavated to gather characterization data to support remediation of past-practice liquid disposal facilities in the 200-CS-1 Operable Unit.

Finally, laboratory experiments were completed to help predict the movement of uranium in the vadose zone at water sites in the Hanford Site 300 Area.

\subsubsection{Tank Farm Characterization}

\section{A. Myers, D. G. Horton, S. P. Reidel, R. J. Serne, and K. D. Reynolds}

Vadose zone characterization activities at single-shell tank farms in fiscal year 2003 were concentrated at the T, TX, and TY Tank Farms in the 200 West Area. Two new boreholes were drilled at Waste Management Area T through subsurface contaminated soil. Also, data became available from three boreholes drilled in 2002 through subsurface contamination at Waste Management Area TX-TY. A summary of available information is presented in this section.

Also, during fiscal year 2003, the Tank Farm Vadose Zone Project published an in-depth report, Field Investigation Report for Waste Management Area B-BX-BY (RPP-10098). This report documents the extensive investigation of subsurface contamination and includes significant new work on the mobility of contaminants in the Hanford Site subsurface. Major conclusions from this report are summarized in this section. This report is a joint work of CH2M HILL Hanford Group, Inc. and numerous outside collaborators including Fluor Hanford, Inc.; Pacific Northwest National Laboratory; Lawrence Livermore National Laboratory; Oak Ridge National Laboratory; and contributors from numerous universities.

\subsubsection{Characterization at Waste Management Area T}

The CH2M HILL Hanford Group Vadose Zone Project advanced two characterization boreholes (C4104 and C4105) in the T Tank Farm. The boreholes were placed in the

\section{Characterization activities further the understanding of physical and chemical properties of the vadose zone.}




\section{The magnitude of contamination found in the three boreholes at the TX Tank Farm is not as great as that found in boreholes at other tank farms.}

vicinity of tank T-106, the site of the largest documented tank leak in the Hanford Site's history. Tank T-106 lost 435,300 liters of liquid in early 1973. The boreholes advanced and sampled during fiscal year 2003 were designed to provide additional information on the movement and fate of contaminants released during the 1973 leak.

Because these boreholes had a finite probability of intersecting highly concentrated contamination, the boreholes were advanced using a closed-end driven casing. Pre-selected intervals were sampled by driving a split-spoon sampler through the end and ahead of the driven casing. This drilling method successfully advanced borehole C4104 to 38.85 meters below ground surface and borehole C4105 to a depth of 39.89 meters. Advancement of both boreholes was halted within the Ringold Formation when the casings could be driven no further. A total of 21 and 22 samples, respectively, were retrieved and submitted for radiological, chemical, and geochemical analyses. Result of the laboratory analyses will become available in fiscal year 2004 and will be summarized in the next annual groundwater report.

Both characterization boreholes were geophysically logged with a spectral gamma tool. Cesium-137, europium-154, europium-152, tin-126, and cobalt-60 were the manmade radionuclides detected in borehole $\mathrm{C} 4104$. Cesium-137, cobalt-60, and europium-154 were the manmade radioisotopes detected in borehole C4105. Table 3.1-1 summarizes the logging results.

\subsubsection{Characterization at Waste Management Area TX-TY}

The CH2M HILL Hanford Group Vadose Zone Project advanced three characterization boreholes (C3830, C3831, and C3832) in the TX Tank Farm in fiscal year 2002. Data from these boreholes became available in fiscal year 2003. Borehole C3830 was drilled to investigate the largest and deepest occurrence of uranium in Waste Management Area TX-TY that is associated with a 1977 leak from tank TX-105. Boreholes C3831 and C3832 were drilled to investigate vadose zone contamination related to a 1984 leak from tank TX-107 in the southwest part of the tank farm.

Advancement of all three boreholes was halted within the Ringold Formation when the casings could be driven no further. Eighteen cores (36 samples) were retrieved from borehole C3830 between depths of 4.54 and 34.6 meters, 20 cores ( 40 samples) were retrieved from borehole C3831 between depths of 4.54 and 34.77 meters, and 19 cores (38 samples) were obtained from borehole C3832 between depths of 4.94 and 34.89 meters. All cores were submitted for radiological, chemical, and geochemical analyses. A summary of those analyses is presented below.

All three characterization boreholes were geophysically logged with a spectral gamma tool. Cesium-137 was the only manmade radionuclide positively identified in borehole C3830; whereas, cesium-137 and cobalt-60 were found in borehole C3831; and cesium-137, cobalt-60, and uranium-238 were found in borehole C3832. Table 3.1-1 summarizes the logging results.

Of the geochemical parameters measured in core samples, $\mathrm{pH}$, electrical conductivity, and concentrations of nitrate, sodium, uranium, and technetium-99 in water extracts are the main indicators of vadose zone contamination. Based on evaluation of these measurements, the borehole data from the TX Tank Farm do not establish the vertical extent of tank contamination, especially in boreholes C3831 and C3832, because contamination was found at the bottom of the boreholes.

The magnitude of contamination found in the three boreholes at the TX Tank Farm is not as great as that found in boreholes at other tank farms. (See Section 3.1 in PNNL-13788 for a summary of contaminants in S and SX Tank Farm boreholes and Section 3.1 in PNNL-14187 for a summary of contaminants in B, BX, and BY Tank Farm boreholes.) Of the three boreholes examined from the TX Tank Farm, borehole C3831 contains the largest amount of contaminants. Figure 3.1-1 shows the depth distribution of $\mathrm{pH}$ and electrical 
conductivity in borehole C3831. For comparison, Figure 3.1-1 also shows data from a nearby uncontaminated well (well 299-W10-27, located east of the TY Tank Farm) and from a highly contaminated well (299-W23-19, located in the south part of the SX Tank Farm). Figure 3.1-2 shows concentrations of technetium-99, sodium, and nitrate in all three characterization boreholes and a highly contaminated borehole at Waste Management Area S-SX.

Because the amount of contamination in the boreholes at the TX Tank Farm is small, the usual indicators of vadose zone contamination (moisture content, $\mathrm{pH}$, electrical conductivity) do not correlate well with zones containing elevated technetium-99, nitrate, sodium, and uranium concentrations.

The moisture content is a direct measure of the mass of fluid in the vadose zone sediment and an increased moisture content, over background values, should represent leaked tank fluids. This does not appear to be the case for samples from the TX Tank Farm boreholes, where higher moisture contents appear more indicative of grain size than contamination.

If it is assumed that tank fluids are generally caustic (often very caustic with $>1 \mathrm{M}$ free hydroxide), elevated $\mathrm{pH}$ profiles should be indicative of zones of sediment that have been affected by leaked fluids. The $\mathrm{pH}$ profile for sediment from borehole C3831 (Figure 3.1-1) shows only slightly elevated $\mathrm{pH}$ at 18.6 meters below ground surface, suggesting possible interactions with alkaline tank fluids. This zone also shows relatively high technetium-99, nitrate, and sodium concentrations (Figure 3.1-2). The zone at about 18.5 meters correlates to a clastic dike mapped at a depth of 18.3 to 18.6 meters. The $\mathrm{pH}$ data at all other depths in borehole C3831 and at all depths in boreholes C3830 and C3832 show a slight increase over the $\mathrm{pH}$ in the uncontaminated borehole (299-W10-27) but do not suggest strong interactions with tank liquids as do the $\mathrm{pH}$ values from the highly contaminated borehole (299-W23-19) at the SX Tank Farm.

Electrical conductivity versus depth for the three boreholes from TX Tank Farm is elevated compared to the electrical conductivity of the nearby uncontaminated borehole 299-W10-27 (Figure 3.1-1). However, except for the contaminated sample associated with the clastic dike in borehole C3831, none of the boreholes at the TX Tank Farm show high electrical conductivity indicative of highly contaminated sediment.

Figure 3.1-2 shows the distribution of contaminants with depth for the boreholes at the TX Tank Farm. The highest contamination is associated with the clastic dike identified at a depth of 18.3 meters in borehole C3831. Contamination at all other depths in borehole C3831 and at all depths in the other two boreholes at the TX Tank Farm is much less than that found in highly contaminated vadose zone sediment (compare with well 299-W23-19, Figure 3.1-2).

\subsubsection{Summary of Significant Findings from the Field Investigation Report for Waste Management Area B-BX-BY}

The Field Investigation Report for Waste Management Area B-BX-BY (RPP-10098) was prepared for the Resource Conservation and Recovery Act (RCRA) Corrective Action Program for single-shell tank farms at the U.S. Department of Energy (DOE) Hanford Site. The DOE Office of River Protection initiated the RCRA Corrective Action Program to investigate the nature and extent of contamination and the associated risk of past and potential future tank waste releases to the environment.

The purpose of the B-BX-BY report (RPP-10098) is to:

- Summarize data and evaluations from the site-specific field investigation activities at Waste Management Area B-BX-BY and from other information sources.

- Evaluate the data to determine the potential risk associated with hypothetical exposure to soil and groundwater at the waste management area boundary.

\author{
The field \\ investigation \\ report for Waste \\ Management Area \\ $B-B X-B Y$ was \\ published in 2003 \\ to fulfill Tri-Party \\ Agreement \\ milestone \\ M-45-55-T02.
}




\section{The future impact}

from waste currently

in the vadose zone is

not expected to

exceed drinking

water standards in

groundwater.
- Recommend one or more interim measures to mitigate the risk or initiate an accelerated corrective measures study to evaluate and compare more complex interim corrective measures, if the potential for near-term risk is excessive.

- Collect data to support waste retrieval and closure of single-shell tanks.

Major conclusions from the report (RPP-10098) are summarized below:

- The future impact from waste currently in the vadose zone that resulted from past releases from the B, BX, and BY Tank Farms is not expected to exceed drinking water standards in groundwater at or beyond the boundary of the waste management area as long as high-volume liquid discharges to the vadose zone are eliminated. However, high technetium-99 concentrations in groundwater measured east of the BX Tank Farm is most likely due to releases from the tank farm.

- Vadose zone contamination levels were lower than generally anticipated prior to the initiation of the field investigation.

- Estimates of technetium-99 distribution during Hanford Site reprocessing, storage, and disposal and the residue left in the vadose zone have been improved and past assumptions corrected. However, the amount of technetium-99 that was initially discharged to the vadose zone and that has already reached groundwater and may reach groundwater in the future is uncertain.

- Complex hydraulic processes play a major role in contaminant movement in Waste Management Area B-BX-BY. Strong evidence exists of extensive lateral migration in the vadose zone at the waste management area. Lateral migration may have extended into Waste Management Area B-BX-BY from adjacent past-practice discharge sites. Ponding of runoff from natural precipitation in the waste management area may have added significant amounts of spatially confined infiltration.

- Borehole soil characterization performed by the Tank Farm Vadose Zone Project and other laboratory measurements by the Groundwater Remediation Project's science and technology tasks have identified precipitated uranium and strontium-90 phases and sorption sites for uranium and strontium-90 (see PNNL-14187, Section 3.1.2). These data indicate limited future mobility unless abnormally high amounts of infiltration occur. Neither uranium nor strontium-90 is expected to significantly impact groundwater in the current moisture and geochemical environment. However, the precipitated uranium phases may function as a long-term source to percolating water if recharge is not controlled.

- Interim measures (e.g., capping boreholes, cutting off inactive water lines, and building surface run-on barriers and diversions) have been implemented in the waste management area. These are expected to mitigate future contamination risks.

\subsubsection{Borehole Geophysics for Vadose Zone Characterization}

\section{R. G. McCain}

The S.M. Stoller Corporation is responsible for borehole geophysical logging at the Hanford Site. Borehole logging equipment currently in use for vadose zone characterization at the Hanford Site includes the spectral gamma logging system and the neutron moisture logging system. An additional logging system, the radionuclide assessment system, was developed and deployed specifically for monitoring operations in tank farms. Those activities are discussed in Section 3.2.3.

The spectral gamma logging system uses a cryogenically-cooled, high-purity germanium detector to detect, identify, and quantify gamma emitting radionuclides in 
the subsurface. Identification of naturally occurring and manmade radionuclides is based on detection of gamma rays that are characteristic of specific radionuclides. A variation of the spectral gamma logging system, known as the high-rate logging system, uses a much smaller detector than the spectral gamma logging system and can collect log data in zones of very high gamma activity where the spectral gamma logging detector is saturated. When used in combination, the spectral gamma logging system and highrate logging system provide a measurement capability from about 0.1 to $10^{9} \mathrm{pCi} / \mathrm{g}$ cesium-137.

The neutron moisture logging system uses a $50 \mathrm{mCi}$ americium/beryllium source and helium-3 detector. Neutrons emitted from the source bombard the surrounding formation and are scattered back to the detector. In geologic media, the dominant mechanism for neutron scattering is interaction with hydrogen atoms, and the count rate at the detector is a function of the amount of hydrogen in the formation, which is generally an indicator of the moisture content. Logs from a neutron moisture logging system are useful as an indication of in situ moisture content and for stratigraphic correlation.

Characterization activities are now underway at past-practice disposal sites in the Hanford 200 Areas. Log data and reports are accessible via the internet at http:// www.gjo.doe.gov/programs/hanf/HTFVZ.html.

Vadose Zone Baseline Characterization in Past-Practice Disposal Facilities. The baseline characterization project for past-practice disposal sites in the Hanford 200 Areas is an extension of the Hanford Tank Farm Vadose Zone Project. Beginning in 2001, spectral gamma logs were collected in existing boreholes associated with pastpractice disposal sites in the Hanford 200 Areas. Characterization began in the 200 East Area with a report on the logging results from the 216-B-35 to 216-B-42 trenches, located west of the BX Tank Farm (GJO-2002-322-TAR). This was followed by reports on the 216-B-8 crib and adjacent sites (GJO-2002-343-TAR); the 216-B-5 injection well and 216-B-9 crib and tile field (GJO-2002-358-TAC); and the 216-B-43 to 216-B-50, 216-B-57, and 216-B-61 cribs (GJO-2003-458-TAC). In fiscal year 2003, logging activities were completed in and around Waste Management Area B-BX-BY. Those logging results are being combined with the logging results in the reports cited above and with previous baseline reports for the B, BX, and BY Tank Farms to produce a comprehensive borehole logging report for the entire area.

Cesium-137, cobalt-60, uranium-238, uranium-235, antimony-125, strontium-90, europium-154, and europium-152 were all detected in Waste Management Area B-BX-BY. The predominant contaminant at the waste management area and adjacent waste sites is cesium-137, which was measured at a maximum concentration of more than 20 million pCi/g in borehole 299-E33-27 (near tank BX-102) and in borehole 299-E33-223 (near tank BX-110). Concentrations of cesium-137>1 million pCi/g were found above $\sim 45$ meters depth in the vicinity of the singe-shell tank farms and in the vicinity of the BY cribs.

Concentrations of uranium-238 from Hanford Site operations were found as high as $1,000 \mathrm{pCi} / \mathrm{g}$ east of tank BX-102. Of the 284 boreholes logged, only 17 encountered detectable amounts of manmade uranium-238. The most extensive area of uranium contamination was interpreted as extending downward and to the northeast from the vicinity of tank BX-102, intercepting the groundwater in the vicinity of borehole 299-E33-18. Evaluation of historical log data suggests that the uranium plume reached the groundwater in this area between 1991 and 1997. This is consistent with groundwater monitoring results, which show elevated uranium levels beginning in $\sim 1994$. Limited evidence of subsurface uranium contamination was found in the vicinity of other waste sites at which uranium disposal is reported.
In fiscal year 2003, spectral gamma logging detected cesium-137, cobalt-60, uranium-238, uranium-235, antimony-125, strontium-90, europium-154, and europium-152 at Waste Management Area B-BX-BY. 


\section{The deeper part of the vadose zone has not been investigated extensively, and the full nature and extent of contamination may not be known.}

\section{Soil-vapor sampling was used to explore the dispersed carbon tetrachloride plume in the vadose zone.}

The maximum concentration of antimony- 127 did not exceed $10 \mathrm{pCi} / \mathrm{g}$. The highest europium-154 concentration encountered was 127 pCi/g near tank BX-101.

In general, contamination that appears to be directly associated with a specific waste site or tank was observed at log depths $<46$ meters in the immediate vicinity of the waste sites. However, most tank farm boreholes and many boreholes associated with the liquid waste sites are $<46$ meters in depth, and groundwater occurs at a depth of $\sim 76$ meters. Hence, the deeper part of the vadose zone has not been investigated extensively, and the full nature and extent of contamination may not be known. Borehole evidence of vadose zone contamination extending to groundwater does exist for processed uranium originating from the vicinity of tank BX-102 and for cobalt- 60 and cesium-137 originating from the BY cribs. Figures 3.1-3 and 3.1-4 show the distribution of cobalt-60 and uranium-238 contamination in the vadose zone in Waste Management Area B-BX-BY and vicinity.

In addition to wells near the Waste Management Area B-BX-BY, selected boreholes in the 200 West Area that were scheduled for decommissioning were also logged in fiscal year 2003. These boreholes had been identified in the original database for baseline characterization. Log data were collected in 23 of 57 boreholes before they were decommissioned.

Finally, geophysical logging of new and existing boreholes for vadose zone characterization to support ongoing remedial investigation at the Hanford Site was accomplished in fiscal year 2003. These holes were logged as requested, and log plots and log data reports were provided to the remedial investigation projects. In some cases, shallow boreholes were installed specifically for spectral gamma logging, and the results from these boreholes were used to identify locations for more detailed investigations.

\subsubsection{Characterization at the 200-PW-1 Operable Unit}

\section{J. Rohay}

Characterization of the carbon tetrachloride vadose zone plume was conducted during fiscal year 2003 as part of the remedial investigation for the 200-PW-1 Operable Unit. The 200-PW-1 Operable Unit waste sites received plutonium-rich and organic-rich waste from several processes located within the Plutonium Finishing Plant complex. A primary component of the organic-rich waste was carbon tetrachloride. The objective of the vadose zone investigation was to locate and characterize the sources of carbon tetrachloride contamination that presently impact groundwater, as well as known and suspect release sites with the potential to impact groundwater in the future.

Soil-vapor sampling and analysis was used to explore the upper vadose zone in the vicinity of the Plutonium Finishing Plant as Step I of the remedial investigation into the dispersed carbon tetrachloride plume at the 200-PW-1 Operable Unit. The sampling was conducted at engineered structures that had the potential to release carbon tetrachloride to the vadose zone. The engineered structures included liquid waste discharge pipelines, liquid waste discharge sites, and solid waste burial ground trenches. The vadose zone sampling was conducted using either the GeoProbe or cone penetrometer direct push technology. Sampling also was conducted through vent risers into the burial ground trenches. The analyses were conducted using a field-screening instrument. Characterization was performed in accordance with the 200-PW-1 Operable Unit Dispersed Carbon Tetrachloride Vadose Zone Plume Sampling and Analysis Plan - Step I (DOE-RL-2001-67).

The Step I soil-vapor sampling outside of the Plutonium Finishing Plant Protected Area was conducted between May and October 2002. The sampling methodology and 
results are available in the 200-PW-1 Operable Unit Report on Step I Sampling and Analysis of the Dispersed Carbon Tetrachloride Vadose Zone Plume (CP-13514) and are summarized in Section 3.1.1.3 of PNNL-14187. The Step I soil-vapor sampling inside the Plutonium Finishing Plant Protected Area was conducted in August 2003.

Soil-vapor samples were collected at 17 sites within the Plutonium Finishing Plant Protected Area (i.e., inside the fence) to investigate potential discharge of carbon tetrachloride-bearing waste to the soil column at those sites. A GeoProbe system was used for subsurface access. The maximum depth achieved using the GeoProbe was 14.5 meters. Samples were collected at depths of 4.6 and 7.6 meters and then increments of 7.6 meters until refusal.

Relatively low concentrations of carbon tetrachloride ( 1 to $4 \mathrm{ppmv}$ ) were detected in some samples collected at six of the sites. At each of the six sites, the highest concentration was detected in the deepest sample. The relatively low concentrations suggest that there are no active sources of contamination in the upper vadose zone at these locations.

\subsubsection{Characterization of the 200-CS-1 Operable Unit}

\section{S. Cearlock}

During fiscal year 2003, characterization activities were performed by Fluor Hanford, Inc. for DOE's Groundwater Remediation Project as part of the 200-CS-1 Operable Unit remedial investigation. The primary objective of the field effort was to characterize the nature and vertical extent of contamination in the vadose zone underlying the 216-A-29 ditch, 216-B-63 trench, and 216-S-10 ditch and pond. Borehole drilling, test pit excavation, surface and borehole geophysical surveys, and analysis of soil samples were conducted during the field activities. Analyses of soil samples are ongoing, and the results will be summarized in the fiscal year 2004 annual report.

Three boreholes were drilled and nine test pits excavated within the 200 Areas on the Hanford Site. One borehole (B8826) was located within the 216-A-29 ditch east of the AP Tank Farm in the 200 East Area. (Three test pits were completed at this location in fiscal year 2002 and details are provided in BHI-01651.) A second borehole (B8827) and two test pits were dug within the 216-B-63 trench, located east of B Tank Farm in the 200 East Area (Figure 3.1-5). The third borehole (B8828, well 299-W26-14) is adjacent to the 216-S-10 ditch, and three test pits were within the ditch located south of the 233-S Building in the 200 West Area (Figure 3.1-6). Four test pits are within the 216-S-10 pond (Figure 3.1-6). An additional test pit was excavated within the 216-S-10 ditch at the original location of the planned borehole B8828 to gather characterization data below the waste site. The borehole was moved adjacent to the ditch to allow it to be completed as a RCRA groundwater monitoring well. Borehole B8828 was completed as monitoring well 299-W26-14 to support RCRA monitoring needs.

A total of 64 samples were collected from the 9 test pits, and 50 split-spoon samples were collected from the boreholes. These samples are being analyzed for a variety of organic and inorganic constituents and radionuclides. The results of the analyses will become available in fiscal year 2004 and will be reported in the 2004 annual groundwater report.

Geophysical logging was completed at all three boreholes using spectral gamma and neutron-moisture detection methods. The only manmade radionuclide detected was cesium-137 in two of the three boreholes. In borehole B8826, at the 216-A-29 ditch, cesium-137 was detected between depths of 0.9 and 2 meters at concentrations up to

\section{Relatively low concentrations of carbon tetrachloride were detected in the vadose zone at the 200-PW-1 Operable}

Unit.

\section{Boreholes and test pits helped characterize the nature and vertical extent of contamination in \\ the vadose zone underlying the \\ 216-A-29 ditch, 216-B-63 trench, and 216-S-10 ditch and pond.}


$62 \mathrm{pCi} / \mathrm{g}$ (at 1.5 meters). Cesium-137 was found between depths of 1.2 and 3.3 meters in borehole B8827, at the 216-B-63 trench, with a maximum concentration of $22.4 \mathrm{pCi} / \mathrm{g}$ at 2.7 meters.

\subsubsection{Area Uranium Leach and Adsorption Studies}

\section{R. J. Serne, C. F. Brown, H. T. Schaef, E. M. Pierce, M. J. Lindberg, Z. Wang, P. L. Gassman, and J. G. Catalano}

\section{Results of laboratory experiments will be used to model uranium mobility to determine the soil cleanup level in the 300 Area.}

The results of laboratory experiments to measure the leaching and adsorption characteristics of uranium in near-surface sediment samples collected from the 300 Area of the Hanford Site were reported in fiscal year 2003 (PNNL-14022). The results will be used to model uranium mobility for the 300-FF-1 and 300-FF-2 Operable Unit waste sites to determine whether the soil cleanup level of 350 picocuries total uranium per gram of soil is protective of groundwater in the 300 Area. This section summarizes the results of the experiments. A complete discussion of the results and the experimental procedures can be found in PNNL-14022.

Uranium is the principal contaminant of concern in the 300 Area of the Hanford Site. Uranium leach rate and distribution coefficient values are key input for modeling contaminant mobility and predicting future impacts to groundwater. (Distribution coefficients are empirical measurements of the ability of sediment to adsorb a contaminant and, therefore, retard the migration of the contaminant through the vadose zone or groundwater.) Literature values for uranium distribution coefficients vary by as much as four orders of magnitude as functions of soil grain size, $\mathrm{pH}$, ionic strength, moisture content, organic matter, and mineralogy (Waite et al. 1994; Kaplan et al. 1998; Hsi and Langmuir 1985). Due to the large variability in uranium distribution coefficients reported in the literature, site-specific studies were performed with sediment from near the surface of the 300 Area.

Eight near-surface sediment samples were collected: three uncontaminated background samples, two uranium-contaminated samples from the 300 Area north process pond, and three uranium-contaminated samples from near the 303-K Building. Physical and chemical properties were characterized for all samples. A series of seven semiselective chemical extraction techniques were used to determine the percentage of uranium present as various phases in the samples. Table 3.1-2 shows the results of the selective extraction experiments. However, the uranium reported to be extracted by a specific step in the table may include uranium that was not completely extracted by a higher step in the table.

Table 3.1-2 shows that the uranium content in the background sediment is primarily bound tightly in crystalline minerals and is not extractable. The uranium extraction characteristic in samples from the 300 Area north process pond markedly differs from the background sediment. The majority of the uranium in samples from the 300 Area north process pond is present as uranyl carbonates and amorphous iron and aluminum hydrous oxides. About $10 \%$ to $20 \%$ of the uranium in the samples is leached with the organic matter.

The greatest amount of uranium removed from the samples from the 303-K Building area are associated with amorphous iron and aluminum oxyhydroxide phases followed by uranium associated with carbonates (other uranium [VI] compounds may also be dissolving in this step). Ten to fifteen percent of the total uranium is leached with the organic material.

All five contaminated samples contained uranium that was extractable mostly as uranyl carbonates and amorphous iron and aluminum oxyhydroxides. The next largest 
pool of uranium was associated with organic material. Less than a few percent of the total uranium was present in water-leachable and cation-exchangeable phases.

Characterization of the samples was followed by a series of flow-through column leach tests, long-term (154 days) static leach tests, batch adsorption tests, and column flow-through adsorption/desorption tests.

A series of large-column leach tests was done to determine the amount of uranium that could be removed by percolating air-saturated distilled water through the sediments. The results from the tests showed that uranium leaching did not follow a constant solubility pattern. Four of the five near-surface sediment samples showed a large, near instantaneous release of a few percent of the total uranium followed by a slower, continual release that lasted for several months. Steady-state uranium leachate concentrations were never attained, and leaching trends were not consistent among the samples. Dissolution kinetics were slow and the measured leach curves most likely represent slow, kinetically-controlled desorption or dissolution.

Long-term static batch leach tests were used to investigate whether steady-state uranium concentration could be attained, ultimately enabling the determination of a desorption distribution coefficient for the slowly leaching fraction observed in the large column leach tests. Aliquots of sediment were taken from the large leach columns, placed into three containers, and contacted with one of three leaching solutions (deionized water, uncontaminated groundwater, and simulated vadose zone porewater) to determine how much of the remaining uranium could be removed over a 6 -month period. Results from the batch leach test showed that $<4 \%$ of the remaining uranium mass was removed by deionized water, which represented rainwater. The groundwater solution was slightly more effective, leaching as much as $10 \%$ of the remaining uranium. The simulated vadose zone porewater solution was the most effective at leaching uranium, removing $\sim 30 \%$ of the residual total uranium mass in two out of the five contaminated samples.

Three batch adsorption experiments were done to investigate the effects of uranium solution concentration, $\mathrm{pH}$, and dissolved inorganic carbon concentration on uranium adsorption onto the uncontaminated sediment. Values of the uranium adsorption distribution coefficient ranged from $0 \mathrm{~mL} / \mathrm{g}$ to $>100 \mathrm{~mL} / \mathrm{g}$ depending on which solution parameter was adjusted.

Results showed that the solution parameter with the greatest impact on uranium adsorption was the dissolved inorganic carbon concentration. Uranium adsorption onto uncontaminated sediment ranged from $\sim 40 \%$ at $0.9 \mathrm{mM} \mathrm{HCO}_{3}^{-}$to $12 \%$ at $2.2 \mathrm{mM}$ $\mathrm{HCO}_{3}^{-}$in solutions with low uranium concentration $(500 \mu \mathrm{g} / \mathrm{L})$. Considerable less sorption was seen in the solution with high uranium concentration $(3,000 \mu \mathrm{g} / \mathrm{L})$, with a range of $\sim 7 \%$ at $2.5 \mathrm{mM} \mathrm{HCO}_{3}^{-}$to $0 \%$ at $12 \mathrm{mM} \mathrm{HCO}_{3}$. The concentration of uranium in solution appeared to have no effect on the uranium distribution coefficient values, a requirement for the use of the linear adsorption isotherm, or distribution coefficient model.

Solution pH was shown to be important in laboratory tests; however, in the field the natural sediment buffers the $\mathrm{pH}$ to a nearly constant value, thus minimizing its overall effect. Results from the batch adsorption tests also showed that uranium sorption onto the background sediment is linear up to uranium concentrations of $3 \mathrm{mg} / \mathrm{L}$ (holding all other parameters constant), which is well above the values found in the upper unconfined aquifer. Thus, the linear isotherm assumption holds for uranium in the 300 Area sediment/porewater environment.

The chemical composition of vadose zone porewater and groundwater in the 300 Area is not constant. Carbonate concentration, pH, and other constituents vary in space and time because of evapotranspiration, transient rain fall/snow events, and changes in river stage. Therefore, the distribution coefficient for uranium (VI) is not a
The solution parameter with the greatest impact on uranium adsorption was the concentration of dissolved inorganic carbon. 


\section{Uranium sorption onto uncontaminated sediment in the 300 Area is highly variable.}

constant even though the adsorption of uranium (VI) from a solution with fixed composition follows the linear isotherm. Therefore, the linear distribution coefficient model, but not the constant distribution coefficient model, is defensible in predicting the fate of uranium in the 300 Area aquifer plume.

Column adsorption tests were done to assess the sorption of uranium onto the background sediment. This test most closely predicts the fate of uranium-contaminated solutions once they come into contact with "clean" or uncontaminated sediment. Uranium adsorption distribution coefficient values ranged from $1.85 \mathrm{~mL} / \mathrm{g}$ in a low ionic strength solution $(500 \mu \mathrm{g} / \mathrm{L})$ to $0.86 \mathrm{~mL} / \mathrm{g}$ in a high ionic strength solution $(3,000 \mu \mathrm{g} / \mathrm{L})$.

Uranium sorption onto uncontaminated sediment in the 300 Area is highly variable and depends on solution conditions. Therefore, predicted distribution coefficient values based on site-specific conditions expected in the 300 Area range from a low of 0 to $1 \mathrm{~mL} / \mathrm{g}$ in the near-surface vadose zone (which is influenced by evapotranspiration) to 2 to $4 \mathrm{~mL} / \mathrm{g}$ in unconfined aquifer sediment that is not influenced by dilution with Columbia River water. (For purposes of comparison, a highly mobile constituent such as technetium-99 will have distribution coefficients between $\sim 0$ and $0.1 \mathrm{~mL} / \mathrm{g}$ and a highly immobile constituent such as cesium-137 or lead will have distribution coefficients in excess of 1,000 mL/g [PNNL-13895]). Although not studied in detail, adsorption distribution coefficient values in the saturated aquifer, where dilution due to river water is present (lower total carbonate solution concentration), could be in excess of $7 \mathrm{~mL} / \mathrm{g}$. 
Table 3.1-1. Summary of Significant Borehole Logging Results from Fiscal Year 2003 Characterization Boreholes at the T and TX Tank Farms

\begin{tabular}{|c|c|c|c|c|}
\hline Borehole & Isotope & $\begin{array}{c}\text { Depths of } \\
\text { Occurrence (m) }\end{array}$ & $\begin{array}{c}\text { Maximum } \\
\text { Concentration }(\mathrm{pCi} / \mathrm{g}) \\
\end{array}$ & $\begin{array}{c}\text { Depth of } \\
\text { Maximum }(\mathrm{m})\end{array}$ \\
\hline \multirow[t]{5}{*}{ C4104 } & Cesium-137 & $\begin{array}{c}0-5.5 \\
15-15.5\end{array}$ & 38 & 15.1 \\
\hline & Europium-154 & $10.8-26$ & 1,960 & 15.1 \\
\hline & Europium-152 & $11.3-24.8$ & 49 & 14.5 \\
\hline & Tin-126 & $13.2-15.4$ & 33 & 15.1 \\
\hline & Cobalt- 60 & $11.1-38.8$ & 58 & 28.5 \\
\hline \multirow[t]{3}{*}{ C4105 } & Cesium-137 & Intermittent depths & 0.4 & 0.15 \\
\hline & Cobalt- 60 & $14.8-37.2$ & 15 & 32.6 \\
\hline & Europium-154 & $\begin{array}{l}14.8-15.5 \\
17.5-20.3\end{array}$ & 21 & 20.3 \\
\hline C3830 & Cesium-137 & $0-3.4$ & 7.5 & 0.3 \\
\hline \multirow[t]{2}{*}{ C3831 } & Cesium-137 & $0-1.2$ & $<2.5$ & $0-1.2$ \\
\hline & Cobalt -60 & $15.8-34.9$ & 61 & 18.7 and 20.9 \\
\hline \multirow[t]{3}{*}{ C3832 } & Cesium-137 & $\begin{array}{c}0-0.3 \\
1.2-1.4\end{array}$ & 0.5 & 0.2 \\
\hline & Cobalt- 60 & $22.9-35.0$ & 1.2 & 24.2 \\
\hline & Uranium-238 & $30.5-33.2$ & 15 & 32.3 \\
\hline
\end{tabular}

Table 3.1-2. Selective Extraction Results for Uranium in Six Near-Surface Sediment Samples ( $\%$ of total uranium removed by each extraction)

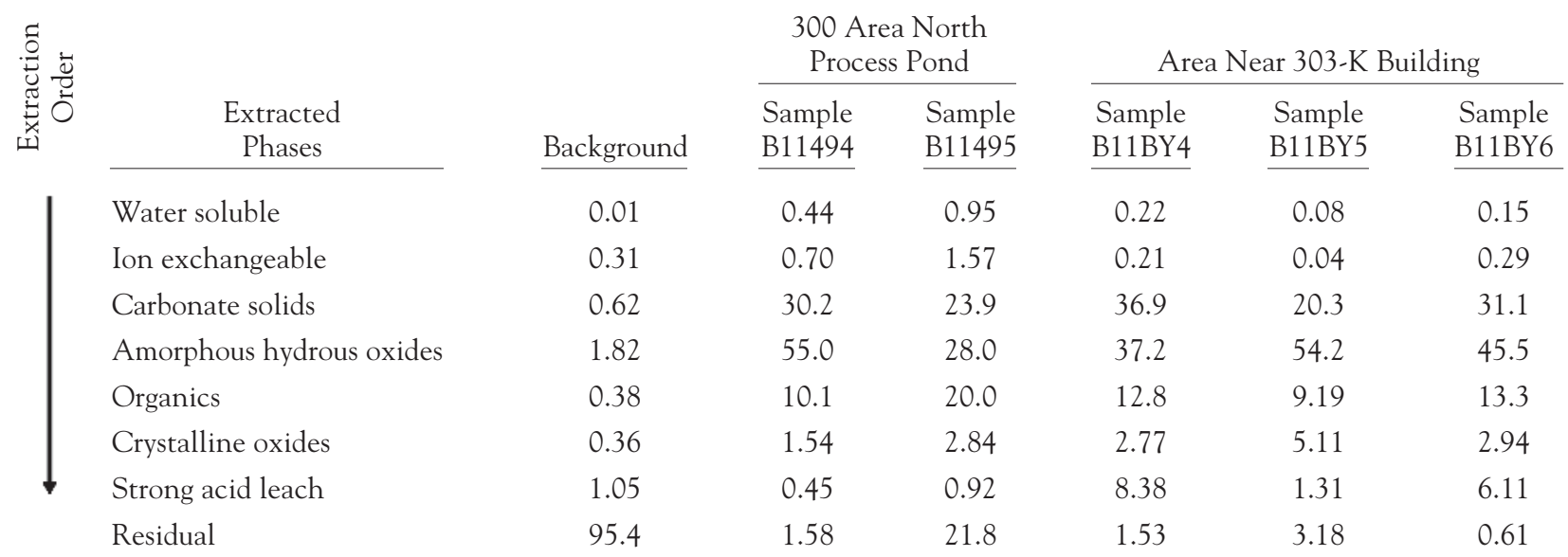


C3831

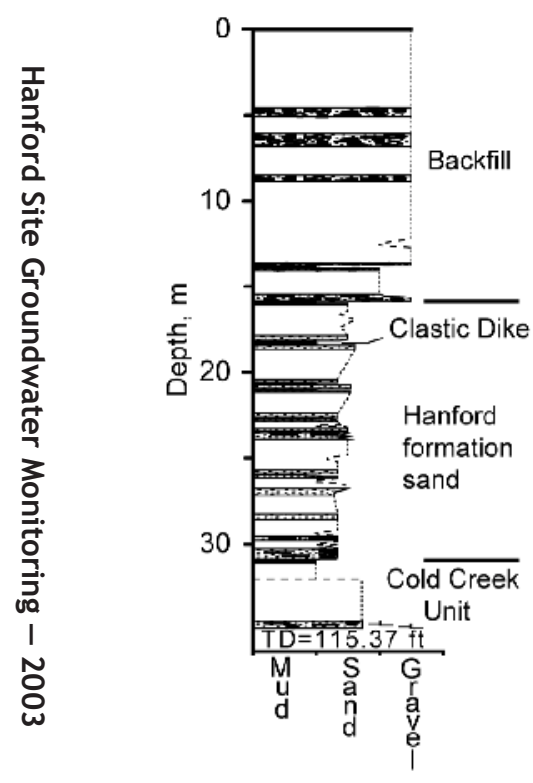

- Fine-Grained Laye - Inferred Lithology $\leftarrow$ Pedogenic $\mathrm{CaCO}_{3}$
Conductivity

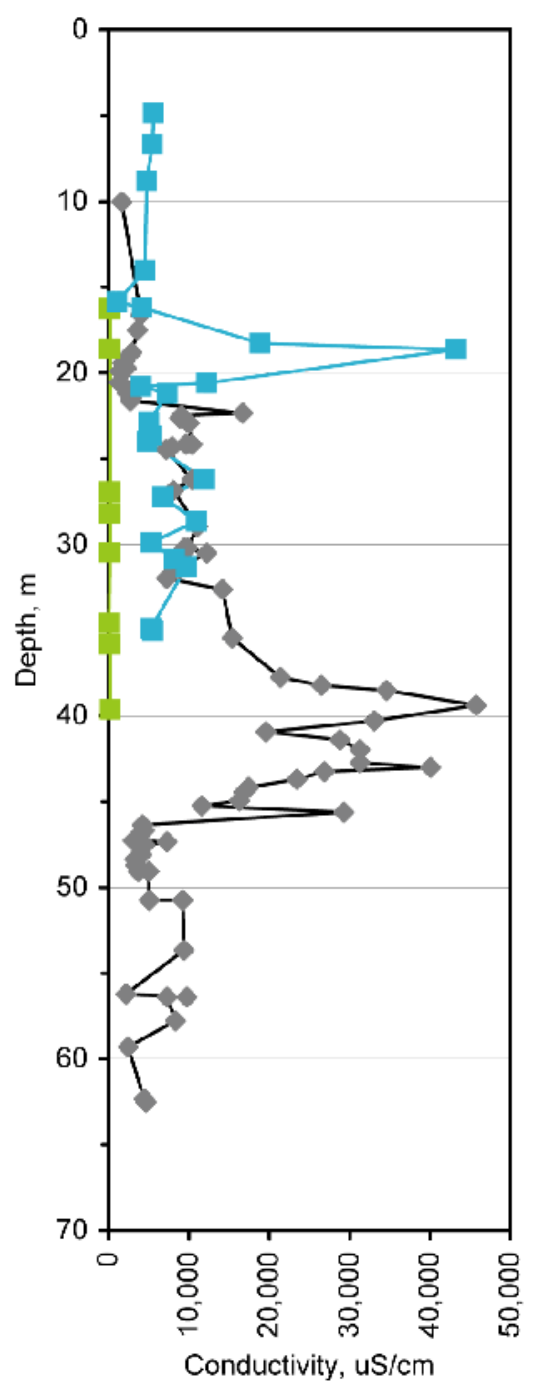

$\mathrm{pH}$
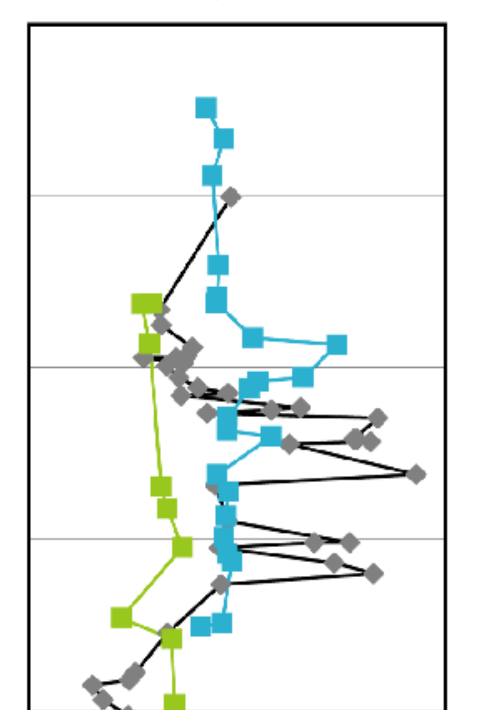

6
299-W10-27

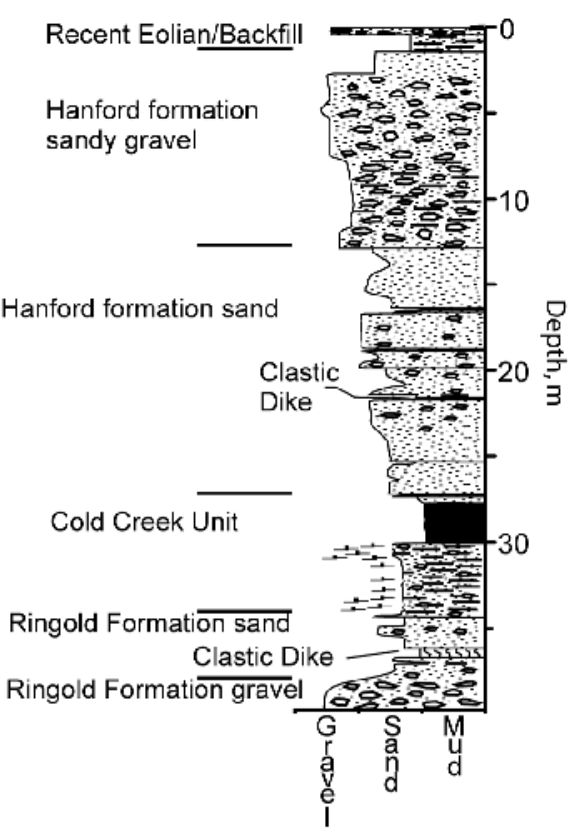

- Fine-Grained Layer

- Pedogenic $\mathrm{CaCO} 3$

Figure 3.1-1. Electrical Conductivity and $\mathrm{pH}$ versus Depth in Characterization Borehole C3831 at TX Tank Farm 


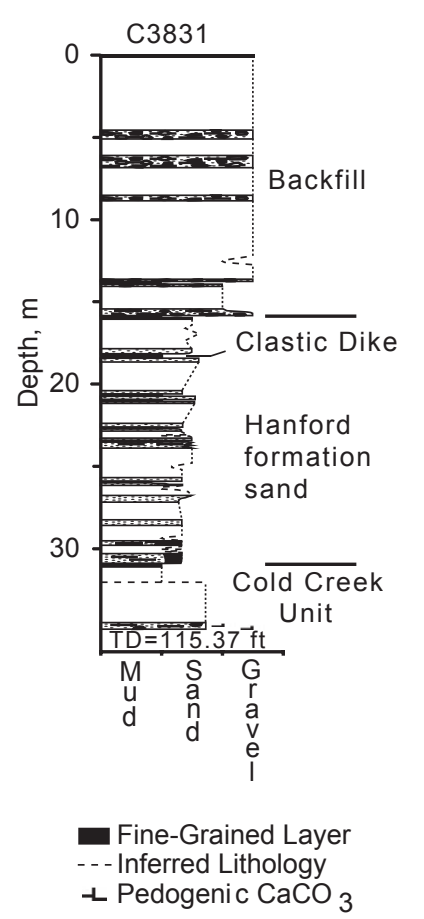

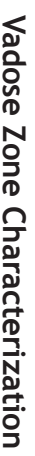
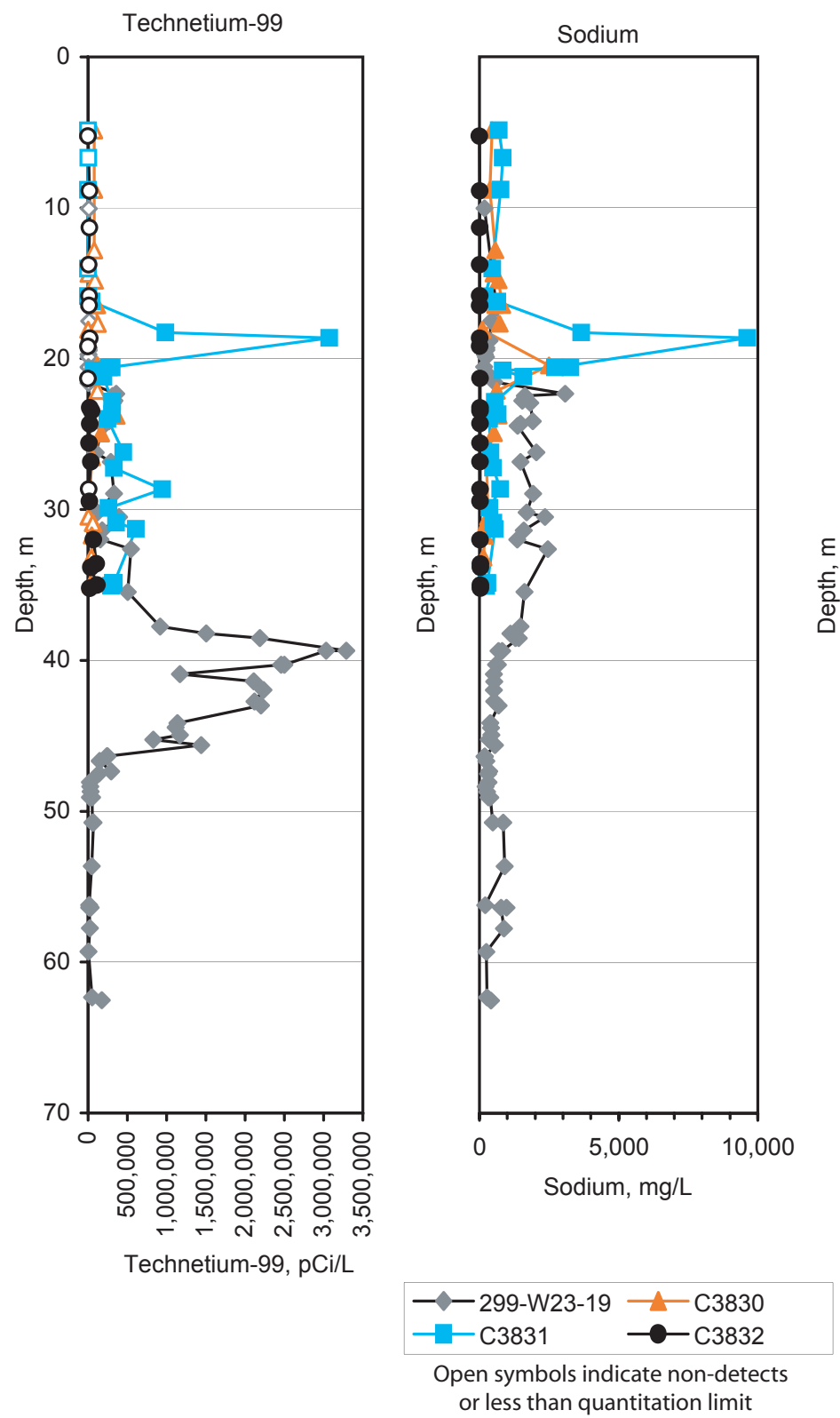

299-W23-19 (B8809)

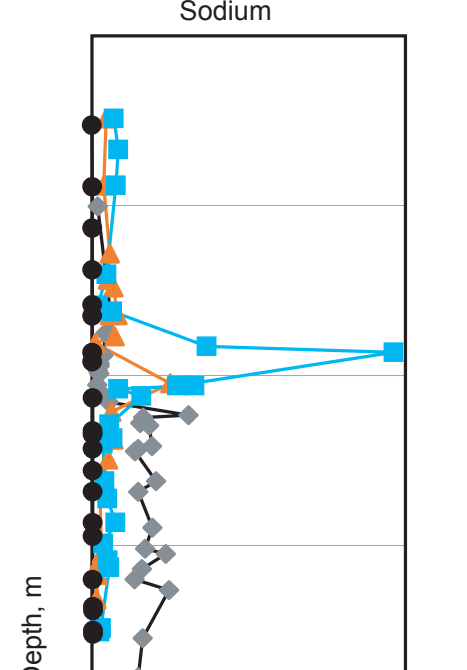

产

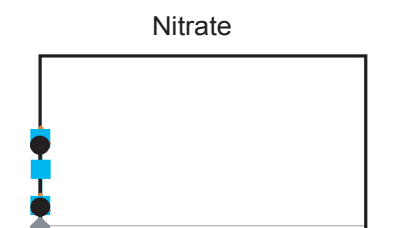

Backfil

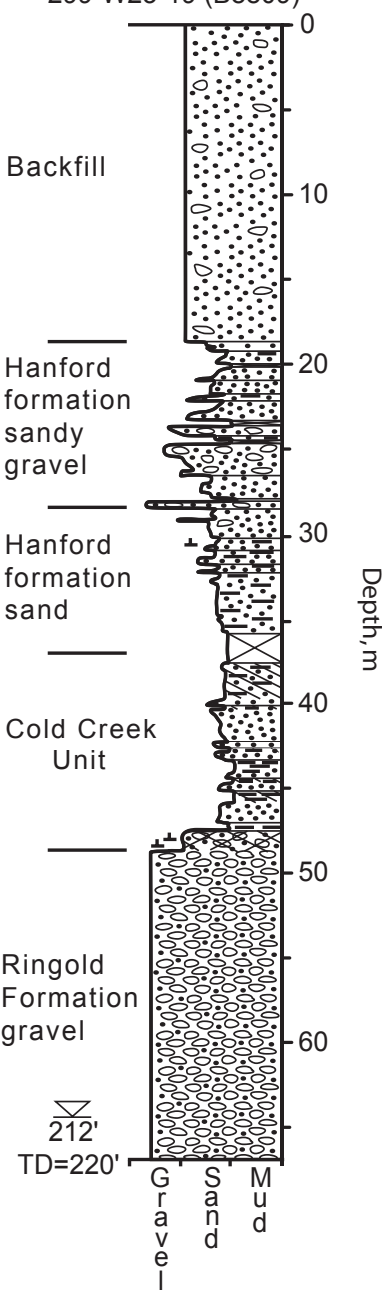

$\square$ No Core + Calcic Paleosol: $\square$ Weak $\square$ Strong

Figure 3.1-2. Concentrations of Contaminant Indicators Technetium-99, Nitrate, and Sodium versus Depth in Characterization Boreholes at TX Tank Farm 


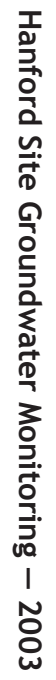

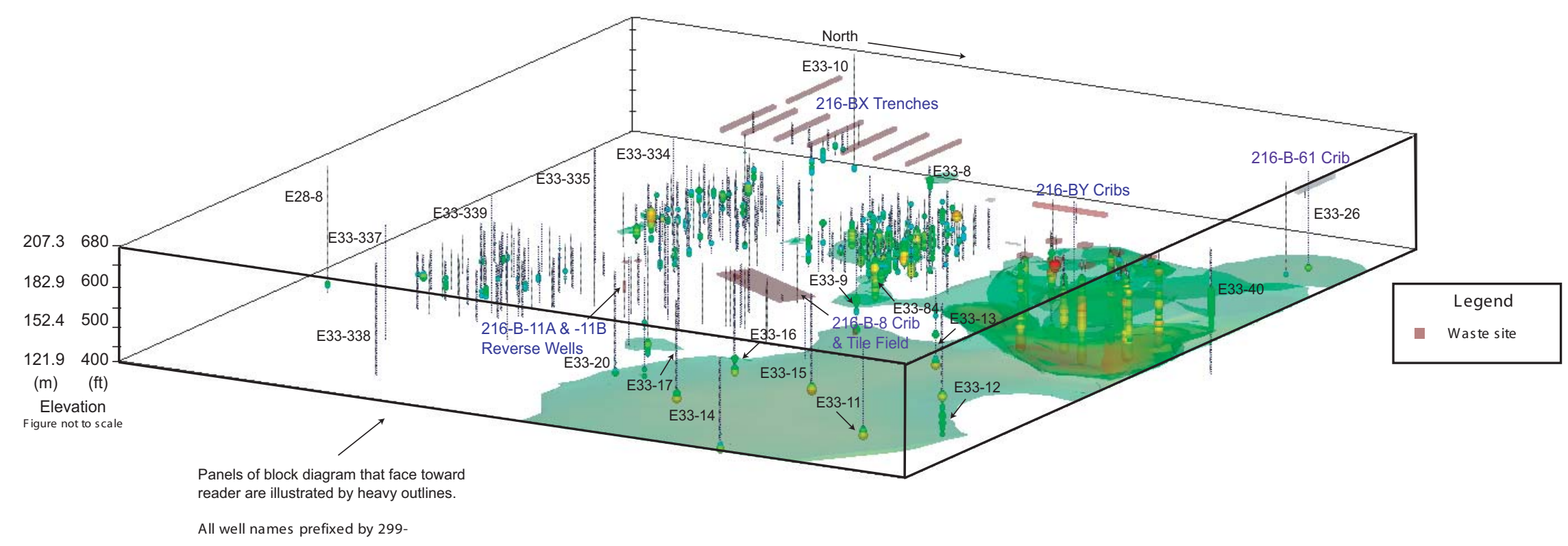

Isolevel $=0.1$

Co-60 Concentration (pCi/g)

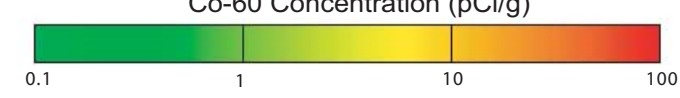

gwf03487

Figure 3.1-3. Cobalt-60 Contamination in the Vadose Zone Near Waste Management Area B-BX-BY 


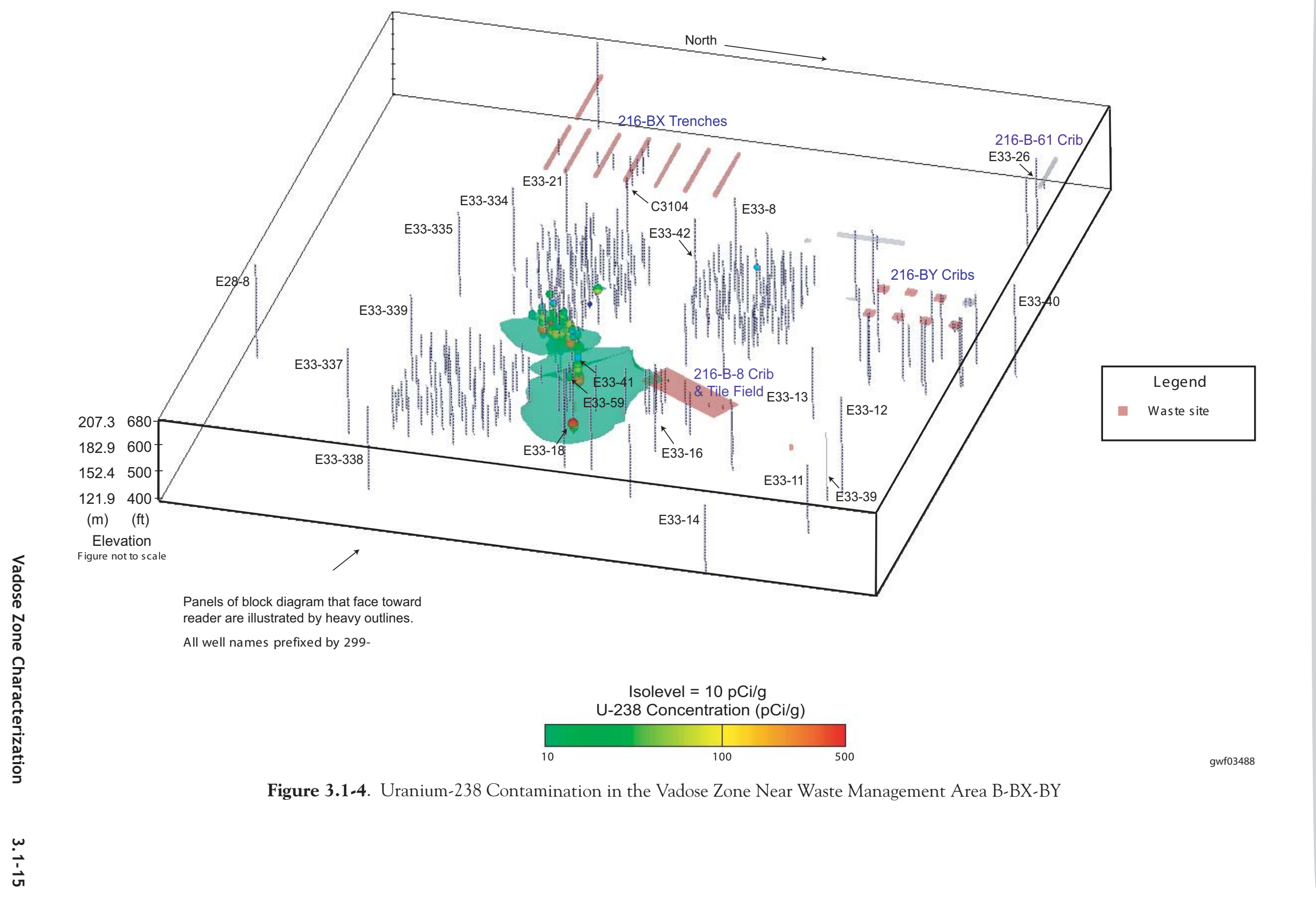




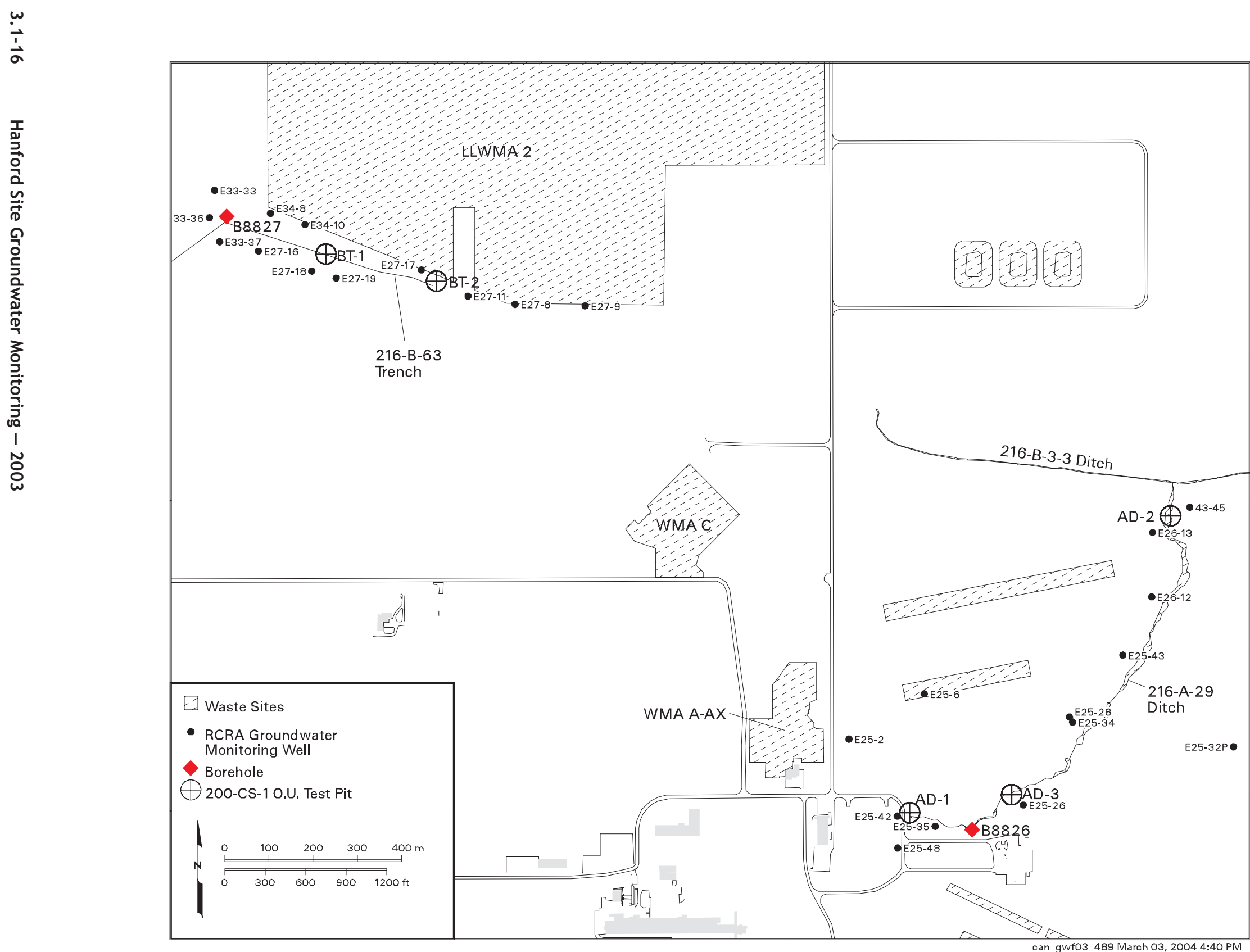

Figure 3.1-5. Locations of Boreholes and Test Pits (designated BT) for Characterization of the 216-A-29 Ditch and 216-B-63 Trench 


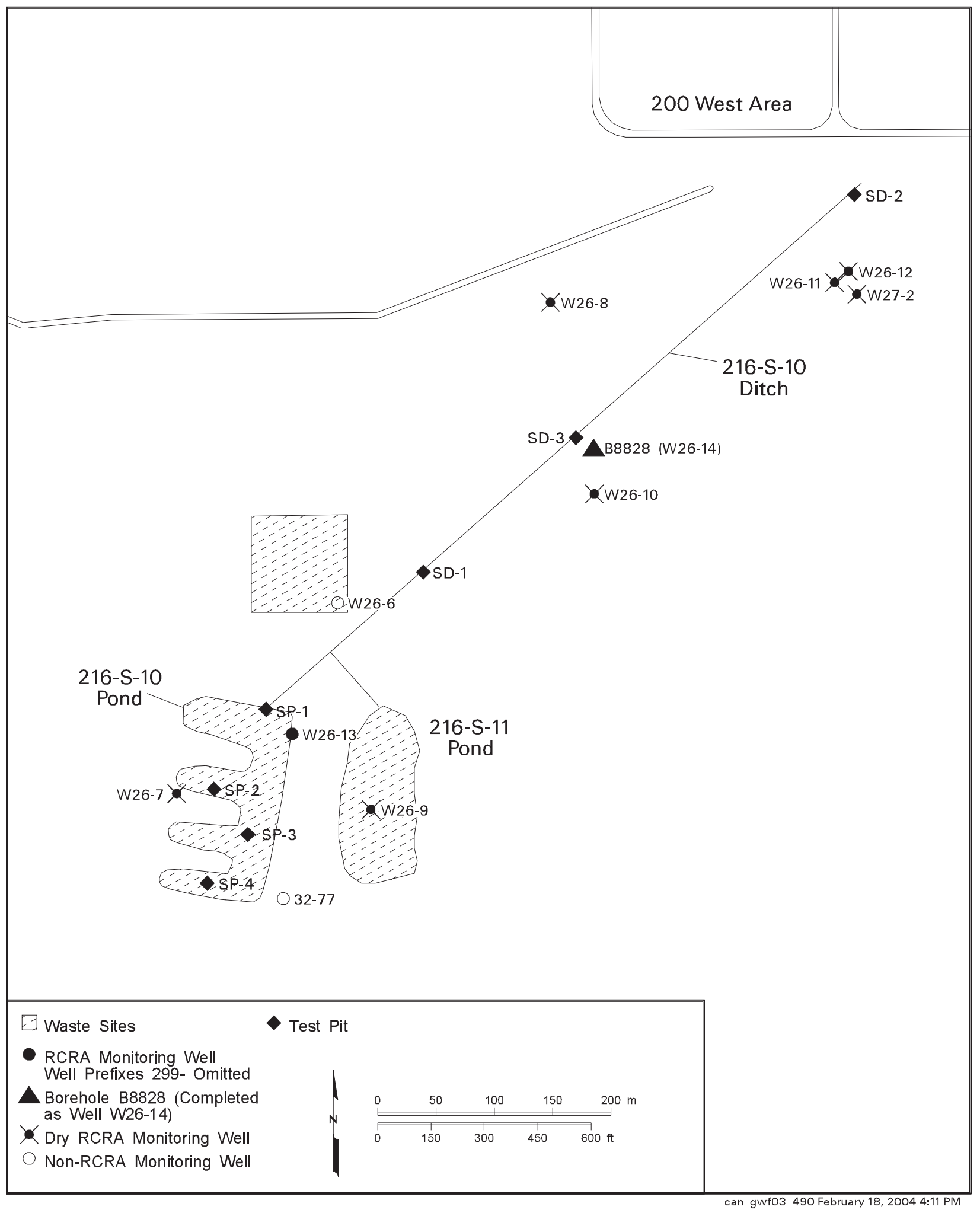

Figure 3.1-6. Locations of Borehole B8828 and Test Pits (designated SP and SD) at the 216-S-10 Ditch and Pond System 


\subsection{Vadose Zone Monitoring}

\section{G. Horton}

Vadose zone monitoring occurred at four major areas on the Hanford Site in fiscal year 2003. Leachate and soil-gas monitoring continued at the Solid Waste Landfill and the Environmental Restoration Disposal Facility. Also, soil-gas monitoring at the carbon tetrachloride expedited-response-action site continued during fiscal year 2003. Finally, geophysical borehole monitoring continued at single-shell tank farms for leak detection and to determine subsurface contaminant migration. This section summarizes these vadose zone monitoring activities.

\subsubsection{Leachate and Soil-Gas Monitoring at the Solid Waste Landfill}

\section{R. A. Del Mar}

The Solid Waste Landfill is a disposal facility in the center of the Hanford Site (part of the Central Landfill illustrated on Figure 2.1-2). The landfill covers an area of $\sim 26.7$ hectares and began operating in 1973 to receive non-hazardous, non-radioactive sanitary waste generated from Hanford Site operations. The Solid Waste Landfill stopped receiving waste in 1996 and an "interim cover" consisting of 0.6 to 1.2 meters of soil was placed over all trenches. Current monitoring at the Solid Waste Landfill consists of quarterly sampling of groundwater, soil gas, and leachate. Recent groundwater monitoring results are discussed in Section 2.11.5.2. This section summarizes leachate and soil-gas monitoring results.

In all, the Solid Waste Landfill consists of $~ 70$ single trenches and 14 double trenches. Based on trench geometry and the thickness of the waste layer, the capacity of a trench per linear foot is 8.4 cubic meters for the single trenches and 30.6 cubic meters for the double trenches. Based on this estimate, total design capacity of the Solid Waste Landfill is $\sim 596,400$ cubic meters.

One of the double trenches overlies a lined, basin lysimeter designed to collect leachate generated by infiltration through the overlying refuse. This lysimeter covers an area of $\sim 88$ square meters. A discharge pipe continuously drains leachate by gravity flow from the basin to a nearby collection pump. However, leachate collected from this lysimeter may not be representative of leachate drainage throughout the entire landfill area because the lysimeter only collects leachate from 1 of 84 trenches, and is installed under one of the newer trenches built after implementation of regulations that restrict land disposal practices. Still, the lysimeter provides some indication of the rate of infiltration and some of the contaminants that may be reaching groundwater.

Leachate is collected from the basin lysimeter every 10 to 14 days. Figure 3.2-1 shows the rate of leachate generated over the past 4 years. Prior to calendar year 2003, the generation rate was consistently between 4 to 8 liters per day. However, during calendar year 2003, the generation rate jumped to $>19$ liters per day. This increase is mainly attributed to above average rainfall recorded at the Hanford Site during the winter of 2002/2003. The Hanford Meteorological Station recorded 12.6 centimeters of rain during the 3-month period from December 2002 through February 2003. This was more than a 90\% increase over the 3-month winter average of 6.5 centimeters recorded at the Hanford Site dating back to 1946. Drainage from the winter rainfall started showing up in the lysimeter collection tank in late April 2003.

The landfill leachate is sampled quarterly for indicator parameters and site-specific contaminants.

\section{Leachate is} collected beneath part of the Solid Waste Landfill. The volume of leachate increased in fiscal year 2003

because of increased precipitation. 


\section{Concentrations of}

some constituents

have been

increasing in

leachate from the

Environmental

Restoration

Disposal Facility.
During fiscal year 2003, several analytes continued to be found in the landfill leachate in concentrations above WAC 173-200 groundwater quality criteria. These constituents include arsenic, manganese, nickel, iron, 1,4-dioxane, 1,4-dichlorobenzene, and tetrachloroethene. In addition, the indicator parameters chloride and total dissolved solids exceeded groundwater quality criteria in fiscal year 2003.

Soil-gas monitoring at the Solid Waste Landfill uses eight shallow monitoring stations located around the perimeter of the landfill. Each station consists of two soil-gas probes at depths of $\sim 2.75$ and 4.6 meters. Soil gas is monitored quarterly to determine concentrations of oxygen, carbon dioxide, methane, and several key volatile organic compounds. No contaminants of concern were discovered above reporting limits during the reporting period.

\subsubsection{Leachate Monitoring at the Environmental Restoration Disposal Facility}

\section{A. St. John and R. L. Weiss}

Bechtel Hanford, Inc. operates the Environmental Restoration Disposal Facility to dispose of radioactive, hazardous or dangerous, and mixed waste generated during waste management and remediation activities at the Hanford Site. In fiscal year 2003, Bechtel Hanford, Inc. published the results of groundwater monitoring and sampling at the Environmental Restoration Disposal Facility during the calendar year 2002 (BHI-01684). Part of the published results contains laboratory analyses of leachate collected from beneath the facility. This section discusses those results.

The Environmental Restoration Disposal Facility began operation in July 1996. Located between the 200 East and 200 West Areas (see Appendix C, Figure C.5), the facility is currently operating two disposal cells that became active during June 2000. Through calendar year 2002, 3.5 million metric tons of remediation waste have been disposed at the facility since operations began in July 1996.

Each disposal cell is lined to collect leachate that is a result of water added as a dust suppressant and natural precipitation. Leachate is pumped from the sumps beneath the cells to tanks. After $\sim 760,000$ liters of leachate are collected, samples are taken and analyzed to provide an inventory to the Effluent Treatment Facility, where the leachate is disposed, and to provide semiannually sampling of leachate for delisting analyses. The purpose of the delisting analyses is to enable handling the leachate as non-hazardous waste. The results are also used to determine whether additional constituents should be added to the groundwater monitoring list of contaminants of concern.

Composite leachate samples were collected in duplicate in June and December 2002. Leachate samples contained detectable concentrations of common metals, anions, and mobile radionuclides. Constituents that were generally increasing in concentration since calendar year 2000 include selenium, nitrate, gross alpha, gross beta, carbon-14, and technetium-99 and total uranium:

- Until June 2001, concentrations of selenium were non-detectable. Since June 2001, the concentration of selenium has gradually increased to an average of $9.6 \mu \mathrm{g} / \mathrm{L}$ during 2003.

- Nitrate concentration which averaged $\sim 260 \mathrm{mg} / \mathrm{L}$ from 2000 to 2002, increased somewhat to an average of $348 \mathrm{mg} / \mathrm{L}$ in 2003.

- Gross alpha averaged $121 \mathrm{pCi} / \mathrm{L}$ from 2000 through 2002. June 2003 values for gross alpha were non-detects, and December 2003 values for gross alpha averaged 556 pCi/L.

- Gross beta concentrations remained fairly stable until June 2001. Since that time, gross beta concentrations have been increasing to an average of $1,050 \mathrm{pCi} / \mathrm{L}$ in December 2002. The increasing gross beta is consistent with increasing technetium-99. 
- The first detectable carbon-14 values were reported in December 2002 at an average value of $30.4 \mathrm{pCi} / \mathrm{L}$.

- Technetium-99 concentrations have been increasing slightly since first reported in June 2001. The average technetium-99 concentration for December 2002 was $1,265 \mathrm{pCi} / \mathrm{L}$.

- Uranium concentration remained stable from December 2000 through December 2001. In calendar year 2002, uranium concentration increased to an average of $824 \mathrm{pCi} / \mathrm{L}$ in December 2002.

The analyses for selenium, nitrate, gross alpha, gross beta, carbon-14, technetium-99, and uranium showed possible increasing concentration trends over the past 3 years. Groundwater monitoring data for these constituents were examined to determine whether the Environmental Restoration Disposal Facility has affected groundwater. In all cases, groundwater concentrations for these constituents remained stable or decreased. Based on this comparison, it appears that the Environmental Restoration Disposal Facility leachate has not had an impact on groundwater at this location.

The target constituents for the groundwater monitoring program are consistent with the leachate monitoring program. At this time, no additional constitutes are recommended for addition to the groundwater monitoring program at the Environmental Restoration Disposal Facility landfill based on that evaluation.

Vadose Zone Monitoring Study at the Environmental Restoration Disposal Facility. In 2002, DOE, EPA, and Ecology agreed to fund a study of vadose zone monitoring at the Hanford Site. The first part of that study (DOE/RL-2003-31) was completed in fiscal year 2003 and evaluated the potential for vadose zone monitoring at the Environmental Restoration Disposal Facility. The second part of the study, to be completed in fiscal year 2004, will evaluate the potential use of vadose zone monitoring at other places on the Central Plateau.

The fiscal year 2003 study recommended that a monitoring system be incorporated into the design of the final caps to be placed over the Environmental Restoration Disposal Facility cells when they are closed. Strategically placed lysimeters and topographic methods to evaluate the integrity of landfill covers were recommended.

The study also concluded that the addition of vadose zone monitoring during the operational phase of the double-lined Environmental Restoration Disposal Facility cells is not required or necessary. However, for newly constructed cells, it was recommended that basin lysimeters be installed below the sumps and that perforated access tubes be installed below the secondary liner and admix layer. Such monitoring systems would provide information on the expected performance of vadose zone monitoring systems and their potential use in future disposal facilities at the Hanford Site. Data collected from the systems could be used to evaluate the vadose zone systems and would not be part of the performance monitoring for the Environmental Restoration Disposal Facility cells.

\subsubsection{Vadose Zone Monitoring at Single-Shell Tank Farms}

\section{R. G. McCain}

The S.M. Stoller Corporation is responsible for borehole geophysical logging at the Hanford Site. From 1995 to 2000, spectral gamma logs from 769 existing monitoring boreholes in the single-shell tank farms were used to characterize the subsurface contamination in the vicinity of the farms. Based on the characterization data, a comprehensive monitoring project for existing boreholes in the single-shell tank farms was established in fiscal year 2001. This project uses the radionuclide assessment system to detect subsurface contaminant plumes and/or movement of existing plumes in the immediate vicinity of the single-shell tanks. Gamma activity levels detected by the radionuclide assessment system

\section{Routine vadose zone monitoring determines if contamination is moving beneath the tanks.}




\section{Soil-vapor extraction is being used to remove carbon tetrachloride from the vadose zone in the 200 West Area.}

are compared against previous data and against the baseline contamination conditions established from the characterization project between 1995 and 2000. By comparing gamma activity between subsequent logging runs, it is possible to identify changes that may indicate contaminant migration of new or existing plumes. Log data and reports are accessible via the internet at http:/www.gjo.doe.gov/programs/hanf/HTFVZ.html.

The intent of the routine monitoring project is to measure gamma activity in each of the 769 existing boreholes in the 12 single-shell tank farms at least once in a 5-year period. Some boreholes have been selected for more frequent monitoring: yearly, semiannually, or quarterly. Monitoring frequency for each borehole is determined by its proximity to known or suspected subsurface contaminant plumes, proximity to tanks classified as leaking, and proximity to tanks known to contain relatively large volumes of drainable liquid. Monitoring results are corrected for radioactive decay when necessary and compared against previous results and against the baseline to determine if statistically significant changes have occurred. Routine monitoring results are summarized on a quarterly basis. Anomalies are investigated using additional logging tools, and a special report or memorandum may be issued if warranted.

During fiscal year 2003, monitoring operations were performed in a limited number of boreholes within each of the 12 single-shell tank farms. In general, contaminant plumes identified by baseline characterization activities appear to be stable over time.

Also in fiscal year 2003, monitoring of subsurface gamma activity and moisture content was performed in support of retrieval operations at tanks U-107, C-106, and S-112. Monitoring gamma activity and moisture content in existing boreholes in the immediate vicinity of the tank is a way to detect leaks during retrieval operations. Geophysical logs were run immediately prior to retrieval operations to provide a preretrieval baseline. During retrieval operations, both spectral gamma logs and neutron moisture logs are collected on a monthly basis. Both types of logs are collected again within a month of completing the retrieval operations and on a quarterly basis thereafter. Additional moisture measurements over limited depth intervals are made by tank farm personnel using hand-held moisture gauges, at a frequency of once per week.

At the end of fiscal year 2003, the saltcake dissolution studies in tank U-107 had been completed and retrieval operations were ongoing in tanks C-106 and S-112. No evidence of leakage associated with retrieval operations was detected.

\subsubsection{Carbon Tetrachloride Monitoring and Remediation}

\section{J. Rohay}

Soil-vapor extraction is being used to remove carbon tetrachloride from the vadose zone in the 200 West Area. The U.S. Environmental Protection Agency and the Washington State Department of Ecology authorized the U.S. Department of Energy to initiate this remediation in 1992 as a Comprehensive Environmental Response, Compensation, and Liability Act (CERCLA) expedited response action. The following discussion summarizes fiscal year 2003 activities associated with the carbon tetrachloride removal. For descriptions of past work, see BHI-00720, WMP-17869, and Section 3.2.3 in PNNL-14187. See Figure 3.2-2 for locations of vapor extraction wells.

The 14.2-cubic-meter-per-minute soil-vapor extraction system operated at the combined 216-Z-1A/216-Z-12/216-Z-18 well field from April 1 through September 30, 2003. The soil-vapor extraction system was not operated at the 216-Z-9 well field during fiscal year 2003 to avoid interfering with characterization sampling that was conducted during drilling of a well at that site. The system was maintained in standby 
mode from October 1, 2002 through March 31, 2003. The 28.3- and 42.5-cubic-meterper-minute soil-vapor extraction systems were not maintained in standby mode during fiscal year 2003. Temporarily suspending soil-vapor extraction operations at each well field allows the carbon tetrachloride concentrations to recharge and be more economically extracted when operations resume.

To track the effectiveness of the remediation effort, soil-vapor concentrations of carbon tetrachloride were monitored at the inlet to the soil-vapor extraction system and at individual online extraction wells during the 6-month operating period. To assess the impact of the soil-vapor extraction system on subsurface concentrations, soilvapor concentrations of carbon tetrachloride were monitored at off-line wells and probes during the entire fiscal year.

Remediation efforts during fiscal year 2003 also included passive soil-vapor extraction.

\subsubsection{Soil-Vapor Extraction}

Soil-vapor extraction to remove carbon tetrachloride from the vadose zone resumed April 1, 2003 at the combined 216-Z-1A/216-Z-12/216-Z-18 well field. Initial online wells were selected within the perimeter of the 216-Z-1A tile field. As extraction continued, wells farther away from the tile field were brought online. Extraction wells open near the less-permeable Cold Creek unit, where the highest carbon tetrachloride concentrations have consistently been detected in the past, were selected to optimize mass removal of contaminant. Initial carbon tetrachloride concentrations measured at the soil-vapor extraction inlet were $\sim 20$ parts per million vapor (ppmv) (Figure 3.2-3). After 3 weeks of extraction, additional wells were added to the system and concentrations increased to nearly 30 ppmv. After 26 weeks of extraction, concentrations had decreased to $\sim 15$ ppmv.

As of September 2003, 78,100 kilograms of carbon tetrachloride have been removed from the vadose zone since extraction operations started in 1991 (Table 3.2-1). Since initiation, the extraction systems are estimated to have removed $7 \%$ of the residual mass at 216-Z-1A/216-Z-12/216-Z-18 well field and 22\% of the mass at 216-Z-9 well field. This estimate assumes that all of the mass that has not been lost to the atmosphere ( $21 \%$ of the original inventory), dissolved in groundwater ( $2 \%$ of the original inventory), or biodegraded ( $1 \%$ of the original inventory) is still available in the vadose zone as residual mass (WMP-17869; WHC-SD-EN-TI-101).

\subsubsection{Monitoring at Off-Line Wells and Probes}

During fiscal year 2003, soil-vapor concentrations of carbon tetrachloride were monitored near the ground surface, near the Cold Creek unit ( 40 meters below ground surface), and near groundwater ( $\sim 66$ meters below ground surface). Soil-vapor concentrations were monitored near the ground surface and groundwater to evaluate whether non-operation of the soil-vapor extraction system negatively affects the atmosphere or groundwater. The maximum concentration detected near the ground surface (between 2 and 10 meters below ground surface) was 22 ppmv. Near the groundwater, at a depth of 55 meters below ground surface, the maximum concentration was 26 ppmv.

Soil-vapor concentrations also were monitored above and within the Cold Creek unit to provide an indication of concentrations that could be expected during restart of the soil-vapor extraction system. The maximum concentration detected near the Cold Creek unit (between 25 and 44 meters below ground surface) was 444 ppmv in well 299-W15-217 (35 meters below ground surface) adjacent to the 216-Z-9 trench. During monitoring in fiscal years 1997, 1998, 1999, 2000, and 2001, the highest carbon tetrachloride concentrations also were detected in this well. Approximately 90 meters south of the 216-Z-9 trench, the maximum carbon tetrachloride concentration detected was 235 ppmv at soil-vapor probe CPT-28 (27 meters below ground surface). Approximately 200 meters north of the 216-Z-9 trench, the maximum carbon tetrachloride
Approximately 78,100 kilograms of carbon tetrachloride have been removed from the vadose zone since extraction operations started in 1991. 


\section{Passive soil-vapor extraction uses naturally-induced pressure gradients to drive soil vapor to the surface.}

concentration detected was $36 \mathrm{ppmv}$ at soil vapor probe CPT-9A (18 meters below ground surface). The maximum carbon tetrachloride concentration detected in the vadose zone overlying the Cold Creek unit (between 11 and 23 meters below ground surface) was 90 ppmv at soil vapor probe CPT-21A (14 meters below ground surface) near the 216-Z-9 trench.

At the 216-Z-1A/216-Z-12/216-Z-18 well field, the maximum carbon tetrachloride concentration detected near the Cold Creek unit was 328 ppmv in well 299-W18-165 (33 meters below ground surface) within the 216-Z-1A tile field. During monitoring in fiscal years 1997 through 2002, the highest carbon tetrachloride concentrations in the 216-Z-1A/216-Z-12/216-Z-18 well field also were detected at wells within the 216-Z-1A tile field.

The temporary suspension of soil-vapor extraction in fiscal year 2003 appears to have caused minimal detectable vertical transport of carbon tetrachloride through the soil surface to the atmosphere. This interpretation is supported by data that show carbon tetrachloride concentrations did not increase significantly at the near-surface monitoring probes. In addition, suspending operations of the soil-vapor extraction system appears to have had no negative impact on groundwater quality, because carbon tetrachloride concentrations did not increase significantly near the water table during that time.

\subsubsection{Passive Soil-Vapor Extraction}

Passive soil-vapor extraction is a remediation technology that uses naturally-induced pressure gradients between the subsurface and the surface to drive soil vapor to the surface. In general, falling atmospheric pressure causes subsurface vapor to move to the atmosphere through wells, whereas rising atmospheric pressure causes atmospheric air to move into the subsurface. Passive soil-vapor extraction systems are designed to use this phenomenon to remove carbon tetrachloride from the vadose zone.

Passive soil-vapor extraction systems were installed at the end of fiscal year 1999 at eight boreholes that are open near the vadose-groundwater interface at the 216-Z-1A/ 216-Z-12/216-Z-18 well field. The passive systems are outfitted with check valves that only allow soil-vapor flow out of the borehole (i.e., one way movement), and canisters holding granular activated carbon that adsorbs carbon tetrachloride upstream of the check valves before the soil vapor is vented to the atmosphere. The check valve prohibits flow of atmospheric air into the borehole during a reverse barometric pressure gradient, which tends to dilute and spread carbon tetrachloride vapors in the subsurface.

The wells are sampled periodically upstream of the granular activated carbon canisters when atmospheric pressure is falling and the wells are venting. The maximum carbon tetrachloride concentrations measured at the four wells (299-W18-6, 299-W18-7, 299-W18-246, and 299-W18-252) in the vicinity of the 216-Z-1A tile field ranged from 24 to 37 ppmv. The maximum carbon tetrachloride concentrations measured at the four wells (299-W18-10, 299-W18-11, 299-W18-12, and 299-W18-247) in the vicinity of the $216-Z-18$ crib ranged from 8 to 15 ppmv. 
Table 3.2-1. Carbon Tetrachloride Inventory in Primary Disposal Sites

\begin{tabular}{|c|c|c|c|}
\hline Well Field & $\begin{array}{c}\text { Estimated } \\
\text { Mass Discharged } \\
1955 \text { to } 1973^{(\mathrm{a})}(\mathrm{kg}) \\
\end{array}$ & $\begin{array}{l}\text { Estimated Mass } \\
\text { Lost to Atmosphere } \\
1955 \text { to } 1990^{(\mathrm{b})}(\mathrm{kg})\end{array}$ & $\begin{array}{c}\text { Mass Removed Using } \\
\text { Soil-Vapor Extraction } \\
1991 \text { to } 2003(\mathrm{~kg}) \\
\end{array}$ \\
\hline $216-Z-1 A$ & 270,000 & 56,700 & $24,294^{(\mathrm{c})}$ \\
\hline $216-Z-9$ & 130,000 to 480,000 & 27,300 to 100,800 & 53,798 \\
\hline $216-Z-18$ & 170,000 & 35,700 & \\
\hline Total & 570,000 to 920,000 & 119,700 to 196,800 & 78,092 \\
\hline
\end{tabular}

(a) Based on DOE/RL-91-32.

(b) Based on WHC-SD-EN-TI-101.

(c) Includes mass removed from 216-Z-18 site; reported as a combined value because the well fields overlap. 


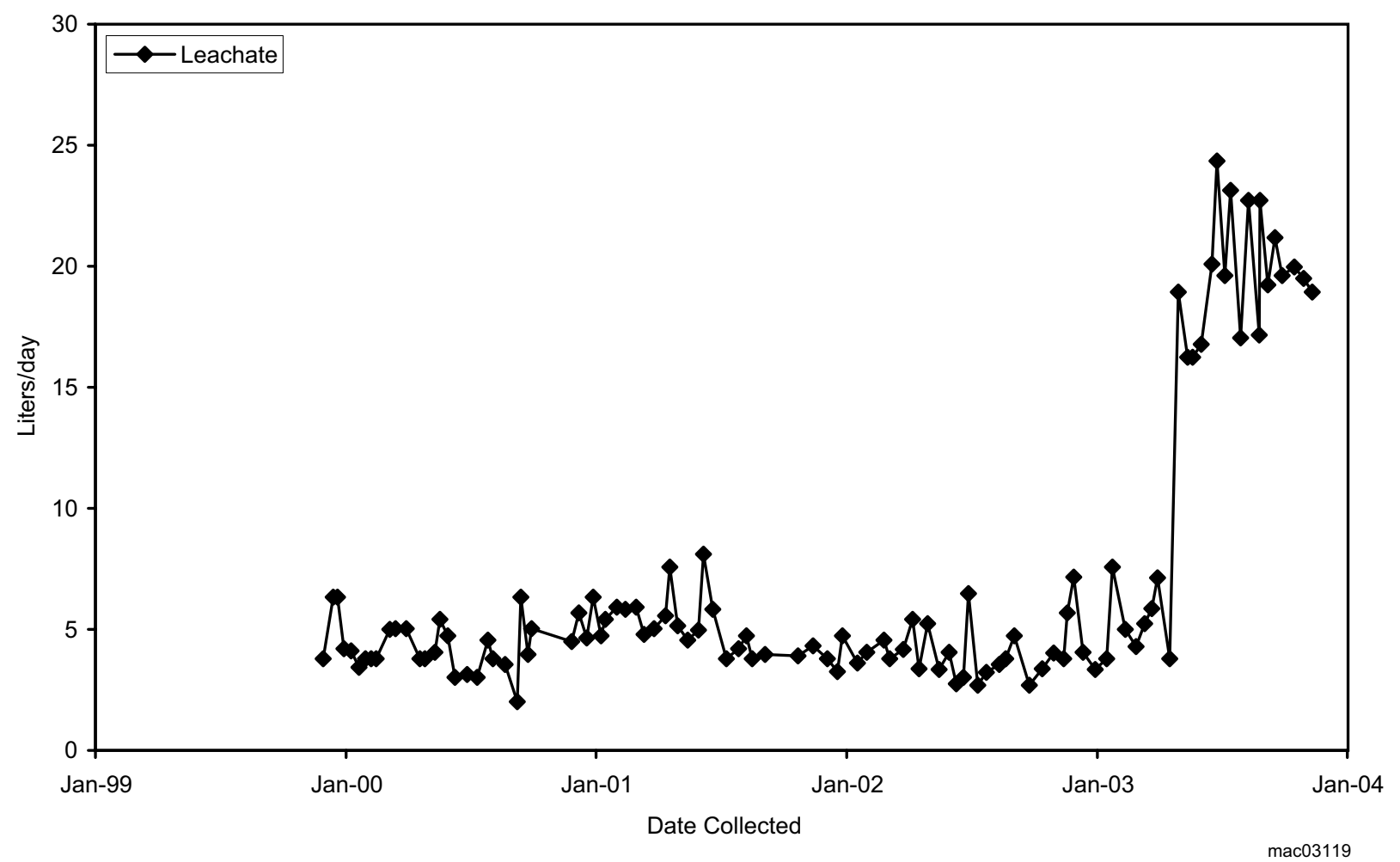

Figure 3.2-1. Leachate Collection Volumes at the Solid Waste Landfill 


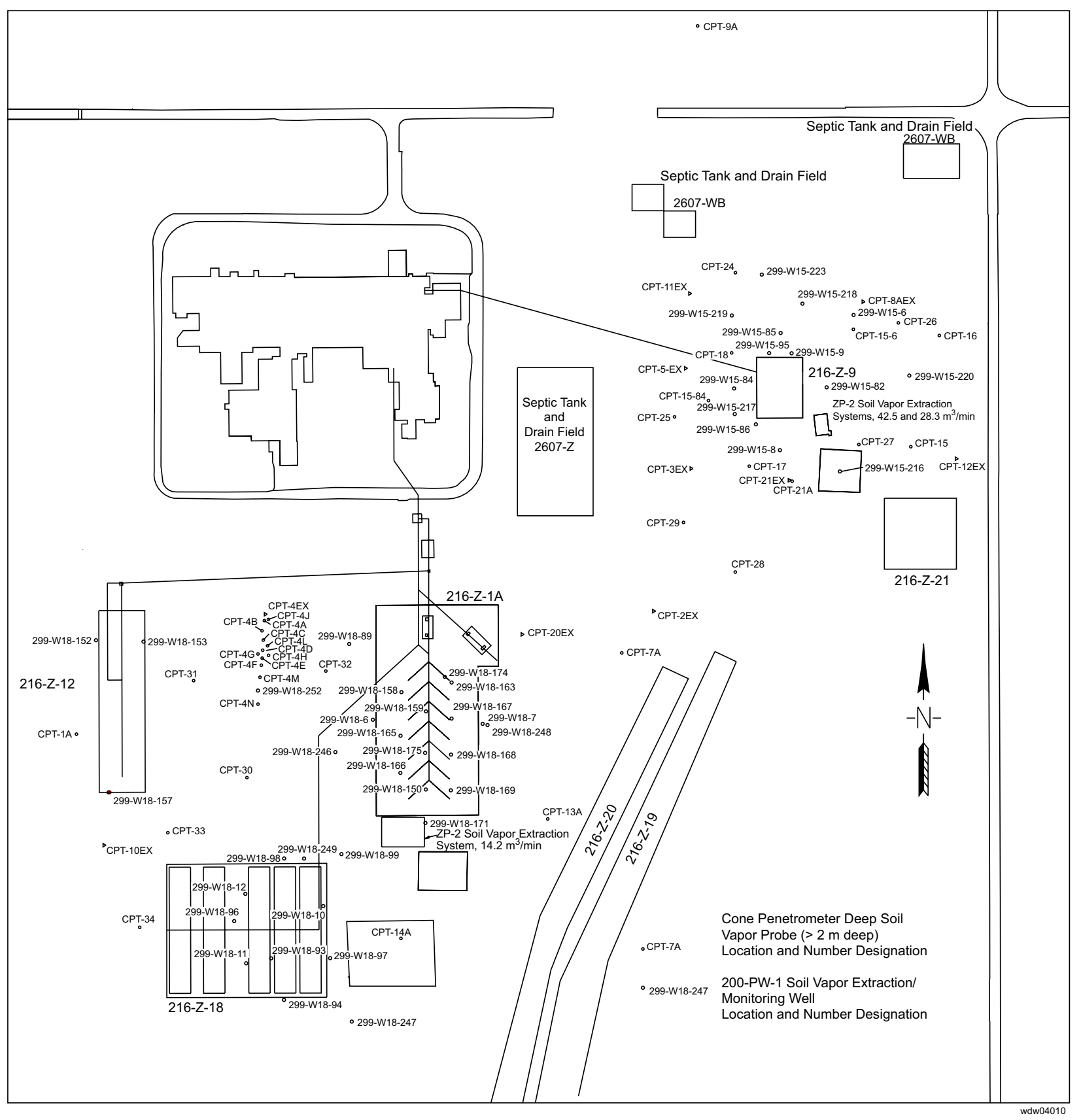

Figure 3.2-2. Locations of Carbon Tetrachloride Vapor-Extraction Wells at the 216-Z-1A/216-Z-12/216-Z-18 and the 216-Z-9 Well Fields 


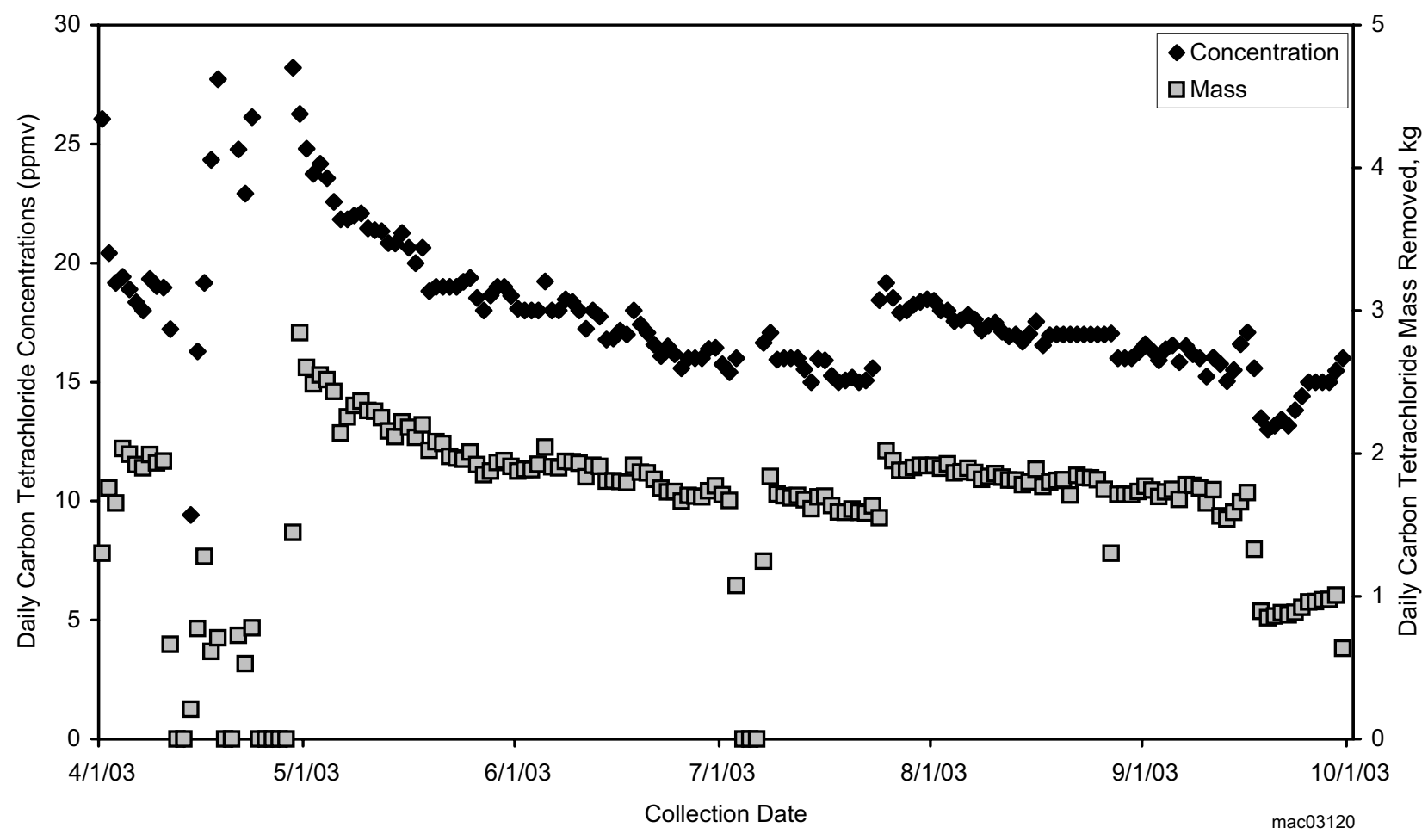

Figure 3.2-3. Time Series Concentrations and Mass of Carbon Tetrachloride in Soil Vapor Extracted from the 216-Z-1A/216-Z-12/216-Z-18 Well Field 


\subsection{Vadose Zone Studies}

\section{G. Horton}

This section summarizes the activities and results of several technical studies done at the Hanford Site in fiscal year 2003 to better understand the vadose zone sediments, vadose zone hydrology, and vadose zone contamination. These studies are designed to result in new, innovative methods for cleanup and monitoring at the Hanford Site. These studies include the application of geochemical tools to study the interactions between vadose zone porewater and contaminants, infiltration studies at a monitored prototype surface barrier site, the development of new tools to measure the influx of water into the subsurface, and the use of computer modeling to estimate the future behavior of surface barriers. A review of the many tests to determine the effects of soil type, plant populations, and precipitation rates on infiltration of soil moisture is also included in this section.

\subsubsection{Field Lysimeter Test Facility}

\section{J. Fayer}

During 2003, a summary of 15 years of testing at the Field Lysimeter Test Facility became available. A lysimeter is a structure used to measure quantities of water used by plants, evaporated from soil, and lost by deep percolation. In 1987, the Protective Barrier Program constructed the Field Lysimeter Test Facility to test the performance of capillary barrier covers (PNL-6810; Wing and Gee 1994) and operated the facility until 1994. Between the end of 1994 and 2003, the Integrated Disposal Facility project (formerly the Immobilized Low-Activity Waste Project) sponsored the tests. During this period, some of the original test treatments were ended and replaced with new tests designed to answer questions about new barrier designs (e.g., modified Resource Conservation and Recovery Act [RCRA] Subtitle C) and barrier degradation mechanisms such as erosion and dune sand migration. Now, Pacific Northwest National Laboratory (PNNL) operates the Field Lysimeter Test Facility, which is located 400 meters west of the Hanford Meteorological Station (between 200 East and 200 West Areas; Figure 3.3-1).

Figure 3.3-2 shows that the Field Lysimeter Test Facility contains a total of 24 lysimeters of three types: 14 drainage, 4 weighing, and 6 small-tube lysimeters. The drainage lysimeters are vertical cylinders that are 3 meters deep and 2 meters in diameter (surface area is 3.1 square meters) and comprise the walls of the Field Lysimeter Test Facility. The weighing lysimeters are boxes with length and width dimensions of 1.5 meters and a depth of 1.7 meters (surface area is 2.3 square meters). The boxes rest on platform scales to enable hourly weight measurements of water gain and loss. The small-tube lysimeters are vertical cylinders that are 3 meters deep and 0.3 meter in diameter (surface area is 0.07 square meter). Unlike the others, the small-tube lysimeters are clear Plexiglas to allow root and soil observations. These lysimeters are located along the inner walls of the Field Lysimeter Test Facility. All lysimeters contain ports for measuring drainage. The drainage and weighing lysimeters contain sensors to measure soil water contents and storage, matric potentials, and temperature.

Since 1987, 12 tests and 26 treatments have been set up in the Field Lysimeter Test Facility to reflect various combinations of soil type and layering and vegetation under ambient and enhanced precipitation. The enhanced precipitation treatment was intended to examine the impact of potentially higher precipitation rates in the future that could result from climate change. The lysimeters were irrigated each month so that ambient precipitation plus irrigation equaled either 2 or 3 times the long-term average monthly precipitation. From November 1987 to October 1990, the enhanced rate was 2 times;
DOE published the

results of 15 years

of testing at the

Field Lysimeter

Test Facility in

fiscal year 2003. 


\section{Lysimeters measure drainage of liquids such as precipitation through soil.}

since November 1990, the enhanced rate has been 3 times. The test configurations are described below along with some of the results.

Hanford Barrier. The objective of this test (and the original objective of the Field Lysimeter Test Facility) is to document the performance of a Hanford barrier, which consists of a 1.5-meter-thick top layer of silt loam resting on top of a sequence of sand to gravel filter layers that rest on basalt riprap. Test results show that with plants, the Hanford barrier continues to limit drainage to well below the design specification of 0.5 millimeter per year. Without plants, the Hanford barrier continues to function under ambient conditions, even under 2 times precipitation during a 3-year test. Only under 3 times precipitation, with no plants, has the Hanford barrier allowed drainage to occur.

Hanford Barrier with Gravel Admix. The objective of this test is to document the impact of a gravel admix on the performance of a Hanford barrier. The admix was created by amending the top 0.2 meter of silt loam with pea gravel ( $15 \%$ by weight) to increase resistance to erosion. This test (shrub-steppe vegetation and ambient precipitation only) continues to show no drainage.

Eroded Hanford Barrier. The objective of this test is to document the performance of an eroded Hanford barrier. To mimic erosion, the thickness of the silt loam layer was reduced from 1.5 to 1.0 meter. In many respects, this design is similar to that of the modified RCRA Subtitle C Cover (see discussion under Modified RCRA Subtitle C Cover). This test (shrub-steppe vegetation only) continues to show no drainage, even for the enhanced precipitation regime.

Gravel Mulch. The objective of this test is to document the performance of a gravel mulch layer above Hanford formation sand. The configuration was 0.15 meter of coarse gravel above 1.35 meters of screened pitrun sand (gravel removed), on top of unscreened pitrun sand. This test was conducted only in the clear-tube lysimeters and did not include vegetation. Although not its primary purpose, this test may be useful to characterize deep drainage rates at the high-level waste tank farms at the Hanford Site. This test continues to show significant drainage (average $=89.1$ millimeters of water per year under ambient precipitation and 332 millimeters of water per year under enhanced precipitation).

Pitrun Sand. The objective of this test is to document the performance of a coarse gravelly sand taken from a nearby borrow pit (hence "pitrun" sand). The configuration is 1.5 meters of screened pitrun sand (to remove the gravel) resting on top of unscreened pitrun sand. This vegetated test continues to generate a significant amount of drainage (average $=21.8$ millimeters of water per year under ambient precipitation and 63.5 millimeters of water per year under enhanced precipitation).

Basalt Side Slope. The objective of this test is to document the performance of basalt riprap that could be used to construct side slopes for surface covers. The configuration is 1.5 meters of unscreened basalt riprap. This material is being tested for side slope use on a larger scale at the prototype surface barrier in the 200-BP-1 Operable Unit (PNNL-11789). This unvegetated test continues to generate a significant amount of drainage, even though it receives only ambient precipitation (average $=53.9$ millimeters per year).

Sandy Gravel Side Slope. The objective of this test is to document the performance of unprocessed local sandy gravel that could be used to construct side slopes for surface covers. The configuration is 1.5 meters of sandy gravel resting on an asphaltic concrete layer in a manner similar to the basalt side-slope test. The sandy gravel material was tested for side slope use on a larger scale at the prototype surface barrier, where it is called cleanfill gravel (PNNL-11789). Although not its primary purpose, this test may be useful to characterize deep drainage rates at the high-level waste tank farms at the Hanford Site that have similar textures. This unvegetated test continues to generate a significant amount of drainage (average $=109$ millimeters of water per year under ambient precipitation and 365 millimeters of water per year under enhanced precipitation). 
Hanford Prototype Barrier. The objective of this test is to document the performance of the Hanford Prototype Barrier design. The configuration is 1 meter of silt loam amended with pea gravel ( $15 \%$ by weight) resting on top of 1 meter of silt loam to give a combined silt loam thickness of 2 meters. Beneath the silt layer are sand and gravel filter layers that rest on top of the asphaltic concrete layer. This design mirrors that of the full-scale prototype surface barrier (PNNL-11789). This vegetated test continues to show no drainage, even under 3 times precipitation.

Hanford Barrier Erosion/Dune Sand Deposition. The objective of this test is to document the performance of the Hanford barrier after erosion of some of the silt loam layer and subsequent deposition of dune sand. The top 20 centimeters of silt loam of the Hanford barrier design was removed and replaced with dune sand obtained from the dune that is aligned along the southern edge of the Integrated Disposal Facility Site (PNNL11957). This test is being conducted with shallow-rooted vegetation, primarily cheatgrass. The presence of dune sand on the Hanford barrier continues to generate a significant amount of drainage under 3 times precipitation. To date, we have observed increased matric potentials under the ambient precipitation treatment but minimal drainage.

Sand Dune Migration. The objective of this test is to document the impact of a sand dune that might migrate onto a surface cover. Two lysimeters were completely filled with dune sand to provide data on the impact of a dune forming on a barrier, as well as provide data on the behavior of dunes that might form around a barrier and elsewhere at the Hanford Site. The dune sand was obtained from the dune that is aligned along the southern edge of the Integrated Disposal Facility Site. This test is being conducted with shallow-rooted vegetation, primarily cheatgrass. Since starting in July 1998, this test has shown clearly that drainage is significant under the 3 times precipitation treatment. In contrast, we have observed no drainage under the ambient precipitation treatment. Matric potentials in the ambient treatment have been rising, so it may be just a matter of time before drainage occurs.

Modified RCRA Subtitle C Cover. The objective of this test is to document the performance of a modified RCRA Subtitle C barrier that was proposed in DOE/RL-93-33. This barrier design meets the requirements for a RCRA Subtitle $\mathrm{C}$ barrier but uses a thinner silt loam soil than the Hanford Prototype Barrier (1 rather than 2 meters). In addition, the silt layer has two modifications. The first is that the upper 0.5 meter of silt loam is amended with pea gravel ( $15 \%$ by weight). The second feature is that the lower 0.5 meter of silt is compacted. The rationale for the compacted layer was to create a low-conductivity layer to impede downward drainage (DOE/RL-93-33). Construction of this test required slight design modifications to the sand filter layer, the gravel drainage layer, and the density of the compacted silt layer (PNNL-13033). Although the testing period is short (3.5 years), this vegetated test continues to show no drainage, even under the 3 times precipitation treatment.

Glass. The objective of this test is to determine the performance of glass waste forms in a field setting that receives enhanced precipitation to accelerate the glass dissolution rate. The lysimeters are packed with vadose zone sediments (predominantly gravelly sand) from the Integrated Disposal Facility Site. The glass waste forms are in the shape of cylinders (20 centimeters diameter; 46 centimeters tall). The glass cylinders are placed in two layers in each lysimeter, three cylinders per layer, for a total of six cylinders per lysimeter. One lysimeter is scheduled to be excavated and the glass cylinders tested in fiscal year 2006 before emplacement of actual glass in the first Integrated Disposal Facility trench. The remaining two lysimeters will continue to be monitored to provide a long-term data record of glass behavior.

\section{Lysimeters have been used to evaluate the performance of the Hanford barrier, which will limit infiltration through waste sites.}




\subsubsection{Vadose Zone Water Fluxmeter Improvements and Tests}

\section{G. W. Gee, Z. F. Zhang, and A. L. Ward}

A wick lysimeter was modified so it could provide nearly instantaneous water-flux measurements and serve as a water fluxmeter. The water fluxmeter consists of a soilfilled tube with a fiberglass wick at the bottom, which has the capability of providing continuous and reliable monitoring of unsaturated water fluxes ranging from $<1$ millimeter per year to $>1,000$ millimeters per year. The water fluxmeter is placed in

\section{DOE modified a}

lysimeter to provide a
better way to measure
water flux.
the ground, below the root zone. The wick applies suction, proportional to its length, and passively drains the soil. Water flows by gravity from the wick through a funnel to an isolated tipping spoon (or similar counting device) where drainage volumes are recorded. In the latest design of the water fluxmeter, water drained from the tipping spoon is routed down to a collection vial where it can be sampled for chemistry (Gee et al. 2003). Data became available from a test of the water fluxmeter at the Hanford Site during fiscal year 2003. Figure 3.3-3 shows a water fluxmeter with solution-collection capability.

To illustrate the performance of the water fluxmeter for drainage monitoring, an example from the Hanford Site is discussed. However, water fluxmeters have now been installed throughout the United States, Germany, Sri Lanka, the Tongan Islands in the Pacific, and several other locations throughout the world.

The Field Lysimeter Test Facility pit is a test site for monitoring drainage from selected surface cover materials. It is located on the Hanford Site, just east of the 200 West Area and adjacent to the Hanford Meteorological Station. The Field Lysimeter Test Facility pit consists of four instrumented caissons, 2.3 meters in diameter and 1.5 meters deep, filled with native soil and sediment being tested as landfill cover materials. The cover materials include (1) a coarse gravel, (2) a dune sand, (3) a 0.1-meter-thick silt loam, and (4) a 1-meter-thick silt loam. A water fluxmeter is located in the center of each caisson. Instruments were installed in the caissons during the fall of 2001. Irrigation was applied to each of the caissons after construction and periodically through February of 2002, after which the cover materials were subject only to natural precipitation. Figure 3.3-4 shows the drainage from the four cover treatments at the Field Lysimeter Test Facility pit.

The data in Figure 3.3-4 illustrate that under the same climatic regime, there can be large differences in drainage as a result of the surface soil materials and their waterholding capacity (soil-water storage). Water-storage capacity in gravel materials is typically $<30$ millmeters per meter whereas for silt loam, it can be as much as 300 millimeters per meter. For landfill covers at arid sites, gravel side slopes can be a source of subsurface water that may contact existing contaminant plumes and move them to the underlying water table. Documentation of subsurface drainage is critical to any analysis of risk resulting from leaving waste in the ground at the Hanford Site or similar arid waste sites.

Similar results have been found at other test locations at the Hanford Site. Drainage occurs at non- or sparsely vegetated waste sites that have coarse sand or gravel surfaces. Examples include sites containing leaking high-level waste tanks and covered trenches found in solid-waste burial grounds where surfaces are kept vegetation-free to minimize plant and animal intrusion (Gee et al. 1992). As much as $40 \%$ or more of the annual precipitation is lost to drainage at barren sites with coarse sands and gravels. Documentation of the actual drainage is required to support the performance assessment of waste sites left in a barren state for more than a few decades because water can 
accumulate and provide transport for contaminants to underlying water tables. Waterflux measurements at such sites will provide operators with information on the extent of the problem and can also be used to evaluate the effectiveness of remediation strategies that include surface-cover placement over waste sites that are vulnerable to leaching.

The ability to measure continuous water and solute flux simultaneously with the same instrument provides a capability that previously was either not available or required multiple sets of instrumentation. The direct measure and simplicity of the new fluxmeters makes them an attractive alternative to other vadose-zone monitoring methods, such as water-content sensors, water-potential sensors, pore-water samplers, and other schemes used in the past to obtain drainage water quantity and quality.

\subsubsection{Mineralogical and Bulk-Rock Geochemical Signatures of Ringold and Hanford Formation Sediment}

\section{Y. Xie, G. V. Last, C. J. Murray, and R. Mackley}

PNNL explored the possibility of applying statistical methods to classify sediment samples belonging to the Hanford and Ringold Formations using mineralogy and geochemical data. A database was constructed consisting of existing mineral chemistry obtained from electron microprobe analyses, bulk-rock analyses obtained by x-ray fluorescence analyses, and petrography. Principal component analysis was used to examine the multivariate structure of the data. In addition, several classification methods were employed to identify classification functions that could be used to distinguish between the two formations.

The results of this study indicate that principal component analysis, discriminant function analysis, and machine learning methods are valuable tools for quantifying mineral and chemical variables and determining which variables are the most effective in distinguishing between Ringold and Hanford Formation sediment. Electron microscopy and petrography data for the Hanford and Ringold Formations from 200 West Area showed significant differences; however, significant spatial variability of electron microscopy data between 200 West and 200 East Areas caused inconsistent variable differences. X-ray fluorescence analyses from 200 West Area also distinguished between the two formations and, when applied to pooled data from 200 East Area, the two formations could still be distinguished. Principal component analyses supported the use of mineralogy and geochemical data for classifying samples from the two formations as well; the petrography data was particularly valuable. Classification routines such as discriminant function analysis and machine learning tools including C4.5 and One R, provided useful and consistent classification of samples. Complete results were published in 2003 (PNNL-14202).

\subsubsection{Isotopic Investigation of Vadose Zone Pore Water}

\section{J. Singleton, P. E. Dresel, and G. V. Last}

Investigators from the Lawrence Berkeley National Laboratory and PNNL used natural isotopes of strontium, carbon, and oxygen as tracers to infer the depositional environment and diagenetic history of buried carbonate layers and to provide constraints on groundwater recharge, flow, and vadose zone/groundwater interaction (Singleton et al. 2002, 2003).

\section{Statistical methods provide valuable tools for quantifying mineral and chemical variables.}


The strontium isotope composition of groundwater samples

provides a way to evaluate groundwater recharge, vadose zone drainage, and the effects from industrial activity.
Clastic sediments of the Hanford formation, the Cold Creek Unit, and the Ringold Formation contain laterally extensive carbonate layers beneath the 200 West Area. The carbonate layers, known as caliche, are associated with high moisture and high ion concentrations in vadose zone pore water. The layers likely impede infiltrating fluids due to their low permeability relative to surrounding sand and gravel and may interact with contaminants migrating through the unsaturated zone. The carbonates have been attributed to soil forming processes during depositional hiatuses with later modification by groundwater (BHI-01203).

The Cold Creek Unit carbonate-cemented sediment forms a zone at a depth of 45 meters beneath the Hanford Site 200 West Area. The carbonate zone ranges from about 0.9 to 4 meters in thickness. Within this zone, carbonate occurs as thin laminae (caliche layers) separated by silty or sandy zones with disseminated carbonate. Whole rock samples of the caliche layers have $\delta{ }^{13} \mathrm{CPDB}$ (Peedee Formation belemnite) values of -8.7 to -4.4 per mil and $\delta{ }^{18} \mathrm{O}$ SMOW (standard mean ocean water) values of 15.2 to 18.6 per mil. Carbon isotope compositions of these samples show a generally positive, linear correlation with oxygen isotope compositions. Disseminated carbonates, on the other hand, have higher $\delta{ }^{13} \mathrm{C}$ PDB values, and lower $\delta{ }^{18} \mathrm{O}$ SMOW values than the caliche layers. Unsaturated zone pore waters at the Hanford Site have $\delta{ }^{18} \mathrm{O}$ SMOW values up to -7.5 per mil near the surface and -17 to -14 per mil at depth, whereas groundwater values are generally -18 to -16 per mil. The caliche layers at the Hanford Site retain an isotopic signature consistent with deposition from strongly evaporated, near surface waters; whereas disseminated carbonates are generally near isotopic equilibrium with less evaporated pore waters suggesting that the disseminated carbonates may be forming today. Preliminary strontium isotope results suggest little modern interaction between the carbonate layers and pore water.

Strontium isotope compositions of samples from more than 270 wells in the unconfined aquifer provide a way to evaluate groundwater recharge, vadose zone drainage, and the effects from Hanford Site operations. Natural recharge to the unconfined aquifer primarily comes from exposed basalt on Yakima Ridge and the Rattlesnake Hills at the west margin of the Hanford Site, and thus groundwater in this area has lower strontium-87/strontium-86 ratios than either Columbia River water or water that has equilibrated with Hanford formation sediment. Artificial recharge of the unconfined aquifer from discharged Columbia River water has resulted in groundwater with high strontium-87/strontium-86 ratios downgradient from infiltration ponds. Transient, high strontium-87 and strontium-86 flushed out of the vadose zone by infiltrating disposal water at the 200 Areas dominates over the shift of strontium isotopes caused by reaction of aquifer sediments with groundwater. Low strontium-87/strontium-86 ratios south of Gable Mountain are evidence for upwelling from the upper confined aquifer, which may affect the shape and concentrations of contaminant plumes in this area.

Groundwater strontium-87/strontium-86 ratios increase systematically from 0.707 to 0.712 along aquifer flow paths, generally running west to east across the Hanford Site. The addition of strontium from interactions with the aquifer sediment and infiltration through the vadose zone causes this variation in strontium isotope composition. The degree to which groundwater strontium-87/strontium-86 composition approaches the composition of dissolving or infiltrating strontium is governed by the groundwater velocity, vadose zone drainage flux, aquifer thickness, and by reaction rates with the aquifer sediment. Vadose zone pore waters are approximately an order of magnitude higher in total strontium concentration than the groundwater; therefore, recharge through the vadose zone has a strong effect on the strontium isotope composition of groundwater. Combining measurements of hydraulic head and aquifer thickness with measurements of groundwater strontium-87/strontium-86 and total strontium concentration allows for estimates of vadose zone drainage flux. The strontium-87/strontium-86 increase along a background profile across the Hanford Site 
is consistent with an average vadose zone flux of 3 to 15 millimeters per year, based on a steady-state model of strontium reactive transport and infiltration.

\subsubsection{Hydrologic Performance of a Prototype 1,000-Year Hanford Barrier}

\section{A. L. Ward, G. W. Gee, and C. D. Wittreich}

Surface barriers form an integral part of the U.S. Department of Energy's (DOE's) waste management strategy. At the Hanford Site alone, an estimated 200 barriers with design lives of 500 to 1,000 years are planned for an area of $\sim 404.7$ hectares. Proven designs, as well as reliable, accurate, and cost-effective monitoring techniques, are needed to ensure post-closure compliance. In an effort to evaluate the long-term performance of field-scale barriers, a prototype Hanford barrier was constructed over the 216-B-57 crib. The barrier was routinely monitored between November 1994 and September 1998 as part of a Comprehensive Environmental Response, Compensation, and Liability Act (CERCLA) treatability test of barrier performance for the 200-BP-1 Operable Unit. The results of this test have been documented in DOE/RL-99-11. Since fiscal year 1998, monitoring has focused on barrier stability and the key components of water balance. The results have been summarized in previous Hanford Site groundwater monitoring reports (e.g., PNNL-14187). This section provides a summary of observations made through fiscal year 2003.

As in previous years, the fiscal year 2003 hydrologic performance monitoring focused on water balance evaluation. The barrier is equipped with 14 automated stations to monitor the components of the water balance.

Precipitation. Precipitation in fiscal 2003 (October 1, 2002 through September 30, 2003 ) totaled 215.90 millimeters. Of this amount, 128 millimeters occurred during the winter (December 2002 through February 2003). Although this is almost twice the long-term average for a Hanford Site winter, it is still slightly less than that observed in fiscal year 1997, which had the maximum winter precipitation recorded at the Meteorological Station since 1946 (PNNL-14242). Fiscal year 2003 also saw a shift in the seasonal distribution relative to the previous year with an almost $50 \%$ decline in summer precipitation, a $150 \%$ increase in the winter precipitation, and a four-fold increase in spring precipitation. These differences translated into large increases in the amount of water stored in the fine-soil profile and increased drainage amounts from the side slopes compared to fiscal year 2002. The cumulative amount of water received by the barrier from November 1, 1994, through the end of September 2003, was 2,340.63 millimeters on the north half (formerly irrigated) and 1,667.76 millimeters on the south half.

Water Storage. Measured soil water contents were used to calculate the amount of water stored in the fine-textured layer as a function of time (Figure 3.3-5). No storage data were collected in fiscal year 1999, hence the break in the record. These data show a well-defined annual cycle in water storage during the 3 years of the treatability test (November 1994 through October 1997). Although plants in both precipitation treatments were able to recycle most of the water intercepted by the barrier, the data show a divergence in the storage values at the end of each summer. On the south side, which was never irrigated, plants removed water to essentially the same minimum each year.

Even though the plants on the irrigated north side were able to remove essentially all of the water received, the lower limit of storage is larger than the non-irrigated side and remained so until at least 2 years after the irrigation had ceased. This may indicate a reduced ability of the irrigated plants to recycle water. Nevertheless, the system had

\section{Surface barriers form an integral part of DOE's waste management strategy.}




\section{Results of testing illustrate the importance of water storage capacity, vegetation, and drainage when designing surface barriers.}

shown a dramatic recovery by mid-2000; by this time differences in the lower limit of storage, between the formerly irrigated and non-irrigated portions, had essentially disappeared, and the water storage values returned to values similar to those observed on the south side of the barrier.

Drainage. Perhaps the most important observation is the extremely low amounts of drainage from the soil-covered plots. During fiscal year 2003, the soil-covered plots generated an average of $3.6 \times 10^{-5}$ millimeters (or $\sim 12$ milliliters) drainage for the entire year or an average cumulative drainage of only 0.08 millimeters over the entire life of the barrier. Thus in 9 years, the soil-covered plots have generated just over $15 \%$ of the drainage amount allowed for a year. Even then, none of this water would have entered the waste zone because of the presence of the asphalt layer. These results clearly show the effectiveness of the soil-covered section in eliminating recharge. In contrast, the side slopes have generated significant amounts of drainage (Figure 3.3-6). In general, the gravel slopes accounted for the most drainage, with the irrigated gravel draining about $23 \%$ of the total precipitation and non-irrigated gravel draining about $21 \%$. In contrast, the non-irrigated rip rap drained only $15 \%$ of precipitation whereas the irrigated rip rap drained 23\%. This discrepancy has been attributed to water loss from wind action on the rock surfaces which acts to reduce drainage from the rock slopes. The non-irrigated part of the Hanford barrier is toward the south, and the primary wind direction at the Hanford Site is from the southwest.

Synopsis. Not all waste sites will require the degree of protection offered by the Hanford barrier. However, the results of the CERCLA treatability test and long-term monitoring program are valuable in guiding the design of more modest covers, especially those sharing similar design concepts. A graded approach to barrier deployment that matches the level of protection to a specific waste site with specific waste stream characteristics will result in tremendous cost savings.

The analysis of seasonal variations in precipitation, especially in winter amounts, is of particular importance for evaluating cover performance and the design of future covers to be used at the Hanford Site. Results thus far illustrate the importance of water storage capacity even in the design of more modest covers. All designs should be capable of storing the expected winter precipitation until it can be recycled by plants in the spring and summer months. The prototype Hanford barrier is designed with a 2-meter silt-loam layer capable of storing 600 millimeters of water, which is more than three times the long-term average precipitation (160 millimeters per year) for the Hanford Site. This capacity has never been exceeded by the barrier, even during treatability tests when the prototype barrier was irrigated. Results also emphasize the importance of choosing the right vegetation to enhance the function of capillary barriers. Native species are particularly resilient and appear capable of recovering from short-term stresses, such as those imposed by elevated precipitation. The design of final barriers, therefore, will require close attention to the choice of plant species, realizing that some maintenance may be required to ensure that the right mix of plant species remain active. With respect to drainage, the data suggest that in arid or semiarid climates, side-slope design will affect the amount of drainage through the edge of the barrier into the subsurface. Thus, design optimization will require an analysis of side-slope configurations and their hydrologic performance to minimize the amount of peripheral recharge.

\subsubsection{STOMP-Based Tool to Optimize Surface Barrier Design}

\section{A. L. Ward, M. D. White, and E. J. Freeman}

Surface barriers are expected to play a critical role in the closure of the Hanford Site's 200 Area, with an estimated 200 barriers to be constructed. Optimizing barrier 
designs for the proposed graded-barrier approach can minimize performance uncertainty and reduce costs that could result from under- or over-engineering. In designing barriers, the environmental interactions that govern barrier performance must be carefully considered (Figure 3.3-7). Successful hydrologic performance depends on a complex interaction of physical, environmental, and biotic processes in which precipitation can be stored in the upper soil layers until it can be recycled to the atmosphere by the plants, routed from the surface by runoff, or moved through the profile to be diverted laterally from the waste. Predicting the hydrologic performance of field-scale surface barriers, therefore, requires an ability to simulate the multidimensional cycling of water, air, and energy. These simulations must include the influences of the local climate to accurately predict the net fluxes at the soil-atmosphere boundary. Most of the tools available for modeling these processes are one-dimensional, which limits their ability to predict the performance of multidimensional field-scale covers.

PNNL developed a computer model, Subsurface Transport Over Multiple Phases (STOMP) to provide scientists and engineers from varied disciplines with multidimensional analysis capabilities for modeling subsurface flow and transport phenomena (PNNL-12034). In fiscal year 2002, the STOMP model was upgraded to include a plant-soil-atmosphere module to support the simulation of barrier performance (PNNL-14388). The necessary modifications were completed in fiscal year 2003 and the model was calibrated using water balance data from the prototype Hanford barrier (Section 3.3.6). The 2003 modifications were made to the part of the model used for solving the equations for coupled water flow, heat transport, and solute transport in variably saturated soil.

The processes of coupled water flow and thermal energy transport in variably saturated soil are described by a set of coupled conservation (mass and energy) equations, associated constitutive laws (Darcy-Buckingham, Fick, Fourier), and equilibrium thermodynamic relations. Quantifying the exchange of matter, energy, and momentum between the soil and atmosphere required a detailed understanding of the interactions between vegetation and the local microclimate. The vertical structure of the mixed vegetation canopy typical of vegetated barriers affects the microclimate by intercepting radiation, extracting momentum from the air flow, and acting as a source or sink for mass and energy. The microclimate surrounding the vegetation also directly impacts the physiological and biophysical processes controlling the exchange of heat and water vapor across the soil-atmosphere continuum. These effects are incorporated into the model using nodal sink terms, based on root distributions, coupled with a surface energy balance that depends on the vegetative canopy. The Shuttleworth-Wallace (1985) model for sparse canopies was used to separate transpiration and soil evaporation on hourly or daily time steps. The model considers most of the important hydrologic processes and uses a recently developed method for describing lateral transfer of water due to saturation dependent anisotropy. Whereas modeling tools currently available make a number of simplifying assumptions to solve these equations, the 2003 modifications to the STOMP code solve the full set of equations.

Although the primary use of the model is to evaluate barrier performance, the model is equally applicable to other problems in waste remediation, such as phytoremediation, estimation of recharge rates, or problems of practical interest in agriculture and forestry. Input parameters for the model include physical characteristics of the vegetation such as canopy characteristics, root distributions, soil hydraulic and thermal properties, and climate data including daily precipitation, maximum and minimum temperatures, solar radiation, atmospheric vapor pressure, and wind speed, all of which are easily obtained from the Hanford Meteorological Station.

Model verification is currently in progress using the same set of test problems used in the verification of PNNL's UNSAT-H model (PNNL-13249). The simulated layered soil has a configuration critical to the performance of capillary barriers. The top
Pacific Northwest National Laboratory modified a computer model in fiscal year 2003 to evaluate barrier performance. 


\section{Results of the fiscal \\ year 2003 model \\ verification show that \\ the model adequately \\ captures diurnal and}

seasonal variations in

components of the

water balance.

\section{Information on clastic}

dikes helps improve

conceptual models to

guide the design of

remedial systems and

closure activities for

waste management

areas.
30 centimeters of the soil profile is a well characterized soil (the composite soil of PNL-5604) with 15\% pea gravel admix. The 30- to 150-centimeter zone is the composite soil only and a coarser drainage gravel is below the depth of 150 centimeters. Figure 3.3-8 shows the saturation profiles from a STOMP simulation using 1962 weather conditions following PNNL-13249. The effect of the capillary break is quite clear. The soil configuration causes water to be retained within the fine textured, composite soil layer (between 390 and 510 centimeters elevation on Figure 3.3-8) making it available for recycling by plants. This soil configuration, which increases the water storage capacity of the fine soil layer, is an integral part of the barrier designs being considered.

The layered soil simulation was repeated with the addition of heat flow (Problem 7.6 of PNNL-13249). Figure 3.3-9 shows a plot of the STOMP simulated air and soil surface temperature for days 143 through 146. Peak soil surface temperatures typically occurred between 1200 hours (noon), when the net solar radiation reached a maximum, and 1500 hours when the air temperature reached its maximum. In general, soil temperature remained above the air temperature except for occasions when condensation of moisture on the surface caused a reduction in latent heat and a decline in soil temperature. This phenomenon is one that is typically ignored in current models but plays an important role in the water balance.

The preliminary results of the fiscal year 2003 model verification show that the model adequately captures diurnal and seasonal variations in components of the water balance: soil water storage, evapotranspiration, and drainage. Unlike previous modeling tools that make several simplifying assumptions to solve coupled water and heat flow equations, the STOMP code solves the full set of equations. The resulting model will have applications in the evaluation of Hanford Site barrier performance as well as other practical problems of waste remediation.

\subsubsection{Impact of Clastic Dikes on Vadose Zone Flow}

\section{A. L. Ward, C. J. Murray, G. W. Gee, Y. Xie, and Z. F. Zhang}

Clastic dikes have been observed in all sedimentary units in the Pasco Basin and on the Hanford Site. Studies have been ongoing to explore the role of these heterogeneous sub-vertical structures on water flow in the vadose zone (PNNL-13788, Section 3.3; PNNL-13404, Section 3.1). High-resolution multi-parameter data sets from a dike exposure were used to develop a two-dimensional numerical model of unsaturated flow. Flow simulations were performed with the STOMP computer code to investigate the subsurface hydraulic structure and its dependence on recharge rate and saturation.

The presence of clastic dikes leads to the development of complex, complementary flow networks that sometimes mask the underlying structure of heterogeneity and whose structure depends on recharge rate. The major finding of this investigation is that at the low fluxes typical of vegetated areas on the Hanford Site, the fine-textured region of the dikes dominate flow; at intermediate fluxes both the coarse sand host matrix and the fine textured regions contribute to flow; and at high input fluxes the coarse-textured host sediments dominate flow. The phenomenon of complementary flow networks is a reflection of a fundamental characteristic of flow in variably saturated heterogeneous systems and cannot be replicated with simplified one-dimensional models or models in which a clastic dike is represented as an effective homogeneous medium with fieldaveraged hydraulic properties. Results of this investigation provide insight into the processes controlling flow in the vadose zone and the conditions under which they are active. This information is being used to improve conceptual models that are needed to guide the design of remedial systems and closure activities for waste management areas. 


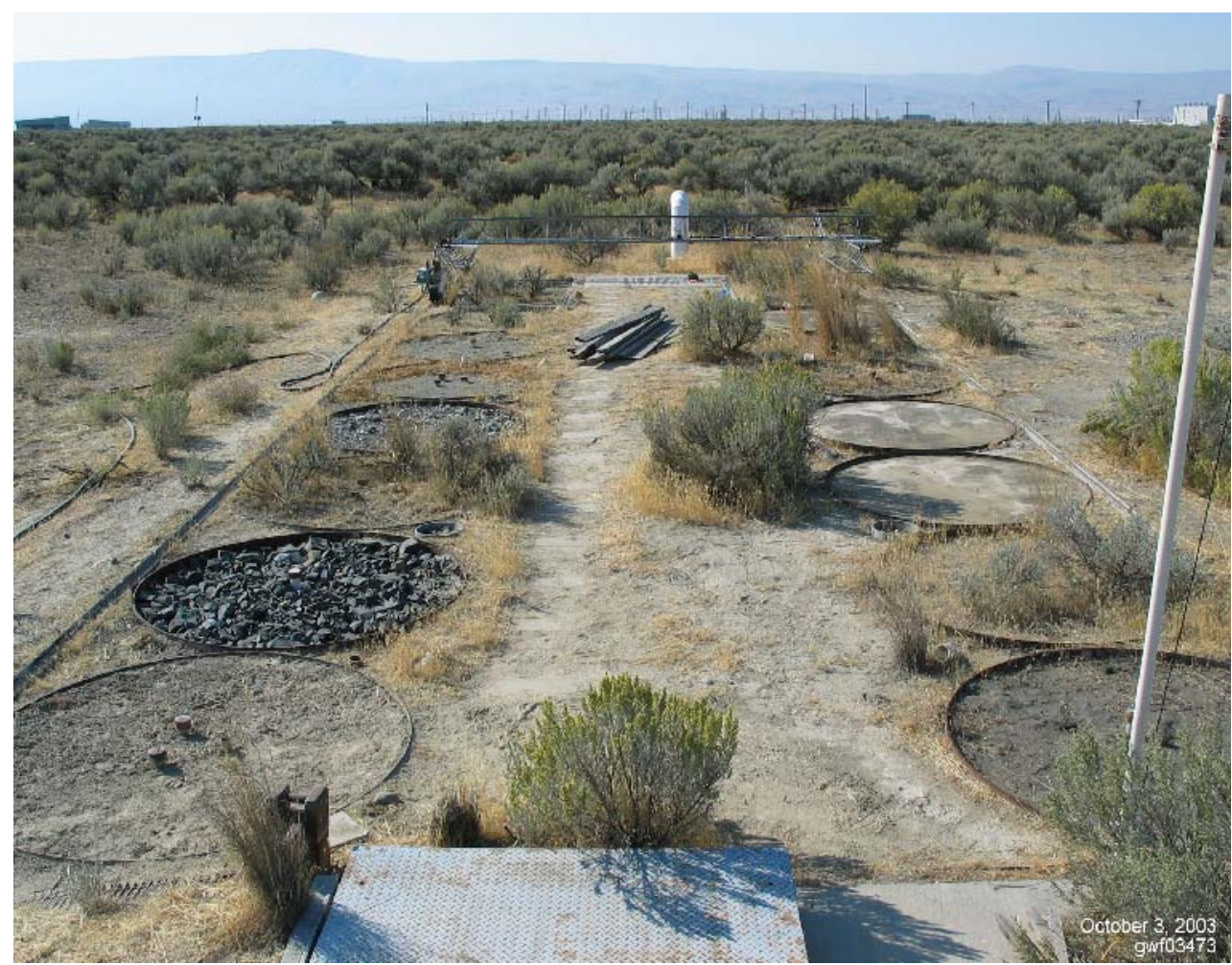

Figure 3.3-1. View of the Field Lysimeter Test Facility Looking Southwest Toward Rattlesnake Mountain 


\section{FIELD LYSIMETER TEST FACILITY}

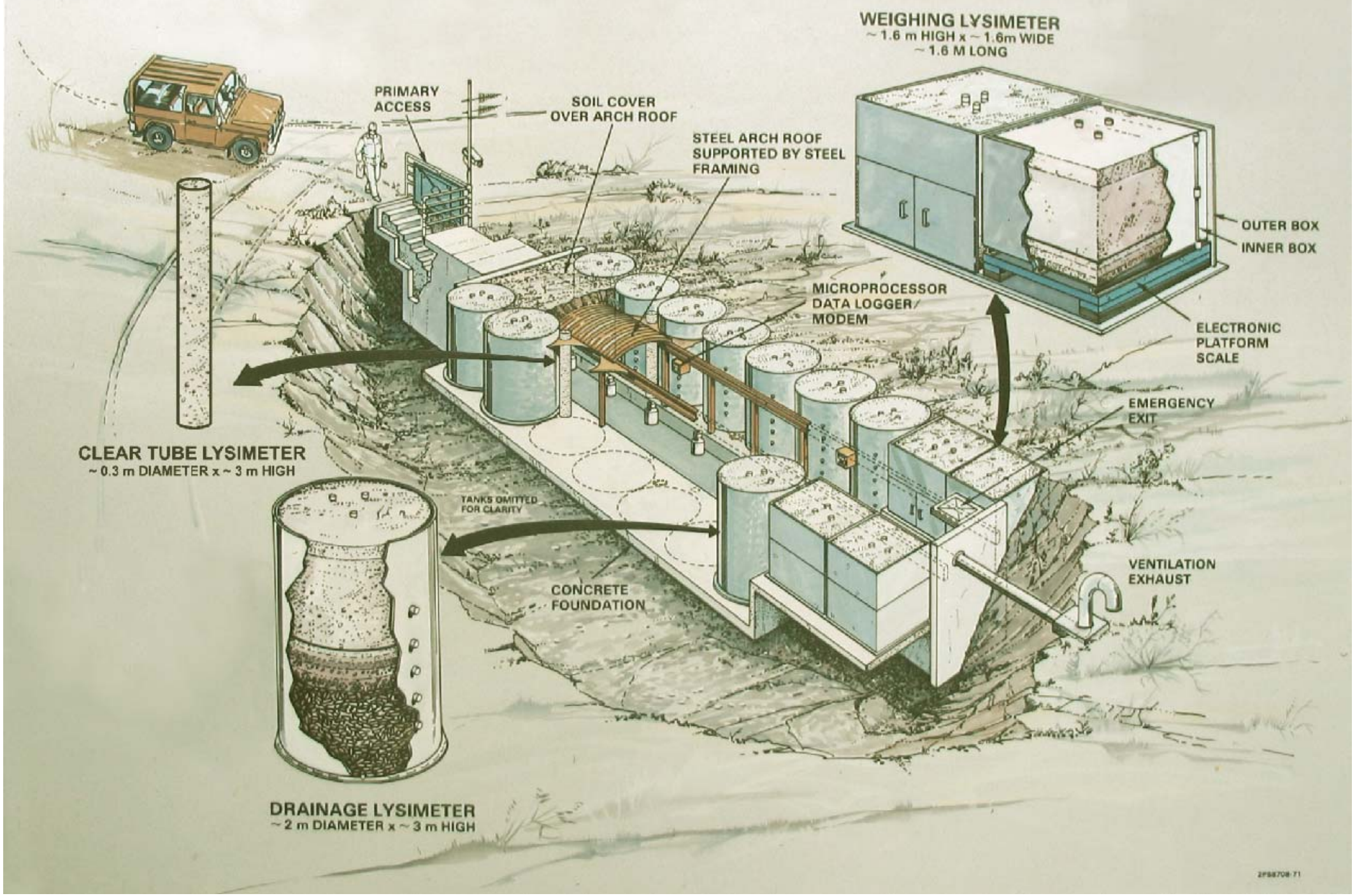

Figure 3.3-2. Drawing of the Field Lysimeter Test Facility 


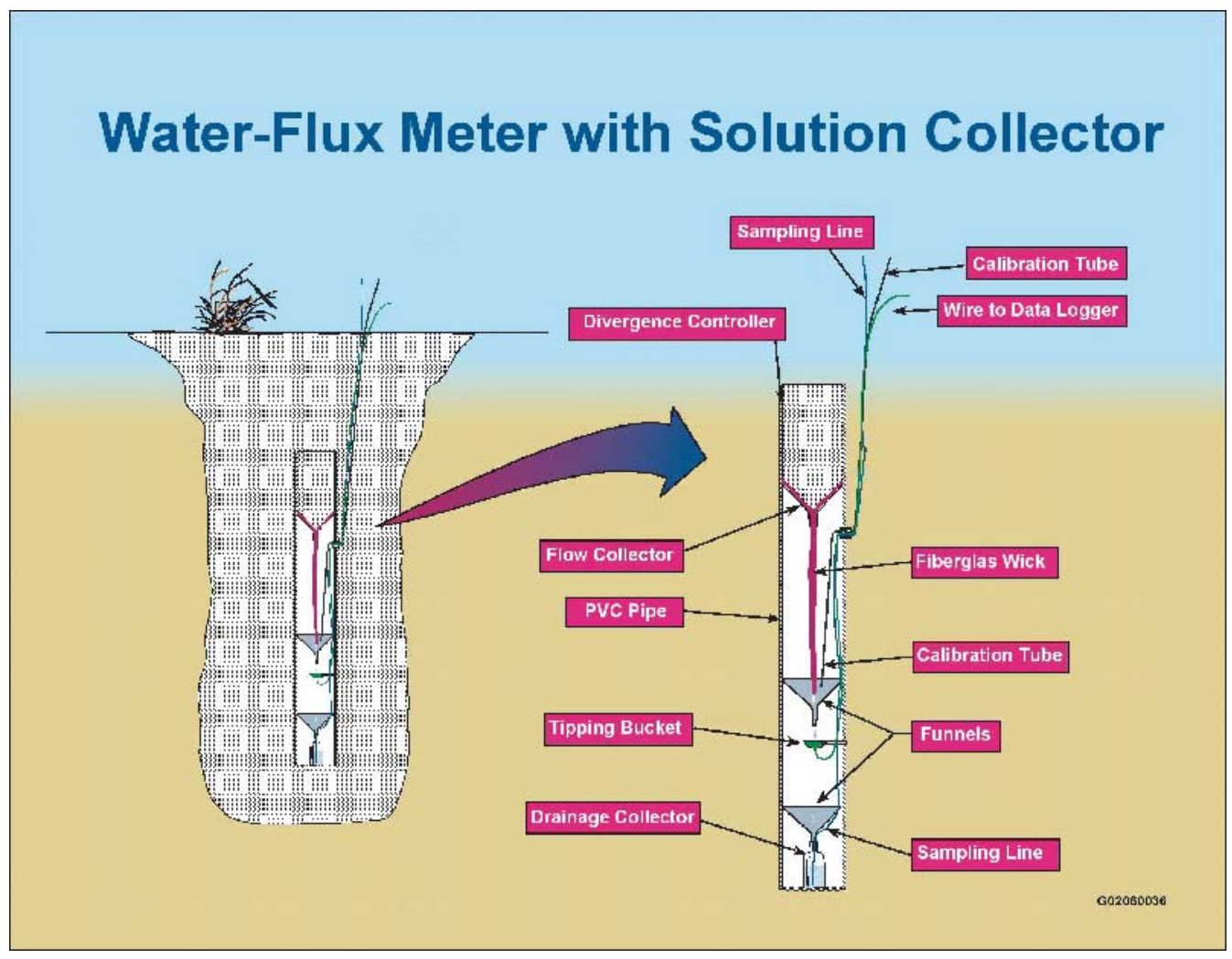

gwf03475

Figure 3.3-3. Water Fluxmeter with Solution Collection Capability (after Gee et al. 2003)

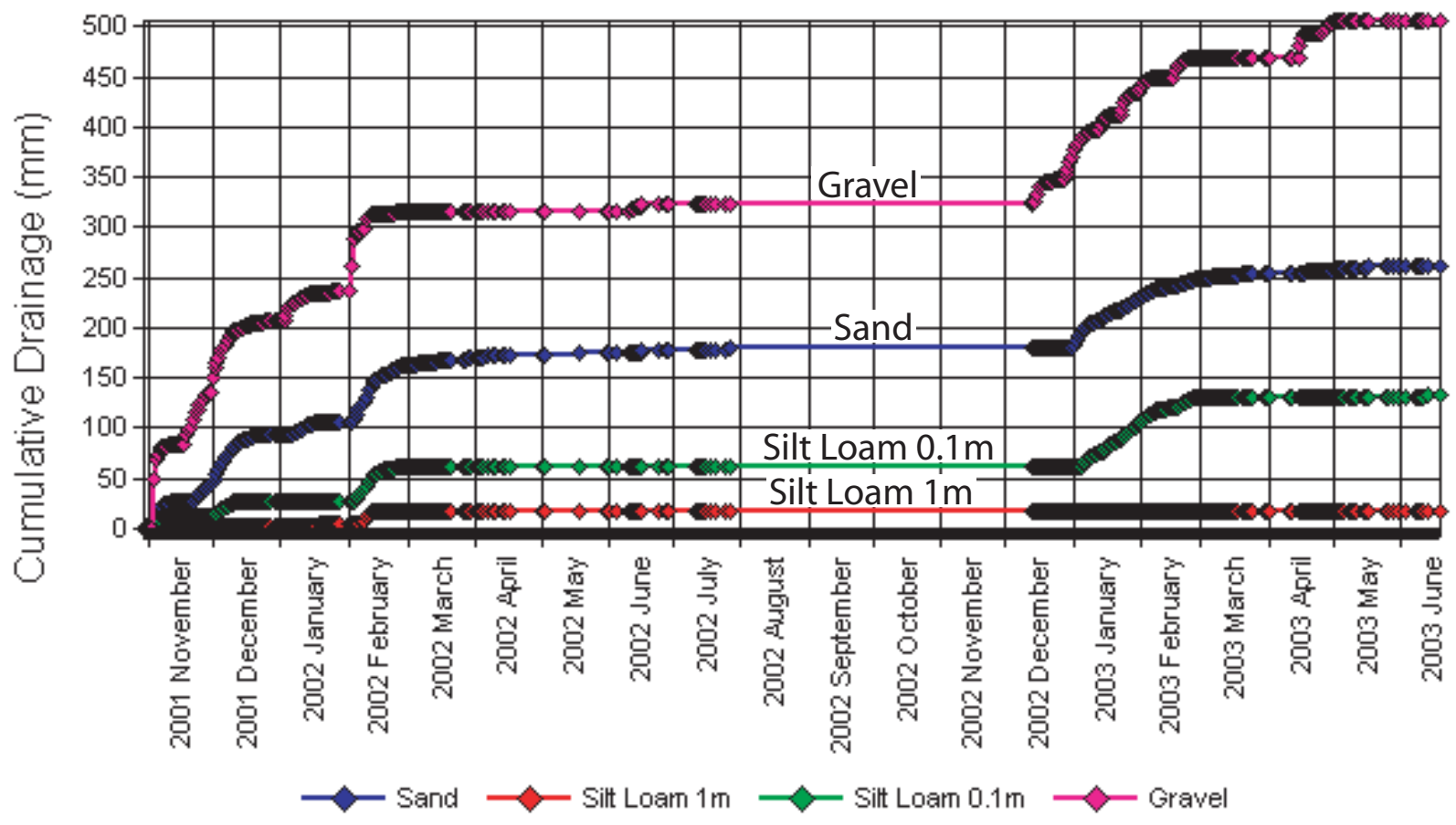

gwf03476

Figure 3.3-4. Water Fluxmeter Data Showing Drainage from Soil Materials Tested at the Hanford Site. After February 2002, all soil materials were subject only to natural precipitation. 


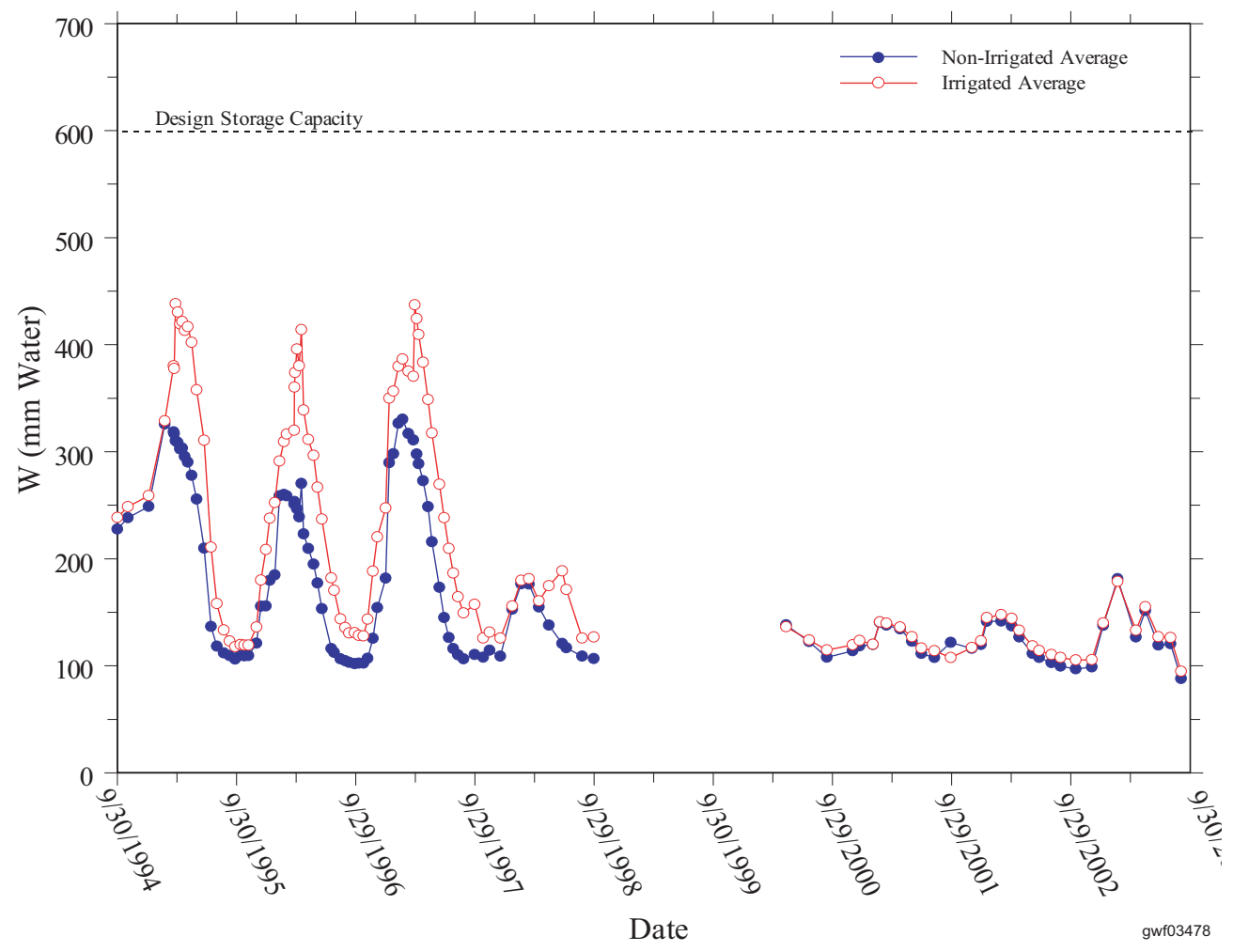

Figure 3.3-5. Temporal Variation in Mean Soil Water Storage on the North (irrigated) and South (non-irrigated) Plots at the Prototype Hanford Barrier, November 1994 through September 2003 (design water storage capacity is 600 millimeters)

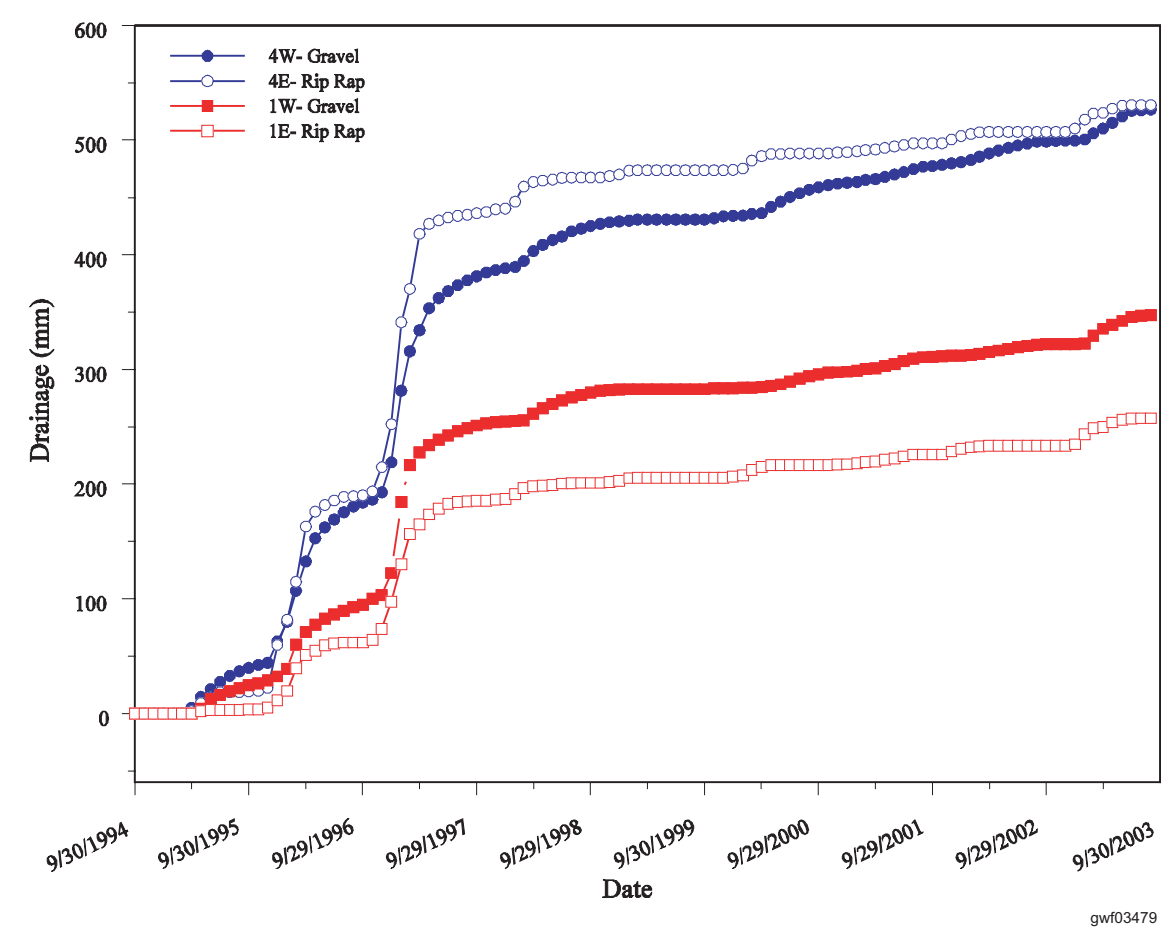

Figure 3.3-6. Cumulative Amounts of Water Diverted by the Asphalt Pad (drainage) from the Side-Slope Plots at the Prototype Hanford Barrier in September 1994 through September 2003. Data in red are from the south side of the barrier; data in blue are from the north side of the barrier. 


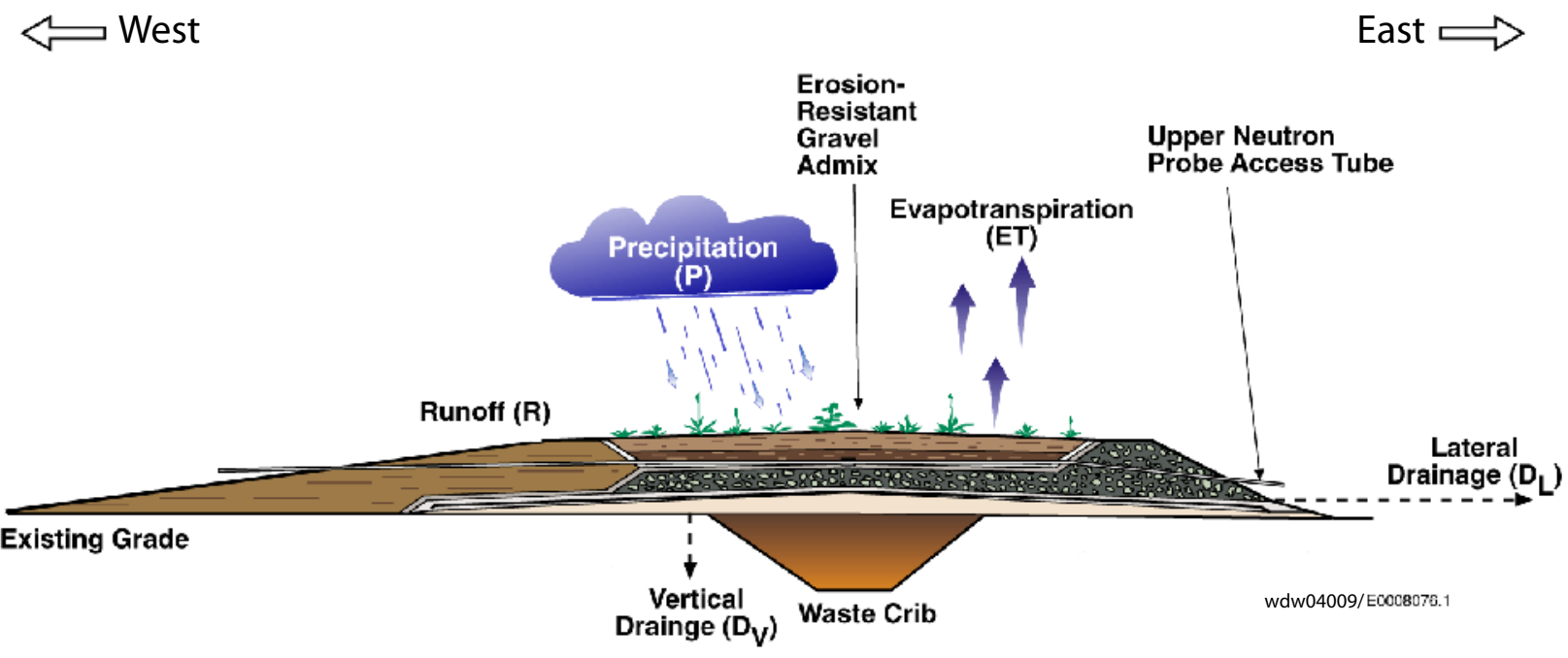

Figure 3.3-7. Primary Environmental Interactions Governing Functional Performance of a Typical 1,000-Year Capillary Barrier

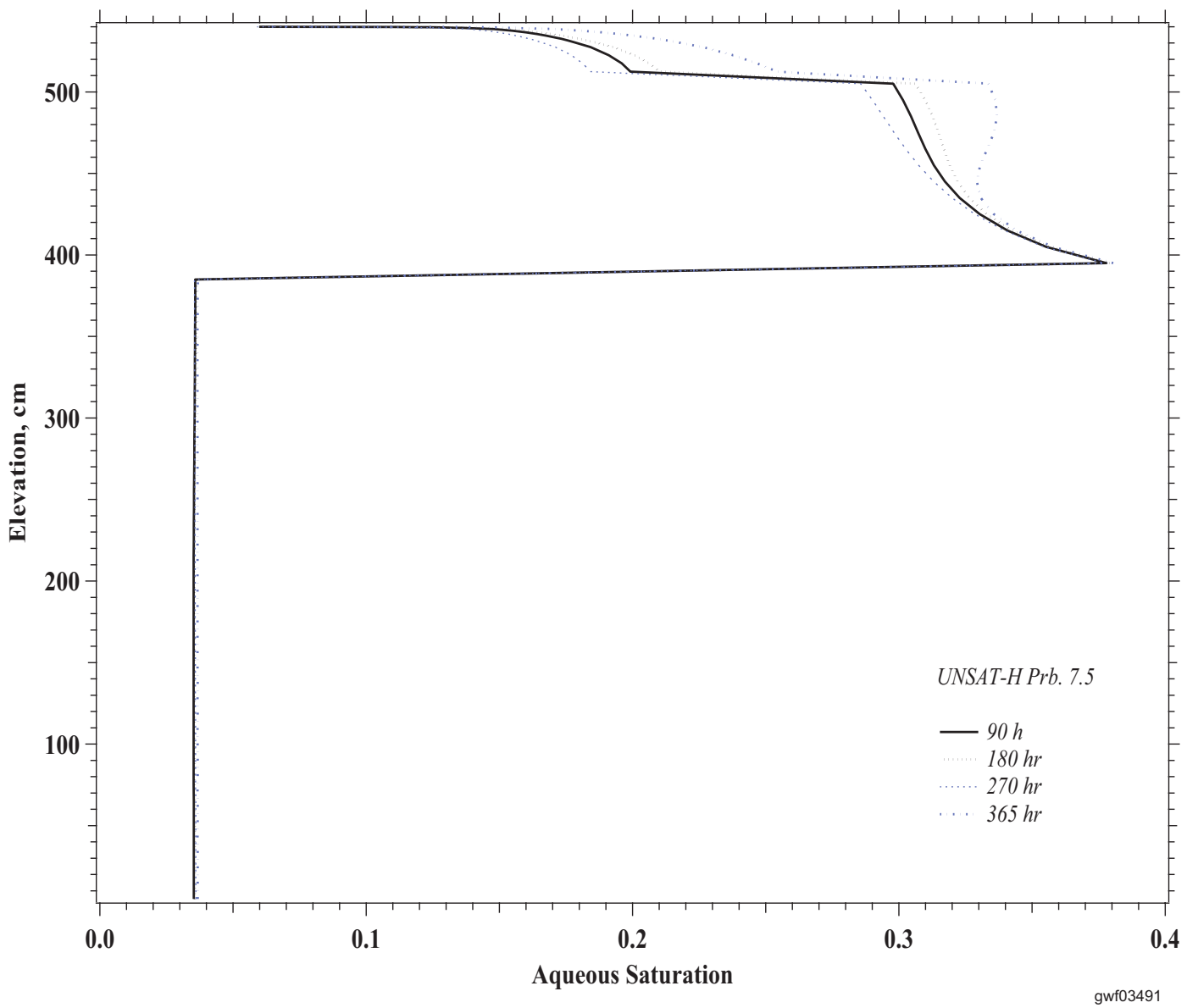

Figure 3.3-8. Simulated Aqueous Saturation as a Function of Depth within a Layered Soil. This configuration causes water to be retained within the fine textured layer making it available for recycling by plants. This configuration, which increases the water storage capacity of the fine soil layer, is an integral part of barrier designs being considered. 


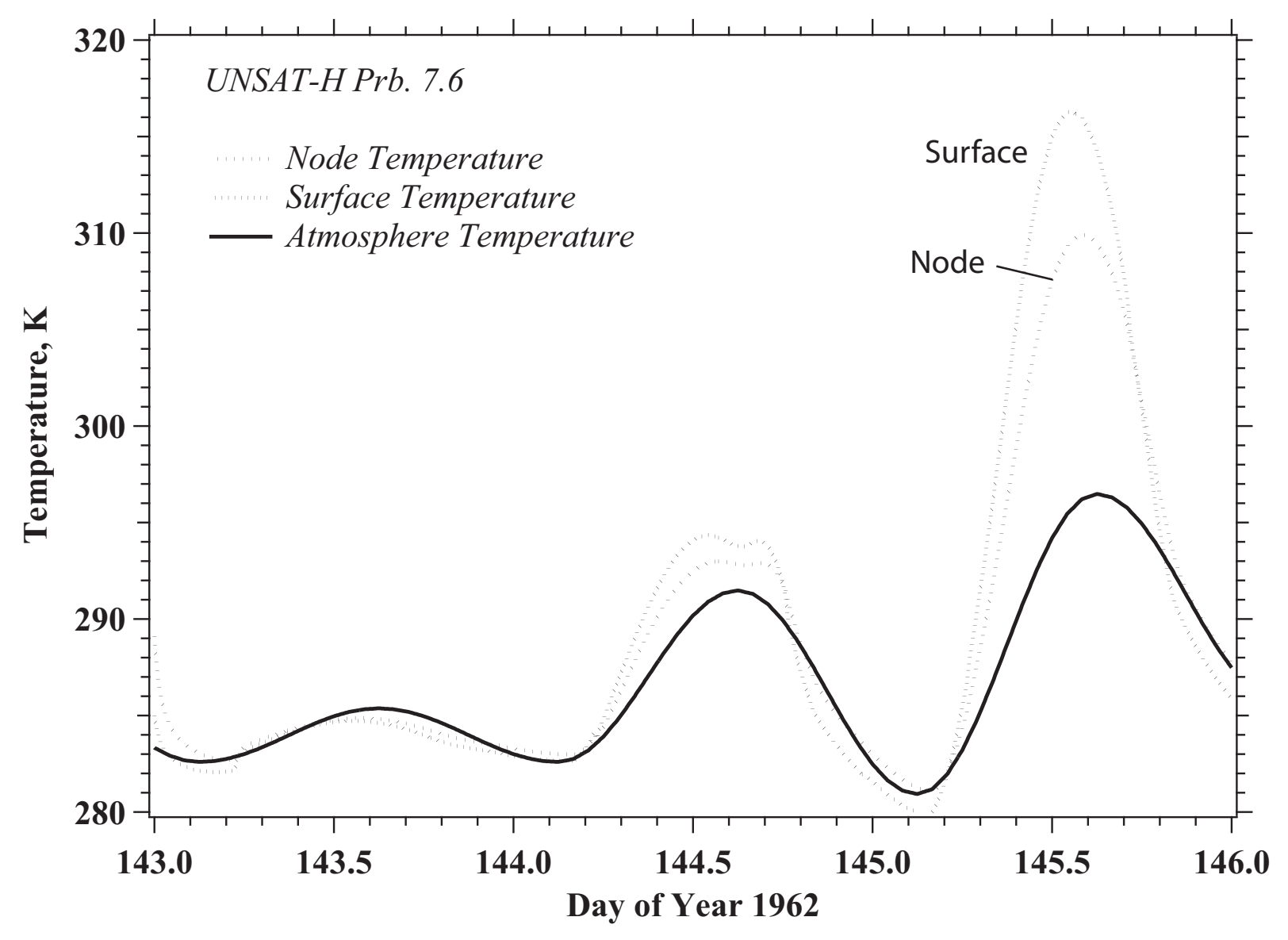

gwf03492

Figure 3.3-9. STOMP Simulated Air and Soil Surface Temperature for Water and Heat Flow in a Layered Soil System Typical of a Capillary Barrier 


\subsection{Groundwater Modeling}

\section{P. D. Thorne}

Computer models are used to forecast future groundwater conditions and the movement of contaminants in groundwater. Such predictions are important in planning waste management and cleanup activities for the Hanford Site. Groundwater modeling activities that address problems on a Hanford site-wide scale, such as contaminant movement from the operational areas on the Central Plateau to the Columbia River, have been consolidated under the Groundwater Performance Assessment Project. The consolidation of site-wide modeling eliminates redundancy and promotes consistency of groundwater models (DOE/RL-2000-11). Other groundwater models are used for problems at a local scale (i.e., $<\sim 10$ kilometers). Local-scale modeling during the past several years has been used to design and evaluate pump-and-treat systems for treatment of local-scale groundwater contaminant plumes, support closure of single-shell tanks, and support waste site remediation decisions. Local-scale models have also been applied to assess groundwater and contaminant movement in the zone of interaction between the unconfined aquifer and the Columbia River (PNNL-13674). Additional information on modeling to support closure of singleshell tanks can be found in DOE/ORP-2003-11.

This chapter summarizes Hanford Site groundwater modeling activities for fiscal year 2003. Section 4.1 reports progress on the continuing development of the consolidated site-wide groundwater model. Section 4.2 describes application of an earlier version of the consolidated model as a component of the System Assessment Capability. Section 4.3 describes local-scale modeling performed to assess groundwater pump-and-treat operations using models other than the consolidated site-wide groundwater model.

\subsection{Site-Wide Groundwater Flow and Transport Model}

Groundwater flow and transport models based on alternative conceptual models, as compared to the "base case" model described in PNNL-13447, are being developed to improve predictions of contaminant transport and to evaluate uncertainty in model results. Uncertainty in model conceptualization has been found to be the most significant source of uncertainty in groundwater modeling (NUREG/CR-6805).

\subsubsection{Development and Calibration of Alternative Conceptual Model 2}

Calibration of a site-wide model based on an alternative conceptual model, referred to as Alternative Conceptual Model 2 (ACM-2), was completed during fiscal year 2003 (PNNL-14398). This alternative model used a zone of hydraulic properties within the most important transmissive hydrogeologic units of the model based on geological "facies." Each facies zone delineates a region where hydraulic properties are expected to be similar based on available geologic and hydrologic information. Six facies zones were defined for model Unit 1, the Hanford formation. Seven zones were defined for model Unit 5, which includes Ringold gravel units $\mathrm{C}$ and $\mathrm{E}$ and upper Ringold sand (BHI-00184). The facies zones defined for ACM-2 model Unit 1 are shown in Figure 4.1-1. Facies zones defined for Unit 5 are shown in Figure 4.1-2. These zones were developed based on textural information in geologic descriptions from well drilling, knowledge of depositional environments, aquifer test information, and hydraulic head responses in wells (PNNL-14398). The 13 facies zones and the remaining 6 hydrogeologic units within the model result in 19 regions of the model that are assigned distinct hydraulic parameters including the hydraulic conductivity, vertical anisotropy, and storage properties of the sediment within that region.

The hydraulic conductivity fields of previous three-dimensional site-wide models have been tied, through scaling factors, to the transmissivity distribution that resulted from an

\section{Groundwater flow and transport models based on alternative conceptual models are being developed to improve predictions of contaminant \\ transport and to evaluate uncertainty in model results.}




\section{Alternative conceptual model 2 resulted in a better \\ fit to measure \\ water-level data \\ and is more \\ technically \\ defensible than \\ previous conceptual \\ models.}

earlier two-dimensional steady-state calibration of the model. ACM-2 also incorporates interaction with the underlying basalt-confined aquifer system, which was included in the site-wide model for the first time as part of ACM-1 (PNNL-13623). Compared the earlier ACM-1 model, the facies-based ACM-2 model resulted in a better fit to measured water level data. The sum of squared residual differences was 9\% lower for ACM-2.

The facies-zone approach used for ACM-2 is more technically defensible because it is based on a more detailed examination of geological data and removes possible errors from the earlier two-dimensional calibration. It is also more suitable for the application of geostatistical methods to develop a range of probable conceptual models that will produce a range of results and thus quantify model uncertainty. As described in PNNL-14398, geostatistical techniques were applied to develop a large number of alternative conceptual models with equally likely areas for the facies zones within Unit 1 based on the available data. Methods were also developed to generate alternative conceptual models with different, equally likely, distributions of low-permeability mud units (Units 4, 6 and 8). Work is continuing on development of a range of alternative conceptual models to capture uncertainty in the model results. Understanding and quantifying the resulting uncertainty in model predictions will strengthen the technical defensibility of groundwater transport predictions and lead to a better basis for waste-management and cleanup decisions.

Another change to ACM-2 compared to earlier models was the addition of "run-on" recharge from upland areas on the western boundary of the model. The Distributed Hydrology Soil Vegetation Model was applied to calculate expected runoff from the upland areas (PNNL-14398). Three runoff areas were defined including Cold Creek Valley, Dry Creek Valley, and Rattlesnake Mountain. Runoff from these areas was applied to model elements as shown in Figure 4.1-3.

\subsubsection{Background Information on the Site-Wide Groundwater Model}

The site-wide groundwater model is based on a conceptual model of the unconfined aquifer system that consists of features and processes that control groundwater flow and contaminant transport within the aquifer. It was developed from the following information:

- Three-dimensional location and extent of major hydrogeologic units within the aquifer.

- Distribution of textural and lithologic properties of aquifer sediments.

- Spatial distributions of hydraulic and transport properties.

- Aquifer boundary conditions including potential groundwater recharge and discharge.

- Distribution and movement of contaminants.

The model consists of nine separate hydrogeologic units, eight of which exist below the water table. The groundwater flow system is bounded by the Columbia River on the north and east and by the Yakima River and basalt ridges on the south and west, respectively. Additional information on the site-wide groundwater model is presented in PNNL-11801 and PNNL-13641.

The effort to incorporate uncertainty in the site-wide model began in 1999 with recommendations from an external peer review panel to establish a new modeling framework that accepts the inherent uncertainty in model conceptual representations, inputs, and outputs (PNNL-13641). This framework will produce a range of predicted results for future groundwater conditions and contaminant transport based on differences in conceptual model assumptions. As described in PNNL-13641, uncertainty in the site-wide groundwater model is being quantified through sensitivity analysis (e.g., alternative conceptual models and future scenarios) for those aspects of the analysis related to vagueness and through uncertainty analysis for those situations where the uncertainty (e.g., for parameters) can be represented by probability density functions. 


\subsection{System Assessment Capability}

The System Assessment Capability is an integrated assessment tool. It includes several linked computer models designed to simulate the movement of contaminants from waste sites through the vadose zone, groundwater, and Columbia River to receptors. It also incorporates modules that calculate the risks to human health and the environment.

Assessments to support the Optimization Strategy for Central Plateau Closure (WMP-18061) and the Final Hanford Site Solid (Radioactive and Hazardous) Waste Program Environmental Impact Statement (HSW EIS) (DOE/EIS-0286F) were performed using the System Assessment Capability during fiscal year 2003. Updates to data sets and software were also made in preparation for performing the 2004 composite analysis. This will be an update of the composite analysis described in PNNL-11800. It is designed to calculate the combined impact of all radiological waste that will be left on the Hanford Site at the time of site closure. The System Assessment Capability software was also modified to allow longer time periods to be simulated so that model runs can be extended to identify the time of peak concentrations that occur up to 10,000 years after site closure.

During fiscal year 2003, the System Assessment Capability was updated with the addition of an atmospheric transport module and with newer versions of models including an updated groundwater flow and transport model. The three-dimensional, base case site-wide groundwater model described in PNNL-13447 was used in the initial assessment performed during 2002 (PNNL-14027). In fiscal year 2003, the model grid was refined around the contaminant plume areas. The original model was based on a 750-meter grid spacing. This was refined to a 250-meter spacing in areas of widespread plumes and 83 meters in areas of smaller plumes. The updated grid is shown in Figure 4.2-1. Some minor changes to the geological interpretation and recharge boundaries were also incorporated in the updated model. Hydraulic conductivities were updated based on a calibration using the new grid. These changes were made to support the upcoming 2004 composite analysis.

The System Assessment Capability uses a stochastic analysis, which means that selected parameters are represented by probability distributions from which values are selected. This results in a range of calculated risks that are designed to encompass the uncertainty in the analysis. For the groundwater module, only the sorption coefficients of contaminants are represented stochastically. Other sources of uncertainty in the groundwater model, including conceptual model uncertainty, will eventually be incorporated based on the strategy described in Section 4.1. The groundwater module of the System Assessment Capability receives contaminant flux from the vadose zone module. It simulates contaminant movement through the uppermost aquifer system to the Columbia River and other potential exposure locations such as wells or seeps. The concentration of contaminants in groundwater is then used in the risk module calculations. Background information on design of the initial System Assessment Capability tool is summarized in BHI-01365. Results of an initial assessment performed with the System Assessment Capability are provided in PNNL-14027 and a description of the software is provided in PNNL-13932 and PNNL-13932-Volume 2.

\subsection{Local-Scale Modeling of Pump-and-Treat Systems}

The Hanford environmental restoration contractor has performed local-scale modeling during the past several years to design and evaluate pump-and-treat systems for groundwater. The Micro-FEM ${ }^{\circ}$ code was used to model capture and injection zones of extraction and injection wells, respectively, and to estimate the area affected by the pump-and-treat systems over time. The model was used to evaluate the hydraulic effects of the remedial action sites in several different operational areas.

\section{During fiscal \\ year 2003, the \\ System Assessment \\ Capability was \\ updated; an \\ atmospheric \\ transport module \\ was added and \\ newer versions of \\ the groundwater \\ flow and transport \\ module were \\ incorporated into \\ the computer \\ model.}


The following list indicates the operational areas and the contaminants of concern being treated at each area:

- 100-KR-4 Operable Unit (100-K Area) - hexavalent chromium.

- 100-NR-2 Operable Unit (100-N Area - strontium-90.

- 100-HR-3 Operable Unit (includes both 100-D and 100-H Areas) - hexavalent chromium.

- 200-UP-1 Operable Unit (200 West Area) - technetium-99 and uranium.

- 200-ZP-1 Operable Unit (200 West Area) - carbon tetrachloride.

During fiscal year 2003, these models were only updated to reflect the changing water-table elevation in the aquifer and changes in pumping rates. Additional information on these models is provided in DOE/RL-99-79, DOE/RL-2002-67, and DOE/RL-2002-05. 


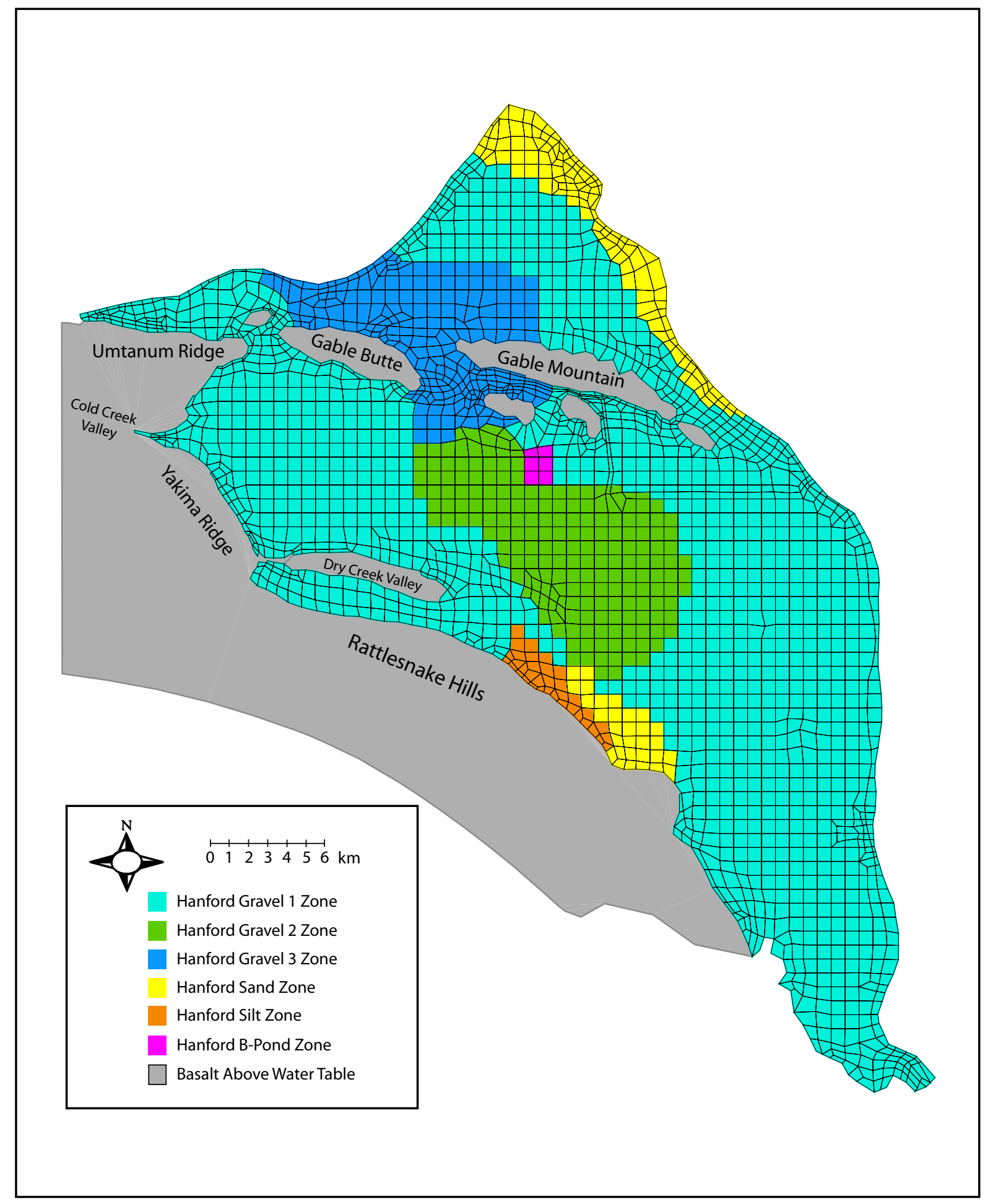

gwf03541

Figure 4.1-1. Facies Zones Defined for Alternative Conceptual Model 2, Unit 1 


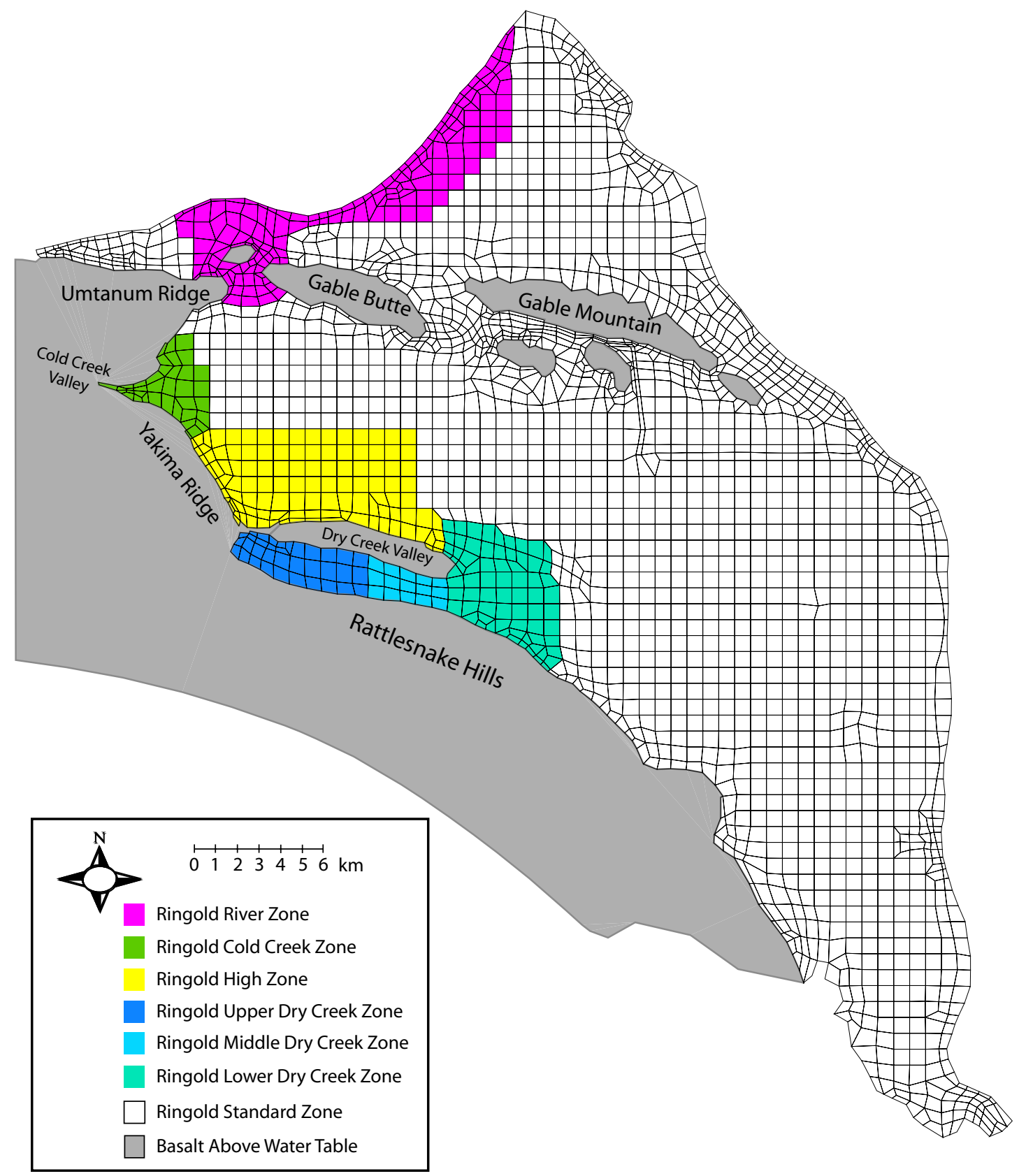

gwf03542

Figure 4.1-2. Facies Zones Defined for Alternative Conceptual Model 2, Unit 5 


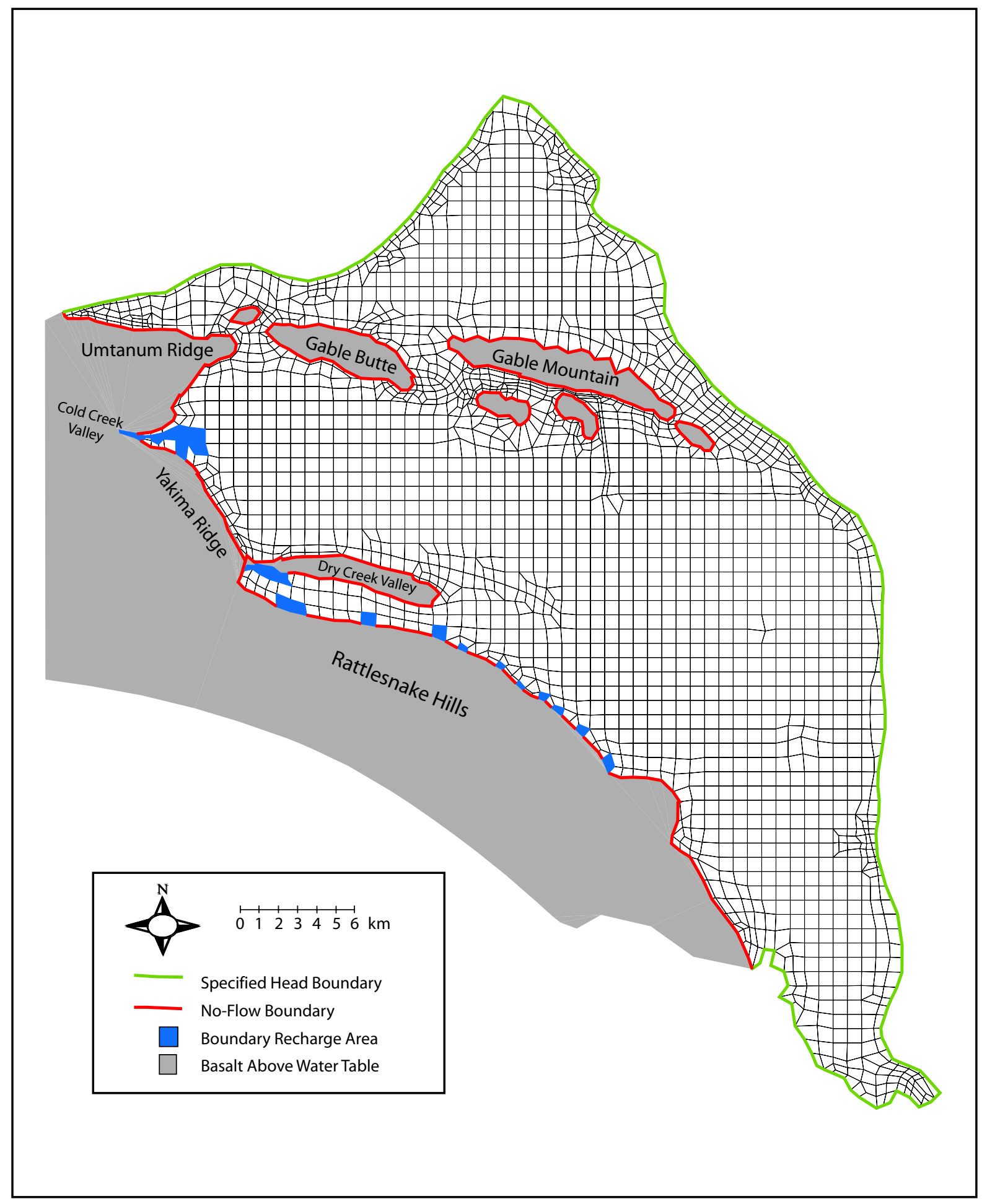

gwf03543

Figure 4.1-3. Runoff Areas (Cold Creek Valley, Dry Creek Valley and Rattlesnake Mountain) Applied to Model Elements Updated System Assessment Capability (SAC) Model Grid 


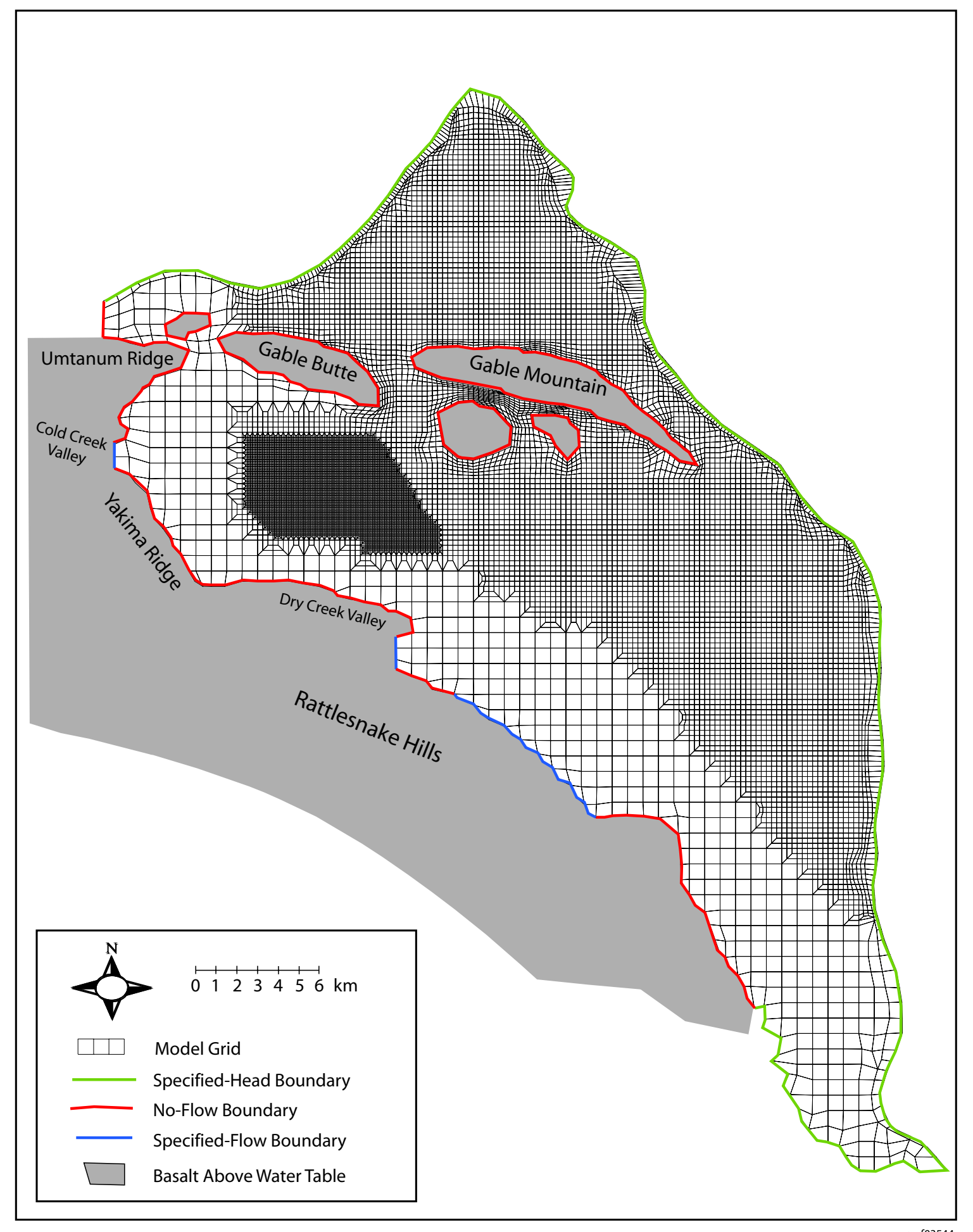

Figure 4.2-1. Updated System Assessment Capability (SAC) Model Grid 


\subsection{Well Installation, Maintenance, and Decommissioning}

\section{B. A. Williams and J. E. Auten}

This section describes new well installation activities conducted on the Hanford Site during calendar year 2003 and well maintenance and decommissioning activities during fiscal year 2003.

\subsection{Well Installation}

The Groundwater Performance Assessment Project (groundwater project) along with the Groundwater Remediation Project define needs for new wells at Hanford. Each year, the groundwater project identifies new wells to maintain compliance with the Resource Conservation and Recovery Act (RCRA) detection and assessment groundwater monitoring requirements and U.S. Department of Energy (DOE) orders, which includes longterm monitoring of regional groundwater plumes and monitoring for the Comprehensive Environmental Response, Compensation, and Liability Act (CERCLA). These compliance issues include ongoing RCRA assessment of groundwater contamination, replacement of monitoring wells that go dry because of the declining water table, replacement of wells that pose contamination risks to the environment, improvement of spatial coverage of the monitoring networks or for plume monitoring, compliance for corrective actions at the 116-H-6 evaporation basins and 300 Area process trenches, and vertical characterization of groundwater contamination. The Groundwater Remediation Project, operated by Fluor Hanford, Inc., determines the need for new remediation (i.e., pump-and-treat systems) and performance assessment monitoring wells annually to fulfill obligations of CERCLA.

Well needs are integrated via the data quality objectives process and documented (e.g., CP-15329). This process integrates the borehole and well data needs of the various Hanford Site projects (i.e., CERCLA, RCRA, and Atomic Energy Act of 1954 [AEA]). Based on the data quality objectives documentation, the Washington State Department of Ecology (Ecology), U.S. Environmental Protection Agency (EPA), and DOE (the Tri-Parties) negotiated an integrated well drilling list that coordinates and prioritizes the requirements of RCRA, CERCLA, and the AEA. In 2003, the Tri-Parties agreed that the highest

Based on groundwater monitoring requirements, DOE, EPA, and Ecology agree on new wells needed and prioritize the requirements of RCRA, CERCLA, and AEA. During calendar year 2003, 18 new wells were installed on the Hanford Site:

- Seven for RCRA monitoring.

- Nine for CERCLA investigations or remediation.

- Two for Natural Accelerated Bioremediation Investigation and Remediation.

Routine well maintenance is performed on a 5-year cycle to support groundwater sampling. Non-routine maintenance varies and depends on specific problems identified in the field. During fiscal year 2003, 243 wells received non-routine maintenance for such things as casing repairs, well labeling, or replacing tubing.

Wells are decommissioned when they are no longer used, they are in poor condition, or they pose an environmental, safety, or health hazard. During fiscal year 2003, 63 wells were decommissioned. 


\section{A revised Tri-Party Agreement milestone includes a prioritized list and schedule for installation of 60 wells over 4 years.}

priority for well installation is completion of the RCRA groundwater detection well networks at the single-shell tank waste management areas and wells needed to upgrade existing CERCLA pump-and-treat systems.

As a result of this integration, the Tri-Parties agreed to revise the existing Hanford Federal Facility Agreement and Consent Order (Tri-Party Agreement, Ecology et al. 1998), Tri-Party Agreement Milestone M-24-00 to allow prioritization of all groundwater well drilling activities at the Hanford Site - not just RCRA; the revised agreement now includes CERCLA and AEA wells along with RCRA. These negotiations have resulted in an approved tentative agreement to install a minimum of 15 wells per year to satisfy the proposed Tri-Party Agreement Milestone M-24-57. The revised milestone includes a prioritized list and schedule for installation of 60 wells over 4 years during calendar years 2003 to 2006. New wells to be installed will continue to be reviewed and approved annually via the Tri-Party Agreement Milestone M-24-00 (Ecology et al. 1998).

During calendar year 2003, a total of 18 new wells were installed at the Hanford Site. The Tri-Parties agreed to install 16 wells, which included 7 RCRA wells, and 9 CERCLA wells, as defined in Tri-Party Agreement Milestone M-24-57. Of the seven RCRA wells, one CERCLA investigation borehole was completed as a RCRA well for the 216-S-10 pond and ditch in the 200 West Area, five boreholes were drilled; ultimately, four wells were completed (C4126 was abandoned due to drilling problems) for Waste Management Area C, and two wells were completed at Waste Management Area A-AX in the 200 East Area. The nine CERCLA wells include two wells in the 100-K Area for chromium extraction and monitoring, three wells for the 100-HR-3 monitoring network at the 100-D Area, one well for the 200-ZP-1 and one well for the 200-UP-1 Operable Unit in the 200 West Area, and two wells to support the tritium investigation at the 618-10 burial ground.

In addition, two wells were installed for the chromate bio-reduction in situ research under the DOE Office of Science and Biological and Environmental Research (Natural Accelerated Bioremediation Investigation and Remediation). Table 5.1-1 lists all new wells completed in calendar year 2003 (Figure 5.1-1).

Data packages for new wells installed during calendar year 2003 will provide detailed information about the wells including the detailed geologic and geophysical descriptions and a complete set of soil and/or groundwater sampling data results (e.g., PNNL-14320 and CP-14265). Detailed drilling and construction records for the new wells can also be located electronically by well identification number at either the Records Management Information System or the Hanford Well Information System [http://apweb02/cfroot/rapidweb/ $\mathrm{phmc} / \mathrm{cp} / \mathrm{hwisapp} /$ managed for DOE by Fluor Hanford, Inc.

During 2003, 60 characterization boreholes (i.e., soil gas probes and GeoProbe/push probes) were installed (Table 5.1-2). Of these, 15 were installed at the $100-\mathrm{K}$ burial ground as soil-gas probes for soil-gas sampling in the vadose zone to investigate tritium sources. The probes will be decommissioned as soon as the investigations are completed. Thirty-eight GeoProbe boreholes were installed for vadose characterization and carbon tetrachloride investigation at the 200-ZP-1 Operable Unit. The other nine boreholes were installed for characterization of various waste sites as listed in Table 5.1-2.

\subsection{Well Maintenance}

Maintenance of groundwater wells is performed to meet regulatory requirements (e.g., Ecology 1994, Condition II.F.2) as part of a scheduled preventive maintenance cycle (routine) or in response to problems identified in the field (non-routine). No routine well maintenance was performed during fiscal year 2003 due to funding constraints. Two hundred and forty-three wells received non-routine maintenance in fiscal year 2003. A summary of maintenance activities by regulatory program is presented in Table 5.2-1. 
Routine maintenance is planned based on a 5 -year cycle to support groundwater sampling and to minimize non-routine maintenance activities. At a minimum, routine maintenance includes the following tasks:

- Removing groundwater sampling pump systems or aquifer-testing equipment.

- Inspecting and repairing or replacing sampling pump systems or aquifer-testing equipment.

- Brushing or cleaning of well casing perforations or well screens.

- Removing debris and fill material.

- Developing the well.

- Performing borehole video camera survey.

- Re-installing sampling pumps and/or aquifer-testing instrumentation/equipment.

- Documenting well conditions and maintenance activities.

Non-routine maintenance tasks are varied and depend on the specific problem encountered at a well; these tasks include both surface and subsurface tasks. Surface tasks include conducting field inspections, well labeling, maintenance and replacement of locking well caps, casing repairs, diagnosis and repair of surface electrical, and pump-discharge fitting. Subsurface tasks include repairing and replacing sampling pumps, performing camera surveys, pump and equipment retrieval, and tubing replacement.

\subsection{Well Decommissioning}

A well becomes a candidate for decommissioning (1) if its use has been permanently discontinued; (2) if its condition is so poor that its continued use is impractical; or (3) it poses an environmental, safety, or public health hazard. At this time, decommissioning is generally driven by the long-range environmental restoration schedule (DOE/RL-96-105) and available funding. Sixty-three wells were decommissioned during fiscal year 2003 (Table 5.3-1).

Decommissioning activities result in the permanent removal of a well, borehole, or piezometer from service and from the Hanford Site active well inventory. Decommissioning is performed in accordance with Ecology standards (WAC 173-160), applicable variances, and conditions defined in the Hanford Facility RCRA Permit (Ecology 1994, Condition II.F.2). Decommissioning involves backfilling a well with impermeable material to prevent vertical movement of water and/or contaminants. Typically, well decommissioning is performed by placing sand across the screened interval, perforating the casing across any confining layers, and pressure grouting those intervals. Where possible, the casing is removed and a brass survey marker identifying the well is set in grout at the surface and over the well location. If the casing cannot be removed, the casing is generally cut $\sim 1$ meter below ground surface and the identifying brass survey marker is set in the grout below land surface; the hole is then backfilled to grade.
Well maintenance activities include casing repairs, repairing and replacing sampling pumps, pump and equipment retrieval, and tubing replacement.

\author{
Wells are filled \\ with grout if they \\ are in poor \\ condition, interfere \\ with surface \\ construction \\ activities, or are no \\ longer used.
}


Table 5.1-1. Well Installations for Calendar Year 2003

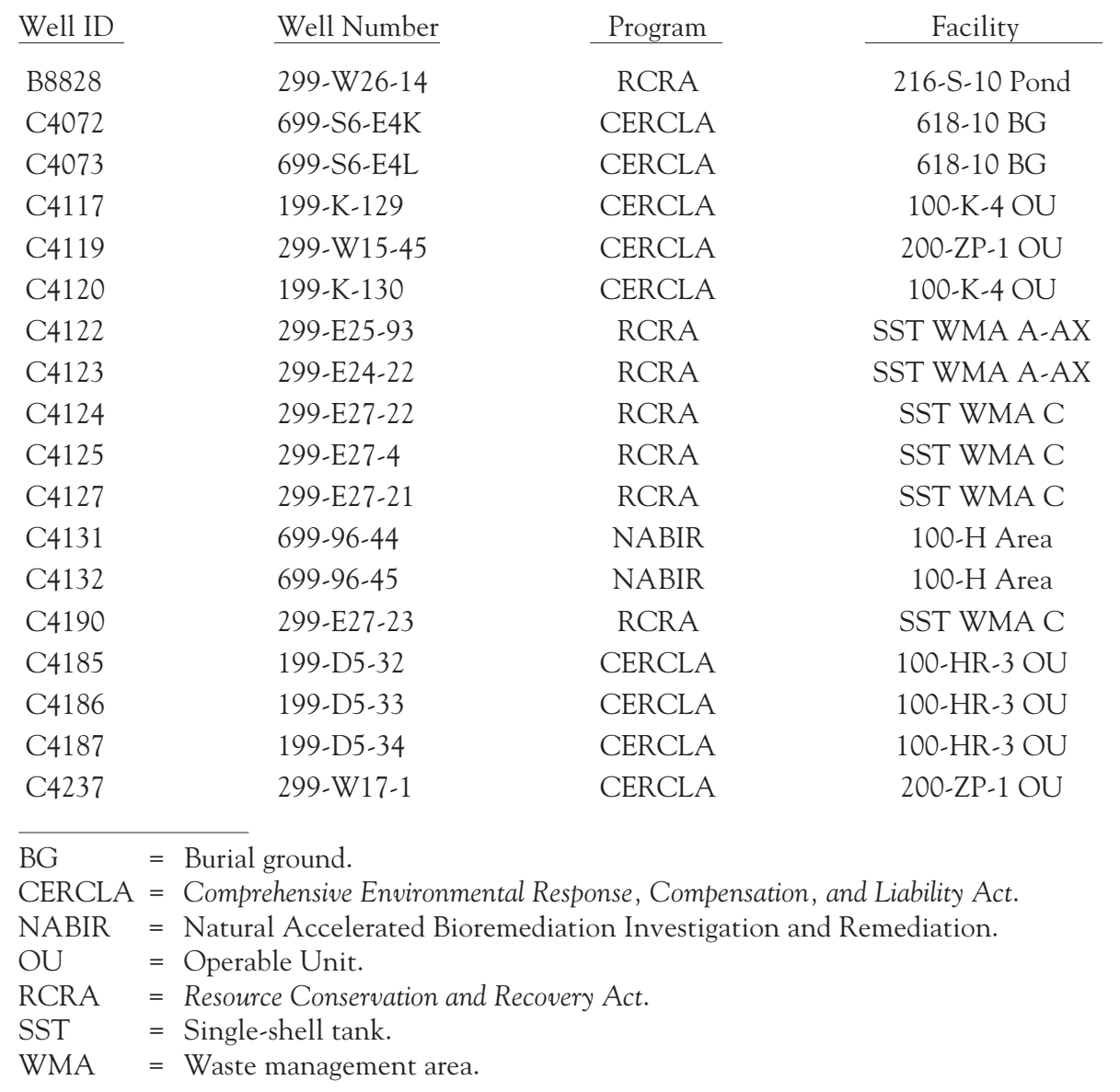


Table 5.1-2. Vadose Characterization Wells, Soil-Gas Probes, and GeoProbe/Push Installations for Fiscal Year 2003

\begin{tabular}{|c|c|c|c|}
\hline Well ID & Well Name & Facility & Location \\
\hline B8826 & B8826 & 216-A-29 Ditch & 200 East Area \\
\hline B8827 & B8827 & 216-B-63 Trench & 200 East Area \\
\hline C3245 & C3245 & 216-A-19 Ditch & 200 East Area \\
\hline C3246 & C3246 & $216-B-12$ & 200 East Area \\
\hline C3247 & C3247 & 216-A-10 Ditch & 200 East Area \\
\hline C3248 & C3248 & 216-A-36B Ditch & 200 East Area \\
\hline C3876 & C3876 & 200-ZP-1 OU & 200 West Area \\
\hline C3877 & C3877 & 200-ZP-1 OU & 200 West Area \\
\hline C3878 & C3878 & 200-ZP-1 OU & 200 West Area \\
\hline C3879 & C3879 & 200-ZP-1 OU & 200 West Area \\
\hline C4059 & C4059 & 200-ZP-1 OU & 200 West Area \\
\hline C4060 & C4060 & 200-ZP-1 OU & 200 West Area \\
\hline C4061 & C4061 & 200-ZP-1 OU & 200 West Area \\
\hline C4062 & C4062 & 200-ZP-1 OU & 200 West Area \\
\hline $\mathrm{C} 4063$ & $\mathrm{C} 4063$ & 200-ZP-1 OU & 200 West Area \\
\hline C4064 & C4064 & 200-ZP-1 OU & 200 West Area \\
\hline C4065 & C4065 & 200-ZP-1 OU & 200 West Area \\
\hline C4066 & C4066 & 200-ZP-1 OU & 200 West Area \\
\hline $\mathrm{C} 4067$ & C4067 & 200-ZP-1 OU & 200 West Area \\
\hline C4068 & C4068 & 200-ZP-1 OU & 200 West Area \\
\hline C4104 & C4104 & 200-ZP-1 OU & 200 West Area \\
\hline C4106 & C4106 & 200-ZP-1 OU & 200 West Area \\
\hline $\mathrm{C} 4107$ & C4107 & 200-ZP-1 OU & 200 West Area \\
\hline C4108 & C4108 & 200-ZP-1 OU & 200 West Area \\
\hline C4110 & C4110 & 200-ZP-1 OU & 200 West Area \\
\hline C4111 & C4111 & 200-ZP-1 OU & 200 West Area \\
\hline $\mathrm{C} 4112$ & C4112 & 200-ZP-1 OU & 200 West Area \\
\hline C4129 & C4129 & 200-ZP-1 OU & 200 West Area \\
\hline C4133 & C4133 & 200-ZP-1 OU & 200 West Area \\
\hline C4136 & C4136 & 200-ZP-1 OU & 200 West Area \\
\hline C4137 & C4137 & 200-ZP-1 OU & 200 West Area \\
\hline C4138 & C4138 & 200-ZP-1 OU & 200 West Area \\
\hline C4146 & C4146 & EAPS & 200 West Area \\
\hline $\mathrm{C} 4147$ & $144-\mathrm{K}-1$ & $118-\mathrm{K}-1 \mathrm{BG}$ & 100-K Area \\
\hline C4148 & $144-K-2$ & $118-\mathrm{K}-1 \mathrm{BG}$ & 100-K Area \\
\hline C4149 & $144-\mathrm{K}-3$ & $118-\mathrm{K}-1 \mathrm{BG}$ & 100-K Area \\
\hline C4150 & $144-\mathrm{K}-4$ & $118-\mathrm{K}-1 \mathrm{BG}$ & 100-K Area \\
\hline C4151 & $144-K-5$ & $118-\mathrm{K}-1 \mathrm{BG}$ & 100-K Area \\
\hline C4152 & $144-\mathrm{K}-6$ & $118-\mathrm{K}-1 \mathrm{BG}$ & 100-K Area \\
\hline $\mathrm{C} 4153$ & $144-\mathrm{K}-7$ & $118-\mathrm{K}-1 \mathrm{BG}$ & 100-K Area \\
\hline C4154 & $144-\mathrm{K}-8$ & $118-\mathrm{K}-1 \mathrm{BG}$ & 100-K Area \\
\hline C4155 & $144-K-9$ & $118-\mathrm{K}-1 \mathrm{BG}$ & 100-K Area \\
\hline C4156 & $144-K-10$ & $118-\mathrm{K}-1 \mathrm{BG}$ & 100-K Area \\
\hline C4157 & $144-\mathrm{K}-11$ & $118-\mathrm{K}-1 \mathrm{BG}$ & 100-K Area \\
\hline C4158 & $144-\mathrm{K}-12$ & $118-\mathrm{K}-1 \mathrm{BG}$ & 100-K Area \\
\hline C4159 & $144-K-13$ & $118-\mathrm{K}-1 \mathrm{BG}$ & 100-K Area \\
\hline C4160 & C4160 & 200-ZP-1 OU & 200 West Area \\
\hline
\end{tabular}


Table 5.1-2. (contd)

\begin{tabular}{|c|c|c|c|}
\hline Well ID & Well Name & Facility & Location \\
\hline C4161 & C4161 & 200-ZP-1 OU & 200 West Area \\
\hline C4162 & C4162 & $200-\mathrm{ZP}-1 \mathrm{OU}$ & 200 West Area \\
\hline C4163 & C4163 & 200-ZP-1 OU & 200 West Area \\
\hline C4164 & C4164 & 200-ZP-1 OU & 200 West Area \\
\hline C4188 & $144-K-14$ & $118-\mathrm{K}-1 \mathrm{BG}$ & 100-K Area \\
\hline C4189 & $144-\mathrm{K}-15$ & $118-\mathrm{K}-1 \mathrm{BG}$ & 100-K Area \\
\hline C4240 & C4240 & $200-\mathrm{ZP}-1 \mathrm{OU}$ & 200 West Area \\
\hline C4241 & C4241 & $200-\mathrm{ZP}-1 \mathrm{OU}$ & 200 West Area \\
\hline C4242 & C4242 & $200-\mathrm{ZP}-1 \mathrm{OU}$ & 200 West Area \\
\hline C4243 & C4243 & $200-\mathrm{ZP}-1 \mathrm{OU}$ & 200 West Area \\
\hline $\mathrm{C} 4244$ & C4244 & $200-\mathrm{ZP}-1 \mathrm{OU}$ & 200 West Area \\
\hline $\mathrm{C} 4245$ & $\mathrm{C} 4245$ & $200-\mathrm{ZP}-1 \mathrm{OU}$ & 200 West Area \\
\hline C4246 & C4246 & $200-\mathrm{ZP}-1 \mathrm{OU}$ & 200 West Area \\
\hline
\end{tabular}

Table 5.2-1. Well Maintenance Summary for Fiscal Year 2003

\begin{tabular}{lcc}
\multicolumn{1}{c}{ Program } & Routine & Non-Routine \\
CERCLA & 0 & 56 \\
RCRA & 0 & 161 \\
LTMC & 0 & 3 \\
Surveillance(a) & 0 & 15 \\
Geophysical Logging Support & 0 & 8 \\
Total & 0 & 243
\end{tabular}

(a) Atomic Energy Act of 1954 monitoring.

CERCLA = Comprehensive Environmental Response, Compensation, and Liability Act.

LTMC = Long-term monitoring - CERCLA.

RCRA = Resource Conservation and Recovery Act. 
Table 5.3-1. Wells Decommissioned During Fiscal Year 2003

\begin{tabular}{|c|c|c|c|}
\hline$\underline{\text { Well ID }}$ & Well Name & $\underline{\text { Well ID }}$ & Well Name \\
\hline A7340 & 299-W14-56 & A4955 & 299-W19-29 \\
\hline A7341 & 299-W14-57 & A7748 & 299-W19-30 \\
\hline A7342 & 299-W14-58 & A4956 & 299-W19-31 \\
\hline A7345 & 299-W14-61 & A4957 & 299-W19-32 \\
\hline A4916 & 299-W15-10 & B2463 & 299-W19-38 \\
\hline A4923 & 299-W15-19 & A7790 & 299-W19-90 \\
\hline A4924 & 299-W15-20 & A4960 & 299-W19-91 \\
\hline A4926 & 299-W15-23 & A4961 & 299-W19-92 \\
\hline A4927 & 299-W15-24 & A4962 & 299-W19-93 \\
\hline A9831 & 299-W15-25 & A4963 & 299-W21-1 \\
\hline A5478 & 299-W18-2 & A7830 & 299-W22-4 \\
\hline A5470 & 299-W18-5 & A4967 & 299-W22-22 \\
\hline A5479 & 299-W18-17 & A7844 & 299-W22-23 \\
\hline A7531 & 299-W18-18 & A4969 & 299-W22-28 \\
\hline A5471 & 299-W18-20 & A7856 & 299-W22-37 \\
\hline A4938 & 299-W18-26 & A7857 & 299-W22-38 \\
\hline A4941 & 299-W18-29 & A4971 & 299-W22-40 \\
\hline A7565 & 299-W18-82 & A7867 & 299-W22-60 \\
\hline A7569 & 299-W18-86 & A7878 & 299-W22-74 \\
\hline A7571 & 299-W18-88 & A4991 & 299-W23-8 \\
\hline A7578 & 299-W18-95 & A7885 & 299-W23-16 \\
\hline A7730 & 299-W18-250 & A7886 & 299-W23-17 \\
\hline A4944 & 299-W19-1 & A7833 & 299-W22-8 \\
\hline A7734 & 299-W19-5 & A7343 & 299-W14-59 \\
\hline A7744 & 299-W19-19 & A7344 & 299-W14-60 \\
\hline A7735 & 299-W19-7 & A9462 & 299-W11-20 \\
\hline A4952 & 299-W19-24 & C4094 & $199-\mathrm{N}-118$ \\
\hline A7745 & 299-W19-23 & C4095 & $199-\mathrm{N}-114$ \\
\hline A7746 & 299-W19-25 & C4096 & $199-\mathrm{N}-115$ \\
\hline A7747 & 299-W19-26 & C4097 & $199-\mathrm{N}-116$ \\
\hline A4953 & 299-W19-27 & C4098 & $199-\mathrm{N}-117$ \\
\hline A4954 & 299-W19-28 & & \\
\hline
\end{tabular}




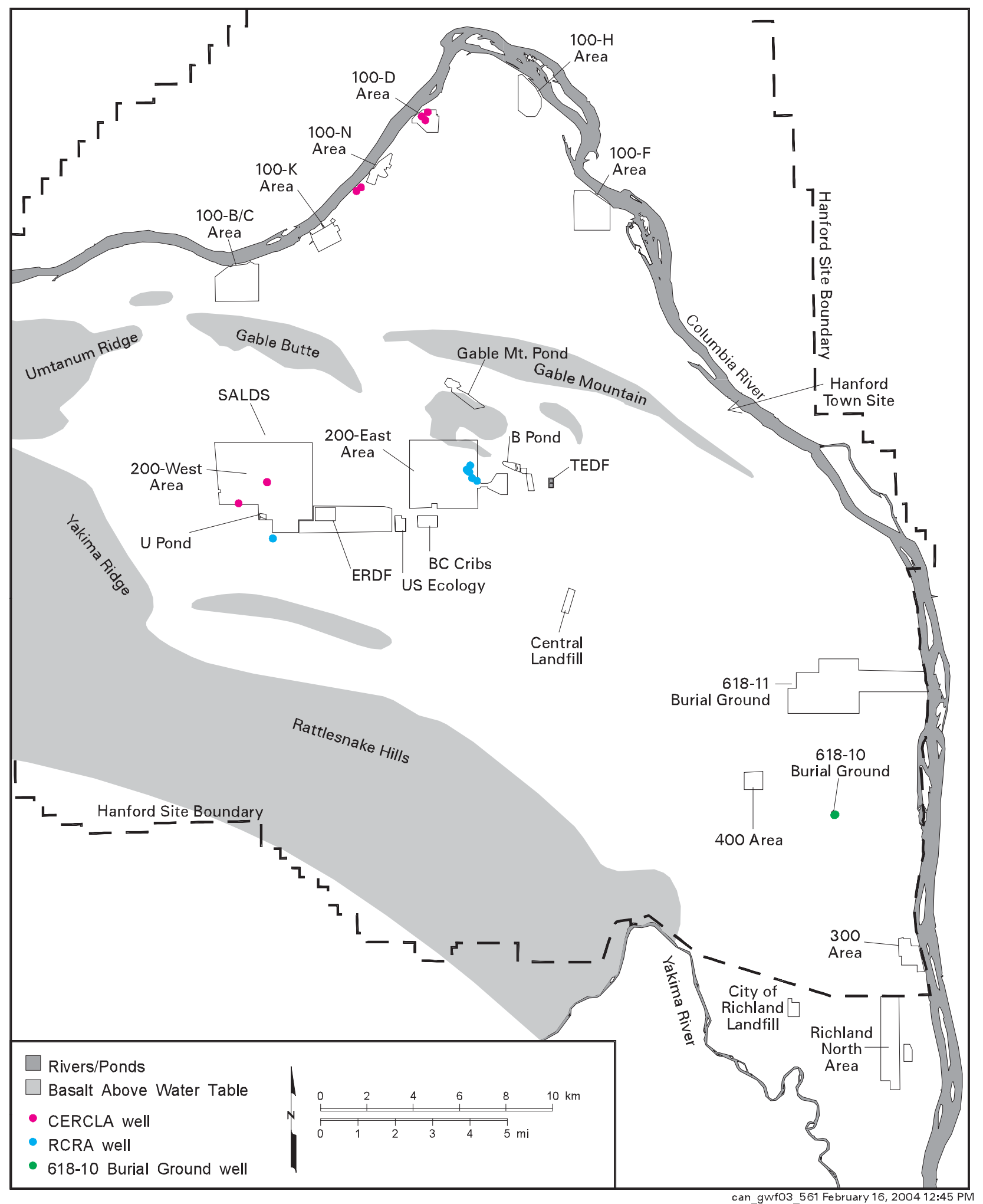

Figure 5.1-1. Groundwater Monitoring Wells Installed in Calendar Year 2003 


\subsection{References}

\section{Public Laws}

Atomic Energy Act of 1954. As amended, Ch. 1073, 68 Stat. 919, 42 USC 2011 et seq.

Comprehensive Environmental Response, Compensation, and Liability Act. 1980. Public Law 96-510, as amended, 94 Stat. 2767, 42 USC 9601 et seq.

Resource Conservation and Recovery Act. 1976. Public Law 94-580, as amended, 90 Stat. 2795, 42 USC 6901 et seq.

\section{Code of Federal Regulations}

40 CFR 264. U.S. Environmental Protection Agency. "Standards for Owners and Operators of Hazardous Waste Treatment, Storage, and Disposal Facilities." U.S. Code of Federal Regulations.

40 CFR 264, Appendix IX. U.S. Environmental Agency. “Ground-Water Monitoring List.” U.S. Code of Federal Regulations.

\section{Washington Administrative Code}

WAC 173-160. Minimum Standards for Construction and Maintenance of Wells. Washington Administrative Code, Olympia, Washington.

WAC 173-200. Water Quality Standards for Ground Waters of the State of Washington. Washington Administrative Code, Olympia, Washington.

WAC 173-200-40. Criteria. Washington Administrative Code, Olympia, Washington.

WAC 173-216. Waste Discharge Permit Program. Washington Administrative Code, Olympia, Washington.

WAC 173-303-645. Release from Regulated Units. Washington Administrative Code, Olympia, Washington.

WAC 173-304. Minimum Functional Standards for Solid Waste Handling. Washington Administrative Code, Olympia, Washington.

WAC 173-304(11). County Planning Requirements. Washington Administrative Code, Olympia, Washington.

WAC 246-290-310. Maximum Contaminant Levels (MCLs). Washington Administrative Code, Olympia, Washington.

BHI-00720, Rev. 6. 2002. Performance Evaluation Report for Soil Vapor Extraction Operations at the Carbon Tetrachloride Site, February 1992 - September 2001/June 2002. VJ Rohay, Bechtel Hanford, Inc., Richland, Washington.

BHI-00184, Rev. 0. 1995. Miocene- to Pliocene-Aged Suprabasalt Sediments of the Hanford Site, South-Central Washington. KA Lindsey, Bechtel Hanford, Inc., Richland, Washington.

BHI-01203. 2000. Nature and Variability of the Plio-Pleistocene Unit in the 200 West Area of the Hanford Site. JL Slate, Bechtel Hanford, Inc., Richland, Washington.

BHI-01365. 2000. Groundwater Vadose Zone Integration Project System Assessment Capability: Assessment Description Requirements Software Design and Test. RL Aaberg, Bechtel Hanford, Inc., Richland, Washington.

BHI-01651, Rev. 0. 2002. 200-CS-1 Operable Unit Test Pit Summary Report for Fiscal Year 2002. CS Cearlock and DL Bowers, Bechtel Hanford, Inc., Richland, Washington.

BHI-01684, Rev. 0. 2003. Groundwater and Leachate Monitoring and Sampling at the Environmental Restoration Disposal Facility, Calendar Year 2002. DA St. John and RL Weiss, Bechtel Hanford, Inc., Richland, Washington. 
City of Richland. 2003a. Horn Rapids Landfill Environmental Monitoring Report - Calendar Year 2002. City of Richland, Public Works Department, Richland, Washington.

City of Richland. 2003b. Horn Rapids Landfill Environmental Monitoring Report - First Quarter 2003. City of Richland, Public Works Department, Richland, Washington.

City of Richland. 2003c. Horn Rapids Landfill Environmental Monitoring Report - Second Quarter 2003. City of Richland, Public Works Department, Richland, Washington.

City of Richland. 2003d. Horn Rapids Landfill Environmental Monitoring Report - Third Quarter 2003. City of Richland, Public Works Department, Richland, Washington.

CP-13514, Rev. 0. 2003. 200-PW-1 Operable Unit Report on Step I Sampling and Analysis of the Dispersed Carbon Tetrachloride Vadose Zone Plume. VJ Rohay and DC Weekes, Fluor Hanford, Inc., Richland, Washington.

CP-14265, Rev. 0. 2003. Calendar Year 2002 RCRA and CERCLA Groundwater Monitoring Well Summary Report. Prepared by CR Martinez, Fluor Hanford, Inc., for the U.S. Department of Energy, Richland, Washington.

CP-15329, Rev. 0. 2003. Data Quality Objective Summary Report for Establishing a RCRA/CERCLA/AEA Integrated 200 West and 200 East Area Groundwater Monitoring Network. Prepared by ME Byrnes (Fluor Hanford, Inc.) and BA Williams (Pacific Northwest National Laboratory) for the U.S. Department of Energy, Richland, Washington.

DOE/EIS-0286F. 2003. Final Hanford Site Solid (Radioactive and Hazardous) Waste Program Environmental Impact Statement. U.S. Department of Energy, Richland Operations Office, Richland, Washington.

DOE/ORP-2003-11, Rev. 0. 2003. Preliminary Performance Assessment for Waste Management Area C at the Hanford Site, Washington. Prepared by FM Mann and M Connelly for the U.S. Department of Energy, Office of River Protection, Richland, Washington.

DOE/RL-89-28, Rev. 2. 1994. 216-B-3 Pond System Closure/Post-Closure Plan. U.S. Department of Energy, Richland Operations Office, Richland, Washington.

DOE/RL-91-32, Draft B. 1991. Expedited Response Action Proposal (EE/CA E EA) for 200 West Area Carbon Tetrachloride Plume, Appendix B. VJ Rohay and VG Johnson for the U.S. Department of Energy, Richland Field Office, Richland, Washington.

DOE/RL-92-23, Rev. 0. 1992. Hanford Site Groundwater Background. U.S. Department of Energy, Richland Operations Office, Richland, Washington.

DOE/RL-92-67, Draft B. 1992. Final Remedial Investigation Study-Environmental Assessment Report for the 1100-EM-1 Operable Unit, Hanford. U.S. Department of Energy, Richland Operations Office, Richland, Washington.

DOE/RL-92-76, Rev. 0. 1994. Remedial Investigation/Feasibility Study Work Plan for the 200-UP-1 Groundwater Operable Unit, Hanford Site, Richland, Washington. U.S. Department of Energy, Richland Operations Office, Richland, Washington.

DOE/RL-93-33, Rev. 0. 1996. Focused Feasibility Study of Engineered Barriers for Waste Management Units in the 200 Areas. U.S. Department of Energy, Richland Operations Office, Richland, Washington.

DOE/RL-93-73, Rev. 2. 1997. 300 Area Process Trenches Modified Closure/Postclosure Plan. U.S. Department of Energy, Richland Operations Office, Richland, Washington.

DOE/RL-93-88. 1994. Annual Report for RCRA Groundwater Monitoring Projects at Hanford Site Facilities for 1993. Prepared by Geosciences Group, Westinghouse Hanford Company, Environmental Division for U.S. Department of Energy, Richland Operations Office, Richland, Washington. 
DOE/RL-94-95, Rev. 1. 1995. Hanford Site Groundwater Remediation Strategy. U.S. Department of Energy, Richland Operations Office, Richland, Washington.

DOE/RL-95-02, Rev. 0. 1995. Treatability Report for the 200-UP-1 Operable Unit - Hanford Site. U.S. Department of Energy, Richland Operations Office, Richland, Washington.

DOE/RL-95-50. 1995. Additional Monitoring Well Installation and Field Sampling Plan for Continued Groundwater Monitoring at the Horn Rapids Landfill. U.S. Department of Energy, Richland Operations Office, Richland, Washington.

DOE/RL-95-73, Rev. 1. 1996. Operation and Maintenance Plan for the 300-FF-5 Operable Unit. Prepared by CH2M HILL Hanford, Inc. for the U.S. Department of Energy, Richland, Washington.

DOE/RL-95-83. 1995. The Pilot-Scale Treatability Test Summary for the 100-HR-3 Operable Unit. U.S. Department of Energy, Richland Operations Office, Richland, Washington.

DOE/RL-95-110. 1996. The N-Springs Expedited Response Action Performance Evaluation Report. U.S. Department of Energy, Richland Operations Office, Richland, Washington.

DOE/RL-95-111. 1997. Corrective Measures Study for the 100-NR-1 and 100-NR-2 Operable Units. U.S. Department of Energy, Richland Operations Office, Richland, Washington.

DOE/RL-96-61. 1997. Hanford Site Background: Part 3, Groundwater Background. U.S. Department of Energy, Richland Operations Office, Richland, Washington.

DOE/RL-96-84, Rev. 0. 1996. Remedial Design Report and Remedial Action Work Plan for the 100-HR-3 and 100-KR-4 Groundwater Operable Units' Interim Action. U.S. Department of Energy, Richland Operations Office, Richland, Washington.

DOE/RL-96-90, Rev. 0. 1997. Interim Action Monitoring Plan for the 100-HR-3 and 100-KR-4 Operable Units. U.S. Department of Energy, Richland Operations Office, Richland, Washington.

DOE/RL-96-105, Rev. 1. 1997. Richland Environmental Restoration Project Baseline, Multi-Year Work Plan. U.S. Department of Energy, Richland Operations Office, Richland, Washington.

DOE/RL-99-11, Rev. 0. 1999. 200-BP-1 Prototype Barrier Treatability Test Report. U.S. Department of Energy, Richland Operations Office, Richland, Washington.

DOE/RL-99-51. 2000. Remedial Design Report and Remedial Action Work Plan for the 100-HR-3 Groundwater Operable Unit In Situ Redox Manipulation. U.S. Department of Energy, Richland Operations Office, Richland, Washington.

DOE/RL-99-79. 2000. Fiscal Year 1999 Annual Summary Report for the 200-UP-1, 200-ZP-1, and 100-NR-2 Pump-andTreat Operations and Operable Units. U.S. Department of Energy, Richland Operations Office, Richland, Washington.

DOE/RL-2000-11, Rev. 1. 2000. Recommendations for Selection of a Site-Wide Groundwater Flow and Transport Model. U.S. Department of Energy, Richland Operations Office, Richland, Washington.

DOE/RL-2000-59, Rev. 0. 2000. Sampling and Analysis Plan for Aquifer Sampling Tubes. U.S. Department of Energy, Richland Operations Office, Richland, Washington.

DOE/RL-2000-72, Rev. 0. 2000. Performance Assessment Monitoring Plan for the Hanford Site Low-Level Burial Grounds. U.S. Department of Energy, Richland Operations Office, Richland, Washington.

DOE/RL-2001-04, Rev. 0. 2001. Annual Summary Report Calendar Year 2000 for the 100-HR-3, 100-KR-4, and 100-NR-2 Operable Units and Pump-and-Treat Operations. U.S. Department of Energy, Richland Operations Office, Richland, Washington. 
DOE/RL-2001-49. 2003. Groundwater Sampling and Analysis Plan for the 200-BP-5 Operable Unit. U.S. Department of Energy, Richland Operations Office, Richland, Washington.

DOE/RL-2001-67, Rev. 1. 2002. 200-PW-1 Operable Unit Dispersed Carbon Tetrachloride Vadose Zone Plume Sampling and Analysis Plan - Step I. U.S. Department of Energy, Richland Operations Office, Richland, Washington.

DOE/RL-2002-05. 2001. Calendar Year 2001 Annual Summary Report for the 100-HR-3, 100-KR-4, and 100-NR-2 Operable Units and Pump-and-Treat Operations. U.S. Department of Energy, Richland Operations Office, Richland, Washington.

DOE/RL-2002-10. 2002. Sampling and Analysis Plan for the 200-UP-1 Groundwater Monitoring Well Network. U.S. Department of Energy, Richland Operations Office, Richland, Washington.

DOE/RL-2002-11, Rev. 0. 2002. 300-FF-5 Operable Unit Sampling and Analysis Plan. Prepared by CH2M HILL Hanford, Inc. for the U.S. Department of Energy, Richland, Washington.

DOE/RL-2002-17, Rev. 0. Sampling and Analysis Plan for the 200-ZP-1 Groundwater Monitoring Well Network. U.S. Department of Energy, Richland Operations Office, Richland, Washington.

DOE/RL-2002-67. 2003. Fiscal Year 2002 Annual Summary Report for 200-UP-1 and 200-ZP-1 Pump-and-Treat Operations. Prepared by DB Erb, RS Edrington, GG Kelty, RF Raidl, and WJ McMahon for the U.S. Department of Energy, Richland, Washington.

DOE/RL-2002-68. 2003. Hanford's Groundwater Management Plan: Accelerated Cleanup and Protection. U.S. Department of Energy, Richland Operations Office, Richland, Washington.

DOE/RL-2003-04, Decisional Draft. 2003. Sampling and Analysis Plan for the 200-PO-1 Groundwater Operable Unit. MJ Hartman and JW Lindberg, Pacific Northwest National Laboratory, Richland, Washington.

DOE/RL-2003-05, Rev. 0. 2003. Fiscal Year 2002 Annual Summary Report for the In Situ Redox Manipulation Operations. U.S. Department of Energy, Richland, Washington.

DOE/RL-2003-09, Rev. 0. 2003. Calendar Year 2002 Annual Summary Report for the 100-HR-3, 100-KR-4, and 100-NR-2 Operable Unit Pump-and-Treat Operations. Prepared by Fluor Hanford, Inc. for the U.S. Department of Energy, Richland, Washington.

DOE/RL-2003-23. 2003. Focused Feasibility Study for the U Plant Closure Area Waste Site. RL Jackson, U.S. Department of Energy, Richland Operations Office, Richland, Washington.

DOE/RL-2003-24. 2003. Proposed Plan for the U Plant Closure Area Waste Site. RL Jackson, U.S. Department of Energy, Richland Operations Office, Richland, Washington.

DOE/RL-2003-30, Rev. 0. 2003. Waste Control Plan for the 200-BP-5 Operable Unit. U.S. Department of Energy, Richland Operations Office, Richland, Washington.

DOE/RL-2003-31. 2003. Study of Vadose Zone Monitoring at the Hanford Site, Task 1, Use in New Cells at the Environmental Restoration Disposal Facility. LG Everett and TW Fogwell, U.S. Department of Energy, Richland Operations Office, Richland, Washington.

DOE/RL-2003-38. 2003. 100-BC-5 Operable Unit Sampling and Analysis Plan. U.S. Department of Energy, Richland Operations Office, Richland, Washington.

DOE/RL-2003-49, Rev. 0. 100-FR-3 Operable Unit Sampling and Analysis Plan. U.S. Department of Energy, Richland Operations Office, Richland, Washington. 
DOE/RL-2003-58. 2003. Fiscal Year 2003 Annual Summary Report for 200-UP-1 and 200-ZP-1 Pump-and-Treat Operations. Prepared by DB Erb, RS Edrington, GG Kelty, RF Raidl, K Sathyanarayana (Fluor Hanford, Inc.) and WJ McMahon (CH2M HILL Hanford Group, Inc.) for the U.S. Department of Energy, Richland, Washington.

Ecology. 1994. Dangerous Waste Portion of the Resource Conservation and Recovery Act Permit for the Treatment, Storage, and Disposal of Dangerous Waste. Permit Number WA 7890008967, as amended. Washington State Department of Ecology, Olympia, Washington.

Ecology - Washington State Department of Ecology, U.S. Environmental Protection Agency, and U.S. Department of Energy. 1998. Hanford Federal Facility Agreement and Consent Order. Document No. 89-10, Rev. 5 (The Tri-Party Agreement), Olympia, Washington.

Ecology. 2000. State Waste Discharge Permit ST 4500. Washington State Department of Ecology, Kennewick, Washington.

EMF-1865, Addenda 31. 2003. Quarterly Groundwater Monitoring Summary Fourth Quarter 2002. Framatome ANP Richland, Inc., Richland, Washington.

EMF-1865, Addenda 33. 2003. Quarterly Groundwater Monitoring Summary Second Quarter 2003. Framatome ANP Richland, Inc., Richland, Washington.

EPA. 2000. "Explanation of Significant Difference for the 300-FF-5 Record of Decision" (see ROD 1996a). Issued by U.S. Environmental Protection Agency, Region 10, and U.S. Department of Energy, Richland Operations Office, Richland, Washington.

EPA. 2001. USDOE Hanford Site First Five Year Review Report. U.S. Environmental Protection Agency, Region 10, Hanford Project Office, Seattle, Washington.

Gee, GW, MJ Fayer, ML Rockhold, and MD Campbell. 1992. "Variations in Recharge at the Hanford Site." Northwest Sci. 66:237-250.

Gee, GW, ZF Zhang, and AL Ward. 2003. "A Modified Water Fluxmeter with Solution Collection Capability." Vadose Zone J. 2:627-633.

GJO-2002-322-TAR. 2002. Hanford 200 Areas Spectral Gamma Baseline Characterization Project, 216-B-35 to -42 Trenches Waste Site Summary Report. Prepared by MACTEC-ERS for the U.S. Department of Energy, Grand Junction Office, Grand Junction, Colorado.

GJO-2002-343-TAR. 2002. Hanford 200 Areas Spectral Gamma Baseline Characterization Project, 216-B-8 Crib and Adjacent Sites Waste Site Summary Report. Prepared by S.M. Stoller Corporation for the U.S. Department of Energy, Grand Junction Office, Grand Junction, Colorado.

GJO-2002-358-TAC. 2002. Hanford 200 Area Spectral Gamma Baseline Characterization Project: 216-B-5 Injection Well and 216-B-9 Crib and Tile Field Waste Site Summary Report. Prepared by S.M. Stoller Corporation for the U.S. Department of Energy, Grand Junction Office, Grand Junction, Colorado.

GJO-2003-458-TAC. 2003. Hanford 200 Areas Spectral Gamma Baseline Characterization Project, 216-B-43 to -50, -57, and -61 Cribs and Adjacent Sites Waste Site Summary Report. Prepared by S.M. Stoller Corporation for the U.S. Department of Energy, Grand Junction Office, Grand Junction, Colorado.

Hausenbuiller, RL. 1972. Soil Science: Principles and Practices. Wm. C. Brown Company Publishers, Dubuque, Iowa.

Hsi, CD and D Langmuir. 1985. "Adsorption of Uranyl onto Ferric Oxyhydroxides: Application of the Surface Complexation Site-Bonding Model." Geochemica et Cosmochimica Acta 49:1931-1941. 
HNF-SD-WM-TI-740, Rev. 0. 1990. Standard Inventories of Chemicals and Radionuclides in Hanford Site Tank Wastes. Prepared by MJ Kupfer, AL Boldt, BA Higley, KM Hodgson, LW Shelton, BC Simpson, RA Watrous, MD. LeClair, GL Borsheim, RT Winward, RM Orme, NG Colton, SL Lambert, DE Place, and WW Schulz for Lockheed Martin Hanford Corporation, Richland, Washington.

Kaplin, DI, TL Gervais, and KM Krupka. 1998. "Uranium (VI) Sorption to Sediments Under High pH and Ionic Strength Conditions.” Radiochimica Acta 225:1-11.

Morrison, RD. 1998. "Determining Surface Release Sources from Soil and Groundwater Contamination." In Environmental Forensics, Determining Liability Through Applied Science, International Business Communications Executive Forum, Houston, Texas, September 24-25, 1998.

Narbutovskih, SM, JP McDonald, R Schalla, and MD Sweeney. 2002. "Application of an In-Well Flowmeter to Determine a Complex Groundwater Flow Pattern." Symposium on Environmental Evaluation and Remediation of Low Permeability and Dual Porosity Environments, ASTM STP 1415, MN Sara and LG Everett (eds.), American Society for Testing and Materials, West Conshohocken, Pennsylvania.

NAVD88. 1988. North American Vertical Datum of 1988.

NUREG/CR-6805. 2002. A Comprehensive Strategy of Hydrogeologic Modeling and Uncertainty Analysis for Nuclear Facilities and Sites. SP Neuman and PJ Wierenga, U.S. Nuclear Regulatory Commission, Office of Nuclear Regulatory Research, Washington, D.C.

Peterson, JM, MM MacDonell, LA Haroun, FA Monette, and RD Hildebrand. 2002. Summary Fact Sheets for Selected Environmental Contaminants to Support Health Risk Analysis. Environmental Assessment Division, Argonne National Laboratory, Chicago, Illinois. Available at: http://www.ead.anl.gov

PNL-5604. 1985. Model Assessment of Protective Barrier Designs. MJ Fayer, W Conbere, PR Heller, and GW Gee, Pacific Northwest Laboratory, Richland, Washington.

PNL-6810. 1989. The Field Lysimeter Test Facility (FLTF) at the Hanford Site: Installation and Initial Tests. GW Gee, RR Kirkham, JL Downs, and MD Campbell, Pacific Northwest Laboratory, Richland, Washington.

PNL-7147. 1989. Final Report: Soil Gas Survey at the Solid Waste Landfill. JC Evans, RM Freeland, DW Glover, and C Veverka, Pacific Northwest Laboratory, Richland, Washington.

PNL-8580. 1993. Water Level Measurements for Modeling Hydraulic Properties in the 300-FF-5 and 100 Aggregate Area Operable Units. MD Campbell, WJ McMahon, and KR Simpson, Pacific Northwest Laboratory, Richland, Washington.

PNL-8869. 1993. Preliminary Potentiometric Map and Flow Dynamic Characteristics for the Upper-Basalt Confined Aquifer System. FA Spane, Jr. and RG Raymond, Pacific Northwest Laboratory, Richland, Washington.

PNL-10817. 1995. Hydrochemistry and Hydrogeologic Conditions Within the Hanford Upper Basalt Confined Aquifer System. FA Spane, Jr. and WD Webber, Pacific Northwest Laboratory, Richland, Washington.

PNNL-11523. 1997. Combination RCRA Groundwater Monitoring Plan for the 216-A-10, 216-A-36B, and 216-A-37-1 PUREX Cribs. JW Lindberg, Pacific Northwest National Laboratory, Richland, Washington.

PNNL-11789. 1997. Hanford Prototype-Barrier Status Report: FY 1997. AL Ward, GW Gee, and SO Link, Pacific Northwest National Laboratory, Richland, Washington.

PNNL-11800. 1998. Composite Analysis for Low-Level Waste Disposal in the 200-Area Platean of the Hanford Site. CT Kincaid, MP Bergeron, CR Cole, MD Freshley, N Hassig, VG Johnson, DI Kaplan, RJ Serne, GP Steile, DL Strenge, PD Thorne, LW Vail, GA Whyatt, and SK Wurstner, Pacific Northwest National Laboratory, Richland, Washington. 
PNNL-11801. 1997. Three-Dimensional Analysis of Future Groundwater Flow Conditions and Contaminant Plume Transport in the Hanford Site Unconfined Aquifer System: FY 1996 and 1997 Status Report. CR Cole, SK Wurstner, MP Bergeron, MD Williams, and PD Thorne, Pacific Northwest National Laboratory, Richland, Washington.

PNNL-11809. 1998. Results of Phase I Groundwater Quality Assessment for Single-Shell Tank Waste Management Areas T and TX-TY at the Hanford Site. FN Hodges, Pacific Northwest National Laboratory, Richland, Washington.

PNNL-11810. 1998. Results of Phase I Groundwater Quality Assessment for Single-Shell Tank Waste Management Area S-SX at the Hanford Site. VG Johnson and CJ Chou, Pacific Northwest National Laboratory, Richland, Washington.

PNNL-11826. 1998. Results of Phase I Groundwater Quality Assessment for Single-Shell Tank Waste Management Areas B-BX-BY at the Hanford Site. SM Narbutovskih, Pacific Northwest National Laboratory, Richland, Washington.

PNNL-11957. 1998. Immobilized Low-Activity Waste Site Borehole 299-E17-21. SP Reidel, KD Reynolds, and DG Horton, Pacific Northwest National Laboratory, Richland, Washington.

PNNL-12023. 1998. Groundwater Monitoring for the 100-K Area Fuel-Storage Basins: July 1996 through April 1998. VG Johnson, CJ Chou, MJ Hartman, and WD Webber, Pacific Northwest National Laboratory, Richland, Washington.

PNNL-12034. 2000. User's Guide of STOMP - Subsurface Transport over Multiple Phases. MD White and M Oostrom, Pacific Northwest National Laboratory, Richland, Washington.

PNNL-12086. 1999. Hanford Site Groundwater Monitoring for Fiscal Year 1998. MJ Hartman (ed.), Pacific Northwest National Laboratory, Richland, Washington.

PNNL-12114. 1999. RCRA Assessment Plan for Single-Shell Tank Waste Management Area S-SX at the Hanford Site. VG Johnson and CJ Chou, Pacific Northwest National Laboratory, Richland, Washington.

PNNL-12114-ICN-1. 2000. RCRA Assessment Plan for Single-Shell Tank Waste Management Area S-SX at the Hanford Site, Interim Change Notice 1. VG Johnson and CJ Chou, Pacific Northwest National Laboratory, Richland, Washington.

PNNL-12114-ICN-2. 2002. RCRA Assessment Plan for Single-Shell Tank Waste Management Area S-SX at the Hanford Site, Interim Change Notice 2. RM Smith, Pacific Northwest National Laboratory, Richland, Washington.

PNNL-12124. 1999. Borehole Data Package for 1998 Wells Installed at Single-Shell Tank Waste Management Area TX-TY. DG Horton and FN Hodges, Pacific Northwest National Laboratory, Richland, Washington.

PNNL-12125. 1999. Borehole Data Package for 1998 Wells Installed at Single-Shell Tank Waste Management Area T. DG Horton and FN Hodges, Pacific Northwest National Laboratory, Richland, Washington.

PNNL-12220. 1999. Sampling and Analysis Plan Update for Groundwater Monitoring - 1100-EM-1 Operable Unit. DR Newcomer, Pacific Northwest National Laboratory, Richland, Washington.

PNNL-12261. 2000. Revised Hydrogeology for the Suprabasalt Upper Aquifer System, 200 East Area and Vicinity, Hanford Site Washington. BA Williams, BN Bjornstad, R Schalla, and WD Webber, Pacific Northwest National Laboratory, Richland, Washington.

PNNL-13014. 2000. Groundwater Monitoring Plan for the Solid Waste Landfill. JW Lindberg and CJ Chou, Pacific Northwest National Laboratory, Richland, Washington.

PNNL-13021. 1999. Water-Level Monitoring Plan for the Hanford Groundwater Monitoring Project. JP McDonald, MA Chamness, and DR Newcomer, Pacific Northwest National Laboratory, Richland, Washington.

PNNL-13022. 2000. Groundwater Quality Assessment Plan for Single-Shell Waste Management Area B-BX-BY at the Hanford Site. SM Narbutovskih, Pacific Northwest National Laboratory, Richland, Washington. 
PNNL-13023. 2001. RCRA Groundwater Monitoring Plan for Single-Shell Tank Waste Management Area A-AX at the Hanford Site. SM Narbutovskih, Pacific Northwest National Laboratory, Richland, Washington.

PNNL-13023-ICN-1. 2002. RCRA Groundwater Monitoring Plan for Single-Shell Tank Waste Management Area A-AX at the Hanford Site, Interim Change Notice 1. SM Narbutovskih, Pacific Northwest National Laboratory, Richland, Washington.

PNNL-13032. 2000. Groundwater Monitoring Plan for the Hanford Site 200 Area Treated Effluent Disposal Facility. DB Barnett, Pacific Northwest National Laboratory, Richland, Washington.

PNNL-13033. 1999. Recharge Data Package for the Immobilized Low-Activity Waste 2001 Performance Assessment. MJ Fayer, EM Murphy, JL Downs, FO Khan, CW Lindenmeier, and BN Bjornstad., Pacific Northwest National Laboratory, Richland, Washington.

PNNL-13078. 1999. Effects of Barometric Fluctuations on Well Water-Level Measurements and Aquifer Test Data. FA Spane, Pacific Northwest National Laboratory, Richland, Washington.

PNNL-13080. 1999. Hanford Site Groundwater: Settings, Sources, and Methods. MJ Hartman (ed.), Pacific Northwest National Laboratory, Richland, Washington.

PNNL-13116. 2000. Hanford Site Groundwater Monitoring for Fiscal Year 1999. MJ Hartman, LF Morasch, and WD Webber (eds.), Pacific Northwest National Laboratory, Richland, Washington.

PNNL-13185. 2000. Groundwater Quality Assessment Plan for Single-Shell Tank Waste Management Area U at the Hanford Site. FN Hodges and CJ Chou, Pacific Northwest National Laboratory, Richland, Washington.

PNNL-13200. 2000. Borehole Data Package for Wells 299-W22-48, 299-W22-49, and 299-W22-50 at Single-Shell Tank Waste Management Area S-SX. DG Horton and VG Johnson, Pacific Northwest National Laboratory, Richland, Washington.

PNNL-13228. 2000. Evaluation of Elevated Tritium Levels in Groundwater Downgradient from the 618-11 Burial Ground Phase I Investigations. PE Dresel, BA Williams, JC Evans, RM Smith, CJ Thompson, and LC Hulstrom, Pacific Northwest National Laboratory, Richland, Washington.

PNNL-13249. 2000. UNSAT-H Version 3.0:Unsaturated Soil Water and Heat Flow Model: Theory, User Manual, and Examples. MJ Fayer, Pacific Northwest National Laboratory, Richland, Washington.

PNNL-13282. 2000. Groundwater Quality Assessment for Waste Management Area U; First Determination. FN Hodges and CJ Chou, Pacific Northwest National Laboratory, Richland, Washington.

PNNL-13326. 2000. Groundwater Sampling and Analysis Plan for the 100-BC-5 Operable Unit. MD Sweeney, Pacific Northwest National Laboratory, Richland, Washington.

PNNL-13327. 2000. Groundwater Sampling and Analysis Plan for the 100-FR-3 Operable Unit. MD Sweeney, Pacific Northwest National Laboratory, Richland, Washington.

PNNL-13367. 2000. Groundwater Monitoring Plan for the Hanford Site 216-B-3 Pond RCRA Facility. DB Barnett, RM Smith, and CJ Chou, Pacific Northwest National Laboratory, Richland, Washington.

PNNL-13367-ICN-1. 2002. Groundwater Monitoring Plan for the Hanford Site 216-B-3 Pond RCRA Facility, Interim Change Notice 1. DB Barnett, Pacific Northwest National Laboratory, Richland, Washington.

PNNL-13378. 2001. Results of Detailed Hydrologic Characterization Tests - Fiscal Year 1999. FA Spane, Jr., PD Thorne, and DR Newcomer, Pacific Northwest National Laboratory, Richland, Washington. 
PNNL-13404. 2001. Hanford Site Groundwater Monitoring for Fiscal Year 2000. MJ Hartman, LF Morasch, and WD Webber (eds.), Pacific Northwest National Laboratory, Richland, Washington.

PNNL-13441. 2000. RCRA Groundwater Quality Assessment Report for Waste Management Area S-SX (November 1997 through April 2000). VG Johnson and CJ Chou, Pacific Northwest National Laboratory, Richland, Washington.

PNNL-13447. 2001. Hanford Site-Wide Groundwater Model Calibration Using Inverse Methodology. CR Cole, MP Bergeron, SK Wurstner, PD Thorne, S Orr, and MI McKinley, Pacific Northwest National Laboratory, Richland, Washington.

PNNL-13612. 2001. Groundwater Quality Assessment Plan for Single-Shell Tank Waste Management Area U. RM Smith, FN Hodges, and BA Williams, Pacific Northwest National Laboratory, Richland, Washington.

PNNL-13612-ICN-1. 2003. Groundwater Quality Assessment Plan for Single-Shell Tank Waste Management Area U, Interim Change Notice 1. RM Smith, Pacific Northwest National Laboratory, Richland, Washington.

PNNL-13623. 2001. Transient Inverse Calibration of Site-Wide Groundwater Model to Hanford Operational Impacts from 1943 to 1996 - Alternative Conceptual Model Considering Interaction with Uppermost Basalt Confined Aquifer. VR Vermeul, CR Cole, MP Bergeron, PD Thorne, and SK Wurstner, Pacific Northwest National Laboratory, Richland, Washington.

PNNL-13641. 2001. Uncertainty Analysis Framework - Hanford Site-Wide Groundwater Flow and Transport Model. CR Cole, MP Bergeron, CJ Murray, PD Thorne, SK Wurstner, and P Rogers, Pacific Northwest National Laboratory, Richland, Washington.

PNNL-13645. 2001. 300 Area Process Trenches Groundwater Monitoring Plan. JW Lindberg and CJ Chou, Pacific Northwest National Laboratory, Richland, Washington.

PNNL-13674. 2001. Zone of Interaction Between Hanford Site Groundwater and Adjacent Columbia River. RE Peterson and MP Connelly, Pacific Northwest National Laboratory, Richland, Washington.

PNNL-13675. 2001. Measurement of Helium-3/Helium-4 Ratios in Soil Gas at the 618-11 Burial Ground. KB Olsen, PE Dresel, and JC Evans, Pacific Northwest National Laboratory, Richland, Washington.

PNNL-13692. 2002. Survey of Radiological and Chemical Contaminants in the Near-Shore Environment at the Hanford Site 300 Area. A Cooperative Environmental Monitoring Project involving the Hanford Site Public Safety and Resource Protection Program (PSRPP) and Washington State Department of Health. GW Patton, BL Tiller, EJ Antonio, TM Poston, and SP Van Verst, Pacific Northwest National Laboratory, Richland, Washington.

PNNL-13788. 2002. Hanford Site Groundwater Monitoring for Fiscal Year 2001. MJ Hartman, LF Morasch, and WD Webber (eds.), Pacific Northwest National Laboratory, Richland, Washington.

PNNL-13801. 2002. Groundwater Quality Assessment Report for Waste Management Area S-SX: (April 2000 through December 2001). VG Johnson and CJ Chou, Pacific Northwest National Laboratory, Richland, Washington.

PNNL-13830. 2002. Borehole Data Package for Calendar Year 2001 RCRA Well Installation at Single-Shell Tank Waste Management Area T. DG Horton, Pacific Northwest National Laboratory, Richland, Washington.

PNNL-13895. 2002. Hanford Contaminant Distribution Coefficient Database and Users Guide. KJ Cantrell, RJ Serne, and GV Last, Pacific Northwest National Laboratory, Richland, Washington.

PNNL-13929. 2002. RCRA Groundwater Quality Assessment Report for Single-Shell Tank Waste Management Area T (January 1998 through December 2001). DG Horton, FN Hodges, VG Johnson, and CJ Chou, Pacific Northwest National Laboratory, Richland, Washington. 
PNNL-13932. 2002. User Instructions for the Systems Assessment Capability, Rev. 0, Computer Codes Volume 1: Inventory, Release, and Transport Modules. PW Eslinger, DW Engel, LH Gerhardstein, CA Lopresti, WE Nichols, and DL Strenge, Pacific Northwest National Laboratory, Richland, Washington.

PNNL-13932-Volume 2. 2002. User Instructions for the Systems Assessment Capability, Rev. 0, Computer Codes Volume 2: Impact Modules. PW Eslinger, C Arimescu, BA Kanyid, and TB Miley, Pacific Northwest National Laboratory, Richland, Washington.

PNNL-14022. 2002. 300 Area Uranium Leach and Adsorption Project. RJ Serne, CF Brown, HT Schaef, EM Price, MJ Lindberg, Z Wang, PL Gassman, and JG Catalano, Pacific Northwest National Laboratory, Richland, Washington.

PNNL-14027. 2002. An Initial Assessment of Hanford Impact Performed with the System Assessment Capability. RW Bryce, CT Kincaid, PW Eslinger, and LF Morasch (eds.), Pacific Northwest National Laboratory, Richland, Washington.

PNNL-14031. 2002. Evaluation of Potential Sources for Tritium Detected in Groundwater at Well 199-K-111A, 100-K Area. RE Peterson, FA Spane, KB Olsen, and MD Williams, Pacific Northwest National Laboratory, Richland, Washington.

PNNL-14033. 2002. Groundwater Monitoring and Assessment Plan for the 100-K Area Fuel Storage Basins. RE Peterson, Pacific Northwest National Laboratory, Richland, Washington.

PNNL-14049. 2002. Data Quality Objectives Summary Report - Designing a Groundwater Monitoring Network for the 200-BP-5 and 200-PO-1 Operable Units. EC Thornton and JW Lindberg, Pacific Northwest National Laboratory, Richland, Washington.

PNNL-14070. 2002. Groundwater Monitoring Plan for the 216-S-10 Pond and Ditch. BA Williams and CJ Chou, Pacific Northwest National Laboratory, Richland, Washington.

PNNL-14098. 2002. Results of Groundwater Monitoring at the Hanford Site 200 Area Treated Effluent Disposal Site-1999 through FY 2002. JT Rieger, Pacific Northwest National Laboratory, Richland, Washington.

PNNL-14099. 2002. Groundwater Conditions at Single-Shell Tank Waste Management Area TX-TY (January 1998 through December 2001). DG Horton, Pacific Northwest National Laboratory, Richland, Washington.

PNNL-14107. 2002. Groundwater Chemistry and Hydrogeology of the Upper Saddle Mountains Basalt-Confined Aquifer South and Southeast of the Hanford Site. DR Newcomer, EC Thornton, and TL Liikala, Pacific Northwest National Laboratory, Richland, Washington.

PNNL-14113. 2002. Results of Detailed Hydrologic Characterization Tests - Fiscal Year 2001. FA Spane, Jr., PD Thorne, and DR Newcomer, Pacific Northwest National Laboratory, Richland, Washington.

PNNL-14186. 2003. Results of Detailed Hydrologic Characterization Tests - Fiscal Year 2002. FA Spane, DR Newcomer, and PD Thorne, Pacific Northwest National Laboratory, Richland, Washington.

PNNL-14187. 2003. Hanford Site Groundwater Monitoring for Fiscal Year 2002. MJ Hartman, LF Morasch, and WD Webber (eds.), Pacific Northwest National Laboratory, Richland, Washington.

PNNL-14202. 2003. Mineralogical and Bulk-Rock Geochemical Signatures of Ringold and Hanford Formation Sediments. Y Xie, GV Last, CJ Murray, and R Mackley, Pacific Northwest National Laboratory, Richland, Washington.

PNNL-14242. 2003. Hanford Site Climatological Data Summary 2002 with Historical Data. DJ Hoitink, KW Burk, JV Ramsdell, and WJ Shaw, Pacific Northwest National Laboratory, Richland, Washington.

PNNL-14249. 2003. Data Package for Calendar Year 2002 RCRA Groundwater Monitoring Wells at Single-Shell Tank Waste Management Area TX-TY. DG Horton, Pacific Northwest National Laboratory, Richland, Washington. 
PNNL-14295. 2003. Hanford Site Environmental Report for Calendar Year 2002. TM Poston, RW Hanf, RL Dirkes, and LF Morasch (eds), Pacific Northwest National Laboratory, Richland, Washington.

PNNL-14295, APP. 2. 2003. Hanford Site Near-Facility Environmental Monitoring Data Report for Calendar Year 2002. CJ Perkins, BM Markes, SM McKinney, RM Mitchell, and RC Roos, Pacific Northwest National Laboratory, Richland, Washington.

PNNL-14301. 2003. Monitoring Plan for RCRA Groundwater Assessment at the 216-U-12 Crib. BA Williams and CJ Chou, Pacific Northwest National Laboratory, Richland, Washington.

PNNL-14320. 2003. Soil Gas Survey and Well Installation at the 618-10 Burial Ground, 300-FF-5 Operable Unit, Hanford Site, Washington. BA Williams, RE Peterson, and KB Olsen, Pacific Northwest National Laboratory, Richland, Washington.

PNNL-14388. 2002. "Optimal Surface Barrier Designs Through Advanced Plant-Soil Atmosphere Dynamics Modeling." In Laboratory Directed Research and Development Annual Report Fiscal Year 2002, AL Ward, MD White, and EJ Freeman, Pacific Northwest National Laboratory, Richland, Washington.

PNNL-14398. 2003. Transient Inverse Calibration of the Site-Wide Groundwater Flow Model (ACM-2): FY03 Progress Report. VR Vermeul, MP Bergeron, CR Cole, CJ Murray, WE Nichols, TD Scheibe, PD Thorne, SR Waichler, and Y Xie, Pacific Northwest National Laboratory, Richland, Washington.

PNNL-14444. 2003. Aquifer Sampling Tube Results for Fiscal Year 2003. MJ Hartman and RE Peterson, Pacific Northwest National Laboratory, Richland, Washington.

PNNL-SA-33304. 2000. "Aquifer-Columbia River Interaction and Groundwater Contamination at the 300 Area of the Hanford Site." JW Lindberg, oral presentation at the $3^{\text {rd }}$ Symposium on the Hydrogeology of Washington State, October 16-18, 2000, Landmark Convention Center, Tacoma, Washington. Organized by the Washington State Department of Ecology, Washington Hydrologic Society, and U.S. Geological Survey.

PNNL-SA-39825. 2003. A Groundwater Quality Assessment at Single-Shell Tank Farms at the DOE Hanford Site. Presented by SM Narbutovskih at Geologic Society of America, Seattle, Washington.

ROD. 1993. Record of Decision, USDOE Hanford 1100 Area, Hanford Site, Richland, Washington (1100-EM-1, 1100-EM-2, 1100-EM-3, and 1100-IU-1 Operable Units). State of Washington Department of Ecology, U.S. Environmental Protection Agency, and U.S. Department of Energy, Richland Operations Office, Richland, Washington.

ROD. 1995a. Declaration of the Record of Decision for the 200-ZP-1 Operable Unit. State of Washington Department of Ecology, U.S. Environmental Protection Agency, and U.S. Department of Energy, Richland Operations Office, Richland, Washington.

ROD. 1995b. Declaration of the Record of Decision for the USDOE Hanford Environmental Restoration Disposal Facility. State of Washington Department of Ecology, U.S. Environmental Protection Agency, and U.S. Department of Energy, Richland Operations Office, Richland, Washington.

ROD. 1996a. Declaration of the Record of Decision for the 100-HR-3 and 100-KR-4 Operable Units. State of Washington Department of Ecology, U.S. Environmental Protection Agency, and U.S. Department of Energy, Richland Operations Office, Richland, Washington.

ROD. 1996b. Record of Decision for the 300-FF-1 and 300-FF-5 Operable Units. State of Washington Department of Ecology, U.S. Environmental Protection Agency, and U.S. Department of Energy, Richland Operations Office, Richland, Washington.

ROD. 1997. Declaration of the Record of Decision for the 200-UP-1 Operable Unit. State of Washington State Department of Ecology, U.S. Environmental Protection Agency, and U.S. Department of Energy, Richland Operations Office, Richland, Washington. 
ROD. 1999a. Amended Record of Decision, Decision Summary and Responsiveness Summary for the 100-HR-3 Operable Unit. U.S. Environmental Protection Agency, Region 10, Seattle, Washington.

ROD. 1999b. Interim Remedial Action Record of Decision for the 100-NR-1 and -NR-2 Operable Units of the Hanford 100-N Area. Washington State Department of Ecology, Olympia, Washington.

RHO-BWI-LD-5. 1978. Geology of Gable Mountain - Gable Butte Area. KR Fecht, Rockwell Hanford Operations, Richland, Washington.

RHO-BWI-ST-5. 1979. "Pasco Basin Hydrology." In Hydrologic Studies Within the Columbia Plateau, Washington: An Integration of Current Knowledge. RE Gephart, FA Spane, Jr., LS Leonhart, DA Palombo, and SR Strait, Rockwell Hanford Operations, Richland, Washington.

RHO-RE-ST-12 P. 1984. An Assessment of Aquifer Intercommunication in the B Pond-Gable Mountain Pond Area of the Hanford Site. MJ Graham, GV Last, and KR Fecht, Rockwell Hanford Operations, Richland, Washington.

RPP-10098, Rev. 0. 2003. Field Investigation Report for Waste Management Area B-BX-BY. AJ Knepp, CH2M HILL Hanford Group, Inc., Richland, Washington.

Shuttleworth, JW and JS Wallace. 1985. "Evaporation from sparse crops-an energy combination theory." Quart. J. R. Met. Soc. 111:839-855.

Singleton, MJ, ME Conrad, K Maher, DJ Depaolo, and GV Last. 2002. "Isotopic Investigation of Pore Water Interaction with Buried Carbonate Layers at the Hanford Site, Pasco Basin, WA". In The Geological Society of America Geoscience Horizons: Denver 2002, Abstracts With Programs. October 27-30, 2002, Annual Meeting of the Geological Society, Denver, Colorado.

Singleton, MJ, K Maher, DJ Depaolo, ME Conrad, and PE Dresel. 2003. "Sr Isotope Compositions of Groundwater in the Hanford Site Unconfined Aquifer as a Record of Flow, Recharge, and Vadose Zone Infiltration." In The Geological Society of America Geoscience Horizons: Seattle 2003, Abstracts With Programs. November 2-5, 2003, Annual Meeting of the Geological Society, Seattle, Washington.

Waite, TD, JA Davis, TE Payne, GA Waychunas, and N Xu. 1994. "Uranium (VI) Adsorption to Ferrihydrite: Application or a Surface Complexation Model." Geochemica et Cosmochimica Acta 58:5465-5478.

WHC-EP-0587. 1992. Groundwater Impact Assessment Report for the 400 Area Ponds. DK Tyler, Westinghouse Hanford Company, Richland, Washington.

WHC-EP-0595. 1993. Westinghouse Hanford Company Operational Groundwater Status Report 1990-1992. VG Johnson, Westinghouse Hanford Company, Richland, Washington.

WHC-SA-1674-VA. 1992. Characterization of a Chromium Plume in Groundwater Along the Columbia River Shoreline, Hanford Site, Washington. RE Peterson and MP Connelly, Westinghouse Hanford Company, Richland, Washington. (Presented at 1992 Fall Meeting, American Geophysical Union, San Francisco, December 7-11, 1992.)

WHC-SD-EN-AP-024, Rev. 1. 1991. Interim Status Ground Water Monitoring Plan for the 200 East Area Liquid Effluent Treatment Facility. JS Schmid, Westinghouse Hanford Company, Richland, Washington.

WHC-SD-EN-AP-132, Rev. 0. 1993. Interim-Status Groundwater Quality Assessment Plan for the Single-Shell Tank Waste Management Areas T and TX-TY. JA Caggiano and CJ Chou, Westinghouse Hanford Company, Richland, Washington.

WHC-SD-EN-AP-185. 1995. Groundwater Monitoring Plan for the 300 Area Process Trenches. JW Lindberg, CJ Chou, and VG Johnson, Westinghouse Hanford Company, Richland, Washington. 
WHC-SD-EN-AP-191, Rev. O. 1996. Assessment Groundwater Monitoring Plan for Single Shell Tank Waste Management Area S-SX. JA Caggiano, Westinghouse Hanford Company, Richland, Washington.

WHC-SD-EN-EV-032, Rev. 0. 1995. Results of Groundwater Quality Assessment Program at the 216-A-29 Ditch RCRA Facility. JM Votava, Westinghouse Hanford Company, Richland, Washington.

WHC-SD-EN-TI-023. 1992. Hydrologic Information Summary for the Northern Hanford Site. MJ Hartman and RE Peterson, Westinghouse Hanford Company, Richland, Washington.

WHC-SD-EN-TI-101. 1993. Carbon Tetrachloride Evaporative Losses and Residual Inventory Beneath 200 West Area at the Hanford Site. Prepared by Ebasco Services for Westinghouse Hanford Company, Richland, Washington.

WHC-SD-EN-TI-199. 1993. Nonradioactive Dangerous Waste Landfill Soil-Gas Survey: Final Data Report. ID Jacques, Westinghouse Hanford Company, Richland, Washington.

WHC-SD-EN-TI-239, Rev. 0. 1994. 100-K Area Technical Baseline Report. RW Carpenter and SL Cotè, Westinghouse Hanford Company, Richland, Washington.

Wing, NR and GW Gee. 1994. "Quest for the Perfect Cap." Civil Engr. 64(10):38-41.

WMP-17869, Rev. 0. 2003. Calendar Year 2003 Semiannual Technical Memorandum for 100-HR-3, 100-KR-4, and 100-NR-2 Pump-and-Treat Operations. RS Edrington and GG Kelty, Fluor Hanford, Inc., Richland, Washington.

WMP-18051, Rev. 0. 2003. Sampling and Analysis Instruction for Aquifer Sampling Tubes Sampling and Installation, Fall 2003. RF Raidl, Fluor Hanford, Inc., Richland, Washington.

WMP-18061. 2003. Optimization Strategy for Central Plateau Closure. Fluor Hanford, Inc., Richland, Washington. 


\section{Appendix A}

Supporting Information for CERCLA Groundwater Operable Units 


\section{Contents}

Supporting Information for CERCLA Groundwater Operable Units ........................................................... A.1

A.1 100-BC-5 Operable Unit ....................................................................................................... A.1

A.2 100-FR-3 Operable Unit ............................................................................................... A.1

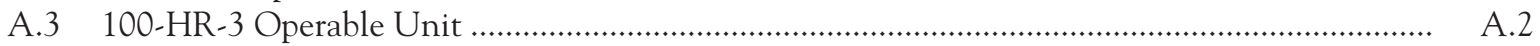

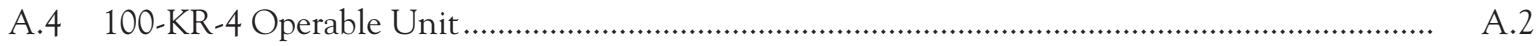

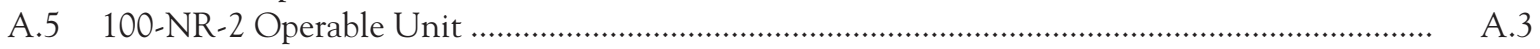

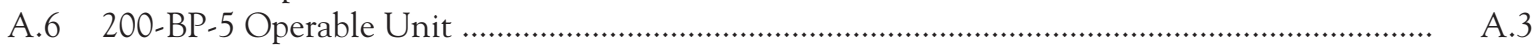

A.7 200-PO-1 Operable Unit .................................................................................................. A.

A.8 200-UP-1 Operable Unit ........................................................................... A.4

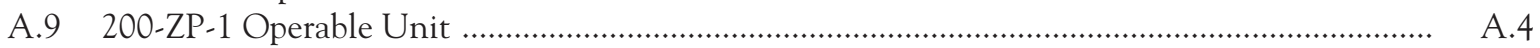

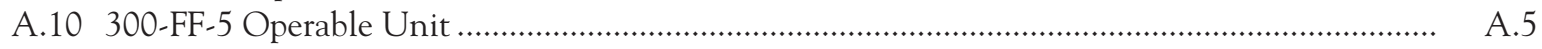

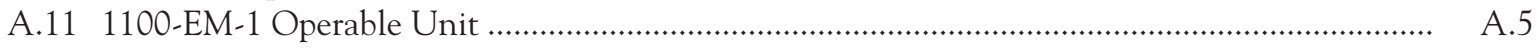

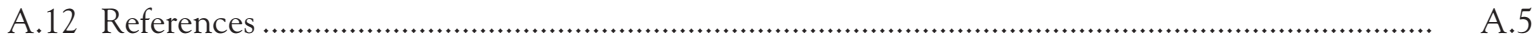

\section{Tables}

A.1 Summary of Groundwater Remediation at CERCLA Operable Units ................................................ A.8

A.2 Wells Not Sampled as Scheduled for CERCLA Facilities, Fiscal Year 2003 ....................................... A.10

A.3 Maximum Concentrations of Constituents by Groundwater Interest Area, Fiscal Year 2003 ............ A.11

A.4 Monitoring Wells and Constituents for the 100-BC-5 Operable Unit ............................................... A.13

A.5 Monitoring Wells and Constituents for the 100-FR-3 Operable Unit ............................................... A.14

A.6 Monitoring Wells and Constituents for the 100-HR-3-D Interim Action Monitoring for 100-D Pump-and-Treat System ............................................................................................... A.15

A.7 100-HR-3-D Long-Term Monitoring Parameters .................................................................................... A.16

A.8 100-HR-3-D Interim Action Monitoring for Redox System ............................................................. A.17

A.9 100-HR-3-H Interim Action Monitoring Parameters for 100-H Pump-and-Treat System ................. A. A.18

A.10 100-HR-3-H Long-Term Monitoring ........................................................................................... A.19

A.11 100-KR-4 Interim Action Monitoring for 100-K Pump-and-Treat System ........................................ A.20

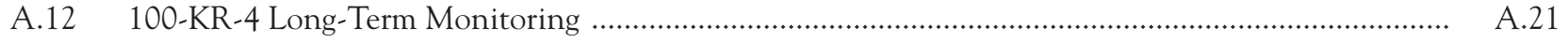

A.13 100-NR-2 Long-Term Monitoring …........................................................................................ A.22

A.14 Monitoring Wells and Constituents for the 200-BP-5 Operable Unit ............................................. A.23

A.15 Monitoring Wells and Constituents for the 200-PO-1 Operable Unit ................................................ A.25

A.16 Monitoring Wells and Constituents for the 200-UP-1 Operable Unit ............................................... A.28

A.17 Monitoring Wells and Constituents for the 200-ZP-1 Operable Unit ............................................... A.29 
A.18 Monitoring Wells and Constituents for the 300-FF-5 Operable Unit .............................................. A.31

A.19 Monitoring Wells and Constituents for the 1100-EM-1 Operable Unit ............................................. A.33

\section{Figures}

A.1 Groundwater Operable Units and Groundwater Interest Areas on the Hanford Site.....

A.34 


\section{Appendix A}

\section{Supporting Information for CERCLA Groundwater Operable Units}

The groundwater and vadose zone beneath contaminated portions of the Hanford Site are divided into 11 groundwater operable units, discussed in alphanumeric order in this appendix. Figure A.1 shows the locations of these units and related groundwater interest areas on the Hanford Site. Table A.1 gives a brief synopsis of remediation activities at each operable unit. Table A.2 lists wells that were not sampled as scheduled during fiscal year 2003. Table A.3 lists the maximum concentrations for contaminants of concern in fiscal year 2003 by groundwater interest area. Tables A.4 through A.19 list the constituents of concern, monitoring wells used in the networks, and the frequency of sampling for each operable unit.

\section{A. 1 100-BC-5 Operable Unit}

A sampling and analysis plan (PNNL-13326) specifies wells, constituents, and sampling frequency for this operable unit. That plan included the same well and constituent lists defined in Hanford Federal Facility Agreement and Consent Order (Tri-Party Agreement; Ecology et al. 1998) Change Control Form M-15-99-03. Subsequent to publication of the sampling and analysis plan, Change Control Form M-15-00-07 was approved, substituting one upgradient well for another. Wells, constituents, and sampling frequencies are shown in Table A.4.

During fiscal year 2003, the objective of monitoring groundwater in this operable unit was to define contaminant plumes and track trends in concentration until final cleanup decisions are made. The Groundwater Performance Assessment Project (groundwater project) met this objective; plumes and trends are discussed in Section 2.2 of the main text.

During fiscal year 2003, all wells were sampled as scheduled, but one well was missing several analyses. Samples from well 699-63-90, located southwest of 100-B/C Area between Umtanum Ridge and Gable Butte, were not analyzed for gross alpha, gross beta, or strontium-90. The well was not scheduled according to the approved constituent list due to human error. The impact of this omission is minimal, since the well is upgradient from contaminant sources in the operable unit.

One seep, 039-2 (Figure 2.2-1), was not sampled for the 100-BC-5 Operable Unit because it was not flowing at the time of sampling in fall 2002. It was sampled in September 2003 for the site-wide Surface Environmental Surveillance Project. Those data will be included in the Hanford Site environmental report for 2003.

In fiscal year 2003, the groundwater project applied the U.S. Environmental Protection Agency's (EPA's) data quality objectives process to groundwater monitoring at the 100-BC-5 Operable Unit (PNNL-14287). Based on the results of that process, the groundwater project developed a new sampling and analysis plan (DOE/RL-2003-38) that EPA approved at the end of fiscal year 2003. The new plan was implemented in fiscal year 2004.

\section{A. 2 100-FR-3 Operable Unit}

A sampling and analysis plan (PNNL-13327) specifies wells, constituents, and sampling frequency for this operable unit. That plan included the same well and constituent lists defined in Tri-Party Agreement Change Control Form M-15-99-02. Subsequent to publication of the sampling and analysis plan, Change Control Form M-15-01-06 was approved, removing well 199-F5-3 from the network and changing quarterly strontium-90 sampling to annual in one well. Wells, constituents, and sampling frequencies that were required for fiscal year 2003 are shown in Table A.5.

During fiscal year 2003, the objective of monitoring groundwater in this operable unit was to define contaminant plumes and track trends in concentration until final cleanup decisions are made. The groundwater project met this objective; plumes and trends are discussed in Section 2.7 of the main text. 
All wells were sampled as scheduled in fiscal year 2003. Two of the three seeps listed in the sampling and analysis plan were not sampled because the specific conductance of the seep water was the same as river water; therefore, the water would not have represented discharging groundwater.

In fiscal year 2003, the groundwater project applied EPA's data quality objectives process to groundwater monitoring of the 100-FR-3 Operable Unit (PNNL-14287). Based on the results of that process, the groundwater project developed a new sampling and analysis plan (DOE/RL-2003-49) that EPA approved at the end of fiscal year 2003. The new plan was implemented in fiscal year 2004.

\section{A. 3 100-HR-3 Operable Unit}

This operable unit includes two remediation systems in the 100-D Area (a pump-and-treat system and an in situ redox system) and a pump-and-treat system in the 100-H Area. In addition to the remedial action monitoring, 100-D and 100-H Area wells are sampled to track contaminant plumes and trends (long-term monitoring).

100-D Pump-and-Treat. Monitoring requirements for this system are included in DOE/RL-96-90, as modified by DOE/RL-96-84. Wells, constituents, and sampling frequencies for interim action monitoring are shown in Table A.6. Table A.7 shows the same elements for long-term monitoring in the 100-D Area, which were derived from Change Control Form 107 as modified by Fluor Hanford, Inc. ${ }^{(a)}$

During fiscal year 2003, all wells were sampled as scheduled. Two shoreline seeps, scheduled as part of 100-HR-3 long-term monitoring, were not sampled. Seep 102-1 was dry. Seep 110-2 inadvertently was not scheduled. It is located near another seep (110-1) that was sampled.

Results of work completed in calendar year 2003 are summarized in Section 2.5 and will be reported fully in an upcoming annual report for the 100-HR-3 Operable Unit.

100-D Redox. Monitoring requirements for this system are described in DOE/RL-99-51. Wells, constituents, and sampling frequencies are shown in Table A.8.

During fiscal year 2003, several quarterly sampling events were missed due to problems in the field (see Table A.2). The impact of these omissions is minimal, since the wells were sampled the other three quarters and nearby wells were sampled all four quarters. One river bottom tube was not sampled, but a nearby aquifer tube was.

Results of work completed in fiscal year 2003 are summarized in Section 2.5 and will be reported fully in an upcoming annual report for the redox system.

100-H Pump-and-Treat. Monitoring requirements for this system are included in DOE/RL-96-90, as modified by DOE/RL-96-84. Wells, constituents, and sampling frequencies for interim action monitoring are shown in Table A.9. Table A.10 shows the same elements for long-term monitoring in the 100-H Area, which were derived from Change Control Form 107 as modified by Fluor Hanford, Inc. ${ }^{(a)}$

During fiscal year 2003, all wells were sampled as scheduled. Results of work completed in calendar year 2003 are summarized in Section 2.6 and will be reported in detail in an upcoming annual report for the 100-HR-3 Operable Unit.

\section{A.4 100-KR-4 Operable Unit}

The most recent performance evaluation and annual summary report (DOE/RL-2003-09) indicates that the pumpand-treat system captures most of the groundwater flow field occupied by the chromium plume. Removal of chromium from the extracted groundwater significantly reduces the amount of chromium available for movement into the river environment. Data on water levels, contaminants, system treatment cost and efficiency, and hydrogeology contribute to building a technical basis for a future final remedy decision. DOE/RL-96-90 and DOE/RL-96-84 describe the operational and environmental monitoring required as part of the interim action. Sampling and analysis is currently governed by a modification to the Tri-Party Agreement (TPA 1996). Tables A.11 and A.12 lists wells, contaminants of concern, and sampling frequencies for the 100-KR-4 Operable Unit. Results of work completed in fiscal year 2003

(a) Letter FH-0205249 from RT Wilde (Fluor Hanford, Inc.) to JS Fruchter (Pacific Northwest National Laboratory), Revised FY 2003 Sampling Schedule for Groundwater Remediation Monitoring, dated November 11, 2002. 
are summarized in Section 2.3. Three wells in the 100-KR-4 Operable Unit (199-K-114A, 199-K-130, and 199-K-18) were not sampled during one month each due to scheduling and pump problems (Table A.2). An upcoming annual report for the 100-KR-4 Operable Unit will describe progress in calendar year 2003.

The 100-KR-4 Operable Unit includes the groundwater that underlies the 100-K Area. Monitoring activities under the Comprehensive Environmental Response, Compensation, and Liability Act (CERCLA) continued during fiscal year 2003 as part of the remedial investigation that will lead to a future record of decision for final groundwater remedial action. A decision regarding final remedial action is expected to follow completion of source remedial actions and $\mathrm{KW}$ and $\mathrm{KE}$ Basins cleanup activities. Institutional controls are currently in place to prevent human access to groundwater beneath the 100-K Area. Groundwater monitoring for the operable unit consists predominantly of annual sampling of wells, with analyses for anions, metals, and radiological indicators. The list of wells, frequency of sampling, and analyses to be performed are described in National Priorities List Agreement/Change Control Form No. 108, dated November 20,1996, as updated by changes documented in letters from the U.S. Department of Energy (DOE) and Fluor Hanford, Inc. to the Washington State Department of Ecology (Ecology) and EPA in September 1998.(b,c)

An interim remedial action is underway to address groundwater contaminated by hexavalent chromium, which poses a threat to aquatic organisms that reside in the interface between the aquifer and the nearby Columbia River (ROD 1996a). A pump-and-treat system is used to reduce the amount of chromium in groundwater in the area between the $116-\mathrm{K}-2$ trench and the Columbia River.

\section{A.5 100-NR-2 Operable Unit}

The monitoring requirements for the pump-and-treat system at this operable unit are specified by Tri-Party Agreement Change Control Form M-15-96-08 as modified by Fluor Hanford, Inc. ${ }^{(c)}$ Wells, constituents, and sampling frequencies for interim action monitoring are shown in Table A.13. During fiscal year 2003, all wells were sampled as scheduled.

Results of work completed in calendar year 2003 are summarized in Section 2.4 and will be reported fully in an upcoming annual report for the 100-NR-3 Operable Unit.

\section{A.6 200-BP-5 Operable Unit}

The CERCLA monitoring objectives for this operable unit, which encompasses the north portion of 200 East Area in the vicinity of B Plant, are similar to the Atomic Energy Act of 1954 (AEA) objectives. The operable unit includes the past-practice sites 216-B-5 injection well, BY cribs, and Gable Mountain Pond. CERCLA groundwater sampling was suspended in the 200-BP-5 Operable Unit until completion and approval of waste management documentation. See Section 2.10 in the main text for additional discussion.

In fiscal year 2002, the groundwater project developed data quality objectives for monitoring the 200-BP-5 Operable Unit (PNNL-14049). During fiscal year 2003, DOE released a sampling and analysis plan (DOE/RL-2001-49), a waste control plan (DOE/RL-2003-30), and conducted initial sampling and analysis activities for this unit. Table A.13 describes the well network, the contaminants of concern, and sampling frequencies. Not all wells could be sampled in fiscal year 2003 because the plans were not approved until May 2003. Two of the wells scheduled for sampling could not be sampled because of pump problems and another well was determined to be dry (Table A.2).

\section{A.7 200-PO-1 Operable Unit}

The 200-PO-1 Operable Unit is a Resource Conservation and Recovery Act (RCRA) past-practice groundwater operable unit, and there is no record of decision. The objective is to monitor groundwater under the requirements for RCRA past practice and for AEA as directed in DOE orders. The long-term goal is to monitor the contaminants of concern until final cleanup decisions are made. Near-field wells are shown in the south portion of Figure 2.11-1, and far-field well locations are shown in Figure 2.1-2.

(b) Letter report 062039 from DM Wanek (U.S. Department of Energy, Richland, Washington) to SM Alexander (Washington State Department of Ecology) and DR Sherwood (U.S. Environmental Protection Agency), Sampling Changes to the 100-HR-3 and 100-KR-4 Operable Units (OU), dated September 16, 1998.

(c) Letter FH-0205249 from RT Wilde (Fluor Hanford, Inc.) to JS Fruchter (Pacific Northwest National Laboratory), Revised FY 2003 Sampling Schedule for Groundwater Remediation Monitoring, dated November 11, 2002. 
A temporary plan was presented that is nearly identical to the plan for monitoring the far-field wells in the RCRA groundwater monitoring plan (PNNL-11523) for the Plutonium-Uranium Extraction (PUREX) cribs and later proposed in a draft sampling and analysis plan. During fiscal year 2003, the operable unit was monitored according to a temporary plan (PNNL-11523). A new sampling and analysis plan was prepared in fiscal year 2003 and approved in early fiscal year 2004. The draft plan also adds requirements for sampling Columbia River shoreline aquifer tubes and two proposed new wells near the $\mathrm{BC}$ cribs.

Most of the near-field wells are sampled annually or semiannually, but many of the far-field wells (600 Area wells between the 200 East Area and the 300 Area) are sampled every 3 years (Table A.14). During fiscal year 2003, two wells were not sampled as scheduled (see Tables A.2 and A.15). Far-field (or major) contaminants of concern include tritium, iodine-129, and nitrate. Near-field (or minor) contaminants of concern include arsenic, chromium, cobalt-60, cyanide, manganese, strontium-90, technetium-99, and vanadium.

Discussion of groundwater contamination at the 200-PO-1 Operable Unit is presented in Section 2.11.

\section{A.8 200-UP-1 Operable Unit}

During fiscal year 2003, the environmental restoration contractor continued to operate a pump-and-treat system in this operable unit, which underlies the southeast 200 West Area (Figure A.1). Table A.15 lists monitoring wells, constituents, and sampling schedule for the 200-UP-1 Operable Unit in effect during fiscal year 2003. The sampling and analysis plan for the 200-UP-1 Operable Unit is described by DOE/RL-2002-10.

Results of the interim action are summarized annually (DOE/RL-2003-58). As of January 2003, the high concentration portions of the technetium-99 and uranium plumes were hydraulically contained and remediated at nearly all wells to levels required by the interim action objectives (ROD 1997). The only exception is well 299-W19-43, which in July 2003 met the record of decision for technetium-99. However, the uranium concentration at well 299-W19-43 (July 11, 2003) was right at the remedial action objective concentration of $480 \mu \mathrm{g} / \mathrm{L}$. Additional details of analytical results are provided in Section 2.9.

The capability to monitor and track changes in plume configuration has been limited by wells going dry in the baseline plume area; three of these wells went dry during fiscal year 2003 (Table A.2). Well 299-W19-46 was added in November 2002 and other wells will be added in fiscal years 2004 and 2005 to improve this situation. As a result of poor well control, the plume maps and evaluation of the extent of remediation are based on historical interpretation and the limited amount of data collected in fiscal year 2003.

To accelerate remediation, and to help with declining extraction production, well 299-W19-43 was converted from a monitoring to an extraction well by moving well head piping and instrumentation from well 299-W19-36. Well 299-W19-36 was re-equipped for extraction at the end of fiscal year 2003, and will be operated in fiscal year 2004 to maintain elevated extraction rates and reduce strain on pumping equipment. Thus, three extraction wells will be available in fiscal year 2004. Section 2.9 in the main text discusses groundwater remediation in more detail. Table A.15 lists contaminants of concern, well network, and sampling frequencies.

\section{A.9 200-ZP-1 Operable Unit}

The environmental restoration contractor continued to operate a pump-and-treat system in this operable unit, which underlies the north half of 200 West Area (Figure A.1). Table A.16 lists monitoring wells, constituents, and sampling schedule for the 200-ZP-1 Operable Unit in effect during fiscal year 2003. The purpose of the pump-andtreat system is to prevent further movement of groundwater contamination from the high concentration portion of the carbon tetrachloride plume and to reduce contaminant mass (ROD 1995). Sampling and analysis for groundwater is controlled by DOE/RL-2002-17.

Results of the interim action are summarized annually (DOE/RL-2003-58). The 200-ZP-1 pump-and-treat system made measurable progress toward meeting its specific objectives in fiscal year 2003. The high concentration portion of the carbon tetrachloride plume continues to move toward the extraction wells and appears to be hydraulically contained based on the contaminant plume maps, contaminant trends, and hydraulic capture analysis.

Section 2.8 of the main text discusses groundwater remediation. Table A.16 provides groundwater monitoring parameters for the 200-ZP-1 Operable Unit. Wells that were not sampled for at least one scheduled event during fiscal year 2003 for the 200-ZP-1 Operable Unit are included in Table A.2. Well 299-W18-24 went dry during fiscal year 
2003 (after it was sampled for the 200-ZP-1 Operable Unit) and another well, 299-W15-16, has an estimated 2 years of life. However, well 299-W15-30 is 15 meters from well 299-W15-16 and is screened over the same general interval and will replace it. Sampling at 299-W15-30 has been added in fiscal year 2004 to establish a contaminant concentration correlation between the two wells.

\section{A.10 300-FF-5 Operable Unit}

The 300-FF-5 Operable Unit is located in the 300 Area and two satellite areas to the northwest of the 300 Area (Figure 2.12-2). Groundwater monitoring for the operable unit is based on a record of decision for the 300-FF-1 and 300-FF-5 Operable Units (ROD 1996b) and the Explanation of Significant Difference for the 300-FF-5 Record of Decision (EPA 2000). The selected remedy for groundwater contamination, as stated in the record of decision, is (a) continued monitoring of groundwater that is contaminated above health-based levels to ensure that concentrations continue to decrease; and (b) institutional controls to ensure that groundwater use is restricted to prevent unacceptable exposures to groundwater contamination. Groundwater monitoring is conducted under an operations and maintenance plan (DOE/RL-95-73), which describes the implementation plans for the "attenuation by natural processes" portion of the selected remedy, and a sampling and analysis plan (DOE/RL-2002-11) that is based on the rationale and strategy of the operations and maintenance plan. During fiscal year 2003, the 300-FF-5 Operable Unit was monitored according to two groundwater monitoring plans. As part of a 2-year trial demonstration of improved intrawell monitoring, PNNL-13645 was the guiding document. Also, an older plan (WHC-SD-EN-AP-185) provides the compliance portion of the monitoring. The objectives of the plan are to (a) monitor contaminants that are above health-based risk levels to ensure that concentrations continue to decrease and (b) implement institutional controls to ensure that groundwater use is restricted to prevent unacceptable exposures (ROD 1996b; EPA 2000). All wells in the network were sampled as scheduled in fiscal year 2003.

Discussion of groundwater contamination at the 300-FF-5 Operable Unit is provided in Section 2.12.

\section{A. 11 1100-EM-1}

The 1100-EM-1 Operable Unit contains DOE's inactive Horn Rapids Landfill. Results of the CERCLA investigation for this operable unit are presented in the final remedial investigation study (DOE/RL-92-67) and the record of decision (ROD 1993). The selected remedy for groundwater is monitored natural attenuation of volatile organic compounds, with institutional controls on drilling of new water supply wells. Monitoring includes analysis for trichloroethene, its breakdown products (e.g., vinyl chloride and 1,1-dichloroethene), and nitrate in wells downgradient of DOE's inactive Horn Rapids Landfill, as recommended in the sampling plan (PNNL-12220). A list of the required wells and constituents are provided in Table A.18. Although some delays in sampling occurred due to operational circumstances (e.g., fire danger), all wells in the 1100-EM-1 network were sampled the planned number of times and for all scheduled constituents in fiscal year 2003. Analytical results for this sampling are discussed in Section 2.13. All monitoring wells were sampled as scheduled during fiscal year 2003.

Discussion of groundwater contamination at the 1100-EM-1 Operable Unit is provided in Section 2.13.

\section{A.12 References}

Atomic Energy Act of 1954. As amended, Ch. 1073, 68 Stat. 919, 42 USC 2011 et seq.

Comprehensive Environmental Response, Compensation, and Liability Act. 1980. Public Law 96-510, as amended, 94 Stat. 2767, 42 USC 9601 et seq.

DOE/RL-92-67, Draft B. 1992. Final Remedial Investigation Study-Environmental Assessment Report for the 1100-EM-1 Operable Unit, Hanford. U.S. Department of Energy, Richland Operations Office, Richland, Washington.

DOE/RL-95-73, Rev. 1. 2002. Operation and Maintenance Plan for the 300-FF-5 Operable Unit. U.S. Department of Energy, Richland Operations Office, Richland, Washington. 
DOE/RL-96-84, Rev. 0-A. 2003. Remedial Design Report and Remedial Action Work Plan for the 100-HR-3 and 100-KR-4 Groundwater Operable Units' Interim Action. U.S. Department of Energy, Richland Operations Office, Richland, Washington.

DOE/RL-96-90, Rev. 0. 1997. Interim Action Monitoring Plan for the 100-HR-3 and 100-KR-4 Operable Units. Prepared by CH2M HILL Hanford, Inc. for the U.S. Department of Energy, Richland Operations Office, Richland, Washington.

DOE/RL-99-51. 2000. Remedial Design Report and Remedial Action Work Plan for the 100-HR-3 Groundwater Operable Unit In Situ Redox Manipulation. U.S. Department of Energy, Richland Operations Office, Richland, Washington.

DOE/RL-2001-49. 2003. Groundwater Sampling and Analysis Plan for the 200-BP-5 Operable Unit. U.S. Department of Energy, Richland Operations Office, Richland, Washington.

DOE/RL-2002-10, Rev 0. 2002. Sampling and Analysis Plan for the 200-UP-1 Groundwater Monitoring Well Network. U.S. Department of Energy, Richland Operations Office, Richland, Washington.

DOE/RL-2002-11, Rev. 0. 2002. 300-FF-5 Operable Unit Sampling and Analysis Plan. U.S. Department of Energy, Richland Operations Office, Richland, Washington.

DOE/RL-2002-17, Rev. 0. 2002. Sampling and Analysis Plan for the 200-ZP-1 Groundwater Monitoring Well Network. U.S. Department of Energy, Richland Operations Office, Richland, Washington.

DOE/RL-2003-09, Rev. 0. 2003. Calendar Year 2002 Annual Summary Report for the 100-HR-3, 100-KR-4, and 100-NR-2 Operable Unit Pump-and-Treat Operations. Prepared by GG Kelty and RF Raidl, Fluor Hanford, Inc., for U.S. Department of Energy, Richland, Washington.

DOE/RL-2003-38. 2003. 100-BC-5 Operable Unit Sampling and Analysis Plan. U.S. Department of Energy, Richland, Washington.

DOE/RL-2003-49. 2003. 100-FR-3 Operable Unit Sampling and Analysis Plan. U.S. Department of Energy, Richland, Washington.

DOE/RL-2003-58. 2003. Fiscal Year 2003 Annual Summary Report for 200-UP-1 and 200-ZP-1 Pump-and-Treat Operations. Prepared by DB Erb, RS Edrington, GG Kelty, RF Raidl, K Sathyanarayana (Fluor Hanford, Inc.) and WJ McMahon (CH2M HILL Hanford Group, Inc.) for the U.S. Department of Energy, Richland, Washington.

Ecology - Washington State Department of Ecology, U.S. Environmental Protection Agency, and U.S. Department of Energy. 1998. Hanford Federal Facility Agreement and Consent Order. Document No. 89-10, Rev. 5 (The Tri-Party Agreement). Olympia, Washington.

Ecology and EPA - Washington State Department of Ecology and U.S. Environmental Protection Agency. 1994. Action Memorandum: N-Springs Expedited Response Action Cleanup Plan, U.S. Department of Energy Hanford Site, Washington. Olympia, Washington.

EPA. 2000. Explanation of Significant Difference for the 300-FF-5 Record of Decision (see ROD 1996b). Issued by U.S. Environmental Protection Agency, Region 10, and U.S. Department of Energy, Richland Operations Office, Richland, Washington.

PNNL-11523. 1997. Combination RCRA Groundwater Monitoring Plan for the 216-A-10, 216-A-36B, and 216-A-37-1 PUREX Cribs. JW Lindberg, Pacific Northwest National Laboratory, Richland, Washington.

PNNL-12220. 1999. Sampling and Analysis Plan Update for Groundwater Monitoring - 1100-EM-1 Operable Unit. DR Newcomer, Pacific Northwest National Laboratory, Richland, Washington.

PNNL-13326. 2000. Groundwater Sampling and Analysis Plan for the 100-BC-5 Operable Unit. MD Sweeney, Pacific Northwest National Laboratory, Richland, Washington. 
PNNL-13327. 2000. Groundwater Sampling and Analysis Plan for the 100-FR-3 Operable Unit. MD Sweeney, Pacific Northwest National Laboratory, Richland, Washington.

PNNL-13645. 2001. 300 Area Process Trenches Groundwater Monitoring Plan. JW Lindberg and CJ Chou, Pacific Northwest National Laboratory, Richland, Washington.

PNNL-14111. 2002. Fiscal Year 2003 Integrated Monitoring Plan for the Hanford Groundwater Monitoring Project. MJ Hartman, P Dresel, JP McDonald, DR Newcomer, and EC Thornton, Pacific Northwest National Laboratory, Richland, Washington.

PNNL-14287. 2003. Data Quality Objectives Summary Report - Designing a Groundwater Monitoring and Assessment Network for the 100-BC-5 and 100-FR-3 Operable Units. MD Sweeney and CJ Chou, Pacific Northwest National Laboratory, Richland, Washington.

Resource Conservation and Recovery Act. 1976. Public Law 94-580, as amended, 90 Stat. 2795, 42 USC 6901 et seq.

ROD. 1993. Record of Decision, USDOE Hanford 1100 Area, Hanford Site, Richland, Washington (1100-EM-1, 1100-EM-2, 1100-EM-3, and 1100-IU-1 Operable Units). Washington State Department of Ecology, U.S. Environmental Protection Agency, and U.S. Department of Energy, Richland Operations Office, Richland, Washington.

ROD. 1995. Declaration of the Record of Decision for the 200-ZP-1 Operable Unit. Washington State Department of Ecology, U.S. Environmental Protection Agency, and U.S. Department of Energy, Richland Operations Office, Richland, Washington.

ROD. 1996a. Declaration of the Record of Decision for the 100-HR-3 and 100-KR-4 Operable Units. Washington State Department of Ecology, U.S. Environmental Protection Agency, and U.S. Department of Energy, Richland Operations Office, Richland, Washington.

ROD. 1996b. Declaration of the Record of Decision, USDOE Hanford Area 300-FF-1 and 300-FF-5 Operable Units, Hanford Site, Benton County, Washington. Washington State Department of Ecology, U.S. Environmental Protection Agency, and U.S. Department of Energy, Richland Operations Office, Richland, Washington.

ROD. 1997. Declaration of the Record of Decision for the 200-UP-1 Operable Unit. Washington State Department of Ecology, U.S. Environmental Protection Agency, and U.S. Department of Energy, Richland Operations Office, Richland, Washington.

ROD. 1999a. Interim Remedial Action Record of Decision for the 100-NR-1 and -NR-2 Operable Units of the Hanford 100-N Area. Washington State Department of Ecology, Olympia, Washington.

ROD. 1999b. Interim Remedial Action Record of Decision for the 100-HR-3 Operable Unit of the Hanford 100-N Area. Washington State Department of Ecology, Olympia, Washington.

TPA. 1996. Modifications to the Groundwater Sampling and Analysis Schedules for the 100-KR-4 Operable Unit Groundwater Sampling Project. Tri-Party Agreement National Priorities List Change Control Form No. 108, November 20, 1996. U.S. Department of Energy, U.S. Environmental Protection Agency, and Washington State Department of Ecology.

WHC-SD-EN-AP-185. 1995. Groundwater Monitoring Plan for the 300 Area Process Trenches. JW Lindberg, CJ Chou, and VG Johnson, Westinghouse Hanford Company, Richland, Washington. 
Table A.1. Summary of Groundwater Remediation at CERCLA Operable Units

\section{Operable Unit \\ 100-KR-4 \\ (Pump-and-Treat) \\ 100-NR-2 \\ (Pump-and-Treat) \\ 100-HR-3 \\ (100-D Area}

Pump-and-Treat)

100-HR-3

(100-D Area

In Situ Redox)

100-HR-3

(100-H Area

Pump-and-Treat)

200-ZP-1

(Pump-and-Treat)
Startup Date

1997

995

Hexavalent chromiun

Hexavalent chromium

Hexavalent chromium

(a) Protect aquatic receptors in the river bottom substrate from contaminants in groundwater entering the Columbia River; (b) Protect human health by preventing exposure to contaminants in the groundwater; and (c) Provide information that will lead to the final remedy (ROD 1996a).

(a) Prevent further movement of contaminants from the highest concentration area of the plume (i.e., carbon tetrachloride inside the 2,000- to 3,000- $\mu \mathrm{g} / \mathrm{L}$ contour);

(b) Reduce contamination in area of highest carbon tetra-

chloride concentrations; and (c) Provide information that will lead to a final remedy (ROD 1995).
Progress at End of Fiscal Year 2003

Decreases chromium to river; 213 kilogram removed, 2.07 billion liters treated since startup

Diverts strontium-90 from river; insignificant aquifer cleanup; 1.45 curies removed, 869 million liters treated, $\sim 12$ curies naturally decayed since 1996.

Two additional extraction wells added; decreases chromium to river; 161 kilograms removed, 921 million liters treated since startup.

Barrier complete; decreases chromium concentration downgradient of barrier.

Decreases chromium to river; 34 kilograms removed, 936 million liters treated since startup; overall decrease in concentrations.

Prevents high-concentration portion of plume from spreading; 7,668 kilograms removed, 2.1 billion liters treated since startup; heart of plume contained. 
Table A.1. (contd)

\begin{tabular}{|c|c|c|c|}
\hline Operable Unit & Startup Date & Contaminant & Objectives \\
\hline $\begin{array}{l}200-Z P-1 \\
\text { (Soil-Vapor } \\
\text { Extraction) }\end{array}$ & 1992 & Carbon tetrachloride & Not applicable \\
\hline $\begin{array}{l}\text { 200-UP-1 } \\
\text { (Pump-and-Treat) }\end{array}$ & 1995 & $\begin{array}{l}\text { Technetium-99 } \\
\text { Uranium }\end{array}$ & $\begin{array}{l}\text { (a) Reduce contamination in areas of highest concentration } \\
\text { to below } 480 \mu \mathrm{g} / \mathrm{L} \text { for uranium, and } 9,000 \mathrm{pCi} / \mathrm{L} \text { for } \\
\text { technetium-99; (b) Reduce potential human health risks } \\
\text { through reduction of contaminant mass; (c) Prevent further } \\
\text { movement of contaminants from the highest concentration } \\
\text { area; and (d) Provide information that will lead to a final } \\
\text { remedy (ROD 1997). }\end{array}$ \\
\hline $300-\mathrm{FF}-5$ & Not applicable & $\begin{array}{l}\text { Uranium and } \\
\text { chlorinated } \\
\text { hydrocarbons }\end{array}$ & $\begin{array}{l}\text { (a) Monitor contaminants above health-based risk levels to } \\
\text { ensure that concentrations continue to decrease and } \\
\text { (b) Implement institutional controls to ensure that ground- } \\
\text { water use is restricted to prevent unacceptable exposures } \\
\text { (ROD 1996b). }\end{array}$ \\
\hline 1100-EM-1 & Not applicable & $\begin{array}{l}\text { Volatile organic } \\
\text { compounds }\end{array}$ & $\begin{array}{l}\text { (a) Attain trichloroethene concentrations }<5 \mu \mathrm{g} / \mathrm{L} \text { at point } \\
\text { of compliance and (b) Protect environmental receptors in } \\
\text { surface water by reducing groundwater concentrations to } \\
\text { safe levels (ROD 1993). }\end{array}$ \\
\hline
\end{tabular}

$\overline{\mathrm{CERCLA}}=$ Comprehensive Environmental Response, Compensation, and Liability Act.

\section{Progress at End of Fiscal Year 2003}

78,100 kilograms removed since startup; concentrations decreased, preventing movement to groundwater.

102 grams technetium-99 removed since startup; concentrations at remedial action objective in extraction well.

180 grams uranium removed since startup; concentrations remained above remedial action objective.

Uranium above and trichloroethene below target levels. Work in progress to determine trends in levels.

Trichloroethene $<5 \mu \mathrm{g} / \mathrm{L}$ at compliance point. Monitoring trends. 
Table A.2. Wells Not Sampled as Scheduled for CERCLA Facilities, Fiscal Year 2003

\begin{tabular}{|c|c|c|c|}
\hline Well & Schedule & Operable Unit & Comments \\
\hline $199-D 4-23$ & $02 / 01 / 03$ & 100-HR-3-D & Electrical problem; one quarter missed \\
\hline 199-D4-31 & $02 / 01 / 03$ & 100-HR-3-D & Electrical problem; one quarter missed \\
\hline 199-D4-39 & $02 / 01 / 03$ & 100-HR-3-D & Pump problem; one quarter missed \\
\hline $199-D 4-48$ & $02 / 01 / 03$ & 100-HR-3-D & Electrical problem; one quarter missed \\
\hline $199-D 4-7$ & 02/01/03 & 100-HR-3-D & Electrical problem; one quarter missed \\
\hline $199-D 4-85$ & $02 / 01 / 03$ & 100-HR-3-D & Pump problem; one quarter missed \\
\hline $199-\mathrm{K}-114 \mathrm{~A}$ & $01 / 01 / 03$ & $100-K R-4$ & Pump problem; one month missed \\
\hline $199-K-130$ & 04/01/03 & $100-$ KR-4 & Scheduling error; one month missed \\
\hline $199-K-18$ & 06/01/03 & $100-K R-4$ & Pump problem; one month missed \\
\hline SK-057-3 & $11 / 10 / 02$ & $100-K R-4$ & Seep; not flowing \\
\hline 299-W10-13 & 03/01/03 & $200-Z P-1$ & Dry \\
\hline 299-W19-14 & $01 / 01 / 03$ & 200-UP-1 & Dry \\
\hline 299-W23-14 & $01 / 01 / 03$ & 200-UP-1 & Dry \\
\hline 299-W26-12 & 01/01/03 & 200-UP-1 & Dry \\
\hline 299-W6-2 & $01 / 01 / 03$ & $200-Z P-1$ & Dry \\
\hline 299-W6-2 & $07 / 01 / 03$ & $200-Z P-1$ & Dry \\
\hline 299-W6-7 & $01 / 01 / 03$ & $200-Z P-1$ & Dry \\
\hline 299-W7-8 & 03/01/03 & $200-\mathrm{ZP}-1$ & Dry \\
\hline $699-31-31$ & $01 / 01 / 03$ & 200-PO-1 & Access road needs repair; annual sample missed \\
\hline 699-S11-E12AP & None & $200-\mathrm{PO}-1$ & $\begin{array}{l}\text { Basalt-confined aquifer; inadvertently scheduled } \\
\text { triennially. }\end{array}$ \\
\hline $699-49-55 \mathrm{~A}$ & $09 / 01 / 03$ & $200-\mathrm{BP}-5$ & Pump problem; annual sample missed \\
\hline $699-53-48 B$ & 07/01/03 & $200-B P-5$ & Dry \\
\hline $699-53-55 B$ & 09/01/03 & $200-B P-5$ & Pump problem; annual sample missed \\
\hline $699-63-90$ & $01 / 01 / 03$ & $100-B C-5$ & Sampled, but some constituents missed \\
\hline
\end{tabular}


Table A.3. Maximum Concentrations of Constituents by Groundwater Interest Area, Fiscal Year 2003

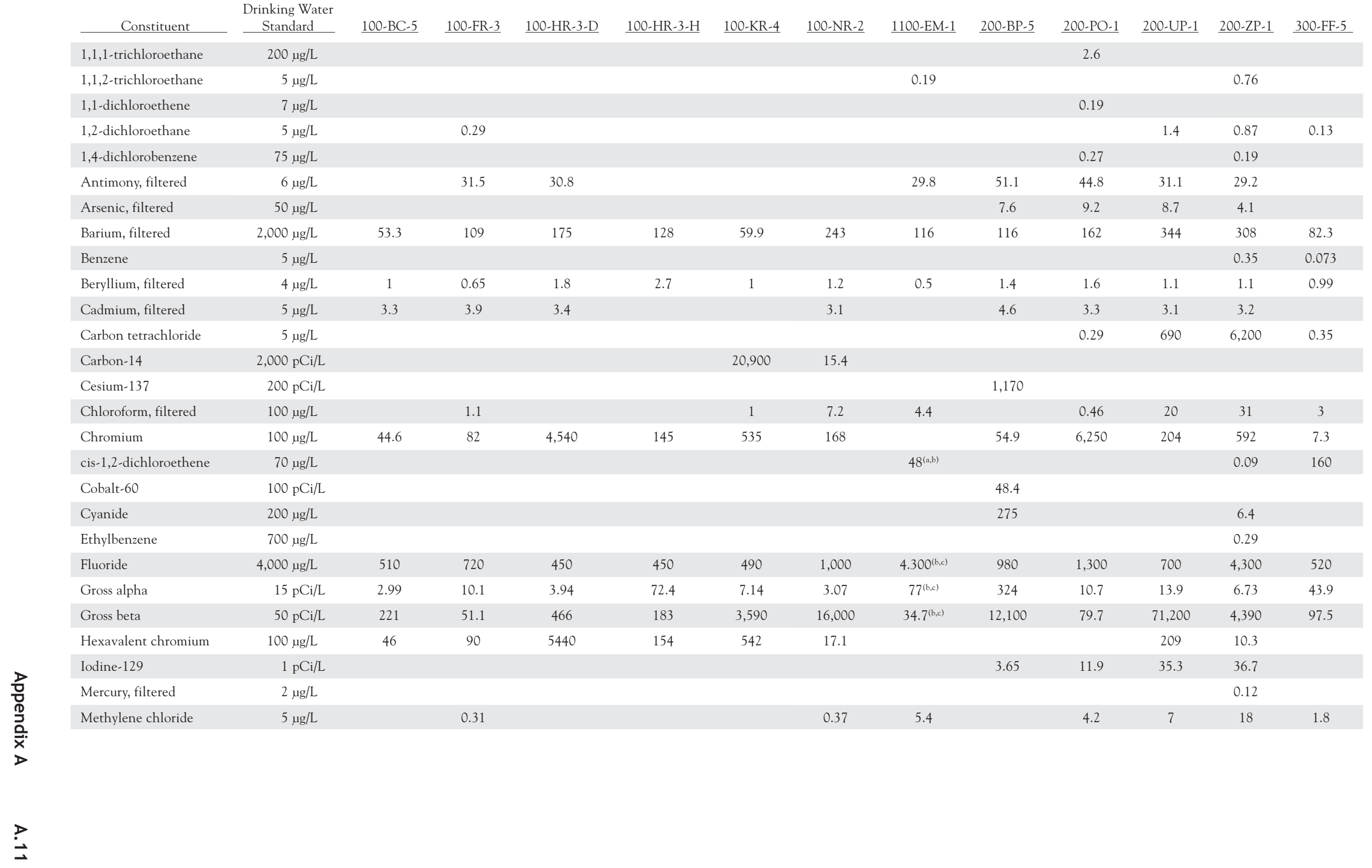


Table A.3. (contd)

\begin{tabular}{|c|c|c|c|c|c|c|c|c|c|c|c|c|c|}
\hline Constituent & $\begin{array}{l}\text { Drinking Water } \\
\text { Standard }\end{array}$ & $\underline{100-B C-5}$ & $100-F R-3$ & 100-HR-3-D & $\underline{100-\mathrm{HR}-3-\mathrm{H}}$ & $100-\mathrm{KR}-4$ & $100-N R-2$ & $\underline{1100-\mathrm{EM}-1}$ & $200-\mathrm{BP}-5$ & $200-\mathrm{PO}-1$ & 200-UP-1 & 200-ZP-1 & $300-F F-5$ \\
\hline Nickel, filtered & $100 \mu \mathrm{g} / \mathrm{L}$ & & & 416 & 21.6 & 28.8 & 17 & & 133 & 864 & 120 & 328 & 41.6 \\
\hline Nitrate & $45,000 \mu \mathrm{g} / \mathrm{L}$ & 27,900 & 177,000 & 107,000 & 474,000 & 195,000 & 228,000 & $261,000^{(b, c)}$ & 735,000 & 170,000 & $1,930,000$ & $2,160,000$ & 134,000 \\
\hline Nitrite & 3,300 $\mu \mathrm{g} / \mathrm{L}$ & & & 7550 & & 135 & 299 & 42.7 & 1120 & 233 & 460 & 361 & 69 \\
\hline Plutonium-238 & $30 \mathrm{pCi} / \mathrm{L}$ & & & & & & & & 0.619 & & & & \\
\hline Plutonium-239/240 & $30 \mathrm{pCi} / \mathrm{L}$ & & & & & & & & 74.8 & & & & \\
\hline Selenium, filtered & $50 \mu \mathrm{g} / \mathrm{L}$ & & & & & & & & & & 5.7 & & \\
\hline Strontium-90 & $8 \mathrm{pCi} / \mathrm{L}$ & 98.9 & 27.8 & 7.06 & 23.2 & 2,440 & 8,000 & & 5,680 & 21.4 & 53.6 & 1.29 & 4.03 \\
\hline Technetium-99 & $900 \mathrm{pCi} / \mathrm{L}$ & 46.7 & & & 986 & 85.4 & & 27 & 10,600 & 287 & 188,000 & 11,117 & 319 \\
\hline Tetrachloroethene & $5 \mu \mathrm{g} / \mathrm{L}$ & & & & & & & 0.26 & & 2.2 & & 1.4 & 0.48 \\
\hline Toluene & $1,000 \mu \mathrm{g} / \mathrm{L}$ & & & & & & & & & 0.89 & & 0.37 & \\
\hline trans-1,2-dichloroethene & $100 \mu \mathrm{g} / \mathrm{L}$ & & & & & & & & & & & & 0.54 \\
\hline Trichloroethene & $5 \mu \mathrm{g} / \mathrm{L}$ & & 9.8 & & & 11 & & $27^{(a, b)}$ & & 0.88 & 11 & 18 & 7.2 \\
\hline Tritium & $20,000 \mathrm{pCi} / \mathrm{L}$ & 32,200 & 11,500 & 29,700 & 6,210 & $1,270,000$ & 31,400 & 250.98 & 27,600 & $5,570,000$ & 634,000 & $2,170,000$ & $3,670,000$ \\
\hline Uranium & $30 \mu \mathrm{g} / \mathrm{L}$ & & & 3.58 & 119 & & & 18 & 554 & 7.19 & 1190 & 367 & 235 \\
\hline
\end{tabular}

(a) City of Richland data; not in HEIS

(b) From offsite contaminant source.

(c) Framatome ANP data; not in HEIS.

Note: Values flagged with "U," "R," and "Y" are excluded from this table.

HEIS = Hanford Environmental Information System. 
Table A.4. Monitoring Wells and Constituents for the 100-BC-5 Operable Unit (adapted from PNNL-13326 and Change Control Form M-15-00-07)

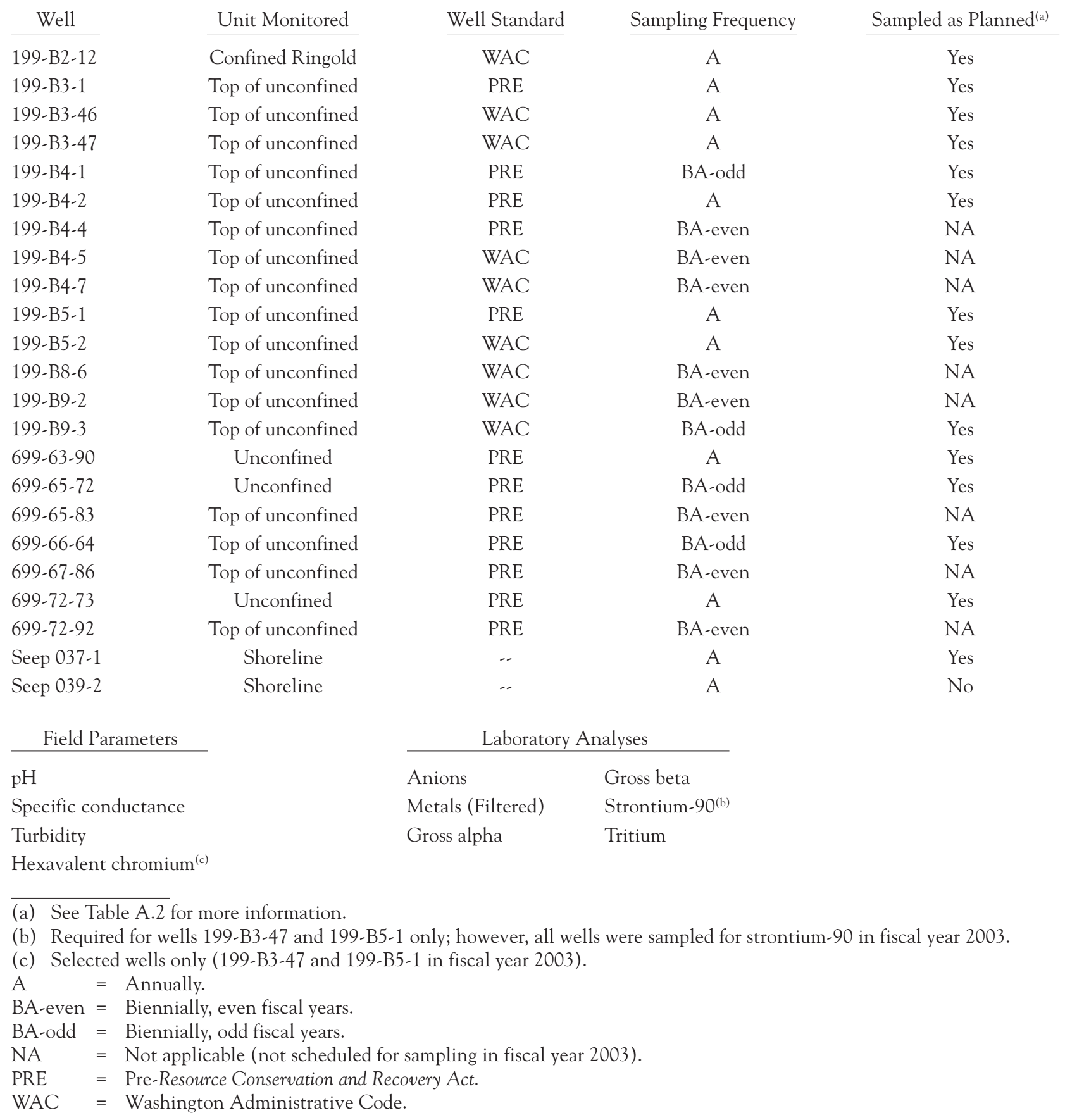


Table A.5. Monitoring Wells and Constituents for the 100-FR-3 Operable Unit (adapted from PNNL-13327 and Change Control Form M-15-01-06)

\begin{tabular}{|c|c|c|c|c|}
\hline Well & Unit Monitored & Well Standard & Sampling Frequency & Sampled as Planned (a) \\
\hline 199-F1-2 & Top of unconfined & WAC & A & Yes \\
\hline 199-F5-1 & Top of unconfined & PRE & A & Yes \\
\hline 199-F5-4 & Top of unconfined & PRE & BA-odd & Yes \\
\hline 199-F5-6 & Top of unconfined & PRE & A & Yes \\
\hline $199-F 5-42$ & Top of unconfined & WAC & A & Yes \\
\hline $199-\mathrm{F} 5-43 \mathrm{~A}$ & Top of unconfined & WAC & $\mathrm{A}$ & Yes \\
\hline $199-F 5-43 B$ & Confined Ringold & WAC & A & Yes \\
\hline $199-F 5-44$ & Top of unconfined & WAC & A & Yes \\
\hline $199-F 5-45$ & Top of unconfined & WAC & $\begin{array}{c}\text { Q (nitrate); } \\
\text { BA-odd (other) }\end{array}$ & Yes \\
\hline 199-F5-46 & Top of unconfined & WAC & $\begin{array}{c}\mathrm{Q} \text { (hexavalent } \\
\text { chromium); A (other) }\end{array}$ & Yes \\
\hline $199-F 5-47$ & Top of unconfined & WAC & BA-even & NA \\
\hline $199-F 5-48$ & Top of unconfined & WAC & BA-even & NA \\
\hline 199-F6-1 & Top of unconfined & WAC & A & Yes \\
\hline 199-F7-1 & Top of unconfined & PRE & BA-even & NA \\
\hline 199-F7-2 & Top of unconfined & WAC & BA-even & NA \\
\hline $199-F 7-3^{(\mathrm{a})}$ & Top of unconfined & WAC & BA-odd & Yes \\
\hline $199-F 8-2$ & Top of unconfined & PRE & BA-even & $\mathrm{NA}$ \\
\hline 199-F8-3 & Top of unconfined & WAC & BA-odd & Yes \\
\hline 199-F8-4 & Top of unconfined & WAC & A & Yes \\
\hline $699-71-30$ & $\begin{array}{l}\text { Top of unconfined to } \\
\text { confined Ringold }\end{array}$ & PRE & BA-odd & Yes \\
\hline $699-77-36^{(a)}$ & $\begin{array}{l}\text { Top of unconfined to } \\
\text { confined Ringold }\end{array}$ & PRE & BA-even & NA \\
\hline $699-81-38^{(a)}$ & $\begin{array}{l}\text { Top of unconfined to } \\
\text { confined Ringold }\end{array}$ & PRE & BA-odd & Yes \\
\hline $699-83-47$ & Top of unconfined & PRE & BA-even & NA \\
\hline $699-84-35 \mathrm{~A}$ & Confined Ringold & PRE & BA-odd & Yes \\
\hline Seep $187-1$ & Shoreline & - & A & No \\
\hline Seep 190-4 & Shoreline & - & A & No \\
\hline Seep 207-1 & Shoreline & - & A & Yes \\
\hline Field Parameters & & \multicolumn{2}{|c|}{ Laboratory Analysis } & \\
\hline $\begin{array}{l}\mathrm{pH} \\
\text { Specific conductance } \\
\text { Temperature } \\
\text { Turbidity }\end{array}$ & & $\begin{array}{l}\text { Anions } \\
\text { Metals (filtered) } \\
\text { Gross alpha } \\
\text { Gross beta }\end{array}$ & $\begin{array}{l}\text { Hexavalent chromium }^{(b)} \\
\text { Strontium-90 } \\
\text { Tritium } \\
\text { Volatile organics }^{(c)}\end{array}$ & \\
\hline
\end{tabular}

(a) See Table A.2 for more information.

(b) Hexavalent chromium analyzed in well 199-F5-46 only.

(c) Volatile organics required in selected wells only. However, in fiscal year 2003 the analysis was run in all wells and seeps.

A $\quad=$ Annually.

BA-even $=$ Biennially, even fiscal years.

BA-odd $=$ Biennially, odd fiscal years.

NA $\quad=$ Not applicable (not scheduled for sampling in fiscal year 2003).

PRE = Pre-Resource Conservation and Recovery Act.

WAC $=$ Washington Administrative Code. 
Table A.6. Monitoring Wells and Constituents for 100-HR-3-D Interim Action Monitoring for 100-D Pumpand-Treat System (from DOE/RL-96-90 as modified by DOE/RL-96-84)

\begin{tabular}{l}
\multicolumn{1}{c}{ Well } \\
\hline \\
199-D8-53 \\
199-D8-54A \\
199-D8-68 \\
199-D8-72
\end{tabular}

199-D8-70

\section{Chromium}

$Q$

Q

Q

Q

$\mathrm{M}$

$\mathrm{M}$
Strontium-90 and Tritium

Extraction Wells ${ }^{(a)}$

SA

SA

SA

SA

\section{Compliance Wells}

\section{A}

A
Sampled as Scheduled
Yes
Yes
Yes
Yes

Yes

Yes

(a) Operational sampling outside scope of groundwater project; data not in HEIS.

HEIS $=$ Hanford Environmental Information System.

$\mathrm{M}=$ Monthly.

$\mathrm{Q}=$ Quarterly.

$\mathrm{SA}=$ Semiannually. 
Table A.7. 100-HR-3-D Long-Term Monitoring Parameters (from Change Control Form 107 as modified $\left.{ }^{[a]}\right)$

\begin{tabular}{|c|c|c|c|c|}
\hline Well & Field Chromium & Field Sulfate & Other ${ }^{(b)}$ & Sampled as Scheduled \\
\hline 199-D2-6 & Q & Q & A & Yes \\
\hline 199-D3-2 & Q & Q & A & Yes \\
\hline 199-D4-13 & $Q$ & Q & A & Yes \\
\hline 199-D4-14 & Q & $Q$ & A & Yes \\
\hline 199-D4-15 & M & M & A & Yes \\
\hline 199-D4-19 & $Q$ & $Q$ & A & Yes \\
\hline 199-D4-20 & Q & Q & A & Yes \\
\hline 199-D4-22 & $Q$ & $Q$ & A & Yes \\
\hline 199-D4-23 & $Q$ & $Q$ & A & Yes \\
\hline 199-D5-13 & Q & -. & A & Yes \\
\hline 199-D5-14 & $Q$ & .- & A & Yes \\
\hline 199-D5-15 & Q & -. & A & Yes \\
\hline 199-D5-16 & $Q$ & .- & A & Yes \\
\hline 199-D5-17 & .- & .- & A & Yes \\
\hline 199-D5-18 & .- & .- & B-03 & Yes \\
\hline 199-D5-19 & .. & .- & B-04 & -. \\
\hline 199-D5-20 & Q & -. & A & Yes \\
\hline 199-D5-36 & $Q$ & Q & A & Yes \\
\hline 199-D5-37 & Q & Q & A & Yes \\
\hline 199-D5-38 & M & M & A & Yes \\
\hline 199-D5-39 & M & M & A & Yes \\
\hline $199-D 5-40$ & $Q$ & $Q$ & A & Yes \\
\hline 199-D5-41 & Q & $Q$ & A & Yes \\
\hline 199-D5-42 & Q & $Q$ & A & Yes \\
\hline 199-D5-43 & M & M & A & Yes \\
\hline 199-D5-44 & Q & Q & A & Yes \\
\hline 199-D8-4 & -. & -. & A & Yes \\
\hline 199-D8-5 & .- & .- & A & Yes \\
\hline 199-D8-54B & .- & .- & A & Yes \\
\hline 199-D8-55 & Q & -. & A & Yes \\
\hline $699-93-48 \mathrm{~A}$ & .- & .. & B- 04 & .. \\
\hline $699-96-49$ & .. & -. & B-03 & Yes \\
\hline $699-97-51 \mathrm{~A}$ & -. & -. & A & Yes \\
\hline \multicolumn{5}{|c|}{ Shoreline Seeps } \\
\hline SD-102-1 & -. & -. & A & No; dry \\
\hline SD-110-1 & -. & -. & A & Yes \\
\hline SD-110-2 & .- & .- & A & $\mathrm{No}^{(c)}$ \\
\hline SD-98-1 & .. & .. & A & Yes \\
\hline
\end{tabular}

(a) Letter FH-0205249 from RT Wilde (Fluor Hanford, Inc.) to JS Fruchter (Pacific Northwest National Laboratory), Revised FY 2003 Sampling Schedule for Groundwater Remediation Monitoring, dated November 11, 2002.

(b) Metals (filtered/unfiltered), anions, gross alpha, gross beta, and tritium.

(c) See Section A.3 for more information.

B-03 = Biennially, fiscal year 2003.

B-04 = Biennially, fiscal year 2004.

$\mathrm{A}=$ Annually.

$\mathrm{M}=$ Monthly.

Q = Quarterly. 
Table A.8. 100-HR-3-D Interim Action Monitoring for Redox System (DOE/RL-99-51)

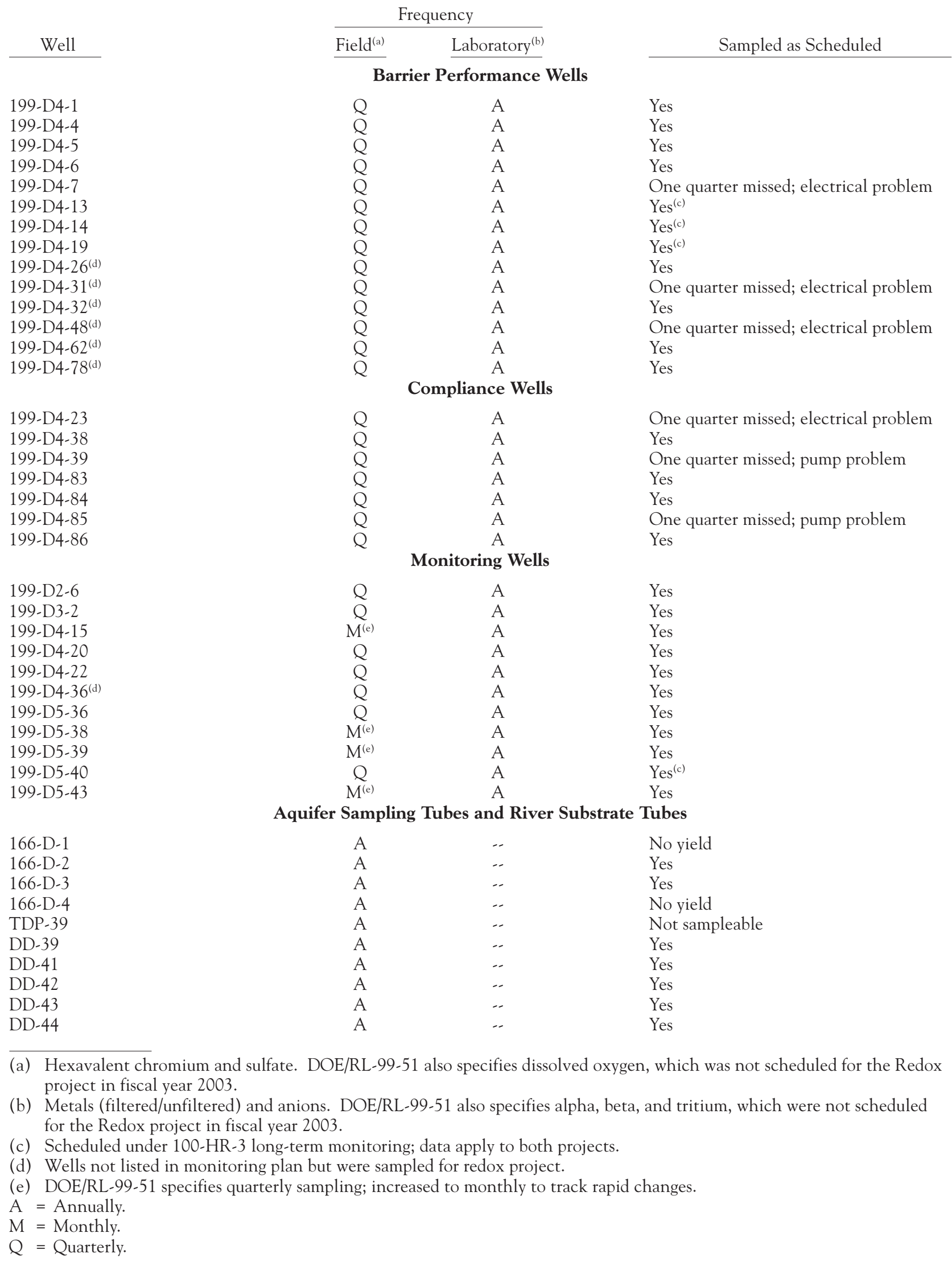


Table A.9. 100-HR-3-H Interim Action Monitoring Parameters for 100-H Pump-and-Treat System (from DOE/RL-96-90 as modified by DOE/RL-96-84)

\begin{tabular}{|c|c|c|c|}
\hline Well & Chromium & Co-Contaminants ${ }^{(a)}$ & Sampled as Scl \\
\hline \multicolumn{4}{|c|}{ Extraction Wells ${ }^{(b)}$} \\
\hline 199-H3-2A & Q & SA & Yes \\
\hline 199-H4-7 & $\widehat{Q}$ & SA & Yes \\
\hline 199-H4-11 & Q & SA & Yes \\
\hline 199-H4-12A & $Q$ & SA & Yes \\
\hline 199-H4-15A & Q & SA & Yes \\
\hline 199-H4-65 & $Q$ & SA & Yes \\
\hline \multicolumn{4}{|c|}{ Injection Wells } \\
\hline 199-H3-3 & .. & .. & \\
\hline 199-H3-4 & -. & -. & \\
\hline $199-\mathrm{H} 3-5$ & -. & -. & \\
\hline \multicolumn{4}{|c|}{ Compliance Wells } \\
\hline 199-H4-4 & M & A & Yes \\
\hline 199-H4-5 & M & A & Yes \\
\hline 199-H4-63 & M & A & Yes \\
\hline 199-H4-64 & M & A & Yes \\
\hline \multicolumn{4}{|c|}{ Performance Wells } \\
\hline 199-H4-3 & .- & SA & Yes \\
\hline 199-H4-6 & .. & SA & Yes \\
\hline 199-H4-8 & .. & SA & Yes \\
\hline 199-H4-10 & .- & SA & Yes \\
\hline 199-H4-12B & .- & SA & Yes \\
\hline 199-H4-12CS & -. & SA & Yes \\
\hline 199-H4-16 & .. & SA & Yes \\
\hline 199-H4-17 & .. & SA & Yes \\
\hline 199-H4-18 & -. & SA & Yes \\
\hline 199-H4-45 & .. & SA & Yes \\
\hline 199-H4-46 & .. & SA & Yes \\
\hline $199-\mathrm{H} 4-48$ & .. & SA & Yes \\
\hline 199-H4-49 & -. & SA & Yes \\
\hline 199-H5-1A & -. & SA & Yes \\
\hline
\end{tabular}

(a) Nitrate, strontium-90, technetium-99, tritium, and uranium.

(b) Operational sampling outside scope of groundwater project; data not in the Hanford Environmental Information System database.

A $=$ Annually.

$\mathrm{M}=$ Monthly.

$\mathrm{Q}=$ Quarterly.

$\mathrm{SA}=$ Semiannually. 
Table A.10. 100-HR-3-H Long-Term Monitoring (from Change Control Form 107 as modified $\left.^{[a]}\right)$

\begin{tabular}{|c|c|c|}
\hline Well & Frequency $^{(\mathrm{b})}$ & Sampled as Scheduled \\
\hline 199-H3-2A & A & Yes \\
\hline 199-H3-2C & B-03 & Yes \\
\hline 199-H4-10 & A & Yes \\
\hline 199-H4-12C & A & Yes \\
\hline 199-H4-13 & A & Yes \\
\hline 199-H4-14 & B-03 & Yes \\
\hline 199-H4-16 & B-03 & Yes \\
\hline 199-H4-17 & B-03 & Yes \\
\hline 199-H4-18 & A & Yes \\
\hline 199-H4-3 & A & Yes \\
\hline 199-H4-4 & A & Yes \\
\hline 199-H4-45 & A & Yes \\
\hline 199-H4-46 & B-03 & Yes \\
\hline 199-H4-47 & B-04 & -. \\
\hline 199-H4-48 & B-04 & .- \\
\hline 199-H4-49 & B-04 & .- \\
\hline 199-H4-5 & A & Yes \\
\hline 199-H4-6 & B-03 & Yes \\
\hline 199-H4-63 & A & Yes \\
\hline 199-H4-64 & A & Yes \\
\hline 199-H4-8 & B-03 & Yes \\
\hline 199-H4-9 & B-04 & .. \\
\hline 199-H5-1A & B-04 & .. \\
\hline 199-H6-1 & A & Yes \\
\hline 699-91-46A & B-04 & -. \\
\hline $699-96-43$ & B-03 & Yes \\
\hline $699-97-43$ & B-04 & -. \\
\hline SH-144-1 & A & Yes \\
\hline SH-145-1 & A & Yes \\
\hline SH-150-1 & A & Yes \\
\hline SH-152-2 & A & Yes \\
\hline SH-153-1 & A & Yes \\
\hline
\end{tabular}

(a) Letter FH-0205249 from RT Wilde (Fluor Hanford, Inc.) to JS Fruchter (Pacific Northwest National Laboratory), Revised FY 2003 Sampling Schedule for Groundwater Remediation Monitoring, dated November 11, 2002.

(b) Metals (filtered/unfiltered), anions, gross alpha, gross beta, and tritium.

$\mathrm{A}=$ Annually.

B-03 = Biennially, fiscal year 2003.

B-04 = Biennially, fiscal year 2004.

$\mathrm{FY}=$ Fiscal year. 
Table A.11. 100-KR-4 Interim Action Monitoring for 100-K Pump-and-Treat System (from DOE/RL-96-90 as modified by DOE/RL-96-84, Rev. 0-A)

\begin{tabular}{|c|c|c|c|}
\hline Well & \multirow[t]{2}{*}{ Chromium } & \multirow{2}{*}{$\frac{\text { Strontium-90 and Tritium }}{\text { Extraction Wells }}$} & \multirow[t]{2}{*}{ Sampled as Scheduled } \\
\hline & & & \\
\hline $199-\mathrm{K}-113 \mathrm{~A}$ & $Q$ & SA & Yes \\
\hline $199-\mathrm{K}-115 \mathrm{~A}$ & $Q$ & SA & Yes \\
\hline $199-\mathrm{K}-116 \mathrm{~A}$ & $Q$ & SA & Yes \\
\hline 199-K-119A & $Q$ & SA & Yes \\
\hline $199-\mathrm{K}-120 \mathrm{~A}$ & Q & SA & Yes \\
\hline $199-\mathrm{K}-125 \mathrm{~A}$ & $Q$ & SA & Yes \\
\hline $199-K-126 \mathrm{~A}^{(\mathrm{a})}$ & $Q$ & SA & Yes \\
\hline $199-\mathrm{K}-127 \mathrm{~A}$ & $Q$ & SA & Yes \\
\hline \multirow[t]{2}{*}{$199-\mathrm{K}-129 \mathrm{~A}$} & $Q$ & SA & Yes \\
\hline & & Injection Wells & \\
\hline $199-K-121 \mathrm{~A}$ & -. & .. & \\
\hline $199-\mathrm{K}-122 \mathrm{~A}$ & -. & -. & \\
\hline $199-\mathrm{K}-123 \mathrm{~A}$ & .- & .- & \\
\hline $199-\mathrm{K}-124 \mathrm{~A}$ & -. & .. & \\
\hline \multicolumn{4}{|l|}{$199-K-128 \mathrm{~A}$} \\
\hline \multicolumn{4}{|c|}{ Compliance Wells } \\
\hline $199-K-18$ & M & A & Missed one month; pump problem \\
\hline $199-K-20$ & M & A & Yes \\
\hline $199-\mathrm{K}-112 \mathrm{~A}$ & M & A & Missed one month; pump problem \\
\hline $199-\mathrm{K}-114 \mathrm{~A}$ & M & $\mathrm{A}$ & Missed one month; pump problem \\
\hline $199-\mathrm{K}-117 \mathrm{~A}$ & M & A & Yes \\
\hline \multirow[t]{2}{*}{$199-K-130 \mathrm{~A}$} & M & A & Yes \\
\hline & \multicolumn{3}{|c|}{ Performance Wells } \\
\hline $199-K-19$ & SA & .. & Yes \\
\hline $199-K-21$ & SA & -. & Yes \\
\hline $199-K-22$ & SA & .- & Yes \\
\hline $199-K-37$ & SA & .- & Yes \\
\hline \multicolumn{4}{|c|}{$\begin{array}{l}\text { (a) Converted to an e } \\
\mathrm{A}=\text { Annually. } \\
\mathrm{M}=\text { Monthly. } \\
\mathrm{Q}=\text { Quarterly. } \\
\mathrm{SA}=\text { Semiannually. }\end{array}$} \\
\hline
\end{tabular}


Table A.12. 100-KR-4 Long-Term Monitoring (from Wilde 2002 ${ }^{[a]}$ )

\begin{tabular}{|c|c|c|c|}
\hline Well & Quarterly & Other & Sampled as Scheduled \\
\hline $199-\mathrm{K}-106 \mathrm{~A}$ & .. & $\mathrm{BA}-04^{(\mathrm{b})}$ & Yes \\
\hline $199-\mathrm{K}-107 \mathrm{~A}$ & Chromium & $A^{(b)}$ & Yes \\
\hline $199-\mathrm{K}-108 \mathrm{~A}$ & Chromium & $\mathrm{A}^{(\mathrm{b})}$ & Yes \\
\hline 199-K-109A & Strontium-90 & $\mathrm{A}^{(\mathrm{b})}$ & Yes \\
\hline $199-K-11$ & .. & $\mathrm{BA}-03^{(\mathrm{b})}$ & Yes \\
\hline $199-\mathrm{K}-110 \mathrm{~A}$ & .. & BA- $04^{(\mathrm{b})}$ & .. \\
\hline $199-\mathrm{K}-111 \mathrm{~A}$ & .. & $\mathrm{A}^{(\mathrm{b}, \mathrm{c})}$ & Yes \\
\hline 199-K-18 & .. & $\mathrm{A}^{(\mathrm{b})}$ & Yes \\
\hline $199-K-19$ & -. & $\mathrm{A}^{(\mathrm{b})}$ & Yes \\
\hline $199-K-20$ & .. & $\mathrm{A}^{(\mathrm{b})}$ & Yes \\
\hline $199-K-21$ & .. & $A^{(b)}$ & Yes \\
\hline $199-K-22$ & -. & $\mathrm{A}^{(\mathrm{b})}$ & Yes \\
\hline $199-K-23$ & -. & $\mathrm{BA}-03^{(\mathrm{b})}$ & Yes \\
\hline $199-K-27$ & Strontium-90 & $\mathrm{BA}-04^{(\mathrm{b})}$ & Yes; BA list also \\
\hline $199-\mathrm{K}-30$ & Strontium-90 & $\mathrm{BA}-03^{(\mathrm{b})}$ & Yes \\
\hline $199-K-31$ & .- & $\mathrm{A}^{(\mathrm{b})}$ & Yes \\
\hline $199-\mathrm{K}-32 \mathrm{~A}$ & -. & $\mathrm{A}^{(\mathrm{b}, \mathrm{c})}$ & Yes \\
\hline $199-K-32 B$ & -. & $\mathrm{A}^{(\mathrm{b})}$ & Yes \\
\hline $199-K-33$ & .. & $\mathrm{A}^{(\mathrm{b}, \mathrm{c})}$ & Yes \\
\hline $199-K-34$ & -. & $\mathrm{BA}^{(\mathrm{b}, \mathrm{c})}$ & Yes \\
\hline $199-K-35$ & .- & $\mathrm{BA}-03^{(\mathrm{b})}$ & Yes; carbon-14 also \\
\hline $199-K-36$ & Chromium & $\mathrm{A}^{(\mathrm{b}, \mathrm{d})}$ & Yes \\
\hline $199-K-37$ & - & $\mathrm{A}^{(\mathrm{b})}$ & Yes \\
\hline $699-70-68$ & .- & $\mathrm{BA}-04^{(\mathrm{b})}$ & -. \\
\hline $699-73-61$ & -. & BA- $-04^{(\mathrm{b})}$ & -. \\
\hline $699-78-62$ & -. & $\mathrm{BA}-04^{(\mathrm{b})}$ & .. \\
\hline SK-057-3 & .. & $A^{(b)}$ & No \\
\hline SK-077-1 & -. & $\mathrm{A}^{(\mathrm{b})}$ & Yes \\
\hline SK-082-2 & .. & $\mathrm{A}^{(\mathrm{b})}$ & Yes \\
\hline
\end{tabular}

(a) Letter FH-0205249 from RT Wilde, Flour Hanford, Inc. to JS Fruchter, Pacific Northwest National Laboratory, Revised FY 2003 Sampling Schedule for Groundwater Remediation Monitoring, dated November 11, 2002.

(b) Metals (filtered/unfiltered), anions, gross alpha, gross beta, gamma, and tritium.

(c) As in (b), plus carbon-14.

(d) As in (b), plus mercury.

$\mathrm{A}=$ Annually.

B-03 = Biennially, fiscal year 2003.

B-04 = Biennially, fiscal year 2004 . 
Table A.13. 100-NR-2 Long-Term Monitoring (from Wilde 2002 ${ }^{[a]}$ )

\begin{tabular}{|c|c|c|c|}
\hline Well & Frequency & Constituents & Sampled as Scheduled \\
\hline $199-\mathrm{N}-14$ & SA & Anions, metals, beta, strontium-90, tritium & Yes \\
\hline $199-\mathrm{N}-16$ & A & $\begin{array}{l}\text { Anions, metals, oil/grease, tributyl phosphate, } \\
\text { beta, strontium- } 90\end{array}$ & Yes \\
\hline $199-\mathrm{N}-17$ & .. & -. & Decommissioned \\
\hline $199-\mathrm{N}-18$ & A & Oil/grease, tributyl phosphate & Yes \\
\hline $199-\mathrm{N}-2$ & A & Anions, metals, beta, strontium-90, tritium & Yes \\
\hline $199-\mathrm{N}-21$ & A & Anions, metals & Yes \\
\hline $199-\mathrm{N}-27$ & A & Anions, metals, alpha, gamma, tritium & Yes \\
\hline $199-\mathrm{N}-3$ & SA & Anions, metals, beta, strontium-90, tritium & Yes \\
\hline $199-\mathrm{N}-32$ & SA & $\begin{array}{l}\text { Anions, metals, beta, gamma, strontium-90, } \\
\text { tritium }\end{array}$ & Yes \\
\hline $199-N-50$ & A & Beta, tritium & Yes \\
\hline $199-N-51$ & A & Beta, tritium & Yes \\
\hline $199-N-54$ & -. & -. & Decommissioned \\
\hline $199-\mathrm{N}-64$ & A & Anions, metals, beta, strontium-90, tritium & Yes \\
\hline $199-\mathrm{N}-67$ & SA & Anions, metals, alpha, beta, strontium-90 & Yes \\
\hline $199-N-70$ & A & $\begin{array}{l}\text { Anions, metals, alpha, beta, gamma, } \\
\text { strontium-90, tritium }\end{array}$ & Yes \\
\hline $199-N-74$ & A & Metals, alpha, beta, gamma & Yes \\
\hline $199-N-75$ & SA & Anions, metals, beta, strontium-90, tritium & Yes \\
\hline $199-N-76$ & SA & $\begin{array}{l}\text { Anions, metals, beta, gamma, strontium-90, } \\
\text { tritium }\end{array}$ & Yes \\
\hline $199-\mathrm{N}-80$ & A & $\begin{array}{l}\text { Anions, metals, alpha, beta, gamma, } \\
\text { strontium-90, tritium }\end{array}$ & Yes \\
\hline $199-\mathrm{N}-81$ & A & Anions, metals, beta, strontium-90, tritium & Yes \\
\hline $199-\mathrm{N}-92 \mathrm{~A}$ & A & Anions, metals, beta, strontium-90, tritium & Yes \\
\hline $199-\mathrm{N}-96 \mathrm{~A}$ & A & Anions, metals, beta, strontium-90, tritium & Yes \\
\hline 199-N-99A & A & Anions, metals, beta, strontium-90, tritium & Yes \\
\hline
\end{tabular}


Table A.14. Monitoring Wells and Constituents for the 200-BP-5 Operable Unit (DOE/RL-2001-49)

\begin{tabular}{|c|c|c|c|c|c|c|c|c|c|c|}
\hline Well & Anions & Cyanide & Gamma & $\underline{\mathrm{I}-129}$ & $\underline{\mathrm{Sr}-90}$ & Tc-99 & Tritium & Uranium & $\underline{\mathrm{Pu}}$ & $\begin{array}{c}\text { Sampled in } \\
\text { Fiscal Year 2003 } \\
\end{array}$ \\
\hline 299-E27-7 & A & & & & & A & & & & Yes \\
\hline 299-E27-14 & A & & & & & A & & & & Yes \\
\hline 299-E27-15 & A & & & & & A & & & & Yes \\
\hline 299-E28-2 & & & A & A & A & A & A & & A & Yes \\
\hline 299-E28-5 & & & A & & A & & & A & A & Yes \\
\hline 299-E28-6 & & & A & & A & & & A & A & Yes \\
\hline 299-E28-8 & & & A & & A & A & & A & A & Yes \\
\hline 299-E28-17 & A & & A & & A & & & A & A & Yes \\
\hline 299-E28-18 & & & & A & & & & A & & No \\
\hline 299-E28-21 & & & & & & & & A & & No \\
\hline 299-E28-23 & & & A & & A & & & A & A & Yes \\
\hline 299-E28-24 & & & A & & A & & & A & A & Yes \\
\hline 299-E28-25 & & & A & & A & & & A & A & Yes \\
\hline 299-E28-26 & A & & & & & A & & A & & Yes \\
\hline 299-E28-27 & A & & A & A & A & A & & A & A & Yes \\
\hline 299-E32-4 & A & & & A & & A & A & & & Yes; no I-129 \\
\hline 299-E32-6 & A & & & & & A & & & & Yes \\
\hline 299-E32-9 & A & & & A & & A & & & & Yes; no I-129 \\
\hline 299-E32-10 & & A & A & & & A & & A & & Yes; no gamma \\
\hline 299-E33-7 & A & A & A & A & & A & & A & & Yes \\
\hline $299-E 33-12^{(b)}$ & & & & & & $\mathrm{T}$ & & & & No \\
\hline 299-E33-13 & & A & & & & A & & A & & No \\
\hline 299-E33-15 & A & & & & & A & & & & Yes \\
\hline 299-E33-16 & A & & & A & & A & & A & & Yes; no I-129 \\
\hline 299-E33-18 & & & & A & & A & & A & & Yes; no I-129 \\
\hline 299-E33-26 & & A & A & & & A & & A & & Yes \\
\hline 299-E33-28 & A & & & & & A & & & & Yes \\
\hline 299-E33-30 & A & & & & & A & & & & Yes \\
\hline 299-E33-34 & A & A & A & A & & A & A & A & & Yes; no I-129 \\
\hline 299-E33-35 & A & A & & & & A & & A & & Yes; no cyanide \\
\hline 299-E33-38 & A & A & A & A & & A & & A & & Yes; no I-129 \\
\hline 299-E33-39 & A & & & A & & A & A & & & Yes \\
\hline 299-E33-41 & & & & & & A & & A & & Yes \\
\hline 299-E33-42 & & & & A & & A & & A & & Yes; no I-129 \\
\hline 299-E33-43 & & & & A & & A & & A & & Yes \\
\hline 299-E33-44 & & & A & & & A & & A & & Yes \\
\hline 299-E33-46 & A & & & & & A & & A & & No \\
\hline 299-E33-338 & & & & & & A & & A & & Yes \\
\hline $699-43-40$ & & & & $\mathrm{~T}$ & & & $\mathrm{~T}$ & & & No \\
\hline $699-45-42$ & & & & $\mathrm{~T}$ & & & $\mathrm{~T}$ & & & No \\
\hline $699-47-60$ & A & & & A & & A & A & & & Yes \\
\hline $699-49-55 \mathrm{~A}$ & A & A & A & A & & A & A & & & No; see Table A.2 \\
\hline $699-49-57 \mathrm{~A}$ & A & A & A & A & & A & A & A & & Yes \\
\hline $699-49-57 \mathrm{~B}^{\mathrm{b}}$ & & & $\mathrm{T}$ & & & $\mathrm{T}$ & & & & No \\
\hline $699-50-53 \mathrm{~A}$ & A & A & A & A & & A & & & & No \\
\hline $699-53-47 \mathrm{~A}$ & A & & & & A & & & & & Yes \\
\hline $699-53-47 B$ & $\mathrm{~T}$ & & & & $\mathrm{~T}$ & & & & & Yes \\
\hline $699-53-48 \mathrm{~A}$ & $\mathrm{~T}$ & & & & $\mathrm{~T}$ & & & & & Yes \\
\hline $699-53-48 B$ & & & & & $\mathrm{~T}$ & & & & & No; dry \\
\hline $699-53-55 \mathrm{~A}$ & & & & & & $\mathrm{~T}$ & & & & Yes \\
\hline
\end{tabular}


Table A.14. (contd)

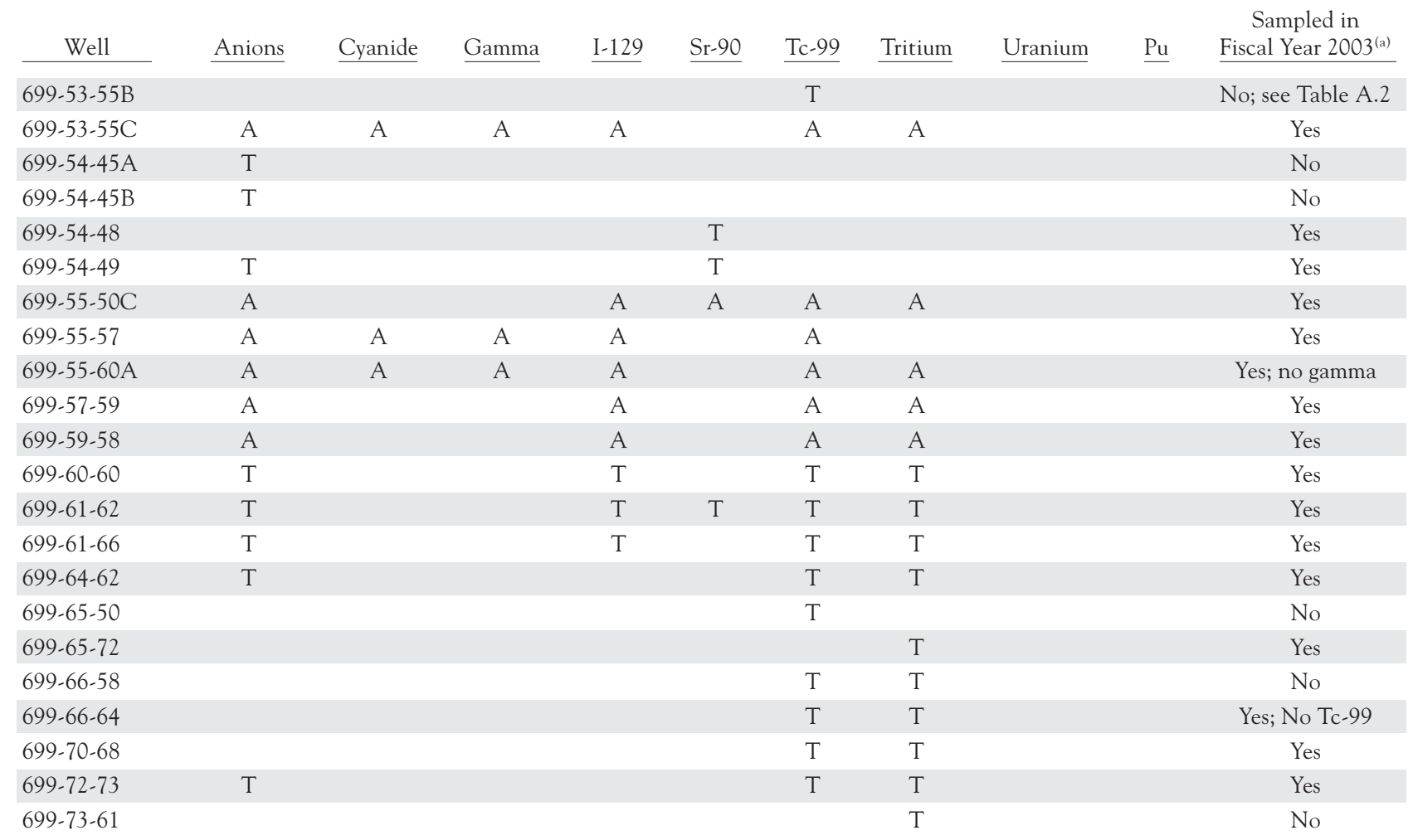

(a) Sampling commenced following approval of sampling and analysis plan and waste control plan in May 2003, so not all wells or constituents were scheduled for sampling in fiscal year 2003. Some wells/constituents listed here were sampled for other operable units or waste management areas.

(b) Basalt-confined aquifer.

A = Annually.

$\mathrm{T}=$ Triennially. 
Table A.15. Monitoring Wells and Constituents for the 200-PO-1 Operable Unit (PNNL-14111 ${ }^{[a]}$ )

\begin{tabular}{|c|c|c|c|c|c|c|c|c|c|c|c|c|c|c|c|c|}
\hline Well & $\underline{\text { Alkalinity }}$ & Alpha & $\underline{\text { Anions }}$ & $\underline{\text { Arsenic }}$ & $\underline{\text { Beta }}$ & Gamma & I-129 & ICP & $\underline{\mathrm{Sr}-90}$ & Tc-99 & $\underline{\text { TOC }}$ & $\underline{\text { TOX }}$ & $\underline{\text { Tritium }}$ & $\underline{\text { Uranium }}$ & $\underline{\mathrm{VOA}}$ & $\begin{array}{c}\text { Sampled } \\
\text { as Planned }\end{array}$ \\
\hline 299-E13-5 & & A & A & & A & A & A & A & A & & & & A & & & Yes \\
\hline 299-E13-14 & & A & A & & A & A & & A & A & & & & A & A & & Yes \\
\hline 299-E16-2 & & & $\mathrm{T}$ & $\mathrm{T}$ & & & $\mathrm{T}$ & & & & & & $\mathrm{T}$ & & & NA \\
\hline 299-E17-9 & & & $\mathrm{T}$ & $\mathrm{T}$ & & & $\mathrm{T}$ & & & & & & $\mathrm{T}$ & & & NA \\
\hline 299-E17-14 & & & $\mathrm{T}$ & $\mathrm{T}$ & & & $\mathrm{T}$ & & & & & & $\mathrm{T}$ & & & NA \\
\hline 299-E17-18 & & & $\mathrm{T}$ & $\mathrm{T}$ & & & $\mathrm{T}$ & & & & & & $\mathrm{T}$ & & & NA \\
\hline 299-E17-19 & & & $\mathrm{T}$ & $\mathrm{T}$ & & & $\mathrm{T}$ & & & & & & $\mathrm{T}$ & & & NA \\
\hline 299-E18-1 & & & $\mathrm{T}$ & $\mathrm{T}$ & & & $\mathrm{T}$ & $\mathrm{T}$ & & & & & $\mathrm{T}$ & & & NA \\
\hline 299-E23-1 & & & $\mathrm{T}$ & $\mathrm{T}$ & & & $\mathrm{T}$ & & & & & & $\mathrm{T}$ & & & NA \\
\hline 299-E24-5 & & & $\mathrm{T}$ & $\mathrm{T}$ & & & $\mathrm{T}$ & & & & & & $\mathrm{T}$ & & & NA \\
\hline 299-E24-18 & & & $\mathrm{T}$ & $\mathrm{T}$ & & & $\mathrm{T}$ & & & & & & $\mathrm{T}$ & & & NA \\
\hline 299-E24-20 & & & $\mathrm{T}$ & $\mathrm{T}$ & & & $\mathrm{T}$ & & & & & & $\mathrm{T}$ & & & NA \\
\hline 299-E25-3 & & & $\mathrm{T}$ & $\mathrm{T}$ & & & $\mathrm{T}$ & & & & & & $\mathrm{T}$ & & & NA \\
\hline 299-E25-6 & & $\mathrm{T}$ & $\mathrm{T}$ & $\mathrm{T}$ & $\mathrm{T}$ & $\mathrm{T}$ & $\mathrm{T}$ & & & $\mathrm{T}$ & & & $\mathrm{T}$ & $\mathrm{T}$ & & NA \\
\hline 299-E25-17 & & & $\mathrm{T}$ & $\mathrm{T}$ & & & $\mathrm{T}$ & & & & & & $\mathrm{T}$ & & & NA \\
\hline 299-E25-18 & & & $\mathrm{T}$ & $\mathrm{T}$ & & & $\mathrm{T}$ & & & & & & $\mathrm{T}$ & & & NA \\
\hline 299-E25-19 & & & $\mathrm{T}$ & $\mathrm{T}$ & & & $\mathrm{T}$ & & & & & & $\mathrm{T}$ & & & NA \\
\hline 299-E25-20 & & & $\mathrm{T}$ & $\mathrm{T}$ & & & $\mathrm{T}$ & & & & & & $\mathrm{T}$ & & & NA \\
\hline 299-E25-22 & & & $\mathrm{T}$ & $\mathrm{T}$ & & & $\mathrm{T}$ & & & & & & $\mathrm{T}$ & & & NA \\
\hline 299-E25-28b & & & $\mathrm{T}$ & $\mathrm{T}$ & & & $\mathrm{T}$ & & & & & & $\mathrm{T}$ & & & NA \\
\hline 299-E25-29P & & & $\mathrm{T}$ & $\mathrm{T}$ & & & $\mathrm{T}$ & & & & & & $\mathrm{T}$ & & & NA \\
\hline 299-E25-29Q & & & $\mathrm{T}$ & $\mathrm{T}$ & & & $\mathrm{T}$ & & & & & & $\mathrm{T}$ & & & NA \\
\hline 299-E25-32P & & & $\mathrm{T}$ & $\mathrm{T}$ & & & $\mathrm{T}$ & & & & & & $\mathrm{T}$ & & & NA \\
\hline 299-E25-32Q & $\mathrm{T}$ & & $\mathrm{T}$ & $\mathrm{T}$ & & & $\mathrm{T}$ & $\mathrm{T}$ & & & & & $\mathrm{T}$ & & & NA \\
\hline 299-E25-34 & & & $\mathrm{T}$ & $\mathrm{T}$ & & & $\mathrm{T}$ & & & & & & $\mathrm{T}$ & & & NA \\
\hline 299-E25-35 & & & $\mathrm{T}$ & $\mathrm{T}$ & & & $\mathrm{T}$ & & & & & & $\mathrm{T}$ & & & NA \\
\hline 299-E25-36 & & & $\mathrm{T}$ & $\mathrm{T}$ & & & $\mathrm{T}$ & & & & & & $\mathrm{T}$ & & & NA \\
\hline 299-E25-37 & & & $\mathrm{T}$ & $\mathrm{T}$ & & & $\mathrm{T}$ & & & & & & $\mathrm{T}$ & & & NA \\
\hline 299-E25-41 & & & $\mathrm{T}$ & $\mathrm{T}$ & & & $\mathrm{T}$ & & & & & & $\mathrm{T}$ & & & NA \\
\hline 299-E25-42 & & & $\mathrm{T}$ & $\mathrm{T}$ & & & $\mathrm{T}$ & & & & & & $\mathrm{T}$ & & & NA \\
\hline 299-E25-43 & & & $\mathrm{T}$ & & & & $\mathrm{T}$ & & & & & & $\mathrm{T}$ & & & NA \\
\hline 299-E25-44 & & & & & & & $\mathrm{T}$ & & & & & & $\mathrm{T}$ & & & NA \\
\hline 299-E25-46 & & & $\mathrm{T}$ & & & & $\mathrm{T}$ & & & & & & $\mathrm{T}$ & & & NA \\
\hline 299-E25-47 & & & $\mathrm{T}$ & & & & $\mathrm{T}$ & & & & & & $\mathrm{T}$ & & & NA \\
\hline $499-50-7$ & & & A & & & & & & & & & & & & & Yes \\
\hline $499-50-8$ & & & A & & & & & & & & & & & & & Yes \\
\hline $699-1-18$ & & & $\mathrm{~T}$ & & & & & & & & & & $\mathrm{~T}$ & & & NA \\
\hline
\end{tabular}


Table A.15. (contd)

\begin{tabular}{|c|c|c|c|c|c|c|c|c|c|c|c|c|c|c|c|c|}
\hline Well & Alkalinity & Alpha & Anions & Arsenic & Beta & Gamma & I-129 & $\underline{\mathrm{ICP}}$ & $\underline{\mathrm{Sr}-90}$ & Tc-99 & $\underline{\text { TOC }}$ & $\underline{\text { TOX }}$ & Tritium & $\underline{\text { Uranium }}$ & $\underline{\mathrm{VOA}}$ & $\begin{array}{c}\text { Sampled } \\
\text { as Planned }\end{array}$ \\
\hline $699-2-3$ & & & $\mathrm{~T}$ & & & & $\mathrm{~T}$ & & & & & & $\mathrm{~T}$ & & & NA \\
\hline $699-8-17$ & & & & & & & & & & & & & & & & NA \\
\hline $699-8-25$ & & & $\mathrm{~T}$ & & & & $\mathrm{~T}$ & & & & & & $\mathrm{~T}$ & & & NA \\
\hline $699-10-54 \mathrm{~A}$ & & A & A & & A & & & & & & & & A & & & Yes \\
\hline 699-10-E12 & A & A & A & & A & A & & A & A & & A & A & A & & & Yes \\
\hline $699-14-38$ & & & $\mathrm{~T}$ & & & & & $\mathrm{~T}$ & & & & & $\mathrm{~T}$ & & & NA \\
\hline $699-17-5$ & $\mathrm{~T}$ & $\mathrm{~T}$ & $\mathrm{~T}$ & & $\mathrm{~T}$ & $\mathrm{~T}$ & $\mathrm{~T}$ & $\mathrm{~T}$ & $\mathrm{~T}$ & $\mathrm{~T}$ & & & $\mathrm{~T}$ & & $\mathrm{~T}$ & NA \\
\hline $699-19-43$ & & & $\mathrm{~T}$ & & & & $\mathrm{~T}$ & $\mathrm{~T}$ & & & & & $\mathrm{~T}$ & & & NA \\
\hline $699-20-20$ & & $\mathrm{~T}$ & $\mathrm{~T}$ & & $\mathrm{~T}$ & $\mathrm{~T}$ & $\mathrm{~T}$ & $\mathrm{~T}$ & & $\mathrm{~T}$ & & & $\mathrm{~T}$ & & & NA \\
\hline 699-20-E5A & & & $\mathrm{T}$ & & & & & & & & & & $\mathrm{T}$ & & & NA \\
\hline 699-20-E12O & & & A & & & & & & & & & & A & & & Yes \\
\hline 699-20-E12S(b) & $\mathrm{T}$ & & $\mathrm{T}$ & & & & & & & & & & $\mathrm{T}$ & & & NA \\
\hline $699-21-6$ & & & $\mathrm{~T}$ & & & & $\mathrm{~T}$ & & & & & & $\mathrm{~T}$ & & & NA \\
\hline $699-22-35$ & & & $\mathrm{~T}$ & & & & $\mathrm{~T}$ & & & & & & $\mathrm{~T}$ & & & NA \\
\hline $699-24-34 \mathrm{C}$ & & & $\mathrm{T}$ & & & & $\mathrm{T}$ & & & & & & $\mathrm{T}$ & & & NA \\
\hline $699-24-46$ & & & A & & & & & & & & & & A & & & Yes \\
\hline $699-26-15 \mathrm{~A}$ & & & $\mathrm{~T}$ & & & & $\mathrm{~T}$ & & & & & & $\mathrm{~T}$ & & & NA \\
\hline $699-26-33$ & & & A & & & & & & & & & & A & & & Yes \\
\hline $699-26-35 \mathrm{~A}$ & & & $\mathrm{~T}$ & & & & $\mathrm{~T}$ & & & & & & $\mathrm{~T}$ & & & NA \\
\hline $699-27-8$ & & & $\mathrm{~T}$ & & & & $\mathrm{~T}$ & & & & & & $\mathrm{~T}$ & & & NA \\
\hline $699-28-40$ & & & $\mathrm{~T}$ & & & & $\mathrm{~T}$ & $\mathrm{~T}$ & & & & & $\mathrm{~T}$ & & & NA \\
\hline $699-29-4$ & & & $\mathrm{~T}$ & & & & $\mathrm{~T}$ & & & & & & $\mathrm{~T}$ & & & NA \\
\hline $699-31-11$ & & & $\mathrm{~T}$ & & & & $\mathrm{~T}$ & & & & & & $\mathrm{~T}$ & & & NA \\
\hline $699-31-31$ & & & A & & & & & & & & & & A & & & $\mathrm{No}^{(\mathrm{e})}$ \\
\hline $699-31-31 \mathrm{P}^{(\mathrm{b})}$ & & & $\mathrm{T}$ & & & & $\mathrm{T}$ & & & & & & $\mathrm{T}$ & & & NA \\
\hline $699-33-42$ & & & $\mathrm{~T}$ & & & & $\mathrm{~T}$ & $\mathrm{~T}$ & & & & & $\mathrm{~T}$ & & & NA \\
\hline $699-33-56$ & & & $\mathrm{~T}$ & & & & & $\mathrm{~T}$ & & & & & $\mathrm{~T}$ & & & Yes \\
\hline 699-34-41B & & & A & & & & A & & & & & & A & & & Yes \\
\hline $699-34-42$ & & & $\mathrm{~T}$ & & & & $\mathrm{~T}$ & & & & & & $\mathrm{~T}$ & & & NA \\
\hline $699-35-9$ & & & $\mathrm{~T}$ & & & & $\mathrm{~T}$ & & & & & & $\mathrm{~T}$ & & & NA \\
\hline $699-37-43$ & & & $\mathrm{~T}$ & & & & $\mathrm{~T}$ & & & & & & $\mathrm{~T}$ & & & NA \\
\hline $699-37-47 \mathrm{~A}$ & & & $\mathrm{~T}$ & $\mathrm{~T}$ & & & $\mathrm{~T}$ & & & & & & $\mathrm{~T}$ & & & NA \\
\hline 699-37-E4 & $\mathrm{T}$ & & $\mathrm{T}$ & & & & $\mathrm{T}$ & $\mathrm{T}$ & & & & & $\mathrm{T}$ & & & NA \\
\hline $699-38-15$ & & & $\mathrm{~T}$ & & & & $\mathrm{~T}$ & & & & & & $\mathrm{~T}$ & & & NA \\
\hline $699-39-39$ & & & $\mathrm{~T}$ & & & & $\mathrm{~T}$ & & & & & & $\mathrm{~T}$ & & & NA \\
\hline $699-40-1$ & & & $\mathrm{~T}$ & & & & $\mathrm{~T}$ & & & & & & $\mathrm{~T}$ & & & NA \\
\hline
\end{tabular}


Table A.15. (contd)

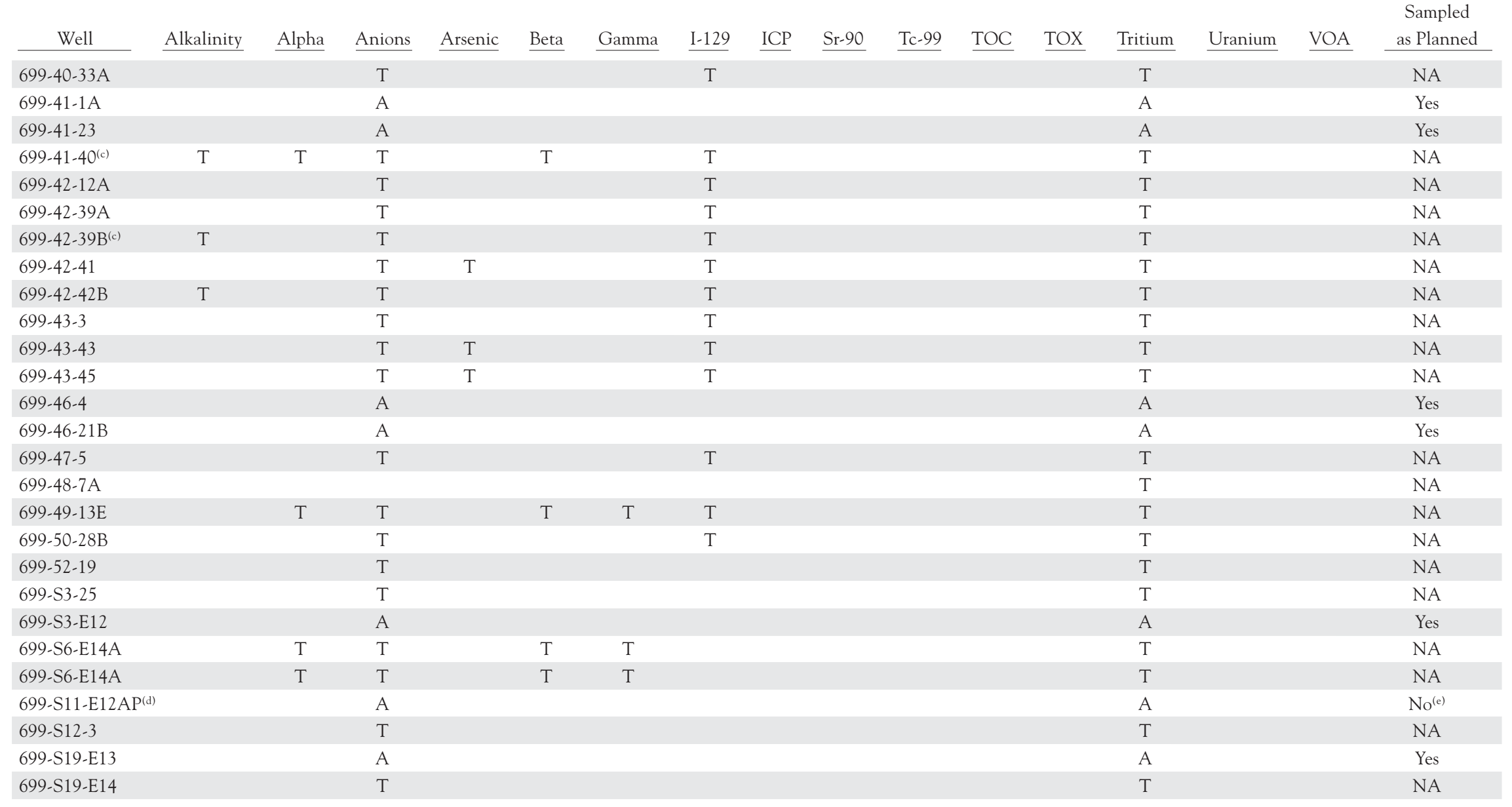

(a) In fiscal year 2003, the 200-PO-1 operable unit monitoring wells were the far-field wells sampled for Plutonium-Uranium Extraction Plant cribs. Those wells were listed in PNNL-14111 under the project names "2PO1-C" and "2PO1-S."

(b) Deep unconfined aquifer

(c) Confined Ringold Formation aquifer

(e) See Table A.2

A $=$ Annually

$\mathrm{ICP}=$ Inductively coupled plasma emission spectroscopy.

$\mathrm{NA}=$ Not applicable; not scheduled for sampling in fiscal year 2003

$\mathrm{T}=$ Triennially (unless otherwise noted, not scheduled for fiscal year 2003).

TOC $=$ Total organic carbon.

$>\quad$ TOX $=$ Total organic halides

VOC $=$ Volatile organic compounds. 
Table A.16. Monitoring Wells and Constituents for the 200-UP-1 Operable Unit (DOE/RL-2002-10)

\begin{tabular}{|c|c|c|c|c|c|c|c|c|c|c|c|}
\hline Well & Anions & Arsenic & Cadmium & $\mathrm{I}-129$ & ICP & $\underline{\text { Sr-90 }}$ & Tc-99 & Tritium & Uranium & $\underline{\mathrm{VOA}}$ & $\begin{array}{l}\text { Sampled as } \\
\text { Planned }\end{array}$ \\
\hline 299-W15-37 & A & A & A & & & & & & A & A & Yes \\
\hline 299-W18-15 & S & S & & & & & & & S & S & Yes \\
\hline 299-W18-21 & A & A & & & & & & & A & A & Yes \\
\hline 299-W18-30 & A & A & & A & & & & & A & A & Yes \\
\hline 299-W18-33 & $\mathrm{s}$ & $\mathrm{s}$ & & & & & & S & S & S & Yes \\
\hline 299-W19-4 & B & & & B & & & B & & B & B & Yes \\
\hline 299-W19-9 & A & A & & A & & & A & & A & A & Yes \\
\hline 299-W19-14 & B & B & & B & & & B & B & B & B & No; dry \\
\hline 299-W19-20 & A & & A & A & & & A & & A & A & $\mathrm{Yes}^{(\mathrm{a})}$ \\
\hline 299-W19-35 & A & & A & A & & & A & & A & A & Yes \\
\hline 299-W19-36 & A & & & A & & & A & & A & A & Yes \\
\hline 299-W19-37 & A & & A & A & & & A & & A & A & Yes \\
\hline 299-W19-39 & A & & & A & & & A & & A & A & Yes \\
\hline 299-W19-40 & A & & & A & & & A & A & A & A & Yes \\
\hline 299-W19-43 & S & & & S & & & $\mathrm{S}$ & & S & S & Yes \\
\hline $299-W 19-46^{(b)}$ & Q & & & Q & & & Q & Q & Q & Q & Yes \\
\hline 299-W22-9 & B & & & B & & B & B & B & B & B & Yes \\
\hline 299-W22-20 & A & & & A & & A & A & A & A & A & Yes \\
\hline 299-W22-26 & A & & A & A & & & & A & A & A & Yes \\
\hline 299-W22-45 & A & & A & A & & A & & A & A & A & Yes \\
\hline 299-W22-46 & A & & & A & & A & A & A & A & A & Yes \\
\hline 299-W22-48 & S & S & S & S & & S & & S & S & S & Yes \\
\hline 299-W22-49 & $\mathrm{s}$ & & $\mathrm{S}$ & $\mathrm{s}$ & & $\mathrm{s}$ & $\mathrm{s}$ & S & S & S & Yes \\
\hline 299-W23-4 & S & S & & & & & & S & S & S & Yes \\
\hline 299-W23-9 & A & & & & & & A & A & A & A & Yes \\
\hline 299-W23-10 & S & & & & & & S & S & S & S & Yes \\
\hline 299-W23-14 & A & A & A & & & & A & A & A & A & No; dry \\
\hline 299-W23-15 & S & & & & & & S & S & S & S & Yes \\
\hline 299-W26-12 & B & & & B & & & B & B & B & B & No; dry \\
\hline 299-W26-13 & B & & & B & & & & B & B & B & Yes \\
\hline $699-32-62$ & B & & & B & B & & & B & & & Yes \\
\hline $699-32-72 \mathrm{~A}$ & B & & & B & & & & B & & B & Yes \\
\hline $699-35-66 \mathrm{~A}$ & B & & & B & B & & & B & & B & $Y_{e s}^{(c)}$ \\
\hline $699-35-70$ & B & & & B & & & & B & & B & Yes \\
\hline $699-35-78 \mathrm{~A}$ & A & A & & & & & & & A & A & Yes \\
\hline $699-36-61 \mathrm{~A}$ & A & & & A & A & & & A & & & Yes \\
\hline $699-36-70 \mathrm{~A}$ & A & & & A & & & A & A & A & A & Yes \\
\hline $699-38-65$ & A & & & A & & & & A & & & Yes \\
\hline $699-38-68 \mathrm{~A}$ & B & & & B & & & B & B & B & B & Yes \\
\hline $699-38-70$ & A & & & A & & & A & A & A & A & Yes \\
\hline $699-40-62$ & B & & & B & & & B & B & B & & Yes \\
\hline
\end{tabular}

(a) Sampled as planned in January 2003, then went dry.

(b) New well.

(c) This well scheduled biennially for 200-UP-1 in fiscal year 2004; however, it was sampled for another project in fiscal year 2003.

$\mathrm{A} \quad=$ Annually.

$\mathrm{B} \quad=$ Biennially; scheduled for fiscal year 2003.

$\mathrm{ICP}=$ Inductively coupled plasma emission spectroscopy.

$\mathrm{S}=$ Semiannually.

VOC $=$ Volatile organic compounds. 
Table A.17. Monitoring Wells and Constituents for the 200-ZP-1 Operable Unit (DOE/RL-2002-17)

\begin{tabular}{|c|c|c|c|c|c|c|c|c|c|c|c|}
\hline Well & Anions & Arsenic & $\underline{\text { Cadmium }}$ & $\underline{\mathrm{I}-129}$ & $\underline{\mathrm{ICP}}$ & $\underline{\mathrm{Sr}-90}$ & $\underline{\text { Tc-99 }}$ & Tritium & $\underline{\text { Uranium }}$ & $\underline{\mathrm{VOA}}$ & $\begin{array}{l}\text { Sampled as } \\
\text { Planned } \\
\end{array}$ \\
\hline 299-W6-2 & S & & S & $\mathrm{S}$ & & & & S & & S & No; dry \\
\hline 299-W6-7 & A & & A & A & & & & A & & A & No; dry \\
\hline 299-W6-10 & A & & A & A & & & & A & A & A & Yes \\
\hline 299-W7-4 & A & & & & & & & & & A & Yes \\
\hline 299-W7-7 & A & & & & & & & A & & A & Yes \\
\hline 299-W7-8 & B & & & & & & & B & & B & No; dry \\
\hline 299-W7-12 & B & & & & & & & B & & B & Yes \\
\hline 299-W8-1 & B & & & & & & & B & & B & Yes \\
\hline 299-W10-1 & A & A & & & A & & & A & & A & Yes \\
\hline 299-W10-4 & S & S & & S & S & & S & S & & S & Yes \\
\hline 299-W10-5 & A & & A & & A & & A & A & & A & Yes \\
\hline 299-W10-13 & B & & & & & & & & & B & No; dry \\
\hline 299-W10-19 & A & & A & & & & & & & A & Yes \\
\hline 299-W10-20 & B & & & & & & & & & B & Yes \\
\hline 299-W10-21 & A & & A & & & & & A & & A & Yes \\
\hline 299-W10-22 & S & & & S & S & & S & S & S & S & Yes \\
\hline 299-W10-23 & A & A & A & A & A & & A & A & A & A & Yes \\
\hline 299-W11-3 & $\mathrm{S}$ & & & S & & & & S & S & S & Yes \\
\hline 299-W11-6 & S & & & S & & & & & S & S & Yes \\
\hline 299-W11-7 & A & A & A & A & A & & A & & A & A & Yes \\
\hline 299-W11-10 & $\mathrm{S}$ & & & & & & & & & $\mathrm{S}$ & Yes \\
\hline 299-W11-13 & S & S & S & $\mathrm{S}$ & S & & S & S & & S & Yes \\
\hline 299-W11-18 & A & & A & A & A & & A & A & A & A & Yes \\
\hline 299-W11-37 & S & & & S & & & & S & S & S & Yes \\
\hline 299-W12-1 & A & & & A & & & & A & & A & Yes \\
\hline 299-W14-14 & A & & A & A & A & & A & A & & A & Yes \\
\hline 299-W15-1 & S & & & & & & & & & S & Yes \\
\hline 299-W15-2 & A & & & & & & A & & & A & Yes \\
\hline 299-W15-7 & S & & & & & & S & & & S & Yes \\
\hline 299-W15-11 & S & & & & & & S & S & & S & Yes \\
\hline 299-W15-15 & A & & A & & & & & & & A & Yes \\
\hline 299-W15-16 & A & & A & & A & & & & & A & Yes \\
\hline 299-W15-31A & S & & & & & & & & & $\mathrm{S}$ & Yes \\
\hline 299-W15-32(a) & A & & A & & A & & & & & A & Yes \\
\hline 299-W15-33(a) & A & & & & & & & & & A & Yes \\
\hline 299-W15-34(a) & A & & & & & & A & & & A & Yes \\
\hline 299-W15-35(a) & A & & & & A & & A & & & A & Yes \\
\hline $299-W 15-36^{(a)}$ & A & & & & & & & & & A & Yes \\
\hline 299-W15-38 & A & & & & A & & & & & A & Yes \\
\hline 299-W15-39 & A & & & & & & & & & A & Yes \\
\hline 299-W15-40 & S & & S & & S & & $\mathrm{S}$ & S & & $\mathrm{S}$ & Yes \\
\hline 299-W15-41 & A & & A & & & & A & A & & A & Yes \\
\hline 299-W15-42 & $Q$ & & & & $Q$ & & $Q$ & & & $Q$ & Yes \\
\hline 299-W15-43 & Q & & & & & & $Q$ & & & Q & Yes \\
\hline 299-W15-765 & Q & & & & & & & & & Q & $\begin{array}{c}\text { New well; } \\
\text { sampled twice } \\
\text { in FY } 2003\end{array}$ \\
\hline 299-W18-1 & A & & A & & & & & & & A & Yes \\
\hline 299-W18-23 & A & & A & & & & & & & A & Yes \\
\hline 299-W18-24 & A & & A & & & & & & A & A & Yes \\
\hline 299-W18-27 & A & & A & & & & & & A & A & Yes \\
\hline $699-39-79$ & B & & B & & & & & & & B & Yes \\
\hline $699-43-89$ & B & B & B & B & B & B & B & B & B & B & Yes \\
\hline
\end{tabular}


Table A.17. (contd)

\begin{tabular}{|c|c|c|c|c|c|c|c|c|c|c|c|}
\hline Well & Anions & Arsenic & $\underline{\text { Cadmium }}$ & $\underline{\mathrm{I}-129}$ & $\underline{\mathrm{ICP}}$ & $\underline{\mathrm{Sr}-90}$ & $\underline{\text { Tc-99 }}$ & $\underline{\text { Tritium }}$ & $\underline{\text { Uranium }}$ & $\underline{\mathrm{VOA}}$ & $\begin{array}{l}\text { Sampled as } \\
\text { Planned }\end{array}$ \\
\hline $699-44-64$ & B & & & B & & & B & B & B & & Yes \\
\hline $699-45-69 \mathrm{~A}$ & B & & & B & & & & & & B & Yes \\
\hline $699-47-60$ & B & & & B & B & & B & B & B & B & Yes \\
\hline $699-48-71$ & S & & & S & & & & S & S & S & Yes \\
\hline $699-48-77 \mathrm{~A}$ & B & & & & & & & B & & B & Yes \\
\hline $699-55-60 \mathrm{~A}$ & B & & & B & B & & B & B & B & B & Yes \\
\hline
\end{tabular}

(a) Extraction well.

A = Annually.

$\mathrm{B}=$ Biennially .

ICP = Inductively coupled plasma emission spectroscopy.

$\mathrm{Q}=$ Quarterly.

$\mathrm{S}=$ Semiannually. 
Table A.18. Monitoring Wells and Constituents for the 300-FF-5 Operable Unit (DOE/RL-2002-11)

\begin{tabular}{|c|c|c|c|c|c|c|c|c|c|c|c|c|c|}
\hline Well & Alkalinity & Alpha & Anions & Beta & $\underline{\text { Gamma }}$ & $\underline{I-129}$ & Metals & $\underline{\mathrm{Sr}-90}$ & Tritium & $\underline{\text { Uranium }}$ & $\underline{\text { Semi-VOA }}$ & VOA & $\begin{array}{r}\text { Sampled } \\
\text { as planned } \\
\end{array}$ \\
\hline $399-1-1$ & S & & S & & & & & & & S & & S & Yes \\
\hline $399-1-2$ & S & & S & & & & & & & S & & S & Yes \\
\hline $399-1-6$ & S & & S & & & & & & & S & & S & Yes \\
\hline $399-1-7$ & S & & & & & & & & & S & & S & Yes \\
\hline $399-1-8$ & S & & & & & & & & & S & & S & Yes \\
\hline $399-1-10 \mathrm{~A}$ & S & & S & & & & & & & S & & S & Yes \\
\hline $399-1-10 B$ & S & & & & & & & & S & S & & S & Yes \\
\hline $399-1-11$ & S & & & & & & & & & S & & S & Yes \\
\hline $399-1-12$ & S & & & & & & & & & S & & S & Yes \\
\hline $399-1-15$ & S & S & & S & & & & & & S & & S & Yes \\
\hline $399-1-16 \mathrm{~A}$ & S & & S & & & & & & & S & & S & Yes \\
\hline $399-1-16 \mathrm{~B}$ & S & & & & & & & & & S & & S & Yes \\
\hline $399-1-17 \mathrm{~A}$ & S & S & S & S & & & & & S & S & & S & Yes \\
\hline $399-1-17 \mathrm{~B}$ & S & & & & & & & & & S & & S & Yes \\
\hline $399-1-18 \mathrm{~A}$ & S & & S & & & & & & & & & & Yes \\
\hline $399-1-18 B$ & S & & & & & & & & S & & & & Yes \\
\hline $399-1-21 \mathrm{~A}$ & S & & & & & & & & S & S & & S & Yes \\
\hline $399-1-21 B$ & S & & & & & & & & & S & & S & Yes \\
\hline $399-2-1$ & S & & & & & & & & & S & & S & Yes \\
\hline $399-2-2$ & S & & & & & & & & & S & & S & Yes \\
\hline $399-3-2$ & S & & & & & & & & & & & S & Yes \\
\hline $399-3-6$ & S & & S & & & & & & S & S & & S & Yes \\
\hline $399-3-10$ & S & & & & & & & & & S & & S & Yes \\
\hline $399-3-11$ & S & S & S & S & & & & S & S & S & & S & Yes \\
\hline $399-3-12$ & S & & S & & & & & & S & S & & S & Yes \\
\hline $399-4-1$ & S & & S & & & & & & S & S & & S & Yes \\
\hline $399-4-9$ & S & & S & & & & & & S & S & & S & Yes \\
\hline $399-4-12$ & S & & S & & & & & & S & S & & S & Yes \\
\hline $399-5-4 B$ & S & & & & & & & & S & & & S & Yes \\
\hline $399-8-5 \mathrm{~A}$ & S & S & S & S & & & & & S & S & & S & Yes \\
\hline $699-12-2 \mathrm{C}$ & S & Q & S & $Q$ & Q & S & A & & $Q$ & $Q$ & & A & $\begin{array}{l}\text { Yes except } \\
\text { I-129 only } \\
\text { once }\end{array}$ \\
\hline $699-13-0 \mathrm{~A}$ & S & $Q$ & S & $Q$ & $Q$ & S & A & & $Q$ & $Q$ & & A & Yes \\
\hline $699-13-1 \mathrm{E}$ & S & $Q$ & S & $Q$ & $Q$ & S & A & & $Q$ & $Q$ & & A & Yes \\
\hline $699-13-2 \mathrm{D}$ & S & $Q$ & S & $Q$ & $Q$ & S & A & & $Q$ & $Q$ & & A & Yes \\
\hline
\end{tabular}




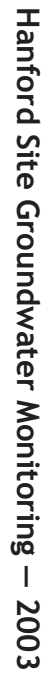

Table A.18. (contd)

\begin{tabular}{|c|c|c|c|c|c|c|c|c|c|c|c|c|c|}
\hline Well & Alkalinity & Alpha & Anions & Beta & Gamma & $\mathrm{I}-129$ & Metals & $\underline{\text { Sr }-90}$ & Tritium & Uranium & $\underline{\text { Semi-VOA }}$ & VOA & $\begin{array}{c}\text { Sampled } \\
\text { as planned }\end{array}$ \\
\hline $699-13-3 \mathrm{~A}$ & S & Q & S & Q & Q & S & A & & Q & Q & & A & Yes \\
\hline 699-S6-E4A & S & S & $\mathrm{S}$ & S & $\mathrm{S}$ & & S & & S & S & S & S & Yes \\
\hline 699-S6-E4B & S & A & & A & A & & & & A & A & & & Yes \\
\hline 699-S6-E4D & S & A & & A & A & & & & A & A & & & Yes \\
\hline 699-S6-E4E & S & A & & A & A & & & & A & A & & & Yes \\
\hline 699-S6-E4K & S & S & S & S & S & & S & & S & S & S & $S$ & Yes \\
\hline 699-S6-E4L & S & S & S & S & $\mathrm{s}$ & & S & & S & S & S & $\mathrm{s}$ & Yes \\
\hline
\end{tabular}

$\mathrm{A}=$ Annually.

$\mathrm{Q}=$ Quarterly.

$\mathrm{S} \quad=$ Semiannually

$\mathrm{VOA}=$ Volatile organic analysis 
Table A.19. Monitoring Wells and Constituents for the 1100-EM-1 Operable Unit (PNNL-12220)

$\frac{1}{\text { Well }}$
699-S27-E12A
$699-S 28-E 12$
$699-S 28-E 13 A$
$699-S 29-E 10 A$
$699-S 29-E 11$
$699-S 29-E 12$
$699-S 29-E 13 A$
$699-S 30-E 10 A$
$699-S 30-E 10 B$
$699-S 30-E 11 A$
$699-S 31-E 10 A$
$699-S 31-E 10 C$
$699-S 31-E 10 D$
$699-S 31-E 11$
$699-S 41-E 12$ (b)

\begin{tabular}{c} 
Frequency(a) \\
\hline A \\
A \\
A \\
A \\
A \\
A \\
A \\
A \\
A \\
A \\
A \\
A \\
A \\
A \\
A
\end{tabular}

Sampled as Planned

(a) Anions and volatile organic analysis except where noted.

(b) Chromium only.

$\mathrm{A}=$ Annually.

Yes
Yes
Yes
Yes
Yes
Yes
Yes
Yes
Yes
Yes
Yes
Yes
Yes
Yes
Yes




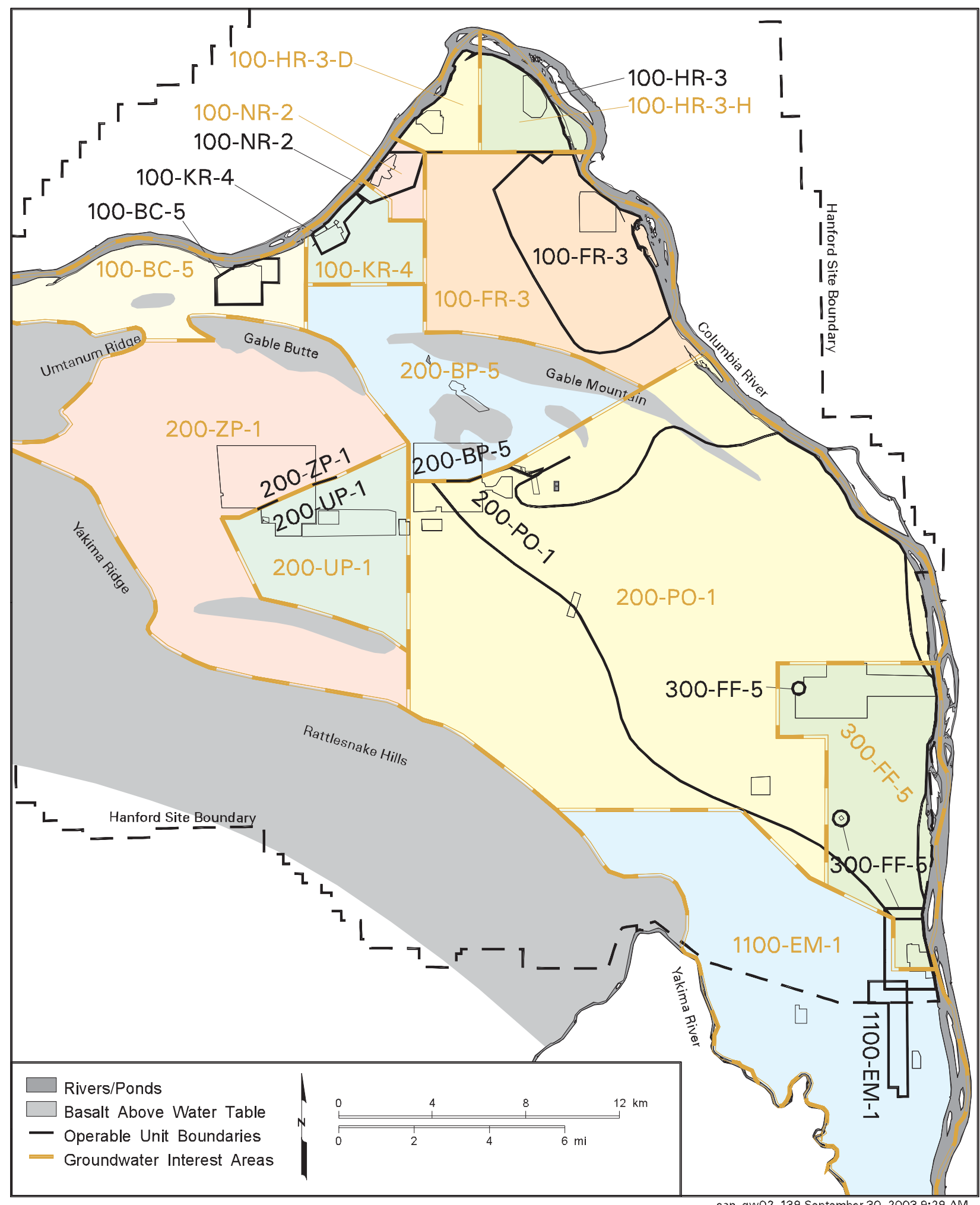

Figure A.1. Groundwater Operable Units and Groundwater Interest Areas on the Hanford Site 


\section{Appendix B}

\section{Supporting Information for RCRA Units}




\section{Contents}

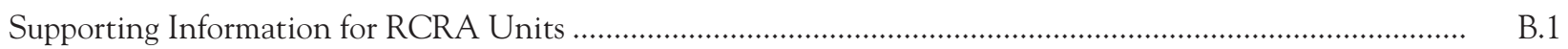

B.1 116-N-1 Liquid Waste Disposal Facility ……................................................................................ B.1

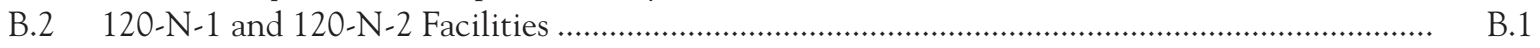

B.3 116-N-3 Liquid Waste Disposal Facility ……….................................................................... B.2

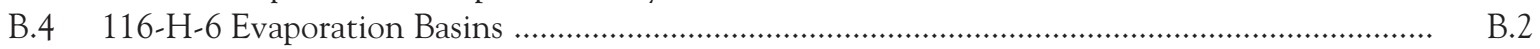

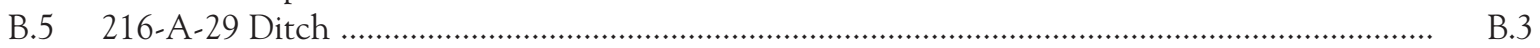

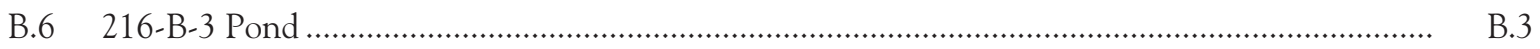

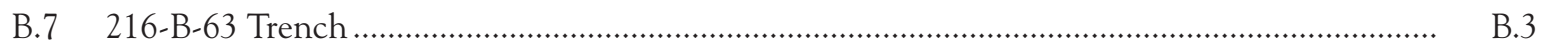

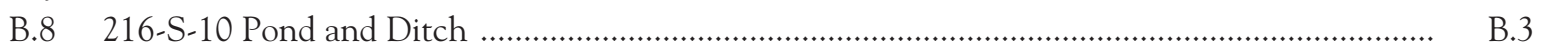

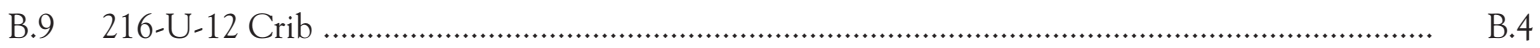

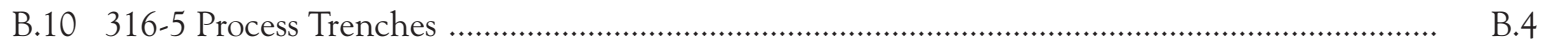

B.11 Integrated Disposal Facility .......................................................................................... B. B

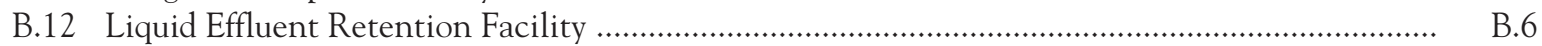

B.13 Low-Level Waste Management Area 1 ........................................................................................ B.6

B.14 Low-Level Waste Management Area 2 ..................................................................................... B.6

B.15 Low-Level Waste Management Area 3 ...................................................................................... B.7

B.16 Low-Level Waste Management Area 4 ……................................................................................. B.

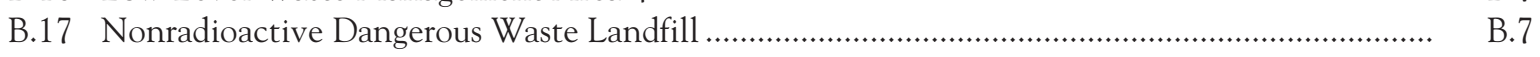

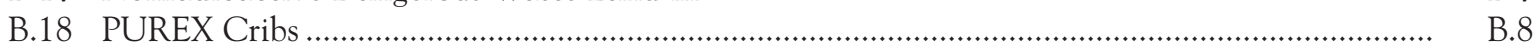

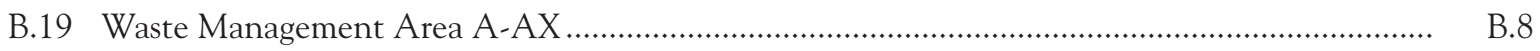

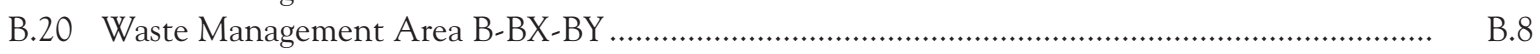

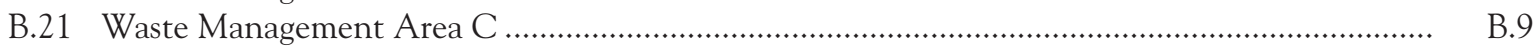

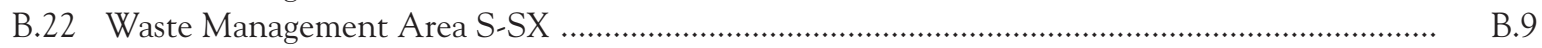

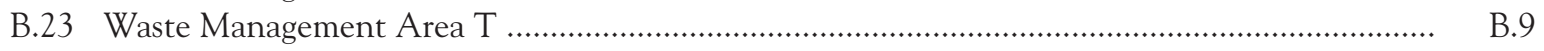

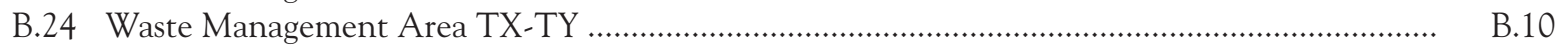

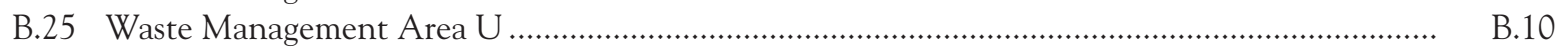

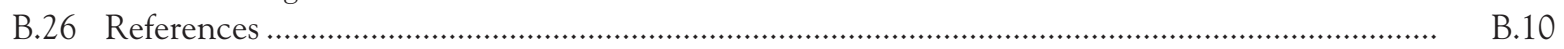

\section{Tables}

B.1 RCRA Interim and Final Status Groundwater Monitoring, September 2003 .................................... B.15

B.2 Estimates of Groundwater Flow Rates at Hanford Site Facilities ....................................................... B. B.17

B.3 Wells Not Sampled as Scheduled for RCRA Facilities, Fiscal Year 2003 ……................................. B.20

B.4 Monitoring Wells and Constituents for 100-N Area Units ............................................................... B.

B.5 Critical Means for 116-N-1 Liquid Waste Disposal Facility for Fiscal Year 2004 Comparisons .......... B.22

B.6 Critical Means for 120-N-1 and 120-N-2 Liquid Waste Disposal Facilities for Fiscal Year 2004

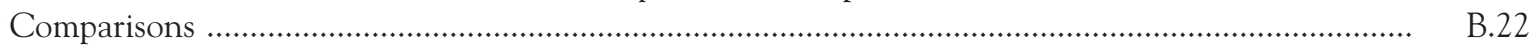

B.7 Critical Means for 116-N-3 Liquid Waste Disposal Facility for Fiscal Year 2004 Comparisons .......... B.23

B.8 Monitoring Wells and Constituents for the 116-H-6 Evaporation Basins ......................................... B..23

B.9 Monitoring Wells and Constituents for the 216-A-29 Ditch ........................................................... B.24 
B.10 Critical Means for the 216-A-29 Ditch for Fiscal Year 2004 Comparisons .......................................... B.24

B.11 Monitoring Wells and Constituents for the 216-B-3 Pond ................................................................ B.25

B.12 Critical Means for 216-B-3 Pond for Fiscal Year 2004 Comparisons .................................................. B.25

B.13 Monitoring Wells and Constituents for the 216-B-63 Trench ……................................................ B.26

B.14 Critical Means for the 216-B-63 Trench for Fiscal Year 2004 Comparisons ....................................... B.26

B.15 Monitoring Wells and Constituents for the 216-S-10 Pond and Ditch ............................................. B.27

B.16 Critical Means for the 216-S-10 Pond and Ditch for Fiscal Year 2004 Comparisons .......................... B.27

B.17 Monitoring Wells and Constituents for the 216-U-12 Crib ............................................................ B.28

B.18 Monitoring Wells and Constituents for the 316-5 Process Trenches ................................................. B.28

B.19 Monitoring Wells and Constituents for the Integrated Disposal Facility ……................................... B.29

B.20 Monitoring Wells and Constituents for the Liquid Effluent Retention Facility ................................. B.29

B.21 Monitoring Wells and Constituents for Low-Level Waste Management Area 1 ............................... B. B.30

B.22 Critical Means for Low-Level Waste Management Area 1 for Fiscal Year 2004 Comparisons ............ B.30

B.23 Monitoring Wells and Constituents for Low-Level Waste Management Area 2 ................................. B.31

B.24 Critical Means for Low-Level Waste Management Area 2 for Fiscal Year 2004 Comparisons ........... B.31

B.25 Monitoring Wells and Constituents for Low-Level Waste Management Area 3 ............................... B.32

B.26 Critical Means for Low-Level Waste Management Area 3 for Fiscal Year 2004 Comparisons ........... B. B

B.27 Monitoring Wells and Constituents for Low-Level Waste Management Area 4 …............................ B.33

B.28 Critical Means for Low-Level Waste Management Area 4 for Fiscal Year 2004 Comparisons ........... B. B

B.29 Monitoring Wells and Constituents for the Nonradioactive Dangerous Waste Landfill ..................... B.34

B.30 Critical Means for Nonradioactive Dangerous Waste Landfill for Fiscal Year 2004 Comparisons ...... B.34

B.31 Monitoring Wells and Constituents for PUREX Cribs 216-A-10, 216-A-36B, and 216-A-37-1 _...... B.35

B.32 Monitoring Wells and Constituents for Waste Management Area A-AX …....................................... B. B.36

B.33 Critical Means for Waste Management Area A-AX for Fiscal Year 2004 Comparisons ..................... B. B.36

B.34 Monitoring Wells and Constituents for Waste Management Area B-BX-BY ...................................... B.37

B.35 Monitoring Wells and Constituents for Waste Management Area C ................................................... B.38

B.36 Monitoring Wells and Constituents for Waste Management Area S-SX ............................................ B. B.39

B.37 Monitoring Wells and Constituents for Waste Management Area T ………........................................ B. B

B.38 Monitoring Wells and Constituents for Waste Management Area TX-TY ……………..................... B.

B.39 Monitoring Wells and Constituents for Waste Management Area U ................................................. B.. B. 


\section{Figures}

B.1 Regulated Units on the Hanford Site Requiring Groundwater Monitoring ….................................. B.43

B.2 Groundwater Monitoring Wells for the 100-N Area RCRA Sites ...................................................... B.44

B.3 Groundwater Monitoring Wells at the 116-H-6 Evaporation Basins ……………………………....... B.45

B.4 Groundwater Monitoring Wells at the 216-A-29 Ditch and PUREX Cribs ....................................... B.46

B.5 Groundwater Monitoring Wells at the 216-B-3 Pond ………............................................................ B.47

B.6 Groundwater Monitoring Wells at the 216-B-63 Trench and Low-Level Waste Management

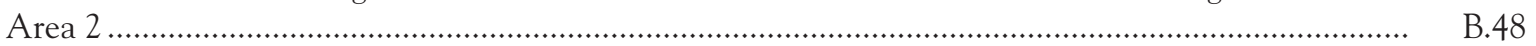

B.7 Groundwater Monitoring Wells at the 216-S-10 Pond and Ditch ................................................... B.49

B.8 Groundwater Monitoring Wells at the 216-U-12 Crib .................................................................... B.50

B.9 Groundwater Monitoring Wells at the 316-5 Process Trenches ......................................................... B.51

B.10 Groundwater Monitoring Wells at the Integrated Disposal Facility …................................................. B.52

B.11 Groundwater Monitoring Wells at the Liquid Effluent Retention Facility …...................................... B. B.53

B.12 Groundwater Monitoring Wells at Low-Level Waste Management Area 1 1........................................ B. B.

B.13 Groundwater Monitoring Wells at Low-Level Waste Management Area 3 ….................................... B. B.55

B.14 Groundwater Monitoring Wells at Low-Level Waste Management Area 4 ….................................... B.56

B.15 Groundwater Monitoring Wells at the Nonradioactive Dangerous Waste Landfill ........................... B. B.57

B.16 Groundwater Monitoring Wells at Waste Management Area A-AX ................................................... B..58

B.17 Groundwater Monitoring Wells at Waste Management Area B-BX-BY .............................................. B..59

B.18 Groundwater Monitoring Wells at Waste Management Area C ........................................................ B. 60

B.19 Groundwater Monitoring Wells at Waste Management Areas S-SX and U ........................................ B. B.

B.20 Groundwater Monitoring Wells at Waste Management Areas T and TX-TY ................................... B. $\quad$ B.62 


\section{Appendix B}

\section{Supporting Information for RCRA Units}

Supplemental information for Resource Conservation and Recovery Act (RCRA) units on the Hanford Site that require groundwater monitoring is provided in this appendix. RCRA regulations are administered under the Washington Administrative Code (WAC) 173-303. Text and tables include the information required by RCRA regulations essential for assessing the adequacy of the monitoring networks. RCRA groundwater monitoring continued during fiscal year 2003 at 24 waste management areas Figure B.1. RCRA units are discussed in alphanumeric order. One new facility, the Integrated Disposal Facility, is scheduled to begin groundwater monitoring in fiscal year 2004 and is included in the descriptions. Table B.1 lists the monitoring status for RCRA facilities at the end of fiscal year 2003. Estimates of groundwater velocity, hydrologic properties, and associated references are shown in Table B.2 for all RCRA sites. Table B.3 lists the RCRA wells that were not sampled as scheduled during fiscal year 2003.

\section{B.1 116-N-1 (1301-N) Liquid Waste Disposal Facility}

The 116-N-1 liquid waste disposal facility is included in the Hanford Facility RCRA Permit (Ecology 1994) and is, therefore, subject to final status monitoring requirements. However, the closure plan (in DOE/RL-96-39) states that RCRA monitoring during closure activities will follow the requirements of BHI-00725. That plan, and a supplemental plan (PNNL-13914), describe an interim status indicator evaluation program (40 CFR 265, as referenced by WAC 173-303-400).

Upgradient and downgradient wells were sampled twice in fiscal year 2003 for contamination indicator parameters $(\mathrm{pH}$, specific conductance, total organic carbon, and total organic halides) and once for groundwater quality and sitespecific parameters, as planned (Table B.4). Due to broken sample bottles, only three replicates for total organic carbon and total organic halides were analyzed in September in upgradient well 199-N-34.

Downgradient well 199-N-3 had pH values below the critical range in March and September 2003. The U.S. Department of Energy (DOE) submitted an assessment report on a previous exceedance ${ }^{(a)}$ to the Washington State Department of Ecology (Ecology) concluding that the below-background $\mathrm{pH}$ is characteristic of the area and does not appear to indicate contamination from the facility. Detection monitoring will continue.

Specific conductance in well 199-N-3 exceeded the critical mean value in March and September 2003. Such exceedances are common in this well, and are related to a non-hazardous, high-conductance plume (WHC-SD-EN-EV-003).

The groundwater flow direction is not expected to change in the near future, and there are no plans to modify the network in fiscal year 2004. Upgradient/downgradient comparison values for indicator parameters have been revised based on recent data for use in fiscal year 2004 comparisons (Table B.5).

\section{B. 2 120-N-1 and 120-N-2 (1324-N/NA) Facilities}

The 120-N-2 (1324-N) surface impoundment and 120-N-1 (1324-NA) percolation pond are included in the Hanford Facility RCRA Permit (Ecology 1994) and are thus subject to final status monitoring requirements. However, the closure plan (in DOE/RL-96-39) states that RCRA monitoring during closure activities will follow the requirements of BHI-00725. That plan, and a supplemental plan (PNNL-13914), describe an interim status indicator evaluation program (40 CFR 265, as referenced by WAC 173-303-400).

(a) Letter report 02-GWVZ-0029 from JG Morse (U.S. Department of Energy, Richland, Washington) to JA Hedges (Washington State Department of Ecology, Kennewick, Washington), Notification of Exceedance of Critical Range for pH in 1301-N Facility, dated July 8, 2002. 
During fiscal year 2003, four of the five monitoring wells for this site were sampled twice for contamination indicator parameters and groundwater quality and site-specific parameters, as planned (Table B.4 and Figure B.2). Downgradient well 199-N-59 contained too little water to sample in March and September 2003.

Average specific conductance values in wells downgradient of the facilities continued to exceed the critical mean values in fiscal year 2003. A previous groundwater quality assessment indicated that the high specific conductance is caused by the non-hazardous constituents sulfate and sodium (WHC-SD-EN-EV-003). Because an assessment has already been completed and non-hazardous constituents caused the high conductance, detection monitoring will continue.

The groundwater flow direction is not expected to change in the near future, and there are no plans to modify the network in fiscal year 2004. Upgradient/downgradient comparison values for indicator parameters were revised based on recent data for use in fiscal year 2004 comparisons (Table B.6).

\section{B. 3 116-N-3 (1325-N) Liquid Waste Disposal Facility}

The 116-N-3 liquid waste disposal facility is included in the Hanford Facility RCRA Permit (Ecology 1994) and is, therefore, subject to final status monitoring requirements. However, the closure plan (in DOE/RL-96-39) states that RCRA monitoring during closure activities will follow the requirements of BHI-00725. That plan, and a supplemental plan (PNNL-13914), describe an interim status indicator evaluation program (40 CFR 265, as referenced by WAC 173-303-400).

During fiscal year 2003, upgradient and downgradient wells were sampled twice for contamination indicator parameters ( $\mathrm{pH}$, specific conductance, total organic carbon, and total organic halides) and once for groundwater quality and site-specific parameters, as planned (Table B.4 and Figure B.2).

Average specific conductance values in downgradient well 199-N-41 continued to exceed the critical mean value in fiscal year 2003. This was a continuation of previous exceedances noted in 1999 through 2002. DOE notified Ecology of that original exceedance and submitted an assessment report that concluded the exceedance was caused by past discharges of non-hazardous constituents. Detection monitoring will continue in fiscal year 2004.

Groundwater flow direction is not expected to change in the near future, and there are no plans to modify the networks during fiscal year 2004. Upgradient/downgradient comparison values for indicator parameters were revised based on recent data for use in fiscal year 2004 (Table B.7).

\section{B.4 116-H-6 (183-H) Evaporation Basins}

This unit continued to be monitored in accordance with a final status corrective-action program during fiscal year 2003 (WAC 173-303-645(11)(g). The unit was incorporated into the Hanford Facility RCRA Permit (Ecology 1994). Groundwater remediation is integrated with the 100-HR-3 Operable Unit, where remediation for chromium is underway. While the pump-and-treat system is operating, RCRA monitoring consists of annual sampling of four wells for chromium, fluoride, nitrate, technetium-99, and uranium (Table B.8 and Figure B.3). The objective of monitoring during the operation of the pump-and-treat system is to determine whether concentrations of the contaminants of concern are decreasing. DOE will propose a change to the monitoring requirements with a permit modification in fiscal year 2004. The proposed change will bring the site under a post-closure monitoring program that is integrated with the Comprehensive Environmental Response, Compensation, and Liability Act (CERCLA) monitoring program, as allowed under Section II.K.7 of the Hanford Facility RCRA Permit (Ecology 1994).

All wells were sampled in November 2002, as planned. Two semiannual letter reports ${ }^{(b)}$ that document the effectiveness of the corrective action program were submitted to Ecology during fiscal year 2003. The current monitoring network was designed to accommodate groundwater flow imposed by the pump-and-treat system, and no changes are planned for fiscal year 2004.

(b) Letter report 03-WMD-0183 from JG Morse (U.S. Department of Energy, Richland, Washington) to JA Hedges (Washington State Department of Ecology, Kennewick, Washington), Resource Conservation and Recovery Act (RCRA) Final Status/Corrective Action Semiannual report for July through December, 2002, dated May 29, 2003.

Letter report 04-AMCP-0078 from KA Klein (U.S. Department of Energy, Richland, Washington) to JA Hedges (Washington State Department of Ecology, Kennewick, Washington), Resource Conservation and Recovery Act (RCRA) Final Status Corrective Action Semiannual Reports for January Through July [sic] 2003, dated November 26, 2003. 


\section{B.5 216-A-29 Ditch}

The 216-A-29 ditch (Figure B.4) is an inactive RCRA facility that is monitored under an interim-status indicator evaluation program (PNNL-13047). The facility has recorded past indicator parameter exceedances for specific conductance. These exceedances continued into fiscal year 2003, with specific conductance exceeding the critical mean of $265 \mu \mathrm{S} / \mathrm{cm}$ in three wells: 299-E25-35, 299-E25-48, and 299-E26-13. The first two of these three wells are at the head end of the decommissioned facility; the rise in specific conductance is attributed to manmade sulfate, a nonhazardous constituent. The rise in well 299-E26-13 cannot be definitively attributed to the rise in sulfate observed at the head end of the 216-A-29 ditch. The concentration rise in this well is similar to a regional elevation of sulfate concentrations throughout the east portion of the 200 East Area. The network wells and constituents list are provided in Table B.9 and statistical comparison data for fiscal year 2004 are listed in Table B.10.

\section{B.6 216-B-3 Pond}

The current monitoring network for the 216-B-3 pond (B Pond) system includes three downgradient wells and one upgradient well (Figure B.5). Samples were collected semiannually in these wells during fiscal year 2003 for the list of constituents shown in Table B.11.

For the past 2 years, groundwater monitoring has been conducted under a temporary variance granted by Ecology. The variance allowed for a trial period of intrawell data comparisons for site-specific constituents. The alternative statistical method used consists of the Shewhart-Cumulative Sum (CUSUM) calculation to determine long-term trends and that is also sensitive to sudden shifts in mean concentrations for each well individually. Baseline data, control limits, and summary statistics for gross beta and specific conductance are reported in Appendix A of PNNL-14187. The variance monitoring was governed by PNNL-13367-ICN-1.

Beginning in January 2004, the facility will return to indicator-parameters-evaluation status using upgradient/ downgradient comparisons until the results of the variance period are evaluated. Critical means for statistical comparisons, which begin in January 2004, are listed in Table B.12. Based on the results of this trial evaluation, Ecology will decide whether to continue, modify, or abandon the alternative approach. During fiscal year 2003, the Shewhart mean-plus-two-sigma level was briefly (and marginally) exceeded in well 699-43-45 for specific conductance. This increase is interpreted as a return to background water quality, following dilution by B Pond discharges (see Section 2.11.3).

\section{B.7 216-B-63 Trench}

Indicator parameter monitoring at the 216-B-63 trench has not provided any evidence of contamination from the facility. Two downgradient wells (299-E33-36 and 200-E33-33) (Figure B.6) exceeded the critical mean for total organic carbon in fiscal year 2003, but the exceedance may be part of an analytical problem with an instrument at one of the contract laboratories supporting the Groundwater Performance Assessment Project (groundwater project) (see discussion in Appendix D). Monitoring wells and the constituent list for the 216-B-63 trench are provided in Table B.13. Critical means for statistical comparison in fiscal year 2004 are listed in Table B.14.

\section{B.8 216-S-10 Pond and Ditch}

During fiscal year 2003, this facility continued to be monitored semiannually under a RCRA interim status indicator evaluation program (Table B.15 and Figure B.7). Statistical evaluations of indicator parameter data have not indicated that the facility has affected the groundwater quality in the uppermost aquifer beneath the site. Upgradient/downgradient comparison values for fiscal year 2004 are listed in Table B.16. The direction of groundwater flow and estimated flow rate are listed in Table B.2. During fiscal year 2003, upgradient well 299-W26-7 went dry and one new downgradient well, 299-W26-14, was added. Before well 299-26-7 went dry, it was sampled twice (December 2002 and June 2003) in fiscal year 2003. The current monitoring network for the 216-S-10 pond and ditch consists of only two shallow downgradient wells and one deeper downgradient well (Table B.15).

Ecology and DOE annually negotiate installation of future monitoring wells under the Hanford Federal Facility Agreement and Consent Order (Tri-Party Agreement; Ecology et al. 1998) Milestone M-24. The chromium concentration 
increased in well 299-W26-7 during fiscal year 2003 to a maximum of $209 \mu \mathrm{g} / \mathrm{L}$ in June 2003 before the well went dry. The new groundwater monitoring plan (PNNL-14070) proposes deepening the upgradient well 299-W26-7 and one other dry downgradient well. Analytical results from the 216-S-10 pond and ditch are discussed in Section 2.9.

\section{B.9 216-U-12 Crib}

This RCRA unit continued to be monitored under an interim status groundwater quality assessment program in fiscal year 2003. A new assessment monitoring plan (PNNL-14301) for the 216-U-12 crib was published during 2003. Assessment monitoring began in 1993 because of elevated specific conductance in two downgradient wells. In fiscal year 2003, network monitoring wells were sampled quarterly for constituents of interest (Table B.17 and Figure B.8).

Based on the results of the assessment investigation (PNNL-11574), the site remains in interim status assessment monitoring because of continued elevated levels of nitrate. Site-wide monitoring evaluates the extent of this plume. The rate and direction of groundwater flow (Table B.2) and the extent of contamination at this site are discussed in Section 2.9.

The crib will not receive additional effluents and is scheduled, according to PNNL-14301, to be closed under an accelerated schedule in accordance with the CERCLA 200-UP-1 Operable Unit planned focused feasibility study (DOE/RL-2003-23) and proposed plan (DOE/RL-2003-24). This process will integrate closure and post-closure requirements for the 216-U-12 crib. As part of this proposed plan (DOE/RL-2003-24), the crib will be closed by September 30, 2006.

Currently, the crib is monitored by only two downgradient wells (299-W22-79 and 699-36-70A) because of declining water levels. Ecology and DOE annually negotiate installation of future monitoring wells under Tri-Party Agreement (Ecology et al. 1998) Milestone M-24.

\section{B.10 316-5 Process Trenches}

The 316-5 process trenches are in a RCRA final status program and groundwater monitoring is conducted in accordance with WAC 173-303-645(11), Corrective Action Program, and Part VI, Chapter 1 of the Hanford Facility RCRA Permit (Ecology 1994). The modified closure plan (DOE/RL-93-73), which is incorporated into the Hanford Facility RCRA Permit, indicates that groundwater remediation is deferred to the CERCLA 300-FF-5 Operable Unit.

The objective of groundwater monitoring during the corrective action period is to demonstrate the effectiveness of the corrective action program by examining the trend of the constituents of interest to confirm that they are attenuating naturally, as expected by the CERCLA record of decision for the 300-FF-5 Operable Unit (ROD 1996). In September 2001, a revised groundwater monitoring plan (PNNL-13645) was implemented for a 2-year evaluation period. Changes over the previous plan included an update on the discussion of hydrogeology and the conceptual model, a change in the number of network wells from 8 to 11 (Figure B.9), and evaluation of the statistical approach to the control chart method (Shewhart-CUSUM). The last groundwater samples collected for this 2-year evaluation period were collected in September 2003. The data will be evaluated, and a report on the 2-year evaluation will be presented to Ecology in fiscal year 2004.

The 300 Area process trenches were closed under a modified closure/post-closure plan (DOE/RL-93-73) and continue to be in the groundwater corrective action program because groundwater contamination continues to exceed groundwater quality criteria (federal drinking water standards). Groundwater monitoring will continue for 30 years during the postclosure monitoring period. The new groundwater monitoring plan (PNNL-13645, hereafter called the revised plan) was submitted to Ecology and was released for public comment in May 2002. This revised plan was in effect under a temporary authorization granted by Ecology for the 2-year trial period. However, because the latest modification of the Hanford Facility RCRA Permit specifies WHC-SD-EN-AP-185 (the previous plan), both plans are being used.

The most significant difference between the previous and revised groundwater monitoring plans is the change in statistical approach. The revised statistical approach is a control chart method that uses a single observation (sample) during any monitoring event rather than four time-independent samples specified by the previous plan. The method monitors each well in the network individually and yet maintains desired site-wide false-positive and false-negative rates. Also, each well showing an exceedance of the drinking water standard of one of the constituents of interest is sampled quarterly to better follow the trends of contaminant concentration. The other wells in the network will continue to be sampled semiannually. To implement the previous plan, four time-independent groundwater samples 
are collected at eight wells twice per year (semiannually). However, to accomplish the time independence between the four samples in a sampling period, the samples are collected in 1-month intervals. The result is that under the previous plan (WHC-SD-EN-AP-185), groundwater samples are collected from the eight network wells for 8 months per year (December, January, February, March, June, July, August, and September).

The revised groundwater monitoring network for the 316-5 process trenches (Figure B.9) includes five well pairs plus one additional well (399-1-11) that is screened in the upper portion of the unconfined aquifer. Each of the well pairs has one shallow and one deep well. The shallow wells are screened at the water table, and the deep wells are screened at the bottom of the unconfined aquifer (above the lacustrine and overbank deposits of the Ringold Formation lower mud unit).

The wells are sampled for the constituents of interest, including total uranium (chemical), and the volatile organic compounds cis-1,2-dichloroethene, trichloroethene, and tetrachloroethene (Table B.18). The sampling schedule is based on the concentrations of the constituents of interest reported at each well. Wells with constituents of interest exceeding drinking water standards are sampled quarterly. The rest are sampled semiannually.

To be in compliance with the previous plan (WHC-SD-EN-AP-185), groundwater samples are collected during the 8 months specified earlier at four well pairs (one shallow and one deep). The constituents of concern are the same as in the revised plan (PNNL-13645). Where the two plans overlap, only one well trip and resulting analyses is performed per well.

The objective of the groundwater monitoring plans (either previous or revised) is to examine the trend of the contaminants of concern to confirm that they are attenuating naturally. The overall concentration of uranium in network wells appears to be decreasing, but the concentration of cis-1,2-dichloroethene appears to be holding steady at levels above the drinking water standard $(70 \mu \mathrm{g} / \mathrm{L})$ in one well.

DOE will propose a change to the monitoring requirements with a permit modification in fiscal year 2004. The proposed change will bring the site under an integrated monitoring program with the 300-FF-5 Operable Unit.

\section{B.11 Integrated Disposal Facility}

The Integrated Disposal Facility will consist of a lined landfill covering 25 hectares located in the south-central part of the 200 East Area (Figure B.10). The landfill will be divided lengthwise into two distinct cells, one for the disposal of low-level radioactive waste and the other for the disposal of mixed waste. The facility will be a RCRAcompliant landfill (i.e., a double-lined trench with leachate collection system) that is $\sim 442$ meters wide by 555 meters in length by up to 15 meters deep. The landfill will contain four layers of waste containers separated vertically by 0.9 meter of soil. The approximate volume of waste to be deposited will be 100 hectare-meters. The waste will be segregated into a RCRA-permitted side and a non-RCRA-permitted side. Construction will begin in September 2004. Currently, the Part B Permit has been submitted to Ecology and is scheduled to be incorporated into the Hanford Facility RCRA Permit (Ecology 1994) in February 2004.

The groundwater monitoring network will consist of two upgradient wells and five downgradient wells (Table B.19). Three wells remain to be installed; two will be installed in the summer of fiscal year 2004, and the third will be installed at a future date when required by facility expansion. The indicator parameters that will be routinely monitored are listed in Table B.19.

The indicator parameters will be used to monitor for hazardous constituents reaching the groundwater as a result of Integrated Disposal Facility operations. Total organic carbon and total organic halides are indicator parameters selected to monitor the impact of RCRA-regulated organic constituents on groundwater quality. Specific conductance is selected as an indicator parameter to monitor the impact of metals and anions on groundwater quality. $\mathrm{pH}$ is a general indicator of groundwater quality. Chromium is included as an indicator parameter because hexavalent chromium is one of the more mobile of the regulated metals expected at the Integrated Disposal Facility and should be one of the first constituents to be detected in groundwater if the regulated facility affects groundwater.

Analyses of alkalinity, anions, and metals are to provide supplemental data on general groundwater chemistry beneath the Integrated Disposal Facility. This information aids data interpretation and quality control. Supplemental parameters will not be used in statistical evaluations. Turbidity is analyzed at the well just before sampling and provides an indication of the groundwater sample quality. 
Monitoring will begin when all wells are ready to be sampled, currently anticipated for late fiscal year 2004. All indicator parameters will be monitored twice each quarter and supplemental parameters once each quarter to determine background concentrations. After the first year, indicator parameters will be monitored semiannually and supplemental parameters annually. In addition, field measurements of temperature and turbidity will be made at each sampling event.

During the first sampling event at each well, samples will be collected for analysis of the Appendix IX constituents (40 CFR 264) included in Chapter 1 of the Integrated Disposal Facility permit application.

\section{B.12 Liquid Effluent Retention Facility}

During fiscal year 2003, the Liquid Effluent Retention Facility was monitored by one upgradient and one downgradient well (Table B.20 and Figure B.11) because the other two downgradient wells failed to produce representative groundwater samples. Negotiations continue between Ecology, DOE, and contractors in an effort to formulate a final status monitoring strategy for the Liquid Effluent Retention Facility. In January 2001, Ecology directed DOE to suspend statistical evaluation of groundwater data at the facility.

\section{B.13 Low-Level Waste Management Area 1}

Groundwater monitoring under interim status requirements continued at this site in fiscal year 2003. The well network was sampled twice for groundwater contamination indicators and site-specific parameters (Table B.21 and Figure B.12). Downgradient monitoring well 299-E33-34 continued to exceed the critical mean for specific conductance during fiscal year 2003. This exceedance is related to the nitrate plume from the vicinity of the BY cribs and not LowLevel Waste Management Area 1.

Total organic carbon results were elevated in the June samples from several wells. The average of quadruplicate results for upgradient well 299-E32-4 (average 1,875 $\mu \mathrm{g} / \mathrm{L}$ ) and downgradient well 299-E33-34 (average 1,475 $\mu \mathrm{g} / \mathrm{L}$ ) exceeded the critical mean comparison value calculated from previous upgradient data. Elevated total organic carbon values have been reported from other sites including the 216-B-63 trench, Waste Management Area C and the Solid Waste Landfill. The exceedance is believed to be a laboratory problem that has since been resolved (see Appendix D). Upgradient/downgradient comparison values for fiscal year 2004 statistical evaluations are listed in Table B.22.

No wells in the network went dry in fiscal year 2003; thus, the monitoring network will remain the same in fiscal year 2004.

DOE submitted an application for a RCRA permit for all the burial grounds in fiscal year 2002 that included final status groundwater monitoring under WAC 173-303-645. Ecology reviewed the application and in fiscal year 2004, DOE will hold workshops with Ecology to resolve Ecology's notices of deficiency. Final status monitoring will begin following the effective date of the permit.

\section{B.14 Low-Level Waste Management Area 2}

This site continued in RCRA interim status indicator evaluation during fiscal year 2003. Wells were sampled twice for groundwater contamination indicators and site-specific parameters (Table B.23 and Figure B.6). Upgradient well 299-E34-7 continued to exceed the critical mean for specific conductance in fiscal year 2003. The major contributors to the increase are sulfate, chloride, and calcium. The source of these constituents is not known. This well also exceeded the critical mean values for total organic carbon and total organic halides in fiscal year 2003. Table B.24 lists the upgradient/downgradient comparison values for fiscal year 2004 statistical evaluations.

The monitoring network for Low-Level Waste Management Area 2 is distributed around the facility on all sides where an unconfined aquifer is present above the basalt surface. Thus, it is suitable for detecting releases from the facility. However, the continued decline in water level is causing additional wells to go dry. One well, 299-E34-3, went dry in late fiscal year 2002 and was not sampled during fiscal year 2003. Monitoring wells in this area are all completed at the top of basalt, so deeper wells are not an option for sampling the unconfined aquifer. 
DOE submitted an application for a RCRA permit for all the burial grounds in fiscal year 2002 that included final status groundwater monitoring under WAC 173-303-645. Ecology reviewed the application and in fiscal year 2004, DOE will hold workshops with Ecology to resolve Ecology's notices of deficiency. Final status monitoring will begin following the effective date of the permit.

\section{B.15 Low-Level Waste Management Area 3}

This site continued in RCRA interim status indicator evaluation during fiscal year 2003. Wells were sampled twice for groundwater contamination indicators and site-specific parameters (Table B.25 and Figure B.13). Indicator parameter data of groundwater contamination from monitoring wells were statistically evaluated, and downgradient results remained less than the comparison values. Table B.26 lists upgradient/downgradient comparison values for fiscal year 2004 statistical evaluations.

Because of the changing direction of groundwater flow and the continuing decline in water levels, this network only marginally monitors this waste management area. All wells were successfully sampled in fiscal year 2003 . Under current flow directions, wells 299-W10-19 and 299-W10-20 remain upgradient of the east portion of the waste management area but are downgradient of the southwest part of the waste management area. Ecology and DOE annually negotiate installation of future monitoring wells under Tri-Party Agreement (Ecology et al. 1998) Milestone M-24.

DOE submitted an application for a RCRA permit for all the burial grounds in fiscal year 2002 that included final status groundwater monitoring under WAC 173-303-645. Ecology reviewed the application and in fiscal year 2004, DOE will hold workshops with Ecology to resolve Ecology's notices of deficiency. Final status monitoring will begin following the effective date of the permit.

\section{B.16 Low-Level Waste Management Area 4}

Wells were sampled semiannually for contamination indicator parameters in accordance with RCRA interim status regulations (Table B.27 and Figure B.14). Downgradient well 299-15-16 continued to exceed the critical mean value for total organic halides in fiscal year 2003. This well was at one time an upgradient monitoring well and is still affected by contamination from other sources. DOE reported the exceedance to the U.S. Environmental Protection Agency (EPA) and Ecology in 1999. Upgradient/downgradient comparison values for fiscal year 2004 statistical evaluations are listed in Table B.28.

One monitoring well, 299-W18-24, went dry during fiscal year 2003. Only a partial sample was obtained in the first round of sampling from this well, and it was declared dry prior to the second semiannual sampling event. This monitoring network requires upgrading to satisfy RCRA requirements. There are currently two downgradient wells (including one deep well) and four upgradient wells (including one deep well). Ecology and DOE annually negotiate installation of future monitoring wells under Tri-Party Agreement (Ecology et al. 1998) Milestone M-24.

DOE submitted an application for a RCRA permit for all the burial grounds in fiscal year 2002 that included final status groundwater monitoring under WAC 173-303-645. Ecology reviewed the application and in fiscal year 2004, DOE will hold workshops with Ecology to resolve Ecology's notices of deficiency. Final status monitoring will begin following the effective date of the permit.

\section{B.17 Nonradioactive Dangerous Waste Landfill}

The Nonradioactive Dangerous Waste Landfill continued in an interim status, indicator parameter evaluation program during fiscal year 2003 (Table B.29 and Figure B.15). Statistical evaluations of groundwater contaminant indicator parameters indicate that the site has not adversely affected groundwater quality. The Nonradioactive Dangerous Waste Landfill groundwater monitoring plan (PNNL-12227) will have to be modified during fiscal year 2004 to remove well 699-26-35A as a background well. The well will not need to be replaced because there are two other background wells for this facility.

The two wells (699-25-33A and 699-26-35C) screened in the Ringold Formation lower permeability unit had reported values of $\mathrm{pH}$ above the background threshold range of 6.64 to 7.85 . The highest reported $\mathrm{pH}$ value was 8.05. These two deeper wells are not used for upgradient/downgradient comparisons. Table B.30 lists upgradient/downgradient comparison values based on recent data for use in fiscal year 2004. 
Sampling and analysis problems were not experienced in the Nonradioactive Dangerous Waste Landfill well network during fiscal year 2003, so there are no planned changes for fiscal year 2004.

\section{B.18 PUREX Cribs}

The 216-A-10, 216-A-36B, and 216-A-37-1 (PUREX) cribs continued to be monitored under a RCRA interim status groundwater quality assessment program in fiscal year 2003 (Table B.31 and Figure B.4). The cribs are monitored as a single waste management area because they have similar hydrogeology and waste constituents. The extent of contamination is discussed in Section 2.11.

Nitrate and manganese remain elevated above their drinking water standards ( $45 \mathrm{mg} / \mathrm{L}$ and $50 \mu \mathrm{g} / \mathrm{L}$, respectively) in wells monitoring the PUREX cribs.

During fiscal year 2003, the water level in well 299-E17-9 dropped to a level where sampling is no longer possible. The well was replaced with well 299-E17-16. However, this substitute well is located southeast of well 299-E17-9 and does not intercept groundwater contamination plumes in a location where concentrations are as high as the 299-E17-9 well location. There are no other changes planned for fiscal year 2004. Flow rates for groundwater in the vicinity of the PUREX cribs are given in Table B.2.

\section{B.19 Waste Management Area A-AX}

Groundwater monitoring at A-AX Tank Farm continued under an interim status indicator evaluation program in fiscal year 2003. Wells were sampled twice for groundwater contamination indicators and site-specific parameters (Table B.32 and Figure B.16). Indicator parameter data from monitoring wells were statistically evaluated, and values from downgradient wells were compared to those established from the upgradient well. The indicator parameters (specific conductance, total organic carbon, and total organic halides) did not exceed critical mean values during fiscal year 2003. The $\mathrm{pH}$ value reported in downgradient well 299-E25-46 for the December 2002 sampling event was 6.81, which is below the critical range of 6.82 to 9.54. Verification sampling conducted in April 2003 showed this value was in error and that the correct $\mathrm{pH}$ value was 7.01. Table B.33 lists updated upgradient/downgradient comparison values for statistical evaluations in fiscal year 2004.

Table B.2 includes the general direction and an estimated rate of groundwater flow. The flow direction, determined using in situ flow measurements with the colloidal borescope and water elevations, is to the southeast. The saturated screen interval ranges from 1.8 to 3.8 meters thick in RCRA network wells while the aquifer thickness is $\sim 27$ meters. The average rate of water-table decline was 25 centimeters in 2003. If this rate continues, some of the RCRA-compliant wells at Waste Management Area A-AX will be dry in $~ 7$ years. One new downgradient well, 299-E24-22, and one new upgradient well, 299-E25-93, were installed during fiscal year 2003 to increase the usefulness of the network to detect groundwater contamination associated with the tank farms. These wells are scheduled for sampling in December 2003.

\section{B.20 Waste Management Area B-BX-BY}

Groundwater quality assessment monitoring continued at this waste management area in fiscal year 2003. Assessment monitoring was initiated in 1996 when the critical mean value for specific conductance was exceeded in a downgradient well. Assessment wells were sampled quarterly, and in some cases, semiannually, in fiscal year 2003. Nitrate and cyanide exceeded drinking water standards in RCRA-compliant wells. Section 2.10 discusses plume extents and contaminant trends.

Originally, the RCRA groundwater monitoring network was designed for groundwater flow toward the northwest, based on regional plume maps. This method was used to determine flow direction because the water table is almost flat in the immediate area of the farms. Assessment studies have determined a southward flow direction across the site (Table B.2; Section 2.9.1 of PNNL-13404). Contaminant migration and results from colloidal borescope investigations indicate a south-to-southeast flow direction at the south boundary of the waste management area. Additional well installations have been planned to improve the coverage of the network.

In fiscal year 2003, the monitoring network included far-field wells (Table B.34 and Figure B.17). Some of these wells are RCRA-compliant, while others are older wells installed to monitor past-practice waste disposal sites. Water 
levels in these wells remained unchanged during fiscal year 2003. Although the aquifer is $\sim 1.7$ meters thick in the north and will eventually go dry, it is $>4$ meters thick along the south border of the waste management area. Most of these wells can be used for at least 5 years. The new wells along the south boundary should be usable after the water table declines to a stable elevation.

\section{B.21 Waste Management Area C}

Interim-status, indicator-evaluation monitoring continued at this site in fiscal year 2003. Wells were sampled quarterly at the request of Ecology due to rising trends in sulfate, nitrate, and calcium currently detected in both upgradient and downgradient wells. In addition, the required detection sampling was conducted twice for indicator and site-specific parameters (Table B.35 and Figure B.18). Four new wells were installed to improve the capability of the detection network to determine if waste associated with the C Tank Farm is compromising groundwater quality.

The groundwater project revised the monitoring plan (PNNL-13024) for this site in 2002 (PNNL-13024-ICN-2). The revision accounts for the variable conditions in upgradient well 299-E27-7. A critical mean for specific conductance could not be calculated using data from this well because four quarters of stable data were not available. Consequently, upgradient/downgradient comparisons are deferred until specific conductance stabilizes or data from new upgradient well 299-E27-22 are available.

A general flow direction to the southwest has been established for this site using in situ flow measurements, plume tracking and water elevations corrected for borehole deviations from vertical. The monitoring network has been revised to reflect the change in interpretation (PNNL-13024-ICN-1). During fiscal year 2003, the site was monitored with the original configuration of wells. The four new monitoring wells, one upgradient and three downgradient, are scheduled to be sampled in December 2003. Preliminary sampling during the drilling of new upgradient well 299-E27-22 indicates very low levels of contamination. Consequently, four stable date points should be obtainable. Upgradient/ downgradient comparisons should begin again in fiscal year 2005. A further discussion of chemical trends is provided in Section 2.10.

\section{B.22 Waste Management Area S-SX}

This site continued to be monitored under an interim status, groundwater quality assessment program during fiscal year 2003. DOE initiated the assessment program in response to a directive from Ecology in 1996. Monitoring wells sampled during the report period and constituents analyzed are listed in Table B.36, and the network configuration is shown in Figure B.19). The most recent revision of the monitoring plan (PNNL-12114) was issued in February 2002 (PNNL-12114-ICN-2). Nitrate and chromium, mobile tank farm contaminants regulated under RCRA, are elevated in downgradient wells. The highest concentrations in the network occur in well 299-W23-19 located adjacent to tank SX-115 in the southwest corner of the SX Tank Farm. This area appears to be the source of the downgradient occurrences of elevated nitrate. The moderately elevated carbon tetrachloride is attributed to past-practice upgradient sources (e.g., Plutonium Finishing Plant cribs, ditches, and trenches). The nearby upgradient crib, 216-S-25, was a major source of nitrate that passes beneath the south end of this waste management area. In addition, elevated but stable concentrations of mobile tank waste contaminants were observed in well 299-W22-48.

The rate and direction of groundwater flow (Table B.2) and the extent of contamination at Waste Management Area S-SX are discussed further in Section 2.9 of the main text.

\section{B.23 Waste Management Area T}

Waste Management Area T continued to be monitored under an interim status groundwater quality assessment program during fiscal year 2003 (Table B.37 and Figure B.20). The groundwater monitoring plan governing fiscal year 2003 groundwater activities at the waste management area is PNNL-12057, amended by PNNL-12057-ICN-1. One well is scheduled to be installed at the waste management area in calendar year 2004.

Evaluation of groundwater data in 2003 indicates that no RCRA-regulated, dangerous waste constituents from Waste Management Area T have affected groundwater. Chromium is found at concentrations greater than the drinking water standard of $100 \mu \mathrm{g} / \mathrm{L}$ at downgradient well 299-W11-41 (141 $\mu \mathrm{g} / \mathrm{L}$ average 2003 concentration) and at downgradient well 299-W11-42 (132 $\mu \mathrm{g} / \mathrm{L}$ average 2003 concentration). However, chromium concentrations in upgradient wells 
299-W10-28 and 299-W10-4 were 105 and $327 \mu \mathrm{g} / \mathrm{L}$, respectively (average annual concentrations). One or more of the upgradient cribs or trenches is the most likely source of elevated chromium in the area of Waste Management Area T.

The direction and rate of groundwater flow (Table B.2) are discussed in Section 2.8 of the main text.

\section{B.24 Waste Management Area TX-TY}

Waste Management Area TX-TY continued to be monitored under an interim status groundwater quality assessment program during fiscal year 2003 (Table B.38 and Figure B.20). The groundwater monitoring plan governing fiscal year 2003 groundwater activities at the waste management area is discussed in PNNL-12072, amended by PNNL-12072-ICN-1. One well is scheduled to be installed at the waste management area in calendar year 2004.

Evaluation of groundwater data in 2003 indicates that chromium occurs in concentrations greater than the drinking water standard $(100 \mu \mathrm{g} / \mathrm{L})$ at downgradient well 299-W14-13. The concentration of chromium in that well ranged between 427 and $540 \mu \mathrm{g} / \mathrm{L}$ in fiscal year 2003. There is some evidence suggesting that the chromium may be from the waste management area. However, nearby cribs also are possible sources for the chromium. Until an alternative source for chromium can be identified with some certainty, Waste Management Area TX-TY remains in groundwater quality assessment monitoring status.

The direction and rate of groundwater flow (Table B.2) are discussed in Section 2.8 of the main text.

\section{B.25 Waste Management Area U}

This unit was monitored under an interim status groundwater quality assessment program in fiscal year 2003 (Table B.39 and Figure B.19). The average specific conductance value in downgradient well 299-W19-41 exceeded the critical mean in August 1999, triggering assessment monitoring. Results of initial assessment studies (PNNL-13282) concluded that there is evidence that both upgradient sources and sources within the waste management area contributed to the elevated nitrate observed in monitoring wells. Thus, assessment monitoring will continue in accordance with the monitoring plan (PNNL-13612 and PNNL-13612-ICN-1).

The rate of groundwater flow is summarized in Table B.2 and the extent of contamination at this site is discussed in Section 2.9.

\section{B.26 References}

40 CFR 264. U.S. Environmental Protection Agency. "Standards for Owners and Operators of Hazardous Waste Treatment, Storage, and Disposal Facilities." U.S. Code of Federal Regulations.

40 CFR 265. U.S. Environmental Protection Agency. "Interim Status Standards for Owners and Operators of Hazardous Waste Treatment, Storage, and Disposal Facilities." U.S. Code of Federal Regulations.

Atomic Energy Act of 1954. As amended, Ch. 1073, 68 Stat. 919, 42 USC 2011 et seq.

BHI-00725. 1996. 100-N Pilot Project: Proposed Consolidated Groundwater Monitoring Program. JV Borghese, MJ Hartman, SP Luttrell, CJ Perkins, JP Zoric, and SC Tindall, Bechtel Hanford, Inc., Richland, Washington.

BNWL-1709. 1973. Collection and Analysis of Pump Test Data for Transmissivity Values. KL Kipp and RD Mudd, Battelle, Pacific Northwest Laboratory, Richland, Washington.

Comprehensive Environmental Response, Compensation, and Liability Act. 1980. Public Law 96-150, as amended, 94 Stat. 2767, 42 USC 9601 et seq.

DOE/RL-93-73, Rev. 4. 1995. 300 Area Process Trenches Modified Closure Plan and Part A, Form 3. U.S. Department of Energy, Richland Operations Office, Richland, Washington.

DOE/RL-96-01. 1996. Annual Report for RCRA Groundwater Monitoring Projects at Hanford Site Facilities for 1995. Prepared by Earth and Environmental Technical Services, Westinghouse Hanford Company, for the U.S. Department of Energy, Richland Operations Office, Richland, Washington. 
DOE/RL-96-39. 1998. 100-NR-1 Treatment, Storage, and Disposal Units Corrective Measure Study/Closure Plan. U.S. Department of Energy, Richland Operations Office, Richland, Washington.

DOE/RL-2003-12, Rev. 0. 2003. Hanford Facility Dangerous Waste Permit Application, Integrated Disposal Facility. U.S. Department of Energy, Richland Operations Office, Richland, Washington.

DOE/RL-2003-23, Draft A. 2003. Focused Feasibility Study for the U Plant Closure Area Waste Sites. Prepared by Fluor Hanford, Inc. for the U.S. Department of Energy, Richland Operations Office, Richland, Washington.

DOE/RL-2003-24, Rev. 0. 2003. Proposed Plan for the U Plant Closure Area Waste Sites. Decisional Draft. Prepared by Fluor Hanford, Inc. for the U.S. Department of Energy, Richland Operations Office, Richland, Washington.

Ecology. 1994. Dangerous Waste Portion of the Resource Conservation and Recovery Act Permit for the Treatment, Storage, and Disposal of Dangerous Waste. Permit Number WA7890008967, as amended. Washington State Department of Ecology, Olympia, Washington.

Ecology - Washington State Department of Ecology, U.S. Environmental Protection Agency, and U.S. Department of Energy. 1998. Hanford Federal Facility Agreement and Consent Order. Document No. 89-10, Rev. 5 (The Tri-Party Agreement), Olympia, Washington.

PNL-5408. 1985. Groundwater Monitoring at the Hanford Site, January-December 1984. CS Cline, JT Rieger, JR Raymond, and PA Eddy, Pacific Northwest Laboratory, Richland, Washington.

PNL-6716. 1988. Interim Characterization Report for the 300 Area Process Trenches. R Schalla, RW Wallace, RL Aaberg, SP Airhart, DJ Bates, JVM Carlile, CS Cline, DI Dennison, MD Freshley, PR Heller, EJ Jensen, KB Olsen, RG Parkhurst, JT Rieger, and EJ Westergard, Pacific Northwest Laboratory, Richland, Washington.

PNL-6728. 1988. Geohydrologic Characterization of the Area Surrounding the 183-H Solar Evaporation Basins. TL Liikala, RL Aaberg, NJ Aimo, DJ Bates, TJ Gilmore, EJ Jensen, GV Last, PL Oberlander, KB Olsen, KR Oster, LR Roome, JC Simpson, SS Teel, and EJ Westergard, Pacific Northwest Laboratory, Richland, Washington.

PNL-6820. 1989. Hydrogeology for the 200 Areas Low-Level Burial Grounds - An Interim Report. GV Last, BN Bjornstad, MP Bergeron, DW Wallace, DR Newcomer, JA Schramke, MA Chamness, CS Cline, SP Airhart, and JS Wilber, Pacific Northwest Laboratory, Richland, Washington.

PNL-8335. 1992. Applications of Three Aquifer Test Methods for Estimating Hydraulic Properties Within the 100-N Area. TJ Gilmore, FA Spane, Jr., DR Newcomer, and CR Sherwood, Pacific Northwest Laboratory, Richland, Washington.

PNNL-11523. 1997. Combination RCRA Groundwater Monitoring Plan for the 216-A-10, 216-A-36B, and 216-A-37-1 PUREX Cribs. JW Lindberg, Pacific Northwest National Laboratory, Richland, Washington.

PNNL-11573. 1997. Groundwater Monitoring Plan for the 183-H Solar Evaporation Basins. MJ Hartman, Pacific Northwest National Laboratory, Richland, Washington.

PNNL-11574. 1997. Results of RCRA Groundwater Quality Assessment Program at the 216-U-12 Crib. BA Williams and CJ Chou, Pacific Northwest National Laboratory, Richland, Washington.

PNNL-11620. 1997. Liquid Effluent Retention Facility Final-Status Groundwater Monitoring Plan. MD Sweeney, CJ Chou, and BN Bjornstad, Pacific Northwest National Laboratory, Richland, Washington.

PNNL-11801. 1998. Three-Dimensional Analysis of Future Groundwater Flow Conditions and Contaminant Plume Transport in the Hanford Site Unconfined Aquifer System: FY 1996 and 1997 Status Report. CR Cole, SK Wurstner, MP Bergeron, MD Williams, and PD Thorne, Pacific Northwest National Laboratory, Richland, Washington.

PNNL-11957. 1998. Immobilized Low-Activity Waste Site Borehole 299-E17-21. SP Reidel, KD Reynolds, and DG Horton, Pacific Northwest National Laboratory, Richland, Washington. 
PNNL-12057. 2001. RCRA Assessment Plan for Single-Shell Tank Waste Management Area T at the Hanford Site. FN Hodges and CJ Chou, Pacific Northwest National Laboratory, Richland, Washington.

PNNL-12057-ICN-1. 2002. RCRA Assessment Plan for Single-Shell Tank Waste Management Area T at the Hanford Site, Interim Change Notice 1. DG Horton, Pacific Northwest National Laboratory, Richland, Washington.

PNNL-12072. 2001. RCRA Assessment Plan for Single-Shell Tank Waste Management Area T at the Hanford Site. FN Hodges and CJ Chou, Pacific Northwest National Laboratory, Richland, Washington.

PNNL-12072-ICN-1. 2002. RCRA Assessment Plan for Single-Shell Tank Waste Management Area T at the Hanford Site, Interim Change Notice 1. DG Horton, Pacific Northwest National Laboratory, Richland, Washington.

PNNL-12114. 1999. RCRA Assessment Plan for Single-Shell Tank Waste Management Area S-SX at the Hanford Site. VG Johnson and CJ Chou, Pacific Northwest National Laboratory, Richland, Washington.

PNNL-12114-ICN-1. 2000. RCRA Assessment Plan for Single-Shell Tank Waste Management Area S-SX at the Hanford Site, Interim Change Notice 1. VG Johnson and CJ Chou, Pacific Northwest National Laboratory, Richland, Washington.

PNNL-12114-ICN-2. 2002. RCRA Assessment Plan for Single-Shell Tank Waste Management Area S-SX at the Hanford Site, Interim Change Notice 2. RM Smith, Pacific Northwest National Laboratory, Richland, Washington.

PNNL-12227. 1999. Groundwater Monitoring Plan for the Nonradioactive Dangerous Waste Landfill. JW Lindberg and MJ Hartman, Pacific Northwest National Laboratory, Richland, Washington.

PNNL-13022. 2000. Groundwater Quality Assessment Plan for Single-Shell Waste Management Area B-BX-BY at the Hanford Site. SM Narbutovskih, Pacific Northwest National Laboratory, Richland, Washington.

PNNL-13023. 2001. RCRA Groundwater Monitoring Plan for Single-Shell Tank Waste Management Area A-AX at the Hanford Site. SM Narbutovskih, Pacific Northwest National Laboratory, Richland, Washington.

PNNL-13023-ICN-1. 2002. RCRA Groundwater Monitoring Plan for Single-Shell Tank Waste Management Area A-AX at the Hanford Site, Interim Change Notice 1. SM Narbutovskih, Pacific Northwest National Laboratory, Richland, Washington.

PNNL-13024. 2001. RCRA Groundwater Monitoring Plan for Single-Shell Tank Waste Management Area C at the Hanford Site. DG Horton and SM Narbutovskih, Pacific Northwest National Laboratory, Richland, Washington.

PNNL-13024-ICN-1. 2002. RCRA Groundwater Monitoring Plan for Single-Shell Tank Waste Management Area C at the Hanford Site, Interim Change Notice 1. SM Narbutovskih, Pacific Northwest National Laboratory, Richland, Washington.

PNNL-13024-ICN-2. 2003. RCRA Groundwater Monitoring Plan for Single-Shell Tank Waste Management Area C at the Hanford Site, Interim Change Notice 2. SM Narbutovskih and CJ Chou, Pacific Northwest National Laboratory, Richland, Washington.

PNNL-13047. 1999. Groundwater Monitoring Plan for the 216-A-29 Ditch. MD Sweeney, Pacific Northwest National Laboratory, Richland, Washington.

PNNL-13282. 2000. Groundwater Quality Assessment for Waste Management Area U: First Determination. FN Hodges and CJ Chou, Pacific Northwest National Laboratory, Richland, Washington.

PNNL-13367. 2000. Groundwater Monitoring Plan for the Hanford Site 216-B-3 Pond RCRA Facility. DB Barnett, RM Smith, and CJ Chou, Pacific Northwest National Laboratory, Richland, Washington.

PNNL-13367-ICN-1. 2002. Groundwater Monitoring Plan for the Hanford Site 216-B-3 Pond RCRA Facility, Interim Change Notice 1. DB Barnett, RM Smith, and CJ Chou, Pacific Northwest National Laboratory, Richland, Washington. 
PNNL-13378. 2001. Results of Detailed Hydrologic Characterization Tests - Fiscal Year 1999. FA Spane, Jr., PD Thorne, and DR Newcomer, Pacific Northwest National Laboratory, Richland, Washington.

PNNL-13404. 2001. Hanford Site Groundwater Monitoring for Fiscal Year 2000. MJ Hartman, LF Morasch, and WD Webber (eds.), Pacific Northwest National Laboratory, Richland, Washington.

PNNL-13441. 2000. RCRA Groundwater Quality Assessment Report for Waste Management Area S-SX (November 1997 through April 2000). VG Johnson and CJ Chou, Pacific Northwest National Laboratory, Richland, Washington.

PNNL-13514. 2001. Results of Detailed Hydrologic Characterization Tests - Fiscal Year 2000. FA Spane, PD Thorne, and DR Newcomer, Pacific Northwest National Laboratory, Richland, Washington.

PNNL-13612. 2001. Groundwater Quality Assessment Plan for Single-Shell Tank Waste Management Area U. RM Smith, FN Hodges, and BA Williams, Pacific Northwest National Laboratory, Richland, Washington.

PNNL-13612-ICN-1. 2003. Groundwater Quality Assessment Plan for Single-Shell Tank Waste Management Area U, Interim Change Notice 1. RM Smith, FN Hodges, and BA Williams, Pacific Northwest National Laboratory, Richland, Washington.

PNNL-13645. 2001. 300 Area Process Trenches Groundwater Monitoring Plan. JW Lindberg and CJ Chou, Pacific Northwest National Laboratory, Richland, Washington.

PNNL-13652. 2001. Geologic and Wireline Borehole Summary from the Second ILAW Borehole (299-E24-21). SP Reidel, DG Horton, and MM Valenta, Pacific Northwest National Laboratory, Richland, Washington.

PNNL-13914. 2002. Groundwater Monitoring Plan for the 1301-N, 1324-N/NA, and 1325-N RCRA Facilities. MJ Hartman, Pacific Northwest National Laboratory, Richland, Washington.

PNNL-14070. 2002. Groundwater Monitoring Plan for the 216-S-10 Pond and Ditch. BA Williams and CJ Chou, Pacific Northwest National Laboratory, Richland, Washington.

PNNL-14112. 2002. Groundwater Monitoring Plan for the 216-B-63 Trench on the Hanford Site. MD Sweeney, Pacific Northwest National Laboratory, Richland, Washington.

PNNL-14113. 2002. Results of Detailed Hydrologic Characterization Tests - Fiscal Year 2001. FA Spane, Jr., PD Thorne, and DR Newcomer, Pacific Northwest National Laboratory, Richland, Washington.

PNNL-14186. 2003. Results of Detailed Hydrologic Characterization Tests - Fiscal Year 2002. FA Spane, DR Newcomer, and PD Thorne, Pacific Northwest National Laboratory, Richland, Washington.

PNNL-14187. 2003. Hanford Site Groundwater Monitoring for Fiscal Year 2002. MJ Hartman, LF Morasch, and WD Webber (eds.), Pacific Northwest National Laboratory, Richland, Washington.

PNNL-14301. 2003. Monitoring Plan for RCRA Groundwater Assessment at the 216-U-12 Crib. BA Williams and CJ Chou, Pacific Northwest National Laboratory, Richland, Washington.

Resource Conservation and Recovery Act. 1976. Public Law 94-580, as amended, 90 Stat. 2795, 42 USC 6901 et seq.

ROD. 1996. Declaration of the Record of Decision for the 300-FF-1 and 300-FF-5 Operable Units. Washington State Department of Ecology, U.S. Environmental Protection Agency, and U.S. Department of Energy, Richland Operations Office, Richland, Washington.

WAC 173-160-400. What are the Minimum Standards for Resource Protection Wells and Geotechnical Soil Borings? Washington Administrative Code, Olympia, Washington.

WAC 173-303. Dangerous Waste Regulations. Washington Administrative Code, Olympia, Washington. 
WAC 173-303-400. Interim Status Facility Standards. Washington Administrative Code, Olympia, Washington.

WAC 173-303-645. Releases from Regulated Units. Washington Administrative Code, Olympia, Washington.

WAC 173-303-645(11)(g). Releases from Regulated Units, Corrective Action Program. Washington Administrative Code, Olympia, Washington.

WHC-EP-0021. 1987. Interim Hydrogeologic Characterization Report and Groundwater Monitoring System for the Nonradioactive Dangerous Waste Landfill, Hanford Site, Washington. DC Weekes, SP Luttrell, and MR Fuchs, Westinghouse Hanford Company, Richland, Washington.

WHC-SD-EN-AP-015. 1989. Revised Ground-Water Monitoring Plan for the 200 Areas Low-Level Burial Grounds. GV Last and BN Bjornstad, prepared by Pacific Northwest Laboratory for Westinghouse Hanford Company, Richland, Washington.

WHC-SD-EN-AP-024. 1990. Interim Status Groundwater Monitoring Plan for the 200 East Area Liquid Effluent Retention Facility. JS Schmid, Westinghouse Hanford Company, Richland, Washington.

WHC-SD-EN-AP-108. 1993. Interim-Status Groundwater Quality Assessment Plan for the 216-U-12 Crib. BA Williams and CJ Chou, Westinghouse Hanford Company, Richland, Washington.

WHC-SD-EN-AP-185. 1995. Groundwater Monitoring Plan for the 300 Area Process Trenches. JW Lindberg, CJ Chou, and VG Johnson, Westinghouse Hanford Company, Richland, Washington.

WHC-SD-EN-DP-047. 1992. Borehole Completion Data Package for the 216-A-29 RCRA Facility Monitoring Wells: Calendar Year 1991. GL Kasza, Westinghouse Hanford Company, Richland, Washington.

WHC-SD-EN-DP-052. 1993. Borehole Completion Data Package for the 216-S-10 Facility, CY-1992. BA Williams and DB Barnett, Westinghouse Hanford Company, Richland, Washington.

WHC-SD-EN-ES-004. 1993. Site Characterization Report: Results of Detailed Evaluation of the Suitability of the Site Proposed for Disposal of 200 Areas Treated Effluent. JD Davis, DB Barnett, LC Swanson, WJ McMahon, and CD Palomares, Westinghouse Hanford Company, Richland, Washington.

WHC-SD-EN-EV-002. 1990. Interim Hydrogeologic Characterization Report for the 216-B-3 Pond. Westinghouse Hanford Company, Richland, Washington.

WHC-SD-EN-EV-003, Rev. 1. 1992. Results of Groundwater Quality Assessment Monitoring at the 1301-N and 1324-N/NA Facilities. MJ Hartman, Westinghouse Hanford Company, Richland, Washington.

WHC-SD-EN-TI-019. 1992. Hydrogeologic Model for the 200 East Groundwater Aggregate Area. MP Connelly, BH Ford, JW Lindberg, SJ Trent, CD Delaney, and JV Borghese, Westinghouse Hanford Company and Pacific Northwest Laboratory, Richland, Washington. 
Table B.1. RCRA Interim and Final Status Groundwater Monitoring, September 2003

\begin{tabular}{|c|c|c|}
\hline TSD Unit or WMA & Monitoring Phase & $\begin{array}{l}\text { Calendar Year into } \\
\text { Site Permit (closing } \\
\text { or operating) }\end{array}$ \\
\hline $\begin{array}{l}116-\mathrm{N}-1 \mathrm{LWDF} \text { and } \\
116-\mathrm{N}-3 \mathrm{LWDF}\end{array}$ & Final status detection & 1999 (closing) \\
\hline $\begin{array}{l}120-\mathrm{N}-1 \text { and } 120-\mathrm{N}-2 \\
\text { facilities }\end{array}$ & Final status detection & 1999 (closing) \\
\hline $\begin{array}{l}\text { 116-H-6 evaporation } \\
\text { basins }\end{array}$ & $\begin{array}{l}\text { Final status corrective } \\
\text { action }\end{array}$ & 1994 (closing) \\
\hline 216-A-29 ditch & Interim status detection & 2005 (closing) \\
\hline 216-B-3 pond & Interim status detection & 2003 (closing) \\
\hline 216-B-63 trench & Interim status detection & 2005 (closing) \\
\hline $\begin{array}{l}216-S-10 \text { pond and } \\
\text { ditch }\end{array}$ & Interim status detection & 2005 (closing) \\
\hline $216-\mathrm{U}-12 \mathrm{crib}$ & Interim status assessment & 2005 (closing) \\
\hline $316-5$ process trenches & $\begin{array}{l}\text { Final status corrective } \\
\text { action }\end{array}$ & 1996 (closing) \\
\hline IDF & Final status detection & $\begin{array}{l}\text { Operating in } \\
2004\end{array}$ \\
\hline LERF & $\begin{array}{l}\text { Final status detection } \\
\text { suspended }\end{array}$ & 1998 (operating) \\
\hline
\end{tabular}

LLBGs (LLWMAs 1, 2,
3, and 4)

NRDWL

PUREX cribs (216-A-10,

216-A-36B, and

216-A-27-1)

SST WMA A-AX

SST WMA B-BX-BY
Interim status detection

Interim status assessment

Interim status detection

Interim status assessment
Monitoring Plan and Comments

BHI-00725. Closure plan states that during and after closure monitoring will continue under the interim status detection plan.

BHI-00725. Post-closure corrective action monitoring plan will be implemented following permit modification. RCRA corrective action decisions pending final record of decision for 100-NR-2 Operable Unit.

PNNL-11573. Unit has contributed to chromium and nitrate contamination. RCRA monitoring continuing without statistical evaluation during period of 100-HR-3 operable unit's interim action for hexavalent chromium. RCRA corrective action decisions pending final record of decision for 100-HR-3 Operable Unit.

PNNL-13047.

PNNL-13367. In 2-year trial period for alternative statistical technique; decision about post-closure monitoring is pending.

PNNL-14112.

PNNL-14070. Network comprises two downgradient wells and one upgradient well due to dropping water table.

PNNL-14301. Crib has contributed to nitrate contamination. Network comprises two downgradient wells and no upgradient wells due to dropping water table.

PNNL-13645. In 2-year trial period for alternative statistical technique. RCRA corrective action decisions pending final record of decision for 300-FF-5 Operable Unit.

New, proposed TSD. Permit application submitted in 2002; operation pending approval. Baseline groundwater monitoring will begin in 2004.

WHC-SD-EN-AP-024. Unconfined aquifer disappearing as water table drops. Network comprises one downgradient well and one upgradient well.

Washington State Department of Ecology directed DOE to cease statistical evaluations. Continuing to monitor available wells.

Interim status detection 2002 (operating)

WHC-SD-EN-AP-015. Permit application submitted in 2002; interim-status monitoring continues until approval of permit. Wells monitoring north part of LLWMA-2 are dry (5 of 16 original wells); 9 of 20 wells in original LLWMA-3 network are dry; current LLWMA-4 network comprises 2 downgradient wells and 4 upgradient wells (of the original 17 wells).

PNNL-12227.

PNNL-11523. Cribs have contributed to nitrate

contamination.

TBD (closing)

TBD (closing)
PNNL-13023.

PNNL-13022. WMA has contributed to nitrate and nitrite contamination. 
Table B.1. (contd)

Calendar Year into Site Permit (closing

TSD Unit or WMA

SST WMA C

SST WMA S-SX

SST WMA T

SST WMA TX-TY

SST WMA U
Monitoring Phase

Interim status detection

Interim status assessment

Interim status assessment

Interim status assessment

Interim status assessment or operating)

Monitoring Plan and Comments

\section{TBD (closing)}

TBD (closing)

TBD (closing)

TBD (closing)

TBD (closing)
PNNL-13024.

PNNL-12114. WMA has contributed to chromium and nitrate contamination.

PNNL-12057.

PNNL-12072.

PNNL-13612. WMA has contributed to nitrate contamination.

$\overline{\mathrm{DOE}} \quad=$ U.S. Department of Energy.

IDF = Integrated Disposal Facility.

LERF = Liquid effluent retention facility.

LLBG = Low-level burial ground.

LLWMA = Low-level waste management area

LWDF = Liquid waste disposal facility.

NRDWL $=$ Nonradioactive Dangerous Waste Landfill.

PUREX = Plutonium-Uranium Extraction (Plant).

RCRA $=$ Resource Conservation and Recovery Act.

SST $=$ Single-shell tank.

TBD $=$ To be determined.

TSD = Treatment, storage, and disposal.

WMA $=$ Waste management area 
Table B.2. Estimates of Groundwater Flow Rates at Hanford Site Facilities

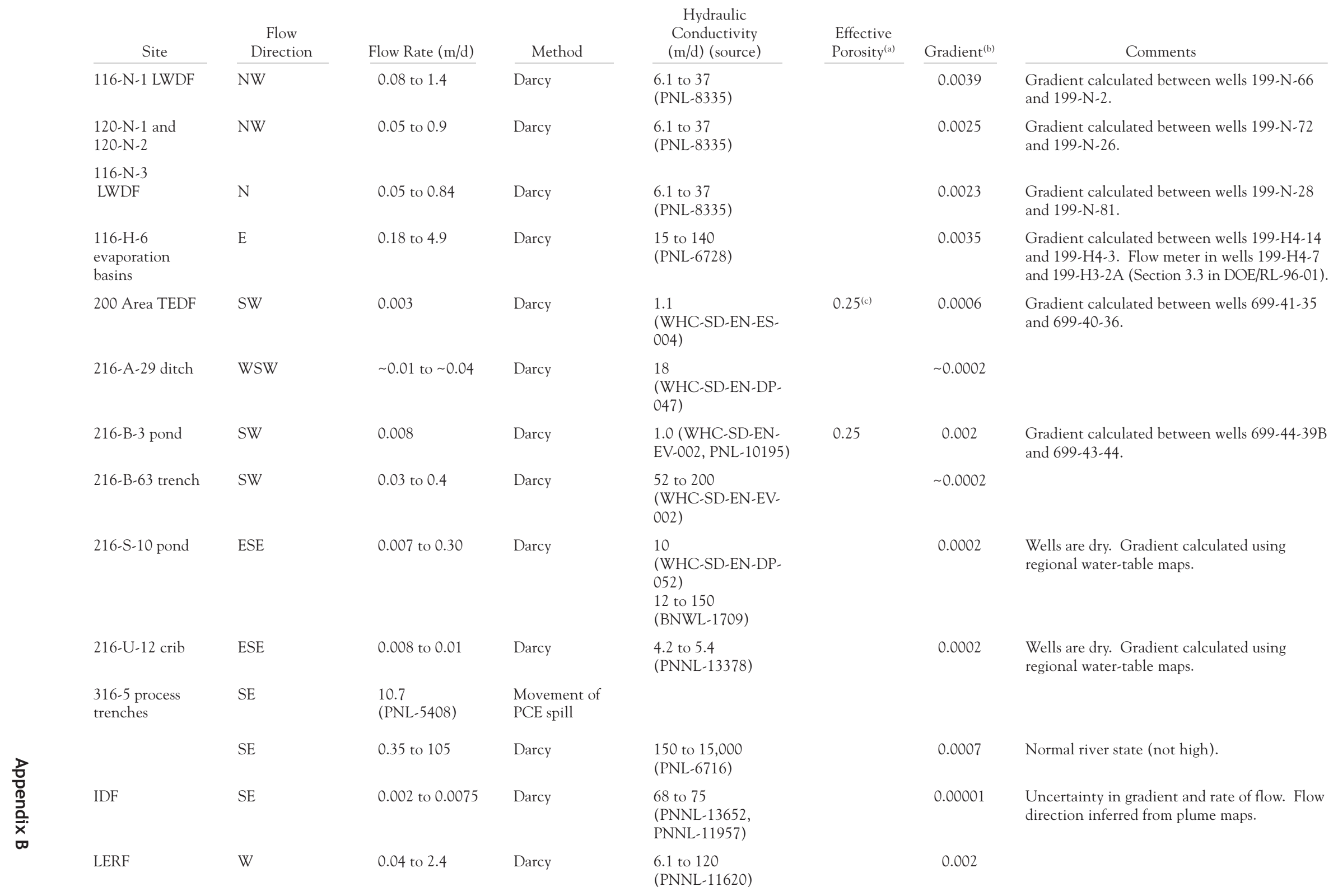


Table B.2. (contd)

Hydraulic

\begin{tabular}{l} 
Site \\
\hline LLWMA 1 \\
LLWMA 2 \\
LLWMA 3 \\
LLWMA 4 \\
NRDWL
\end{tabular}

PUREX cribs

SWL

WMA A-AX

WMA B-BX-BY

WMA C SW

WMA S-SX

\section{WSW}

(north half)

SSE to SE

(south half)

Flow

NW

W to SW

$70^{\circ} \mathrm{E}$ of $\mathrm{N}$

to ENE

plume maps)

SE

$125^{\circ} \mathrm{E}$ of $\mathrm{N}$

(based on

SE

E to ESE $125^{\circ} \mathrm{E}$ of $\mathrm{N}$
(based on $\sim 0.01$ to $\sim 1.6$

$\sim 0.04$ to $\sim 0.6$

0.0001 to 0.14

0.2 to 0.7

0.015 to 0.02

0.3 to 0.0006

0.013 to 0.02

1.7 to 3.3

0.8

1.2 to 2.3

0.07 to 0.14

0.009 to 0.36
Flow Rate (m/d)

(PNL-6820)
Conductivity (m/d) (source)

73 to 760

(PNL-6820)

430 to 2,000

0.02 to 9.8

(PNL-6820)

24

(PNL-6820)

518 to 1,524

(WHC-EP-0021)

18 to 3,000

(PNNL-11523)

640 to 1,280

(PNL-6820)

1,981 to 2,519

(WHC-SD-EN-TI

019)

Darcy

1,615

(WHC-SD-EN-TI-

019)

\section{1,067 to 2,073}

(WHC-SD-EN-TI-019)

Contaminant

travel time

(PNNL-13441)

NA

Darcy

0.58 to 17.2

(aquifer test data)
Effective

Porosity $^{(a)} \quad$ Gradient $^{(\mathrm{b})}$

0.00006

$\sim 0.00003$

$$
\text { gradient. }
$$

Uncertainty with flow direction, rate, and

Gradient calculated between wells 299-E34-10 and 299-E27-9. Uncertainty with flow direction, rate, and gradient.

0.0014 Flow direction from trend-surface analysis.

0.003

Flow direction is variable due to effects of pump-and-treat system.

0.00001 Uncertainty with gradient and rate of flow. Flow direction inferred from plume maps.

0.00001

Uncertainty with gradient and rate of flow. Flow direction inferred from plume maps.

0.00001

Uncertainty with gradient and rate of flow. Flow direction inferred from plume maps.

0.2 to 0.3

0.00026

0.3

0.00015

0.00033

NA

Based on inferred contaminant travel time between 216-S-25 crib and downgradient wells 299-W23-15 and 299-W22-46, and between wells 299-W22-46 and 299-W22-83.

0.09 to $0.12 \quad 0.0018$ to 0.0019
Based on aquifer tests (PNNL-13514 and PNNL-14113). 
Table B.2. (contd)

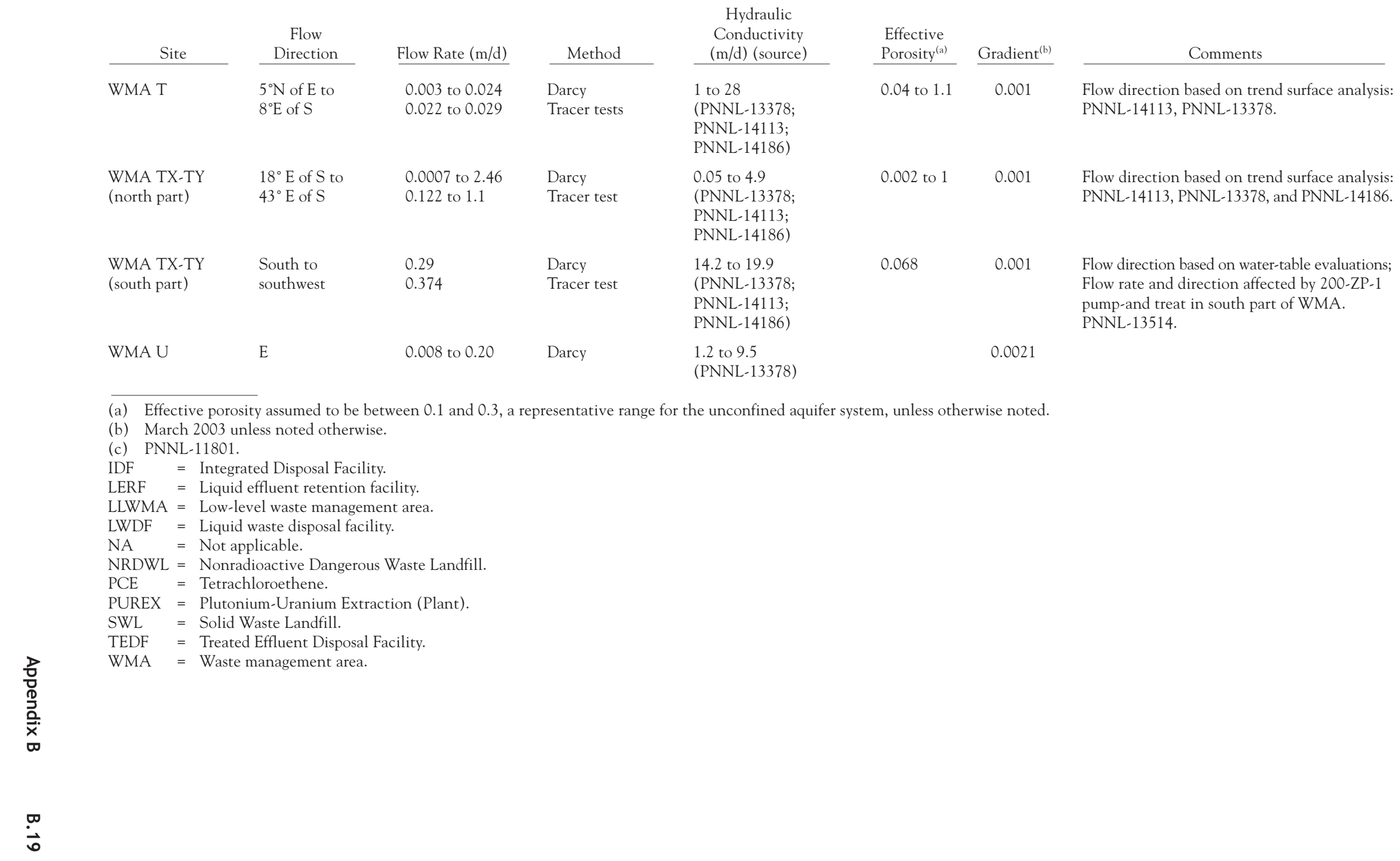


Table B.3. Wells Not Sampled as Scheduled for RCRA Facilities, Fiscal Year 2003

\begin{tabular}{|c|c|c|c|}
\hline Well & Schedule & Site & Comments \\
\hline $199-N-59$ & 03/01/03 & $120-\mathrm{N}-1$ & Temporarily dry \\
\hline $199-N-59$ & 09/01/03 & $120-\mathrm{N}-1$ & Temporarily dry \\
\hline 299-E17-9 & 04/01/03 & PUREX & Dry; one semiannual sample missed \\
\hline 299-E26-11 & $09 / 01 / 03$ & LERF & Change to semiannual in December and June \\
\hline 299-E34-3 & $10 / 01 / 02$ & LLBG (2) & Dry \\
\hline 299-E34-3 & $04 / 01 / 03$ & LLBG (2) & Dry \\
\hline 299-W10-13 & 03/01/03 & LLBG (3) & Dry in fiscal year 2002 \\
\hline 299-W10-13 & 09/01/03 & LLBG (3) & Dry in fiscal year 2002 \\
\hline 299-W10-27 & $02 / 01 / 03$ & WMA TX-TY & Pump problem; one quarter missed \\
\hline 299-W11-30 & $11 / 01 / 02$ & WMA T & Dry in fiscal year 2002 \\
\hline 299-W11-30 & 05/01/03 & WMA T & Dry in fiscal year 2002 \\
\hline 299-W18-24 & $07 / 01 / 03$ & LLBG (4) & Dry; one semiannual sample missed \\
\hline 299-W7-8 & $03 / 01 / 03$ & LLBG (3) & Dry in fiscal year 2002 \\
\hline 299-W7-8 & 09/01/03 & LLBG (3) & Dry in fiscal year 2002 \\
\hline
\end{tabular}

LERF $=$ Liquid Effluent Retention Facility.

LLBG = Low-level burial ground.

PUREX = Plutonium-Uranium Extraction Plant.

WMA $=$ Waste management area. 
Table B.4. Monitoring Wells and Constituents for 100-N Area Units (adapted from PNNL-13914)

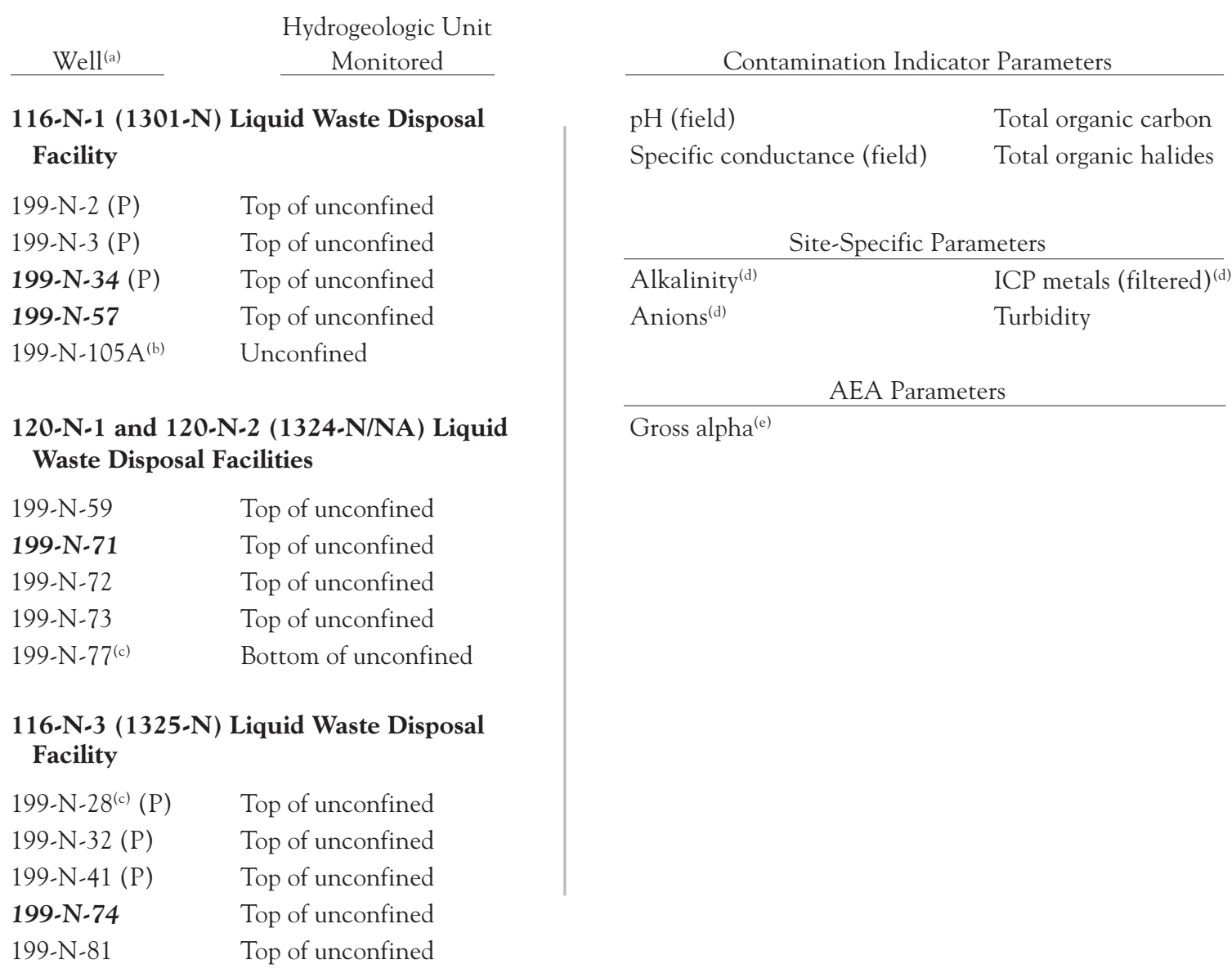

(a) All wells constructed to WAC 173-160-400 standards unless noted (P), pre-RCRA. All wells sampled semiannually.

(b) Extraction well; screened over entire thickness of aquifer.

(c) Used for supplemental information; no statistical evaluations.

(d) Annually for 116-N-1 and 116-N-3 liquid waste disposal facilities.

(e) Gross alpha analyzed for wells 199-N-59 and 199-N-77 only.

Bold italic $=$ Upgradient wells.

AEA $=$ Atomic Energy Act of 1954 .

ICP = Inductively coupled plasma emission spectroscopy.

RCRA = Resource Conservation and Recovery Act. 
Table B.5. Critical Means for 116-N-1 (1301-N) Liquid Waste Disposal Facility for Fiscal Year 2004 Comparisons $^{(\mathrm{a})}$

\begin{tabular}{|c|c|c|c|c|c|c|c|}
\hline Constituent, unit & $\mathrm{n}$ & df & $t_{c}$ & $\begin{array}{c}\text { Average } \\
\text { Background } \\
\end{array}$ & $\begin{array}{l}\text { Standard } \\
\text { Deviation } \\
\end{array}$ & $\begin{array}{l}\text { Critical } \\
\text { Mean }\end{array}$ & $\begin{array}{c}\text { Upgradient/ } \\
\text { Downgradient } \\
\text { Comparison Value }\end{array}$ \\
\hline $\begin{array}{l}\text { Specific conductance, } \\
\mu \mathrm{S} / \mathrm{cm}\end{array}$ & 8 & 7 & 5.4079 & 518 & 103.7 & 1,113 & 1,113 \\
\hline Field pH & 8 & 7 & 6.0818 & 7.818 & 0.146 & {$[6.88,8.76]$} & {$[6.88,8.76]$} \\
\hline $\begin{array}{l}\text { Total organic carbon, }{ }^{(b)} \\
\mu \mathrm{g} / \mathrm{L}\end{array}$ & 8 & 7 & 5.4079 & 421.35 & 379.330 & 2,597 & $2,600^{(c)}$ \\
\hline $\begin{array}{l}\text { Total organic halides, }{ }^{(b)} \\
\mu / / L\end{array}$ & 8 & 7 & 5.4079 & 5.975 & 4.575 & 32.2 & 32.2 \\
\hline
\end{tabular}

(a) Based on semiannual sampling events from March 2002 to September 2003 for upgradient wells 199-N-57 and 199-N-34.

(b) Critical means calculated from values reported below vendor's specified method detection limit.

(c) Rounded to the nearest tenth.

$\mathrm{df}=$ Degrees of freedom $(\mathrm{n}-1)$.

$\mathrm{n}=$ Number of background replicate averages.

$\mathrm{t}_{\mathrm{c}}=$ Bonferroni critical $\mathrm{t}$-value for appropriate $\mathrm{df}$ and 20 comparisons.

Table B.6. Critical Means for 120-N-1 and 120-N-2 (1324-N/NA) Liquid Waste Disposal Facilities for Fiscal Year 2004 Comparisons $^{(a)}$

\begin{tabular}{|c|c|c|c|c|c|c|c|}
\hline Constituent, unit & $\mathrm{n}$ & df & $t_{c}$ & $\begin{array}{c}\text { Average } \\
\text { Background } \\
\end{array}$ & $\begin{array}{l}\text { Standard } \\
\text { Deviation } \\
\end{array}$ & $\begin{array}{l}\text { Critical } \\
\text { Mean }\end{array}$ & $\begin{array}{c}\text { Upgradient/ } \\
\text { Downgradient } \\
\text { Comparison Value }\end{array}$ \\
\hline $\begin{array}{l}\text { Specific conductance, } \\
\mu \mathrm{S} / \mathrm{cm}\end{array}$ & 5 & 4 & 7.5288 & 366.2 & 14.9 & 489 & 489 \\
\hline Field $\mathrm{pH}$ & 5 & 4 & 9.0294 & 8.138 & 0.045 & {$[7.69,8.58]$} & {$[7.69,8.58]$} \\
\hline $\begin{array}{l}\text { Total organic carbon, }{ }^{(b)} \\
\mu \mathrm{g} / \mathrm{L}\end{array}$ & 5 & 4 & 7.5288 & 280.5 & 181.215 & 1,775 & $1,780^{(c)}$ \\
\hline $\begin{array}{l}\text { Total organic halides, }{ }^{(b)} \\
\mu \mathrm{g} / \mathrm{L}\end{array}$ & 5 & 4 & 7.5288 & 6.385 & 2.226 & 24.7 & 24.7 \\
\hline
\end{tabular}

(a) Based on semiannual sampling events from September 2001 to September 2003 for upgradient well 199-N-71.

(b) Critical means calculated from values reported below vendor's specified method detection limit.

(c) Rounded to the nearest tenth.

$\mathrm{df}=$ Degrees of freedom $(\mathrm{n}-1)$.

$\mathrm{n}=$ Number of background replicate averages.

$\mathrm{t}_{\mathrm{c}}=$ Bonferroni critical $\mathrm{t}$-value for appropriate $\mathrm{df}$ and 12 comparisons. 
Table B.7. Critical Means for 116-N-3 (1325-N) Liquid Waste Disposal Facility for Fiscal Year 2004 Comparisons $s^{(a)}$

\begin{tabular}{|c|c|c|c|c|c|c|c|}
\hline Constituent, unit & $\mathrm{n}$ & $\underline{\mathrm{df}}$ & $t_{c}$ & $\begin{array}{c}\text { Average } \\
\text { Background } \\
\end{array}$ & $\begin{array}{c}\text { Standard } \\
\text { Deviation } \\
\end{array}$ & $\begin{array}{l}\text { Critical } \\
\text { Mean }\end{array}$ & $\begin{array}{c}\text { Upgradient/ } \\
\text { Downgradient } \\
\text { Comparison Value } \\
\end{array}$ \\
\hline $\begin{array}{l}\text { Specific conductance, } \\
\mu \mathrm{S} / \mathrm{cm}\end{array}$ & 5 & 4 & 8.1216 & 358.7 & 10.4 & 451 & 451 \\
\hline Field $\mathrm{pH}$ & 5 & 4 & 9.7291 & 8.12 & 0.032 & {$[7.78,8.45]$} & {$[7.78,8.45]$} \\
\hline $\begin{array}{l}\text { Total organic carbon, }{ }^{(b, c)} \\
\mu \mathrm{g} / \mathrm{L}\end{array}$ & 5 & 4 & 8.1216 & 179 & 94.515 & 1,020 & 1,360 \\
\hline $\begin{array}{l}\text { Total organic halides, } \\
\mu \mathrm{g} / \mathrm{L}\end{array}$ & 5 & 4 & 8.1216 & 7.86 & 2.358 & 28.8 & 28.8 \\
\hline
\end{tabular}

(a) Based on semiannual sampling events from September 2001 to September 2003 for upgradient well 199-N-74.

(b) Critical means calculated from values reported below vendor specified method detection limit.

(c) Upgradient/downgradient comparison value is the most recent determined limit of quantitation (see Table D.23).

df $=$ Degrees of freedom $(n-1)$.

$\mathrm{n}=$ Number of background replicate averages.

$\mathrm{t}_{\mathrm{c}}=$ Bonferroni critical $\mathrm{t}$-value for appropriate $\mathrm{df}$ and 16 comparisons.

Table B.8. Monitoring Wells and Constituents for the 116-H-6 (183-H) Evaporation Basins (adapted from PNNL-11573)

\begin{tabular}{|c|c|c|c|}
\hline Well ${ }^{(\mathrm{a})}$ & $\begin{array}{l}\text { Hydrogeologic Unit } \\
\text { Monitored }\end{array}$ & \multicolumn{2}{|c|}{ Dangerous Waste Constituents } \\
\hline 199-H4-3 (P) & Top of unconfined & Chromium (filtered) & Nitrate \\
\hline $199-\mathrm{H} 4-7^{(b)}$ & Top of unconfined & Fluoride & \\
\hline $199-\mathrm{H} 4-12 \mathrm{~A}^{(\mathrm{b})}$ & Top of unconfined & \multicolumn{2}{|c|}{ Site-Specific Parameters } \\
\hline \multirow[t]{5}{*}{ 199-H4-12C } & Mid-depth unconfined & Alkalinity & $\mathrm{pH}$ \\
\hline & & Anions & Specific conductance \\
\hline & & ICP metals (filtered) & Turbidity \\
\hline & & \multicolumn{2}{|c|}{ Other Parameters ${ }^{(c)}$} \\
\hline & & Technetium-99 & Uranium \\
\hline
\end{tabular}

(a) All wells constructed to WAC 173-160-400 standards unless noted (P), pre-RCRA. All wells are sampled annually.

(b) Also a CERCLA extraction well.

(c) Radionuclides not typically subject to RCRA monitoring, but included in the current Hanford Facility RCRA Permit (Ecology 1994) for this facility.

CERCLA = Comprehensive Environmental Response, Compensation, and Liability Act.

ICP = Inductively coupled plasma emission spectroscopy.

RCRA $=$ Resource Conservation and Recovery Act. 
Table B.9. Monitoring Wells and Constituents for the 216-A-29 Ditch (adapted from PNNL-13047)

\begin{tabular}{|c|c|c|c|}
\hline Well $^{(\mathrm{a})}$ & $\begin{array}{c}\text { Hydrogeologic Unit } \\
\text { Monitored } \\
\end{array}$ & \multicolumn{2}{|c|}{ Contamination Indicator Parameters } \\
\hline 299-E25-26 & Upper unconfined & $\mathrm{pH}$ (field) & Total organic carbon \\
\hline 299-E25-28(b) & Deep unconfined & Specific conductance (field) & Total organic halides \\
\hline 299-E25-32P & Top of unconfined & & \\
\hline 299-E25-34 & Top of unconfined & \multicolumn{2}{|c|}{ Site-Specific Parameters } \\
\hline 299-E25-35 & Top of unconfined & Alkalinity & Phenols \\
\hline 299-E25-48 & Top of unconfined & Anions & Turbidity \\
\hline 299-E26-12 & Top of unconfined & ICP metals (filtered) ${ }^{(c)}$ & \\
\hline 299-E26-13 & Top of unconfined & & \\
\hline $699-43-45$ & Top of unconfined & & \\
\hline
\end{tabular}

(a) All wells constructed to WAC 173-160-400 standards. All wells sampled quarterly.

(b) Used for supplemental information; no statistical evaluations.

(c) Analyzed annually.

Bold italic $=$ Upgradient wells.

ICP = Inductively coupled plasma emission spectroscopy.

Table B.10. Critical Means for the 216-A-29 Ditch for Fiscal Year 2004 Comparisons $^{\left(a^{2}\right.}$

\begin{tabular}{|c|c|c|c|c|c|c|c|}
\hline Constituent, unit & $\mathrm{n}$ & $\underline{\mathrm{df}}$ & $t_{c}$ & $\begin{array}{c}\text { Average } \\
\text { Background } \\
\end{array}$ & $\begin{array}{l}\text { Standard } \\
\text { Deviation } \\
\end{array}$ & $\begin{array}{l}\text { Critical } \\
\text { Mean }\end{array}$ & $\begin{array}{c}\text { Upgradient/ } \\
\text { Downgradient } \\
\text { Comparison Value } \\
\end{array}$ \\
\hline $\begin{array}{l}\text { Specific conductance, } \\
\mu S / c m\end{array}$ & 4 & 3 & 15.145 & 236.2 & 2.0 & 271 & 271 \\
\hline Field $\mathrm{pH}$ & 4 & 3 & 19.118 & 8.349 & 0.036 & {$[7.59,9.11]$} & {$[7.59,9.11]$} \\
\hline $\begin{array}{l}\text { Total organic carbon, } \\
\mu \mathrm{g} / \mathrm{L}\end{array}$ & 4 & 3 & 15.145 & 289.38 & 142.235 & 2,698 & $2,700^{\text {(c) }}$ \\
\hline $\begin{array}{l}\text { Total organic halides, }{ }^{(b, d)} \\
\mu g / L\end{array}$ & 4 & 3 & 15.145 & $\mathrm{NC}$ & $\mathrm{NC}$ & $\mathrm{NC}$ & 14.9 \\
\hline
\end{tabular}

(a) Based on semiannual sampling events from April 2002 to April 2003 for upgradient well 699-43-45.

(b) Critical mean cannot be calculated because essentially all measurements are below vendor's specified method detection limit.

(c) Rounded to the nearest tenth.

(d) Upgradient/downgradient comparison value is the most recent determined limit of quantitation (see Table D.23).

$\mathrm{df}=$ Degrees of freedom $(\mathrm{n}-1)$.

$\mathrm{n}=$ Number of background replicate averages.

$\mathrm{NC}=$ Not calculated

$\mathrm{t}_{\mathrm{c}}=$ Bonferroni critical $\mathrm{t}$-value for appropriate $\mathrm{df}$ and 32 comparisons. 
Table B.11. Monitoring Wells and Constituents for the 216-B-3 Pond (adapted from PNNL-13367-ICN-1)

\begin{tabular}{ll}
\multicolumn{1}{c}{ Well $^{(\text {a) }}$} & \multicolumn{1}{c}{$\begin{array}{c}\text { Hydrogeologic Unit } \\
\text { Monitored }\end{array}$} \\
$699-42-42 B$ & Top of uppermost \\
$699-43-44$ & Bottom of uppermost \\
$699-43-45$ & Top of uppermost \\
$699-44-39 B$ & Top of uppermost
\end{tabular}

Site-Specific Indicator Parameters

\begin{tabular}{lc}
$\begin{array}{l}\text { Gross alpha } \\
\text { Gross beta }\end{array}$ & Specific conductance (field) \\
& Site-Specific \\
& Parameters \\
\hline Anions $^{(\mathrm{b})}$ & Nitrate $^{(\mathrm{c})}$ \\
Arsenic $^{(\mathrm{c})}$ & Phenols $^{(\mathrm{b})}$ \\
Metals (filtered, unfiltered) $^{(\mathrm{b}, \mathrm{d})}$ & Tritium $^{(\mathrm{c})}$ \\
Iodine-129(c) $^{\text {(c) }}$ & Turbidity
\end{tabular}

(a) All wells constructed to WAC 173-160-400 standards. All wells sampled semiannually.

(b) Analyzed annually.

(c) Constituents of site-wide concern; selected wells analyzed under AEA monitoring.

(d) ICP plus cadmium, lead, mercury, and silver.

Bold italic $=$ Upgradient well.

AEA $=$ Atomic Energy Act of 1954 .

ICP = Inductively coupled plasma emission spectroscopy.

Table B.12. Critical Means for the 216-B-3 Pond for Fiscal Year 2004 Comparisons $^{(\mathrm{a})}$

\begin{tabular}{|c|c|c|c|c|c|c|c|}
\hline Constituent, unit & $\mathrm{n}$ & df & $t_{c}$ & $\begin{array}{c}\text { Average } \\
\text { Background } \\
\end{array}$ & $\begin{array}{l}\text { Standard } \\
\text { Deviation }\end{array}$ & $\begin{array}{l}\text { Critical } \\
\text { Mean }\end{array}$ & $\begin{array}{c}\text { Upgradient/ } \\
\text { Downgradient } \\
\text { Comparison Value }\end{array}$ \\
\hline $\begin{array}{l}\text { Specific conductance, } \\
\mu \mathrm{S} / \mathrm{cm}\end{array}$ & 5 & 4 & 8.1216 & 260.4 & 9.5 & 345 & 345 \\
\hline Field $\mathrm{pH}$ & 5 & 4 & 9.7291 & 8.14 & 0.051 & {$[7.60,8.68]$} & {$[7.60,8.68]$} \\
\hline $\begin{array}{l}\text { Total organic carbon, } \\
\mu \mathrm{g} / \mathrm{L}\end{array}$ & 5 & 4 & 8.1216 & 598.15 & 301.433 & 3,280 & 3,280 \\
\hline $\begin{array}{l}\text { Total organic halides, }{ }^{(b)} \\
\mu \mathrm{g} / \mathrm{L}\end{array}$ & 5 & 4 & 8.1216 & $\mathrm{NC}$ & $\mathrm{NC}$ & $\mathrm{NC}$ & 14.9 \\
\hline
\end{tabular}

(a) Based on semiannual sampling events from June 1999 to June 2001 for upgradient well 699-44-39B. Background levels will be revised when four quarters of data are available in 2004.

(b) Critical mean cannot be calculated because essentially all measurements are below vendor's specified method detection limit. Upgradient/downgradient comparison value is the most recent determined limit of quantitation (see Table D.23).

$\mathrm{df}=$ Degrees of freedom $(\mathrm{n}-1)$.

$\mathrm{n}=$ Number of background replicate averages.

$\mathrm{NC}=$ Not calculated

$t_{c}=$ Bonferroni critical $t$-value for appropriate $\mathrm{df}$ and 16 comparisons. 
Table B.13. Monitoring Wells and Constituents for the 216-B-63 Trench (adapted from PNNL-14112)

\begin{tabular}{|c|c|c|c|}
\hline Well $^{(\mathrm{a})}$ & $\begin{array}{c}\text { Hydrogeologic Unit } \\
\text { Monitored }\end{array}$ & \multicolumn{2}{|c|}{ Contamination Indicator Parameters } \\
\hline 299-E27-8 & Top of unconfined & $\mathrm{pH}$ (field) & Total organic carbon \\
\hline 299-E27-9 & Top of unconfined & Specific conductance (field) & Total organic halides \\
\hline 299-E27-11 & Top of unconfined & & \\
\hline 299-E27-16 & Top of unconfined & \multicolumn{2}{|c|}{ Site-Specific Parameters } \\
\hline 299-E27-17 & Top of unconfined & Alkalinity $^{(\mathrm{b})}$ & Phenols $^{(b)}$ \\
\hline 299-E27-18 & Top of unconfined & Anions $^{(\mathrm{b})}$ & Turbidity \\
\hline 299-E27-19 & Top of unconfined & \multicolumn{2}{|l|}{ ICP metals (filtered) ${ }^{(\mathrm{b})}$} \\
\hline 299-E33-33 & Top of unconfined & & \\
\hline 299-E33-36 & Top of unconfined & \multicolumn{2}{|c|}{ AEA Parameters ${ }^{(c)}$} \\
\hline 299-E33-37 & Top of unconfined & Gross alpha & Gross beta \\
\hline 299-E34-8 & Top of unconfined & & \\
\hline 299-E34-10 & Top of unconfined & & \\
\hline
\end{tabular}

(a) All wells constructed to WAC 173-160-400 standards. All wells sampled semiannually.

(b) Analyzed annually.

(c) Analyzed to support AEA monitoring.

Bold italic $=$ Upgradient wells.

AEA $=$ Atomic Energy Act of 1954 .

ICP = Inductively coupled plasma emission spectroscopy.

Table B.14. Critical Means for the 216-B-63 Trench for Fiscal Year 2004 Comparisons $^{\left({ }^{(a)}\right.}$

\begin{tabular}{|c|c|c|c|c|c|c|c|}
\hline Constituent, unit & $\mathrm{n}$ & $\underline{\mathrm{df}}$ & $t_{c}$ & $\begin{array}{c}\text { Average } \\
\text { Background }\end{array}$ & $\begin{array}{l}\text { Standard } \\
\text { Deviation } \\
\end{array}$ & $\begin{array}{l}\text { Critical } \\
\text { Mean }\end{array}$ & $\begin{array}{c}\text { Upgradient/ } \\
\text { Downgradient } \\
\text { Comparison Value }\end{array}$ \\
\hline $\begin{array}{l}\text { Specific conductance, } \\
\mu \mathrm{S} / \mathrm{cm}\end{array}$ & 20 & 19 & 4.267 & 416.9 & 28.5 & 541 & 541 \\
\hline Field $\mathrm{pH}$ & 20 & 19 & 4.572 & 8.063 & 0.064 & {$[7.76,8.36]$} & {$[7.76,8.36]$} \\
\hline $\begin{array}{l}\text { Total organic carbon, }{ }^{(b)} \\
\mu \mathrm{g} / \mathrm{L}\end{array}$ & 20 & 19 & 4.267 & 288.375 & 187.587 & 1,109 & 1,360 \\
\hline $\begin{array}{l}\text { Total organic halides, }{ }^{(b, c)} \\
\mu \mathrm{g} / \mathrm{L}\end{array}$ & 20 & 19 & 4.267 & $\mathrm{NC}$ & $\mathrm{NC}$ & $\mathrm{NC}$ & 14.9 \\
\hline
\end{tabular}

(a) Based on semiannual sampling events from October 2001 to April 2003 for upgradient wells 299-E27-8, 299-E27-9, 299-E27-11, 299-E27-17, and 299-E34-10.

(b) Upgradient/downgradient comparison value is the most recently determined limit of quantitation (see Table D.23).

(c) Critical mean cannot be calculated because essentially all measurements are below vendor's specified method detection limit.

$\mathrm{df}=$ Degrees of freedom $(\mathrm{n}-1)$.

$\mathrm{n}=$ Number of background replicate averages.

$\mathrm{NC}=$ Not calculated

$\mathrm{t}_{\mathrm{c}}=$ Bonferroni critical $\mathrm{t}$-value for appropriate $\mathrm{df}$ and 48 comparisons. 
Table B.15. Monitoring Wells and Constituents for the 216-S-10 Pond and Ditch (adapted from PNNL-14070)

\begin{tabular}{|c|c|}
\hline Well $^{(a)}$ & $\begin{array}{c}\text { Hydrogeologic Unit } \\
\text { Monitored } \\
\end{array}$ \\
\hline 299-W26-7 & Top of unconfined \\
\hline 299-W26-13 & Top of unconfined \\
\hline 299-W26-14 & Top of unconfined \\
\hline 299-W27-2(c) & Base of unconfined \\
\hline
\end{tabular}

\begin{tabular}{|c|c|}
\hline \multicolumn{2}{|c|}{ Contamination Indicator Parameters } \\
\hline pH (field) & Specific conductance (field) \\
\hline Total organic carbon ${ }^{(b)}$ & Total organic halides ${ }^{(b)}$ \\
\hline \multicolumn{2}{|c|}{ Site-Specific Parameters } \\
\hline Alkalinity $^{(\mathrm{d})}$ & ICP metals (filtered) $)^{(\mathrm{d})}$ \\
\hline Anions $^{(\mathrm{d})}$ & Phenols ${ }^{(\mathrm{b}, \mathrm{d})}$ \\
\hline Hexavalent chromium & Turbidity ${ }^{(\mathrm{e})}$ \\
\hline$(\text { filtered })^{(\mathrm{e})}$ & Volatile organic compounds $s^{(\mathrm{e})}$ \\
\hline
\end{tabular}

(a) All wells constructed to WAC 173-160-400 standards and sampled semiannually. Well 299-W26-7 went dry after fiscal year 2003 sampling.

(b) Not analyzed in well 299-W27-2.

(c) Used for supplemental information; no statistical evaluation.

(d) Analyzed annually only.

(e) Analyzed semiannually.

Bold italic $=$ Upgradient wells.

ICP = Inductively coupled plasma emission spectroscopy.

Table B.16. Critical Means for the 216-S-10 Pond and Ditch for Fiscal Year 2004 Comparisons $^{(a)}$

\begin{tabular}{|c|c|c|c|c|c|c|c|}
\hline Constituent, unit & $\mathrm{n}$ & df & $t_{c}$ & $\begin{array}{c}\text { Average } \\
\text { Background } \\
\end{array}$ & $\begin{array}{l}\text { Standard } \\
\text { Deviation } \\
\end{array}$ & $\begin{array}{l}\text { Critical } \\
\text { Mean }\end{array}$ & $\begin{array}{c}\text { Upgradient/ } \\
\text { Downgradient } \\
\text { Comparison Value }\end{array}$ \\
\hline $\begin{array}{l}\text { Specific conductance, } \\
\mu \mathrm{S} / \mathrm{cm}\end{array}$ & 4 & 3 & 10.8689 & 269.8 & 2.2 & 296 & 296 \\
\hline Field $\mathrm{pH}$ & 4 & 3 & 13.745 & 8.109 & 0.041 & {$[7.49,8.73]$} & {$[7.49,8.73]$} \\
\hline $\begin{array}{l}\text { Total organic carbon, }{ }^{(b, c)} \\
\mu \mathrm{g} / \mathrm{L}\end{array}$ & 4 & 3 & 10.8689 & 195.625 & 90.884 & 1,300 & 1,360 \\
\hline $\begin{array}{l}\text { Total organic halides, }(c, d) \\
\mu \mathrm{g} / \mathrm{L}\end{array}$ & 4 & 3 & 10.8689 & $\mathrm{NC}$ & $\mathrm{NC}$ & $\mathrm{NC}$ & 14.9 \\
\hline
\end{tabular}

(a) Based on semiannual sampling events from December 2001 to June 2003 for upgradient well 299-W26-7, which went dry in 2003. Background levels will be revised when data from a new upgradient well are available.

(b) Critical mean calculated from values reported below vendor's specified method detection limit.

(c) Upgradient/downgradient comparison value is the most recently determined limit of quantitation (see Table D.23).

(d) Critical mean cannot be calculated because essentially all measurements are below vendor specified detection limit.

df $=$ Degrees of freedom (n-1).

$\mathrm{n}=$ Number of background replicate averages.

$\mathrm{NC}=$ Not calculated.

$\mathrm{t}_{\mathrm{c}}=$ Bonferroni critical $\mathrm{t}$-value for appropriate $\mathrm{df}$ and 12 comparisons. 
Table B.17. Monitoring Wells and Constituents for the 216-U-12 Crib (adapted from WHC-SD-EN-AP-108 and PNNL-14301)

\begin{tabular}{|c|c|}
\hline Well (a) & $\begin{array}{c}\text { Hydrogeologic Unit } \\
\text { Monitored } \\
\end{array}$ \\
\hline 299-W22-79 & Top of unconfined \\
\hline $699-36-70 \mathrm{~A}$ & Top of unconfined \\
\hline
\end{tabular}

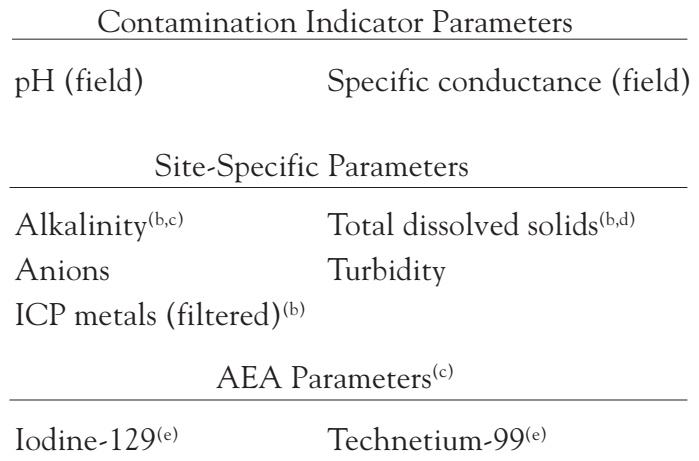

(a) Both wells constructed to WAC 173-160-400 standards and sampled quarterly.

(b) Analyzed annually.

(c) Analyzed to support AEA monitoring.

(d) Well 699-36-70A only.

(e) Analyzed semiannually.

AEA = Atomic Energy Act of 1954 .

$\mathrm{ICP}=$ Inductively coupled plasma emission spectroscopy.

Table B.18. Monitoring Wells and Constituents for the 316-5 Process Trenches

\begin{tabular}{|c|c|}
\hline \multicolumn{2}{|c|}{ Adapted from PNNL-13645 } \\
\hline Well (a) $^{(\mathrm{a})}$ & $\begin{array}{c}\text { Hydrogeologic Unit } \\
\text { Monitored } \\
\end{array}$ \\
\hline $399-1-7$ & Top of unconfined \\
\hline $399-1-8(\mathrm{~S})$ & Bottom of unconfined \\
\hline $399-1-10 \mathrm{~A}$ & Top of unconfined \\
\hline 399-1-10B (S) & Bottom of unconfined \\
\hline $399-1-11$ & Top of unconfined \\
\hline $399-1-16 \mathrm{~A}$ & Top of unconfined \\
\hline $399-1-16 \mathrm{~B}$ & Bottom of unconfined \\
\hline $399-1-17 \mathrm{~A}$ & Top of unconfined \\
\hline 399-1-17B (S) & Bottom of unconfined \\
\hline $399-1-21 \mathrm{~A}(\mathrm{~S})$ & Top of unconfined \\
\hline $399-1-21 B(S)$ & Bottom of unconfined \\
\hline
\end{tabular}

\begin{tabular}{|c|c|}
\hline Well $^{(\mathrm{b})}$ & $\begin{array}{c}\text { Hydrogeologic Unit } \\
\text { Monitored }\end{array}$ \\
\hline 399-1-10A & Top of unconfined \\
\hline $399-1-10 B$ & Bottom of unconfined \\
\hline $399-1-16 \mathrm{~A}$ & Top of unconfined \\
\hline $399-1-16 B$ & Bottom of unconfined \\
\hline 399-1-17A & Top of unconfined \\
\hline $399-1-17 B$ & Bottom of unconfined \\
\hline $399-1-18 \mathrm{~A}$ & Top of unconfined \\
\hline $399-1-18 B$ & Bottom of unconfined \\
\hline
\end{tabular}

Field-Measured Parameters

Site-Specific Parameters
$\begin{aligned} & \text { cis-1,2-dichloroethene } \\ & \text { Tetrachloroethene }\end{aligned}$

$\mathrm{pH} \quad$ Turbidity

Specific conductance

Tetrachloroethene

AEA Parameters

Uranium

(a) All wells constructed to WAC 173-160-400 standards. Wells sampled quarterly unless noted (S), semiannually.

(b) All wells constructed to WAC 173-160-400 standards. All wells sampled for four consecutive months, twice per year (semiannually).

AEA = Atomic Energy Act of 1954 . 
Table B.19. Monitoring Wells and Constituents for the Integrated Disposal Facility (adapted from DOE/RL-2003-12)

\section{Well(a)}

299-E17-22

299-E17-23

299-E17-25

299-E24-21

Proposed downgradient well 1

Proposed downgradient well 2

Proposed upgradient well 3
Contaminants of Concern ${ }^{(\mathrm{b})}$

40 CFR 264, Appendix IX

\begin{tabular}{ll}
\multicolumn{2}{c}{ Indicator Parameters ${ }^{(c)}$} \\
\hline Chromium (filtered) & Total organic carbon \\
$\mathrm{pH}$ & Total organic halides
\end{tabular}

Specific conductance (field)

\begin{tabular}{lc} 
& Supplemental Parameters \\
\hline Alkalinity & ICP metals \\
Anions & Turbidity (field)
\end{tabular}

(a) All wells constructed to WAC 173-160-400 standards. All wells completed at the top of the unconfined aquifer. One upgradient well and one downgradient well scheduled for installation in late fiscal year 2004. The second downgradient well is proposed for an unspecified time in the future.

(b) Sampled one time per well.

(c) Sampled two times per quarter for 1 year to establish background, then four times semiannually (total of eight samples per well per year) thereafter.

(d) Sampled semiannually.

ICP = Inductively coupled plasma emission spectroscopy.

Table B.20. Monitoring Wells and Constituents for the Liquid Effluent Retention Facility (adapted from WHC-SD-EN-AP-024)

Well $^{(\mathrm{a})}$

299-E26-10 (S)

299-E26-11 (Q)
Hydrogeologic Unit

Monitored
Top of unconfined
Top of unconfined

\begin{tabular}{|c|c|}
\hline \multicolumn{2}{|c|}{ Contamination Indicator Parameters ${ }^{(\mathrm{b})}$} \\
\hline $\mathrm{pH}$ (field) & Total organic carbon \\
\hline Specific conductance (field) & Total organic halides \\
\hline \multicolumn{2}{|c|}{ Site-Specific Parameters } \\
\hline Alkalinity ${ }^{(c)}$ & Phenols ${ }^{(c)}$ \\
\hline Ammonium $^{(c)}$ & Temperature \\
\hline Anions $^{(c)}$ & Turbidity \\
\hline ICP metals (filtered) $)^{(c)}$ & Volatile organic compound \\
\hline \multicolumn{2}{|c|}{ AEA Parameters ${ }^{(\mathrm{d})}$} \\
\hline Gross alpha $^{(\mathrm{c})}$ & Gross beta ${ }^{(c)}$ \\
\hline
\end{tabular}

(a) Both wells constructed to WAC-160-400 standards. Both wells sampled quarterly.

(b) Statistical evaluations suspended in January 2001 because only one downgradient well is not dry.

(c) Analyzed annually.

(d) Analyzed to support AEA monitoring.

Bold italic $=$ Upgradient well.

AEA $=$ Atomic Energy Act of 1954 .

ICP = Inductively coupled plasma emission spectroscopy.

(Q) $\quad=$ Sampled quarterly.

(S) $\quad=$ Sampled semiannually. 
Table B.21. Monitoring Wells and Constituents for Low-Level Waste Management Area 1 (adapted from WHC-SD-EN-AP-015)

\begin{tabular}{|c|c|c|c|}
\hline Well $^{(\mathrm{a})}$ & $\begin{array}{c}\text { Hydrogeologic Unit } \\
\text { Monitored } \\
\end{array}$ & \multicolumn{2}{|c|}{ RCRA Contamination Indicator Parameters } \\
\hline 299-E28-26 & Top of unconfined & $\mathrm{pH}$ (field) & Total organic carbon \\
\hline 299-E28-27 & Top of unconfined & Specific conductance (field) & Total organic halides \\
\hline 299-E28-28 & Top of unconfined & \multirow{2}{*}{\multicolumn{2}{|c|}{ RCRA Site-Specific Parameters }} \\
\hline $299-E 32-2$ & Top of unconfined & & \\
\hline 299-E32-3 & Top of unconfined & Alkalinity & Mercury (filtered) \\
\hline 299-E32-4 & Top of unconfined & Anions & Phenols ${ }^{(b)}$ \\
\hline 299-E32-5 & Top of unconfined & ICP metals (filtered) & Turbidity \\
\hline $299-E 32-6$ & Top of unconfined & Lead (filtered) & \\
\hline 299-E32-7 & Top of unconfined & & \\
\hline 299-E32-8 & Top of unconfined & \multicolumn{2}{|c|}{ AEA Parameters ${ }^{(c)}$} \\
\hline 299-E32-9 & Top of unconfined & Gross alpha & Tritium \\
\hline 299-E32-10 & Top of unconfined & Gross beta & Uranium \\
\hline 299-E33-28 & Top of unconfined & Technetium-99(d) & \\
\hline 299-E33-29 & Top of unconfined & & \\
\hline 299-E33-30 & Top of unconfined & & \\
\hline 299-E33-34 & Top of unconfined & & \\
\hline 299-E33-35 & Top of unconfined & & \\
\hline
\end{tabular}

(a) All wells constructed to WAC 173-160-400 standards. All wells sampled semiannually.

(b) Analyzed annually.

(c) Analyzed to support AEA monitoring.

(d) Performance assessment parameter.

Bold italic $=$ Upgradient wells.

AEA $\quad=$ Atomic Energy Act of 1954 .

ICP = Inductively coupled plasma emission spectroscopy.

Table B.22. Critical Means for Low-Level Waste Management Area 1 for Fiscal Year 2004 Comparisons ${ }^{(a)}$

\begin{tabular}{|c|c|c|c|c|c|c|c|}
\hline Constituent, unit & $\mathrm{n}$ & $\underline{\mathrm{df}}$ & $t_{c}$ & $\begin{array}{c}\text { Average } \\
\text { Background } \\
\end{array}$ & $\begin{array}{l}\text { Standard } \\
\text { Deviation } \\
\end{array}$ & $\begin{array}{l}\text { Critical } \\
\text { Mean }\end{array}$ & $\begin{array}{c}\text { Upgradient/ } \\
\text { Downgradient } \\
\text { Comparison Value } \\
\end{array}$ \\
\hline $\begin{array}{l}\text { Specific conductance, } \\
\mu \mathrm{S} / \mathrm{cm}\end{array}$ & 28 & 27 & 4.1542 & 477.8 & 49.4 & 687 & 687 \\
\hline Field $\mathrm{pH}$ & 28 & 27 & 4.4138 & 8.020 & 0.110 & {$[7.53,8.51]$} & {$[7.53,8.51]$} \\
\hline $\begin{array}{l}\text { Total organic carbon, }{ }^{(b)} \\
\mu \mathrm{g} / \mathrm{L}\end{array}$ & $25^{(c)}$ & 24 & 4.2304 & 410.55 & 162.641 & 1,112 & 1,360 \\
\hline $\begin{array}{l}\text { Total organic halides, }{ }^{(\mathrm{b}, \mathrm{d})} \\
\mu \mathrm{g} / \mathrm{L}\end{array}$ & 28 & 27 & 4.1542 & $\mathrm{NC}$ & $\mathrm{NC}$ & $\mathrm{NC}$ & 14.9 \\
\hline
\end{tabular}

(a) Based on semiannual sampling events from December 2001 to June 2002 for upgradient wells 299-E28-26, 299-E28-27, 299-E28-28, 299-E32-4, 299-E33-28, 299-E33-29, and 299-E33-35.

(b) Upgradient/downgradient comparison value is the most recently determined limit of quantitation (see Table D.23).

(c) Excluded suspected total organic carbon values analyzed in June 2003 from wells 299-E28-27, 299-E32-4, and 299-E33-28.

(d) Critical mean cannot be calculated because essentially all of the measurements are below vendor's specified method detection limit.

$\mathrm{df}=$ Degrees of freedom $(\mathrm{n}-1)$.

$\mathrm{n} \quad=$ Number of background replicate averages.

$\mathrm{NC}=$ Not calculated.

$\mathrm{t}_{\mathrm{c}} \quad=$ Bonferroni critical $\mathrm{t}$-value for appropriate $\mathrm{df}$ and 68 comparisons. 
Table B.23. Monitoring Wells and Constituents for Low-Level Waste Management Area 2 (adapted from WHC-SD-EN-AP-015)

\begin{tabular}{|c|}
\hline Well $^{(a)}$ \\
\hline 299-E27-8 \\
\hline 299-E27-9 \\
\hline 299-E27-10 \\
\hline 299-E27-11 \\
\hline 299-E27-17 \\
\hline 299-E34-2(b) \\
\hline $299-E 34-5^{(\mathrm{d})}$ \\
\hline 299-E34-7 \\
\hline 299-E34-9 \\
\hline 299-E34-10 \\
\hline 299-E34-12 \\
\hline
\end{tabular}

Hydrogeologic Unit
Monitored

Top of unconfined

Top of unconfined

Top of unconfined

Top of unconfined

Top of unconfined

Top of unconfined

Top of unconfined

Top of unconfined

Top of unconfined

Top of unconfined

Top of unconfined
RCRA Contamination Indicator Parameters

\begin{tabular}{ll}
\hline $\begin{array}{l}\mathrm{pH} \text { (field) } \\
\text { Specific conductance (field) }\end{array}$ & \multicolumn{1}{c}{$\begin{array}{l}\text { Total organic carbon } \\
\text { Total organic halides }\end{array}$} \\
& \\
\multicolumn{1}{c}{ RCRA Site-Specific } & Parameters \\
\hline Alkalinity & Mercury (filtered) \\
Anions & Phenols (c) \\
ICP metals (filtered) & Polychlorinated biphenyls \\
Lead (filtered) & Turbidity
\end{tabular}

AEA Parameters ${ }^{(e)}$

\begin{tabular}{ll}
\hline Gross alpha & Technetium-99(f) \\
Gross beta & Tritium \\
Iodine-129 & Uranium $^{(f)}$
\end{tabular}

(a) All wells constructed to WAC 173-160-400 standards. All wells sampled semiannually.

(b) This well went dry during fiscal year 2003 after sampling was completed.

(c) Analyzed annually.

(d) Used for supplemental information; no statistical evaluation.

(e) Analyzed to support AEA monitoring.

(f) Performance assessment parameters.

Bold italic $=$ Upgradient wells.

AEA $\quad=$ Atomic Energy Act of 1954 .

ICP = Inductively coupled plasma emission spectroscopy.

RCRA $=$ Resource Conservation and Recovery Act.

Table B.24. Critical Means for Low-Level Waste Management Area 2 for Fiscal Year 2004 Comparisons ${ }^{(a)}$

\begin{tabular}{|c|c|c|c|c|c|c|c|}
\hline Constituent, unit & $\mathrm{n}$ & df & $t_{c}$ & $\begin{array}{c}\text { Average } \\
\text { Background } \\
\end{array}$ & $\begin{array}{l}\text { Standard } \\
\text { Deviation }\end{array}$ & $\begin{array}{l}\text { Critical } \\
\text { Mean }\end{array}$ & $\begin{array}{c}\text { Upgradient/ } \\
\text { Downgradient } \\
\text { Comparison Value }\end{array}$ \\
\hline $\begin{array}{l}\text { Specific conductance, } \\
\mu \mathrm{S} / \mathrm{cm}\end{array}$ & 6 & 5 & 7.9757 & 714.1 & 83.2 & 1,431 & 1,431 \\
\hline Field $\mathrm{pH}$ & 6 & 5 & 9.2355 & 7.995 & 0.095 & {$[7.05,8.94]$} & {$[7.05,8.94]$} \\
\hline $\begin{array}{l}\text { Total organic carbon, } \\
\mu \mathrm{g} / \mathrm{L}\end{array}$ & 6 & 5 & 7.9757 & 699.17 & 321.328 & 3,467 & $3,470^{(b)}$ \\
\hline $\begin{array}{l}\text { Total organic halides, }{ }^{(c, d)} \\
\mu \mathrm{g} / \mathrm{L}\end{array}$ & 6 & 5 & 7.9757 & 3.306 & 1.284 & 14.4 & 14.9 \\
\hline
\end{tabular}

(a) Based on semiannual sampling events from April 2000 to April 2003 for upgradient well 299-E27-10. Data from well 299-E34-7 are excluded due to elevated levels of all indicator parameters.

(b) Rounded to the nearest tenth.

(c) Critical mean calculated from values below vendor's specified method detection limit.

(d) Upgradient/downgradient comparison value is the most recently determined limit of quantitation (see Table D.23).

$\mathrm{df}=$ Degrees of freedom $(\mathrm{n}-1)$.

$\mathrm{n}=$ Number of background replicate averages.

$\mathrm{t}_{\mathrm{c}}=$ Bonferroni critical $\mathrm{t}$-value for appropriate $\mathrm{df}$ and 40 comparisons. 
Table B.25. Monitoring Wells and Constituents for Low-Level Waste Management Area 3 (adapted from WHC-SD-EN-AP-015)

\begin{tabular}{|c|c|c|c|}
\hline Well $^{(\mathrm{a})}$ & $\begin{array}{c}\text { Hydrogeologic Unit } \\
\text { Monitored } \\
\end{array}$ & \multicolumn{2}{|c|}{ RCRA Contamination Indicator Parameters } \\
\hline 299-W7-1 & Top of unconfined & $\mathrm{pH}$ (field) & Total organic carbon \\
\hline 299-W7-3(b) & Deep unconfined & Specific conductance (field) & Total organic halides \\
\hline 299-W7-4 & Top of unconfined & & \\
\hline 299-W7-5 & Top of unconfined & \multicolumn{2}{|c|}{ RCRA Site-Specific Parameters } \\
\hline 299-W7-7 & Top of unconfined & Alkalinity & cury (filtered) \\
\hline 299-W7-12 & Top of unconfined & Anions & hols \\
\hline 299-W8-1 & Top of unconfined & ICP metals (filtered) & tile organic compounds \\
\hline $299-W 10-14^{(\mathrm{b})}$ & Deep unconfined & \multicolumn{2}{|l|}{ Lead (filtered) } \\
\hline 299-W10-19 & Top of unconfined & & \\
\hline $299-W 10-20$ & Top of unconfined & \multicolumn{2}{|c|}{ AEA Parameters ${ }^{(c)}$} \\
\hline \multirow[t]{4}{*}{ 299-W10-21 } & Top of unconfined & Gross alpha & Tritium \\
\hline & & Gross beta & Turbidity \\
\hline & & Iodine-129(d) & \multirow[t]{2}{*}{ Uranium $^{(\mathrm{d})}$} \\
\hline & & Technetium-99(d) & \\
\hline
\end{tabular}

(a) All wells constructed to WAC 173-160-400 standards. All wells sampled semiannually.

(b) Used for supplemental information; no statistical evaluations.

(c) Analyzed to support AEA monitoring.

(d) Performance assessment parameters.

Bold italic $=$ Upgradient wells.

AEA $=$ Atomic Energy Act of 1954 .

ICP = Inductively coupled plasma emission spectroscopy.

RCRA $=$ Resource Conservation and Recovery Act.

Table B.26. Critical Means for Low-Level Waste Management Area 3 for Fiscal Year 2004 Comparisons ${ }^{(a)}$

\begin{tabular}{|c|c|c|c|c|c|c|c|}
\hline Constituent, unit & $\mathrm{n}$ & $\underline{\mathrm{df}}$ & $t_{c}$ & $\begin{array}{c}\text { Average } \\
\text { Background } \\
\end{array}$ & $\begin{array}{l}\text { Standard } \\
\text { Deviation } \\
\end{array}$ & $\begin{array}{l}\text { Critical } \\
\text { Mean }\end{array}$ & $\begin{array}{c}\text { Upgradient/ } \\
\text { Downgradient } \\
\text { Comparison Value }\end{array}$ \\
\hline $\begin{array}{l}\text { Specific conductance, } \\
\mu \mathrm{S} / \mathrm{cm}\end{array}$ & 12 & 11 & 4.7979 & 479.6 & 55.9 & 758 & 758 \\
\hline Field $\mathrm{pH}$ & 12 & 11 & 5.2381 & 8.125 & 0.196 & {$[7.05,9.20]$} & {$[7.05,9.20]$} \\
\hline $\begin{array}{l}\text { Total organic carbon, }{ }^{(b)} \\
\mu \mathrm{g} / \mathrm{L}\end{array}$ & 12 & 11 & 4.7979 & 310.42 & 211.267 & 1,365 & $1,370^{\text {(c) }}$ \\
\hline $\begin{array}{l}\text { Total organic halides, } \\
\mu \mathrm{g} / \mathrm{L}\end{array}$ & 12 & 11 & 4.7979 & 162.048 & 160.990 & 966 & 966 \\
\hline
\end{tabular}

(a) Based on semiannual sampling events from March 2002 to September 2003 for upgradient wells 299-W10-19, 299-W10-20, and 299-W10-21.

(b) Critical mean calculated from values below vendor's specified method detection limit.

(c) Rounded to the nearest tenth.

df $=$ Degrees of freedom $(n-1)$.

$\mathrm{n}=$ Number of background replicate averages.

$\mathrm{t}_{\mathrm{c}}=$ Bonferroni critical $\mathrm{t}$-value for appropriate $\mathrm{df}$ and 36 comparisons. 
Table B.27. Monitoring Wells and Constituents for Low-Level Waste Management Area 4 (adapted from WHC-SD-EN-AP-015)

\begin{tabular}{|c|c|}
\hline Well ${ }^{(\mathrm{a})}$ & $\begin{array}{c}\text { Hydrogeologic Unit } \\
\text { Monitored } \\
\end{array}$ \\
\hline 299-W15-15 & Top of unconfined \\
\hline 299-W15-16 & Top of unconfined \\
\hline 299-W15-17 & Deep unconfined \\
\hline 299-W18-21 & Top of unconfined \\
\hline $299-W 18-22^{(\mathrm{b})}$ & Deep unconfined \\
\hline 299-W18-23 & Top of unconfined \\
\hline 299-W18-24(c) & Top of unconfined \\
\hline
\end{tabular}

\begin{tabular}{|c|c|}
\hline \multicolumn{2}{|c|}{ RCRA Contamination Indicator Parameters } \\
\hline $\mathrm{pH}$ (field) & Total organic carbon \\
\hline Specific conductance (field) & Total organic halides \\
\hline \multicolumn{2}{|c|}{ RCRA Site-Specific Parameters } \\
\hline Alkalinity & Mercury (filtered) \\
\hline Anions & Phenols \\
\hline ICP metals (filtered) & Turbidity \\
\hline Lead (filtered) & Volatile organic compounds \\
\hline \multicolumn{2}{|c|}{ AEA Constituents ${ }^{(\mathrm{d})}$} \\
\hline Gross alpha & Technetium-99 \\
\hline Gross beta & Tritium \\
\hline Iodine-129 & \\
\hline \multicolumn{2}{|c|}{ Performance Assessment Parameters } \\
\hline
\end{tabular}

(a) All wells constructed to WAC 173-160-400 standards. All wells sampled semiannually.

(b) Used for supplemental information; no statistical evaluations.

(c) This well went dry in fiscal year 2003; only a partial sample was obtained for the first semiannual event.

(d) Analyzed to support AEA monitoring.

Bold italic $=$ Upgradient wells.

AEA $\quad=$ Atomic Energy Act of 1954 .

ICP = Inductively coupled plasma emission spectroscopy.

RCRA = Resource Conservation and Recovery Act.

Table B.28. Critical Means for Low-Level Waste Management Area 4 for Fiscal Year 2004 Comparisons ${ }^{(a)}$

\begin{tabular}{|c|c|c|c|c|c|c|c|}
\hline Constituent, unit & $\mathrm{n}$ & $\underline{\mathrm{df}}$ & $t_{c}$ & $\begin{array}{c}\text { Average } \\
\text { Background } \\
\end{array}$ & $\begin{array}{l}\text { Standard } \\
\text { Deviation } \\
\end{array}$ & $\begin{array}{l}\text { Critical } \\
\text { Mean }\end{array}$ & $\begin{array}{c}\text { Upgradient/ } \\
\text { Downgradient } \\
\text { Comparison Value }\end{array}$ \\
\hline $\begin{array}{l}\text { Specific conductance, } \\
\mu \mathrm{S} / \mathrm{cm}\end{array}$ & 12 & 11 & 4.3034 & 470.1 & 86.5 & 858 & 858 \\
\hline Field $\mathrm{pH}$ & 12 & 11 & 4.7248 & 7.941 & 0.099 & {$[7.46,8.43]$} & {$[7.46,8.43]$} \\
\hline $\begin{array}{l}\text { Total organic carbon, } \\
\mu \mathrm{g} / \mathrm{L}\end{array}$ & $10^{(\mathrm{b})}$ & 9 & 4.6231 & 432.75 & 290.938 & 1,843 & $1,840^{\text {(c) }}$ \\
\hline $\begin{array}{l}\text { Total organic halides, } \\
\mu \mathrm{g} / \mathrm{L}\end{array}$ & 12 & 11 & 4.3034 & 26.112 & 21.696 & 123.3 & 123.3 \\
\hline
\end{tabular}

(a) Based on semiannual sampling events from January 2002 to July 2003 for upgradient wells 299-W15-15, 299-W18-21, and 299-W18-23.

(b) Excluded suspected total organic carbon values analyzed in July 2003 from wells 299-W15-15 and 299-W18-21.

(c) Rounded to the nearest tenth.

df $=$ Degrees of freedom $(n-1)$.

$\mathrm{n}=$ Number of background replicate averages.

$t_{c}=$ Bonferroni critical $t$-value for appropriate $\mathrm{df}$ and 16 comparisons. 
Table B.29. Monitoring Wells and Constituents for the Nonradioactive Dangerous Waste Landfill (adapted from PNNL-12227)

\begin{tabular}{|c|c|c|c|}
\hline \multirow{2}{*}{$\frac{\text { Well }^{(\mathrm{a})}}{699-25-33 \mathrm{~A}^{(\mathrm{b})}}$} & \multirow{2}{*}{$\begin{array}{c}\begin{array}{c}\text { Hydrogeologic Unit } \\
\text { Monitored }\end{array} \\
\text { Top of LPU(c) }\end{array}$} & \multicolumn{2}{|c|}{ Contamination Indicator Parameters } \\
\hline & & $\mathrm{pH}$ (field) & Total organic carbon \\
\hline $699-25-34 \mathrm{~A}$ & Top of unconfined & Specific conductance (field) & Total organic halides \\
\hline $699-25-34 B$ & Top of unconfined & & \\
\hline $699-25-34 \mathrm{D}$ & Top of unconfined & \multicolumn{2}{|c|}{ Site-Specific Parameters } \\
\hline $699-26-33$ & Top of unconfined & Anions & Turbidity \\
\hline $699-26-34 \mathrm{~A}$ & Top of unconfined & ICP metals (filtered) & Volatile chlorinated \\
\hline $699-26-34 \mathrm{~B}$ & Top of unconfined & Phenols ${ }^{(\mathrm{d})}$ & hydrocarbons \\
\hline $699-26-35 A$ & Top of unconfined & & \\
\hline $699-26-35 C^{(b)}$ & Top of LPU ${ }^{(c)}$ & & \\
\hline
\end{tabular}

(a) All wells constructed to WAC 173-160-400 standards. All wells sampled semiannually.

(b) Used for supplemental information; no statistical evaluation.

(c) Low-permeability unit (LPU) in upper Ringold Formation.

(d) Analyzed annually.

Bold italic $=$ Upgradient wells.

ICP = Inductively coupled plasma emission spectroscopy.

Table B.30. Critical Means for Nonradioactive Dangerous Waste Landfill for Fiscal Year 2004 Comparisons ${ }^{(a)}$

\begin{tabular}{|c|c|c|c|c|c|c|c|}
\hline Constituent, unit & $\underline{\mathrm{n}}$ & df & $t_{c}$ & $\begin{array}{c}\text { Average } \\
\text { Background } \\
\end{array}$ & $\begin{array}{l}\text { Standard } \\
\text { Deviation } \\
\end{array}$ & $\begin{array}{l}\text { Critical } \\
\text { Mean }\end{array}$ & $\begin{array}{c}\text { Upgradient/ } \\
\text { Downgradient } \\
\text { Comparison Value }\end{array}$ \\
\hline $\begin{array}{l}\text { Specific conductance, } \\
\mu \mathrm{S} / \mathrm{cm}\end{array}$ & 5 & 4 & 9.0293 & 536.6 & 16.0 & 695 & 695 \\
\hline Field $\mathrm{pH}$ & 5 & 4 & 10.802 & 7.226 & 0.070 & {$[6.40,8.05]$} & {$[6.40,8.05]$} \\
\hline $\begin{array}{l}\text { Total organic carbon, }{ }^{(b)} \\
\mu \mathrm{g} / \mathrm{L}\end{array}$ & 5 & 4 & 9.0293 & 211.5 & 175.692 & 1,949 & $1,950^{(c)}$ \\
\hline $\begin{array}{l}\text { Total organic halides, }{ }^{(b)} \\
\mu g / L\end{array}$ & 5 & 4 & 9.0293 & 3.06 & 1.337 & 16.3 & 16.3 \\
\hline
\end{tabular}

(a) Based on most recent sampling events from February 2001 to September 2003 for upgradient well 699-26-34A.

(b) Critical mean calculated from values reported below vendor's specified method detection limit.

(c) Rounded to the nearest tenth.

$\mathrm{df}=$ Degrees of freedom $(\mathrm{n}-1)$.

$\mathrm{n}=$ Number of background replicate averages.

$\mathrm{t}_{\mathrm{c}}=$ Bonferroni critical $\mathrm{t}$-value for appropriate $\mathrm{df}$ and 24 comparisons. 
Table B.31. Monitoring Wells and Constituents for PUREX Cribs 216-A-10, 216-A-36B, and 216-A-37-1 (adapted from PNNL-11523)

\begin{tabular}{|c|c|c|c|}
\hline Well ${ }^{(a)}$ & $\begin{array}{c}\text { Hydrogeologic Unit } \\
\text { Monitored } \\
\end{array}$ & \multicolumn{2}{|c|}{ Contamination Indicator Parameters } \\
\hline \multicolumn{2}{|c|}{ Upgradient Wells } & $\mathrm{pH}(\text { field })^{(\mathrm{b})}$ & Specific conductance (field) (b) \\
\hline 299-E24-18 & Top of unconfined & & \\
\hline 299-E25-31 & Top of unconfined & \multicolumn{2}{|c|}{ Site-Specific Parameters } \\
\hline \multicolumn{2}{|c|}{ Near-Field Wells - 216-A-10 Crib } & Alkalinity & ICP metals (filtered) \\
\hline 299-E17-1 (P) & Top of unconfined & Ammonium ion & Phenols \\
\hline 299-E17-19 & Top of unconfined & Anions $^{(\mathrm{b})}$ & Turbidity $^{(\mathrm{b})}$ \\
\hline 299-E24-16 (Q) & Top of unconfined & Arsenic (filtered) & \\
\hline \multicolumn{4}{|c|}{ Near-Field Wells - 216-A-36B Crib } \\
\hline 299-E17-14 (Q) & Top of unconfined & \multicolumn{2}{|c|}{ AEA Parameters ${ }^{(c)}$} \\
\hline 299-E17-16 & Top of unconfined & Gross alpha & Iodine-129(b) \\
\hline 299-E17-18 & Top of unconfined & Gross beta & Strontium-90 \\
\hline \multicolumn{4}{|c|}{ Near-Field Wells - 216-A-37-1 Crib } \\
\hline 299-E25-17 (P) & Top of unconfined & & \\
\hline 299-E25-19 (P,Q) & Top of unconfined & & \\
\hline $699-37-47 \mathrm{~A}$ & Top of unconfined & & \\
\hline \multicolumn{2}{|c|}{ Far-Field Wells ${ }^{(\mathrm{d})}$} & & \\
\hline 57 wells & Unconfined & & \\
\hline
\end{tabular}

(a) Wells constructed to WAC 173-160-400 standards unless noted (P), pre-RCRA. Wells sampled semiannually unless noted (Q), quarterly.

(b) Far-field wells analyzed for these constituents only.

(c) Analyzed to support AEA monitoring.

(d) Far-field wells sampled annually to triennially.

AEA $=$ Atomic Energy Act of 1954 .

ICP = Inductively coupled plasma emission spectroscopy.

PUREX = Plutonium-Uranium Extraction (Plant).

RCRA = Resource Conservation and Recovery Act. 
Table B.32. Monitoring Wells and Constituents for Waste Management Area A-AX (adapted from PNNL-13023-ICN-1)

\begin{tabular}{|c|c|}
\hline Well ${ }^{\text {(a) }}$ & $\begin{array}{l}\text { Hydrogeologic Unit } \\
\text { Monitored } \\
\end{array}$ \\
\hline 299-E24-19 & Top of unconfined \\
\hline 299-E24-20 & Top of unconfined \\
\hline 299-E24-22(b) & Top of confined \\
\hline 299-E25-40(c) & Top of unconfined \\
\hline 299-E25-41 & Top of unconfined \\
\hline 299-E25-46 & Top of unconfined \\
\hline 299-E25-93(b) & Top of confined \\
\hline
\end{tabular}

\begin{tabular}{|c|c|}
\hline \multicolumn{2}{|c|}{ Contamination Indicator Parameters } \\
\hline pH (field) & Total organic carbon \\
\hline Specific conductance (field) & Total organic halides \\
\hline \multicolumn{2}{|c|}{ Site-Specific Parameters } \\
\hline Alkalinity & ICP metals (filtered) \\
\hline Anions & Phenols ${ }^{(\mathrm{d})}$ \\
\hline \multicolumn{2}{|c|}{ AEA Parameters ${ }^{(\mathrm{e})}$} \\
\hline Gross beta ${ }^{(\mathrm{d})}$ & Technetium-99(d) \\
\hline Gross gamma ${ }^{(\mathrm{d})}$ & Tritium $^{(\mathrm{d})}$ \\
\hline Iodine-129(d) & Uranium $^{(\mathrm{d})}$ \\
\hline Strontium-90(d) & \\
\hline
\end{tabular}

(a) All wells constructed to WAC 173-160-400 standards. All wells sampled semiannually.

(b) New well constructed in fiscal year 2003. First samples scheduled for December 2003.

(c) Information only; not used in statistical evaluations.

(d) Annually.

(e) Analyzed to support AEA monitoring.

Bold italic $=$ Upgradient wells.

AEA $=$ Atomic Energy Act of 1954 .

ICP = Inductively coupled plasma emission spectroscopy.

Table B.33. Critical Means for Waste Management Area A-AX for Fiscal Year 2004 Comparisons $^{(a)}$

\begin{tabular}{|c|c|c|c|c|c|c|c|}
\hline Constituent, unit & $\mathrm{n}$ & $\underline{\mathrm{df}}$ & $t_{c}$ & $\begin{array}{c}\text { Average } \\
\text { Background } \\
\end{array}$ & $\begin{array}{l}\text { Standard } \\
\text { Deviation } \\
\end{array}$ & $\begin{array}{l}\text { Critical } \\
\text { Mean }\end{array}$ & $\begin{array}{c}\text { Upgradient/ } \\
\text { Downgradient } \\
\text { Comparison Value } \\
\end{array}$ \\
\hline $\begin{array}{l}\text { Specific conductance, } \\
\mu \mathrm{S} / \mathrm{cm}\end{array}$ & 5 & 4 & 8.6103 & 369.2 & 29.5 & 647 & 647 \\
\hline Field $\mathrm{pH}$ & 5 & 4 & 10.3063 & 8.136 & 0.073 & {$[7.31,8.96]$} & {$[7.31,8.96]$} \\
\hline $\begin{array}{l}\text { Total organic carbon, } \\
\mu \mathrm{g} / \mathrm{L}\end{array}$ & $4^{(\mathrm{b})}$ & 3 & 12.9240 & 531.25 & 126.697 & 2,362 & $2,360^{(c)}$ \\
\hline $\begin{array}{l}\text { Total organic halides, }{ }^{(d)} \\
\mu g / L\end{array}$ & 5 & 4 & 8.6103 & $\mathrm{NC}$ & $\mathrm{NC}$ & $\mathrm{NC}$ & 14.9 \\
\hline $\begin{array}{l}\text { (a) Based on semiannu } \\
\text { be revised when da } \\
\text { (b) Excluded suspected } \\
\text { (c) Rounded to the nea } \\
\text { (d) Critical mean cann } \\
\text { limit. Upgradient } / \\
\text { df }=\text { Degrees of freedo } \\
\mathrm{n}=\text { Number of backg } \\
\mathrm{NC}=\text { Not calculated. } \\
\mathrm{t}=\text { Bonferroni critic }\end{array}$ & $\begin{array}{l}\text { sampli } \\
\text { from } n \\
\text { tal or } \\
\text { st tent } \\
\text { be cal } \\
\text { ongra } \\
(\mathrm{n}-1) \\
\text { und re }\end{array}$ & $\begin{array}{l}\text { ic } \\
\text { ated } \\
\text { it } \mathrm{cc}\end{array}$ & $\begin{array}{l}\text { from July } \\
\text { lient wells } \\
\text { on values } \\
\text { cause esse } \\
\text { arison va } \\
\text { erages. }\end{array}$ & $\begin{array}{l}1 \text { to June } 200 \\
\text { available. } \\
\text { lyzed in June } \\
\text { ally all measur } \\
\text { is the most re }\end{array}$ & $\begin{array}{l}\text { upgradien } \\
\text { from well } \\
\text { hts are belo } \\
\text { y determin }\end{array}$ & $\begin{array}{l}\text { E24-20. } \\
\text { endor's specif } \\
\text { mit of quanti }\end{array}$ & $\begin{array}{l}\text { ackground levels will } \\
\text { method detection } \\
\text { ion (see Table D.23) }\end{array}$ \\
\hline
\end{tabular}


Table B.34. Monitoring Wells and Constituents for Waste Management Area B-BX-BY (adapted from PNNL-13022)

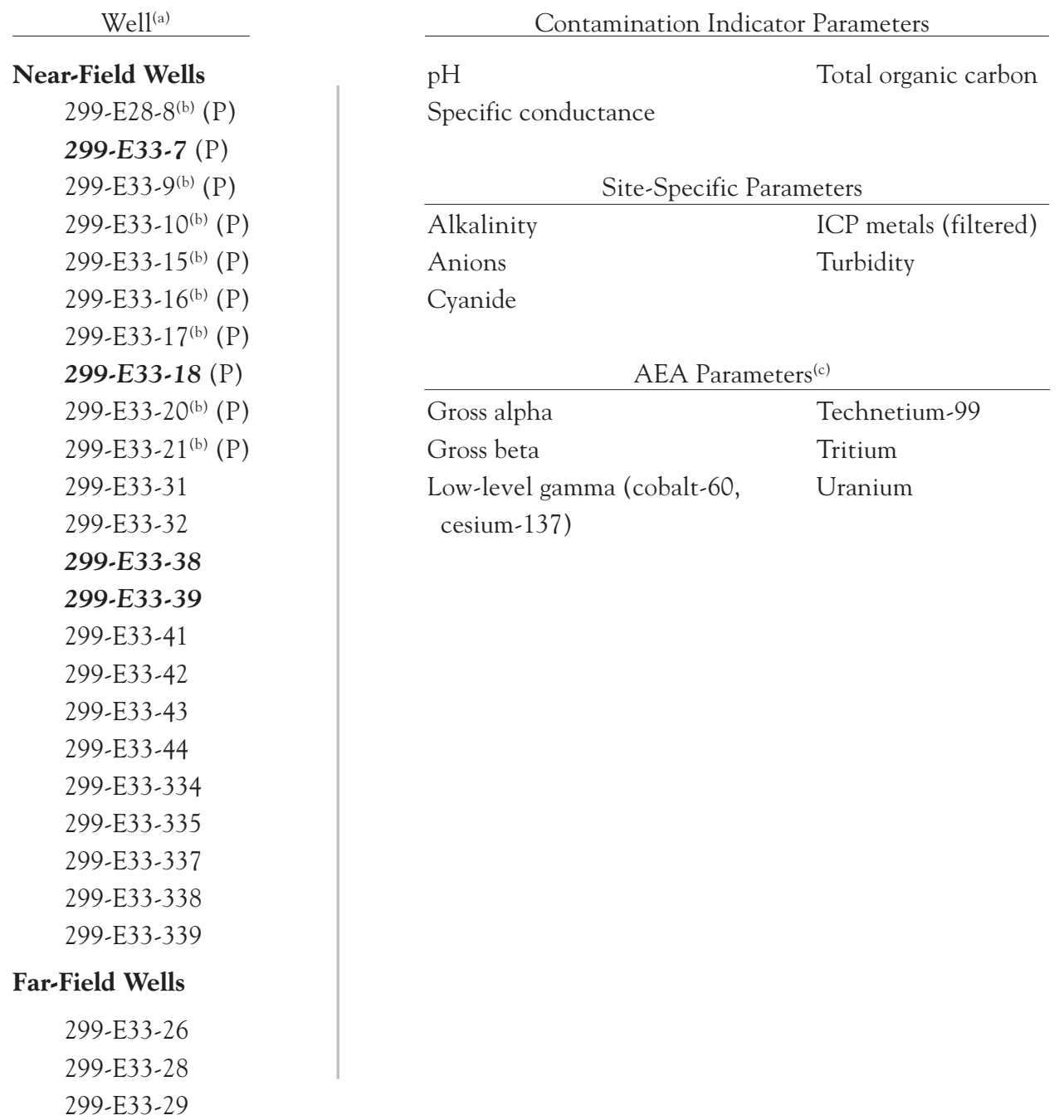

(a) All wells constructed to WAC 173-160-400 standards unless noted (P), pre-RCRA, and are completed in the unconfined aquifer. Wells sampled quarterly.

(b) Sampled to support RCRA assessment.

(c) Analyzed to support AEA monitoring.

Bold italic $=$ Upgradient wells.

AEA $=$ Atomic Energy Act of 1954 .

ICP = Inductively coupled plasma emission spectroscopy.

RCRA = Resource Conservation and Recovery Act. 
Table B.35. Monitoring Wells and Constituents for Waste Management Area C (adapted from PNNL-13024-ICN-1)

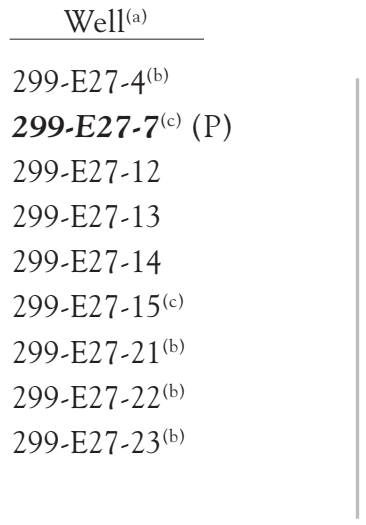

\begin{tabular}{|c|c|}
\hline \multicolumn{2}{|c|}{ Contamination Indicator Parameters } \\
\hline $\mathrm{pH}$ (field) & Total organic carbon \\
\hline Specific conductance (field) & Total organic halides \\
\hline \multicolumn{2}{|c|}{ Site-Specific Parameters } \\
\hline Alkalinity & ICP metals (filtered) \\
\hline Anions & Phenols \\
\hline Cyanide & Turbidity \\
\hline \multicolumn{2}{|c|}{ AEA Parameters ${ }^{(\mathrm{d})}$} \\
\hline Gamma scan & Technetium-99 \\
\hline Gross beta & Total uranium \\
\hline
\end{tabular}

(a) All wells constructed to WAC 173-160-400 standards unless noted (P), pre-RCRA. All wells completed at the top of the unconfined aquifer. All wells sampled semiannually.

(b) New well constructed in fiscal year 2003. First sampling scheduled for December 2003.

(c) Used for supplemental information; no statistical evaluation.

(d) Analyzed to support AEA monitoring.

Bold italic $=$ Upgradient well.

AEA $=$ Atomic Energy Act of 1954 .

ICP = Inductively coupled plasma emission spectroscopy.

RCRA = Resource Conservation and Recovery Act. 
Table B.36. Monitoring Wells and Constituents for Waste Management Area S-SX (adapted from PNNL-12114-ICN-1)

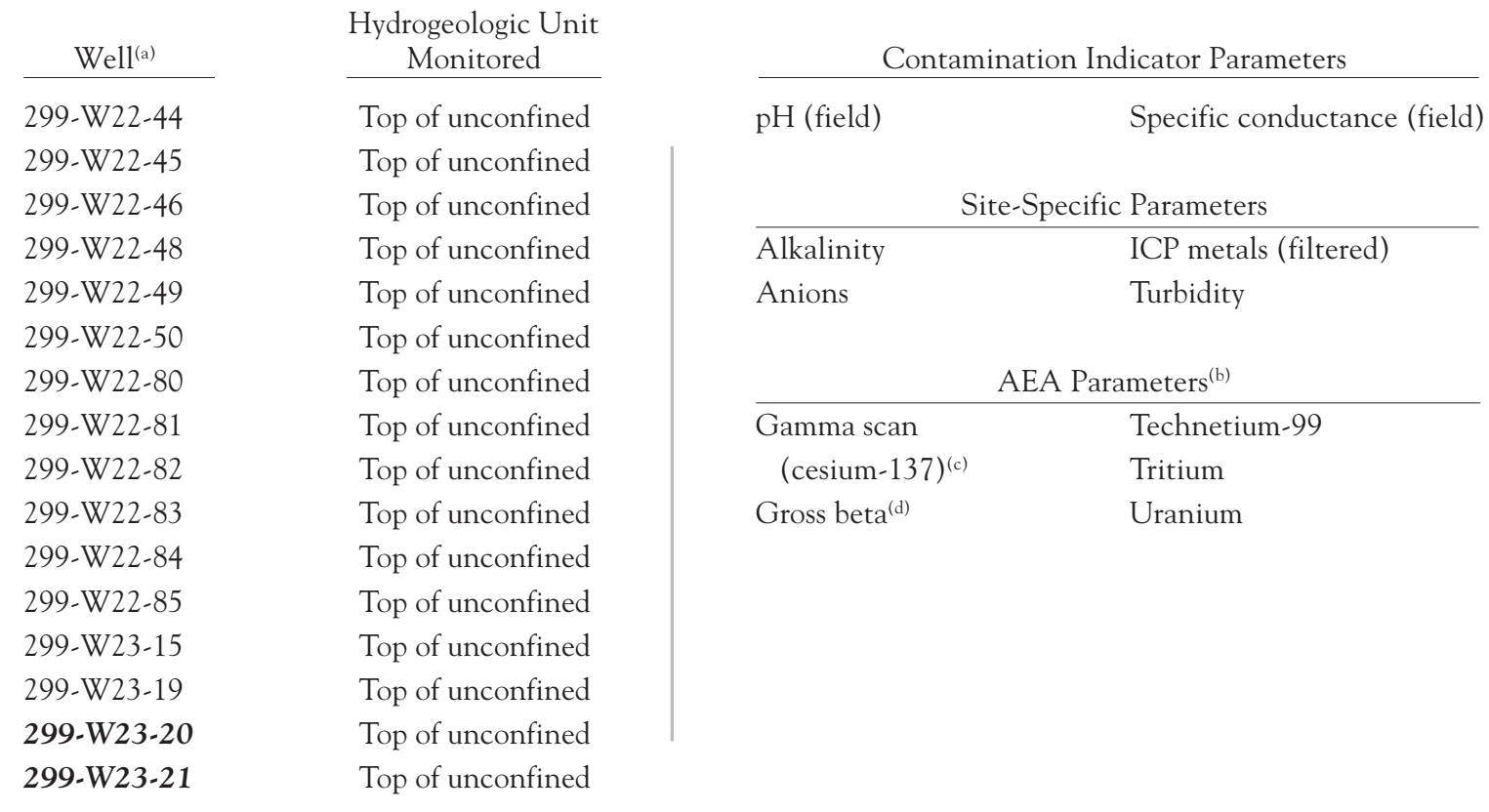

(a) All wells constructed to WAC 173-160-400 standards. All wells sampled quarterly, except for certain constituents as noted.

(b) Analyzed to support AEA monitoring.

(c) Analysis done only on well 299-W23-19 annually.

(d) Analysis done only on well 299-W23-19 quarterly.

Bold italic $=$ Upgradient wells.

AEA $=$ Atomic Energy Act of 1954 .

ICP = Inductively coupled plasma emission spectroscopy. 
Table B.37. Monitoring Wells and Constituents for Waste Management Area T (adapted from PNNL-12057-ICN-1)

$\frac{\text { Well(a) }}{\text { 299-W10-1 (P) }}$
299-W10-4 (P)
299-W10-8 (P)
299-W10-22 (S)
299-W10-23
299-W10-24
299-W10-28
299-W11-7 (S,P)
299-W11-12 (P)
299-W11-39
299-W11-40
299-W11-41
299-W11-42

\begin{tabular}{l}
$\begin{array}{c}\text { Hydrogeologic Unit } \\
\text { Monitored }\end{array}$ \\
\hline Top of unconfined \\
Top of unconfined \\
Top of unconfined \\
Top of unconfined \\
Top of unconfined \\
Top of unconfined \\
Top of unconfined \\
Top of unconfined \\
Top of unconfined \\
Top of unconfined \\
Top of unconfined \\
Top of unconfined \\
Top of unconfined
\end{tabular}

\begin{tabular}{lc}
\multicolumn{2}{c}{ Contamination Indicator Parameters } \\
\hline $\mathrm{pH}$ (field) & Specific conductance (field) \\
& Site-Specific $^{\text {Parameters }}{ }^{(\mathrm{b})}$ \\
\hline Alkalinity & ICP metals (filtered) \\
Anions & Turbidity (field) \\
& \\
& AEA Parameters \\
& (c) \\
\hline Gamma scan (cesium-137, & Iodine-129 \\
cobalt-60) & Strontium-90 \\
Gross alpha & Technetium-99 \\
Gross beta & Tritium \\
&
\end{tabular}

(a) All wells constructed to WAC 173-160-400 standards unless noted (P), pre-RCRA. All wells sampled quarterly unless noted (S), semiannually.

(b) Constituent list varies by well.

(c) Analyzed to support AEA monitoring.

Bold italic $=$ Upgradient wells.

AEA $=$ Atomic Energy Act of 1954 .

ICP $=$ Inductively coupled plasma emission spectroscopy.

RCRA $=$ Resource Conservation and Recovery Act. 
Table B.38. Monitoring Wells and Constituents for Waste Management Area TX-TY (adapted from PNNL-12072-ICN-1)

\begin{tabular}{|c|c|c|c|}
\hline Well(a) & $\begin{array}{c}\text { Hydrogeologic Unit } \\
\text { Monitored } \\
\end{array}$ & \multicolumn{2}{|c|}{ Contamination Indicator Parameters } \\
\hline 299-W10-17 & Top of unconfined & $\mathrm{pH}$ (field) & Specific conductance (field) \\
\hline 299-W10-26 & Top of unconfined & & \\
\hline 299-W10-27 & Top of unconfined & \multicolumn{2}{|c|}{ Site-Specific Parameters ${ }^{(\mathrm{b})}$} \\
\hline 299-W14-5 (P) & Top of unconfined & Alkalinity & ICP metals (filtered) \\
\hline 299-W14-6 (P) & Top of unconfined & Anions & Turbidity \\
\hline 299-W14-13 & Top of unconfined & & \\
\hline 299-W14-14 & Top of unconfined & \multicolumn{2}{|c|}{ AEA Parameters $^{(\mathrm{c})}$} \\
\hline 299-W14-15 & Top of unconfined & \multirow{2}{*}{$\begin{array}{l}\text { Gamma scan (cesium-137, } \\
\text { cobalt-60) }\end{array}$} & Iodine-129 \\
\hline 299-W14-16 & Top of unconfined & & Strontium-90 \\
\hline 299-W14-17 & Top of unconfined & Gross alpha & Technetium-99 \\
\hline 299-W14-18 & Top of unconfined & Gross beta & Tritium \\
\hline 299-W14-19(d) & Top of unconfined & & \\
\hline 299-W15-40 & Top of unconfined & & \\
\hline 299-W15-41 & Top of unconfined & & \\
\hline 299-W15-44(d) & Top of unconfined & & \\
\hline 299-W15-763 & Top of unconfined & & \\
\hline 299-W15-765 & Top of unconfined & & \\
\hline
\end{tabular}

(a) All wells constructed to WAC 173-160-400 standards unless noted (P), pre-RCRA. All wells sampled quarterly, but not all constituents are sought quarterly.

(b) Constituent list varies by well.

(c) Analyzed to support AEA monitoring.

(d) New well added in fiscal year 2003.

Bold italic $=$ Upgradient wells.

AEA $=$ Atomic Energy Act of 1954 .

ICP = Inductively coupled plasma emission spectroscopy.

RCRA = Resource Conservation and Recovery Act. 
Table B.39. Monitoring Wells and Constituents for Waste Management Area U (adapted from PNNL-13612)

$\frac{\text { Well }^{\text {(a) }}}{\text { 299-W18-30 }}$

299-W18-30

299-W18-31

299-W18-40

299-W19-12(b)

299-W19-41

299-W19-42

299-W19-44

299-W19-45
Contamination Indicator Parameters

\begin{tabular}{|c|c|}
\hline $\mathrm{pH}$ (field) & Specific conductance (field) \\
\hline \multicolumn{2}{|c|}{ Site-Specific Parameters } \\
\hline Alkalinity & ICP metals (filtered) \\
\hline Anions & Volatile organic compounds ${ }^{(\mathrm{c})}$ \\
\hline \multicolumn{2}{|c|}{ AEA Parameters ${ }^{(\mathrm{d})}$} \\
\hline Gamma scan ${ }^{(c)}$ & Technetium-99 \\
\hline Gross alpha $a^{(\mathrm{c})}$ & Tritium $^{(\mathrm{c})}$ \\
\hline Iodine-129(c) & \\
\hline
\end{tabular}

(a) All wells constructed to WAC-173-160-400 standards. All wells sampled quarterly. All wells completed at the top of the unconfined aquifer.

(b) Used for supplemental information; no statistical evaluations.

(c) Annually.

(d) Analyzed to support AEA monitoring.

Bold italic $=$ Upgradient wells.

AEA $=$ Atomic Energy Act of 1954 .

ICP = Inductively coupled plasma emission spectroscopy. 


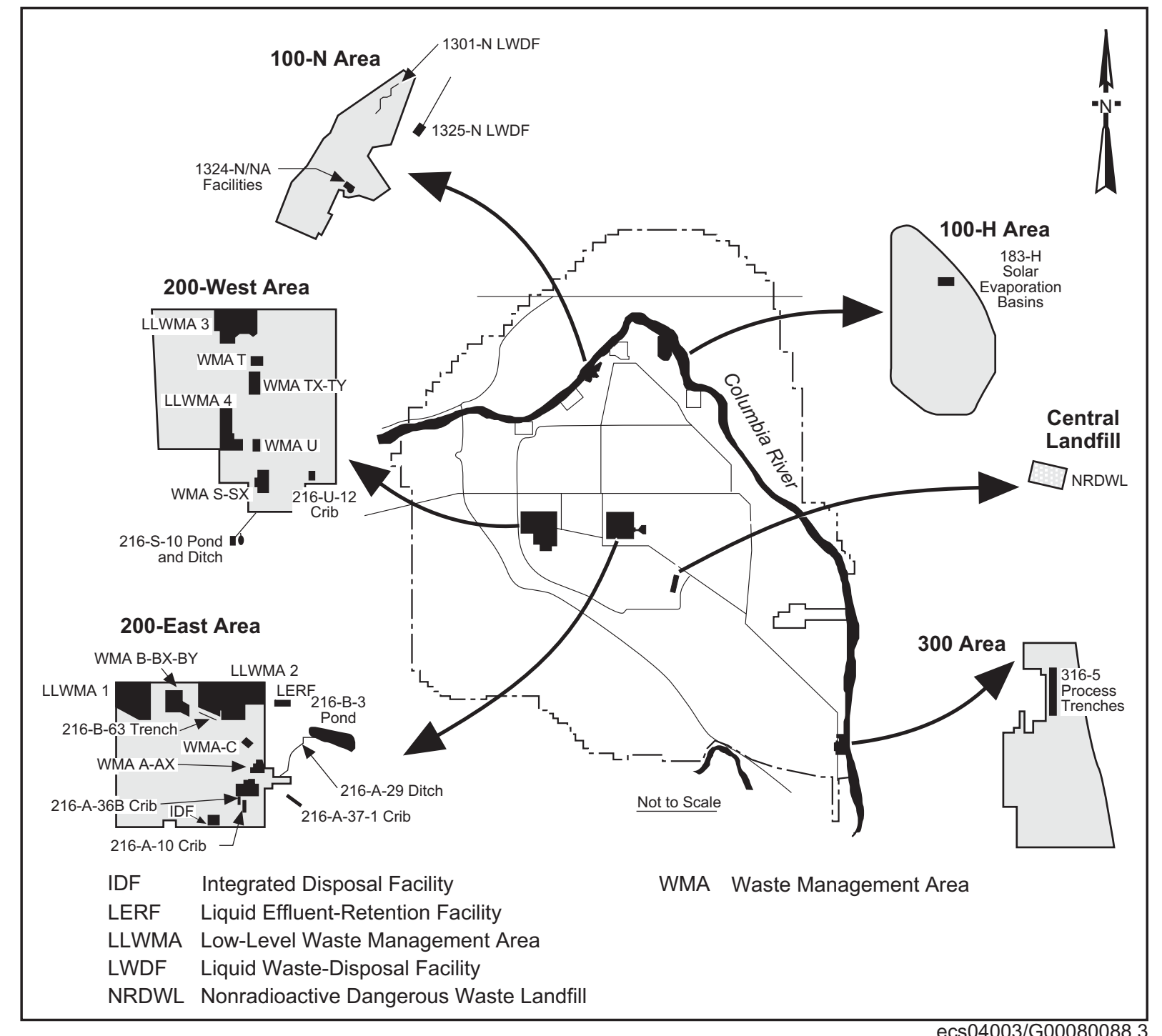

Figure B.1. Regulated Units on the Hanford Site Requiring Groundwater Monitoring. The 216-A-10, 216-A-36B, and 216-A-37-1 cribs are monitored as a single waste management unit, PUREX Cribs. 


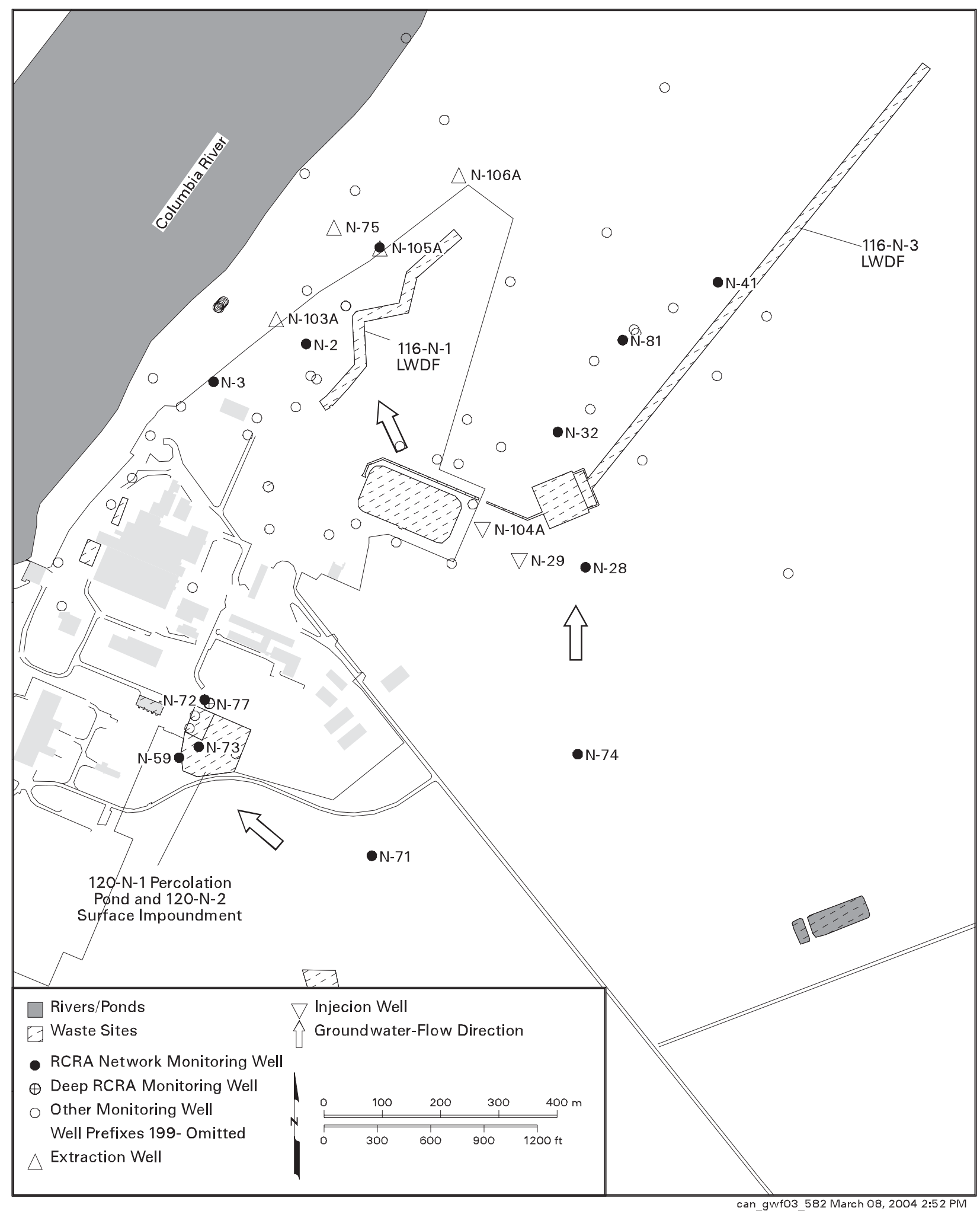

Figure B.2. Groundwater Monitoring Wells for the 100-N Area RCRA Sites 


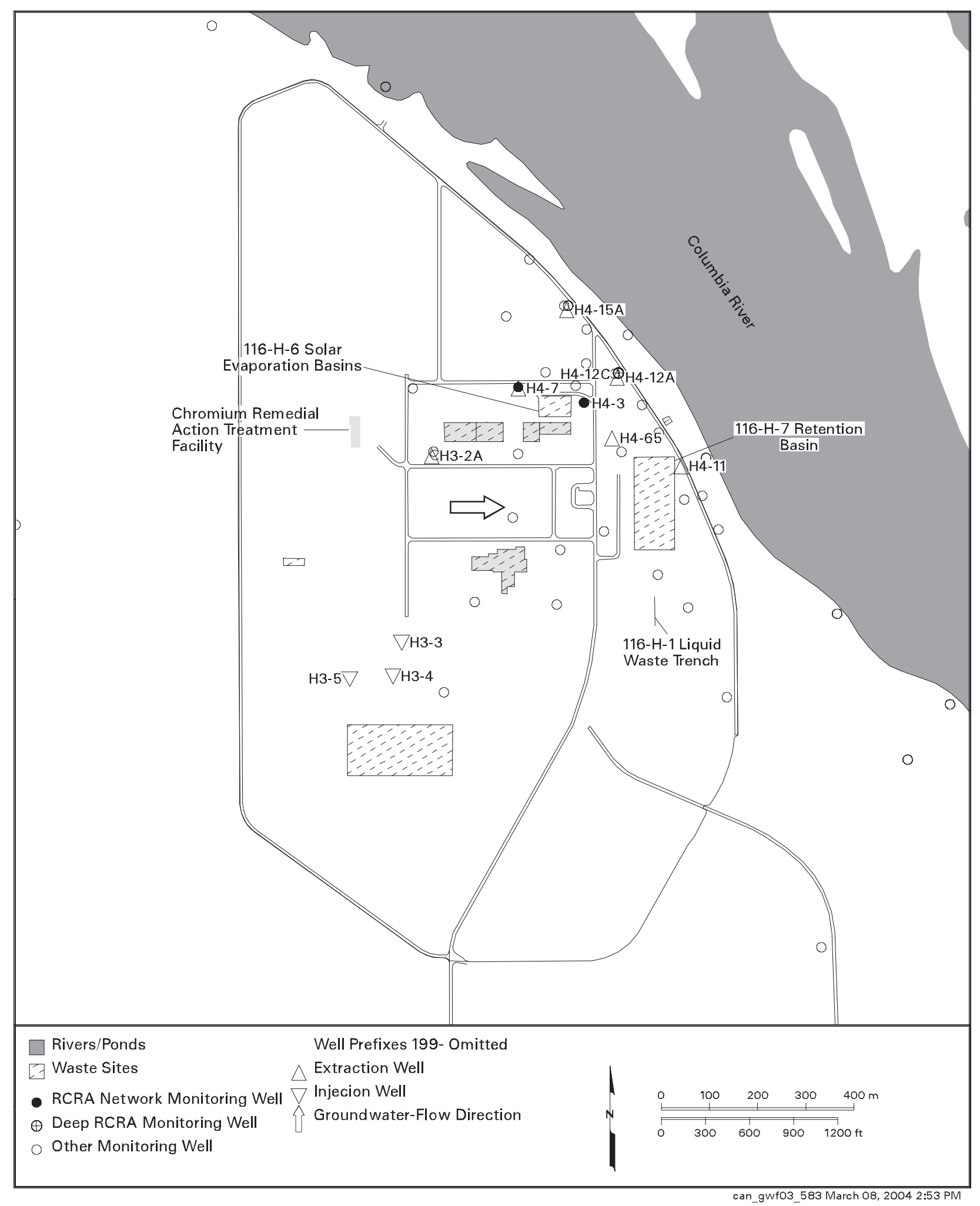

Figure B.3. Groundwater Monitoring Wells at the 116-H-6 (183-H) Evaporation Basins 


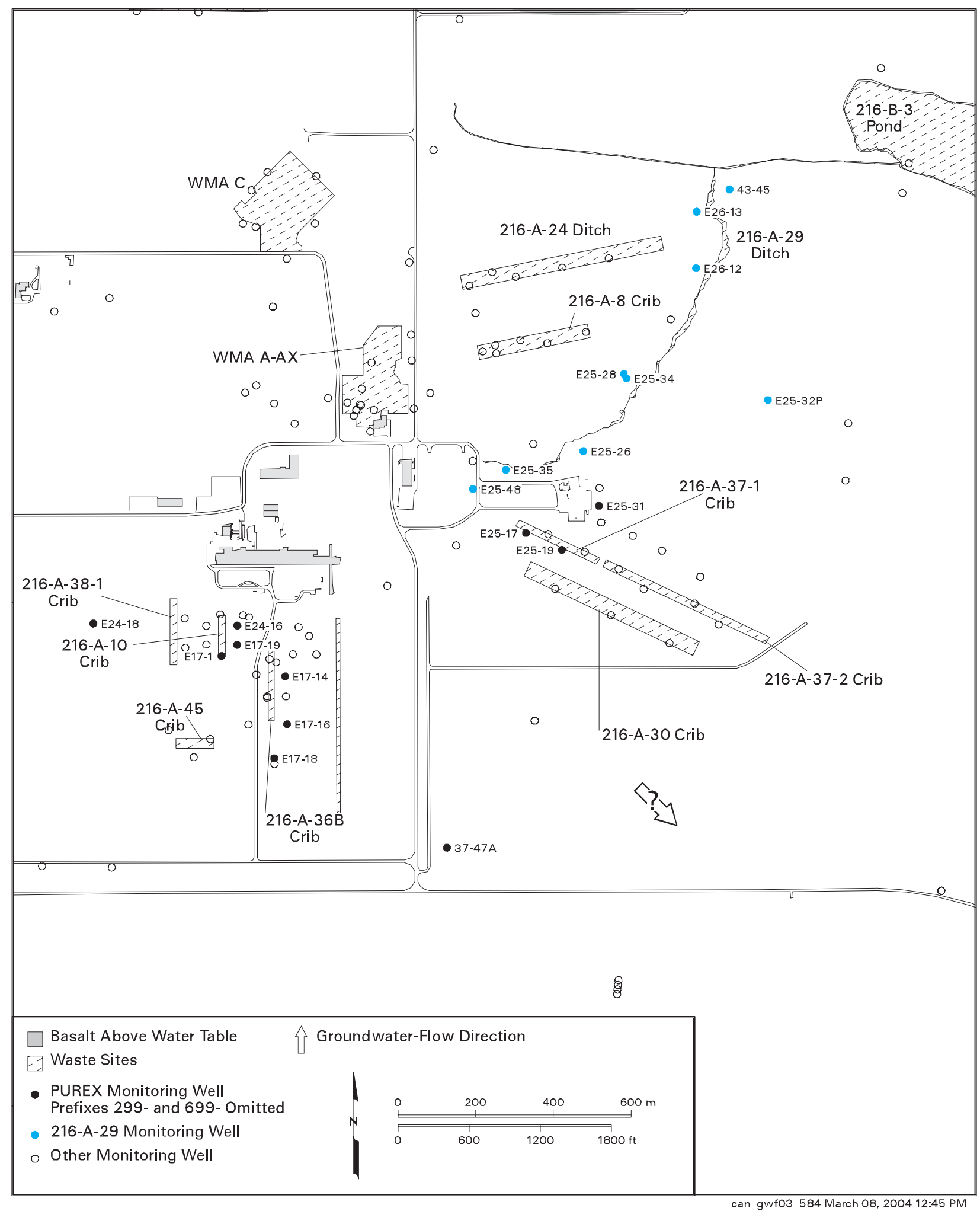

Figure B.4. Groundwater Monitoring Wells at the 216-A-29 Ditch and PUREX Cribs 


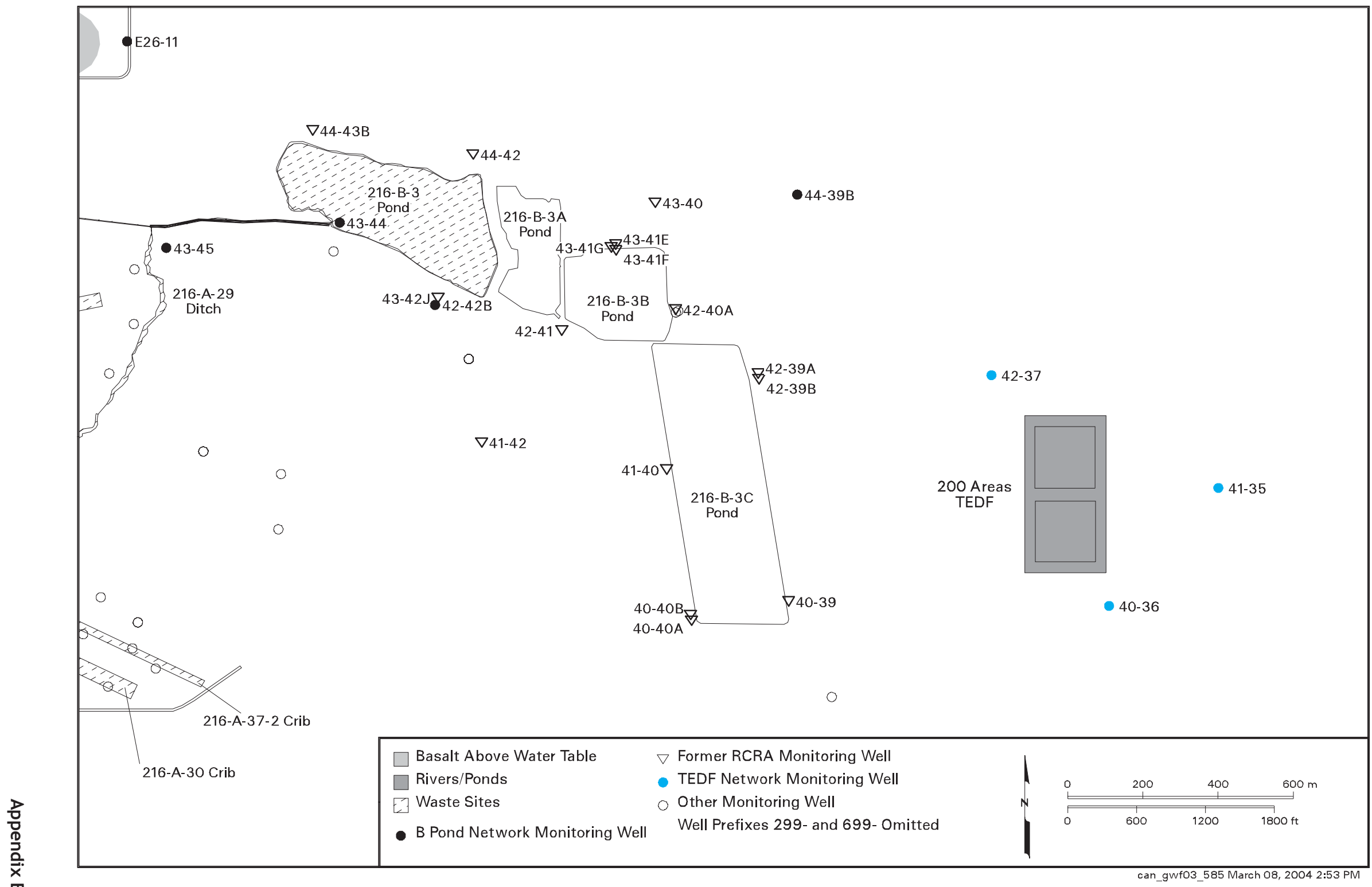

Figure B.5. Groundwater Monitoring Wells at the 216-B-3 Pond 


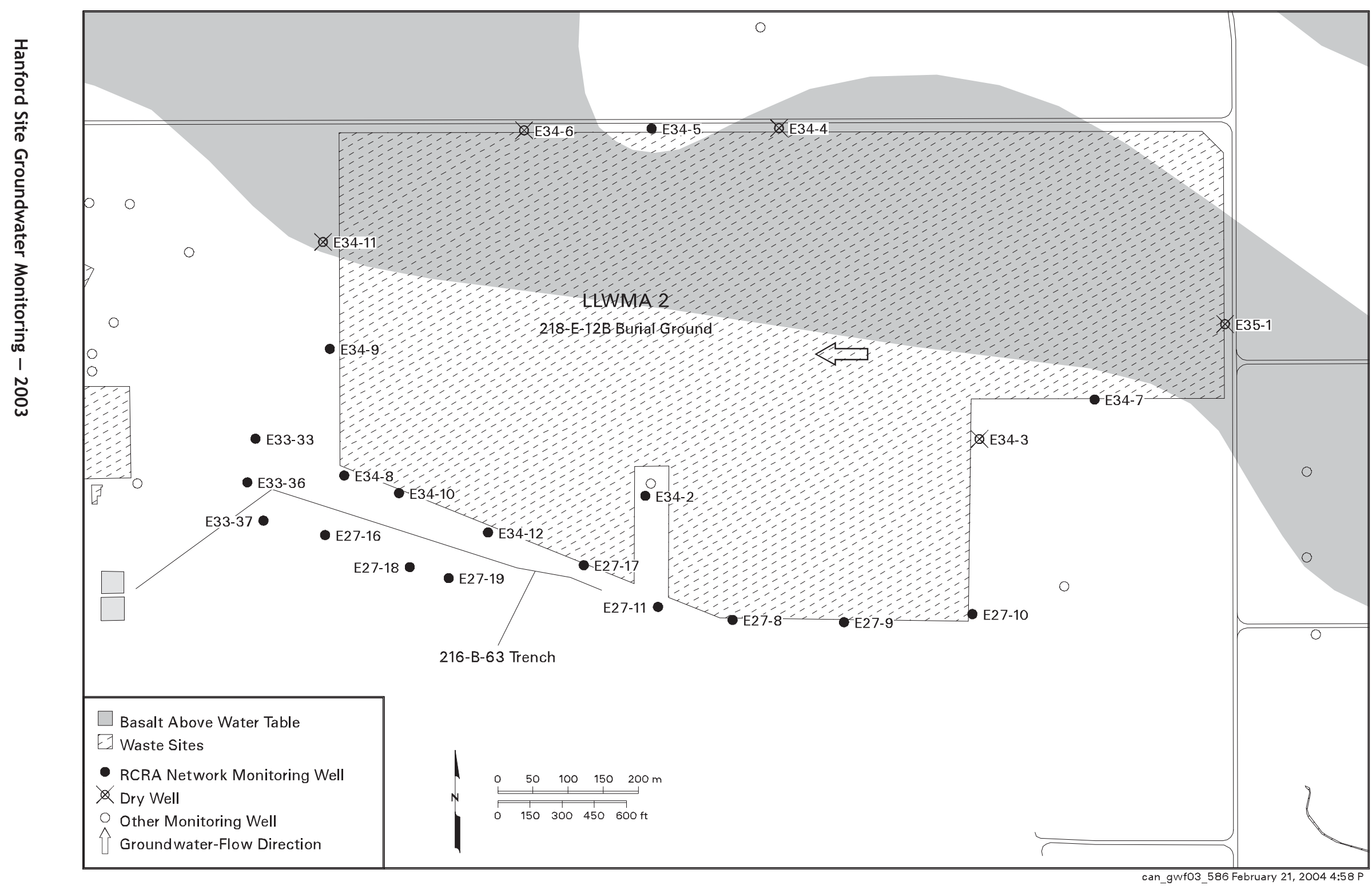

Figure B.6. Groundwater Monitoring Wells at the 216-B-63 Trench and Low-Level Waste Management Area 2 


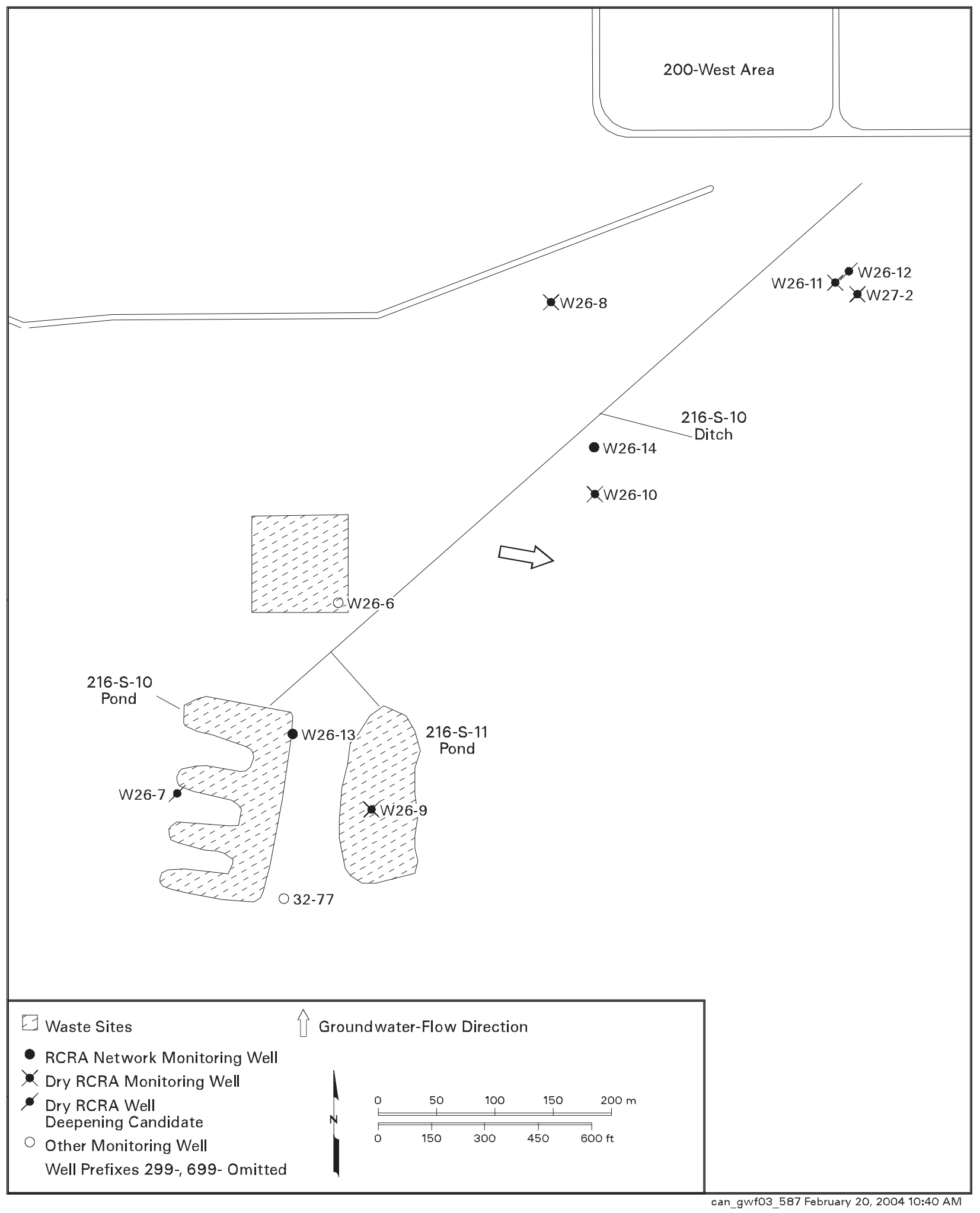

Figure B.7. Groundwater Monitoring Wells at the 216-S-10 Pond and Ditch 


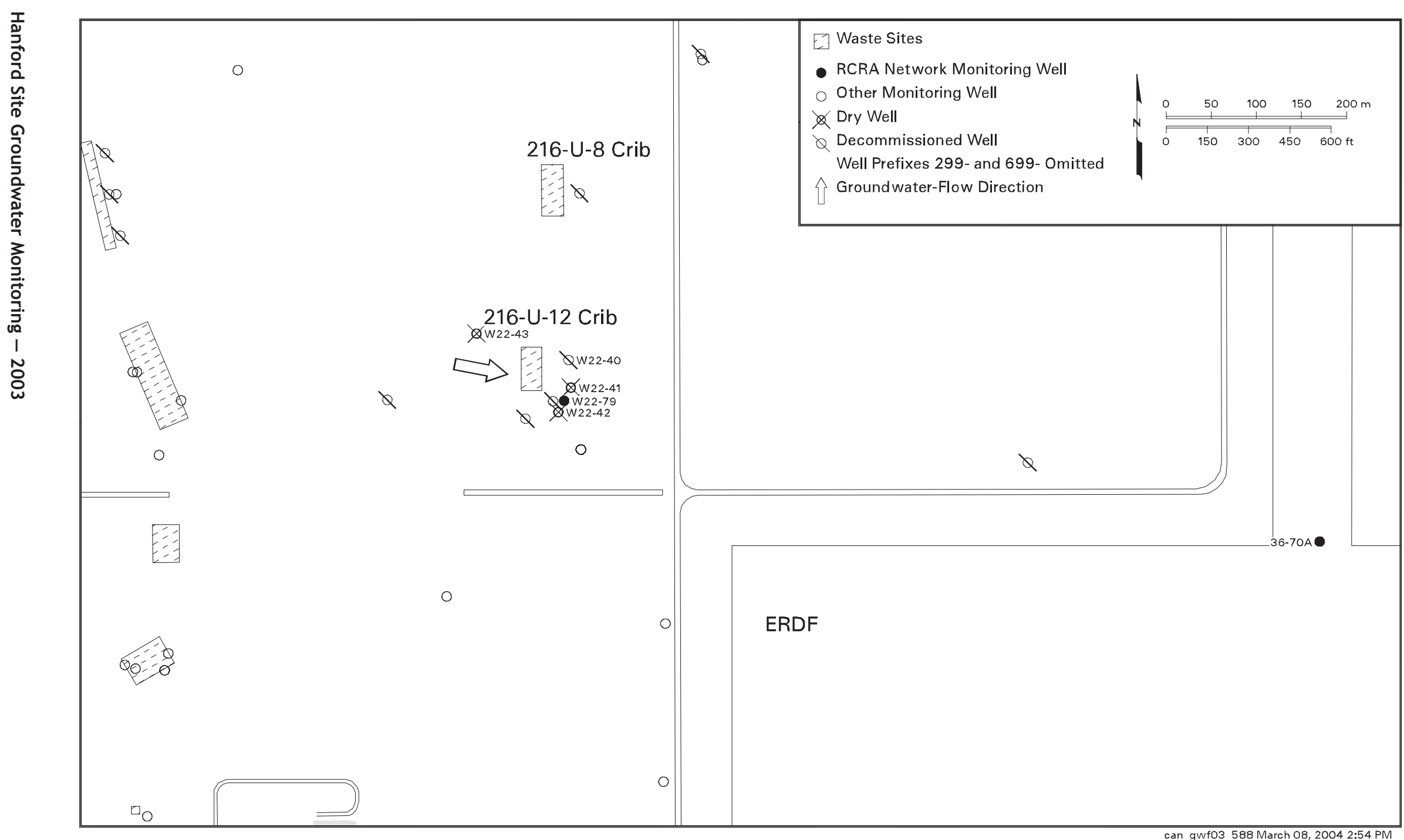

Figure B.8. Groundwater Monitoring Wells at the 216-U-12 Crib 


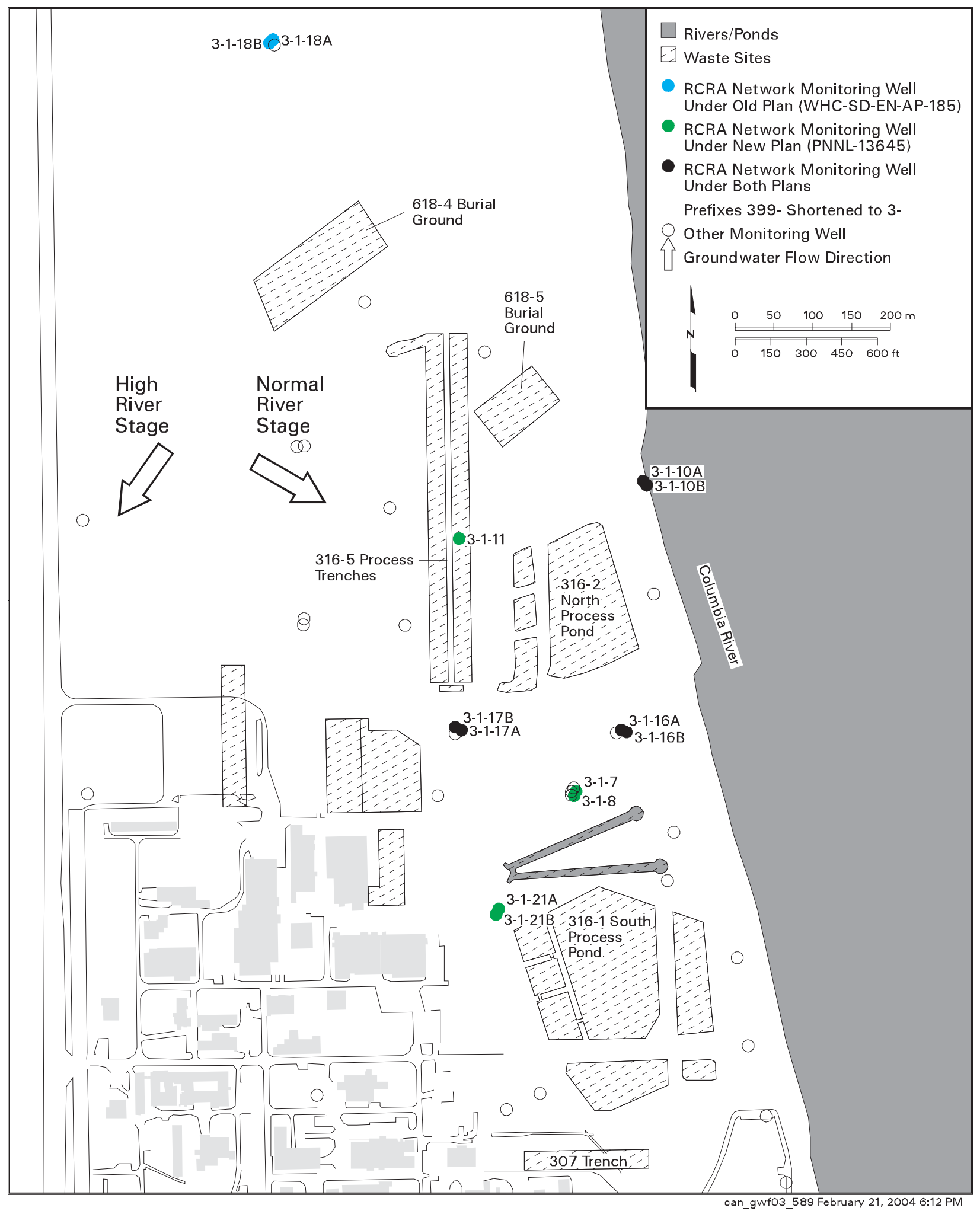

Figure B.9. Groundwater Monitoring Wells at the 316-5 Process Trenches 


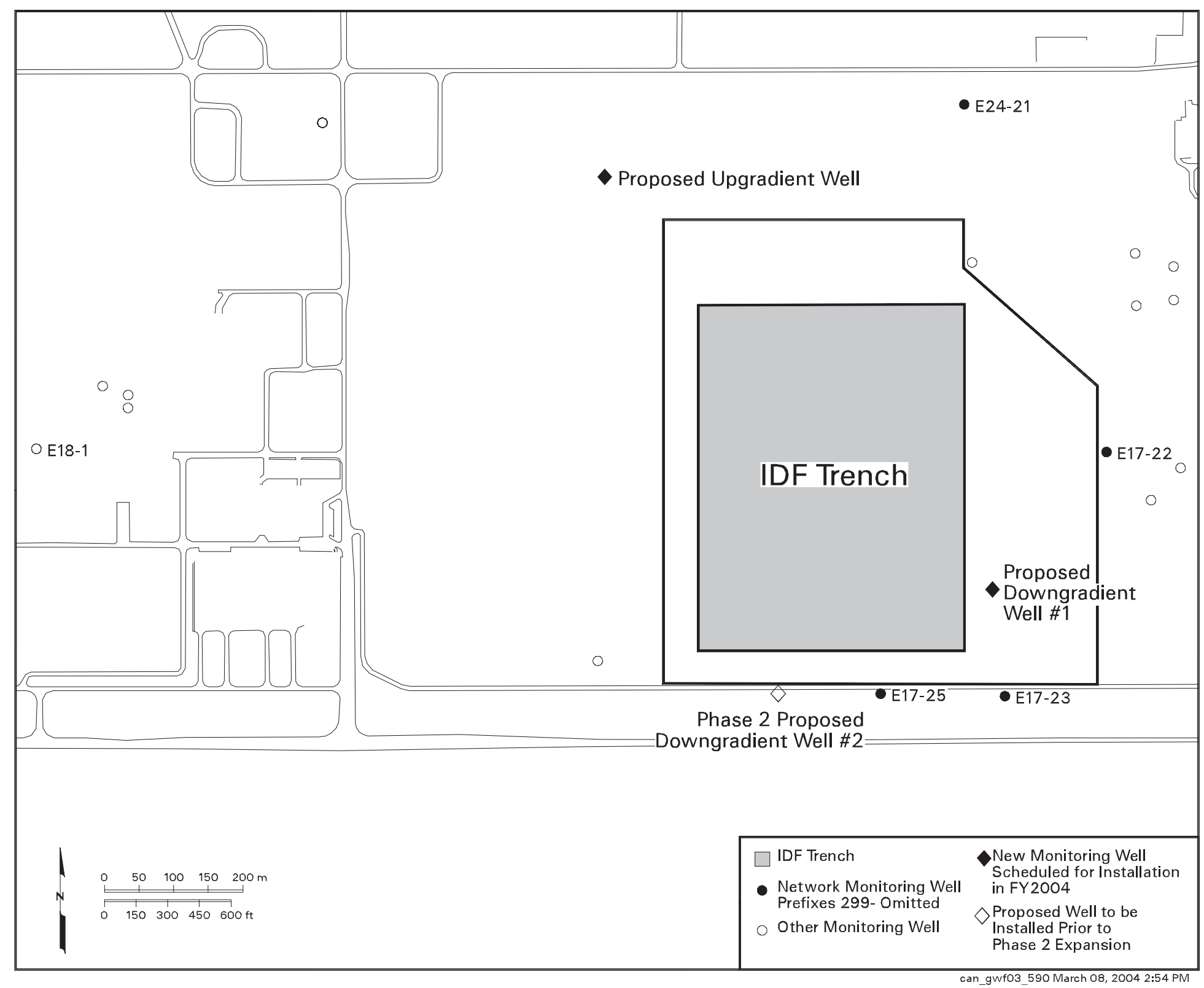

Figure B.10. Groundwater Monitoring Wells at the Integrated Disposal Facility 


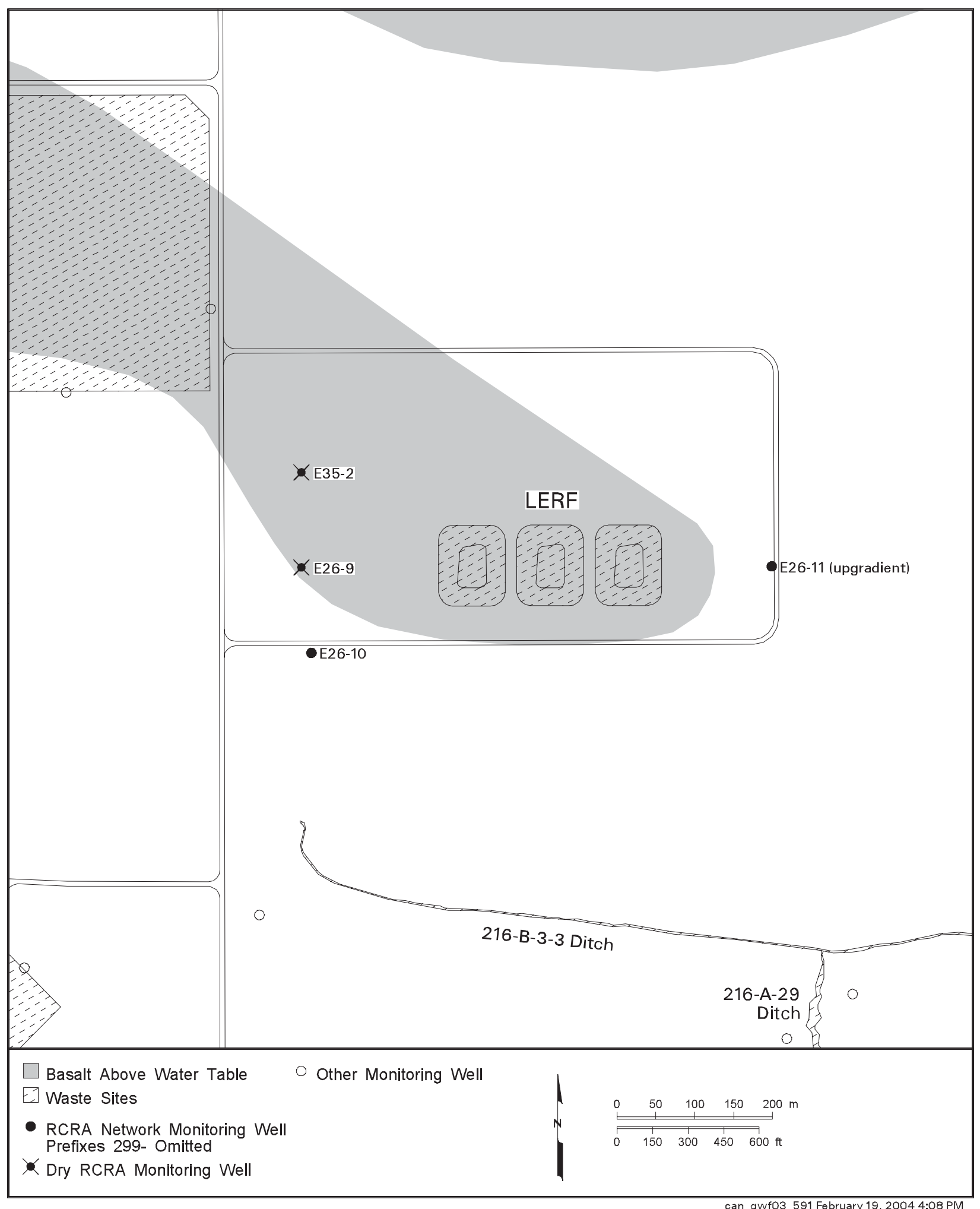

Figure B.11. Groundwater Monitoring Wells at the Liquid Effluent Retention Facility 


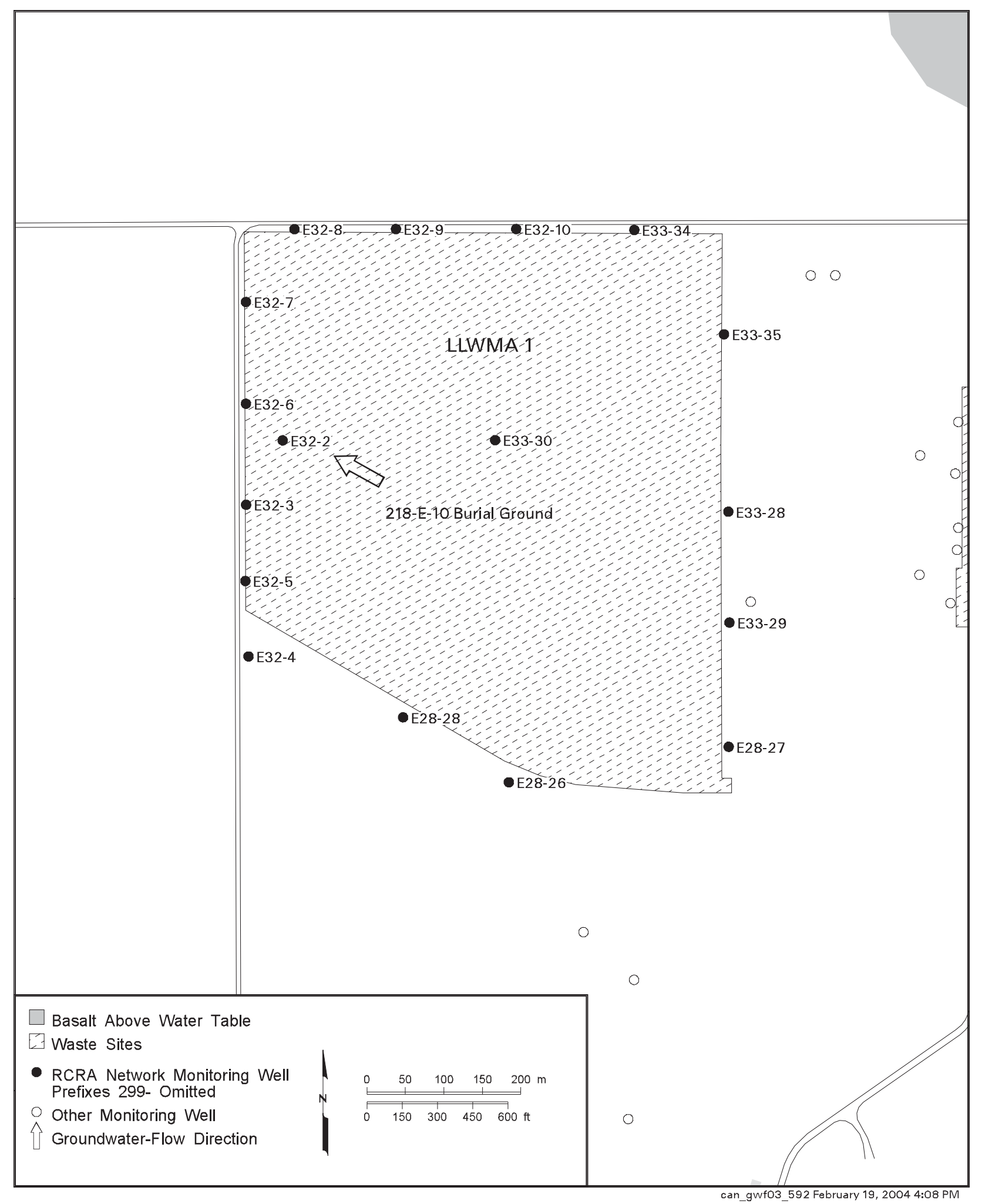

Figure B.12. Groundwater Monitoring Wells at Low-Level Waste Management Area 1 


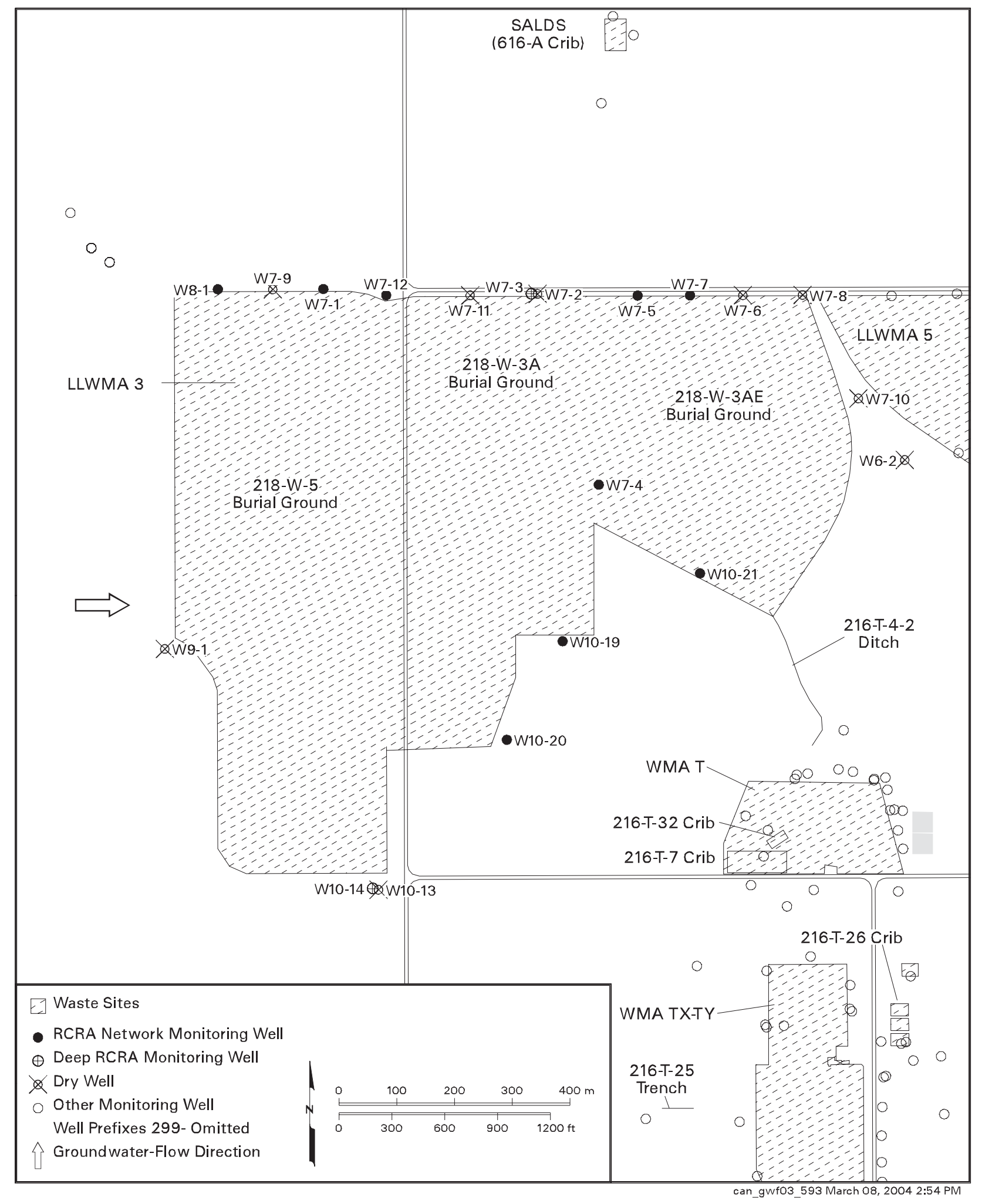

Figure B.13. Groundwater Monitoring Wells at Low-Level Waste Management Area 3 


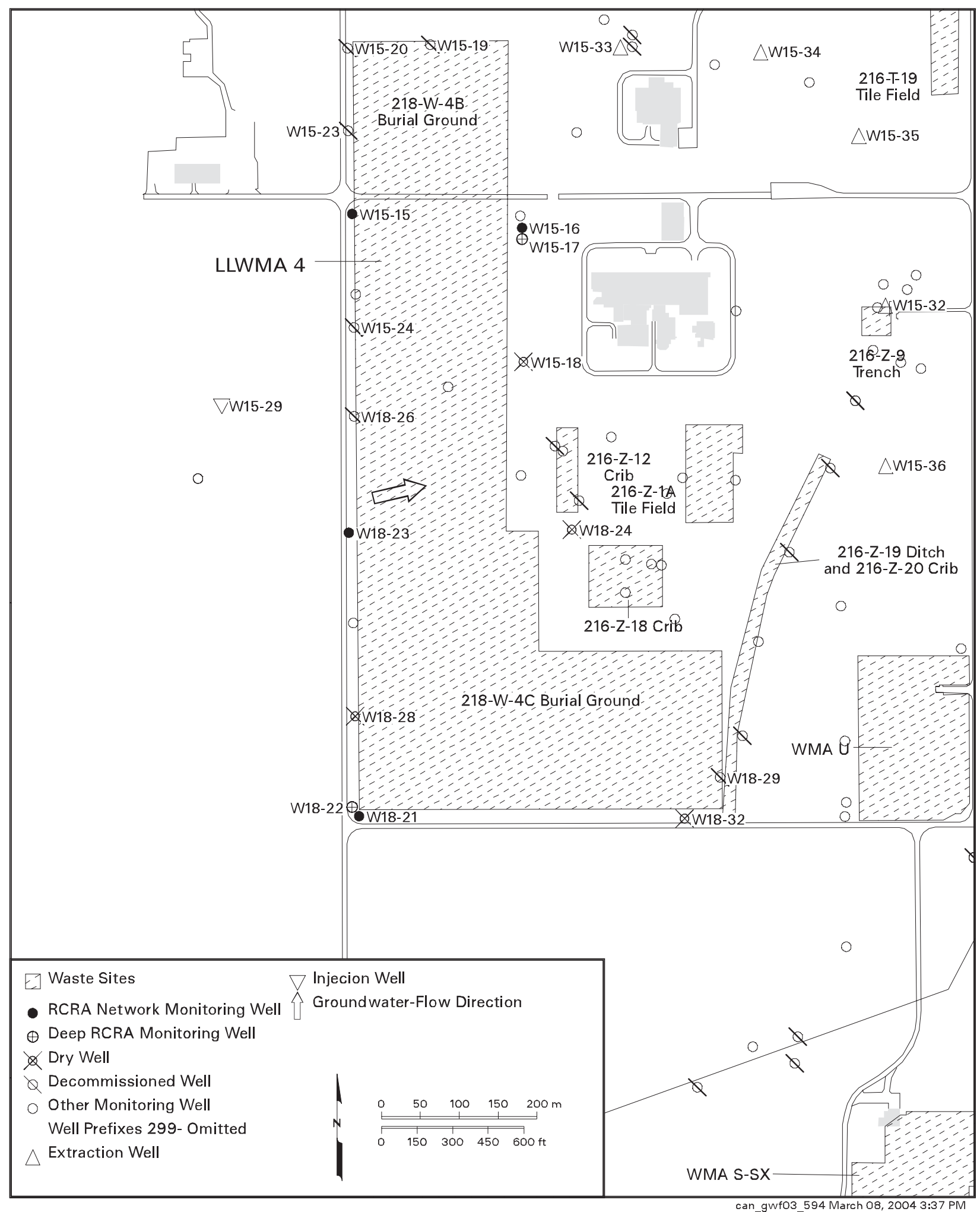

Figure B.14. Groundwater Monitoring Wells at Low-Level Waste Management Area 4 


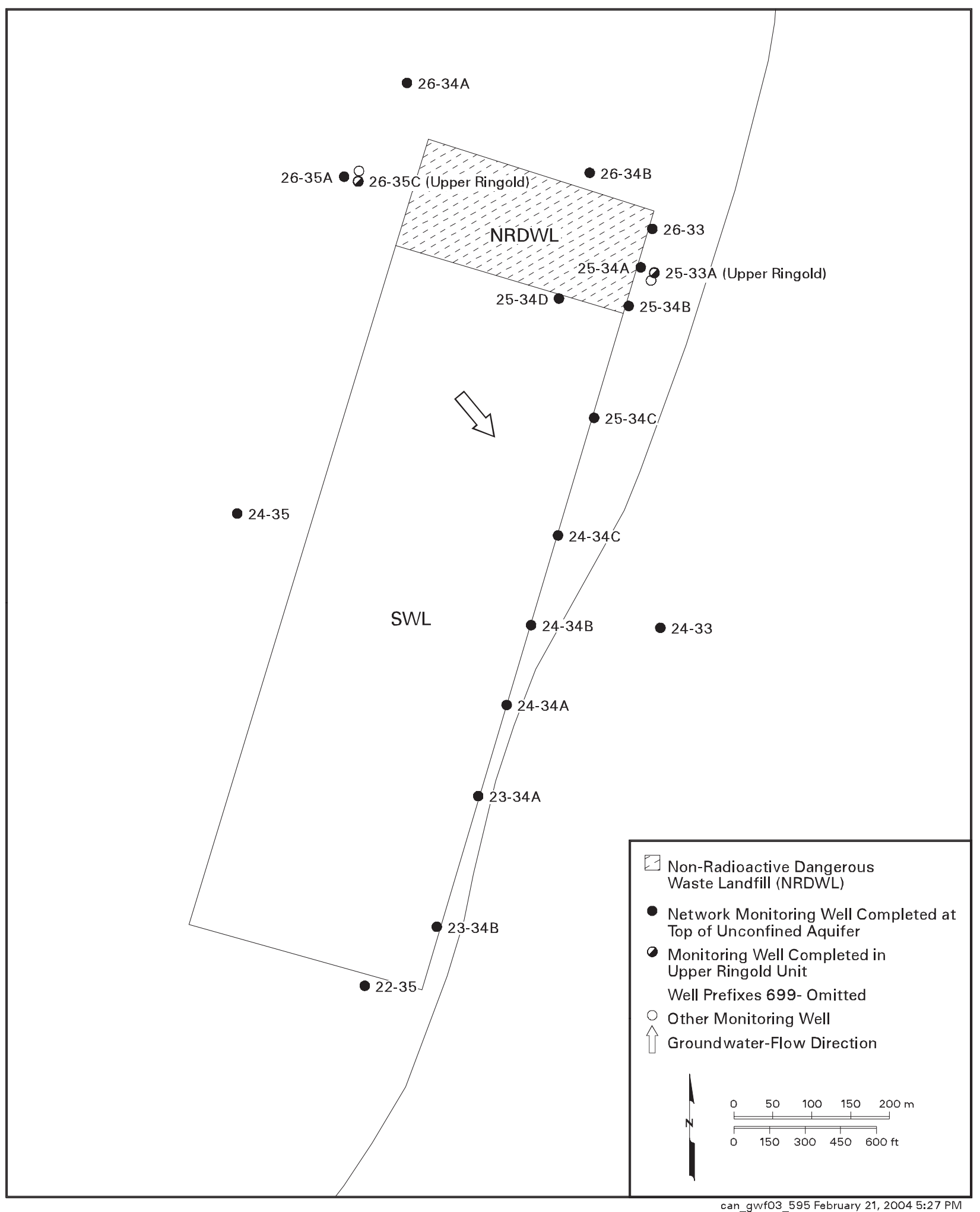

Figure B.15. Groundwater Monitoring Wells at the Nonradioactive Dangerous Waste Landfill 


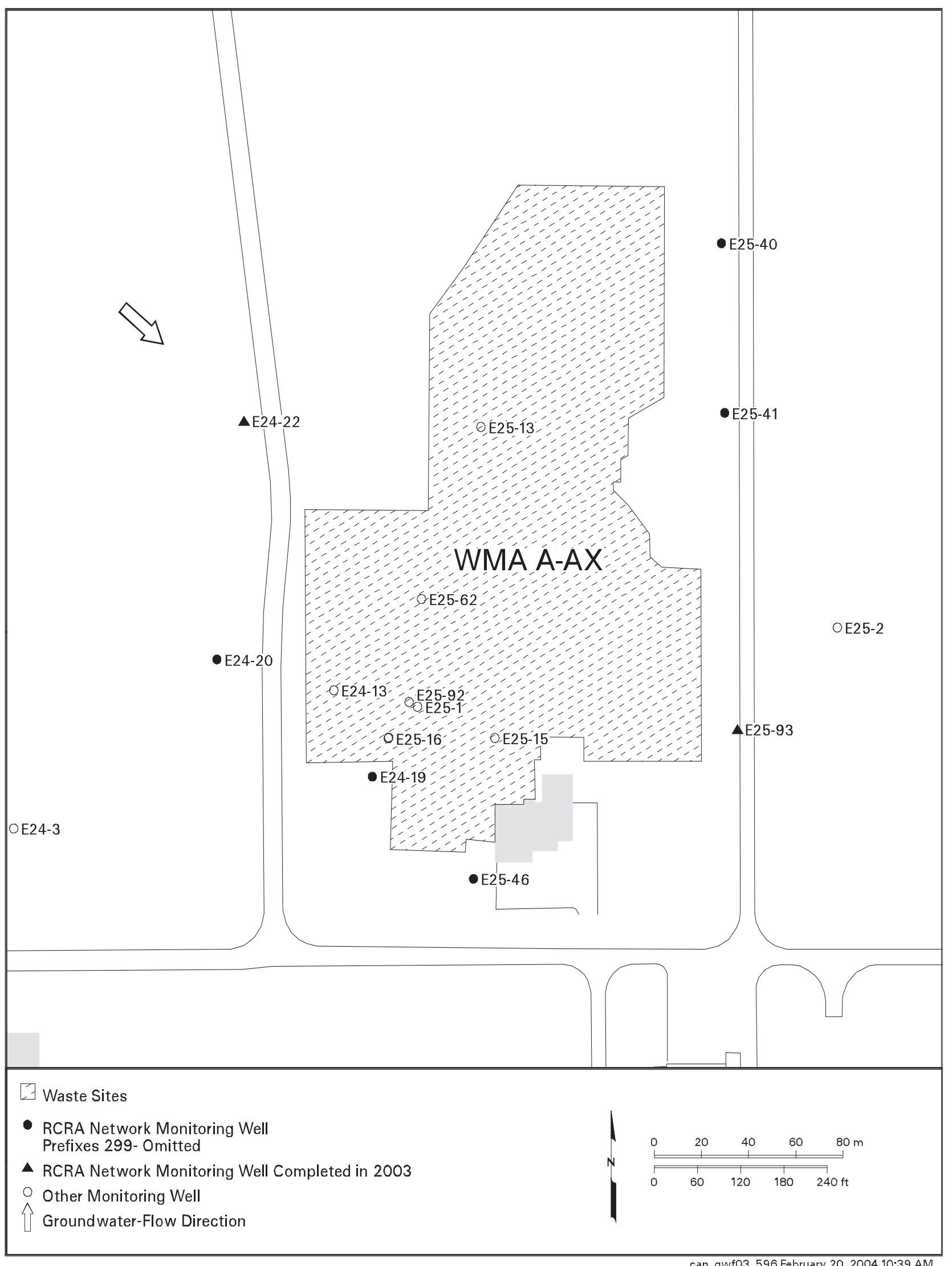

Figure B.16. Groundwater Monitoring Wells at Waste Management Area A-AX 


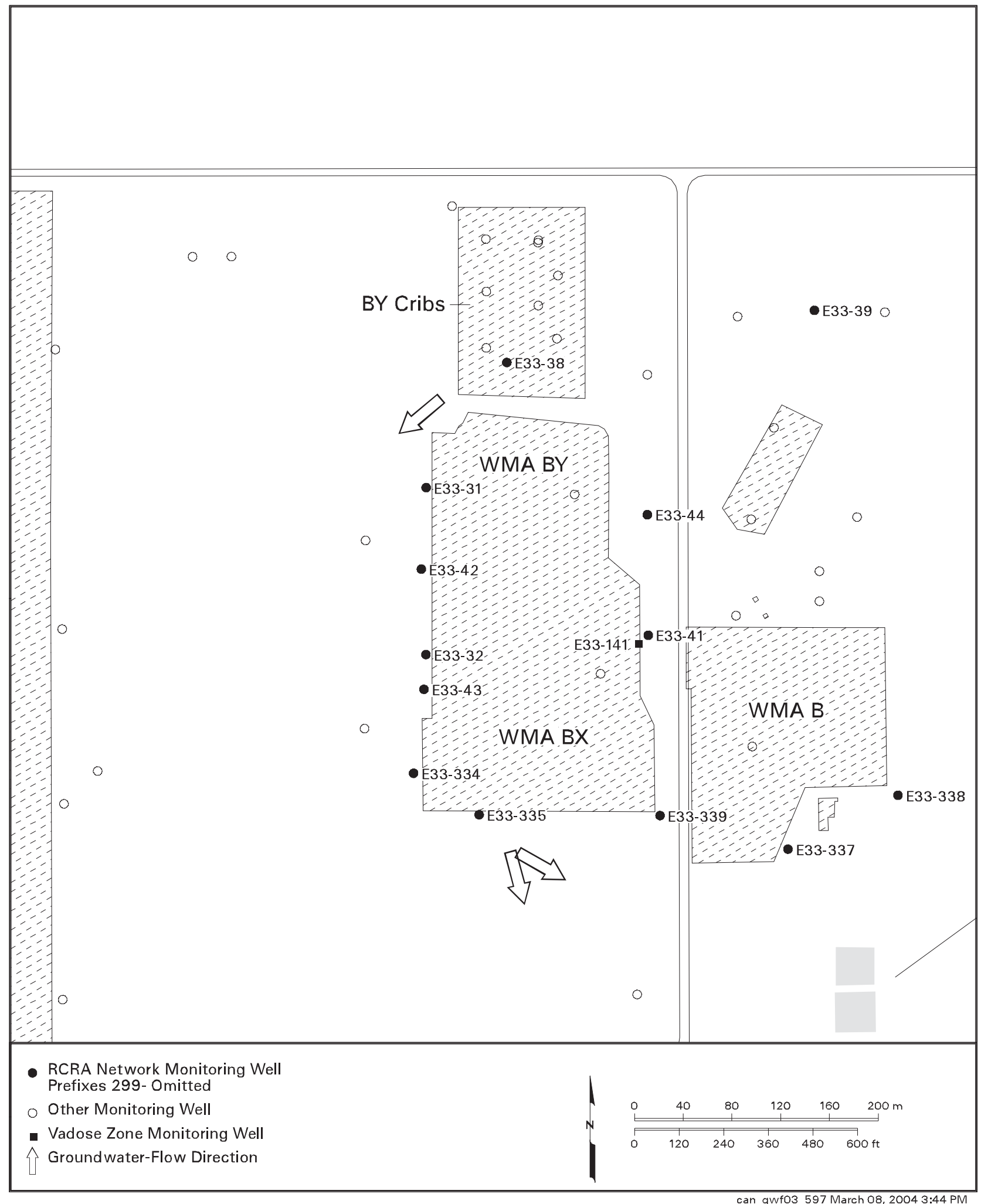

Figure B.17. Groundwater Monitoring Wells at Waste Management Area B-BX-BY 


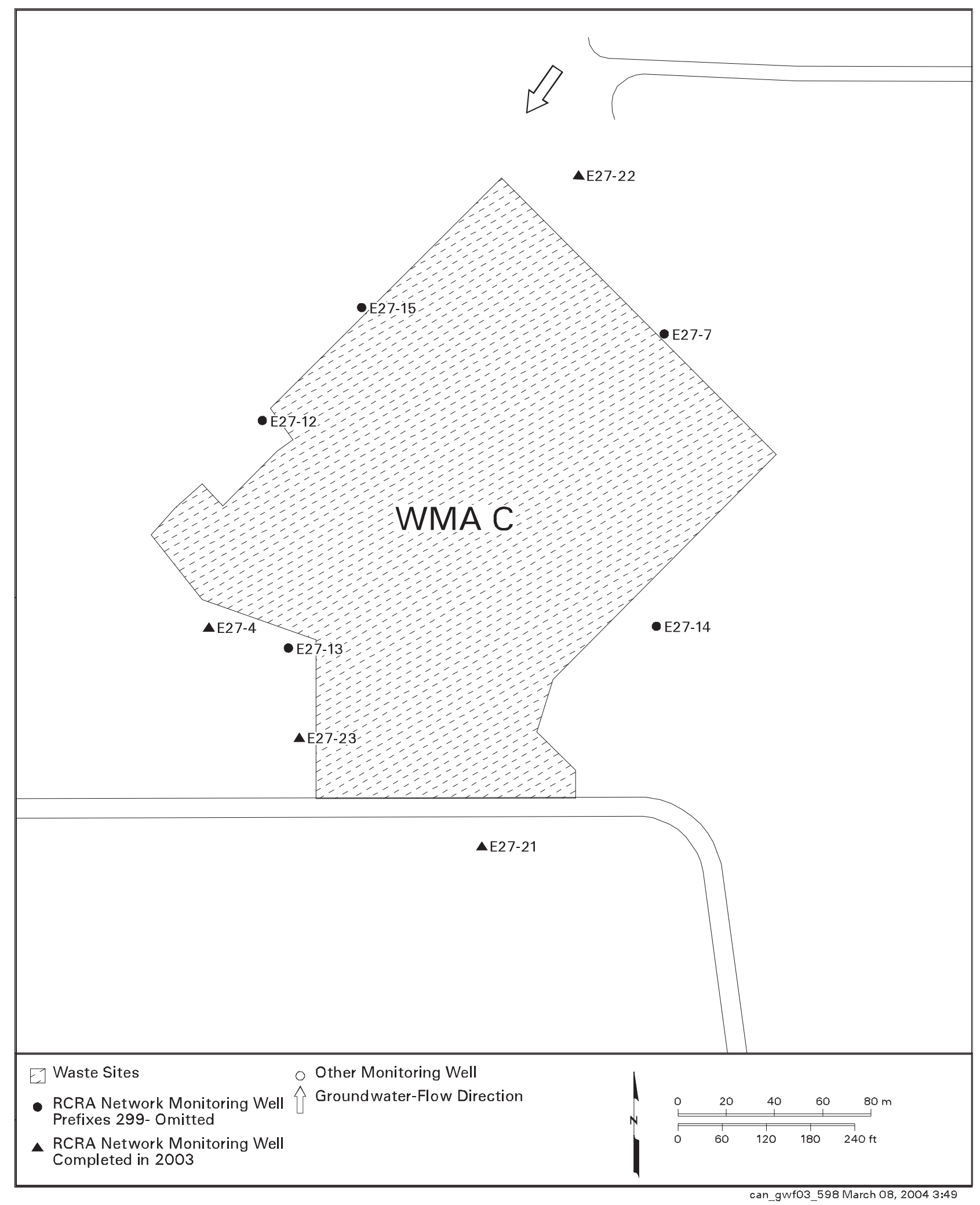

Figure B.18. Groundwater Monitoring Wells at Waste Management Area C 


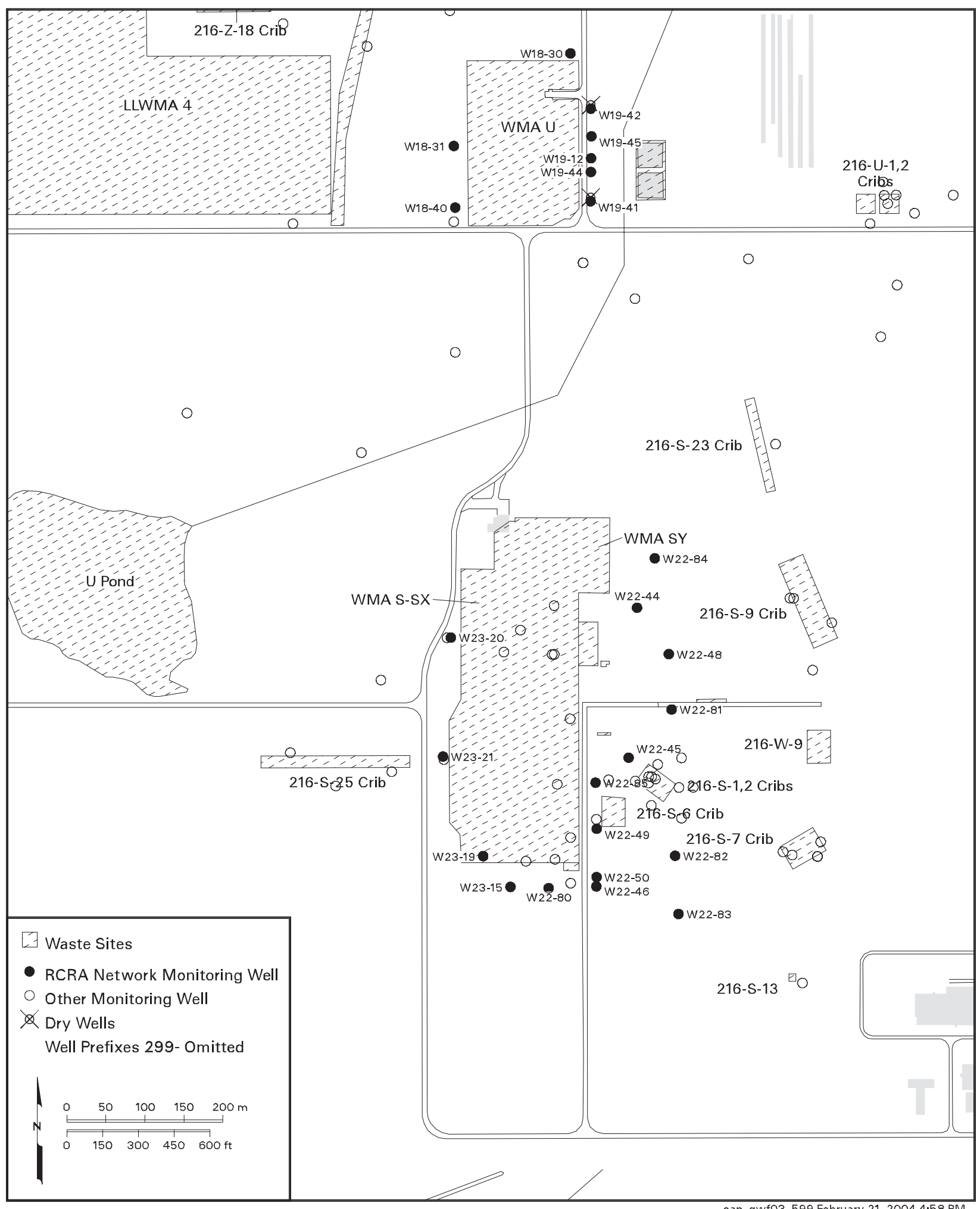

can gwf03 599 February 21, 2004 4:58 PM

Figure B.19. Groundwater Monitoring Wells at Waste Management Areas S-SX and U 


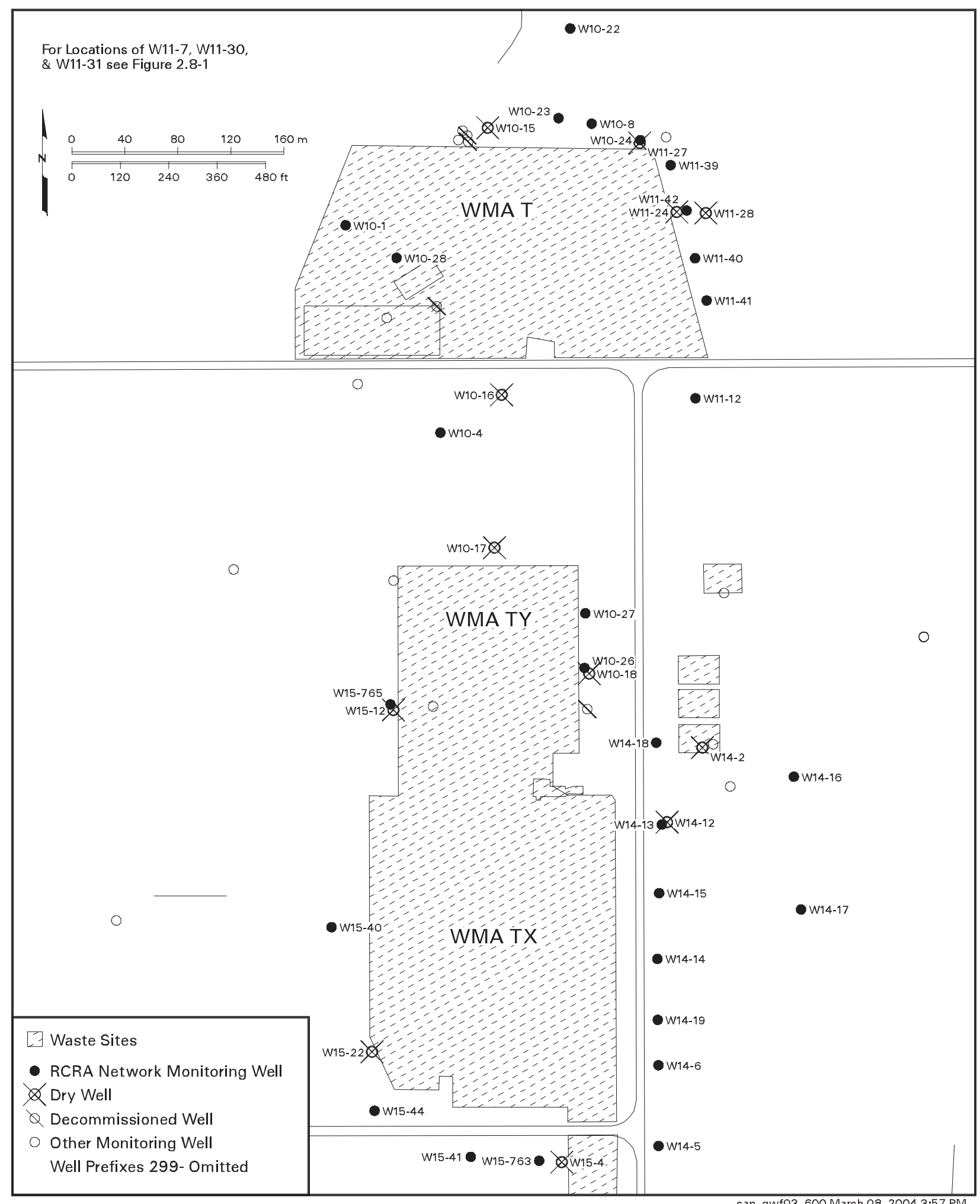

Figure B.20. Groundwater Monitoring Wells at Waste Management Areas T and TX-TY 


\section{Appendix C}

\section{Supporting Information for Other Regulated Sites}




\section{Contents}

Supporting Information for Other Regulated Sites ............................................................................... C.1

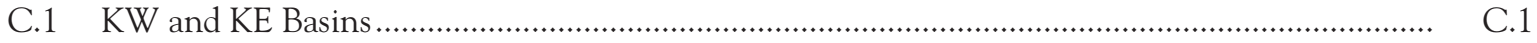

C.2 200 Area Treated Effluent Disposal Facility …….......................................................................... C.1

C.3 4608 B/C Process Ponds and 400 Area Water Supply Wells ............................................................ C.1

C.4 Environmental Restoration Disposal Facility ……........................................................................ C.2

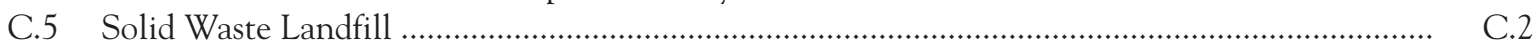

C.6 State-Approved Land Disposal Site ………............................................................................. C.3

C.7 Performance Assessment at Low-Level Waste Management Areas 1-4 …................................... C. C.3

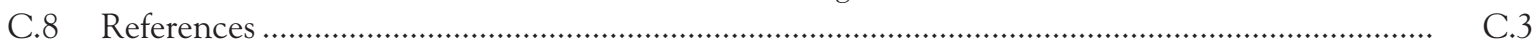

\section{Tables}

C.1 Wells Not Sampled as Scheduled in Fiscal Year 2003 ..................................................................... C.5

C.2 Monitoring Wells and Constituents for the KE and KW Basins ........................................................ C.5

C.3 Monitoring Wells, Constituents, and Enforcement Limits for the 200 Area Treated Effluent Disposal Facility

C.6

C.4 Monitoring Wells, Constituents, and Enforcement Limits for the 400 Area Process Ponds ............... C.6

C.5 Monitoring Wells and Constituents for the Environmental Restoration Disposal Facility ................ C.7

C.6 Monitoring Wells and Constituents for the Solid Waste Landfill ........................................................ C.7

C.7 Sampling Results for Required Constituents at the Solid Waste Landfill .......................................... C.8

C.8 Results of Shapiro and Francia Test for Normality and Background Threshold Values for the

Solid Waste Landfill ...................................................................................................................... C.10

C.9 Monitoring Wells, Constituents, and Enforcement Limits for the State-Approved Land

Disposal Site

C.11

\section{Figures}

C.1 Regulated Units on the Hanford Site Requiring Groundwater Monitoring ….................................... C.12

C.2 Groundwater Monitoring Wells at the 100-K Basins ........................................................................ C.13

C.3 Groundwater Monitoring Wells at the 200 Area Treated Effluent Disposal Facility ........................... C.14

C.4 Groundwater Monitoring Wells at the 400 Area Process Ponds ........................................................ C.15

C.5 Groundwater Monitoring Wells at the Environmental Restoration Disposal Facility ........................ C.16

C.6 Groundwater Monitoring Wells at the Solid Waste Landfill .................................................................. C.17

C.7 Groundwater Monitoring Wells at the State-Approved Land Disposal Site ...................................... C.18 


\section{Appendix C}

\section{Supporting Information for Other Regulated Sites}

The appendix provides constituent lists, well network configurations, and other ancillary information for regulated facilities that fall outside of Resource Conservation and Recovery Act (RCRA) and Comprehensive Environmental Response, Compensation, and Liability Act (CERCLA) programs. Some network wells in the facilities discussed below are shared with RCRA or CERCLA facilities (e.g., the State-Approved Land Disposal Site). Figure C.1 shows the general locations of these facilities. Table C.1 lists the wells not sampled as scheduled during fiscal year 2003.

\section{C.1 KW and KE Basins}

The basins associated with the KW and KE Reactors currently store spent nuclear fuel that originated primarily in the N Reactor. The Spent Nuclear Fuels Project is underway to remove the fuel from the basins, improve the integrity of its encapsulation, and transport it to a more secure storage site in the Central Plateau region. The Spent Nuclear Fuels Project also will remove a large amount of highly radioactive sludge and shielding water that has accumulated in the basins. The Hanford Federal Facility Agreement and Consent Order (Tri-Party Agreement; Ecology et al. 1998) Milestone M-34-00 describes the scope and schedule for this major Hanford Site cleanup endeavor. Completion of the basin cleanup project is expected by 2006.

Groundwater monitoring near the basins is conducted under the Atomic Act of 1954 to (a) describe groundwater movement in the area and (b) characterize the impact of past and potential future loss of shielding water to the ground. The U.S. Department of Energy (DOE) monitors groundwater around these facilities to comply with requirements for nuclear fuel and waste storage facilities (DOE Order 5400.1 [IV]9b). The Hanford Site environmental monitoring plan (DOE/RL-91-50) describes the regulatory basis for monitoring these facilities.

During fiscal year 2003, monitoring revealed no evidence of ongoing loss of water to the ground from either of these basins. Monitoring continues to track groundwater contamination caused by past leakage from the KE Basin. Tritium concentrations increased significantly at two wells near the northwest corner of the KE Reactor, and at one well on the east side of the KW Reactor. No direct cause for these increases has yet been discovered, but they are not believed to be related to shielding water loss from the basins. An off-normal occurrence report has been filed with regard to these increases.

The monitoring network and sampling schedule were last revised during fiscal year 2002 (PNNL-14033; Table C.2 and Figure C.2). Section 2.3 provides discussion of monitoring results.

\section{C.2 200 Area Treated Effluent Disposal Facility}

State waste discharge permit (WAC 173-216) governs groundwater sampling and analysis in the three monitoring wells at this facility (Table C.3 and Figure C.3). The constituent list and frequency of sampling are specified in the permit. A groundwater monitoring plan (PNNL-13032) describes details of the monitoring program. Wells were sampled quarterly during fiscal year 2003 as scheduled.

No permit criteria for constituents in groundwater were exceeded in fiscal year 2003. The groundwater monitoring network continues to show that effluent from the facility is not taking a direct route to the uppermost aquifer, but is likely moving southward within the Hanford formation.

\section{C.3 4608 B/C Process Ponds and 400 Area Water Supply Wells}

The $4608 \mathrm{~B} / \mathrm{C}$ ponds (also called the 400 Area process ponds) are regulated under WAC 173-216. The permit, issued on August 1, 1996, and modified on February 10, 1998, defines groundwater enforcement limits applied during 
fiscal year 2003 (Table C.4 and Figure C.4). Groundwater quality met permit conditions in fiscal year 2003. A recent modification of the permit (Ecology 2003) indicates that groundwater monitoring activities for this facility will be discontinued effective October 1, 2003.

The water supply in the 400 Area, which comes from wells, is also monitored to maintain compliance with drinking water standards. In the past, tritium concentrations have exceeded the drinking water standard $(20,000 \mathrm{pCi} / \mathrm{L})$ in the backup water supply wells, but levels remained below the standard in fiscal year 2003 (see Section 2.11.4.2). Water supply sampling indicates that tritium in the drinking water is maintained at a level below the 4-millirem-per-year dose equivalent standard. Groundwater quality for the 400 Area is discussed in Section 2.11. Sampling frequency was reduced from monthly to quarterly beginning in fiscal year 2002. The wells were sampled three times in fiscal year 2003. They could not be sampled one quarter because the flush line was plugged.

\section{C.4 Environmental Restoration Disposal Facility}

This facility is a landfill authorized by CERCLA that is designed to meet RCRA requirements of Subpart N, 40 CFR 264. The groundwater monitoring network consists of one upgradient and three downgradient wells that are sampled semiannually (Table C.5 and Figure C.5). In addition, the facility has a system to collect and remove leachate that helps evaluate whether the liner system is performing within design standards. BHI-00873 describes the sampling plan for groundwater monitoring. In fiscal year 2003, leachate monitoring detected low levels of common metals, anions, and mobile radionuclides (see Section 3.2). Groundwater monitoring results showed that concentrations of some constituents of concern remained elevated. Possible upward trends were noted for gross beta in two downgradient wells and total chromium in one downgradient well. This contamination most likely is a result of migration of groundwater plumes from the 200 West Area. High zinc concentrations continued in one downgradient monitoring well and may indicate continued galvanic corrosion of well components. Another downgradient well previously had high zinc concentrations as well. This well was repaired in 2000 and initial results following the repair showed much lower zinc values, but recent analyses have shown erratic results for this cation.

\section{C.5 Solid Waste Landfill}

State dangerous waste regulations (WAC 173-304) govern groundwater monitoring at this landfill. The final closure plan for the site has been implemented. Wells are sampled quarterly for constituents specified in WAC 173-304 plus the site-specific constituents including various chlorinated hydrocarbons, filtered arsenic, and 1,4-dioxane (Table C.6 and Figure C.6).

Statistical evaluations of the constituents specified in WAC 173-304 for landfills (Table C.7 and Table C.8) revealed that eight exceeded their background threshold levels (or range for $\mathrm{pH}$ ) during fiscal year 2003:

- Specific conductance exceeded its threshold level $(583 \mu \mathrm{S} / \mathrm{cm})$ in all eight of the downgradient wells in the monitoring network.

- Sulfate exceeded its threshold level $(47.2 \mathrm{mg} / \mathrm{L})$ in five of the eight downgradient wells.

- Reported results for $\mathrm{pH}$ were lower than the background threshold range (6.68 to 7.84) in four downgradient wells.

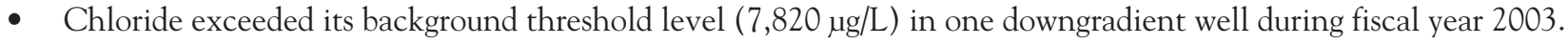

- Various results for ammonia, chemical oxygen demand, coliform bacteria, and temperature were anomalies in several Solid Waste Landfill network wells, but these results may have been caused by errors in sampling or analysis.

Tritium exceeded its drinking water standard at many of the monitoring wells on the east side of the landfill, but the source is upgradient. Two chlorinated hydrocarbons equaled or exceeded WAC 173-200 groundwater quality criteria in at least one well of the Solid Waste Landfill network during fiscal year 2003. Eleven wells exceeded groundwater quality criteria for 1,1-dichloroethane and tetrachloroethene. Section 2.8 discusses monitoring results for the Solid Waste Landfill.

The monitoring network for the Solid Waste Landfill has two upgradient wells and eight downgradient wells. During fiscal year 2003, one downgradient well (699-25-34C) along the southeast side of the landfill had a water-level decline that was significant enough to prevent further sampling. During fiscal year 2004, discussion with the Washington 
State Department of Ecology will determine whether the well should be replaced or deepened or whether the well network can function adequately with the dry well.

\section{C.6 State-Approved Land Disposal Site}

A state waste discharge permit (WAC 173-216) requires groundwater monitoring at this site. The permit was granted in June 1995, and the site began to operate in December 1995 (see PNNL-13121). Groundwater monitoring for tritium only is conducted in 19 wells near the facility (Table C.9 and Figure C.7). The permit stipulates requirements for groundwater monitoring and establishes enforcement limits for concentrations of 15 constituents in 3 additional wells immediately surrounding the facility (Table C.9).

During fiscal year 2003, tritium concentrations in proximal wells 699-48-77A and 699-48-77D generally decreased. Tritium concentrations remained highest in well 699-48-77C. This reflects the result of the delayed penetration of effluent deeper into the aquifer from historical tritium discharges. Tritium-tracking wells along the north boundary of the 200 West Area continue to go dry. Wells 299-W6-8 and 299-W7-8 became unserviceable during late fiscal year 2002, and hence, was not sampled during fiscal year 2003. Also, well 299-W7-6 went dry after the January 2003 sample. However, because of the original high density of wells located in this area, the wells that became dry have not as yet significantly affected the network coverage.

No permit enforcement limits were exceeded during fiscal year 2003. Evaluation of the well network indicates that well coverage is currently adequate to satisfy groundwater monitoring requirements. Monitoring results are discussed in Section 2.8.

\section{C.7 Performance Assessment at Low-Level Waste Management Areas 1-4}

Groundwater performance assessment continued at the four low-level waste management areas during fiscal year 2003 (see Sections B.13 through B.16). The well networks for these facilities were sampled twice for performance assessment parameters iodine-129, technetium-99, and uranium in Low-Level Waste Management Areas 2, 3, and 4. Only technetium-99 is sampled as a performance assessment parameter in Low-Level Waste Management Area 1 (see Tables B.21, B.23, B.25, and B.27).

\section{C.8 References}

40 CFR 264, Subpart N. U.S. Environmental Protection Agency. "Landfills." U.S. Code of Federal Regulations.

Atomic Energy Act of 1954. As amended, Ch. 1073, 68 Stat. 919, 42 USC 2011 et seq.

BHI-00873. 1996. Description of Work for Routine Groundwater Sampling at the Environmental Restoration Disposal Facility. BH Ford, Bechtel Hanford, Inc., Richland, Washington.

Comprehensive Environmental Response, Compensation, and Liability Act. 1980. Public Law 96-510, as amended, 94 Stat. 2767, 42 USC 9601 et seq.

DOE Order 5400.1. General Environmental Protection Program. U.S. Department of Energy, Washington, D.C.

DOE/RL-91-50, Rev. 3. 2000. Environmental Monitoring Plan, United States Department of Energy, Richland Operations Office. Prepared by personnel from Pacific Northwest National Laboratory; Fluor Daniel Hanford, Inc.; Waste Management Federal Services of Hanford, Inc.; and Bechtel Hanford, Inc. for the U.S. Department of Energy, Richland Operations Office, Richland, Washington.

Ecology. 2003. State Waste Discharge Permit Number ST-4501. Washington State Department of Ecology, Kennewick, Washington. 
Ecology - Washington State Department of Ecology, U.S. Environmental Protection Agency, and U.S. Department of Energy. 1998. Hanford Federal Facility Agreement and Consent Order. Document No. 89-10, Rev. 5 (The Tri-Party Agreement). Olympia, Washington.

PNNL-13014. 2000. Groundwater Monitoring Plan for the Solid Waste Landfill. JW Lindberg and CJ Chou, Pacific Northwest National Laboratory, Richland, Washington.

PNNL-13032. 2000. Groundwater Monitoring Plan for the Hanford Site 200 Area Treated Effluent Disposal Facility. DB Barnett, Pacific Northwest National Laboratory, Richland, Washington.

PNNL-13121. 2000. Groundwater Monitoring and Tritium-Tracking Plan for the 200 Area State-Approved Land Disposal Site. DB Barnett, Pacific Northwest National Laboratory, Richland, Washington.

PNNL-14033. 2002. Groundwater Monitoring and Assessment Plan for the 100-K Area Fuel Storage Basins. RE Peterson, Pacific Northwest National Laboratory, Richland, Washington.

Resource Conservation and Recovery Act. 1976. Public Law 94-580, as amended, 90 Stat. 2795, 42 USC 6901 et seq.

Shapiro, SS. 1980. "How to Test Normality and Other Distributional Assumptions." In ASQC Basic References in Quality Control: Statistical Techniques, Vol. 3, EJ Dudewicz (ed.), American Society of Quality Control, Milwaukee, Wisconsin.

WAC 173-160-400. What are the Minimum Standards for Resource Protection Wells and Geotechnical Soil Borings? Washington Administrative Code, Olympia, Washington.

WAC 173-200. Water Quality Standards for Ground Waters of the State of Washington. Washington Administrative Code, Olympia, Washington.

WAC 173-216. State Waste Discharge Program. Washington Administrative Code, Olympia, Washington.

WAC 173-304. Minimum Functional Standards for Solid Waste Handling. Washington Administrative Code, Olympia, Washington.

WAC 173-304-490. Ground Water Monitoring Requirements. Washington Administrative Code, Olympia, Washington. 
Table C.1. Wells Not Sampled as Scheduled in Fiscal Year 2003

\begin{tabular}{|c|c|c|c|}
\hline Well & Schedule & Site & Comments \\
\hline 299-E34-3 & $10 / 01 / 02$ & LLBG (2) PA & Dry \\
\hline 299-E34-3 & $04 / 01 / 03$ & LLBG (2) PA & Dry \\
\hline 299-W10-13 & 03/01/03 & LLBG (3) PA & Dry \\
\hline 299-W10-13 & 09/01/03 & LLBG (3) PA & Dry \\
\hline 299-W18-24 & 07/01/03 & LLBG (4) PA & Dry; one semiannual sample missed \\
\hline 299-W6-8 & $01 / 01 / 03$ & SALDS & Dry \\
\hline 299-W7-6 & 01/01/03 & SALDS & Dry \\
\hline 299-W7-6 & 07/01/03 & SALDS & Dry \\
\hline 299-W7-8 & 03/01/03 & $\begin{array}{l}\text { LLBG (3) PA/ } \\
\text { SALDS }\end{array}$ & Dry \\
\hline 299-W7-8 & 09/01/03 & LLBG (3) PA & Dry \\
\hline 499-S0-7 & $10 / 01 / 02$ & $400 \mathrm{DW}$ & Maintenance problems; one quarter missed \\
\hline 499-S0-8 & $10 / 01 / 02$ & $400 \mathrm{DW}$ & Maintenance problems; one quarter missed \\
\hline 499-S1-8J & $10 / 01 / 02$ & $400 \mathrm{DW}$ & Maintenance problems; one quarter missed \\
\hline $699-25-34 \mathrm{C}$ & 08/01/03 & SWL & Dry; one quarter missed \\
\hline
\end{tabular}

$400 \mathrm{DW}=400$ Area drinking water supply wells.

LLBG $=$ Low-level burial ground.

$\mathrm{PA} \quad=$ Performance assessment.

SALDS $=$ State-Approved Land Disposal Site.

SWL $\quad=$ Solid Waste Landfill.

Table C.2. Monitoring Wells and Constituents for the KE and KW Basins (adapted from PNNL-14033)

\begin{tabular}{|c|c|c|c|}
\hline Well $^{(\mathrm{a})}$ & $\begin{array}{c}\text { Hydrogeologic Unit } \\
\text { Monitored } \\
\end{array}$ & \multicolumn{2}{|c|}{ Field Parameters } \\
\hline $199-K-27(\mathrm{P})$ & Top of unconfined & $\mathrm{pH}$ & Temperature \\
\hline 199-K-29 (P) & Top of unconfined & Specific conductance & Turbidity \\
\hline $199-K-30(P)$ & Top of unconfined & & \\
\hline 199-K-32A & Top of unconfined & \multicolumn{2}{|c|}{ Site-Specific Parameters ${ }^{(\mathrm{b})}$} \\
\hline $199-K-33(\mathrm{~S})$ & Top of unconfined & Anions & ICP metals (filtered) \\
\hline $199-K-34$ & Top of unconfined & Carbon-14 & Trichloroethene \\
\hline $199-K-106 \mathrm{~A}$ & Top of unconfined & & \\
\hline 199-K-107A & Top of unconfined & \multicolumn{2}{|c|}{ AEA Parameters } \\
\hline 199-K-108A (S) & Top of unconfined & Gross alpha & Technetium-99 \\
\hline 199-K-109A & Top of unconfined & Gross beta & Tritium \\
\hline 199-K-110A (S) & Top of unconfined & Strontium-90 & \\
\hline $199-K-111 \mathrm{~A}$ & Top of unconfined & & \\
\hline
\end{tabular}

(a) All wells constructed to WAC 173-160-400 standards unless noted (P), pre-RCRA. All wells sampled quarterly unless noted (S), semiannually. Note: Well 199-K-33 was decommissioned in June 2003.

(b) Sampling frequency varies by constituent.

AEA = Atomic Energy Act of 1954 .

ICP = Inductively coupled plasma emission spectroscopy.

RCRA = Resource Conservation and Recovery Act. 
Table C.3. Monitoring Wells, Constituents, and Enforcement Limits for the 200 Area Treated Effluent Disposal Facility (adapted from PNNL-13032)

\begin{tabular}{|c|c|c|c|}
\hline Well (a) & Hydrogeologic Unit & Constituent $\mathrm{t}^{(\mathrm{b})}$ and Enf & $\operatorname{imit}(\mu \mathrm{g} / \mathrm{L})$ \\
\hline $699-40-36$ & Ringold confined & Cadmium $=5$ & Lead $=10$ \\
\hline $699-41-35$ & Ringold confined & $\mathrm{pH}=6.5$ to $8.5 \mathrm{pH}$ units & \\
\hline $699-42-37$ & Ringold confined & & \\
\hline
\end{tabular}

(a) All wells constructed to WAC 173-160-400 standards unless noted (P), pre-RCRA.

(b) All wells sampled quarterly. All wells also monitored for ICP metals, anions, trace metals, alkalinity, specific conductance, total dissolved solids, turbidity, gross alpha, gross beta, and low-level tritium (annually). No enforcement limits for those constituents.

Bold italic $=$ Upgradient well.

ICP = Inductively coupled plasma emission spectroscopy.

RCRA = Resource Conservation and Recovery Act.

Table C.4. Monitoring Wells, Constituents, and Enforcement Limits for the 400 Area Process Ponds (specified in state waste discharge permit)

\begin{tabular}{|c|c|c|c|}
\hline Well $^{(\text {a) }}$ & $\begin{array}{l}\text { Hydrogeologic Unit } \\
\text { Monitored }\end{array}$ & \multicolumn{2}{|c|}{ Constituent and Enforcement Limit $(\mu \mathrm{g} / \mathrm{L})^{(\mathrm{b}, \mathrm{c})}$} \\
\hline $699-2-6 \mathrm{~A}$ & Unconfined aquifer & Cadmium (unfiltered) $=10$ & Mercury (unfiltered) = 2 \\
\hline $699-2-7(\mathrm{P})$ & Unconfined aquifer & Chromium (unfiltered) $=50$ & $\mathrm{pH}=$ Monitor only \\
\hline $699-8-17(\mathrm{P})$ & Unconfined aquifer & Lead (unfiltered) $=50$ & Sulfate $=$ Monitor only \\
\hline & & Manganese (unfiltered) $=50$ & $\begin{array}{l}\text { Total organic carbon = Monitor } \\
\text { only }\end{array}$ \\
\hline
\end{tabular}

(a) All wells constructed to WAC 173-160-400 standards unless noted (P), pre-RCRA.

(b) Defined as the average of four quarterly measurements from a well. Average to be calculated using the four most recent quarterly measurements from a well.

(c) Enforcement limit in groundwater shall be met in point-of-compliance well 699-2-7.

Bold italic $=$ Upgradient well.

RCRA = Resource Conservation and Recovery Act. 
Table C.5. Monitoring Wells and Constituents for the Environmental Restoration Disposal Facility (adapted from BHI-00873)

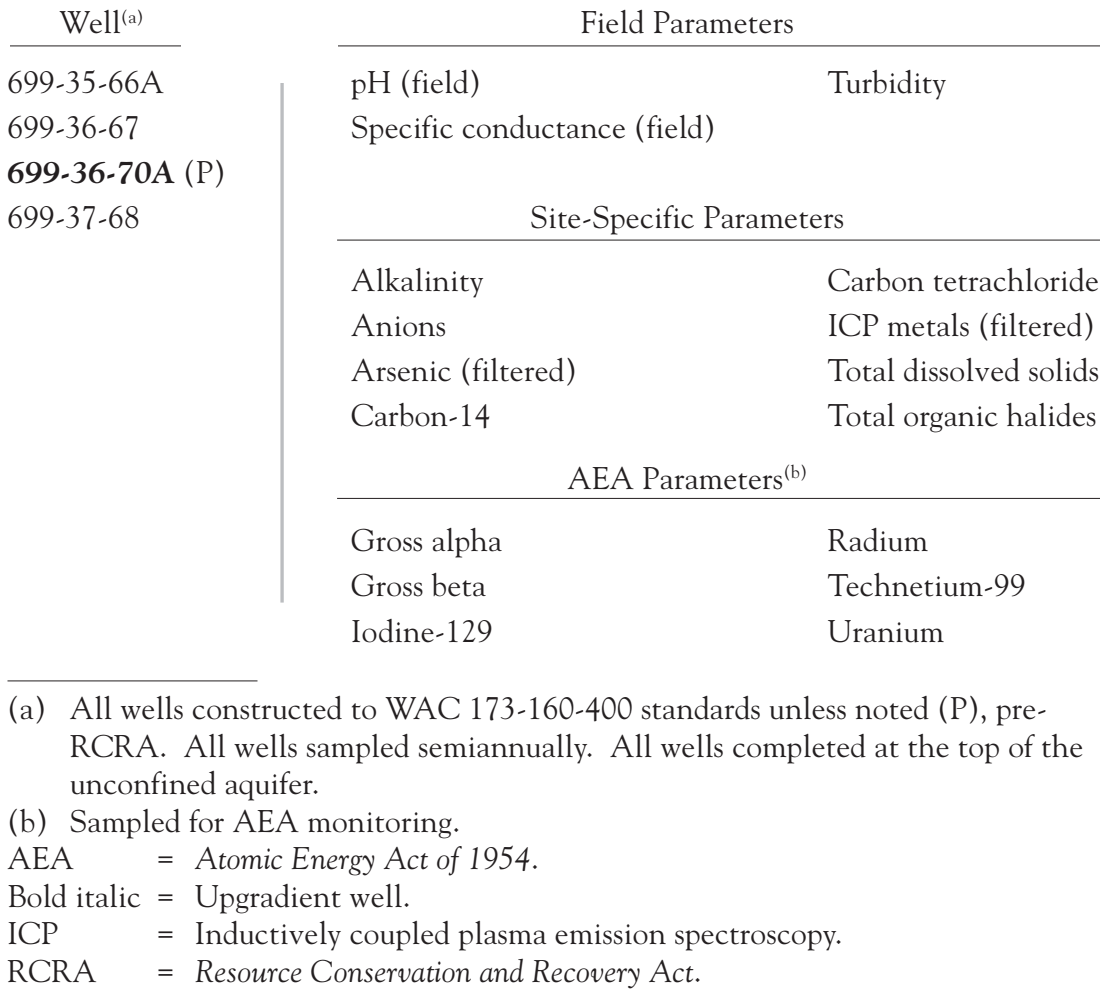

Table C.6. Monitoring Wells and Constituents for the Solid Waste Landfill (adapted from PNNL-13014)

\begin{tabular}{|c|c|c|}
\hline Well $^{(\text {a) }}$ & \multicolumn{2}{|c|}{ Parameters/Constituents Required by WAC 173-304-490 } \\
\hline $699-22-35$ & Ammonia as nitrogen & Nitrite \\
\hline $699-23-34 \mathrm{~A}$ & Chemical oxygen demand & pH (field) \\
\hline $699-23-34 B$ & Chloride & Specific conductance (field) \\
\hline $699-24-33^{(\mathrm{b})}(\mathrm{P})$ & Dissolved iron & Sulfate \\
\hline $699-24-34 \mathrm{~A}$ & Dissolved zinc & Temperature (field) \\
\hline $699-24-34 B$ & Manganese & Total coliform \\
\hline $699-24-34 \mathrm{C}$ & Nitrate & Total organic carbon \\
\hline $699-24-35$ & & \\
\hline $699-25-34 C^{(c)}$ & \multicolumn{2}{|c|}{ Site-Specific Parameters } \\
\hline $699-26-35 A$ & $\begin{array}{l}\text { Anions } \\
\text { ICP metals (filtered) }\end{array}$ & Volatile organic compounds \\
\hline
\end{tabular}

(a) All wells are constructed to WAC 173-160-400 standards unless noted (P), pre-RCRA. All wells sampled quarterly. All wells completed at the top of the unconfined aquifer.

(b) Used for supplemental information; no statistical evaluations.

(c) Well went dry following May 2003 sampling event.

Bold italic $=$ Upgradient wells.

ICP = Inductively coupled plasma emission spectroscopy.

RCRA = Resource Conservation and Recovery Act. 
Table C.7. Sampling Results for Required Constituents ${ }^{(a)}$ at the Solid Waste Landfill
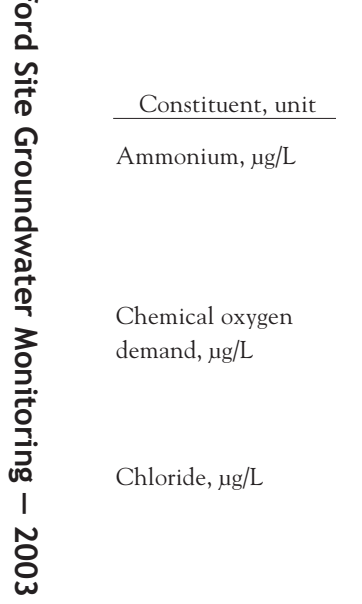

10,000

November $2002<4,800$ February 2003 May 2003

August 2003

5,000

$<3,600$
$<3,600$

7,820

November 2002

2003

August 2003

5,700

6,600

6,700
6,900

Coliform bacteria,

$\mathrm{Col} / 100 \mathrm{ml}$

3.7

November 2002

February 2003

May 2003

August 2003

Iron, filtered, $\mu \mathrm{g} / \mathrm{L}$

160

November 2002 February 2003 May 2003

August 2003

Manganese, filtered,

10

$\mu \mathrm{g} / \mathrm{L}$

Nitrate, $\mu g / L$

29,000

February 2003

May 2003

August 2003

November 2002

February 2003

May 2003

August 2003

Nitrite, $\mu \mathrm{g} / \mathrm{L}$

November 2002
February 2003

May 2003

August 2003

$\frac{699-23-34 \mathrm{~A}}{238}$

$<14.5$
$<26.3$

$<26.3$

$<4,800$

$<4,800$

5,300
10,300

5,900

7,100

6,800

6,800
6,950

1
0

0.5

0

51.4
42.8$$
\begin{gathered}
49.4 \\
55.25
\end{gathered}
$$$$
55.25
$$

2.6

4.65
0.955

15,100

14,600

13,300

14,400

$<36.1$

$<36.1$

$<24.3$

$\begin{array}{cc}<14.5 & 320 \\ <14.5 & <14.5 \\ <26.3 & <26.3 \\ <26.3 & <26.3 \\ <4,800 & <4,800 \\ <4,800 & <4,800 \\ 8,000 & 8,000 \\ \mathbf{1 5 , 0 0 0} & 9,000 \\ 5,800 & 5,900 \\ 6,800 & 7,100 \\ 6,200 & 6,900 \\ 6,900 & 6,800\end{array}$

72,400

0
0

517

39.5

42.8

49.4
76

2.9

3.2

5.1
1.8

16,400

16,150

14,200

16,800

$<36.1$

$<36.1$
$<36.1$

$<24.3$$$
\begin{aligned}
& <14.5 \\
& <14.5
\end{aligned}
$$$$
<26.3
$$$$
<26.3
$$

$<4,800$

$<4,800$

9,000
$<3,600$

5,900

6,400

6,600

6,900

139
$<14$.
$<26$.
$<26$.
$<4,800$
$<4,800$
$<3,600$
$<3,600$
6,100
6,600
6,500
7,100

0

0

3.1

54

53.5

49.4
49.4

3.3

4
5.7

1.1

12,800

11,500

10,600

12,400

$<36.1$
$<36.1$

$<36.1$

$<24.3$$$
0
$$$$
\text { ( }
$$

42.8

49.

2.2 \begin{tabular}{c} 
Well \\
$699-24-35$ \\
\hline
\end{tabular}

Well
699-25-34C

304

$<14.5$
$<26.3$

$<26.3$

$<4,800$

$<4,800$

$<3,600$

11,000

83

7,200

6,800
6,800

269

$<14.5$
$<26.3$

$<26.3$

$<4,800$

$<4,800$

6,000
$<3,600$

6,400

6,400

6,300

6,600

$$
\begin{aligned}
& 0 \\
& 0 \\
& 0
\end{aligned}
$$

37.7

49.4
49.4

2.6
4.8

14,150

13,700

11,100

14,600

$<36.1$
$<36.1$

$<36.1$

$<24.3$
Well

26-35A

242

$<26.3$

$<26.3$

$<4,800$

$<4,800$

7,000

$<3,600$

7,200

6,900

7,300

7,500

42

18.5

42.8

49.4
49.4

1.9

1.6

3.4

16,800

16,800

17,300

17,700

$<36.1$

$<36.1$
$<36.1$
$<24.3$ 
Table C.7. (contd)

\begin{tabular}{|c|c|c|c|c|c|c|c|c|c|c|c|c|}
\hline Constituent, unit & Value $^{(b)}$ & Date & $\begin{array}{c}\text { Well } \\
699-22-35 \\
\end{array}$ & $\begin{array}{c}\text { Well } \\
699-23-34 \mathrm{~A} \\
\end{array}$ & $\begin{array}{c}\text { Well } \\
699-23-34 \mathrm{~B} \\
\end{array}$ & $\begin{array}{c}\text { Well } \\
699-24-33 \\
\end{array}$ & $\begin{array}{c}\text { Well } \\
699-24-34 \mathrm{~A} \\
\end{array}$ & $\begin{array}{c}\text { Well } \\
699-24-34 \mathrm{~B} \\
\end{array}$ & $\begin{array}{c}\text { Well } \\
699-24-34 \mathrm{C}\end{array}$ & $\begin{array}{c}\text { Well } \\
699-24-35 \\
\end{array}$ & $\begin{array}{c}\text { Well } \\
699-25-34 \mathrm{C}\end{array}$ & $\begin{array}{c}\text { Well } \\
699-26-35 \mathrm{~A} \\
\end{array}$ \\
\hline \multirow[t]{4}{*}{ Field $\mathrm{pH}$} & \multirow[t]{4}{*}{$6.68-7.84$} & November 2002 & 7.07 & 6.58 & 6.71 & 6.82 & 6.66 & 6.68 & 7.5 & 6.9 & 6.92 & 7.19 \\
\hline & & February 2003 & 6.91 & 6.61 & 6.7 & 6.78 & 6.63 & 6.63 & 6.97 & 6.94 & 7.33 & 7.2225 \\
\hline & & May 2003 & 7 & 6.59 & 6.81 & 6.86 & 6.78 & 6.79 & 6.89 & 6.89 & 8.28 & 7.25 \\
\hline & & August 2003 & 6.96 & 6.59 & 6.67 & 6.85 & 6.68 & 6.72 & 6.91 & 6.9 & (c) & 7.185 \\
\hline \multirow{4}{*}{$\begin{array}{l}\text { Specific conductance, } \\
\mu \mathrm{S} / \mathrm{cm}\end{array}$} & \multirow[t]{4}{*}{583} & November 2002 & 843 & 765 & 815 & 776 & 708 & 722 & 770 & 597 & 694 & 553 \\
\hline & & February 2003 & 834 & 743 & 800 & 776 & 694 & 721 & 752 & 578 & 679 & 545 \\
\hline & & May 2003 & 843 & 741 & 797 & 780 & 693 & 706 & 743 & 605 & 839 & 544 \\
\hline & & August 2003 & 822 & 753 & 795 & 752 & 653 & 722 & 703 & 592 & (c) & 548 \\
\hline \multirow[t]{4}{*}{ Sulfate, $\mu \mathrm{g} / \mathrm{L}$} & \multirow[t]{4}{*}{47,200} & November 2002 & 48,600 & 49,200 & 48,200 & 43,100 & 46,700 & 47,800 & 41,100 & 45,200 & 42,600 & 38,880 \\
\hline & & February 2003 & 46,500 & 48,200 & 48,800 & 42,800 & 45,100 & 44,800 & 41,000 & 44,600 & 41,600 & 38,300 \\
\hline & & May 2003 & 48,500 & 47,550 & 47,000 & 42,200 & 42,800 & 44,800 & 41,600 & 46,300 & 88,900 & 39,400 \\
\hline & & August 2003 & 49,500 & 48,800 & 50,700 & 41,300 & 46,400 & 46,900 & 41,100 & 47,800 & (c) & 40,200 \\
\hline \multirow[t]{4}{*}{ Temperature, ${ }^{\circ} \mathrm{C}$} & \multirow[t]{4}{*}{20.7} & November 2002 & 18.4 & 18.4 & 18.4 & 19.8 & 18.8 & 18.6 & 18.5 & 17.8 & 19.1 & 19.4 \\
\hline & & February 2003 & 17.7 & 17.5 & 17.5 & 19.3 & 17.8 & 18.2 & 17.9 & 17.2 & 18 & 18.95 \\
\hline & & May 2003 & 19 & 18.3 & 18.2 & 19.7 & 18.7 & 18.8 & 18.5 & 19.2 & 17.6 & 20.6 \\
\hline & & August 2003 & 18.9 & 24.2 & 18.7 & 19.4 & 18.5 & 20 & 18.9 & 18.3 & (c) & 19.6 \\
\hline \multirow{4}{*}{$\begin{array}{l}\text { Total organic carbon, } \\
\mu \mathrm{g} / \mathrm{L}\end{array}$} & \multirow[t]{4}{*}{1,360} & November 2002 & 1,800 & 1,100 & 2,800 & 1,900 & 1,700 & 2,800 & 1,700 & 1,900 & 980 & 1,400 \\
\hline & & February 2003 & 2,200 & 1,800 & 2,200 & 1,800 & 1,500 & 1,600 & 140 & 1,400 & 660 & 1,575 \\
\hline & & May 2003 & 6,600 & 7,100 & 4,900 & 5,600 & 6,200 & 7,100 & 6,200 & 5,000 & 3,300 & 4,000 \\
\hline & & August 2003 & 8,700 & $<390$ & $<390$ & $<390$ & $<390$ & $<390$ & $<390$ & 5,100 & (c) & 3,625 \\
\hline \multirow[t]{4}{*}{ Zinc, filtered, $\mu \mathrm{g} / \mathrm{L}$} & \multirow[t]{4}{*}{42.3} & November 2002 & $<2.2$ & $<2.2$ & 3.8 & 15.6 & 4 & $<2.2$ & 7.4 & 3.4 & 4.9 & 8.8 \\
\hline & & February 2003 & 3.2 & $<1.8$ & 3.2 & 11.7 & $<1.8$ & 2.2 & 7.9 & 2.9 & 6.3 & 8.6 \\
\hline & & May 2003 & $<3.5$ & $<3.5$ & 4.9 & 11.4 & $<3.5$ & $<3.5$ & 8 & 5.7 & 6.6 & 7.6 \\
\hline & & August 2003 & $<3.5$ & $<3.5$ & $<3.5$ & 4.6 & $<3.5$ & 4.4 & 7.8 & $<3.5$ & (c) & 6.7 \\
\hline
\end{tabular}

(a) WAC 173-304.
(b) Number obtained from Table C.8, background threshold value.

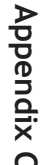

Results in bold type exceed background threshold value. 
Table C.8. Results of Shapiro and Francia Test for Normality and Background Threshold Values for the Solid Waste Landfill

\begin{tabular}{|c|c|c|c|c|c|}
\hline Constituent, ${ }^{(a)}$ unit & $\begin{array}{l}\text { Test Statistic, } \\
\text { W' Log Value } \\
\end{array}$ & $\begin{array}{l}\text { Test Statistic, } \\
\text { W' Raw Data } \\
\end{array}$ & $\begin{array}{c}\text { Critical Value, }{ }^{(b)} \\
\text { W'}^{\prime} \alpha \\
\end{array}$ & $\begin{array}{c}\text { Upper } \\
\text { Tolerance Limit }\end{array}$ & $\begin{array}{c}\text { Background } \\
\text { Threshold Value }\end{array}$ \\
\hline Temperature, ${ }^{\circ} \mathrm{C}$ & $0.953 \mathrm{~s}$ & $0.961 \mathrm{~s}$ & 0.963 & $20.7^{(c)}$ & 20.7 \\
\hline Specific conductance, $\mu \mathrm{S} / \mathrm{cm}$ & $0.978 \mathrm{~ns}$ & $\mathrm{NA}$ & 0.960 & $583^{(\mathrm{d})}$ & 583 \\
\hline Field $\mathrm{pH}$ & $0.988 \mathrm{~ns}$ & NA & 0.963 & {$[6.68,7.84]^{(\mathrm{d})}$} & {$[6.68,7.84]$} \\
\hline Total organic carbon, $\mu \mathrm{g} / \mathrm{L}$ & $\mathrm{NC}$ & $\mathrm{NC}$ & $\mathrm{NC}$ & $\begin{array}{c}842^{(c)} \\
1,360^{(e)}\end{array}$ & 1,360 \\
\hline Chloride, $\mu \mathrm{g} / \mathrm{L}$ & $0.954 \mathrm{~s}$ & $0.962 \mathrm{~s}$ & 0.963 & $7,820^{\text {(c) }}$ & 7,820 \\
\hline Nitrate (as $\mathrm{NO}_{3}^{-}$), $\mu \mathrm{g} / \mathrm{L}$ & $0.833 \mathrm{~s}$ & $0.844 \mathrm{~s}$ & 0.963 & $29,000^{(c)}$ & 29,000 \\
\hline Nitrite (as $\mathrm{NO}_{2}^{-}$), $\mu \mathrm{g} / \mathrm{L}$ & $\mathrm{NC}$ & $\mathrm{NC}$ & $\mathrm{NC}$ & $66^{(f)}$ & 66 \\
\hline Ammonium (as $\mathrm{NH}_{3}^{-}$), $\mu \mathrm{g} / \mathrm{L}$ & $\mathrm{NC}$ & $\mathrm{NC}$ & $\mathrm{NC}$ & $\begin{array}{l}90^{(c)} \\
118^{(e)}\end{array}$ & 118 \\
\hline Sulfate, $\mu g / L$ & $0.983 \mathrm{~ns}$ & NA & 0.963 & $47,200^{(d)}$ & 47,200 \\
\hline Iron, dissolved, $\mu \mathrm{g} / \mathrm{L}$ & $0.960 \mathrm{~s}$ & $0.802 \mathrm{~s}$ & 0.962 & $\begin{array}{l}160^{(\mathrm{c})} \\
65.3^{(\mathrm{e})}\end{array}$ & 160 \\
\hline Zinc, dissolved, $\mu \mathrm{g} / \mathrm{L}$ & $\mathrm{NC}$ & $\mathrm{NC}$ & $\mathrm{NC}$ & $\begin{array}{l}42.3^{(\mathrm{c})} \\
5.9^{(\mathrm{e})}\end{array}$ & 42.3 \\
\hline Manganese, dissolved, $\mu \mathrm{g} / \mathrm{L}$ & $\mathrm{NC}$ & $\mathrm{NC}$ & $\mathrm{NC}$ & $\begin{array}{l}10^{(c)} \\
3.6^{(e)}\end{array}$ & 10 \\
\hline $\begin{array}{l}\text { Coliform bacteria, } \\
\text { colonies } / 100 \mathrm{ml} \\
\text { Chemical oxygen }\end{array}$ & $\begin{array}{l}\mathrm{NC} \\
\mathrm{NC}\end{array}$ & $\begin{array}{l}\mathrm{NC} \\
\mathrm{NC}\end{array}$ & $\begin{array}{l}\mathrm{NC} \\
\mathrm{NC}\end{array}$ & $\begin{array}{c}3.7^{(f)} \\
10,000^{(f)}\end{array}$ & $\begin{array}{c}3.7 \\
10,000\end{array}$ \\
\hline
\end{tabular}

demand, $\mu \mathrm{g} / \mathrm{L}$

(a) Constituents are specified in WAC 173-304-490(2)(d). Data collected from March 1993 to May 2000 from upgradient well 699-24-35 and 699-26-35A.

(b) Obtained from Table A-9 (Shapiro 1980) for $\alpha=5 \%$.

(c) Maximum value reported.

(d) Based on log-normal distribution.

(e) Based on limit of quantitation using method detection limit (see Tables D.23 and D.24).

(f) Based on laboratory practical quantitation limit.

NA $=$ Not applicable.

$\mathrm{NC}=$ Not calculated; insufficient measured values.

$\mathrm{ns}=$ Not significant at 0.05 level of significance.

$\mathrm{s} \quad=$ Significant at 0.05 level of significance. 
Table C.9. Monitoring Wells, Constituents, and Enforcement Limits for the State-Approved Land Disposal Site (adapted from PNNL-13121)

\begin{tabular}{ll}
\multicolumn{1}{c}{ Well ${ }^{\text {(a) }}$} & $\begin{array}{l}\text { Hydrogeologic Unit } \\
\text { Monitored }\end{array}$ \\
\cline { 2 - 2 } 299-W6-6 (A) & Bottom of unconfined \\
299-W6-7 (A) & Top of unconfined \\
299-W6-11 (A) & Top of unconfined \\
299-W6-12 (A) & Top of unconfined \\
299-W7-1 (A) & Top of unconfined \\
299-W7-3 (S) & Bottom of unconfined \\
299-W7-5 (S) & Top of unconfined \\
299-W7-6 (S) & Top of unconfined \\
299-W7-7 (S) & Top of unconfined \\
299-W7-9 (A) & Top of unconfined \\
299-W7-12 (A) & Top of unconfined \\
299-W8-1 (A) & Top of unconfined \\
699-48-71 (A,P) & Unconfined \\
699-48-77A (Q) & Ringold unit E; upper \\
699-48-77C (Q) & Ringold unit E; mid \\
& to lower \\
699-48-77D (Q) & Ringold unit E; upper \\
699-49-79 (A,P) & Top of unconfined \\
699-51-75 (S,P) & Top of unconfined \\
699-51-75P (A,P) & Lower unconfined
\end{tabular}

\begin{tabular}{lc}
\multicolumn{1}{c}{ Constituent } & Enforcement Limit $(\mu \mathrm{g} / \mathrm{L})$ \\
\hline Acetone & 160 \\
Benzene & 5 \\
Cadmium, total & 10 \\
Chloroform & 6.2 \\
Copper, total & 70 \\
Lead, total & 50 \\
Mercury, total & 2 \\
pH & 250,000 \\
Sulfate & 100 \\
Tetrahydrofuran & 500,000 \\
Total dissolved solids & \\
& \\
\hline Gross alpha & Strontium-90 units \\
Gross beta & Tritium
\end{tabular}

(a) All wells constructed to WAC 173-160-400 standards unless noted (P), pre-RCRA. Wells noted (A) sampled annually, (Q), quarterly, and (S), semiannually.

AEA = Atomic Energy Act of 1954.

RCRA = Resource Conservation and Recovery Act. 


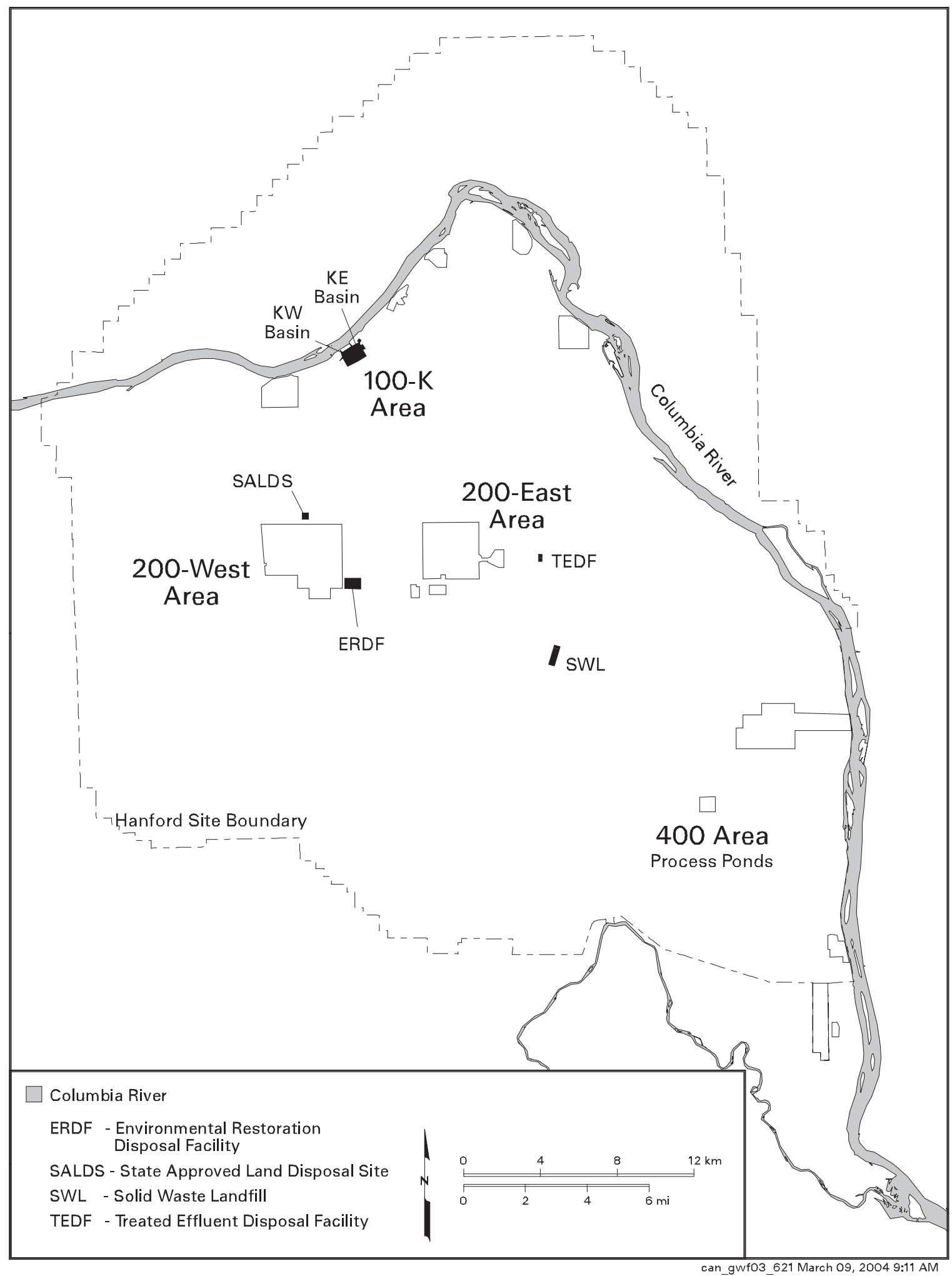

Figure C.1. Regulated Units (other than RCRA and CERCLA units) on the Hanford Site Requiring Groundwater Monitoring 


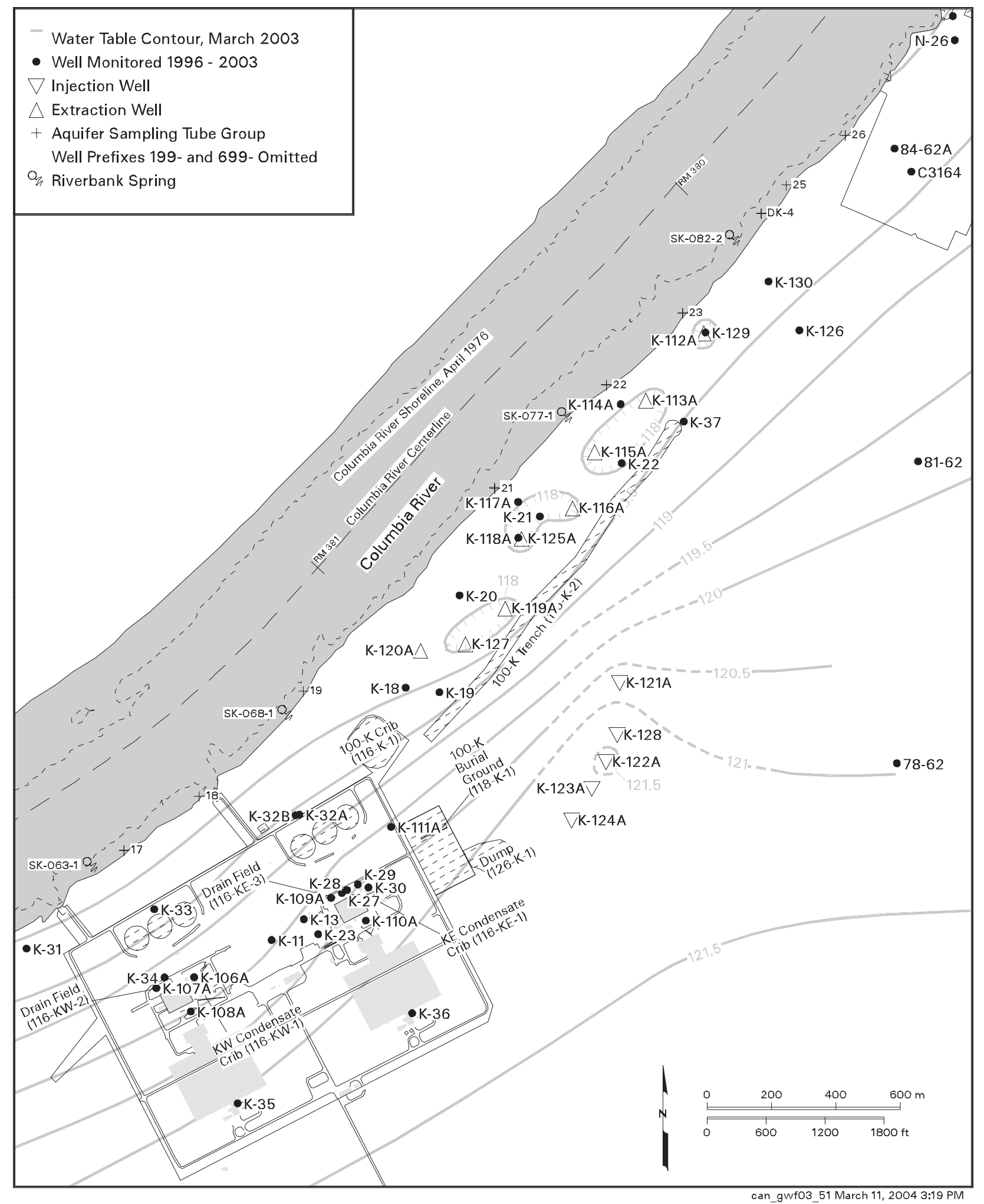

Figure C.2. Groundwater Monitoring Wells at the 100-K Basins 


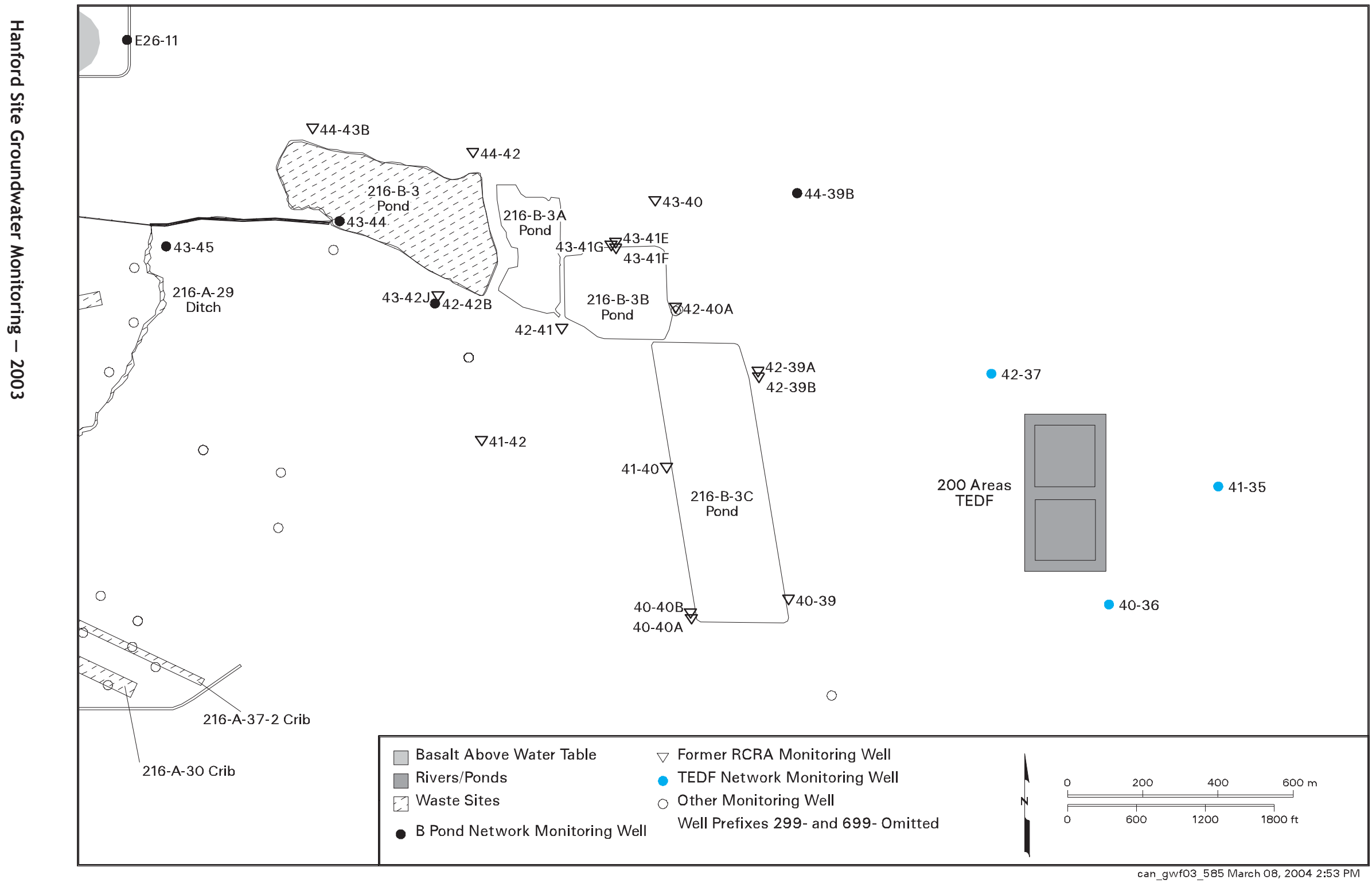

Figure C.3. Groundwater Monitoring Wells at the 200 Area Treated Effluent Disposal Facility 
Ponds

Waste Sites

- 4608 B/C Network Monitoring Well

Other Monitoring Well

Upgradient Well 699-8-17

Shown on Figure 2.1-2

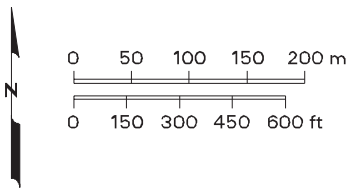

400 Area

Process Ponds

(4608 B/C)

E-

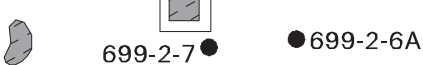

Sanitary Sewage

Lagoon

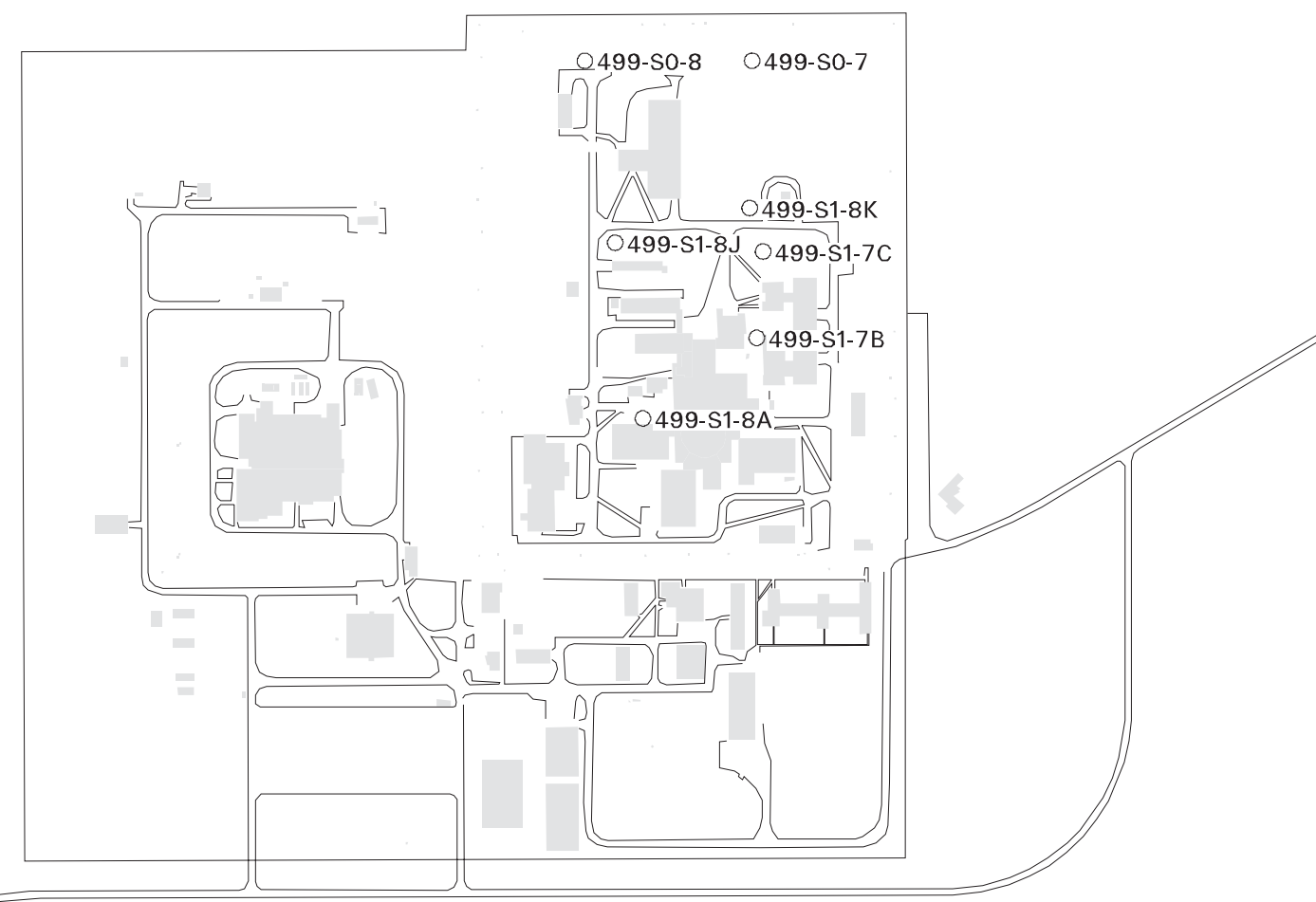

can gwf03 340 March 08, 2004 12:44 PM

Figure C.4. Groundwater Monitoring Wells at the 400 Area Process Ponds 


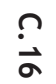

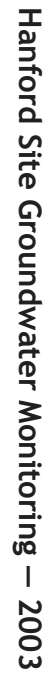

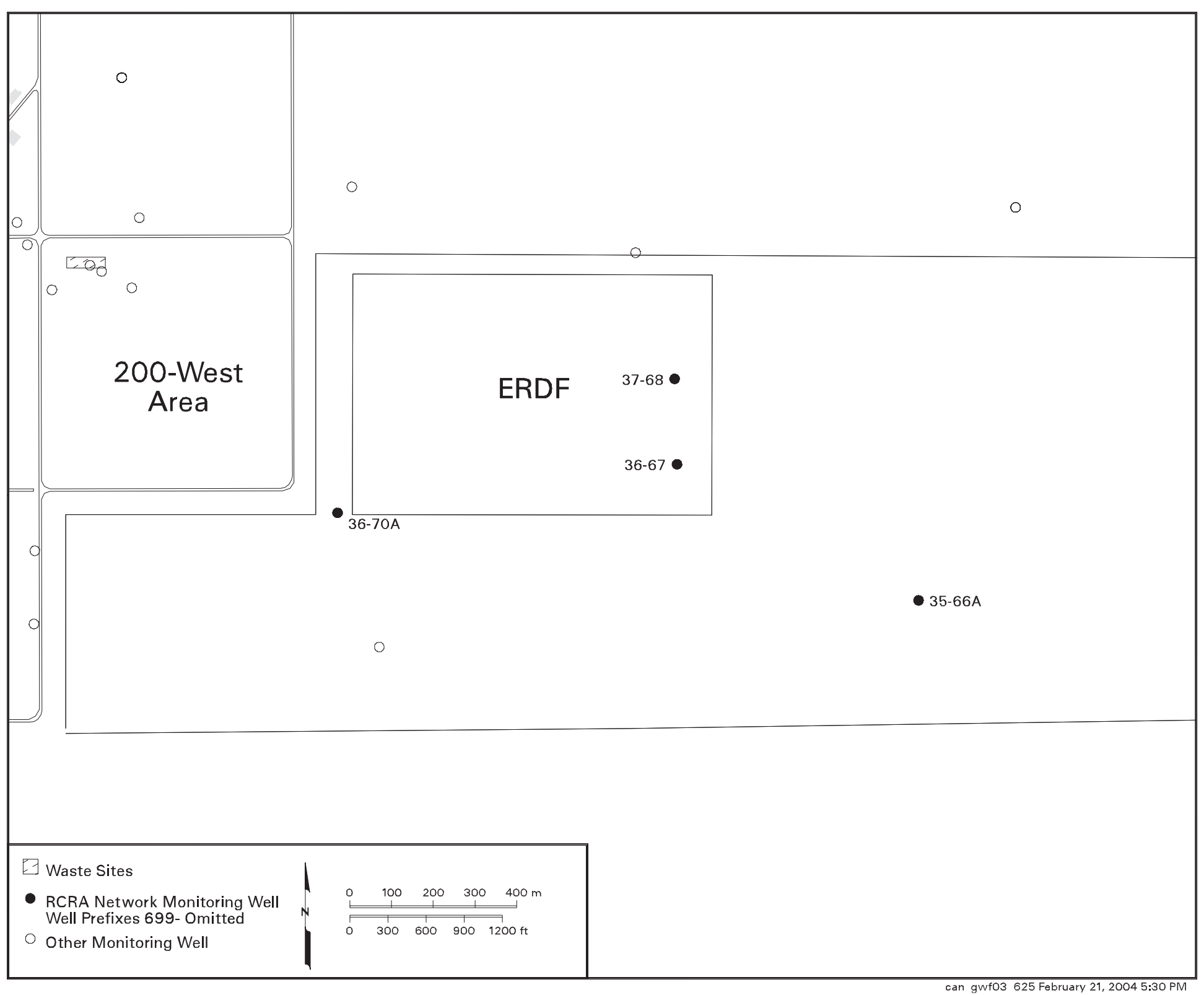

Figure C.5. Groundwater Monitoring Wells at the Environmental Restoration Disposal Facility 


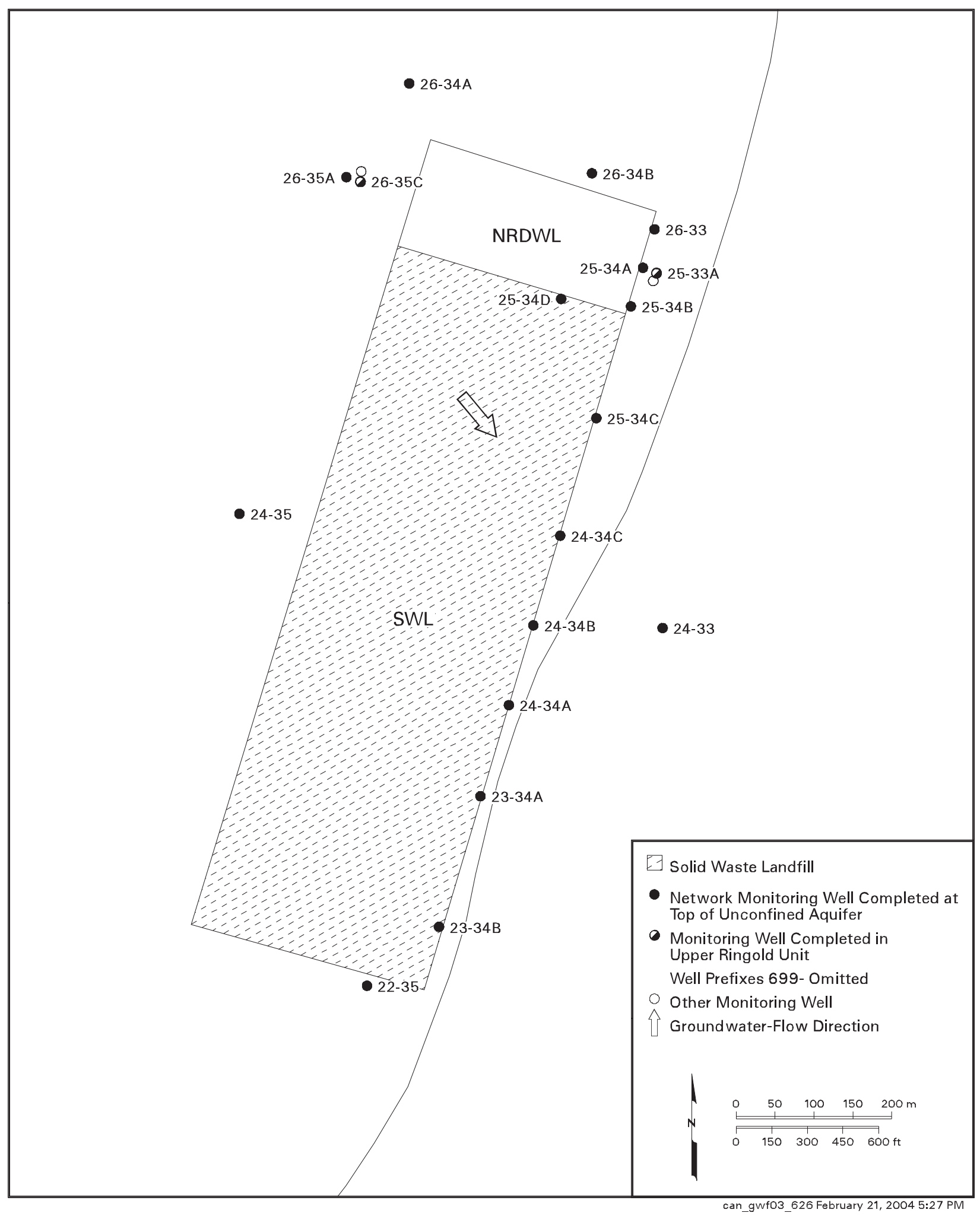

Figure C.6. Groundwater Monitoring Wells at the Solid Waste Landfill 


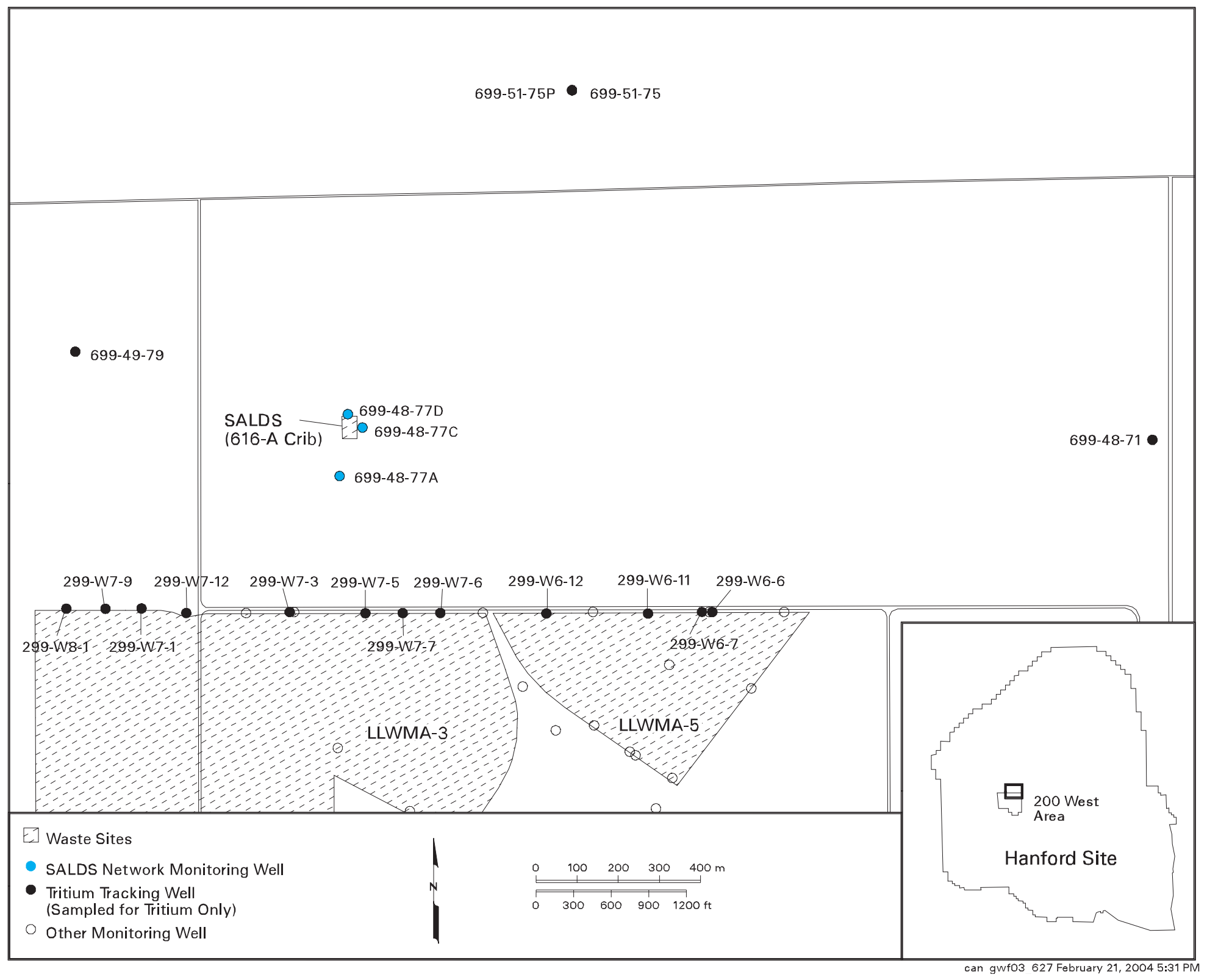

Figure C.7. Groundwater Monitoring Wells at the State-Approved Land Disposal Site 


\section{Appendix D}

\section{Quality Assurance and Quality Control}




\section{Contents}

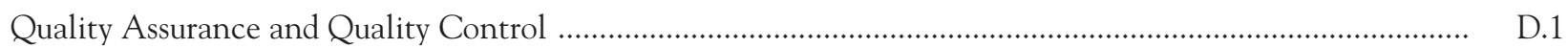

D.1 Sample Collection and Analysis .......................................................................................... D.1

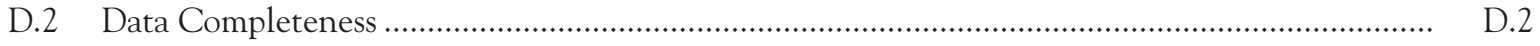

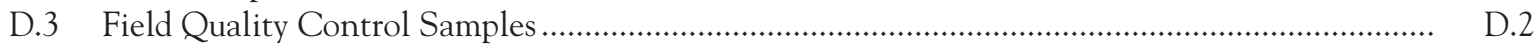

D.3.1 Long-Term Monitoring …….................................................................................... D.

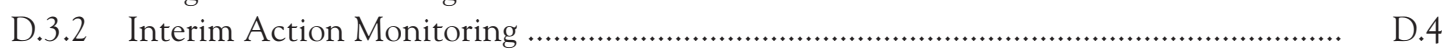

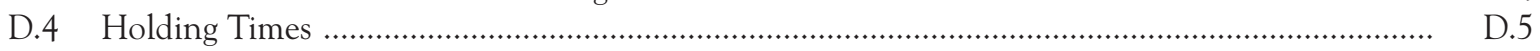

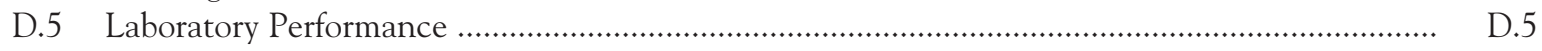

D.5.1 Nationally Based Performance Evaluation Studies .......................................................... D.6

D.5.1.1 Water Pollution and Water Supply Studies ................................................... D.6

D.5.1.2 DOE Quality Assessment and Mixed Analyte Performance Evaluation

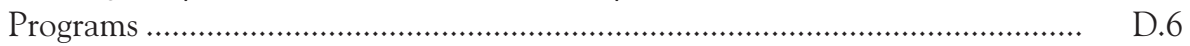

D.5.1.3 InterLaB RadCheM Proficiency Testing Program Studies .............................. D. D

D.5.2 Double-Blind Standard Evaluation ……….................................................................... D.7

D.5.3 Laboratory Internal QA/QC Programs ………............................................................. D. D

D.5.3.1 Issue Resolution ...................................................................................... D. D.10

D.5.3.2 Laboratory Audits/Assessments ........................................................................ D. D.10

D.6 Limit of Detection, Limit of Quantitation, and Method Detection Limit ................................. D.11

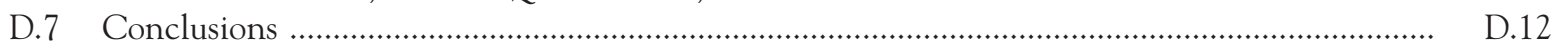

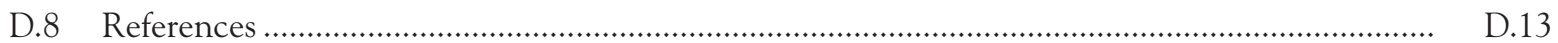

\section{Tables}

D.1 Long-Term Monitoring Full Trip Blanks Exceeding Quality Control Limits ……............................... D. D.15

D.2 Long-Term Monitoring Field Transfer Blanks Exceeding Quality Control Limits ................................ D. D.15

D.3 Long-Term Monitoring Equipment Blanks Exceeding Quality Control Limits ....................................... D. D.16

D.4 Long-Term Monitoring Field Duplicates Exceeding Quality Control Limits ........................................ D.17

D.5 Long-Term Monitoring Split Sample Results for Total Organic Carbon ………..................................... D.18

D.6 Interim Action Monitoring Field Blank Detections ………………......................................................... D. D.18

D.7 Interim Action Monitoring Field Duplicates Exceeding Quality Control Limits ............................... D.19

D.8 Interim Action Monitoring Interlaboratory Splits Exceeding Quality Control Limits .......................... D.19

D.9 Groundwater Performance Assessment Project Maximum Recommended Holding Times ................... D. D.20

D.10 Summary of Severn Trent-St. Louis Water Pollution Performance Evaluation Studies ......................... D. D.21

D.11 Summary of Lionville Laboratory Water Pollution Performance Evaluation Studies ........................... D. D.21

D.12 Summary of Severn Trent Interlaboratory Performance, Fiscal Year 2003 ............................................ D. D.22

D.13 Summary of Eberline Services Interlaboratory Performance, Fiscal Year 2003 ..................................... D. D.22 
D.14 Summary of Severn Trent Laboratories Double-Blind Spike Determinations ......................................... D.23

D.15 Summary of Lionville Laboratory, Inc. and Eberline Services Double-Blind Spike Determinations ..... D.24

D.16 Percentage of Out-of-Limit Quality Control Results by Category, Severn Trent Laboratories ............... D. D.24

D.17 Method Blank Results, Severn Trent Laboratories ............................................................................. D. D.25

D.18 Laboratory Control Samples, Severn Trent Laboratories ………………………................................... D. D.26

D.19 Matrix Spikes and Matrix Spike Duplicates, Severn Trent Laboratories ................................................. D. D.27

D.20 Matrix Duplicates, Severn Trent Laboratories ................................................................................... D.29

D.21 Summary of Issue Resolution Forms Received from Severn Trent Laboratories for Fiscal Year 2003 ..... D.30

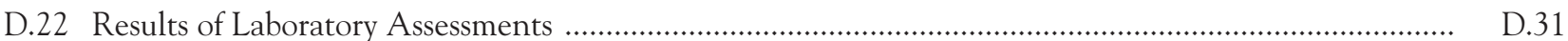

D.23 Summary of Analytical Laboratory Detection/Quantitation Limits Determined from Field Blank Data, Severn Trent Laboratories ................................................................................................ D. D. D

D.24 Summary of Detection and Quantitation Limits, Severn Trent Laboratory .......................................... D. D.34 


\section{Appendix D}

\section{Quality Assurance and Quality Control}

\section{J. Thompson}

This appendix presents fiscal year 2003 quality assurance/quality control (QA/QC) information for long-term and interim action groundwater monitoring at the Hanford Site. The phrase "long-term monitoring" refers to monitoring performed to meet the requirements of the Resource Conservation and Recovery Act (RCRA) and the Atomic Energy Act of 1954 (AEA). Long-term monitoring also includes monitoring performed at Comprehensive Environmental Response, Compensation, and Liability Act (CERCLA) sites with no groundwater remediation. Pacific Northwest National Laboratory (PNNL) manages long-term monitoring via the Groundwater Performance Assessment Project (groundwater project). Interim action monitoring encompasses monitoring at sites with active groundwater remediation under CERCLA. Fluor Hanford, Inc. provided oversight for interim action groundwater monitoring during fiscal year 2003. For both categories of groundwater monitoring, PNNL managed sample scheduling, sample collection, analytical work, and entry of associated information into the Hanford Environmental Information System (HEIS) database.

The QA/QC practices used by the groundwater project assess and enhance the reliability and validity of field and laboratory measurements conducted to support these programs. Accuracy, precision, and detection are the primary parameters used to assess data quality (Mitchell et al. 1985). Representativeness, completeness, and comparability may also be evaluated for overall quality. These parameters are evaluated through laboratory QC checks (e.g., matrix spikes, laboratory blanks), replicate sampling and analysis, analysis of blind standards and blanks, and interlaboratory comparisons. Acceptance criteria have been established for each of these parameters. When a parameter is outside the criteria, corrective actions are taken to prevent a future occurrence.

The QA/QC practices for RCRA samples are based on guidance from the U.S. Environmental Protection Agency (EPA) (EPA 1986a [SW-846] and 1986b [OSWER-9950.1]). U.S. Department of Energy (DOE) orders and internal requirements provide the guidance for the collection and analysis of samples for other long-term monitoring. The QA/QC practices for the groundwater project are described in the project-specific QA plan (PNNL-SA-40114). Guidance for interim action monitoring QA/QC practices is provided in project-specific documents (e.g., BHI-00038; DOE/RL-90-08; DOE/RL-91-03; DOE/RL-91-46; DOE/RL-92-76; DOE/RL-96-07; DOE/RL-96-90; DOE/RL-97-36). A glossary of QA/QC terms is provided in PNNL-13080. Additional information about the QA/QC program and fiscal year 2003 data (e.g., results of individual QC samples and/or associated groundwater samples) is available on request.

\section{D.1 Sample Collection and Analysis}

\section{J. Thompson and D. L. Stewart}

Fluor Hanford, Inc. nuclear chemical operators, under the supervision of Duratek Federal Services, Inc., conducted groundwater sampling for fiscal year 2003. Their tasks included bottle preparation, sample set coordination, field measurements, sample collection, sample shipping, well pumping, and coordination of purgewater containment and disposal. Duratek's statement of work ${ }^{(a)}$ defines quality requirements for sampling activities. Groundwater project staff review all sampling procedures before the procedures are implemented.

Groundwater project staff periodically reviewed sample collection activities performed by nuclear chemical operators from Fluor Hanford, Inc. The purpose of the surveillances was to ensure that samples were collected and submitted to the laboratories in accordance with high-quality standards. Nine surveillances were conducted in the following areas: bottle preparation; sample collection (two events); water-purification system maintenance; measurement of groundwater

(a) SOW-409744-A-B3. 2001. Statement of Work between Pacific Northwest National Laboratory and Duratek Federal Services, Inc., Richland, Washington. 
levels; decontamination of sampling equipment; calibration of field instruments; training and associated documentation; and sample packing, shipping, and storage. A few minor procedural deviations were identified. Corrective actions for eight of these surveillances have been received and accepted.

During fiscal year 2003, Severn Trent Laboratories, Incorporated, St. Louis, Missouri (STL St. Louis), performed most of the routine analyses of Hanford groundwater samples for hazardous and non-hazardous chemicals. Lionville Laboratory, Incorporated, Lionville, Pennsylvania (Lionville Laboratory), served as a secondary laboratory for chemical analyses of split samples and blind standards.

Severn Trent Laboratories, Incorporated, Richland, Washington (STL Richland), performed the majority of radiological analyses on Hanford groundwater samples. Eberline Services, Richmond, California, also analyzed samples for radiological constituents.

Standard methods from EPA and American Society for Testing and Materials (ASTM) were used for the analysis of chemical constituents. Methods employed for radiological constituents were developed by the analyzing laboratories and are recognized as acceptable within the radiochemical industry. Descriptions of the analytical methods used are provided in PNNL-13080.

\section{D.2 Data Completeness}

\section{J. Thompson}

Data judged to be complete are data that are not suspect, rejected, associated with a missed holding time, out-oflimit field duplicate or field blank, or qualified to indicate laboratory blank contamination. For fiscal year 2003, 87\% of the groundwater project data were considered complete. Potentially invalid data were flagged in the database. The percentages of data flagged were $1.9 \%$ for field QC problems, $0.2 \%$ for exceeded holding times, $0.0 \%$ for rejected results, $0.4 \%$ for suspect values, and $10.8 \%$ for laboratory blank contamination. These values are similar to the percentages observed in fiscal year 2002.

Specific evaluation of completeness for interim action groundwater monitoring was not performed for this report. Completeness issues are primarily assessed as part of site-specific validation activities. No validation activities were performed on interim action groundwater monitoring data in fiscal year 2003.

\section{D.3 Field Quality Control Samples}

\section{J. Thompson and R. L. Weiss}

Field QC samples include field duplicates, split samples, and three types of field blanks. The three types of field blanks are full trip, field transfer, and equipment blanks. Field duplicates are used to assess sampling and measurement precision. Split samples are used to confirm out-of-trend results and for interlaboratory comparisons. Field blanks provide an overall measure of contamination introduced during the sampling and analysis process.

\section{D.3.1 Long-Term Monitoring (Groundwater Performance Assessment Project)}

The groundwater project's criteria for evaluating the analytical results of field QC samples are as follows:

- field duplicates - Results of field duplicates must have precision within 20\%, as measured by the relative percent difference. Only those field duplicates with at least one result greater than five times the method detection limit or minimum detectable activity are evaluated.

- split samples - Results must have a relative percent difference $<20 \%$. Only those results that are greater than five times the method detection limit or minimum detectable activity at both laboratories are evaluated.

- field blanks - For most chemical constituents, results above two times the method detection limit are identified as suspected contamination. However, for common laboratory contaminants such as acetone, methylene chloride, 2-butanone, toluene, and phthalate esters, the limit is five times the method detection limit. Results for metals are 
flagged if they exceed two times the instrument detection limit. For radiological data, blank results are flagged if they are greater than two times the total propagated analytical uncertainty.

If a field blank does not meet the established criteria, it is assumed that there are potential problems with the data for all associated samples. For full-trip and field-transfer blanks, an associated sample is one that was collected on the same day and analyzed by the same method as a full-trip or field-transfer blank. For equipment blanks, an associated sample is one that has all of the following in common with an equipment blank:

- collection date

- collection method/sampling equipment

- analysis method

Data associated with out-of-limit field blanks are flagged with a $Q$ in the database to indicate a potential contamination problem. A Q is also applied to both duplicate results when their precision exceeds the QC limits.

The percentages of acceptable field blank $(4,821 / 5,006=96 \%)$ and duplicate $(2,780 / 2,824=98 \%)$ results evaluated in fiscal year 2003 were high, indicating little problem with contamination and good precision overall. None of the split samples collected during the year met the evaluation criteria, but the results from these samples helped identify and troubleshoot a problem with total organic carbon analyses.

Tables D.1 through D.4 summarize the field blank and field duplicate results that exceeded QC limits. To assist with their evaluation, the tables are divided into the following categories, where applicable: general chemical parameters, ammonia and anions, metals, volatile organic compounds, semivolatile organic compounds, and radiological parameters. Constituents not listed in the tables had 100\% acceptable field blanks and/or field duplicates.

With the exception of semivolatile organic compounds, all classes of constituents had results that were flagged as potentially contaminated because of out-of-limit field blank results. Sixty-one percent of the out-of-limit blank results were less than quantifiable limits. A few constituents such as chloride, nitrate, sodium, sulfate, and uranium had several quantifiable field blank results, but the concentrations were much lower than the levels of these constituents in almost all groundwater samples.

Relative to fiscal year 2002, the number of field blank results for total organic carbon that exceeded the QC limits decreased significantly. One out of 81 results was greater than two times the detection limit. Last year, $41 \%$ of the field blanks exceeded the QC limits. Unfortunately, the improved performance on field blanks did not correlate to improved method accuracy for regular groundwater samples. The primary laboratory had problems with high-biased results for total organic carbon during most of the year.

Thirty-five field blank results for metals exceeded the QC limits. In general, the field blank concentrations were similar to those from last year. Most of the unacceptable results were within a factor of 5 of the instrument detection limits. All of the metals with out-of-limit field blank results had one or more comparable method-blank results, suggesting that the elevated field blank values were caused by false detections or laboratory contamination.

Concentrations of five volatile organic compounds exceeded the QC limits in one or more field blanks. Methylene chloride was the predominant volatile contaminant, accounting for $95 \%$ of the out-of-limit results. Levels of acetone and 2-butanone were also out of limits in two field blanks. Laboratory contamination is the suspected source of these common contaminants, because similar concentrations also were measured in several method blanks. Trace levels of carbon disulfide and carbon tetrachloride also were measured in field blanks. These compounds had low frequencies of detection (i.e., $<2 \%$ ) in field blanks, and the overall impact on the data is minor.

Gross beta, tritium, and uranium were the only radiological constituents with out-of-limit field blank results. Although the field blank concentrations of gross beta and tritium were low, they were greater than levels of these constituents in some of the associated groundwater samples. In contrast, the field blank concentrations for uranium were significantly lower than the levels in the associated samples. All three constituents were measured in one or more laboratory method blanks at concentrations similar to the field blank values.

Comparison of full-trip and equipment blank results suggests that the use of non-dedicated sampling equipment at some wells did not have a significant impact on data quality. Overall, fewer constituents were detected in equipment blanks, and the concentrations of most constituents were lower in equipment blanks. However, only a limited comparison can be made because only 7 equipment blanks were collected compared to 79 full trip blanks. The percentages of outof-limit results were generally higher in equipment blanks for those constituents detected in both types of blanks. 
Duplicate results were flagged for all constituent classes (Table D.4). Overall, the relative number of flagged duplicate results was very low $(<2 \%)$, but the percentages of unacceptable results were high for several constituents based on the number of duplicates that met the evaluation criteria. The metals and radiological parameters categories accounted for approximately two-thirds of the out-of-limit results. Most of the associated samples were unfiltered; thus, suspended solids in heterogeneous sample fractions may have caused some of the discrepancies in the results. The majority of the out-of-limit duplicate results appear to be anomalous instances of poor precision based on other QC indicators such as the results from the blind standards and laboratory duplicates (discussed in Sections D.5.2 and D.5.3). In several cases, the laboratory was asked to re-analyze or investigate duplicate results with a very high relative percent difference, but the checks did not reveal the source of the problem. Especially poor agreement was observed between a pair of results for the following: alkalinity $(124,000$ and $226,000 \mu \mathrm{g} / \mathrm{L})$, gross alpha $(14.0$ and $26.9 \mathrm{pCi} / \mathrm{L})$, and uranium $(0.842$ and $5.69 \mu \mathrm{g} / \mathrm{L})$. Swapped samples or procedural deviations at the laboratory may have caused the unmatched results.

During the second quarter of the fiscal year, groundwater project staff observed that several results for total organic carbon were significantly higher than previous measurements. For example, at several sites the concentrations increased from a historical average of $\sim 200$ to $400 \mu \mathrm{g} / \mathrm{L}$ to values over $1,500 \mu \mathrm{g} / \mathrm{L}$. The suspect values were flagged in the database, and several steps were taken to investigate the problem. Results from field and laboratory blanks were reviewed, and all of the results were either non-detected or just slightly above the detection limit. Additionally, the data were examined for possible trends in analysis dates, pump types, sampling personnel, and well locations. No obvious connections between these variables and the elevated values were determined. Twenty-five split samples were collected from seven wells during the last two quarters of the year to help investigate the problem. STL St. Louis and Lionville Laboratory analyzed the samples. Although none of the results met the QC evaluation criteria, the data for most of the samples show distinctly higher concentrations were determined by the St. Louis laboratory (Table D.5). Lionville Laboratory's results are generally consistent with historical data for the associated wells, suggesting that STL St. Louis' results were biased high. The problem was discussed with the St. Louis laboratory, and laboratory staff discovered that an under-pressurized gas line was affecting the sparging of samples during the analysis. Since the sparging process removes carbonate and bicarbonate (i.e., inorganic carbon) from the sample, inadequate sparging would produce high-biased results. Field and method blanks would not be affected, however, because the blanks are prepared from deionized water. The laboratory corrected the gas pressure in August, and more recent data suggest the overall problem has been resolved.

\section{D.3.2 Interim Action Monitoring}

Trained staff collected samples in accordance with approved procedures. In general, field QC samples consisted of field duplicates, splits, equipment blanks, and trip blanks. Field QC data are evaluated as necessary to make decisions that may modify or terminate a remedial action. In fiscal year 2003, no evaluations were necessary for decision-making purposes.

Field QC data were examined to monitor laboratory operations and to identify potential problem areas where improvements were necessary. Evaluation criteria were essentially the same as those used for the groundwater project with the following exceptions:

- Field blanks were evaluated based on the number of detections (rather than the groundwater project's approach of using two times the detection limit as an acceptance criterion). Sample-specific detection limits were not captured for interim action monitoring samples, making an identical evaluation impossible.

- The $20 \%$ relative percent difference criterion for field duplicate and split sample results was relaxed for sample analytical results near (i.e., typically within five times) nominal method detection limits. This accounts for expected increased analytical error when values are close to detection limits.

For field blank samples, $>89 \%$ of all results were returned as non-detected. Over $80 \%$ of the detected organic constituents were common laboratory contaminants, and in most cases, detected compounds also were measured at similar levels in the analytical batch blank. Evaluation of other field blank sample results showed no evidence of unexpected or excessive contamination of blanks in the field or by the laboratory. The constituents and levels of contamination found should have no impact on decision making for interim action monitoring. This is comparable, but slightly better than last year's results ( $88 \%$ non-detect) and still improved over previous years ( $80 \%$ to $85 \%$ ). Blank detects are summarized in Table D.6. 
Field duplicate and split results showed $<10 \%$ exceeding the criteria used for evaluation. The percentage of out-oflimit splits was $\sim 2$ times higher than the relative number of out-of-limit duplicates. The criteria used to evaluate splits are likely more restrictive than necessary because they are based on similar criteria for laboratory replicate evaluation (i.e., analysis of multiple aliquots from the same sample container by the same laboratory in the same analytical batch).

As noted in previous years, metals analysis by the inductively coupled plasma method accounts for the largest group of results exceeding the criteria. Field duplicate evaluations are summarized in Table D.7, and interlaboratory split evaluations are summarized in Table D.8.

Previous evaluations noted an apparent non-random variability in interlaboratory splits for analysis of some metals at low levels. At levels below $\sim 50 \mu \mathrm{g} / \mathrm{L}$, results reported by STL St. Louis were noted greater than Lionville Laboratory for vanadium; the other comparisons showed no identifiable trends in results.

Overall evaluation indicates no significant issues between procedures and analyses performed by the laboratories providing services to the interim action monitoring program. The general performance for fiscal year 2003 is similar to the previous year.

\section{D.4 Holding Times}

\section{S. Sklarew}

Holding time is the elapsed time period between sample collection and analysis. Samples should be analyzed within recommended holding times to minimize the possibility of changes in constituent concentrations caused by volatilization, decomposition, or other chemical alterations. Samples are also refrigerated to slow potential chemical reactions within the sample matrix. Maximum recommended holding times for constituents frequently analyzed for the groundwater project are listed in Table D.9. Radiological constituents do not have recommended maximum holding times because these constituents are not typically lost under ambient temperatures when appropriate preservatives are used. Results of radionuclide analysis are corrected for decay from sampling date to analysis date.

During fiscal year 2003, recommended holding times were exceeded for 86 out of 6,213 (1.4\%) of the groundwater project's non-radiological sample analysis requests. A sample analysis request is defined as a sample that is submitted for analysis by a particular analytical method. In general, the missed holding times should not have a significant impact on the data. Results for samples with missed holding times are flagged with an $\mathrm{H}$ in the database. Holding times were exceeded for 86 out of 6,113 (1.4\%) of STL St. Louis' sample analysis requests. Of these, the constituents with the most missed holding times were anions by ion chromatography (66 samples), alkalinity ( 9 samples), and cyanide (6 samples). Shipping delays and laboratory QC failures caused most of the missed holding times. STL Richland did not exceed holding times for the 49 coliform samples. Lionville Laboratory did not exceed holding times for the 50 analysis requests that were processed for the groundwater project. The missed holding times were discussed with STL St. Louis to help laboratory staff identify areas where improvements are needed.

Specific evaluation of adherence to analytical holding times for interim action monitoring was not performed for this report. Analytical holding times are monitored as part of ongoing sample and data management activities throughout the year. However, interim action monitoring data are not flagged for missed holding times. No remediation decisions were affected by missed holding times in fiscal year 2003.

\section{D.5 Laboratory Performance}

\section{J. Thompson, D. S. Sklarew, and D. L. Stewart}

Laboratory performance is measured by several indicators, including nationally based performance evaluation studies, double-blind standard analyses, laboratory audits, and internal laboratory QA/QC programs. This section provides a detailed discussion of the performance indicators for STL St. Louis and STL Richland. Brief summaries of performance measures for Lionville Laboratory and Eberline Services also are presented throughout this section. The majority of the laboratory's results were within the acceptance limits, indicating good performance overall. 


\section{D.5.1 Nationally Based Performance Evaluation Studies}

During fiscal year 2003, Environmental Resources Associates and DOE conducted nationally based studies to evaluate laboratory performance for chemical and radiological constituents. STL St. Louis and Lionville Laboratory participated in the EPA sanctioned Water Pollution and Water Supply Performance Evaluation studies conducted by Environmental Resources Associates. STL Richland and Eberline Services took part in DOE's Quality Assessment Program. STL Richland participated in the Environmental Resources Associates' InterLaB RadCheM Proficiency Testing Program. All four laboratories took part in DOE's Mixed Analyte Performance Evaluation Program. Results of those studies related to groundwater monitoring at the Hanford Site are described in this section.

\section{D.5.1.1 Water Pollution and Water Supply Studies}

The purpose of water pollution and water supply studies is to evaluate the performance of laboratories in analyzing selected organic and inorganic compounds. Every month, an accredited agency such as Environmental Resource Associates distributes standard water samples to participating laboratories. These samples contain specific organic and inorganic analytes at concentrations unknown to the participating laboratories. After analysis, the laboratories submit results to the accredited agency, which uses regression equations to determine acceptance and warning limits for the study participants. The results of these studies, expressed in this report as a percentage of the results that the accredited agency found acceptable, independently verify the level of laboratory performance.

For the five water pollution studies in which STL St. Louis participated this year (ERA WP-97, 99, 100, 101, and 102), the percentage of acceptable results submitted to the groundwater project ranged from $80 \%$ to $100 \%$ (Table D.10); three of these studies had a limited number of analytes. Of the 27 different constituents with unacceptable results, total Kjeldahl nitrogen was out of limits in all three studies in which it was analyzed; conductivity was out of limits in both studies in which it was analyzed; and a number of base/neutral compounds were out of limits in one out of two studies. The laboratory provided information about possible causes for many of the unacceptable results and suggested corrective actions where appropriate. The constituents that were out of limits last year are mainly within limits this year. Overall, the unacceptable results should not have a significant impact on Hanford groundwater samples.

Lionville Laboratory participated in water pollution studies WP-92 and 96 this year; one of the studies had a limited number of analytes. For the results submitted to the groundwater project, the percentage of Lionville's acceptable results ranged from $99 \%$ to $100 \%$ (Table D.11). Only two constituents were out of limits in one study. The laboratory provided information about possible causes for the unacceptable results and suggested corrective actions where appropriate. Overall, the unacceptable results should not have a significant impact on Hanford groundwater samples.

\section{D.5.1.2 DOE Quality Assessment and Mixed Analyte Performance Evaluation Programs}

DOE's Quality Assessment Program evaluates how laboratories perform when they analyze radionuclides in water, air filter, soil, and vegetation samples. This discussion considers only water samples. The program is coordinated by the Environmental Measurements Laboratory in New York. The Environmental Measurements Laboratory provides blind standards that contain specific amounts of one or more radionuclides to participating laboratories. Constituents analyzed can include americium-241, cesium-134, cesium-137, cobalt-60, gross alpha, gross beta, plutonium-238, plutonium-239, strontium-90, tritium, uranium-234, uranium-238, and total uranium. After sample analysis, each participating laboratory forwards the results to the Environmental Measurements Laboratory for comparison with known values and with results from other laboratories. The Environmental Measurements Laboratory evaluates the accuracy of the results based on the historical analytical capabilities for the individual analyte/matrix pairs. Using a cumulative normalized distribution, acceptable performance yields results between the 15th and 85th percentiles. Acceptable with warning results are between the 5 th and 15 th percentile and between the 85 th and 95 th percentile. Not acceptable results include the outer 10\% ( $<5$ th percentile or $>95$ th percentile) of historical data (EML-618, 621).

For the two studies conducted this year, QAP57 and QAP 58 (EML-618 and 621, respectively), the percentage of STL Richland's acceptable results ranged from $85 \%$ to $100 \%$ (Table D.12). The unacceptable results were for gross alpha and gross beta. Four constituents (18\%) had results that were evaluated as acceptable with warning (Table D.12). 
The percentage of Eberline Services' results that was acceptable ranged from 92\% to 100\% (Table D.13). The unacceptable result was for gross alpha. Three constituents had results that were evaluated as acceptable with warning (Table D.13).

DOE's Mixed Analyte Performance Evaluation Program examines laboratory performance in the analysis of soil and water samples containing metals, volatile and semivolatile organic compounds, and radionuclides. This report considers only water samples. The program is conducted at the Radiological and Environmental Sciences Laboratory in Idaho Falls, Idaho, and is similar in operation to DOE's Quality Assessment Program discussed above. DOE evaluates the accuracy of the Mixed Analyte Performance Evaluation Program results for radiological and inorganic samples by determining if they fall within a $30 \%$ bias of the reference value.

Preliminary results for STL Richland for fiscal year 2003 (MAPEP-02-W10) were all acceptable (Table D.12). Results are not yet available for STL St. Louis, Eberline Services, or Lionville Laboratory.

\section{D.5.1.3 InterLaB RadCheM Proficiency Testing Program Studies}

The purpose of the InterLaB RadCheM Proficiency Testing Program, conducted by Environmental Resources Associates, is to evaluate the performance of laboratories in analyzing selected radionuclides. The program provides blind standards that contain specific amounts of one or more radionuclides in a water matrix to participating laboratories. Environmental Resources Associates standards were prepared for the following radionuclides/parameters: barium-133, cesium-134, cesium-137, cobalt-60, gross alpha, gross beta, iodine-131, radium-226, radium-228, strontium-89, strontium-90, tritium, uranium, and zinc-65. After sample analysis, the results were forwarded to Environmental Resources Associates for comparison with known values and with results from other laboratories. Environmental Resources Associates bases its control limits on the EPA's National Standards for Water Proficiency Testing Studies Criteria Document (NERL-Ci-0045).

In the two studies in which STL Richland participated this year (RAD 51 and 52), 29 constituents were analyzed. All were acceptable (Table D.12).

Eberline Services does not participate in the Environmental Resources Associates program.

\section{D.5.2 Double-Blind Standard Evaluation}

The groundwater project forwarded blind QC standards to STL Richland and St. Louis, Lionville Laboratory, and Eberline Services during fiscal year 2003. Blind spiked standards were generally prepared in triplicate and submitted to the laboratories to check the accuracy and precision of analyses. For most constituents, the standards were prepared in a groundwater matrix from a background well. Some special metals standards from the fourth quarter were prepared in organic free, deionized water. In all cases, the standards were submitted to the laboratories in double-blind fashion (i.e., the standards were disguised as regular groundwater samples). After analysis, the laboratory's results were compared with the spiked concentrations, and a set of control limits were used to determine if the data were acceptable. Generally, if a result was out of limits, the data were reviewed for errors. In situations where several results for the same method were unacceptable, the results were discussed with the laboratory, potential problems were investigated, and corrective actions were taken if appropriate.

Tables D.14 and D.15 list the number and types of blind standards used in fiscal year 2003 along with the control limits for each constituent. Overall, $88 \%$ of the blind spike determinations were acceptable. This is lower than the percentage from the previous year (95\%), although several additional constituents were evaluated this year. Thirtythree out of 295 results were out of limits for STL Richland and St. Louis. Total organic carbon, total organic halides, cyanide, cadmium, silver, elemental strontium, chloroform, trichloroethene, gross alpha, plutonium-239, and tritium were the constituents with out-of-limit results. Collectively, Lionville Laboratory and Eberline Services had 7 out of 31 unacceptable results. The affected constituents were total organic carbon, cyanide, and gross beta.

Most of STL St. Louis' results for total organic carbon were biased high, and three were outside the acceptance limits. Typical recoveries ranged from $107 \%$ to $121 \%$. A similar tendency was observed in last year's blind standard results. The standards with the out-of-limit recoveries were spiked at the lowest level $(1,010 \mu \mathrm{g} / \mathrm{L}$, which is approximately equal to the laboratory's practical quantitation limit). The results from the third quarter were initially biased high by a factor of 2. As discussed earlier, the laboratory had some problems with the analysis during this timeframe, which 
likely caused the results to be elevated. STL St. Louis re-analyzed the samples after the sparge-gas problem had been corrected, and the re-analysis results were acceptable. All of the fourth-quarter results were also within the acceptance limits.

Fourteen of 27 results for total organic halides from STL St. Louis were out of limits. Half of the unacceptable results were for standards spiked with 2,4,6-trichlorophenol. Three of the standards are believed to have been spiked incorrectly, based on a confirmatory analysis by gas chromatography-mass spectroscopy. The other phenolic standards with the out-of-limit results were spiked at a concentration close to the method detection limit. All of the unacceptable results for the standards spiked with volatile organic compounds had low recoveries (50\% to 70\%). PNNL staff performed in-house analyses on splits of the volatile standards and confirmed that the standards were spiked at the proper concentrations. Consequently, the reason for the low bias appears to be volatilization or weak retention of the volatile analytes on the charcoal cartridges used in the analysis. The laboratory investigated the out-of-limit results but was unable to determine the source of error. Low-biased total organic halide results are of concern because of the potential for not detecting halogenated organics at RCRA sites. However, even with a 50\% negative bias, detection should occur at concentrations well below the limit of quantitation (discussed in Section D.6).

STL St. Louis' results for cyanide were highly variable for the standards submitted during the third and fourth quarters. Recoveries ranged from $40 \%$ to $102 \%$. The laboratory re-analyzed those samples with out-of-limit results, and in some cases, the re-analysis results were acceptable. Reasons for the low recoveries are unknown, but loss of cyanide during sample distillation is suspected.

During August, some special blind standards containing metals were submitted to STL St. Louis to evaluate the laboratory's inductively coupled plasma mass spectroscopy (ICP-MS) capability. Two concentration levels were included in the study. High-level standards were spiked at concentrations ranging from 100 to 2,000 $\mu \mathrm{g} / \mathrm{L}$ (10 to 100 times greater than the ICP-atomic emission spectroscopy [AES] detection limits). Low-level standards were spiked at 1/10 the concentrations of the high-level standards. The standards were analyzed by both ICP-MS and traditional ICPAES for confirmatory purposes. Since many of the low-level standards' results were reported as non-detected by both methods, only the high-level results are included in this evaluation. A study to investigate the practical detection limits for the ICP-MS method is planned for next fiscal year. All of the ICP-AES results were acceptable, indicating that the standards had been prepared correctly. Cadmium, silver, and strontium had low recoveries by ICP-MS. Matrix interferences appeared to be responsible for the low-biased results, because the low-level spike results for these elements were acceptable, and matrix spikes associated with the high-level standards had low recoveries. These results have been discussed with STL St. Louis, and the laboratory is planning to investigate this problem further.

In general, STL Richland performed well on the analysis of radiological blind standards. Six results were outside the QC limits. Of these, three (tritium) are believed to be associated with incorrectly spiked standards. The out-oflimit results for gross alpha were from the second quarter; recoveries ranged from $71 \%$ to $73 \%$. A procedural error at the laboratory may have caused the results to be biased low.

Lionville Laboratory had one out-of-limit result for total organic carbon and three unacceptable results for cyanide. The total organic carbon result was biased high (129\% recovery), but the standard was spiked at a level near the laboratory's practical quantitation limit $(1,000 \mu \mathrm{g} / \mathrm{L})$. Reasons for the out-of-limit cyanide results are unknown. STL St. Louis had acceptable recoveries on splits of these standards, indicating that the standards were spiked correctly. The impact of the out-of-limit results is minimal because Lionville Laboratory did not analyze many routine groundwater samples for total organic carbon or cyanide during fiscal year 2003.

Eberline Services analyzed 12 blind standards for gross beta; all three of the results from the first quarter were approximately twice as high as the expected concentrations. The laboratory re-analyzed the samples with the out-oflimit results, but the re-analysis results were consistent with the original values. Since Eberline Services served as a backup laboratory ( $<10$ samples analyzed for gross beta), the impact of the out-of-limit results is minor.

Fluor Hanford, Inc. sent no blind standards as part of interim action monitoring to the commercial laboratories in fiscal year 2003. The great similarity of matrices between the long-term and interim action monitoring samples and common use of the same laboratories make additional analysis of blind standards redundant.

\section{D.5.3 Laboratory Internal QA/QC Programs}

STL Richland, STL St. Louis, Eberline Services, and Lionville Laboratory maintain internal QA/QC programs that generate data on analytical performance by analyzing method blanks, laboratory control samples, matrix spikes 
and matrix spike duplicates, matrix duplicates, and surrogates (see PNNL-13080 for definitions of these terms). This information provides a means of assessing laboratory performance and the suitability of a method for a particular sample matrix. Laboratory QC data are not currently used for in-house validation of individual sample results unless the laboratory is experiencing unusual performance problems with an analytical method. An assessment of the laboratory QC data for fiscal year 2003 is summarized in this section. STL data are discussed in detail first. Table D.16 provides a summary of the STL QC data by listing the percentage of QC results that were out of limits for each analyte category and QC parameter. Additional details are presented in Tables D.17 through D.20. Constituents not listed in these tables did not exceed STL's QC limits. A brief summary of Lionville Laboratory and Eberline Services data is presented at the end of the section.

Most of this year's laboratory QC results were within acceptance limits, suggesting that the analyses were in control and reliable data were generated. Nevertheless, a number of parameters had unacceptable results.

Evaluation of results for method blanks was based on the frequency of detection above the blank QC limits. In general, these limits are two times the method detection limit for chemical constituents and two times the total propagated error for radiochemistry parameters. For common laboratory contaminants such as 2-butanone, acetone, methylene chloride, phthalate esters, and toluene, the QC limit is five times the method detection limit.

Table D.17 summarizes method blank results from STL Richland and St. Louis. The ammonia and anions category had the greatest percentages of method blank results exceeding the QC limits. The following parameters had $>10 \%$ of method blank results outside the QC limits: specific conductance, chloride, sulfate, iron, tin, methylene chloride, carbon-14, and uranium. The out-of-limit method blank results for specific conductance are not a significant problem because the values are much lower than the levels measured in Hanford Site groundwater. Similarly, the highest method blank results for chloride $(0.2 \mathrm{mg} / \mathrm{L})$, sulfate $(0.36 \mathrm{mg} / \mathrm{L})$, magnesium $(350 \mu \mathrm{g} / \mathrm{L})$, sodium $(379 \mu \mathrm{g} / \mathrm{L})$, and elemental strontium $(0.086 \mu \mathrm{g} / \mathrm{L})$ are lower than the respective levels measured in Hanford groundwater. The percentage of out-of-limit method blanks for nitrogen in ammonia, aluminum, beryllium, cadmium, calcium, copper, magnesium, and sodium decreased significantly compared to last year, while the percentage for vanadium and carbon-14 increased.

Table D.18 summarizes results for the laboratory control samples from STL Richland and St. Louis. Only volatile organic compounds and semivolatile organic compounds had $>1 \%$ of their measurements outside the QC limits. Specific compounds with $>10 \%$ of out-of-limit laboratory control samples included 1,1,2,2-tetrachloroethane, TPH gasoline, 2,4-dinitrophenol, 4,6-dinitro-2-methylphenol, 4-nitrophenol, Aroclor-1016, chrysene, delta-BHC, and uranium-238. In all of these cases except the phenols, the number of QC samples analyzed was limited $(<20)$.

Table D.19 summarizes results for the matrix spikes and matrix spike duplicates from STL Richland and St. Louis. The general chemical parameters and ammonia and anions categories had the greatest percentage of matrix spikes/ spike duplicates exceeding the QC limits. This represents an increase compared to last year's results for these two categories. Fewer than $5 \%$ of the matrix spikes or matrix spike duplicates for metals, volatile organic compounds, semivolatile organic compounds and radiochemistry parameters were out of limits. Table D.19 indicates which constituents had $>10 \%$ of matrix spikes/spike duplicates out of limits.

Matrix duplicates were evaluated by comparing the relative percent difference to the QC limit for results that were five times greater than the method detection limit or the minimum detectable activity. Table D.20 lists the constituents that exceeded the relative percent difference limits. The semivolatile organic compounds category had the greatest percentage of matrix duplicates exceeding the QC limits. This represents an increase compared to last year's results for this category. All other categories had fewer than 3\% of their measurements outside the QC limits. Constituents with $>10 \%$ of matrix duplicates out of limits are listed in Table D.20.

Surrogate data included eight compounds each for volatile organics and for semivolatile organics. For volatile organic compounds, $3.6 \%$ of the surrogate results were outside of QC limits; the corresponding percentage for semivolatile organic surrogates was $4.5 \%$.

QC data for Eberline Services and Lionville Laboratory were limited for fiscal year 2003 because these laboratories did not analyze many samples for the groundwater project. Lionville Laboratory analyzed method blanks, laboratory control samples, matrix spikes, and matrix duplicates for total organic carbon and cyanide. All of the QC data were within limits. Eberline Services QC data were limited to gross beta and strontium-90. All of the QC data were within limits. 


\section{D.5.3.1 Issue Resolution}

Issue resolution forms are documents that are used to record and resolve problems encountered with sample receipt, sample analysis, missed hold times, and data reporting (e.g., broken bottles or QC problems). The laboratories generate the forms and forward them to the groundwater project as soon as possible after a potential problem is identified. The forms provide a means for the project to give direction to the laboratory on resolution with the issues. The documentation is intended to identify occurrences, deficiencies, and/or issues that may potentially have an adverse effect on data integrity.

Table D.21 indicates the specific issues identified during fiscal year 2003 and the number of times these occurred. The number of issues identified by the laboratories was small compared to the total number of analytical requests submitted ( 12,500, consisting of $\sim 17,400$ bottles). The frequencies of the individual issues increased in most categories prior to receipt at the laboratory but decreased in others after receipt at the laboratory. Most of the increases are related to the increase in the number of analytical requests submitted during fiscal year 2003. This increase of analytical requests is due to the addition of the interim action monitoring program samples being submitted to these laboratories. Previously, the samples were submitted to the secondary laboratory and were managed by Bechtel Hanford, Inc. The number of hold time issues was primarily related to delays caused by the need for radiological screens prior to shipment. A small percentage of the hold time issues were related to shipping delays.

\section{D.5.3.2 Laboratory Audits/Assessments}

Laboratory activities are regularly assessed by surveillance and auditing processes to ensure that quality problems are prevented and/or detected. Regular assessment supports continuous process improvement. Five assessments of the commercial analytical laboratories were performed. Four of these audits were conducted by the DOE-sponsored Environmental Management Consolidated Assessment Program (EMCAP), and one audit was conducted by a joint team of Bechtel Hanford, Inc. and PNNL representatives.

The goal of the EMCAP is to design and implement a program to consolidate site audits of commercial and DOE environmental laboratories providing services to DOE Environmental Management. The specific audit objectives of the EMCAP were to assess the ability of the laboratories to produce data of acceptable and documented quality through analytical operations that follow approved and technically sound methods and to handle DOE samples and associated waste in a manner that protects human health and the environment.

The four EMCAP audits were performed at the following laboratories: STL St. Louis, May 20-22, 2003; Eberline Services, June 3-5, 2003; Lionville Laboratory, June 24-26, 2003; and STL Richland, August 12-14, 2003. The assessment scope of the EMCAP audits included the following specific functional areas: (1) QA management systems and general laboratory practices, (2) data quality for organic analyses, (3) data quality for inorganic and wet chemistry analyses, (4) data quality for radiochemistry analysis, (5) hazardous and radioactive materials management, and (6) verification of corrective-action implementation from previous audit findings.

The purpose of the joint Bechtel Hanford, Inc. and PNNL assessment, conducted on March 18 to 20, 2003, was to evaluate the continued support of analytical services to Hanford Site contractors as specified in the statement of work between Flour Hanford, Inc. and STL. ${ }^{(b)}$ The audit was based on the analytical and QA requirements for both groundwater and multi-media samples as specified in the statement of work. The primary areas of focus were personnel training, procedure compliance, sample receipt and tracking, instrument operation and calibration, equipment maintenance, instrumentation records and logbooks, implementation of STL's QA Management Plan in accordance with Hanford Analytical Services Quality Assurance Document (HASQARD, Volumes 1 and 4, DOE/RL-96-68), and the implementation of corrective actions for deficiencies identified in previous audits.

A total for 16 findings and 31 observations were noted for the 4 EMCAP audits, and 7 findings and 6 observations were identified in the joint Bechtel Hanford, Inc. and PNNL audit. Results of each of these audits are summarized in Table D.22. Corrective actions have been accepted for all the audits, and verification of the corrective actions will be performed in future audits. All laboratories have been qualified to continue to provide analytical services for samples generated at DOE sites.

(b) RFSH-SOW-93-0003, Rev. 6. 1999. Environmental and Waste Characterization of Analytical Services. Statement of Work between Fluor Daniel Hanford, Inc. and Severn Trent Laboratories, Richland, Washington. 
In addition to many of the past audit findings being closed, several proficiencies for all of the laboratories were noted in each audit this year, indicating that the laboratories are improving their processes and continuing to provide quality analytical services. Continued assessments of the laboratories are planned for the upcoming year to further evaluate performance and to ensure those corrective actions for the past findings and observations have been implemented.

\section{D.6 Limit of Detection, Limit of Quantitation, and Method Detection Limit}

\section{J. Chou, D. S. Sklarew, and C. J. Thompson}

Detection and quantitation limits are essential to evaluate data quality and usefulness because they provide the limits of a method's measurement. The detection limit is the lower limit at which a measurement can be differentiated from background. The quantitation limit is the lower limit where a measurement becomes quantifiably meaningful. The limit of detection, limit of quantitation, and method detection limit are useful for evaluating groundwater data.

The limit of detection is defined as the lowest concentration level statistically different from a blank (Currie 1988). The concentration at which an analyte can be detected depends on the variability of the blank response. For the purpose of this discussion, the blank is taken to be a method blank.

In general, the limit of detection is calculated as the mean concentration in the blank plus three standard deviations of that concentration (EPA/540/P-87/001, OSWER 9355.0-14). The blank-corrected limit of detection is simply three times the blank standard deviation. At three standard deviations from the blank mean, the false-positive and the false-negative error rates are each $\sim 7 \%$ (Miller and Miller 1988). A false-positive error is an instance when an analyte is declared present but is, in fact, absent. A false-negative error is an instance when an analyte is declared absent but is, in fact, present.

The limit of detection for a radionuclide is typically computed from the counting error associated with each reported result (e.g., EPA 520/1-80-012) and represents instrumental or background conditions at the time of analysis. In contrast, the limit of detection and limit of quantitation for the radionuclides shown in Table D.23 are based on variabilities that result from both counting errors and uncertainties introduced by sample handling. In the latter case, distilled water, submitted as a sample, is processed as if it were an actual sample. Thus, any random cross-contamination of the blank during sample processing will be included in the overall error, and the values shown in Table D.23 are most useful for assessing long-term variability in the overall process.

The limit of quantitation is defined as the level above which quantitative results may be obtained with a specified degree of confidence (Keith 1991). The limit of quantitation is calculated as the blank mean plus 10 standard deviations of the blank (EPA/540/P-87/001, OSWER 9355.0-14). The blank-corrected limit of quantitation is simply 10 times the blank standard deviation. The limit of quantitation is most useful for defining the lower limit of the useful range of concentration measurement technology. When the analyte signal is 10 times larger than the standard deviation of the blank measurements, there is a $95 \%$ probability that the true concentration of the analyte is within $\pm 25 \%$ of the measured concentration.

The method detection limit is defined as the minimum concentration of a substance that can be measured and reported with a $99 \%$ confidence that the analyte concentration is greater than zero. The method detection limit is determined from analysis of a sample in a given matrix containing the analyte (Currie 1988). The method detection limit is 3.14 times the standard deviation of the results of seven replicates of a low-level standard. Note that the method detection limit, as defined above, is based on the variability of the response of low-level standards rather than on the variability of the blank response.

For this report, total organic carbon, total organic halides, and radionuclide field blank data are available for limit of detection and limit of quantitation determinations. The field blanks are QC samples that are introduced into a process to monitor the performance of the system. The use of field blanks to calculate the limit of detection and the limit of quantitation is preferred over the use of laboratory blanks because field blanks include error contributions from sample preparation and handling, in addition to analytical uncertainties. Methods to calculate the limit of detection and the limit of quantitation are described in detail in Appendix A of DOE/RL-91-03. The results of the limit of detection and limit of quantitation determinations are listed in Table D.23. 
Because of the lack of blank data for other constituents of concern, it was necessary to calculate approximate limit of detection and limit of quantitation values by using variability information obtained from low-level standards. The data from the low-level standards are obtained from laboratory method detection limit studies. If low-level standards are used, the variability of the difference between the sample and blank response is increased by a factor of 2 (Currie 1988, p. 84). The formulas are summarized below:

$$
\begin{aligned}
\mathrm{MDL} & =3.14 \times \mathrm{s} \\
\mathrm{LOD} & =3 \times(\sqrt{2} \times \mathrm{s}) \\
& =4.24 \times \mathrm{s} \\
\mathrm{LOQ} & =10 \times(\sqrt{2} \times \mathrm{s}) \\
& =14.14 \times \mathrm{s}
\end{aligned}
$$

where $s=$ standard deviation from the seven replicates of the low-level standard.

The results of limit of detection, limit of quantitation, and method detection limit calculations for most nonradiological constituents of concern (besides total organic carbon and total organic halides) are listed in Table D.24. The values in the table apply to STL St. Louis only.

Specific evaluation of detection-limit issues for the interim action groundwater monitoring program was not performed for this report. Detection-limit issues are primarily assessed as part of site-specific validation activities. No validation activities were performed on interim action groundwater monitoring data in fiscal year 2003.

\section{D.7 Conclusions}

Overall, assessments of fiscal year $2003 \mathrm{QA} / \mathrm{QC}$ information indicate that groundwater monitoring data are reliable and defensible. Sampling was conducted in accordance with reviewed procedures. Few contamination or other samplingrelated problems were encountered that affected data integrity. Likewise, laboratory performance was excellent in most respects, based on the large percentages of acceptable field and laboratory QC results. Satisfactory laboratory audits and generally acceptable results in nationally based performance evaluation studies also demonstrated good laboratory performance. However, the following areas of concern were identified and should be considered when interpreting groundwater monitoring results:

- A few QC samples were probably swapped in the field or at the laboratory based on a small number of unusually high field blank results and duplicate results with poor precision. The same problem likely occurred for a small number of groundwater samples. Mismatched results for key constituents should be identified during data review.

- Several indicator parameters, anions, metals, volatile organic compounds, and radiological parameters were detected at low levels in field and/or laboratory method blanks. The most significant contaminants were alkalinity, copper, iron, methylene chloride, total organic halides, and zinc.

- Maximum recommended holding times were exceeded for $\sim 1.4 \%$ of groundwater project samples that were analyzed by non-radiological methods. Anions were primarily affected, though the data impacts are considered minor.

- A laboratory problem caused several results for total organic carbon to be biased high. Samples collected during the last three quarters of the fiscal year may have been affected. The problem has been corrected, and most of the anomalous results have been flagged in the database.

- STL St. Louis had several out-of-limit blind-standard results for total organic halides. Most of the results had a low bias, suggesting that groundwater results for total organic halides may also be biased low. Both STL St. Louis and Lionville Laboratory had performance problems with cyanide and total organic carbon. Unacceptable blind-standard results were also reported by STL Richland for gross alpha, plutonium-239, tritium, and uranium. Finally, Eberline Services had out-of-limit results for gross beta. 


\section{D.8 References}

Atomic Energy Act of 1954, as amended, Ch. 1073, 68 Stat. 919, 42 USC 2011 et seq.

BHI-00038, Rev. 2. 1995. 200-ZP-1 Groundwater Sampling and Analysis Plan/Quality Assurance Plan. KM Singleton, Bechtel Hanford, Inc., Richland, Washington.

Comprehensive Environmental Response, Compensation, and Liability Act. 1980. Public Law 96-510, as amended, 94 Stat. 2767, 42 USC 9601 et seq.

Currie, LA. (ed.). 1988. "Detection in Analytical Chemistry: Importance, Theory, and Practice." ACS Symposium Series 361, American Chemical Society, Washington, D.C., pp. 17, 79-92.

DOE/RL-90-08. 1992. Remedial Investigation/Feasibility Study Work Plan for the 100-BC-5 Operable Unit, Hanford Site, Richland, Washington. U.S. Department of Energy, Richland Operations Office, Richland, Washington.

DOE/RL-91-03. 1991. Annual Report for RCRA Groundwater Monitoring Projects at Hanford Site Facilities for 1990. Prepared by Geosciences Group, Westinghouse Hanford Company, Environmental Division for U.S. Department of Energy, Richland Operations Office, Richland, Washington.

DOE/RL-91-46. 1996. RCRA Facility Investigation/Corrective Measures Study Work Plan for the 100-NR-2 Operable Unit Hanford Site, Richland, Washington. U.S. Department of Energy, Richland Operations Office, Richland, Washington.

DOE/RL-92-76. 1994. Remedial Investigation/Feasibility Study Work Plan for the 200-UP-1 Groundwater Operable Unit, Hanford Site, Richland, Washington. U.S. Department of Energy, Richland Operations Office, Richland, Washington.

DOE/RL-96-07. 1996. 200-ZP-1 IRM Phase II and III Remedial Design Report. U.S. Department of Energy, Richland Operations Office, Richland, Washington.

DOE/RL-96-68, Rev. 2. 1998. HASQARD, Volumes 1 and 4. Hanford Analytical Services Quality Assurance Requirements Documents. U.S. Department of Energy, Richland Operations Office, Richland, Washington.

DOE/RL-96-90, Draft A. 1996. Interim Action Monitoring Plan for the 100-HR-3 and 100-KR-4 Operable Units. Prepared by CH2M HILL Hanford, Inc. for U.S. Department of Energy, Richland Operations Office, Richland, Washington.

DOE/RL-97-36, Rev. 2. 1997. 200-UP-1 Groundwater Remedial Design/Remedial Action Work Plan. U.S. Department of Energy, Richland Operations Office, Richland, Washington.

EML-618. December 2002. Semi-Annual Report of the Department of Energy, Office of Environmental Management, Quality Assessment Program. PD Greenlaw and A Berne, Environmental Measurements Laboratory, U.S. Department of Energy, New York.

EML-621. June 2003. Semi-Annual Report of the Department of Energy, Office of Environmental Management, Quality Assessment Program. PD Greenlaw and A Berne, Environmental Measurements Laboratory, U.S. Department of Energy, New York.

EPA. 1986a. Test Methods for Evaluating Solid Waste: Physical/Chemical Methods, SW-846, Third Edition. Office of Solid Waste and Emergency Response, U.S. Environmental Protection Agency, Washington, D.C. Available online at: http://www.epa.gov/epaoswer/hazwaste/test/sw846.htm

EPA. 1986b. RCRA Groundwater Monitoring Technical Enforcement Guidance Document. OSWER-9950.1, U.S. Environmental Protection Agency, Washington, D.C.

EPA 520/1-80-012. 1980. Upgrading Environmental Radiation Data. Health Physics Report HPSR-1. JE Watson, Office of Radiation Programs, U.S. Environmental Protection Agency, Washington, D.C. 
EPA/540/P-87/001, OSWER 9355.0-14. 1987. A Compendium of Superfund Field Operations Methods. U.S. Environmental Protection Agency, Washington, D.C., pp. 16-3 to 16-5.

EPA-600/4-81-004. 1981. Environmental Radioactivity Laboratory Intercomparison Studies Program: Fiscal Year 1980-81. AB Jarvis and L Siu, U.S. Environmental Protection Agency, Las Vegas, Nevada.

Keith, LH. 1991. Environmental Sampling and Analysis: A Practical Guide. Lewis Publishers, CRC Press, Inc., Boca Raton, Florida, pp. 93-115.

MAPEP-02-W10. 2003. Water Sample MAP-02-10 Performance Report. U.S. Department of Energy, Mixed Analyte Performance Evaluation Program, Radiological and Environmental Sciences Laboratory, Idaho Falls, Idaho.

Miller, JC and JN Miller. 1988. Statistics for Analytical Chemistry, Second Edition. Ellis Horwood Limited, Chichester, England, pp. 115-116.

Mitchell, WJ, RC Rhodes, and FF McElroy. 1985. "Determination of Measurement Data Quality and Establishment of Achievable Goals for Environmental Measurements." Quality Assurance for Environmental Measurements, ASTMSTP 867.

NERL-Ci-0045. 1998. National Standards for Water Proficiency Testing Studies Criteria Document. U.S. Environmental Protection Agency, Washington, D.C.

PNNL-13080. 1999. Hanford Site Groundwater: Setting, Sources and Methods. MJ Hartman (ed.), Pacific Northwest National Laboratory, Richland, Washington.

PNNL-SA-40114. 2003. The Groundwater Performance Assessment Project Quality Assurance Plan. Pacific Northwest National Laboratory, Richland, Washington.

Resource Conservation and Recovery Act. 1976. Public Law 94 580, as amended, 90 Stat 2795, 42 USC 6901 et seq. 
Table D.1. Long-Term Monitoring Full Trip Blanks Exceeding Quality Control Limits

\begin{tabular}{|c|c|c|c|c|c|}
\hline Constituent & $\begin{array}{r}\text { Number } \\
\text { Out of } \\
\text { Limits } \\
\end{array}$ & $\begin{array}{c}\text { Number of } \\
\text { Analyses }\end{array}$ & $\begin{array}{c}\text { Percent Out } \\
\text { of Limits }\end{array}$ & $\begin{array}{l}\text { Range of QC } \\
\text { Limits }^{\left({ }^{(a)}\right.}\end{array}$ & $\begin{array}{c}\text { Range of Out-of- } \\
\text { Limit Results }\end{array}$ \\
\hline \multicolumn{6}{|c|}{ General Chemical Parameters } \\
\hline $\begin{array}{l}\text { Alkalinity } \\
\text { Chemical oxygen demand } \\
\text { Total organic carbon } \\
\text { Total organic halides }\end{array}$ & $\begin{array}{l}4 \\
1 \\
1 \\
1\end{array}$ & $\begin{array}{r}47 \\
3 \\
79 \\
59\end{array}$ & $\begin{array}{r}8.51 \\
33.33 \\
1.27 \\
1.69\end{array}$ & $\begin{array}{c}2,376-8,086 \mu \mathrm{g} / \mathrm{L} \\
7,128-9,600 \mu \mathrm{g} / \mathrm{L} \\
286-1,000 \mu \mathrm{g} / \mathrm{L} \\
4.40-7.96 \mu \mathrm{g} / \mathrm{L}\end{array}$ & $\begin{array}{c}22,000-94,000 \mu \mathrm{g} / \mathrm{L} \\
8,000 \mu \mathrm{g} / \mathrm{L} \\
670 \mu \mathrm{g} / \mathrm{L} \\
6.5 \mu \mathrm{g} / \mathrm{L}\end{array}$ \\
\hline \multicolumn{6}{|c|}{ Ammonia and Anions } \\
\hline $\begin{array}{l}\text { Chloride } \\
\text { Fluoride } \\
\text { Nitrogen in nitrate } \\
\text { Sulfate }\end{array}$ & $\begin{array}{r}11 \\
6 \\
4 \\
9\end{array}$ & $\begin{array}{l}57 \\
57 \\
57 \\
57\end{array}$ & $\begin{array}{r}19.30 \\
10.53 \\
7.02 \\
15.79\end{array}$ & $\begin{array}{r}58.2-89.8 \mu \mathrm{g} / \mathrm{L} \\
61.6-80.6 \mu \mathrm{g} / \mathrm{L} \\
8.8-22.3 \mu \mathrm{g} / \mathrm{L} \\
74.8-108.1 \mu \mathrm{g} / \mathrm{L}\end{array}$ & $\begin{array}{c}59-410 \mu \mathrm{g} / \mathrm{L} \\
62-94 \mu \mathrm{g} / \mathrm{L} \\
16-25 \mu \mathrm{g} / \mathrm{L} \\
150-340 \mu \mathrm{g} / \mathrm{L}\end{array}$ \\
\hline \multicolumn{6}{|c|}{ Metals } \\
\hline $\begin{array}{l}\text { Antimony } \\
\text { Beryllium } \\
\text { Cobalt } \\
\text { Copper } \\
\text { Iron } \\
\text { Manganese } \\
\text { Nickel } \\
\text { Sodium } \\
\text { Vanadium } \\
\text { Zinc }\end{array}$ & $\begin{array}{r}2 \\
2 \\
4 \\
2 \\
1 \\
2 \\
1 \\
1 \\
11 \\
5\end{array}$ & $\begin{array}{l}47 \\
47 \\
47 \\
47 \\
47 \\
47 \\
47 \\
47 \\
47 \\
47\end{array}$ & $\begin{array}{r}4.26 \\
4.26 \\
8.51 \\
4.26 \\
2.13 \\
4.26 \\
2.13 \\
2.13 \\
23.40 \\
10.64\end{array}$ & $\begin{array}{c}45.6-89.6 \mu \mathrm{g} / \mathrm{L} \\
0.52-1.46 \mu \mathrm{g} / \mathrm{L} \\
4.4-10 \mu \mathrm{g} / \mathrm{L} \\
1.72-6.4 \mu \mathrm{g} / \mathrm{L} \\
5.6-98.8 \mu \mathrm{g} / \mathrm{L} \\
1.18-3.8 \mu \mathrm{g} / \mathrm{L} \\
20-31.6 \mu \mathrm{L} / \mathrm{L} \\
163.6-320 \mu \mathrm{g} / \mathrm{L} \\
2.8-20.8 \mu \mathrm{g} / \mathrm{L} \\
2.6-7 \mu \mathrm{g} / \mathrm{L}\end{array}$ & $\begin{array}{c}44.8-46.5 \mu \mathrm{g} / \mathrm{L} \\
0.65-1.1 \mu \mathrm{g} / \mathrm{L} \\
4.6-6.5 \mu \mathrm{g} / \mathrm{L} \\
3.5-42.3 \mu \mathrm{g} / \mathrm{L} \\
47.6 \mu \mathrm{g} / \mathrm{L} \\
0.81-2.3 \mu \mathrm{g} / \mathrm{L} \\
10.5 \mu \mathrm{g} / \mathrm{L} \\
556 \mu \mathrm{g} / \mathrm{L} \\
4.8-9.1 \mu \mathrm{g} / \mathrm{L} \\
2.8-19.7 \mu \mathrm{g} / \mathrm{L}\end{array}$ \\
\hline \multicolumn{6}{|c|}{ Volatile Organic Compounds } \\
\hline Methylene chloride & 5 & 17 & 29.41 & $0.6-1.5 \mu \mathrm{g} / \mathrm{L}$ & $1.6-6.1 \mu \mathrm{g} / \mathrm{L}$ \\
\hline \multicolumn{6}{|c|}{ Radiological Parameters } \\
\hline $\begin{array}{l}\text { Gross beta } \\
\text { Tritium } \\
\text { Uranium }\end{array}$ & $\begin{array}{r}2 \\
4 \\
17\end{array}$ & $\begin{array}{l}33 \\
44 \\
26\end{array}$ & $\begin{array}{r}6.06 \\
9.09 \\
65.38\end{array}$ & $\begin{array}{r}2.2-3.4 \mathrm{pCi} / \mathrm{L}^{(\mathrm{b})} \\
6.4-320 \mathrm{pCi} / \mathrm{L}^{(\mathrm{b})} \\
0.0007-0.046 \mu \mathrm{g} / \mathrm{L}^{(\mathrm{b})}\end{array}$ & $\begin{array}{r}3.3-5.33 \mathrm{pCi} / \mathrm{L} \\
17.1-276 \mathrm{pCi} / \mathrm{L} \\
0.0101-0.101 \mu \mathrm{g} / \mathrm{L}\end{array}$ \\
\hline
\end{tabular}

(a) Because method detection limits may change throughout the year, the limits are presented as a range. However, each result was evaluated according to the method detection limit in effect at the time the sample was analyzed.

(b) The limit for radiological analyses is determined by the sample-specific total propagated uncertainty.

$\mathrm{QC}=$ Quality control.

Table D.2. Long-Term Monitoring Field Transfer Blanks Exceeding Quality Control Limits

\begin{tabular}{|c|c|c|c|c|c|}
\hline Constituent & $\begin{array}{l}\text { Number } \\
\text { Out of } \\
\text { Limits } \\
\end{array}$ & $\begin{array}{c}\text { Number of } \\
\text { Analyses }\end{array}$ & $\begin{array}{c}\text { Percent Out } \\
\text { of Limits }\end{array}$ & $\begin{array}{c}\text { Range of QC } \\
\text { Limits }{ }^{(a)} \\
(\mu \mathrm{g} / \mathrm{L}) \\
\end{array}$ & $\begin{array}{c}\text { Range of Out-of- } \\
\text { Limit Results } \\
(\mu \mathrm{g} / \mathrm{L})\end{array}$ \\
\hline 2-butanone & 1 & 101 & 1.0 & 0.58 & 15 \\
\hline Acetone & 1 & 101 & 1.0 & 3.3 & 11 \\
\hline Carbon disulfide & 1 & 101 & 1.0 & 0.86 & 1.2 \\
\hline Carbon tetrachloride & 1 & 101 & 1.0 & 0.3 & 0.4 \\
\hline Methylene chloride & 74 & 101 & 73.3 & 1.5 & $1.6-13$ \\
\hline
\end{tabular}

(a) Because method detection limits may change throughout the year, the limits are presented as a range. However, each result was evaluated according to the method detection limit in effect at the time the sample was analyzed.

$\mathrm{QC}=$ Quality control. 
Table D.3. Long-Term Monitoring Equipment Blanks Exceeding Quality Control Limits

\begin{tabular}{|c|c|c|c|c|c|}
\hline Constituent & $\begin{array}{l}\text { Number } \\
\text { Out of } \\
\text { Limits } \\
\end{array}$ & $\begin{array}{c}\text { Number of } \\
\text { Analyses }\end{array}$ & $\begin{array}{l}\text { Percent Out } \\
\text { of Limits }\end{array}$ & $\begin{array}{l}\text { Range of } \mathrm{QC} \\
\text { Limits }^{(a)}(\mu \mathrm{g} / \mathrm{L})\end{array}$ & $\begin{array}{l}\text { Range of Out-of- } \\
\text { Limit Results }(\mu \mathrm{g} / \mathrm{L})\end{array}$ \\
\hline \multicolumn{6}{|c|}{ General Chemical Parameters } \\
\hline Total organic halides & 4 & 5 & 80.0 & $4.40-7.96$ & $10.1-12.4$ \\
\hline \multicolumn{6}{|c|}{ Ammonia and Anions } \\
\hline $\begin{array}{l}\text { Chloride } \\
\text { Nitrogen in nitrate }\end{array}$ & $\begin{array}{l}2 \\
1\end{array}$ & $\begin{array}{l}3 \\
3\end{array}$ & $\begin{array}{l}66.7 \\
33.3\end{array}$ & $\begin{array}{c}58.2 \\
8.8\end{array}$ & $\begin{array}{c}68-85 \\
41\end{array}$ \\
\hline \multicolumn{6}{|c|}{ Metals } \\
\hline $\begin{array}{l}\text { Aluminum } \\
\text { Copper } \\
\text { Manganese } \\
\text { Zinc }\end{array}$ & $\begin{array}{l}1 \\
2 \\
1 \\
2\end{array}$ & $\begin{array}{l}3 \\
3 \\
3 \\
3\end{array}$ & $\begin{array}{l}33.3 \\
66.7 \\
33.3 \\
66.7\end{array}$ & $\begin{aligned} 22.4 & -60.8 \\
5.2 & -6.2 \\
1.18 & -3 \\
2.6 & -3.6\end{aligned}$ & $\begin{array}{c}48 \\
5.9-9.8 \\
1.9 \\
8.6-10\end{array}$ \\
\hline
\end{tabular}

(a) Because method detection limits may change throughout the year, the limits are presented as a range. However, each result was evaluated according to the method detection limit in effect at the time the sample was analyzed.

$\mathrm{QC}=$ Quality control. 
Table D.4. Long-Term Monitoring Field Duplicates Exceeding Quality Control Limits

\begin{tabular}{|c|c|c|c|c|c|}
\hline Constituent & $\begin{array}{c}\text { Total } \\
\text { Number of } \\
\text { Duplicates } \\
\end{array}$ & $\begin{array}{l}\text { Number of } \\
\text { Duplicates } \\
\text { Evaluated }^{(a)} \\
\end{array}$ & $\begin{array}{l}\text { Number Out } \\
\text { of Limits } \\
\end{array}$ & $\begin{array}{c}\text { Percent Out } \\
\text { of Limits } \\
\end{array}$ & $\begin{array}{c}\text { Range of } \\
\text { Relative Percent } \\
\text { Differences }^{(\mathrm{b})} \\
\end{array}$ \\
\hline \multicolumn{6}{|c|}{ General Chemical Parameters } \\
\hline Alkalinity & 49 & 49 & 1 & 2.0 & 58.3 \\
\hline Oil and grease & 2 & 1 & 1 & 100.0 & 55.4 \\
\hline Specific conductance & 4 & 1 & 1 & 100.0 & 26.5 \\
\hline \multicolumn{6}{|c|}{ Ammonia and Anions } \\
\hline Bromide & 3 & 1 & 1 & 100.0 & 136.8 \\
\hline Chloride & 57 & 57 & 1 & 1.8 & 20.6 \\
\hline Cyanide & 7 & 1 & 1 & 100.0 & 57.4 \\
\hline Nitrogen in ammonia & 7 & 1 & 1 & 100.0 & 179.1 \\
\hline Nitrogen in nitrite & 57 & 1 & 1 & 100.0 & 20.9 \\
\hline \multicolumn{6}{|c|}{ Metals } \\
\hline Cadmium & 73 & 1 & 1 & 100.0 & 133.3 \\
\hline Copper & 59 & 1 & 1 & 100.0 & 152.0 \\
\hline Iron & 59 & 12 & 5 & 41.7 & $24.8-43.9$ \\
\hline Manganese & 59 & 17 & 2 & 11.8 & $23.7-28.0$ \\
\hline Potassium & 59 & 21 & 2 & 9.5 & $20.1-32.0$ \\
\hline Vanadium & 59 & 18 & 1 & 5.6 & 20.0 \\
\hline Zinc & 59 & 17 & 1 & 5.9 & 95.4 \\
\hline \multicolumn{6}{|c|}{ Volatile Organic Compounds } \\
\hline 1,1,1-trichloroethane & 22 & 5 & 1 & 20.0 & 34.5 \\
\hline 1,4-dichlorobenzene & 22 & 1 & 1 & 100.0 & 136.0 \\
\hline 2-butanone & 21 & 1 & 1 & 100.0 & 135.2 \\
\hline Acetone & 21 & 1 & 1 & 100.0 & 125.6 \\
\hline Methylene chloride & 22 & 2 & 2 & 100.0 & $98.2-168.0$ \\
\hline \multicolumn{6}{|c|}{ Semivolatile Organic Compounds } \\
\hline Tributyl phosphate & 1 & 1 & 1 & 100.0 & 28.6 \\
\hline \multicolumn{6}{|c|}{ Radiological Parameters } \\
\hline Carbon-14 & 1 & 1 & 1 & 100.0 & 22.0 \\
\hline Gross alpha & 33 & 5 & 2 & 40.0 & $23.6-63.1$ \\
\hline Gross beta & 37 & 18 & 4 & 27.8 & $21.5-35$ \\
\hline Iodine-129 & 17 & 3 & 1 & 33.3 & 185.1 \\
\hline Technetium-99 & 32 & 18 & 4 & 22.2 & $20.1-25.1$ \\
\hline Uranium & 30 & 30 & 3 & 10.0 & $23.9-148.4$ \\
\hline Uranium-238 & 1 & 1 & 1 & 100.0 & 23.4 \\
\hline
\end{tabular}

(a) Duplicates with both results $<5$ times the method detection limit or minimum detectable activity were excluded from the evaluation.

(b) In cases where a non-detected result was compared with a measured value, the method detection limit or minimum detectable activity was used for the non-detected concentration. 
Table D.5. Long-Term Monitoring Split Sample Results for Total Organic Carbon

\begin{tabular}{|c|c|c|c|c|}
\hline Well & $\begin{array}{l}\text { Sampling } \\
\text { Date }\end{array}$ & $\begin{array}{l}\text { Number of Split } \\
\text { Sample Pairs }\end{array}$ & $\begin{array}{l}\text { STL St. Louis Average } \\
\text { Concentration }(\mu \mathrm{g} / \mathrm{L})^{(\mathrm{a})}\end{array}$ & $\begin{array}{c}\text { Lionville Laboratory Average } \\
\text { Concentration }(\mu \mathrm{g} / \mathrm{L})^{(\mathrm{a})}\end{array}$ \\
\hline 299-E33-33 & $06 / 25 / 03$ & 4 & 1,725 & $675^{(\mathrm{b})}$ \\
\hline 299-E33-33 & $07 / 31 / 03$ & 4 & 1,275 & $515^{(b)}$ \\
\hline 299-E33-34 & $07 / 31 / 03$ & 4 & 1,600 & 648 \\
\hline 299-E33-36 & $06 / 25 / 03$ & 4 & 2,375 & $550^{(b)}$ \\
\hline 299-E33-36 & $07 / 31 / 03$ & 4 & 1,250 & $528^{(b)}$ \\
\hline $699-22-35$ & 08/13/03 & 1 & 8,700 & $500^{(b)}$ \\
\hline $699-23-34 \mathrm{~A}$ & 08/14/03 & 1 & $390^{(b)}$ & $500^{(b)}$ \\
\hline $699-24-34 \mathrm{~B}$ & $08 / 14 / 03$ & 2 & $390^{\text {(b) }}$ & $500^{(b)}$ \\
\hline $699-24-35$ & 08/13/03 & 1 & 5,100 & 690 \\
\hline
\end{tabular}

(a) In cases where total organic carbon was not detected, the method detection limit was used to calculate the average.

(b) One or more results were non-detected.

Table D.6. Interim Action Monitoring Field Blank Detections

\begin{tabular}{|c|c|c|c|c|c|}
\hline Constituent & $\begin{array}{l}\text { Number of } \\
\text { Detects }\end{array}$ & $\begin{array}{l}\text { Number of } \\
\text { Analyses }\end{array}$ & $\begin{array}{l}\text { Percent Out } \\
\text { of Limits }\end{array}$ & $\begin{array}{l}\mathrm{RDL}^{(\mathrm{b})} \\
(\mu \mathrm{g} / \mathrm{L})\end{array}$ & $\begin{array}{c}\text { Range of } \\
\text { Detected Results } \\
(\mu \mathrm{g} / \mathrm{L})\end{array}$ \\
\hline \multicolumn{6}{|c|}{ Anions } \\
\hline Chloride & 1 & 12 & 8.3 & 500 & 91 \\
\hline Fluoride & 1 & 12 & 8.3 & 500 & 120 \\
\hline Nitrate & 3 & 12 & 25.0 & 250 & $29.7-66.4$ \\
\hline Sulfate & 1 & 12 & 8.3 & 500 & 230 \\
\hline \multicolumn{6}{|c|}{ Metals } \\
\hline Aluminum & 1 & 16 & 6.3 & 200 & 40.6 \\
\hline Beryllium & 1 & 16 & 6.3 & 5 & 0.88 \\
\hline Copper & 7 & 16 & 43.8 & 25 & $0.99-25.0$ \\
\hline Iron & 2 & 16 & 12.5 & 100 & $23.0-55.4$ \\
\hline Potassium & 1 & 16 & 6.3 & 5,000 & 3,900 \\
\hline Zinc & 4 & 16 & 25.0 & 20 & $2.6-15.4$ \\
\hline \multicolumn{6}{|c|}{ Volatile Organic Compounds } \\
\hline 1,2-dichloroethane & 1 & 5 & 20.0 & 5 & 0.28 \\
\hline Carbon tetrachloride & 1 & 5 & 20.0 & 5 & 0.66 \\
\hline Methylene chloride & 3 & 5 & 60.0 & 5 & $2.9-5.3$ \\
\hline \multicolumn{6}{|c|}{ Radiological Parameters } \\
\hline Uranium & 1 & 1 & 100.0 & 1 & 0.36 \\
\hline Tritium & 1 & 9 & 11.1 & $200^{(c)}$ & $291^{(c)}$ \\
\hline
\end{tabular}

(a) Results that were $<5$ times the method detection limit and where method blank contamination was also present were excluded from the evaluation.

(b) Contractually defined required detection limit.

(c) Units for tritium are $\mathrm{pCi} / \mathrm{L}$. 
Table D.7. Interim Action Monitoring Field Duplicates Exceeding Quality Control Limits

\begin{tabular}{|c|c|c|c|c|c|}
\hline Constituent & $\begin{array}{c}\text { Total } \\
\text { Number of } \\
\text { Duplicates } \\
\end{array}$ & $\begin{array}{l}\text { Number of } \\
\text { Duplicates } \\
\text { Evaluated }^{(a)}\end{array}$ & $\begin{array}{c}\text { Number } \\
\text { Out of } \\
\text { Limits } \\
\end{array}$ & $\begin{array}{c}\text { Percent Out } \\
\text { of Limits }\end{array}$ & $\begin{array}{c}\text { Range of } \\
\text { Relative Percent } \\
\text { Differences } \\
\end{array}$ \\
\hline \multicolumn{6}{|c|}{ Ammonia and Anions } \\
\hline Fluoride & 11 & 7 & 2 & 28.6 & $27-70$ \\
\hline Nitrate & 11 & 11 & 1 & 9.0 & 50 \\
\hline \multicolumn{6}{|c|}{ Metals } \\
\hline Aluminum & 18 & 1 & 1 & 100.0 & 26 \\
\hline Vanadium & 18 & 16 & 2 & 12.5 & $39-45$ \\
\hline Zinc & 18 & 4 & 1 & 25.0 & 93 \\
\hline \multicolumn{6}{|c|}{ Radiological Parameters } \\
\hline Uranium & 5 & 4 & 2 & 50.0 & $37-54$ \\
\hline Technetium-99 & 2 & 1 & 1 & 100.0 & 25 \\
\hline Strontium-90 & 5 & 3 & 1 & 33.3 & 40 \\
\hline
\end{tabular}

(a) Duplicates with both results $<5$ times the method detection limit or minimum detectable activity were excluded from the evaluation.

Table D.8. Interim Action Monitoring Interlaboratory Splits Exceeding Quality Control Limits

\begin{tabular}{|c|c|c|c|c|c|}
\hline Constituent & $\begin{array}{c}\text { Total } \\
\text { Number } \\
\text { of Splits }\end{array}$ & $\begin{array}{c}\text { Number } \\
\text { of Splits } \\
\text { Evaluated }^{(a)}\end{array}$ & $\begin{array}{l}\text { Number } \\
\text { Out of } \\
\text { Limits }\end{array}$ & $\begin{array}{l}\text { Percent Out } \\
\text { of Limits }\end{array}$ & $\begin{array}{c}\text { Range of } \\
\text { Relative Percent } \\
\text { Differences }\end{array}$ \\
\hline \multicolumn{6}{|c|}{ Metals } \\
\hline Aluminum & 12 & 3 & 2 & 66.6 & $49-105$ \\
\hline Chromium & 12 & 10 & 2 & 20.0 & $47-82$ \\
\hline Iron & 12 & 7 & 5 & 71.4 & $22-73$ \\
\hline Manganese & 12 & 2 & 1 & 50.0 & 24 \\
\hline Potassium & 12 & 8 & 1 & 12.5 & 25 \\
\hline Vanadium & 12 & 9 & 7 & 77.8 & $23-100$ \\
\hline Zinc & 12 & 9 & 3 & 33.3 & $21-149$ \\
\hline \multicolumn{6}{|c|}{ Radiological Parameters } \\
\hline Carbon-14 & 1 & 1 & 1 & 100.0 & 29 \\
\hline Gross beta & 7 & 4 & 2 & 50.0 & $43-50$ \\
\hline \multicolumn{6}{|c|}{ General Organics } \\
\hline Diesel range organics & 1 & 1 & 1 & 100.0 & 141 \\
\hline Oil and grease & 1 & 1 & 1 & 100.0 & 156 \\
\hline \multicolumn{6}{|c|}{ Fixed Laboratory-Field Analyses } \\
\hline Hexavalent chromium & 53 & 42 & 4 & 9.5 & $22-139$ \\
\hline Sulfate & 12 & 12 & 1 & 8.3 & 27 \\
\hline
\end{tabular}

(a) Split sample pairs with both results $<5$ times the method detection limit or minimum detectable activity were excluded from the evaluation. 
Table D.9. Groundwater Performance Assessment Project Maximum Recommended Holding Times

\begin{tabular}{|c|c|c|}
\hline Method & Constituent & Holding Time \\
\hline 8010/8020/8260 (SW-846) & Volatile organics & 14 days \\
\hline $8270(\mathrm{SW}-846)$ & Semivolatile organics & $\begin{array}{l}7 \text { days before extraction; } 40 \text { days } \\
\text { after extraction }\end{array}$ \\
\hline $8081(\mathrm{SW}-846)$ & Pesticides & $\begin{array}{l}7 \text { days before extraction; } 40 \text { days } \\
\text { after extraction }\end{array}$ \\
\hline $8082(\mathrm{SW}-846)$ & Polychlorinated biphenyls & $\begin{array}{l}7 \text { days before extraction; } 40 \text { days } \\
\text { after extraction }\end{array}$ \\
\hline $8040(\mathrm{SW}-846)$ & Phenols & $\begin{array}{l}7 \text { days before extraction; } 40 \text { days } \\
\text { after extraction }\end{array}$ \\
\hline $6010(S W-846)$ & Inductively coupled plasma metals & 6 months \\
\hline 7060 (SW-846) & Arsenic & 6 months \\
\hline $7131(\mathrm{SW}-846)$ & Cadmium & 6 months \\
\hline $7191(\mathrm{SW}-846)$ & Chromium & 6 months \\
\hline $7421(\mathrm{SW}-846)$ & Lead & 6 months \\
\hline $7470(\mathrm{SW}-846)$ & Mercury & 28 days \\
\hline $7740(\mathrm{SW}-846)$ & Selenium & 6 months \\
\hline $7841(\mathrm{SW}-846)$ & Thallium & 6 months \\
\hline 9012 (SW-846) & Cyanide & 14 days \\
\hline $9020(\mathrm{SW}-846)$ & Total organic halides & 28 days \\
\hline $9060(\mathrm{SW}-846)$ & Total organic carbon & 28 days \\
\hline $9131(\mathrm{SW}-846)$ & Coliform & 1 day \\
\hline 120.1 (EPA-600/4-81-004 & Conductivity & 28 days \\
\hline 160.1 (EPA-600/4-81-004) & Total dissolved solids & 7 days \\
\hline 300.0 (EPA-600/4-81-004) & Bromide & 28 days \\
\hline 300.0 (EPA-600/4-81-004) & Chloride & 28 days \\
\hline 300.0 (EPA-600/4-81-004) & Fluoride & 28 days \\
\hline 300.0 (EPA-600/4-81-004) & Nitrate & 48 hours \\
\hline 300.0 (EPA-600/4-81-004) & Nitrite & 48 hours \\
\hline 300.0 (EPA-600/4-81-004) & Phosphate & 48 hours \\
\hline 300.0 (EPA-600/4-81-004) & Sulfate & 28 days \\
\hline 310.1 (EPA-600/4-81-004) & Alkalinity & 14 days \\
\hline 350.1 (EPA-600/4-81-004) & Ammonia & 28 days \\
\hline 410.4 (EPA-600/4-81-004) & Chemical oxygen demand & 28 days \\
\hline
\end{tabular}


Table D.10. Summary of Severn Trent-St. Louis Water Pollution (WP) Performance Evaluation Studies

\begin{tabular}{|c|c|c|c|c|c|}
\hline Accreditation I horatou & $\begin{array}{c}\text { WP-97 } \\
\text { April } 2003 \\
\text { Acceptable }\end{array}$ & $\begin{array}{c}\text { WP-99 } \\
\text { June } 2003 \\
\text { Acceptable }\end{array}$ & $\begin{array}{c}\text { WP-100 } \\
\text { July } 2003 \\
\text { Acceptable }\end{array}$ & $\begin{array}{c}\text { WP-101 } \\
\text { August } 2003 \\
\text { Acceptable }\end{array}$ & $\begin{array}{c}\text { WP-102 } \\
\text { September } 2003 \\
\text { Acceptable }\end{array}$ \\
\hline & & & & & \\
\hline Associates & $214 / 220^{(a)}$ & $7 / 7$ & $5 / 6^{(\mathrm{b})}$ & $4 / 5^{(\mathrm{b})}$ & $190 / 212^{\text {(c) }}$ \\
\hline
\end{tabular}

(a) Unacceptable results were for conductivity, $\mathrm{pH}$, orthophosphate as $\mathrm{P}$, total phosphorus as $\mathrm{P}, 1,2$-dichloroethane, and grease and oil.

(b) Unacceptable result was for total Kjeldahl nitrogen.

(c) Unacceptable results were for total Kjeldahl nitrogen, conductivity, acenaphthene, acenaphthylene, benzo(a)anthracene, benzo(b)fluoranthene, bis(2-chloroethoxy)methane, bis(2-chloroethyl)ether, 4-chlorophenyl-phenylether, 2,4-dinitrotoluene, 2,6-dinitrotoluene, bis(2-ethylhexyl)phthalate, fluoranthene, fluorene, hexachlorobenzene, hexachlorobutadiene, hexachlorocyclopentadiene, isophorone, $\mathrm{N}$-nitrosodimethylamine, $\mathrm{N}$-nitroso-di-n-propylamine, phenanthrene, and 1,2,4-trichlorobenzene.

Table D.11. Summary of Lionville Laboratory Water Pollution (WP) Performance Evaluation Studies

\begin{tabular}{lcc} 
& $\begin{array}{c}\text { WP-92 } \\
\text { November 2002 } \\
\text { Acceptable } \\
\text { Accreditation Laboratory }\end{array}$ & $\begin{array}{c}\text { WP-96 } \\
\text { March 2003 } \\
\text { Acceptable }\end{array}$ \\
\cline { 2 - 2 } $\begin{array}{l}\text { Environmental Resource } \\
\text { Associates }\end{array}$ & $1 / 1^{\text {(a) }}$ & Results/Total \\
\hline
\end{tabular}

(a) Makeup for WP-90.

(b) Unacceptable results were for sodium and dicamba. 
Table D.12. Summary of Severn Trent Interlaboratory Performance, Fiscal Year 2003

\begin{tabular}{cc} 
Radionuclides & $\begin{array}{c}\text { Number of Results } \\
\text { Reported for Each }\end{array}$ \\
\hline DOE Quality Assessment Program (QAP57, 58) \\
Environmental Measurements Laboratory
\end{tabular}

Americium-241, cesium-134, cesium-137,

\section{DOE Mixed Analyte Performance Evaluation Program (MAPEP-02-W10)} Radiological and Environmental Sciences Laboratory

Americium-241, cesium-134, cesium-137,

1 $1^{(\mathrm{c})}$ cobalt-57, cobalt-60, iron-55, manganese-54, nickel-63, plutonium-238, plutonium-239/240, strontium-90, technetium-99, uranium-234/233, uranium-238, zinc-65

\section{ERA InterLaB RadCheM Proficiency Testing Program (RAD 51, 52) Environmental Resource Associates}

Gross alpha, gross beta, radium-226, radium-228, uranium

Cesium-134, cesium-137, cobalt-60, 3

(a) Control limits from EML-618 and EML-621.

(b) One result each for cesium-134, plutonium-238, plutonium-239, and strontium-90 was acceptable but outside warning limits.

(c) Preliminary results from STL Richland.

(d) Control limits from National Standards for Water Proficiency Testing Studies Criteria Document.

(e) These constituents were analyzed twice in one study.

Table D.13. Summary of Eberline Services Interlaboratory Performance, Fiscal Year 2003

\begin{tabular}{|c|c|c|}
\hline Radionuclides & $\begin{array}{l}\text { Number of Results } \\
\text { Reported for Each } \\
\end{array}$ & $\begin{array}{l}\text { Number Within } \\
\text { Acceptable Control Limits } \\
\end{array}$ \\
\hline \multicolumn{3}{|c|}{$\begin{array}{l}\text { DOE Quality Assessment Program (QAP57, 58) } \\
\text { Environmental Measurements Laboratory }\end{array}$} \\
\hline $\begin{array}{l}\text { Americium-241, cesium-134, cesium-137, } \\
\text { cobalt-60, gross beta, plutonium-238, } \\
\text { plutonium-239, strontium-90, tritium, } \\
\text { uranium-234, uranium-238, uranium }\end{array}$ & 2 & $2^{(a, b)}$ \\
\hline Gross alpha & 2 & $1^{(\mathrm{a}, \mathrm{b})}$ \\
\hline
\end{tabular}

(a) Control limits from EML-618 and EML-621.

(b) One result each for gross alpha, plutonium-238, and plutonium-239 was acceptable but outside warning limits. 
Table D.14. Summary of Severn Trent Laboratories Double-Blind Spike Determinations

\begin{tabular}{|c|c|c|c|c|c|}
\hline Constituent & Laboratory & $\begin{array}{l}\text { Sample } \\
\text { Frequency } \\
\end{array}$ & $\begin{array}{l}\text { Number of } \\
\text { Results } \\
\text { Reported }^{(a)} \\
\end{array}$ & $\begin{array}{l}\text { Number of } \\
\text { Results Outside } \\
\text { QC Limits } \\
\end{array}$ & $\begin{array}{c}\text { Control } \\
\text { Limits }^{(c)}(\%) \\
\end{array}$ \\
\hline \multicolumn{6}{|c|}{ General Chemical Parameters } \\
\hline Specific conductance & St. Louis & Quarterly & 12 & 0 & \pm 25 \\
\hline $\begin{array}{l}\text { Total organic carbon } \\
\text { (potassium hydrogen phthalate } \\
\text { spike) }\end{array}$ & St. Louis & Quarterly & 16 & 2 & \pm 25 \\
\hline $\begin{array}{l}\text { Total organic halides } \\
\text { (2,4,6-trichlorophenol spike) }\end{array}$ & St. Louis & Quarterly & 14 & 7 & \pm 25 \\
\hline $\begin{array}{l}\text { Total organic halides (carbon } \\
\text { tetrachloride, chloroform, and } \\
\text { trichloroethene spike) }\end{array}$ & St. Louis & Quarterly & 13 & 7 & \pm 25 \\
\hline \multicolumn{6}{|l|}{ (x) } \\
\hline Cyanide & St. Louis & Quarterly & 13 & 2 & \pm 25 \\
\hline Fluoride & St. Louis & Quarterly & 12 & 0 & \pm 25 \\
\hline Nitrogen in nitrate & St. Louis & Quarterly & 12 & 0 & \pm 25 \\
\hline \multicolumn{6}{|c|}{ Metals } \\
\hline Aluminum & St. Louis & Annually & 4 & 0 & \pm 25 \\
\hline Arsenic & St. Louis & Annually & 2 & 0 & \pm 25 \\
\hline Barium & St. Louis & Annually & 4 & 0 & \pm 25 \\
\hline Beryllium & St. Louis & Annually & 4 & 0 & \pm 25 \\
\hline Boron & St. Louis & Annually & 2 & 0 & \pm 25 \\
\hline Cadmium & St. Louis & Annually & 4 & 2 & \pm 25 \\
\hline Calcium & St. Louis & Annually & 4 & 0 & \pm 25 \\
\hline Chromium & St. Louis & Semiannually & 7 & 0 & \pm 20 \\
\hline Cobalt & St. Louis & Annually & 4 & 0 & \pm 25 \\
\hline Copper & St. Louis & Annually & 4 & 0 & \pm 25 \\
\hline Iron & St. Louis & Annually & 4 & 0 & \pm 25 \\
\hline Lead & St. Louis & Annually & 2 & 0 & \pm 25 \\
\hline Magnesium & St. Louis & Annually & 2 & 0 & \pm 25 \\
\hline Manganese & St. Louis & Annually & 4 & 0 & \pm 25 \\
\hline Nickel & St. Louis & Annually & 4 & 0 & \pm 25 \\
\hline Potassium & St. Louis & Annually & 2 & 0 & \pm 25 \\
\hline Selenium & St. Louis & Annually & 2 & 0 & \pm 25 \\
\hline Silicon & St. Louis & Annually & 2 & 0 & \pm 25 \\
\hline Silver & St. Louis & Annually & 4 & 2 & \pm 25 \\
\hline Sodium & St. Louis & Annually & 4 & 0 & \pm 25 \\
\hline Strontium & St. Louis & Annually & 4 & 2 & \pm 25 \\
\hline Thallium & St. Louis & Annually & 2 & 0 & \pm 25 \\
\hline Titanium & St. Louis & Annually & 2 & 0 & \pm 25 \\
\hline Vanadium & St. Louis & Annually & 4 & 0 & \pm 25 \\
\hline Zinc & St. Louis & Annually & 4 & 0 & \pm 25 \\
\hline \multicolumn{6}{|c|}{ Volatile Organic Compounds } \\
\hline Carbon tetrachloride & St. Louis & Quarterly & 12 & 0 & \pm 25 \\
\hline Chloroform & St. Louis & Quarterly & 12 & 1 & \pm 25 \\
\hline Trichloroethene & St. Louis & Quarterly & 12 & 2 & \pm 25 \\
\hline \multicolumn{6}{|c|}{ Radiological Parameters } \\
\hline $\begin{array}{l}\text { Gross alpha (plutonium-239 } \\
\text { spike) }\end{array}$ & Richland & Quarterly & 12 & 2 & \pm 25 \\
\hline Gross beta (strontium-90 spike) & Richland & Quarterly & 12 & 0 & \pm 25 \\
\hline Cesium-137 & Richland & Annually & 3 & 0 & \pm 30 \\
\hline
\end{tabular}


Table D.14. (contd)

\begin{tabular}{|c|c|c|c|c|c|}
\hline Constituent & Laboratory & $\begin{array}{c}\text { Sample } \\
\text { Frequency }\end{array}$ & $\begin{array}{l}\text { Number of } \\
\text { Results } \\
\text { Reported }^{(a)} \\
\end{array}$ & $\begin{array}{l}\text { Number of } \\
\text { Results Outside } \\
\text { QC Limits } \\
\end{array}$ & $\begin{array}{c}\text { Control } \\
\text { Limits }^{(\mathrm{c})}(\%) \\
\end{array}$ \\
\hline \multicolumn{6}{|c|}{ Radiological Parameters (contd) } \\
\hline Cobalt -60 & Richland & Annually & 3 & 0 & \pm 30 \\
\hline Iodine-129 & Richland & Semiannually & 6 & 0 & \pm 30 \\
\hline Plutonium-239 & Richland & Quarterly & 12 & 1 & \pm 30 \\
\hline Strontium-90 & Richland & Semiannually & 6 & 0 & \pm 30 \\
\hline Technetium-99 & Richland & Quarterly & 12 & 0 & \pm 30 \\
\hline Tritium & Richland & Semiannually & 6 & 3 & \pm 30 \\
\hline Uranium-238 & Richland & Quarterly & 12 & 0 & \pm 30 \\
\hline
\end{tabular}

(a) Blind standards were generally submitted in duplicate, triplicate, or quadruplicate.

(b) Quality control limits are given in the Groundwater Performance Assessment Project's Quality Assurance plan.

(c) Each result must be within the specified percentage of the known value to be acceptable.

$\mathrm{QC}=$ Quality control.

Table D.15. Summary of Lionville Laboratory, Inc. and Eberline Services Double-Blind Spike Determinations

\begin{tabular}{|c|c|c|c|c|c|}
\hline Constituent & Laboratory & $\begin{array}{l}\text { Sample } \\
\text { Frequency }\end{array}$ & $\begin{array}{l}\text { Number of } \\
\text { Results } \\
\text { Reported }^{(a)}\end{array}$ & $\begin{array}{c}\text { Number of Results } \\
\text { Outside QC } \\
\text { Limits }^{(\mathrm{b})}\end{array}$ & $\begin{array}{c}\text { Control } \\
\text { Limits }^{(c)}(\%)\end{array}$ \\
\hline \multicolumn{6}{|c|}{ General Chemical Parameters } \\
\hline $\begin{array}{l}\text { Total organic carbon (potassium } \\
\text { hydrogen phthalate spike) }\end{array}$ & Lionville & Quarterly & 14 & 1 & \pm 25 \\
\hline \multicolumn{6}{|c|}{ Ammonia and Anions } \\
\hline Cyanide & Lionville & Annually & 3 & 3 & \pm 25 \\
\hline \multicolumn{6}{|c|}{ Radiological Parameters } \\
\hline Gross beta (strontium-90 spike) & Eberline & Quarterly & 12 & 3 & \pm 25 \\
\hline
\end{tabular}

(a) Blind standards were submitted in triplicate or quadruplicate.

(b) Quality control limits are given in the Groundwater Performance Assessment Project's Quality Assurance plan.

(c) Each result must be within the specified percentage of the known value to be acceptable.

$\mathrm{QC}=$ Quality control.

Table D.16. Percentage of Out-of-Limit Quality Control Results by Category, Severn Trent Laboratories (Richland and St. Louis)

\begin{tabular}{|c|c|c|c|c|c|c|c|}
\hline $\begin{array}{c}\text { Quality Control } \\
\text { Parameter }\end{array}$ & $\begin{array}{c}\text { General } \\
\text { Chemistry } \\
\text { Parameters }\end{array}$ & $\begin{array}{c}\text { Ammonia } \\
\text { and Anions }\end{array}$ & Metals & $\begin{array}{l}\text { Volatile Organic } \\
\text { Compounds }\end{array}$ & $\begin{array}{c}\text { Semivolatile } \\
\text { Organic } \\
\text { Compounds }\end{array}$ & $\begin{array}{c}\text { Radiological } \\
\text { Parameters } \\
\end{array}$ & Total \\
\hline Method blanks & 1.5 & 8.1 & 3.5 & 1.0 & 0.001 & 1.8 & 2.3 \\
\hline $\begin{array}{l}\text { Laboratory control } \\
\text { samples }\end{array}$ & 0.3 & 0 & 0 & 1.6 & 2.5 & 0.4 & 0.9 \\
\hline Matrix spikes & 9.0 & 8.9 & 0.4 & 2.2 & 4.8 & 2.7 & 2.4 \\
\hline Matrix duplicates & 1.3 & 0.2 & 0 & 2.7 & 9.6 & 1.7 & 2.4 \\
\hline Surrogates & .. & .. & .. & 3.6 & 4.5 & .. & 3.8 \\
\hline
\end{tabular}


Table D.17. Method Blank Results, Severn Trent Laboratories (Richland and St. Louis)

\begin{tabular}{|c|c|c|c|}
\hline Constituent & $\begin{array}{l}\text { Percent Out } \\
\text { of Limit }^{(a)}\end{array}$ & $\begin{array}{c}\text { Number of } \\
\text { Analyses }\end{array}$ & $\begin{array}{l}\text { Concentration Range } \\
\text { of Out-of-Limit Results }\end{array}$ \\
\hline \multicolumn{4}{|c|}{ General Chemical Parameters } \\
\hline $\begin{array}{l}\text { Total general chemical parameters } \\
\text { Conductivity }\end{array}$ & $\begin{array}{r}1.5 \\
45.5\end{array}$ & $\begin{array}{r}328 \\
11\end{array}$ & $0.43-0.58 \mu \mathrm{S} / \mathrm{cm}$ \\
\hline \multicolumn{4}{|c|}{ Ammonia and Anions } \\
\hline $\begin{array}{l}\text { Total ammonia and anions } \\
\text { Bromide } \\
\text { Chloride } \\
\text { Fluoride } \\
\text { Nitrogen in nitrate } \\
\text { Sulfate }\end{array}$ & $\begin{array}{r}8.1 \\
4.5 \\
17.9 \\
5.8 \\
3.7 \\
15.8\end{array}$ & $\begin{array}{r}1,030 \\
22 \\
190 \\
190 \\
190 \\
190\end{array}$ & $\begin{array}{c}0.087 \mathrm{mg} / \mathrm{L} \\
0.059-0.2 \mathrm{mg} / \mathrm{L} \\
0.064-0.13 \mathrm{mg} / \mathrm{L} \\
0.01-0.014 \mathrm{mg} / \mathrm{L} \\
0.18-0.36 \mathrm{mg} / \mathrm{L}\end{array}$ \\
\hline \multicolumn{4}{|c|}{ Metals } \\
\hline $\begin{array}{l}\text { Total metals } \\
\text { Aluminum } \\
\text { Beryllium } \\
\text { Chromium } \\
\text { Copper } \\
\text { Iron } \\
\text { Lead } \\
\text { Magnesium } \\
\text { Manganese } \\
\text { Potassium } \\
\text { Silver } \\
\text { Sodium } \\
\text { Strontium } \\
\text { Tin } \\
\text { Vanadium } \\
\text { Zinc }\end{array}$ & $\begin{array}{r}3.5 \\
8.7 \\
8.4 \\
1.8 \\
3.9 \\
11.7 \\
7.4 \\
1.9 \\
5.8 \\
1.0 \\
0.9 \\
4.8 \\
1.0 \\
50.0 \\
9.6 \\
6.9\end{array}$ & $\begin{array}{r}2,099 \\
103 \\
107 \\
110 \\
102 \\
103 \\
27 \\
103 \\
104 \\
103 \\
106 \\
104 \\
103 \\
2 \\
104 \\
102\end{array}$ & $\begin{array}{c}23.8-131 \mu \mathrm{g} / \mathrm{L} \\
0.0013-1.5 \mu \mathrm{g} / \mathrm{L} \\
2.6-3.1 \mu \mathrm{g} / \mathrm{L} \\
1.8-4.6 \mu \mathrm{L} / \mathrm{L} \\
8.4-112 \mu \mathrm{g} / \mathrm{L} \\
0.93-2.4 \mu \mathrm{g} / \mathrm{L} \\
163-350 \mu \mathrm{g} / \mathrm{L} \\
1.4-2.5 \mu \mathrm{g} / \mathrm{L} \\
2,710 \mu \mathrm{L} / \mathrm{L} \\
7.6 \mu \mathrm{L} / \mathrm{L} \\
204-379 \mu \mathrm{g} / \mathrm{L} \\
0.086 \mu \mathrm{g} / \mathrm{L} \\
7.8 \mu \mathrm{g} / \mathrm{L} \\
2.9-16.8 \mu \mathrm{g} / \mathrm{L} \\
4-17.3 \mu \mathrm{g} / \mathrm{L}\end{array}$ \\
\hline \multicolumn{4}{|c|}{ Volatile Organic Compounds } \\
\hline $\begin{array}{l}\text { Total volatile organic compounds } \\
\text { 2-butanone } \\
\text { 4-methyl-2-pentanone } \\
\text { Acetone } \\
\text { Methylene chloride }{ }^{(b)}\end{array}$ & $\begin{array}{r}1.0 \\
1.7 \\
1.7 \\
7.8 \\
14.5\end{array}$ & $\begin{array}{r}3,008 \\
115 \\
115 \\
115 \\
117\end{array}$ & $\begin{array}{r}5.4-6.1 \mu \mathrm{g} / \mathrm{L} \\
0.77-2.3 \mu \mathrm{g} / \mathrm{L} \\
3.6-7.0 \mu \mathrm{g} / \mathrm{L} \\
1.6-4.5 \mu \mathrm{g} / \mathrm{L}\end{array}$ \\
\hline \multicolumn{4}{|c|}{ Semivolatile Organic Compounds } \\
\hline $\begin{array}{l}\text { Total semivolatile organic compounds } \\
\text { 2,3,4,6-tetrachlorophenol }\end{array}$ & $\begin{array}{l}0.001 \\
2.6\end{array}$ & $\begin{array}{r}1,707 \\
39\end{array}$ & $8.4 \mu \mathrm{g} / \mathrm{L}$ \\
\hline \multicolumn{4}{|c|}{ Radiological Parameters } \\
\hline $\begin{array}{l}\text { Total radiological parameters } \\
\text { Carbon-14 } \\
\text { Gross alpha } \\
\text { Gross beta } \\
\text { Strontium-90 } \\
\text { Tritium } \\
\text { Uranium }\end{array}$ & $\begin{array}{r}1.8 \\
14.3 \\
1.4 \\
1.4 \\
3.8 \\
2.4 \\
15.5\end{array}$ & $\begin{array}{r}1,138 \\
7 \\
69 \\
71 \\
53 \\
164 \\
71\end{array}$ & $\begin{array}{c}36.6 \mathrm{pCi} / \mathrm{L} \\
12.9 \mathrm{pCi} / \mathrm{L} \\
3.98 \mathrm{pCi} / \mathrm{L} \\
1.17-1.25 \mathrm{pCi} / \mathrm{L} \\
17.4-29.2 \mathrm{pCi} / \mathrm{L} \\
0.0238-0.217 \mathrm{pCi} / \mathrm{L}\end{array}$ \\
\hline
\end{tabular}

(a) Quality control limits are twice the method detection limit.

(b) Quality control limits are five times the method detection limit. 
Table D.18. Laboratory Control Samples, Severn Trent Laboratories (Richland and St. Louis)

Constituent

Total general chemical parameters

Total organic carbon

Total ammonia and anions

Total metals

Total volatile organic compounds

1,1,1-trichloroethane

1,1,2,2-tetrachloroethane

1,1,2-trichloroethane

1,1-dichloroethane

1,2-dichloroethane

2-butanone

4-methyl-2-pentanone

Acetone

Carbon disulfide

Carbon tetrachloride

Chloroform

Methylene chloride

Toluene

TPH gasoline

Vinyl chloride

Total semivolatile organic compounds

2,4,5-trichlorophenol

2,4,6-trichlorophenol

2,4-dichlorophenol

2,4-dimethylphenol

2,4-dinitrophenol

2,6-dichlorophenol

2-chlorophenol

2-methylphenol

2-nitrophenol

2-sec-Butyl-4,6-dinitrophenol

3-+4-methylphenol

4,6-dinitro-2-methylphenol

4-chloro-3-methylphenol

4-nitrophenol

Aroclor-1016

Chrysene

delta-BHC

Oil and grease

Pentachlorophenol

Phenol

Total radiological parameters

Technetium-99

Uranium-238
Percent Out of Limit

\section{General Chemical Parameters}

1.1

330

Ammonia and Anions

0.0

1,030

Metals

0.0

1,992

Volatile Organic Compounds

1.6
0.9
33.3

2,217

115

33.3

0.9

0.9

1.7

3.5

2.6

7.0

0.9

0.8

0.9

1.7

5.1

12.5

0.9

\section{Semivolatile Organic Compounds}

$\begin{array}{rr}2.5 & 1,162 \\ 2.5 & 40\end{array}$

$2.5 \quad 40$

$2.4 \quad 41$

$2.5 \quad 40$

$10.0 \quad 40$

$3.2 \quad 31$

$2.5-40$

$2.4 \quad 41$

$2.4 \quad 41$

$2.9-35$

$3.2-31$

$10.0 \quad 40$

$2.5 \quad 40$

$10.0 \quad 40$

$25.0 \quad 4$

$11.1 \quad 9$

$50.0-2$

$9.1-11$

$2.4+41$

$2.4 \quad 41$

Radiological Parameters

\section{4}


Table D.19. Matrix Spikes and Matrix Spike Duplicates, Severn Trent Laboratories (Richland and St. Louis)

$$
\text { Constituent }
$$

Total general chemical parameters

Total organic carbon

Total organic halides

Total ammonia and anions

Chloride

Cyanide

Fluoride

Nitrogen in nitrate

Nitrogen in nitrite

Phosphate

Sulfate

Total metals

Antimony

Cadmium

Chromium

Iron

Nickel

Silver

Strontium

Tin

Zinc

Total volatile organic compounds

1,1,1-trichloroethane

1,2-dichloroethane

4-methyl-2-pentanone

Benzene

Carbon tetrachloride

Chloroform

Chloromethane

Ethylbenzene

Methylene chloride

TPH gasoline

Total semivolatile organic compounds

2-(2,4-dichlorophenoxy)propionic acid

2,2-dichloropropionic acid

2,4,5-T

2,4,5-TP (silvex)

2,4,5-trichlorophenol

2,4,6-trichlorophenol

2,4-D

2,4-dichlorophenol

2,4-dimethylphenol

2,4-dinitrophenol

2,6-dichlorophenol

2-chlorophenol

2-methylphenol

2-nitrophenol

2-sec-Butyl-4,6-dinitrophenol

4-(2,4-dichlorophenoxy)butyric acid

4,6-dinitro-2-methylphenol

4-chloro-3-methylphenol

4-methylphenol

4-nitrophenol
Percent Out of Limit

\section{General Chemical Parameters}

9.0

11.1

6.1

99

66

Ammonia and Anions

$$
8.9
$$

3.2

25.9

14.3

19.0

3.2

16.7

1.5

Number of Analyses

(1)

Metals

$\begin{array}{rr}0.4 & 3,618 \\ 1.1 & 178 \\ 1.6 & 190 \\ 1.1 & 186 \\ 0.6 & 178 \\ 0.6 & 178 \\ 1.1 & 178 \\ 1.1 & 178 \\ 33.3 & 6 \\ 0.6 & 178\end{array}$

\section{Volatile Organic Compounds}

$\begin{array}{rr}2.2 & 2,176 \\ 0.9 & 110 \\ 2.7 & 112 \\ 3.6 & 110 \\ 0.9 & 114 \\ 20.5 & 112 \\ 4.5 & 112 \\ 33.3 & 6 \\ 0.9 & 110 \\ 5.5 & 110 \\ 7.7 & 26\end{array}$

\section{Semivolatile Organic Compounds}

$\begin{array}{rr}4.8 & 1,672 \\ 50.0 & 4 \\ 25.0 & 4 \\ 50.0 & 4 \\ 50.0 & 4 \\ 8.8 & 57 \\ 5.3 & 57 \\ 50.0 & 4 \\ 3.4 & 59 \\ 5.3 & 57 \\ 12.3 & 57 \\ 2.3 & 44 \\ 1.8 & 57 \\ 3.4 & 59 \\ 6.8 & 59 \\ 10.4 & 48 \\ 50.0 & 4 \\ 14.0 & 57 \\ 1.8 & 57 \\ 25.0 & 8 \\ 8.8 & 57\end{array}$


Table D.19. (contd)

Constituent

Aroclor-1016

Chrysene

Dibenz[a,h]anthracene

Hexachlorocyclopentadiene

Hexachloroethane

Pentachlorophenol

Phenol

TPH diesel

Total radiological parameters

Technetium-99
Percent Out of Limit

Semivolatile Organic Compounds (contd)

$$
25.0
$$

15.4

7.7

15.4

15.4

13.6

1.7

12.5

Radiological Parameters

2.7

4.9
Number of Analyses

\section{8}

13

13

13

13

59

59

24

148

81 
Table D.20. Matrix Duplicates, Severn Trent Laboratories (Richland and St. Louis)

Constituent

Total general chemical parameters

Total organic carbon

Total organic halides

Total ammonia and anions

Nitrogen in ammonia

Nitrogen in nitrate

Sulfate

Total metals

Total volatile organic compounds

1,1,1-trichloroethane

1,1-dichloroethene

2-butanone

4-methyl-2-pentanone

Acetone

Bromomethane

Carbon disulfide

Carbon tetrachloride

Methylene chloride

Tetrachloroethene

TPH gasoline

Trichloroethene

Vinyl chloride

Total semivolatile organic compounds

2-(2,4-dichlorophenoxy)propionic acid

2,2-dichloropropionic acid

2,3,4,6-tetrachlorophenol

2,4,5-T

2,4,5-TP (silvex)

2,4,5-trichlorophenol

2,4,6-trichlorophenol

2,4-D

2,4-dichlorophenol

2,4-dimethylphenol

2,4-dinitrophenol

2,6-dichlorophenol

2-chlorophenol

2-methylphenol

2-nitrophenol

2-sec-Butyl-4,6-dinitrophenol

3-+4-methylphenol

4-(2,4-dichlorophenoxy)butyric acid

4,6-dinitro-2-methylphenol

4-chloro-3-methylphenol

4-chloroaniline

4-methylphenol

4-nitrophenol

Aroclor-1016

Aroclor-1260
Percent Out of Limit

\section{General Chemical Parameters}

1.3

2.3

2.9

452

176

68

\section{Ammonia and Anions}

0.2

2.6

0.4

0.4

1,405

39

252

256

Metals

0.0

1,809

Volatile Organic Compounds

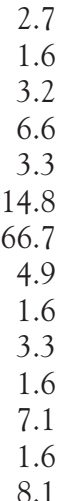

1,201

1.6

3.2

6.6

3.3

14.8

66.7

4.9

1.6

3.3

1.6

7.1

1.6

8.1

31

61

61

61

3

61

63

61

62

14

62

Semivolatile Organic Compounds

9.6
25.0
50.0
12.1
25.0
25.0
12.2
12.2
25.0
14.3
4.9
17.1
6.1
9.8
14.3
14.3
8.1
12.1
25.0
4.9
9.8
12.5
16.7
26.8
25.0
25.0

1,148

4

4

33

4

4

41

41

4

42

41

41

33

41

42

42

37

33

4

41

41

8

6

41

4 
Table D.20. (contd)

\section{Constituent}

Percent Out of Limit

Semivolatile Organic Compounds (contd)

Benzo(ghi)perylene

Dibenz[a,h]anthracene

12.5

37.5

25.0

12.5

Indeno(1,2,3-cd)pyrene

Oil and grease

Pentachlorophenol

Phenol

TPH diesel
9.5

16.7

28.6

7.1
Number of Analyses

\author{
8
}

8

4

8

21

42

42

14

Radiological Parameters

Total radiological parameters 1.7 60.0

14.3

\section{0}

2.9

5.1

4.9

1.2

4.5
1,038

5

7

50

69

59

82

83

66

Table D.21. Summary of Issue Resolution Forms Received from Severn Trent Laboratories (Richland and St. Louis) for Fiscal Year 2003

Number of Occurrences

\begin{tabular}{lccc}
\multicolumn{1}{c}{ Issue Category } & Prior to Receipt at the Laboratory & After Receipt at the Laboratory \\
Hold time missed & 241 & 53 \\
Broken bottles & 3 & 3 & 43 \\
Missing samples & 60 & 6 & 99 \\
Temperature deviation & 21 & 17 \\
pH variance & & 38 \\
Bottle size/type (insufficient volume) & & \\
Chain of custody forms incomplete & & \\
Laboratory QC out of limits & & \\
Analytical preparation deviations & & \\
Method failures/discontinued analyses & &
\end{tabular}


Table D.22. Results of Laboratory Assessments

\begin{tabular}{|c|c|c|c|c|}
\hline Laboratory & Audit Team & Findings & Observations & Summary of Results \\
\hline STL-St. Louis, MO & EMCAP & 10 & 8 & $\begin{array}{l}\text { Findings related to insufficient documentation for training, } \\
\text { internal chain of custody not maintained for fractions, lack of } \\
\text { procedures or incomplete procedures, lack of control charts } \\
\text { for method QC, and lack of initial verification of standards. } \\
\text { Observations related to inconsistent general laboratory } \\
\text { practices. }\end{array}$ \\
\hline $\begin{array}{l}\text { Eberline Services- } \\
\text { Richmond, CA }\end{array}$ & EMCAP & 0 & 4 & $\begin{array}{l}\text { Observations related to QA Management systems and general } \\
\text { laboratory practices (i.e., training documentation, expired } \\
\text { standards, incomplete documentation). }\end{array}$ \\
\hline $\begin{array}{l}\text { Lionville Laboratory, } \\
\text { Inc.-Lionville, PA }\end{array}$ & EMCAP & 3 & 11 & $\begin{array}{l}\text { Findings related to use of expired standards, unclear documen- } \\
\text { tation of sample disposition, and receiving and inspecting of } \\
\text { samples outside the fume hood. Observations were related to } \\
\text { incomplete procedures, lack of procedures, and inconsistent } \\
\text { general practices within the laboratory. }\end{array}$ \\
\hline STL-Richland, WA & EMCAP & 3 & 8 & $\begin{array}{l}\text { Findings related to lateness in the annual review of Radiation } \\
\text { Radiation Protection Program, incomplete site-specific infor- } \\
\text { mation in the Waste Management Plan, and mis-match in the } \\
\text { STL acceptance criteria for standard verification to the } \\
\text { requirements of the Basic Order Agreement. Observations } \\
\text { related to incomplete procedures, missing reviews of logbooks, } \\
\text { and inconsistent general practices within the laboratory. }\end{array}$ \\
\hline STL-St. Louis, MO & $\begin{array}{l}\text { PNNL/BHI } \\
\text { Joint Team }\end{array}$ & 7 & 6 & $\begin{array}{l}\text { Findings related to inadequate compliance to STL procedures, } \\
\text { inadequate training of personnel, inadequate standard certi- } \\
\text { fication, insufficient SOPs and document control, inadequate } \\
\text { implementation of the HASQARD requirements in the STL } \\
\text { QA Program. Observations related mostly to inconsistent } \\
\text { general laboratory practices. }\end{array}$ \\
\hline
\end{tabular}

\begin{tabular}{ll}
\hline BHI & $=$ Bechtel Hanford, Inc. \\
EMCAP & $=$ Environmental Management Consolidated Audit Program. \\
HASQARD & $=$ Hanford Analytical Services Quality Requirements Document. \\
PNNL & $=$ Pacific Northwest National Laboratory. \\
QA & $=$ Quality assurance. \\
QC & $=$ Quality control. \\
SOP & $=$ Standard operating procedure. \\
STL & $=$ Severn Trent Inc.
\end{tabular}


Table D.23. Summary of Analytical Laboratory Detection/Quantitation Limits Determined from Field Blanks Data, Severn Trent Laboratories (Richland and St. Louis)

\begin{tabular}{|c|c|c|c|c|c|}
\hline Period $^{(a)}$ & $\begin{array}{c}\text { Number of } \\
\text { Samples }\end{array}$ & Mean & $\begin{array}{c}\text { Standard } \\
\text { Deviation }\end{array}$ & $\begin{array}{c}\text { Limit of } \\
\text { Detection }\end{array}$ & $\begin{array}{c}\text { Limit of } \\
\text { Quantitation }\end{array}$ \\
\hline \multicolumn{6}{|c|}{ Constituent: Total Organic Carbon $(\mu \mathrm{g} / \mathrm{L})$} \\
\hline $\begin{array}{l}12 / 14 / 01-11 / 15 / 02 \\
03 / 12 / 02-03 / 07 / 03 \\
05 / 17 / 02-06 / 24 / 03 \\
10 / 04 / 02-09 / 29 / 03 \\
\text { Summary }\end{array}$ & $\begin{array}{l}50^{(b)} \\
59 \\
64 \\
73 \\
73\end{array}$ & $\begin{array}{r}150.38 \\
90.37 \\
64.06 \\
66.10 \\
66.10\end{array}$ & $\begin{array}{l}122.49 \\
128.94 \\
128.06 \\
135.88 \\
135.88\end{array}$ & $\begin{array}{l}370^{(c)} \\
390 \\
380 \\
410 \\
410\end{array}$ & $\begin{array}{l}1,220^{(c)} \\
1,290 \\
1,280 \\
1,360 \\
1,360\end{array}$ \\
\hline \multicolumn{6}{|c|}{ Constituent: Total Organic Halides ( $\mu \mathrm{g} / \mathrm{L}$ ) } \\
\hline $\begin{array}{l}12 / 14 / 01-11 / 15 / 02 \\
03 / 12 / 02-03 / 04 / 03 \\
06 / 06 / 02-06 / 25 / 03 \\
10 / 04 / 02-09 / 29 / 03 \\
\text { Summary }\end{array}$ & $\begin{array}{l}48 \\
52 \\
55 \\
59 \\
59\end{array}$ & $\begin{array}{l}0.61 \\
0.57 \\
0.56 \\
0.62 \\
0.62\end{array}$ & $\begin{array}{l}1.12 \\
1.36 \\
1.36 \\
1.49 \\
1.49\end{array}$ & $\begin{array}{l}3.3^{(c)} \\
4.1 \\
4.1 \\
4.5 \\
4.5\end{array}$ & $\begin{array}{l}11.2^{(c)} \\
13.6 \\
13.6 \\
14.9 \\
14.9\end{array}$ \\
\hline \multicolumn{6}{|c|}{ Constituent: Cesium-137 (pCi/L) } \\
\hline $\begin{array}{l}10 / 18 / 02-12 / 13 / 02 \\
01 / 07 / 03-03 / 24 / 03 \\
05 / 14 / 03-09 / 29 / 03 \\
\text { Summary }\end{array}$ & $\begin{array}{r}4 \\
8 \\
3 \\
15\end{array}$ & $\begin{array}{r}-0.79 \\
0.15 \\
-0.95 \\
-0.32\end{array}$ & $\begin{array}{l}1.36 \\
1.19 \\
0.44 \\
1.15\end{array}$ & $\begin{array}{l}4.08^{(\mathrm{c})} \\
3.58 \\
1.32 \\
3.46\end{array}$ & $\begin{array}{l}13.61^{(\mathrm{c})} \\
11.95 \\
4.40 \\
11.53\end{array}$ \\
\hline \multicolumn{6}{|c|}{ Constituent: Cobalt-60 (pCi/L) } \\
\hline $\begin{array}{l}10 / 18 / 02-12 / 13 / 02 \\
01 / 07 / 03-03 / 24 / 03 \\
05 / 14 / 03-09 / 29 / 03 \\
\text { Summary }\end{array}$ & $\begin{array}{r}4 \\
8 \\
3 \\
15\end{array}$ & $\begin{array}{r}0.30 \\
-0.18 \\
0.71 \\
0.13\end{array}$ & $\begin{array}{l}1.43 \\
1.11 \\
0.47 \\
1.13\end{array}$ & $\begin{array}{l}4.30^{(c)} \\
3.33 \\
1.40 \\
3.38\end{array}$ & $\begin{array}{l}14.33^{(\mathrm{c})} \\
11.11 \\
4.68 \\
11.27\end{array}$ \\
\hline \multicolumn{6}{|c|}{ Constituent: Europium-152(pCi/L) } \\
\hline 02/05/03-09/29/03 & 8 & 0.91 & 2.02 & $6.05^{(\mathrm{c})}$ & $20.18^{(c)}$ \\
\hline \multicolumn{6}{|c|}{ Constituent: Europium-154 (pCi/L) } \\
\hline $\begin{array}{l}10 / 18 / 02-12 / 13 / 02 \\
01 / 07 / 03-03 / 24 / 03 \\
05 / 14 / 03-09 / 29 / 03 \\
\text { Summary }\end{array}$ & $\begin{array}{r}4 \\
8 \\
3 \\
15\end{array}$ & $\begin{array}{r}1.47 \\
-0.32 \\
1.45 \\
0.51\end{array}$ & $\begin{array}{l}4.57 \\
3.16 \\
4.05 \\
3.71\end{array}$ & $\begin{array}{c}13.71^{(\mathrm{c})} \\
9.48 \\
12.15 \\
11.14\end{array}$ & $\begin{array}{l}45.71^{(\mathrm{c})} \\
31.61 \\
40.51 \\
37.13\end{array}$ \\
\hline \multicolumn{6}{|c|}{ Constituent: Europium-155 (pCi/L) } \\
\hline $\begin{array}{l}10 / 18 / 02-12 / 13 / 02 \\
01 / 07 / 03-03 / 24 / 03 \\
05 / 14 / 03-09 / 29 / 03 \\
\text { Summary }\end{array}$ & $\begin{array}{r}4 \\
8 \\
3 \\
15\end{array}$ & $\begin{array}{r}1.73 \\
-0.38 \\
-0.61 \\
0.13\end{array}$ & $\begin{array}{l}1.50 \\
1.64 \\
1.21 \\
1.54\end{array}$ & $\begin{array}{l}4.50^{(c)} \\
4.91 \\
3.64 \\
4.62\end{array}$ & $\begin{array}{l}15.00^{(\mathrm{c})} \\
16.37 \\
12.14 \\
15.40\end{array}$ \\
\hline \multicolumn{6}{|c|}{ Constituent: Gross Alpha (pCi/L) } \\
\hline $\begin{array}{l}10 / 02 / 02-12 / 18 / 02 \\
01 / 06 / 03-03 / 24 / 03 \\
04 / 03 / 03-06 / 23 / 03 \\
07 / 08 / 03-09 / 08 / 03 \\
\text { Summary }\end{array}$ & $\begin{array}{r}16 \\
10 \\
8 \\
4 \\
38\end{array}$ & $\begin{array}{r}0.04 \\
0.13 \\
0.06 \\
-0.00 \\
0.06\end{array}$ & $\begin{array}{l}0.20 \\
0.25 \\
0.09 \\
0.05 \\
0.19\end{array}$ & $\begin{array}{l}0.60^{(c)} \\
0.76 \\
0.27 \\
0.16 \\
0.57\end{array}$ & $\begin{array}{l}1.99^{(c)} \\
2.54 \\
0.89 \\
0.53 \\
1.91\end{array}$ \\
\hline \multicolumn{6}{|c|}{ Constituent: Gross Beta $(\mathrm{pCi} / \mathrm{L})$} \\
\hline $\begin{array}{l}10 / 02 / 02-12 / 13 / 02 \\
01 / 06 / 03-03 / 24 / 03 \\
04 / 03 / 03-06 / 23 / 03 \\
07 / 08 / 03-09 / 08 / 03 \\
\text { Summary }\end{array}$ & $\begin{array}{l}16 \\
11^{(b)} \\
8 \\
4 \\
39\end{array}$ & $\begin{array}{l}0.48 \\
0.80 \\
1.01 \\
1.17 \\
0.75\end{array}$ & $\begin{array}{l}0.62 \\
0.66 \\
1.12 \\
1.51 \\
0.86\end{array}$ & $\begin{array}{l}1.85^{(c)} \\
1.99 \\
3.35 \\
4.53 \\
2.57\end{array}$ & $\begin{array}{c}6.18^{(c)} \\
6.63 \\
11.18 \\
15.09 \\
8.57\end{array}$ \\
\hline
\end{tabular}


Table D.23. (contd)

\begin{tabular}{|c|c|c|c|c|c|}
\hline Period & $\begin{array}{c}\text { Number of } \\
\text { Samples }\end{array}$ & Mean & $\begin{array}{c}\text { Standard } \\
\text { Deviation } \\
\end{array}$ & $\begin{array}{l}\text { Limit of } \\
\text { Detection }\end{array}$ & $\begin{array}{c}\text { Limit of } \\
\text { Quantitation }\end{array}$ \\
\hline \multicolumn{6}{|c|}{ Constituent: Iodine-129 (pCi/L) } \\
\hline $10 / 02 / 02-12 / 18 / 02$ & 8 & -0.02 & 0.07 & $0.22^{(\mathrm{c})}$ & $0.72^{(\mathrm{c})}$ \\
\hline $01 / 09 / 03-02 / 13 / 03$ & 5 & -0.04 & 0.06 & 0.19 & 0.63 \\
\hline $04 / 03 / 03-06 / 23 / 03$ & $3^{(\mathrm{b})}$ & 0.00 & 0.24 & 0.73 & 2.43 \\
\hline $07 / 08 / 03-09 / 08 / 03$ & 4 & -0.07 & 0.04 & 0.12 & 0.40 \\
\hline Summary & 20 & -0.03 & 0.10 & 0.31 & 1.05 \\
\hline \multicolumn{6}{|c|}{ Constituent: Strontium-90 (pCi/L) } \\
\hline $10 / 02 / 02-12 / 18 / 02$ & 5 & 0.07 & 0.07 & $0.22^{(\mathrm{c})}$ & $0.75^{(\mathrm{c})}$ \\
\hline $01 / 06 / 03-03 / 04 / 03$ & 7 & 0.14 & 0.07 & 0.21 & 0.70 \\
\hline $07 / 08 / 03-09 / 29 / 03$ & 2 & 0.27 & 0.23 & 0.70 & 2.33 \\
\hline Summary & 14 & 0.14 & 0.1 & 0.30 & 0.98 \\
\hline \multicolumn{6}{|c|}{ Constituent: Technetium-99 (pCi/L) } \\
\hline $10 / 02 / 02-12 / 18 / 02$ & 9 & -0.00 & 5.60 & $16.8^{(c)}$ & $56.0^{(c)}$ \\
\hline $01 / 06 / 03-03 / 12 / 03$ & 9 & 1.33 & 5.82 & 17.5 & 58.2 \\
\hline $04 / 03 / 03-06 / 17 / 03$ & 8 & 4.75 & 4.25 & 12.8 & 42.5 \\
\hline $07 / 10 / 03-09 / 15 / 03$ & 7 & 7.96 & 6.36 & 19.1 & 63.6 \\
\hline Summary & 33 & 3.20 & 5.54 & 16.6 & 55.4 \\
\hline \multicolumn{6}{|c|}{ Constituent: Tritium (pCi/L) } \\
\hline $10 / 04 / 02-12 / 18 / 02$ & 17 & 121.9 & 96.9 & $291^{(\mathrm{c})}$ & $969^{(\mathrm{b})}$ \\
\hline $01 / 06 / 03-03 / 24 / 03$ & 12 & 39.7 & 86.5 & 259 & 865 \\
\hline $04 / 03 / 03-06 / 23 / 03$ & 11 & 100.0 & 86.2 & 258 & 862 \\
\hline $07 / 08 / 03-09 / 15 / 03$ & 9 & 73.7 & 70.6 & 212 & 706 \\
\hline Summary & 49 & 88.0 & 87.8 & 263 & 878 \\
\hline \multicolumn{6}{|c|}{ Constituent: Tritium - Low-Level Method $(\mathrm{pCi} / \mathrm{L})$} \\
\hline $01 / 06 / 03-02 / 12 / 03$ & 3 & 24.0 & 14.8 & $44^{(c)}$ & $148^{(c)}$ \\
\hline \multicolumn{6}{|c|}{ Constituent: Uranium ( $\mu \mathrm{g} / \mathrm{L})$} \\
\hline $10 / 04 / 02-12 / 27 / 02$ & $7^{(\mathrm{b})}$ & 0.015 & 0.007 & $0.037^{(\mathrm{d})}$ & $0.087^{\text {(d) }}$ \\
\hline $01 / 06 / 03-03 / 24 / 03$ & 6 & 0.022 & 0.016 & 0.072 & 0.186 \\
\hline $04 / 03 / 03-06 / 23 / 03$ & $7^{(\mathrm{b})}$ & 0.042 & 0.039 & 0.157 & 0.428 \\
\hline 07/10/03 - 09/18/03 & 7 & -0.005 & 0.068 & 0.200 & 0.679 \\
\hline Summary & 27 & 0.019 & 0.041 & 0.141 & 0.428 \\
\hline
\end{tabular}

(a) Time period covered for total organic carbon and total organic halides is a moving average of four quarters.

(b) Excluded outliers.

(c) Limit of detection (blank corrected) equals 3 times the blank standard deviation; limit of quantitation (blank corrected) equals 10 times the blank standard deviation. Numbers are rounded.

(d) Limit of detection equals the mean blank concentration plus 3 standard deviations; limit of quantitation equals the mean blank concentration plus 10 standard deviations. Numbers are rounded. 
Table D.24. Summary of Detection and Quantitation Limits, Severn Trent Laboratory (St. Louis)

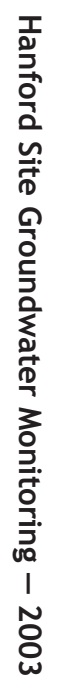

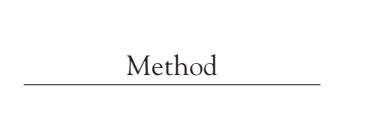

EPA-600/4-81-004, 120.1 EPA-600/4-81-004, 160.1 EPA-600/4-81-004, 310. EPA-600/4-81-004, 410.4

EPA-600/4-81-004, 413.1

EPA-600/4-81-004, 300.0 EPA-600/4-81-004, 300.0 EPA-600/4-81-004, 300.0 EPA-600/4-81-004, 300.0 EPA-600/4-81-004, 300.0 EPA-600/4-81-004, 300.0 EPA-600/4-81-004, 300.0

EPA-600/4-81-004, 350.

SW-846, 9012

SW-846, 6010
SW-846, 6010
SW-846, 6010
SW-846, 6010
SW-846, 6010
SW-846, 6010
SW-846, 6010
SW-846, 6010
SW-846, 6010
SW-846, 6010
SW-846, 6010
SW-846, 6010
SW-846, 6010
SW-846, 6010
SW-846, 6010
SW-846, 6010
SW-846, 6010
SW-846, 6010
SW-846, 6010
SW-846, 6010
SW-846, 6010

SW 846,6010

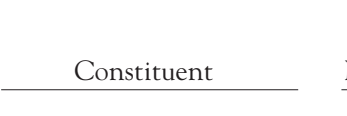

\begin{tabular}{c} 
Initial \\
$\operatorname{MDL}^{(a)}(\mu \mathrm{g} / \mathrm{L})$ \\
\hline
\end{tabular}

Initial

Initial

Ending Values,

Effective Date

\section{General Chemical Parameters}

Conductivity $^{(\mathrm{b})}$

Total dissolved solids

Alkalinity

Chemical oxygen demand

Oil and grease

0.147
4,392
4,043
4,800
915

Bromide

Chloride

Fluoride $^{(c)}$

Nitrogen in nitrate

Nitrogen in nitrite

Phosphate

Sulfate

Nitrogen in ammonia

Cyanide

Aluminum $^{(\mathrm{d})}$
Antimony $^{(\mathrm{d})}$
Barium $^{(\mathrm{d})}$
Beryllium $^{(\mathrm{d})}$
Cadmium $^{(\mathrm{d})}$
Calcium $^{(\mathrm{d})}$
Chromium $^{(\mathrm{d})}$
Cobalt $^{(\mathrm{d})}$
Copper $^{(\mathrm{d})}$
Iron $^{(\mathrm{d})}$
Lead $^{(\mathrm{d})}$
Magnesium $^{(\mathrm{d})}$
Manganese $^{(\mathrm{d})}$
Nickel $^{(\mathrm{d})}$
Potassium $^{(\mathrm{d})}$
Silver $^{(\mathrm{d})}$
Sodium $^{(\mathrm{d})}$
Strontium $\left.^{(e l e m e n t a l)}\right)^{(\mathrm{d})}$
Tin $^{(\mathrm{d})}$
Vanadium $^{(\mathrm{d})}$

Zinc(d)

Zinc $^{(d)}$

$\begin{array}{cc}0.198 & 0.662 \\ 5,931 & 19,778 \\ 5,459 & 18,206 \\ 6,482 & 21,615 \\ 1,236 & 4,120\end{array}$

\section{Ammonia and Anions}

$$
\begin{aligned}
& 24.7 \\
& 39.3 \\
& 41.9
\end{aligned}
$$

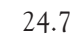$$
41.9
$$$$
5.9
$$

14.7

107

50.5

16.116

$$
6.284
$$

\section{Metals}

$$
20.3
$$$$
\begin{array}{r}
16 \\
6.5
\end{array}
$$$$
\begin{aligned}
& 6.5 \\
& 0.17
\end{aligned}
$$$$
2
$$$$
\begin{array}{r}
2 \\
148
\end{array}
$$$$
2
$$

$\begin{array}{rc}27.4 & 91.4 \\ 21.6 & 72.1 \\ 8.8 & 29.3 \\ 0.2 & 0.8 \\ 2.7 & 9 \\ 199.8 & 666.5 \\ 2.7 & 9 \\ 5.4 & 18 \\ 10.4 & 34.7 \\ 19.6 & 65.3 \\ 12.2 & 40.5 \\ 186.3 & 621.4 \\ 1.1 & 3.6 \\ 16.2 & 54 \\ 1,796 & 5,989 \\ 8.1 & 27 \\ 189 & 630.4 \\ 2 & 6.8 \\ 26.7 & 89.2 \\ 3.1 & 10.4 \\ 1.8 & 5.9\end{array}$

$\begin{array}{llll}05 / 13 / 03 & 0.486 & 0.656 & 2.189 \\ 05 / 13 / 03 & 3.497 & 4.722 & 15.75 \\ 05 / 13 / 03 & 1,188 & 1,604 & 5,350 \\ 05 / 13 / 03 & 3,564 & 4,813 & 16,049\end{array}$

Ending

LOQ $(\mu \mathrm{g} / \mathrm{L})$

5,350
6,049

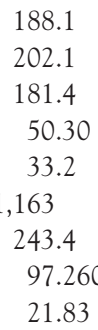


Table D.24. (contd)

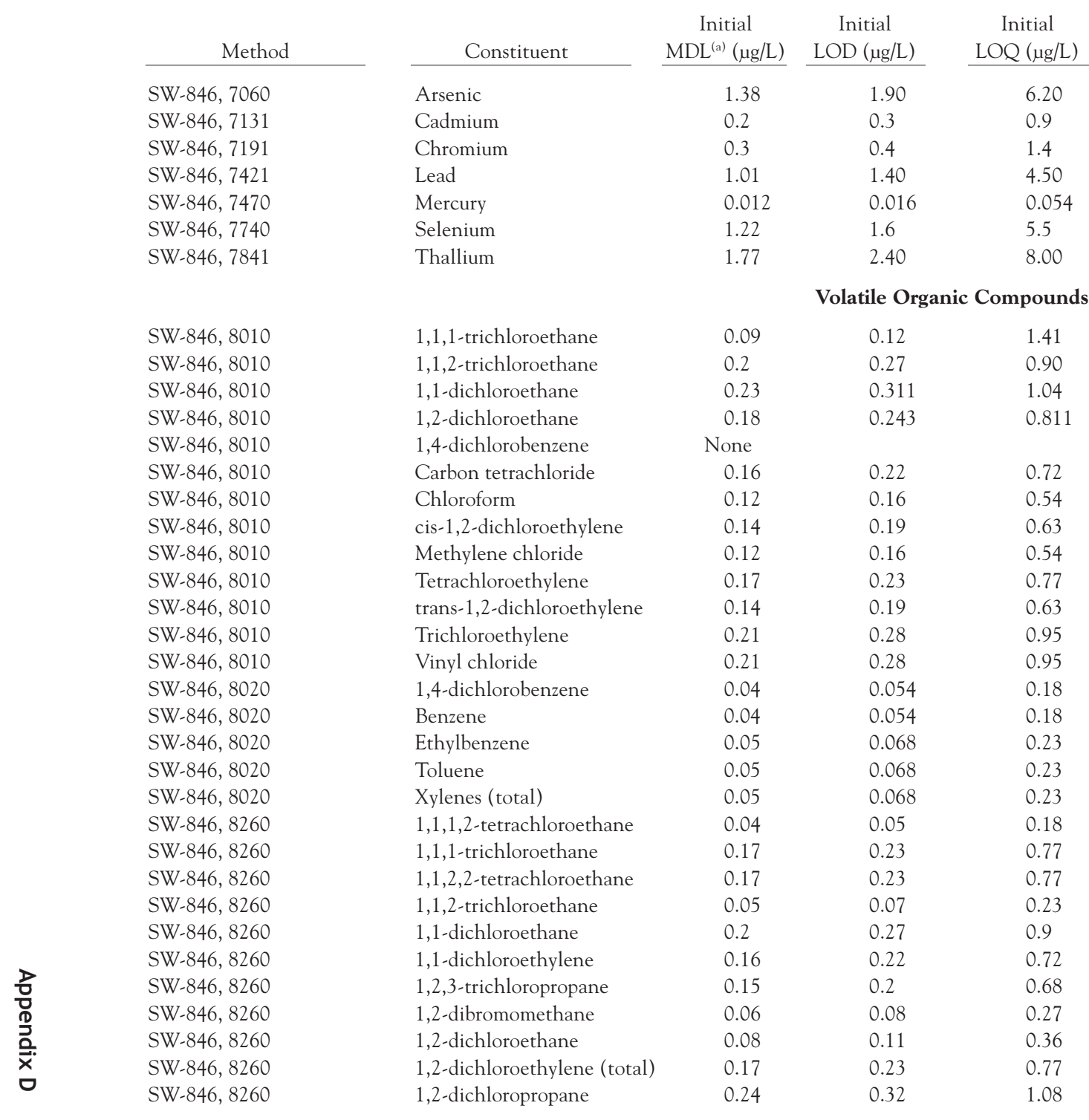


Table D.24. (contd)

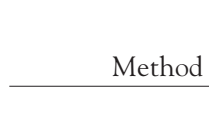

SW-846, 8260 SW-846, 8260 SW-846, 8260

SW-846, 8260

SW-846, 8260

SW-846, 8260

SW-846, 8260

SW-846, 8260

SW-846, 8260

SW-846, 8260

SW-846, 8260

SW- 846,8260

SW-846, 8260

SW-846, 8260

SW-846, 8260

SW-846, 8260

SW-846, 8260

SW-846, 8260

SW-846, 8260

SW-846, 8260

SW-846, 8260

SW-846, 8260

SW-846, 8260

SW-846, 8260

SW-846, 8260

SW-846, 8260

SW-846, 8260

SW-846, 8260

SW-846, 8260

SW-846, 8260

SW-846, 8260

SW-846, 8260

SW-846, 8260

SW-846, 8260

SW-846, 8260

SW-846, 8260

WTPH_Gasoline
Initial Initial LOQ $(\mu \mathrm{g} / \mathrm{L}) \quad$ Ending Values,

$\operatorname{MDL}^{(a)}(\mu \mathrm{g} / \mathrm{L})$

1,4-dichlorobenzene

1,4-dioxane

1-butanol

2-butanone

2-hexanone

4-methyl-2-pentanone

Acetone

Acetonitrile

Acrolein

Benzene

Bromodichloromethane

Bromoform

Bromomethane

Carbon disulfide

Carbon tetrachloride

Chlorobenzene

Chloroethane

Chloroform

Chloromethane

cis-1,2-dichloroethylene

cis-1,3-dichloropropene

Dichlorodifluoromethane

Ethyl cyanide

Ethylbenzene

Methylene chloride

Styrene

Tetrachloroethylene

Tetrahydrofuran

Toluene

trans-1,2-dichloroethylene

trans-1,3-dichloropropene

Trichloroethene

Vinyl acetate

Vinyl chloride

Xylenes (total)

1,4-dichlorobenzene

$\mathrm{TPH}$, gasoline fraction

$\begin{array}{cc}0.15 & 0.5 \\ 15.0 & 50.0 \\ 6.17 & 20.6 \\ 0.39 & 1.31 \\ 0.19 & 0.63 \\ 0.47 & 1.58 \\ 0.89 & 2.97 \\ 3.65 & 12.2 \\ 2.88 & 9.59 \\ 0.09 & 0.32 \\ 0.24 & 0.81 \\ 0.27 & 0.9 \\ 0.82 & 2.75 \\ 0.58 & 1.94 \\ 0.20 & 0.68 \\ 0.11 & 0.36 \\ 0.43 & 1.44 \\ 0.09 & 0.32 \\ 0.27 & 0.90 \\ 0.08 & 0.27 \\ 0.32 & 1.08 \\ 0.43 & 1.44 \\ & \\ 0.19 & 0.63 \\ 0.41 & 1.35 \\ 0.09 & 0.32 \\ 0.23 & 0.77 \\ 2.35 & 7.84 \\ 0.16 & 0.54 \\ 0.23 & 0.77 \\ 0.07 & 0.23 \\ 0.22 & 0.72 \\ 0.27 & 0.9 \\ 0.34 & 1.13 \\ 0.38 & 1.26 \\ 3.44 & 0.23 \\ 0.07 & \end{array}$

0.5

20.6

1.31

1.58

9.59

0.32

0.9

2.75

0.68

0.36

1.44

0.90

1.44

0.63

0.32

0.54

0.72

1.26
11.48

0.23 \begin{tabular}{ccc}
$\begin{array}{c}\text { Ending } \\
\operatorname{MDL}^{(a)}(\mu \mathrm{g} / \mathrm{L})\end{array}$ & $\begin{array}{c}\text { Ending } \\
\mathrm{LOD}(\mu \mathrm{g} / \mathrm{L})\end{array}$ & $\underline{\mathrm{LOQ}(\mu \mathrm{g} / \mathrm{L})}$ \\
\hline
\end{tabular}
03/01/03

0.41

0.55 
Table D.24. (contd)

\begin{tabular}{|c|c|c|c|c|c|c|c|c|c|}
\hline & Method & Constituent & $\begin{array}{c}\text { Initial } \\
\operatorname{MDL}^{(a)}(\mu \mathrm{g} / \mathrm{L})\end{array}$ & $\begin{array}{c}\text { Initial } \\
\text { LOD }(\mu \mathrm{g} / \mathrm{L})\end{array}$ & $\begin{array}{c}\text { Initial } \\
\text { LOQ }(\mu \mathrm{g} / \mathrm{L})\end{array}$ & $\begin{array}{l}\text { Ending Values, } \\
\text { Effective Date }\end{array}$ & $\begin{array}{c}\text { Ending } \\
\operatorname{MDL}^{(a)}(\mu \mathrm{g} / \mathrm{L})\end{array}$ & \multicolumn{2}{|r|}{$\begin{array}{c}\text { Ending } \\
\text { LOQ }(\mu \mathrm{g} / \mathrm{L})\end{array}$} \\
\hline & \multicolumn{9}{|c|}{ Semivolatile Organic Compounds } \\
\hline & SW-846, 8015 & TPH, diesel function & 5 & 6.75 & 22.52 & 02/01/03 & 0.06 & 0.081 & 0.27 \\
\hline & SW-846, 8040 & 2,3,4,6-tetrachlorophenol & 3.73 & 5.04 & 16.8 & & & & \\
\hline & SW-846, 8040 & 2,4,5-trichlorophenol & 2.91 & 3.93 & 13.1 & & & & \\
\hline & SW-846, 8040 & 2,4,6-trichlorophenol & 2.65 & 3.58 & 11.9 & & & & \\
\hline & SW-846, 8040 & 2,4-dichlorophenol & 2.9 & 3.92 & 13.1 & & & & \\
\hline & SW-846, 8040 & 2,4-dimethylphenol & 3.75 & 5.06 & 16.9 & & & & \\
\hline & SW-846, 8040 & 2,4-dinitrophenol & 3.45 & 4.66 & 15.5 & & & & \\
\hline & SW-846, 8040 & 2,6-dichlorophenol & 2.66 & 3.59 & 12.0 & & & & \\
\hline & SW-846, 8040 & 2-chlorophenol & 2.65 & 3.58 & 11.9 & & & & \\
\hline & SW-846, 8040 & 2-methylphenol (cresol, o-) & 2.79 & 3.77 & 12.6 & & & & \\
\hline & SW-846, 8040 & 2-nitrophenol & 2.65 & 3.58 & 11.9 & & & & \\
\hline & SW-846, 8040 & $\begin{array}{l}\text { 2-sec-Butyl-4,6-dinitrophenol } \\
\text { (DNBP) }\end{array}$ & 1.43 & 1.93 & 6.44 & & & & \\
\hline & SW-846, 8040 & 3,4-methyl phenol & 3.54 & 4.78 & 15.9 & & & & \\
\hline & SW-846, 8040 & 4,6-dinitro-2-methyl phenol & 4.02 & 5.43 & 18.1 & & & & \\
\hline & SW-846, 8040 & 4-chloro-3-methylphenol & 2.78 & 3.75 & 12.5 & & & & \\
\hline & SW-846, 8040 & 4-nitrophenol & 2.81 & 3.79 & 12.7 & & & & \\
\hline & SW-846, 8040 & Pentachlorophenol & 2.5 & 3.38 & 11.3 & & & & \\
\hline & SW-846, 8040 & Phenol & 3 & 4.05 & 13.5 & & & & \\
\hline & SW-846, 8082 & Aroclor-1016 & 0.22 & 0.3 & 0.99 & & & & \\
\hline & SW-846, 8082 & Aroclor-1221 & 0.22 & 0.3 & 0.99 & & & & \\
\hline & SW-846, 8082 & Aroclor-1232 & 0.49 & 0.66 & 2.21 & & & & \\
\hline & SW-846, 8082 & Aroclor- 1242 & 0.2 & 0.27 & 0.9 & & & & \\
\hline & SW-846, 8082 & Aroclor-1248 & 0.14 & 0.19 & 0.63 & & & & \\
\hline & SW-846, 8082 & Aroclor-1254 & 0.38 & 0.51 & 1.71 & & & & \\
\hline & SW-846, 8082 & Aroclor- 1260 & 0.19 & 0.26 & 0.86 & & & & \\
\hline & SW-846, 8270 & 1,2,4,5-tetrachlorobenzene & 1.98 & 2.67 & 8.92 & 03/01/03 & 0.53 & 0.72 & 2.39 \\
\hline & SW-846, 8270 & 1,2,4-trichlorobenzene & 2.55 & 3.44 & 11.48 & 03/01/03 & 0.45 & 0.61 & 2.03 \\
\hline & SW-846, 8270 & 1,2-dichlorobenzene & 2.58 & 3.48 & 11.62 & 03/01/03 & 0.28 & 0.38 & 1.26 \\
\hline & SW-846, 8270 & 1,3-dichlorobenzene & 2.5 & 3.38 & 11.26 & $03 / 01 / 03$ & 0.29 & 0.39 & 1.31 \\
\hline & SW-846, 8270 & 2,2'-oxybis(1-chloropropane) & 2.75 & 3.71 & 12.38 & 03/01/03 & 0.27 & 0.36 & 1.22 \\
\hline & SW-846, 8270 & 2,4,5-trichlorophenol & 1.98 & 2.67 & 8.92 & $03 / 01 / 03$ & 0.64 & 0.86 & 2.88 \\
\hline & SW-846, 8270 & 2,4,6-trichlorophenol & 1.73 & 2.34 & 7.79 & 03/01/03 & 0.44 & 0.59 & 1.98 \\
\hline ס & SW-846, 8270 & 2,4-dichlorophenol & 1.7 & 2.30 & 7.66 & 03/01/03 & 0.27 & 0.36 & 1.22 \\
\hline$\stackrel{D}{2}$ & SW-846, 8270 & 2,4-dimethylphenol & 2.73 & 3.69 & 12.29 & 03/01/03 & 5.31 & 7.17 & 23.91 \\
\hline$\vec{x}$ & SW-846, 8270 & 2,4-dinitrophenol & 1.26 & 1.70 & 5.67 & 03/01/03 & 1.74 & 2.35 & 7.84 \\
\hline$\hat{\sigma}$ & SW-846, 8270 & 2,4-dinitrotoluene & 2.15 & 2.90 & 9.68 & 03/01/03 & 0.62 & 0.84 & 2.79 \\
\hline & SW-846, 8270 & 2,6-dinitrotoluene & 1.85 & 2.50 & 8.33 & $03 / 01 / 03$ & 0.68 & 0.92 & 3.06 \\
\hline
\end{tabular}


Table D.24. (contd)

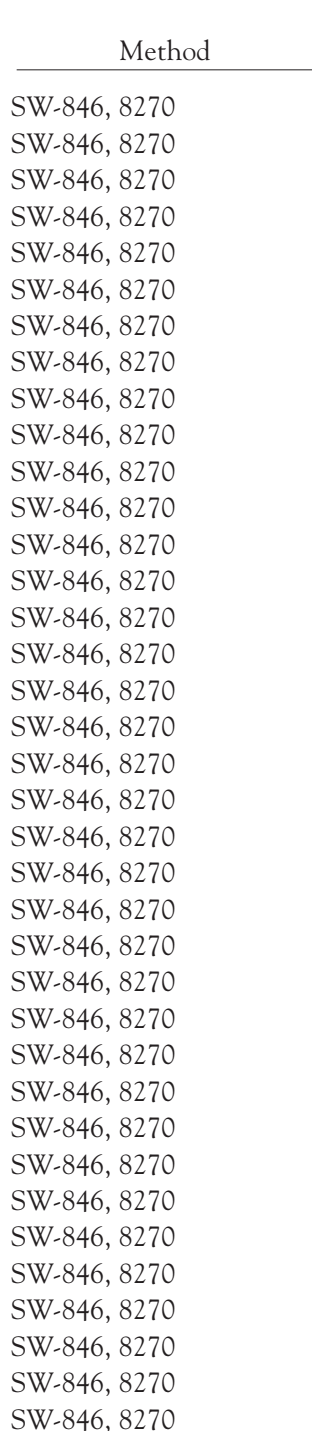

\begin{tabular}{|c|c|c|}
\hline Constituent & $\begin{array}{c}\text { Initial } \\
\mathrm{MDL}^{(a)}(\mu \mathrm{g} / \mathrm{L}) \\
\end{array}$ & $\begin{array}{c}\text { Initial } \\
\text { LOD }(\mu \mathrm{g} / \mathrm{L})\end{array}$ \\
\hline 2-chloronaphthalene & 2.56 & 3.46 \\
\hline 2-chlorophenol & 1.45 & 1.96 \\
\hline 2-methylnaphthalene & 2.36 & 3.19 \\
\hline 2-methylphenol (cresol, o-) & 1.24 & 1.67 \\
\hline 2-nitroaniline & 2.45 & 3.31 \\
\hline 2-nitrophenol & 2 & 2.70 \\
\hline 3,3'-dichlorobenzidine & 1.3 & 1.76 \\
\hline 3-nitroaniline & 1.42 & 1.92 \\
\hline 4,6-dinitro-2 methyl phenol & 1.38 & 1.86 \\
\hline 4-bromophenylphenyl ether & 3.06 & 4.13 \\
\hline 4-chloro-3-methylphenol & 1.49 & 2.01 \\
\hline 4-chloroaniline & 1.63 & 2.20 \\
\hline 4-chlorophenylphenyl ether & 2.69 & 3.63 \\
\hline 4-methylphenol (cresol, p-) & 1.51 & 2.04 \\
\hline 4-nitroaniline & 1.44 & 1.94 \\
\hline 4-nitrophenol & 0.63 & 0.85 \\
\hline Acenaphthene & 2.47 & 3.34 \\
\hline Acenaphthylene & 2.35 & 3.17 \\
\hline Aniline & 1.86 & 2.51 \\
\hline Anthracene & 2.44 & 3.29 \\
\hline Benzo(a)anthracene & 2.08 & 2.81 \\
\hline Benzo(a)pyrene & 1.8 & 2.43 \\
\hline Benzo(b)fluoranthene & 1.82 & 2.46 \\
\hline Benzo(ghi)perylene & 1.27 & 1.71 \\
\hline Benzo(k)fluoranthene & 2.05 & 2.77 \\
\hline Benzyl alcohol & 1.79 & 2.42 \\
\hline $\operatorname{Bis}(2$-chloroethoxy)methane & 2.05 & 2.77 \\
\hline Bis(2-chloroethyl) ether & 2.69 & 3.63 \\
\hline Bis(2-ethylhexyl) phthalate & 3.19 & 4.31 \\
\hline Butylbenzylphthalate & 2.88 & 3.89 \\
\hline Chrysene & 1.89 & 2.55 \\
\hline Di-n-butylphthalate & 2.21 & 2.98 \\
\hline Di-n-octylphthalate & 2.22 & 3.00 \\
\hline Dibenz[a,h]anthracene & 2.02 & 2.73 \\
\hline Dibenzofuran & 2.48 & 3.35 \\
\hline Diethylphthalate & 2.41 & 3.25 \\
\hline & & \\
\hline
\end{tabular}

Initial
$\mathrm{LQ}(\mu \mathrm{g} / \mathrm{L})$ LOQ $(\mu \mathrm{g} / \mathrm{L})$

11.53
6.53

6.53
10.63

5.58

5.58
11.03

9.01

5.85

6.39

6.21

13.78

6.71

7.34

12.11

6.80

6.48

2.84

11.1

10.6

8.38

10.99

9.37

8.11

8.20

5.72

9.23

8.06

9.23

12.11

14.37

12.97

8.51

9.95

10.0

9.10

11.2

10.9
9.41
Ending Values, Effective Date

03/01/03

03/01/03

03/01/03

03/01/03

03/01/03

03/01/03

$03 / 01 / 03$

03/01/03

03/01/03

03/01/03

03/01/03

03/01/03

03/01/03

03/01/03

03/01/03

03/01/03

$03 / 01 / 03$

03/01/03

03/01/03

03/01/03

03/01/03

03/01/03

$03 / 01 / 03$

$03 / 01 / 03$

03/01/03

03/01/03

$03 / 01 / 03$

03/01/03

03/01/03

$03 / 01 / 03$

03/01/03

03/01/03

03/01/03

03/01/03

03/01/03

03/01/03

03/01/03

\begin{tabular}{|c|}
\hline $\begin{array}{c}\text { Ending } \\
\operatorname{MDL}^{(a)}(\mu \mathrm{g} / \mathrm{L})\end{array}$ \\
\hline 0.28 \\
\hline 0.25 \\
\hline 0.37 \\
\hline 0.24 \\
\hline 0.65 \\
\hline 0.64 \\
\hline 1.33 \\
\hline 0.56 \\
\hline 0.53 \\
\hline 0.42 \\
\hline 0.37 \\
\hline 1.09 \\
\hline 0.44 \\
\hline 7.14 \\
\hline 1.01 \\
\hline 0.81 \\
\hline 0.35 \\
\hline 0.34 \\
\hline 0.29 \\
\hline 0.39 \\
\hline 0.47 \\
\hline 1.1 \\
\hline 0.83 \\
\hline 1.21 \\
\hline 1.47 \\
\hline 0.33 \\
\hline 0.37 \\
\hline 0.43 \\
\hline 2.67 \\
\hline 0.55 \\
\hline 0.6 \\
\hline 0.47 \\
\hline 5.12 \\
\hline 1.35 \\
\hline 0.36 \\
\hline 0.24 \\
\hline 0.68 \\
\hline
\end{tabular}

Ending $\underline{\operatorname{LOD}(\mu \mathrm{g} / \mathrm{L})}$

0.38
0.34
0.50
0.32
0.88
0.86
1.80
0.76
0.72
0.57
0.50
1.47
0.59
9.64
1.36
1.09
0.47
0.46
0.39
0.53
0.63
1.49
1.12
1.63
1.98
0.45
0.50
0.58
3.61
0.74
0.81
0.63
6.91
1.82
0.49
0.32
0.92

Ending LOQ $(\mu \mathrm{g} / \mathrm{L})$

1.26

1.13

1.67

1.08
2.93

2.88

5.99

2.52

2.39

1.89

1.67

4.91

1.98

32.2

4.55

3.65

1.58

1.53

1.31

1.76

2.12

4.95

3.74
5.45

6.62

1.49

1.67

1.94

12.02

2.48

2.70

2.12

23.06

6.08

1.62

1.08
3.06 
Table D.24. (contd)

\begin{tabular}{|c|c|c|c|c|c|c|c|c|}
\hline Method & Constituent & $\begin{array}{c}\text { Initial } \\
\operatorname{MDL}^{(a)}(\mu \mathrm{g} / \mathrm{L}) \\
\end{array}$ & $\begin{array}{c}\text { Initial } \\
\text { LOD }(\mu \mathrm{g} / \mathrm{L})\end{array}$ & $\begin{array}{c}\text { Initial } \\
\text { LOQ }(\mu \mathrm{g} / \mathrm{L})\end{array}$ & $\begin{array}{l}\text { Ending Values, } \\
\text { Effective Date }\end{array}$ & $\begin{array}{c}\text { Ending } \\
\operatorname{MDL}^{(a)}(\mu \mathrm{g} / \mathrm{L}) \\
\end{array}$ & $\begin{array}{c}\text { Ending } \\
\text { LOD }(\mu \mathrm{g} / \mathrm{L}) \\
\end{array}$ & $\begin{array}{c}\text { Ending } \\
\mathrm{LOQ}(\mu \mathrm{g} / \mathrm{L}) \\
\end{array}$ \\
\hline SW-846, 8270 & Fluoranthene & 1.78 & 2.40 & 8.02 & $03 / 01 / 03$ & 0.44 & 0.59 & 1.98 \\
\hline SW-846, 8270 & Fluorene & 2.55 & 3.44 & 11.5 & 03/01/03 & 0.38 & 0.51 & 1.71 \\
\hline SW-846, 8270 & Hexachlorobutadiene & 2.01 & 2.71 & 9.05 & 03/01/03 & 0.41 & 0.55 & 1.85 \\
\hline SW-846, 8270 & Hexachlorocyclopentadiene & 2.11 & 2.85 & 9.50 & $03 / 01 / 03$ & 2.4 & 3.24 & 10.81 \\
\hline SW-846, 8270 & Hexachloroethane & 2.33 & 3.15 & 10.49 & $03 / 01 / 03$ & 0.24 & 0.32 & 1.08 \\
\hline SW-846, 8270 & Indeno(1,2,3-cd)pyrene & 1.47 & 1.98 & 6.62 & $03 / 01 / 03$ & 1.24 & 1.67 & 5.58 \\
\hline SW-846, 8270 & $\mathrm{~N}$-nitroso-di-n-propylamine & 2.49 & 3.36 & 11.21 & $03 / 01 / 03$ & 0.89 & 1.20 & 4.01 \\
\hline SW-846, 8270 & $\mathrm{~N}$-nitrosodimethylamine & 1.57 & 2.12 & 7.07 & $03 / 01 / 03$ & 0.46 & 0.62 & 2.07 \\
\hline SW-846, 8270 & $\mathrm{~N}$-nitrosodiphenylamine & 1.64 & 2.21 & 7.39 & 03/01/03 & 0.45 & 0.61 & 2.03 \\
\hline SW-846, 8270 & Naphthalene & 2.64 & 3.56 & 11.9 & $03 / 01 / 03$ & 0.3 & 0.41 & 1.35 \\
\hline SW-846, 8270 & Pentachlorophenol & 1.29 & 1.74 & 5.81 & $03 / 01 / 03$ & 0.58 & 0.78 & 2.61 \\
\hline SW-846, 8270 & Phenanthrene & 2.5 & 3.38 & 11.3 & $03 / 01 / 03$ & 0.4 & 0.54 & 1.80 \\
\hline SW-846, 8270 & Phenol & 0.91 & 1.23 & 4.10 & $03 / 01 / 03$ & 0.26 & 0.35 & 1.17 \\
\hline SW-846, 8270 & Pyrene & 2.19 & 2.96 & 9.86 & $03 / 01 / 03$ & 0.46 & 0.62 & 2.07 \\
\hline
\end{tabular}

(a) MDLs for many constituents changed during the fiscal year. For these constituents, the initial MDL, LOD, and LOQ were in effect until the date the values were updated (ending values, effective date). In cases where the MDL did not change, no ending values are listed.

(b) $\mu \mathrm{Mhos} / \mathrm{cm}$

(c) Between March 13, 2003, and May 12, 2003, a third MDL (value not shown in table) was in effect for this compound.

(d) Two instruments (standard and trace level) were used for samples analyzed by method 6010. MDL values for the standard instrument were included in this table. MDL values for the trace instrument were typically 2 to 10 times lower, but in several cases, the MDL values for the trace instrument were the same as or higher than those reported for the standard instrument.

LOD $=$ Limit of detection

LOQ = Limit of quantitation.

MDL $=$ Method detection limit 


\section{Distribution of Printed Full Report}

No. of

Copies

1 S. Lilligren

Environmental Specialist

ERWM, Nez Perce Tribe

P.O. Box 365

Lapwai, ID 83540

1 Washington State Department of Ecology

P.O. Box 47600, MS 7600

Olympia, WA 98504-7600

\section{Onsite}

11 DOE Richland Operations Office

B. L. Charboneau

A6-33

R. D. Hildebrand (3)

J. G. Morse

K. M. Thompson (3)

A. C. Tortoso

Public Reading Room (2)

A6-38

A6-38

A6-38

A6-38

$\mathrm{H} 2-53$

2 Fluor Hanford, Inc.

L. C. Swanson

E6-35

J. D. Davis

E6-35

8 Washington State Department of Ecology

F. W. Bond

B5-18

J. A. Caggiano

B5-18

D. Goswami (4)

B5-18

A. D. Huckaby

Z. Maine
No. of

Copies

3 U.S. Environmental Protection Agency

$\begin{array}{ll}\text { C. E. Cameron } & \text { B5-01 }\end{array}$

D. A. Faulk B5-01

L. E. Gadbois B5-01

31 Pacific Northwest National Laboratory

D. B. Barnett K6-81

C. J. Chou K6-81

P. E. Dresel K6-96

J. S. Fruchter K6-96

M. J. Hartman (6) K6-96

D. G. Horton K6-81

J. L. Julya K6-75

J. W. Lindberg K6-81

S. P. Luttrell (6) K6-96

J. P. McDonald K6-96

L. F. Morasch K6-86

S. M. Narbutovskih K6-81

C. A. Newbill K6-96

R. M. Smith K6-96

D. L. Stewart K6-96

M. D. Sweeney K6-81

C. J. Thompson K6-96

E. C. Thornton K6-96

W. D. Webber K6-96

Hanford Technical Library (2) P8-55 


\section{Distribution of Summary Booklet with CD Report}

No. of

Copies

Offsite

S. Arlt

City of Richland

P.O. Box 190

Richland, WA 99352

M. Ault

US Ecology, Inc.

P.O. Box 638

Richland, WA 99352

J. T. Bachmaier

U.S. Department of Energy

Forrestal Building, EH-412

1000 Independence Avenue, S.W.

Washington, D.C. 20585

J. R. Beaver, Mayor

Kennewick City Council

210 West Sixth Avenue

Kennewick, WA 99336

N. Bell

Northwest Environmental Advocates/Hanford Watch

133 Southwest Second Avenue, Suite 302

Portland, OR 97204-3526

M. E. Benitz, Jr.

Benton County Commissioner

620 Market Street

Prosser, WA 99350

J. O. Boda

U.S. Department of Energy

Cloverleaf Building, EM-34

19901 Germantown Road

Germantown, MD 20874-1290

T. D. Bowden

912 N. 48th Street

Seattle, WA 98103

T. E. Carpenter

Government Accountability Project

West Coast Office, Suite 1215

1402 3rd Avenue

Seattle, WA 98101
No. of

Copies

2 Center for Isotope Geochemistry

Lawrence Berkeley National Laboratory

1 Cyclotron Road, Building 70A4418

Berkeley, CA 94720-8179

ATTN: J. N. Christensen

M. Conrad

J. Chasse

Energy Northwest

P.O. Box 968

Richland, WA 99352

2 Confederated Tribes of the Umatilla Indian

Reservation

Environmental Planning/Rights Protection

P.O. Box 638

Pendleton, OR 97801

ATTN: S. Harris

J. H. Richards

D. Crumpler

8208 W. Deschutes Place

Kennewick, WA 99336

R. A. Danielson

Washington State Department of Health

5508 Englewood Avenue

Yakima, WA 98908

G. De Bruler

Columbia River United

P.O. Box 912

Bingen, WA 98605

B. W. Drost

Geological Survey

U.S. Department of the Interior

1201 Pacific Avenue, Suite 600

Tacoma, WA 98402

B. Floyd

for City of Richland

7601 W. Clearwater Avenue, Suite 105

Kennewick, WA 99336

T. Friend

SAIC

3250 Port of Benton Boulevard

Richland, WA 99352 
No. of

Copies

A.J.K. Fyall

Benton County Planning Department

P.O. Box 910

Prosser, WA 99350

H. Gucinski, Chair

Pacific Northwest Natural Area Committee

3200 Jefferson Way

Corvallis, OR 97331

A. Haymaker

1721 Cottonwood Drive

Pasco, WA 99301

R. E. Isaacson

2106 Lee Boulevard

Richland, Washington 99352

R. E. Jaquish

Washington State Department of Health

1232 Vintage Avenue

Richland, WA 99352

R. Jim

Confederated Tribes and Bands of the Yakama Nation

Environmental Restoration/Waste Management 2808 Main Street

Union Gap, WA 98903

2 Idaho National Engineering and Environmental Laboratory

P.O. Box 1625, MS-2107

Idaho Falls, ID 83415-2107

ATTN: J. M. Hubbell

J. B. Sisson

K. Klaus

Brookhaven National Laboratory

Building 51

Upton, NY 11973

B. Langille

Duratek Commercial Services

1009 Commerce Park Drive, Suite 100

Oak Ridge, TN 37830

R. J. Leaumont

Lower Columbia Basin Audubon Society

9016 Sunset Terrace

Pasco, WA 99301
No. of

Copies

D. Leavitt

Science and Engineering Assoc. Inc.

3205 Richards Lane, Suite A

Santa Fe, NM 87507

J. Loving

U.S. Department of Energy

Forrestal Building, Room 3E094

1000 Independence Avenue, S.W.

Washington, DC 20585

L. Maas

Framatome ANP Richland, Inc.

2101 Horn Rapids Road

Richland, WA 99352

S. McDaniel

South Columbia Basin Irrigation District

P.O. Box 1006

Pasco, WA 99301

K. Moser

Vista Engineering Technologies

8203 W. Quinault, Building C, Suite 200

Kennewick, WA 99336

S. McNutt

City of Richland

3102 Twin Bridges Road

Richland, WA 99352

2 Nez Perce Tribe

Environmental Restoration/Waste Management

P.O. Box 365

Lapwai, ID 83540-0365

ATTN: L. Lilligren

P. Sobotta

2 K. Niles

State of Oregon Office of Energy

625 Marion Street N.E.

Salem, OR 97310

R. Patt

1655 S. Elm $\# 405$

Canby, OR 97013

G. M. Pollet

Executive Director

Heart of America, NW

Cobb Building, Suite 208

1305 Fourth Avenue

Seattle, WA 98101 
No. of

Copies

D. Postma

Bureau of Reclamation

U.S. Department of the Interior

P.O. Box 815

Ephrata, WA 98823

R. K. Price

4200 W. 19th

Kennewick, WA 99338

W. Riggsbee

Confederated Tribes and Bands of the

Yakama Nation

1216 W. Kennewick Avenue

Kennewick, WA 99336

J. A. Riley

Washington State Department of Health

P.O. Box 453

Post Falls, ID 83877-0453

J. Rhodrick

U.S. Department of Energy

Cloverleaf Building, EM-43

19901 Germantown Road

Germantown, MD 20874-1290

S. Saldanha

1920 NE Terre View Drive, D 108

Pullman, WA 99163

F. J. Schelling

Sandia National Laboratories

P.O. Box 5800, MS-0779

Albuquerque, NM 87185-0779

J. R. Schinner

11382 Canary Drive

Ijamsville, MD 21754

L. Seelatsee

Wanapum People

Grant County P.U.D.

30 "C" Street S.W.

P.O. Box 878

Ephrata, WA 98823

M. Sully

Neptune and Company

1505 15th Street, Suite B

Los Alamos, NM 87544
No. of

Copies

L. C. Treichel

U.S. Department of Energy, EM-43

Cloverleaf Building 2116

19901 Germantown Road

Germantown, MD 20874

J. VanLeer

Cascadia Community College

18345 Campus Way NE

Bothell, WA 98011

M. G. Waddell

Earth Sciences and Resources Institute

University of South Carolina

Columbia, SC 29208

3 Washington State Department of Health

Division of Radiation Protection

P.O. Box 47827

Olympia, WA 98504-7827

ATTN: M. Dunkelman

D. McBaugh

S. VanVerst

P. H. Wicks

North Wind, Inc.

829 Goethals Drive

Richland, WA 99352

L. Williams

Jason Associates

3250 Port of Benton Boulevard

Richland, WA 99352

\section{Onsite}

\section{DOE Richland Operations Office}

C. A. Babel H6-60

T. W. Ferns A2-17

B. L. Foley A6-38

J. B. Hall A2-15

H. B. Hathaway A2-17

R. D. Hildebrand (20) A6-38

K. D. Leary A6-38

R. G. McLeod K8-50

J. G. Morse (10) A6-38

J. P. Sands A3-04

J. M. Silko A5-13

G. L. Sinton A6-38

K. M. Thompson (20) A6-38 
No. of

Copies
A. C. Tortoso
A.6-38
D. C. Ward
A2-17

2 DOE Office of River Protection

R. W. Lober

R. M. Yasek

H6-60

H6-60

Bechtel Hanford, Inc.

K. R. Fecht

$\mathrm{HO}-02$

2 CH2M HILL Hanford, Inc.

D. A. St. John

R. L. Weiss

H9-02

H9-01

6 CH2M HILL Hanford Group, Inc.
A. Amonette
E6-35
T. E. Jones
E6-35
A. J. Knepp
$\mathrm{H} 6-03$
D. A. Myers
E6-35
D. G. Stock
H. A. Sydnor
$\mathrm{HO}-50$
E6-35

3 Duratek Federal Services of Hanford, Inc.

L. P. Diediker

H8-13

J. A. Winterhalder

E6-35

R. T. Wilde

E6-35

5 Duratek Federal Services, Northwest

Operations

J. J. Dorian

H1-11

M. G. Gardner

H1-11

D. J. Moak

C. J. Perkins

S. H. Worley

H1-11

H1-11

H1-11

\section{Fluor Hanford, Inc.}

M. A. Baechler

E6-35

J. V. Borghese

E6-35

M. E. Byrnes

C. W. Connell

R. A. Daughety

J. D. Davis

R. A. Del Mar

D. B. Erb
No. of

Copies

B. H. Ford

E6-35

J. G. Hogan

H1-11

R. L. Jackson

E6-35

V. G. Johnson

E6-35

L. M. Kelly

S4-21

E6-35

E6-35

R. O. Mahood

E6-35

F. Mann

K. M. McDonald

R3-12

W. J. McMahon E6-35

S. M. Price H8-12

R. F. Raidl

E6-35

V. J. Rohay

E6-35

J. C. Sonnichsen H8-12

L. C. Swanson E6-35

B. Thackaberry E6-35

S. J. Trent A0-21

J. D. Williams R3-62

C. D. Wittreich H9-03

M. I. Wood H8-44

2 Freestone Environment Services

D. K. Tyler

B6-07

M. Serkowski

B6-07

\section{MACTEC ERS}

P. D. Henwood B2-62

S. E. Kos B2-62

3 Washington State Department of Ecology

B. L. Becker-Khaleel B5-18

J. Price B5-18

D. G. Singleton B5-18

81 Pacific Northwest National Laboratory

D. H. Bacon K9-33

M. P. Bergeron K9-36

C. A. Brandt K6-85

R. W. Bryce E6-35

J. W. Buck K6-04

R. J. Cameron K6-96

Y. Chien K6-81

C. R. Cole K9-36

S. F. Conley K6-75

R. L. Dirkes K6-75

P. E. Dresel (5) K6-96

W. J. Deutsch K6-81 
No. of

Copies

O. T. Farmer

M. J. Fayer

E. J. Freeman

M. D. Freshley

J. S. Fruchter (10)

G. W. Gee

D. R. Geist

R. E. Gephart

T. J Gilmore

S. M. Goodwin

R. W. Hanf

M. J. Hartman (15)

P. S. Henry

J. M. Keller

E. A. Lepel

S. P. Luttrell

M. D. Johnson

C. T. Kincaid

C. K. Knudson

G. V. Last

T. L. Liikala

P. D. Meyer
P $8-50$

K9-33

K9-36

K9-33

K6-96

K9-33

K6-85

K9-88

K6-81

P7-07

K6-75

K6-96

K6-75

K9-36

P8-01

K6-96

K6-96

K9-33

K6-04

K6-81

K6-96

$\mathrm{BPO}$
No. of

Copies

T. G. Naymik

K6-96

D. R. Newcomer K6-96

K. B. Olsen K6-96

B. E. Opitz

M. S. Peffers

K6-75

R. E. Peterson

S. P. Reidel

J. T. Rieger

R. G. Riley

K. Rhoads

R. J. Serne

D. S. Sklarew

F. A. Spane, Jr.

P. D. Thorne

V. R. Vermeul

G. Whelan

B. A. Williams

M. D. Williams

S. K. Wurstner

J. M. Zachara

Hanford Technical Library (2)
BSRC

K6-96

K6-81

K6-96

K6-96

K3-54

K6-81

K6-96

K6-96

K9-33

K6-96

K9-36

K6-81

K9-36

K9-36

K8-96

P8-55 